\title{
Fritz Müller
}

\section{Werke, Briefe und Leben}

Gesammelt und herausgegeben

von

Dr. Alfred Möller

Erster Band

Gesammelte Schriften

soweit sie bereits früher im Druck erschienen sind

Mit 303 Abbildungen im Text und einem Atlas mit 85 Tafeln

\section{Text}

Abteilung 1:

Arbeiten aus den Jahren 1844-1879 (Nr. 1-124)

(Seite 1-800)

Mit 157 Abbildungen im Text und Tafel $1-57$ im Atlas

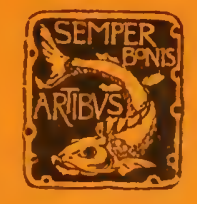

Jena

Verlag von Gustav Fischer 1915 
Morphologie und Biologie der Algen. Von Dr. Friedrich Oltmanns sität Freibung i. Br. Zwei Bände. I'reis: 32 ?

Erster Band: Spezieller Teil. Mit 3 farbigen und 173 schwarzen Abbilu. im Text. 1904 .

Preik: :20 Mlark.

InhaIt: I. Chrysomonalineae. II. Heterocontae. III. Chryptomonadineas. IV. Euglenaceae. V. I inoflagellata. VI. Acontae. V'II. Chlorophỵcrae. V'III. Phaeophyceae. IX. Rhodophycene.

Zweiter Band: Allgemeiner Tril: Mil 3 Tafeln nnd I50 Abbildungen im Text. 190:).

Preis: 12 Mark.

Inhalt: I. Spstem der Algen. IJ. hie Entwicklnng der Fortpflanzungsorgane. III. Die Algenzelle. IV. Die ihrung If Algen. V. Die [,ebensbedingungen. VI. Vegctationsperiorlen. .. Reizerscheinungen. VIII. P'olimorphismus. IX. Generationswechsel. X. An? assungen. XI. Hilfsmittel nn] Arberitsmethoden.

\%eitschrift für Physiologie, Bd. YII, Heft 2/3:

Jeden, der über Algen arbeitct, wird dicses großangelegrte W'erk ein $11 n$. entbehrlicher Wegweiser sein.

Oesterreich. botanische \%eitschrift, 190J, Nr. 12:

Wie der erste Band enthält auch der zweite eine Fülle von $\Lambda$ ngaben; or boweist sorgfilltigste Literaturbenützung und eigene Untersuchungen. Wir besitzen uunmehr in flom Oltmannschen Buche eine ungemein wertvollo / us a mmenfassung der die Algen betreffenden morphologischen, entwicklungsgeschichtlichen nnd ökologischen Kenntnisse.

ivetstein.

Naturwissenschaftliche WTochenschrift, rom 28. Januar 1906:

.. Ein mustergültiges Kompendium für jerlen, der sich $11 n \mathrm{Alg}$ gen kümmert oder etwas wesentliches von ihnen zu erfahren wïnscht.

Die Geographie der Farne. Ton H. Christ, Basel. Mit cinem Titellilil. graphien) im Text und 3 Karten. 1910. I'reis: 12 Mark.

I. Teil: Die Farne unter den kinflüssen von Boden nud Klima. Die larne als mesotherme Hygrophyten mind als Xerophyten.

11. Teil: l)ie Farnfloren. 1. (mundlagen der F'loristik, 2. Die filorengebicte. 3. Florengeschichtlicher Ueherblick. - Einige Literatmmachwoise. Erlänterungen zu den liarten.

Geographische 7eitschrift, 17. Jahrg, 1911, 4. Heft:

Wie kam eiu zweiter war der Verf. berufen, die geographische Verbreitumg der Farne in zusammenhïngender Darstellung zu geben. Ein Stndium von meln als 30 Jahren rerschaffte ihn die erforderliche Spezialkeminis und eine erntanliche Vertrautheit mit den Lokalfloren aller Länder. So tritt das neue Werk des Verf. in vollendeter lorm uns entgegen, gediegen im Inhalt, glänzend in der Darstellung, reich ansgestattet mit Bildern, die volles Lob verdienen. li. I'ax.

Die Farnkräuter del El’de. Beschreibende Darstellung der (ieschlechter und wichtigeren Arten der Farnpfianzen. Nit besonderer Berücksichtigung der Exotisphen. Ton H. Christ, Basel. Mit 291 Ablildungen. 1897 .

l'reis: 12 Mark.

Englers botanische Jahrbïcher, 1898, Bl. 26, Heft 1:

IVer sich in die Kenntnis der Firne einarbeiten und kleinere Sammlungen danach ordnen will, wird das Buch mit großem Vorteil gebrauchen. Nanentlich ist co zur Finfïhrung für (iärtuer besonilers geeignet.

Boden und Klima auf kleinstem Raum. Versuch einer exakten Behand-

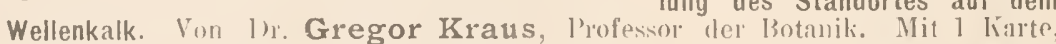
7 Tafoln und 5) Ahbildumgen im Text. 1911. l'reis: 8 .lark.

InhaIt: Einlestmog. I. Was Karbonat des Wellenkalkhodens: I. Das Mnttergestrin. 2. Der Boden. - II. Bodenphysikalisches nund Kilimatisches: I. Botenban (Vorpholngie des Borlens): Bodenprolit. liörnnng (Körnigkeit) des liodens. 2. Wassergehalt des Bodens. - III. lemperatur. - IV. Hygrometrisclies. - V. Anemonctrie. - Literatur.

liotanisches Zentrallbla1t, lid. 117, Nr. 18:

bie Arbeit bedentet einen großen Fortschitit in der Forschungsmenloole mud in suscrem Yerstänhnis fïr die Ursachen der l'flanzenvertrihnng. l)er Verf, zeigt nnter Mitteilnng eines großen in jahrelangen Studion in giinstigem lielände am Tebergang des Spessartsandsteins in dem Wellenkatk des Maintales gewomenen Naterials, daß anf kleinstem Ranm in der Natur eine mendliche Mannigfaltigkeit chemisch und physikalisch rershiaden gebanter Standorte gegeben ist, deren lieschaffenhrit für die Pflanzenverteilung mafgehende liedentung hesitzt. Büsgen. 


\section{Fritz Müller}

\section{Werke, Briefe und Leben}

Gesammelt und herausgegeben

von

Dr. Alfred Möller

Erster Band

\section{Gesammelte Schriften}

soweit sie bereits früher im Druck erschienen sind

Mit 303 Abbildungen im Text und einem Atlas mit 85 Tafelı

\section{Text}

Abteilung 1:

Arbeiten aus den Jahren 1844-1879 (Nr. 1-124)

Seite $1-800$

Mit 157 Abbildungen im Text und Tafel 1-57 im Atlas

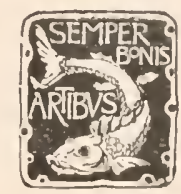

Jena

Verlag von Gustav Fischer

1915 
Alle Rechte vorbehalten

$$
11163
$$




\section{Vorwort.}

Es war mir, dem unterzeichneten IIcrausgeber, vergönnt, drei Jahre lang (1890-93) in Blumenau, dem langjährigen Wohnorte Fritz Müllers, botanischmykologischen Arbeiten mich widmen zu dürfen. Fritz Müller, dem ich durch verwandtschaftliche Beziehungen nahestand, führte mich in den Tropenwald der südbrasilianischen Küste ein, nahm an meinen Arbeiten, die or in jeder Hinsicht zu fördern suchte, den lebhaftesten Anteil und war mir in fast täglichem Verkehr ein immer gleich gütiger und bereitwilliger Lehrer und väterlicher Freund. So lernte ich den großen Biologen, den genialen Beobachter der lebenden Natur persönlich kennen, lieben und verehren.

So gewissenhaft Fritz Müller in der täglichen Aufzeichnung seiner Beobachtungen war, so gern er über sie sprach und in Briefen an gleichstrebende Naturforscher in aller Welt rückhaltlos berichtete, so wenig kümmerte ihn das weitere literarische Schicksal dieser Mitteilungen. Ein Meister der Sprache, der deutsch, englisch und portugiesisch in gleicher Gewandtheit und Vollendung schrieb, spanische, französische, dänische, schwedische, italienische, ungarische Arbeiten ohne sichtliche Mühe mit Freuden las, verstand er es ausgezeichnet, die Ergebnisse langer mühsamer, oft Tage und Jahre umfassender Peobachtungen in knappster Form zusammenzufassen, und ein einfacher Brief auf dünnem, mit seiner kleinen klaren Schrift bis zum äußersten Rande gefülltem Ueberseepapier trug oftmals wertvolle wissenschaftliche Arbeit zu irgendeinem literarischen Freunde, dem die Veröffentlichung überlassen blieb. Nie hat Fritz Müller Korrekturen der unter seinem Namen veröffentlichten Abhandlungen und Abbildungen gesehen, und so ist es nicht zu verwundern, daß er sich häufig über allzu viele oder sinnstörende Druckfehler und über mangelhafte Wiedergabe seiner Zeichnungen zu beklagen hatte. Weit störender war es für alle Verehrer des großen Naturforschers, daß infolge der geschilderten Umstände seine reiche Lebensarbeit in beispielloser Weise in alle Winde zerstreut wurde, und daß manch reicher Schat\%. nur in Briefen niedergelegter Beobachtungen der Oeffentlichkeit ganz vorenthalten blieb.

Bei dem hohen Ansehen, welches Fritz Müllers Name im Laufe der Jahre sich in der ganzen Welt erwarb, wurde der wesentliche Inhalt seiner gedruckten Abhandlungen freilich in weiteren Kreisen bekannt; die Urschriften aber, in viele Jahrgänge vieler Zeitschriften zerstreut, blieben denen schwer zu- 
gänglich, die sie gründlich studieren, nachprüfen oder aus ihnen die dort so reichlich gebotene Anregung zu weiteren Beobachtungen schöpfen wollten. Ein Ueberblick über den unendlich reichen Gesamtertrag dieses ganz der Naturforschung geweihten Lebens war überhaupt unmöglich.

Als im Mai 1897 Fritz Müller die Augen für immer geschlossen hatte, erstand vor mir gleich einer moralischen Pflicht die Aufgabe, alles zu sammeln, was er an wissenschaftlichen Mitteilungen hinterlassen hatte, und über seinen eigenartigen Lebens- und Entwicklungsgang die noch erreichbaren Nachrichten zu gewinnen, damit es dereinst vielleicht möglich würde, diesem deutschen Forscher in fremden Landen in der deutschen Literatur ein würdiges Denkmal zu setzen.

Meine seit nunmehr I7 Jahren fortgesetzten Sammlungen hatten sich allmählich der erreichbaren Vollständigkeit genähert. Die Briefe wissenschaftlichen Inhalts waren von den Empfängern meist gesammelt und sorgsam aufbewahrt; sie wurden mir für den beabsichtigten Zweck bereitwillig zur Verfügung gestellt. Der ursprüngliche Plan, mit der Veröffentlichung dieser Briefe zu beginneı, erwies sich aber bald als unausführbar. Vielfach war der Inhalt der Briefe ganz, noch öfter teilweise in den gedruckten Aufsätzen enthalten, dann wieder war zum Verständnis ein Hinweis auf diese unerläßlich. Man mußte also die gedruckten Arbeiten sämtlich zur Hand haben, wenn unnötige Wiederholungen vermieden und die Briefe in nutzbringender Form der Allgemeinheit zugänglich gemacht werden sollten. Es sind nun im ganzen 250 gedruckte Abhandlungen aufgefunden und in diesem Bande vereinigt worden. Von ihnen ist nur eine: „Für Darwin“ selbständig im Buchhandel erschienen. Die übrigen sind auf 36 verschiedene deutsche und ausländische Zeitschriften und Vereinsberichte und auf sehr viele Jahrgänge derselben verteilt. Es wäre unmöglich gewesen, all diese zum Teil schwer zugänglichen Bände auf lange Zeit zur Verfügung zu haben. So ergab sich der nun zur Ausführung in Angriff genommene Plan der Arbeit. Die gedruckten Abhandlungen Fritz Müllers mußten zuerst gesammelt herausgegeben werden, für die Folge ist dann die Veröffentlichung der Briefe und die Schilderung des Lebensganges in Aussicht genommen.

Inzwischen stellte mich mein Beruf vor neue Aufgaben, welche meine Zeit und Kraft völlig in Anspruch nahmen - Wohl war eine Zusammenstellung der gedruckten Abhandlungen schon von Loew (Ber. der Deutschen Botan. Ges. 1897 Bd. XV S. 24) mit i ro Nummern, von Ludwig (Botanisches Centralblatt I897) mit Ioo Nummern veröffentlicht, meine eigenen Nachforschungen hatten manches hinzugefügt; um aber die mögliche Vollständigkeit $\mathrm{zu}$ erreichen, war planmäßige Arbeit in einer großen Bibliothek erforderlich. Um Verhandlungen mit einem Verlage zu beginnen, mußte auch der Umfang der einzelnen Schriften festgestellt und die Zahl der vorhandenen Abbildungen und Tafeln ermittelt werden. Da hatte ich das Glück, in meinem Assistenten, Herrn Forstassessor Bandow, die zur Vollendung der Arbeit unentbehrliche Hilfe zu gewinnen. Bandow hatte sich mit dem Lebensgange und der Lebensarbeit Fritz Müllers vertraut gemacht und bald für die zu leistende Arbeit ein lebhaftes Verständnis und freudige Begeisterung entwickelt. Er arbeitete längere Zeit in der Berliner Bibliothek, und seinen emsigen selbstlosen Bemühungen war es zu danken, daß im Laufe weniger Monate die Sammlung so vollständig 
wurde, wie sie nun vorliegt. Auch weiterhin widmete er sich der einmal übernommenen Aufgabe mit der ihm eigenen peinlichen Gewissenhaftigkeit und bis zum 31. Juli I9I4, bis zum Beginn der Arbeit über Trichodactylus (S. $11 ; 1)$ salı er sie nach und nach entstehen, alle Korrekturen lasen wir gemeinsam. Die Pflicht der Dankbarkeit gebietet, dem treuen Mitarbeiter und lieben lireuncle, der sein junges Leben dem Vaterlande gab, an dieser Stelle ein Denkmal zu setzen, das seinen Namen allen denen aufbewahrt, die aus den Gesammelten Schriften Fritz Müllers Belehrung und Anregung schöpfen werden.

\section{Max Bandow}

wurde am 28. Juni I88I zu Oppeln als Sohn des verstorbenen Baurats Bandow geboren, besuchte das Gymnasium seiner Vaterstarlt und das Falck-Realgy'mnasium zu Berlin, welches er im Herbst 1900 mit dem Zeugnis der Reife verließ. Er wilnncte sich der preußischen Forstverwaltungslaufbaln, studierte zunächst zwei Semester Rechtsund Staatswissenschaften in Berlin und besuchte dann die Forstakademie Elserswalde. Nachdem er im Sommer I 904 das Forstreferendarexamen bestanden hatte, diente er als Einjährig-Freiwilliger beim Garde-Schützenbataillon, studierte fernere zwei Semester Rechts- und Staatswissenschaften in Berlin und förderte seine forstliche Auslilclung in der vorgeschriebenen zweijährigen praktischen Tätigkeit in verschiedenen preußisclien Oberförstereien. Nach bestandenem Forstassessorexamen im Frühjahr ı gos war Bandow zunächst Assistent an der forstlichen, sodann seit in1 I an der mykologischen Abteilung der Hauptstation des forstlichen Versuchswesens zu Eberswalde. Bandow war seit I9Io verheiratet und hinterließ seine Witwe mit einem beim Torle des Vaters ein Jahr alten Sohne Albrecht.

Ausgestattet mit einer guten Beobachtungsgabe und bemerkenswerter Handgeschicklichkeit, vor allem aber mit einer nie nachlassenden Gewissenhaftigkeit und Zuverlässigkeit, fand er in den Aufgaben der mykologischen Abteilung ein ilm balcl lebhaft erfreuendes Arbeitsgebiet, auf dem er manche schëne Erfolge erreichte. Daneben aber widmete er sich mit großer Hingabe der Arbeit für die Herausgabe cler vorliegenden gesammelten Schriften Fritz. Müllers, und seiner fleißigen Tätigkeit war es zu danken, daß die im Herbst I9I3 begonnene Drucklegung ohne wesentlichen Aufenthalt fortschreiten und binnen Jahresfrist nahezu vollendet werden kunnte.

Unmittelbar aus der friedlichen Arbeit des ihm lieb gewordenen Laboratoriums rief ihn der Mobilmachungsbefehl am 2. August nach Ortelsburg zum I. Jägrerbataillon, als dessen Reserveoffizier er ins Feld an die russische Grenze rückte. $\Lambda m$ 22. und 23. August lag die 2. Kompagnie, welcher Bandow angehörte, in Scluützcngräben vor dem Dorfe Lahna mit der Front nach Neidenburg. Am 2.3. mußte sich die Kompagnie ihrem Auftrage gemäß nach Eintreffen stärkerer feindlicher lỉifte durch das Dorf nach Norden auf die Brigade zurückziehen. Hierbei kam es in Lalna zu einem heftigen Nah- und Nachtkampf. Dort fiel Bandow, sofort tïdlich getruffen.

Russische Hände bereiteten ihm auf deutschem Boden dicht beim Dorfe Lahnit das Heldengrab.

Die Drucklegung des Werkes ist in erster Linie dem verständniswollent Entgegenkommen des Verlages zu danken. Trot\% weitgehenden Entgegenkommens der Verlagsfirma war indessen ohne erhebliche Zuschüsse unser P'lun nicht zu verwirklichen. Mußten doch allein 85 Tafeln neu hergestellt wrreden. Die erforderlichen Zuschüsse sind von dem Herrn Kultusminister, von dem Herrn Landwirtschaftsminister und aus den Mitteln der Albert Samson-Stiftung gegeben worden. 
Für die Förderung und tatkräftige Unterstützung des Werkes habe ich daher Seiner Exzellenz dem Minister der geistlichen und Unterrichtsangelegenheiten Herrn ron Trott zu Solz,

Herrn Ministerialdirektor Wirklichen Geheimen Oberregierungsrat Dr. Schmidt,

Herrn Geheimen Regierungsrat Professor Dr. Krüß,

Seiner Exzellenz dem Minister für Landwirtschaft, Domänen und Forsten Freiherrn ron Schorlemer,

Seiner Exzellenz dem Ministerialdirektor und Oberlandforstmeister a. D. Herrn Wesener,

dem Herrn Regierungs- und Forstrat Gernlein,

sodann dem Kuratorium der Albert Samson-Stiftung und insbesondere

Herrn Geheimen Obermedizinalrat Professor Dr. Waldeyer

den ehrerbietigsten und herzlichsten Dank zu sagen.

Es lag der Gedanke nahe, Fritz Müllers Arbeiten in zoologische und botanische zu trennen und so gesondert zum Druck zu bringen. 151 könnten als überwiegend zoologisch, 83 als botanisch bezeichnet werden, 5 gehören ebensowohl der einen, wie der anderen Richtung an; etwa 1 I Arbeiten blieben dann noch in unsicherer Stellung. Aber Fritz Müllers Arbeit weilte mit besonderer Liebe auf den Grenzgebieten botanischer und zoologischer Forschung; die Beziehungen der Blumen zu den Insekten, die Feigenwespen, die Ameisen der Cecropien beschäftigten ihn auf das lebhafteste, und was er hierüber schrieb, hätte man doppelt drucken müssen. Bald entschied ich mich dafür, alle Arbeiten in der durch die Zeit der Veröffentlichung gegebenen Reihenfolge zu ordnen, dies um so mehr, weil dabei das Lebenswerk des großen Naturforschers auf clas getreueste zum Spiegelbilde seiner Lebensgeschichte wird.

Im Anfange des brasilianischen Aufenthaltes war seine Arbeit ganz der Meeresfauna gewvidmet; später, als er seinen Wohnsitz mehr ins Innere des Landes verlegte, stehen die Blütenbiologie, Befruchtungsversuche, Vererbungserscheinungen (Abutilon) im Mittelpunkte seiner nie ruhenden Tätigkeit. Viele Jahre wurden dann der Beobachtung der Insekten, zuerst der Termiten, dann der stachellosen Honigbienen gewidmet; gegen Ende der zoer Jahre folgen die überraschenden Entdeckungen über Duftorgane der Schmetterlinge. Diese wurden abgelöst von den unendlich mühsamen, aber höchst erfolgreichen Studien über die Phryganiden, von denen die über Steingeröll zu Tale springenden Urwaldbäche Blumenaus ein ungeahnt reiches Beobachtungsmaterial lieferten. In die 8oer Jahre fallen die Beobachtungen von Feigeninsekten. Dann aber wendet sich Fritz Müller im Alter wieder der „scientia amabilis“ zu. Die Fülle der Bromelien hatte seine Aufmerksamkeit erregt, mit Hilfe seiner scharfüugigen, klettergewandten Enkel sammelte er aus den Baumkronen die vielgestaltigen Formen, die ihn während seiner letzten Lebensjahre vollauf beschäftigten.

Das Bild seines Lebens, welches durch die Reihenfolge seiner Arbeiten dargestellt wird, sollte nicht zerstört werden.

Daß die Arbeiten so, wie sie geschrieben waren, zum Teil also englisch, französisch und portugiesisch wiedergegeben werden mußten, konnte nicht zweifelhaft sein. Um sie aber der Wissenschaft wirklich nutzbar zu machen, erschien 
eine Uebersetzung zum mindesten der purtugiesischen Arbeiten crwünscht. Die Abhandlung über die Gehäuse (ler Trichopterenlarven (S. 69fff.) hatte schon Hermann Müller, der Bruder, im Jahre ıs8o für die Zeitschrift für wissenschaftliche Zoologie übersetzt; hier wurde der deutsche Text neben den portugiesischen gesetzt. Da diese Anordnung dem Zwecke am besten zu dienen schien, wurde sie auch für die späteren umfangreichen Abhandlungen aus den Archivos do Museu Nacional gewählt.

Inzwischen waren nun schon mehrere portugiesische Abhandlungen, insbesondere diejenigen über die Duftorgane der Schmetterlinge, ganzseitig gedruckt. Thre deutschen Uebersetzungen wurden daher in einem Anhange angefügt.

Bei der Uebersetzung hat Herr E. Ule, zurzeit in Berlin, in bereitwilligster Weise seine Hilfe geliehen, wofür ich hier den herzlichsten Dank ausspreche. Indessen sind seine Uebersetzungen von mir so stark überarbeitrt worden, daß ich für die neu gewählte Fassung und etwaige Irrtümer ebenso wie für die ron mir allein übersetzten Arbeiten (Nachtrag zum Inhaltsverzeichnis a f) auch allein die Verantwortung tragen muß.

Offensichtliche Druckfehler habe ich überall ohne weitere Bemerkung berichtigt. In vielen zweifelhaften Fällen durfte ich mich mit Rückfragen an Herrn Prof. Dr. G. W. Müller in Greifswald, an Herrn Prof. Dr. G. Lindau in Berlin und auch an meinen hiesigen Kollegen Herrn Prof. Dr. Wolff wenden, denen ich für ihre jederzeit bereitwillig geleistete Hilfe zu Dank verpflichtet bin. - Daß trotz aller aufgewendeten Mühe Druckfehler dennoch durchgreschlüpft sind, bitte ich mit der Schwierigkeit der Aufgabe für einen durch Amtspflichten gebundenen Herausgeber zu entschuldigen.

Fritz Müllers gesammelte Schriften sind zum weitaus größten Teile Tàtsachensammlungen. So feinsinnig und anzichend seine Betrachtungen über die Tatsachen und ihre Verknüpfung auch sind, so wenig sie fehlen, da wo man sie zu erwarten berechtigt ist, der ihnen gewidmete Raum ist verschwindend gering gegenüber dem durch die meisterhafte Darstellung der Tatsachen selbst in Anspruch genommenen. Die Zuverlässigkeit und Gewissenhaftigkeit der Beobachtung aber, die Schärfe der Prüfung des Beobachteten, das staunenswerte Gedächtnis, welches die Vorstellung des Beobachters mit greifbar deutlichen Vergleichsbildern füllte, der Reichtum seiner Vorstellungsgabe, die durchaus eigenartige Versuchsanstellung und die Unermüdlichkeit in deren Verfolgung, das sind die großen Eigenschaften, die Fritz Müller zum "Fürsten der Benbachter" werden liefien. Deshalb können seine Arbeiten nie veralten, und dadurch rechtfertigt sich ihre Sammlung und Herausgabe.

Eberswalde, im Mai i9 5.

I)r. Alfred Möller. 


\section{Inhalts-Verzeichniss.}

\begin{tabular}{|c|c|c|c|c|}
\hline$\dot{0}$ & Titel & Aus & Bemerkungen & $\stackrel{\mathscr{\nu}}{\ddot{\Perp}}$ \\
\hline $\mathbf{I}$ & $\begin{array}{l}\text { Ueber Hirudo tessulata und margi- } A \\
\text { nata O. F. Müller. I Textfig. }\end{array}$ & $\begin{array}{l}\text { Archiv für Naturgesch. } \\
\text { I } 844 \text { I }\end{array}$ & - & I \\
\hline 2 & $\begin{array}{l}\text { De Hirudinibus circa Berolinum huc- } \\
\text { usque observatis }\end{array}$ & -1 & Dissertation Berlin 1844 & 6 \\
\hline 3 & Clepsine costata, neue Art. 2 Textfigg. H & Ebenda $\quad$ I 846 I & 一 & 23 \\
\hline 4 & $\begin{array}{l}\text { Ueber Gammarus ambulans, neue Art. I } \\
3 \text { Textfigg. }\end{array}$ & Ebenda $184^{6} \mathrm{I}$ & - & 26 \\
\hline 5 & $\begin{array}{l}\text { Ueber die Geschlechtstheile von Clepsine } \mathrm{N} \\
\text { und Nephelis. Taf. I }\end{array}$ & $\begin{array}{l}\text { Müllers Archiv für Ana- } \\
\text { tomie I } 846\end{array}$ & - & 30 \\
\hline 6 & $\begin{array}{l}\text { Bemerkungen in Betreff des Geschlechts-S } \\
\text { verhältnisses bei den Hirudineen }\end{array}$ & $\begin{array}{l}\text { Steenstrup, Untersuch. üb. } \\
\text { das Vorkommen des } \\
\text { Hermaphroditismus in } \\
\text { der Natur, aus d. Däni- } \\
\text { schen übersetzt von C. } \\
\text { Hornschuch, Greifs- } \\
\text { wald i } 846\end{array}$ & 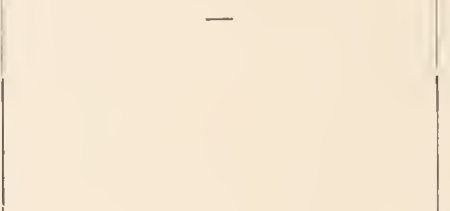 & 36 \\
\hline 7 & $\begin{array}{l}\text { Zur Kenntniss des Furchungsprocesses } \\
\text { im Schneckenei. Taf. II }\end{array}$ & $\begin{array}{l}\text { Archiv für Naturgesch. } \\
\text { I } 848 \text { I }\end{array}$ & - & $4^{\circ}$ \\
\hline 8 & $\begin{array}{c}\text { Orchestia Euchore und Gryphus, neue } \\
\text { Arten aus der Ostsee, Taf. III, } \\
\text { und }\end{array}$ & Ebenda $\mathbf{I}_{4} 8$ I & 一 & 44 \\
\hline & $\begin{array}{l}\text { Bemerkungen zu Zaddachs Synopseos } \\
\text { Crustaceorum Borussicorum prodro- } \\
\text { mus }\end{array}$ & Ebenda 1848 I & - & $5^{\circ}$ \\
\hline 9 & $\begin{array}{l}\text { Ueber die Begattung der Clepsine com-Z } \\
\text { planata Sav. }\end{array}$ & $\begin{array}{l}\text { Zeitung f. Zoologie, Zoo- } \\
\text { tomie u. Paläozoologie } \\
\text { v. d'Alton I } 849 \text { I }\end{array}$ & - & $5^{2}$ \\
\hline I0 & $\begin{array}{l}\text { Tanais Rhynchites und balticus, neue } \\
\text { Arten aus der Ostsee. Taf. IV I }-4\end{array}$ & $\begin{array}{l}\text { Archiv für Naturgesch. } \\
\text { I } 852 \text { I }\end{array}$ & - & 56 \\
\hline II & $\begin{array}{l}\text { Eine Beobachtung über die Beziehung I } \\
\text { der Gattungen Caligus und Chalimus. } \\
\text { Taf. IV } 5-6\end{array}$ & Ebenda 1852 I & 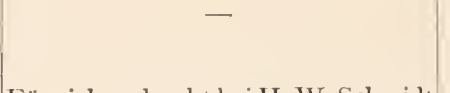 & 59 \\
\hline 12 & $\begin{array}{l}\text { Beiträge zur Kenntniss der Landplana- } \\
\text { rien }\end{array}$ & $\begin{array}{l}\text { Abhandl. d. Naturforsch.- } 1 \\
\text { Ges. in Halle } 1856 \\
\text { Bd. } 4\end{array}$ & $\begin{array}{l}\text { Für sich gedruckt bei H. W. Schnidt } \\
\text { Halle I857; S. auch Ann. and } \\
\text { Mag. of Nat. History I857 XX } \\
\text { p. I-I } 2 \text {. }\end{array}$ & 61 \\
\hline I3 & & $\begin{array}{l}\text { Archiv für Naturgesch. } \\
\text { I } 857 \text { I }\end{array}$ & $\begin{array}{l}\text { s. auch Ann. and Mag. of Nat. His- } \\
\text { tory } 1857 \times X \text { p. I3 }-15\end{array}$ & 75 \\
\hline I4 & $\begin{array}{l}\text { Einiges tiber die Annelidenfauna der } \\
\text { Insel Sa. Catharina an der brasi- } \\
\text { lianischen Küste. Taf. V, VI. }\end{array}$ & Ebenda I 858 I & - & 76 \\
\hline I 5 & Die Magenfäden der Quallen & $\begin{array}{l}\text { Zeitschr. f. wissenschaftl. } \\
\text { Zoologie } 1858 \mathrm{IX}\end{array}$ & $\begin{array}{l}\text { s. auch Ann. and Mag. of Nat. IIis- } \\
\text { tory } 1859 \text { p. } 446-447\end{array}$ & 83 \\
\hline I6 & $\begin{array}{l}\text { Zwei neue Quallen von Santa Catha- } \\
\text { rina, Tamoya laplonema und quadru- } \\
\text { mana. Taf. VII, VIII, IX }\end{array}$ & $\begin{array}{l}\text { Abhandl. d. Naturforscl.- } \\
\text { Ges. in Halle } 1859 \mathrm{~V}\end{array}$ & $\begin{array}{l}\text { Für sich gedruckt bei H. W. Schmidt } \\
\text { Halle I } 859\end{array}$ & 85 \\
\hline 17 & $\begin{array}{l}\text { Polypen und Quallen von Santa Catha- } \\
\text { rina. Die Formwandlungen der Li- } \\
\text { riope catharinensis n. sp. Taf. X, XI }\end{array}$ & $\begin{array}{l}\text { Archiv für Naturgesch. } \\
\text { I859 I }\end{array}$ & (1) & 93 \\
\hline 18 & $\begin{array}{l}\text { Polypen und Quallen von Santa Catha- } \\
\text { rina. Philomedusa Vogtii n. sp. } \\
\text { I Textfig. }\end{array}$ & Ebenda I860 I & $\begin{array}{l}\text { s. Ann. and Mag. of Nat. History } \\
\text { I } 860 \text { p. } 432--436\end{array}$ & IOI \\
\hline
\end{tabular}




\begin{tabular}{|c|c|c|c|c|}
\hline$\dot{0}$ & TiteI & Aus & Bemerkungen & ज्ञ. \\
\hline
\end{tabular}

I9 Beschrcibung einer Brachiopodenlarve. Reichert u. I)ubois-Rey-s. Ann. and Nag. of Nat. History 105 Taf. XII mond $\mathrm{Arch}$. f. Anatom. $\quad 1860$ p. 3 Io u. Physiol. 1860

20 Das Kolonialnervensystem der Moos- Archiv für Naturgesch. s, auch Anat. Journ. microsc. Sc. 184, I 1 I 1 thicre nachgewiesen an Scrialaria 1860 I I p. 300-305; Ann. des sc. Coutinhii n. sp. Taf. XIII-XIV

nat. I862 IV Sér. Zont. Tome is p. 212 ; Arch. sc, phys. et nitt. Genc̀ve 1862 P. I79-180; Firoricps Notiz. 1861 III p. 155-157; Arch. per la zool. l'anatomia e fisiologia $186 \mathrm{I}$ I p. 100-101

21 Cunina Köllikeri 11. sp. Taf. XV Ebenda 1861 I

5. Arch. sc. phys. et nat. fienive 116 1862 p. $101-102$.

22 Die Brachiopodenlarve von Santa Ca- Ebenda 1861 I tharina. 2. Beitrag

23 Ueber die systematische Stellung der Ebenda 1 86 I I Charybdeiden

24 Polypen und Quallen von Santa Catha-Ebenda I86I I rina. Olindias sambaquiensis n. sp. Taf. XVI

25 Ueber die angebliche Bilateralsym-Ebenda I861 I metrie der Rippenquallen

26 Die Rhizocephalen, eine neue Gruppe Ebenda I 862 I schmarotzender Kruster. Taf. X VII

27 Entoniscus Porcellanae, eine neue Ebenda I862 I Schmarotzer-Assel. Taf. XVIII

28 Die Verwandlung der Porcellanen. Ebenda I862 I Taf. XIX

29 Bruchstück zur Entwicklungsgeschichte Ebenda I862 I der Maulfüsser. Taf. XX

30 Ein zweites Bruchstück aus der Ent-Ebenda I863 I wicklungsgeschichte der Maulfüsser. Taf. XXI

3 I Dic Verwandlung der Garneelen. Erster Ebenda I863 I Beitrag. Taf. XXII

32 Die zweite Entwicklungsstufe der Ebenda 1863 I IVurzelkrebse (Rhizocephalen). Taf. XXIII

33 Ueber die Ursache der Strömungen in Ebenda 1863 I der Leibeshöhle der Sertularinen

34 Ueber eigenthiimliche Gebildc in der Ebenda 1863 I Samenflüssigkeit von Janthina. Taf. XXIV

35 Observations sur la Respiration des Ann. d. sc. nat. 1863. Ocypodiens 4 Sér. Zool. Tome 20 p. 272

36 Ueber den Bau der Scheerenasseln Archiv fiir Naturgesch. (Aseliotes hétéropodes M. Edw.) I864 I

37 Ein Wort über die Gattung Herklotsia Ebenda 1864 I J. E. Gray u. Nachtrag dazu

$3^{8}$ Für Darwin. Leipzig bei Engelmann 1864. 67 Textfigg.

s. Ann. and Mag. of Nat. IIist. I $861 \quad 123$ Vill p. $505-506$

s. wie vor. $1862 \times$ p. $6-12 \quad 126$

$\begin{array}{lll}- & 132\end{array}$

s. wic vor. 1862 p. $475-479$ und 137 Arch. sc. phys. et nat. Genive 1862 p. $376-378$ s. Ann. and Mag. of Nat. Hist. 1862 P. $475-479$

s. Ann. and Mag. of Nat. IIist. $18 \mathrm{~h} 2$ if 1 P. $44-50$

s. wie vor. 1862 p. $87-93$ 11. Irch. 147 sc. nat. et phys. Gineve 186,3 p. $351--352$

s. Ann. and Mag. of Nat. History 153 I $86_{3}$ p. $47-50$

s. wic vor. 1863 p. I3- in u. Arch. 15i sc. pliys. et nat. Gineve $I^{8} 86_{3}$ p. $196-197$

A. Ann. and Mag. of Nat. History 167 1864 XIV p. $104-115$

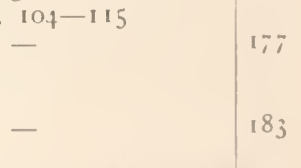

s. Ann. and Mag. of Nat. IIist. 185 1864 XIV p. 430-433: Quart. Jolim. microscop. Sc. N. Ser. Vol. $\begin{array}{llll}5 & 1865 & \text { P. } 55\end{array}$

Englische Uebersetzung von Dallas, 200 London bei Murray 1869; französische Uebersetzung von I) curay Bull. scient. Dép. du Nord 1883; Auszinge: Arch. sc. phys. et nat. Gèneve 1865 p. $154-163$; Ribl. Univ. 1865 Bull. scient. P. I 54 ff. ; Ann. and Mag. of Nat. History I 865 XV p. $4^{10-416}$ 


\begin{tabular}{|c|c|c|c|c|}
\hline$\dot{0}$ & Titel & Aus & Bemerkungen & 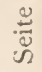 \\
\hline
\end{tabular}

39 Description of a new Genus of Am-Ann, and Mag. of Nat. phipod Crustacea: Batea n. gen. History $1865 \mathrm{XV}$ p. Taf. XXV

to Ueber Cumaceen $276-277$

4I Ueber die Randbläschen der Hydroid-Schultzes Arch. f. mikroquallen. I 'Textfig. skop. Anatom. I865 I

42 Ueber Darwinella aurea, einen Schwamm Ebenda mit sternförmigen Hornnadeln. Taf. XXVI

43 Notes on some of the Climbing-Plants Journ. Linn. Soc. of Lon-s.

near Desterro in South Brazil. Taf. don; Bot. I 865 XXVII

s. Kosmos I 88283 XII p. $321--285$ 329; Bot. $\mathrm{Ztg}$. 1866 p. 5 \% -60 u. $65-69$

t+ Ueber das Holz einiger um Desterro Botan. Zeitung I 866 24. S. Journ. Linn. Soc. 1865 IX 289 wachsender Kletterpflanzen. Taf. Jahrg. p. 344-349 XXVIII

45 Ueber die Befruchtung der Martha Ebenda (Posoqueria) fragrans nebst Nachwort von D. F. L. von Schlechtendal. Taf. XXIX

46 Ueber Balanus armatus und einen Ba-Archiv für Naturgesch., s. stard dieser Art und des Balanus 1867 I improvisus var. assimilis Darw. Taf. $\mathrm{XXX}, \mathrm{XXXI}, \mathrm{XXXII}$

t7 Notizen uiber die Geschlechtsverhält- Botanische Zeitung I868 nisse brasilianischer Pflanzen $\quad$ Bd. 26

$4^{8}$ Befruchtuugsversuche an Cipó alho Ebenda (Bignonia)

19 Ueber Befruchtungserscheinungen bei Ebenda Orchideen

50 Exkursionsberichte aus Südbrasilien Flora I 86 ?

5 I Ueber einige Befruchtungserschei-Botanische Zeitung 1869 nungen

52 Ueber eine dimorphe Faramea Ebenda

53 Umwandlung von Staubgefässen inStem- Botanische Zeitung 1870 pel bei Pegonia. Uebergang von Bd. 28 Zwitterblïthigkeit in Getrenntblïthigkeit bei Chamissoa. Triandrische Varietät eines monandrischen Epidendrum. Taf. XXXIII

54 On the Modification of the Stamens in Journ. Linn. Soc. (Bot.) a Species of Begonia. 5 Textfig. I 87 I XI

55 Botanische Notizen

Botanische Zeitung I870

56 Die Bewegung des Blüthenstieles von Jen. Zeitschr. f. NaturAlisma wissenschaft I870 $\mathrm{V}$

57 Bemerkungen über Cypridina. Taf. Ebenda I $870 \mathrm{~V}$ XXXIV, XXXV

58 Bruchstïcke zur Naturgeschichte der Ebenda i87I VI Bopyriden. Taf, XXXVI, XXXVII

59 Ueber den Trimorphismus der Ponte-Ebenda I87 I VI derien. 4 Textfigg.

60 Remarks on some white Ants Proc. Bost. Soc. of Nat.

Hist. I 87 I

ó I Bestäubungsversuche an Abutilon-Arten Jen. Zeitschrift f. NaturI u. II. I 2 Textfigg. wissenschaft I873 VII

62 Beiträge zur Kenntniss der Termiten. Ebenda 1873 VII und I, II mit Nachtrag, III und Anhang, I875 IX IV. I4 Textfigg. Taf. XXXVIII -XLIII

63 Larvae of Membracis serving as Milk-Nature 1873 VIII und cattle to a Brazilian species of Honey- $1874 \mathrm{X}$ bees. 7 Textfigg.

64 Recent researches of Termites and Nature I874 IX Honey-bees

65 The Habits of various Insects Ebenda $1874 \mathrm{X}$

s. American Naturalist 1874 VIII 486 p. $554-556$

p. $254-259 ; \Lambda$ nn. and Mag. of Nat. Ilistory 1874 p. 202-204 und Nature 1875 XII p. 218

Ann. and Mag. of Nat. History

I 868 p. $393-4$ I 2

s. auch No. 53 89 


\begin{tabular}{|c|c|c|c|c|}
\hline$\dot{0}$ & Titel & Aus & Bemerkungen & ע. \\
\hline
\end{tabular}

66 Stachellose brasilianische Honigbienen Der Zoolog. Garten I875 s. Revista agı icolit do Inj]. Institute f')? liluminense de Agricultura Rio

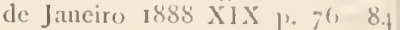

67 Poeys Beobachtungen über die Natur- Ebenda geschichte der Honigbiene von Cuba. Melipona fulvipes Guér.

68 Aus Brasilien (Meliponen)

Eichstädter Bienenztg. 875 Bd. 3

69 On Brazil Kitchen Middens, Habits Nature X111 1876 of $\Lambda$ nts etc.

70 Einige Worte ïber Leptalis. 2 Textfigg. Jen. Zeitschr. 1876 Bd. 10 Eichstäder Bicnenzeitung 1857,502 Bd. 32 S. $91-94$

I Aeglea Odebrechtii nov. spec. Taf. XLIV Ebenda

72 Ueber das Haarkissen am Blattstiel der Ebenda Imbauba (Cecropia), das Gemüsebeet der Imbaubaanieise. I Textfig.

73 Aus Brasilien (Meliponen)

Eichstädter Bienen $z$ tg. 1877 Bd. 33

74 Ueber Haarpinsel, Filzflecke und ähn-Jenaische Zeitschrift $1877 \mathrm{~s}$ liche Gebilde auf den Flügeln männ- X licher Schmetterlinge

\section{$\mathrm{X} I$}

Aus einem Briefe Fritz Müllers aus Flora 1877

Brasilien (Flora des Hochlandes)

76 A correlaçāo das flores versicolores e Archiv. do Museu nacio-D dos insectos pronubos nal do Rio de Janciro 1877 II

77 As maculas sexuaes dos individuos Ebenda 1877 II masculinos das especies Danais Erippus e D. Gilippus. Taf. XLV

78 Os orgãos odoriferos das especies Epi- Ebenda calia Acontius, Linn. e de Myscelia Orsis, Drury. Taf. XLVI

79 Os orgãos odoriferos nas pernas de Ebenda certos Lepidopteros. Supplemento. Taf, XLVII, XI,VIII

8o Tischgenossenschaft zweier Raupen

81 Der Minhociio

Der Zoologische Garten s. 1877 18. Jahrg.

82 Nectar absondernde Drüsen, init einer Nature 1877 XVI Erwiderung von Thomas Belt

83 Ueber Blumen und Insekten. Brief Ebenda mit Einleitung von $\mathrm{Ch}$. Darwin

84 Maracujáfalter

85 Die Grannen von Aristida

86 Beobachtungen an brasilianisch. Schmet- Ebenda

terlingen I. I. Die Flügeladern der

Schmetterlingspuppen. 2. Die Duft-

schuppen der männlichen Maracujá-

falter. 6 Textfigg.

87 Fortsetzung des vorigen. II. 3. Die Ebenda I $877 / 78$ II Duftschuppen der $\sigma^{7}$ von Dione Vanillae. 4. Kommt auch geschlechtliche Auswahl von Seiten des ơ vor? 7 Textfigg.

88 Fortsetzung des vorigen III. 5. Acraca Ebenda und die Maracujáfalter als Raupen, Puppen und Schmetterlinge. 4 Textfiguren
Stettiner Entomol. Ztr. Uebersetzt ins Englische bei I.ong1877 38. Jahrg. staff, liutterfly-Hunting in many lands, London 1912

Englische Uehersetzung lei Long- 585 staff, Butterfly-Hunting wic ulsen 


\begin{tabular}{|c|c|c|c|}
\hline$\stackrel{\circ}{\circ}$ & Titel & Aus & Bemerkungen \\
\hline
\end{tabular}

89 Der Rückschlag der Kreuzung weit Kosmos I $877 / 78$ II abstehender Formen. I Textfig.

90 Der sprachlose Urmensch und die Ebenda Sprachlosigkeit der Kinder

91 Pflanzengattungen, an denen mir be-Stettin. Entomol. Ztg.

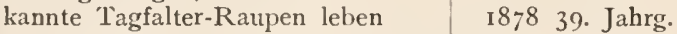

1) I a Proboscis capable of sucking the Nectar Nature 1873 VIII of Angrecum sesquipedale. (Erst) nachträglich aufgefundene und dahcr nicht an der richtigen Stelle eingereihte Veröffentlichung. Der Herausg.) I Textfig.

92 Sccnt-fans of a Sphinx-moth. I Textfig. Proc. Ent. Soc. Lond. I 878 93 Notes on Brazilian Entomology (Odours Trans. Entomol.Soc. Lonemitted by Butterflies and Moths) don 1878

94 Os orgãos odoriferos da Antirrhaea Archiv. do Museu Nacio- D Archaea Hübner. Taf. XLIX nal do Rio de Janciro 1878 III

95 A prega costal das Hesperideas. Taf. Ebenda L-LI

96. Macrosilia cluentius

Nature Vol. XVIJ I 878

97. Uebcr die Naupliusbrut der Garneelen Zeitschr. f. wissenschaftl.

Zoologie 1878 Bd. 30
O

98 Die Stinkkölbchen der weiblichen Ma- Ebenda racujáfalter. Taf. LII

99 Ueber Numenia Acontius

Zool. Anz. I878 I. Jahrg.

I oo Ueber Gcrüche von Schmctterlingen Ebenda

IOI Ueber die Vortheile der Mimicry bei Ebenda Schmetterlingen

I02 Wo hat der Moschusduft der Schwărmer Kosmos 1878 III seinen Sitz?

103 In Blumen gefangene Schwärmer Ebenda

104 Blumen der Luft

Ebenda

I05 Die Königinnen der Meliponen

I 06 Hesperiden-Blumen Brasiliens

Ebenda

Ebenda I 878/79 IV

I 7 On a remarkable case of mimicry of Trans. Entom. Soc. LonEueides pavana with Acraea Thalia don 1879 Proc. II 108 Epicalia Acontius. Ein ungleiches Ehc- Kosmos I878/79 IV paar. 6 Textfigg.

I09 Kritik über: Dr. Paul Kramer, Theorie Ebenda und Erfahrung, Beiträge zur Beurtheilung des Darwinismus, Halle, L. Nebert I 877

1 Io Phryganiden-Studien. 3 Textfigg.

Ebenda

Zool. Anz. I 879 2. Jahrg.

I 2 Sobre as casas construidas pelas larvas Archivos do Museu Nade Insectos trichopteros da Provincia cion. do Rio de Janeiro de Santa Catharina. Supplemento. Taf. LIII, LIV, LV, LVI

I 878 III

113 Ueber die von den Trichopterenlarven Zeitschr. f. wissenschaftl. s. Nature XXIII I88o p. I92 der Provinz Santa Catharina verfertigten Gehäuse. Nachtrag. Uebersetzung des vorigen von Dr. Hermann Müller, Lippstadt

114 Extracts from letters regarding Brazilian Proc. Entomol. Soc. Loncaddis-flies

Zoologie 1880 Bd. 35

utsche Uebersetzung auf S. 1448625

dieses Werkes; englische Uebersetzung bei Longstaff, ButterflyHunting in many lands, London I 9 I 2

Deutsche Uebersetzung auf S. I454 631 dieses Werkes; englische wie vor.

Ann. and Mag of Nat. Hist. I $878 \quad 639$

Vol. I p. $48 \mathrm{I}-485$, Vol. 2 p. 426 $-427$

Englische Uebersetzung bei Long- 643 staff, Butterfly-Hunting, London I9I 2

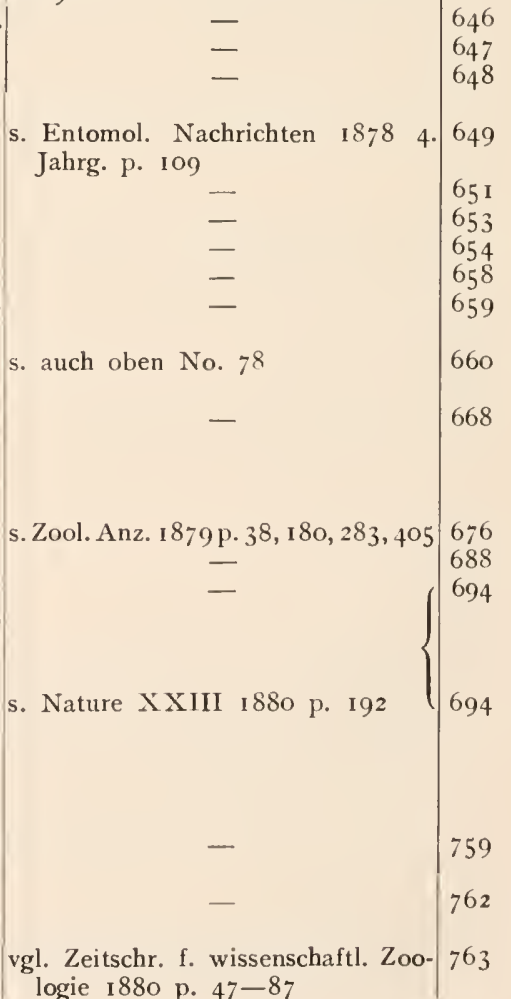

I 5 On a trichopterous insect belonging to Ebenda the family Leptoceridae with branchiae.

I 6 Notes on the Cases of some South Ebenda Brazilian Trichoptera

logie 1880 p. $47-87$ 
117 On a frog having eggs on its back. On Nature 1879 the abortion of the hairs on the legs of certain caddis-flies (Phryganiden). 3 Textfigg.

I 8 Bud-Variation in Bananas

I 9 Schützende Färbung und die Farben-Kosmos 1879 V empfindung der Tiere

I 20 Ituna und Thyridia, ein merkwïrdiges Ebenda Beispiel von Mimicry bei Schnetterlingen. 4 Textfigg.

121 Ein Käfer mit Schmetterlingsrüssel. Kosmos 1879/80 VI I Textfig.

122 Wasserthiere in Baumwipfeln. 1 Textfig. Ebenda Taf. LVII

Violo do Rio de Janeiro 1879 Vol. 4

124 On a curious insect from Brazil (Pal-Trans. Entom. Soc, of tostoma torrentium) London 1879 Proc.

I 25 A metamorphose de un insecto diptero Archiv. do Museu Nac. do (Paltostoma torrentium)

Primeira parte: Descripcão do exterior da larva. Taf. LVIII

Secunda parte: Anatomia da larva. Taf. LIX

Terceira parte: Anatomia da larva. Taf. LX

Quarta parte: Chrysalida e insecto perfeito. Taf. LXI

I 26 Erklärung Rio de Janeiro 1879 IV

eutsche Uebersetzung

dieses Werkes: siche a a Erklïrung auf $\$$. 831

Trans. Entom. Soc. of London 7 \% I 879 Proc.

- $\sin$

cutsche Uebersetzung auf $\$ .14 \% 0$ So 1 dieses Werkes; vgl. auch No. 131

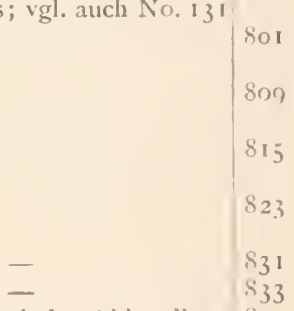

1 28 Palaemon Potiuna. Ein Beispiel ab- Zoolog. Anz. 1880 3.vgl. die portugiesische Abhandlung 837 gekürzter Verwandlung. Berichtigung Jahrg.

I 29 A ehnlichkeit von Blumen und Früchten. Kosmos 1880 VII I Textfig.

130 Branch-cutting Beetles Nature 1880 Vol. 22

131 Paltostoma torrentium. Eine Mücke Kosmos 1880/8 I VIII mit zweigestaltigen Weibchen. II Textfigg.

132 Die Imbauba und ihre Beschützer (Az-Ebenda teca instabilis). 8 Textfigg.

133 Zur Kritik der Absonderungstheorie Kosmos I880/8I VIII

134 Haeckels biogenetisches Grundgesetz bei Ebenda der Neubildung verlorener Glieder

135 Farbenwechsel bei Krabben und Gar-Ebenda neelen

136 Movements of Plants

Nature 1880/8 I Vol. 23

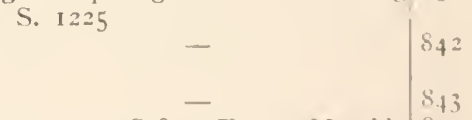

vgl. No. 125 S. 801 ; Entom. Monthly: $8_{4+1}$

Mag. Vol. 17 p. 225-22f;

Naturhıstoriker (Knauer) 3 lid. 1880 No. + p. 30

Ebenda

I37 The movements of Leaves

138 Atyoida Potimirim, eine schlamm-Kosmos I88 I IX fressende Süsswassergarncele. 20 Textfigg.

139 Verirrte Blätter. I Textfig.

Ebenda

140 Two Kinds of Stamens with different Nature i 88 I Vol. 24 Funct. in the same Flower. I Textfig.

I 4 I Leaves injured at Night by free Ra-Ebenda diation

142 Verwandlung und Verwandtschaft der Zoolog. Anz, 188I IV Blepharoceriden

143 Eine Beobachtung an Trigona mirim Kosmos 1881/82 X

144 Eine Pflanze, welche bei Nacht die Ebenda

Himmelsgegenden anzeigt 
ํ.

Titel

Aus

Bemerkungen

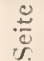

145 Bcmerkcnswertc Fällc erworbener Aehn- Kosmos $1881 / 82 \mathrm{X}$ lichkeit bei Schmetterlngen (Taf.

I.XII) nebst einem Nachtrag: Ange- Ebenda $188_{3}$ XIII bissene Flügcl von Acraea Thalia. I Textfig.

I $t^{6}$ Bemcrkungen zu: Hildebrand, Die Englers Botan. Jahrbuch Lebensdaucr und Vegetationsweise 1882 II der Pflanzen, ihre Ursachen und ihrc Entwicklung

147 Crotalaria cajanaefolia

I t8 Einc Bcobachtung an Bauhinia brasi-Ebenda liensis. 2 Textfigg.

I 49 Bericht über: Graf zu Solms-Laubach, Ebcnda

Dic Herkunft, Domestication und

Verbrcitung des gewölnlichen Feigenbaumes (Ficus Carica L.)

150 Caprificus und Feigenbaum

Ebenda

I5I Die gefügelose organische SubstanzEbenda $18_{2} / 8_{3}$ XII der Termiten-Nester

I 52 Corbula intermedia

Ebenda

153 Ein Schmetterling, der einen Kolibri Ebcnda nachahmt. I Textfig.

154 Bericht und Bemerkungen ïber: Dr. Ebenda Paul Mayer, Zur Naturgcschichte der Feigeninsekten

155 Zweigklimmer. Taf. LXIII

Ebenda

156 Die Farben der Puppen von Papilio Ebenda Polydamas

157 Wie die Raupe von Eunomia Eagrus Ebenda ihre Haare verwendct. I Textfig.

I58 Animal Intelligence

Naturc I 882/83 XXVII Ucbersctzung in Kosmos $1882 / 83$

(1882 P. $912-914$; Bot. Centrbl. XI I 882 p. $3^{8}+-386$

Trans. Entom. Soc. Proc. $1888 \$ 99$ p. XXIII

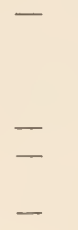

904

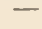

s. Botan. Centralbl. $188_{\mathbf{j}}$ XIV p. 934 $13-14$

s. Botan. Centralbl. I 883 XIV 939 p. 72-73; forner No. 43 und 44 dieses Verzeichnisses

Trans. Entom. Soc. Proc. 1883 p. 948 XXIII, XXIV

Trans. Entom. Soc. Proc. 1883 p. 949 XXIV, XXV

159 Two Kinds of Stamens with Different Ebenda Functions in the same Flower. 2 Textfigg.

I60 Bcricht über: The colour and patterns Kosmos I882 $/ \$_{3}$ XII of insects by Dr. H. А. Hagen

I6I Die Blumen des Melonenbaumes. I Kosmos 1883 XIII Textfig.

162 Arbeitstheilung bei Staubgefässen von Ebenda Pollenblumen. 10 Textfigg.

I $6_{3}$ Einige Nachträge zu Hildebrands Buch: Kosmos $188_{4}$ XIV Die Verbreitungsmittel der Pflanzen nebst Berichtigung. Taf. IXXIV

164 Einige Eigenthümlichkeiten der Eich-Kosmos $188_{3}$ XIII hornia crassipes

I65 Biologische Beobachtungen an Blumen Ber. d. Deutsch. Bot Ges. Südbrasiliens. I Textfig. I 883 I

166 Eine Aufgabe für Lepidopterologen Berl. Entomol. Zeitschr. I 883 XXVII

167 Drymonema an der Küste Brasiliens Zool. Anz. 1883 VI 168 Der $\Lambda$ nhang am Hinterleibe der Acraea- Ebenda Weibchen

I69 Christian Conrad Sprengel

Nature $188_{3} / 8_{4} \quad$ XXIX und 1884 XXX

170 Anfrage Chr. K. Surengel bctreffend Kosmos 1884 XIV

171 Butterflies as Botanists

Nature I 884 XXX

172 On the larvae and pupac of some Proc. Entom. Soc. LonNymphalinae und Hcliconinac , don 1884

XII p. $460-462$
vo. 140 und 162 dieses Verzeichnisses

\section{$-$}

s. Bot. Centralbl. XV p. IO2-IO3

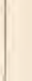

s. Bot. Centralbl. $188+\mathrm{XX}$ p. 234 $-237$

s. Bot. Centralbl. 1883 X VI p. 299988 - joo; Biolog. Centralbl. 1 886,87 VI p. 299; Trans. Linn. Soc. I 882 I6 III

Botan. Centralbl. 1883 XV p. $164-166$ 
173 Die Verzweigung von Stromanthe Ber. d. Deutsch. Bot. Ges. Tonckat. I Textfig. I884

I 74 Jugendgeschichte der Wurzelkrebse. Kosmos I 884 XIV (Eine Besprechung.)

I75 Die Zwiegestalt der Männchen der Ebenda nordamerikanischen Flußkrebse. (Bericht.)

I 76 Wird Philodendron durch Schnecken Kosmos 1884 XV bestäubt?

I 77 Fühler mit Beisswerkzeugen bei Mücken- Ebenda puppen. 4 Textfigg.

I78 Die Blütenjaare der Marantaceen. Ber. d. Deutsch. Bot. Ges. 5 Textfigg. 1885 III

I 9 Eine zweizählige Blume von $\mathrm{He}$-Ebenda dychium. I Textfig.

I 80 Endständige Zingiberaceenblüten. I Ebenda Textfig.

I 8 I Das Ende des Blütenstandes und die Kosmos I885 XVI Endblume von Hedychium. Taf. LXV u. l.XVI

182 Wie entsteht die Gliederung der In-Kosmos I 885 XVII sektenfühler?

183 Die Zwitterbildung im Tierreiche Ebenda

184 Einige Nachträge zu Hildebrands Buch : Ebenda Die Verbreitungsmittel der Pflanzen. 4 Textfigg.

I 85 Wurzeln als Stellvertreter der Blätter. Ebenda I Textfig.

186 Biologische Beobachtungen an brasi-Verhandl. d. Bot. Ver. lianischen Orchideen

187 Notes on Fig-Insects

. Prov. Brandenburg 1886 XXVIII

Trans. Entom. Soc. Lon-Die Seite 1067 ist irrtümlich als 1066 don 1886

ı 88 Neue Beobachtungen über Feigen-Biol. Centralbl. I886 VI wespen

189 Feigenwespen. Bericht über: Gustav Kosmos I886 XVIII Mayr, Feigeninsekten

190 Critogaster und Trichaulus

Kosmos 1886 XIX

191 Bericht über: Die Geschlechterdifferen- Kosmos I 886 X VIII zierung bei den Feigenbäumen von Graf zu Solms-Laubach

192 Zur Kenntnis der Feigenwespen

193 Zur Kenntnis der Feigenwespen

Entom. Naclir. 1886 X II

Ebenda I 887 XIII

194 Besprechung von „Brooks, The law of Kosmos 1886 XVIII Heredity

195 Knospenlage der Blumen von Feijoa. Ber. d. Deutsch. bot. Ges.s I Textfig. I 886 IV

196 Feijoa, ein Baum, der Vögeln seine Kosmos I 886 X VIII Blumenblätter als Lockspeise bietet. I Textfig.

197 Ein Züchtungsversuch an Mais Kosmos I886 XIX

198 Einige neue Beispiele langer Lebens- Biol. Centralbl. 1886/8; fähigkeit von Samen und Rhizomen VI

199 Die Nymphen der Termiten

200 Ueber dic Gattung Chimarrha

Entom. Nachr. I887 XIII

202 Eine deutsche Lagenopsyche. I Textfig. Ebenda

203 Nebenspreiten an Blättern einer Be-Ber, d. Deutsch. bot. Ges. s. \begin{tabular}{l|l} 
gonia. I Textfig. & $1887 \mathrm{~V}$
\end{tabular}

204 Schiefe Symmetrie bei Zingiberaceen-Ebenda blumen. 3 Textfigg.

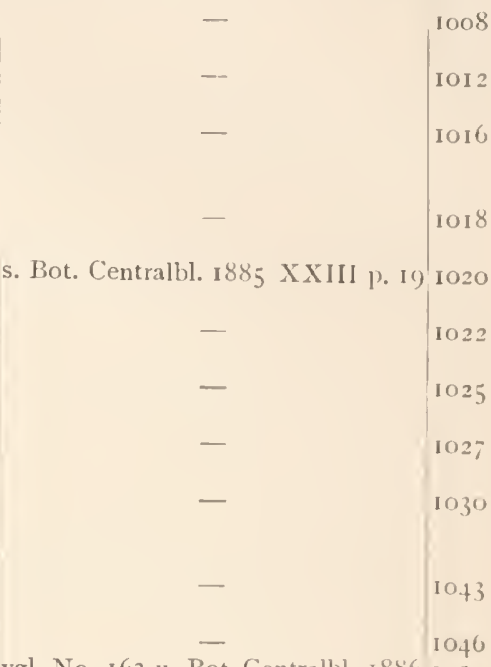

vgl. No. 163 u. Bot. Centralbl. 1886 1059 $\mathrm{XXV}$ p. $202-203$

s. Bot. Centralbl. I $886 \times \mathrm{XXV}^{\mathrm{N}}$ p. 202 ; Biol. Centralhl. V i 88586 p. $; 65$
Ber. d. Deutsch. Bot. Ges. 1886,1068 Heft II

s. Bot. Centralbl. 1886 XXVII Io-0 p. 189-192; Biolog. Centralbl. I $885 / 86 \mathrm{~V}$ ). $745-74^{6}$

s. Bot. Centralbl. I886 XXVIII I0 87 p. 228; Biolog. Centrallhl. VI I 886 p. 483

Bot. Centralls. 188; Ххх 1045 p. $43-44$

. Bot. Centralbl. IS80 XXVI Iow p. 2I8-219; Biolog. Centralbl. I 886 VI p. I9I-I92

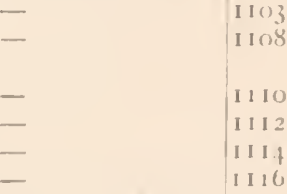

Bot. Centrall, 188- XXXIIIII p. $364-305$ 


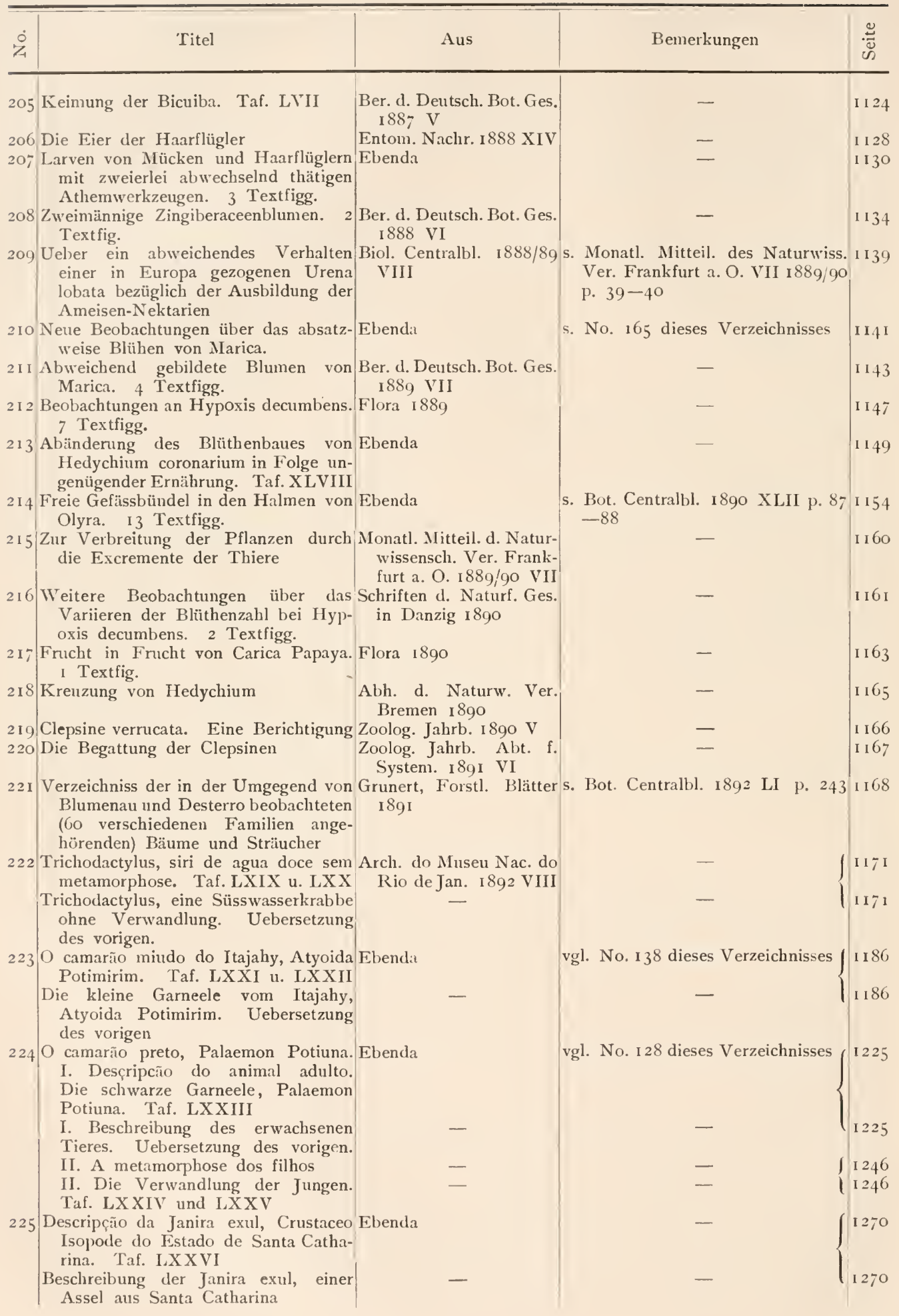




\begin{tabular}{|c|c|c|c|c|}
\hline$\dot{0}$ & Titel & Aus & Bemerkungen & 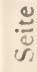 \\
\hline
\end{tabular}

226 Die Bambusratte, Dactylomys am-Der Zuol, Garten 1892 blyonyx

227 Bemerkungen über brasilianische Bro-Englers Jalırb. f. system. s. auch No. 231 meliaceen. 2 Textfigg.

Pflanzengeschichte und Pflanzengeograph. 1892 $\mathrm{XV}$

228 Die Tillandsia augusta der Flora flu-Ber. d. Deutsch. bot. Ges. minensis. I Textfig. $1892 \mathrm{X}$

229 Geradläufige Samenanlagen bei Holıen-Ebenda I893 XI bergia. Taf. LXXVII

230 Aechmea Heningsiana und Billbergia Ebenda Schimperiana Wittm.

23 I Die Bromeliaceen von Blumenau Gartenflora 1893

232 Mischlinge von Ruellia formosa und Abhandl. d. Naturw. Ver. silvaccola

Bremen 1893

233 Ueber Unfruchtbarkeit bei Bestäubung Ebenda mit eigenem Pollen

234 Ueber epiphytische Gewächse

Ebenda

$235 \mathrm{Zum}$ Diagramm der Zingiberaceen-Flora I 895 Blüte. 5 Textfigg.

236 Contribution towards the history of a Trans. Entom. Soc. Lon-vol. new form of larvae of Psychodidae don 1895 (Diptera), from Brazil. Taf. LXXVIII
u. LXXIX

237 Die Untergattnng Nidulariopsis Mez. Ber. d. Deutsch. Bot. Ges. Taf. LXXX

238 Die Keimung

239 Orchideen von unsicherer Stellung. Ebenda Taf. LXXXII

240 Billbergia distacaia Mez. I Textfig. Ebenda

24 I Das Ende der Blütenstandsachsen von Ebenda Eunidularium

242 Blumenblätter und Staubfäden von Ebenda Canistrum superbum. I Textfig.

243 Die Bromelia silvestris der Flora flu-Ebenda 1896 XIV minensis. Taf. LXXXIII

244 Einige Bemerkungen über Bromeliaceen Flora 1896 u. I89j I-XIII. Taf. LXXXIV u. LXXXV und 3 Textfigg.

245 Ein Fall von Naturauslese bei unge-Flora 1897 Bd 84. Erschlechtlicher Fortpflanzung

gänzungsband

246 Ein Versuch mit Doppelbestäubung Flora I897 Bd 83

247 Mischlinge von Ruellia formosa und Jenaische Zeitschr. 1898 s. auch No. 232 silvaccola XXXI

$24^{8}$ Observaçũes sobre a fauna marinha da Revista Museu Paulista costa de Santa Catharina mit Ueber- 1899 III setzung:

Beobachtungen über die Meeresfauna der Küste von Santa Catharina s. Bot. Centralbl. 1893 LV p. 1601301

gl. No. 142 und $20^{-}$dieses Ver-132; zeichnisses 
$\mathrm{N}$ achtrag.

Uebersetzung portugiesischer Arbeiten Fritz Müllers.

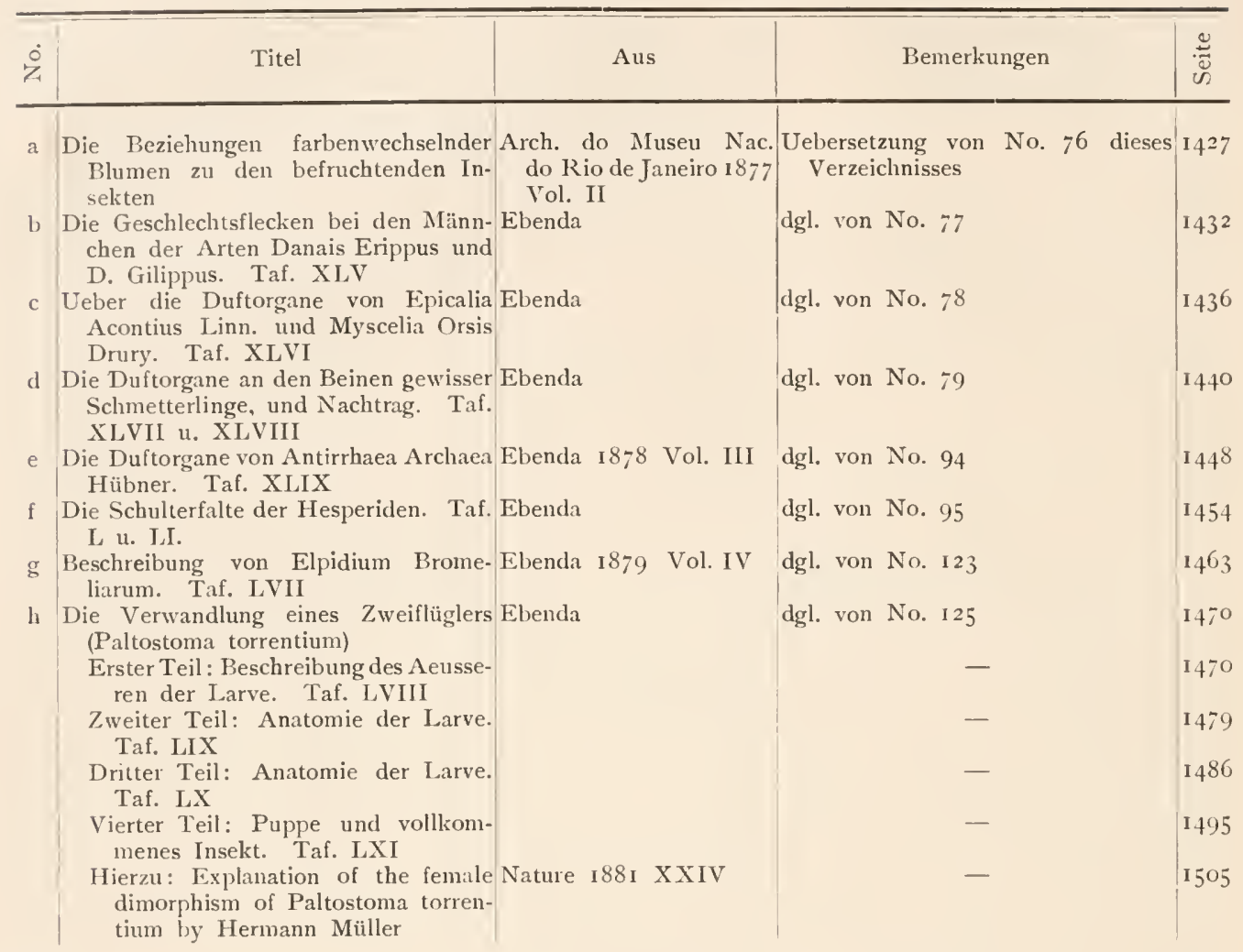




\section{Ueber Hirudo tessulata und marginata O. F. Müll. $\left.{ }^{1}\right)$.}

Mit I Textfigur.

Seit man Linné's Genus Hirudo in kleinere Gattungen geteilt hat, finden sich O. F. Müller's Hirudo tessulata und marginata ${ }^{2}$ ) von den verschiedenen Schriftstellern den verschiedensten dieser neugebildeten Gattungen zugerechnet.

Hirudo tessulata wurde von Blainville ${ }^{3}$ ) zu Erpobdella (Nephelis Sav.), von Auduin ${ }^{4}$ ) zu Clepsine gezählt, und von Moquin-Tandon ${ }^{5}$ ) als Synonym zu sciner Piscicola tessellata gezogen. Ja Blainville ${ }^{6}$ ) führte sie später gleichzeitig unter Ichthyobdella (Piscicola Lam.) und als Varietät von Erpobdella (Nephelis) vulgaris auf.

Hirudo marginata stellten Blainville und Audouin früher zu Clepsine ${ }^{7}$, nach dem aber Carena sie als Hir. cephalota beschrieben ${ }^{8}$ ) und als wahrscheinlich zu zu Haemocharis Sav. (Piscicola Lam.) gehörig bezeichnet, und nachdem MoquinTandon ${ }^{9}$ ) die Benennung in Piscicola marginata geändert, traten auch sie dieser letzteren Ansicht bei ${ }^{10}$ ).

Schon eine genauere Vergleichung der von O. F. Müller und Braun ${ }^{11}$ ) gegebenen Beschreibungen beweist, dass beide Arten nur zu der Gattung Clepsine gehören können. Kein anderer der bekannten Blutegel trägt seine Jungen unterm Bauche mit sich, wie es Müller von H. tessulata, Braun von H. marginata (varicgata Braun) beobachtet hat; bei keinem andern Blutegel ist ein geficderter Darmkanal von aussen sichtbar.

Dass H. tessulata von Blainville zu Nephelis gestellt worden ist, beruht lediglich auf der Uebereinstimmung in der Zahl der Augen; allein die acht Augen von H. tessulata stehen in zwei Längsreihen, eine Stellung, die gerade der Gattung

I) Archiv für Naturgeschichte I844. I. pg. 370-376. Taf. X, Fig. I4.

2) Histor. vermium Tom. I, pars II. pg. 45 u. 46 .

3) Dictionn. des Sc. nat. Tom. 47 pg. $26 \mathrm{r}$.

4) Dict. classique d'hist. nat Tom. 4. pg. 208, Tom. I5. pg. I09.

5) Monogr. de la Fam. des Hirud. pg. I33.

6) Dict. des Sc. nat. Tom. 57 pg. $55^{8}, 564$.

7) Blainville, 1. c. Tom. 47. pg. 266. Audouin, 1. c. Tom. 4. pg. 208.

8) Mem. dell. Accad. di Torino, Vol. XXV.pg. 298, 3 16; Vol. XXVIII. pg. 336.

9) Monogr. pg. I32.

Io) Blainville, l. c. Tom. 57. pg. 558. Audouin, l. c. Tom. I5 pg. I 10.

II) Braun, Systematische Beschreibung einiger Egelarten. Berlin, I805. pg. 56, 61.

Fritz Müllers gesammelte Schriften. 
Clepsine eigenthümlich ist; die Augen von Nephelis bilden dagegen, wie die von Sanguisuga, Haemopis, etc. einen Halbkreis. Zu Piscicola hat man beide Arten stellen zu müssen geglaubt wegen der deutlichen Sonderung des Kopfes; allein selbst der Kopf, der hier aus mehreren Ringen zusammengesetzt ist, hat keine Aehnlichkeit mit dem aus einem einzigen Stücke bestehenden Mundsaugnapf von Piscicola geometra.

Uebrigens ist Moquin-Tandon's Piscicola tessellata weder, wie er meint, die Hir. tessulata O. F. Müll., noch auch eine Piscicola, denn sie hat weder acht Augen, noch einen aus einem Stück bestehenden, sondern aus zahlreichen Ringen zusammengesetzten Kopf. Die Vergleichung der von Saint-Amans ${ }^{1}$ ) gegebenen Beschreibung und Abbildung, die Moquin-Tandon nur excerpirt und copirt hat, hat es mir sehr wahrscheinlich gemacht, dass es nichts anderes ist, als H. marginata.

Soviel ergiebt sich aus dem, was über beide Arten bei den verschiedenen Schriftstellern vorliegt; um jedoch ihre Stellung unter der Gattung Clepsine noch fester zu begründen, will ich noch einige ihrer für diese Gattung bezeichnendsten Eigenthümlichkeiten hervorheben. Beide Arten kommen nämlich um Berlin vor, und ich habe so Gelegenheit gehabt, sie sowohl lebend zu beobachten, als zu zergliedern. H. marginata findet sich gar nicht selten zwischen den Blättern der Wasserpflanzen (besonders Sparganium und Stratiotes) in allen Seen, wie auch in den Gräben des Thiergartens; H. tessulata, die seit O. F. Müller im erwachsenen Zustande nicht wieder beobachtet $\mathrm{zu}$ sein scheint (Braun sah nur ziemlich junge Individuen), fand ich nur selten in leeren Anodontenschaalen und an faulenden Aesten im Tegler See.

Der Körper beider Arten ist bei erwachsenen Individuen verhältnissmässig kurz, breit und nach vorn stark verschmälert; bei jüngeren Exemplaren von H. marginata, und nach O. F. Müller auch von $H$. tessulata ist er schmaler, vorn und hinten ziemlich gleich breit. Er ist ungemein flach, wodurch die den Clepsinen eigenthümliche Fähigkeit, sich in eine Kugel einzurollen, bedingt wird. Die Zahl der Ringe ist gegen 60 .

Die Nervenknoten des Bauchstrangs, die sich in gleicher Anzahl, wie bei Nephelis und Piscicola finden, schicken jederseits einen einzigen Nervenfaden aus, der sich dann ohne bemerkbare Anschwellung verästelt ${ }^{2}$ ). Die einzelnen Ganglien liegen um je drei Ringe voneinander entfernt, während bei Piscicola in jedem Ring, bei Nephelis, Sanguisuga, u. s. w. in jedem fünften Ring ein Ganglion liegt. Daher bei gleicher Anzahl von Ganglien bei Piscicola 20, bei Clepsine 6o, bei Nephelis roo Leibesringe gezählt werden. Ebenso wiederholen sich alle in der Mehrzahl vorhandenen Organe, wie Darmanhänge, Gefässklappen, Hodenbläschen, von drei zu drei Ringen, wie sich denn auch in der Zeichnung äusserlich dieses Zahlenverhältniss geltend macht (Segmens ternés, Savigny).

I) Hirudo oscillatoria Saint-Amans, Mém. de la Soc. Linnéenne de Paris. Tom. III, pg. I93, Vol. VIII. (besonders Fig. 5, wo auch die Augen, obgleich vom Verf. als solche nicht erkannt, deutlich gezeichnet sind).

2) Auf diesen Bau des Nervensystems hat zuerst Audouin bei Clepsine complanata aufmerksam gemacht; ich habe ihn bei allen von mir untersuchten Clepsinen gefunden. Bei Albione, wo auch jedes Ganglion nur ein Nervenpaar ausschickt, schwellen diese Nerven vor ihrer Teilung in ein sehr deutliches Ganglion an, nach Audouin (Dict. classique d'hist. nat. Tom. I5. pg. I1 5) und R. Wagner (Isis 1834, pg. 131.) 
Der Verdauungs-Apparat der Clepsinen ist theils durch einen in dem dünnhäutigen Oesophagus gelegenen vorstreckbaren fleischigen Rüssel, theils dadurch ausgezeichnet, dass nicht nur der Magen, sondern auch der Darm mit seitlichen Blindsäcken versehen ist, was sich meines Wissens bei keinem anderen Blutegel findet. Diese grosse Verästelung des Nahrungskanals erreicht nun gerade ihr Maximum in H. tessulata und marginata. Der Magen hat bei beiden Arten 7 Paar seitlicher Anhänge, von denen das letzte sich zu beiden Seiten des Darms bis in die Gegend des Saugnapfs erstreckt, und an der äussern Seite 5 secundäre Blindsäcke trägt. Bei $\mathrm{H}$. tessulata sind alle diese Anhänge ungetheilt, bei $H$. marginata hat jeder der zwölf vordern Anhänge drei, jeder der zehn Nebenanhänge des letzten Paares zwei, oft mannigfach ausgebuchtete Zweige. Der zwischen den beiden letzten Magenanhängen gelegene Darm hat jederseits vier Blindsäcke, die nach den Seiten über die Magenanhänge hinweggehen 1 ). Ausser diesen Anhängen, die sie mit den übrigen einheimischen Arten der Gattung Clepsine gemein haben, besitzen H. tessulata und marginata noch ein besonderes System von Blindsäcken, nämlich vier Paar vor dem Magen gelegener Anhänge, von denen das vordere nach vorn, die mittleren seitlich, das hintere nach hinten gerichtet ist. Diese Anhänge sind selten mit Nahrungsstoff gefüllt und deutlich von aussen wahrnehmbar; wenn sie es sind, so zeigen sie meist eine von der des Magens verschiedene Färbung. Dass sie ein besonderes, dem eigentlichen Magen nicht zuzuzählendes System bilden, scheint mir theils aus der oft verschiedenen Farbe ihres und des Mageninhalts, theils aus der von den Magenanhängen abweichenden Gestalt, theils aus der Richtung des vordersten und hintersten Paares wahrscheinlich; denn auch bei den Magen- und Darmanhängen der meisten Arten ist das vorderste Paar

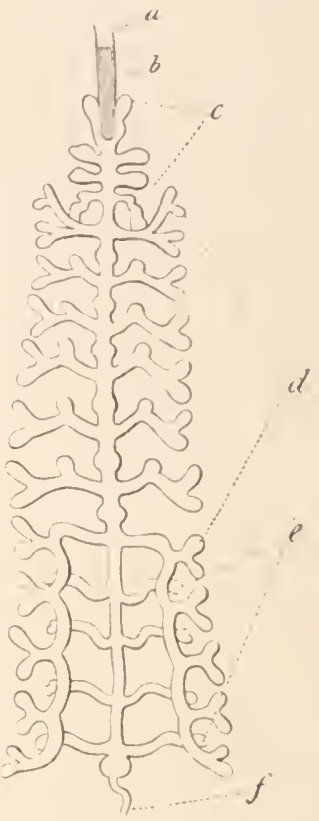

Nabrungskanal von Clepsine marginata.

$a$ Oesophagus; $b$ Rüssel; $c$ die 4 Paar vor dem Magen gelegener Anhänge; d die 7 Paar Magenanhänge; $e$ die 4 Paar Darmanhänge; $f$ Rectum. nach vorn, das hinterste nach hinten gerichtet. Vor diesen Anhängen beginnt der Rüssel, der bei den übrigen Arten sogleich vor dem Magen anfängt; da-

I) Filippi, der neuerdings die Clepsinen zum Gegenstand einer speciellen anatomischen Untersuchung gemacht hat, betrachtet die beiden letzten langen Magenanhänge als Coeca, den zwischen ihnen liegenden Theil des Darmkanals als Rectum. (Lettera del Dott. F. de Filippi al Sign. Dott. M. Rusconi sopra l'anatomia e lo sviluppo delle Clepsine. Pavia 1839. p. I2). Ich glaube nicht, dass man diesem letzten Paare eine andere Bedeutung beilegen kann, als den übrigen Magenanhängen; sein Inhalt ist stets dem der andern ganz gleich; selbst in der Form ist es bei einer der Clepsine complanata Sav. nahe stehenden, wahrscheinlich neuen Art kaum davon verschieden, indem es sehr kurz ist, und noch vor dem zweiten Paar der Darmanhänge endet. Der von Filippi als Rectum angesprochene Teil scheint mir gerade der Hauptsitz der Verdauung zu sein, während der Magen hauptsächlich als Reservoir des Nahrungsstoffs dienen mag. So sah ich den Mageninhalt bei einer H. marginata durch sechs Monate (Oktober bis $A$ pril) unverändert dieselbe Farbe behalten; sobald er dagegen in den Darm getreten ist, wird seine Farbe geändert. Auch sieht man ihn im Darme der fast farblosen Clepsine hyalina Moqu. Tand. durch eine deutliche peristaltische Bewegung umhergetrieben; ein sehr schönes Schauspiel, das mich oft Stunden lang gefesselt hat. 
durch wird er natürlich hier auf ein verhältnissmässig weit geringeres Volumen reducirt. Namentlich ist diess bei H. tessulata der Fall, wo er bei einem ${ }_{1} 1 / 2$ Zoll langen Exemplar kaum länger als bei einer 4 Linien langen Clepsine hyalina war.

Das Blut der $\mathrm{H}$. tessulata und marginata ist, wie bei allen Clepsinen, farblos ${ }^{1}$ ); das von Nephelis und Piscicola bekanntlich roth.

Die Geschlechtstheile, die ich bei der grossen H. tessulata genauer untersuchen konnte, bieten zwar im Einzelnen manche Abweichungen von denen der Clepsine complanata, sind aber nach ganz demselben Typus gebaut. Dass $\mathrm{H}$. tessulata und marginata, wie die übrigen Clepsinen, ihre Jungen unterm Bauche mit sich tragen, habe ich schon früher angeführt.

Nach allem diesem scheint mir kein Ziveifel über die systematische Stellung beider Arten zu bleiben, denn die einzigen bedeutenderen Unterschiede von den andern einheimischen Clepsinen bestehen in der deutlichen Sonderung des Kopfes, dem verhältnissmässig grossen Saugnapf und der Anwesenheit der vor dem Magen gelegenen Anhänge des Nahrungskanals.

Schliesslich mögen hier noch die Diagnosen beider Arten und ihre zahlreichen Synonyme Platz finden; eine ausführlichere Beschreibung scheint mir durch die von O. F. Müller gegebene, an der nichts wesentliches zu ändern wäre, unnöthig gemacht.

Clepsine tessulata.

Corpus gelatinosum, mollissimum, dilatatum, cinereo-viride, dorso macularum flavescentium seriebus $2-6$ notato, margine cinereo flavoque tessulato. Caput subdistinctum. Oculi 8 , in series duas longitudinales antice convergentes dispositi. Long $18-20^{\prime \prime \prime}$, Lat. $4-5^{\prime \prime \prime}$.

Hirudo tessulata. O. F. M üll., Hist. verm. Tom. I, pars II, pg. 45.

Hirudo tessulata, Der Spion. Braun, Syst. Beschreibung einiger Egelarten pg. 56. Tab. VI. Fig. 6-io.

Hirudo (Erpobdella) tessellata. Bla inville, Dict. des Sc. nat. Tom. 47. pg. 26 I.

Erpobdella vulgaris var. tessulata. Id. Ibid. Tom. 57. pg. 564.

Ichthyobdella tessellata. Id. Ibid. Tom. 57. pg. $55^{8}$.

Clepsine marginata.

Corpus subcartilaginosum, dilatatum, fusco-viride, dorso macularum flavescentium seriebus quatuor, linearum ejusdem coloris serie media notato, margine flavo-albofuscoque tessulato. Caput distinctissimum. Oculi 4 , postici majores, magis inter se distantes. Long. ${ }^{\prime \prime \prime}$, Lat. $2-2 \frac{1}{2}{ }^{\prime \prime}$.

1) Das Gefässsystem hat Filippi ganz übersehen; was er als Seitenstämme beschreibt, ist eine längs des Randes verlaufende Höhle ohne scharfe Conturen, welche sich, wenn das Thier stark zwischen zwei Glasplatten gedrückt wird, durch Zerreissung der Darmhaut mit dem Darminhalt füllt. Ich sah ein dünnhäutiges mit Klappen versehenes contractiles Rückengefäss, ein Bauchgefäss, und jederseits, doch bis jetzt noch nicht deutlich in ihrem ganzen Verlaufe, zwei Seitengefässe. Somit bedarf auch wohl Filippi's etwas abentheuerliche Ansicht (1. c. p. Io) von einem unmittelbaren Uebergang des Nahrungsstoffs aus dem Darmkanal in das Gefässsystem keiner besonderen Widerlegung. Die Contractionen des Rückengefässes lassen sich bei den kleinern durchsichtigen Arten und bei den Jungen der grössern unterm Mikroskop beobachten; die Klappen öffnen sich, wenn der hinter ihnen, und schliessen sich, wenn der vor ihnen gelegene Theil des Gefässes sich zusammenzieht. 
Hirudo marginata. O. F. M üll. Hist. vermium Tom. I, pars II, pg. 46.

Hirudo variegata. Der gesellige Egel. Braun, Syst. Beschreib. einiger Egelarten, pg. 6r. Tab. VII. Fig. I-6.

Hirudo cephalota. Carena, Mem. dell. Accad. di Torino. Vol. XXV. pg. 298, 316; Tab. XII, Fig. I9. Vol. XXVIII, pg. 336.

Hirudo oscillatoria. Saint-A mans, Mém. de la Soc. Linn. de Paris. Tom. III, pg. I93, pl. VIII.

Piscicola marginata. Moqu. Tand. Monogr. de la Fam. des Hirud. pg. I32. Tab. VII. Fig. 2.

Piscicola tessellata. Id. Ibid. pg. I33. Tab. VII. Fig. 3. (excl. Synon. Hir. tessulata O. F. Müll.)

Hirudo (Glossobdella) cephalota. Blainville, Dict. des Sc. nat. Tom. 47, pg. 266. Ichthyobdella marginata. Id. Ibid. Tom. 57 , pg. $55^{8}$. 


\section{De Hirudinibus circa Berolinum hucusque observatis ${ }^{1}$ ).}

„Caeterum, nullius in verba jurans, aliorum inventa consarcinare haud institui; quae ipse quaesivi, reperi, repetitis vicibus diversoque tempore observavi, ..... propono."

O. F. Mueller, Histor. vermium.

\section{Caput primum.}

\section{$\S 1$. Familiae diagnosis.}

Hirudinum ${ }^{2}$ ) nomine vermesannulati designantur, setis et branchiis carentes, ore et ano praediti, pede disciformi ${ }^{3}$ ) carnoso fulcris cartilagineis destituto postice terminati.

Quibus notis facile ab aliis omnibus vermibus distinguuntur. Discis enim suctoriis sic dictis praeter Hirudines nonnisi Entozoa Trematoda gaudent, generaque dua incertae sedis, novissimis temporibus detecta, Gyrodactylus Nordm., et Myzostoma Leuck. (Cyclocirra J. Muell.) E quibus Trematoda ano carent, Gyrodactylus discum radiis cartilagineis suffultum gerit, Myzostoma ${ }^{4}$ ) discis pluribus neque in extrema corporis parte positis, pedibusque praeterea parvis carnosis instructum est.

Quem locum in zoologiae systemate naturali Hirudinum familia obtineat, non satis inter auctores constat. Cuvier e. g. et Latreille cum Lumbricis, Naidibus, Gordiis in Abranchiorum Cuv. vel Enterobranchiorum Latr. ordine ponunt ${ }^{5}$ ); cum Sipunculis in Apodum ordine Wiegmann ${ }^{6}$ ). Optime fortasse naturae convenientem haberes Burmeisteri ${ }^{7}$ ) sententiam, qui Hirudines cum Entozois Trematodibus et

I) Dissertatio inauguralis zoologica quam consensu et auctoritate amplissimi philosophorum ordinis in alma literarum universitate Friderica Guilelma Berolinensi pro summis in philosophia honoribus rite capessendis die XIV. m. decembris A. MDCCCXLIV. h. l. q. s. publice defendet auctor Fridericus Mueller Thuringus. Berolini, typis fratrum Schlesinger.

2) Annélides Hirudinées Sav.; Entomozoaria Apoda Myzocephala Monocotylaria seu Bdellaria Blainv. (exclusis tamen generibus Epibdella Bl., Nitzschia Baer, Axine Ok., Capsala Bosc, inter Entozoa Trematoda potius referendis); Trematodes Ascocoeli Malacobdellei s. Hirudinei Burmeist. (hunc in familia circumscribenda secutus sum).

3) seu, ut plerisque audit, disco suctorio; at talem non esse, Brandtius jam demonstravit. (Mediz. Zool. Bd. II. pg. 230.)

4) Cf. Lovén, Wiegm. Archiv. I 842. Bd. I, pg. 306. Tab. VIII.

5) Cuvier, Règne animal, Tom. III; Latreille, familles nat. du règne animal. I 825.

6) Wiegmann, Handbuch der Zoologie.

7) Burmeister, Handbuch der Naturgesch. Bd. II. 
Planarieis (Turbellariis Dendrocoelis Ehrbg.) in eundem ordinem conjunxit, communi Trematodum nomine ab illo designatum.

Planariis saltem Clepsinarum genus corporis forma depressa, proboscide qua nutrimentnm hauritur, intestino ad arboris instar in ramos diviso, sanguine decolore, aliisque notis haud absimile ${ }^{1}$ ). Sed structura interna diversissima; sanguinis circuitus e. g. in Hirudinibus omnibus vasorum contractione, in Trematodibus et Planariis motu vibratorio valvularam filiformium quae intra vasa existunt, efficitur; nervorum systema in illis ad Articulatorum normam compositum, a qua et in Trematodibus, et, quantum innotuit ${ }^{2}$, in Planariis longe recedit, et quae alia.

Ipse Savignyo potissimum et Milne-Edwards ${ }^{3}$ ) adstipularer, qui ordinem vermium proprium hanc nostram familiam constituere arbitrantur.

\section{§2. Forma externa.}

Hirudinum corpus plus minus elongatum, in aliis exacte cylindricum, in aliis subcylindricum, ventre plano, in aliis valde depressum, dilatatum; versus extremitatem utramque plus minus attenuatum; plerumque molle lubricum, in quibusdam duriusculum, cartilaginosum, in una e nostris specie mollissimum gelatinosum.

Annulorum numerus secundum genera diversus, in codem vero animali constans, neque, ut in Lumbricis, aetate auctus. Caput et pedem versus annuli et angustiores et breviores fieri, ad latera corporis prominere solent, quo margo crenatus vel dentatus apparet.

Caput, i. e. maxime antica corporis pars oculos gerens, maxillas et annulum nerveum qui oesophagum cingit includens, modo distincte a corpore separatum, modo prorsus cum eo confusum est; modo annulis pluribus compositum, modo) exannulatum. Contractione peculiari in disci formam redactum affigendo inservit. Oculis plerumque binis usque denis instructum est, in figuras varias in superiore ejus facie dispositis; raro oculis caret. Oculi non e simplicibus pigmenti acervulis constant, sed sphaeras referunt, quarum altera dimidia pars pellucida, altera pigmento in pullis rubro, in adultis nigro vestita est. Quam oculorum structuram, a Brandtio jam in Sanguisuga observatam, ipse distinctissime in Aulastomate, Nephelide, Clepsinis omnibus, minus distincte in Piscicola vidi.

Os raro (in Branchiobdella) exacte terminale, plerumque subinferum, annulis primis incompletis ad labri instar prominentibus. In aliis inerme, in aliis maxillis tribus (superiore duabusque lateralibus) vel duabus (superiore et inferiore), in aliis denique proboscide exsertili tubulosa armatum.

Postice corpus ped $\mathrm{e}^{4}$ ) disciformi carnoso, ex annulis pluribus confusis, uti ganglia docent, exorto terminatur, modo exacte terminali, h. e. in axem corporis

I) Magis adhuc ad Planarias et Trematoda accedere videtur Malacobdella grossa Blainv. (Hirudo grossa O. F. Muell. Zool. D. Prodr.) in Molluscorum quorundam marinorum pallio parasitica, atque Hirudinula illa, quam in Caligo curto Kröyer observavit. (cf. Isis, I 841 pg. 195.)

2) F. F. Schulze, De Planariarum vivendi rat. etc. 1)g. 39.

3) Savigy, Système des $\Lambda$ nnélides. - Milne-Edwards, in Lamarck, An. sans vertèbres. Fd. II.

4) Pedis nomen servavi, quia usum organi optime exprimit; aptius fortasse cauda diceretur; sicuti enim in cauda Vertebratorum medulla dorsalis, ita hic medulla ventralis ultra anum prolongatur. Anum supra caudam situm esse, multis mirum visum est; quod ad me, si infra inveniretur, aeque mirum mihi videretur, ac si in Vertebrato quodam rcctum columnam vertebrarum perforans in dorso aperiretur. 
perpendiculari, modo oblique terminali, modo infero. Supra pedem in dorsi fine anus situs est. Capite et pede alternatim affixis, erucarum geometrarum more Hirudines progrediuntur. Quaedam corpore musculorum a dorso ad ventrem descendentium ope deplanato et ancipite reddito habilissime natare, aliae corpus in globum involvere valent.

\section{§ 3. Partes internae.}

Tractus intestinalis duae praesertim in Hirudinibus observantur formae diversae, vario nutrimenti genere definitae. Nam omnes quidem e regno animali victum petunt, sed aliae (Nephelis, Aulastoma) partes solidas devorant, aliae (Sanguisuga, Haemopis, Piscicola, Clepsine) succos tantum animalium exsugunt.

Illis oesophagus longus carnosus inermis aut maxillis minutis armatus, plicis fortibus longitudinalibus instructus; ventriculus amplus tubum simplicem vix in quinto quovis annulo parum angustatum referens, appendicibus lateralibus aut prorsus destitutus aut ad extremitatem posticam duabus gracillimis donatus; intestinum amplum, in parte anteriore plicis validis circularibus rugulosis munitum, in anum maximum abiens.

His tractus intestinalis minus simplex. Oesophagus in Sanguisuga et Haemopide brevis musculosus maxillis tribus validis armatus, in Clepsine membranaceus proboscidem musculosam cylindricam basi in bulbum incrassatam includens. Ventriculus appendicibus lateralibus coecis, quarum numerus in variis varius, instructus, atque in Sanguisuga et Haemopide sphincteribus in plures quasi divisus; appendicum par ultimum ceteris plerumque multo longius, juxta et sub intestino versus posteriora descendens. Intestinum angustum, in Sanguisuga, Haemopide, Piscicola exappendiculatum, in Clepsine appendicum lateralium paribus quatuor instructum. Rectum angustissimum in anum exiguum desinens.

Digestio in iis, qui partibus solidis vescuntur, celerrime, in iis qui sanguinem sugunt, lentius fit, et minus quidem lente in is qui Molluscorum, lentissime in iis qui Vertebratorum sanguinem. Aulastoma e. g. in una hebdomade Nephelides duodecim devorare vidi; Clepsinae hyalinae, quae Planorbium succis nutritur, diebus quatuor usque octo, Clepsinae marginatae, quae Pisces et Batrachia aggreditur, mensibus sex et ultra ad coenam unicam digerendam opus esse observavi; imo Sanguisugae annorum plurium spatio egere dicuntur.

Quod ad glandulas secernentes attinet cum canali alimentari conjunctas, h e par Hirudinibus omnibus esse videtur. In Sanguisuga, Aulastomate, Nephelide telam illam fuscam vel flavescentem spongiosam constituit, quae undique fere tractum intestinalem cingens totum paene inter illum et corporis parietes spatium occupat. In Branchiobdella coecula brevissima refert, globulos virescentes includentia quibus totus canalis alimentaris, oesophago et recto exceptis, circumdatur. In Clepsine tessulata supra ventriculi superficiem ductuli flavescentes observantur, quorum plures e centro communi radiorum instar progrediuntur; acidi nitrici pauxillo adjecto color eorum viridis evadit, quo ductulos hepaticos esse probatur. Glandulas salivales Brandt in Sanguisugis observavit.

Vasorum systema formas duas offert typice diversas; in aliis enim (Sanguisuga, Aulastomate, Nephelide) circulatio horizontalis, in aliis (Branchiobdella, Piscicola, Clepsine) verticalis. 
I11 is vasa dua lateralia, quae contrahendo sanguinem propellunt; vas ventrale gangliorum seriem cum medulla ventrali includens; vas dorsale in aliis satis magnum, in aliis (Nephelide) fortasse nullum. Sanguis, in omnibus hisce ruberrimus, in altero semper vase laterali prorsum, in altero retrorsum fluit. Directio vero fluendi pluries per horam mutatur, ita ut mox in vase dextro prorsum, in sinistro retrorsum, mox in dextro retrorsum, in sinistro prorsum fluat. Sinul fluctuatio existit, qua sanguis ab altero ad alterum latus per vascula transversa transit ${ }^{1}$ ).

$\mathrm{H}$ is vas dorsale contractile, cordis munere fungens, in Piscicola et Clepsine valvulis instructum. Vas ventrale medullam ventralem non includens; hoc quoque in Branchiobdella et Piscicola contrahitur; num in Clepsine, nescio; valvulis etiam in Piscicola munitum. Vasa lateralia in Branchiobdella non hucusque reperta; in Piscicola dua valvulis destituta, non contractilia; in Clepsine, uti videtur, plura exigua, rete singulare formantia, quorum tamen decursum completum plane perspicere nondum valui. Sanguinem pallidiorem, rubescentem, flavescentem, vel omni colore destitutum, in Branchiobdella et Clepsine vase dorsali prorsum semper propelli vidi, in Piscicala quoque valvulae directionis mutationem vetare vid('ntur ${ }^{2}$ ).

Respiratio, cujus organa peculiaria desiderantur ${ }^{3}$ ), in reti capillari cutaneo fieri videtur. Cui ut recens semper aqua advehatur, singulari modo, secundum genera vario, corpus moveri solet. In aliis enim corpus solo pede (in Sanguisuga et affinibus), vel pede simul et capite (in Clepsine) fixum motu undulatorio sursum et deorsum flectitur; in aliis (Piscicola, Branchiobdella) corpus pede fixum atque in lineam rectam extensum coni superficiem describit, cujus apex in pede positus est.

Ad utrumque corporis latus prope vas laterale in quinto quovis annulo in Sanguisuga et Aulastomate vesiculae parvae membranaceae sitae sunt, in facie ventrali apertac, quibuscum canales in ansam flexi (schleifenförmige Organe auctorum) cohaerent. Hae respirationis organa a pluribus habitae atque vesiculae respiratoriae nuncupatae. Nihil vero cum respiratione commune eas habere, eo jam patet, quod si Sanguisugam vivam aperire velis, eas prorsus albas neque vero reti respiratorio praeditas invenies. Id potius iis tribuendum videtur munus, ut mucum quo corpus lubricum reddatur, secernant.

Nervorum systema Articulatorum typum sequitur; habent enim ganglion oesophago superpositum (cerebrale); et gangliorum ventralium seriem, filis binis

I) In Nephelide vulgari facile hic circulationis modus observari potest, si modo individua pellucidiora eliguntur; expositionem ejus accuratissimam figuris illustratam dedit J. Mueller (Meckels Archiv, I828 19g. 22. Tab. I, fig. I et 2).

Cf. etiam Dugès, Ann. des Sc. nat. Tom. 15 pg. 308. R. Wagner, Isis 1832 pg. 635 sqq. In Sanguisuga quoque et Aulastomate, si viva aperiuntur, vasorum lateralium contractiones facile conspiciuntur.

2) Facillime in Clepsinis pullis sub microscopio vasis dorsalis contractiones et valvulae observantur. Vas dorsale amplum, valde flexuosum, in tertio quovis annulo valvula instructum, cujus forma similis, ac in Piscicola. In Clepsine tessulata caute a dorso aperta lentis jam ope valvulas conspicies. De Piscicola, quam ipse non dissecui, cf. Leo, Muellers Archiv 1835. pg. 4 r9 sqq. Tab. XI.

3) Branchiae Hirudinibus omnibus deesse videntur; nam in Branchcllio Sav. yuoque appendices illas laterales branchiiformes, quibus hoc genus excellit, nihil de branchiarum natura habere Blainville olsservavit. (Dict. des Sc. nat. Tom. 57 pg. 557.) Etiamsi vero branchiae hae esscnt, tamen cum Hirudinibus potius hunc vermem conjungerem, quam cum Arenicola, toto coelo diversa, uti Latreillium fecissc videmus. (Famill. natur. du règne anim. pg. 244.) 
valde sibi approximatis conjunctorum. Ganglion ventrale primum cum cerebrali filis binis oesophagum cingentibus cohaeret; ganglion ultimum, in pede positum, maximum, e pluribus coalitum. Numerus gangliorum ventralium viginti duo omnibus esse videtur, Branchiobdella excepta, cui decem tantum; singula aequali a se invicem distant annulorum numero, secundum genera diverso; annulis quinis nimirum in Sanguisuga et affinibus, (quaternis in Albione), ternis in Clepsine, binis in Branchiobdella Astaci, singulis in Piscicola. Quo fit, ut gangliorum numero haud mutato centum circa annuli in Sanguisuga, sexaginta ${ }^{1}$ ) in Clepsine, viginti in Piscicola numerentur. Eodem modo, ut ganglia, alia quoque organa pluries obvia in quinto quovis annulo in Sanguisuga, tertio in Clepsine repetuntur; quae ratio numerica jam etiam extrinsecus in colorum dispositione apparet. Quod ut brevi designetur, Sanguisugarum annuli quinati, Clepsinarum ternati (Segmens ternés Sav.) dici possent.

Nervus sympathicus in Sanguisuga a Brandtio observatus; gangliis tribus constat minutis pone maxillas positis, quae cum cerebro filis tenuissimis conjunguntur, et filo nerveo exiguo supra ventriculum decurrente.

Hirudines omnes hermaphroditae; aperturae genitales, anterior et posterior, in linea media ventris, capiti propiores, sitae. Partium genitalium internarum fabricam hic transeam, uberius hanc in capite tertio expositurus.

\section{$\S 4$. Generum diagnoses.}

Hirudines omnes uno eodemque genere Linnaeus amplectebatur; at, cum postea accuratiori examini subjectas tantopere inter se differre pateret, ut vix tam arcto generis vinculo conjungi posse viderentur, unicum illud Linnaeanum genus a Savignyo aliisque in plura minora dissolvebatur; jamque, quod genus antea fuerat, familiae dignitatem accepit.

$\mathrm{E}$ quibus generibus, quae intra Germaniae fines occurrunt, ita distinguuntur:

Sect. I. Corpus valde depressum, dilatatum, in globum se involvens. Caput a corpore discretum aut indiscretum, ex annulis pluribus compositum. Annuli ternati.

Genus i. C1epsine. Os edentatum, proboscide exsertili armatum. Oculi (2-8.)

Sectio II. Corpus elongatum, plus minus depressum, angustum. Caput a corpore haud discretum ex annulis pluribus compositum. Annuli quinati.

A. Oesophagus longus. Anus maximus.

Genus 2. Nephelis. Os inerme. Oesophagus plicis tribus longitudinalibus. Oculi 8.

Genus 3. Aulastoma. Os maxillis tribus minutis armatum. Oesophagus plicis longitudinalibus numerosis. Oculi го.

B. Oesophagus brevis. Anus exiguus.

Genus 4. Haemopis. Maxillae tres validae non compressae, obtuse parum dentatae. Oculi ı.

1) Neque vero 76, ut Moquin-Tandon dicit. 
Genus 5. Sanguisuga. Maxillae tres validae, compressae, argute multidentatae. Oculi Iо.

Sectio III. Corpus elongatum teres. Caput a corpore discretum, exannulatum.

Genus 6. Piscicola. Annuli vix distincti. Maxillae nullae. Oculi.

Genus 7. Branchiobdella. Annuli distinctissimi. Maxillae duae planae triangulares. Oculi nulli.

\section{§ 5. Generum in sectiones distributio.}

Plures jam auctores Hirudinum genera in sectiones distribuere conati sunt, alio aliam sibi notam externam pro dividendi norma assumente; appendices branchiiformes e. g., capitis et oris formam Savignyo ${ }^{1}$ ), oculorum praesentiam et defectum Latreillio ${ }^{2}$ ), maxillarum evolutionem Burmeistero ${ }^{3}$ ). At, cum ex totius organismi constructione vivendique ratione, neque vero e singulo quodam charactere, quem e reliquorum complexu pro libitu tibi elegeris, omnis classificatio naturalis derivanda sit, quid mirum, parum et inter se, et cum ipsa horum animalium natura has distributiones convenire; modo enim genera diversissima (Clepsine et Sanguisuga; Trochetia et Branchiobdella; Piscicola, Clepsine et Nephelis) in eandem sectionem conjuncta, modo similia (Aulastoma, Sanguisuga) in diversas divulsa videmus.

Mihi, quae apud nos obviam veniunt genera (exclusis igitur Branchellio Sav., Albione Sav., Trochetia Dutr., Bdella Sav., Malacobdella Blainv.) in tres quas supra proposui sectiones dividenda videntur, habitu externo, partium internarum fabrica, vivendi modo distinctissimas, quarum notas brevi sequentibus exponam.

Sectio prima Clepsinarum genus amplectitur. His corpus valde depressum, plus minus dilatatum, subtus planum vel concavum, facultate in globum sese involvendi donatum; qua facultate, si vivas observas, primo intuitu distinguuntur. Annuli ternati. Caput modo distinctum, modo indistinctum, annulatum. Pes inferus.

1) Sect. I. Sangsues Branchelliennes. Des branchies saillans. Ventouse orale d'une seule pièce séparée du corps par un fort étranglement. Ouverture circulaire. Branchellion.

Sect. 2. Sangsues Albioniennes. Point de branchies. Ventouse orale d'une seule pièce séparée du corps par un fort étranglement. Ouverture sensiblement longitudinale. Albione. Haemocharis (= Piscicola).

Sect. 3. Sangsues Bdelliennes. Point de branchies. Ventouse orale de plusieures pièces, peu ou point séparée du reste du corps; ouverture transverse comme à deux lèvres. Bdella. Sangui . suga. Haemopis. Nephelis. Clepsine. cf. Sav. Syst. des. Annél. pg. ro6.

2) I. Point d'yeux. Trochetia, Branchiobdella.

II. Des yeux. A. Albione Haemocharis.

B. Bdella. Sanguisuga. Nephelis. Haemopis. Clepsine.

Latr. Famill. nat. du règne anim. pg. 246.

3) A. Ohne oder mit unvollkommnen Kiefern. Branchiobdella. Piscicola. Clepsine. Nephelis.

Albione. Aulastoma.

B. Mit grösseren harten am Rande meist gezähnten Kiefern. Haemopis. Hirudo (= Sanguisuga) Bdella. Burmeister, Handb. der Naturgesch. Bd. II. 
Oculi 2, 4, 6, vel 8. in series duas longitudinales parallelas vel antice convergentes dispositi. Oesophagus plus minus longus, membranaceus, proboscide tubulosa exsertili armatus. Maxillae nullae. Ventriculus et intestinum appendicibus coecis lateralibus utrinque instructa. Circulatio verticalis, vase dorsali nimirum sanguinem colore destitutum propellente. Vas ventrale gangliorum seriem non includens. Ganglion quodvis nervorum par unicum emittens. Ova, in capsulam cartilagineam haud inclusa, aut sub ventre secum gerunt, aut ad corpora aliena deposita, quiete iis donec pulli excludantur supersedentes, quasi incubant. Pullos ventri affixos secum portant. Pede et capite fixis corpus motu undulatorio flectere amant. Natare nequeunt.

Sectione secunda genera Nephelis, Aulastoma, Haemopis, Sanguisuga comprehenduntur. His corpus elongatum angustum, plus minus depressum, capite indistincto annulato, pede oblique terminali, annulis quinatis, Oculi 8 vel $\mathrm{Io}$, in figuram semicircularem vel hippocrepidiformem dispositi. Oesophagus musculosus, proboscide carens. Maxillae tres, vel, si desunt, oesophagi plicae tres longitudinales. Ventriculus appendicibus lateralibus saepius instructus; intestinum semper iis caret. Circulatio horizontalis, vasis lateralibus nimirum pulsantibus. Sanguis ruberrimus. Vas ventrale gangliorum seriem includens. Ganglion quodvis nervorum paria dua emittens. Ova plura pariunt in capsulam cartilagineam communem inclusa ${ }^{1}$ ). Ovis depositis mater prolis non amplius curam habet. Pede fixo corpus antice liberum motu undulatorio flectere solent. Corpore deplanato habilissime natant.

Tertiam denique sectionem Piscicola et Branchiobdella constituunt. Horum corpus teres, elongatum, capite distincto, exannulato, pede exacte terminali. Proboscis nulla; maxillae nullae, aut duae planae triangulares. Intestinum exappendiculatum. Circulatio verticalis, vasibus dorsali et ventrali contractilibus. Sanguis pallide rubens vel flavescens. Vas ventrale gangliorum seriem haud includens. Ova capsulis cartilagineis tecta pariunt; num vero hae capsulae embryones singulos includant, an plures, nondum, quantum scio, constat. In Branchiobdellae capsulis omnibus, quas perscrutatus sum, pullos singulos vidi. Prolis cura nulla. Pede fixae corpore in lineam rectam extenso conum describere amant. Parasitice in Piscibus et Crustaceis vitam degunt ${ }^{2}$ ).

I) Hae ovorum capsulae, quales Hirudinum genera laudata, Lumbricini, Naides pariunt, nullo modo, ut saepius fit, cum Planariarum (lacteae, torvae etc.) ovis comparari possunt, omnino diversis. Illae enim (Nephelidis saltem et Lumbricinorum plurium, quas observavi) ova completa vitello, albumine, chorio composita, materia nutriente structuram nullam offerente circumdata includunt. In Planariarum contra ovis recenter partis ne ullum quidem germinis vestigium conspicuum; tota cellulis granula minutissima globulosque majores continentibus repleta, quae primo post partum tempore motu singulari quasi peristaltico, a celeberrimo v. Siebold detecto praeditae sunt. Sero demum prima embryonum vestigia apparent. Praeterea Planariaruın ova in ipso jam matris utero formantur; capsulae vero (in plerisque saltem, si non in omnibus) extra, muci superficie, quo involuta ova eduntur, in integumentum cartilagineum coagulante.

2) Quod ad locum attinet generibus extra patriae fines obviis assignandum, cum parum de eorum structura interna sciamus, incertas tantum de eo conjecturas proferre licet. Branchellion Sav. tribum proprium constituere videtur, Malacobdella Blv. in Clepsinarum fortasse vicinio collocanda, Albione cum Piscicola et Branchiobdella conjungenda erit. Bdella Sav. (Limnatis Moqu. Td.) et Trochetia Dutr. quin sectioni nostrae secundae adscribendae, vix dubito. Ejusdem sectionis Hirudinem lineatam O. F. Müll. esse suspicor, etiamsi oculorum (sex) numcro differat. Quae omnia accuratius horum animalium examen postea docebit. 


\section{§ 6. Mutuae generum relationes.}

Quod ad mutuas relationes attinet, quae inter singula genera existunt, Clepsinae notis plerisque ab aliis omnibus longe recedenti Nephelis quodammodo accedit genitalium femineorum structura (cf. Cap. III).

Nephelidi proximum Aulastoma nutrimenti genere ideoque canalis alimentaris fabrica. Haec enim sola e nostris genera partibus solidis (vermiculis, carne etc.) vescuntur. Utrique oesophagus longus carnosus, ventriculus amplus simpliciter tubulosus, intestinum aeque amplum, in anum, ut pro tali nutrimenti genere opus est, maximum abiens.

Jam vero Aulastoma maxillis exiguis et appendicum ventriculi pari unico gracili a Nephelide transitum struit ad Haemopidem et Sanguisugam, maxillis validis armatas, appendicibus ventriculi numerosis amplissimis instructas. Quibuscum etiam oculorum numero, genitalium structura, aliisque notis congruit.

Haemopis et Sanguisuga arctissimo affinitatis vinculo conjunctae et vix in duo genera sejungendae, oesophago brevi, maxillis validis armato; ventriculo appendicibus amplissimis instructo et sphincteribus in plures quasi diviso; intestino angusto in anum exiguum aperto a reliquis discrepantes, levioribus tantum inter se differunt notis; maxillis nimirum in Haemopide non compressis, dentes paucos obtusos, in Sanguisuga compressis, dentes plurimos acutos gerentibus, et genitalium masculorum structura.

Piscicola systemate vasorum, vase dorsali nimirum contractili valvulis instructo, et epididymide haud in glandulae formam contorta (cf. Cap. III.) cum Clepsine congruit, intestini forma ad Haemopidem et Sanguisugam accedere videtur.

Branchiobdella denique, Piscicolae quidem inter omnes simillima, multis tamen rationibus, pro parte, ut oculorum defectus, e vita parasitica explicandis, et ab hac, et aliis omnibus Hirudinibus longe recedit.

\section{Caput secundum.}

\section{Hirudinum Berolinensium expositio systematica.}

Sectio I. Hirudines corpore valde depresso dilatato in globum se involvente; capite distincto aut indistincto, annulis pluribus composito, annulis ternatis.

\section{Genus I. Clepsine.}

Os edentatum proboscide exsertili armatum.

$$
\text { Oculi }(2-8 .)
$$

Hirudines dilatatae subtus planae vel concavae, dorso elevatac; pullos secum ferentes. Braun.

Glossiphonia et Glossopora Rawl. Johns. Helluo spec. Oken. Clepsine Sav. Glossobdella Blainv.

Clepsinis omnibus corpus plus minus pellucidum, modo duriusculum cartilaginosum, modo mollissimum gelatinosum, coloribus minus obscuris utplurimum ornatum. 
Tractus intestinalis magis quam in alio ullo genere complicatus. Oesophagus plerisque longus membranaceus, proboscidem carnosam tubulosam cylindricam basi in bulbum incrassatam includens. Haec in aliis (ut $\mathrm{Cl}$. hyalina) maxima quartam fere corporis partem longitudine aequans, in aliis ( $\mathrm{Cl}$. tessulata) valde exigua facile praetervidenda; antice crenata apparet; protruditur musculis gracilibus ab oris regione ad bulbum proboscidis descendentibus; retrahitur fibris muscularibus a postica bulbi parte in ventriculi parietes dispersis. Oesophagum sequitur ventriculus longus angustus appendicum coecarum paribus 5 usque 7 (in nostris) instructus. Hae plus minus longae, modo simplices, modo in ramos plures divisae; par ultimum ceteris plerumque multo longius ad utrumque corporis latus versus posteriora descendens, appendicibus secundariis in latere exteriore interdum instructum; raro (in Cl. verrucata) anterioribus vix longius. Praeter haec $5-7$ appendicum paria omnibus communia in $\mathrm{Cl}$. marginata et tessulata ventriculus alio adhuc appendicum systemate gaudet, proventriculum quasi constituente. (cf.pg. I5.) Inter ultimum appendicum ventriculi par intestinum tenue descendit, appendicum lateralium paribus quatuor instructum. Hoc in pellucidioribus ( $\mathrm{Cl}$. hyalina, tessulata) motus peristaltici phaenomenon offert. Tum pars brevis in globulum dilatata sequitur, e qua rectum angustum spiraliter saepius tortum egreditur, in anum exiguum loco solito situm abiens.

Aliae, quibus hoc genus excellit, notae supra jam expositae (Cap. I. $\S 5$.); id tantum hic adjiciam, nervorum par illud unicum e quovis ganglio ventrali progrediens modo dimidiam corporis latitudinem indivisum percurrere (ut in Cl. verrucata, complanata), modo paulo postquam e ganglio egressum, in ramos plures solvi (ut in Cl. tessulata).

Clepsinae aquas puriores fossarum, lacuum, fluviorum habitant. Extra aquam mox pereunt. Nutriuntur aliae Molluscorum, aliae Vertebratorum sanguine. Pullos ventre affixos secum portant.

I. Clepsine marginata mihi $\left.{ }^{1}\right)$.

Corpus subcartilaginosum, dilatatum, fuscoviride, dorso macularum flavescentium seriebus 4 , linearum ejusdem coloris serie media notato; margine flavo, albo, fuscoque tessulato. Oculi 4 , postici majores magis inter se distantes.

Long. max. $10^{\prime \prime \prime}$.

Hirudo marginata O. F. Muell. Hist. verm. Tom. I. pars II. pg. 46.

Hir. variegata. Der gesellige Egel. Braun, Systemat. Beschreib. einiger Egelarten. pg. 6I. Tab. VII, fig. I-6.

Hir. cephalota Carena, Mem. dell. Accad. di Torino. Vol. XXV. pg. 298. Tab. XII, fig 19. Vol. XXVIII. pag. 336 .

Hir. oscillatoria Saint-Amans. Mém. de la Soc. Linnéenne de Paris. Tom. III. pg. I93. pl. VIII.

Piscicola marginata Moqu. Tand. Monograph. de la Fam. des Hirud. pg. I32. Tab. VII. fig. 2. Piscicola tessellata Id. Ibid. pg. I 33. Tab. VII, fig. 3. (exclus. synon. Hir. tessulata O. F. Muell.)

Hir. (Glossobdella) cephalota Bla inv. Dict. des Sc. nat. Tom. 47. pg. 266. Ichthyobdella marginata I d. Ibid. Tom. 57. pg. $5^{88 .}$

I) Hujus generis et hanc et sequentem speciem esse, alio jam loco (Wiegmann's Archiv I844. Bd. I. pg. 370) uberius demonstravi. 
Corporis color admodum variat, plerumque fusco viridis, interdum pulcherrime viridis, interdum viridi-flavus, ventre semper pallidiore. Dorsum punctorum flavescentium annulis ternis distantium seriebus + longitudinalibus; inter quas series alia linearum transversalium ejusdem coloris e punctis singulis interdum compositarum observatur. Margo subinteger. Caput distinctum, ovale, apice marginibusque hyalinum, striis fuscis transversis et maculis flavescentibus una media duabusque utrinque lateralibus ornatum. Oculi 4, quorum duo postici majores magis inter se distant. Pes magnus corporis fere latitudine, radiis fuscis punctisque flavescentibus radiis interpositis ornatus. Intestinum extrinsecus plerumque conspicuum, viride, flavum vel ruberrimum. Ventriculi proprii appendices utrinque septem, quarum sex priores transversae in ramos tres, saepe varie crenatos vel lobatos dividuntur, ultima vero juxta corporis latera ad pedem usque extensa latere externo appendicibus secundariis quinque bifurcis munita est. Ante ventriculum proprium aliud appendicum systema, proventriculus, paribus 4 constans, quorum primum prorsum, secundum et tertium lateraliter, quartum retrorsum spectat. Intestini tenuis, ut in omnibus, appendices utrinque 4. Proboscis parva.

Juniores angustae, Piscicolae habitu haud absimiles; adultae dilatatae. Amoris tempore testiculorum paria undecim et ovaria extrinsecus pellucent ${ }^{1}$ ).

Habitat aquas puriores rivorum et lacuum, ubi haud infrequens ad plantarum folia et ramos arborum dejectos offenditur. (Thiergarten, See bei Tegel, Grunewald.)

Per totam Europam occurrere videtur; in Dania ab O. F. Muellero, in Germania a Braunio et memet ipso, in Italia a Carena, in Gallia a Saint-Amans pulcherrima haecce omnium species observata est.

Batrachiorum gyrinis sanguinem eam exsugere vidi; Mollusca non aggreditur. Mensibus Majo et Junio ovorum $(60-80)$ flavo-viridium parit acervum, cui quiete supersedet, donec pulli post hebdomadem circa exclusi matris ventri sese affigant, et $a b$ illa secum ferantur.

2. Clepsine tessulat a mihi.

Corpus gelatinosum mollissimum dilatatum, cillereo-viride, dorsomacularum flavescentium seriebus 2 -6 notato. Caput subdistinctum. Oculi 8 , in series duas longitudinales antice convergentes dispositi.

Long. I $8^{\prime \prime \prime}$

Hirudo tessulata O. F. Mue ll. Hist. verm. Tom. I, p. II. pg. 45.

- , Der Spion, Braun, Systemat. Beschr. pg. 56. Tab. VI. fig. 6-io.

Erpobdella vulgaris var. tessellata. I d. Ibid. Tom. 57. pg. 584.

Ichthyobdella tessellata. I d. Ibid. Tom. 57 . pg. $55^{8}$.

Corpus mollissimum, quale in Medusis, in junioribus angustius, in adultis latissimum, cinereo-viride, rarius pallide violaceum, atomis fuscis adspersum. In dorso maculae flavescentes series duas v. plures longitudinales constituentes; in ventre aperturae genitales macularum albidarum instar conspicuae. Margo leviter crenatus.

I) Quas Saint-Amans (l. c.) describit ventris maculas sanguineas „en forme d'y grec," ventriculi appendices fuisse suspicor. 
Caput orbiculare, animali quiescente, ut iam O. F. Mueller notavit, a cauda vix distinguendum. Oculi 8, in series duas longitudinales dispositi, atri, areis albis cincti. - Intestini appendicum numero cum Clepsine marginata congruit, forma differt. Ventriculi enim appendicum paria sex priora itemque paris ultimi appendices secundariae simplices neque ramosae vel bifurcae. Proboscis tam exigua ut vix quartam tertiamve capitis partem longitudine aequet. - Testiculorum paria sex amoris tempore extrinsecus conspicua.

Elegantem hanc speciem in Dania O. F. Mueller detexit; juniora exempla Braun prope Neo-Ruppinum observavit. Alibi hucusque nondum reperta esse videtur. Ipse in lacu prope Tegel inveni, ubi rarissima ad arborum ramos dejectos et in Anodontum testis vacuis occurrit.

Vertebratorum, (piscium vel Batrachiorum) sanguine nutriri videtur, ut $\mathrm{Cl}$. marginata. Saepius enim contento sanguineo vel atropurpureo ventriculum scatentem reperi, Mollusca vero, quae ei obtuli, nunquam aggressa est. Mense Junio ova plurima (trecenta O. F. Mueller, CL et supra ego numeravimus) saturate vitellina deponit, iisque donec pulli excludantur, quasi incubat. Aspectum quo nil pulchrius mater offert pullis centum et quod excedit onusta; in quovis enim pullo ventriculus elegantissime pinnatus, vitello virescente farctus, oculique octo coccinei conspicui.

Mirum est, quanta de hac specie tam clare et distincte ab O. F. Muellero descripta apud Blainvilleum et Moquin-Tandonium confusio. Blainville enim oculorum numero ductus Nephelidi generi eam adnumeravit ipsique postea Nephelidi vulgari tanquam varietatem subjunxit. Moquin-Tandon, qua solet levitate, Hirudinem oscillatoriam Saint-Amans hanc Muelleri speciem esse arbitratus, Piscicolae generi eam adscripsit; imo vero tantum abest, ut vix a Clepsine tessulata Hir. oscillatoria differat (Moqu. Td. Monogr. pg. I8), ut vix ullan potius reperire possis notam, qua Saint-Amansii cum exactissima O. F. Muelleri descriptione congruat.

\section{Clepsine verrucata mihi.}

Corpus subcartilaginosum dilatatum antice vix angustatum, dorso viridi-fuscescenteverrucarumvaldeprominentium seriebus sex notatum. Caput subdistinctum. Oculi 6 (rarissime 4) seriebus duabus longitudinalibus subparallelis dispositi. Appendicum ventriculi paria 7 , par ultimum inter appendicum intestini par primum et secundum terminatum ${ }^{1}$ ).

I) Non potui quin hunc characterem magis anatomicum quam zoologicum in diagnosin reciperem; quamvis enim toto jam habitu satis a sequente differat, nullas tamen reperire valui notas externas quibus satis distincte $a b$ ea discernatur. Ceterum haec quoque nota quodammodo externa, intestino nimirum saepissime, quoties cibo repletum, extrinsecus conspicuo. Alias quoque quae apud nos occurrunt species, si cibo repletas invenias, facillime paris ultimi appendicum ventriculi longitudine et forma distinguere poteris.

Terminatur enim ultimum ventriculi appendicum par inter intestini appendicum

A. par primum et secundum in Cl. verrucata,

B. secundum et tertium in Cl. complanata,

C. - tertium et quartum in Cl. bioculata, 
Long. $14^{\prime \prime \prime}$.

Corpus dilatatum aequali fere, in animali quiescente, antice et postice latitudine. Dorsi color primarius virescens, lineolis vero fuscis creberrimis fuscescit. Verrucae conicae albidae, valde prominentes seriebus sex longitudinalibus supra dorsum dispositae; aliae minores irregulariter sparsae. Verrucarum series duae intermediae lineis fuscis longitudinalibus conjunctae. Margo crenatus pallidior. Venter albovirescens, atomis fuscis minutis adspersus; in anteriore ventris parte pori genitales conspicui, annulis fuscis utplurimum cincti.

Caput subdistinctum, quando protenditur semiellipticum, affixum orbiculare, pedi tunc, si a ventre adspicias, simillimum; apice album, postice fasciis pallide fuscis transversis notatum. Annuli corporis duo v. tres capiti proximi reliquis multo obscuriores, nigricantes, collare quasi formantes. Oculi sex, vix unquam quatuor, in lineas duas longitudinales subparallelas dispositi.

Proboscis ut in sequentibus omnibus magna. Ventriculi appendicum paria 7 . gracilia, leviter retrorsum arcuata; par ultimum jam ante secundum intestini appendicum par terminatum. Intestini appendicum par primum breve, paria tria ultima sat longa gracilia retrorsum arcuata.

A Clepsine complanata, cui simillima, differt magnitudine, corpore minus cartilaginoso molliore, crassiore, antice minus angustato; colore; poris genitalibus annulo obscuro cinctis; capite subdistincto; verrucarum dorsi numero, forma, colore; intestini denique appendicum numero et forma. Haec sola nota per omnem actatem constans; jam enim pullos vix exclusos matris ventri adhuc adhaerentes facile ea distingues.

Moribus quoque differt; complanata omnium segnissima, haec multo vividior.

Reperi hanc speciem, nondum quantum scio observatam, vel cum complanata confusam, in lacu prope Tegel, ubi rara ad ramos arborum dejectos occurrit.

Mollusca Gasteropoda exsugit. Ova non observavi; at pullis plurimis (centum et ultra) onustas plures mensibus Majo et Junio offendi.

\section{Clepsine complanata Sav.}

Corpus subcartilaginosum duriusculum dilatatum anticeacuminatum, cinereo vel fuscoviride, dorso fusco-maculato, verrucarum vix prominentium seriebus duabus longitudinalibus notatum. Caput indistinctum. Oculi sex in series duas longitudinales subparallelas dispositi. A ppendicum rentriculi paria sex, par ultimum inter appendicum intestini parsecundum et tertim terminatum.

D. pone par quartum in reliquis, et tunc quidem:

a. appendicibus secundariis aut caret, in Cl. Carenae,

b. aut instructum est, et quidem:

$\alpha$. quatuor in Cl. hyalina,

$\beta$. quinque,

I. simplicibus in Cl. tessulata,

2. bifurcis in $\mathrm{Cl}$. marginata. 
Long. I $2^{\prime \prime \prime}$.

Hirudo complanata O. F. M u ell. Hist verm. Tom. I, pars II, pg. 47.

- - Carena, Mem. dell. Acad. di Torino. Tom. XXV. pg. 297.

- - Der Faule, Braun, Syst. Beschreib. pg. 58, Taf. VI, fig. I I-I6. Glossiphonia tuberculata Rawl. Johns. Treatise on the med. Leech. pg. 25 .

Glossopora tuberculata. I d. Further Observ. on the med. Leech. pg. 49.

Clepsine complanata Sav. Syst. des Annélides, pg. I 20.

- - Moqu. Tand. Monogr. pg. IOI. Tab. IV, fig. I.

Pavia i 839 . pg. 5 .

Filippi, Lettera sopra l'anatomia e lo sviluppo delle Clepsine.

Glossobdella complanata. Bla inv. Dict. des Sc. nat. Tom. 47. pg. 263. Tom. 57. pg. 51 5 .

Corpus dilatatum, maxime depressum, duriusculum (presque crustacé Moqu. Td.), antice acuminatum, in caput indiscretum sensim abiens. Color admodum variat; dorsum plerumque fusco vel cinereo viride, interdum griseum, rarissime rubescens, punctis et lineolis fuscis modo aequaliter totam superficiem obtegentibus, modo in figuras elegantissimas dispositis ornatum. Verrucae seriebus duabus dispositae, singulae lineis longitudinalibus fuscis conjunctae, albidae, punctis glandulosis aureis circa 15 quaevis notata, maculas plerumque magis quam verrucas constituentes. Raro enim prominent; quod si fit, non conum acutum, ut in $\mathrm{Cl}$. verrucata, sed hemisphaeram referunt. Verrucae praeterea minores, punctis glandularibus aureis et hae notatae, saepius aut irregulariter sparsae, aut in lineas longitudinales plus minus regulariter dispositae, observantur. Margo crenatus. Venter pallidior, punctorum fuscorum seriebus duabus ab ore ad pedem usque decurrentibus notatus. Caput indistinctumî; oculi sex in series duas longitudinales parallelas parumve antice convergentes dispositi.

Appendicum ventriculi paria sex, simplicia vel crenata, parum retrorsum arcuata; par ultimum inter intestini appendicum par secundum et tertium terminatur. Appendicum intestini paria duo priora breviora prorsum, duo posteriora retrorsum spectant.

Per totam Europam, uti videtur, vulgatissima; legerunt in Suecia Bergmann, in Dania O. F. Mueller, in Brittania Rawlins Johnson, in Gallia Moquin-Tandon, in Italia Carena, Risso, Filippi. Ipse aeque frequentem in aquis stagnantibus et fluviis Marchiae, quam in rivulis qui a Thuringiae montibus decurrunt, observavi.

Omnium segnissima, per totos saepe dies locum haud mutans. Physas, Planorbes, Limnaeos aggreditur; pullos Nephelidis quoque sanguinem sugere vidi. Primo vere (Februario, Martio) ova circa 70 albida ad saxa, plantas, vel vitrum, in quo servatur, deponit, iisque immobilis tanquam incubans per hebdomadis spatium supersedet. Tunc pulli excluduntur, quos ventri affixos secum fert.

\section{Clepsine hyalina Moqu. Td.}

Corpus subcartilaginosum hyalinum dilatatum, antice neque vero posticeangustatum, flavicans. Caput indistinctum. Oculisex.

Long. $5^{\prime \prime \prime}$.

Hirudo hyalina O. F. M u el1. Hist. verm. Tom. I. p. II. pg. 49.

Clepsine hyalina Moqu. Tand. Monogr. pg. Io6.

Glossobdella hyalina Blainv. Dict. des Sc. nat. Tom. 47. pg. 263. Tom. 57. pg. 565.

Corpus pellucidissimum, valde depressum, latum; versus extremitatem posticam latissimum, anteriora versus sensim angustatum, postice rotundatum vel medio 
emarginatum, pede postice prominente. Color pallide flavescens; quando animal extenditur vix conspicuus, quando contrahitur, citrinus. Dorsum punctulis v. striulis nigricantibus interdum adspersum. Margo subinteger, crenis nudo oculo haud conspicuis. Oculi sex, vel interdum, secundum O. F. Mueller, pari primn deficiente, quatuor; paris primi minores approximati, rarissime in unum confusi; paris secundi et tertii majores, remoti, aequaliter distantes.

Appendicum ventriculi paria 6; paria 5 anteriora retrorsum arcuata, plerunque simplicia, rarius unum alterumve apice bilobum; par ultimum intestini appendices omnes excedens, usque ad pedem fere extenditur et appendicibus secundariis 4 simplicibus in latere externo instructum est. Intestini appendicum paria 4, brevia, pulcherrimum motus peristaltici spectaculum observatoris oculo offerentia. Proboscis magna, quartam vel quintam corporis partem longitudine aequans.

Hirudinem hyalinam O. F. Muell. hanc neque sequentem esse, ex descriptione ab illo data luculenter patet. Nam et oculorum situm accurate exposuit et appendices secundarias paris ultimi appendicum ventriculi, quae sequenti desunt, observavit.

Rarius in lacubus nostris (See bei Tegel, Plötzensee et alibi) occurrit, inter Stratiotis folia saepe latitans; facile et propter minutiem et propter corpus prorsus hyalinum praetervidenda.

Segnissima. Nutritur Gasteropodum minorum (Physae, Valvatae, Planorbis nitidi, spirorbis etc.) sanguine. Ova pallide virescentia 10-30 parit, neque vero, ut Cl. marginata, tessulata, complanata, ad corpora aliena deponit, sed sub ventre secum portat, uti sequentes.

\section{Clepsine Carenae Moqu. Tand.}

Corpus subcartilaginosum dilatatum antice acuminatum, postice angustatum, albo cinereum, dorso atomis fuscis dense adsperso; marginibus et capite immaculatis. Caput indistinctum. Oculi sex.

Long. $5^{\prime \prime \prime}$.

Hirudo papillosa Braun, Syst. Beschr. pg. 64. Tab. VII, fig. 7-Io.

Hir. trioculata Carena, Mem. dell. Accad. di Torino. Vol. XXV. pg. 303. Vol. XXVIII.

pg. 334 .

- - Blainv. Dict. des Sc. nat. Tom. 47. pg. 267.

Clepsine Carenae Moqu. Tand. Monogr. pg. I05. Tab. IV. fig. 4.

Glossobdella Carenae Blainv. Dict. des Sc. nat. Tom. 57. pg. 565 .

Corpus pellucidum depressum, partem mediam versus latissimum, antice acuminatum, versus posteriora angustatum, postice rotundatum, pede haud prominente.

Color albo-cinereus; dorsum punctis fuscis modo pallidioribus modo nbscurioribus in lineas longitudinales plus minus regulariter dispositis adspersum, quibus, si animal contrahitur, totum fuscum apparet. Caput et margines punctis carent; linea media dorsi aut immaculata aut punctorum nigricantium acervulo in tertio quovis annulo ornata. Margo subinteger. Oculi sex; paris primi maxime approximati in unum paene confusi; item et secundus atque tertius cujusvis lateris oculus sibi proximi subcoalescentes. Quo fit, ut tres tantum oculi, nisi lente fortissima contempleris, adesse videantur. Cacterum oculi paris secundi et tertii non, ut in C1. hyalina, aeque distantes, sed paris tertii a se invicem remotiores. 
Appendicum ventriculi paria 5 (in $\mathrm{Cl}$. hyalina 6), quorum par ultimum flexuosum intestini quidem appendices omnes, ut in $\mathrm{Cl}$. hyalina, excedit, appendicibus vero secundariis caret. Proboscis magna.

Praecedenti satis similis; differt corporis forma et colore, oculorum situ, pede haud prominente, ventriculi appendicibus. Ad Cl. bioculatam corporis parte anteriore acuminata, nec non colore quodammodo accedit.

Hirudinem papillosam Braun huc referendam esse diagnosis ab illo proposita suadet, in qua capite acuminato, striis tribus minutissimis nigris (oculis) in labio superiore praeditam esse dicit; colorem quoque cinereo-fuscum ei tribuit, at Cl. hyalina flavescens.

In lacubus, fossis, fluviis ad plantas aquaticas minus frequens offenditur. (Thiergarten, Grunewald, Schaafgraben, Spree.)

Antecedente vix vividior. Nutrimento inserviunt Gasteropoda minora, quorum succos bibit. Majo et Junio ova $10-30$ pallide virescentia parit, quae sub ventre secum fert.

\section{Clepsine bioculata Sav.}

Corpus subcartilaginosum, depressum, angustum, antice acuminatum, albo-cinereum, fusco punctatum. Caput indistinctum. Oculi 2 .

Long. $8^{\prime \prime}$.

Hirudo bioculata O. F. Muell. Hist. verm. Tom. I. p. II. pg. 4 I.

Carena, Mem. dell. Accad. di Torino. Vol. XXV. pg. 302.

- - der Läufer, Braun, Syst. Beschr. pg. 53. Tab. VI, fig. I-5.

Glossiphonia perata Rawl. Johns. Treatise on the Med. Leech. pg. 26.

Glossopora punctata Rawl. Johns. Further Observ. on the Med. Leech. pg. 5o.

Clepsine bioculata Sav. Syst. des Annél. pg. I I 9.

- - Moqu. Tand. Monogr. pg. IO2. Tab. IV, fig. 2.

- - Filippi, Lettera sopra l'anatomia e lo sviluppo delle Clepsine pg. 6. Glossobdella bioculata B la inv. Dict. des Sc. nat. Tom. 47. pg. 265. Tom. 57. pg. 565 . ? Helluo bioculatus Oken, Lehrb. der Naturgesch. Thl. III, Abth. I. pg. $367^{1}$ ).

Corpus angustius magisque elongatum, quam in reliquis generis speciebus; antice acuminatum, margine annulis valde prominentibus quasi serrulatum vel dentatum. Color sordide albus vel griseus, punctis fuscescentibus variegatus; linea media dorsi, capite, marginibus subinmaculatis. Oculi duo approximati. In undecimo circiter corporis annulo tuberculum cartilagineum flavo-fuscum conspicitur, rarissime deficiens, cujus analogon in alia nulla specie vidi. Pullis adhuc deest.

Ventriculi appendicum paria sex, quorum quinque anteriora brevia lateraliter spectant, ultimum amplum appendicibus secundariis destitutum inter appendicum intestini par tertium et quartum terminatur. Proboscis magna.

Frequentissima ubicunque in fossis, stagnis, fluviis per totam Europam (Sueciam, Daniam, Brittaniam, Germaniam, Galliam, Italiam) occurrit.

I) Interrogationis signum adjeci; magis enim in Planariam, quam in Clepsinem nostram ejus descriptio quadrat. En, quae dicit: Zwei Augen. Leib flach, schwarz, unten grau, I" lang (Pl. torva?); bisweilen ganz weiß. (Pl. lactea?) 
Omnium vividissima, unde etiam Braun nomine germanico „der Läufer“ designavit. Gasteropodum, ut reliquae, succos sugit. Majo et Junin ova parit albida, vix quiddam rubicunda, ventrique affixa secum portat, ut jam Rawlins-Johnson et Filippi observaverunt. Quid vero Rawlins-Johnson cum marsupio suo abdominali ${ }^{1}$ ) sibi velit, in quo ova includantur, haud intelligo. Nihil enim tale quid observare potui, nisi forte ventrem contractione peculiari concavum redditum ita designare voluerit auctor laudatus. Rayerum, qui hanc capsulas globosas fuscas parere contendit, Planariam lacteam potius quam Clepsinem nostram observasse, Filippi jam notavit.

Huic specierum expositioni observationes quasdam Clepsinarum propagationem spectantes adjungam, zoologorum attentione non prorsus fortasse indignas.

Copulam in Cleps. tessulata saepius vidi. Reciproca est, ut in Sanguisugis, ita ut utrumque animal maris simul et feminae vicibus fungatur. Utrumque enim alterius abdomini capite sese affigens, vaginam penis replicatam in alterius vulvam (s. porum genitalem posteriorem) introducit. Tali modo conjuncta per totos dies sedent.

Cleps. complanatas, quamvis plurimas amoris tempore continua attentione observaverim, coëuntes nunquam observavi; sed eodem fere ante ovorum partum tempore, quo Cleps. tessulatae coire solent, singulare mihi in Cleps. complanatis sese obtulit phaenomenon, cujus neque analogon inter reliqua animalia reperire ${ }^{2}$ ), neque explicationem dare valeo. Ad utrumque nimirum faciei ventralis latus organa singularia filiformia, tres usque quinque corporis annulos longitudine aequantia modo simplicia, modo ad basin usque bipartita exseruntur, modo singula modo plura, mode in anteriore modo in posteriore corporis parte. Haec per plures dies propendent, dum animal, alioquin segnissimum, multo alacrius in vitro suo circumvagatur. Simul substantiae floccosae albidae magna copia secernitur, totam mox vasis in quo servantur aquam turbidam reddens.

Inter phaenomenon hoc et propagationem relationem quandam existere, nullus dubito; plurimas enim Cleps. complanatas per tria semestria domu observavi, neque vero alio unquam tempore organa haec filiformia eas exserere vidi, dum amoris tempore ne una quidem inter triginta et plures non exserebat. Praeterea his organis exsertis, ut in Cleps. tessulata post coitum, ovariorum motus peristalticus, quo ova a funiculis suis solvuntur, incipit. Quo vero munere fungantur haec organa, nescio; anatomica quoque disquisitione nihil de eo docente. Nam corpora quidem in crura dua reflexa divisa in tertio quovis annulo utrinque sub tractus intestinalis appendicibus latentes reperi, quibus replicatis organa illa filiformia fortassis formantur; num autem cum testiculis, quibus interjacent, aliave apparatus sexualis parte cohaereant, videre haud contigit.

Corpora similia etiam in Cleps. verrucata, marginata, tessulata inveni, quamvis in nulla praeter complanatam specie organa filiformia exseri vidi. In Cleps.

I) When the whole of the ova are excluded, they are received into the abdominal pouch of the parent, where they constantly remain, until their contents are fully evolved.

Rawl. Johns. further Observat. on the medic. Leech, pg. 58.

2) Nisi forte appendiculae generatrices a Morrenio (De Lumbr. terrestr. pg. 77.) sic dicta, quas in Lumbrico terrestri auctor laudatus, in aliis pluribus Lumbricinis Cel. Dr. Hoffmeister et ipse observavimus, Cleps. complanatae organis filiformibus analogae. 
tessulata haec corpora Sanguisugae vel Aulastomatis vesiculis respiratoriis sic dictis cum organis ansiformibus, quae eodem loco sitae sunt, quodammodo similia.

Brevi post coitum in Cleps. tessulata, post organa filiformia exserta in Cleps. complanata, motus ovariorum peristalticus incipit, extrinsecus conspicuus, quo ova de funiculis suis solvuntur. Eundem ovariorum motum etiam in Cleps. marginata, hyalina, Carenae, bioculata vidi. Ova soluta paucos post dies, albuminis strato tenuissimo et chorio subtili hyalino munita pariuntur. Omnes enim spezies modo laudatae oviparae ${ }^{1}$.

Pariendi actum saepissime in Cleps. complanata, interdum etiam in Cleps. tessulata observavi. Corpore et ante et pone vulvam quam maxime coarctato, anterior corporis pars sub posteriorem ita inflectitur, ut vulva faciem ventralem partis posterioris spectet. Fortibus tunc et quasi convulsivicis contractionibus ova eduntur eorumque ea, quae primum egressa, a subsequentibus versus latera et dorsum propelluntur, donec in medio dorso ab utroque latere congredientia annulum completum corpus cingentem efficiunt. $\mathrm{Ex}$ hoc annulo caput protrahens mater ovorum acervum vitro apprimit, ubi mox muci, quo ova involuta sunt, superficies in membranam tenuem pellucidam coagulatur. Tales ovorum acervos tres usque septem ova dena usque quadragena continentes Cleps. tessulata et complanata, unum tantum ovis 6o-80 compositum Cleps. marginata parit. Ovorum numerus, et color, itemque amoris tempus secundum species variat, ut supra in specierum descriptionibus notavi.

Ovis ad vitrum vel plantam aquaticam vel mollusci testam lapidemve depositis Cleps. tessulata, marginata, complanata immotae supersedent, ea quasi incubantes, donec septem fere usque decem diebus praeterlapsis pulli excludantur, quas tunc mater ventri affixos secum fert. Contra Cleps. hyalina, Carenae, bioculata ipsa jam ova sub ventre secum portant, neque vero ad corpus alienum deponunt. Quod etiam de Cleps. paludosa, apud nos non obvia, observavit Carena. Cleps. verrucata quomodo sese habeat, nescio; omnes enim quas reperi pullos jam exclusos sub ventre fovebant ${ }^{2}$.

I) Oviparas esse Cleps. bioculatam jam Rawlins Johnson, Cleps. bioculatam, Carenae, complanatam Filippi observarunt. Contra Moquin-Tandon Cleps. complanatam; Carena Cleps. bioculatam, Carenae (Hir. trioculat. Car.) marginatam (Hir. cephalot. Car.) viviparas esse contendunt.

2) Reliqnam dissertationis partem imprimendam haud curavi, cum generum reliquorum expositio parum novi contineat, genitalium vero fabrica, capite tertio explicanda, vix sine tabulis adjectis satis clare demonstrari posse videretur. 


\section{Clepsine costata, neue $\left.\operatorname{Art}^{1}\right)$.}

Mit 2 Textfiguren.

Diagnose: Corpus subcartilaginosum dilatatum fuscescens. Dorsum vitta media longitudinali flava, nigro interrupta, lineisque punctorum obscuriorum prominulis utrinque binis ternisve quasi costatum. Oculi duo, subrotundi. Long. $12-16^{\prime \prime \prime}$.

Die Zahl der Augen unterscheidet diese neue Art fast von allen bis jetzt beschriebenen Hirudineen; unter den Clepsinen stimmen nur Cl. bioculata Sav. und sanguinea Filippi hierin mit ihr überein ${ }^{2}$ ); von beiden ist sie durch die übrigen der angegebenen Charaktere, so wie durch den unten zu beschreibenden Bau des Nahrungskanals hinreichend verschieden. In Gestalt und Art der Bewegung steht sie der $\mathrm{Cl}$. marginata zunächst, und bildet gewissermassen ein Mittelglied zwischen dieser und der Cl, verrucata.

Der Körper ist von etwas knorpliger Konsistenz, sehr flach, bei erwachsenen Individuen sehr breit und nach vorn verschmälert; bei den Jungen ziemlich schmal. Seine Farbe ist grünlichbraun, auf dem schwach convexen Rücken bedeutend dunkler als auf der ganz flachen Bauchseite. Mitten über den Rücken verläuft vom Mund bis zum After eine gelbe Binde, die durch drei oder mehr schwarze Flecken (von ungleicher Lage und Ausdehnung bei verschiedenen Individuen) unterbrochen wird. Auf dem Kopf, der minder deutlich als bei $\mathrm{Cl}$. marginata gesondert ist, wird diese gelbe Binde breiter und trägt hier die beiden anselnlichen, dem Vorderende sehr nahe liegenden, schwarzen rundlichen Augenpunkte. Zwischen dieser mittleren Binde und dem Seitenrand verlaufen jederscits 2-3 durch dunklere Punkte gebildete Längslinien. Die deutlichste dieser Linien ist von drei zu drei Ringen durch einen weissen Punkt unterbrochen. Sowohl diese Längslinien, als die mittlere Binde springen ziemlich stark vor und geben so dem Thier ein geripptes Ansehen. Der Fuss ist gross, und auf der oberen Seite mit weissen Radien gezeichnet. Der seitliche Rand des Körpers erscheint grekerbt, jeder dritte Ring desselben ist durch dunklere Farbe ausgezcichnet.

Die inneren Theile zeigen alle wesentlichen Eigenthümlichkciten der Clepsinen. - Von jedem Ganglion des Bauchstrangs (dessen einzelne Ganglien um je drei Ringe von einander entfernt sind) geht jederseits ein cinziger Nerv ab, der sich jedoch bald weiter theilt.

I) Archiv für Naturgeschichte, I846. I. pg. 82-85. Taf. III, Fig. I u. 2.

2) Ausserdem hat Risso (Hist. des princip. product. de l'Europe mérid. Tom. 4. p. 429) cine Sanguisuga marginata mit zwei Augen beschrieben. 
Die männlichen Geschlechtstheile zeichnen sich aus durch eine auffallend grosse Ruthenscheide (Fig I c), und dadurch, dass die Epididymis deutlich in zwei Abschnitte gesondert ist; der in die Ruthenscheide einmündende vordere (Fig. $1 d$ ) ist enger, von einer festen sehnigen glänzenden Haut umschlossen, und von blassgelber Farbe, der hintere (Fig. 1e), der die unmittelbare erweiterte Fortsetzung des gemeinschaftlichen Hodenausführungsganges seiner Seite ist, ist auffallend weit, anscheinend drüsig, von einer zarten Haut bekleidet und weiss von Farbe. Die Zahl der Hodenbläschen, die ausser der Zeit der Fortpflanzung bei den Clepsinen so leicht zu übersehen sind, kann ich nicht bestimmt angeben.

Der Uterus (Fig. $1 f$ ) steht in der Mitte zwischen dem

Fig. I.

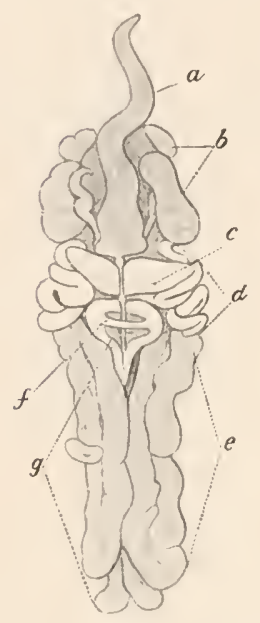
der Cl. complanata und tessulata; mit dem der ersteren stimmt er in der Form, mit dem der letzteren durch seine fleischige Beschaffenheit überein. In der Figur ist der obere Querbalken desselben etwas nach hinten gezogen, um den darunter liegenden Theil und den Durchtritt des Nervenstrangs deutlicher zu zeigen. - An ihn heften sich zu beiden Seiten die unter Magen und Epididymis nach hinten steigenden Schläuche (Fig. I $g$ ) an, welche

Fig. 2.

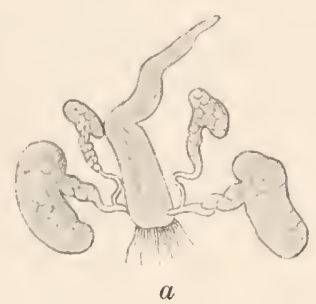

Fig. I. Rüssel, Speicheldrüsen und Genitalien der Clepsine costata, von oben. Der die Genitalien bedeckende Magen ist weggenommen. $a$ Rüssel ; $b$ Speicheldrüsen; $c$ Ruthenscheide ; $d$ vorderer, blassgelber, $e$ hinterer weisser Theil der Epididymis ; $f$ Uterus; $g$ die die keimbereitenden Stränge einschliessenden Schläuche.

Fig. 2. Rüssel mit den Speicheldrüsen is olirt. a Muskelfasern, die sich auf dem Magen ausbreiten, und zum Zurïckziehen des Rüssels dienen. ästelt. So lässt sich auch diese Art durch Zahl und Form ihrer Magenanhänge scharf von allen übrigen unterscheiden, während auch hier die Vierzahl der allen andern Hirudineen fehlenden Darmanhänge als ein sämmtlichen Clepsinen gemeinsames Merkmal sich bestätigt.

Die wichtigste anatomische Eigenthümlichkeit unserer Art ist jedoch der Bau des vor dem Magen gelegenen Theils des Nahrungskanals. - Bekanntlich nähren sich die einheimischen Clepsinen theils von den Säften der Mollusken, theils (Cl. marginata und tessulata) vom Blute der (Fische (?) und) Batrachier. Bei jenen beginnt gleich vor dem Magen der lange cylindrische muskulöse Rüssel während bei diesen, deren Magen übrigens durch bedeutendere Verästelung sich auszeichnet, vor demselben noch ein besonderes System von seitlichen An- 
hängen des Nahrungskanals eingeschoben, und dadurch der Rüssel auf cin verhältnismässig weit geringeres Volumen reducirt ist ${ }^{1}$ ). Clepsine costata schliesst sich im Bau des Magens eng an die letzteren an; dagregen beginnt gleich vor demselben ein ausnehmend langer, nicht cylindrischer, sondern nach vorn immer enger werdender Rüssel (Fig. I $a$, Fig. 2), und jederseits liegen neben diesem Rüssel, vor dem Magen, der Ruthenscheide und dem vorderen Theile der Epididymis zwei ansehnliche weisse Drüsen, eine kleine vordere, und eine grössere hintere (Fig. I $b$, Fig. 2), deren ziemlich lange, anfangs weitere und nocl von Drüsenmasse umgebene Ausführungsgänge, sich nahe dem Hinterende des Rüssels vereinigen und sich hier in die Seiten desselben einsenken. Man darf sie wohl ohne Bedenken als Speicheldrüsen bezeichnen. Bei keiner anderen Clepsine kenne ich ähnliche Drüsen; dagegen erinnert ihre Lage an das vor dem Magen gelegene System von Anhängen bei Cl. marginata und tessulata. Sollten diese vielleicht dieselbe Function haben, während sie in der einfacheren Form einer blossen Ausstülpung des Nahrungskanals auftreten? -

Das Vaterland der Clepsine costata ist die $\mathrm{Krim}$, wo sie dic Sümpfe der Jaila, d. h. der Hochgebirge am Südrande der Halbinsel bewohnt. Ich erhielt mehrere Exemplare die Herr Prof. Dr. C. Koch in Jena lebend aus ihrer Ileimath mitgebracht, durch die Güte des Herrn Geh. Rath Joh. Müller. Nach des Herrn Entdeckers freundlicher Mittheilung sollen sie in ihrem Vaterlande auf ähnliche Weise, wie unsere Sanguisugen, gefangen und medicinisch benutzt werden. Allerdings macht es der Bau ihres Magens wahrscheinlich, dass sie rom Wirbelthierblute leben; allein umsonst suchte ich nach einem Apparate, mittels dessen sie in die Haut des Menschen einzudringen im Stande wären; auch gelang es weder Herrn Prof. Koch, noch mir, sie an uns zum Saugen zu bringen, so dass dnch wohl die betreffende Anwendung einer weitern Bestätigung zu becürfen scheint.

r) Siehe S. 3 . 


\section{Ueber Gammarus ambulans, neue $\left.\mathrm{Art}^{1}\right)$.}

Mit 3 Textfiguren.

Als einzige Repräsentanten der Ordnung der Amphipoden im Gebiet der deutschen Süsswasserfauna sind bis jetzt wohl nur die beiden von Gervais zuerst unterschiedenen Gammarus-Arten zu betrachten, der G. fluviatilis Edw. (Roeselii Gerv.) und G. pulex Fabr., da Koch's G. putaneus nur eine durch den Aufenthaltsort bedingte Varietät zu sein scheint. Diesen beiden kann ich eine neue sehr eigenthümliche Art derselben Gattung hinzufügen, die ich zu Anfang Juni dieses Jahres in einem mit Lemna und Hydrocharis bewachsenen Graben bei Greifswald auffand.

Schon Grösse, Farbe, allgemeine Körperform und Manieren unterscheiden sie zur Genüge von den genannten Arten. Sie ist im ausgestreckten Zustande gegen $2^{\prime \prime \prime}$ lang, einförmig dunkel schwärzlich- oder bräunlichgrün gefärbt, selten heller und mehr gelblich, und trägt auf der Stirn zwischen beiden Augen einen lebhaft schwefel- oder citronengelben querovalen, hinten in der Regel ausgerandeten Fleck, der zugleich sich schwach über seine Umgebung erhebt. Der Körper ist weit wenigerzusammengedrückt, breiter, an den Seiten gew ölbter, als sonst in dieser und den verwandten Gattungen gewöhnlich, und damit steht im Zusammenhang eine von der unserer anderen Arten abweichende Bewegungsweise, nach welcher ich den Namen dieser Art gewählt habe. Diese besteht nämlich in der Regel nicht in dem sprungweisen Schwimmen auf der Seite, sondern in einem aufrechten Gange. Dabei werden die drei letzten Abdominalsegmente, die sehr kurz und zu einem Stück verwachsen sind, so untergeschlagen, dass ihre Rückenfläche wagrecht auf dem Boden aufliegt; betrachtet man dabei den Körper von oben, so sieht man an seiner hintern Hälfte die drei letzten wahren Fusspaare seitlich weit hervortreten, während die vier vorderen Paare fast immer unter dem Thorax verborgen bleiben. Dies ist auch die gewöhnliche Stellung des ruhenden Thieres. Nur selten, besonders wenn es gestört und verfolgt wird, schwimmt es nach Art des G. pulex, oder ruht auf der Seite, die letzten Fusspaare nach dem Rücken in die Höhe geschlagen.

Der Kopf ist klein, ohne vorspringende Stirn, mit ziemlich kleinen rundlichen Augen.

I) Archiv für Naturgeschichte, 1846, I, p. 296-300. Taf. X Fig. $\Lambda$-C. 
Die oberen Antennen sind etwa um die Hälfte länger als die untern und erreichen ungefähr ein Drittel der Körperlänge; die drei cylindrischen fast gleich langen Glieder des Stiels, der bis etwa zur Mitte des letzten Stielgliedes der unteren reicht, nehmen der Reihe nach an Dicke ab; die Geisse1, gegen $1 \frac{1}{2}$ mal so lang als der Stiel, besteht aus 14 Gliedern; die Nebengeissel, ausserordentlich klein, wenig länger als das erste Geisselglied und dreimal dünner als dasselbe, ist aus zwei Gliedern zusammengesetzt (Fig. 3). Das erste und zweite Glied der unteren Antennen sind kurz, ersteres mit einem nach unten und vorn gerichteten konischen Fortsatz, in welchem ein cylindrischer Kanal zu verlaufen scheint, das dritte und vierte Glied lang, cylindrisch; die Geisse1, wenig länger als das letzte, vierte Stielglied, besteht aus sechs Gliedern. Sämmtliche Geisselglieder der Antennen tragen an ihrem Ende kurze Borsten; die Stielglieder sind der ganzen Länge nach mit einzelnen Borsten besetzt.

Fig. I.

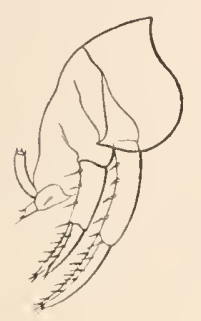

Fig. 2.

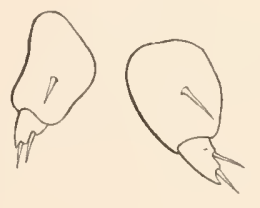

Fig. 3 .

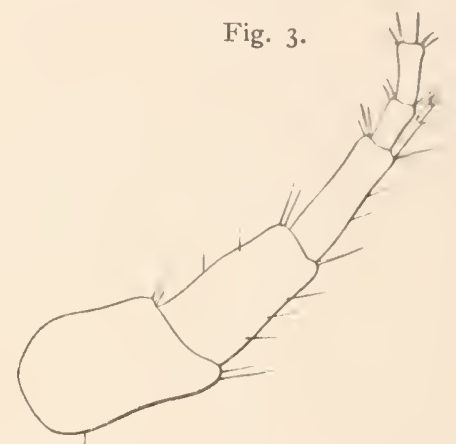

Fig. I. Die 4 letzten Hinterleibssegmente, mit den 3 letzten Paaren der Afterfüsse und den Schwanz* anbängen.

Fig. 2. Das letzte Paar der Afterfüsse, stärker vergrössert. gen Geissel.

Fig. 3. Der Stiel der obern Antennen mit der kleinen Nebengeissel und dem Anfange der 1 \& gliedri.

Bis zum vierten Segment des Thorax nimmt der Körper an Breite, und die ansehnlichen Epimerien, die am Rande schwach gewimpert sind, an Grösse zu. Der Rücken zeigt weder auf diesen noch auf einem der folgenden Segmente eine Spur von Zähnen oder Dornen. Die vier ersten Fusspaare, wie gewölnnlich nach vorn gerichtet, sind klein und schwach, weit kürzer als die drei letzten, von denen das sechste das längste ist. Die $\mathrm{Hände} \mathrm{am} \mathrm{ersten} \mathrm{und} \mathrm{zweiten} \mathrm{Parare}$ sind fast vollkommen gleich gebildet, nur dass die des zweiten Paares, wie der ganze Fuss, etwas länger und schlanker sind. Das 4te und 5te Glied dieser Paare sind stark verdickt, letzteres (das Handglied) länglich viereckig, und wie die beiden vorhergehenden Glieder, an der hintern Seite mit zahlreichen starken Borsten bewaffnet. Die Klaue, mässig gekrümmt, reicht bis zum Ende des fast gerade abgestutzten mit kurzen Borsten besetzten Randes der Hand.

Die ersten Glieder der langen drei letzten walıren Fusspaare sind von beträchtlicher Grösse, oblong, doch nach unten etwas verschmälert, (die des siebenten Paares sind die breitesten), am Hinterende gezähnelt mit feinen kurzen Borsten in den Buchten der Zähne und etwas stärkeren am Vorderrande. 
Die grossen, ovalen, die Eier schützenden Lamellen der Weibchen sind am Rande mit einzeln stehenden langen Wimpern besetzt. Die Weibchen, deren Anzahl die der Männchen bedeutend zu überwiegen scheint, wurden in der Mitte des Juni mit Eiern angetroffen und gegen Ende des Monats begannen die entwickelten Jungen die Bruthöhle der Mutter zu verlassen.

Die drei ersten Abdominalsegmente sind ein wenig länger als die des Thorax; die vordere Ecke ihres untern freien Randes ist abgerundet, die hintere in eine nach hinten gerichtete Spitze verlängert. Die Schwimmfüsse, welche sie tragen, sind von gewöhnlichem Bau, nur dass die langen Borsten, mit denen ihre Aeste besetzt sind, einfach und nicht, wie z. B. bei G. pulex und locusta, gefiedert sind.

Die drei folgenden, letzten Abdominalsegmente sind kurz und und $\mathrm{zu}$ einem einzigen ungegliederten Stück verschmolzen ${ }^{1}$ ), das an seiner untern Seite die drei letzten Afterfusspaare, an seinem Ende zwei kleine cylindrische, an der Spitze mit (in der Regel 5) kurzen Dornen bewehrte bewegliche Schwanzanhänge trägt. Die Enden der Basalglieder des $4^{\text {ten }}$ und 5 ten Afterfusspaares liegen in gerader Linie mit dem Hinterleibsende; natürlich ist also das Basalglied des weiter nach vorn eingelenkten 4ten Paares länger als das des 5ten; die beiden Aeste des 4 ten Paares sind gleich, etwas länger als ihr Basalglied, und überragen die des folgenden Paares, dessen Aeste etwa von gleicher Länge mit ihrem Basalglied, und bei dem der äussere Ast unbedeutend kürzer als der innere ist. Basalglieder und Aeste sind am Hinterrand und an der Spitze mit starken kurzen Dornen bewehrt; ich zählte deren (ohne die Enddornen) 4 an den Aesten des 4ten und dem innern Aste des 5ten, 3 am äussern Aste dieses letzteren Paares. Die Afterfüsse des sechsten Paares endlich sind ganz rudimentär, kaum als eine winzige Spitze zwischen dem vorhergehenden Paare und den Schwanzanhängen vortretend; sie bestehen aus einem dicken konischen Basalglied, auf welches ein kurzes an seiner Hinterseite mit einigen Borsten besetztes weit kleineres Endglied aufgesetzt ist (Fig. 2).

Unter den bekannten Arten der Gattung ist eigentlich keine, die der eben beschriebenen besonders nahe stände; am meisten scheinen noch mit ihr übereinzustimmen G. Ermanii Edw. aus Kamschatka, bei dem aber die sehr kurzen letzten Afterfüsse zwei Aeste tragen und die Schwanzanhänge ohne Haare und Dornen sind (Edw. Hist. nat. des Crust. III. p. 49) und G. Zebra Rathke von der Küste Norwegens, bei dem aber die Nebengeissel völlig ungegliedert, die einfachen letzten Afterfüsse ansehnlich gross, die Schwanzanhänge ganz rudimentär sind (Nov. Act. Ac. Caes. Leop. Vol. XX. p. I. p. 74).

I) Selbst bei den jüngsten Thieren, die man der Bruthöhle der Mutter entnommen, ist keine Gliederung $z u$ erkennen. Ueberhaupt sind diese Jungen den Alten schon ganz ähnlich; der Hauptunterschied liegt in der geringern Zahl der Geisselglieder, deren man an den oberen Antennen 4, an den unteren 3 zählt, während die Nebengeissel schon ihre 2 Glieder besitzt. Das Längenverhältniss der Fühler unter sich, zum Körper, der Stiele zu den Geisseln ist übrigens ziemlich wie später, indem die geringere Zahl der Geisselglieder durch verhältnissmässig grössere Länge ersetzt wird. Ausserdem sind die Dornen, Borsten etc. noch weit weniger ausgebildet; die Zähnelung am Hinterrande des ersten Gliedes am 5 ten $\rightarrow 7$ ten Fusspaare, die Dornen der Afterfüsse des $4^{\text {ten }}$ und 5 ten Paares, mit Ausnahme der Enddornen, fehlen noch, die Schwanzanhänge tragen einen einzigen Dorn am Ende etc. Das sechste Paar der Afterfüsse ist verhältnissmässig grösser, doch ganz von derselben Form, wie beim Erwachsenen. 
Rathke hält es für nicht unzweckmässig, die mit der zuletzt genannten Art durch die Merkmale: „yeux circulaires, fausses pates abdominales de la sixième paire ne portant pas deux grands articles ciliés" übereinstimmenclen Arten als eigene Gattung von Gammarus abzusondern. In diese würde auch der G. ambulans zu stellen sein. Ueberhaupt dürften wohl dic in Form und Zahl ihrer Theile so verschiedenen Afterfüsse und Schwanzanhänge ein passenderes Moment für die generische Sonderung der zahlreichen unter Gammarus und Amphithoe begriffenen Arten abgeben, als die Nebengeissel; denn gewiss sind durch Modificationen im Bau der für die Bewegung der Amphipoden so wichtigen Afterfüsse bedeutendere Differenzen in der ganzen Lebenswcise bedingt, als durch die An- oder Abwesenheit der Nebengeissel, die überdies bei mehreren Gammarus $\mathrm{zu}$ einer fast verschwindenden Kleinheit herabsinkt (G. ambulans, Zcbra u. s. w.), und gewiss ist z. B. unser G. ambulans bei weitem mehr als die grosse Mehrzahl der Amphithoe-Arten von den typischen Formen seiner Gattung (G. pulex, locusta) verschieden.

Schliesslich die Diagnose der Art:

Gammarus ambulans, fronte inermi, oculis subrotundis, antennis superioribus inferiores excedentibus, flagello auxiliari minimo biarticulato instructis, dorso laevi, pedibus spuriis paris sexti simplicibus, conicis, perexiguis, appendicibus caudae duabus, brevibus, cylindricis, apice spinulosis.

Long. $2^{\prime \prime \prime}$, antennar. sup. $0,8^{\prime \prime \prime}$. 


\title{
Ueber die Geschlechtstheile von Clepsine und Nephelis ${ }^{1}$.
}

\author{
Mit Tafel I.
}

In derselben Abhandlung, in welcher Treviranus seine seitdem so viel besprochenen Ansichten über die Geschlechtstheile und die Fortpflanzung des medicinischen Blutegels entwickelt, beschreibt er auch die Geschlechtstheile von Nephelis vulgaris mit dem besonderen Bemerken, dass dieselben hier wesentlich verschieden gebaut seien ${ }^{2}$ ). Ebenso erscheint auch in der von Filippi gegebenen Beschreibung des Geschlechtsapparats der Clepsinen derselbe typisch verschieden von dem aller übrigen Hirudineen ${ }^{3}$ ).

Nach den Untersuchungen, die ich selbst darüber angestellt, scheint mir dagegen derselbe gemeinsame Plan, nach welchem die Geschlechtstheile in den Gattungen Sanguisuga, Haemopis, Aulastoma, Piscicola gebaut sind, auch in den beiden genanten Gattungen der Bildung derselben zu Grunde zu liegen, und theils in dieser Hinsicht, theils weil sich daraus eine, meines Erachtens unzweifelhafte Deutung der einzelnen Theile des Geschlechtsapparats auch für den medicinischen Blutegel ergiebt, glaube ich die nachfolgenden, leider oft noch unvollständigen Beobachtungen der Mittheilung nicht ganz unwerth.

Bei Clepsine tessulata ${ }^{4}$ ), die sich sowohl ihrer Grösse als der weichen, fast gallertartigen Konsistenz ihres Körpers wegen vor allen andern Arten zu anatomischen Untersuchungen eignet, liegen jederseits auf der Bauchseite nach aussen von den bei den Clepsinen besonders entwickelten vom Bauch nach dem Rücken aufsteigenden Muskeln (Filippi's fasci abdomino-dorsali) sechs Hoden (Fig. I.a), d. h. ziemlich grosse, ovale, äusserst dünnwandige Bläschen, die ausser der Zeit der Fortpflanzung zusammengefallen und leicht $\mathrm{zu}$ übersehen sind, während dieser Zeit aber von einer milchigen Flüssigkeit strotzen und durch die Bauchdecken hindurch schon von aussen sich wahrnehmen lassen. Von oben werden sie zum Theil durch den Magen bedeckt, zwischen dessen seitlichen Anhängen sie liegen. Nach aussen von ihnen verläuft jederseits ein ausserordentlich feiner Ausführungsgang (Fig I.b) nach vorn bis in die Gegend des siebenten Bauchganglions; hier

I) Müllers Archiv für Anatomie. 1846. pg. 138-I48. Taf. VIII.

2) Tiedem. und Trevir. Zeitschr. für Phsysiol. Bd. 4 pg. I66.

3) Filippi, lettera sopra l'anat. e lo sviluppo delle Clepsine. Pavia 1839.

4) Cf. Wiegmann's Archiv. I844. Bd. I, pg. $370=$ Gesammelte Schriften pg. I. 
verdickt er sich plötzlich zur Epididymis (Fig. 1.c), die sich nach innen unter den Magen wendet, allmälig an Dicke zunehmend, mit mannichfachen Biesungen in der Mittellinie bis etwa zum letzten Hodenpaare nach hinten geht, und ron da wieder nach vorn bis vor das sechste Ganglion zurückkchrt; hier bildet sie mehrere kurze verschlungene Windungen und mündet in das vordere Ende einer zweischenkligen, dickwandigen, sehnigglänzenden Scheide (Fig. 1.d), die zwischen dem sechsten und siebenten Ganglion nach aussen sich öffnet. - Einen besondern Penis scheint diese Scheide nicht einzuschliessen, sondern selbst, indem sio sich theilweise nach aussen umstülpt, dessen Stelle zu vertreten.

Drei Ringe hinter der männlichen Geschlechtsöffnung liegt, wie jene in der Mittellinie, die weibliche. Sie führt zu einem fleischigen, cylindrischen Uterus (Fig. 3. a, Fig. 4.), der zuerst in der Länge von etwa drei Ringen nach hinten gerichtet ist, dann nach oben und vorn sich umbiegt und über der äussern Geschlechtsöffnung sich in zwei schief nach vorn und aussen gerichtete Schenkel theilt, die durch einen an beiden Enden verdickten Querbalken wieder verbunden werden. Der nach hinten und der darüber liegende, nach vorn gerichtete Theil des Uterus sind durch zahlreiche sehnige Fasern verbunden; durch die von den beiden Schenkeln desselben und dem Querbalken gebildete Oeffnung geht der Bauchnervenstrang hindurch. An den beiden Enden des Querbalkens beginnen zwei ungemein lange dünnhäutige Sclläuche (lïg. 3.b), die sich, unter dem Magen umschlungen von den Windungen der Epididymis, bis nahe ans hintere Ende des Körpers erstrecken. Anfangs ziemlich eng, erweitern sie sich bald, und enthalten in diesem weiteren, hinteren Theile den Körper an Länge mehrfach übertreffende, gewundene Stränge, die an dem hinteren blinden Ende der Schläuche festzusitzen scheinen. Die Zahl dieser Stränge, ob einer oder mehrere in jedem Schlauche, konnte ich nicht mit Bestimmtheit ermitteln, da es mir nie gelang, ihre Wandungen ohne Zerreissen vollständig zu entwickeln.

Ganz ähnlich ist der Bau der Geschlechtstheile bei Clepsine complanata (Fig. 5.) und verrucata ${ }^{1}$ ); sie unterscheiden sich hauptsächlich dadurch, dass der Uterus dünnhäutig ist, und sich gleich an der Geschlechtsöffnung in zwei kurze, gerade nach den Seiten gerichtete Schenkel theilt, die von oben durch den darüber liegenden häutigen Querbalken gedeckt werden, So scheinen, wenn man nicht auf den Nervenstrang achtet, der auch hier unter dem Querbalken hindurch geht, auf den ersten Blick die beiden langen Schläuche, in denen die gewundenen Stränge eingeschlossen sind, unmittelbar in eine gemeinsame äussere Oeffnung zu münden. Die Zahl der Hodenbläschen ist nach den Arten verschieden; so zählte ich 6 Paar bei Cl. tessulata, ı bei $\mathrm{Cl}$. complanata, 11 bei $\mathrm{Cl}$. marginata (Hirud. marginata O. F. M ü11.) ${ }^{2}$ ).

I) F. Müller, diss. de hirudinibus circa Berolinum observatis. Berol. 1 844 . p. $23=$ Gesamnelte Schriften pg. 6.

2) Filippi hat die Hoden der Clepsinen, die verhältnismässig weit grösser sind, als bei irgend einem andern Egel, meist übersehen oder wenigstens (bci Cl. padulosa, I. c. Pg. I I) nicht als Thcile des Geschlechtsapparats erkannt; Hoden sind ihm die oben als Epididymis bczeichneten Kanäle, die er mit einem gemeinschaftlichen Atrium an der vordern Geschlechtsöffnung beginnen und mit ihren sehr feinen Enden in der Nähe des Mundes sich anheften lässt. Noch abweichender ist seine Beschreibung der weiblichen Organe; die beiden langen Schläuche sollen hinten zusammenhängen, und an dieser Vcreinigungrsstellc bei Cl. paludosa sechs kurze blinde Anhänge tragen, bei $\mathrm{Cl}$. complanata mit vier in Sichlcifen gebogenen Kanälchen ver- 
Bei $\mathrm{Nephelis}^{1}$ ) sind die weiblichen Organe denen der Clepsinen einigermaassen ähnlich. Wie dort, finden sich zwei lange, weite häutige Schläuche (Fig. $6 a$ ), die sich zu den Seiten der Ganglienkette unter dem Darmkanal vom ioten oder i I ten Ganglion an nach vorn erstrecken, zwischen dem 7ten und 8ten Ganglion sich verengern, nach innen biegen und in die beiden Enden eines kurzen zweischenkligen Uterus (Fig. 6b) einmünden. In diesen Schläuchen sind lange, ziemlich dicke, wenig gewundene Stränge eingeschlossen.

Sehr abweichend ist dagegen die Form der männlichen Geschlechtstheile. Vom hinteren Ende des Körpers bis etwa zum I Iten Ganglion liegt jederseits neben und unter dem Darmkanal eine aus zahlreichen kleinen Bläschen, den Hodenbläschen, zusammengesetzte Drüse (Fig. 6c), an deren unterer Seite ein feiner Ausführungsgang (Fig. 6d) nach vorn verläuft. Sobald dieser aus der Drüse heraustritt, verdickt er sich, bekommt eine feste, sehnig-glänzende Haut, und bildet so die Epididymis (Fig. 6e), die in dicht verschlungenen Windungen nach aussen und unten von den weiblichen Organen bis etwa zum gten Ganglion sich nach vorn erstreckt und hier sich wieder in einen dünnen Kanal (Fig. $6 f$ ) verengt, der anfangs stark gebogen, dann immer enger und gerader werdend bis zum 5ten Ganglion geht, hier sich nach innen und hinten umbiegt und in das nach vorn gerichtete Ende einer zweischenkligen, dickwandigen, sehnigen Scheide (Fig. $6 g$ ) einmündet. Die Oeffnung dieser Scheide, welche auch hier keine besondere Ruthe einzuschliessen scheint, liegt fünf Ringe vor der weiblichen Geschlechtsöffnung. Alle innern Geschlechtstheile sind durch ein dichtes Zellgewebe an die Körperwand und den Darmkanal befestigt, während bei den Clepsinen die Epididymis sowohl, als sämmtliche weibliche Organe völlig frei in der Leibeshöhle liegen ${ }^{2}$.

Die wesentliche Uebereinstimmung der Genitalien unserer beiden Gattungen mit denen von Sanguisuga, Haemopis, Aulastoma, Piscicola werde ich nach der gegebenen Beschreibung kaum noch besonders hervorzuheben brauchen. Die Hoden erscheinen überall in Form dünnhäutiger Bläschen, auf der Bauchseite zu beiden Seiten des Darmkanals liegend, bald einzeln und wenig zahlreich (6- I 2 Paare), bald in grosser Anzahl und jederseits zu einer traubigen Drüse zusammengehäuft (Nephelis). Die Hoden jeder Seite haben einen gemeinschaftlichen Aus-

versehen sein; die gewundenen Stränge sollen sich bis zur Geschlechtsöffnung erstrecken und in ein gemeinschaftliches Atrium sich öffnen, etc. - Alle diese Angaben muss ich nach wiederholten, mit aller mir möglichen Sorgfalt angestellten Untersuchungen, wenigstens für Cl. tessulata, complanata, verrucata, bestimmt verneinen.

I) Ich untersuchte N. vulgaris und atomaria Moqu. Tand, die sich übrigens wohl kaum scharf als Arten trennen lassen.

2) Treviranus hat l. c. die Hoden übersehen und deshalb, wie Filippi bei den Clepsinen, die Epididymis als Hoden bezeichnet; auch lässt er, wahrscheinlich nur in Folge eines Schreib- oder Druckfehlers, die weibliche Geschlechtsöffnung vor der männlichen liegen. Moquin-Tandon, der die männlichen Organe ganz richtig beschreibt, giebt eine mir unerklärliche Abbildung der weiblichen Genitalien seiner Neph. Gigas (Monograph. Tab. III. Fig. 7), nach welcher sie fast ganz wie bei Sanguisuga oder Aulastoma gebaut sein würden. Aeusserlich soll N. Gigas nur durch ihre Grösse sich von N. vulgaris unterscheiden, mit der sie auch nach Moquin-Tandons Zeichnungen im Bau des Darmkanals und der männlichen Organe vollkommen übereinstimmt. Sollte wirklich eine so auffallende Verschiedenheit der weiblichen Theile bei zwei sonst zum Verwechseln ähnlichen Arten sich finden? - Im Text geschieht der weiblichen Organe von Nephelis nirgends auch nur mit einem Worte Erwähnung. 
gang, der bei allen sehr lang und in einem grossen Teile seines Verlaufs beträchtlich verdickt ist. Dieser dickere Theil, die Epididymis, ist bei Nephelis, Aulastoma, Haemopis, Sanguisuga in Form einer Drüse verschlungen, und bei Piscicola ${ }^{1}$ ) zu einer Samenblase erweitert. - Als wesentliche Bestandtheile des weiblichen Apparats, der stets nach innen und hinten von dem männlichen liegt, finden sich $\left.{ }^{2}\right) \mathrm{mehr}$ oder weniger lange gewundene Stränge, eingeschlossen in zwei häutige Säcke, die bald kleine rundliche Bläschen darstellen (bei Sanguisuga ${ }^{3}$ ), Haemopis, Aulastoma, Piscicola), bald grosse, lange Schläuche (Nephelis, Clepsine). - Ueberall findet sich eine einzige männliche und eine weibliche Geschlechtsöffnung, beide in der Mittellinie des Körpers, und zwar die erstere vor der zweiten gelegen.

Was nun die Deutung der einzelnen Theile betrifft, so sind neuerdings bekanntlich drei ganz verschiedene Ansichten verfochten worden. Aus der leicht zu beobachtenden Thatsache, dass bei Sanguisuga aus der vordern Geschlechtsöffnung ein penisartiges Organ, aus der hintern die Eier austreten, schloss man zunächst auf die männliche und weibliche Natur der mit diesen Oeffnungen in Verbindung stehenden Theile, eine Ansicht, die wir z. B. von Moquin-Tandon, Brandt, R. Wagner vertreten finden. Dagegen erhob sich Treviranus, der die sogenannten Hoden von Sanguisuga als Bildungsstätte der Eier, die Epididymis als Hoden angesehen wissen will; die Eier sollen durch die Hoden hindurchgehen, da befruchtet werden und bei der Begattung, schon befruchtet, in den Uterus eines andern Individuums übergeführt werden, um daselbst mit nährender Materie (abgesondert durch die beiden sogenannten Ovarien) und einer schützenden Hülle versorgt zu werden. Henle ${ }^{4}$ ) endlich kehrte die alte Ansicht geradezu um; die sogenannten Hoden liess er mit Treviranus die Keime der Eier, die in den Ovarien eingeschlossenen Stränge den Saamen bilden, bei der Begattung also die Eier aus den weiblichen Organen des einen in die männlichen des andern Individuums treten, da befruchtet werden und sich weiter entwickelı.

Schon die Vergleichung der äussern Form der Theile in den verschiedenen Gattungen (namentlich die grosse Entwicklung der mit dem Uterus in Verbindung stehenden Schläuche bei Clepsine und Nephelis, so wie die Epididymis von Piscicola und Clepsine, die ganz deutlich als blosse Verdickung des Ausführungsgangs der Hoden erscheint) machte mir die Ansicht von Treviranus, der er auch selbst bei Nephelis untreu geworden ist, sehr unwahrscheinlich, noch ehe es mir gelungen war, durch direkte Beobachtungen an Clepsine tessulata sie bestimmt zu widerlegen und die Richtigkeit der älteren zu beweisen.

Im Mai beginnen nämlich bei Clepsine tessulata die ausser der Zeit der Fortpflanzung ziemlich dünnen in den beiden langen Schläuchen eingeschlossenen Stränge anzuschwellen und durch die Bauchdecken hindurch von aussen sichtbar zu werden. Unter dem Mikroskop sieht man um diese Zeit in ihrem Innern zahlreiche. von dem übrigen Gewebe scharf abgegrenzte kleine elliptische Zellen mit deutlichem Kern (Fig. 7. 8.), die schnell an Umfang zunehmen, als Anschwellungen mehr und

1) Cf. Leo, in Mü Il. Arch. 1835.pg. 419. Tab. XI.

2) Gewiss auch bei Piscicola und Haemopis, wo sie noch nicht nachgewiesen sind.

3) Cf. Henle, in Müll. Arch. 1835. Tab. XIV. Fig. 8.

4) Müll. Archiv 1835. pg. 574 .

Fritz Müllers gesammelte Scbriften. 
mehr über die Oberfläche der Stränge vortreten, bis sie endlich in Form kleiner Kugeln, deren Durchmesser dem des Stranges etwa gleich ist, fast ganz aus der Substanz derselben hervorgetreten sind (Fig. 9, 10), und dann schon dem blossen Auge wie Perlen an eine Schnur angereiht erscheinen, während das Mikroskop deutlich das Purkinje'sche Bläschen und den Wagner'schen Keimfleck wahrnehmen lässt. Etwa zu dieser Zeit (Ende Mai, Anfang Juni) findet die Begattung statt. Sie ist, wie bei Sanguisuga, gegenseitig; mit dem Fusse festsitzend saugt jedes der beiden Individuen mit dem Kopf sich an der Bauchseite des andern fest, worauf ein konisches Organ aus der vordern Geschlechtsöffnung sich ausstülpt und in die hintere des andern Thieres eintritt; so vereinigt sitzen die Thiere meist mehrere Tage lang ${ }^{1}$ ). Kurz nach der Begattung beginnen die beiden langen Schläuche eine lebhafte peristaltische Bewegung, die wahrscheinlich dazu dient, die Eier von den Strängen abzulösen; denn bald findet man sie frei in der Höhle der Schläuche. Der Keimfleck und das Purkinje'sche Bläschen verschwinden, die anfangs weisse Farbe ändert sich in ein schönes Dottergelb um, und um das Ei bildet sich, durch eine sehr dünne Schicht farblosen Eiweisses vom Dotter getrennt, ein zartes Chorion. Eine Woche etwa nach der Begattung werden die Eier ( 150 und darüber) gelegt; über ihnen bleibt das Thier (wie Cl. complanata und marginata) bis zum Auskriechen der Jungen gleichsam brütend sitzen, worauf die, wie bei allen Clepsinen, noch sehr unentwickelten Jungen an den Bauch der Mutter sich festheften und von ihr ziemlich lange Zeit mit herumgetragen werden.

In der Flüssigkeit der Hodenbläschen zeigt das Mikroskop zu der Zeit, wo die Eier in den Strängen sichtbar zu werden beginnen, eigenthümliche spindelförmige Körper (Fig. I I), die aus einer Zelle mit körnigem Inhalt und deutlichem Kern zu bestehen scheinen, von der nach zwei entgegengesetzten Seiten eine ungemeine Menge äusserst feiner, mit den Spitzen vereinigter Fäden ausgehen. Unter diesen finden sich bald einzelne, bei denen die Fäden an der Spitze sich mehr oder weniger $z u$ trennen und der Zellenkern undeutlich zu werden beginnt. Je mehr sich die Eier entwickeln, um so mehr treten auch die Fäden auseinander, bis sie nach allen Seiten hin auseinanderstehen (Fig. 12) und endlich sich voneinander trennen und frei in den Hodenbläschen schwimmen. So lange diese Fäden in den Hoden verweilen, sah ich nie die mindeste Bewegung an ihnen; als ich jedoch zwei Individuen untersuchte, die, um sich zu begatten, sich schon aneinander festgesogen hatten, fand ich die Epididymis von eben solchen Fäden strotzend, die in einer sehr lebhaften vibrirenden Bewegung begriffen waren und sich so als Saamenthierchen zu erkennen gaben.

Bei Clepsine tessulata sind also in der That die sogenannten Hodenbläschen die Bildungsstätten des Saamens, und die mit der hintern Genitalöffnung zusammen-

I) Diese Weise der Begattung scheint jedoch in der Gattung Clepsine nicht allgemein; vergl. über Cl. complanata meine Diss. de hirudinibus etc. Berol. I 844 pg. $33=$ Gesammelte Schriften pg. 2I. Wührend der Zeit der Fortpflanzung wurde bei dieser Art auch eine ziemlich lebhafte Fluctuation einer farblosen Flüssigkeit längs der Seitenränder des Körpers beobachtet, die ich anfangs, durch Filippi's Darstellung des Gefässsystems verleitet, für Blutbewegung nahm. Allein theils sind die Strömungen, worauf mich Herr Geh. Rat Joh. Müller, dem ich diese, so wie die l. c. beschriebenen penisartigen Organe zu zeigen Gelegenheit hatte, aufmerksam machte, nicht durch scharfe Conturen begrenzt, theils konnte ich sie eben nur zur Zeit 'der Fortpflanzung beobachten, zu welcher sie also in besonderer Beziehung zu stehen scheinen. 
hängenden Theile die weiblichen, die das Eigenthümliche haben, dass die keimbereitenden, gewundenen Stränge, also die eigentlichen Ovarien, eingeschlossen sind in den eileitenden Schläuchen (die den bei Sanguisuga gewöhnlich sogenannten Ovarien entsprechen).

Aehnliche Körper, wie die aus den Hoden von Cl. tessulata beschriebenen, sind schon von Henle aus der Epididymis von Sanguisuga abgebildet worden ${ }^{1}$ ); ganz wie bei Sanguisuga finden sie sich bei Aulastoma, und in etwas anderer Form auch in den Hoden von Nephelis (Fig. I4). Wahrscheinlich bilden sie sich aus den von Treviranus und Henle als Eikeime betrachteten rundlichen Körperchen, die sich in den Hoden von Sanguisuga ${ }^{2}$ ), Aulastoma und Nephelis (Fig. I4) finden.

Bei Nephelis und Aulastoma, die bekanntlich nicht alle Eier gleichzeitig ablegen, wie die Clepsinen, ist es auch leicht, im Mai und Juni die Eier sogar gleichzeitig in allen Stadien der Entwicklung zu beobachten, theils noch ganz. klein und völlig in der Substanz der Stränge eingeschlossen, theils mehr oder weniger daraus hervorgetreten und deutlich mit Purkinje'schem Bläschen und Keimfleck versehen (Fig. I6), theils endlich schon abgelöst und frei im sogenannten Eierstock, ohne Keimbläschen und Keimfleck, aber mit einer dünnen Eiweissschicht und einem zarten Chorion bekleidet, ganz wie man sie auch in den eben gelegten Cocons von Nephelis findet.

Mit Aulastoma stimmen aber Sanguisuga, Haemopis, Piscicola so genau in der Form der Zeugungstheile überein, dass man gewiss auch hier die Hodenbläschen als saamenbereitend, als eigentliche Eierstöcke dagegen die in den sogenannten Eierstöcken eingeschlossenen (bei Haemopis und Piscicola freilich noch nicht einmal nachgewiesenen) Stränge wird anzusehen haben.

\section{Erklärung der Abbildungen auf Tafel I.}

Fig. I. Männliche Organe von Clepsine tessulata. a Hoden, b Ausführungsgänge, $c$ Epididymis, $d$ Ruthenscheide.

Fig. 2. Die Ruthenscheide zwischen zwei Glasplatten gepresst.

Fig. 3. Weibliche Organe derselben. a Uterus, 6 Eierstöcke.

Fig. 4. Der Uterus, stärker vergrössert.

Fig. 5. Geschlechtstheile von Clepsine complanata. (Die Hoden mit ihren Ausführungsgängen sind weggelassen.) $a$ Epididymis, $b$ Ruthenscheide, $c$ Eierstöcke, $d$ Uterus.

Fig. 6. Geschlechtstheile von Nephelis vulgaris var. atomaria (Hirud. atomaria Carena). $a$ Eierstöcke, $b$ Uterus, $c$ Hoden, $d$ Ausführungsgang derselben, e Epididymis, $f$ vasa ejaculatoria seminis, $g$ Ruthenscheide.

Fig. 7. Ein Stück der in den langen Schläuchen eingeschlossenen Stränge von Clepsine tessulata.

Fig. 8. Ein Theil desselben mehr vergrössert.

Fig. 9. Ein eben solches Stück zur Zeit der Begattung, natürl. Grösse.

Fig. IO. Dasselbe vergrössert.

Fig. I I. Die spindelförmigen Körperchen der Hodenflüssigkeit von Cleps. tessul.

Fig. I 2. Dieselben, weiter entwickelt.

Fig. I3. Spermatozoen, aus der Epididymis derselben.

Fig. I4. Inhalt der Hodenbläschen von Nephelis vulgaris.

Fig. I 5. Das freie Ende eines Eierstrangs von Neph. vulg.

Fig. I6. Ein reifes Ei daraus, stärker vergrössert.

I) M üll. Archiv I835. Tab. XIV. Fig. 4 b.

2) Müll. Archiv l. c. Fig. 6 a. 


\section{Bemerkungen im Betreff des Geschlechtsverhältnisses bei den Hirudineen ${ }^{1}$ ).}

$\mathrm{Zu}$ den Tieren, die bis jetzt trotz der mannichfach unter einander abweichenden und sich widersprechenden Ansichten über die Bedeutung ihrer Geschlechtswerkzeuge doch einstimmig als hermaphroditisch betrachtet worden sind, gehört die Familie der H ir u d in een; auch hier ist vom Hrn. Verf. der Hermaphroditismus in Zweifel gezogen und der Nachweis getrennter Geschlechter mit ziemlicher Ausführlichkeit versucht worden (S. 5 I u. folg.); allein - wie mir scheint — mit wenig Glück. Es liegt der gegebenen Darstellung eine teils unvollständige, teils falsche Auffassung der anatomischen Verhältnisse zu Grunde, und sie entbehrt so der festen Basis, auf die allein eine sichere physiologische Deutung sich gründen kann.

Zunächst Aulastoma. -- Hier sind in der Beschreibung der vom Verf. als „mehr ruhende Partie“, als unbeteiligt am eigentlichen Fortpflanzungsgeschäft betrachteten Teile, der sogenannten Eierstöcke (Fig. I 2, $a^{1}, a^{1}$ ), die in denselben eingeschlossenen gewundenen Stränge übergangen, die von Sanguisuga schon vor geraumer Zeit Henle beschrieben und abgebildet hat (Müll. Archiv, I835, Tab. XIV, Fig. 8), und die hier in ganz gleicher Weise sich finden. Wären diese in den Monaten Mai, Juni einer genaueren Untersuchung unterworfen worden, so würde sich der Verf. leicht überzeugt haben, dass hier und nicht in den Hodenbläschen $(\mathrm{a}, \mathrm{a})$ die wahre Bildungsstätte der Eier zu suchen ist. Für letztere Meinung wird nur eine Figur von I Jenle (a. a. O. Fig. b, b) angeführt, die aber weder Keimbläschen und Keimfleck, noch irgend welche Aehnlichkeit mit den Eiern zeigt, die man in den frischgelegten Cocons der Hirudineen, z. B. der Nephelis, findet. Dagegen lassen sich zur angegebenen Zeit an den in den sog. Eierstöcken eingeschlossnen Strängen alle Entwicklungsstufen der Eier verfolgen'2). Man findet sie teils noch ganz in die Substanz der Stränge eingebettet, teils wie Perlen über ihre Oberfläche vortretend und dann deutlich mit Keimbläschen und Keimfleck versehen, teils schon, von den Strängen abgelöst,

I) Aus: „Steenstrup, Untersuchungen über das Vorkommen des Hermaphroditismus in der Natur, aus dem dänischen übersetzt von C. Hornschuch mit Bemerkungen von Crepelin, Fritz Müller, Karsch, Max Schultze und dem Uebersetzer". Greifswald, I 846 pg. I Io-I I4.

2) Man hat die Bläschen $\left(a^{1} a^{1}\right)$ sorgfältig bloszulegen, unverletzt herauszuschneiden und auf einer Glasplatte behutsam zu öffnen. 
frei in der Höhle der Bläschen und dann ganz übereinstimmend mit den in den frischgelegten Nepheliscocons enthaltenen. Diese Eier fand ich zur genannten Zeit bei allen von mir untersuchten Individuen, und gleichzeitig bei allen in den Hodenbläschen (a, a) die brombeerförmigen Körper, in der Epididymis („Zusammenwicklungen" des Verf.) die vom Verf. als Scheinsame angesprochenen blumenkohlartigen Körper, die ich bei Clepsine deutlich als eine Entwicklungsstufe der wahren Samenfäden erkannt habe (cf. Müll. Archiv, I846, S. 146, Taf. VIII, Fig. I I-I3 = Gesammelte Schriften S. 34, Taf. I, Fig. II-I3).

Bei Clepsine complanata hat Verf. ganz richtig die Hodenbläschen (Fig. 8 u. 9, a, a) als Bildungsstätten des Samens nachgewiesen und die Eier an den in den Schläuchen $(\beta, \beta)$ eingeschlossenen gewundenen Strängen gefunden; allein die Schlüsse, die aus diesen an sich richtigen Beobachtungen gezogen werden, verlieren dadurch alle Gültigkeit, dass der anatomische Zusammenhang der Teile durchaus verkannt ist. Ich hoffe, wegen dieses categorischen Ausspruchs nicht der Anmassung geziehen zu werden; lange Zeit hat mich das specielle Studium des Baus der Clepsinen beschäftigt; die Untersuchung der kleinern, ihrer knorpligen Consistenz halber grosse Schwierigkeiten darbietenden Cleps. complan a ta wurde durch gleichzeitige Sectionen der grossen weichen C1. t es s u 1 a ta controlliert, und ausserdem ergaben diese Untersuchungen eine wesentliche Uebereinstimmung des Geschlechtsapparats der Clepsinen mit dem von Nephelis, Piscicola, A ulastoma, Sanguisuga, während bei des Verf. Darstellung alle Analogie mit diesen Gattungen verschwindet (S. meinen Aufsatz über die Geschlechtsteile von Clepsine und Nephelis in Müll. Arch. I 846 p. I 38 Tab. VIII = Gesammelte Schriften pg. 30 Taf. I). Der Verbindungsgang (b, b) zwischen den Hodenbläschen (a, a) und den in den Säcken $(B, B)$ eingeschlossenen gewundenen Strängen, den Verf. für seine Theorie braucht und zeichnet, existiert nicht, eben so wenig als diese Stränge sich an der hintern Geschlechtsöffnung ausmünden. - Die Kanäle $\left(b^{1}, b^{1}\right)$ enden nicht blind am Kopfende, wie Verf. Filippi nachschreibt, sondern biegen, wie auch schon Grube nachgewiesen (in seinen Untersuchungen über die Entwicklungsgesch. der Clepsinen, Königsberg I 844. S. 8.), vor dem ersten Hodenbläschen ihrer Seite nach aussen um, und verlaufen, sehr verdünnt, aussen neben der Reihe der Hodenbläschen nach hinten, und sind eben nichts, als die verdickten Ausführungsgänge derselben, entsprechend der Epididymis (den „Zusammenwicklungen") bei A ulastoma und Sanguisuga.

In den Hodenbläschen nun finden sich die Brombeerzellen und dieselben spindelförmigen Körper, die Verf. auch in der Epididymis $\left(b^{1}, b^{1}\right)$ gefunden und als "Scheinsamen" bezeichnet; in der Epididymis sah ich zur Zeit der Begattung bei Cleps. tessulat a freie sich lebhaft bewegende Samenfäden, so dass über die männliche Natur dieser Teile kein Zweifel sein kann, eben so wenig, als über die weibliche Natur der in den Säcken $(B, B)$ eingeschlossenen Stränge, in denen sich die Eier von ihrem ersten Auftreten bis zu ihrer Reife (d. h. dem Loslösen von den Strängen) verfolgen lassen. Beides, Samen und Eier, finden sich gleichzeitig in allen Individuen zur betreffenden Jahreszeit; wollte man ein Einbringen der Brombeerkörper durch Begattung annehmen (die übrigens bei Cleps. tessulata erst zur Zeit der Eireife Statt hat und gegenseitig ist), so hätte dies keinen denkbaren Zweck, da keine Verbindung zwischen Hodenbläschen und Eiersträngen besteht. 
Also männliche und weibliche Organe, die ihre Produkte gleichzeitig in demselben Individuum entwickeln, d. h. Hermaphroditismus.

Verf. hat verschiedene Zellengebilde aus den Hodenbläschen als erste Entwicklungszustände der Eier abgebildet und meint, dass sie durch den (nicht existierenden) Verbindungsgang $(\mathrm{b}, \mathrm{b})$ in die Stränge der Säcke $(\beta, \beta)$ träten, betrachtet demnach diese Stränge als Eileiter seiner WVeibchen. Gesetzt selbst, dieser Verbindungsgang wäre vorhanden und dies Uebertreten erwiesen, so wäre es jedenfalls ein fabelhafter Eileiter, der den Zweck hätte (denn was immer geschieht, kann doch nicht ein unglücklicher Zufall sein), die Eier durch seine Wände durchfallen zu lassen.

Was endlich des Verf. „indirecte Erfahrung“ über das getrennte Geschlecht der Clepsinen betrifft (S. 58), gleichsam das argumentum ad hominem, so gibt diese ein treffendes Beispiel, wie man in Folge einer vorgefassten Meinung, - denn die Clepsinen dürfen nun einmal nicht Zwitter sein - gegen die einfachsten Folgerungen aus den klarsten Tatsachen sich verblenden kann. Allerdings sind zur Zeit, wo die Eier zuerst in den Strängen der Säcke $(B, \beta)$ sich bemerklich machen, die Hodenbläschen strotzend gefüllt mit Brombeerzellen; allerdings nehmen letztere an Zahl ab, wie die Eier sich weiter entwickeln; allerdings ist zur Zeit der Reife der Eier kaum eine Spur derselben in den Hodenbläschen zu finden, - ich habe sie sogar ganz vermisst, - allerdings müssen, soll Hermaphroditismus mit gegenseitiger oder Selbstbefruchtung Statt haben (es sei denn, dass das früher gereifte Sperma bis zur Reife der Eier in besondern Behältern bewahrt werde), beiderlei Geschlechtsstoffe gleichzeitig ihre höchste Entwicklung zeigen. Aber ist denn das hier nicht der Fall? - Wie die Eier, so schreiten die Brombeerzellen in ihrer Entwicklung fort, werden zu den spindelförmigen Körpern (.,Scheinsamen“ des Verf.), und diese lösen sich in freie Samenfäden; natürlich werden der Brombeerzellen dabei immer weniger und zuletzt verschwinden sie ganz; sie sind ja eben nicht die letzte, höchste, sondern die erste, niedrigste Entwicklungsstufe des Samens. - Weil zur Zeit der Eireife bei den eiertragenden ( $\mathrm{d}$. h. bei allen erwachsnen) Individuen keine Brombeerzellen in den Hodenbläschen sich finden, sollen sie nicht dort abgesondert sein können (???), sondern von aussen eingeführt (und wahrscheinlich während des Reifens der Eier zur Befruchtung verwandt worden) sein. Mir ist kein Beispiel bekannt, wo der Same in dieser seiner ersten Entwicklungsform zum Behuf der Befruchtung auf ein andres Individuum übertragen würde.

Auch für die Planarien möchte die Verteilung der Geschlechter auf verschiedne Individuen noch näher nachzuweisen sein. Alle Exemplare von Plan. He11uo O. F. Mü11. (ein Vortex nach Örsted's System, der sie fälschlich mit den augenlosen P1. vulva, viridata, punctata, confundirt: Entwurf u. S. w. S. 42), die ich in grosser Anzahl im Mai und Juni d. J. in einem Graben bei Greifswald sammelte, waren mit zahlreichen braunen Eiern versehen, und bei allen, die ich mikroscopisch untersuchte, fand ich eine kuglige Blase, mit lebhaft sich bewegenden Samenfäden gefüllt. Der gänzliche Mangel männlicher Tiere, das Vorkommen des Samens bei allen eiertragenden, möchte wenigstens für eine unbefangene Anschauung die Zwitterbildung hier wahrscheinlicher erscheinen lassen, als die Verteilung des männlichen und weiblichen Zeugungsapparats auf verschiedene Individuen. 
Zum Schluss noch eine zoologische Bemerkung. Bei Gelegenheit der Regenwürmer wird Rhynchelmis Limosella Hoffm. angeführt und als nicht gleich mit Euaxes filirostris Grube bezeichnet (S. 48). Hoffmeister selbst, mit welchem ich kurz vor dem Antritt seiner unglücklichen Reise, auf einer Exkursion von Berlin nach Tegel, seinen Rhynchelmis sammelte, hielt denselben für identisch mit Grube's Euaxes und auch ich habe keinen Unterschied gefunden zwischen diesen gewiss autentischen Exemplaren und Grube's Beschreibung. 


\title{
Zur Kenntniss des Furchungsprocesses im Schneckeneie ${ }^{1}$ ).
}

\author{
Mit Tafel II.
}

Van Beneden bemerkt in seiner Entwicklungsgeschichte der Aplysia depilans bei Gelegenheit des Furchungsprocesses: „En même temps que le vitellus ce divise, il sort de l'intérieur une vésicule blanche, contenant un liquide transparent, et qui va se perdre dans l'albumen. Cette vésicule est quelquefois suivie d'une seconde qui suit la même marche. Cette vésicule, simple ou double, sort de la même manière du vitellus des Limaces, et, d'après M. M. Dumortier et Pouchet, de Limnées. Comment faudrait-il la déterminer? Sa constance mérite une attention toute particulière." (Ann. des Sc. nat. II ${ }^{e}$ Sér. Zool. Tom. XV. I84 I p. I 26.)

Schon che mir diese früheren Beobachtungen zu Gesicht gekommen, war auch ich bei Untersuchungen über die Entwicklung einer kleinen Ostsceschnecke ${ }^{2}$ ), aus der Gruppe der Phlébentérés dermobranches von Quatrefages, auf ähnliche Bläschen und auf ihre Beziehung zum Furchungsprocess aufmerksam geworden. Die wichtige Rolle, die sie dabei spielten, liess mich ein allgemeineres Vorkommen derselben vermuthen, - eine Vermuthung, die durch die angeführte Stelle, wenigstens für die Gasteropoden, vollkommen bestätigt wurde. Um so mehr fühle ich mich veranlasst, durch baldige Publication der durch zahlreiche Beobachtungen gewonnenen Resultate die Aufmerksamkeit der Naturforscher auf diesen Gegenstand zu lenken, der für die Theorie des Fiurchungsprocesses von besonderer Wichtigkeit werden dürfte.

Das frisch gelegte Ei unserer Schnecke enthält im normalen Zustande (die nicht gar seltenen, namentlich für die Erklärung der Eischalenbildung be-

I) Archiv für Naturgeschichte, I848. I. p. I-6. Taf. I.

2) Das selten über 3-4"' lange Thierchen ist schon von O. F. Müller (Hist. verm. Vol. l. p. 2. I774. pg. 7o) als Fasciola capitata, später von O. Fabricius (Danske Vidensk. Selsk. naturvid. og math. Afhandl. Anden Deel. 1826. pg. 23 und Isis 1845. pg. 66) als Planaria limacina beschrieben. Von Johnston ist es (Lond. Mag. of Nat. Hist. IX. pg. 79), wie ich aus einem Citat in Oersted's Werk über Plattwürmer ersehe, schon richtig als Gasteropod erkannt und mit dem barbarischen Namen Lim a pontia (!) nigra belegt worden. Auf dem Greifswalder Museum hat diesen Hr. Dr. Creplin in den richtiger gebildeten Pontolimax (varians) ungewandelt. 
bemerkenswerthen Abweichungen sind hicr ohne Interesse) - ein bis drei eigelbe Dotter mit zarter Dotterhaut und meist noch mit nicht recht scharf umschriebenem hellen Fleck als Rest des Purkinjeschen Bläschens, um diese Dotter eine ziemlich dünne, trübe, nur wenig durchscheinende, anscheinend körnige Eiweissschicht, die von einer structurlosen, dünnen, durchsichtigen Schalenhaut umschlossen ist. Die Form des Eies ist durch den Druck der benachbarten mehr oder weniger unregelmässig.

Sofort nach dem Legen beginnt das Eiwciss durch Wasseraufnahme aufzuquellen; es wird durchsichtiger und zeigt sich aus kleinen, lose nebeneinander liegenden Zellen bestehend; bald lösen sich auch diese Zellen auf und eine ganz wasserhelle Schicht liegt zwischen dem Dotter und der Schale, die jetzt zu einem regelmässigen Ellipsoïd ausgedehnt ist, dessen grosse Achse 4 bis 6 mal den Durchmesser des sphärischen Dotters übertrifft.

Sobald das Eiweiss etwas durchsichtiger zu werden beginnt, - meist schon Io bis I5 Minuten nach dem Legen, - fällt in der Nähe des Dotters ein die Eiweisszellen an Grösse weit übertreffendes Bläschen in die Augen, gefüllt mit einer schwach gelblichen Flüssigkeit, in der wenig zahlreiche moleculare Körnchen schwimmen. Der Auflösungsprocess der Eiweisszellen beginnt fast constant an der von diesem Bläschen entferntesten Stelle des Eies und un das Bläschen herum sieht man, wenn er seinem Ende naht, die letzten Spuren der Eiweisszellen. - Der Furchungsprocess dagegen geht ohne Ausnahme aus von der dem Bläschen zugewandten Seite des Dotters, und da auch in seinem weitern Verlauf durch die Lage des Bläschens die Richtung der theilenden Furchen und der neu sich bildenden Furchungskugeln bedingt wird, mag dasselbe weiterhin mit dem Namen Richtungsbläschen, vesicula directrix, bezeichnet werden.

Zunächst nun zeigt sich (Fig. I), dem Richtungsbläschen zugewandt, ein hellerer Saum im Dotter; die Dottermasse zieht sich etwas von der Dotterhaut zurück (Fig. 3, a), ein ähnlicher Vorgang findet am entgegengesetzten Pole statt und bald wird eine den ganzen, nun mehr oder weniger in die Breite gezogenen Dotter durchsetzende Furche bemerklich (Fig. 2). Das Richtungsbläschen liegt in der die beiden so entstandenen Furchungskugeln trennenden Ebene oder derselben sehr nahe. Eine besondere Haut um die Furchungskugeln konnte ich noch nicht wahrnehmen, wohl aber meist, nahe der dem Richtungsbläschen zugekehrten Fläche, in jeder derselben einen helleren runden, besonders bei stärkerem Druck deutlichen Fleck. - Ob es Zufall, dass ich in den um diese Zeit und später untersuchten Eiern meist $\mathrm{z}$ wei kle inere Richtungsbläschen, in den früher untersuchten meist nur ein grösseres wahrnahm, oder ob auch dies Bläschen seinen Furchungsprocess hat, der sich aber auf ein einmaliges Zerfallen in zwei beschränken würde, oder ob endlich, wie Van Beneden annimmt, das zweite Bläschen während der Furchung de l'intérieur du vitellus aufsteigt, kann ich nicht bestimmt entscheiden.

Weiterhin finden sich die beiden Furchungskugeln, jede von einer besonderen Haut umschlossen und ohne gemeinsame Haut, meist soweit auseinanderweichend, dass sie nur eben sich berühren. Eine helle Stelle zeigt sich, dem Richtungsbläschen zugekehrt, in jeder Kugel (Fig. 3, b), und durch eine von dieser Stelle ausgehende neue Furche (Fig. 4) werden beide Kugeln halbirt und der Dotter ist so durch zwei aufeinander senkrechte Ebenen, in deren Durchschnittslinie die 
Richtungsbläschen liegen, in vier Kugeln zerklüftet. Diese vier Kugeln (Fig. 5) bieten sich der Beobachtung meist in einer auf der Sehaxe senkrechten Ebene liegend und verdecken dann natürlich die Richtungsbläschen (Fig. 5, a), wenn nicht eine Lücke zwischen ihnen dieselben gewahren lässt (Fig. 5, b); leichter fallen sie in die Augen, wenn, wie in seltneren Fällen (Fig. 5, c), die Ebene der Kugeln vertikal steht.

Die vier folgenden Furchungskugeln entstehen nicht durch ein Zerfallen der vier erst gebildeten in gleiche Theile, sondern zeigen sich anfangs als kleine, fast ganz wasserhelle, nur wenig Dotterkörperchen enthaltende Bläschen, die mit den älteren abwechselnd an der den Richtungsbläschen zugewandten Seite derselben hervortreten (Fig. 6, $a, b$ ), allmählich mehr Dottermasse in sich aufnehmen und auf der älteren Kosten zu einer diesen gleichen Grösse heranwachsen (Fig. 7). Wie sie aus denselben hervorgehen und während ihres Wachstums mit denselben zusammenhängen, ist mir nicht klar geworden. Ihre mit den älteren alternirende Lage wird besonders deutlich, wenn man Eier, deren vier Furchungskugeln, wie meist der Fall, in einer horizontalen Ebene liegen, (am besten nach vorherigem Betupfen mit Weingeist) stärker presst (Fig. 6, c).

Für den weiteren Verlauf des Furchungsprocesses, der, wie von den Schnecken bekannt, bis zur Umwandlung des Dotters in eine Kugel mit wieder fast glatter Oberfläche fortschreitet, habe ich die Beziehung der Richtungsbläschen zur Lage der neuen Furchungskugeln noch nicht specieller nachzuweisen vermocht; die Verhältnisse werden durch die grössere Zahl der Furchungskugeln zu complicirt. Im Allgemeinen jedoch ist auch jetzt noch ihr Einfluss nicht zu verkennen (cf. Fig. 8). - Nach Ablauf des Furchungsprocesses ist die erste weitere Erscheinung das Auftreten zarter Flimmercilien an der einen (vorderen) Hälfte des noch kugligen Embryo und die damit beginnende Bewegung desselben. Bei Embryonen, deren Bewegung noch eine sehr langsame war und nur in leichten Schwankungen, noch nicht in vollständiger Drehung bestand, fand ich die Richtungsbläschen meist in der Nähe des vorderen bewimperten Theiles, so dass also dieser Theil, das Kopfende, dem Ausgangspunkte der Furchung zu entsprechen scheint. Sobald die Bewegungen des Embryo einigermassen lebhaft werden, kann natürlich die Lage der Richtungsbläschen keine constante mehr bleiben; sie scheinen jedoch bis zum Ausschlüpfen der (wie bei Doris, Aplysia etc.) mit nautilusartiger Schale und Deckel versehenen, mittelst der langen Wimpern des grossen zweilappigen Mundsegels sehr hurtig umherschwimmenden Jungen unverändert sich zu erhalten.

Dies das Verhältniss der Richtungsbläschen zum Furchungsprocess und ihre muthmassliche Beziehung zur Bildung des Embryo. - Welches aber ist nun ihre eigentliche Bedeutung? Wo und wie entstehen sie und welchen Zusammenhang haben sie mit den frühern Vorgängen der Zeugung? - Noch bin ich zu keinem Resultate darüber gelangt, (was überhaupt leichter an Schnecken, die nicht durch ihre Kleinheit die Zergliederung erschweren, zu gewinnen sein wird) und kann nur zwei vereinzelte Beobachtungen anführen, die kaum eine Vermuthung in dieser Hinsicht auszusprechen berechtigen. - Das eine Mal nämlich vermisste ich bei Untersuchung einer kürzlich gelegten, ausnahmsweise kleinen Eierschnur in allen Eiern das Richtungsbläschen in seiner gewöhnlichen Form, fand dagegen in einem einzigen $\mathrm{Ei}$ ein ähnliches Bläschen, anscheinend etwas grösser und mit langen 
Wimpern besetzt, durch die es die benachbarten Eiweisszellen in einen lebhaften Strudel versetzte. Der Dotter erschien homogen, ohne Spur von Purkinje'schen Bläschen oder von beginnender Furchung. In einem Theile dieser Eierschnur, der erst nach 24 Stunden untersucht wurde, war noch keine Veränderung der Dotter eingetreten, während sonst in Tagesfrist der Furchungsprocess fast beendigt zu sein pflegt (bei einer Temperatur von durchschnittlich $+20^{0} \mathrm{R}$.). War dies bewimperte Bläschen ein früherer Entwicklungszustand der Richtungsbläschen, und fehlten diese vielleicht eben deshalb, weil sie noch nicht zur nöthigen Reife gelangt, in den übrigen Eiern?

Ganz ähnliche Bläschen, eine leicht gelbliche Flüssigkeit mit einzelnen kleinen Körnchen umschliessend wie die Richtungsbläschen, aber mit langen Wimpern besetzt und durch diese in rascher drehender Bewegung, beobachtete ich ein zweites Mal in grosser Menge, als ich einen Theil des Geschlechtsapparats, die Theilungsstelle des Ausführungsgangs der Zwitterdrüse in Eileiter und Samengang mit mehreren in deren unmittelbarer Nähe einmündenden Nebenorganen, unter das Microscop gebracht, in der aus diesen Theilen ausgetretenen Flüssigkeit. In welchem Theile des gerade an dieser Stelle sehr complicirten Apparates sie enthalten gewesen, konnte ich nicht ermitteln; später habe ich sie noch nicht wieder gefunden.

Es liegt nahe, bei den langen Wimperfäden dieser Bläschen an die bei unserer Schnecke einfach fadenförmigen, freilich mindestens noch 3 bis 4 mal so langen Spermatozoïden zu denken. - Doch, es wird gerathener sein, vor der Hand und bis genügendere Anhaltspunkte vorliegen, auf alle theoretisirenden Betrachtungen zu verzichten.

\section{Erklärung der Abbildungen auf Tafel II.}

Von den beigegebenen Figuren sind Fig. I-8 unmittelbar aus dem Text klar. In allen sind die Richtungsbläschen durch $a$ bezeichnet; wo sie in der Zcichnung fehlen, werden sie durch den Dotter verdeckt. - Fig. 3 stellt zwei in einer Eierschnur nebeneinander gefundene Eier dar, das eine $(a)$ mit zwei Dottern im Beginn der Furchung, das andere $(b)$ mit einem einzelnen schon in zwei Furchungskugeln zerfallenen Dotter; beachtenswert ist, wie ausser der Grösse auch die Lage der Richtungsbläschen und der hellen Stelle des Dotters sie unterscheidet. - Die Figuren 6, c sind nach mit Weingeist betupften, stärker gepressten Eiern gezeichnet; daher auch die schärfere Umgrenzung der hellen Flecken der Kugeln.

Fig. 9-12 geben eine schematische Darstellung des Furchungsprocesses in seiner Beziehung zu den Richtungsbläschen. Denkt man sich nämlich durch die Mitte des Dotters ein rechtwinkliges Coordinatensystem der $x y z$ so gelegt, dass die Axe der $z$ durch das (hier als stets einfach angenommene) Richtungsbläschen geht und die Ebene der y'z dic erste Furchungsebene bildet, so geben die Fig. a die Projection des Dotters und Bläschens auf die Ebene der $x y$, die Fig. b auf die Ebene der $x z$, die Fig. c auf dic Ebene der $y z$, die Fig. d auf eine durch die Axe cler $z$ gehende Ebene, welche den rechten Winkel zwischen den Ebenen der $x z$ und $y z$ halbirt; und zwar entspricht Fig. 9 den in Fig. I, Fig. Io dem in Fig. 3, b, - Fig. I I dem in Fig. 5, Fig. I 2 endlich dem in Fig. 6 dargestellten Zustande des Dotters. 


\section{Orchestia Euchore und Gryphus, neue Arten aus der Ostsee ${ }^{1}$ ).}

Mit Tafel III.

Die Gattungen Talitrus und Orchestia bilden eine durch mehrfache Eigenthümlichkeiten des Baues und der Lebensweise ausgezeichnete Gruppe der Familie der Gammarinen, deren Arten vorzugsweise wärmeren Meeren anzugehören, in den arktischen Gewässern, der eigentlichen Heimath der typischen Gammarinen, dagegen ganz zu fehlen scheinen ${ }^{2}$ ).

In Bezug auf diese geographische Verbreitung der Gruppe, zugleich als Beitrag zur Kenntniss der heimischen Fauna, mag die Entdeckung zweier neuen Ostsee-Arten nicht ohne Interesse sein. Ueberdies sind dieselben auch in systematischer Hinsicht bemerkenswerth. Während nämlich die genannten beiden Gattungen in der Kürze der obern Antennen, im Bau der Mundtheile (Mangel des Mandibularpalpus u.s.w.), in der Grösse des fünften Epimerienpaares, in der Weise der Bewegung, zahlreiche gemeinsame Abweichungen darbieten von dem gewöhnlichen Verhalten der Gammarinen, werden sie bekanntlich von einander einzig durch das bei Orchestia mit grossen Händen versehene zweite Fusspaar unterschieden. Dass nun auch dies Merkmal keinen Gattungsunterschied begründen könne, dafür liefern die beiden zu beschreibenden Arten einen neuen Beleg, indem danach bei ihnen wie bei Orchestia platensis Kr., die Männchen zu Orchestia, die Weibchen zu Talitrus gestellt werden müssten. Einstweilen mögen sie, nach Kröyer's Vorgang, als Orchestien beschrieben werden.

Orchestia Euchore (Fig. I) ist von ziemlich schlanker Gestalt, mässig von den Seiten zusammengedrückt, von schmutzig bräunlicher Farbe und gegen 5 " lang.

Der Kopf ist, wie gewöhnlich, mässig gross ohne vorspringende Stirn, mit runden, ansehnlichen, schwarzen, dem Scheitel sehr nahestehenden, etwa um die

I) Archiv für Naturgeschichte. 1848. p. 53-64. Taf. IV.

2) Unter den zahlreichen von $\mathrm{K}$ röyer beschriebenen grönländischen Amphipoden findet sich kein Thier dieser Gruppe; eine einzige Art, Orch. mudrosiensis Kr., durch den Bau der Antennen und Kieferfüsse schon an Gammarus sich annähernd, ist von der an Gammarinen so reichen norwegischen Küste bekannt geworden; dagegen sind z. B. aus Aegypten unter 5 Gammarinen 2 Orchestia und I Talitrus, aus Südamerika unter ebenso viel 3 Orchestien, aus Neuholland und Neuseeland I Amphithoe, I Orchestia und I Talitrus beschrieben. 
Breite ihres Durchmessers von einander entfernten A ugen; der Rücken glatt; die Epimerien gross, das erste Paar kürzer und besonders schmäler, das fünfte, unten tief ausgerandete, weit breiter als die dazwischenliegenden; das sechste und siebente klein; alle am unteren Rande kurz und schwach bewimpert.

Die obern Antennen, etwa von der Länge des Kopfes, reichen bis zum Ende des vorletzten Stielgliedes der unteren; ihre 5 gliedrige Geissel ist fast ebenso lang als der 3gliedrige Stiel.

Die untern Antennen erreichen etwa $1 / 3$ der Körperlänge; Stiel und Geissel sind gleich lang, letztere besteht aus I6-18 Gliedern, von denen das erste doppelt so lang als die folgenden. Kurze Borsten finden sich am Ende der Geisselglieder und zerstreut längs der ganzen Stielglieder.

Die Mundtheile zeigen nichts Besonderes: die Mandibeln (Fig. 2) ziemlich dick, ohne alle Spur eines Palpus, an der einwärts gebogenen Spitze in mehrere hornige Zacken gespalten, darunter an der Innenseite sechs kurzgefiederte Borsten; unter diesen eine ansehnliche gefurchte Kaufläche; die Unterlippe (Fig. 3) fast bis auf den Grund gespalten; des ersten Maxillenpaares (Fig. 4) äussere Platte an der Spitze mit 8 bis 9 starken, an der Innenseite stumpf gezälnnten hornigen Dornen, die schmale innere Platte mit zwei einwärts gebogenen Federborsten; eine lange Federborste an der Innenseite der innern Platte des $z$ weiten Maxillenpa a res (Fig. 5); der Palpus der Kieferfüsse (Fig. 6) kurz, mit kurzem abgerundeten Endgliede.

Die Füsse des ersten Paares sind ziemlich schwach; das vierte Glied derselben nach dem Ende stark verbreitert, (von dreieckiger Form), am unteren hintern Winkel mit starken Borsten bewaffnet und beim $\delta$ mit einem häutigen Saum eingefasst; das fünfte Glied ist beim đo nach dem Ende verbreitert, unten gerade abgeschnitten, am hintern Rande mit einem häutigen Saum eingefasst (Fig. 7), beim 우 von gleichmässiger Breite, ohne häutigen Saum, doch mit etwas stärkeren Borsten längs des hinteren Randes (Fig. 9). Die starke wenig gekrümmte Klaue (Fig. 8), deren Basis die halbe Breite vom untern Rande des 5ten Gliedes einnimmt, ist anscheinend zweigliedrig und trägt etwa in der Mitte ihres Innenrandes zwei kurze dünne etwas gebogene Dornen.

Die Füsse des zweiten Paares sind durchweg bei beiden Geschlechtern verschieden. Die der Männchen (Fig. Io) sind kräftige Greiffüsse; das erste Glied von ziemlich gleichmässiger Breite; die drei folgenden, besonders das vierte, sehr kurz; das 5te von sehr ansehnlicher Grösse, elliptisch (Breitc zur Länge etwa wie $3: 4$ ), mit schiefem, mässig convexen mit kurzen Borsten besetzten unteren Rande und einem kleinen abgerundeten Vorsprung an dessen hinteren Ende. Die kräftige Klaue, von derselben Krümmung wie der untere Rand des fünften Gliedes, und längs des Innenrandes einzelne sehr kurze fast haarförmige Borsten tragend, reicht bis $\mathrm{zu}$ dem erwähnten Vorsprung.

Das zweite Fusspaar der Weibchen (Fig. ${ }^{3}$ ) ist dünn und schwach; das erste Glied ist blattförmig verbreitert, nach der Spitze stark verschmälert, mit vorderem convexen gewimperten und hinterem geraden Rande; das vierte und fünfte von ziemlich gleicher Grösse; und Form, nach unten stark verbreitert mit einem häutigen Saum längs des Hinterrandes. Am Ende des vorderen geraden Randes des fünften Gliedes (Fig. I4) ist die kurze ziemlich stark gekrümmte 
Klaue inserirt; sie reicht bis zum Ende eines von ihrer Basis schief nach unten und hinten gerichteten geraden, dicht und kurz bewimperten Randes, und wird überragt durch das abgerundete Ende des häutigen Saumes, der den längeren convexen hinteren Rand einfasst. Die Seiten dieses Gliedes tragen längs der Grenze des häutigen Saumes mehrere Reihen dünner Borsten. - Das gegenseitige Verhältniss der 5 Fussglieder und der Klaue dieses Paares ist beim Männchen ungefähr wie

beim Weibchen, wie

$$
10: 3: 3: 2: 15: 10
$$

$$
9: 4: 3: 5: 5: 1 \text {. }
$$

Diese auffallende Geschlechtsverschiedenheit ist indess um so weniger ausgeprägt, je jünger die Thiere sind; noch bei einem Männchen von 3/4 der Länge des Erwachsenen, welches 4 Geisselglieder an den oberen, 13 an den unteren Antennen besass, war die Hand (Fig. 12 ) auffallend klein; bei einem anderen von der halben Länge des Erwachsenen, mit 3 Geisselgliedern der oberen, 12 der unteren Antennen, stand auch die Form der Hand (Fig. 11) so in der Mitte zwischen der männlichen und weiblichen Bildung, dass danach allein das Geschlecht nicht zu erkennen gewesen wäre.

Die übrigen Fusspaare zeigen nichts Auffallendes, als dass beim Männchen das dritte und vierte Glied des siebenten Paares verdickt sind (Fig. I, $a$ ), während beim Weibchen dies Paar dem sechsten ganz gleich gebildet ist. Die Längenverhältnisse der 7 Fusspaare sind annähernd folgende:

$$
9:\left\{\begin{array}{l}
15, \text { ठ } \\
11, \text { o }
\end{array}\right\}: 14: 12: 13: 18:\left\{\begin{array}{l}
21, \text { ठ } \\
16, \text { o }
\end{array}\right\}
$$

Die Kiemen des ersten Paares (Fig. I3, b), am Grunde des zweiten Fusspaares befestigt, sind lang und schmal, 4-5mal so lang als breit, und w urm förmig gebogen; die übrigen vier Paare (Fig. 15) weit kürzer und von ovaler Gestalt; alle mit einzelnen sehr zarten krausen Haaren besetzt.

Die Eierplatten der Weibchen, am Grunde des zweiten bis fünften Fusspaares sind lang, schmal, am Rande lang gewimpert; sie nehmen, bei ziemlich gleicher Breite, der Reihe nach an Länge ab, so dass die erste (Fig. 13,c) gegen $4 \mathrm{mal}$, die letzte nur doppelt so lang als breit ist.

Die Schwimmfüsse sind schmächtig; das Basalglied, besonders des ersten Paares, weit länger als die aus gegen 8 Gliedern bestehenden, mit wenigen kurz und fein gefiederten Borsten besetzten Aeste.

Von den drei letzten Afterfusspaaren, den Springfüısen, ist das erste bei weitem das längste, das dritte (Fig. 16) sehr kurz mit einem einzigen konischen Endgliede. - (Das Verhältniss dieser drei Fusspaare ist etwa $8: 5: 2$ ).

Es ist endlich ein einziger Schwanzanhang (Fig, I 7) vorhanden, eine ziemlich dicke, in der Mitte seicht ausgerandete Platte, die jederseits am Ende sowohl als auf der obern Fläche mit drei Dornen bewaffnet ist.

Zunächst verwandt mit der eben beschriebenen Art ist die Orchestia platensis Kr. ${ }^{1}$ ) von Montevideo, unterschieden jedoch durch die nur 14 gliedrige Geissel der unteren Antennen, durch die elliptischen Augen, die unbewaffnete Klaue des

1) Kröyer's Naturhistorisk Tidsskrift. Ny Räkke. Bd. I. Iff 3. 1844. p. 304 . 
ersten Fusspaars, den abgestutzten nicht ausgerandeten, mit nur ro Borsten besetzten Schwanzanhang. Von dem Männchen unterscheidet sich ferner Orch. littorea Leach durch die fast rudimentäre Klaue des ersten Fusspaares; von dem Weibchen Talitrus saltator Edw. durch das weit kräftigere erste Fusspaar, durch das nach dem Ende verdünnte 5te Glied desselben, dessen ganzen Endrand die Klaue einnimmt, durch Form und Grössenverhältniss der letzten Glieder des zweiten Fusspaares u. S. w., T. Beaucoudraii Edw. durch die das Ende des fünften Gliedes überragende Klaue des zweiten Fusspaares.

Ich fand die Orchestia Euchore an der Ostküste Rügens, an dem steinigen Strande zwischen Sassnitz und Stubbenkammer, in immenser Häufigkeit. Wo nur irgend zwischen den Steinen, sicher vor den Wellen des Meeres, unter einer Decke von Laub oder Tang ein feuchtes Plätzchen sich fand, da sah man, sobald man die Decke hob, hunderte nach allen Seiten mit ungemeiner Behendigkeit in grossen Sätzen davonspringen und kaum hatte man ein Thier gefasst, so war auch schon der ganze Schwarm in die Spalten des umliegenden Gerölles verschwunden.

Orchestia Gryphus (Fig. I 8) ist im Habitus dem Talitrus saltator Edw. sehr ähnlich, von mehr gedrungenem Bau als O. Euchore, wenig seitlich zusammengedrückt, von blassgelblicher Farbe, glänzend glatt und gegen $4^{\prime \prime}$ lang.

Der Kopf ist mässig gross, ohne vorspringende Stirn, mit runden schwarzen Augen, die etwa um das Doppelte ihres Durchmessers von einander entfernt stehen; der Rücken glatt; die Epimerien, wie bei O. Euchore, der vordere untere Rand des ersten besonders stark bewimpert.

Die oberen Antennen sind etwas kürzer als der Kopf; der dreigliedrige Stiel, dessen mittelstes Glied das bei weitem längste, ist über doppelt so lang, als die 6gliedrige Geissel. Die unteren Antennen des Männchens erreichen etwa die Hälfte der Körperlänge; das erste und zweite Glied des Stieles sind sehr kurz; das vierte, leicht nach unten gekrümmt, bildet reichlich die Hälfte des ganzen Stiels und ist von ungefähr gleicher Länge mit der aus 20 Gliedern bestehenden Geissel. Die Borsten an den Seiten der Stiel- und am Ende der Geisselglieder sind sehr kurz. Beim Weibchen $\left.{ }^{1}\right)$ sind die unteren Antennen weit kürzer, zeigen jedoch dasselbe gegenseitige Verhältniss der einzelnen Stielglieder und des Stiels zur Geissel; - sie erreichen nur 1/5 der Körperlänge (?).

Die Mundtheile zeigten sich nur durch die weit stärker vorspringende Kaufläche der Mandibeln, über welcher nur vier Federborsten gezählt wurden, von denen der O. Euchore verschieden.

Das erste Fusspaar des Männchens (Fig. 19) ist von mässiger Grösse; das erste Glied lang, mit vorderem geraden, hinterem etwas convexen Rande, wenig nach dem Ende zu verbreitert; die beiden folgenden kurz; das vierte nach dem Ende zu stark verbreitert; das fünfte etwas kürzer als das vorhergehende,

I) Ich muss bemerken, dass das einzige Weibchen, welches sich unter meinen Exemplaren befand, noch nicht völlig ausgewachsen war; die Grösse differirte nicht inerklich von der des ausgewachsenen Männchens, doch hatte die Geissel der unteren Antennen nur 15 Glieder und die Eierplatten waren in einem noch sehr unentwickelten Zustande. Uebrigens pflegt ja in unserer Familie die relative Länge der Antennen, im Verhältniss zum Körper, von Alter ziemlich unabhängig zu sein, inindestens nicht mit der Zunahme der absoluten Länge und der Gliederzahl in gleichem Masse zu wachsen. 
gleichmässig breit; alle am hintern Rande mit ziemlich starken Borsten bewaffnet; das vierte und fünfte am hinteren unteren Winkel mit kleinen abgerundeten häutigen Vorsprüngen versehen; die Klaue (Fig. 20) stark, halb so lang als das fünfte Glied, anscheinend zweigliedrig mit einem kleinen gekrümmten Dorn in der Mitte des Innenrandes. - Beim W eibchen zeigte dieses Fusspaar eine ganz gleiche Bildung; nur wurden (vielleicht als blosse Altersdifferenz) die häutigen Vorsprünge am 4ten und 5 ten Gliede und der Dorn an der Klaue vermisst.

Die Füsse des zweiten Paares sind beim Männchen (Fig. 2 I) kräftige Greiffüsse von sehr charakteristischer Form: das erste Glied ist lang, ziemlich schmal und gleichmässig breit; das zweite und das knieförmig gebogene dritte kurz; das vierte bildet nur einen schmalen Wulst an der Basis des sehr grossen fünften; dies ist sehr breit und theilt sich in einen dickeren und längeren vorderen (oder oberen) und einen kürzeren, schmäleren, in eine scharfe Spitze auslaufenden hinteren (oder unteren) Ast, die einen Winkel von ungefähr $45^{\circ}$ einschliessen. Im Grunde des zwischen beiden Aesten liegenden tiefen Ausschnittes findet sich ein kleiner flach gewölbter Vorsprung. An der Spitze des vorderen Astes inserirt sich die starke, schwach und besonders nur nach der Spitze zu gebogene Klaue, die nicht völlig bis zur Spitze des hinteren Astes reicht und längs des Innenrandes einzelne sehr kurze, feine Borsten trägt, während der ihr gegenüberliegende Rand des vorderen Astes mit etwas stärkeren Borsten besetzt ist. - Das zweite Fusspaar des Weibchens (Fig. 22) hat grosse Aehnlichkeit mit dem der Orch. Euchore; nur ist das erste Glied weniger blattförmig erweitert und hat den vorderen und hinteren Rand in gleicher Weise gebogen; das vierte Glied ist etwas länger als das fünfte, hat seine grösste Breite nahe der Basis und zeigt hier am hintern Rande einen starken, gerade abgestutzten Vorsprung; das fünfte Glied mit der Klaue (Fig. 23) ist ganz wie bei Orch. Euchore gebildet, nur wurden ein paar stärkere Borsten am Ende des der Klaue gegenüberliegenden schiefen Randes, die dort sich finden (cf. Fig. 14), hier vermisst.

Die übrigen Füsse sind von gewöhnlichem Bau; das sechste und siebente Paar von fast gleicher Länge und auch beim Männchen von gleicher Form, ohne Verdickung des dritten und vierten Gliedes am siebenten Paare. - Die Längenverhältnisse der Füsse sind annähernd (beim ठ), wie:

$$
\text { I0: I I : I } 2: \text { I0: } 9: \text { i } 5: \text { I } 5 \text {. }
$$

Die Kiemen des ersten Paares (Fig. 24) sind wie bei Orch. Euchore lang, schmal, wurmförmig gebogen; die des zweiten und dritten (Fig. 25) kürzer und breiter, doch noch etwas gebogen; die des vierten und fünften Paares (Fig. 26) endlich einfach oval.

Die Schwimmfüsse sind mässig stark, alle drei Paare von fast gleicher Länge; die Basalglieder etwas kürzer (etwa um 1/5) als die aus ungefähr einem Dutzend Gliedern bestehenden mit Federborsten besetzten Aeste.

Die drei Springfusspaare (Fig. 27) stehen etwa in dem Verhältniss von $4: 2: 1$; das Basalglied des ersten verhält sich zu dessen äusserem und innerem Aste, wie $5: 4: 3$; beim zweiten sind Basalglied und äusserer Ast gleich lang, wenig länger als der innere Ast; das letzte (Fig. 28) trägt auf einem dicken konischen Basalglied ein einziges weit schmäleres, an Länge diesem ziemlich gleiches Endglied. 
Der Schwanzanhang bildet eine einzige, dicke, seicht ausgerandete Platte von der Länge der letzten Springfüsse, mit sechs Borsten an seinem Ende und gegen 10 an seiner oberen Fläche.

Das Männchen der Orchestia Gryphus unterscheidet sich von allen bei Edwards (Hist. nat. des Crust. III. p. 15) aufgeführten Arten dadurch, dass nicht, wie dort als allgemeines Merkmal hingestellt wird, die Füsse des ersten Paares eine kleine unvollkommen scheerenförmige Hand besitzen, sondern einfache Geh- oder Grabfüsse sind. Auch sonst ist unter allen beschriebenen Arten nur die ägyptische O. Deshayesii A ud. ähnlich, und zwar nach der kurzen von Edwards gegebenen Beschreibung in hohem Grade. - Das Weibchen unterscheidet sich von Talitrus saltator Edw. durch das bei weitem schwächere erste Fusspaar, von T. Beaucoudraii Edw.. wie Orch. Euchore.

Von Orchestia Gryphus wurden nur wenige Exemplare an der Ostküste Rügens, an dem sandigen Gestade zwischen dem Peerd (auf Mönchgut) und dem Kieköwer gefunden in Gesellschaft des dort sehr häufigen Talitrus saltator.

Eine genügende Diagnose unserer beiden Arten aufstellen zu wollen, würde vergeblich sein, bevor eine kritische Revision der bisher beschriebenen Talitrus und Orchestia stattgefunden; manches, was in den vorhandenen Beschreibungen als oft fast einziges Art-, selbst als Gattungsmerkmal betrachtet wird, - Länge der unteren Antennen, Bildung der ersten beiden Fusspaare, Verdickung des siebenten Fusspaares, - mag auch hier als blosser Geschlechtsunterschied sich herausstellen. Es genüge einstweilen für die drei Arten, deren auffallende Geschlechtsdifferenz bis jetzt bekannt ist, und die später wahrscheinlich in eine eigene Gattung vereinigt werden müssen, die wichtigsten sowohl gemeinschaftlichen als unterscheidenden Merkmale hervorzuheben:

Orchestia platensis, Euchore et Gryphus inter se conveniunt:

Antennis sup. capitis longitudinem haud aut vix superantibus; mandibulis palpi ne vestigio quidem gaudentibus; maxillarum paris Ii lamina interna angusta setis pinnatis curvatis duabus instructa; palpi pedum maxillarium articulo ultimo brevi lato rotundato; pedibus II paris in of manu valido instructis, in $ᄋ$ debilibus, ungue exiguo articuli $\mathrm{Vi}$ foliaceo-dilatati, cujus margini anteriori inseritur, apicem haud superante praeditis; branch is $\mathrm{I}^{\mathrm{i}} \mathrm{p}$ aris angustis elongatis flexuosis; pedibus saltatoriis paris ultimi exiguis conicis, stylo terminali unico donatis; 1 a mina caudali unica crassiuscula, spinis ornata.

Differunt :

Orchestia platensis $\mathrm{Kr}$.

Antenn is su perioribus caput longitudine aequantibus aut vix superantibus; antennis inf. vix tertiam corporis partem longitudine aequantibus, pedunculo flagellum I 4 articulatum parum excedente; oculis ellipticis; primi pedis articulo quinto apicem versus in o dilatato, haud dilatato in + , ungue valido inermi; manu pedis secundi in $\delta$ lata ovali; pedis septimi articulo quarto in $\delta$ incrassato, in o gracili; la mina caudali truncata; longitudine linearum 6 .

Orchestia Euchore F. Müll.

Antennis superioribus caput, inferioribus tertiam corporis partem, harum pedunculo flagellum 18 articulatum longitudine aequantibus; oculis rotundis; primi pedis articulo quinto apicem versus in $\delta$ dilatato, haud dilatato in , 
ungue valido spinulis duabus in margine interiore armato; manu pedis secundi in o ovali; pedis septimi articulo quarto in $\delta^{*}$ incrassato, in g gracili; 1 a mina c a ud ali emarginata; long. 5 "'.

Orchestia Gryphus F. Müll.

Antennis sup. capite brevioribus; inferioribus in $\delta$ dimidiam, in 우 quintam (?) corporis partem longitudine aequantibus, flagello 20 articulato pedunculi dimidiam subaequante; oculis rotundis; primi pedis articulo quinto nec in $\sigma^{\prime \prime}$, nec in + dilatato, ungue valido spinula unica in margine interiore armato; manu pedis secundi lata, incisura profunda in ramos duos divisa, anteriorem longiorem latiorem unguigerum, posteriorem acuminatum; pedis septimi articulo quarto in utroque sexu gracili; lamina caudali emarginata; long. ${ }^{\prime \prime \prime}$.

\section{Bemerkungen zu Zaddach's Synopseos Crustaceorum Borussicorum prodromus ${ }^{1}$ ).}

I. In dem Gattungscharakter von Leptocheirus ist (1. c. p. 7) der Mangel der Nebengeissel an den obern Antennen aufgenommen. Eine solche ist aber bei L. pilosus Zadd., der einzigen, im Greifswalder Bodden nicht eben seltenen Art, in der That vorhanden, wenn auch in sehr rudimentärem Zustande, reducirt auf ein einziges kleines Glied, welches kaum die halbe Breite und $1 / 2$ bis $3 / 4$ der Länge des ersten Geisselgliedes erreicht und an der Spitze mehrere Borsten trägt, unter denen in der Regel eine, oft das zweite Geisselglied überragend, durch Länge sich auszeichnet. Da diese winzige Nebengeissel meist an der innern Seite des ersten Geisselgliedes verborgen liegt, würde sie leicht der Aufmerksamkeit entgehen, wenn dieselbe nicht durch die an der Seite dieses Gliedes hervortretenden Endborsten derselben darauf hingelenkt würde.

2. Die Jaera der Ostsee, die von Zaddach (1. c. p. I I) als J. Kröyerii Edw. ausführlicher beschrieben wird und die ebenfalls im Greifswalder Bodden und an der Rügenschen Küste unter Steinen einzeln vorkommt, kann ich nicht für die genannte Art halten.

Milne Edwards sagt nämlich von seiner Jaera Kröyerii (Hist. nat. des Crust. III. p. I49): „corps très-étroit; ... l'abdomen se termine par un petit prolongement scutiforme de chaque côté duquel est une échancrure semicirculaire où s'insèrent les dernières fausses pates." - Unsere Jaera dagegen ist nur kaum dreimal so lang als breit und eine solche schildförmige Verlängerung des Hinterleibes fehlt ihr; im Gegentheil zeigt das Ende desselben (Fig. 29), wie auch Zaddach richtig angiebt, einen breiten mehr oder weniger tiefen Ausschnitt, in welchem die styli caudales liegen.

I) Archiv für Naturgeschichte. 1848. I. p. $62-64$. 
Diese Unterschiede berechtigen wohl, sie als eigene Art zu betrachten, die sich von Jaera Kröyerii durch die angegebene Abweichung im Bau des Hinterleibes und den breiteren Körper, und wie diese von J. nivalis Kr. durch die Länge der äussern Antennen, von J. albifrons Leach durch die von einander weit entfernten Augen unterscheidet. Sie giebt ein neues Beispiel für die Eigenthümlichkeit der Crustaceenfauna der Ostsee und mag den Namen Jaera baltica führen.

\section{Erklärung der Abbildungen auf Tafel III.}

Fig. I. Orchestia Euchore ơ, dreimal vergrüssert.

Fig. 2. Mandibel derselben.

Fig. 3. Unterlippe.

Fig. 4. Erste Maxille.

Fig. 5. Zweite Maxille.

Fig. 6. Kieferfüsse.

Fig. 7. Erstes Fusspaar des $\delta$.

Fig. 8. Klaue desselben, mehr vergrössert.

Fig. 9. Die letzten Glieder desselben Fusspaares vom ㅇ.

Fig. IO. Zweites Fusspaar des $\delta$.

Fig. II u. I 2. Dasselbe von jüngeren Männchen.

Fig. I3. Dasselbe vom Weibchen; $a$ epimerum, $b$ erste Kieme, $c$ Eierplatte.

Fig. I4. Dieses Fusses fünftes Glied mit der Klaue, stärker vergrössert.

Fig. 15. Kieme des zweiten Paares.

Fig. I 6. Letztes Hinterleibsfusspaar.

Fig. I 7. Schwanzanhang, von oben.

Fig. I 8. Orchestia Gryphus đే, viermal vergrössert.

Fig. I 9. Erstes Fusspaar des $\delta$.

Fig. 20. Dessen Klaue, stärker vergrössert.

Fig. 2 I. Zweites Fusspaar des $\delta$.

Fig. 22. Dasselbe vom ?.

Fig. 23. Dieses Fusses fünftes Glied mit der Klaue, stärker vergrössert.

Fig. 24. Kieme des ersten,

Fig. 25. des zweiten,

Fig. 26. des fünften Paares.

Fig. 27. Die drei letzten Hinterleibssegmente.

Fig. 28. Letztes Hinterleibsfusspaar, mehr vergrössert.

Fig. 29. Hinterleib der Jaera baltica, von oben. 


\section{Ueber die Begattung der Clepsine complanata Sav. $\left.{ }^{1}\right)$.}

(Glossiphonia sexoculata Moq. Tand. Monogr. ed. 2.)

Die älteste Beobachtung über die Begattung der Clepsinen scheint in folgender paradox klingenden Mittheilung von Henle (Müll. Arch. r 837.p. 88)

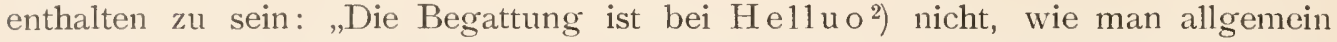
nach der Analogie des medicinischen Blutegels annimmt, eine gegenseitige, sondern ein Individuum spielt die Rolle des Männchens, das andere die des Weibchens. Der doppelte Penis des Männchens, nur zur Begattungszeit sichtbar, sitzt auf der linken Seite des Rückens, etwas weiter nach hinten, als die gewöhnlich sogenannte weibliche Geschlechtsöffnung am Bauche; er wird in die vordere am Bauche gelegene Geschlechtsöffnung des anderen Thieres, die nach Moquin Tandon als männlich gilt, eingeführt. Dieses, das Weibchen, hat aber auch nicht selten einen doppelten, dem Rückenpenis des Männchens ganz ähnlichen Penis am Bauche ganz umsonst hervorgestreckt, vor der Oeffnung, welche den Rückenpenis des Männchens aufnimmt. Die inneren Geschlechtstheile beider in der Begattung begriffenen Thiere enthalten aber sowohl Eier, als bewegliche Fäden." - Scheint nicht diese Darstellung Allem, was wir über den Bau der Clepsinen wissen, geradezu Hohn zu sprechen? Es sind zwei Geschlechtsöffnungen in der Mittellinie der Bauchfläche vorhanden, von denen die vordere mit aller Bestimmtheit als männliche, die hintere als weibliche anzusprechen ist: mit der Rückenfläche stehen die inneren Geschlechtstheile in keinerlei Verbindung; das Thier zeigt in allen seinen Organen vollkommene seitliche Symmetrie; - und nun soll links auf dem Rücken ein Penis hervortreten, um in die vordere männliche Geschlechtsöffnung eines anderen Individuums eingeführt zu werden, während oft dies andere als Weibchen fungierende Individuum einen ähnlichen Penis „ganz umsonst" am Bauche vor der männlichen Geschlechtsöffnung hervorstreckt! - Dass trotz alledem Henle, wenn er auch das Gesehene falsch deutet, wenigstens richtig gesehen, wird das Folgende ergeben.

Eine weitere Mittheilung über die Begattung der Clepsinen, nach im Frühjahr 1844 angestellten Beobachtungen, gab ich selbst in meiner Inauguraldisser-

I) Zeitung für Zoologie, Zootomie und Palaeozoologie von E. D'Alton und H. Burmeister. I849. I. p. 197 - 199.

2) Die Gattung Helluo Ok. umfasste bekanntlich Nephelis und Clepsine Sav.; auf Nephelis aber kann sich Henle's Mittheilung wohl nicht beziehen, da hier nach Johnson's Beobachtung (cf. Moq. Tand. Monogr. des Hirud. ed. 2. p. 168) die Begattung ganz wie bei Sanguisuga geschehen soll. 
tation „de hirudinibus circa Berolinum hucusque observatis." Berol. I 844. p. 33. = Ges. Schriften p. 21. - Clepsine tessulata sah ich in gegenseitiger Begattung Tage lang vereinigt; bei Clepsine complanata gelang es mir nicht, eine Begattung zu beobachten; dagegen fand ich kurz vor dem Eierlegen an beiden Seiten der Bauchfläche bald einzeln, bald in mehrfacher Zahl, bald dem vorderen, bald dem hinteren Körperende näher, eigenthümliche fadenförmige, 3 bis 5 Körperringen an Länge gleiche, einfache oder bis zum Grunde zweispaltige Körper vorgestreckt, ohne über ihren etwaigen Zusammenhang mit den Geschlechtstheilen und über ihre Function etwas Näheres ermitteln zu können. Sie erinnerten mich an die sogenannten Penes der Lumbricinen (appendiculae generatrices nach Morren), die freilich, selbst vollkommen räthselhaft, für ihre Deutung keinen Anhaltspunkt bieten konnten.

Im Frühjahr dieses Jahres hatte ich endlich Gelegenheit, an zahlreichen ausgezeichnet grossen Exemplaren von Clepsine complanata (an Stratiotes aloides in Gräben bei Loitz an der Peene gefangen) wiederholt den Vorgang der Begattung vollständiger $\mathrm{zu}$ verfolgen:

Aus den Hoden tritt die Samenflüssigkeit durch die engen seitlichen Ausführungsgänge in die langen gewundenen sog. Nebenhoden (cf. Mü11. Arch. I846. Tab. VIII. fig. 5, $\mathrm{a}=$ Ges. Schriften Taf. I. fig. 5, a). Erschien vorher ein ununterbrochener milchweisser Streifen zu jeder Seite der in der Mittellinie der Bauchfläche durchschimmernden Eierstöcke, indem die prall gefüllten Hodenbläschen sich gegenseitig berührten, so lassen sich nun bald die einzelnen sich entleerenden Hoden unterscheiden und in einigen Tagen sind diese kaum hirsekorngrossen, um je drei Ringe von einander entfernten weisslichen Flecken zusammengeschrumpft. An ihrer Stelle sieht man nun nicht selten die gefüllten Windungen der Nebenhoden durch die Bauchdecken durchschimmern, die jedoch öfter durch die unter ihnen liegenden Eierstöcke vollständig dem Auge entzogen werden. - Das Mikroskop zeigt nun in den Nebenhoden zu garbenförmigen Bündeln vereinigte, unbewegliche Spermatozoïden; die grossen scheibenförmigen Zellenkerne, denen diese bei ihrer Entwicklung aufsitzen, scheinen nicht mit aus den Hoden überzutreten. - Durch die Nebenhoden gelangt die Samenmasse in die beiden von der vorderen Geschlechtsöffnung quer nach aussen gehenden Schenkel der sog. Ruthenscheide (cf. a. a. O. fig. 5, b), -dehnt diese, hier sich ansammelnd, aus und lässt sie in diesem gefüllten Zustande als einen weissen Querbalken, in dessen Mitte die Geschlechtsöffnung, durch die Bauchwand durchschimmern. - Mit langgerecktem Vorderende nach allen Seiten hin tastend wandert nun das sonst so träge Thier munter umher, bis es ein anderes Individuum seiner Art entdeckt. An dieses saugt es mit dem Kopfe sich an, drückt die männliche Geschlechtsöffnung fest an dessen Leib, und indem es nach einiger Zeit sich langsam wieder entfernt, lässt es aus dieser Oeffnung die von einer ziemlich derben, anscheinend structurlosen Hülle ungebene in der Ruthenscheide angesammelte Samenmasse austreten, welche während des Andrückens der Geschlechtsöffnung an das andere Individuum angeklebt worden ist. - Es geschieht also die Begattung bei Clepsine complanata, wie bei den Cepha1opoden, bei Cyclopsina u.s. w., durch Spermatophoren. Es bestehen dieselben aus zwei meist ihrer ganzen Länge nach fest mit einander verklebten (den beiden Schenkeln der Ruthenscheide entsprechenden) Schläuchen, die von der dünneren Anheftungsstelle aus allmälig nach dem zuletzt austretenden kolbigen Ende zu 
sich rerdicken, an diesem Ende eine dünne kurze hakenförmig nach aussen gebogene, mit einem feinen Kanal versehene Spitze tragen, und prall mit Spermatozoïdenbündeln gefüllt sind. - Meist werden diese Samenschläuche auf der Bauchfläche, am gewöhnlichsten an der vorderen Körperhälfte, nahe der weiblichen Geschlechtsöffnung angeheftet; häufig genug aber auch, wenn das brünstige Männchen nicht rasch und bequem genug unter den platt aufliegenden Bauch des Weibchens gelangen kann, am Rande des Körpers oder auf dem Rücken. So erklärt sich der vom Rücken entspringende in die vordere Geschlechtsöffnung des anderen Thieres eingeführte doppelte Penis, den Henle beobachtete, als ein dem Rücken angehefteter, aus dieser Oeffnung vortretender Samenschlauch, und der "ganz umsonst" am Bauche des Weibchens vorgestreckte Penis als ein eben solcher Samenschlauch, mit dem dasselbe zufällig kurz zuvor von irgend einem andern Individuum beschenkt worden war.

Die entleerte Ruthenscheide füllt sich nun aufs Neue mit Samenflüssigkeit, und auf gleiche Weise werden neue Spermatophoren erzeugt und abgesetzt, bis in etwa zwei Tagen der gesammte Samenvorrath des Thieres verbraucht ist. Die angehefteten Spermatophoren entleeren sich ziemlich rasch ihres Inhaltes; bei den an der Bauchfläche befestigten wirkt bei dieser Entleerung mit der Druck, den das Thier darauf ausübt, indem es mit Kopf und Schwanzscheibe festsitzend in wellenförmigen Bewegungen den Körper bald von der Unterlage entfernt, bald gegen sie anpresst; bei jedesmaligem Anpressen kann man oft ein weisses Wölkchen aus dem Samenschlauch austreten und sich im Wasser vertheilen sehen. Gleichzeitig beobachtete ich einige Male deutlich ein abwechselndes Oeffnen und Schliessen der weiblichen Geschlechtsöffnung (bei diesen Exemplaren, wie bei Cleps. verrucata F. Müll, von einem dunkeln Ring umgeben und deshalb sehr in die Augen fallend), die so das mit Wasser verdünnte Sperma gleichsam einzuschlucken schien. Spermatozoïden in lebhafter Bewegung, meist einzeln, selten zu kleinen Bündeln vereinigt, fand ich um die noch an ihren Strängen festsitzenden Eier (a. a. O. fig, 9 u. Io), in den sie umschliessenden weiten Schläuchen (a. a. O. fig. 5, c), den gewöhnlich sogenannten Eierstöcken.

Gefüllt fallen die Spermatophoren durch ihre Grösse (bis über I" lang) und ihre milchweisse Färbung sehr in die Augen, weit weniger nach der Entleerung; sie sind nun sehr zusammengefallen, fast ganz farblos und durchsichtig, und bleiben in diesem Zustande, in welchem allein ich sie früher beobachtet hatte, oft noch Tage lang hängen.

$\mathrm{Ob}$ bei anderen Arten der Gattung Clepsine (nur von Cl. tessulata ist bis jetzt meines Wissens die Begattung beobachtet), ob in andern Gattungen der Familie der Hirudineen eine ähnliche Spermatophorenbildung vorkommt, müssen weitere Beobachtungen lehren. Mehr als wahrscheinlich ist mir aber ihr häufigeres Vorkommen in der Familie der Lumbricinen; denn als Spermatophoren glaube ich jetzt die längst bekannten räthselhaften Anhänge deuten zu müssen, die man bald als Appendiculae generatrices, bald als Penes beschrieben hat. Aus den Angaben von Hoffmeister über diese Anhänge (W. Hoffm., die bis jetzt bekannten Arten aus der Familie der Regenwürmer. Braunschweig 1845. p. 8 von Lumbric. Agricola; p. 30 von L. riparius; p. 4 I von Criodrilus lacuum), die ich zum Theil aus eigener Anschauung bestätigen kann, ergeben sich nämlich folgende 
Gründe für diese Deutung: ihr Vorkommen zur Zeit der Fortpflanzung und in der Gegend der Geschlechtstheile, - ihr Mangel an Zusammenhang mit inneren Organen, - ihre Veränderlichkeit nach Zahl und Ort der Anheftung. An die sonstige Uebereinstimmung, die im Gegensatz zu den übrigen Anneliden, Blutegel und Regenwürmer in Bezug auf Fortpflanzung zeigen (IIermaphroditismus, Bildung von Eierkapseln, Mangel der Metamorphose), dürfte in zweiter Reihe zu erinnern sein, um eine ähnliche Bedeutung der ähnlichen Organe bei unserer Clepsine und den genannten Lumbricinen wahrscheinlich $z u$ machen. - Zu entscheidenden Untersuchungen über diese Penes der Regenwürmer dürfte sich besonders der grosse, an den Wurzeln von Sagittaria im Teglersee bei Berlin häufige Criodrilus lacuum $\mathrm{H}$ of $\mathrm{fm}$. eigenen, an dem ich in den Sommermonaten diese Anhänge nie vermisst habe.

\section{Notiz 1).}

Ueber die Fortpflanzung von Sphaeroma Aega u.s.w. ist durch den Mangel blattförmiger Anhänge zur Bildung einer äusseren Bruttasche die Ansicht veranlasst worden, dass diese Thiere ihre Eier dem Wasser zum Brüten übergeben, eine Ansicht, die namentlich von $\mathrm{R}$ ath ke ausgesprochen worden ist. (Entwicklung der Crustaceen in Burdach's Physiologie. 2. Ausg. und Nov. Act. Ac. Nat. Cur. vol. XX. p. I. 1843. p. 29.) Diese Ansicht ist wenigstens für Sphaeroma unrichtig. Die jungen Sphaeromen entwickeln sich vielmehr im Leibe der Mutter; Sphaeromaist lebendig gebärend, wie ich mich an einer in der Ostsee bei Greifswald sehr häufigen, noch unbenannten Art zu überzeugen Gelegenheit hatte.

I) Findet sich unmittelbar im Anschluss an die vorstehende Arbeit an derselben Stelle. 


\title{
Tanais Rhynchites und balticus, neue Arten aus der Ostsee $\left.{ }^{1}\right)$.
}

\author{
Mit Tafel IV, Fig. I-4.
}

Im Sommer 1848 fand ich im Greifswalder Bodden zwischen Furcellaria fastigiata Lamx. (Fucus furcellatus Linn.) einige kleine Crustaceen aus der sonderbaren Gattung Tanais, die sich bei näherer Untersuchung als zwei neuen Arten angehörig erwiesen. Die damals entworfene Beschreibung blieb aus Mangel an Material und Zeit unvollendet und deshalb unpublicirt. Jetzt im Begriffe, die Gestade der Ostsee für immer zu verlassen, habe ich keine Aussicht, das Fehlende selbst ergänzen zu können; das damals Aufgezeichnete mag also wenigstens dienen, das Vorkommen dieser Thiere in der Ostsee zu constatieren und die anwohnenden Zoologen auf diese interessanten Bürger ihrer Fauna aufmerksam zu machen.

Die Stellung der neuen Arten unter den bisher beschriebenen ergibt sich zunächst aus folgender Uebersicht:

I. Der unbewegliche Finger der Scheere des ersten Fusspaares ist die gerade Fortsetzung vom Ende des vorletzten Gliedes.

A. Obere Fühler lang ( $2 / 3$ der Körperlänge) T. Edwardsii Kr.

B. Obere Fühler kurz.

I. Schwanzanhänge ohne Nebengeissel, dreigliedrig. T. tomentosus Kr., und die Edwards'schen Arten.

2. Schwanzanhänge mit Nebengeissel; dieselbe

a. eingliedrig: T. Savignyi Kr., dubius Kr., balticus F. Müll.

b. zweigliedrig: T. gracilis Kr., Oerstedii Kr.

II. Der unbewegliche Finger keulenförmig, von der Basis des vorletzten Gliedes senkrecht abstehend. - T. Curculio Kr., T. Rhynchites F. Müll.

Tanais Rhynchites ist glänzend gelblichweiss gefärbt, etwa $3 \mathrm{~mm}$ lang, etwa $1 / 2 \mathrm{~mm}$ breit. Das grosse Kopfschild, von etwa $1 / 4$ der gesammten Körperlänge, ist von hinten nach vorn erst allmählich, dann plötzlich in einen $1 / 3$ der Kopflänge betragenden, dünnen gerade vorgestreckten, schnabelartigen Fortsatz ausgezogen, der an seiner Spitze die Fühler, an deren Basis die Augen trägt. Die oberen Fühler, von etwa $1 / 6$ der Körperlänge, ziemlich plump, 5-gliedrig;

Archiv für Naturgeschichte. I852. I. p. 87-90. Taf. IV, Fig. I-4. 
stehen dicht nebeneinander am Vorderende des schnabelförmigen Fortsatzes; das erste Glied ist das längste. Die unteren Fühler, etwas dünner und kürzer als die oberen, sind auch 5-gliedrig (mit sechstem rudimentären Endgliede); die 3 ersten Glieder sind kurz und dick, das vierte schlank und so lang wie die drei ersten zusammengenommen.

Dicht hinter dem Grunde der oberen Fühler liegen die schwarzen rundlichen Augen. Das erste Fusspaar (Fig. I u. 2) ist unförmlich gross und dick; mit ausgestrecktem Endgliede beträgt seine Länge über die Hälfte der gesammten Körperlänge. Fünf Glieder sind daran mit Bestimmtheit zu unterscheiden: das fast quadratförmige erste Glied articulirt mit seinem obern Rand und der hinteren oberen Ecke mit dem Körper; der hintere und untere Rand sind frei; an den vorderen Rand (die Füsse in ihrer gewöhnlichen Lage, gerade nach vorn gerichtet) schliessen sich das zwveite und dritte Glied an. Während nämlich in der obern Hälfte dieses Randes das grosse dritte Glied unmittelbar mit dem ersten sich verbindet, sind dieselben in der untern Hälfte durch das kleine dreieckige zweite Glied getrennt. Das dritte Glied, das breiteste von allen, ist viereckig und die untere Hälfte seines Vorderrandes in eine ziemlich gerade nach vorn und etwas nach abwärts gerichtete gleichmässig breite Lamelle mit oberer abgerundeter und unterer fast rechtwinkliger Vorderecke verlängert. Diese Lamelle bedeckt einen Theil der Aussenfläche des folgenden Gliedes. Dies vierte Glied, etwas kürzer und schon an der Basis etwas schmäler als das vorige, ist nach der Spitze zu allmählich verdünnt. Von seinem unteren Rande entspringt, ziemlich rechtwinklig zu der Achse des Gliedes ein keulenförmiger Fortsatz mit gerade abgestutztem Ende; den Stiel der Keule deckt am Grunde nach aussen die vorspringende Lamelle des dritten Fussgliedes. Die Länge dieser Keule, die den unbeweglichen Finger der Scheere bildet, beträgt etwa $1 / 6$ von der des Fusses; der bewegliche Finger, oder das 5 te Fussglied ist ziemlich schlank, wenig gebogen, von fast $1 / 3$ der gesammten Länge des Fusses; seine Spitze trifft, wenn er eingeschlagen wird, einen kleinen Einschnitt dicht vor dem abgestutzten Ende der Keule.

Die sechs freien Thoraxringe, wie der Hinterleib, bieten nichts von den bekannten Arten auffallend Abweichendes; der sechste letzte und längste Hinterleibsring, in der Mitte seines Hinterrandes ausgerandet, trägt die Schwanzanhänge von etwa $1 / 10$ der Körperlänge. Ihr dickeres Grundglied ist mit einem innern viergliedrigen und einem äussern sehr kleinen eingliedrigen Zweige versehen.

Die einzige verwandte Art ist T. Curculio Kr., die Kröyer im Öresund fand; als unterscheidende Merkmale können dienen:

T. Curculio: Kopfschild über $1 / 3$, obere Antennen fast $1 / 4$, Schwanzanhänge $1 / 8$ der Körperlänge; untere Antennen $2 / 3$ der Länge der oberen; Hinterleib stumpf abgerundet, Schwanzanhänge viergliedrig.

T. Rhynchites: Kopfschild unter $1 / 3$, obere Antennen $1 / 6$, Schwanzanhänge $1 / 10$ der Körperlänge; untere Antennen 4/5 der Länge der oberen; Hinterleib ausgerandet, Schwanzanhänge fünfgliedrig (Grundglied und viergliedriger Endzweig).

Tanais balticus, die zweite neue Art, milchweiss, $2 \mathrm{~mm}$ lang, stimmt in Gestalt und gegenseitigem Verhältnisse der einzelnen Körpertheile fast vollständig mit T. Savignyi überein, den Kröyer bei Madeira auffand. - Es genügt also, ihre unterscheidenden Merkmale hervorzuheben. Die Schwanzanhänge sind bei 
unserer Art fünfgliedrig, bei T. dubius von Bahia sechsgliedrig, bei T. Savignyi siebengliedrig; T. Örstedii aus dem Öresund unterscheidet sich durch den kürzeren Kopf $(1 / 6$ der Körperlänge, hier $1 / 5-1 / 4)$ und die zweigliedrige Nebengeissel der Schwanzanhänge; T. gracilis aus Spitzbergen durch dieselben Merkmale, den schlankeren Körper, und die längern Scheerenfinger (länger als die Hand). - Mit den übrigen Arten ist keine Verwechslung möglich.

Bei T. balticus wurden grosse Lamellen für die Eier beobachtet; die untersuchten Exemplare waren Weibchen; bei T. Rhynchites wurden sie vermisst. Möglich dass die Thiere nicht specifisch, sondern nur sexuell verschieden sind. Aehnliche Verschiedenheit der Fussbildung zeigen Männchen und Weibchen bei Orchestia; die abweichende Kopfbildung von T. Rhynchites liesse sich eben aus der Bildung des ersten Fusspaares erklären; Antennen und Schwanzanhänge stimmen überein. - Bei genügendem Material und Beobachtung der Jugendzustände wird diese Frage sich leicht beantworten.

\section{Erklärung der Abbildungen auf Taf. IV.}

Fig. I. Fuss des ersten Paares von Tanais Rhynchites, von der äusseren;

Fig. 2. derselbe von der innern Seite gesehen.

Fig. 3. Tanais balticus F. Müll.

Fig. 4. Scheere des ersten Fusspaares von demselben Thiere, mehr vergrössert. 


\section{Eine Beobachtung über die Beziehung der Gattungen Caligus und Chalimus ${ }^{1}$ ).}

Mit Tafel IV, Fig. 5 und 6.

Schon längst hat Kröyer als höchst wahrscheinlich nachgewiesen, dass die Gattung Chalimus Burm. nur ein Jugendzustand von Caligus sei. Im September I 846 fand ich auf einem am Ostseestrande frisch ausgeworfenen Cyprinus rutilus oder erythrophthalmus eine grosse Menge eines Schmarotzerkrebses, dessen Bewegungsorgane vollkommen mit Caligus übereinstimmten, dessen Weibchen als Zeichen der Geschlechtsreife meist Eiersäcke trugen, der aber trotz dieser Geschlechtsreife mit einem Haftapparat, wie der Burmeister'sche Chalimus versehen war.

Zwischen diesen ausgebildeten Thieren fand sich ein etwas kleineres, das sich durch seine milchige Undurchsichtigkeit noch ausserdem vor den übrigen fast wasserhellen auszeichnete. Die Loupe zeigte an ihm die Gruben am Stirnrand nur wenig entwickelt und Abweichungen in der Bildung der Fühler und Füsse. Um diese näher mit dem Mikroscope zu untersuchen, sollte das Thier, unverletzt zu undurchsichtig, durch Nadeln zerstückelt werden. Aber was geschah? Ich streifte durch die Nadeln eine Haut ab, unter der ein regelrechter Caligus (ठ) zum Vorschein kam; die Haut, so viel sich erkennen liess, zeigte in ihren Anhängen die grösste Aehnlichkeit mit Caligus Scombri. So stimmte z. B. das zweite Fühlerpaar (nach Kröyer's Bezeichnungsweise) vollkommen mit der Kröyerschen Abbildung überein. $\mathrm{Zu}$ bemerken mag noch sein, dass der neue Haftapparat des Caligus nicht in, sondern hinter dem Haftapparat des Chalimus ${ }^{2}$ ) lag.

Kröyer's Vermuthung war so durch directe Beobachtung bestätigt.

Das Genus Chalimus, wie es Burmeister aufgestellt, kann sonach, als blosser Jugendzustand, nicht fermer bestehen. Es liesse sich aber fragen: soll man nicht diese geschlechtsreifen Caligus mit Haftapparat, von den übrigen ohne Haft-

I) Archiv für Naturgeschichte. I852. I. p. 9I-92. Taf. IV, Fig. 5 und 6.

2) Im Original steht irrtümlich „Caligus“. Der Herausgeber. 
apparat, als eigenes Genus trennen und für dasselbe etwa den Namen Chalimus beibehalten? Da in allen übrigen Stücken bis auf die Zahl der Borsten an den Füssen die vollständigste Uebereinstimmung mit Caligus stattfindet, scheint mir eine solche Trennung nicht gerechtfertigt.

Ich schlage für die, auch abgesehen vom Haftapparate mit keiner der bisher beschriebenen übereinstimmende Art den Namen Caligus appendiculatus vor.

\section{Erklärung der Abbildungen auf Taf. IV.}

Fig. 5. Caligus appendiculatus F. Müll. ㅇ. a Zweites Fusspaar.

Fig. 6. Zweites Fusspaar des Männchens. 


\section{Beiträge zur Kenntniss der Landplanarien ${ }^{1}$ ).}

Die Reisen des englischen Forschers Charles Darwin ${ }^{2}$ ) haben uns mit einer reichen Fauna von $\mathrm{L}$ a $\mathrm{ndpla}$ narien in den feuchten Urwaldregionen Südamerikas bekannt gemacht, welche die Aufmerksamkeit der Zoologen im hohen Grade verdienen. Musste zunächst die Eigenthümlichkeit des Vorkommens überraschen, dass Würmer aus der Ordnung der Turbellarien, die wir in unseren Gegenden nur in Wasser zu finden gewohnt sind, und welche ihres äusserst weichen, zarten und aller festen Stützen entbehrenden Körperparenchyms willen ausschliesslich in diesem Medium zu leben bsstimmt zu sein schienen, in zahlreichen Arten als Landbewohner auftreten, so wurde nicht weniger unser Interesse in Anspruch genommen durch die Angaben über die ansehnliche Grösse dieser Thiere, den bunten Farbenschmuck, die Nemertinenartige Gestalt verbunden mit der inneren Organisation der Planarien unserer süssen Wässer. Das Verlangen nach neuen und ausführlicheren Nachrichten über die Naturgeschichte dieser Urwaldbewohner ist leider seit jenen Mittheilungen des verdienten Reisenden nur sehr dürftig befriedigt worden. Es gewährte mir daher eine besondere Freude, solche von einem bewährten Forscher zu erhalten, dem Dr. Fritz Müller, seit einigen Jahren in der Colonie Blumenau in Südbrasilien, jetzt in Desterro auf der Insel St. Catharina ansässig. Wenn dieselben auch unter ungünstigen äusseren Umständen und ohne die wünschenswerthen optischen Hülfsmittel entworfen sind, so stehe ich doch nicht an, dieselben, als werthvolle Erweiterungen unserer bisherigen Kenntniss bietend, mitzutheilen. Ich benutze zugleich die Gelegenheit, was wir durch Darwin und einige Andere über diese Thiere erfahren haben, zusammenzustellen und füge endlich die Resultate einiger mikroskopischen Untersuchungen über den feineren Bau dieser Thiere hinzu, welche ich an einem von Herrn Burmeister mitgebrachten und mir zu beliebiger Benutzung übergebenen in Spiritus wohlerhaltenen Exemplare anstellte.

Bekanntlich entdeckte schon O. Fr. Müller, der Begründer unserer Kenntniss der Turbellarien, eine auf dem Lande unter Steinen in feuchter Erde lebende Art, von ihm Planaria terrestris genannt (Vermium terr. et fluv. hist. II, p. 68). Nach

I) Nach Mittheilungen des Dr. Fritz Müller in Brasilien und nach eigenen Untersuchungen von Dr. Max Schultze, Prof. an der Univ. Halle. Aus „Abhandlungen der Naturforschenden Gesellschaft" in Halle. 1856 . 4. Bd. p. 19-38.

2) Naturwissenschaftliche Reisen, deutsch von E. Dieffenbach, 1844, p. 28. Annals and Magaz. of natur. hist. vol. XIV, I 844 , p. 24 I. 
der kurzen Beschreibung, welche der berühmte dänische Zoologe von diesem Thiere gab, besitzt dasselbe einen fast cylindrischen, nur an der Bauchseite etwas abgeplatteten, 8 Linien langen, $2 / 3$ Linien breiten Körper, ist oben schwärzlich grau, unten weiss gefärbt, und lässt am vorderen Ende zwei kleine schwarze Augenpunkte erkennen. Dugès sah dieselbe Art in Frankreich (Ann. d. sc. nat. I sér. Tom. XXI, p. 82) und fügte den Müller'schen Angaben noch hinzu, dass auch die Lage der Mundöffnung, die Gestalt des muskulösen Schlundes und die baumförmigen Verästelungen des Darmcanales, das männliche Begattungsglied und die Samengefässe mit den gleichen Theilen unserer Südwasserarten übereinstimmen.

Mein Freund Fritz Müller ist, so viel mir bekannt, der einzige, welcher seit jener Zeit das Thier wieder gefunden hat, das jedenfalls zu den seltneren gehört. Es war in der Gegend von Grimmen bei Greifswald, wo einige Exemplare unter Steinen entdeckt wurden, die leider nur mit der Lupe untersucht werden konnten, doch die von Dugès beschriebenen Theile alle erkennen liessen.

Die mir in verschiedenen Briefen zugegangenen Mittheilungen F. Müller's über die brasilianischen Landplanarien stelle ich in Folgendem zusammen:

„Uebereinstimmend mit den Planarien des süssen Wassers ist die Lage der Mundöffnung, gegen das hintere Drittheil an der Unterseite des Körpers sowie die dendrocoele Natur des Darmcanales; an letzterem finden sich die gewöhnlichen 3 Hauptäste, ein vorderer und zwei hintere, deren Zweige mehrfach getheilt zu sein pflegen. Der Rüssel erscheint, wie er durch die Haut hindurchschimmert, als langer Cylinder, in dessen Mitte die Mundöffnung als Querspalte sichtbar ist. Bei näherer Untersuchung des herausgenommenen Rüssels findet man indess, dass er sich in einen ansehnlichen flachen Napf oder eine Scheibe ausbreiten lässt, die bald mehr elliptisch, bald mehr rund, im Umfange bald fast ganzrandig, bald mehr weniger tief gelappt ist, und in ihrem Grunde etwas vor der Mitte eine ziemlich enge Schlundöffnung zeigt, eine Bildung, die bei mehreren der grösseren Seeplanarien, aber nicht bei unseren Süsswasserarten vorkommt. In der Ruhe werden die seitlichen Ränder so eingerollt und das ganze Organ so zusammengefaltet, dass es sich als Cylinder mit vorderer wellig gebogener Längsspalte darstellt.

Abweichend von der Gattung Planaria ist die langstreckige Körperform, die geringe Abplattung, das spitz zulaufende vordere Körperende. Der Habitus ist so oft weit mehr der einer Nemertine als einer Planarie. Abweichend ebenfalls, so weit sie erkannt, sind die Augen, die in ungemeiner Anzahl vorhanden sind, aber auch nicht wie bei Planaria nigra eine einfache Reihe bilden, die regelmässig am vorderen Rande sich hinzieht, sondern nahe am Vorderrande in dichte Streifen oder Flecke zusammengedrängt sind, von da aus in einer unregelmässigen Reihe, die nach hinten immer laxer wird, bis zum Hinterende längs der Seitenränder sich erstrecken.

Diese Eigenthümlichkeiten wie der Aufenthaltsort berechtigen wohl sie von den Wasserplanarien generisch zu trennen. Man könnte nach Analogie von Typhloplana, Leptoplana für sie den Namen Geoplana bilden. Sie lieben mässig feuchte Orte, unter Holz, Rinde, Steinen, zwischen Blätternn der Bromeliaceen (doch nicht in dem daselbst angesammelten Wasser). Tags scheinen sie zu ruhen, 
Nachts umherzuschweifen. Eier, etwas grösser als von Planaria ulvae, ziemlich rundlich und schwerlich einem anderen Thiere angehörig, wurden einmal unter Holz gefunden.

Eine naheliegende Frage ist, ob die Geoplanen, wie ihre Verwandten im Wasser, auf der Körperoberfläche Flimmerhaare tragen. In Ermangelung eines Mikroskopes bestreute ich, eines Experimentes in Joh. Müller's physiologischen Vorlesungen mich erinnernd, ein recht grosses Exemplar der Geoplana rufiventris mit ein wenig Arrowrootmehl und sah nun dieses auf dem Rücken constant vorwärts und dabei bisweilen etwas nach aussen, auf der Bauchseite hinterwärts sich fortbewegen, wodurch die Existenz der Flimmerhaare ausser Zweifel gestellt scheint.

Die bisher beobachteten Arten sind:

I. Geoplana tristriata, blassgelblich grün, mit drei schmalen dunkeln Längslinien auf dem Rücken, Bauch heller. Grösste Breite nach dem zweiten Drittheil der Länge, hier der Mund. Liebt das Kopfende aufwärts aufzubiegen. An der Biegungsstelle jederseits eine dichtgedrängte Gruppe von Augenpunkten, die sich in unregelmässiger Reihe bis zum Hinterende fortsetzen. Der vorderste Rand des Kopfes scheint augenlos. Länge $1^{1} \frac{1}{2}$ Zoll, Breite $I^{1} / 2$ Linie. Häufig.

2. Geoplana octostriata, Habitus und Augen wie bei der vorigen, Farbe blassgelb, Bauch weisslich, auf dem Rücken jederseits vier dunkelbraune, genäherte Längsstreifen, weit breiter als die Längslinien der vorigen. Nicht selten.

3. Geoplana elegans, Habitus ähnlich, doch nach vorn etwas weniger verjüngt, ${ }_{2}^{1} \frac{1}{2}$ Zoll lang bei I Linie Breite. Augenpunkte sehr klein, bilden vorn eine ziemlich breite dichte Binde, die nach hinten schmaler und weniger dicht wird und in eine einfache Reihe übergeht. Farbe gelb, Bauch blasser, auf der Mitte des Rückens ein breiterer dunkelschwarzer Längsstreif, zwischen diesem und dem Seitenrande jederseits ein schmalerer dunkelorangefarbener Längsstreif. Nur einmal gefunden.

4. Geoplana pallida, von ähnlicher Gestalt wie die vorige. Farbe gelblichweiss mit einem einzigen, schmalen schwärzlichen Längsstreifen auf dem Rücken. In mehreren Exemplaren zwischen Brettern.

5. Geoplana atra, dunkelschwarz, unten grau, fast cylindrisch, vorn und hinten wenig verschmälert. Die Augen schwer erkennbar, doch vorhanden. Der Rüssel mehr cylindrisch wie bei den Süsswasserplanarien, doch immer noch am Mundende viel weiter als am Schlundende. Länge 9 Linien, Breite $1 / 2$ Linie. Einmal unter der Rinde einer morschen Figueira (Ficus doliaria ?) gefunden.

6. Geoplana marginata, Rücken und Bauch dunkelschwarzbraun glänzend, goldgelbe schmale Längsbinden auf der Mitte des Rückens, breitere mattergelbe Binden längs der Seitenränder; in diesen die Augenpunkte sehr deutlich sichtbar, vorn dicht gedrängt, hinten in einfacher loser Reihe. Das 3-4 Zoll lange, einige Linien breite, vorn und hinten ziemlich stark verjüngte Thier kroch im Hause.

7. Geoplana rufiventris, Rücken dunkelbraun, Bauch ziegelroth; vorn und hinten mässig verschmälert. Die Augen in mehreren Reihen dicht gruppirt, 
an den Rändern des vorderen Körpertheils deutlich, hinten nicht wahrgenommen. Das einige Linien breite, mehrere Zoll lange Thier an Holz gefunden.

8. Geoplana olivacea, Bauch gelblichgrau, Rücken grünlich braun mit dunkelbrauner hell eingefasster Längsbinde, nach dem Rande zu dunkler, nach dem Kopfende heller. Augen längs des ganzen Körperrandes, vorne dichter, hinten sehr einzeln. Nicht selten.

9. Geoplana Nephelis, ähnlich in Gestalt der vorigen, doch etwas weniger langgestreckt, erinnert in Gestalt und Farbe an eine Nephelis. Der Rücken einfarbig braun, der Bauch heller. Nicht selten.

10. Geoplana Maximiliani, fast wie die vorige, der Rücken mit einer helleren gelblichen Längsbinde. Von der vorigen ist diese Art aber noch dadurch unterschieden, dass Mund und Geschlechtsöffnung weit mehr nach hinten liegen und der Penis fast kuglig, dagegen bei G. Nephelis lang cylindrisch ist. Auch erschien bei letzterer die Rüsselöffnung ganzrandig, bei G. Maximiliani dagegen (in einem Weingeistexemplar untersucht) tief fünflappig.

I I. Geoplana marmorata, Länge 4 Zoll, Breite 4 Linien, die Augenpunkte bieten nichts Besonderes dar. Die Rückenseite ist blass röthlichgrau mit schwarzen Fleckchen, die in unregelmässige, vielfach anastomosierende Längsreihen geordnet sind, die Bauchseite ist blassgrau. Der Rüssel ist in einen flachen Napf mit welligem Rande (an einem Weingeistexemplar) ausbreitbar.

I 2. Geoplana pulchella, das vordere Drittheil des Körpers oben bräunlich ziegelroth mit ovalen weisslichen Flecken, unten grau mit weisslicher Binde in der Mitte. Augenpunkte nahe dem Vorderrande ziemlich gedrängt, die Reihe derselben am Vorderrande nicht unterbrochen, in den zwei hinteren Dritteln vermisst. Etiva zolllang bei reichlich I Linie Breite, nach vorn nicht sehr stark verschmälert. Einmal beobachtet.

13. Geoplana subterranea, bietet schon durch ihr Vorkommen ein besonderes Interesse, indem sie den Kreis der Lebensbedingungen, unter denen dieser Thierform zu bestehen gestattet ist, aufs neue erweitert zeigt. Nachdem man Plattwürmer in dem klaren Quellwasser der Gebirge, wie in den Seen und Mooren des Flachlandes, unter den Steinen der Seeküste wie an den fluthenden Tangen mitten im Weltmeere gefunden, nachdem sich die Aussicht auf eine reiche Landplanarienfauna eröffnet hat, die im feuchten Moose, unter Steinen und Rinden sich birgt und bis in die Wipfel des Urwaldes aufsteigt, wo sie zwischen den stachligen Blättern der Bromelien, ein stets feuchtes Asyl findet - so kommen nun auch Erdplanarien zum Vorschein, Genossen der Regenwürmer und Engerlinge. In bezeichnendem Gegensatze zu ihren über der Erde lebenden farbigen, augenreichen Gattungsgenossen ist diese im Dunkeln hausende Geoplana ohne Farbenschmuck und Farbensinn, milchweiss und augenlos. Im Habitus entfernt sich diese Art mehr als irgend eine von der typischen Planarienform. Ihr gleichmässig schmaler, sehr langer, an den Enden abgerundeter Körper, der bei ciner Länge von $2-3$, selbst über 4 Zoll, kaum dic Breite von $3 / 4$ Linie erreicht, giebt ihr vollständig das Ansehen einer Nemertine. Die milchweisse Farbe erhält, wenn der Darm gefüllt ist, durch den durchschimmmernden Inhalt 
desselben einen mehr weniger lebhaften Anflug von Fleischfarbe oder Rosenroth. Die Mundöffnung ist ungewöhnlich weit nach hinten gerückt, die Genitalöffnung liegt ganz in der Nähe des Hinterendes. Der Rüssel ist glockenförmig, der Darm von gewöhnlicher Form, seine Seitenzweige einfach oder gablig, dichtstehend.

Das Thier lebt besonders in lockerem, sandigem, aber auch schwerem, zähem Lehmboden in Gesellschaft des Lumbricus corethrurus ${ }^{1}$ ). Es mag

1) Die von F. Müller entworfene Beschreibung dieses interessanten neuen Regenwurms, welche auch in Wiegmanns Archiv für Zoologie demnächst abgedruckt wird, lautet:

Lumbricus corethrurus, Bürstenschwanz, der gemeinste der hiesigen Regenwürmer und fast in jeder Scholle urbaren Landes zu finden; ziemlich schlank, weich, leicht zerreissend; die Haut fast farblos, durchscheinend, so dass die Körperfarbe hauptsächlich durch Darm nnd Blutgefässe bedingt ist, daher meist am Vorderende mehr röthlich, in der Mitte mehr grau, hinten blass röthlichweiss erscheint. Der Gürtel ist oben bräunlich gelb. Die Messung von 9 gürteltragenden Thieren, - in Weingeist getödtet, weil im Leben die Länge stets wechselt, - ergab in Mittel 28"' Länge, wovon $3^{\prime \prime \prime}$ auf den Gürtel, 4 "' auf die davorliegenden Ringe kommen. Der Körper ist cylindrisch, vom Gürtel nach vorn verjüngt, hinterwärts ziemlich gleichmässig dick. Die Zahl der Ringe ist etwa 200-250; vor dem Gürtel liegen 13; der Gürtel, den man oft vermisst, umfasst deren 8 . Der vorderste Ring ist längsgerieft, wie die drei vordern bei Geoscolex maximus Leuck. Wenn das Thier tastend das Kopfende vorstreckt, scheinen aus dem ersten Ringe noch ein oder zwei ähnliche vorzutreten nebst einem langgestielten, keulenförmigen Kopflappen. - Die Borsten zeigen an den allervordersten Ringen die gewöhnliche Stellung, dass die 4 Borsten jeder Seite paarweise genähert sind; so bleibt das obere Paar bis zum Gürtel, während die beiden Borsten des unteren Paares immer weiter auseinander rücken; vom Gürtel hinterwärts sieht man jederseits nur noch 2 Reihen einzelner Borsten; es sind das, von unten wach oben geżählt, die erste und dritte Reihe; letztere verläuft ziemlich in der Mitte zwischen Bauch und Rücken; die 2 te und 4te Borste haben eine mit jedem Ringe wechselnde Höhe der Insertion, ohne dass dabei eine bestimmte Norm in die Augen fiele; bald $z$. B. sieht man sie abwechselnd höher und tiefer gestellt, so dass also die des 1 ten, 3 ten, 5 ten ... und wieder die des 2 ten, 4 ten, 6 ten... Ringes in derselben Längslinie liegen; bald steigen 3 auf und 2 wieder nieder, so dass die am 1 ten und 5ten Ringe gleich hoch stehen, die am 2ten und 4ten höher und noch höher die am dritten; bald auch behaupten sie an mehreren Ringen hintereinander dieselbe Höhe, u. s. w. Nach einer grössern oder geringern Zahl z. B. 20 oder 30 Ringen hören auch die beiden noch bestehenden Borstenreihen auf regelmässig fortzugehen, erst die untere, dann die obere in der Mitte der Seiten verlaufende; auch diese Borsten schwanken nun von Ring zu Ring in der Höhe der Insertion. Diese anscheinend vollkommen chaotische Borstenstellung regelt sich nun in der Nähe des Hinterrandes wieder in der IVeise, dass jeder Ring 8 in nahezu gleicher Entfernung von einander stehende Borsten trägt, die mit denen der nächstanliegenden Ringe alterniren, wodurch denn 16 Längsreihen (oder auch 3 Schraubenlinien) von Borsten entstehen. Merkwürdig ist, dass diese sunderbare Borstenstellung bei jüngeren Thieren sich noch nicht findet; diese haben am Vorderende jederseits zwei Reihen gepaarter Borsten, die sich weiter hinten in 4 Reihen einzeln stehender Borsten auflösen.

Die Borsten am vordern Theile des Körpers sind zarter und scheinen schwach hakenförmig gekrümmt; die am hintersten Theile sind sehr stark, gerade, bernsteinfarbig, stehen auf deutlichen Höckerchen und scheinen nicht vollständig zurückgezogen werden zu können. Der ganze Schwanz erhält durch diese I6reihigen starken Borsten ein bürstenartiges Ansehen. - Der Magen ist stark musculös. Die Eierhüllen sind fast kugelrund, farblos, opalisirend; ich fand darin nie mehr, als ein Junges. -

Diese kurze Beschreibung wird genügen, eine ungefähre Vorstellung von unserem Regenwurme $z u$ geben und ihn wenigstens von den bisher beschriebenen Arten leicht unterscheiden lassen. Obwohl man die Anordnung und Gestalt der Borsten als wesentliche Gattungsmerkmale der Regenwürmer anzusehen pflegt und demnach unser hierin so eigenthümlicher Wurm die Aufstellung eines neuen Genus gebieterisch zu fordern scheint, so habe ich mich doch, namentlich der regelmässig beborsteten Jungen wegen, nicht dazu entschliessen mögen, ehe nicht irgend ein erhebliches anatomisches oder physiologisches Moment diese Trennung rechtfertigt, wie es $z$. B. bei Euaxes und dem einer näheren Untersuchung so werthen Criodrilus der Fall ist. Vielleicht dürfte sich ein solches Moment herausstellen bei weiterer Verfolgung einer 
befremden, dass ein so weiches Thierchen, das kaum leise Berührung verträgt, in diesem Medium existiren und sich Wege bahnen könne. Diese Schwierigkeit lösen die Regenwürmer, die den Boden so durchwühlen, dass er wie ein Schwamm von glatten Gängen verschiedener Weite in allen Richtungen durchsetzt ist. Zum Dank dafür werden die Regenwürmer von dem Plattwurm aufgefressen oder vielmehr ausgesogen. Diese Art der Nahrung war aus der Farbe des Darminhaltes unschver zu erschliessen. Ich habe aber auch Geoplanen getroffen, die eben einen jungen Lumbricus mit dem vorgestülpten Rüssel gepackt hielten und deren Darm sich mit frischem Blute zu füllen begann.

Zur mikroskopischen Untersuchung des inneren Baues wäre diese Art vor allen anderen geeignet, nicht nur ihrer Durchsichtigkeit wegen, sondern auch desshalb, weil man sie mit einiger Geduld in beliebiger Menge aus der Erde bröckeln kann. Alle übrigen Geoplanen bekommt man nur selten zu Gesicht, wie das ja auch mit der europäischen Planaria terrestris von O. F. Müller der Fall ist."

So weit die Mittheilungen meines Freundes Fritz Müller.

Es sei mir gestattet, diesen Artbeschreibungen zunächst die von anderer Seite bekannt gewordenen hinzuzufügen, die sich in ausländischen Zeitschriften zerstreut finden und bisher nirgends zusammengestellt wurden. Was den Gattungsnamen Geoplan a betrifft, so scheint derselbe so passend gewählt, dass die Zoologen demselben ihre Zustimmung gewiss nicht versagen werden. Das Bedürfniss, die Landplanarien von den übrigen generisch zu trennen, empfand schon Darwin, indem er sagt: „Die Landplanarien gehören zu dem Genus Planaria Dugès Polycelis Ehrbg.; sie können aber eine besondere Abtheilung dieser Gattung bilden, characterisirt durch ihren mehr rundlichen schmalen Körper und die meist vorhandenen Längsstreifen von sehr glänzenden Farben." Dessenungeachtet stellte Darwin keinen neuen Namen für dieselben auf. Ausser dem englischen Reisenden

Eigenthümlichkeit, die mich veranlasst hat, dies unscheinbare Thierchen dem zoologischen Publicum vorzuführen. Fast bei allen grösseren Exemplaren fällt sofort etwa zu Ende der dritten Viertels der Körperlänge eine kleine Stelle auf, die lebhafter geröthet, wie entzündet aussieht; oft erscheint hier auf der Rückseite die zartere Haut aufgetrieben und gleichsam einen kleinen Bruchsack zu bilden. Bei in Spiritus getöteten Exemplaren nimmt sich diese Stelle aus wie ein zweiter nur viel kleinerer Gürtel, indem sie sich scharf alssetzt, ein wenig über die davor- und dahinterliegenden Ringe erhebt, wohl weil bei der Zusammenziehung des Körpers die hier schwächere Haut und Muskelschicht weniger Widerstand leistet. Betrachtet man nun diese Stelle, die ich an keinem der sehr zahlreichen erwachsenen Thiere, die ich in diesen Tagen darauf angesehen, vermisst habe, mit der Lupe, so findet man, dass sie aus 5 bis ro mehr oder weniger deutlich geschiedenen, schmalen borstenlosen, allem Anscheine nach neugebildeten Ringen bestelit.

Eine beginnende Quertheilung war beim Anblick dieser Neubildung mein erster Gedanke; allein dann hätten sich doch Exemplare finden sollen, die aus solcher Quertheilung hervorgegangen wären, denen entweder ein gehöriges Vorderende oder der Bürstenschwanz gefehlt hätte; solche habe ich vergeblich gesucht. Bei einer, an 9 Exemplaren vorgenommenen Zählung der Ringe fanden sich zwischen Gürtel und dieser Stelle nahezu gleichviel Ringe, etwa Iıо; die unbedeutenden Differenzen können aus Verzählen entstanden sein; dagegen schwankte die Zahl der dahinterliegenden Ringe von 60 bis fast zum Doppelten. So könnte denn vielleicht diese Stelle eine Bildungsstätte neuer Schwanzringe sein.

Eine, durch alle Jahreszeiten fortgesetzte Beobachtung mag vielleicht auch ohne Mikroskop Gewissheit schenken.

Itajahy, Anfang Juni 1856.

F. Müller. 
beschrieben noch Blanchard und Leidy Landplanarien. Ersterer ${ }^{\mathrm{l}}$ ) erhielt zwei in Spiritus aufbewahrte Exemplare einer von Claude Gay in Chile beobachteten Art, die er zu anatomischen Untersuchungen benutzte, über welche weiter unten berichtet wird. Blanchard nannte dieselbe Polycladus Gayi. Der Gattungsname kann nicht auf sämtliche Landplanarien ausgedehnt werden, und bleibt vorläufig nur dieser Species. Dasselbe ist der Fall mit dem von Leidy ${ }^{2}$, einer nordamerikanischen Landplanarie gegebenen Namen Rhynchodemus.

Die Darwin'schen Land planarien, deren Beschreibung ich aus den Annals and Magazine of nat. hist. vollständig übersetze, die ich aber mit dem neuen Gattungstramen Geoplan a einführe, sind folgende:

14. Geoplana vaginuloides. Die Mündung des Nahrungscanals liegt um zwei Drittheile der ganzen Körperlänge vom vorderen Ende entfernt. Die Breite des Mundes $1 / 60$ Zoll; $3 / 10$ Zoll weiter nach hinten ist die sehr deutlich markirte Geschlechtsöffnung gelegen. Zahlreiche Augen in regelmässigen Abständen an dem vorderen Ende des Thieres, unregelmässig rings um den Rand der Bauchseite. Der vordere Theil des Körpers verschmälert, mit fast zugespitztem Ende und einer Grube an der unteren Seite, das hintere Ende mit abgerundeter Spitze. Der Körper convex, auf dem Scheitel abgeflacht. Die Seiten und der Fuss schmutzigorange, weiter nach oben auf jeder Seite zwei Streifen eines blassen Primel-gelb, äusserlich mit Schwarz eingefasst, in der Mitte des Rückens ein glänzend schwarzer Streifen; diese Streifen werden schmaler nach beiden Enden zu. Länge des völlig ausgedehnten Thieres $2 \% / 10$ Zoll, grösste Breite $13 / 100$ Zoll.

Gefunden unter der Rinde eines abgehauenen Baumes im Walde bei Rio Janeiro.

I5. Geoplana elegans. Die Lage der Oeffnungen wie in Geoplana vaginuloides. Der vordere Theil des Körpers ein wenig verschmälert. Die Augen fehlen am vorderen Ende und nur wenige sind rund um den Rand des Fusses. Die Farben sind schön, der Rücken schneeweiss, mit zwei nahe an einander liegenden röthlich braunen Streifen; gegen die Seiten mit einigen sehr feinen parallelen Streifen derselben Farbe; der Fuss weiss, nach aussen und am Rande des Körpers getrübt durch ein hellschwärzliches Purpur. Der Körper unkreist von drei farblosen Ringen, in deren zwei hinteren die Oeffnungen gelegen sind. Länge ein Zoll, Breite gleichförmiger und grösser im Verhältniss zur Länge als bei der vorigen Art.

Aufenthalt wie bei der vorigen.

16. Geoplana pulla. Der Saugmund kuglig, wenn er in Spiritus hervorgestreckt und zusammengezogen ist. Die Augen sind zahlreich und liegen in regelmässigen Zwischenräumen am vorderen Theile des Körpers. Der Körper ist leicht plattgedrückt, allmählig verdickt nach dem vorderen verschmälerten und unten ausgehöhlten Ende. Der Rücken tief umbrabraun, mit einem mittleren schmalen Streifen von spargelkohlbrauner Farbe, welcher über

I) Historia de Chile p. Claude Gay. Vers pl. I, Fig. 2 (konnte ich nicht vergleichen). Annales d. sc. nat. 3 ser. T. VIII, p. 140. u. 289 .

2) Proceedings of the Academy of natural sciences of Philadelphia. Vol. V, I850-I851, p. 24I 
die ganze Länge reicht; der Fuss wieder spargelbraun mit zwei hellen Flecken für die Oeffnungen. Länge im vollkommen ausgedehnten Zustande ${ }_{1}^{9} / 10$ Zoll, Breite $1 / 10$ Zoll.

Sehr häufig unter Steinen, Montevideo und Maldonado (Juni, August).

I7. Geoplana bilinearis. Die Augen zahlreich in regelmässigen Abständen gelagert. Der Körper ist fast cylindrisch, schmal, von fast gleichmässiger Breite. Die Farbe oben blassschmutziggelb, mit zwei Streifen von dunkelbraun, welche sich nach den Enden des Körpers näher rücken und schliesslich vereinigen. Länge im ausgedehnten Zustande $\mathrm{I}^{3} / 10$ Zoll, Breite $\% / 100$ Zoll.

Aufenthalt wie bei G. pulla.

I8. Geoplana nigrofusca. Die Nahrungsöffnung ist um etwas weniger als zwei Drittel der ganzen Länge von dem vordersten Ende entfernt; die Geschlechtsöffnung bei zusammengezogenem Körper um ${ }^{25} /{ }_{100}$ Zoll mehr nach hinten gelegen. Die Augen sind sehr zahlreich, die an der äussersten Spitze sehr klein und in regelmässigen Entfernungen von einander, die am Rande des Körpers gelegenen in Gruppen zu zweien oder dreien angeordnet. Der Körper sehr abgeplattet, gegen das vordere Ende bedeutend verschmälert, das hintere Ende schnell zugespitzt. Die Farbe ist auf dem Rücken gleichmässig schwarzbraun, an der Bauchseite blasser. Die Länge des Körpers im ausgedehnten Zustande 2 Zoll, die Breite $3 / 10$ Zoll.

Aufenthalt unter faulem Holze: Maldonado (Mai).

19. Geoplana pallida. Die Mundöffnung und die Geschlechtsöffnung sind bei etwas zusammengezogenem Körper $2 / 10$ Zoll von einander entfernt. Die Schlundröhre misst 15/100 Zoll in der Länge; ihr Rand ist sehr ausgebuchtet. Die Augen sind zahlreich, I I stehen dicht aneinander an dem vorderen Körperende, die anderen am Rande in Gruppen zu zweien oder dreien auch fast ausschliesslich an der vorderen Körperhälfte. Der Körper ist sehr flach, beide Enden sind zugespitzt. Die Farbe ist oben und unten weiss, der Darm schimmert röthlich durch. Beim Kriechen beträgt die Länge 3 Zoll, die Breite 2/10 Zoll.

Aufenthalt unter Steinen auf trocknen Hügeln bei Valparaiso (Juli).

20. Geoplana elongata, die Mund- und die Geschlechtsöffnung sind nicht bekannt. Augen fehlen. Das hintere Ende des Körpers ist stumpf und abgerundet. Die Farbe auf dem Rücken sepiabraun mit einem schmalen dunkelbraunen Mittelstreifen, die Seite des Körpers hellbraun schmal eingefasst, unmittelbar am Rande wieder dunkelbraun; die Bauchseite hellbraun. Die Länge des Körpers beträgt beim Kriechen 5 Zoll, im stark zusammengezogenen Zustande nur $I^{5} / 10$ Zoll, die Breite beim Kriechen 13/100 Zoll, zusammengezogen 4/10 Zoll.

Aufenthalt in faulem Holze in waldigen Bergen. Cap Tres Montes, westl. Amerika (December).

21. Geoplana semilineata, der Körper rundlich, oben grünlich schwarz gefärbt mit sehr kleinen weissen Punkten, über die vordere Hälfte des Körpers erstrecken sich 4 parallele Streifen von hellorangegelber Farbe, von welchen nur die beiden mittleren, einander mehr genäherten in die hintere Hälfte 
des Körpers reichen. Die Unterseite ist bleifarben, mit ungefärbten Stellen für die Oeffnungen.

Aufenthalt unter Steinen auf einer der Chonos-Inseln im Norden von Cap Tres Montes (December).

22. Geoplana maculata, die Enden des Körpers sehr dünn, die Breite fast gleichmässig. Die Farbe ist auf der Rückseite schwarz mit zahlreichen länglichen, verschieden grossen gelben Flecken; die Unterseite weiss und schwarz gefleckt. Die Länge beim Kriechen I $7 / 10$ Zoll, die Breite $2 / 10$ Zoll.

Aufenthalt in einem Walde in Valdivia (Februar).

23. Geoplana Tasmaniana, die Schlundröhre ist sehr ausdehnbar, die Mundöffnung beinahe in der Mitte der Unterseite, die Geschlechtsöffnung 1/10 Zoll weiter nach hinten, beim Kriechen $2 / 10$ Zoll. Die Augen sind am ganzen Rande der Unterseite des Körpers zerstreut, doch zahlreicher am vorderen Ende. Beide Enden des Körpers sind zugespitzt. Die Farbe der Rückseite ist schmutzig honiggelb, ein dunkelbrauner, jederseits hell umbrabraun eingefasster Längsstreifen verläuft über ihre Mitte. Die Bauchseite ganz weiss. Länge beim Kriechen $1 \frac{1}{2}$ Zoll, im zusammengezogenen Zustande 8/10 Zoll.

Unter umgefallenen Bäumen in den Wäldern von Vandiemensland häufig (Februar).

Von diesen durch Darwin bekannt gewordenen Arten stimmen einige höchst wahrscheinlich mit den von F. Müller beobachteten überein. So dürfte die G. elegans des Letzteren in der G. vaginuloides (Darwin) aufgehen, die G. pulla (Darwin) mit G. olivacea oder Maximiliani (Müller) identisch sein. Einen endgültigen Entscheid könnten wohl nur Abbildungen liefern, welche aber weder von Darwin gegeben noch von Fr. Müller bisher eingegangen sind. Sollte eine Verschiedenheit der beiden erstgenannten sich später herausstellen, so müsste die G. elegans Müller's einen anderen Namen erhalten, da dieser bereits von Darwin einer anderen Species, der oben unter No. I5 aufgeführten, beigelegt worden. In jedem Falle muss aber die G. pallida Müller's umgetauft werden, da Darwin's gleichnamige das Recht der Priorität in Anspruch nimmt. Letztere könnte ihrer reinweissen Farbe wegen, an die G. subterranea Müller's erinnern, wenn nicht die bestimmt betonte Abwesenheit der Augen der unterirdisch lebenden Art ihre Berechtigung als besondere Species genügend ausspräche.

Die zu den bisher aufgeführten 23 Species noch hinzukommenden beiden von Blanchard und Leidy beschriebenen, oben bereits erwähnten Arten sind:

24. Geoplana (Polycladus) Gayi (Blanchard), auf dem Rücken schwarzgrün gefärbt mit weisser Mittellinie, der Rand mit breiter Orange-Einfassung, welche von zwei schmalen schwarzen Linien begränzt wird; die Bauchseite orange.

Länge 85-90 Millimeter, Breite ungefähr 30 Millimeter.

Aufenthalt in Chile an feuchten Orten auf der Erde.

25. Geoplana (Rhynchodemus) sylvatica (Leidy), Körper länglich spindelförmig, vorn verschmälert, hinten zugespitzt, die Bauchseite etwas abgeplattet. Farbe auf dem Rücken grau mit zwei braunen Streifen längs der Mittellinie und einem queren gleichfalls braunen Fleck in oder dicht hinter der Mitte, der Bauch weisslich. Das Kopfende braun, aufwärts gebogen, zeigt zwei 
schwarze, seitlichgelegene Augen. Länge 2-5 Linien, Breite in vorderen Viertel $1 / 8$ Linie, im hintern $1 / 4$ Linie.

Aufenthalt zwischen Steinen, Blumentöpfen etc. in den Gärten von Philadelphia, sowie unter Holz und Rindenstücken in den Wäldern der Umgegend.

Als 26ste Art schliesst sich dieser letztgenannten endlich an die Geoplana (Planaria) terrestris O. F. Müller's, die einzige, bisher in Europa beobachtete Species. Wir gedachten derselben bereits oben.

Was uns Darwin und Leidy über die Anatomie der Landplanarien mittheilen, bezieht sich nur auf die mit blossem Auge oder geringen Vergrösserungen wahrnehmbaren Theile, den Verdauungsapparat, die ausführenden Theile des Geschlechtsapparates und die Augen, und findet seine volle Bestätigung in den oben mitgetheilten Angaben von F. Müller. Die Form des verzweigten Darmes ist bei allen dieselbe wie bei unseren bekannten Süsswasserarten, ebenso die Lage der Mundöffnung. Nur die Gestalt der Schlundröhre weicht, wie F. Müller besonders hervorhebt, bei mehreren Arten wesentlich ab, indem die Cylinderform mehr zur Trompetenform mit vielfach gefaltetem Rande der äusseren Mündung geworden. Die Geschlechtsöffnung liegt durchweg hinter dem Munde und ist stets einfach, wodurch sich die Landplanarien von den grösseren meerischen Formen, die wir namentlich durch Quatrefages $\left.{ }^{1}\right)$ kennen gelernt haben, und deren ich selbst einige untersuchen konnte ${ }^{2}$ ), entfernen. Penis und Samenleiter sind bei mehreren Arten erkannt worden. Wo Augen vorhanden sind, finden sich entweder $\mathrm{z} w \mathrm{w}$, bei G. terrestris und G. sylvatica, oder viele und diese sind dann stets am Rande des Thieres in ziemlich gleichmässigen Abständen gruppenweise oder mehr einzeln vertheilt. Dass dieselben einen lichtbrechenden Körper enthalten, führen Darwin und Leidy an.

Mit obigen Angaben über die Lage der Mund- und Geschlechtsöffnung stimmt, was Blanchard von seiner Gattung Polycladus meldet, nicht überein. Hier soll die Mundöffnung statt im hinteren im vorderen Drittheil des Körpers und die Geschlechtsöffnung noch weiter nach vorn liegen. Aus der weiteren Beschreibung des Thieres geht jedoch deutlich hervor, dass diesen Angaben nur eine Verwechselung von hinten und vorn zu Grunde liegt, welche verzeihlich sein mag, da Blanchard das Thier nicht lebend sah ${ }^{3}$ ). Bei solcher Auffassung verlieren aber natürlich die Angaben von Blanchard über das Centralnervensystem von Polycladus Gayi auch allen Werth. Dasselbe soll aus zwei über der Samenblase befindlichen Gehirnganglien und zwei nach hinten (vorn) laufenden Strängen bestehen, welche wieder durch mehrere (bis 14) kleine Ganglien unterbrochen sind. Welches Organ hier mit dem Nervensystem verwechselt worden, lässt sich schwer

I) Annales des sciences natur. 3 ser. Tom. IV, p. I 29.

2) Verhandlungen der physikal. medicinischen Gesellschaft in Würzburg Bd. IV, 1854, p. 222.

3) Uebrigens ist dies, wie ich beiläufig anführe, nicht der erste Irrthum der Art, in welchen dieser Forscher hier verfallen. Bei dem, in dem Darm von Cyprinus Brama sehr gemeinen Caryophyllaeus ist ihm derselbe Irrthum unterlaufen. (Annales des sciences natur. 3 ser. Tom. X, p. 324, Tab. I 2, Fig. 1, 2. Auch hier wird das mit den Generationsorganen versehene Ende zum vorderen gestempelt, während es in der That, wie auch alle älteren Beobachter richtig erkannten, das hintere ist. 
sagen, jedenfalls können über der Samenblase keine Gehirnganglien liegen, sondern diese müssen am entgegengesetzten Körperende gesucht werden.

Bei diesem immerhin dürftigen Stande unserer Kenntniss von dem Baue der Landplanarien kam es mir sehr erwünscht, ein Exemplar eines solchen Thieres zur Untersuchung zu erhalten. Dasselbe war von Herrn Burmeister bei Rio Janeiro gefunden und lebend in Spiritus gesetzt, in welchem es sich bis auf eine zufällige Verletzung in der Mitte des Körpers recht gut erhalten hatte. Zur mikroskopischen Untersuchung waren die Gewebe freilich nur zum Theil noch gut brauchbar. Doch gelang es, mit Hülfe des. Glycerins, das zur Aufhellung von Spirituspräparaten für das Mikroskop oft vortreffliche Dienste leistet, eine Einsicht in den feineren Bau mehrerer Organsysteme zu erhalten. Leider stand die Entwickelung der Generationsorgane bei dem Thiere so zurück, dass über die Geschlechtsdrüsen gar Nichts ermittelt werden konnte.

Unser Exemplar gehört keiner der oben characterisirten 26 Arten an und führe ich dasselbe unter dem Namen von Geoplana Burmeisteri in das System ein. Die Länge beträgt $2 \frac{1}{2}$ Zoll, die grösste Breite hinter der Mitte des Körpers fast $1 / 2$ Zoll, die Dicke I Linie. Der Körper ist nach vorn und hinten zugespitzt, nach hinten schneller, nach vorn sehr allmählig verjüngt und in eine lange Spitze ausgezogen. Die Farbe ist auf dem Rücken sepiabraun, am Vorderende schwarzbraun, ein hellbrauner Streifen von 1/2 Linie Breite läuft in die Mitte des Rückens vom vordersten bis zum hintersten Ende, sehr deutlich und scharf von fast schwarzen Rändern begränzt im vorderen Viertel des Thieres, dann verwaschen und erst in der Nähe des hinteren Endes wieder deutlicher. Auf dem Rücken finden sich ferner eine Menge kleiner kreissrunder weisslicher Pünktchen zerstreut, welche eben noch mit blossem Auge erkannt werden können, in der vorderen Hälfte kleiner sind und dichter stehen als in der hinteren, und nach dem Kopfende zu endlich ganz verschwinden. Die Unterseite ist gleichmässig graugelb, zeigt dicht hinter der Mitte die Mundöffnung, aus welcher in unserem Exemplar das vielfach gefaltete, trichterförmig erweiterte Mundende des Schlundrohres hervorragt und 5 Linien weiter nach hinten die sehr kleine Geschlechtsöffnung. Augen wurden bei mikroskopischer Untersuchung des Randes der vorderen Körperhälfte aufgefunden und stellen in einfacher Reihe ziemlich dicht hintereinander liegende, meist halbmondförmig gestaltete schwarzbraune Pigmentflecke dar, in deren nach aussen gerichteter Concavität ein runder, durchsichtiger Körper liegt, welcher das Licht nicht auffallend stark bricht und in dieser Beziehung ganz dem gleichgelagerten, als Linse zu deutenden Körper des Auges unserer Süsstvasserplanarien gleicht.

Die mikroskopische Untersuchung der Haut bestätigte zunächst die von F. Müller ausgesprochene, übrigens nach seiner oben mitgetheilten Beobachtung des Beweises durch das Mikroskop kaum mehr bedürfende Vermuthung, dass ein Wimperepithelium hier so gut wie bei den übrigen Turbellarien vorhanden sei. Wenn auch im Allgemeinen durch die Aufbewahrung in Spiritus der Wimperüberzug sehr gelitten hatte, so konnten an einzelnen Stellen doch die Epithelialzellen mit ihrer Wimperkrone unzweifelhaft erkannt werden. Ob freilich dieser Wimperüberzug ein ganz allgemeiner sei oder, wie bei vielen Schnecken, nur an einzelnen Körperstellen vorhanden, liess sich nicht entscheiden. Doch dürfte nach 
Analogic der übrigen Turbellarien kaum ein Zweifel an der gleichmässigen Verbreitung jenes Ueberzuges gerechtfertigt sein. Die Wimperzellen sind farblos und meist von Keilgestalt. Unverkennbar war an mehreren derselben die Verdickung der vorderen, Wimpern tragenden Zellmembran, welche diesen Epithelialgebilden eben so allgemein zuzukommen scheint, wie den Cylinderzellen des Darmes nach den Beobachtungen von Funke und Kölliker. Unter ihnen befindet sich eine Lage unregelmässig sechseckiger Pigmentzellen, welche der Sitz der eigentlichen Hauptfärbung sind. Gänzlich vermisst wurden in der Haut unserer Geoplana stäbchenförmige Körper, welche bekanntlich den Süss- und SeewasserPlanarien so allgemein zukommen. Dieselben lassen sich, wie ich mehrfach bemerkt habe, in Spiritus sehr gut conserviren, und konnte ihr Mangel demnach schwerlich in der Aufbewahrungsmethode begründet sein.

Unter den Zellen der Haut folgt wie bei den übrigen Turbellarien ein Hautmuskelnetz und zwar zunächst eine einfache Lage dicht aneinander gefügter Längsfasern. Darunter befindet sich eine dichtere Schicht quergela gerter Muskelelemente. Erstere lösen sich im Zusammenhange mit den Zellen der Oberhaut leicht als dünnes Häutchen von den Kreismuskeln ab, die ihrerseits eine innige Verbindung mit den Eingeweiden, namentlich den feineren Endzweigen des Darmrohres eingehen, so dass sie nicht ohne anhängende Theile der letzteren abgehoben werden konnten. Der Zustand der Maceration, in welchem sich durch die mehrjährige Aufbewahrung unsere Geoplan a befand, erleichterte die Trennung der genannten Schichten, welche im frischen Zustande schwerlich ausführbar gewesen wäre.

Die Elemente dieser Muskelschichten sind lange Fasern von o,0006-0,002 Linien Breite, durchaus homogen, ohne Unterschied von Hülle und Inhalt, ohne Spuren von Querstreifen, ganz denen gleichend, welche ich bei den Rhabdocoelen unter den Turbellarien beschrieben und abgebildet habe (Beiträge zur Naturgeschichte der Turbellarien, 1850), und wie sie sich bei den grösseren Dendrocoelen des Wassers finden. Schmale und breite sind untermischt, die schmaleren an Zahl bei weitem überwiegend, die breiteren theilen sich öfter, in einzelnen Fällen sieht man pinselförmige Ausstrahlungen an denselben.

Den von den Ringmuskeln umgebenen Raum fand ich fast ganz ausgefüllt vom Darmcanale, indem, wie schon angeführt wurde, von dem secernirenden Theile der Geschlechtsorgane, welcher sich bei geschlechtsreifen Thieren in grösserer oder geringerer Ausdehnung sicher zwischen die Verzweigungen des Darmes einschieben wird, in unserem Exemplare Nichts wahrgenommen werden konnte. Nur in der unmittelbaren Nähe der Geschlechtsöffnung nahm das kuglige Begattungsglied einen verhältnissmässig bedeutenden Raum ein. Den Anfang des Darmrohres bezeichnete die äusserlich vorragende, gefaltete Mundöffnung des Schlundrohres, von weisser Farbe, aus sehr dicht verfilzten schmalen Muskelfasern gebildet. Das Schlundrohr setzt sich unter der Haut verborgen und ziemlich die ganze Dicke des Thieres einnehmend als ein etwa I I,inie starker und 4 Linien langer Cylinder nach vorn fort. Von ihm entspringen an dem der Mundöffnung antgegengesetzten Ende 3 Zweige des Darmes, einer nach vorn in der Richtung des Schlundrohres verlaufend und unter Abgabe zahlreicher rechtwinklig abstehender Aeste allmählig verschmälert bis in die Nähe des vorderen Endes 
reichend, und zwei nach hinten gehende Aeste, welche nach rückwärts umgebogen längs des Schlundrohres und über dasselbe hinaus bis an das hintere Ende reichen, und nach aussen zahlreiche Zweige abgeben. Diese Haupt- und die grösseren Nebenzweige des Verdauungsrohres besitzen stark muskulöse Wandungen und einen inneren kleinzelligen Epithelialbelag. Mit der immer mehr ins Feine gehenden Theilung der Seitenäste des Nahrungscanales verdünnt sich die Muskelschicht immer mehr, während die Epithelialzellen grösser und dunkler granulirt werden, bis letztere die an die Ringmuskeln der Haut innen angehefteten traubigen Enden der Darmverzweigungen ausschliesslich darstellen, nur von zarter structurloser Hülle umgeben. Diese grosszelligen letzten Enden des verzweigten Verdauungsrohres dürften in ihrer Function einer Leber verglichen werden.

Die Muskelfasern des Nahrungscanales gleichen zum grossen Theile den oben geschilderten der Haut. Ausser diesen finden sich aber noch andere muskulöse Elemente in der ganzen Ausdehnung dieses Canalsystems, welche den organischen Muskelfaserzellen höherer Thiere in der Form nicht unähnlich sind. Es sind dies meist spindelförmige, abgeplattete Körper mit abgerundeten oder unregelmässig gerissenen Enden von ähnlicher Grösse und Gestalt, wie die breiten kurzen Muskelfaserzellen aus Arterienhäuten, die ich in meiner Inauguraldissertation: De arteriarum notione, structura etc., I 849, tab. III, Fig. 2 u. 4 abgebildet habe. Dieselben sind durchsichtig, blass, farblos, nicht körnig, dagegen mit einer Andeutung von Längsstrichelung versehen und entweder homogen, oder zeigen einen körnigen centralen Streifen, welcher entweder durch die ganze Länge des faserzellenähnlichen Gebildes läuft, oder nur im Centrum auf eine kürzere Strecke wahrnehmbar ist. Dieser Streifen besitzt in der Mitte immer eine Anschwellung und ist nach den Enden zugespitzt, hat aber keine Aehnlichkeit mit einem scharfumschriebenen Kerne, sondern erinnert eher an die körnigen Axenstränge der Muskelfäden, welche nenerdings C. Semper von den Schnecken beschrieben hat (Zeitschr. f. wiss. Zoologie, Bd. VIII, p. 345, Tab. VII, F̈ig. 10). Die Gestalt der beschriebenen Körper variirt mannigfach. Wenn auch die Spindelform die gewöhnliche ist, so kommen auch einzelne keulenförmige vor, welche an einem Ende in einen längeren Faden ausgezogen sind, andere gleichen Bruchstücken von Fasern, und noch andere stellen wirklich längere Fasern dar, gleichen dabei in ihrem Lichtbrechungsvermögen und der Andeutung einer Längsstrichelung clen Spindelkörpern vollkommen, wenn ihre Breite auch eine geringere ist, so dass ein Uebergang der einen Form zur andern nicht verkannt werden kann. Alle diese Elemente kommen in den Wandungen des Verdauungsrohres mit schmäleren Muskelfasern, wie ich sie in der Haut gelegen beschrieb, gemischt vor, und zeigen wieder deutliche Uebergänge zu diesen, so dass ich namentlich aus diesem Grunde den Schluss auf die muskulöse Natur auch der Spindelkörper zu ziehen nicht anstehe. Es scheint demnach, als wenn die breitesten unter den Muskelbändern im Körper unserer Geoplana aus einzelnen, den Faserzellen der höheren Thiere ähnlichen Elementen zusammengesetzt wären, welche sich nach der Maceration leicht isoliren lassen, oder, wo sie fester bereits verbunden waren, leicht abbrechen, während die schmäleren lange continuirliche Fäden bilden, an welchen eine Verschmelzung aus mehreren Zellen nicht mehr wahrzunehmen oder überhaupt niemals vorhanden gewesen ist. 
In dem Schlundrohre unseres Thieres fand ich einen Bissen eingeschlossen, welcher aus der Reibeplatte und den Kiefern einer Schnecke mit anhängenden muskulösen Theilen bestand. Es spricht diese Beobachtung wie die Angabe von F. Müller über den Vernichtungskrieg, welchen die Geoplana subterranea gegen die Regenwürmer führt, gegen die Annahme von Darwin, dass die Landplanarien sich nur von vegetabilischer Kost nährten und zwar von zersetztem Holze, an welchem man sie rornehmlich findet. Darwin hielt zwar einige Exemplare 2 I Tage eingesperrt ohne ihnen anderes zur Nahrung zu reichen wie faules Holz, und wuchsen die Thiere in dieser Zeit beträchtlich. Doch möchte diese Beobachtung immer noch nicht entscheidend sein, da der Darm auf seinen Inhalt nicht untersucht wurde. Unser Exemplar enthielt nicht eine einzige Pflanzenzelle in demselben.

Vom Nervensysteme konnte durch Präparation Nichts dargestellt werden, und von den Generationsorganen habe ich nur noch den an der Geschlechtsöffnung als kugligen Körper von $1 / 2$ Linie Durchmesser leicht isolirbaren Penis und die Samenblase zu erwähnen. Letztere enthielt keine Spermatozoiden. Die wahre Gestalt dieser contractilen und ganz aus feinen Muskelfasern gebildeten Organe wird nur die Untersuchung frischer Exemplare ermitteln können. Ein Gleiches gilt von den Geschlechtsdrüsen, dem Wassergefässsystem u. s. w. Immer aber würde eine Aufbewahrung dieser so äusserst zarten Thiere behufs späterer histologischer Untersuchungen in einer Lösung von doppelt chromsaurem Kali I-2 Gran auf eine Unze Wasser dem Spiritus bei weitem vorzuziehen sein, und empfehle ich diese Lösung allen Sammlern aufs wärmste. 


\section{Lumbricus corethrurus, Bürstenschwanz $\left.{ }^{1}\right)$.}

Der Inhalt der Abhandlung ist in der Anmerkung S. 65-66 der gesammelten Schriften wiedergegeben. Angefügt ist noch die folgende Notiz des Herausgebers des Archivs:

Die obige Mittheilung ist mir im Januar 1857 mit folgendem Schreiben des Hrn. Prof. Max Schultze in Halle zugegangen, welches manchem Leser des Archives von Interesse sein dürfte:

Mit besten Grüssen sende ich Ihnen anbei die Beschreibung eines neuen Regenwurmes von Dr. Fritz Müller in Colonie Blumenau in Brasilien, Ihnen bekannt durch seine früheren Beiträge zu Ihrem Archiv, in welchem auch diese Zeilen wohl einen Platz finden dürften.

Nachdem Müller mehrere Jahre Landbauer in der genannten Colonie gewesen und kaum Zeit zu naturwissenschaftlichen Beobachtungen, geschweige denn dazu hatte, solche in einer mittheilbaren Form niederzuschreiben, dürfen wir jetzt auf reichlich erfolgende Mittheilungen und Sammlungen von ihm hoffen. Er ist seit Kurzem als Lehrer der Mathematik an einer neugegründeten Schule in Desterro auf der Insel St. Catharina angestellt, wohnt unmittelbar am Meere, dessen Fauna er mir in beredten begeisterten Worten als eine ausserordentlich mannichfaltige schildert, und wird sich zoologischen Studien nunmehr so viel es seine Zeit erlaubt widmen. Ich freue mich ungemein, dass eine so tüchtige Kraft der Wissenschaft wiedergewonnen ist. Ein Mikroskop habe ich ihm jetzt auch durch Burmeister hinüber geschickt.

I) Archiv für Naturgeschichte 1857. I. p. I13 116. 


\title{
Einiges über die Annelidenfauna der Insel Santa Catharina an der brasilianischen Küste $\left.{ }^{1}\right)$. \\ (Aus einer brieflichen Mittheilung an Prof. Grube.)
}

\author{
Mit Tafel V und VI.
}

Die nachfolgenden Bemerkungen über brasilianische von Herrn Dr. Fr. M üller gesammelte Anneliden glaube ich dem wissenschaftlichen Publikum um so weniger vorenthalten zu dürfen, da uns von exotischen Thieren dieser Klasse so wenig bekannt, die hier besprochenen von Herrn Dr. Müller lebend beobachtet und darunter viele neue Gattungen aufgestellt sind. Wir entnehmen daraus zugleich, dass die grüne Blutfarbe bei den Anneliden weiter verbreitet ist, als wir bisher gewusst, dass auch bei den Polynoën verschiedene Arten verschieden gefärbtes Blut besitzen, und dass sich die Zahl der Anneliden mehrt, denen das sonst so allgemein vorkommende lebhaft pulsirende Rückengefäss und übcrhaupt verzweigte Gefässe fehlen, und bei denen, wie es scheint, das Blut nur wandungslos in der Leibeshöhle vorkommt, und zwar ein Blut, dessen Farbstoff nicht an seiner Flüssigkeit, sondern an den in ihm sehr zahlreich vorkommenden ganz regelmässig geformten Körperchen haftet. Was an genauerer Unterscheidung der hier erwähnten Arten noch mangelt, das werden hoffentlich bald zu erwartende Nachträge ergänzen.

Ed. Grube.

... Wie zu erwarten stand, sind alle hiesigen Arten neu: Ihre Zahl beläuft sich auf etwa 6o, die sich, wie folgt, unter die einzelnen Familien verteilen:

Fam. Aphroditea. 4 Polynoë (Lepidonote-) und 2 Palmyraarten. Letztere dadurch interesssant, dass alle Segmente gleich ausgestaltet sind und Rückencirren tragen, auch das grüne Blut der P. obscura ist eine bemerkenswerthe Eigenthümlichkeit. Von den Polynoën hat die gemeinste Art (P. fusca) eine grössere Zahl von Elytren als alle übrigen Lepidonoten, nämlich 2 I $\mathrm{Paar}^{2}$ ), die auf die 45 Segmente so vertheilt sind, dass sie dem 2 ten, 4 ten, 5 ten, 7 ten, gten u. s. w. 25 sten, 27 sten, 28 sten, 3 osten, 3 Isten, 34sten, 36 sten, 38 sten, 4 Isten zukommen.

I) Archiv für Naturgeschichte 1858. I. p. 21I-220. Taf. VI. u. VII.

2) Nicht mehr die einzige Art mit 2 I Elytrenpaaren. Gr. 
P. 1 unifera mit 37 Segmenten trägt ihre ${ }_{5}$ Paar Elytren auf dem 2ten, 4 ten, 5ten, 7 ten u.S. w., I 9 ten, 2 Isten, 24sten, 27 sten, 3osten, 33sten Segment.

Bei dieser und P. pallida beobachtet man Flimmerepithelium auf der Basis der Ruder, wo es auch sonst öfter vorkommt.

Fam. Eunicea. I Diopatra, I Onuphis, 3-4 Eunice, 3 I.umbriconereis und I neue Gattung ${ }^{1}$ ).

Die Lumbriconereis sind entschieden nicht blosse Jugendzustände, wie für die eine Art die beobachteten Eier und Spermatozoiden, für die anderen beiden die sehr eigenthümliche Gebiss- und Borstenbildung berveist.

Diopatra hat grünes Blut. Die Normalzahl der Aftercirren der Euniceen, die ich bei allen unseren Arten finde, ist 4, selten gleich lang wie bei 2 Lumbriconereis, meist die untere beträchtlich kürzer und selbst fast verschwindend klein. Die Borsten in vollzähliger Entwickelung zeigen 6 verschiedene Formen an demselben Ruder, von unten nach oben in folgender Ordnung: I) Rückenborsten, bisweilen fast gerade und den Aciculis ähnlich, selten die einzige Bewaffnung des Ruders bildend; 2) ein Bündel zusammengesetzter Borsten; 3) Aciculae meist in mehrfacher Zahl, bisweilen mit knopfförmiger Spitze, bisweilen in eine haarförmige Spitze auslaufend; 4) ein Bündel haarförmiger Borsten, denen sich bisweilen paleenähnliche Borsten beigesellen; 6) endlich einige sehr zarte nach dem Rückencirrus zu sich erstreckende, nicht aus der Haut austretende Borsten.

Vielfache Eigenthümlichkeiten hat die Gattung Anisoceras' Gr. (Taf. V. Fig. 1). Der elliptische Kopflappen trägt 2 Paar Augen, "nahe dem Seitenrande I Paar geringelter und daneben ein zweites Paar plumper ungeringelter Fühler. Das zweiringlige Mundsegment, das beiderseits wulstig neben dem Kopflappen vorspringt, ist anhangslos. Die ziemlich schlanken Ruder mit drei Lippen (Taf. V. Fig. 2), einer unteren und zwei oberen, über der unteren ein Büschel sichelförmiger, zwischen den oberen ein Büschel einfacher Borsten, eine einzelne Acicula, ein kurzer Bauch- und ein ziemlich langer zweigliedriger Rückencirrus. Keine Kiemen. Vier Aftercirren. Das abweichendste ist indessen das Gebiss, indem hier die Kiefer in eine grosse Zahl (gegen I Oo) einzelner Zähne zerfallen, die jederseits vier paarweis genäherte gebogene Längsreihen bilden. Auch die Färbung ist eigenthümlich, indem der gelbliche Körper auf dem Rücken jedes Segments zwei braunrothe Querbinden trägt.

Die unteren Fühler scheinen nicht den äusseren Rückenfühlern der Euniceen zu entsprechen, sondern ähnliche nur beträchtlicher entwickelte und an die sogenannten Fühlercirren der Spiodeen erinnernde Organe, wie sie sich bei den Larven der Onuphis finden.

Fam. Lycoridea. 6 Arten Nereis, meist aus der Abtheilung Nereilepas. Für diese scheint mir die Deutung des grossen oberen Züngelchens als Kieme unzweifelhaft. Eine bis jetzt nur einmal beobachtete Art hat grünes Blut.

1) Herr Dr. Müller hatte noch nicht das Heft der Videnskabelige Meddelelser fra den naturhistoriske Forening i Kjöbenhavn vom Jahre 1856 in Händen, in welchen ich p. 60 die hier beschriebene Gattung bereits unter dem Namen Anisoceras aufgestellt und darauf aufmerksam gemacht habe, dass auch delle Chiaie eine zu derselben gehörige Art unter dem Namen Nereis Rudolphii in seinen Memorie beschrieben. Die Art, welche Herr Dr. Müller vor Augen gehabt, scheint mir dieselbe, die Oerstedt bei Punta arenas gefunden und die wir in der oben genannten Zeitschrift als Anisoceras vittata beschrieben. Gr. 
Fam. Phyllodocea. Eine kleine Eulalia und eine Hesione, letztere (H. picta) mit weissen Querbinden auf schwärzlichem Grunde und mennigrothem Grundgliede der Rücken- und Fühlercirren ist vielleicht die schönst gefärbte der bekannten Anneliden. Sie ist fühlerlos (Taf. V. Fig. 3). Rothes Blut, dicht aneinander liegende Hälften des Nervenstranges und büschelförmige Ovarien entfernen sie von den eigentlichen Phyllodoceen.

Fam. Syllidea. Eine Art Syllis, die vielleicht wegen der Randpapillen des Rüssels eine eigene Gattung Lalage bilden muss, wenn den übrigen Syllis diese Papillen wirklich fehlen. Wie arm sind hier diese beiden in nordischen Meeren so reichen Familien im Vergleiche mit den Euniceen.

Fam. Glycerea. Eine neue Gattung:

Glycinde.

Mit reichlicher bewaffnetem Rüssel als irgend ein anderer Wurm (Taf. V. Fig. 4. 5. 6). Randpapillen und nahe dem Rande ein Kreis von etwa 20 schwarzen Kieferspitzchen, von denen die zwei untersten ansehnlich gross sind. Auf der Rückenseite zwei Längsbinden farbloser aufwärtsgekrümmter Zähne (mehrere ıoo), kleinere Zähnchen auf seiner Bauchfläche und einzelne flache Plättchen zerstreut an den Seiten. Kopflappen geringelt, die vier Fühlerchen zweigliedrig, ein Paar Augen an seiner Basis, ein zweites nahe der Spitze. Keine Kiemen. Rückenund Bauchcirrus und zwei blattförmige Lippen an jedem der beiden Borstenbüschel. Zwei lange untere und zwei rudimentäre kuglige obere Aftercirren. Ich vermisse bis jetzt bei diesem Thiere Gefässe. Die Flüssigkeit der Leibeshöhle hat Blutfarbe, enthält zahlreiche grosse flache kreisrunde Scheibchen (von $1 / 40$ Millimeter Durchmesser ${ }^{1}$ )) und scheint die Stelle des Blutes zu vertreten.

Spec. Glycinde multidens.

Fam. Amytidea?

Sigambra Grubii. Kopflappen nicht deutlich vom langen Mundsegmente geschieden mit zweilappiger Stirne; zwei winzigen Stirn- und drei NackenFühlern (Taf. V. Fig. 9), jederseits zwei Paar Fühlercirren; der obere des hinteren Paares sehr lang, zwischen denen des hinteren Paares ein Borstenbündelchen. Ruder einästig mit einem Bündel einfacher Borsten und einer Acicula, kurzer fadenförmiger Bauch- und langer schmal blattförmiger Rückencirrus, in dessen Basis versteckt sich eine zweite Acicula, begleitet von einem einzelnen gestreckten Häkchen ('Taf. V. Fig. 7 u. 8). Zwei lange Aftercirren; zahlreiche kurze Segmente. Rüssel cylindrisch mit Randpapillen, Darm mit seitlichen Fortsätzen in die Basis der Ruder. Blut gelblich.

Fam. Ariciea. 2 Arten Spio(?), I Leucodore, I Magelona (nov. gen.), I Gisela n. g., 4 Cirratulus, I Aricia, I Theodisca n. g., I Cherusca n. g., I Hermundura. Sie sehen, wie reichlich diese Familie oder vielmehr das Gemisch heterogener nur durch negative Charaktere vereinigter Thiere hier vertreten ist. $\mathrm{Ob}$ wirklich Leuckart's Leucodore mutica der sogenannten Fühler entbehrt,

I) Wir hätten hier also ein drittes Beispiel von einer frei im Leibe einer Annelide fluctuirenden an regehnässigen gefärbten Körperchen reichen Flüssigkeit, beim Mangel von Gefässen. An Glycera und Capitella haben Quatrefages, van Beneden, Oersted und ich älnnliches beobachtet. Gr. 
möchte ich, beiläufig bemerkt, bezweifeln; da die Spionen leicht diese Organe verlieren und nicht selten ohne dieselben angetroffen werden.

$$
\text { Magelona. }
$$

Kopflappen flach, häutig, breit herzförmig; zwei sehr lange mit cylindrischen Papillen besetzte sogenannte Fühlercirren, ich sage sogenannte, da ich in der That kaum eine Analogie zwischen diesen Organen und den Fühlercirren anderer Rapacia finde.

Vordere Körperabtheilung aus 9 Segmenten mit zweizeiligen Bündeln einfacher Borsten, jedes mit einer cirrenartigen Lippe. Die sehr zahlreichen Segmente der hinteren Körperabtheilung tragen jederseits eine untere und eine obere Querreihe gestreckter Häkchen (Taf. V. Fig. I I) und zwischen beiden zwei cirrenartige fadenförmige oder schmal blattförmige Fortsätze. Zwei Aftercirren. Wenig vorstülpbarer Rüssel. Darm in der hinteren Körperabtheilung zwischen je zwei Segmenten sehr stark eingeschnürt. Das Blut blassviolett mit sehr zahlreichen Blutkügelchen. Rücken- und Bauchgefäss; an der Grenze je zweier Segmente der hinteren Körperabtheilung entspringt aus jedem derselben ein Seitengefäss; diese laufen neben einander nach aussen, dann geschlängelt nach hinten und enden in eine gemeinsame contractile Blase (Taf. V. Fig. Io). Weitere Gefässe scheinen zu fehlen. Das Blut fluctuirt sehr lebhaft, doch in stets wechselnder Richtung. In der vorderen Körperabteilung scheint das Blut gefässlos die Leibeshöhle zu füllen, und dringt in den Kopflappen und die Fühlercirren.

Spec. Magelona papillicornis.

\section{Gisela.}

Herzförmiger Kopflappen; zwei Paar Augen. Ein Büschel Haarborsten zwischen einer breit blattförmigen unteren und oberen Lippe, von denen die letztere in einen cirrusähnlichen Faden ausläuft; auf der Bauchseite eine Querreihe Hakenborsten, von denen eine einfach S-förmig und stärker ist, die anderen einen kurzen scharf umgebogenen Schnabel haben (Taf. V. Fig. 12). Von der oberen Lippe läuft eine niedrige häutige Lamelle mit stark flimmerndem Rande quer über den Rücken und scheint als Kieme zu fungieren. Die vorderen Segmente sind abweichend ausgestaltet. Zwei Aftercirren.

Spec. Gisela heteracantha.

\section{Theodisca.}

Theodisca schliesst sich im Baue der seitlichen Fortsätze an Aricia an, unterscheidet sich aber durch einen einzig dastehenden Rüssel, der dendritisch in zahlreiche fingerförmige mit Flimmerepithelium bedeckte Lappen zerschlitzt ist (Taf. V. Fig. 14).

Ruder der hinteren Segmente Taf. V. Fig. 13, Aftersegment Taf. V, Fig. 15. Spec. Theodisca aurantiaca.

Herm undura.

Kopflappen zweispitzig oder vielmehr in zwei einstülpbare Stirnfühler (Taf. VI. Fig. I9) auslaufend. Zweiästige Ruder, der lange untere Ast mit farbloser Acicula und einem Büschel zahlreicher ziemlich starker einfacher Borsten; der sehr kurze obere $\Lambda$ st hat als einzige Bewaffnung eine Acicula, kürzer und stärker als die 
des untern (Taf. VI. Fig. 21. Keine Kiemen. Zwei seitlich abstehende und ein kurzer unpaariger Aftercirrus (Taf. VI. Fig. 20).

Spec. Hermundura tricuspis.

\section{Cherusca.}

Winziger Kopflappen mit unpaarem Fühler, auf seinem Rücken (oder dem des isten Segments?) ein ästiger Anhang, fast wie eine Terebellenkieme! Die seitlichen Fortsätze aller Segmente mit einer oberen und unteren blattförmigen Lippe. Borsten des Isten Segments ein Bündel gerader und ein Bündel schwach S-förmig gebogener Borsten, am 2ten und 3ten Segmente einige dieser S-förmigen Haken und ein Bündel zarter Haarborsten, am 4ten bis 6ten Segmente nur diese letzteren, ebenso am 7 ten bis i 3 ten, an denen die Enden der beiden Lippen in spatelförmige Paleen übergehen, die diesen Weichtheilen nicht ein-, sondern aufgepflanzt sind! (Taf. VI. Fig. I8). Die übrigen Segmente mit mehreren Büscheln verschiedener starker Haarborsten und im oberen Theile des Ruders mit einem Säckchen voll äusserst zahlreicher loser, in Masse goldglänzender sehr zarter kurzer Borstchen, die bei jedem Reize in Menge entleert werden und mit dem aus dem vorderen Theile des Ruders austretenden Schleime das Thier umgeben (Taf. VI. Fig. 16). Drei Aftercirren (Taf. VI. Fig. 17). Diese hintere Körperabtheilung ist unendlich lang, ich habe schon über fusslange Fragmente, aber noch kein unversehrtes Exemplar des sehr schmalen und flachen äusserst zerbrechlichen Thieres gefunden.

Keine dieser sonderbaren Aricieen ist etwa nur Larvenzustand: ich habe alle mit entwickelten Zeugungsstoffen beobachtet.

Familie? Drilidium.

Der kurze rundliche Körper hat gegen 20 undeutlich geschiedene Segmente; ein deutlicher Kopflappen, zwei Augen, Mund am Vorderende, daneben ein paar längere Papillen (Fühler?), winzige Borstenhöcker mit einer Acicula und ein zwischen zwei kurzen Lippen vortretendes Bündel von etwa fünf einfachen lanzettförmigen Borsten. Haut mit kleinen Papillen besetzt. Kurzer muskulöser Schlund und weiter häutiger etwas gebogener Darm, der frei in der Leibeshöhle liegt. Das Thier, frei im Meerwasser aufgefischt, war nur $3 \frac{1}{2}$ Millimeter lang, hatte aber die Leibeshöhle voll Eier in verschiedenen Stadien der Entwickelung.

Fam. Pherusea. Ein Siphonostomum. Die sogenannten oberen Fühler sind ohne Zweifel Kiemen, das beweist ihr Blutreichthum und ihr ungewöhnlich lebhaft wimperndes Flimmerepithelium, auch die sogenannten unteren Fühler scheinen mir wenig Anspruch auf diesen Namen zu haben.

Fam. Maldania. I Clymene und i Ammochares vielleicht nicht verschieden von A. Ottonis, dessen Beschreibung mir nicht mehr erinnerlich ist. Clymene hat einen vorstülpbaren Rüssel. Die zerschlitzte Kopfmembran des Ammochares ist ziemlich blutreich und flimmert, und ist deshalb wohl als Kieme anzusprechen. Blut roth. Zahlreiche blinde frei in der Jeibeshöhle flottirende Gefässe.

Fam. Terebellacea. Etwa ein halb Dutzend Terebella, I Terebellides, I Isolda nov. gen., I Sabellides?, 1 Polycirrus.

Terebellides anguicomus (Taf. VI. Fig. 22). 17 Paar Borstenbündel, Hakenborsten gestreckt, fehlen unter dem isten bis ften Borstenbüschel, unter dem 5 ten 
sind sie von abweichender Form (Taf. VI. Fig. 23). Der hintere Körpertheil mit Flösschen, die sehr winzige Häkchen tragen, ist durch eine Einschnürung in zwei Abtheilungen geschieden, die vordere mit I I-I 2 ziemlich langen, die hintere mit gegen 30 sehr kurzen Segmenten. Keine Aftercirren, kein die Fühlfäden deckendes Blatt, diese zahlreich, zart mit lanzettlich verbreiterter Spitze. Kiemen aus vier verwachsenen Blättern bestehend, die beiden unteren oder hinteren sehr klein und nur an der Spitze als schmale Züngelchen vortretend, die obern mit queren kreisförmigen Lamellen besetzt. Vor dem muskulösen Magen zwei dunkelbraune Drüsen. Einer der gemeinsten unserer Ringelwürmer.

\section{Is olda.}

Ueber dem Lippenblatte wenig zahlreiche kurze Fühlfäden, acht Kiemenfäden auf dem Rücken dicht beisammen, die vier äussern einfach, die vier innern mit doppelter Reihe von Nebenfäden (Taf. VI. Fig. 26). Ausser dieser Form der Kiemen erinnert das Thier auch dadurch bei oberflächlicher Betrachtung an die Serpulaceen, dass es die Kiemen meist in der Richtung der Körperachse aus dem häutigen Rohre vorstreckt. Kiemen und Fühlfäden flimmern. Im hinteren Theile des Körpers nur Flösschen mit kurzen Häkchen; vorn Bündel einfacher Borsten und untere Häkchenreihen, an deren Stelle bei den ersten Borstenbüscheln eine dichte Reihe kurzer, gerader Borsten; die Bewaffnung des ersten Segments beschränkt sich auf einen einzigen starken Stachel mit kurzer sichelförmiger Spitze. Blut blassroth mit einem Stich in's Grünliche.

Spec. Isolda pulchella.

Sabellides? Das Thier, das ich seiner einfachen fadenförmigen Kiemen wegen vorläufig hierher stelle, hat sonst, so viel ich mich der Sars'schen Beschreibung erinnere, wenig Aehnlichkeit mit dessen Art. Das Lippenblatt, 3/4 des Umkreises bildend, umgiebt kreisförmig den Mund und trägt am Rande und darüber die zahlreichen langen und ziemlich starken röthlichgrauen Fühlfäden, die durch kein Blatt von oben gedeckt sind. Kiemenfäden sehr zahlreich in sechs Gruppen den sechs Kiemen der Terebellen entsprechend, können sich pfropfenzieherartig zusammenziehen. Körper von gewöhnlicher Terebellenform, lang, mit Borstenbüscheln und Häkchenreihen an allen Segmenten.

Polycirrus? beobachtete ich erst in wenigen unvollständigen Exemplaren. Ein ziemlich langes Blatt über dem Munde trägt zahlreiche hohle Fäden mit Flimmerepithelium, in denen das rothe Blut mit auffallend grossen Blutkörperchen durch Contraktion dieser Fäden lebhaft hin und her wogt. Die Querreihen der Häkchen beginnen unter dem 7 ten Borstenbüschel.

Fam. Hermellacea. I Sabellaria, I Centrocorone.

Fam. Serpulacea. 4 Sabellen ${ }^{1}$ ), i Protula, I Eupomatus und verschiedene Serpula- und Spirorbisröhren.

I) Die von Herrn Dr. Müller hier angeführten von ihm für neu gehaltenen Arten scheinen mir noch nicht so genau charakteisirt, dass man sie mit Sicherheit von allen übrigen unterscheiden könnte; weshalb ich es im Interesse der Wissenschaft für räthlicher halte, ihre Namen hier vorläufig noch nicht mitzutheilen. 


\section{Erklärung der Abbildungen auf Tafel V und VI.}

Fig. I. Vorende von Anisoceras vittata Gr. Oerst.

Fig. 2. Ruder derselben.

Fig. 3. Kopflappen von Hesione picta.

Fig. 4. Zahn von Glycinde multidens.

Fig. 5. Grössere Kieferspitzen von Glycinde multidens.

Fig. 6. Kleinere Kieferspitzen von Glycinde multidens.

Fig. 7. Ruder von Sigambra Grubii.

Fig. 8. Hakenborste von Sigambra Grubii.

Fig. 9. Vorderende von Sigambra Grubii.

Fig. I 0 . Gefässschlinge von Magelona papillicornis.

Fig. I I. Hakenborste von Magelona papillicornis.

Fig. I 2. Querreihe von Hakenborsten von Gisela heteracantha.

Fig. I3. Ruder der hinteren Segmente von Theodisca aurantiaca.

Fig. I4. Rüssel von Theodisca aurantiaca.

Fig. I 5. Aftersegment von Theodisca aurantiaca.

Fig. I6. Ruder der hinteren Körperabtheilung von Cherusca nitens. a Säickchen mit losen Borsten. $b$ Schleimkügelchen.

Fig. I 7. Aftersegment von Cherusca nitens.

Fig. I 8. Palee des 7.- I3. Segments von Cherusca nitens.

Fig. I9. Einstülpbaare Stirnfühler von Hermundura tricuspis.

Fig. 20. Aftersegment von Hermundura tricuspis.

Fig. 2I. Ruder von Hermundura tricuspis.

Fig. 22. Terebellides anguicomus.

Fig. 23. Hakenborste unterm 5. Borstenbüschel von Terebellides anguicomus.

Fig. 24. Hakenborste unterm 6.-I7. Borstenbüschel desselben Thieres.

Fig, 25. Hakenborste der Flösschen desselben Thieres.

Fig. 26. Vorende von Isolda pulchella.

Fig. 27. Aftersegment von Isolda pulchella.

Fig. 28. Borsten vor dem Borstenwechsel von Sabella.

Fig. 29. Borsten des ersten Segments nach dem Borstenwechsel von Sabella.

Fig. 3o. Borsten der hinteren Segmente von Sabella.

Fig. 3I. Aftersegment einer Sabella.

Fig. 32. Augen mehr vergrössert von derselben.

Fig. 33. Hakenborsten vor dem Borstenwechsel von derselben. 


\section{Die Magenfäden der Quallen ${ }^{1}$ ).}

Man kennt seit lange bei den höheren Schirmquallen, den Familien der Rhizostomiden, Medusiden, Pelagiden und Charybdeiden, Gruppen tentakelähnlicher Fäden in der Nähe des Mundes, die mit langsam wurmförmiger Bewegung begabt, mit Flimmercilien bedeckt und mehr weniger reichlich mit Nesselorganen ausgestattet sind. Sie scheinen den Quallen der genannten Familien allgemein zuzukommen und dürften das einzige sie von den niederen Quallen (Cryptocarpae Eschsch., Gymnophthalmata Forb., Craspedota Gegenb.) scheidende gemeinsame Merkmal sein. Der Mangel des Velum wenigstens, den Gegenbaur als solches betrachtet, ist es eben so wenig, als die Bedeckung der Randkörperchen, von der Forbes den Namen der Steganophthalmata entlehnte; zwei mit Charybdea marsupialis Pér. in den wesentlichsten Zügen ihres Baues übereinstimmende Arten, Tamoya haplonema und quadrumana mihi, deren ausführliche Beschreibung ich dieser Tage meinem Freunde Max Schultze übersandte, haben ein höchst entwickeltes Velum.

Weniger übereinstimmend, als über das Vorkommen, lauten die Angaben über die Bedeutung dieser Fäden. Ihr constantes Vorkommen in der Nähe der Geschlechtsorgane bei den ersten drei Familien gab Veranlassung, sie als ,fühlerähnliche Anhänge der Geschlechtsorgane" zu bezeichnen und damit implicite eine Beziehung zur Geschlechtsfunction auszusprechen. Gegenbaur, der sie bei Nausithoe und Charybdea als hohle mit der Magenhöhle in Verbindung stehende Fäden beschreibt, erklärt sie als Reservoirs der im Gastrovascularsystem sich bewegenden Flüssigkeit. Milne Edwards bezeichnet sie bei Charybdea als canaux biliaires. Leuckart parallelisirt sie den von ihm als nierenartige Absonderungsorgane gedeuteten Mesenterialfilamenten der Actinien.

Soweit ich darüber Angaben finde, werden sie allgemein als hohl und vom Gastrovascularsystem frei nach aussen oder in die Geschlechtshöhlen gerichtet beschrieben.

Ich hatte Gelegenheit, diese Fäden bei den genannten beiden Arten von Tamoya, bei einer Rhizostomide und bei einer grossen Chrysaora zu untersuchen, ohne mich einer der gegebenen Deutungen anschliessen zu können.

Bei Tamoya finden sich die Geschlechtsorgane in den weiten Seitentaschen des Magens, entfernt von den dem blossen Auge als trübe Streifen der Magen-

I) Zeitschrift für wissenschaftliche Zoologie. I858. IX. p. 542-543. 
haut erscheinenden Gruppen der Magenfäden, so dass also wenigstens hier an eine nähere Beziehung beider Organe nicht zu denken ist.

Bei allen 4 Arten finde ich die Fäden solid und in die Höhle des Magens gerichtet, letzteres ist bei allen, namentlich bei Chrysaora leicht zu constatiren, wo sie eine Länge von einigen Zoll erreichen; ersteres wird besonders nach Behandlung mit Chromsäurelösung deutlich, worauf sich die Rindenschicht leicht von dem durchsichtigen bei frischen Fäden allerdings einer Höhle ähnlich erscheinenden soliden Centralstrang abpinseln lässt. Dadurch ist denn für unsere Arten die Erklärung von Gegenbaur unmöglich gemacht.

Nahe liegt es dagegen, an eine Beziehung der Magenfäden zur Verdauung zu denken. Diese Vermuthung zu bestätigen oder zu widerlegen, bedeckte ich Muskeln aus einer Krabbenscheere und ein Stück vom Hintertheile eines Alpheus mit den einer lebenden Tamoya haplonema entnommenen Magenfädengruppen und übergoss sie mit ein wenig Seewasser. Entsprechende Stücke legte ich in reines Seewasser. Letztere zeigten sich nach Io bis I 2 Stunden nicht merklich verändert. Dagegen war unter dem Einfluss der Magenfäden das Fleisch des Alpheus vollständig, das aus der Krabbenscheere fast ganz zu einer trüben Flüssigkeit gelöst; die schwärzlichgrüne Schaale des Alpheus hatte sich röthlich gefärbt; ein schleimig erweichter Rest auf der Chitinplatte, von der die Muskeln der Krabbenscheere entspringen, liess unterm Mikroskop noch seine Muskulatur erkennen. Die Magenfäden zeigten sich noch frisch, flimmernd und wie gewöhulich in langsam wurmförmiger Bewegung.

$\mathrm{Ob}$ nun ein eigenthümliches von dem der übrigen Magenwand verschiedenes Secret von den Fäden erzeugt wird, oder ob sie nur zur Vergrösserung der verdauenden Magenfläche dienen, ist allerdings hiermit noch nicht entschieden, ersteres jedoch mir wahrscheinlicher, da ich unregelmässig rundliche dunkel contourirte Körperchen von o,OI Millimeter Durchm., die ich auf der Oberfläche der Fäden und in der umgebenden Flüssigkeit bei Tamoya fand, im übrigen Theile des Magens vermisste.

Auffallend sind die bei Tamoya sehr spärlich, bei den beiden anderen Arten sehr reichlich den Fäden eingestreuten Nesselorgane, wie sie auch Will bei Cephea, Gegenbaur bei Charybdea fand. Bei Tamoya und Chrysaora könnte man sie auf Bewältigung lebend verschluckter Beute beziehen. Was aber können sie in der centralen Höhle unserer polystomen Rhizostomide bedeuten, die weit entfernt liegt von den Oeffnungen der Arme? 


\section{Zwei neue Quallen von Santa Catharina $\left.{ }^{1}\right)$. Tamoya haplonema und quadrumana.}

Mit Tafel VII, VIII und IX.

Das Meer von Santa Catharina scheint nicht eben reich an Quallenarten zu sein; doch finden sich unter diesen mehrere in systematischer wie in anatomischer Hinsicht besonders merkwürdige Formen. $\mathrm{Zu}$ diesen rechne ich vor allen die beiden nachstehend näher zu beschreibenden Schirmquallen, die am Strande der Praia de fora bei Desterro gefunden wurden.

Die eine derselben, Tamoya quadrumana mihi gehört zu den seltneren Arten; im Laufe zweier Jahre bekam ich nur 3 Exemplare zu Gesicht. Weit häufiger ist die andere, Tamoya haplonema mihi, von der ich bisweilen an einem Tage über ein Dutzend fand.

Des Gemeinsamen beider Arten ist so viel, dass ich ihre Beschreibungen in eine zusammenfasse, der Schilderung jedes Organes die specifischen Differenzen anschliessend.

Der K örper ist glockenförmig, von wasserheller, recht fester Substanz und deshalb wenig veränderlicher Form, aussen bedeckt mit kleinen flachwarzigen Erhabenheiten, auf denen weissliche Fleckchen, Gruppen von Nesselzellen, liegen. Bei T. haplonema ist die Glocke höher ( $15 \mathrm{~cm}$ hoch, bei ${ }_{2} \mathrm{~cm}$ Durchm.), mit flachem Scheitel, fast senkrecht niedersteigenden Wänden und ziemlich viereckig im Querschnitt; bei T. qua drumana niedriger ( $10 \mathrm{~cm}$ hoch, bei $12 \mathrm{~cm}$ Durchm.), der Halbkugel sich nähernd, mit gewölbtem Scheitel und nach unten ansehnlich erweitert. Durch Längsfurchen sind die Seiten der Glocke aussen in 8 Längswülste getheilt, 4 schmälere dickere, den Ecken des vierseitigen Querschnitts bei T. haplon ema entsprechend, und 4 breitere, flachere. Ich bezeichne der Kürze wegen auch bei T. quadrumana erstere als Eck-, letztere als Seitenwülste. Bei T. haplonema sind die Wülste in ihrer ganzen Länge ziemlich gleich breit, die Seitenwülste reichlich doppelt so breit als die Eckwülste; diese letzteren sind fast in der ganzen Länge von einer mittleren Längsfurche durchzogen und ausserdem finden sich auf jeder Seitenwulst im unteren Drittel noch zwei nach unten convergirende seitliche Furchen. Bei T. quadrumana sind die Eckwülste oben,

I) Abhandlungen der Naturforschenden Gesellschaft in Halle. I859. V. p. I - 12. Taf. I, II, III. 
die Seitenwülste unten breiter (beide oben $3 \mathrm{~cm}$, unten erstere $2 \mathrm{~cm}$, letztere $6 \mathrm{~cm}$ ), die Mittelfurche der Eckwülste durchzieht nur deren oberes Drittel, während auf den Seitenwülsten zwei parallele Längsfurchen ein mittleres $3 \mathrm{~cm}$ breites Feld abgrenzen. Entsprechend den äusseren Furchen verlaufen ähnliche auf der Innenfläche der Glocke und ausserdem findet sich hier eine mittlere Längsfurche der Seitenwülste, bei T. quadrumana nur im unteren Drittel, bei T. haplonema in der ganzen Länge, jedoch häufig mehr als allmälige Verdünnung der Glockensubstanz, denn als scharfe Furche ausgeprägt. Bisweilen zeigt sich auch bei beiden Arten eine entsprechende schwache äussere Furche.

Vom unteren Ende der Eckwülste entspringen 4 sehr ansehnliche Fortsätze. Bei T. haplonema sind sie einfach keulenförmig, seitlich zusammengedrückt, mit scharfer äusserer und innerer Kante, 6 bis $7 \mathrm{~cm}$ lang, $4 \mathrm{~cm}$ hoch, am Ende einen bis gegen 5 Fuss langen bränlichen Fangfaden tragend ${ }^{1}$ ). Weit weniger einfach sind sie bei T. quadrumana; hier ist dieser abwärts gerichtete und etwas einwärts gebogene Fortsatz am Ursprung rundlich, $16-18 \mathrm{~mm}$ dick, wird aber bald seitlich zusammengedrückt, mit scharfer äusserer und innerer Kante; seine Länge am inneren Rande beträgt etwa $45 \mathrm{~mm}$; der äussere Rand trägt 10 bis I I schwertförmige seitlich comprimirte mit der Spitze etwas einwärts gebogene Fortsätze, von denen der erste unpaare von der Mittellinie, die folgenden paarig von den Seiten des äusseren Randes entspringen. Sie nehmen an Länge $\mathrm{ab}$ von dem ersten $45 \mathrm{~mm}$ bis zum letzten $10-15 \mathrm{~mm}$ langen; an der Basis deckt jeder folgende von aussen den vorhergehenden und am Ende trägt jeder einen sehr langen bräunlich gefärbten Fangfaden.

Die Fangfäden sind hohl, sehr contractil (mit deutlicher Längsmuskelschicht), und erscheinen durch in Querbinden geordnete Nesselzellen wie geringelt. Sie scheinen kaum zu brennen, haften dagegen sehr fest an Gegenständen, mit denen sie in Berührung kommen; halbverdaute Fische im Magen der T. ha plon ema fand ich noch von einem Stück Fangfaden umschlungen. Die Nesselzellen dieser Art sind spindelförmig, 0,06 $\mathrm{mm}$ lang bei 0,015 $\mathrm{mm}$ Dicke, und jede ist von etwa sechs soliden cylindrischen Fäden ( $0,09 \mathrm{~mm}$ lang, 0,004 $\mathrm{mm}$ dick) umgeben, die vom Rande einer die Basis der Nesselzelle umhüllenden Scheide zu entspringen scheinen. Bei T. quadruma na finden sich grössere spindelförmige Nesselzellen (o,o56 mm lang, o,008 $\mathrm{mm}$ dick) und kleinere (0,012 mm lang, o,003 mm dick), jede Art für sich in Querstreifen geordnet: die mit den kleinen Nesselzellen sind schmäler, aber weit zahlreicher. Der Kanal der Fangfäden setzt sich fort durch die Anhänge der Glocke und steht auf unten näher zu bezeichnende Weise mit dem Gastrovasculärsysteme in Verbindung.

Ziemlich in gleicher Höhe mit dem Ursprung der keulen- oder handförmigen Anhänge findet sich mitten auf den Seitenwülsten eine Querspalte, die in eine die Substanz der Glocke fast vollständig durchsetzende Nische führt. Sie ist von einer bei $T$. ha plon ema stärker entwickelten kreisförmigen Wulst umgeben und nach abwärts erstreckt sich von ihr bis über den Rand der Glocke ins Velum hinein eine zungenförmige Wulst, schmaler und dicker bei T. quadrumana,

1) Ein einziges Mal sah ich an einem der 4 keulenförmigen Anhänge einen zweiten überzähligen Fangfaden. (Fig. 2.) 
flacher und als Fortsetzung des von den convergirenden Seitenfurchen begrenzten Feldes erscheinend bei T. haplonema. Im Grunde der Nische sitzt der gestielte Randkörper.

Der untere Rand der Glocke ist eingefasst von einem reichlich zollbreiten häutigen $\mathrm{Velum}$, das bisweilen schlaff niederhängt, bisweilen mehr oder weniger quergespannt erscheint.

Der dünnhäutige $\mathrm{Mag}$ en nimmt den Grund der Glocke ein; er erscheint aufgeblasen mehr weniger kuglig und ist durch eine engere verschliessbare Stelle von dem sehr beweglichen, am Ende erweiterten, vierkantigen und in 4 Lappen gespaltenen Mundtrichter geschieden. Der Mundtrichter ist durch eine Schicht Gallertsubstanz verdickt, die indess viel weicher ist, als die der Glocke, und die auf der Mitte jedes Lappens eine abgerundete Längsrippe bildet. In ihrer Lage entsprechen diese Lappen den Seiten der Glocke (also den Randkörperchen). Bei T. quadrumana ist der Mundtrichter relativ länger als bei T. haplonema, wo er in der Regel selbst nicht bis zur Hälfte der Glockenhöhe niederreicht.

Abwechselnd mit den Mundlappen zeigt die Magenwand 4 trübe Streifen, die schon durch die Loupe in Gruppen äusserst zahlreicher wurmförmiger und langsam wurmförmig bewegter in die Höhle des Magens ragender Fäden von 5-6 mm Länge und 0,15-0,2 mm Dicke sich auflösen. Bei T. haplonema erstrecken sich diese Streifen in gerader aufwärts gerichteter Linie durch die zwei oberen Drittel der Magenwand; die Fäden sind meist ein- bis zweimal in je 2 bis 3 lange Aeste getheilt, selten stärker verästelt. Bei T. quadrumana sind die Streifen hufeisenförmig gebogen, der Bogen dem Grunde der Glocke, die Schenkel dem Munde zugekehrt, und die Fäden unverästelt. - Die Flimmercilien, mit denen diese Fäden bedeckt sind, erzeugen eine lebhafte nach deren Spitze gerichtete Strömung; einzelne kleine Nesselzellen finden sich namentlich am unteren Theile der Fäden; ausserdem zeigt ihre Oberfläche unregelmässig rundliche, dunkel contourirte Körperchen von o,o I mm Durchm., und ähnliche, wahrscheinlich Secret der Fäden, fanden sich in der umgebenden Flüssigkeit. Man ist beim ersten Blick durchs Mikroskop versucht, diese Fäden für hohl zu halten; indessen weist eine nähere Untersuchung die scheinbare Höhle als einen soliden durchsichtigen Centralstrang nach. Nach Behandlung mit Chromsäurelösung lässt sich leicht die äussere Schicht von dem Centralstrange abpinseln.

Aehnliche wurmförmige Fäden, wie die unserer beiden Arten, sind bei den meisten einer näheren Untersuchung unterworfenen höheren Schirmquallen gefunden worden. Indess weichen von denen der Tamoya die der übrigen Quallen nach den früheren Angaben dadurch ab, dass sie hohl sind (so nach Gegenbaur bei Nausithoe und Charybdea), nach aussen oder in die Geschlechtshöhlen ragen, und in unmittelbarer Nähe der Geschlechtsorgane sitzen. Letzteres ist jedenfalls ein reeller und charakteristischer Unterschied der Rhizostomiden, Medusiden und Pelagiden von Tanoya; dagegen möchten wohl die ersteren Angaben einer neuen Bestätigung bedürfen; wenigstens finde ich bei einer $\mathrm{R} h \mathrm{izos}$ to mide und bei einer grossen Chrysaora, wo sie eine Länge von einigen Zoll erreichen, die Magenfäden ebenfalls solid und in die Höhle des Magens gerichtet.

Der Magen ist bei T. haplonema nur an den Ecken des Glockengrundes befestigt, während die ganze Breite der Seiten offen bleibt als Eingang in 4 weite 
Seitentaschen. Trotz dieses breiten Eingangs findet durch die straff herübergespannte Magenhaut ein vollständiger Abschluss statt, so dass man Magen oder Seitentaschen ziemlich stark aufblasen kann, ohne dass Luft aus einem in das andere übertritt. - Weit complicirter sind diese Verhältnisse bei T. quadrumana; stülpt man hier, was leicht geschehen kann, die Glocke um, und entfernt Mundtrichter und Magen, so erscheint der Boden der Glocke als ein Viereck mit abgerundeten Ecken und leicht ausgebuchteten Seiten, jene den Eckwülsten, diese den Seiten der Glocke entsprechend. Der Ausbucht jeder Seite liegt eine stark gewölbte $16 \mathrm{~mm}$ lange, $14 \mathrm{~mm}$ breite eiförmige Wulst vor, zu deren Seiten von der hier stark verdickten Glocke zwei ansehnliche fingerförmige Fortsätze ausgehen. Sie sind drehrund, 4 bis $5 \mathrm{~cm}$ lang, an der Basis gegen $2 \mathrm{~cm}$ dick, allmälig verjüngt, mit abgerundeter Spitze; ihre Substanz ist etwas weicher, als die der Glocke. Der Magen nun inserirt sich im ganzen Umfang des Vierecks, mit Ausnahme der Ausbucht der Seiten, soweit ihnen die eiförmige Wulst vorliegt; hier bleibt der Eingang in die Seitentaschen.

Diese Seitentaschen nehmen die ganze innere Seitenwand der Glocke ein; ihre innere Wand inserirt sich der Glocke längs der Mittelfurche der Eckwülste; sie entsprechen also in ihrer Lage den Randkörpern und wechseln ab mit den fangfadentragenden Anhängen. Nach unten reichen sie bis zum Ursprung dieser Anhänge und $\mathrm{zu}$ den Randkörperchen, und zwischen diesen 8 Puncten noch etwas tiefer abwärts, bei T. haplon em a mehr geradlinig am Glockenrande endend, während bei T. quadrumana ein breiterer Fortsatz der Seitentasche zu jeder Seite der handförmigen Anhänge, ein schmälerer zu jeder Seite der Randkörperchen bis ins Velum niedersteigt. Vom unteren Rande der Seitentaschen und bei $\mathrm{T}$. quadrumana besonders von diesen Fortsetzungen derselben gehen dendritisch verzweigte nicht anastomosirende Kanäle bis zum Rande des Velum.

Seitentaschen und fangfadentragende Anhänge wechseln ab, wie bereits erwähnt ist; jede Seitentasche communicirt mit den beiden Anhängen und also jeder Anhang mit den beiden Seitentaschen, zwischen denen er liegt. Der Anhang entspringt nämlich mit breiter Basis von der Aussenseite des Glockenrandes, während ein schmaler Fortsatz seines Innenrandes an dessen Innenseite sich inserirt gerade da, wo die Grenzlinie beider Seitentaschen unten endet; so bleibt zwischen den oben abgerundet endenden Seiten des Anhangs und den gleichfalls gerundet endenden Eckwülsten der Glocke jederseits eine schmale Spalte, die aus der unteren Ecke der Seitentasche in den Kanal des Anhangs führt. Dieser Kanal ist bei T. haplonema anfangs dreieckig, später viereckig und am untern Ende schmal elliptisch; letztere Form hat er durchweg bei T. quadrumana; wo er einen Ast für jeden Finger abgiebt.

Wenn nun auch auf diese Weise der Kanal der Fangfäden ins Gastrovasculärsystem, also auf die Unterseite der Glocke führt, so ist es doch hier augenscheinlicher als sonst, dass die Fangfäden selbst nicht auf dieser Unterseite entspringen, wie es Gegenbaur als allgemeines Gesetz betrachten möchte. Im Gegensatz hierzu möchte ich unterständige Fangfäden, wie bei Sthenonia, als einen Ausnahmsfall betrachten. Für Gegenbaur's Craspedota wenigstens erscheint es als offener Widerspruch, gleichzeitig das Velum als Fortsetzung des Schirms an- 
zusehen und die stets nach aussen vom Velum befindlichen Randfäden der Unterfläche zuzutheilen.

$\mathrm{Ob}$, wie nach der Analogie zu vermuthen, auch in den Stiel der Randkörperchen ein Fortsatz der Seitentaschen geht, ist mir nicht ganz klar geworden. Flimmerbewegung sah ich nie in diesem Stiele. -

Die 8 fingerförmigen Fortsätze, die bei T. quadrumana paarweise vom Glockengrunde niederhangen, sind, wie Finger vom Handschuh, lose umhüllt von einer dünnen Haut, deren Höhle unten rings in offener Verbindung steht mit den Seitentaschen; von diesen aus aufgeblasen überragt sie die Spitze des Fingers noch um einige Linien. -

Die Gallertsubstanz des Mundtrichters setzt sich bei derselben Art von dessen Kanten (abwechselnd also mit den Reifen der Magenfäden) nach oben in die Magenwand bis zwischen die fingerförmigen Anhänge fort als ein etwa $1 \mathrm{~cm}$ breiter flacher Streifen; dieser ist von einem schmalen Kanale durchzogen, von dem unter spitzem Winkel zahlreiche mehrfach verzweigte und mit kurzen fiedrig gestellten Reiserchen dicht besetzte Aeste abgehen. Durch lebhafte Flimmerbewegung wird aus dieser äusserst zierlichen dendritischen Drüse eine feine, dunkle Körnchen führende Flüssigkeit nach aussen gefördert. Die Mündung des Kanals scheint noch innerhalb des Magens zu liegen, doch führt eine Rinne weiter nach unten bis in den Mundtrichter, so dass diese Drüse jedenfalls als Excretionsorgan zu deuten ist.

In der Lage diesen Drüsen entsprechend finden sich bei T. haplonema 4 dünne verticale Scheidewände, die vom Magen zur Mitte der Seitentaschen gehen und den Raum zwischen Magen und Glocke in ${ }_{4}$ Kammern theilen. Ihre Ausdehnung unterliegt individuellen Schwankungen; bisweilen reichen sie an den Seitentaschen fast bis zu den Randkörperchen, am Magen bis zum Ursprung der Mundlappen nieder. Ein der Drüse der T. quadru mana entsprechendes Organ konnte ich in ihnen nicht auffinden.

Das ganze Innere der Glocke, Velum, Seitentaschen, Magen u. s. w. sind mit theils einzelnen, theils in rundliche Gruppen vereinigten Nesselzellen besetzt, die ein lebhaftes Brennen verursachen; sie sind von kurz elliptischer Form, etwa 0,024 mm lang bei o,or $6 \mathrm{~mm}$ Durchm.

Das Nervensystem ist bei beiden Arten mit überraschender Deutlichkeit ausgeprägt. In der Höhe der Randkörperchen verläuft in der inneren Wand der Seitentaschen ein schmaler, weisslicher oder gelblicher Streif ringförmig um die Höhle der Glocke, jederseits eingefasst von einem durchsichtigen Saume; bei günstiger Beleuchtung ist er bisweilen selbst von aussen durch die Substanz der Glocke hindurch wahrnehmbar, tritt aber mit besonderer Deutlichkeit hervor, wenn man die Seitentaschen aufbläst; minder nachgiebig als deren Wandungen bildet der Streifen dann eine Furche auf den aufgetriebenen Taschen. Diese geringere Nachgiebigkeit wird dadurch veranlasst, dass der Nervenring eingebettet liegt in eine dünne Leiste Gallertsubstanz, die als solche dem Gefühl erkennbar, dem Auge zunächst als der erwähnte helle Saum erscheint. Bei T. haplonema ist sie dicker und gewölbter als bei T. quadrumana. Bei letzterer fand ich den Nervenring o, IO mm bis $0,12 \mathrm{~mm}$, den hellen Saum jederseits etwa doppelt so breit. 
Dem Ursprung der handförmigen Anhänge gegenüber bei T. quadrumana, soweit hier die Wand der Seitentaschen im Niveau des Nervenrings der Glocke sich anheftet, in einer Länge von etwa $3 \mathrm{~mm}$, verdickt sich der Nerv bis auf $0,33 \mathrm{~mm}$ und sendet vom untern Rande dieses Ganglions gegen 20 verschiedene starke (0,02 bis $0,06 \mathrm{~mm}$ dicke) Fäden ab, die bald nach ihrem Ursprung von dem hier abgehenden undurchsichtigen Velum verdeckt werden, und theils in diesem, theils und wohl hauptsächlich in dem handförmigen Anhange sich verbreiten mögen. Bei T. haplon em a sind diese Ganglien weniger ansehnlich, die abgehenden Nerven weniger zahlreich, jedoch dicker als bei T. quadrumana.

Eine zweite Stelle. wo in Niveau des Nervenrings die Haut der Seitentaschen an die Glocke herantritt, ist an den Randkörperchen; auch hier findet sich eine Anschwellung, von der ein ansehnlicher Nerv in den Stiel des Randkörperchens tritt. Dieser Stiel entspringt im Grunde der Nische von deren oberer Wand, wo die Glockensubstanz ihre geringste Dicke hat, und trägt am Ende einen unregelmässig kugligen Körper von etwa I mm Durchm., blassgelblicher Farbe, und aussen, wenigstens stellenweise, von Flimmercilien bedeckt. In diesen sind eingebettet zunächst ein mehr weniger endständiger elliptischer gelber Körper von $0,75 \mathrm{~mm}$ Durchm., aus einer unregelmässig krystallinischen, $z$ wischen den Zähnen knirschenden, in Süure nicht löslichen Masse gebildet; ob derselbe auch nach Innen durch eine besondere Haut abgegrenzt ist, also als Krystallsack bezeichnet werden kann, weiss ich nicht. Dann zwei stark lichtbrechende Körper, ein grösserer kugliger von $0,33 \mathrm{~mm}$ Durchm., dem Stiele näher liegend, und ein kleinerer von minder regelmässiger Form, zwischen diesem und dem krystallinischen Endkörper. Sie zeigen sich aus kugligen Zellen von 0,02 bis $0,03 \mathrm{~mm}$ Durchm. zusammengesetzt, werden durch Säuren undurchsichtig weiss, und sind bis auf ein aus dem Randkörper vorragendes Segment von schwarzem Pigment umgeben, das feinkörnig und in kleinen Zellen von 0,005 bis 0,008 mm Durchm. enthalten ist. Von dieser der T. ha plonema entnommenen Beschreibung zeigen die Randkörperchen der T. quadrumana keine wesentliche Abweichung. Kann man die lichtbrechende, von schwarzem Pigment umgebene Kugel unbedenklich als Auge deuten, so scheint es dagegen zweifelhaft, ob man den unregelmässig krystallinischen, dicht umschlossenen Endkörper ohne Weiteres den frei in einer Blase bewegten Otolithen der Mollusken oder den Randbläschen der niederen Schirmquallen (Aequorea, Eucope u.s.w.) mit ihren kugligen, stark lichtbrechenden Concretionen parallelisiren und als Gehörorgan ansprechen darf.

Weitere Nerven sah ich vom Nervenring nicht abgehen und konnte namentlich keine aufwärts gerichteten Fäden auffinden, ebensowenig als einen zweiten Nervenring in der Nähe des Mundtrichters, wie ihn die Angaben von Agassiz würden vermuthen lassen.

Die Geschlechtsorgane ist man gewohnt, bei den mit Magenfäden versehenen Quallen in deren unmittelbarer Nähe zu suchen; bei Tamoya indess finden sie sich weder an diesem Orte, noch in der sonst gewöhnlichen Form. Sie bilden breite, dünne Platten von sehr verschiedener Ausdehnung, die in der ganzen Länge des Seitenrandes der Seitentaschen entspringen und frei in deren Höhle hineinragen. Ihre Seitenränder sind mehr weniger parallel, die freien Enden abgerundet. Sie sind sehr dünnn, zart, leicht zerreisslich, von leicht getrübter gelb- 
licher oder weisslicher Färbung. Die jüngeren kürzeren sind meist auch schmäler; in Verlauf des Wachsens scheinen mehrere benachbarte zu verfliessen, wobei bisweilen rundliche Lücken bleiben. Die Ovarien scheinen in der Regel beträchtlichere Ausdehnung zu erlangen als die Hoden; erstere fand ich bei T. quadrumana, von der ich kein Männchen sah, bis $16 \mathrm{~cm}$ lang bei $2 \mathrm{~cm}$ Breite, also weit länger als irgend eine Dimension der Seitentasche. Sie scheinen in ihrer ganzen Substanz Eier zu entwickeln, die sich in den verschiedensten Reifegraden nebeneinander finden; sie sind elliptisch, farblos, mit feinkörnigem Dotter und deutlichem Keimbläschen und Keimfleck; die grössten, die ich (bei T. quadrumana) salı, hatten 0,I6 mm Länge, 0, I 2 mm Breite, das Keimbläschen $0.04 \mathrm{~mm}$, der Keimfleck o,oo8 mm Durchm. Die Hoden (der T. haplonema) scheinen aus einer einzigen Lage langer Röhren mit von 0,025 bis über $0,06 \mathrm{~mm}$ wechselnder Weite gebildet, die bald gestreckt und parallel verlaufen, bald in mäandrische Windungen verschlungen und mannigfach ausgebuchtet sind, bald sich auf kürzere unregelmässige Zellen reduciren. Die reifen Spermatozoiden sind cercarienförmig mit $0,004 \mathrm{~mm}$ dickem, rundlichem Kopfe und sehr feinem haarförmigem Anhang.

Was nun die verwandtschaftlichen Beziehungen und die systematische Stellung unserer Arten betrifft, so scheint ihnen unter den näher bekannten die von Gegenbaur genauer beschriebene Charybdea marsupialis Pér. am nächsten sich anzuschliessen und unbedenklich in dieselbe Familie mit ihnen vereinigt werden zu können. Die ganze Architectonik der Glocke ist dieselbe; ebenso ist der Bau der Randkörperchen und der mit weiten Seitentaschen versehene Magen übereinstimmend. Freilich würde man dann nicht mehr mit Gegenbaur das Velum als scheidendes Merkmal zwischen höheren und niederen Schirmquallen ansehen können und ein anderes Unterscheidungszeichen suchen müssen, wenn man überhaupt die in den Systemen von Eschholtz, Forbes und Gegenbaur angenommene Zweitheilung beibehalten will. Ein solches charakteristisches Merkzeichen der höheren Schirmquallen, Rhizostomiden, Medusiden, Pelagiden und Charybdeiden, würden die Ma g e $\mathrm{n}$ fäden bieten können. Indessen scheint die Entwicklungsgeschichte eher auf eine Dreitheilung hinzuweisen in Quallen mit polypenförmigen Ammen, Quallen mit Polypen als Ammen und Quallen ohne Generationswechsel. Ob unsere Quallen nun nicht in die letzte dieser Abtheilungen eintreten würden, mit denen sie die taschenförmigen Fortsätze des Magens gemein haben, in denen sich die Geschlechtsproducte bilden, müssen fernere Beobachtungen lehren. -

Die Gattung Tamoya der Familie der Charybdeiden einreihend, wird es nöthig, die von Gegenbaur gegebene Charakteristik dieser Familie zu modificiren. Das Gemeinsame der ärei Arten zusammenfassend, würde sie sich vorläufig wie folgt, stellen lassen: Körper glockenförmig mit 4 (blatt-, keulen- oder handförmigen) hohle Fangfäden tragenden Randanhängen. Zwischen ihnen 4 in Nischen geborgene Randkörper mit Krystallsack und Augen. Magen im Grunde der Glocke, die der 4-lappige Mundtrichter nicht überragt, mit 4 Gruppen Magenfäden und 4 Seitentaschen. scheiden :

Die beiden so vereinigten Gattungen würden sich durch folgende Charaktere 
Charybdea.

Glockenrand in Lappen getheilt. Fortsätze des Magens mit Seitencanälen. Fangfäden in die Seitencanäle mündend. Magen und Mundtrichter nicht geschieden.

(?) Magenfäden hohl, in die Höhle der Glocke gerichtet.
T a moy a.

Glockenrand mit ganzrandigem Velum. Seitentaschen ohne Nebencanäle.

Fangfäden in die Seitentaschen mündend. Magen gegen den Mundtrichter verschliessbar.

Magenfäden solid, in die Magenhöhle gerichtet.

\section{Erklärung der Abbildungen auf Tafel VII, VIII und IX.}

Fig. I. Tamoya haplonema, halbe nat. Gr.

Fig. 2. Keulenförmiger Anhang mit 2 Fangfäden.

Fig. 3. Querschnitt der Glocke in der Höhe der Nischen.

Fig. 4. Desgl. $2 \mathrm{~cm}$ höher.

Fig. 5. Längsschnitt durch den Ursprung des keulenförmigen Anhangs.

Fig. 6. 7. 8. Querschnitte desselben, oben, mitten und unten.

Fig. 9. Längsschnitt durch die Nische.

Fig. Io. Der untere Theil der Glocke von Innen.

Fig. I I. Eingang in den Kanal des keulenförmigen Anhangs, von Innen; der innere Fortsatz des Anhangs durchschnitten und zurückgebogen.

Fig. 2-I I in nat. Gr. Es bedeutet in diesen Figuren a Eckwulst der Glocke. $b$ Innenwand der Seitentasche. $c$ Scheidewand zwischen Magen und Glocke. $d$ Genitalplatten. n Nervenring. v Velum.

Fig. I 2. Verzweigung der Gastrovasculärsystems im Velum, etwas vergrössert.

Fig. 13. Nesselzellen der Fangfäden; $a$ mit vorgetretenem Nesselfaden; $b$ mit den umgebenden soliden Fäden; $c$ einzelne dieser Fäden, abgerissen.

Fig. I 4. Nesselzellen aus der Magenwand.

Fig. I 5. Solide Achsenstränge der Magenfäden, vergr.

Fig. I6. Randkörper, desgl.

Fig. I 7. Das grössere Auge desselben, stärker vergr. a Pigmentzellen, noch mehr vergr.

Fig. I 8. Tamoya quadrumana, halbe nat. Gr.

Fig. I 9. Handförmiger Anhang.

Fig. 20. Eingang der Nische.

Fig. 2 I. Längsschnitt durch die Nische; $a$ Scheitel der Glocke; $b$ eiförmige Wulst am Eingang der Seitentaschen; $c$ Verdickung der Glocke, von der die fingerförmigen Anhänge entspringen; $d$ Innenwand der Seitentasche; $v$ Velum.

Fig. 22. Querschnitt nach der Linie $A B$ (Fig. 2I); $a$ Aussenwand der Glocke $b$ Wulst unterhalb der Nische; $c$ Wand des Fortsatzes der Seitentasche.

Fig 23. Verzweigung des Gastrovasculärsystems ins Velum, von Innen; $a$ Grenzlinie der Seitentaschen; $b$ Fortsätze der Seitentaschen ; $c$ Wulst unterhalb der Nische; $n$ Nervenring.

Fig. $19-23$ in nat. Gr.

Fig. 24. Grund der Glocke, halbe nat. Gr.

Fig. 25. Ende eines Magenfadens, vergr. a Körperchen aus der umgebenden Flüssigkeit.

Fig. 26. Magen und Mundtrichter, nat. Gr.; die Glocke ist ungestülpt, der Magen aufgeblasen.

Fig. 27. Einige Aeste der dendritischen Drüse, schwach vergr.

Fig. 28. Ganglion an der Basis der handförmig. Anhänge, vergr. a Seitentaschen. $b$ Fortsätze derselben ins Velum. c Innere Mittelfurche der Eckwülste. $d$ Heller Saum des Nervenrings. $v$ Velum.

Fig. 29. Ei aus dem Ovarium, vergr.

Fig. 3o. Genitalplatten von Tamoya hap Ionema, nat. Gr.

Fig. 3I-33. Stücke der Hoden derselben Art, vergr. 


\title{
Polypen und Quallen von Santa Catharina $\left.{ }^{1}\right)$.
}

\section{Die Formwandlungen der Liriope catharinensis n. sp. ${ }^{2}$ )}

\author{
Mit Tafel X und XI.
}

Liriope catharinensis ist - und ich gab ihr deshalb diesen Namen -, die häufigste Schirmqualle im Meere von Santa Catharina. Sie schliesst sich eng an die Liriope mucronata Gegenb. an, besitzt, wie diese, vier längere und vier bedeutend kürzere Randfäden, ganzrandigen Mund, farbloses Gastrovasculärsystem, so wie die frei in den Magen ragende konische Spitze des Magenstiels, unterscheidet sich aber durch geringere Grösse, da sie kaum je $6 \mathrm{~mm}$ im Durchmesser überschreiten dürfte, durch 20 bis 30 röthlich gefärbte rundliche Nesselknöpfe am Mundsaume und durch röthliche Färbung des Stromas, in das die in ringförmige Wülste geordneten Nesselzellen der Fangfäden eingebettet sind. Diese Hinweisung auf L. mucronata genügt, ein vorläufiges allgemeines Bild des Thieres zu geben; ich wende mich daher sofort zu näherer Betrachtung der einzelnen Theile.

Der Schirm, vollkommen farblos und glashell, bildet eine Glocke von etwa $5 \mathrm{~mm}$ Durchmesser mit kuglig gewölbtem Scheitel; die Höhe, nicht unbedeutenden individuellen Schwankungen unterworfen, mag durchschnittlich $2 / 3$ des Durchmessers betragen. Die Gallertsubstanz ist ansehnlich dick und nimmt meist die reichliche Hälfte der Höhe ein. Aus der Mitte der hohlen Fläche entspringt als solider Fortsatz des Schirms ein etwa $2 \mathrm{~mm}$ langer, $0,4 \mathrm{~mm}$ dicker, in eine konische Spitze auslaufender Zapfen (Fig. 2), an den, etwa 0,5 $\mathrm{mm}$ von der Spitze, sich der Magen inserirt. Die verästelten Fasern, die Max Schultze aus der Gallertsubstanz der höheren Medusen beschrieben hat und die ich höchst entwickelt schon im frischen Zustande und bei schwacher Vergrösserung leicht

I) Archiv für Naturgeschichte. I859. I. p. 3 I0-32I. Taf. XI.

2) Der Name Liriope ist zwei Mal vergeben, einmal an die in Rede stehende Meduse von Lesson (Histoire nat. des zoophytes. Acalèphes p. 331), zum anderen an einen Krebs von Rathke (Beiträge zur Fauna Norwegens p. 60). Es könnte zweifelhaft erscheinen, welchem der beiden Thiere als dem früher getauften der Name verbleiben soll, da die beiden angeführten Werke in ein und demselben Jahre (1843) erschienen sind. Doch stammt Lesson's Name offenbar aus früherer Zeit, da er, wie aus Agassiz Nomenclator zoologicus zu schliessen, schon in dem freilich nicht im Buchhandel erschienenen Prodome d'une Monographie des Meduses von Lesson, Rochefort 1837 enthalten ist. Somit würde der Krebs zurückstehen, und schlage ich vor, dessen Namen in Liriopsis umzuwandeln.

Max Schultze. 
bemerklich bei mehreren niederen Quallen (Aeginiden, Aequorea etc.) wviederfand, sind bei unserer Liriope sehr zart und wurden mir erst durch Behandlung mit Chromsäurelösung sichtbar. Sie verästeln sich unter sehr spitzen Winkeln. deren Schenkel vorherrschend eine radiäre Richtung zu haben scheinen. Ich bemerke ausdrücklich, dass ich diese Fasern auch in dem von Gegenbaur bei L. mucronata für hohl erklärten Magenstiel verfolgt habe.

Der Magen hängt, wenn das Thier ruhig im Wasser schwebt, als cylindrisches Rohr (von 1,5 $\mathrm{mm}$ Länge und 0, I5 mm Durchmesser) von seinem Stiele nieder, schon für das blosse Auge durch seine geringere Durchsichtigkeit scharf gegen den glashellen Stiel sich absetzend. Er besitzt dieselbe Beweglichkeit und zeigt deshalb dieselbe wunderbare Vielgestaltigkeit, die man an dem Magenrohre anderer Quallen beobachtet. Nicht selten verkürzt er sich so, dass die Spitze des Magenstiels mehr oder weniger vorsieht, eine vollständige Umstülpung, wie sie Gegenbaur von L. mucronata beschreibt und abbildet, sah ich nur bei absterbenden Thieren. Der Rand zeigt keine Spur von Lappenbildung, ist dagegen geziert mit einer Reihe von etwa 25 rundlichen blassröthlichen Knöpfchen (Fig. 2 und 3) von 0,03 bis $0,04 \mathrm{~mm}$ Durchmesser, in welche reichliche Nesselzellen eingelagert sind. Vereinzelte Nesselzellen finden sich auch sonst in der Nähe des Mundsaumes.

Das ganz farblose und sehr zartwandige Gastrovascularsystem ist bei hungernden Thieren schwer zu erkennen; die mattweisse Trübung, die auch bei diesen im Absterben sich zeigt, ist mehr geeignet zu verwirren, als ein klares Bild zu geben. Dagegen ist es auf das Prächtigste bei recht lebenskräftigen eine tüchtige Mahlzeit verdauenden Thieren zu sehen. Hier strotzt es von durchscheinenden, lebhaft umherströmenden Kügelchen von o,o I bis o,oI5 mm Durchmesser, die theils durch Flimmercilien, theils durch die Contractionen des Magens in Bewegung gesetzt werden. Vom Magen steigen vier Gefässe am Magenstiele in die Höhe, und nachdem sie (etwa o,16 mm breit) aus dem Grunde der Glocke sich abwärts auf die innere Seitenfläche gewendet, erweitern sie sich $\mathrm{zu}$ breiten, flachen, ovalen Taschen von wechselnder Ausdehnung (etwva I,3 mm lang und 0,9 bis I mm breit), die fast bis $z u$ dem Ringgefässe niederreichen, mit dem sie durch einen kurzen, weiten, nach dem Ringgefässe zu verbreiterten Kanal in Verbindung stehen. In der Mitte zwischen den Einmündungen der Radiärgefässe zeigt das weite Ringgefäss eine ansehnliche Bucht (Fig. 23), indem sein innerer Rand einen nach innen convexen Bogen beschreibt, - eine Andeutung der centripetalen Gefässe der Geryonia proboscidalis. - Die festen Elemente der ernährenden Flüssigkeit sieht man besonders gegen Ende der Verdauung aus dem Magen in die Gefässe, aus diesen in jenen strömen und hier ebenfalls durch Flimmern umhergetrieben. Einen komischen Anblick gewährte bei einem solchen in der Verdauung beobachteten Thiere ein Stück seines Fangfadens, was mit einer Anzahl Cyclopiden verschluckt worden war, und während diese verdaut wieder ausgestossen wurden, noch ganz unversehrt wurmartig im Magen herum und schliesslich zum Munde hinauskroch. - Man bewundert die Geschicklichkeit, mit der durch stellenweise Contractionen und Erweiterungen des Magenrohrs die ausgesogenen Chitinhüllen der meist aus kleinen Krustern (Cyclopiden, Mysis etc.) bestehenden Nahrung von den assimilirten Stoffen gesondert und endlich entfernt 
werden, ohne dass dabei ein Körnchen der ernährenden Flüssigkeit mit verloren ginge. $\mathrm{Zu}$ anderen Zeiten ist der Magen gegen die Gefässe abgeschlossen; durch Druck des Deckgläschens sieht man letztere oft unmittelbar über dem Magen durch hineingepresste Ernährungsflüssigkeit ansehnlich aufgetrieben, ohne dass diese in den Magen entweicht (Fig. 2).

Der Einmündung der Radiärgefässe gegenüber setzt sich das Gastrovascularsystem fort in die hier entspringenden Fangfäden, in deren Basis man bisweilen die im Ringkanale umhertreibenden Körperchen eintreten und flimmernd bewegt sieht. Wenn diese Fäden in voller Ausdehnung vom ruhenden Thiere niederhangen, übertreffen sie es vielmals an Länge und erscheinen dem blossen Auge als zarte Perlenschnüre; während jetzt die Perlen etwa um ihren vierfachen Durchmesser von einander entfernt sind, verfliessen sie vollkommen bei starker Contraction der Fangfäden, die sich dann als röthliche den Durchmesser des Thieres kaum übertreffende Würstchen darstellen. Jene Perlen sind ringförmige Wülste, die in einem röthlichen Stroma zahlreiche längliche Nesselzellen eingebettet enthalten.

Zwischen den Fangfäden finden sich im Umkreise des Schirmrandes vier kurze Tentakel, von etwa o,8 $\mathrm{mm}$ Länge und $0,05 \mathrm{~mm}$ Dicke; in jeder Beziehung so verschieden von jenen, dass ich sie nicht mit gleichem Namen bezeichnen mag; - sie entspringen nicht vom Ringgefässe, sondern über demselben von der Aussenfläche des Schirms, sind solid mit grosszelliger Achse, wenig beweglich und namentlich nicht contractil in der Richtung ihrer Länge. Beim ruhenden Thiere sind sie starr nach aussen und etwas nach oben gerichtet; sie sind leicht gebogen, nach der Spitze schwach verjüngt und tragen an der oberen Hälfte der convexen in der gewöhnlichen Lage aus- und abwärts gerichteten Seite etiva 8 halbkuglige Nesselballen (von Eschscholtz bei Eurybia als Saugwarzen bezeichnet).

Die Nesselzellen (Fig. 8) sind von gewöhnlicher Form und der durch verdünnte Säuren leicht zum Vorschnellen zu bringende Nesselfaden erschien einfach, ohne weitere Bewaffnung erkennen zu lassen.

Um das Ringgefäss zieht sich ein ziemlich undurchsichtiger gelblicher Saum der namentlich nach aussen scharf contourirte rundliche Zellen von 0,005 bis o,oo8 mm Durchmesser zeigt und auf dem mehr oder weniger reichliche Nesselzellen liegen. An der Basis der Tentakel und in der Mitte zwischen diesen Stellen zeigt er längliche Anschwellungen, denen die sogenannten „Randbläschen“ aufsitzen. Mit aller Wahrscheinlichkeit ist er als Nervenring zu deuten; dafür spricht ausser den Randbläschen tragenden Anschwellungen, dass sich von jeder dieser Anschwellungen ein zarter, aber scharf begrenzter Strang nach oben verfolgen lässt, vier zur Basis der Tentakel, vier zu Punkten, an denen das jüngere Thier dem erwachsenen meist vollständig fehlende Tentakel getragen hat (Fig. 6 und 7).

Unter dem Ursprunge der Tentakel, den Raum zwischen diesem und dem entsprechenden Ganglion des Nervenrings ziemlich vollständig füllend, so wie schief nach oben, neben dem Ursprunge der Fangfäden, die aus dem Ringgefässe hervorgehend dicht über dem Nervenring nach aussen treten, - sitzt auf der Aussenfläche des Schirms je ein sogenanntes „Randbläschen“. Die rund- 
lichen Blasen haben etwa $0,03 \mathrm{~mm}$ Durchmesser und zeigen eine doppelte Contour; am oberen Rande entfernt sich die innere von der äusseren, eine Art breiten, kurzen Stiel bildend, auf dem eine gelbliche Kugel von 0,02 mm Durchmesser aufsitzt. Diese, dem Stiele gegenüber leicht ausgehöhlt, umfasst hier eine kleinere, stark lichtbrechende Kugel (Fig. 9). - Häufiger bietet sich das Randbläscher. dem Auge so dar (Fig. 10), dass man die grössere Kugel als Halbmond der kleineren sich anschliessend sieht, seltener so, dass sie als concentrische Hülle derselben erscheint.

Diese Struktur der Randbläschen mag, wenn auch bei anderen Arten weniger leicht erkennbar, ziemlich häufig vorkommen; den Halbmond neben der lichtbrechenden Kugel sehe ich in meinen älteren Zeichnungen von Olindias n. gen. und finde ihn auch in den 5 bis 7 solcher Kugeln enthaltenden Randbläschen einer Eucope, und das Randbläschen „mit einer nochmals besonders umhüllten Concretion", das Gegenbaur von Geryonia proboscidalis erwähnt, scheint auf etwas Aehnliches hinzuweisen. - Wie man sonst mit Ehren berg jeden Pigmentfleck als Auge anzusprechen pflegte, so ist man seit der Entdeckung der Gehörbläschen der Mollusken sehr freigebig mit dem Namen Gehörorgan gewesen und auch die Randbläschen der Quallen erhalten jetzt allgemein diese Deutung. Nach der gegebenen Beschreibung muss ich mich gegen diese Ansicht und für die Auffassung von Agassiz erklären, der in ihnen Augen sieht (pigmentlose Augen kommen, beiläufig bemerkt, auch bei den Cyclopiden vor), und werde daher weiterhin das „Randbläschen“ als Auge, die „kuglige Concretion“ als Linse, die grössere Kugel, in welche diese eingebettet ist, als Sehnerven bezeichnen. Wenn ich von Auge und Sehnerven spreche, will ich indess damit keineswegs behaupten, dass in diesen Organen das Licht als Licht empfunden werde. Im Gegentheil scheint es mir kaum statthaft, eine Differenzirung in spezifische Sinnesnerven anzunehmen, wo sich oft nur mit Mühe Spuren eines Nervensystems nachweisen lassen. Wie wir mit der Hand die tropische Mittagssonne leicht vom Schatten unterscheiden, wie wir diese Unterscheidung erleichtern können durch schwarze Bemalung oder eine passend angebrachte Linse, - so mögen auch viele niedere Thiere im Lichte nur die begleitenden Wärmestrahlen empfinden. Ja, eine mit dunkelem Pigment überlagerte Nervenanschwellung, wie es üblich ist, als Auge zu bezeichnen, erscheint geradezu widersinnig, wenn man darunter nicht ein solches Wärmeauge verstehen will; denn wie sollte die Empfindung des Lichtes dadurch vermittelt werden, dass man den Nerven durch eine undurchsichtige Hülle gegen das Licht schützt?

Das Velum ist von mässiger Breite, quergespannt und wie gewöhnlich, der Sitz reichlicher Ringmuskelfasern. An der Unterfläche des Schirms sind die Ringmuskeln schwächer entwickelt, als man sie sonst bei Schirmquallen zu sehen gewohnt ist, sie finden sich auch am Magenstiel. Von den Einmündungsstellen der Radiärgefässe in das Ringgefäss entspringen vier radiäre Faser$z$ üge in einer Breite von etwa $0,16 \mathrm{~mm}$, verschmälern sich rasch bis auf ein Drittel dieser Breite und lassen sich so auf der Mitte der Radiärgefässe bis in die Nähe des Magenstiels verfolgen. Acht breitere Faserzüge begleiten seitlich die Radiärgefässe vom oberen Rande der taschenförmigen Erweiterungen an, treten mit ihnen auf den Magenstiel und füllen hier den ganzen Raum zwischen 
den Gefässen. Die Muskeln scheinen aus spindelförmigen Fasern zusammengesetzt, oder um lieber das Beobachtete statt des Erschlossenen anzuführen, man sieht eine feine parallele Strichelung, ohne die einzelnen Striche auf eine grössere Länge verfolgen $\mathrm{zu}$ können.

Die Geschlechtsst offe entwickeln sich in der der Schirmhöhle zugekehrten Wand der taschenförmigen Erweiterungen der Radiärgefässe. Die Ovarien erscheinen fast durchsichtig, die Hoden stärker weisslich getrübt, so dass sich schon mit blossem Auge Männchen und Weibchen ziemlich sicher unterscheiden lassen. Die Eier bilden eine einzige Schicht und finden sich nebeneinander in der verschiedensten Grösse bis zu $0,13 \mathrm{~mm}$ Durchmesser, mit deutlichem Keimbläschen von 0,03 mm Durchmesser und Keimfleck; sie erhalten durch gegenseitigen Druck meist unregelmässige Formen; die reiferen springen hüglig in die Schirmhöhle vor. Die Samenfäden sind stecknadelförmig mit ellipsoidischem Knopf und zartem langen Faden. Die Geschlechtsproducte werden nicht, wie Gegenbaur anzunehmen scheint, nach innen ins Gastrovascularsystem, sondern nach aussen entleert. Für die Männchen konnte ich dies durch direkte Beobachtung constatiren und für die Weibchen wird es mehr als wahrscheinlich durch die Analogie mit den Männchen, mit anderen Quallen und durch das Hervorragen der Eier in die Schirmhöhle.

Indem ich von der Beschreibung des geschlechtsreifen Thieres übergehe zur Schilderung der Formwandlungen, die es während des Heranwachsens erleidet, bedauere ich mit Bezeichnung einer empfindlichen Lücke beginnen zu müssen. Versuche, in der Gefangenschaft junge Brut zu erhalten, blieben bis jetzt ohne Erfolg; das dem Folgenden zu Grunde liegende Material wurde aus dem Meere gefischt; ich muss daher den Beweis schuldig bleiben, dass die jüngsten allerdings höchst einfachen Formen direkt aus dem Eie der Liriope hervorgegangen sind, - ein Beweis, der um so wünschenswerther wäre, da ich bei denselben das sonst dergleichen Embryonen charakterisirende Flimmerkleid vermisse, und da wir wissen, dass die in der Verdauungshöhle der Aeginiden sprossenden Jungen in gleich unvollkommenem Zustande sich von der Mutter lösen, wenn auch nicht sie verlassen.

Die jüngsten mir zur Beobachtung gekommenen Embryonen (Fig. 13) sind kuglig von 0,2 bis $0,3 \mathrm{~mm}$ Durchmesser, durchsichtig, von kleinzelligem Gefüge und zeigen eine geschlossene Höhle, die etwa $1 / 3$ des Durchmessers einnimmt und excentrisch dicht unter der Oberfläche der Kugel gelagert ist. An dieser Stelle zeigt letztere eine die innere Höhle etwas überragende und über das Niveau der Kugel unbedeutend sich erhebende minder durchsichtige Platte. Der nächste Fortschritt (Fig. 14) ist die Eröffnung der inneren Höhle durch Bildung eines Lochs in dieser Platte, die sich bald durch ihre Contractionen als Velum zu erkennen giebt. Im Umkreise derselben erscheinen (Fig. I5) vier warzenförmige Hervorragungen, um sich zu kurzen Tentakeln zu entwickeln (Fig. 16), die ein endständiges Nesselknöpfchen und über diesem ein kurzes Fädchen tragen. Zwischen ihnen in einem dem Mittelpunkte näheren Kreise sprossen paarweis, je zwei einander gegenüberstehende zu gleicher Zeit, vier andere Tentakel hervor (Fig. 17), die bald die älteren an Länge übertreffen. Jetzt beginnt auch das Gastrovascular- 
system deutlicher hervorzutreten; man unterscheidet das matte Ringgefäss, an dessen Rand die jüngeren Tentakel entspringen, so wie bei günstig geöffnetem Velum den Magen und vier nach den älteren Tentakeln gerichtete Radiärgefässe. Der Durchmesser des Thieres ist auf etwa $0,35 \mathrm{~mm}$ gestiegen. - Bei einem Durchmesser von etwa $0,4 \mathrm{~mm}$ (Fig. 18) haben die jüngeren Tentakel die Länge des Halbmessers erreicht, und an der Basis des älteren Paares, das sich durch zwei Nesselballen von dem jüngeren mit einem einzigen endständigen Nesselknopfe versehenen unterscheidet, beginnen die ersten Augen sich zu entwickeln. Im Umkreise des Ringgefässes treten Nesselzellen auf. - Ohne weitere wesentliche Veränderung, als das Auftreten neuer Nesselballen an den vier jüngeren Tentakeln und die Entwickelung von vier vollständigen Augen an deren Basis, erreicht das Thier die Grösse von 0,8 mm (Fig. I 9). Wollte man es jetzt klassificiren, so würden es seine starren Tentakel zu Gegenbaur's Trachynemiden verweisen; ihre unbedeutenden Krümmungen sind weniger erheblich, als ich sie bei einer mit acht Tentakeln versehenen Trachynemidenlarve beobachtete. - Man sieht um diese Zeit häufig eine eigenthümliche Bewegung des Thieres Fig. I9, B). Das Velum wird fast bis zu völligem Verschlusse contrahirt, und gleichzeitig die die Radiärgefässe begleitenden Muskeln, wodurch die Schirmhöhle eine vierlappige Gestalt annimmt; die Tentakel werden durch diese Contractionen nach innen geschlagen und schnellen dann plötzlich wieder nach aussen. - In dieser Periode scheinen die Jungen von Liriope oder verwandten Gattungen schon verschiedentlich beobachtet worden zu sein. So von Eschscholtz, dessen Eurybia exigua nur durch den Mangel der auch bei unserer Liriope später fehlenden älteren Tentakel sich unterscheidet; (die angeblichen Magentaschen finden ihre Erklärung im Hinblicke auf unsere Fig. I9, B oder 23). So auch von Gegenbaur, dessen Eurybiopsis anisostyla noch vollständiger unserem Thiere gleicht, freilich aber sehr wesentlich durch vier, nicht den kleineren, sondern den grösseren Tentakeln entsprechende Radiärgefässe sich unterscheiden würde, wenn diese Angabe nicht vielleicht auf einem Irrthume beruht. - Es werden also die Gattungen Eurybia und Eurybiopsis als blosse Jugendzustände von Rüsselquallen eingehen müssen.

Bis zu dieser Zeit haben die Thiere so ziemlich ihre ursprüngliche Kugelform bewahrt; (man sehe die auch für unser Thier passende Seitenansicht, die Gegen baur von Eurybiopsis giebt). Jetzt beginnt eine Verdünnung der Schirmmasse, und eine Ausdehnung der Glockenöffnung, wodurch die auf der Unterfläche liegenden Tentakel nach dem Rande und endlich nach dem Rücken geschoben werden. Das Thier erscheint dadurch sehr verflacht, oft nicht einmal halbkuglig und beginnt erst mit Ausbildung der vollständigen Liriopeform sich wieder zu mästen. Zu mästen; denn die auch bei erwachsenen Thieren erheblich schwankende Dicke des Schirms scheint hauptsächlich von dem sparsameren oder reichlicheren Futter abzuhangen, das die Thiere finden. Eine Anzahl Liriope, die über eine Woche in reinem Seewasser gehungert hatten, zeigten alle auffallend flache Schirme.

Um nun von der Eurybiaform zu der der ausgebildeten Liriope zu gelangen, müssen noch die Fangfäden und vier Augen auftreten, und muss der Magenstiel und die Bewaffnung des Mundsaumes sich ausbilden. 
Das erste Auftreten der Fangfäden sah ich bei einem Thiere von I mm Durchmesser (Fig. 20), wo zwei gegenüberstehende als kurze zapfenförmige Ausstülpungen des Ringgefässes sich zeigten und zwar dicht neben dem durch zwei ältere Tentakel gezogenen Durchmesser. Die nervöse Natur des das Ringgefäss umgebenden Saumes und der von ihm zu den Tentakeln gehenden zarten Stränge zugegeben, so begreift sich, dass die Fangfäden nicht in, sondern n eben diesem Durchmesser auftreten, da sie sonst den Tentakelnerven durchbrechen müssten, und ebenso ersieht man, weshalb die Augen in ihrer Lage den Tentakeln und nicht den Fangfäden entsprechen. - Die Fangfäden entwickeln sich also ebenfalls paarweise, je zwei gegenüberliegende zu gleicher Zeit, und dasselbe gilt von den vier noch fehlenden Augen. Zuerst erscheint von diesen der Sehnerv (Fig. I 2) als gelbliches Kügelchen, das ohne scharfe Grenze auf dem Nervenring aufsitzt, genau in dem durch zwei ältere Tentakel gezogenen Durchmesser. Von diesem hebt sich dann, wenn er ziemlich seine definitive Grösse erreicht hat, die anfangs querelliptische Blase ab (Fig. I I, C), und endlich tritt auf ihm die anfangs fast punktförmige aber schon jetzt stark lichtbrechende Linse auf (Fig. I I, B).

Etwa gleichzeitig mit dem Auftreten der Augen erscheint die erste Spur des Stiels in dem breiten Grunde des noch kurzen Magens, an dessen Rand schon früher (Fig. 2I) die Nesselknöpfchen sichtbar geworden sind. Der Stiel bildet anfangs einen ganz frei in die Magenhöhle ragenden Kegel, dessen Basis bei weiterem Wachsthume den ganzen Grund des Magens füllt (Fig. 22). Indem jetzt die Magenwand mit dem Umfange der Kegelbasis verwächst, wird der Magen natürlich bei weiterer Verlängerung des kegelförmigen Zapfens von dem Schirme abgehoben (Fig. 23, B) und endlich aus der Glocke hinausgeschoben, und so ist denn, bei einem Durchmesser von 3 bis $4 \mathrm{~mm}$ die vollkommene Liriopeform hergestellt. Mit der Verlängerung des Stiels hält die Verlängerung des Magenrohrs gleichen Schritt, so dass die ältesten Thiere sich ebenso durch einen besonders langen Magen, wie durch einen besonders langen Stiel auszeichnen.

Thiere, die vollständig und wohl entwickelt alle zwölf Randanhänge tragen, sind nicht eben selten; auffallender Weise steht dann hier deren Länge im umgekehrten Verhältnisse zu ihrem Alter; indess pflegen früher oder später die ältesten für das erwachsene Thier äusserst winzigen Tentakelchen sich zu verlieren und selten nur sieht man eins oder das andere bei geschlechtsreifen Thieren erhalten.

Desterro, April i 859.

\section{Erklärung der Abbildungen auf Tafel X und XI.}

Fig. 5-7 und $13-20$ sind 5 omal, 9 und ro sind $175 \mathrm{mal}$, I I und $\mathrm{I} 2$ sind 35 omal vergrössert. In allen bedeutet: $F$. Fangfaden, $G$. Radiärgefäss, $M$. Magen, $N$. Nervenring, $R$. Ringgefäss, $S$. äussere Grenze der Schirmhöhle, $t$. ältere, $T$. jüngere Tentakel, $T$. Velum.

Fig. I. Liriope catharinensis (6mal vergr.), von den Fangfäden ist kaum $1 / 3$ der Länge gezeichnet.

Fig. 2. Magenstiel und Magen, unterm Druck des Deckgläschens (3omal).

Fig. 3. Nesselknopf vom Mundrand (I 5omal).

Fig. 4. Stück des Fangfadens in mässiger Contraction (Ioomal). 
Fig. 5. Tentakel von aussen.

Fig. 6. Ursprung dessselben von innen.

Fig. 7. Ursprung des Fangfadens von aussen.

Fig. 8. Nesselzelle aus dem Endballen der Tentakel (50omal).

Fig. 9 u. Iо. Augen neben der Basis der Fangfäden.

Fig. I I. Augen eines Thiers von 2,5 $\mathrm{mm}$ Durchmesser. A. von der Basis der Tentakel. B. und C. von der Basis der Fangfäden.

Fig. I 2. Auge von der Basis des Fangfadens eines Thieres von 2,2 mm Durchmesser.

Fig. I3-20. Jugendzustände der Liriope catharinensis von 0,25 bis I mm Durchmesser - In Fig. I 8 sind Magen und Ringgefässe wegen stark contrahirten Velums nicht sichtbar; Fig. I9, B zeigt die Tentakel eingeschlagen. Alle Ansichten sind von unten, mit Ausnahme von Fig. I 3, B und Fig. I 5 .

Fig. 2I. Magen eines Thieres von $2 \mathrm{~mm}$ Durchmesser (3omal), von unten.

Fig. 22. Magen eines Thieres von $2,2 \mathrm{~mm}$ Durchmesser, mit etwas umgebogenem Mundrande.

Fig. 23. A. Thier von 2,5 $\mathrm{mm}$ Durchmesser, in der Verdauung begriffen, mit strotzend gefüllten Gefässen (I 6rnal). B. Magenstiel desselben (40mal).

Fig. 24. Schematischer Längsschnitt durch den Ursprung der Tentakel. $n$ Tentakelnerv? S. Schirm.

Fig. 25. Schematischer Längsschnitt durch den Ursprung der Fangfäden. 


\section{Polypen und Quallen von Santa Catharina ${ }^{1}$ ). Philomedusa Vogtii n. sp.}

Mit I Textfigur.

Die Schirmquallen werden von den mannichfachsten Schmarotzerthieren heimgesucht. Infusorien wimmeln in den Hoden der Tamoya; Trematoden und andere Eingeweidewürmer finden sich oft in Menge in der Gallertsubstanz verschiedener Arten; Asseln, Amphipoden und ein glasheller Palaemon bewegen sich in dem Schleime der Scheibe und der Arme, deren Nesselfäden anderen Krustern raschen Tod bringen, und eine im Verhältnis zum Wohnthiere riesige Krabbe (Libinia?) pflegt zwischen den vier die Armplatte der Rhizostomiden tragenden Säulen zu sitzen. Vor allen merkwürdig aber unter diesen Schmarotzern und wohl werth einer besonderen Beschreibung erschien mir der actinienähnliche Polyp, dem die folgenden Zeilen gewidmet sind, theils als das erste parasitisch lebende Thier dieser Gruppe, theils weil seine fast quallenartige Durchsichtigkeit einen leichten und sicheren Einblick in seine übrigens sehr einfachen anatomischen Verhältnisse gestattet.

Philomedusa Vogtii, wie ich das Thier benenne ${ }^{2}$ ), erscheint, wenn sie die Leibeshöhle mit Wasser aufgeschwellt hat, als cylindrischer Schlauch von etwa $30 \mathrm{~mm}$ (selten bis $50 \mathrm{~mm}$ ) Länge und etwa $5 \mathrm{~mm}$ Dicke. Das Hinterende ist in der Regel schwach verjüngt, kuglig abgerundet oder mehr weniger trichterförmig eingezogen. Am vorderen Ende steht ein Kranz von zwölf kurzen (gegen $4 \mathrm{~mm}$ langen), plumpen, cylindrischen T e n ta k eln mit abgerundeter geschlossener Spitze, die bald in einer Ebene ausgebreitet, bald schief nach vorn gestreckt, besonders häufig aber nach hinten zurückgebogen getragen werden. Die Tentakel sind sämmtlich von nahezu gleicher Länge; doch kann man, obschon diese Ungleichheit oft durch verschiedenen Contractionszustand derselben verwischt wird, sechs längere und sechs mit ihnen abwechselnde etwas kürzere unterscheiden. Zwischen je zwei Tentakeln beginnend durchziehen zwölf seichte Längsfurchen die Oberfläche

I) Archiv für Naturgeschichte. I860. I. p. 57-63. Taf. II, Fig. I.

2) Den Gattungsnamen wïhlte ich nach der Lebensweise; durch den Artnamen sei es mir gestattet, meine Hochachtung Hrn. C. Vogt zu bezeigen, in dem ich neben dem geistvollen Naturforscher zugleich den rüstigen Kämpfer für die Principien verehre, deren Unterdrückung auch mich aus der alten Heimath scheuchte und eine neue an den gastlichen Gestaden von Santa Catharina suchen liess. 
des Körpers und stossen in der Mitte des Hinterendes strahlig zusammen. Die Färbung des Thieres beschränkt sich in diesen Zustande auf eine weissliche Trübung; bei stärkster Contraction, die ihm die Gestalt eincr Feige mit zwölf I ängsfurchen und zahlreichen Querrunzeln zu geben pflegt, concentriert sie sich zu cinem schmutzigen, mehr oder weniger ins Röthliche ziehenden Gelb. Die Fühler erscheinen bisweilen schwach röthlich gefärbt, und innen an ihrer Basis pflegt ein undurchsichtiger, hellgelber Ring zu liegen; weniger constant finden sich ähnliche Flecken aussen an ihrer Basis und bräunliche Flecken zwischen ihnen.

Die ganze Oberfläche des Körpers trägt einen kurzhaarigen Flimmerüberzug, sowie auch überall, in besonderer Menge jedoch an den Tentakeln, länglich schmale Nesselzellen von o,o I 2 bis 0,0 I6 mm Länge sich finden.

Die Form des M u ndes ist eine sehr wechselnde. Wenn die Tentakel schief hinterwärts gebogen sind, pflegt er als weit offener Trichter zu erscheinen, umgeben von elf durch scharfe Furchen geschiedenen Wülsten, die ebenso viel Tentakeln vorliegen. Einer der kürzeren Tentakel bleibt dabei ohne vorliegende Wulst, während die den beiden benachbarten entsprechenden Wülste sich durch ihre Breite auszeichnen, wie denn überhaupt den längeren Tentakeln breitere, den kürzeren schmälere Wülste entsprechen. Der Mund erscheint selten fast rund, meist in die Länge gezogen in der Richtung des durch den wulstlosen Tentakel gehenden Durchmessers. Diesem Tentakel entsprechend bleibt zwischen den beiden anliegenden Wülsten eine ziemlich tiefe Rinne, an deren äusserem Ende jede dieser Wülste sich in einen kleinen zungenförmigen Fortsatz auszieht. Ein dritter ähnlicher Fortsatz liegt zwischen diesen beiden, dem wulstlosen Tentakel gegenüber. Diese drei Fortsätze, meist weiss und undurchsichtig, fallen besonders ins Auge, wenn bei schief vorwärts gerichteten Tentakeln der Mund fast geschlossen ist; die Wülste, die nichts sind, als eigenthümliche Aufblähungen der Leibeshöhle, sind dann ziemlich abgeflacht und

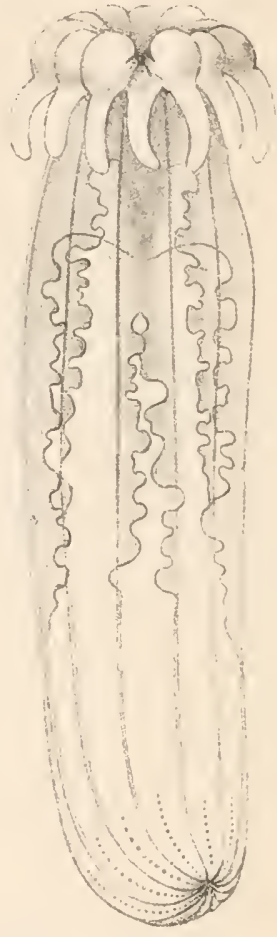

Philomedusa Vogtii in ausgedehntem $\mathrm{Zu}$ stande, 3 mal vergrössert. die zungenförmigen Fortsätze erheben sich, gerade vorgestreckt, über deren Niveau.

Die Mundwülste, die sie trennenden Furchen und die an den zungenförmigen Fortsätzen beginnende Rinne ziehen sich fort in den kurzen, etwa die doppelte länge der Tentakel erreichenden Magen, die unmittelbare Fortsetzung des Mundtrichters. Die Ränder der Rinne scheinen sich in der ganzen Länge des Magens zu einer vollständigen Röhre zusammenlegen zu können. Im Grunde steht der Magen durch eine weite Oeffnung in Verbindung mit der Leibeshöhle, in die man nicht selten von Munde aus hineinsehen kann. Wenn er sich schliesst durch Aneinanderlegen seiner Wände, erscheint er platt; schmal in der Richtung des durch die Rinne gelegten Durchmessers, breit in darauf senkrechter Richtung gesehen. In letzterer seitlicher Ansicht sieht man, dass er auf der Seite der Rinne weiter in die Leibeshöhle hineinragt, als auf der entgegengesetz.ten. 
Die weite Leibeshöhle ist durchweg mit Flimmercilien bekleidet. Um den Magen herum ist sie durch musculöse Wände in I 2 Kammern getheilt, die den Tentakeln entsprechen und in deren Höhle sich fortsetzen. Die Scheidewände reichen nicht vollständig bis zum Vorderende, vielmehr bleibt hier in jeder ein rundes Loch als Communication zwischen je zwei benachbarten Kammern. Auf diese Weise wird an der Basis der Tentakel eine Art Ringcanal um den Mund hergestellt. Selten sieht man an anderen Stellen die Scheidewände von Iücken durchbrochen. - Nach hinten setzen sich die Scheidewände, den Längsfurchen folgend, fort bis ans Ende des Körpers, bilden aber jenseits des Magens nur sehr niedrige Vorsprünge in die weite Leibeshöhle. Sie scheinen aus zwei Lamellen gebildet; wenigstens erscheinen sie, gerade von aussen betrachtet, als zwei dunkle durch einen hellen, schmalen, mittleren geschiedene Streifen.

Von der Insertion am Magen bis zu Anfang des hintersten Drittels oder Viertels der Länge sind die Scheidewände eingefasst von einem breiten wellig oder krausenartig gefalteten gelblichen, ziemlich undurchsichtigen Saume, dessen frei in der Leibeshöhle flottirender Rand wulstig verdickt ist. An diesem etwa $0,1 \mathrm{~mm}$ breiten Rande, den eine hellere Linie scharf gegen die Krause absetzt, ist die Flimmerbewegung besonders lebhaft und es sind ihm reichliche Nesselzellen von doppelter Länge und Dicke der in der äusseren Haut sich findenden eingelagert. Diese zwölf $\mathrm{Kr}$ a usen verhalten sich verschieden in ihrer Erstreckung nach vorn und hinten und zeigen dabei in noch deutlicherer Ausprägung die schon in der Bildung des Mundes angedeutete bilaterale Symmetrie in Bezug auf eine durch die Achse des Körpers und die Mundrinne gelegte Ebene. In ihrer Erstreckung nach hinten betrachtet erscheinen, wenn man von der Seite der Mundrinne aus zählt, constant als die längsten das Iste, 3te und 5te Paar der Krausen. von mittlerer Länge das 6te Paar, als die kürzesten das 2te und 4te Paar. Diese beiden letzten Paare dagegen reichen am weitesten nach vorn, indem die betreffenden Scheidewände am Magen nur etwa bis zu dessen Mitte herabsteigen; das 3 te, 5te und 6te Paar inseriren sich am Magengrunde, während die beiden Scheidewände des ersten Paares noch über den Magen hinaus eine nach innen geschlossene Kammer bilden. - Die verdickten Ränder der Krausen glaube ich als Analoga der Mesenterialfäden der Actinien betrachten zu dürfen, die hier nur die Eigenthümlichkeit haben, in ihror ganzen Länge angeheftet zu sein. Dic Krausen selbst dürften sich als Bildungsstätten der Geschlechtsstoffe ausiveisen, von denen ich bis jetzt an zahlreichen, seit fast einem Jahre untersuchten Thieren noch keine unzweideutigen Spuren auffand.

Bei grösseren Actinien pflegt nur das Hervorspritzen feiner Wasserstrahlen beim Anfassen die Anwesenheit kleiner Oeffnungen der Leibeshöhle zu verrathen; bei unserem Thiere sind diese Oeffnungen selbst mit Leichtigkeit wahrzunehmen. Sie zeigen sich schon den blossen Auge als I 2 radiäre Reihen heller Punkte am hintersten Theile der Körpers, die mit den Längsfurchen abwechseln. Ihre Zahl wächst mit dem Alter und steigt bei den grössten Exemplaren bis gegen 20 in einer Reihe. Ihr Durchmesser ist verschieden; die grösste Oeffnung, die mir vorkam, war o, I mm lang und halb so breit. Unter dem Mikroskope kann man die durch die Flimmercilien der Leibeshöhle umhergetriebenen Partikelchen bisweilen aus ihnen austreten sehen. Durch Contraction der Leibes- 
wand werden sie natürlich geschlossen, sind aber auch selbständiger Verengerung und Schliessung fähig; sich verengend erscheinen sie von einem hellen Hofe umgeben; sind sie geschlossen, so zeigt sich an ihrer Stelle ein heller Fleck.

Die Mitte des Hinterendes ist bei dem wassergefüllten Thiere vollkommen geschlossen; bei rascher Contraction verschliesst sich dagegen hier eine weite Oeffnung zum Austritte des Wassers ${ }^{1}$ ), durch die dabei nicht selten Theile der Krausen vorfallen. Bei einem grossen Exemplare, das ich zu bequemerer Beobachtung in ein Reagensgläschen brachte, sah ich, nachdem es sich wieder aufgeschwellt hatte, einen schmalen Strang vom Ende einer der längeren Krausen straff nach der Mitte des Hinterendes herübergespannt, der, wie ich wusste, vorher nicht vorhanden gewesen war. Nach einer durch Erschütterung des Glases bewirkten neuen leichten Contraction des Thieres begann der Strang sich vom Hinterende $\mathrm{zu}$ entfernen und mit ausserordentlicher Langsamkeit und unter Bewahrung seiner geradlinigen Form sich zusammenzuziehen; er erwies sich so als ein bei der ersten Contraction eingeklemmtes, bei der durch die neue Contraction bewirkten Erschliessung der Endöffnung wieder frei gewordenes Stück der betreffenden Krause.

Ich fand die Philomedusa Vogtii zuerst vereinzelt an Olindias (nov, gen. Eucopidarum) an der Unterfläche der Scheibe sitzen, später in Menge an Chrysaora, wo sie an den Armen, in den Geschlechtshöhlen, im Magen und seinen Nebentaschen sich aufhält. Von einer einzigen Qualle der letzteren Gattung habe ich schon über 20 unserer Polypen abgelesen. - Die den Quallen entnommenen Thiere pflegen Stücke der Fangfäden, der Genitalien, der Magenfäden u.s.w. des Wohnthiers im Magen zu haben und in ihrer Leibeshöhle trifft man oft Nesselzellen der Qualle an. Sie vertragen, wie die Actinien, gut die Gefangenschaft, können monatelang hungern und lassen sich auch andere als Quallenkost, namentlich Anneliden, schmecken. Hat man eine grössere Zahl in demselben Gefässe, so werden bisweilen kleinere von grösseren verschluckt und leben in deren Leibeshöhle wenigstens wochenlang weiter, wie es scheint ohne gegenseitige Störung des Befindens.

Die Thiere vermögen mit jeder beliebigen Stelle des Leibes sich anzuheften, wahrscheinlich mittelst der Nesselzellen, die überhaupt auch in den Fangfäden der Quallen grössere Dienste als Haftorgane, wie durch ihr Gift zu leisten scheinen. Sie klettern nicht selten an der Wand der Glasgefässe empor und pflegen sich dann mit dem Munde anzusaugen. Ehe sie zu behaglicher Ruhe sich aufgeschwellt, ist ihre Gestalt eine sehr wechselnde, je nachdem dieser oder jener Körpertheil stärker contrahirt ist, je nachdem die Tentakel eingezogen oder vorgestreckt sind u. s. w. - Alle ihre Bewegungen sind sehr träge; sie bleiben, in Ruhe gelassen, Tage lang auf dem Boden des Glases liegen oder an derselben Stelle der Wand hängen, ohne andere Bewegungen als Contractionen der Ringmuskeln, die von Zeit zu Zeit in langsam fortschreitenden Wellen von vorn nach hinten verlaufen. Desterro, im Mai I 859.

I) Ebenso bei Cerianthus (vergl. Jules Haime in den Annales des sciences nat. 4. ser. Tom. I. p. 34I), mit welchem Polypen der oben beschriebene manche Verwandtschaft hat, freilich stimmt die Zahl und besonders die Stellung der Tentakeln nicht, deren Cerianthus eine doppelte, Philomedusa eine einfache Reihe besitzt. Uebrigens wäre in Betreff der systematischen Stellung zu berücksichtigen, dass die Thiere, wie oben steht, noch nicht geschlechtsreif beobachtet sind.

Max Schultze. 


\title{
Beschreibung einer Brachiopodenlarve').
}

\author{
Mit Tafel XII.
}

Die Formwandlungen der niederen Thiere haben in den letzten Jahrzehenden zu den Lieblingsgegenständen zoologischer Forschung gehört, und selten wohl hat ein Gegenstand dankbarer, mit einer reicheren Fülle der überraschendsten Entdeckungen die auf ihn gewandte Mühe belohnt. Für die Mehrzahl der grösseren Thiere liegen jetzt, Dank diesen vielseitigen Bemühungen unserer Zeitgenossen, wenigstens die Grundzüge ihres Entwicklungsganges offen, und bietet auch der Ausbau im Einzelnen der Zukunft noch ein reiches Feld für anziehende Untersuchungen, so bleiben doch kaum noch wenige Gruppen übrig, über deren frühere Zustände nicht wenigstens Andeutungen oder wahrscheinliche Vermuthungen vorhanden wären. Jedenfalls die wichtigste unter diesen in Bezug auf Entwicklung noch im tiefsten Dunkel liegenden Gruppen ist, trotz ihrer spärlichen Vertretung in der lebenden Thierwelt, die der Brachiopoden.

Mit freudiger Ueberraschung begrüsste ich daher den Anblick einer unverkennbaren Brachiopodenlarve, eines um so unerwarteteren Fundes, als mir erwachsene Brachiopoden unseres Meeres noch nicht bekannt sind ${ }^{1}$. Ich eile, dies erste Bruchstück aus der Formenreihe der Brachiopodenentwicklung zur Kenntnis der Zoologen zu bringen, hoffend, dass es ferneren Nachforschungen gelingen werde, die früheren und späteren Schicksale des interessanten Thierchens aufzuklären.

Um sich zunächst ein vorläufiges Bild der allgemeinen Umrisse desselben zu machen, denke man sich ein zweiklappiges fast kreisrundes Muschelchen von 0,4 mm Durchmesser; die Schalen vollkommen gleichseitig, aber ungleich; eine grössere, schwach gewölbte Rückenschale, welche ringsum die ganz flache, hinten (am Schlussrand) ausgebuchtete Bauchschale überragt; an der Stelle des Schlosses eine quer-ovale Platte zwischen den Schalen. Mantel rings offen. Im Umkreis der Schalen ragen fünf Paar derber Borsten vor, unter denen das vierte nach hinten gerichtete durch Länge und Stärke sich auszeichnet, und die mit Ausnahme

1) Reichert und Dubois R.'s Archiv für Anat. u. Physiol. I860. p. 72-80. Taf. I B.

2) Hier die Bemerkung, dass ich neuerdings von dem Verfasser obenstehenden Aufsatzes ein Stückchen einer bei Desterro gefundenen Pinna-Schalc zugesandt erhielt, an welchem die Bauchschale einer Crania oder verwandten Brachiopode angeheftet war. Max Schultze. 
des fünten hintersten im Mantel der Bauchschale wurzeln. Eine Reihe zarterer haarförmiger Borsten entspringt jederseits dem Nantel der Rückenschale und krümmt sich bogig nach unten über die Bauchschale. - Das Thier ist, wie die Schale, vollkommen symmetrisch in Bezug auf eine durch die Mitte des Hinterrandes senkrecht auf diesen gelegte Ebene. Der eigentliche Leib, rundlich im Umriss, nimmt die Mitte der hinteren Schalenhälfte ein; ein weiter flaschenförmiger Magen, daneben zwei Gehörblasen, nach vorn zwei dunkle Augenflecke fallen daran zunächst in's Auge. Die vordere Schalenhälfte füllen vier Paar cylindrischer Arme, zwischen denen vorn ein unpaarer rundlicher Knopf und hinter diesem der Mund zu sehen ist. Auf gemeinsamem Stiele aus der Tiefe vorgeschoben breiten sich die Arme strahlig um den Mund aus und mit Hülfe ihres reichen Flimmerkleides schwimmt das Thier langsam umher.

Zur näheren Betrachtung der einzelnen Theile übergehend, so sind beide Schalen sehr dünn, biegsam, blass hornfarbig, ziemlich durchsichtig. Die Rücken schale überragt rings die Bauchschale; sie ist flach schildförmig gewölbt, o,4 I mm breit, $0,38 \mathrm{~mm}$ lang. Ein ziemlich genaues Bild ihres Umfanges erhält man, wenn man über derselben Geraden, der grössten Breite der Schale, vorn einen Halbkreis, hinten eine Ellipse beschreibt, deren Achsen sich wie 6:7 rerhalten. Die Bauchschale, 0,3 mm lang, $0,38 \mathrm{~mm}$ breit, ist ganz flach; ihre Ränder laufen bei dem ruhenden Thiere denen der Rückenschale in einer Entfernung von etwa o,02 mm parallel, - mit Ausnahme des Hinterrandes, an dem sich eine flache Ausbucht findet, wodurch hier die Entfernung der Schalenränder auf $0,05 \mathrm{~mm}$ steigt. Der Rand der Bauchschale erscheint in einer Breite von etwa $0,025 \mathrm{~mm}$ dunkler, mehr oder weniger röthlich braun gefärbt.

Mit ihrem Hinterrande dem ausgebuchteten Hinterrande der Bauchschale anliegend, gewahrt man zwischen den Schalen eine querovale Plat te, o,o6 mm lang, o, I I mm breit, mit dunklerem, oft braunröthlich gefärbtem, ringförmigem Rande. Sie haftet an der Bauchschale, deren Bewegungen sie folgt, und steht mit der Rückenschale nur durch Muskeln in Verbindung.

Der die Schalen auskleidende rings offene Mantel ist in der Mitte beider Schalen sehr dünn und so bildet sich hier ein scharf umschriebenes helles Feld, dessen Breite etwa $3 / 5$ von der der Rückenschale beträgt, und innerhalb dessen das ruhende Thier geborgen liegt. Dies helle Feld ist umgeben von einem minder durchsichtigen wulstigen Saume von etwa $0,04 \mathrm{~mm}$ Breite, in welchem ich einige Male (in der Rückenschale) radiär verlaufende einfache oder am Ende gablige, nach innen offene, nach aussen geschlossene Canäle bemerkte.

In diesem verdickten Saume wurzeln Borsten von zweierlei Art: stärkere, hornfarbige, wagerecht aus der Schale vorstehende und zartere, haarförmige, farblose, die sich bogig um den entgegengesetzten Schalenrand krümmen. Im Mantel der Bauchschale finden sich vier Paar Borsten der ersten Art, die der beiden vordersten Paare sind etwa $0,15 \mathrm{~mm}$ lang und in der Ruhe nach vorn und etwas nach innen gerichtet, wobei die Spitzen der beiden vordersten sich kreuzen; die des dritten Paares, das an der breitesten Stelle der Schale entspringt, wenden sich nach aussen und etwas nach hinten, sind nur $0,09 \mathrm{~mm}$ lang und überragen kaum den Rand der Bauchschale. Alle sind ganzrandig und leicht S-förmig gebogen. Weit ansehnlicher sind die Borsten des vierten Paares, sie entspringen 
etwa I $\mathrm{mm}$ rom Hinterrande der Bauchschale und reichlich eben so weit von der Mittellinie; während die gerade Entfernung ihrer Spitze von der Wurzel o,3 mm beträgt, bilden sie einen nach aussen gewölbten Bogen von $0,07 \mathrm{~mm}$ Höhe. Dem gleichförmig breiten Stiele folgt etiva zu Ende des ersten Viertels ihrer Länge eine spindelförmige $0,02 \mathrm{~mm}$ breite Verdickung, von der aus sich die Borste allmälig verjüngt, bis zu der vieder sanft auswärts gebogenen Spitze. In ihrem Endtheile und in mehr als der Hälfte ihrer Länge ist die Borste am Aussenrande und seitlich mit kurzen hinterwärts gerichteten Dornen oder Zähnchen besetzt. In der Ruhe sind diese Borsten meist gerade hinterwärts, bisweilen mehr nach aussen, seltener so nach innen gerichtet, dass ihre Spitzen sich kreuzen. Zwischen dem ziveiten und dritten Paare der eben beschriebenen Borsten finden sich zivei Paar Borsten der zweiten Art.

Nur das fünfte und hinterste Paar der stärkeren Borsten gehört der Rückenschale an, liegt zwischen den Borsten des vierten Paares, ist hintervärts gerichtet und entspricht in Grösse und Form den beiden vorderen Paaren der Bauchschale. Desto zahlreicher sind in der Rückenschale die Borsten der zweiten Art; sie bilden jederseits eine dem Rande in einer Entfernung von etwa $0,07 \mathrm{~mm}$ parallel laufende Reihe; vorn bleibt zwischen den beiden vordersten Borsten ein freier Raum von I mm, während die hintersten den grossen Borsten des vierten Paares gegenüber entspringen. Ihre Zahl steigt auf 30 bis 40 , sie sind haarförmig, ganzrandig, farblos, elastisch, die mittelsten längsten etwa $0,2 \mathrm{~mm}$ lang. Unter dem Rande der Bauchschale vorgetreten, biegen sie sich um diesen nach unten und innen. Die beiden hintersten sieht man bisweilen neben den stärkeren Borsten des fünften Paares wagerecht nach hinten ragen.

Der eigentliche Leib des Thieres (der fälschlich sogenannte Eingeweidesack), nimmt den grössten Theil von der hinteren Hälfte des hellen Mittelfeldes ein, ist vorn abgerundet und mit seiner ganzen oberen und unteren Fläche den Schalen angeheftet. Die Musculatur, die neben dieser Anheftung an den Leib des Thieres die einzige Verbindung der Schalen bildet, ist mir nicht ganz klar geworden; ein breites Muskelpaar, das an den vorderen Ecken des Leibes von der Rückenschale entspringt und nach hinten zur Bauchschale geht, sowie ein schmaleres von den Seiten der querovalen Platte nach aussen und etwas nach vorn zur Rückenschale gehendes Muskelpaar scheinen die wesentlichsten für die Bewegungen der Schalen. Sie lassen sich nicht füglich als „Schliessmuskeln" bezeichnen, da die Schalen, durch die Platte aus einander gehalten, stets nahezu gleiche Entfernung von einander zu bewahren scheinen; einseitig wirkend, drehen sie die Bauchschale (weit seltener, wenn diese gegen andere Körper gestützt ist, sieht man Drehung der Rückenschale), und durch gleichzeitige Wirkung der beiderseitigen Muskeln wird die Bauchschale nach vorn geschoben.

Die vordere Hälfte des hellen Feldes ist ziemlich vollständig gefüllt durch die vier Paar Arme, die in der Ruhe knieförmig gebogen sind, so dass das Knie nach hinten, die Spitze wieder nach vorne sieht; seltener ist das hinterste Paar zu beiden Seiten des Leibes nach hinten geschlagen. Sie werden getragen von einem in der Ruhe auf ein Minimum verkürzten gemeinsamen Stiel, der in einem ansehnlichen querovalen $\mathrm{K} n \circ \mathrm{pf}$ von $0,05 \mathrm{~mm}$ Breite endet. Dieser pflegt sich dicht an den Vorderrand des hellen Feldes zu legen, und ist namentlich in 
seiner vorderen Hälfte dunkler bräunlich roth gefärbt. An der Bauchfläche des Armstieles liegt der wulstig umrandete M u nd, dessen Form je nach seinen verschiedenen Contractionszuständen sehr wechselt; er erscheint enger oder weiter, als Quer- oder Längsspalte, besonders oft auch T förmig, d. h. begrenzt von drei nach vorn convexen Bogen, einem vorderen unpaaren und zwei kleineren hintern. Um den Mund sind nun die Arme in einer von vorn und oben nach hinten und unten geneigten Ebene geordnet, so dass also das vorderste Paar nach der Rücken-, das hinterste unter dem Munde und nach der Bauchschale zu liegt. Sie sind von gleicher Grösse, cylindrisch, etwa $0,03 \mathrm{~mm}$ dick und $0,15 \mathrm{~mm}$ lang, scheinen hohl zu sein und sind mit (ihrem Durchmesser an Länge fast gleichkommenden) Flimmercilien bekleidet.

Vom Munde aus läuft ein musculöser Schlund im Armstiele gerade nach hinten und tritt in einen die ganze Länge der Leibeshöhle einnehmenden, weiten, hinten flaschenförmig verbreiterten Magen, der blass dottergelb gefärbt und im Gegensatze zu dem ganzen übrigen Thiere undurchsichtig ist. Man sieht in ihm grosse Zellen von o,oo6 mm Durchmesser und auf seiner Bauchseite mehr oder weniger ausgeprägte rundliche braune Flecken von kleinzelligem Gefüge (künftige Leber?). Ein Darm liess sich nicht auffinden, vielmehr erschien der Magen rings geschlossen.

Von Geschlechtsorganen und Gefässsystem war ebenfalls keine Spur zu entdecken; Herzen sind daher schwerlich vorhanden, da sie sich durch ihre Pulsationen hätten verrathen müssen.

Seitlich, doch mehr der Rückenfläche genähert, liegt jederseits nahe der Vorderecke des Leibes ein dunkel schwarzbrauner A ugenfleck von ovaler Form (Durchmesser o,OI5 und O,OI3 mm), dessen längerer Durchmesser schief nach hinten und aussen gerichtet ist. $\mathrm{Zu}$ den Seiten des Magens und über denselben (der Rückenschale zu) liegen zwei ansehnliche Gehörblasen von o,o4 mm Durchmesser, in denen man 20 bis 30 Otolithen (von etwa $0,002 \mathrm{~mm}$ ) in. lebhafter tanzender Bewegung erblickt. Das Nervensystem scheint schon deutlich ausgeprägt zu sein, ist aber nur dann bruchstückweise wahrzunehmen, wenn es gelingt, durch Drehen des Deckgläschens die Schalen ohne zu grosse Verletzung des Thieres aus einander zu schieben; ich verspare die Mittheilung meiner fragmentarischen Beobachtungen, bis sich mir aus ihnen ein zusammenhängendes, durch wiederholte Prüfung gesichertes Bild gestaltet.

Da der Schwerpunkt des auf die Kante gestellten Thieres in die Rückenschale fällt, sieht man es fast immer auf dieser Schale liegen; auch beim Sch wimmen scheint sie stets die untere zu sein. Das Schwimmen geschieht durch die Flimmerbewegung der die Arme bekleidenden Cilien; die Arme werden zu diesem Behufe aus der Schale vorgeschoben, strecken sich und breiten sich strahlig um den Mund aus. Dass dabei der Nund vorausgehe, würde ich, als selbstverständlich, nicht erwähnen, hätte man nicht neuerdings den seltsamen Gedanken gehabt, bei den Brachiopoden das Vorn und Hinten nach der Lage nicht des Mundes, sondern des Afters zu bestimmen. - Häufiger als das Schwimmen hat man Gelegenheit, das' sonderbare Kriechen des Thieres $\mathrm{zu}$ beobachten, welches durch abwechselndes Drehen der Bauchschale nach rechts und links bewirkt wird. Dabei schiebt sich das Thier namentlich durch Anstemmen der starken Borsten des 
vierten Paares vorwärts. Gleichzeitig werden, wenn die Bauchschale z. B. sich nach links dreht, die um den linken Rand derselben sich krümmenden haarförmigen Borsten der Rückenschale durch den gegen sie drückenden Schalenrand gestreckt, um bei der folgenden Drehung nach rechts in ihre Ruhelage zurück zu schnellen und so, Algenfäden u. dgl. umfassend, das Thier festzuhalten. - Die Arme liegen bei diesen Drehungen der Bauchschale ruhig in der Rückenschale.

Dass nun unser Thier nur den Brachiopoden angereiht werden könne, wird nach der gegebenen Beschreibung keiner weiteren Erörterung bedürfen. Der erste Eindruck, dass es eine Larve sei, den mir später verschiedene Gründe zweifelhaft machten, bestätigte sich schliesslich durch einige Fortschritte der Entwick$1 \mathrm{ung}$ an denselben Thieren, die ich in der eben beschriebenen Form beobachtet hatte. Sie beschränken sich auf den kurzen Zeitraum von ein bis zwei Tagen, nach welcher Zeit die Thiere starben, geben aber immerhin einige Andeutungen für den weiteren Gang der Entwicklung. Die querovale Platte tritt unter der bis zum Vorderrande der Rückenschale vorgeschobenen Bauchschale vor, beginnt sich nach hinten $\mathrm{zu}$ verlängern und ein faseriges Ansehen $\mathrm{zu}$ zeigen (Stiel?); sie folgt, nach wie vor, den Bewegungen der Bauchschale; - hinten und rechts vom Magen ausgehend, und sofort sich nach vorn wendend tritt ein anscheinend noch blind geschlossener Darm auf, die erste Störung der vollkommenen Symmetrie; ein feinzelliges Gewebe erscheint vorn in der Leibeshöhle zu den Seiten des Magens und verhindert die Otolithen von der Bauchseite aus zu sehen; - der Magen wird durchsichtiger und lebhaftes Flimmern in demselben sichtbar.

Alle beobachteten Exemplare (und ich konnte mir einige Wochen hindurch täglich wenigstens einige verschaffen) waren von ganz gleicher Grösse. Dass grössere nicht vorkommen, erklärt sich aus den eben erwähnten Veränderungen, die auf ein nahes Festsetzen hinweisen; der Mangel jüngerer Formen mag vielleicht daher rühren, dass sie bis dahin in der Schale der Mutter verweilen.

Dies die bis jetzt beobachteten Thatsachen. Wenn schon sie im Allgemeinen mehr geeignet scheinen, die Neugierde zu wecken als zu befriedigen, Fragen anzuregen als zu lösen, - so lassen sich immerhin schon einige Folgerungen aus ihnen herleiten.

Zunächst ergiebt sich, dass der Theil des Brachiopodenleibes, der in der Larve Augen und Gehörblasen trägt, in welchem sich also die Centraltheile des Nervensystems mit Grund vermuthen lassen, nicht wohl als blosser „Eingeweidesack" bezeichnet werden kann.

Ferner beantwortet sich definitiv die Frage nach dem Vorn und Hinten, Oben und Unten der Brachiopoden und zwar zu Gunsten der herkömmlichen Terminologie und gegen die von C. Vogt vertretene Ansicht, der sich mit Hintenansetzung aller übrigen Organe durch die Lage des Afters hat leiten und verleiten lassen. Hätte der eifrige Vertreter des Individualismus auch diesen Thieren ihr Recht werden lassen, nach ihrer eigenen individuellen Natur und nicht nach einer vagen Analogie mit den Muscheln gelagert zu werden, so würde er schwerlich dem After diesen Vorrang vor dem Munde eingeräumt haben, so wenig als bei Gasteropoden und anderen mit seitlichem After versehenen Thieren. 
Die Bedeutung unserer Larve für die systematische Stellung der Brachiopoden näher $\mathrm{zu}$ erörtern, muss ich mich enthalten, da ich die neueren Forschungen über Bryozoen nur durch Jahresberichte kenne und ich selbst nur wenige Formen derselben ziemlich oberflächlich untersucht habe. Dem Eindruck des ersten Anblicks folgend würde gewiss Jeder, der unser Thier lebend zwischen lebenden Muschellarven und Cellularien gesehen, ihm ohne Bedenken seine Stelle zur Seite der letzteren anweisen. Was dabei zunächst als ähnlich in's Auge fällt, die kreisförmig gestellten Tentakel, steht in auffallendem Gegensatz zu der Armbildung der erwachsenen Brachiopoden. Aber ob überhaupt unser Thier als Larve einer der bekannten Brachiopodenformen angehört, und nicht vielmehr dem noch unbekannten Repräsentanten einer neuen Gruppe mit kreisförmig gestellten Armen, die dann in ähnlicher Weise den Meeresbryozoen mit Tentakelkranz entsprechen würde, wie die gewöhnlichen Brachiopoden den zweiarmigen Bryozoen des süssen Wassers?

Desterro, Ende März I 859.

\section{Erklärung der Abbildungen auf Tafel XII.}

Fig. I. Brachiopodenlarve aus dem Meere von Santa Catharina, mit zurückgezogenen Armen; Durchmesser 0,4 mm.

Fig. 2. Dieselbe schwimmend.

Fig. 3. Ein Stück der Borste $B$. 


\section{Das Kolonialnervensystem der Moosthiere, nachgewiesen an Serialaria Coutinhii n. sp. ${ }^{1}$ ).}

Mit Tafel XIII und XIV.

Bei Thieren, die auf gemeinsamem Thierstock zu Kolonieen vereinigt leben beobachtet man häufig Bewegungen des ganzen Stockes oder einzelner Thiere, die zwar willkürlich, nicht aber vom Willen der Einzelthiere abhängig, sondern von diesen wie auf höheren Befehl ausgeführt erscheinen. Dies gilt auch von den Moosthieren. Bei einer Pedicellina, deren Thierzelle von einem $3 \frac{1}{2} \mathrm{~mm}$ langen starren auf dickerem beweglichen Sockel stehenden Stiele getragen wird, dauern die Bewegungen dieses Stieles tagelang nach dem Verluste des Thieres unverändert fort; bei einer weit kleineren Art derselben Gattung, die als Schmarotzer auf Moosthieren und Hydroiden hier sehr häufig ist, beginnen die in ganzer Länge beweglichen Stiele schon auf das Lebhafteste sich zu bewegen, wenn das Thier an ihrer Spitze kaum als Knospe angedeutet ist. Ich erinnere auch an die bei Mimosella gracilis von $\mathrm{Hincks}$ beobachteten gemeinsamen und gleichzeitigen Bewegungen der doppeltfiedrig angeordneten Thierzellen. Wo nun überhaupt bei solchen Thieren, wie es bei den Bryozoen der Fall ist, Nerven sich nachweisen lassen, da ist mit Grund zu vermuthen, dass nicht nur bei jedem Einzelthiere als Sitz des Einzelwillens, sondern dass auch in dem Thierstocke als Sitz der Kolonialverwaltung ein Nervensystem bestehen werde. Der Nachweis freilich dieses Nervensystems wird für die Mehrzahl der Moosthiere von äusserster Schwierigkeit sein; um so schwieriger, je reducirter, verkalkter, undurchsichtiger, - um so leichter, je entwickelter, weicher, durchsichtiger der Thierstock ist. In dieser Beziehung nun dürfte nicht leicht eine ausgezeichnetere Art zu finden sein, als eine im Meere von Santa Catharina nicht eben seltene Serialaria, deren Thierstock aus bis über zolllangen, dünnhäutigen fast vollkommen durchsichtigen Gliedern besteht. Hier ist denn nun auch in der That ein Kolonialnervensystem so leicht erkennbar, mit so überraschender Deutlichkeit in die Augen fallend, wie ich Aehnliches sonst nur an dem Nervensysteme der Salpen gesehen zu haben mich entsinne. 
Die Darstellung des Kolonialnervensystems als einzigen Zweck dieses Aufsatzes betrachtend, beschränke ich die vorauszuschickende Beschreibung des Thieres auf das zum Erkennen der Art und zum Verständnisse des Folgenden Nothwendige, und übergehe namentlich den inneren Bau der Einzelthiere.

Der sparrig verästelte, nach allen Seiten über spannenweit zwischen Tangen sich ausbreitende Thierstock der Serialaria Coutinhii mihi ${ }^{1}$ ) besteht aus walzenförmigen Gliedern, die bis über $40 \mathrm{~mm}$ Länge bei I,35 $\mathrm{mm}$ Dicke erreichen, und, von Glied zu Glied sich verjüngend, bis zu o,1 mm dicken Endzweigelchen herabsinken. Die Verästelung des Stockes erscheint im Allgemeinen trichotomisch in der Weise, dass vom Ende jedes Astes drei ungleich starke Zweige abgehen, die beiden stärkeren nahezu in gleicher Ebene mit dem Aste, der dritte schwächere einen Winkel von etwa $60^{\circ}$ mit der Ebene der beiden anderen bildend. An den äussersten Verzweigungen verfolgt man leicht die Entstehung dieser Verästelungsweise: am Ende des Astes tritt zunächst ein einzelner neuer Trieb als gerade Fortsetzung des Astes auf (fig. 1, $a^{\prime}$ ), wird aber später (fig. I, $a^{\prime \prime}$ ) durch einen zweiten (fig. I, $b^{\prime}$ ), der bald darauf neben ihm entspringt, mehr und mehr zur Seite gedrängt, so dass der Winkel zwischen diesen Zweigen oft bis über $120^{0}$ steigt. Der dritte, wieder jüngere Zweig (fig. 1, c) zwischen den beiden älteren, in einer auf der Ebene derselben senkrechten Ebene sich entwickelnd, pflegt jene Ebene der beiden älteren kaum merklich hinabzudrängen, so dass dieselben eben nahezu in gleicher Ebene mit dem Aste bleiben. Bisweilen, doch immer erst viel später, und nachdem sich die früheren längst weiter verästelt haben, tritt dem dritten gegenüber noch ein weit schwächerer vierter Zweig auf (fig. 1, d); selten selbst ein fünfter, eine Zahl, die ich noch nicht überschritten sah. Das relative Alter der Zweige bleibt meist sehr deutlich ausgeprägt in ihrer Dicke und Iänge, so wie in dem Grade ihrer weiteren Verästelung.

Die Glieder des Stockes sind weich, biegsam, doch dabei elastisch, etwa wie ein unterbundenes mit Wasser straff gefülltes Darmstück; ihre in kochender Kalilauge nicht gelöste, also wohl aus Chitin bestehende zarte aber dabei feste Hülle ist, wie der fast flüssige Inhalt, von fast wasserheller Durchsichtigkeit; eine leichte gelbliche Trübung wird durch ein unmittelbar unter der Hülle gelegenes Pigment bedingt. Die jüngsten Zweige zeigen sich weniger durchsichtig, während bei den älteren vielerlei thierische und pflanzliche Schmarotzer oft den Einblick hindern.

[Späterer Zusatz: Nach Beobachtungen an anderen ctenostomen Bryozoen vermuthe ich, dass die einzelnen Glieder durch eine von der Hülle ausgehende quere Scheidewand getrennt sind.]

Der Stock haftet an Tangen u.s.w. mittelst sehr vereinzelter Wurzelfäden, die bald am Ende der Aeste an Stelle der Zweige (fig. 2, $a$ ), bald an unbestimmten Stellen des Stammes, besonders zwischen den Thierzellen entspringen (fig. 2, $b$ ) und deren Ende sich flächenartig und lappig auf dem Tange ausbreitet.

Die Thierzellen stehen in Längsreihen am oberen Theile der Zweige, deren unterer Theil in verschiedener Erstreckung leer bleibt, bald in ununterbrochener

I) Die Art benannte ich nach Herrn Dr. Jő̃o Jos é Coutinho, früheren Präsidenten der Provinz. Santa Catharina, dem ich die Musse zu wissenschaftlichen Arbeiten, und dem also die Wissenschaft dankt, was mir etwa hier zu ihrer Förderung zu leisten vergönnt sein sollte. 
dichtgedrängter Folge, bald mit einzelnen kurzen Lücken, bald (an den ältesten, bisweilen selbst thierlosen Aesten) nur in einzelnen wenig zahlreichen Gruppen. Sie erscheinen einseitswendig (wie bei Serialaria cornuta und lendigera lam.) an den jüngsten Endzweigelchen, an den übrigen aber in zwei mehr oder weniger diametral gegenüberstehenden Reihen. Es treten nämlich zuerst zwei dicht nebeneinanderstehende Reihen auf, nach aussen von diesen bilden sich zwei neue Reihen jüngerer Zellen; ihnen folgt wieder nach aussen ein dritter, ein vierter Nachwuchs u. s. f., während die ältern Thiere absterben und endlich auch ihre Zellen abfallen. Wenn, wie es an alten Aesten vorkommt, bei diesem Vorrücken der jungen Brut der Durchmesser überschritten wird, schlägt natürlich scheinbar die Ordnung um, indem nun die Knospen sich nach innen von den beiden Reihen reifer Thiere finden. - Die Zellen sind häutig, in voller Ausdehnung gegen o, $6 \mathrm{~mm}$ lang und von $0,2 \mathrm{~mm}$ auf $0,1 \mathrm{~mm}$ Durchmesser verjüngt; sie sitzen mit kuglig abgerundeter Basis schief auf, nach der Spitze des Zweiges zu sich neigend und tragen am Ende, beim Uebergange in die Tentakelscheide einen Kranz o,o4 bis 0,05 mm langer, zarter, flacher, farbloser Borsten. Bei tiefem Zurückziehen des Thieres wird ein volles Drittel der Zelle eingestülpt, und diese nimmt dann eine mehr eiförmige Gestalt an. Die alten Zellen ohne Thiere, deren Vorderende stets eingestülpt ist, erscheinen kürzer und dicker und von ellipsoidischer Form.

Das Thier, das einen Kranz von acht $0,3 \mathrm{~mm}$ langen Tentakeln trägt, ist in der Zelle so gelagert, dass die Darmseite der Spitze, die Schlundseite dem Ursprunge des Zweiges sich zuwendet; bei tiefem Zurückziehen richtet sich der eingestülpte Zelientheil schief nach der Darmseite, um hier auf die Mitte der nicht eingestülpten Zellenwand zu stossen; von da wendet sich die Tentakelscheide quer nach der Schlundseite und steigt an dieser bis zum Zellengrunde nieder.

Die Beachtung dieser Lagerungsverhältnisse, so wie der Richtung, in der sich die neuen Thierknospen bilden, erleichtert wesentlich das rasche Zurechtfinden an kleinen Stückchen, wie sie in den Gesichtskreis des Mikroskops fallen; die weiteren Verhältnisse der Einzelthiere sind nicht von Belang für die Auffassung des Kolonialnervensystems, zu dessen Darstellung ich jetzt mich wende.

Das Nervensystem jedes Zweiges besteht aus einem andessen Ursprungliegenden ansehnlichen Ganglion, aus einemvon diesem ausgehenden den $Z$ weig der Länge nach durchziehenden Nervenstamme, dersich am oberen Ende in Aeste theilt für die Ganglien der hier entspringenden Stengelglieder, und aus einem reichen Nervenplexus, der dem Stamme aufliegt, und diese Ganglien, so wie die Basalganglien der Einzelthiere verbindet.

Die Basalganglien der Zweige (fig. $3-5, G$ ) liegen genau an der Grenze Zwischen Ast und Zweig und in der Achse des letzteren; sie sind meist von kugliger Form, oder auch etwas in die Länge gezogen und melır spindelförmig und von körnigem (kleinzelligem?) Gefüge. Blass und durchscheinend in den jüngsten Zweigelchen, erhalten sie bald eine schwach gelbliche Färbung und werden undurchsichtig. Ihre Grösse steigt von o,03 mm Durchmesser (in einem ganz jungen erst $0,2 \mathrm{~mm}$ langen Zweigelchen gemessen) bis über $0,1 \mathrm{~mm}$ Durchmesser.

Vom Basalganglion läuft in gerader Linie und mit fast gleichbleibender Dicke (je nach dem Alter 0,01 bis $0,05 \mathrm{~mm}$ ) ein Nervenstam $\mathrm{m}$ bis nahe ans Ende 
des Zweiges (fig. 3-5, S), jedoch nicht in der Achse, sondern sich der Seite der Oberfläche mehr oder weniger nähernd, an welcher die ersten Thierknospen sich bilden, und die ich kurzweg als die obere bezeichnen will. Meist ist er einfach, bisweilen in zwei dicht aneinanderliegende oder stellenweise etwas auseinanderweichende Stämme getheilt, selten nur (in alten Aesten) auf kürzere oder längere Strecken in einen langmaschigen Plexus mit 3 bis 4 Hauptstämmen aufgelïst. Er ist von blasser Farbe und hat zarte glatte Contouren.

Die Basalganglien und die Hauptnervenstämme sind bei günstiger Beleuchtung oft schon mit der Loupe recht gut wahrzunehmen.

Der oberen Seite des Nervenstammes liegt, bald ihn dicht überdeckend, bald in weiteren Maschen ihn überspinnend, ein Plexus dünnerer Nerven auf (fig. 3 bis $5, P$ ), der sich seitlich nach der Ursprungslinie der Thierzellen ausbreitet und besonders reich am Ende des Zweiges zwischen den Basalganglien der folgenden Stengelglieder entwickelt. In diesem Endplexus scheint jedoch ausser den Aesten zu den eben bezeichneten Ganglien auch wenigstens noch eine bogige Brücke zwischen je zweien derselben dem Systeme des glatten Hauptnervenstammes anzugehören. Die Nerven des Plexus unterscheiden sich nämlich von dem Hauptstamme besonders dadurch, dass ilıre Oberfläche durch aufgelagerte kernhaltige Zellen uneben und mehr oder weniger knotig oder höckerig erscheint. Chromsäurelösung macht diese Zellen schwinden; die Nerven erhalten dadurch schärfere nun gradlinige Contouren, denen noch die Kerne jener Zellen als kleine stärker lichtbrechende Körnchen aufsitzen. - Es ist dieser Plexus besonders entwickelt an dem mit Thierzellen besetzten Theile der Zweige und namentlich von äusserster Complication in älteren Aesten, an denen schon eine Reihe successiver Generationen sich gefolgt sind. Nach dem Ursprunge der Zweige pflegt er seitlich nicht über den Nervenstamm hinauszugehen und ist dann kaum von ihm zu unterscheiden; bei der Ansicht von oben erscheinen dann beiderseits unebene Contouren, während die Seitenansicht oben die unebenen Contouren des Plexus, unten die glatten des Nervenstammes zeigt. In diesem thierlosen Theile der Zweige vermisst man bald alle peripherischen Nerven, bald sieht man einzelne meist rücklaufende Fäden, bald auch findet sich ein ziemlich entwickelter Plexus, der dann aber vertical vom Stamme aufwärts sich ausbreitet, während die Ausbreitung des Plexus zwischen den Thierzellen mehr oder weniger horizontal ist. In Bezug auf letzteren Plexus sei noch erwähnt, dass man bisweilen, doch nicht constant, seine Fäden unter der Ursprungslinie der Thierzellen zu einem etwas stärkeren Grenzstrang zusammenfliessen sieht.

Es bleibt mir der Zusammenhang des eben geschilderten Knonialnervensystems mit den Einzelthieren zu besprechen. Dieser Zusammenhang ist nicht immer leicht zu erkennen. Damit die zu untersuchende Gegend nicht von den meist dicht gedrängten Thierzellen verdeckt werde, müssen diese seitlich liegen; dann aber fällt dieselbe Gegend theils dicht an den Rand (les cylindrischen Zweiges, theils fast in dieselbe Ebene mit dem Hautpigmente und wird aus beiden Gründen oft fast undurchsichtig; ausserdem pflegt der Magen des zurückgezogenen Thieres störend in den Weg zu treten. Indessen lassen sich doch fast an jedem Zweige ein oder das andere Thier oder leichter noch Knospen herausfinden, an denen dieser \%usammenhang unzweideutig zu erkennen ist. An der 
Grenze zwischen Zweig und Thierzelle, halb in jenen, halb in diese hineinragend, liegt ein kugliges Ganglion von 0,04 bis 0,05 mm Durchmesser (in jungen Knospen kleiner), das einerseits mit den Nerven des Plexus in Verbindung steht, während ich nach der anderen Seite einen von ihm zum Darme gehenden Nerven beim erwachsenen Thiere einigemal gesehen zu haben glaube und bei Knospen mit Bestimmtheit gesehen habe. Den vorauszusetzenden Zusammenhang dieses Basalganglions mit dem Oesophagealganglion vermochte ich nicht nachzuweisen.

Auch die Wurzeln, mögen sie nun am Ende der Aeste, oder in der Reihe der Thierzellen, oder sonstwo am Aste entspringen, haben ihr Basalganglion und ihren sie durchziehenden Nervenstamm. Bei ihrem ersten Auftreten sind die Einzelthiere und die Zweige des Thierstocks durch nichts Wesentliches ausser dem Orte ihres Ursprungs, die Wurzeln aber von beiden nicht einmal hierdurch unterschieden und es findet Leuckart's geistvolle Lehre vom Polymorphismus auf diese drei verschiedenen Gebilde eine ungezwungene Anwendung.

Es steht zu erwarten, dass ein ähnliches Kolonialnervensystem auch andern Moosthieren mit besonderm von den Thierzellen geschiedenen Stocke zukommen werde, während, wo Zelle aus Zelle sprosst, wenigstens im Grunde der Zellen liegende und durch Nervenfäden mit einander verbundene Ganglien sich vermuthen lassen. [Späterer Zusatz: Die Basalganglien der Zweige und ihren Nervenstamm habe ich bei verschiedenen Moosthieren mit reusenartigem Verschlusse der Zellen, Ctenostomata Allm., erkannt; in keiner der übrigen Abtheilungen vermochte ich aber bis jetzt unzweideutige Spuren des Kolonialnervensystems aufzufinden.]

Desterro, im Januar 1860.

\section{Erklärung der Abbildungen auf Tafel XIII und XIV.}

Fig. I. Bruchstück einer Kolonie von Serialaria Coutinhii F. Müll. 6mal vergr. Mit $a$ ist der erste, mit $b$ der zweite, mit $c$ der dritte, mit $d$ der vierte am Ende des vorhergehenden Stengelgliedes sprossende Zweig bezeichnet. $w$ junge Wurzeln.

Fig. 2. Zweig mit Wurzeln, I 2 mal vergr. $a$ auf Tang $(T)$ haftende, $b$ jüngere Wurzeln, $c$ warzenförmige Wurzellnospe.

Fig. 3-5. Kolonialnervensystem der Serialaria. Fig. 3 u. 4 sind 9omal, fig. 5 ist 5 omal vergr. Fig. 3 stellt das Nervensystem aus dem Gelenk $A$ in fig. 1 : fig. 4 dasselbe aus dem Ende eines erst zwei noch unverästelte Endzweige tragenden Astes dar. Es bezeichnet in diesen Figuren: $G$ Basalganglion der Zweige, $g$ Basalganglion der Einzelthiere, $S$ Nervenstamm der Zweige, $P$ Nervenplexus, der demselben aufliegt, $R$ Grenzstrang desselben an der Ursprungslinie der Einzelthiere. Fig. 4 zeigt Nervenstamm und Plexus von oben, fig. 5 von unten. Thieres.

Fig. 6. Thierknospe von $0,06 \mathrm{~mm}$ Durchmesser. Basalganglion. e Anlage des

Fig. 7. Aeltere Thierknospe. $g$ Basalganglion. $e$ Anlage des Thieres. $"$ Nerv von jenem zu diesem. $P$ Nerven des Koloniahnervenplexus. Fig. 0 u. 7 sind gomal vergrössert. 


\title{
Cunina Köllikeri n. sp. $\left.{ }^{1}\right)$.
}

Beitrag zur Naturgeschichte der Aeginiden.

\author{
Mit Tafel XV.
}

Eine der räthselhaftesten Thatsachen in der an Rüthseln noch so reichen Naturgeschichte der Schirmquallen ist das von Kölliker ${ }^{2}$ ) beobachtete Vor kommen sechszehnstrahliger "Stenogaster" im Magen eines zehnstrahligen „Eurystoma“. Die Bedeutung der bis jetzt vereinzelt stehenden Beobachtung ist wenig gewürdigt worden, indem man bald dieses Vorkommen selbst, bald die Verschiedenheit in der Tentakelzahl der beiden Formen als zufällig ansah, - bald also, wie K ölliker, sie als ,unmöglich im Zusammenhange stehen'de" Arten, bald wieder die Stenogaster einfach als junge Eurystoma auffasste. Weder das Eine aber noch das Andere ist zufällig. Stenogaster ist die Brut von Eurystoma, kann sich aber unmöglich in letzteres verwandeln, da die Zahl seiner Magentaschen und Tentakel eine viel grössere ist.

Seit März I859 kenne ich eine achtstrahlige Cunina mit zwölfstrahliger Brut, - Zahlen, die fast genau in demselben Verhältnisse stehen, wie die von Kölliker beobachteten 10 und 16 , - erst kürzlich jedoch fand ich Musse und reichen Stoff zu einer näheren Untersuchung. Die Hoffnung, in der ich sie unternahm, das Räthsel dieser auffallenden Thatsache zu lösen, ist leider getäuscht worden. Immerhin scheint mir aber die Mittheilung meiner Beobachtungen gerechtfertigt, da sie wenigstens dienen werden, die Aufmerksamkeit aufs Neue jener zu wenig beachteten Entdeckung Kölliker's zuzuwenden.

Nach dem Entdecker jener überaus merkwürdigen Thatsache nenne ich die Qualle, an der ich sie unzählige Male bestätigen konnte, Cunina Köllikeri. Sie gehört zu den häufigeren Quallen unseres Meeres und findet sich namentlich in diesem Sommer in Menge, so dass ich einmal in einer Stunde über 50 Stück sammeln konnte.

Die glashelle Gallertscheibe der Cunina Köllikeri (fig. I) wurde bis zu $6,5 \mathrm{~mm}$ Durchm. beobachtet; schon bei der Hälfte dieses Durchmessers pflegen indessen alle Theile vollzählig vorhanden zu sein und noch früher schon, vor vollständiger Entwickelung der Randbläschen, tritt die Geschlechtsreife ein. Je

1) Archiv für Naturgeschichte 186 I. I. p. 42-52. Taf. IV.

2) v. Sieb. und Köll. Zeitschr. für wiss. Zool. 1853. Bd. IV. S. 327. 
nach der Dicke der Gallertscheibe zeigt ihre Rückenfläche verschiedene Wölbungsgrade von ziemlich flacher Scheibenform bis zur Halbkugel. Meist ist die Wölbung nicht gleichmässig, sondern der Scheitel stärker, selbst kuppelartig hervortretend, der mittlere Gürtel geradlinig niedersteigend oder selbst flach eingesenkt, und der Rand wieder in stärkerer Krümmung abwärts gebogen.

Der Rand zeigt, dem Ursprunge der Tentakel entsprechend, acht sclımale, tiefe, unterhalb von der Randhaut überbrückte Einschnitte; die dadurch gebildeten Lappen sind in der Mitte breiter und bald durch einen einfachen Bogen begrenzt, bald, wenn sie mehr als ein Randbläschen tragen, zwischen je zweien derselben seicht eingekerbt. Von ihrem Rande schlägt sich die mässig breite (nicht von Kanälen durchzogene) Randhaut (fig. 2 u. 3, v), nach innen. Da ihr freier Saum einen Kreis bildet, ist sie natürlich von sehr wechselnder Breite, am breitesten den Tentakeln, am schmälsten der Mitte der Randlappen gegenüber.

Die Unterfläche der Scheibe ist in der Mitte eben oder fast unmerklich gewölbt, im Umkreise in sanfter Neigung abwärts steigend. Den ebenen Theil nimmt der Magen ein, dessen Durchmesser etwa der Hälfte des Scheibendurchmessers gleichkommt. Vom Umkreise des Magens bis zum Ursprunge der Tentakel erstrecken sich die acht Magentaschen, die nur durch schmale Scheidewände getrennt werden. Diese Scheidewände springen mit einer abgerundeten Wulst in den Magen vor und sind von ziemlich gieichmässiger Breite, weshalb denn natürlich die Magentaschen in gleichem Verhältnisse mit ihrer Entfernung vom Mittelpunkte sich verbreitern. Die flach ausgebreitete untere Magenhaut, die dem frei niederhängenden Magenrohre anderer Quallen entspricht, gleicht ihnen in wunderbarer Contractilität. Der $\mathrm{Mund}$ (fig. 2, 3, 4, I I), fast stets in langsamer Bewegung, ist bald völlig geschlossen, bald so weit geöffnet, dass die Eingänge der Seitentaschen und die vorspringenden Wülste der sie trennenden Scheidewände entblösst werden. In der Regel erscheint er als ganzrandige runde oder eiförmige Oeffnung von wechselnder Weite in der Mitte, oder nach jeder beliebigen anderen Stelle des Magens verschoben. Diese Kreisform kann er bis zu fast völligem Verschlusse bewahren, oder dann auch die Form einer Längsspalte, eines Kreuzes u. s. w. annehmen (fig. 4). Muskelfasern konnte ich in dieser Magenhaut nicht sehen; sie dürften wohl überhaupt bei Quallen nur da zu suchen sein, wo rasche Bewegungen in stets gleicher Richtung auszuführen sind, nicht aber als Vermittler langsamer proteusartiger Zusammenziehungen.

Ich erwähne bei Gelegenheit des Magens, dass die Nahrung unserer Qualle hauptsächlich in einer kleinen hier sehr häufigen Physophoride (Agalmopsis?) zu bestehen scheint, die ich einmal wirklich gefangen sal, während ich oft Nesselorgane im Magen der Cunina fand, die mit denen aus den Nesselknöpfen der Agalmopsis vollständig übereinstimmten.

In der Magenhöhle und ihren Nebentaschen besteht Flimmerbewegung.

Die Tentakel (fig. 5) entspringen mit verdickter Basis in den Einschnitten des Scheibenrandes, dem Grunde der Magentaschen gegenüber, sie verjüngen sich allmählich und enden mit abgerundeter Spitze. Ihre Länge wechselt von noch nicht einem Drittel bis über zwei Drittel des Scheibendurchmessers; ihre eigenen Bewegungen sind langsam und unerheblich und dürften sie sich kaum bis zur Hälfte ihrer grössten Lünge verkürzen können. Wie bei verwandten Arten werden 
sie bald strahlig ausgebreitet, wobei ihre Spitze leicht abwärts gebogen ist, bald mehr auf- oder abwärts gerichtet. Die angeschwollene Basis des Tentakels ist aus grossen kernhaltigen Zellen zusammengesetzt, nach oben geht sie in die aus einer einfachen Reihe querer Zellen gebildete Achse über, nach unten setzt sie sich mit einer kegelförmig zugespitzten, geraden oder seltener gebogenen, aus 3 bis 5 grossen Zellen bestehenden Wurzel in die Gallertscheibe fort. Die zienlich dünne Rindenschicht enthält kleine runde Nesselorgane eingelagert, die besonders gegen die Spitze hin dichter gedrängt sind und eine weissliche Trübung oder leicht gelbliche Färbung bedingen. Eine „scheidenartige Umhüllung“, die Ge genbaur der Tentakelbasis der Aeginiden zuschreibt, sah ich nicht; man müsste denn die seitlich durch die Randlappen der Gallertscheibe und unterhalb durch die Randhaut gebildete Rinne so bezeichnen, in die die Basis des abwärts gebogenen Tentakels sich einlegt.

Die Randbläschen, die ich auch hier, - wenn sie überhaupt Sinnesorgane sind, für Augen halte, sitzen am Saume der Randlappen; bei jüngeren Thieren eins, bei älteren drei an jedem derselben, indem neben jenem crsten noch jederseits ein neues sich bildet. Diese seitlichen Randbläschen kann man an verschieden alten Thieren durch alle ihre Entwicklungsstufen verfolgen. Die Randbläschen (fig. 8) sind elliptisch oder verkehrt eiförmig von etwa 0,06 bis $0,08 \mathrm{~mm}$ Länge und $0,04 \mathrm{~mm}$ Dicke, sitzen mit stielförmig verdünnter Basis auf und haben meist eine einzige rundliche oder elliptische endständige Concretion; von der Basis zieht sich ein zartcontourirter, feinkörniger Strang zur Concretion, um sie becherförmig zu umfassen. Bisweilen findet sich eine zweite kleinere Concretion unterhalb der endständigen, selten mehrere (fig. 9).

Die Aehulichkeit dieser Randbläschen mit den Gehörorganen der Mollusken und Ringelwürmer ist noch geringer, als selbst bei Linope, Eucope, Aequorea u. S. w., und es würde kaum noch ein Schimmer von Aehnlichkeit bleiben, wenn sich der mehrfach nachgewiesene Verbindungsgang der letztern mit der Körperoberfläche, den ich gleichfalls bei jungen Terebellen $\left.{ }^{1}\right)$ sah, als allgemein vorhanden ausweisen sollte.

Oberhalb jedes Randbläschens ist die Gallertsubstanz des Randlappens wulstig verdickt und auf diesem IVulste verläuft centripetal ein bis etwa $0,2 \mathrm{~mm}$ langer und $0,03 \mathrm{~mm}$ breiter scharf begrenzter Streifen, dessen Oberhautzellen rundliche Nesselorgane erzeugen. Die Bildung der entsprechenden Nesselstreifen beginnt vor dem Auftreten der seitlichen Randbläschen. Wie bei anderen Aeginiden werden die Randlappen der Scheibe häufig nach innen umgebogen, in welcher Lage dann die Nesselstreifen von den Randbläschen strahlig nach aussen verlaufen (fig. 2, 3).

Dem Nervensysteme glaube ich zurechnen zu müssen einmal einen matten am Saume der Randlappen sich hinziehenden Streifen, in dem man zart contourirte Zellen von o,006 bis $0,008 \mathrm{~mm}$ Durchmesser unterscheidet, der bei den Randbläschen anschwillt (fig. 8, g) und den schon erwähnten Strang zur Concretion

1) Diese jungen Terebellen, die in eiförmige Schleimmassen sich hüllend, sehr lange, bis zur Ausbildung der Kiemen, im Meere herumtreiben, haben auch das Eigenthümliche, nach dem Verschwinden der Pigmentflecke des Kopflappens noch ein schwarzes Augenpaar zu entwickeln. Sie scheinen zu Terebella annulicornis mihi zu gehören. 
abgiebt, und zweitens ein paar ansehnliche, ziemlich undurchsichtige, weit stärker contourirte Wülste an der Basis jedes Tentakels (fig. $5, g$ ), die ähnliche, aber gleichfalls schärfer contourirte Zellen zeigen und zu denen ich wiederholt jenen anderen Streifen verfolgt zu haben glaube.

Als bezeichnende Eigent hüm 1 ichkeiten der Cunina Köllikeri dürften aus vorstehender Beschreibung die Zahl der Tentakel und Magentaschen, die Länge der Tentakel, die Zahl und Form der Randbläschen und die oberhalb derselben liegenden Nesselstreifen hervorzulieben sein. Es ist dabei zu bemerken, dass wenn schon acht die gewöhnlichste Zahl der Tentakel und Magentaschen ist, doch auch Ausnahmen nicht selten beobachtet werden. Während einiger Tage merkte ich die Tentakelzahl aller untersuchten Thiere an und fand dabei 70 mit 8,4 mit 7 . eins mit 6 und eins mit 9 Tentakeln, wobei ich mich überzeugte, lass die 7-und 6-strahligen nicht etwa, was auch vorkommt, aber leicht an den Magentaschen und Randbläschen zu crkennen ist, nur zufällig einen Tentakel eingebüsst hatten.

Die grosse Mehrzahl der beobachteten Exemplare trugen in reicher Menge junge Brut im Magen und dessen Seitentaschen (fig. I1); nicht selten, bei etwa 30 Proz. der bruttragenden, wurden gleichzeitig reife, lebhaft wimmelnde Spermatozoiden gefunden; zweimal unter 76 Thieren fanden sich geschlechtsreife Männchen ohne Brut. Eier wurden nie gesehen. Die beiden Männchen ohne Brut waren kleinere Thiere ohne seitliche Randbläschen, die Männchen mit Brut hatten ebenfalls grossentheils die Randbläschen noch nicht vollständig entwickelt und ihre Brut hatte selten schon mehr als vier Tentakel; alle durch Grösse ausgezeichneten Exemplare hatten nur Brut, meist in allen möglichen Entwickelungszuständen. Es scheint demnach, dass mit dem Erlöschen der Samenbildung die Erzeugung von Brut durch Knospung beginnt, während man a priori eher das Ungekehrte hättc erwarten sollen.

Die Bildungsstätten des Samens sind, wie schon durch Leuckart bekannt wurde, die Scheidewände der Magentaschen, um deren freies Ende sie sich hufeisenförmig herumzichen. Die Spermatozoiden (fig. Io) sind cercarienförmig mit rundem Kopfe von etwa $0,003 \mathrm{~mm}$ Durchmesser und zartem, langem Faden.

Die frei im Magen und seinen Nebentaschen liegende Brut lässt sich zurück verfolgen bis zu rundlichen kleinzelligen Körpern von 0,03 mm Durchmesser, die mit aller Wahrscheinlichkeit herzuleiten sind von etwa gleichgrossen mit verdünntem Stiele aufsitzenden Wucherungen der Magenwand (fig. 12). Diese letzteren wurden im Verhältnisse zur Menge der Brut nur selten angetroffen, was aber vielleicht in der Raschhcit ihrer Bildung und Ablösung seine Erklärung findet. Wie die innere Magenfläche, so sind auch diese Knospen und so ist die sämmtliche Brut im Innern des Magens mit zartem Flimmerkleide bedeckt, so zart, dass es kaum genügt, die jüngeren Larven langsam herum zu bewegen. Man muss dieses natürlich, wie die Flimmerhaare selbst, ausserhalb des Magens beobachten; wahrscheinlich weil sie die Brut nur im Magen untersucht, übersahen Kölliker und Gegenbaur das Flimmerkleid. Wenn auch durch dieses die Cuninasprösslinge von anderen knospend an Quallen und Hydroiden erzeugten Jungen abweichen, so hat doch diese Verschiedenheit durchaus nichts Auffallendes; vielmehr erscheint es natürlich, dass die Oberfläche der Knospe die Eigenthümlichkeit der Oberfläche theilt, aus der sie sich erhebt. Leicht denkbar ist es, dass bei 
anderen Aeginidensprösslingen das Flimmerkleid sich stärker entwickele und sich längere Zeit während des freien Lebens im Meere erhalte und jedenfalls wird die nur auf das Flimmerkleid der jungen Aeginopsis begründete Annahne, dass die Aeginiden ohne Generationswechsel direkt aus dem Eie entstehen, eines neuen und anderweitigen Beweises bedürfen.

Bei $0,05 \mathrm{~mm}$ Durchmesser fängt die Abgrenzung einer äusseren aus kugligen Zellen gebildeten Schicht an, sich bemerklich zu machen (fig. I3); der innere Raum scheint hohl zu sein. Bei o,os mm länge wird die Gestalt eiförmig und bald zieht sich das spitzere Ende in einen Tentakel aus (fig. 1+) mit Nesselzellen an der Spitze und grösseren quergestellten Zellen im Innern. Ein zweiter Tentakel tritt auf (fig. 15), die Magenhöhle wird deutlicher (fig. 16) und schon jetzt oder wenig später (fig. 22) öffnet sich der Mund und es lässt sich eine Scheidung der Leibeswand in zwei Schichten erkennen. Häufig nimmt jetzt das Junge Formen an, die auffallend an Aeginopsis erinnern durch die zwei gegenüberstehenden oft lang ausgedehnten und gekrümmten rückenständigen Tentakel.

Die Achse der Tentakel entsteht aus der inneren Schicht der Leibeswand als warzenförmige Wucherung, der gegenüber sich in der äusseren Schicht einige Nesselzellen entwickeln (fig. 19, f). Bald erhebt sich über der zum Zapfen verlängerten Warze auch die äussere Schicht (fig. 19,e) und wird als Rindenschicht von der sich verlängernden Achse mit emporgehoben, während die Nesselzellen sich vermehren, doch aber stets auf die Spitze beschränkt bleiben.

Die Ordnung des Auftretens der folgenden Tentakel zu ermitteln wird sehr erschwert durch ihre ungemeine Contractilität, die sie mit dem ganzen Körper theilen und die wunderbar absticht gegen ihre spätere Starrheit. Tentakel, deren Länge eben noch den Durchmesser des Körpers übertraf, sieht man sich vollständig zurückziehen und für schwächere Vergrösserungen, die nicht die Nesselzellen zeigen, verschwinden. Es scheint indess die durch die Stellung der beiden ersten Tentakel angedeutete bilaterale Anordnung sich auch bei der Bildung der folgenden zu behaupten, die paarweise zu den Seiten der durch das erste Paar bestimmten Geraden auftreten. Bei der Normalzahl 12 scheint die Reihenfolge die zu sein (fig. 19), dass zuerst ein mittleres Paar $(b, b)$ auftritt, im Kreuz mit dem ersten $(a, a)$; dann ein Tentakel zu jeder Seite des ersten, wie des zweiten Tentakels $(c, c, d, d)$; endlich ein Paar vor und ein anderes hinter den mittleren Tentakeln $(e, e, f, f)$.

Nicht selten bleibt die Zahl der Tentakel auf I I oder 10 , seltener auf 9 beschränkt, ein einziges Mal zählte ich deren 13 .

Ich habe bereits des frühzeitigen Auftretens der Mundöfnung gedacht; merkwürdiger als dieses aber ist das frühzeitige Fressen der Jungen. Eine Cunina hatte eine kleine Agalmopsis gepackt und hielt sie einige Stunden fest, um ihr ein gutes Stück abzuverdauen, worauf der Rest munter weiter schwamm. Die Cunina wurde bald darauf unter das Mikroskop gebracht; es war ein Männchen mit nur wenig jüngerer Brut. Diese Jungen alle hatten, soweit sie einen Mund hatten, denselben mit Nesselorganen aus den Nesselknöpfen der Agalmopsis (fig. 17, a) gefüllt (fig. 17). Zeitig auch ist in der Magenhöhle der Jungen und besonders lebhaft am Mundsaume lilimmerbewegung sichtbar. 
Die Tentakel pflegen rollständig vorhanden zu sein bei Jungen von $0,3 \mathrm{~mm}$ Durchmesser. Nun beginnt, bei rasch fortschreitendem Wachsthume die Unwandlung in die regelmässig strahlige Form. Der Körper wächst zu einer unterhalb der Tentakel vorspringenden Scheibe aus und erhält durch sie feste Umrisse. Ihr Umfang ist ein regelmässiges Vieleck mit anfangs geraden, später einwärts gebogenen Seiten, die in ihrer Lage den Tentakeln entsprechen (fig. 20). An den vorspringenden Ecken entwickeln sich die Randbläschen (fig. 21). Der clie Tentakel überragende Theil des Körpers scheidet sich in die durchsichtigeren Lappen der Gallertscheibe, die halbkreisförmig zwischen je zwei Tentakeln vorspringen, und in die zwischen ihnen ausgespannte Randhaut. - Der früher kreisförmige Umfang des Magens wird wellig gebogen; die flachen Buchten vertiefen und erweitern sich zu den Magentaschen. Die Nesselstreifen oberhalb der Randbläschen werden deutlich und damit hat das Junge alle charakteristischen Theilo der Alten.

Wie andere ihrer Brutstätte entschlüpfende junge Quallen, z. B. die Sprösslinge der Campanularien, dehnt sich unsere junge Cunina in den ersten Stunden nach dem Verlassen des Magens wie durch Aufquellen merklich aus, indem gleichzeitig die bis dahin trübe Scheibe zu wasserheller Durchsichtigkeit sich aufhellt. Sie hat nun bis $2 \mathrm{~mm}$ Durchmesser und gleicht in allen wesentlichen Merkmalen, die Zahlenverhältnisse ausgenommen, der achtstrahligen Cunina. Im Habitus weicht sie besonders ab durch die noch ganz flache Scheibe mit wagrecht ausgrebreitetem Rande und dadurch auffallender hervortretender Kerbung, so wie durch die kürzeren Tentakel ( $1 / 5$ des Scheibendurchmessers), die kaum den Scheibenrand überragen. Die Form der Tentakel (fig. 28) ist plumper, ihre Rindenschicht dicker, - die Nesselstreifen oberhalb der Randbläschen endlich (fig. 29) sind noch weit kürzer, als bei der erwachsenen Cunina. Da die Umgrenzung des Magens und seiner Taschen nur schwierig zu erkennen ist, kann man leicht in Versuchung kommen, die Randlappen der Gallertscheibe für Magentaschen zu nehmen ${ }^{1}$ ).

Jüngere zwölfstrahlige Cunina, wie man sie leicht in der Gefangenschaft züchtet, wurden auch einigemal frei im Meere aufgefischt; ältere bis jetzt noch nicht, und bis dies gelungen, erscheint es rathsam, alle Erklärungsversuche zurückzuhalten.

Ich hob hervor, dass bei den im Magen Knospen treibenden Aeginiden das Flimmerkleid jüngerer Formen nicht für ihre Entstehung aus Eiern beweisend ist, und will zum Schlusse noch eine Beobachtung mittheilen, die es mir wahrscheinlich macht, dass im Gegentheile auch bei dieser Familie ein Aufammen durch Polypen vorkommt.

$\mathrm{Zu}$ Anfang dieses Jahres fing ich eine Liriope catharinensis, der ein langer blassgelblicher Zapfen aus dem Munde hervorhing. Bei näherer Untersuchung ergab sich derselbe als eine aus dichtgedrängteı Quallenknospen bestehende Aehre,

I) Bei Betrachtung der Figuren, die G egenbaur von seinen Aeginetaarten giebt, kann ich mich des Verdachtes nicht entschlagen, dass bei den meisten derselben dieser Missgriff geschehen sei, dass sic also zu Cunina gehören. Auch die Beschreibungen geben nicht die Ueberzengung des Gegentheils. Ich verweise namentlich auf die Peschreibung und Abbildung der Aegineta globosa, deren ,trichterfömig eingezogener Magen" mir ein wahres Paradoxon scheint. Es dürfte die ganze Gattung einer nenen kritischen Prïfung zu unterwerfen sein. 
deren Ende die Liriope verschluckt hatte (fig. 30). Der frei vorhängende Theil hatte $1,75 \mathrm{~mm}$ Länge und die grössten Quallenknospen fast 0,5 $\mathrm{mm}$ Durchmesser. Sie waren fast halbkuglig und die gewölbte frläche sass mit kurzem Stiele an der gemeinsamen Achse fest. Am freien Rande erhoben sich acht halbkuglige Randbläschen mit kugliger Concretion; etwa in der Mitte zwischen Rand und Scheitel sprossten abwechselnd mit den Randbläschen acht kurze plumpe Tentakel hervor. Auf der freien, ebenen oder flach grewölbten Fläche der Knospe zeigte sich ein grosser ganzrandiger Mund, der in einen flach ausgebreiteten Magen führte.

Alle diese Eigenthümlichkeiten stimmen mit der achtstrahligen Form von Cunina Köllikeri, während nicht die entfernteste Aehnlichkeit mit irgend einer andern der im Laufe von vier Jahren hier von mir beobachteten Quallen besteht.

\section{Erklärung der Abbildungen auf Tafel XV.}

Die Figuren 12-2I sind gomal vergrössert; die Vergrösserung der übrigen ist auf der Tafel selbst angegeben. Ueberall bedeutet $l$ Randlappen der Scheibe, m Magen, n Nebentasche desselben, $v$ Randhaut, $g$ Ganglion.

Fig. I. Cunina Köllikeri n. sp. von der Seite.

Fig. 2. Aelteres und

Fig. 3. jüngeres Exemplar von unten mit eingeschlagenem Randlappen.

Fig. t. Mund des letzteren in verschiedenen Formen, die er in kurzer Zeit annahm.

Fig. 5. Tentakel von oben.

Fig. 6. Stück Tentakel, um die Längsstreifung und

Fig. 7. ein anderes, um die Zellen der Achse und deren Kerne zu zeigen.

Fig. 8. Randbläschen und Nesselstreifen.

Fig. 9. Randbläschen von ungewöhnlicher Form.

Fig. Io. Fast reife Spermatozoiden, deren Fäden sich langsam zu bewegen beginnen.

Fig. I 1. Cunina Köllikeri mit Brut im Magen, von unten.

Fig. 12-2I. Entwickeiung der Brut von der festsitzenden Knospe bis zum Auftreten der Randbläschen am regelmässig strahligen Thiere.

Fig. I5. Zeigt dasselbe Thier in zwei verschiedenen Formen.

Fig. I7. Junges mit Nesselorganen von Agalmopsis (I7, a) im Munde.

Fig. 20. Von unten und 21 von oben.

Fig. 22. Junges bei stärkerer Vergrösserung, um die beiden Schichten der Leibeswand und das Flimmerkleid zu zeigen.

Fig. 23. Zellen aus der Tentakelspitze desselben, mit jungen Nesselorganen.

Fig. 24. Ein Junges in vier verschiedenen Formen, die es in kurzer Zeit annahnı.

Fig. 25. Junge mit auffallend lang ausgestreckten Armen.

Fig. 26. Zwölfstrahlige Cunina nach dem Verlassen der Magenhöhle, von oben.

Fig. 27. Eine andere mit neun Tentakeln, von unten.

Fig. 28. Tentakel und

Fig. 29. Randbläschen und Nesselstreifen von derselben.

Fig. 30. Aehre von Medusenknospen (Cunina?) aus dem Magen von Liriope catharinensis vorlängend.

Desterro, December 1860. 


\section{Die Brachiopodenlarve von Santa Catharina').}

\section{Zweiter Beitrag.}

Die Brachiopodenlarve, die ich vor zwei Jahren auffand und beschricb \%), wurde von mir auch im vorigen und in diesem Jahre wiederholt, wenn auch nur selten, beobachtet; ihr Vorkommen scheint sich auf den Spätsommer, auf die Nonate Februar bis April zu beschränken.

Meinen früheren Angaben über die schwärmende larve habe ich nur einige Bemerkungen über das Schwimmen des Thieres nachzutragen. Iclı brachte damals, um etwaigen Veränderungen bequem mit dem Mikroskope folgen zu können, meine Larven in Uhrgläser, wodurch ich die Gelegenheit verlor, ihr behagliches Umhertreiben im freieren Raume zu beobachten. Bringt man die Thierchen in grössere Gläser mit reinem Seewasser, so sieht man sie bald langsam emporsteigen : die schwach klaffenden Schalen stehen senkrecht, der Schlossrand nach unten; dicht vor dem Vorderrande breiten sich die acht Arme strahlig und wagerecht aus mit leicht abwärts gebogener Spitze und über die Ebene der Arme ragt der zwischen dem obersten Paare liegende rundliche Knopf empor; die starken Borsten des vierten Paares zeigen dabei die in meiner früheren Abbildung gezeichnete Richtung. So treiben sie nahe der Oberfläche langsam herum. Bei stärkerer Erschütterung, oder auch sonst, ohne erkennbare Ursache, ziehen sie die Arme ein und schliessen die Schalen, die sofort langsam sich umkehren und mit dem Mundrande voraus zu Boden sinken. Werden auf diesem Wege die Arme wieder vorgestreckt, so dreht sich auch der Schlossrand sogleich wieder nach unten.

Die Dauer dieses Schwärmstadiums überstieg bei den eingefangenen Larven nie 5-6 Tage, meist schon früher setzten sie sich fest, am Boden oder an den Seiten des Glases; in letzterem, fünfmal beobachteten lialle stets den Nund nach unten gerichtet. Die Bauchschale wird dabei stark nach vorn gezogen, so dass ihr Vorderrand den der Rückenschale erreicht oder überragt, und die bis dahin zwischen den Schalen verborgene querovale Platte (der Stiel) tritt hervor, indem sie sich, wie es scheint, um den ausgebuchteten Hinterrand der Bauchschale vollständig herumdreht und so ihr vorderer Rand zum hinteren wird. Den ersten

I) Archiv für Naturgeschichte i861. p. 53-56.

2) Archiv für Anatomie und P'hysiologie herausgegeben von Reichert und du Bois Reymond I860. 1). 72. $=$ Gesamm. Schriften pg. 105 . 
Tạ oder länger hält sich das Thier vollständig zurückgezogen und ruhig; dann pflegt es, bei leicht geöffneten Schalen, die Arme halb vorzustrecken, die dann ab und zu, bald einzeln, bald zu mehreren, zuckend nach innen schlagen, - ganz wie man es bei den Armen der Meeresbryozoen zu sehen gewohnt ist.

Nach wenigen Tagen beginnen am Vorderrande, in dem Raume, der zwischen den zarteren Borsten der Rückenschale frei bleibt, neue rasch hervorwachsende Borsten hervorzusprossen. Bei einem Thiere, das etwa nach einer Woche abgelöst wurde, zählte ich deren gegen 20, die meist der Rückenschale angehörten. 1)ie längsten erreichten o,8 mm Länge, also das Doppelte des Durchmessers der Schale. Sie sind gerade, farblos, zart contourirt, am Grunde bis o,006 mm dick, in eine feine Spitze auslaufend, ungegliedert und mit zarten bis $0,02 \mathrm{~mm}$ langen, schief aufwärts gerichteten Seitenborsten weitläufig besetzt. Die Weichtheile desselben Thieres zeigten keine auffallende Veränderung mit Ausnahme der schon weit vorgeschrittenen Rückbildung der Sinneswerkzeuge. Die Augen hatten sich in Gruppen von etwa ı schwarzen Punkten aufgelöst; die früher prallkugligen Gehörblasen waren zu länglichen Säckchen zusammengeschrumpft, die eng die jetzt regungslosen Gehörsteinchen umschlossen. Bei etwas älteren Thieren vermisste ich jede Spur von Sinneswerkzeugen, ohne dass sie deshalb ihre Empfindlichkeit gegen das Licht eingebüsst hätten. Dem vollen Sonnenlichte ausgesetzt, begannen sie sogleich die Rückenschale heftig nach rechts und links zu drehen.

Eine meiuer Larven hielt sich vier Wochen am Leben; sie setzte sich fest in der Nacht rom 12. zum 13. Februar und starb am 13. März, an dem ich ausnahmsweise nicht nach ihr gesehen hatte. So erfuhr ich ihren Tod erst Tags darauf, als schon die Weichtheile fast ganz zerstört waren. Die älteren Borsten der freilebenden Larve schienen noch vollständig vorhanden zu sein. Ausser diesen und den Fiederborsten des Vorderrandes fand sich, etwa in der Mitte zwischen der Mittellinie und dem Ursprunge der grossen Borsten des vierten Paares, jederseits eine gerade, glatte, schief nach hinten vorstehende Borste von o,2 mm Länge, wenig dicker als die stärkeren Hinterborsten, aber weit stärker contourirt.

Höchst auffallend ist es, dass ich, theils schon vor zwei Jahren, nach Abschluss meiner ersten Mittheilung, theils im Laufe dieses Sommers, wiederholt frei im Meere schwimmende Larven auffischte, die offenbar weiter in ihrer Entwicklung vorgeschritten waren, als die ältesten meiner ansässigen jungen Brachiopoden. Ihnen allen fehlte die querovale Platte, fehlte jede Spur von Sinnesorganen, fehlten die Fiederborsten des Vorderrandes und mehr oder weniger vollständig die älteren Borsten. Von den zarteren bogig gekrümmten Borsten waren meist noch einige da und diese schienen unverkürzt, so dass die fehlenden wohl durch Ausfallen verloren gegangen waren. Dagegen werden die stärkeren Borsten allmählich vom Frunde aus aufgesaugt. So wenigstens die Borsten des vierten Paares. Diese fand ich mehrmals noch in etwa halber Länge vorhanden, den Stiel mit der spindelförmigen Anschwellung verschwunden, während die Spitze durch ihre eigenthümliche Krümmung und Zähnelung leicht erkennbar blieb. Bei einem anderen unzweifelhaft älteren Thiere war noch etwa $1 / 5$ der Länge rorhanden, so (lass sie nicht einmal mehr den Schalenrand überragten. Dieses Thier, das älteste, das ich überhaupt untersucht, hatte bis auf diesen schwachen Rest alle älteren I3orsten verloren. Dagegen hatten die beiden geraden glatten Horsten, die bei 
jenem ältesten festsitzenden Thiere kaum aus der Schale hervorzutreten begannen, die doppelte Länge des Schalendurchmessers erreicht und wurden, in dicke Muskelscheiden eingefügt, von dem Thiere kräftig und lebhaft bewegt, bald wagerecht ausgebreitet, bald wieder hinten gekreuzt.

Die Weichtheile haben während dieser vollständigen Umgestaltung der Beborstung keine wesendichen Veränderungen erlitten. Der rundliche Magen, nach vorn bis zur Mitte des Längsdurchmessers reichend, zeigt noch die beiden dunklen Flecken jüngerer Larven, die an zwei ähnliche Flecken gewisser Bryozoenlarven erinnern. Hinten entspringt vom Magen der Darm, um sich an und unter dessen Rande nach rechts und dann nach vorn zu biegen und etwa in der Mitte seiner rechten Seite zu endigen. Vom vorderen Ende des Magens geht die Speiseröhre (bei in die Schale zurückgezogenem Thiere) gerade nach vorn bis halbivegs zum Vorderrande der Schale und biegt dann nach unten um, so dass der Mund wieder nahe vor dem Magen zu liegen kommt. Die Arme, namentlich die beiden mittleren Paare, sind länger und schmächtiger geworden und der Knopf zwischen dem vorderen Paare hat an Umfang abgenommen. - Gefässe oder ein pulsirendes Herz wurden noch nicht erkannt.

Desterro, Mitte März 1861. 


\section{Ueber die systematische Stellung der Charybdeiden $^{1}$ ).}

Die Eschscholtz'sche Abtheilung der Discophorae phanerocarpae bildete eine wohlumschriebene Gruppe engverwandter Thiere, verbunden durch eine grosse Zahl gemeinsamer Merkmale: die Scheibe ein flaches, glattes Kugelsegment, aber beim Schwimmen starker Wölbung fähig, mit gekerbtem Rande, in dessen Einschnitten, stets in der Achtzahl, die Randkörperchen mit in Säuren unlöslichen Krystallen; keine Randhaut; um den Mund vier Arme und mit ihnen wechselnd, in besonderen Gruben, die Geschlechtstheile als krausenförmig gefaltete, bogig gekrümmte Bänder; an gleicher Stelle die Magenfäden u. s. w. - Der Mund freilich bald frei geöffnet (M edusiden), bald geschlossen und statt seiner zahlreiche Oeffnungen an den Armen (Rhizostomiden); allein diese Eigenthümlichkeit der Rhizostomiden, so bedeutungsvoll sie jedenfalls ist für ihre ganze Ernährungsweise, störte doch nicht die morphologische Einheit der Gruppe, da sie unschwer aus der gewöhnlichen Mundform sich ableitete \%). Einige später entdeckte etwas abweichende Form der Medusiden thaten ebenfalls der Einheit des Gesammtbildes, das sie nur vervollständigten, keinen Eintrag ${ }^{3}$ ). - Ein anderes aber ist es mit der Familie der Charybdeiden, die Gegenbaur seinen

I) Archiv für Naturgeschichte I86I. I. p. 202-3 II.

2) Gegenbaur (Zeitschr. f. wiss. Zool. VIII. S. 210 Anm.) erklärt die Polystomie der Rhizostomiden für ein mit dem allgemeinen Plane der Medusen unvereinbares Paradoxon und bezweifelt selbst das Faktum. Das Faktum ist leicht zu constatiren und neuerdings wiederholt, auch von mir, constatirt worden. Auch die Erklärung scheint mir ziemlich auf der Hand zu liegen. Eine temporäre Polystomie, wenn man es so nennen will, kann man leicht bei Hydroidquallen sehen, wenn sich die Ränder eines vielgefalteten vierlappigen Mundsaumes da und dort an einander legen. So wird auch die Polystomie der Rhizostomiden entstehen durch Verwachsung der häutigen Blätter, die die Arme der Phanerocarpen umfassen. Wo die Oeffnungen der Arme die Form langer Spalten haben, die sich oft in riemenförmige Tentakel fortsetzen, wie bei einer Cephea der südbrasilianischen Küste, kann über diese Entstehungsweise kaum ein Zweifel l,leiben. Schwieriger zu erklären scheint die Durchbrechung des Armstiels, oder sein „Entspringen mit vier Wurzeln," wie es bei derselben Cephea und nach Forskål bei C. octostyla vorkommt.

3) So Nausithoe Köll. mit ihren acht überaus einfachen Geschlechtsdrüsen und Trichoplea n. g. mit Randkörpern in tiefen Nischen auf der Unterfläche und 2 Zoll von dem ungetheilten Rande der zwei Spannen in Durchmesser haltenden Scheibe. Unter den älteren minder genau gekannten Arten ist wohl Medusa Persea Forsk. (Rhizostoma Eschsch.) trotz des ungetheilten Randes und der grossen Randhaut mit Sicherbeit zu den "Acraspeda“ zu stellen. 
Acraspeda, den Eschscholtz'schen Phanerocarpae anreihte. Die Charybdea marsupialis Pér. und mehr noch die von mir beschriebenen Tamnya haplonema und quadrumana stellen sich fast in allen wesentlichen Zügen ilıres Baues jenem allgemeinen Bilde aufs Schroffste entgegen: eine Glocke mit tiefgefurchten Seiten und breiter Randhaut, fast keines Formwechsels fähig; die Randkörperchen in der Vierzahl, fern vom Rande, in tiefen Nischen an der Aussenfläche der Glocke; ein langer Mundtrichter nach Art der Thaumantias; Geschlechtstheile als breite häutige Platten in den weiten Seitentaschen des Magens und daher fern von den Magenfäden; Fangfäden auf eigenthümlichen keulen- oder handförmigen Fortsïtzen, ein scharf ausgeprägtes Nervensystem u. s. f.

Fast noch auffallender tritt den gewöhnlichen Medusen in der äusseren Form, und nur diese ist bekannt, die Charybdea periphylla Pér. entgegen; gleichsam eine Tamoya quadrumana mit auf 16 vermehrten und ihrer Fangfäden beraubten handförmigen Anhängen.

Vermittelnde Uebergangsformen sich vorzustellen zwischen den Charybdeiden einer-, den Medusiden und Rhizostomiden andererseits, oder auch beide Gruppen herzuleiten aus einer gemeinsamen Grundform, die wesentlich mehr enthielte, als die allgemeinen Züge aller Hydromedusen, scheint somit kaum thunlich. Das anschaulich frische Bild der Eschscholtz'schen Phanerocarpen würde schattenhaft verblassen durch die Aufnahme der Charybdeiden, und jedenfalls wäre ihre Vereinigung eine durchaus unnatürliche.

Und doch, wenn man die übliche Zweitheilung der Scheibenquallen beibehalten will, an der die Systeme von Forbes, Lütken und Gegenbaur nichts geändert haben, als die Namen ${ }^{1}$ ), und die selbst da wiederkehrt, (in Bezug auf die Quallenformen), wo die Discophorae, und mit Recht, nicht mehr als systematische Einheit anerkannt werden, wie in den Acalephen und Hydroiden von R. Leuckart, so können die Charybdeiden nur unter den höheren Scheibenquallen ihre Stelle finden, mit denen sie wenigstens noch die Magenfäden und den in Säuren unlöslichen Inhalt der Randkörper gemein haben. Noch ferner stehen sie, das bedarf keiner weiteren Erörterung, der Quallenbrut der Hydroiden.

Schon bei Gelegenheit der Beschreibung der Tamoyen gedachte ich deshalb einer wohl vorzuziehenden Dreitheilung der Scheibenquallen und vermuthete, dass diese sich auf die Entwickelungsgeschichte würde stützen lassen. Früher schon, wenn auch später erst die Kunde davon in mein Exil drang, hatte R. Leuckart demselben Gedanken folgend, die Abtheilung der Ceratostera gebildet, aber bald wieder aufgegeben. Denn jene Vermuthung hat sich bekanntlich als durchaus unbegründet erwiesen. Krohn sah die Pelagia noctiluca sich ohne Brutwechsel entwickeln, während Busch die Brut der kaum generisch zu sonderıden Chrysaora bis zur Polypenform verfolgte. Unter den Hydroiden haben Gegenbaur das Trachynema ciliatum, und ich die Gerynnia (Liriope) catharinensis als wahrscheinlich direkt aus dem Ei erwachsend kennen gelehrt, während im Gegen-

I) Nicht den Grund oder das Eintheilungsprincip, wie Gegenbaur will. Eschscholtz betrachtet keineswegs die „Keimwülste“ weder als einziges, noch wichtigstes Merkmal der Phanerocarpen; schon er stellt, wie Gegenbanr, die Einschnitte des Randes voran und kennt sehr wohl ,den häutigen weichen Ringlappen am Rande der Scheibe" als gemeinsames Merkmal seiner Cryptocarpen. 
theile die nur auf das Flimmerkleid der jungen Aeginopsis gebaute Annahme einer direkten Entwickelung der Aeginiden durch die flimmernde Brut im Magen der Cunina Köllikeri ihre Stütze verlor.

Trotzdem ist die damals mir vorschwebende Gruppirung der Scheibenquallen durch jede neue Untersuchung immer plausibler geworden. Es scheint mir, dass hier, wie so manches Mal, die unbefangene Anschaumng der älteren Beobachter das Rechte getroffen, indem sie mit der Charybdea marsupialis und periphylla die Ch. bitentaculata vereinigten, die heute als Aeginopsis mediterranea J. Müll. oder Aeg. bitentaculata Köll. ${ }^{1}$ ) in der Familie der Aeginiden Ggb. am Ende der Cryptocarpen zu stehen pflegt. Nicht dass ich die Vereinigung von Charybdea und Aeginopsis in dieselbe Gattung, oder auch nur, nach dem Beispiele von L ütken, in dieselbe Familie befürworten möchte; aber ich meine, dass die Familien der Charybdeiden und Aeginiden Ggb. zu ciner den Siphonophoren, Hydroiden und Acalephen (im Sinne R. Leuckart's) gleichwerthigen Gruppe der Hydromedusen zu vereinigen seien. Die höchstorganisirte aller bekannten Hydromedusen, und vielleicht aller Coelentrraten, die Tamoya quadrumana mit den, wie es schien, die tiefunterste Stufe in der Reihe der Quallen behauptenden Aeginiden zusammenzustellen, die zum Theil selbst, wie Eurystoma Köll., nur mit der durch die Randhaut theilweise geschlossenen Aushöhlung der unteren Körperfläche verdauten ${ }^{2}$ ), schien mir freilich lange Zeit etwas waglich. Seit ich eine gerade diesem Eurystoma in Form, wie in der Entwickelung der im Magen knospenden Brut höchst ähnliche Art selbst eingehender untersuchen konnte, und seit mir Eschscholtz's treffliches „System der Acalephen" wieder zur Hand ist, ist mir dieses Bedenken geschwunden und ich halte jetzt meine Ansicht für hinreichend begründet, um sie der Beurtheilung der Zoologen vorlegen zu dürfen.

Von der Unvereinbarkeit der Charybdeiden mit den A calephen R. Lt. ist schon gesprochen. In ganz ähnlichem Gegensatze stehen die Cunina, Aeginopsis und ihre Verwandten zu den übrigen Cryptocarpen oder den Hydroidquallen. - Die Scheibe dieser letzteren, obwohl von sehr wechselnder Form, ist doch stets ganzrandig, und wie bei den Acalephen glatt, oder etwa mit schwach vorspringenden von der Mitte des Rückens ausgehenden Leisten versehen; sie haben stets Strahlgefässe und Ringkanal, und zwar erstere, ausser bei sehr grosser Menge, in fester Zahl; Randbläschen, wenn vorhanden, sind stets rundlich und sitzend; die Randfäden, von sehr wechselndem Bau, nehmen doch stets die unmittelbare Nähe des Ringgefässes ein. In der Bildung der Geschlechtstheile endlich schliessen sich die Hydroidquallen den Acalephen oder Phanerocarpen an; denn, obschon von ungemeinem Formenreichthum, dessen äusserste Bildungen indessen durch eine ziemlich engschliessende Reihe von Zwischenformen verbunden sind, - von dem mundlosen Geschlechtskolben der Corymorphaquallen bis

1) Die abweichende Fürbung darf kaum als Artunterschied gelten, in einer Thiergruppe, wo, wie bei den Acalephen (Rhizostoma, Chrysaora u. a.) und Hydroiden (Corymorpha), die reichste Mannichfaltigkeit der Färbung innerhalb der Art fast als Regel gelten kann.

2) Ich glaubte diese wohl irrthümliche Darstellung Kölliker's nicht bloss auf Gegenbaur's Autorität hin anzweifeln zu dürfen, dessen Angaben ich bei anderen Quallen nicht immer ganz bewährt gefunden hatte, und noch weniger auf Grund eines aprioristischen ,allgemeinen Planes der Medusen." 
zu den dichtgedrängten Bäumchen längs der Strahlgefässe der Olindias $\left.{ }^{1}\right)$, - sn nehmen sie doch stets die äussere Wand des Gastrovasculärsystems ein und entleeren ihre Produkte nach aussen. - Dagegen ist die Scheibe der Cunina und ihrer Verwandten häufig, wo nicht immer, am Rande gekerbt ${ }^{2}$ ), und, wie bei den Charybdeiden, von mehr weniger tiefen, mehr weniger weit auf die Rückenfläche sich fortsetzenden Furchen durchzogen; der Magen hat breite Seitentaschen in oft schwankender Anzahl, nie Strahlgefässe oder Ringkanal; die Randbläschen sind meist gestielt; die Tentakel, nie die Zahl der Magentaschen überschreitend, sind stets rückenständig, oft sehr fern rom Rande entspringend; ausserdem sind sie bald durch eine eigenthümliche Starrheit, bald wieder durch „,eine bei anderen Medusen gar nicht bemerkte Beweglichkeit" (Eschsch.) ${ }^{3}$ ) ausgezeichnet. Die Geschlechtsstoffe der Cunina bilden sich im Innern der Seitentaschen und zwar in den seitlichen Winkeln derselben, von wo ihre Bildungsstätte hufeisenförmig von einer Tasche zur andern sich hinüberzieht.

Nach alle dem ist die Verbindung der Cunina, Aeginopsis u. s. w. mit den Hydroiden eine ebenso lockere und gezwungene, durch keinerlei Uebergänge vermittelte, wie es die der Charybdeiden mit den Acalephen ist. Wenn also die Ausscheidung dieser beiden Familien aus ihrem jetzigen Verbande keinem ernstlichen Bedenken unterliegen dürfte, so scheint ein solches auch ihrer Vercinigung nicht entgegenzustehen. Wohl liegt zwischen Cunina und Tamoya cine weite Kluft, aber nicht weiter als zwischen den tentakel-, augen- und mundlosen Quallen von Corymorpha und Olindias, zwischen Nausithoe und Cephea, - eine

1) Olindias n. g. Habitus der Thaumantias mediterranea Ggb., vier Strahlgefässe und zahlreiche (bis über 100) rücklaufende Gefässe; am Rande äusserst dehnbare Fangfäden und wenig bewegliche Teutakel, beide hohl und von unbestimmter Zahl; am Grunde der Tentakel paarweise die Randbläschen; Geschlechtstheile baumförmig verästelt längs der Strahlgefässe. - Vermuthlich sind auch die „Fangfäden“ an den Strahlgefässen von Melicertum nichts anderes als Geschlechtstheile, und dies um so eher als auch in der Bildung der Randfäden Olindias zunächst an Melicertum sich anschliesst. - Als Uebergangsbildung von magenständigen zu peripherischen Geschlechtstheilen lässt sich, um mich nicht auf noch unbeschriebene Formen zu berufen, selbst Lizzia Köllikeri anführen, wo nach Gegenbaur's von mir an einer verwandten Art bestätigter Beobachtung, die dem Magen anliegende Geschlechtsdrüse von einem Aste des Strahlgefässes durchzogen ist.

2) Gegenbaur ist der Ansicht, dass der Besitz eines Velum's einen uneingeschnittenen Rand des Körpers vorausetze, und aus diesen Grunde, wie es scheint, leugnet er gegen Eschscholtz, Kölliker und im Widerspruche mit sich selhst, die Kerbung des Randes der Aeginiden. Denn bei Aegineta flavescens lïsst er die Gallertsubstanz sich in beträchtlicher Dicke auf die Magentaschen fortsetzen; dazwischen also sind nur häutig überspannte Lücken oder Einschnitte der Gallertsubstanz, d. h. „des Körpers," da bei den eines Ringgefässes entbehrenden Aeginiden doch nur das Aufhören der Gallertsubstanz die Grenze zwischen Körper und Velum bezeichnen kann. Wie die Muskelhaut der Unterfläche sich bei den Aeginiden über einen gekerbten Rand fortsetzt, so kann die Randhaut auch wieder bei ganzrandiger Scheibe fehlen, selbst bei Hydroidquallen; ich vermag wenigstens keine Spur derselben aufzufinden bei einem kleinen, stets mit umgestulpter Scheibe schwimmenden Campanulariasprösslinge, Tintinnabulum resupinatum n. sp.

3) So bei Aegina sulfurea, wie sie in Eschsch. System S. 9, oder Aeg. citrea, wie sie S. II 3 heisst. Die zweite Eschscholtz'sche Art, Aegina rosea, dürfte von dieser zu trennen und zu Cunina zu stellen sein, da es nach Eschscholtz's Abbildung (Taf. IO. Fig. 3 a) natürlicher scheint, dem Magen sechs dem Ursprunge der Tentakel gegenüber ausgebuchtete Nebentaschen, als deren zwölf zuzuschreiben. - Wemm man mit Gegenbaur die A eginiden durch, ,starre Tentakel“ kennzeichnet, so ist die Wahl des Namens nach einer durch das gerade Gegentheil vor allen anderen Medusen ausgezeichneten Art nicht als besonders glücklich zu bezeichnen. 
Kluft wie zwischen junger Brut und erwachsenem Thier, über die die Phantasie leicht durch Zwischenstufen einen allmählichen Uebergang findet, - und nicht eine durch unvereinbare Merkmale errichtete Scheidewand. Von den seichten Furchen in der flachen, leicht gekerbten, oft schon (nach Gegenbaur) knorpelharten Scheibe mehrerer Cunina führt die Zwischenform der Aegina citrea zu Charybdea marsupialis und zu den complicirten Glocken der Tamoyen, während auch den beiden äussersten Gattungen, die weder bei Hydroiden noch Acalephen beobachtete Verbindung einer Randhaut mit nicht ganzrandiger Scheibe als gemeinsames Merkmal zukommt. Von cler flach ausgespannten Magenhaut der Cunina mit ihrem einfachen proteusartigen Munde, wie sie sich ähnlich bei Aegineta, Polyxenia, Aeginopsis bitentaculata wiederholt, leiten die vier Arme am Munde der Aeginopsis Laurentii Brdt. zu der Magenbildung der Charybdea und Tamoya. Ebenso lässt sich die Form der Geschlechtsteile von Tamoya zwanglos aus denen der Cunina herleiten, aber weder die eine noch die andere auf die bei Hydroiden und Acalephen entwickelte Grundform zurückführen. Wenn Tamoya quadrumana eine ganze Reihe ganz neuer, bei Cunina selbst nicht angedeuteter Theile, wenn sie ein wohlentwickeltes Nervensystem hat, so liegt darin nichts Auffallendes; einige derselben, wie die acht fingerförmigen Fortsätze im Grunde der Glocke und die dendritischen Drüsen, fehlen ja spurlos selbst noch der T. haplonema.

Wesentlich verschieden ist allerdings die Bildung der Randkörperchen; allein theils wissen wir noch nichts über die Entwickelung derselben bei Charybdea und Tamoya, noch über ihren Bau bei den Zwischenformen Aegina citrea und Aeginopsis Laurentii, theils ist ihr Unterschied nicht erheblicher als zwischen den Augenflecken und Randbläschen der Hydroiden.

Ebenso ist die Tentakelbildung eine durchaus abweichende, - aber immerhin durch ihren rückenständigen Ursprung den Randfäden der Hydroiden und Acalephen gemeinsam sich entgegenstellend. Die Tentakel der Cunina sind starr, die der Tamoya contractil; aber auch die der jungen Caninabrut sind letzteres. Die Tentakel der Cunina sind solid, die der Tamoya hohl; aber hohle und solide Tentakel zeigen auch sonst nächstverwandte Gattungen, wie die verschiedenen Campanulariasprösslinge ${ }^{1}$ ); ja beiderlei Formen finden sich gleichzeitig oder nacheinander bei demselben Thiere (Liriope). Also auch hierin dürfte ein Grund gegen die Vereinigung unserer beiden Familien nicht zu suchen sein; was aber besonders für dieselbe spricht, ist, dass es zur Zeit nicht einmal möglich ist, eine scharfe Grenze zwischen beiden zu ziehen und die mittleren Formen mit Sicher-

1) Den Campanulariensprösslingen mit soliden, wenig beweglichen Tentakelı, ganz ähnlich denen der Campanularien selbst, schlage ich vor, den Dalyell'schen Namien Tintinnabulum zu lassen; es scheint, dass sie stets schon mit einer grösseren Tentakelzahl geboren werden. Hierher gehört auch Eucope polystyla Ggb. Was Gegenbaur bei dieser Art als rundliche in die Substanz der Scheibe gerichtete Auftreibungen des Ringgefässes beschreibt und abbildet, dürfte nach dem nahe verwanden Tintinnabulum resupinatum n. sp. zu schliessen, die verdickten Wurzeln der Tentakel sein. Die Campanulariensprösslinge mit hohlen, an der Basis erweiterten, sehr contraktilen Fangfüden, die beim Freiwerden deren stets uur vier, und von vier weiteren die ersten Spuren zu haben scheinen (Eucope Ggb., excl. E. polystyla), haben meines Erachtens Anspruch auf den Namen Thaumantias; denn es scheint mir kaum zweifelhaft, dass zu ihnen, und nicht zur Th. mediterranea Ggb. die beiden Eschscholtz'schen Thaumantiasarten zugehören, und für sie wäre also bei einer Trennung der Gattung der alte Name zu erhalten. 
heit der einen oder der anderen zuzuweisen. So Aegina citrea, welche durch die Form der Glocke, durch die Vierzahl der Arme und die grosse Beweglichkeit der Tentakel, und Aeginopsis Laurentii, welche durch die vier Arme am Munde den höheren Formen sich anschliesst. So auch Charybdea periphylla Pér., welche (lurch die Gestalt der Randanhänge an Tamnya quadrumana erinnert, aber durch die Vielzahl derselben von den übrigen Charybdeiden sich entfernt.

Ich möchte demnach die Charybeiden in folgender Weise dem Systeme der Hydromedusen einreihen:

\section{Hydromedusae.}

1. Röhrenquallen, mit Einschluss der freien Geschlechtsthiere (Chrysnmetra).

2. Hydroiden.

a. Tubularinen nebst den Hydroidquallen ohne Sinnesorgane oder mit Augenflecken.

b. Sertularinen nebst den Hydroidquallen mit Randbläschen ${ }^{1}$ ).

In Bezug auf Entwickelung finden sich in dieser Gruppe:

( ) Polypen ohne freie Geschlechtsthiere.

ß) Polypen mit freien Geschlechtsthieren.

v) Freie Geschlechtsthiere ohne Polypen (Trachynema, Liriope).

3. Acalephen R. Lt. (Discophorae phanerncarpae Eschsch.).

a. E in mündige (Medusidae Eschsch.).

b. Vielmündige (Rhizostomidae Eschsch.).

4. A eginoiden (Aegineae Lütk.).

a. Niedere. Cunina (mit Aegina rosea Eschsch.); Aegineta; Polyxenia; Aeginopsis bitentaculata.

b. Höhere, Charybdeiden. Aeginopsis Laurentii (?); Aegina (citrea); Charybdea (marsupialis); Tamoya; Periphylla (Ch. periphylla Pér.).

Desterro, Mai 186 I.

I) Gegenbaur ist meines Wissens der Erste gewesen, der bei den Hydroidquallen die systematische Wichtigkeit der Ocellen und Randbläschen hervorgehoben und auf die Verschiedenheit der Raudfäden Gewicht gelegt hat, wie denn überhaupt die von ihm aufgestellten Familien der "Craspedota“ durch Natiurlichkeit und nicht ausschliessliche Betonung eines Merkmals sich sehr vorteilhaft vor den von Forbes und selbst von $\mathrm{Lütken} \mathrm{vorgeschlagenen} \mathrm{auszeichnen,} \mathrm{und} \mathrm{als} \mathrm{bequemer} \mathrm{Ausgangspunkt} \mathrm{für} \mathrm{weitere} \mathrm{systematische}$ Versuche dienen können. Künftigen Pearbeitern möchte ich besonders eine sorgfältige Beachtung der Randfäden empfehlen, durch die, wie es scheint, u. a. eine schärfere Unschreibung der Geryoniden und Thaumantiaden Ggb. möglich sein wird. 


\title{
Polypen und Quallen von Santa Catharina $\left.{ }^{1}\right)$.
}

\section{Olindias sambaquiensis n. sp.}

\author{
Mit Tafel XVI.
}

Beschreibungen vereinzelter neuer Thiere, die nur die Zahl der schon verzeichneten Arten anschwellen, ohne einen tieferen Einblick in ihren Bau, einen freien Ueberblick über ihre verwandtschaftlichen Beziehungen zu gewähren, sind im Allgemeinen mehr geeignet, den Fortschritt der Wissenschaft zu erschweren, als zu fördern, indem sie nur den zu bewältigenden Stoff und nicht auch entsprechend die zur Bewältigung nöthige Kraft mehren. Wenn daher ihre Veröffentlichung einer Rechtfertigung bedarf, so würde sie für die farbenprächtigste Scheibenqualle unserer Küste theils in dem eigenthümlichen Baue ihrer Geschlechtstheile, in der Anordnung ihrer Gefässe, Randfäden und Randbläschen liegen, die sie zu einer vor vielen merkwürdigen und lehrreichen Art machen, theils in dem Lichte, das von ihr aus auf einige ältere wenig bekannte Formen zu fallen scheint, - wenn mir nicht schon dadurch ausführlichere Mittheilungen über sie geboten wären, dass ich ihrer bereits wiederholt anderweitig Erwähnung gethan ${ }^{2}$ ).

Olindias sambaquiensis erscheint zu Zeiten, namentlich im Winter, bei ruhiger See in grosser Menge in der Nähe des Ufers. Ich sah sie zuerst im Winter 1856 bei der Ortschaft Sambaqui, nördlich von Desterro, an der Westküste der Insel Santa Catharina.

Die glashelle Scheibe ist farblos, seltener leicht röthlich angehaucht, und von mittlerer Festigkeit $\left.{ }^{3}\right)$. Sie wurde bis zu so8 $\mathrm{mm}$ Durchm. beobachtet, doch nur einmal unter vielen Hunderten; in der Regel schwankt der Durchmesser geschlechtsreifer Thiere $z w$ ischen 50 bis $70 \mathrm{~mm}$; - das jüngste, noch völlig geschlechtslose Thier, das zur Beobachtung kam, hatte $16 \mathrm{~mm}$ Durchmesser. - Die Oberfläche der Scheibe bildet im Zustande der Ruhe einen flachen Kugelabschnitt, dessen Höhe etwa $1 / 3$ bis $1 / 4$ des Durchmessers beträgt. In der Mitte springt die Gallertsubstanz als stark gewölbter Hügel nach unten vor, wodurch hier ihre

I) Archiv für Naturgeschichte I861, I. p. 312-319. Taf. IX.

2) Im Archiv fïr Naturgeschichte 1859. Bd. I. p. 31.4. Z. 6 v. u. steht durch einen Druckfehler Plindias statt Olindias.

3) Die Festigkeit der hier häufigeren grösseren Scheibenquallen ordnet sich in aufsteigender Reihe etwa wie folgt: Medusa, Chrysaora, Olindias, Cephea, Mesonema, Tamoya. 
Dicke etwa $1 / 6$ des Durchmessers erreicht; am Rande des Hügels, dessen Durchmesser etwa $1 / 4$ des Durchmessers der Scheibe misst, ist sie nur noch halb so dick und verjüngt sich von da an allmählich nach dem Scheibenrande zu.

Die quergespannte $\mathrm{R}$ andhaut ist ziemlich schmal, aber wie die stark entwickelte Muskelschicht der Unterfläche .kräftiger Zusammenziehungen fähig, die die Scheibe des schwimmenden Thieres mehr als halbkuglig krümmen (fig. 5). Dabei pflegt sich die Unterfläche gürtelweise stärker zusammenzuzichen und dazwischen bleiben scharf vorspringende Parallelkreise, die der Unterfläche das Ansehen einer Crinoline mit ihren Reifen geben. Auffallende Gruppen von Nesselzellen fehlen der Scheibe; einzelne finden sich unterhalb in der Nähe des Randes. Die Ansatzstelle des Magens bildet ein Viereck, dessen Seiten etwa 1/5 des Scheibenhalbmessers betragen. Von hier hängt der Magen als mundwärts beträchtlich erweitertes Rohr nieder, und erreicht, wenn das ruhende Thier ihn, wie tastend, umherschwingt, fast clie Länge des Scheibenhalbmessers. Der Mundrand ist krausenartig gefaltet und in vier Zipfel ausgezogen, die den Ecken des Magengrundes in ihrer Lage entsprechen. Einzelne Nesselzellen finden sich überall auf der innern flimmernden Magenwand; ein Saum aus dichtgedrängten, länglichen, etwa $0,02 \mathrm{~mm}$ langen Nesselzellen umzieht den Mundrand.

Von den Ecken des Magengrundes gehen vier ziemlich weite Strahlgefässe zum Ringgefässe des Randes und von diesem wieder eine grosse Zahl blinder Gefässröhren rücklaufend dem Mittelpunkte zu. Bei jenem grössten Thiere wurden zwischen zwei Strahlgefässen 27 rü cklaufende Gefässe gezählt. Bei jüngeren Thieren lässt sich an der verschiedenen Länge dieser Ciefässe erkennen, dass sich zunächst eines in der Mitte zwischen zwei Strahlgefässen bildet, dann eines in der Mitte jedes so gebildeten Achtelkreises. Weiter ist strenge Regelmässigkeit ihres Auftretens selten zu verfolgen. Die ältesten und längsten dieser Gefässe reichen bis in die Nähe des Magens. Ihr Verlauf ist in der Regel in gerader Linie mittelpunktwärts. Abweichungen davon, Theilungen der rücklaufenden Gefässe, Verbindungen derselben unter sich oder mit den Strahlgefässen kommen öfter vor. Ich vermuthe, dass diese Unregelmässigkeiten, meist wenigstens, Folge von Verletzungen sind.

Den Rand hält eine dreifache Reihe in Form und meist auch in Färbung auffallend verschiedener Anhänge besetzt. $\mathrm{Zu}$ äusserst eine Reihe Tentakel von wenig veränderlicher ungefähr dem Halbmesser der Scheibe gleichkommender Länge. Sie pflegen in Zahl und Lage mehr oder weniger genau den Strahl- und rücklaufenden Gefässen zu entsprechen. Die den Strahlgefässen entsprechenden stehen ziemlich hoch (bis etwa $4 \mathrm{~mm}$ ) über dem Rande; kaum tiefer die 4 dazwischenliegenden; dann folgen 8 merklich tiefer stehende, dann 16 wieder tiefer; was darüber hinausgreht, und ihre Zahl steigt oft über 80 und selbst 100 , steht dicht am Rande. Die Tentakel sind hohl und mit dem Ringgefässe in Verbindung, zu dem sich von dem Ursprunge der etwas rückenständigen eine nach dem Ringgefässe zu stark verengte Verbindungsröhre (fig. 4, v) hinzieht. Nesselwülste, deren dichtgedrängte, langgestreckte Nesselzellen doppelt so lang sind wie die des Mundsaumes, umgeben dic Tentakel, bald quer, bald schief gestellt, selten aber vollständige Ringe bildend. In der Ruhe sind die über dem Rande stehenden Tentakel meist schief nach aussen und oben gerichtet mit sanft abwärtsgebogener 
Spitze, die anderen hängen nach unten. Diese letzteren sind, wie das erwähnte geschlechtslose Thier bewies, dem sie noch fehlten, die jüngeren. Wahrscheinlich entstehen alle unmittelbar am Ringgefässe und entfernen sich bei fortschreitendem Wachsthume der Scheibe von demselben, so dass also die Höhe ihrer Anheftung ihr Alter anzeigen und dass die Ordnung ihres Auftretens dieselbe, wie bei den rücklaufenden Gefässen sein würde.

Nach innen von den Tentakeln, am Rande selbst, steht in weił grösserer, etwa dreifacher Zahl, die Reihe der Fangfäden, die sich fast immer durch verschiedene Färbung, wesentlicher aber durch ungemeine Dehnbarkeit von jenen unterscheiden. Auch sie sind hohl und am Ursprunge nicht erweitert, sondern verengt; ihre Nesselzellen, die denen der Tentakel gleichen, sind in meist ringförmige Wülste geordnet. Zusammengezogen sind sie etwa von der Länge der Tentakel, können sich aber über fusslang ausdehnen. Diese Ausdehnung scheint mir hier, wie in ähnlichen Fällen (Liriope, Eucope u. s. w.), eine rein passive zu sein, ein allmähliches langsames Erschlaffen. Wenn Olindias mit zusammengezogenen schopfartig nachschleifenden Fangfäden herumgeschwommen ist und sich dann ruhig schwebend in einem hohen Glase hält, von Zeit zu Zeit durch einen leichten Ruck ihrem langsamen Niedersinken entgegenwirkend, so sieht man, während die älteren Tentakel strahlig sich ausbreiten, die Fangfäden ganz allmählich sich senken und ausdehnen; die verbindenden farblosen Fäden zwischen den anfangs dichtgedrängten Nesselwülsten entschwinden dabei fast dem Auge und man glaubt einen dichten Regen goldener Perlen zu sehen; am Boden des Glases bilden die niedergesunkenen Enden ein dichtes Gewirr von Schlangen, aus dem ab und zu einzelne plötzlich in die Höhe zucken, um sich wieder langsam und anscheinend nur dem Gesetze der Schwere folgend niederzusenken, so dass dieser goldene Regen der Danaë ununterbrochen fortdauert. - Man hat gemeint, dass beim Zusammenziehen der Fangfäden der Scheibenquallen Flüssigkeit aus denselben in die Gefässe übertreten müsse, da sie dabei nur unbedeutend an Dicke zunehmen, aber dabei vielleicht ausser Acht gelassen, dass bei gleichbleibendem Inhalte die Länge im umgekehrten quadratischen Verhältnisse der Dicke sich ändert, dass also z. B., wenn der Faden von zwei Fuss auf einen Zoll sich zusammenzieht, die Dicke noch nicht ganz 5 mal grösser wird. Dem Augenscheine nach - und eine Messung dürfte kaum ausführbar sein, - ist mir die Aenderung der Dicke diesem Verhältnisse ganz entsprechend vorgekommen.

Endlich findet sich eine ebenfalls ansehnliche /ahl (gegen 200 bei einem Thiere von $45 \mathrm{~mm}$ Durchmesser) ganz kurzer Randanhänge, die an die keulenförmigen Anhänge der Thaumantias mediterranea Ggb. crinnern, aber hohl sind. Vielleicht sind es nur junge Fangfäden.

Bei dem mehrfach erwähnten geschlechtslosen Thiere waren die Fangfäden verhältnissmässig weit kürzer und viel weniger zahlreich (20 bis 30 ), die Tentakel länger als bei erwachsenen Thieren. Es ist nicht unwahrscheinlich, dass, wie bei Liriope, noch jüngere Formen nur Tentakel besitzen.

Die Randbläschen (fig. + ) sitzen paarweise am Ursprunge der Tentakel: sie sind rundlich oder ellipsoidisch von $0,2 \mathrm{~mm}$ Durchmesser mit einfacher lichtbrechender Kugel von $0,03 \mathrm{~mm}$, die wie bei Liriope befestigt ist. Ihr Inhalt ist 
meist wasserhell; ein paarmal sah ich feine Körnchen darin herumtreiben, wie von Flimmerhaaren bewegt.

Die Geschlechtstheile (fig. 2) nehmen den grössten Theil der Strahlgefässe ein, nur eine kleine Strecke in der Nähe des Magens freilassend. Sic treten zuerst auf als einfache walzenförmige Ausstülpungen der Gefässwand, die sich später unregelmässig baumartig verästelt (fig. 3), und bis über $8 \mathrm{~mm}$ Länge erreichen können. Sie flimmern nicht nur innen, wie alle Gefässe, sondern auch auf ihrer äusseren Oberfläche, unter der sich Samen oder Eier bilden. Hoden und Eierstöcke zeigen für das unbewaffnete Auge keine Verschiedenheit. Bei einem Thiere mittlerer Grösse zählte ich gegen jo I3̈̈umchen an einem Strahlgrefässe.

Vielfach verschiedene Färbung bei Thieren derselben Art ist häufig bei Polypen und Quallen (Gorgonia, Corymorpha, Cephea, Chrysitora u. s. w.); schwerlich aber dürfte hierin ein anderes Thier unserer Olindias gleichkommen. Man denke sich alle Mischungen von Gelb, Roth, Braun, Schwarz, - in allen Abstufungen von leisem Anfluge bis zu voller Sättigung; und in allen möglichen Zusammenstellungen an Fangfäden und Tentakel, Gefässe und Geschlechtstheile, Magen und Nesselsaum des Mundrandes vertheilt. Besonders häufig erscheinen Fangfäden, Randstummelchen und Geschlechtstheile gelb (schwefel-, goll-, orangegelb), die Gefässe rosenroth, der Magen gelb oder morgenroth mit dunklerem Nesselsaume, die Tentakel braun; häufig auch sind Fangfäden, Gefässe und Mundsaum rosenroth, die Tentakel brennend ziegelroth, die Geschlechtstheile gelblichweiss. Bisweilen ist das ganze Thier farblos bis auf den blassrosenrothen Mundsaum, mennigrothe Tentakelspitzen und leicht grelblich getrübte Geschlechtstheile, - oder wieder, um aus der endlosen Menge verschiedener Färbungen noch das Gegentheil hiezu hervorzuheben, die Fangfäden sind schwefelgelb, die Tentakel rothbraun, die Randstummelchen und Geschlechtstheile schwarz, die Gefässe schwarzbraun, der Magen bräunlich mit gelbem Saume. - Die Färbung der Gefässe hat ihren Sitz in der der Scheibe zugekehrten Wand (s. fig. 2), das Ringgefäss ist stets farblos. An Fangfäden und Tentakeln ist der körnige Farbstoff besonders an den Nesselwülsten angchäuft. - Bei den Thieren desselben Schwarmes, d. h. bei den gleichzeitig an der Küste erscheinenden, pflegt eine bestimmte Färbung vorzuherrschen, wie z. B. an manchen Tagen nur gelbe, an anderen fast nur rothe Fangfäden gesehen werden.

Im Magen der Olindias finden sich öfters Fischreste; als Schmarotzer trifft man an ihr bisweilen Philomedusa Vogtii.

Es ist bezeichnend für die Unsicherheit, die noch in der Anordnung der Scheibenquallen herrscht, dass der Versuch, Olindias in die Systeme ron Esch scholtz, Forbes, Lütken, Gegenbaur einzureihen, sie zu den Oceaniden von Eschscholtz, den Geryoniden von Forbes, den Aequoreaden ron Lütken führt, ohne dass sie weder mit Occania, noch mit Geryonia oder Acquorea Aehnlichkeit hat, und dass sie in Ge gen ba u r's System gar nicht Platz findet, da sie durch dic Randbläschen von den Thaumantiaden, durch dic Bildung der Geschlechtstheile von den Eucopiden ausgeschlossen wird.

Die einzige Gattung, zu der sie verwandtschaftliche Beziehung zu haben scheint, ist Melicertum Oken; auch bei diesen finden sich Randfäden von 
verschiedener Grösse und in verschiedener Höhe angeheftet, und ausserdem bis jetzt völlig räthselhafte Fäden („,cirri“ Eschsch.) längs der Strahlgefässe, die vielleicht im Hinblicke auf Olindias als Geschlechtstheile gedeutet werden dürfen.

Als Gattung smerkmale von Olindias lassen sich vorläufig die folgenden hervorheben: Magen ein häutiges Rohr; Strahlgefässe 4, mit baumförmig verästelten Geschlechtstheilen besetzt; zahlreiche rücklaufende Gefässe; äusserst dehnbare Fangfäden und weniger bewegliche Tentakel ${ }^{1}$ ) in grosser, unbestimmter Zahl ; beide hohl und mit dem Ringgefässe in Verbindung; Randbläschen paarweise am Grunde jedes Tentakels.

$$
\text { Desterro, Juni i } 86 \text { I. }
$$

1) Mit den von mir bei Liriope als Tentakel bezeichneten Anhängen haben die der Olindias im Gegensatz zu den Fangfäden gemein: die mehr rückenständige Anheftung, die geringere Dehnbarkeit, und wahrscheinlich das frühere Auftreten im Laufe der Entwickelung. Auch auf eine nähere Beziehung zum Nervensysteme scheint die Lage der Randbläschen an ihrem Ursprunge hinzuweisen. Trotzdem also die Tentakel der Olindias hohl sind, die der Liriope nicht, glaubte ich sie mit gleichem Namen bezeichnen zu dürfen.

\section{Erklärung der Abbildungen auf Tafel XVI.}

Fig. I. Olindias sambaquiensis, ruhig im Wasser schwebend, nat. Grösse. Von den Fangfäden hat nur der kleinere Theil der Länge Platz gefunden.

Fig. 2. Geschlechtstheile eines anderen Thieres, in seitlicher Ansicht, nat. Grösse.

Fig. 3. Einzelne Geschlechtsbäumchen, um die Art der Verästelung zu zeigen.

Fig. 4. Randbläschen, vergrössert. $r$ Ringgefäss. $t$ Tentakel. $v$ Verbindungsröhre zwischen beiden.

Fig. 5. Schwimmendes Thier, im senkrechten Durchschnitte. $f$ Fangfäden. $h$ Randhaut. 


\section{Ueber die angebliche Bilateralsymmetrie der Rippenquallen ${ }^{1}$.}

Bei strahligen Thieren ist $\mathrm{n} u \mathrm{r}$ das Vorn vom Hinten, oder das Oben vom Unten, bei zweiseitigen Thieren gleichzeitig das Vorn vom Hinten und das Oben vom Unten verschieden. Strahlige Thiere sind durch so viel Ebenen, als Strahlen vorhanden, zweiseitige durch eine einzige Ebene in symmetrische Hälften theilbar; strahlige Thiere haben eine Achse, den Durchschnitt jener Ebenen, zweiseitige nur jene Mittelebene und keine Achse. In einfacher Zahl können bei strahligen Thieren nur die in der Achse liegenden Theile vorhanden sein; alle Theile in der Mitte und auf der Grenze der Strahlen wiederholen sich in einfacher, alle anderen Theile in doppelter Strahlenzahl. Bei zweiseitigen Thieren können in einfacher Zahl alle in der Mittelebene liegenden Theile auftreten und alle Theile ausserhalb dieser Ebene sind paarweise vorhanden.

Lässt man die Trennungsebenen der Strahlen mit Beibehaltung ihrer gegenseitigen Lage um die Achse sich drehen, so wird durch dieselben fortwährend das Thier in congruente Stücke geschnitten; zweiseitige Thiere sind überhaupt nicht in congruente Stücke zerlegbar. Jeder einzelne Strahl eines Strahlthieres ist zweiseitig symmetrisch; zweiseitige Thiere sind durch ihrer Längsrichtung parallele Ebenen nicht in Stücke theilbar, die selbst wieder zweiseitig symmetrisch wären.

Bei paariger Strahlenzahl, also bei 2-, 4-, 6strahligen Thieren schneidet ausserdem jede durch die Achse gelegte Ebene den Körper in congruente Hälften und jeder dieser Durchschnitte wird selbst wieder durch die Achse in congruente Hälften getheilt. Zweiseitige Thiere sind (wie auch die Strahlthiere mit ungerader Strahlenzahl), überhaupt nicht in congruente Hälften theilbar; - eine rechte Hälfte lässt sich nicht durch eine linke ersetzen und aus zwei rechten Hälften congruenter Thiere nicht ein ganzes Thier machen. Würden dagegen zwei congruente paarigstrahlige Thiere auf gleiche Weise in congruente Hälften geschnitten, so würden sich beliebige zwei dieser vier Hälften zu einem ganzen Thiere zusammenfügen lassen.

Jecle durch die Mitte eines Strahls gelegte Ebene, so wie jede Trennungsebene zweier Strahlen theilt patarig-strahlige Thiere in zweiseitig angeordnete

I) Archiv für Naturgeschichte I861. I. p. 320-325. 
Hälften. Die Hälften eines zweiseitigen Thieres, rechts und links von der Mittelebene, sind, jede für sich betrachtet, nicht mehr zweiseitig angeordnet.

Leicht liesse sich die Reihe dieser Merkmale, die scharf und schroff die strahlige von der zweiseitigen Anordnung des Thierleibes scheiden, noch weiter fortspinnen. Ich breche sie hier ab, denn schon höre ich fragen: wozu überhaupt diese müssige Aufzählung selbst verständlicher Unterschiede zwischen Dingen, die Niemand je verwechseln kann? Genügt es nicht, einen Seestern neben einem Krebse gesehen zu haben, oder selbst nur die Bezeichnungen strahlig und zweiseitig zu hören, um nie in Zweifel zu kommen, welche der beiden Anordnungsweisen man vor sich habe? - Man sollte es meinen; doch den Beweis des Gegentheils liefern u. a. die Rippenquallen. Nach allen angeführten Merkmalen und wie man auch sonst sich die Begriffe mathematisch zergliedern möge, ergeben sie sich als vollkommen strahlige und zwar $z$ weistrahlige Thiere und zeigen diesen Bau in vollster Regelmässigkeit und strengster Durchführung ausgeprägt, ohne die leiseste Spur eines Ueberganges zu zweiseitiger Anordnung. - Und doch scheint die herrschende Ansicht des Tages die entgegengesetzte zu sein. Vorsichtig zweifelnd spricht sich Burmeister aus: „die Rippenquallen scheinen nach beiden Typen gebaut zu sein, doch herrscht eine reguläre Eiform vor ${ }^{1}$ )." Andere betrachten sie geradezu als „Zweiseitig-symmetrische" Thiere, oder doch als Uebergangsform „vom Radiärtypus zum bilateral-symmetrischen“. So A gassiz ${ }^{2}$, Vogt, Gegenbaur. Die gewichtigen Stimmen solcher Gegner nöthigten mich zu einer etwas umständlicheren Auseinandersetzung des an sich allerdings höchst einfachen Gegenstandes; mit dieser Auseinandersetzung der Unterschiede zwischen strahligen und zweiseitigen Thieren ist zugleich auch schon mein Beweis für die Stellung der Rippenquallen unter den ersteren gegeben. Es bleibt mir übrig, die Gründe der entgegenstelienden Ansicht zu besprechen, die ich leider nirgends in den mir zugänglichen Schriften zusammenhängend dargestellt finde.

Die nächste Veranlassung, die Rippenquallen als zweiseitige Thiere oder als Mittelding zwischen diesen und den strahligen anzusehen, hat wohl die „von zwei Seiten comprimirte“ Körperform vieler Arten und namentlich die lang ausgezogene Bandform von Cestum gegeben, inden Vogt den ,symmetrischen 'Typus“" am deutlichsten ausgeprägt findet, und auch Gegenbaur „die Bilateralsymmetrie ilıren Gipfelpunkt" erreichen lässt. Konnte nun diese auffallende Form des Venusgürtels wohl Anlass geben zu einer neuen Prüfung seines Rechtes als Strahlthier, so kann sie doch so wenig als Beweis dagegen geltend gemacht werden, als etwa die Kugelgestalt eines eingerollten Sphäroma dasselbe aus der Reihe der zweiseitigen Thiere ausschliesst. - Die Rippenquallen als zweistrahlige Thiere aufgefasst, verliert zudem jene Bandform alles Auffallende; neben die Cydippen mit kreisrundem Querschnitte stellen sich dann die Cestum in ganz ähnlicher Weise, wie neben die kugligen Echinus die langstrahligen Asterien und Ophiuren.

Einen zweiten Grund zur Annahme einer "Bilateralsymmetrie" scheint die Zweizahl verschiedener Theile, der Trichteröffnungen, Mundschirme, Magengefässe, Senkfäden u. s. w. abgegeben zu haben. - „Selbst bei den sonst radiär gebauten

1) Gicschichte der Schöpfung. 6. Auflg. p. 330.

2) Nach den Jahresberichten von V. Carus und R. L.cuckart. 
Beroën" findet Gegenbaur in den beiden Trichteröffnungen „die bilaterale Symmetrie angedeutet ${ }^{1}$ " uud lässt die beiden Senkfäden cler Cydippen u. a. „nach bilateraler Symmetrie“ vertheilt sein \%. In Zweizahl vorhanden ist nun allerdings sogar die Mehrzahl der Theile zweiseitiger Thiere; die Vertheilung aber dieser doppelt vorhandenen Theile bei den Rippenquallen, ihr ausschliessliches Vorkommen in zwei aufeinander senkrechten Ebenen, weit entfernt, Beweis „bilateraler Symmetrie" zu sein, ist vielmehr etwas damit. clurchaus Unverträgliches und vorbunden mit der Vierzahl aller Theile ausserhalb dieser Ebenen ein sicheres Kennzeichen $z$ weistrahliger Anordnung. Ganz abgesehen übrigens von den oben aufgestellten Merkmalen strahliger und zweiseitiger Thiere, so ist zu verwundern, dass man den Widerspruch nicht bemerkt hat, der darin liegt, gleichzeitig die Trichteröffnungen und die Senkfäden als bilateral-symmetrisch zu betrachten. Sind es die Trichteröffnungen, so liegen z. B. bei Mnemia die Schmalseiten und Mundschirme rechts und links, die Breitseiten mit Senkfäden ${ }^{3}$ ) und Magengefässen oben und unten. Sind es die Senkfäden, so finden sich die Breitseiten und Magengefässe rechts und links, die Schmalseiten, Mundschirme und Trichteröffnungen oben und unten. Eine Annahme führt die andere ad absurdum. Bei beiden Annahmen ist überdiess, im Widerspruche mit dem wesentlichsten Grundzuge zweiseitigen Baues, kein Unterschied zwischen Bauch und Rücken vorhanden.

Eine weitere hierher gehörige Bemerkung Gregenbaur's ist mir unverständlich geblieben. Es soll bei den Ctenophoren der Radiärtypus der Cölenteraten in den bilateral-symmetrischen übergehen, ,indem an zwei symmetrischen Körperhälften eine überwiegende Ausbildung der einzelnen Theile erfolgt ${ }^{4}$ )." Da das Thier nicht mehr als zwei Hälften hat, also die beiden Hälften mit überwiegender Ausbildung der Theile das ganze Thier ausmachen, so begreift man nicht, wo die in der Ausbildung zurückbleibenden Theile Raum finden. W'ollte man aber unter „Hälften“ nur gegenüberliegende Körpertheile verstehen, - und man ist allerdings gewohnt, in naturgeschichtlichen Werken eine ganz neue mathematische Sprache zu finden, - so würde auch ebensowenig das bei Rippenquallen vorkommende, als ein für „bilateral-symmetrischen Typus“ bezeichnetes V'erhältniss ausçesproch('n sein. Oder sind etwa die Trichteröffnungen und Mundschirme überwiegend ausgebildete Magengefässe und Senkfäden, oder auch umgekehrt? - Oder sind unsere eigenen Arme und Beine überwiegende Ausbildungen irgend welcher Theile unserer Rücken- und Bauchfläche?

In gewohnter einfach lichtvoller Weise hat C. Vogt in den zoologischen Briefen $\left.{ }^{5}\right)$ die Unterschiede zwischen strahligem und zweiseitigem Baue auseinandergesetzt. Nach dieser seiner eigenen Darstellung hätte er die Rippenquallen unbedingt als vollkommen strahlig gebaut bezeichnen müssen. Und doch hat auch er von dem ,langen Querband“ des Venusgürtels sich irren lassen, das, wie er in „Ocean und Mittelmeer" bemerkt, ,durch einen Schnitt, welchen man quer auf dic Achse des Bandes führt, in zwei vollkommen gleiche Hälften gespalten werden

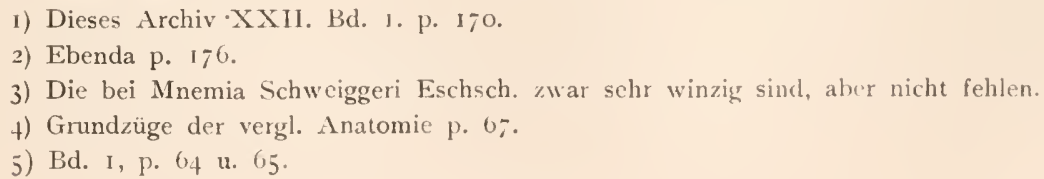


kann, in denen sich auch nicht die mindeste Spur einer radiären Anordnung erkennen lässt;“ - es genügt. hinzuzusetzen: „,so wenig, als in einem einzelnen Strahle irgend eines anderen Strahlthieres," um zu zeigen, dass die nicht zu bestreitende Thatsache nichts gegen die strahlige Anordnung des Thieres beweist. I'nd macht man noch darauf aufmerksam, dass die Hälften in der That vollkommen gleich. d. h. nicht bloss symmetrisch, sondern congruent sind, und dass jede derselben eine zweiseitige Anordnung erkennen lässt, so ist damit eine Eigenthümlichkeit bezeichnet, die wohl allen paarig-strahligen Thieren, aber nicht cinem einzigen zweiseitigen zukommt.

Sind aber nicht, wenn auch vollkommene Strahlthiere, schon als $\mathrm{zw}$ wistrahlig die Rippenquallen den $z$ weiseitigen Thieren näher stehend, als andere mehrstrahlige Thiere, und somit immerhin als Mittelglied zu betrachten? Ich meine: Nein. - Die nur in dem Namen liegende scheinbare Aehnlichkeit verschwindet, sobald man ,zweiseitig“ mit „nicht strahlig“ vertauscht. Im Gegentheile, je geringer die Zahl eines thierischen oder pflanzlichen Theiles, um so sicherer pflegt sie festgehalten zu werden. Und so wäre auch hier zu vermuthen, dass, je geringer die Strahlenzahl, um so strenger durchgeführt der strahlige Bau sein werde, und dass ein Uebergang in andere Anordnungsweisen sich eher bei hoher, als bei niederer Strahlenzahl werde finden lassen. Die Erfahrung bestätigt diese Vermuthung: abgesehen von den Echinodermen, bei denen Johannes M üller's Scharfblick überall Spuren zweiseitiger Anordnung erkannte, so finden sich solche unter den Cölenteraten, z. B. bei der I 2strahligen Philomedusa Vogtii und bei der jungen Brut der ebenfalls vielstrahligen Cunina Köllikeri. In vollster Strenge dagegen zeigt sich der strahlige Bau bei vielen vierstrahligen Scheibenquallen und bei den zweistrahligen Rippenquallen, die also auch in dieser Beziehung als ächte Cölenteraten sich ausweisen.

Desterro, im Juni is6ı. 


\title{
Die Rhizocephalen. eine neue Gruppe schmarotzender Kruster $\left.^{-1}\right)$.
}

\author{
Mit Tafel XVII.
}

Rathke's Beiträge zur Fauna Norwegens schliessen mit der Beschreibung: zweier Thiere, Peltogaster paguri und carcini, die mir schon beim Lesen der vortrefflichen Abhandlung als die merkwürdigsten der ganzen reichhaltigen Sammlung erschienen und seitdem einen der ersten Plätze behauptet haben in der Reihe der Thiere, die selbst zu untersuchen mich verlangte. Zu dieser Untersuchung wurde mir kürzlich Gelegenheit durch die Entdeckung zweier nahe verwandton Arten; ihre Ergebnisse waren zum Theil so überraschend, aus dem Kreise der gewohnten Vorstellungen heraustretend, dass es mir bei deren Mittheilung in der That eine Beruhigung ist, an den europäischen Küsten jene beiden Verwandten z.u wissen und auf sie die Fachgenossen zur Prüfung meiner Angaben verweisen zu können.

Der in den Leib des Wirthes eingesenkte Kopf dieser scheinbaren Würmer treibt pflanzenartig Wurzeln, hohle Röhren, die vielverzweigt dessen Eingeweide umspinnen, und ihre Brut stellt sich in die Mitte zwischen die der Lernaeen und der Rankenfüsser. Sie bilden also eine neue Abtheilung schmarotzender Kruster, die ich nach jener ersten Eigenthümlichkeit Rhizocephala nenne. Es steht zu erwarten, dass in diesen Rhizocephalen sich eine reiche Fundgrube neter Formen eröffnen werde, da jeder der beiden Krebse, die ich bis jetzt in grösserer /ahl untersuchen konnte, eine Art ernährt. Leider fehlen mir alle Hülfsmittel zur Bestimmung dieser Wohnthicre; doch werden sie spätere Besucher unserer Küste auch ohne weitläufige Beschreibung leicht wiederfinden. Fast unter jedem Steinc werden sie eine schwärzlichgrüne, glattscheerige, ungemein flinke Porcellana treffen, und kaum minder häufig einen kleinen Pagurus, der fast ausschliesslich in den Gehäusen eines Cerithium Obdach sucht.

Der Schmarotzer der Porcellana mag L.ernacodiscus Porcellanae, cler des Einsiedlerkrebses Sacculina purpurea heissen. Ich beschreibe zunächst die beiclen geschlechtsreifen Thiere und dann ihre I arven.

I) Archiv für Naturgeschichte 1802. I. P. I-9. Taf. I. 
Lernacodiscus Porcellanae (fig. 1-4) findet sich ziemlich häufig I), meist einzeln, selten zu zweien, dem Schwanze seines Wirthes an einem der vorderen Ringe angeheftet, und füllt oft vollständig den Raum zwischen Schwanz und Brustschild. Er hat die Gestalt einer fleischigen und blass gelblichfleischfarbenen Scheibe, die bis über $10 \mathrm{~mm}$ breit wird, bei etwas geringerer länge. Vorn und hinten ist die Scheibe tief ausgebuchtet und jederseits in 5 bis 7 Tappen getheilt, deren meist verbreitertes Ende häufig wieder eingebuchtet ist. Auf der Rückenfläche der Scheibe, die dem Schwanze der Porcellana zugekehrt ist, sieht man in der Nähe des Randes oft noch jenen Lappen ähnliche kleinere Hervorragungen. Auf der Bauchfläche, die sich dem Brustschilde der Porcellana zuwendet, fällt zunächst der Eierstock (fig. 2, b) in die Augen, der fast die ganze Fläche bis an den Ursprung der Randlappen einnimmt, hinten eine breite und seichte Bucht, vorn aber einen schmalen hinterwärts keulenförmig verbreiterten und ihn bis zur Hälfte theilenden Einschnitt hat.

Unter (lem Eierstocke (der Bauchfläche näher) liegen nahe dem Vorderrande der Scheibe zwei sehr ansehnliche rundliche oder nierenförmige Drüsen (fig. 2, c) von dem eigenthümlich durchscheinenden Ansehen, das so häufig den Hoden niederer Thiere zukommt; ihre anfangs engen, später erweiterten und dann sehr dünnhäutigen und schwer zu verfolgenden Ausführungsgänge verlaufen an ihrer inneren Seite nach hinten; ich vermuthe, dass sie am hinteren Rande des Eierstocks in die gleich zu erwähnende Bruthöhle münden. Gleichfalls unter dem Eierstocke und in ihren Umrissen demselben entsprechend, aber auch dessen vorderen Einschnitt füllend breitet sich eine zartwandige Höhle aus, die eine röthliche durchsichtige Flüssigkeit enthält; dass es eine einzige Höhle ist, wird deutlich, wenn sie sich zusammenzieht; im ausgedehnten Zustande könnte man versucht sein, ein Netzwerk zwischen den einzelnen Eiergruppen sich hinziehender Röhren anzunehmen, die von einer im vorderen Einschnitte des Eierstocks liegenden Blase ausgingen, indem dann über den stärker vorspringenden Eiern die Farbe cler dünnen Flüssigkeitsschicht fast unmerklich wird und deutlicher nur in den Furchen zwischen ihnen hervortritt.

In der hinteren Ausbucht der Scheibe findet sich eine ansehnliche, von gekerbtem Rande umfasste Oeffnung (fig. 2, a), durch die man unter abwechselndem Ausdehnen und Zusammenziehen des Körpers das Wasser ein- und ausströmen sieht. Sie führt zu einer weiten Bruthöhle, von deren Ausdehnnng man sich am leichtesten überzeugt, wenn man sie mittelst einer fein ausgezogenen Glasröhre aufbläst. Man sieht dann, dass sie die ganze Rückenfläche einnimmt, ausgenommen den vorderen Einschnitt des Eierstocks, und sich in die Randlappen erstreckt, die nur Aussackungen derselben sind. Man findet die Bruthöhle meist prall gefüllt mit Eiern, die namentlich ihrer äusseren Wand ankleben und alle gleich alt sind. Wenn sie sich der Reife nähern, erscheint der Rand der Scheibe durchsichtiger und rndlich Randlappen und Rücken schwarz punktirt durch die Augen der jungen Brut, die gleichzeitig ausschwärmt. Zwei Tage nach dem Ausschwärmen fand ich bei einem Thiere schon wieder frische, in totaler Furclnung begriffene Fier (fig. 7) in der Bruthöhle. - Das in die Bruthöhle einströmende Wasser dient 
meines Erachtens nur dem Athmen der Eier, die ziemlich vollständig seinen Zutritt zum Leibe der Mutter hemmen dürften. Auch bei vielen anderen Krustern mag die Befestigung der Eier am mütterlichen Körper weniger durch den gewährten Schut\%, als durch den steten Wasserwechsel für die Entwickelung der Brut nöthig sein; selbst der Reife nahe sind mir vom leeibe der Muttur gelöste Eier von Krabben und Garneelen immer 7 urunde gegangen, während das gefangen gehaltene Weibchen sie sicher ausbrütet.

In der vorderen Ausbucht der Scheibe liegt ein gewölbtes Chitinschild (fig. 2, s) mit concentrischen Streifen, zwischen clenen bräunliche Farbetheilchen abgelagert zu sein pflegen. Aus seiner Mitte entspringt ein kurzer Hals, der die Haut der Porcellana durchbohrt. Innen umgiebt ihn ein starker Chitinring ron 0,2 bis $0,3 \mathrm{~mm}$ Durchmesser, der sich in eine zackige nach oben erweiterte, goldglänzende Krone fortsetzt. Je nach dem Alter des Thieres ist diese Krone (fig. 2, 3, 4, k) verschieden entwickelt. Sie entsteht durch Chitinisirung der Kopfhaut. Einzelne kleine Chitinplättchen (fig. 3, 4. b) trifft man bisweilen noch oberhalb der Krone, die von cler weichen Kopfhaut nur wenig überragt wird. - Von der oberen Fläche des Kopfes, an clem ich von Mund, Angen, Fühlem keine Spur fand, entspringen nun zahlreiche Röhren (fig. 3, 4, w), bis $z u 10,15 \mathrm{~mm}$ weit, die zum Theil, namentlich die äusseren, schon in der Nähe blind enden, zum Theil, sich vielfach verästelnd, besonders nach dem Darme der Porcellana sich hinziehen, ihn weithin, selbst bis in die Brust hinein, umspinnen und zuletzt in blinde Reiserchen auslaufen. Nicht selten sieht man bis über o,5 mm dicke, ans zahlreichen einzelnen Röhren geflochtene Stränge den Weg zum Darme der Porcellana nehmen. Diese Wurzeln, so kann man sie nach Ansehen und Verrichtung nennen, enthalten in ihrer zarten Haut zahlreiche Fettkügelchen, die sich durch weit geringere und dabei gleichförmige Grösse leicht von den Fetttheilchen im Schwanze des Krebses unterscheiden.

Dafür, dass die Wurzeln durch den Hals mit dem weiten Flüssigkeitsbehälter unter dem Eierstocke in Verbindung stehen, hat man einen sehr einfachen und sicheren Beweis in einem vor Auffindung der Wurzeln mir unerklärlichen Umstande; wenn man den Knpf des Schmarotzers aus dem Leibe des Wirthes herauslöst, und bisweilen schon, wenn man den Schwanz der Porcellana rom Bruststücke lnsreisst, erfolgt ein augenblickliches und höchst augenfälliges Erblassen des I.ernaendiscus durch Entleeren jener röthlichen Flüssigkeit. Ob die mit blinden Wurzeln beginnende Höhle für die ernährende Flüssigkeit, die man kium Verdauungshöhle nennen kann, auch blind endige, muss ich noch unentschieden lassen, obgleich mir ein öfter gesehener schmaler Fortsat\% nach der Oeffnung der Pruthöhle zu eine Ausmünclung an dieser Stelle wahrscheinlich macht.

Nach Männchen des Lernaeodiscus habe ich um so eifriger ausgeschant, dat Rathke in der Bruthöhle von Peltogaster paguri einen kleinen Krebs, seine Liriope pygmaea, beobachtet hat; allein bis jetzt olnne Erfolg. In cler aus den erwähnten grossen Drüsen gewnnnenen Flüssigkeit sehe ich dagegen bewegliche Theilchen, deren Gestalt genau zu erkennen mein Mikroskop nicht ausreicht; nach der Art ihrer Bewegung trage ich kaum liedenken, die Flüssigkeit für Samen zu erklären. 
Sacculina purpurea (fig. 5 u. 6), der Schmarotzer unseres kleinen Einsiedlerkrebses, scheint nicht minder häufig zu sein. als Lernaeodiscus. Nachdem ich einmal auf ihn aufmerksam geworden, konnte ich aus den während einer Ebbe gesammelten Schneckenhäusern über $30 \mathrm{mit}$ ihm behaftete Paguren herausklopfen. Der Schmarotzer hängt als dicke, schwach gebogene, purpurrothe Wurst, die bis über $6 \mathrm{~mm}$ lang und halb so dick beobachtet wurde, am Anfange des weichen Hinterleibes und zwar an dessen linker gewölbter Seite, sein etwas dickeres Hinterende mit der Oeffnung der Bruthöhle dem Kopfe des Wirthes und also der Mündung des Schneckenhauses zuwendend. - Der Anheftungspunkt liegt auf der hohlen Seite der Wurst, dem hinteren Ende etwas näher; die Enden erscheinen von oben kuglig abgerundet.

Der Gast ist ebenso windschief wie sein Wirth; wenn man als untere die hohle Fläche nimmt, mit der das Thier festsitzt, und das Hinten durch die Oeffnung der Bruthöhle bestimmt, so ist von den beiden Seiten, die unterhalb durch Darm und Eierstock, auf dem Rücken durch eine seichte Furche geschieden sind, hinten die linke, vorn die rechte stärker entwickelt. Vorn ist die Verschiedenheit unbedeutend, hinten so stark, dass die Oeffnung der Bruthöhle ganz nach der rechten Ecke des Hinterrandes gedrängt ist. Diese Oeffnung bildet eine kleine längsspalte, und lässt dieselbe Wasserströmung gewahren, wie bei Lernaeodiscus. Links läuft der hintere Rand meist in eine mehr oder weniger deutliche, scharfe Ecke aus. Der Darm und der darüber liegende Eierstock bilden einen ziemlich schmalen, hinten und vorn verjüngten Streifen, der sich vom Anheftungspunkte vorwärts fast bis zum Vorderrande, hinterwärts bis zur Oeffnung der Bruthöhle erstreckt. - Die ganze übrige Wurst ist Bruthöhle. Die nahende Reife der Eier verräth sich durch blassere, mehr durchscheinende Färbung.

Der concentrisch geriefte Schild am Anheftungspunkt ist schwach entwickelt; die goldene Krone im Innern des Wirthes (fig. $6, k$ ) dadurch von der des Lernaeodiscus verschieden, dass von dem Ringe einzelne breite Aeste abgehen, deren breite Zweige allmählich in die dünnere Kopfhaut verfliessen, während Lernaendiscus spitze, scharf umschriebene Zacken hat. Die dem Kopfe entsprossenden W'urzeln erstrecken sich auf der linken Seite des Pagurus nach hinten und bilden zwvischen den Leberschläuchen ein dichtes Büschel aus wenigen Hauptstämmen entspringender Röhren. Man kann aus diesem Büschel ziemlich leicht die es durchsetzenden Leberschläuche hervorziehen und es so vollständig isoliren (fig. 5, $\mathrm{B}, w)$. Die Farbe des Wurzelbüschels ist dunkelgrasgrün; es schimmert deutlich durch die dünne Leibeswandung des Pagurus hindurch.

Die L,arven der beiden Schmarotzer haben so viel Uebereinstimmendes, dass ich nur die des Lernaeodiscus beschreibe und für die der Sacculina nur auf das von jener Abweichende aufmerksam machen werde.

Die L a rve von Lernaeodiscus (fig. 8) ist $0.2 \mathrm{~mm}$ lang, vorn $0,12 \mathrm{~mm}$ breit und nach hinten anfangs schwach, im letzten Drittel rascher verjüngt. Am Hinterende trägt sie zwei kurze Spitzen. Der schwach gewölbte Vorderrand läuft jederseits in cin kurzes an der Spitze etwas nach hinten gebogenes Horn aus. Den Rücken deckt ein Schild, das den Körper vorn und seitlich un $0, \mathrm{O}_{4}$ bis $0,05 \mathrm{~mm}$ überragt; hinten deckt es kaum den Ursprung der beiden Spitzen und ebenso nur den Anfang der Hörner des Stirnrandes. 
Auf der Unterfläche liegt in geringer Entfernung vom Vorderrande ein grosses, etwas quergezogenes und vorn meist seicht ausgerandetes schwarzes Auge, von dem sich ein starker Nerv hinterwärts verfolgen lässt, dem aber ein lichtbrechender Körper zu fehlen scheint. Die Borsten zu den Seiten des Auges, auf die Max Schultze bei den jungen Rankenfüssern aufmerksam gemacht hat, vermisse ich.

Die Ursprungsstelle der drei Fusspaare liegt etwa in der Mitte zwischen Mittellinie und Seitenrand; das vorderste entspringt dicht hinter dem Auge, das letzte am Ende des zweiten Fünftels der Länge. Das vorderste hat ein dickes cylindrisches Grund-, und ein kurzes Endglied mit zwei längeren Borsten; - das zweite trägt auf dickem Grundgliede einen längeren äusseren (und vorderen) Ast mit fünf, und einen kürzeren inneren mit drei langen Borsten; - das dritte Fusspaar ist bedeutend kürzer und schwächer als das zweite; sein äusserer Ast trägt vier, der innere zwei längere Borsten. Die längeren Aeste sind geringelt, doch nicht deutlich gegliedert.

Zwischen dem mittleren Fusspaare entspringt ein dreieckiger Schnabel mit rückwärtsgerichteter Spitze. Der weite Darm, der den Schnabel noch etwas nach vorn überragt, ist in den ersten Tagen noch dicht mit brauner Dottermasse gefüllt. Hinter dem letzten Fusspaare ist bisweilen eine leichte Einschnürung des Körpers zu sehen.

Die Larve der Sacculina ist verschieden durch ein viel grösseres, die Stirnhörner und Endspitzen weit überragendes Rückenschild, durch Mangel des Auges, durch mehr eiförmige Gestalt des Leibes und gerade, schief vorwärts gerichtete Stirnhörner. Ausserdem fand ich bei ihr die bei Lernaeodiscus vermissten Borsten in der Nähe des Vorderrandes und hinter dem letzten Fusspaare zu jeder Seite des Darmes ein Häufchen bräunlicher undurchsichtiger Körnchen (Harn?), von dem ich ebenfalls bei Lernaeodiscus nichts finden kann.

Nach den gegebenen Beschreibungen würden sich als bezeichnende Eigenthümlichkeiten der Rhizocephalen, die in die Mitte zwischen Siphonostomen und Rankenfüssern zu stellen sein dürften, folgende hervorheben lassen:

Crustacea Rhizocephala. L arve mit drei Paar Schwimmfüssen, von denen die beiden hintern zweiästig, mit zwei seitlichen Stimhörnern, zwei Spitzen am Ende des Leibes und häutigem Rückenschild. Erwachsenes Thier weichhäutig, ungegliedert, ohne Augen, Fühler, Füsse und (?) Mund. Kopf in das Wohnthier eingesenkt, an Grunde zu einem Chitinkranze erhärtet, durch wurzelartige blinde Fortsätze Nahrung aufnehmend. Zwitter mit beweglichen Syermatozoiden (?), ohne Eiersäcke (wie die Rankenfüsser), mit weiter hinten geöffneter Bruthöhle.

Gattungen:

1) Peltogaster Rthk. ${ }^{1}$.

2) Sacculina. Körper unsymmetrisch, wurstförmig; Kopf mitten auf der Bauchfläche. - Larve ohne Auge, mit zwei Stimborsten.

1) Nach mehr als 15 Jahren sind mir die Einzelheiten von $R$ ath ke's Beschreibungen zu selır entschwunden, um diese Gattung charakterisieren oder selbst nur entscheiden zu können, ob nicht Sacculina damit zu vereinigen sei.

Fritz 11 üllers gesamelte Schriften. 
3) Lernaeodiscus. Körper symmetrisch, scheibenförmig, Kopf am Vorderrande der Scheibe. - Larve mit Auge, ohne Stirnborsten.

Desterro. Ende Juli 186 .

\section{Erklärung der Abbildungen auf Tafel XVII.}

Fig. I. Lemaeodiscus am Schwanze der Porcellana angeheftet, wenig vergr.

Fig. 2. Ein kleineres Exemplar, v. d. Bauchseite, I 5 mal vergr. a Oeffnung der Bruthöhle. $b$ Eierstock. c Hoden (?). s Chitinschild. $k$ Krone. - Der weiche Teil des Kopfes fehlt.

Fig. 3 u. 4. Der innerhalb der Porcellana liegende Theil von Lernaeodiscus, 25 mal vergr. $l$ einzelne Chitinplättchen. $k$ Krone. $z$ Wurzeln. $d$ Darm der Porcellana.

Fig. 5. Sacculina purpurea, 3 mal vergr. $A$ von unten. $B$ von der rechten Seite. $a, b, k$ wie in fig. 2.

Fig. $6^{1}$ ). Der innerhalb des Pagurus liegende Theil (ler Sacculina, I 5 mal vergr. $k$ Krone. $w$ Wurzeln.

Fig. 7. Ei aus der Bruthöhle des Lemaeodiscus, in totaler Furchung, 9omal vergr.

Fig. 8. Erster Jugendzustand des Lernaeodiscus, I 8omal vergr. von unten.

Fig. 9. Erster Jugendzustand der Sacculina, v. oben, I 8omal vergr.

I) Siehe auch Fig. 7 der Tafel XXIII.

Anmerk. des Herausgebers des Archivs für Naturg. Der Herr Verf., dem wir schon so werthvolle an der brasilianischen Küste angestellte Beobachtungen verdanken, lıat offenbar die neueren Mittheilungen über Peltogaster ct. (dies Archiv XXI. p. 15 und XXV. p. 232) nicht gekannt; ebenso wenig die Beobachtungen von Wright und Anderson New. Phil. Journ. VII, p. 312, sonst würde er dieselben erwähut haben. Die Beobachtungen der Letzteren von den sich im Wirthe verästelnden Canälen, werden durch unseren Verf. auf das Vollständigste bestätigt. Un durch eine Rückfrage bei der weiten Entfernung des Verf. diese interessante Mittheilung nicht zu verzögern, habe ich sie unverändert abdrucken lassen. 


\title{
- Entoniscus Porcellanae, eine neue Schmarotzerassel ${ }^{1}$ ).
}

\author{
Mit Tafel XVIII.
}

Als äusserstes Glied in der Reihe der durch Schmarotzerleben verkümmerten Asseln galt bis jetzt die Gattung Bopyrus. Weit über diese Grenze hinaus entfernt sich von Lebensweise und Bau der frei lebenden Asseln und von seiner eigenen jugendlichen Gestalt ein Schmarotzer derselben Porcellana, um deren Darm Lernaeodiscus seine Wurzeln schlingt und in deren Kiemenhöhle, beiläufig bemerkt, nicht selten ein Bopyrus sich ansiedelt.

Das Weibchen dieses Schmarotzers liegt in einem dünnhäutigen Schlauche zwischen Leber, Darm und Herz des Wirthes; sein Kopf hat Augen und Fühler verloren und den Magen in sich aufgenommen; die Brust ist zu einem regungslosen, ungegliederten, mit ungeheuren Brutblättern besetzten Schlauche geworden; der lange whrmförmige äusserst bewegliche Hinterleib hat säbelförmige Beine und kuglig über ihn hervorquellend, wie in einem Bruchsacke, liegt am Anfange seines ersten Gliedes das Herz!

Als erster Binnenassel gab ich dem Thiere den Namen Entoniscus Porcellanae.

Das Weibchen (fig. 1) erreicht eine Länge von Io bis $15 \mathrm{~mm}$. Der Kopf bildet einen etwa $1 \mathrm{~mm}$ langen, 1,5 $\mathrm{mm}$ breiten weisslichen, weichen, rundlichen Klumpen. Oberhalb ist er durch eine seichte Längsfurche etwa wie ein Hirn in zwei gewölbte Hälften geschieden, zwischen denen vorn und unten ein kurzer abgerundeter Lappen vorspringt. Etwas vor der Mitte der ziemlich flachen Unterfläche sieht man als winzige Längsspalte den Mund, und um ihn - wahrscheinlich Andeutungen früher deutlicherer Mundtheile - verschiedene Linien, für die ich, da ich sie im Einzelnen nicht zu deuten weiss, auf die Abbildung (fig. 5) verweise. Die Aehnlichkeit des Kopfes mit einem Hirne wird noch erhöht durch unregelmässige Furchen, die ihn fast wie Hirnwindungen durchzichen. \%erzupft man die äussere Haut, so sieht man, dass sie herrühren von zahlreichen kegelförmigen Blindsäckchen, deren fettreichem Inhalte der Kopf seine weisse Farbe dankt und die den früher als Leber gedeuteten Blindsäckchen am vorderen Theile des Darmes von Bopyrus entsprechen dürften. Von Fühlern und Augen ist bei geschlechtsreifen Weibchen nichts zu finden; bei einem jüngeren sah ich einmal

1) Archiv für Naturgeschichte 1802. I. p. 10-18. Taf. II. 
ein paar plumpe kurze Zipfel über dem unpaaren unteren Lappen, die wahrscheinlich Fühlerreste waren.

Aufwärts sich biegend bildet der Kopf einen stumpfen Winkel mit der Brust und ist nur unbedeutender Bewegung von oben nach unten fähig. Ganz regungslos scheint das lange schlauchförmige ungegliederte Bruststück zu sein, das Leber und Eierstöcke fast vollständig füllen; beide fallen durch lebhafte Färbung sofort in die Augen, jene durch ein prachtvolles gesättigtes Orange, diese durch ein röthliches Violett. Die Leber besteht aus zwei auf der Bauchseite dicht aneinander gelagerten etwa 0,2 bis $0,3 \mathrm{~mm}$ weiten Schläuchen, die $0,5 \mathrm{~mm}$ vom Hinterende der Brust blind beginnen und sich bis an den Kopf erstrecken. Die Eierstöcke nehmen die Rückenseite ein, über die sie in unregelmässigen Hügeln herıorragen und lassen vorn eben so viel freien Raum, wie die Leber hinten. Füsse habe ich in der Regel selbst bei jüngeren Weibchen, die wegen der weniger entwickelten Brutblätter leichter darauf zu untersuchen sind, völlig vermisst. Einige Male, und nicht gerade bei jüngeren, traf ich einen oder den anderen in Form kurzer, kegelförmig zugespitzter, rückwärtsgekrümmter, mit kleinen Borstchen zerstreut besetzter Zipfelchen (fig. 7). $\mathrm{Zu}$ ungeheueren, vielgefalteten, gelappten und zerschlitzten häutigen Lappen sind dagegen die Brutblätter entwickelt. Wo ich sie deutlich zählen konnte, - denn oft erscheinen sie als eine einzige kaum entwirrbare, gewaltige Blätterkrause, - fand ich sechs Paar! Sie sind durchzogen ron engen baumförmig verästelten Gängen, in die man bisweilen durch den Druck des Deckglases die Galle aus der zersprengten Leber hineintreiben kann und enthalten äusserst zahlreiche dichtgedrängte Fettkügelchen eingelagert.

Wenn man schon bei Bopyrus verwundert die Eiermenge betrachtet, die sich unter ihrer breit schildförmigen Brust anhäuft, so ist dieselbe bei Entoniscus noch weit erstaunlicher; sie bildet unregelmässig zusammengeballte Haufen, deren Breite oft der Länge der Brust gleichkommt, die sie rorn und hinten bisweilen noch weit überragen, so dass nicht selten der ganze Körper vollständig in ihnen versteckt ist. Und während Bopyrus, wie andere Asseln, jede Brut erst vollständig sich entwickeln und ausschwärmen lässt, ehe er neue Eier legt, häuft Entoniscus eine ganze Reihe aufeinander folgender Bruten gleichzeitig um sich an, so dass man Stoff für die ganze Entwickelungsgeschichte den Brutblïttern desselben Thieres entnehmen könnte.

Dem Bruststücke folgt ein weit dünnerer höchst beweglicher, sechsgliedriger Hinterleib, von sehr wechselnder Länge, bald weit kürzer, bald über anderthalb Mal so lang wie die Brust. Diese Verschiedenheiten der Länge rühren namentlich her von den beiden ersten zu langen Cylindern ausgezogenen Ringen. Bei einem Thicre ron I $4 \mathrm{~mm}$ Länge finde ich für die Länge des ersten Hinterleibsringes 2,3; des 2 ten 2; des 3 ten 1,2 ; des 4 ten 0,32 ; des 5 ten 0,25 und des 6 ten $0,38 \mathrm{~mm}$; die Dicke war beim ersten Ringe 0,25 und beim letzten $0,2 \mathrm{~mm}$. Die 5 ersten Ringe tragen nahe ihrem hinteren Ende ein Paar ungegliederter säbelförmiger borstenloser Füsse; die des dritten Paar's sind die lïngsten und reichen bis zum Ende des vorletzten Ringes. Die Füsse lassen sich nicht nur heben und senken, sondern auch seitlich ausspreiten. Das letzte (rlied des Hinterleibes (fig. 6) ist am Ende oben abgestutzt und hat unterhalb einen bis zu seiner Mitte reichenden V förmigen Ausschnitt. - An der Bauchfläche des 1sten und 2ten Hinterleibs- 
ringes, und weniger entwickelt an der des 3 ten, zicht sich jederseits eine weit vorspringende contractile Hautfalte hin; ihr stark wellig gebogener Rand enthält eine gefässartige Höhlung, die sich in den Rand des entsprechenden Fusses fortsetzt.

Am Anfange des ersten Hinterleibsringes trägt dessen Rückenfläche eine bruchsackartige Ausstülpung von etwa $0,5 \mathrm{~mm}$ Länge und fast gleicher Höhe; darin liegt das ziemlich matt pulsirende Herz.

Wenn nun im Baue des Weibchens kaum die Blinddärmchen am Anfange des Verdauungsrohres, die beiden Leberschläuche, und das am Anfange des Hinterleibes liegende kurze Herz an Bopyrus erinnern, so tritt die Verwandtschaft mit dieser Assel unverkennbar hervor in den Männchen (fig. 2 u. 3), die wie dort fast beständige Begleiter des Weibchens, aber viel zwerghafter und daher zwischen den unendlichen Eicrmassen leicht zu übersehen sind. In der Regel findet sich nur eines; ein einziges Mal sah ich ihrer zwei auf dem Leibe derselben Dame spazieren gehen.

Das Männchen ist gegen o,8 mm lang, kaum 3-4mal länger als dic eben ausgeschlüpften Jungen; in der Mitte der Brust erreicht die Breite fast $1 / 3$ der Länge; von da $\mathrm{ab}$ ist der Körper schwach nach vorn, stark nach hinten verjüngt. Die Brust ist deutlich in 7, der Hinterleib in 6 Ringe geschieden; die Grenze zwischen Kopf aber und erstem Brustringe ist nur durch eine tiefe seitliche Einschnürung angedeutet. Der Kopf (fig. 8) hat die Gestalt eines Trapezes mit abgerundeten Ecken, dessen Höhe der kürzeren der parallelen Seiten etwa gleich und die Hälfte der längeren hinteren ist. Er trägt ein Paar ungegliederter, platter, viereckiger Fühler; mit der inneren Seite entspringen sie von der Unterfläche des Kopfes, die vordere schliesst sich dem Stirnrande desselben an, die hintere ist ihr ziemlich gleichlaufend und die äussere richtet sich schief nach hinten und aussen. An der vorderen, stumpfen Ecke steht eine Gruppe kurzer, einwärts gekrümmter Borsten. Augen fehlen oft; sind sie vorhanden, so sind sie vom Kopfe bis fast an den Hinterrand des damit verschmolzenen ersten Brustringes gerückt. Der Ursprung des dreieckigen Saugrüssels liegt auf der hinteren Grenze des Kopfes; seine Spitze legt sich zwischen den Ursprung der Fühler.

Die sechs vorderen Brustringe tragen nahe dem Rande zu fast sitzenden ungegliederten rundlichen Klumpen verkümmerte Füsse (fig. 9), mit denen nichts desto weniger das Thier sich ziemlich rasch von der Stelle hilft. Der 7 . Ring ist fusslos, trägt aber am hinteren Rande jederseits einen warzenförmigen Vorsprung und auf diesem die Geschlechtsöffnung.

Der hinterwärts stark verjüngte Hinterleib ist ohne Anhänge, wie bci den Männchen zweier anderen hiesigen Bopyriden; der letzte Ring zeichnet sich durch grössere länge vor den übrigen aus und ist am Ende mit winzigen Dörnchen besetzt.

Von innern Theilen fallen zunächst zwei weite, stark bräunlich gefärbte, contractile Leberschläuche auf, die im isten oder 2ten Hinterleibsringe blind beginnen und bis zum 2ten Brustringe sich erstrecken. Zwischen ihnen verläuft der Darm. Ueber Darm und Leber lagert sich jederseits ein weiter schlauchförmiger Hode, der von der schon erwähnten Geschlechtsöffnung durch 3 bis 4 Ringe nach 
rorn sich erstreckt und in der Regel in jedem nach aussen eine seitliche Aussackung hat. - Das Herz sieht man dicht hinter der Leber pulsiren.

Ebenso ähnlich, wie die Männchen, sind die Larven (fig. 4) denen ron Bopyrus. Der flache asselförmige Körper ist etwa $0,2 \mathrm{~mm}$ lang und halb so breit; die grösste Breite fällt auf den zten und 3ten Brustring, von wo sich der Körper hinterwärts bis auf 0,04 . vorwärts bis auf $0,06 \mathrm{~mm}$. die Breite des fast geradlinigen Stirnrandes, verschmälert. Von der Länge nimmt etwa $1 / 5$ der Kopf, den Rest nehmen zu gleichen Theilen Brust und Hinterleib ein, von denen jedes deutlich in sechs Ringe geschieden ist. Der Kopf trägt oberhalb nahe der hinteren Ecke zwei rundliche schwarze Augenflecke, wie es scheint, ohne lichtbrechenden Körper, unterhalb zwei kurze dicke zweigliedrige vordere Fühler, die nur mit ihren Endborsten den Kopfrand überragen, und zwei lange hintere Fühler, die gerade unter den Augen entspringen und bis zum Anfange des Hinterleibes reichen; sie sind sechsgliedrig; das vorletzte. Glied und das letzte borstenförmige sind die längsten. - Im Munde, der nahe dem Hinterrande des Kopfes liegt, konnte ich nur 2 Kiefer unterscheiden. - Dicht am Vorderrande des Kopfes fällt ein rundlicher, vorn ausgerandeter, aus hellen runden Körnchen gebildeter Fleck in die Augen; er erinnerte mich an den Fleck, den man am Kopfe vieler Amphipoden bemerkt (besonders deutlich bei dem Gammarus ambulans der pommerschen Torfmoore, auch bei Leptocheirus pilosus Zadd.).

Die fünf vorderen Brustringe tragen gleichgebildete Füsse, die nahe an deren Rande entspringen; man unterscheidet an ihnen zwei längere cylindrische Grundglieder, ein kurzes drittes Glied, ein verdicktes eiförmiges Handglied von der Länge des 1. Grundgliedes und eine schwachgekrümmte kräftige Klaue, die reichlich halb so lang, wie das Handglied ist. - Am sechsten Fusspaare, das dem Rande weniger nahe entspringt, sind nur drei Glieder zu unterscheiden: ein cylindrisches Grundglied, ein winziges zweites und ein elliptisches Endglied, das $0,04 \mathrm{~mm}$ lang und halb so breit ist. Dieses Fusspaar pflegt dem Leibe dicht anzuliegen mit einwärtsgerichtetem Grund- und rückwärts gewandtem Endgliede.

Der Hinterleib trägt zunächst vier Paar Schwimmfüsse mit halbmondförmigem Grundgliede, das etwa in der Mitte der gewölbten Seite so angeheftet ist, dass das eine wenig längere Horn nach innen und etwas nach hinten, das andere nach vorn und aussen gerichtet ist. Die Entfernung der Hörner ist $0,03 \mathrm{~mm}$. Das äussere Horn trägt ein lanzettförmiges Endglied, das gerade in den Ausschnitt des Halbmondes passt und an seinem schief abgeschnittenen Ende drei Borsten von etwa doppelter Länge des Gliedes trägt. Bisweilen ist dieses Endglied am vierten Paare merklich kleiner, als an den drei vorderı; meist aber sind sie alle gleich. Am inneren Horne der drei vorderen Grundglieder steht eine einfache Borste; bald fand ich diese Borsten alle gleich lang, etwas länger als die des Endgrliedes, öfter die 2te und 3te merklich kürzer, die letzte nur $1 / 3$ der Länge der ersten erreichend. Dem 4. Schwimmfusspaare fehlt diese Borste. Der 5te Hinterleibsring trägt einen schmalen und kurzen borstenlosen Anhang (fig. 13). der in eine längere innere und kürzere äussere Spitze gespalten ist. Endlich zu den Seiten des letzten Hinterleibsringes stehen ansehnliche Anhänge mit dickem Grundgliede und zwei schlanken zweigliedrigen Endästen, von denen der äussere unbedeutend länger ist. Das letzte dornförnige Glied dieser Aeste ist gerade; ein 
kurzer Dorn findet sich aussen an Ende des Grundgliedes und des ersten Gliedes der Aeste.

Die Thierchen kriechen nicht besonders behend, schwimmen aber recht hurtig. Die ruckweise Bewegung, im Vereine mit den langbeborsteten Schwinmfüssen und dem durch die seitlichen Anhänge gablig erscheinenden Schwanze, giebt ihnen dabei eine entfernte Aehnlichkeit mit Cyclops.

Das Weibchen des Entoniscus ist in Innern der Porcellana so gelagert, dass sein Kopf zwischen den Blindsäckchen der L.eber verborgen liegt; dann zieht es sich hinterwärts und unterm Herzen bis ans Ende der Kopfbrust; die Brutblätter reichen sogar bisweilen noch ziemlich weit in den Hinterleib hinein. Das ganze Thier, auch Kopf und Mund, ist ziemlich eng umschlossen von einem häutigen Schlauche, der sich nach hinten in einen engeren Ausführungsgang fortsetzt, und bis auf die Grenze zwischen Brustschild und dem freien Ringe sich verfolgen lässt, der bei den Porcellanen das verkümmerte fünfte Fusspaar trägt. Dieser umhüllende Schlauch entsteht wahrscheinlich, indem der junge Entoniscus, um ins Innere der Porcellana zu gelangen, die weiche Haut jenes Gelenkes nicht durchbricht, sondern vor sich herstülpt. So könnte man ihn, als in einer Einstülpung der äusseren Haut seines Wirthes lebend, einen äusseren Schmarotzer nennen, wie Bopyrus und andere Asseln, obwohl er zwischen Leber, Darm und Herz sich bettet und von den Windungen der Samengänge umschlungen ist.

Nicht selten finden sich 2, einmal traf ich sogar 3 Entonicus bei derselben Porcellana.

Sicher umschlossen von dem umhüllenden Schlauche bedarf das Männchen des Entoniscus nicht die scharfkralligen Klammerfüsse der Bopyrusmännchen, und das Weibchen hat wiederum eine ausreichende Bürgschaft für die eheliche Treue seines Genossen in jenen Klumpfüssen, die ihm einen Ausflug ins freie Meer unmöglich machen.

In Bezug auf das Vorkommen habe ich noch eines bemerkenswerthen Lmstandes zu gedenken, dass nämlich häufig Lernaeodiscus und Entoniscus bei derselben Porcellana sich finden. Aufınerksam geworden auf dieses Verhältniss und wohl wissend, wie trüglich Schätzungen von Zahlenverhältnissen olne wirkliche Zählung sind, habe ich über die Schmarotzer von 1000 vom 4. Juli bis 1. August untersuchten Porcellanen Buch geführt. Glücklicherweise wurde diese Untersuchung dadurch sehr erleichtert, dass auch Entoniscus von aussen zu erkennen ist, indem bei stark zurückgebogenem Schwanze bald die Leber oder die Eierstöcke, bald die Eier zwischen den Brutblättern, oder selbst die schwarzen Aeugelchen der jungen Brut in dem Gelenke hinter dem Brustschilde durchschimmern. Es fanden sich Lernaeodiscus bei 84, Entoniscus bei 49 unter jenen 1000 Porcellanen; danach hätte man beí $49 \times 8+$ unter einer Million, oder bei 4 unter Tausend beide Schmarotzer zugleich finden sollen, während sie 2 Imal $\left.^{1}\right)$ vereinigt vorkamen, also 5 mal häufiger, als die Häufigkeit jeder einzelnen Art erwarten liess. - Die Erklärung dieses häufigen gemeinsamen Vorkommens glaube ich darin zu finden,

I) Wobei weder die jüngeren, von aussen nicht erkennbaren Entoniscus mitgezählt wurden, dic sich später bei den Lernaeodiscus tragenden Porcellanen fanden, noch auch die mit Entoniscus behafteten, die nur noch die goldene Krone abgefallener Lernaeodiscus an sich trugen. 
dass Lernaeodiscus ein dichtes Aneinanderschliessen von Schwanz und Brustschild hindert und so dem jungen Entoniscus den Zugang zur Bauchfläche der Porcellana erleichtert.

Desterro, Anfang August I86I.

\section{Erklärung der Abbildungen auf Tafel XVIII.}

Fig. I. Entoniscus Porcellanae, Weibchen, nach Entfernung der Eier aus den Brutblättern, I 5 mal vergr. $e$ Eierstock, $h$ Herz, $l$ Leber.

Fig. 2. Männchen, bei gleicher Vergrösserung.

Fig. 3. Dasselbe, gomal vergr. h Hoden, / Leber, a Augen.

Fig. 4. Larve, den Brutblättern des Weibchens entnommen, I 80 mal vergr.

Fig. 5. Mund des Weibchens und dessen Umgebung, 9omal vergr.

Fig. 6. Letzter Hinterleibsring desselben, $45^{\text {mal }}$ vergr.

Fig. 7. Füsse von der Brust desselben, gomal vergr.

Fig. 8. Kopf des Männchens; v. oben; wie alle folgende Figuren, i 80 mal vergr.

Fig. 9. Fuss desselben.

Fig. IO-14. Füsse dẹr Larve; fig. Io vom letzten Brustringe; fig. I I vom ersten, I 2 vom dritten, I3 vom fünften und 14 vom sechsten Hinterleibsringe. 


\title{
Die Verwandlung der Porcellanen $\left.{ }^{1}\right)$.
}

\author{
Vorläufige Mittheilung.
}

Mit Tafel XIX.

Seit zwei Jahren kenne ich eine Zoëa, die sich durch den Mangel des Rückenstachels und durch ungemeine Länge des gerade vorgestreckten Stirnhorns vor ihren Verwandten auszeichnet; doch erst vor wenigen Monaten erkannte ich in ihr den Sprössling derselben Porcellana, deren sonderbare Schmarotzer ich in meinen letzten Aufsätzen den Lesern des Archivs vorführte. Inzwischen fand ich Gelegenheit, die junge Brut von noch zwei anderen Porcellaniden zu untersuchen. Die eine ist eine kleinere Porcellana mit fast kreisrundem Rückenschilde, die sich selten an Felswänden zwischen Polypen und Moosthieren findet; - die andere (Fig. I-3) hält sich schmarotzend auf einigen Arten afterloser Seesterne auf und unterscheidet sich im ganzen Aussehen, in den Scheeren, und besonders durch die Kürze der äusseren Fühler so sehr von den eigentlichen Porcellanen, dass ich sie als Vertreter einer eigenen Gattung ansehe und Porcellina stellicola nenne ${ }^{2}$.

Da diese Porcellana-Larven in allen wesentlichen Verhältnissen mit der Zoëaform der jungen Krabben übereinstimmen, verspare ich ihre ausführliche Beschreibung für eine grössere Arbeit über die Jugendzustände der Krabben, zu der ich seit längerer Zeit Stoff sammle und beschränke mich für jetzt auf eine übersichtliche Schilderung ihres Baues.

Der Rückenschild ist von eiförmigem Umrisse und deckt nicht nur oben und seitlich den vorderen ungegliederten Körpertheil, sondern auch die ersten freien Ringe des Hinterleibes. Gerade vorgestreckt entspringt scinem Vorderrande ein Stachel oder Horn, das die länge des Schildes bis über 5 mal (bei der kleineren Porcellana 3mal) übertrifft. Zwei ähnliche Stacheln erstrecken sich vom Hinterrande des Schildes gleichlaufend (bei Porcellina bisweilen auseinanderweichend) gerade nach hinten; bei der kleineren Porcellana (Fig. 10), wo sie nur $2 / 3$ der Länge des Schildes erreichen, ist ihre Spitze leicht abwärts gebogen und nahe ihrem Ursprunge tragen sie einen ansehnlichen schief nach unten und vorn gerichteten Dorn; bei der gemeinen Porcellana sind sie unten mit einer ganzen Reihe kleiner Dornen weitläufig besetzt und übertreffen schon die Länge des

1) Archiv für Naturgeschichte 1862. I. p. 194-199. Taf. VII.

2) Noch merkwürdiger durch ibre Lebensweise ist eine andere Porcellana (P. Creplinii n. sp.), die sich paarweise in der Röhre des Chaetopterus pergamentaceus aufhält. 
Schildes. dessen mehr als dreifache länge sie bei Porcellina erreichen. So ist bei dieser letzten Art der Schild der eben ausgeschlüpften Jungen mit seinen Fiortsätzen doppelt so lang, als der der Mutter.

Ausser diesem wunderlichen Rückenschilde ist nur noch die Bildung des zu cincr Flosse verbreiterten 1 etzten $\mathrm{R}$ ing es auffallend von anderen jungen Krabben verschieden. Es ist bekannt, dass der letzte Ring der Krabbenlarven jederseits in ein oft sehr ansehnliches Horn sich auszieht, und dass in der mittleren Bucht zwischen diesen Hörnern jederseits drei kurze gefiederte Borsten zu stehen pflegen. Bei den Porcellanen sind die seitlichen Hörner durch unbedeutende Stacheln vertreten, und der mittlere Theil springt zwischen ihnen so weit vor, dass der ganze Schwanz ungefähr die Gestalt einer Raute annimmt. Besonders langgezogen, über doppelt so lang als breit, ist derselbe bei Porcellina. An jeder der beiden hinteren Seiten der Raute stehen 5 lange gefiederte Borsten. (Eine Mittelform, näher jedoch den Porcellanen sich anschliessend, bildet der Schwanz der jungen Paguren.)

In allem Uebrigen, dem Bane der Augen, Fühler, Mundtheile und Füsse, so wie der inneren Theile, stimmen die jungen Porcellanen vollständig mit rlen jungen Krabben überein und zeigen keine grössere Verschiedenheit von ihnen, als sie selbst oder jene unter sich.

Hier wie dort sind die vorderen Fühler (Fig. 5, a) ungegliedert und haben einen starken Nervenknoten in der Nähe ihrer Spitze, von der ausser einigen winzigen Borstchen zwei (bei Porcellina drei) längere eigenthümliche Fäden entspringen. Sie sind ron gleichmässiger Dicke, oder seltener schwach verjüngt, enden abgerundet und unterscheiden sich ausserdem durch sehr zarte Umrisse und matte Trübung von anderen Borsten. Dieselben Fäden kehren übrigens wieder auch an den vorderen Fühlern der jungen Bopyriden (besonders deutlich bei Entoniscus Cancrorum n. sp.) und Rankenfüssern, bei welchen letzteren sie einzeln auf einem winzigen Grundgliede dicht neben dem Auge entspringen.

Die hinteren F ühler (Fig. 5, b) zeigen bei Porcellina stellicola schon grosse Aehnlichkeit mit denen des erwachsenen Thieres (Fig. 2); dasselbe aufgetriebene Grundglied mit der bekannten Oeffnung des noch immer streitigen Sinnesorganes, dasselbe spitzig dreieckige zweite Glied, von dem aussen und oben hier eine mehrgliedrige Geissel, dort ein einfacher stachelförmiger Fortsatz entspringt. Dieselben Stücke in ganz ähnlicher (restalt finden sich auch bei den anderen Arten ${ }^{1}$ ).

Die M undtheile (Fig. 5) bestehen aus einer höchst ansehnlichen Oberlippe (c), zwei starken, scharf gezähnten, wie es scheint, tasterlosen Oberkiefern (d), einer zweitheiligen Unterlippe $(e)$ und zwei Paaren Unterkiefer $(f, g)$. Der vordere Unterkiefer (Fig. 8) ist in drei, der hintere (Fig. 9) in fünf mit starken, zum Theil gezähnten oder gefiederten Borsten bewehrte Blätter gespalten, und letzterer trägt nach aussen noch eine grössere häutige Platte, die nach hinten in einen fingerförmigen Fortsatz ausläuft, der Fortsatz trägt eine, die Platte selbst vorn und am Rande sechs gefiederte Borsten. Diese Platte ist aufwärts gebogen und zwischen Leib und Rückenschild in beständiger Bewegung.

1) Bei der \%oëa einer kleinen Xantho erreichen die äusseren Fühler (†̈ig. II) die Länge des Stirnhorns und die spätere Geissel ist von fast verschwindender Kleinheit. 
Die beiden Schwi m m fuspare bestehen aus einem starken cylindrischen Grundgliede und je zwei Endästen, der innere Ast, den das Thier vorwärts zu strecken liebt, hat vier, der äussere, der nach aussen und oben geschlagen zu werden pflegt, zwei weniger deutlich geschiedene Glieder. Am Ende des äusseren Astes stehen vier längere Fiederborsten, eine einzelne Fiederborste am Ende des

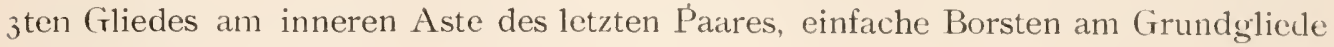
und an allen Gliedern des inneren Astes.

Hinter dem Ursprung der Sclıwimmfüsse beginnt der sechsgliedrige anhangslose Hinterleib, der oben etwas hinter der Mitte des Rückenschildes von cliesem sich loslöst.

Der Magen ist etwas erweitert, und zeigt schon (wenigstens bei Porcellina) mit Borsten besetzte Längsleisten; neben ihm liegen jederseits zwei vorwärts und zwei rückwärts gerichtete Jeberblindsäcke; ler Darm verläuft gerade und öffnet sich etwas vor der Mitte des Schwanzringes.

Das Herz, am Hinterende der Brust gelegen (bei jungen Krabben unter dem Ursprunge des Rückenstachels), scheint schon ganz wie beim erwachsenen Thiere gebaut zu sein und dieselben Gefässe abzugeben. Das vordere unpaare Gefäss lässt sich leicht bis fast zur Spitze des Stirnhorns verfolgen, dessen oberer Wand es anliegt. Blutkörperchen sind in den ersten Tagen äusserst sparsam (was indessen nicht für alle Zoëa gilt).

In jedem Hinterleibsringe liegt ein ansehnlicher Nervenknoten, der clurch zwei getrennte Stränge mit seinen Nachbarn in Verbindung tritt; im vorderen Theile des Thieres konnte ich das Nervensystem im Zusammenhange noch nicht mit rechter Schärfe erkennen.

Wenn es leicht ist, in reichlicher Zahl sich die frühesten Zustände der verschiedensten Krustenthiere zu verschaffen, so ist es um so schwieriger, über ihre späteren Schicksale Aufschluss zu erhalten. Obschon die Porcellanen zu den aller gemeinsten Krustern gehören, fand ich crst ein einziges Mal (im December vorigen Jahres) eine ältere Larve (Fig. 6, 7). An cler Stelle, wo ich sie fing, lebt weder Porcellina stellicola, noch Porcellana Creplinii; die Larven aber der gemeinen und der kleineren Porcellana sind schon durch die hinteren Fortsätze des Rückenschildes auf den ersten Blick zu unterscheiclen und so kann diese Jarve unbedenklich der ersteren Art zugetheilt werden, von deren frühester Form sie nur durch 12 (statt Io) Borsten des Schwanzringes und durch die Anwesenheit je eines Paares kurzer ungegliedlerter Inhänge an den vier vorhergehenden Ringen verschieden ist. Diese eine Larve war zum Glück ungemein lehrreich dadurch, dass sie, der Häutung nahe, schon die neuen Glieder mit verschicdener Deutlichkeit innerhalb der alten wahrnehmen liess.

Die neuen äusseren Fühler hatten eine vielgliedrige Creissel, F üsse mit grossen Scheeren und andere nicht vollständig zu entwirrende Gliedmassen waren hinter den Schwimmfüssen angelegt, so wie innerhalb des Schwanzringes eine fücherförmige Endflosse (Fig. 7).

Wenn somit die Larve selbst sich eng an den frühesten Jugendzustand anschliesst, so dürfte das aus der nächsten Häutung hervorgehende Thier kaum noch wesentlich von der erwachsenen Porcelland verschieden sein. 
So weit meine zu rorläufiger Mittheilung geeigneten Beobachtungen. Ihr Ergebniss fasse ich in einige kurze Sätze zusammen:

Die Zoëaform der Krabben entbehrt vollständig der fünf eigentlichen Fusspaare und selbst der sie tragenden Ringe.

Die Schwimmfüsse der Zoëa werden zu Kieferfüssen der Krabbe.

Die Porcellanen sind Krabben, die auf der Stufe der Megalops stehen geblieben sind ${ }^{1}$.

Desterro, Anfangs November i86I.

I) Auch bei Milne Edwards stehen bekanntlich Megalops und Porcellana in derselben Familie.

\section{Erklärung der Abbildungen auf Tafel XIX.}

Fig. I. Porcellina stellicola n. g. et n. sp. 5mal vergr.

Fig. 2. Aeussere Fühler derselben, $25 \mathrm{mal}$ vergr.

Fig. 3. Fünftes Fusspaar des Männchens derselben, $45 \mathrm{mal}$ vergr.

Fig. t. Jüngste $Z$ ö̈aform derselben, v. oben, i 5 mal vergr.

Fig. 5. Kopftheil derselben, v. unten, gomal vergr. $a$ vordere, $b$ hintere Fühler, $c$ Oberlippe, $d$ Oberkiefer, $e$ Unterlippe, $f$ erstes, $g$ zweites Paar der Unterkiefer. 6 inal vergr.

Fig. 6. A eltere $Z$ ö̈aform der (in Santa Catharina) gemeinen Porcellana,

Fig. 7. Schwanzende derselben (45mal vergr.). Im Innern sieht man die fächerfürnige Schwanzflosse des nächstfolgenden Zustandes angelegt.

Fig. 8. Erster und

Fig. 9. Zweiter Unterkiefer der jüngsten Zoëaform der gemeinen Porcellana.

Fig. Io. Hintere Fortsätze des Rückenschildes ron der jüngsten Zoëaform einer lileineren Porcellana.

Fig. 1 1. Aeussere Fühler der jüngsten Zoëaform einer kleinen Xantho. g Geissel. 


\title{
Bruchstück zur Entwickelungsgeschichte der Maulfüsser $\left.{ }^{1}\right)$.
}

\author{
Mit Tafel $\mathrm{XX}$.
}

Seit lange kennt man unter dem Namen Zoëa Jugendzustände der Krabben und Einsiedlerkrebse, die sich besonders durch den Mangel der zehn Füsse auszeichnen, denen die erwachsenen Thiere den Namen der Decapoden rerdanken. Denen der Krabben aufs Engste sich anschliessende Zoëaformen beschrieb ich kür\%lich von den Porzellankrebsen. Aber auch bei gewissen Garneelen und Maulfüssern kommen, wie ich seitdem fand, ähnliche Zustände vor. Ueber die Verwandlungsgeschichte der ersteren, die bald, wie bei Rankenfüssern und Wurzelkrebsen (Rhizocephalen), mit monoculusartigen Formen anhebt, um durch sehr eigenthümliche Zoëa- und Mysis-ähnliche Zustände hindurchzugehen, bald mit Zoëaformen beginnt, die in Bau und Art der Bewegung denen der Einsiedlerkrebse ähneln, während bei wieder anderen bekanntlich kaum von einer Verwandlung die Rede sein kann, hoffe ich in Kurzem eine einigermassen vollständige Uebersicht geben zu können; bei letzteren habe ich fürs Erste keine Aussicht zu neuen Beobachtungen und theile daher mit, was ich über die einzige bis jetzt gefundene Iarve aufgezeichnet habe.

Das 3,25 mm lange Thierchen (Fig. 1) hat im Allgemeinen die Gestalt und hat auch in vollem Masse die glashelle Durchsichtigkeit einer Alima. Die Körperringe sind fast in gleicher Zahl, wie bei erwachsenen Maulfüssern vorhanden; denn nur der sechste und siebente Hinterleibsring sind noch nicht von einander geschieden; aber wie bei den Zoëa der Krabben und Porzellankrebse fehlen noch spurlos die Anhänge der sechs hinteren Brustringe ${ }^{2}$ ), und die Seitenblätter der Schwanzflosse ${ }^{3}$ ).

1) Archiv für Naturgeschiclite 1862. I. p. 353-361. Taf. XiII.

2) Der überaus gezwungenen Auffassung, die die Brust der Kruster, wie die der Inselitcn, anf drei Ringe beschränken will, habe ich mich nie befreunden können. Sie wırd, scheint mir, durch die Entwicklnngsgeschichte der einer Verwandlung unterliegenden Krebse widerlcgt, während dic althcrkömmliche augenfällige Grenzlinie zwischen Brust und Hinterleib dadurch bestïtigt wird. Nur die Rücksicht auf die Insekten konnte von dieser $a b$ und zu jener neucn künstlichen Demarcationslinie hinfübren. Wenn nun aber überlaupt Kruster in ihren Körpcrabschnitten mit Sicherheit den Insckten vcrglcichbar sind, so sind es gewisse Zoëraformen (z. B. von Pagurus) mit drei Paar Mundtheilen, drei Paar Füssen und anhangslosem Hinterleibe. l)iese drei Finsspaare wcrden nun allerdings, wie jene Auffassung will, zu Kieferfissen des Krebses, aher die fünf eigentlichen Fusspaare desselben entstehen nicht etwa aus dem Hinterleibe dcr Zoëa, wälırend hinten ein neues "Postabdomen" hervorsprosst, - sondern sic entstehen vor dem Hinterleibe und lïufig gleichzeitig und in gleicher Form mit dem dritten Pare dcr Kieferfüsse. Sie sind als ein den lnsekten ganz fehlender Zuwachs zur Brust zu betrachten, und es wiederholt sich hier noch einmal der Vorgang, dass nach dem Auftreten neuer hinterer Füsse die vorderen ilırer ursprünglichen Verrichtung untren und zu Fühlern oder Fresswerkzeugen werden.

3) Die beiden letzten Hintcrleibsringe, die meist so auffallend von den vorhergelıenden ab- 
Das Schild, das die drei hintersten Brustringe unbedeckt lässt, ist flach, fast gar nicht seitlich herabgebogen. Sein hinterer Theil hat ungefähr die Gestalt einer sog. Seemaus, also eines Vierecks, dessen Ecken in vor- und hinterwärts gerichtete Spitzen ausgezogen, dessen Vorder- und Hinterrand gleich breit (etwa $2 / 3$ der Iänge), und dessen Seiten sanft gewölbt sind. Der Hinterrand ist in der Mitte, so weit er dem Körper aufliegt, ausgebuchtet. Die vorderen Ecken liegen über dem Ursprunge der hinteren Fühler; zwischen ihnen setzt sich das Schild nach vorne fort, rasch sich verjüngend und in eine Spitze auslaufend, die den Körper um etwa 1/6 seiner länge überragt. Die Länge des vom Schilde bedeckten vorderen verhält sich $\mathrm{zu}$ der des hinteren unbedeckten Körpertheiles etwa wie $3: 5$.

Der vorderste, Augen und Fühler tragende Abschnitt des Körpers (Fig. 2), der fast ganz von einer ansehnlichen Nervenmasse gefüllt ist, bildet ein $0,28 \mathrm{~mm}$ langes, hinten ebenso, vorn halb so breites Viereck, in dessen Mitte auf der Unterseite ein kurzer vorwärts gerichter Dorn steht. Von seinen vorderen Ecken entspringen die Augen, deren äusserste Wölbungen, wenn sie gerade seitwärts gerichtet. $0,5 \mathrm{~mm}$ ron einander entfernt sind; $1 / 3$ dieser Entfernung kommt auf den Stirnrand und die schlanken Grundglieder der Stiele. Das Endglied des Augenstieles bildet einen schiefen Kegel, dessen vorderer Rand etwa $\% / 3$ des hinteren misst; letzterem kommt der Durchmesser der Grundfläche etwa gleich, über welche sich das eigentliche Auge wölbt.

Unter dem Stirnrande sieht man in der Mitte eines halbkreisförmigen Vorsprunges ein kleines schwarzes un pares $\mathrm{A} u g \mathrm{e}$, welches vielleicht darauf hindeutet, dass auch hier die Entwickelung mit einäugigen Zuständen beginnt.

Etwas näher den Augen als den hinteren Fühlern entspringen vom Rande des Körpers die vorderen Fühler, die auf dreigliedrigem Stiele einen zweigliedrigen oberen und einen ungegliederten unteren Ast tragen und etwa 1/s der Körperlänge erreichen. Von den drei Gliedern des Stieles ist das mittlere halb so lang als jedes der beiden anderen; die beiden ersten sind walzenförmig, das dritte nach oben verdickt. Der obere Ast ist schlank, von der I.̈̈nge des Stiels und trägt eine lange Borste am Ende des ersten, zwei am Ende des kurzen zweiten Gliedes. Der untere Ast ist kegelförmig zugespitzt, kürzer, aber weit dicker als der obere, mit langer Endborste; er trägt (Fig. 3) etwa in der Mitte seiner oberen Fiäche sechs dünne, walzenförmige Fäden oder "Stäbchen" mit abgerundeter Spitze und sehr zarten Umrissen. Die drei oberen sind etwa $0,2 \mathrm{~mm}$ lang; die drei unteren erreichen nur $1 / 3$ dieser Länge.

In Bezug auf diese „Stäbchen“ an den inneren Fühlern der Krustar sei mir eine kleine Abschweifung gestattet. Es scheinen diese Gebilde, auf die man in neuerer Zeit bei niederen Krustern von mehreren Seiten aufmerksam geworden ist ${ }^{1}$ ) sehr allgemein in der ganzen Klasse verbreitet $z u$ sein. Ich fand

weichen, denselben unter eigenem Namen, als Schwanz, entgegenzustellen, lässt sich ebenfalls aus der Entwickelungsgeschichte der Genannten rechtfertigen

I) Schüdler sal sie 1846 bei Acanthocercus, L, y dig 1851 bei Branchipus, später bei Polyphemus u. a. Daphniden, Max Schultze 1852 bei Balanenlarven. Auch, ,eigenthümliche, schotenförmige, gestielte Anhängsel" (Fig. 12), die mir 1846 am dritten und den folgenden Geisselgliedern der inneren Fühler des Sphaeroma der Ostsee auffielen, dürften trotz der abweichenden Gestalt hierher gehören. 
sie bei verschiedenen Copepoden, bei den Larven von Balanen und Rhizocephalen, bei jungen Bopyrus, bei Tanais u. a. lsopoden, bei Caprella, bei vielen Gammarinen, bei Hyperia, bei Cuma und Bodotria und bei allen stielaugigen Krebsen. die ich darauf untersuchte. Ich vermisste sie nur bei einigen Schmarotzern (Bopyrus, Cymothoa) und landbewohnenden Krustern (Ligia, Orchestia). Von zwei hiesigen Arten der letztgenannten Gattung fehlen sie der einen, während die andere sie besitzt ${ }^{1}$ ). Ihre Zahl und Anordnung, ilure Grösse und Form unterliegt vielfacher Verschiedenheit. Ein einziges Stäbchen fand ich an der Spitze der Fühler bei mehreren Isopoden (Fig. 15), mitten am Fühler bei einem Copepoden (Fig. 18); einen Fächer von etwa zehn Stäbchen bei jungen Bopyrus (Fig. 13). Bei Isopoden, Caprellen, Amphipoden pflegen sie zu einem oder zweien an der Spitze und auf der unteren Seite der Geisselglieder zu stehen, bald aller, bald mit Ausnahme der unteren (Fig. I4. 17). Bei Squilla, wo der äussere Ast der inneren Fühler sich nochmals spaltet, fand ich sie zu drei am Ende der I4 letzten Glieder des kürzeren 42-gliedrigen Zweiges. Bei den Decapoden scheinen sie meist den Anfang der Geissel einzunehmen und das Ende frei zu lassen. So bei Mysis, wo sie bei einer Art (Fig. Io) sich auf einem eigenen Vorsprung zusammendrängen. So auch bei Krabben, Porcellanen und Paguren (Fig. 8), wo sie in grösster Zahl und ansehnlichster Grösse (bis $1 \mathrm{~mm}$ lang) vorkommen und in einer oder mehreren Querreihen die dicken kurzen Glieder des einen aus verdickter Basis rasch verjüngten Fühlerastes besetzt halten. Wo die vorderen Fühler noch als Füsse dienen. fehlen die Stäbchen, wie bei Garneelenlarven 2), oder entspringen vom Körper selbst, wie bei den Jarven der Balanen und Rhizocephalen.

Die Gestalt der Stäbchen ist in der Regel einfach walzenförmig; unten zwiebelförmig angeschwollen und hier mit derberer Hülle versehen fand ich sie bei Squilla (Fig. 11), bei einer kleinen Garneele (Ilippolyte? Fig. 9) und bei Ocypoda. Das Ende ist meist halbkuglig abgerundet und zeigt bisweilen einen kleinen stärker lichtbrechenden Fleck. Bei der erwähnten Garneele (Fig. ga) war dem abgerundeten Ende ein kurzes, zartes Spitzchen aufgesetzt. Biswerilen sind sie nach dem Ende zu verjüngt; so fand ich sie bei Pagurus; hicr, wie bei Krabben und Porcellanen, sind sie durch zarte Ringfurchen in kürzere oder längere Glieder

I) Zusatz von M. Schultze: Ausführlicher noch als an den Fritz Müller bekannten Stellen sind die in Rede stehenden Gebilde geschildert von de la Valette in seiner Inauguraldissert. de (iammaro puteano 185\%, von Leydig Naturgeschichte der Daphniden 1860. p. $42-46$ und am genauesten von demselben in dem Archiv für Anatomie und Physiologie 1860. „Ueber Feruchs- und Gehörorgane cler Krebse und Insekten“ p. 28 I ff. Leyding kommt wie Fritz Müller zu dem Schlusse, dass die Gebilde aller Wahrscheinlichkeit nach Geruchsorga ne seien. Was aber als das eigentlich (barakteristische für die als Geruchsorgane zu deutenden Anhänge zu gelten habe, geht auch aus Leydig's Darstellung noch nicht hervor, doch dürfte vorläufig, abgeseben von ihrem Sitze an den Antennen (bei den Krebsen am imneren Fühlerpaare), ihıem Nervenreichthume und einer gewissen Zartheit der äusseren IIaut die stumpf geendigte Spitze und der Anschein einer Oeffnung an derselben als charakteristisch gelten. IIiernach würden die zuerst von mir bei Balanenlarven beschriebenen neben dem Auge entspringenden borstenartigen Fühler (siehe Zeitschr. f. wiss. Zoologie Bd. IV. I852. p. I9I), welche spätere Reobachter übersahen, firitz M üller aber wiederfand und mit zu den Geruchsorganen rechnet, eher Tastorgane sein. '

2) Die Fühler der Garneelen sind umgewandelte Schwimnfüsse; schwerlich aber umgekehrt die Ruderfüsse der Daphnien ,,umgeformte Antennen.“ 
getheilt und kegelförmig zugespitzt. Bei grösseren Stäbchen erscheint der Inhalt bisweilen zart längsgestreift, oder man sieht längsgeordnete feinste Körnchen.

Aeste und einen vinzigen Taster; der hintere (Fig. 6) ist ein ganz ungegliedertes längliches Stummelchen mit einigen Borstchen am Ende.

Welches ist nun wohl die Verrichtung dieser stäbchentragenden Fühlergeisseln? Will man nicht an einen uns Landbewohnern ganz fehlenden Sinn denken, - und dafür liesse sich allerdings die Verkümmerung der inneren Fühler bei landbewohnenden Krustern, bei Asseln, bei Orchestia, bei Ocypoda ${ }^{1}$ ) anführen - so wird man kaum umhin können, sie als Geruchswerkzeuge zu deuten. Zum Betasten fester Körper sind sie bei den Krabben, wo ihr Stäbchenbesatz gerade am reichsten entwickelt ist, untauglich wegen ihrer Lage, ihrer geringen Länge und selbst wohl wegen jener so zarten, leichtverletzlichen Anhänge. Bewegungen des Wassers wahrzunehmen, wozu ebenfalls schon ihre Kürze sie wenig passend erscheinen lässt, hindert sie eine lebhafte vom Munde aus bei ihnen vorüberziehende Strömung. In einer solchen vom Munde wegführenden Strömung wird man ebenfalls kein Geschmackswerkzeug suchen wollen. Es bleibt so von unsern fünf Sinnen nur der Geruch übrig. Derselbe kann Thieren nicht fehlen, die sich durch stark riechende Köder anlocken lassen. Sieht man nun, wie die inneren Fühler der Krabben, Porcellanen, Paguren, in fast ununterbrochener Bewegung sind, in kurzen, raschen Schlägen mit ihrem Stäbchenbüschel das Wasser gleichsam durchfühlend, das in beständigem Strome bei ihnen vorüberzieht, so darf man sie wohl für ebenso geeignet zu Wahrnehmung von Gerüchen halten, wie die bisher als Geruchswerkzeuge gedeuteten Teile im Grundgliede der äusseren oder inneren Fühler hierzu ungeeignet erscheinen, da ihnen das unerlässlichste Erforderniss eines Geruchwerkzeuges, leichter und freier Zutritt des Wassers, abgeht ${ }^{2}$ ).

\section{Ich kehre zurück zu unserer Larve.}

Die hinteren Fühler entspringen ebenfalls vom Rande des Körpers an den hinteren Ecken des erwähnten, Augen und Fühler tragenden Vierecks; kaum kürzer als die vorderen bestehen sie aus einem zweigliedrigen Stiele und einem gegen das abgerundete Ende etwas verbreiterten und mit Borsten besetzten blattförmigen Endgliede, das dem Stiele an Länge gleichkommt und in der Ruhe hinterwärts gerichtet ist. Die gegliederte Geissel der erwachsenen Maulfüsser vermisse ich.

Der Mund liegt in der Mitte zwischen den vier seitlichen Ecken des Schildes; vor ihm eine ansehnliche helmförmige Oberlippe; zu seinen Seiten die anscheinend tasterlosen Oberkiefer (Fig. 4), mit je drei spitzen Zähnen bewaffnet, die nach hinten an Länge zunehmen und an ihrem vorderen Rande wieder fein gezähnelt sind. Dann folgen zwei Paar schwach entwickelter Un ter kiefer; der vordere (Fig. 5) hat zwei mit je drei dornartigen Borsten bewaffnete

1) Auch bei Gelasimus finde ich die Stäbchen ungewöhnlich zart und kurz.

2) Wenn Leydig (Histologie p. 280) mit Recht Bedenken trïgt, eine Höhlung, in der sich ,allerlei Detritus“ anzuhäufen pflegt, ohne Weiteres als „Ohrhöhle“ anzuerkennen, so dürfte dieser wenig zugängliche Raum mil seiner Ansammlung verwesender Stoffe gewiss noch weniger sich als "Nasenhöhle“ empfehlen. 
Das nächstfolgende Fusspaar ist dünn, schlank, fünfgliederig, und reicht zu den Seiten des Mundes nach vorn bis fast zum Ursprunge der hinteren Fühler; seine beiden letzten kurzen Glieder pflegen einwärts und rückwärts gerichtet zu sein.

Dicht dahinter entspringen die ansehnlichen R a ubfüsse. Das Thierchen liebt sie, während es senkrecht im Wasser schwebt, weit ausgespreizt zu tragen (Fig. 1). Dann reicht das Grundglied quer nach aussen bis zum Rande des Schildes; das zweite und dritte bilden einen gegen das Ende schwach verdickten, I mm langen Stiel, der schief nach oben gerichtet bis zur Höhe der Augen reicht; das vierte Glied ist kurz und undeutlich geschieden und verbindet den Stiel mit dem wagerecht nach aussen gerichteten, 1 mm langem Handgliede, das schwach keulenförmig verdickt ist und am geraden Innenrande einen längeren und eine Reihe ganz kurzer Dornen trägt. Die Klaue endlich ist schwach gekrümmt, ungezähnt und hat etwa $2 / 3$ der Länge des Handgliedes. Am Grunde der Raubfüsse bemerkt man einen kleinen rundlichen, blatt- oder blasenförmigen Anhang.

Hinter den Raubfüssen folgen sechs anhangslose Ringe; die drei vorderen, noch vom Schilde bedeckt, aber nicht mit ihm verwachsen, nehmen nach hinten an Länge zu und verhalten sich etwa wie $2: 3: 4$; zusammen sind sie halb so lang als die drei hinteren, die unter einander gleich sind. Die sechs Ringe zusammen sind $0,75 \mathrm{~mm}$ lang; ihre Breite beträgt $0,2 \mathrm{~mm}$.

Um die Hälfte breiter, an den Gelenken etwas eingeschnürt und an den hinteren Ecken mit je einem kurzen Dorne bewehrt, erscheinen die folgenden fünf Ringe, die zusammen reichlich $1 / 4$ der Körperlänge ausmachen. Die vier vorderen von diesen fünf Ringen tragen Schwimmfüsse (Fig. 7), die alle in gleicher Weise gebildet sind; ein $0,3 \mathrm{~mm}$ langes, kräftiges, an Ende etwas verbreitertes Grundglied trägt zwei etwa halb so lange mit Borsten besetzte Endblätter, von (lenen das innere gegen das Ende seines Innenrandes einen kleinen fingerförmigen Fortsatz hat. Kiemen fehlen noch vollständig.

Der Schwanz endlich, aus einem einzigen Stücke bestehend, bildet ein ansehnliches, viereckiges Blatt von etwa 1/5 der Körperlänge und kaum minderer Breite; seine Seitenränder sind sanft gewölbt, sein Hinterrand seicht ausgebuchtet; 16 winzige Zähnchen stehen in dieser Ausbucht, ein etwas längeres an jeder Hinterecke und sechs an jedem Seitenrande.

Der einzige Maulfüsser, den ich hier kenne, ist eine Squilla, wenig oder nicht verschieden von Squ. Mantis. Ihm wird wahrscheinlich die eben beschriebene Larve zugehören. Junge Squillen derselben \rt von etwa $10 \mathrm{~mm} \mathrm{Länge,} \mathrm{gleichen}$ schon ganz den Erwachsenen bis auf die geringere Zahl der Fühlerglieder, der Zähne an den Raubfüssen, der Kiemenfäden u. dergl. - Sie hatten noch die glashelle Durchsichtigkeit unserer Larve und besassen, wie diese, ein unpaares Auge.

Desterro, im Januar 1862. 


\section{Erklärung der Abbildungen auf Tafel XX.}

Fig. I. Zoëaform ${ }^{1}$ ) eines Maulfüssers aus dem Meere v'on Santa Catharina, I 5 mal vergr.

Fig. 2-7. Einzelne Theile desselben, stärker (9omal) vergr.

Fig. 2. Vorderster Theil des Körpers, v. u.

Fig. 3. Vordere Fühler, v. d. Seite.

Fig. 4. Oberkiefer.

Fig. 5. Vorderer Unterkiefer.

Fig. 6. Hinterer Unterkiefer.

Fig. 7. Die beiden letzten Ringe der Brust und der erste des Hinterleibs mit einem seiner Schwimmfüsse.

Fig. 8-I 8. Stäbchen von den inneren Fühlern verschiedener Kruster; 9omal vergr. (mit Ausnahme von Fig. IO, I2 u. I6). s Stamm, a äusserer, $i$ innerer Ast des Fühlers,

$\therefore$ Blutgefäss.

Fig. 8. von einem kleinen Pagurus. 8 a. Die Spitze eines der Stäbchen.

Fig. 9. Von einer kleinen Garneele (Hippolyte?). 9 a. Die Spitze stärker vergr.

Fig. IO. Von Mysis (45mal vergr.).

Fig. I I. Von Squilla.

Fig. I 2. Von dem Sphäroma der Ostsee (Vergrösserung unbestimmt).

Fig. I3. Von einem jungen Bopyrus.

Fig. I 4. I 5. Von zwei verschiedenen Tanaisarten.

Fig. I6. Von Caprella (I Somal vergr.) $g$ Ganglion (?)

Fig. I 7. Von Gammarus.

Fig. I 8. Von einem Copeproden.

1) Ich möchte den Namen Zoëa auf alle Krebslarven ausdehnen, die 2 Paar Fühler, 3 Paar Mundtheile und 2 bis 3 Paar Füsse an der Brust besitzen, aber noch der 5 bis 6 letzten Paare der Brustfüsse entbehren. 


\title{
Ein zweites Bruchstück aus der Entwickelungs- geschichte der Maulfüsser ${ }^{-1}$ ).
}

\author{
Mit Tafel XXI.
}

Durch die bei einer Art ungemein reich entwickelten „Stäbchen" der inneren Fühler waren mir neuerdings die Hyperien merkwürdig geworden. Ich fing daher ein Thierchen ein, das in seinen Umrissen und durch die Art, wie es in rinem Gewimmel anderer kleiner Krebsthiere herumschwamm, an Hyperia erinnerte, und das mir durch den grünen Schimmer seiner Augen und seine Durchsichtigkeit aufgefallen war. Schon die einfache Linse zeigte, dass es nicht war wofür ich es gehalten, und eine nähere Untersuchung ergab Folgendes:

Das bis auf die Augen farblose Thier ist fast $2 \mathrm{~mm}$ lang. Sein Leib lässt drei sehr verschieden ausgestattete, nahezu gleich lange Abschnitte unterscheiden: der vordere ist ungegliedert, trägt Augen, Fühler, Mundtheile und ein ansehnliches Rückenschild, das von seiner hinteren Grenze weit nach hinten vorspringt; der mittlere, ganz von diesem Schild bedeckt, besteht aus fünf Ringen, die zweiästige Schwimmfüsse tragen; der hintere Abschnitt ist anhanglos, aus drei kurzen Ringen und einem grossen Schwanzblatte gebildet.

Die Mitte des geraden Stirnrandes trägt ëinen, ein wenig abwärts gerichteten spitzen Fortsatz, dessen Länge etwa der halben Breite des Stirnrandes gleichkommt. Seitlich, vorn an den Stirnrand sich anschliessend, springen die grossen, ungestielten und unbeweglichen, beinahe halbkugelig gewölbten A ugen vor, dcren Oberfläche in regelmässig sechsseitige Feldchen (von 0,025 mm Durchmesser) getheilt ist, und deren grüner Schimmer schon erwähnt wurde. Zwischen ihnen liegt auf der Unterfläche ein kleiner scharf umschriebenor schwarzer A ugenfleck. Hinter diesem entspringt ein kleiner vorwärts gerichteter Dorn (Fig. 2, c). Noch etwas weiter nach hinten, doch noch zwischen den Augen und ihnen genähert, stehen die inneren Fühler (Fig. 2, a; Fig. 3), die auf kurzem dünnen Stiele ein längres Endglied tragen und nur mit ihrer äussersten Spitze den Stirnrand überragen. Ausser drei Borsten an der Spitze und einer am Aussenrande tragen sie oberhalb, nahe der Spitze, drei meist stark gekrümmte, einfach walzenförmige Stäbchen mit abgerundetem Ende. Die äuss eren F ühler (Fig. 2, b) entspringen dicht hinter den Augen, nahe dem Seitenrande des Körpers, sind drei-

I) Archiv für Naturgeschichte. 186,3. I. p. I-7. Taf. I. 
gliedrig, reichen ein- und vorwärts sich krümmend bis zur Mitte des Endgliedes der inneren Fühler und tragen an der Spitze sechs gefiederte Borsten.

Den M und, der etwas hinter der Mitte des vorderen Leibesabschnittes gelegen ist, umgeben Oberlippe, Unterlippe, ein Paar Oberkiefer und ein einziges Paar Unterkiefer. Die Oberlippe (Fig. 4, $a$ ) überdeckt vollständig die Oberkiefer; ihr freier Rand erscheint bald sanft gewölbt, bald (bei stärkerer Zusammenziehung der Fig. $4, m$ gezeichneten Muskeln) in der Mitte ausgebuchtet. An den Oberkiefern (Fig. 4, b) unterscheidet man einen mehr oberflächlich nach hinten und innen mehr in der Tiefe und nach vorn gelegenen Theil ${ }^{1}$, von denen jeder mit mehreren Zähnen bewaffnet ist. Die beiden Hälften der Unter lippe (Fig. 4, $c$; Fig. 5) stossen in der Mittellinie zusammen; ihr Rand ist dicht mit kurzen Haaren besetzt. Der Unterkiefer (Fig. 4, d) hat zwei übereinandergelegene mit einwärtsgerichteten Dornen bewaffnete Vorsprünge; der dem Körper nähere trägt vier kürzere, der andere drei längere Dornen; nach hinten von ersterem liegt ein kleiner ungegliederter Anhang (Fig. 4, $d^{\prime}$ ), dessen Innenrand einige kurze Borsten trägt, und der wohl als äusserer Ast (fouet, M. Edw.) z.u deuten ist.

Mit der Rückenfläche des vorderen Leibesabschnittes ist das ansehnliche Schild verwachsen. Es beginnt hinter den Augen und reicht bis über den mittleren Leibesabschnitt hinaus, je nach dessen verschiedener Zusammenziehung: noch einen bis drei Ringe des hinteren Abschnittes bedeckend. Seine Breite ist vorn $1 / 3$ der Körperlänge (den Stirnfortsatz nicht mitgerechnet), hinten etwas geringer. Es ist seitlich nur wenig abwärts gebogen. Seine hinteren Ecken sind in zwei starke hinterwärts gerichtete Spitzen ausgezogen, (I änge $=2 / 3$ des Stirnfortsatzes) und einen (halb so langen) Stachel trägt die Mitte des Hinterrandes. Ein winziges Höckerchen (Fig. $7, n$ ) findet sich in der Mittellinie des Schildes am Anfange des letzten Drittels des unverwachsenen Theiles. Der (an den Seitentheilen einwärts gekrümmte) Rand des Schildes ist eingefasst mit einem schmalen, dünnen, fein und unregehmässig gezähnelten Saume (Fig. 7, s).

Der mittlere Leibesabschnitt ist, wie gesagt, aus fünf Ringen zusammengesetzt und trägt fünf Paar $z$ weiästiger F üsse (Fig. 4, e; Fig. 6). die bis auf einige Unterschiede in der Beborstung übereinstimmend gebildet sind; alle haben einen dicken zweigliedrigen Stamm, einen stärkeren zweigliedrigen inneren und einen schwächeren ungegliederten äusseren $\mathrm{Ast}$, der von dem inneren um die Länge seines kurzen Endgliedes überragt wird. Der äussere Ast trägt vier lïngere gefiederte Borsten am Ende, eine an seinem Aussenrande und beim vierten und fünften Fusspaare ausserdem zwei kürzere Borsten an seinem Frunde. Das Endglied des inneren Astes trägt beim fünften Fusspaare drei, beim dritten und vierten vier lange Borsten und ausser diesen bei den ersten beiden Fusspaaren einen am Ende schwach einwärts gekrümmten Dorn etwa von halber länge des Astes. Kürzere Borsten stehen am Innenrande des inneren Astes.

Die drei folgenden anhanglosen Ringe machen zusammen kaum 1/9 der Körperlänge aus und tragen jederseits je ein winziges rückwärts gerichtetes Dörnchen.

I) Dieser tiefer gelegene Theil des Oberkiefers ist wahrscheinlich von mir bei der älteren nur einmal gesehenen Maulfüsserlarve übersehen worlen. 
Der Schwanz ist ein ansehnliches spatelförmiges Blatt von 0.3 der Leibeslänge; seine Breite kommt in der Nitte der I,änge fast gleich, ist hinten nur wenig geringer, vorn nur halb so gross. Der ziemlich gerade Hinterrand trägt vier grössere, schmale und spitze Zähne; zwei davon nehmen die hinteren Ecken ein; zwischen jedem von diesen und dem nächsten der beiden mittleren Zähne stehen vier, zwischen den beiden mittleren stehen zwei halb so lange Zähnchen; vier bis fünf weit kleinere Dörnchen stehen in jeder der so gebildeten 13 Buchten. Jeder Seitenrand trägt in seiner hinteren Hälfte drei schmale rückwärts gerichtete Zühne.

Das Verdauungrohr, von ziemlich gleichbleibender Weite, steigt vom Munde schief nach vorn in die Höhe, um dann umbiegend gerade zum After zu laufen, der am Anfange des Schwanzblattes gelegen ist. Im hinteren Theile des vorderen Leibesabschnittes nimmt es die farblose Absonderung von zwei vorderen und zwei hinteren weiten Leberschläuchen (Fig. $7, l$ ) auf. I)ie vorderen Leberschläuche sind kurz, schief nach vorn und aussen gerichtet, die hinteren begleiten den Darm bis fast zum Schwanze und haben vorn eine ansehnliche Erweiterung (Fig, 8, $l^{\prime \prime}$ ).

Das dem Darme aufliegende Herz ( $\mathrm{Fig} .7, a)$ bildet in den fusstragenden Ringen einen gleichmässig weiten Schlauch, der im vorderen Leibesabschnitte, über der erwähnten Erweiterung der hinteren Leberschläuche, sich aufs Doppelte erweitert und im hinteren Drittel dieses Abschnittes endet. Hier, an seinem vorderen Ende, wird es durch zwei ansehnliche dreieckige seitliche Muskelbündel (Fig. $7, i$ ) an die Rückenwand befestigt. Für den Eintritt des Blutes sind fünf Paar Oeffnungen vorhanden, ein Paar nahe dem hinteren Ende des vorderen Leibesabschnittes, die folgenden ungefähr den Grenzen der fünf fusstragenden Ringe entsprechend. Die vier vorderen Paare (Fig. 7, b) bilden ansehnliche mit Klappen versehene Spalten; die des letzten Paares (Fig. $7, c$ ) sah ich einmal sehr deutlich kreisförmig; andere Male waren sie minder deutlich zu erkennen und schienen den vorderen ähnlich zu sein. - Innere balkenartige Muskeln fehlen dem Herzen.

Die vom Herzen abgehenden Gefässe beschränken sich auf ein vorderes und ein hinteres. Am Eingange des ersteren (Fig. 9) liegen ähnliche Klappen, wie an den seitlichen Spalten. - Von diesem vorderen Gefässe geht ein starker unpaarer Ast zwischen Schlund und Hirn nach unten, ein anderer jederseits nahe dem Stirnrande bis zum Auge, während der schwache Endagt etwa in der Mitte des Stirnfortsatzes sich öffnet. Das aus den Aesten des vorderen (iefässes austretende Blut strömt in der leibeshöhle lebhaft nach hinten. Das hintere Giefäss endet mit weiter Oeffnung (Fig. $7, h$ ) etwas hinter dem After.

Selbst durch schwachen Druck des Deckgläschens, der eben hinreicht, das Thier festzuhalten, wird der Blutlauf in Schwanzblatte leicht gestört; die dem Gefässe entströmenden Blutkörperchen zögern oder stocken ganz in der Nähe der hinteren Ecken, und man hat dann hier Gelegenheit, aufs Gemächlichste die merkwürdige eigene Bewegung der Blutkörperchen (Fig. 10) zu beobachten, die Lieberkühn bei den farblosen Blutzellen der Wirbelthiere kennen gelehrt hat. Sie besteht bei unseren Krebschen hauptsächlich darin, dass das Blutkörperchen einen oder zwei kurze spitze Fortsätze ausschickt, und ist so langsam, dass man sie nur an der nach einiger Zeit veränderten Gestalt des Blutkörperchens 
erkennt. Man überzeugt sich leicht, dass diese Formveränderungen, und dass die unregelmässigen Gestaiten der Blutkörperchen nicht etwas Krankhaftes, etwa eine Erscheinung des Absterbens sind, wie man wohl geglaubt hat; denn dieselben mannichfachen Gestalten, die nach und nach dasselbe im Schwanzblatte ruhende Blutkörperchen annimmt, findet man wieder in dem kreisenden Blute des eben eingefangenen lebensfrischen Thieres.

Meine lückenhafte und der Nachprüfung bedürftige Beobachtung über die Anordnung des Nervensystems übergehe ich.

Ueber die Deutung des eben beschriebenen Krebschens als Maulfüsser1 a rve dürfte namentlich nach dem Bau des Herzens kaum ein Zweifel sein. Ob sie zu derselben Art, oder wenigstens in dieselbe Entwickelungsreihe mit der älteren Larve gehört, die ich vor Kurzem beschrieb, ist schwerer zu entscheiden. Doch vermuthe ich es. Unter einer nicht unbedeutenden Zahl von Krebslarven, die ich kenne, sind diese beiden die einzigen, die das kleine Dörnchen zwischen dem Ursprunge der Fühler besitzen. Jedenfalls gehört die Larve einem in der Nähe der Küsten lebenden Thiere an; die sieben Exemplare, die ich untersuchte, fing ich an drei aufeinander folgenden Tagen bei anhaltendem Südwinde, bei dem niemals Thiere der hohen See in unsere Bucht kommen.

Gehören beide Larven zusammen, so wird die Entwickelung jener älteren aus dieser jüngeren kaum anders vor sich gehen können, als dass die drei vorderen Fusspaare sich in das zweite Paar der Unterkiefer und die zwei ersten Paare der Kieferfüsse umbilden, und dass zwischen ihnen und den beiden hinteren Fusspaaren die sechs anhanglosen Ringe der älteren Larve entstehen.

Desterro, Mitte Februar i 862.

\section{Erklärung der Abbildungen auf Tafel XXI.}

Fig. I ist $45 \mathrm{mal}, 2$ bis 8 sind gomal, 9 und 10 sind I Somal vergrössert.

Fig. 1. Stomatopodenlarve von Praia de fora bei Desterro, v. u.

Fig. 2. Die Fühler, in ihrer gegenseitigen Lage, v. u. $a$ der rechte innere, $b$ der linke äussere Fühler; $c$ der kleine Dorn zwischen ihnen.

Fig. 3. Spitze des vordern Fühlers, v. d. Seite.

Fig. 4. Mundtheile in natürlicher Lage; $a$ Oberlippe; $b$ Oberkiefer; $c$ Unterlippe; d Unterkiefer; $d^{\prime}$ äusserer Ast desselben; $e$ Fuss des ersten Paares; $m$ Muskeln der Oberlippe.

Fig. 5. Unterlippe.

Fig. 6. Fuss des vierten Paares; $a$ äusserer, $i$ innerer Ast.

Fig. 7. Herz und Gefässe von oben. a Herz; b Spalten zum Eintritte des Blutes; r runde Oeffnungen ohne Klappen; $d$ Klappen am Ursprunge des vorderen Gefässes; e vorderes Gefäss; $f$ Ast desselhen, der zwischen Schlund und Hirn nach unten geht; $g$ hinteres Gefäss; $h$ dessen hintere Oeffnung; i Flügelmuskeln des Herzens; j Muskeln, (lie den Schlund an den Rücken heften; $k$ Muskeln, die den After öffnen; l Leber; m Auheftungsstelle des Rückenschildes; " ein kleiner Dorn des Rückenschildes; $s$ der gezähnelte Saum desselben.

Fig. 8. Der vordere 'Teil der Leber, v. o. S Schlund; d Darm: $l$ rordere, $l$ ' hintere Leberschläuche; $l^{\prime \prime}$ Erweiterung der letzteren.

Fig. 9. Ursprung des vorderen Gefässes aus dem Herzen. a eine nft \%u beobachtende doch nicht bleibende Einschnürung dieses Gefässes.

Fig. 10. Blutkörperchen. 


\section{Die Verwandlung der Garneelen $\left.{ }^{1}\right)$. \\ Erster Beitrag.}

Mit Tafel XXII.

Milne Edwards deutete als wahrscheinlich der Gattung Penëus zugehörige Garneelenlarve einen kleinen Krebs, den man früher als eigene Gattung Cryptopus Latr., den Schizopoclen zugezählt hatte. Krebschen, die im allgemeinen Ansehen noch enger den Schizopoden sich anschliessen, im Besitze dreier Scheerenpaare mit Cryptopus und Penëus übereinstimmen, beobachtete ich in mehreren Arten und konnte sie zurückverfolgen zu scheerenloser Mysisform, von da zur Gestalt einer Zoëa, und eine Arl weiter bis zur Gestalt eines Nauplius, zu jener jugendlichen Grundform also, die schon die Rhizocephalen und I.ernaeen mit den Rankenfüssern und der formenreichen Gruppe der Cyclopen verbindet.

Von der Zoëaform wurden fünf verschiedene Arten und einige derselben ziemlich häufig während des ganzen Sommers beobachtet; die unveränderte Naupliusform, wahrscheinlich dieselbe, in der das Thier aus dem Eie schlüpft. kam ein einziges Mal ( 13 . December) zur Beobachtung ${ }^{2}$.

Der Körper dieser jüngsten Larve (Fig. 1) ist ungegliedert, birnförmig, $0,4 \mathrm{~mm}$ lang, vorn abgerundet und $0,2 \mathrm{~mm}$ breit, nach hinten bis auf $1 / 5$ der Körperlänge verjüngt, hinten abgestutzt und seicht ausgerandet. Nahe dem Vorderrande steht ein kleines, schwarzes, scharfunschriebenes Auge. Der Hinterrand trägt jederseits eine starke gerade Borste von lialber Körperlänge und daneben einen kurzen Dorn. Der Unterfläche des Leibes entspringen sechs schlanke, langbeborstete Füsse, von denen die vorderen und mittleren $4 / 5$, die hinteren etwa die Hälfte der Körperlänge erreichen. Die vorderen stehen dicht am Stirnrande, die mittleren nahe dahinter, die hinteren etwa in der Nitte cles Körpers. Dic vorderen sind einfach, die mittleren und hinteren zweiästig; der hintere Ast erscheint als unmittelbare Fortsetzung des Stammes, und ist stärker, bei den hinteren Füssen auch viel länger als der vordere. Deutliche Gliederung ist nirgends an

1) Archiv für Naturgeschichte. I863. I. p. 8-23. Taf. II.

2) Dies beweist, dass wenigstens zur Zeit der Fortpflanzung die Eltern sich nicht in der Nähe des Strandes aufhalten, da sonst umgekehrt die jüngsten Larven die häufigsten sein müssten. Einc dem Penëus Caramote nahe stehende Art, die hier häufig unter dem Namen Camarão verspeist wird, erscheint im Sommer überhaupt nur spärlich und kaum je über mittelgross auf dem Markte. 
den Füssen zu erkennen, eine Andeutung ron vier bis fünf Gliedern ist am hinteren Aste der mittleren Füsse zu sehen. Eine starke Borste von Körperlänge steht nebst einigen kürzeren an der Spitze der vorderen Füsse, zwei an der Spitze des vorderen Astes, sechs am vorderen Rande und der Spitze des hinteren Astes der mittleren Füsse; je zwei Borsten an der Spitze und eine unter derselben an jedem Aste der hinteren Füsse.

Das Thierchen ist ziemlich undurchsichtig und von bräunlicher Färbung, die besonders an der Spitze der Füsse stärker hervortritt. Die Bildung des Mundes und der inneren Theile wurde nicht beobachtet.

Die ziemlich biegsamen Füsse bilden mit ihren sparsamen langen Borsten eben kein rasch förderndes Bewegungswerkzeug. Ein Mann, der senkrecht im Wrasser schwebend, mit weit ausgebreiteten Armen, schwanke Weidengerten in der Hand, sich emporarbeiten wollte, würde etwa ein Bild der eigenthümlichen Bewegungsweise geben, an der man auf den ersten Blick unter Hunderten anderer kleiner Kruster diese Nauplius und die daraus hervorgehende Zoëa erkennen kann ${ }^{1}$ ).

Bei einer wenig grösseren (o,5 mm langen) Larve (Fig. 2), die in allgemeiner Körpergestalt, Bildung der Füsse und Färbung mit der vorigen übereinstimmt (am I3. Januar gefangen), hat sich das Hinterende in zwei dicke kegelförmige Zapfen ausgezogen, an deren Spitze jetzt die beiden langen Schwanzborsten stehen, begleitet nach innen von je zwei, nach aussen von je drei kürzeren, zum Theil noch dornartigen Borsten. Auch die Zahl der Borsten an den mittleren Füssen hat sich vermehrt. Als erste Andeutung des Rückenschildes zieht sich ziemlich in der Mitte des Körpers eine Hautfalte quer über den Rücken. Die hinteren Füsse sind mehr nach vorn und näher an die Mittellinie, an den zwischen ihnen liegenden Mund gerückt, vor welchem, zwischen den mittleren Füssen eine grosse helmförmige Oberlippe (,Mundkappe“) gelegen ist. Der kurze Stamm dieser Füsse hat sich fast kuglig verdickt; offenbar bildet sich in seinem Inneren irgend ein neuer Theil, dessen Umrisse aber noch nicht deutlich hervortreten. Hinter dem Munde, das mittlere Drittel der Körperlänge füllend, sind aus der Bauchfläche vier Paar langer plumper Zapfen hervorgesprosst, die sich hinterwärts dem Körper anlegen. In der Gestalt der ersten beiden Paare lassen sich schon die späteren Unterkiefer erkennen.

Eng an diese Larve schliessen sich vier andere an, die - wahrscheinlich demselben Schwarme entstammend - gleichzeitig (24. Januar) gefangen wurden. In der Anschwellung am Grunde der hinteren Füsse (Fig. 3) sind deutlich die Umrisse des späteren Oberkiefers zu erkennen; aus dem hinteren Aste hat sich der lebende Inhalt mehr oder weniger vollständig zurückgezogen; der vordere Ast ist noch ziemlich gefüllt, aber schon zu sehen, dass auch ihm nach der Häutung Borsten fehlen werden. Von diesen Füssen wird also, ausser dem zum Oberkiefer umgewandelten Stamme, nur ein kurzes borstenloses Stummelchen übrig bleiben. -. (Ein solches, durch seine dunkle bräunliche Färbung sehr augenfällig, wurde

I) An dieser Bewegungsweise hatte ich nit blossem Auge das eben beschriebene Thierchen als Penc̈uslarve erkannt; das Mikroskop liess diese Deutung, wenn nicht als irrig, so doch als höchst unwahrscheinlich erscheinen. Einen Monat später fanden sich Mittelformen, die dem unbewaffneten Auge gegen das Mikroskop Recht gaben; letzteres allein hätte mich wahrscheinlich nie die wahre Natur meines Nauplius ahnen lassen. 
in der That einmal, am 3. Januar, bei einer sehr jungen \%oëa beobachtet; sehr bald aber schwindet auch dieses vollständig.) - Zwischen dem Ursprunge der beiden vorderen Füsse sind jetzt schon zwei ansehnliche in der Nittellinie zusammenstossende Ganglien zu unterscheiden. Im vorderen Winkel zwischen diesen beiden Ganglien liegt das Auge, umgeben von mehreren kleinen orangefarbenen Kügelchen (Oeltröpfchen?). Ueber dem Auge, es von oben verdeckend, hat sich ein trübes, feinkörniges Gewebe gebildet, dem jederseits ein kleines, durchsichtiges, halbkuglig über den Stirnrand vorspringendes Knöpfchen aufsitzt. Darm, I.eber und Herz sind schon in ähnlicher Form vorhanden, wie bei den jüngeren Zoëa. Wahrscheinlich schon mit der nächsten Häutung, darauf deuten die bereits angelegten Borsten derselben hin, treten die Fussstummel in Thätigkeit und aus dem Nauplius wird eine Zoëa, auf deren Anhänge sich schon ungezwungener dic für die erwachsenen Thiere üblichen Namen anwenden lassen. Ich bezeichne also weiterhin die beiden ersten Fusspaare des Nauplius als Fühler, das dritte als Oberkiefer, von den vier neuen Fusspaaren die beiden vorderen als Unterkiefer, die hinteren als Kieferfüsse.

Als Zoëa (Fig. 4-8) wurde unsere Larve von 0,8 bis I,6 $111 m$ länge beobachtet. Während dieses Lebensabschnittes entwickeln sich die paarigen Augen; es bilden sich io oder 11 neue Ringe, an dem ersten derselben ein Fusspaar und an den fünf folgenden die Anlagen von solchen, so wie endlich die seitlichen Schwanzanhänge. Diese neuen Theile sind natürlich in sehr wechselnder Gestalt zu finden; im Uebrigen erleiden die Thiere keine erheblichen Veränderungen, selbst nicht in der Grösse; denn die Zunahme der Länge rührt fast ausschliesslich von der wachsenden Ausdehnung der 1 I neuen Ringe her.

Das Rückenschild, o, 4 bis $0,5 \mathrm{~mm}$ lang, ist anfangs fast kreisrund und flach ausgebreitet. Bald biegt es sich herab und deckt von den Seiten die Mundtheile und die Grundglieder der Füsse. Hinten erhält es, sn weit es dem Körper aufliegt, eine seichte Ausbuchtung: Während es bei seinem ersten Auftreten (s. o.) hinter dem jetzigen Oberkiefer von dem Körper sich abhebt, geschieht dies hinter dem zweiten Paare der Kieferfüsse und frei vorspringend deckt es noch $2-3$ der neu sich bildenden Ringe. Vorn ist es zuerst von den aneinanderstossenden Augen bedeckt (Fig. 4); wenn diese später auseinanderweichen, überdeckt es den Zwischenraum und den Grund der Augenstiele mit einem dreieckigen Fortsatze, der in einen bis $0,12 \mathrm{~mm}$ langen Stachel ausläuft (Fig. 7). Andere stachelförmige Fortsätze fehlen ihm.

Unter diesem vordersten Theile des Rückenschildes und den paarigen Augen liegt das un paare A uge: die ganze Breite $(\mathrm{O}, \mathrm{I} \mathrm{mm})$ zwischen dem Ursprunge der vorderen Fühlerr füllen zwei ansehnliche Ganglien, dic in der Mittellinie zusammenstossen; ihre vorderen Flächen sind stark gewölbt und über beide spannt sich in einem ziemlich halbkreisförmig gewölbten Bogen die L.eibeshaut. Aus der Tiefe des so zwischen den Ganglien und der Haut frei bleibenden Raumes erhebt sich ein keulenförmiges Stäbchen (.,Krystallkegel"), das fast die Haut erreicht und in seinem unteren Theile von schwarzen Farbkörnchen umlagert ist. Die Haut schien mir bei dieser Art ohne linsenförmige V'rrdickungen zu sein.

Die F ühler bilden noch das hauptsächlichste Bewegungswerkzeug, während sie bei allen anderen \%oëa (der Maulfüsser, Krabben, Porcellanen, Paguren und 
der in Zoëaform das Ei verlassenden Garneelen) nichts mit der Ortsbewegung zu thun haben.

Die vorderen (inneren) Fühler $(0,4 \mathrm{~mm}$ lang) erscheinen jetzt in vier (ilieder geschieden, von denen das erste fast die Hälfte der Länge einnimmt; die längste der drei starken Endborsten hat fast die doppelte Länge des Fühlers. Dicht an den Endborsten, nach aussen von ihnen, stehen ein oder zwei zarte o, $09 \mathrm{~mm}$ lange Stäbcheu, und ein oder zwei andere etwas unter der Spitze an der Aussenseite des Endgliedes. Die hinteren (äusseren) Fühler sind jetzt dicht an die Seite der inneren gerückt und erreichen nur etwa $2 / 3$ von deren Länge; ilhr dicker Stamm lässt 2, der innere (vordere) Ast 3, der äussere (hintere) bis Io Glieder unterscheiden. Wie früher ist der innere Ast wenig kürzer aber viel schmächtiger als der äussere. Die Zahl der gefiederten Borsten des äusseren Istes steigt bis auf 10 , von denen + an der Spitze, die anderen am Ende der sechs vorhergehenden Glieder stehen.

Die grosse Oberlippe $(L)$ hat etwa die Gestalt eines preussischen Soldatenhelmes, den man sich nur breiter und dessen Schirm man sich bedeutend vergrössert und in der Mitte ausgerandet denken müsste. Der Helm, dessen Spitze vorwärts gerichtet ist, $1^{\text {t }}$ unbeweglich und von ihm gehen Muskeln in den beweglichen Schirm, der sich deckend über den Mund und einen Theil der Oberkiefer legt.

Von den kräftigen Oberkiefern $(I I I)$ fällt bei Betrachtung des unverlctzten Thieres von unten nur ein langer 2-3-spitziger Zahn in die Augen, der weit über die tiefer gelegene mit niedrigen Leisten und Höckern besetzte Kaufläche vorspringt. Am Grunde des Zahnes, nach der Kaufläche zu, stehen mehrere derbe, mit kurzen Dörnchen besetzte Borsten (Fig. 8). - Die Oberkiefer sind tasterlos. Es scheint clies eine Eigenthümlichkeit zu sein, in der alle Zoëa mit den Insekten übereinstimmen und die hier doppelt auffallend ist, da nicht nur das erwachsene Thier Kiefertaster besitzt, sondern auch die jüngeren Larven an dieser Stelle zweiästige Füsse besitzen, aus denen die Kiefer hervorgehen.

An den Unterkiefern $(I V, V)$ unterscheidet man den Stamm mit Vorsprüngen an seiner Innenseite, die fast das Ansehen von Gliedern haben und mit starken, zum Theil dornartigen, zum Theil gezähnelten oder gefiederten Borsten besetzt sind, - einen mehrgliedrigen Endtheil (inneren Ast?), der an Innenseite und Spitze längere und zartere Borsten trägt, - und einen kleinen länglichen blattförmigen Anhang (äusseren Ast, fouet M. Edw. Fig. 5, a, a) an dessen Rande cinige wenige zarte Borsten stehen. An den Unterkiefern des ersten Paares $(I V)$ hat der Stamm 2 längere, an denen des zweiten $(V)+$ kürzere Vorsprünge, an jenen der Endtheil 3, an diesen 5 Glieder.

Die Kieferfüsse $(V I, V I I)$ scheinen wenig bei der Ortsbewegung mitzuwirken. Sie bestehen aus einem, namentlich am ersten Paare dicken Stamme, cinem längeren 4-5-gliedrigen inneren und einem kürzeren ungegliederten äusseren Aste. Ausser den Endborsten finden sich Borsten von verschiedener Länge auch am Innenrande des Stammes und des inneren Astes, so wie am Aussenrande des äusseren. Das erste Paar ist länger und kräftiger als das zweite.

Dic beiden Liste des Schwanzes treten jetzt, durch eine halbkreisförmige Ausbucht getrennt, unter ungefähr rechtem Winkel auseinander, erscheinen am 
Ende abgerundet und erhalten am inneren Rande zweimal eine neue Borste, so dass deren Zahl erst auf 7, dann auf 8 an jedem Aste steigt. Die älteste Borste bleibt durch grössere länge $(0,4 \mathrm{~mm})$ kenntlich, die äusserste, der ebenfalls sch beim jüngsten Nauplius vorhandene Dorn, bleibt dadurch von den übrigen unterschieden, dass sie glatt ist, während die anderen mit kurzen Dörnchen und längeren Haaren fiedrig besetzt sind.

Das Verdauungsrolır hat nichts Besonderes; der After, anfangs endständig (Fig. +) rückt später auf die Bauchseite bis fast zur Mitte des letzten Ringes (Fig. 7). Die L eber, von gelblicher Farbe, besteht aus drei Paar weiten Schläuchen, (einem vorderen oberen, einem seitlichen, einem hinteren unteren), und hat in ihrem Baue ebenfalls Nichts von anderen Zoëa Abweichendes.

Die Lage des Herzens $(h)$ ist die gewöhnliche, am Ende des mit dem Rückenschilde verwachsenen Leibesabschnitts; mit fortschreitender Ausdchnung des Schildes rückt auch das Herz allmählich weiter nach hinten. So liegt es bei den älteren Nauplius über dem dritten Fusspaare (Oberkiefer), jetzt über dem sechsten und siebenten (Kieferfüssen). Der Bau des Herzens dagegen weicht auffallend ab von dem der älteren Thiere ebenso, wie von den anderen Decapodenlarven. Es gleicht dem vordersten erweiterten Abschnitte des Herzens der kürzlich von mir beschriebenen jüngeren Maulfüsserlarve. Es fehlen nämlich die sich kreuzenden Balken im Innern und die Zahl der Spalten für den Eintritt des Blutes ist auf zwei beschränkt, die im hinteren Theile des Herzens auf dessen Unterseite liegen. Diese zwei Spalten sind ungemein augenfällig und ich glaube die Angabe, dass sie die einzigen sind, mit aller Bestimmtheit machen zu können. Oft und lange habe ich bẹi dieser und verwandten Arten den Lauf der Blutkügelchen durchs Herz und in dessen Nähe verfolgt, und nie sie anders als hier eintreten schen; von vorn herkommende Blutkörperchen sah ich einigemal dicht am Herzen entlang gleiten, um zu diesen hinteren Spalten zu gelangen. Auch dürften die später trotz des inneren Balkenwerks leicht zu erkennenden übrigen Spalten jetzt an dem einfachen Schlauche kaum zu übersehen sein. - Ein Gefäss entspringt am Vorderende, ein zweites unter dem abgerundeten Hinterende des Herzens. Am Ursprunge des ersteren wurden Klappen gesehen. Andere (iefässe scheinen noch zu fehlen. Ein grosser Theil des aus dem vorderen Theile des Körpers zurückkehrenden Blutes macht, wie bei anderen Zoëa, einen Unweg durch das Rückenschild.

Dies die Theile, die während dieses ganzen Zeitraums sich ziemlich unverändert erhalten,

Von den neu auftretenden Theilen sind der Zeitfolge nach zuerst die paarigen A ugen zu betrachten; denn schon bei den ältesten Nauplius war ihre erste Spur zu erkennen (s. o.). Sie bilden bald cine ansehnliche, über dem vorderen Theile des Rückenschildes liegende. den Stirnrand überragende, vorn ausgerandete Masse (Fig. 4). Nahe ihrer äusseren, hinteren Ecke tritt ein schwarzer Farbfleck auf, von dem aus sich bald strahlige linien zur Oberfläche des späteren eigentlichen Auges verfolgen lassen (Fig. 6); nach vorn und innen davon unterscheidet man den verdickten Selınerven, hinter dem ein freier, später von einem Muskel durchsetzter Raum bleibt. Die anfangs dicht zusammenstossenden Iugen rücken nun rasch auscinander, so dass das unpaare Auge und in ganzer Preit. die (ranglien, zwischen denen es liegt, wieder von oben sichtbar werden. 
Eigenthümliche Gebilde, die ich nicht zu deuten weiss und die den anderen beobachteten Arten zu fehlen scheinen, sind die beiden halbkugligen durchsichtigen Knöpfchen, die schon bei den ältesten Nauplius am Stirnrande vorspringen. Sie verhalten sich anfangs als zarte fast kugliche wasserhelle Bläschen (Fig. 4, o), später als winzige mehr derbhäutige und undurchsichtige zitzenförnige Anhänge am Vorderrande der Augenstiele während des ganzen Larvenlebens (Fig. 9, o).

Die neuen Ringe, an denen später die Brust- und Afterfüsse sich entwickeln, bilden anfangs einen ungegliederten, weichen, kurzen, aber rasch sich verlängernden Gürtel. Noch ehe dieser Gürtel die Länge des hinter ihm liegenden Leibesabschnittes erreicht, lässt sich eine anfangs freilich wenig deutliche Sonderung in 11 Ringe wahrnehmen. Anfangs sind diese ziemlich gleich lang, ja die vorderen länger und deutlicher geschieden; gegen Ende dieses Zeitraumes aber bilden die fünf hinteren etwa $1 / 3$ der gesammten Körperlänge, von denen die sechs vorderen kaum 1/9 ausmachen, während der Rest der Länge halb vor und halb hinter diesen neuen Ringen liegt ${ }^{1}$ ). Die fünf hinteren neuen Ringe (Hinterleibsringe) erhalten am hinteren Rande in der Mitte des Rückens ein kurzes Dörnchen und der letzte derselben ausserdem eins an jeder Seite. Von inneren Theilen ist in diesen neuen Ringen anfangs nur der Darm deutlich unterscheidbar, später bildet sich die Kette der Nervenknoten aus und erst gegen Ende dieses Zeitraums sondern sich die Muskeln in scharf geschiedene Bündel.

Die n eu en An hänge sprossen an der Bauchseite der entsprechenden Ringe als anfangs einfache Zapfen hervor, die aber bald einen längeren äusseren und kürzeren inneren Ast unterscheiden lassen. Zuerst und schon, wenn eben eine Sonderung der neuen Ringe sich bemerklich zu machen anfängt, das dritte Paar der Kieferfüsse und die Seitenblätter des Schwanzfächers, weit später auf einmal die fünf Paare der Brustfüsse. Die Aeste der Kieferfüsse erhalten vor Ablauf dieses Zeitraums ausgebildete Endborsten, bleiben aber noch ungegliedert, die Brustfüsse bleiben borstenlose Stummel. Die seitlichen Schwanzblätter, die unmittelbar (ohne Gelenk) dem Grundgliede aufsitzen, erhalten einzelne kurze Borstchen, besonders die Spitze des längeren äusseren Blattes; die langen Fiederborsten der späteren Zeit fehlen noch. Durch das Hervorsprossen der Schwanzanhänge an der Bauchseite unterscheiden sich unsere Thiere nicht nur von den Porcellanen, sondern auch von denjenigen Garneelen, die in Zoëaform das Ei verlassen und bei denen, wie bei Porcellana, diese seitlichen Schwanzblätter innerhalb der breiten Schwanzflosse angelegt werden.

Den allmählichen Aenderungen, die das Ansehen des Thieres durch die Ausbildung der paarigen Augen, der neuen Leibesringe und ihrer Anhänge erleidet, folgt, wenn es eine Länge von etwa $1,6 \mathrm{~mm}$ erreicht hat, eine neue tiefgreifende, plötzliche Verwandlung, der Uebergang in die Mysisform (Fig. 9). Die Fühler

1) Ob der erste dieser 11 Kinge, wie ich glaube, schon bei Beginn dieses Zeitraums vorhanden ist, ob also alle 14, oder nur Io Ringe als wirklich neu zu bezeichnen sind, lasse ich unentschieden. In letzterem Falle hätte man: in ersten Zeitra um (Nauplius) fünf ursprüngliche Ringe (Fühler, Oberkiefer, schwanz) und die Bildung von fünf neuen (für Unterkiefer und Kieferfüsse); im zw eiten Zeitraum (Zoëa) Bildung von $2 \times 5$ neuen Ringen, von denen die cinen (Brustringe) jetzt, die andern (Hinterleibsringe) im dritten Zeitraum (Mysisform) l'ussstummel erlalten. Dies einfache Verhältniss jedoch, weit entfernt, ein allgemeingültiges zu sein, würde nicht einmal für alle Arten der Gattung Penëus passen. 
hören auf der Bewegung zu dienen; sie werden abgelöst durch den langen Hinterleib, der eben noch wie eine nutzlose last mühsam nachgeschleppt wurde und dessen kräftige Muskeln jetzt das Thier in hüpfender Bewegung weiter schnellen, - und durch die langbeborsteten Brustfüsse.

Das R ü ckenschild, mit noch ungezähneltem Stirnfortsatze, hat am Vorderrande jederseits zwei kurze Zähne erhalten, einen über dem Auge, den anderen an der unteren Ecke. Es deckt nach Kurzem die Brustringe vollständlig, von denen anfangs einige wenigstens oberhalb noch unbedeckt bleiben.

Die vorderen Fühler (Fig. 12, I) haben ihre langen Borsten verloren. Die drei ersten Glieder erscheinen jetzt als Stiel, indem nach innen von dem vierten, stäbchentragenden Gliede ein zweiter anfangs ungegliederter, in eine einfache Borste auslaufender Ast sich entwickelt.

Der äussere Ast der hinteren Fühler (Fig. 12, IIa) ist zur Schuppe des Garneelenfühlers geworden, zu einem ungegliederten Blatte, dessen Aussenrand in einen kurzen Zahn ausläuft, während die weiter vorspringende Spitze und der Innenrand mit langen Fiederborsten besetzt sind. Neben diesem Blatte, nach innen und unten, steht ein kurzer, borstenloser, ungegliederter Zapfen, aus dem später die Geissel des Fühlers hervorgeht. Ob dieser Zapfen aus dem inneren Aste des Zoëafühlers sich entwickelt, oder neu sich bildet, während jener innere Ast vollständig schwindet, lasse ich unentschieden; wahrscheinlich ist mir letzteres; ich glaube, dass man die Geissel des Garneelenfühlers als mittleren Ast (palpe M. Edw.) zu betrachten hat.

Die schon bei Zoëa vorhandenen Füsse haben keine auffallende Veränderung erlitten. Das dritte Paar der Kieferfüsse gleicht jetzt den beiden vorhergehenden. Die fünf neuen Fusspare (Fig. I I) haben anfangs alle dieselbe Bildung; der ungegliederte Stamm trägt einen kurzen, ebenfalls ungegliederten inneren Ast mit zwei Endborsten und einen doppelt so langen, in seiner oberen Hälfte geringelten und mit langen Borsten besetzten äusseren Ast, der in fast beständiger strudelnder Bewegung ist.

Am Schwanze (Fig. Io) sind die Seitenblätter jetzt auf kurzem Grundgliede beweglich eingelenkt und mit langen Fiederborsten besetzt; das Mittelstück (der siebente Hinterleibsring) erscheint länger und schmäler, als wenn man die beiden auseinanderweichenden Aeste bis zu fast völliger Verschmelzung zusammengeschoben hätte; die Borsten der Zoëa sind vollzählig erhalten, aber zu kurzen Dornen zusammengeschrumpft. Der After liegt am Anfange dieses letzten Ringe's.

Um dieselbe Zeit findet eine bedeutende Veränderung des Herzens statt, das vier neue Spalten für den Eintritt des Blutes und innere Muskelbalken erhäit.

In dieser Mysis-ähnlichen Gestalt wurde unsere Larve von kaum 2 bis $4,5 \mathrm{~mm}$ Iänge beobachtet. Während dieses Zeitraumes bilden sich die Gehörwerkzenge, die Scheeren und Gangfüsse aus, Oberkiefertaster, Afterfüsse und Kiemen "erden angelegt.

Die Geisseln der Fühler verlängern und gliedern sich; bei Thieren von 4 bis $4,5 \mathrm{~mm}$ Länge sind die beiden Geisseln der inneren fiühler dreigliedrig: die äussere, etwas kürzere, trägt etwa sieben Stübrhen; die Geissel der äusseren Fühler erreicht fast die länge der Schuppe. 
Im Grundgliede des inneren Fühlers bildet sich das Gehörwerkzeug. Das untere Drittel dieses Gliedes erhält nach aussen eine Auftreibung, die oben durch einen halbmondförmigen Ausschnitt begrenzt wird (Fig. 12). Im Inneren dieser Auftreibung unterscheidet man bald (bei Thieren von $3 \mathrm{~mm}$ Länge) eine längliche Höhle. In der Höhle erscheint wenig später ein kugliger, stark lichtbrechender Gehörstein und in der halbmondförmigen Ausbucht drei bis vier kurze gefiederte unten kuglig verdickte Borstchen (Fig. 15). Der Gehörstein scheint nicht frei in der Höhle zu liegen, sondern (wie es im Schwanze der Mysis der Fall ist) durch zarte Fädchen gehalten zu werden, die von einem nach innen von der Höhle gelegenen Nervenknoten ausgehen.

Der vorwärts gerichtete Dorn der Oberlippe beginnt zu schwinden, ist aber noch bei,$+ 5 \mathrm{~mm}$ langen Thieren als kleines Spitzchen zu erkennen. Am () berkiefer erscheint etwa zur Zeit, wo die Gehörsteine sich bilden, der Taster als kleine Warze, die sich bald verlängert, aber ungegliedert und borstenlos bleibt.

Die Scheeren zeigen sich schon bei 2,8 $\mathrm{mm}$ langen Thieren angedeutet, indem der noch unger:liederte innere Ast der entsprechenden drei Fusspaare innen unter der Spitze einen :-1.inen Vorsprung erhält. Bei Thieren von $3.5 \mathrm{~mm}$ Länge sind diese Füsse schon wie beim erwachsenen Thiere gegliedert und jener Vorsprung (der unbewegliche Scheerenfinger) erreicht $\% \frac{1}{3}$ der Länge des Endgliedes (des beweglichen Fingers), das noch seine beiden Endborsten trägt (Fig. 14). Auch am vierten und fünften Paare der Brustfüsse (Fig. 13) ist jetzt der innere Ast in fünf Glieder getheilt und übertrifft schon um etwas die Länge des äusseren. Bei $4.5 \mathrm{~mm}$ langen Thieren sind die Scherenfinger gleich lang; am vierten und fünften Fusspaare sieht man einen spitzen Vorsprung, die Klaue, neben den Endborsten, und namentlich am vierten übertrifft die Länge des eigentlichen Fusses schon weit die des äusseren Astes.

Die Afterfüsse sind schon bei $2,8 \mathrm{~mm}$ langen Thieren als kleine Warzen erkennbar: anfangs sind sie einfach und es ist, wie bei den Brustfüssen, der äussere Ast, der sich zuerst entwickelt. Bei Thieren von $4,5 \mathrm{~mm}$ länge sind sie schon recht ansehnlich (Fig. 16), aber noch ohne Gliederung und Borsten, und der innere Ast erscheint nur als unbedeutender Anhang des äusseren.

Die Anfänge der Kiemen sind als kleine rundliche Wucherungen am Frunde der Kieferfüsse und Scheerenfüsse schon bei Thieren unter $+\mathrm{mm}$ Länge zu erkennen; später auch am vierten Paare der Brustfüsse.

Von der 4,5 mm langen Mysis-artigen Larve ist nur ein kleiner Sclıritt noch zur Garneelenform. Die jüngsten in dieser Gestalt beobachteten Thiere waren etwa 5 mm lang. Ihr Stirnhorn hatte oben drei Zähne. Die Fühler hatten keine V'eränderung erlitten. An den Augen war der kleine Anhang nicht mehr zu sehen. Das unpaare Auge war sehr undeutlich geworden. Die Oberlippe hatte ihren Dorn vollständig verloren, der Taster des Oberkiefers zwei Glieder und kurze Bnrsten erhalten. Die beiden vorderen Paare der Kieferfüsse haben sich dem Munde dicht angelegt und sind weit kürzer als das dritte. Die äusseren Aeste der Brustfüisse. die bei manchen Pen̈̈us (als sog. palpus flagelliformis) sich lebenslänglich erhalten, sind vollständig verschwunden. Die Afterfüsse haben (am äusseren Aste) Filieder und Borsten erhalten. Das mittlere Blatt des Schwanzfüchers ist nach hinten verjüngt und trägt am gerade abgeschnittenen Hinterrande 
Io Dornen, von denen die an den Ecken die längsten sind; drei kürzere Dornen stehen an jedem Seitenrande. Die Kiemen (eine über dem vierten Brustfusse, je zwei über den vorhergehenden) sind noch ganzrandige längliche Blätter (fiederspaltig bei $9 \mathrm{~mm}$ langen Thieren). Die Leber fängt an durch Bildung neuer Schläuche und Verästelung der älteren eine zusammengesetztere Form anzunnehmen. Ueber 9- in mm lang wurde das Thier noch nicht beobachtet.

Eine zweite Larvenart ist als ältere Zoëa leicht dadurch von der eben besprochenen zu unterscheiden, dass der Vorderrand des Schildes ausser dem mittleren noch jederseits einen kürzeren seitlichen schief nach vorn und aussen gerichteten stachelförmigen Fortsatz hat. Dabei ist sie auf gleicher Stufe der Entwickelung grösser und wurde als Zoëa bis $2,3 \mathrm{~mm}$ lang gesehen. Jüngere \%oёa, denen noch die Fortsätze des Schildes fehlen, sind denen der ersten Art so

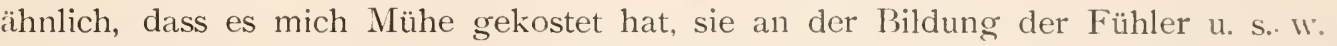
unterscheiden zu lernen. Am unpaaren Auge dieser zweiten Art (Fig. 17) bildet die Haut meist zwei linsenförmige Verdickungen zu den Seiten des Stäbchens; einnal sah ich eine einzige grössere dem Stäbchen gegenüber. Zwischen den beiden Nervensträngen der Bauchkette lässt sich ein unpaares von Knoten zu Knoten verlaufendes Fädchen unterscheiden (das den anderen Arten schwerlich fehlt, aber noch nicht deutlich bei ihnen gesehen wurde). Trotz der ungemeinen Aehnlichkeit mit der ersten Art ist der Gang der Entwickelung ein etwas abweichender, indem das dritte Paar der Kieferfüsse und die Schwanzanhänge nicht vor-, sondern gleichzeitig mit den Brustfüssen auftreten.

Eine dritte Art (Fig. I 8-22) wurde von jüngeren I,2 mm langen Zoëa, bei denen die neuen Ringe noch von gleicher Länge waren und eben die ersten Stummel des dritten Paares der Kieferfüsse und der Schwanzanhänge sich gebildet hatten, bis zu $3 \mathrm{~mm}$ langen, mit drei unvollkommenen Scheerenpaaren und Afterfüssen versehenen Mysis-ähnlichen Formen verfolgt. Sie ist ausgezeichnet durch sehr reiche Bewaffnung des Rückenschildes und der Hinterleibsringe mit stachelförmigen Fortsätzen; auch das mittlere Blatt des Schwanzfächers ist bei der Mysisform in zwei lange Spitzen ausgezogen (Fig. 2I). Der Gang der Entwickelung scheint ganz wie bei der ersten Art zu sein; die Form des Grundgliedes der inneren Fühler bei den ältesten zur Beobachtung gekommenen Larvoll (Fig. 22) lässt vermuthen, dass auch hier ein dem der ersten Art ähnliches Ohr sich bilden werde.

Von zwei weiteren Arten, deren Zoëa in der Bildung der Fühler, der dorntragenden Oberlippe, des vielgliedrigen zweiten Unterkicfers, des Schwanzes, des Herzens u. s. w. sich eng an die drei anderen anschliessen, wurde die eine bis jetzt nur bis zur scheerenlosen Mysisform verfolgt, die andere aber, die drei Scheerenpaare erhält, entfernt sich im Gange ihrer Entwickelung so weit von den übrigen, dass ich ihre Verwandlungsgeschichte einer besonderen Sichilderung vorbehalte.

Desterro, im März I862. 


\section{Erklärung der Abbildungen auf Tafel XXII.}

Die ganzen Thiere, so wie Fig. Io und I9, sind 45mal, Fig. 3 und 17 sind I8omal, Fig 20 bis 22 sind 25 mal, alle übrigen gomal vergrössert. Die römischen Zahlen $I$ bis YIX bezeichnen die den i9 Paaren des erwachsenen Thieres entsprechenden Anhänge. c. Geissel des zweiten Paares; a äusserer, $i$ innerer Ast der Anhänge; $L$ Oberlippe: "h Herz; l leber; $l$ 'vorderer, l" mittlerer, l" hinterer Leberschlauch; o Anhang am Auge von unbekannter Bedeutung; $s$ mittlerer Stirnfortsatz; $t$ orangefarbene Oeltröpfchen.

Fig. I. Jüngerer N a uplius eines Penëus aus dem Meere von Sta. Catharina I. o.

Fig. 2. A elterer $\mathrm{N}$ a uplius desselben v. d. S.

Fig. 3. Drittes Fusspaar eines noch etwas älteren Nauplius mit der Anlage der Oberkiefer, A v. u., B. v. d. S.

Fig. 4. Jüngere $Z$ oёa desselben, v. o.

Fig. 5. Mundtheile derselben Zoëa, v. u.

Fig. 6. Augen e.ner etwas älteren Zoëa.

Fig. 7. A eltere Z $\mathrm{z} \ddot{\mathrm{a}}$ desselben, v. u.

Fig. 8. Oberkief er einer älteren Zoëa.

Fig. 9. Jüngere My sis form desselben, v. d. S.

Fig. Io. Schwanz cicuselben Thieres, v. u.

Fig. I I. Fuss des I 3 ten Paares, von demselben Thiere.

Fig. I 2. Fühler einer $3,3 \mathrm{~mm}$ langen Larve, v, u.

$\left.\begin{array}{l}\text { Fig. I 3. Fuss des I 2ten } \\ \text { Fig. I 4. Fuss des I } 3 \text { ten }\end{array}\right\}$ Paares von einer 3,5 mm langen Larve.

Fig. I 5. Theil vom Grundgliede der inneren Fühler mit ausgebildetem Gehörwerkzenge, von einer etwa $4 \mathrm{~mm}$ langen Larve.

Fig. I6. Füsse des I8ten Paares, von einer $4,5 \mathrm{~mm}$ langen Larve, v. d. S.

Fig. I7. Unpaares Auge von der Zoëa einer nahe verwandten Art, v. u.

Fig. I8. Z ö̈a einer dritten Art kurz ror der Verwandlung in die Mysisform, ․ d. Seite.

Fig. I 9. Hinterer Theil des Rückenschildes derselben, r. o.

Fig. 20. Hinterer Theil des Rückenschildes von einer $3 \mathrm{~mm}$ langen mysisförmigen Lirve derselben Art, v. o.

Fig. 21. Schwanz derselben mysisförmigen Larve, v. u.

Fig. 22. Stirnfortsatz und innerer Fühler derselben, v. o. 


\title{
Die zweite Entwickelungsstufe der Wurzelkrebse $\left.(\text { Rhizocephalen })^{1}\right)^{2}$ ).
}

\author{
Mit Tafel XXIII.
}

Drei Tage ungefähr, nachdem die jungen Wurzelkrebse in Naupliusform die Bruthöhle ihrer Mutter verlassen, verwandeln sie sich, wie ich kürzlich an drei verschiedenen Arten beobachtete, in eine neue von der ersten sehr abweichende Gestalt, die sich auf's Allerengste anschliesst an die zweite Entwickelungsstufe der Rankenfüsser ${ }^{3}$. Dieselbe Form des zu einer muschelähnlichen Schale zusammengeklappten Rückenschildes, dieselbe Bildung der in ähnlicher Weise nirgends sonst wiederkehrenden Haftfüsse, der zwölf langbeborsteten Schwimmfüsse und der Schwanzanhänge, und natürlich also vollkommen dieselbe Art der Bewegung. Nur die paarigen Augen fehlen.

Da somit die Wurzelkrebse sich als nächste Verwandte der Ra nkenfüsser herausstellen, so scheint es passend, auch auf die früheste Jugendform beider Gruppen noch einmal vergleichend zurückzublicken. Die Birnform

I) Archiv für Naturgeschichte. 1863. I. p. 24-33. Taf. III, Fig. I-7.

2) Der Verfasser bemerkt bei Uebersendung des hier folgenden Aufsatzes an den Unterzeichneten, dass er auf den Abdruck verzichte, wenn der in demselben beschriebene Cypris-ähnliche Entwickelungszustand der Rhizocephalen bereits bekannt sei. Nun hat allerdings Lilljeborg diesen Entwickelungszustand von Peltogaster sulcatus gesehen (Ann. and Mag. of nat. history 3. ser. Vol. VII. I86I. p. 57), auch ist die von Fritz Müller auf Grund seiner Untersuchungen ausgesprochene Ansicht, dass die Rhizocephalen Rankenfüsser seien, nicht neu, vielmehr von Anderson und Lilljeborg bereits vorgebracht und begründet. Aber Lilljeborg sah die Cypris-ähnlichen Jungen von Peltogaster nur als le ere Schalen an älteren Entwickelungsstufen desselben Thieres ansitzen, woraus durchaus noch nicht mit Nothwendigkeit das Hervorgehen des einen aus dem andern geschlossen werden kann, wie auch Fr. M üller hervorhebt, der eine ähnliche Beobachtung wie Lilljeborg machte; neu dagegen und eine wesentliche Lücke ausfüllend sind die Beobachtungen von Fritz Müller über die direkte Umwandlung der aus dem Eie geschlüpften Jungen in die Cypris-Form. Danach und wegen der mancherlei anderweitigen Beobachtungen und gehaltvollen Bemerkungen, welche in dem nachstehenden Aufsatze meines geschätzten Freundes enthalten sind, glaube ich bei der verehrlichen Redaction dieses Archives den unveränderten Abdruck desselben be. antragen zu dürfen.

Max Schultze.

3) Leider kann ich in meiner literarischen Einüde weder Darwin's ausführliche Darstellung dieser Larven, noch die Arbeiten seiner Vorgänger vergleichen. Junge Balaniden hatte ich häufig Gelegenheit zu untersuchen und konnte an ihnen die von Krohn geschilderte Verwandlung des Nauplius in die sog. cyprisähnliche Gestalt verfolgen.

Fritz II üllers gesammelte Schriften. 
des ungegliederten Leibes, die Zahl der langborstigen Füsse, ron denen die beiden vorderen einfach, die vier hinteren zweiästig sind, und das selten fehlende unpaare Auge haben sie gemein mit zahlreichen anderen jungen Krebschen. Sie stimmen unter sich überein und unterscheiden sich von anderen Nauplius durch die seitlichen Hörner des breiten, wenig gewölbten Stirnrandes und vielleicht durch die beiden zarten ungegliederten Fäden (Riechfäden). die auf der Bauchseite neben dem Auge entspringen ${ }^{1}$ ). Im Gegensatze zu den jungen Rankenfüssern mit ihrem wohlentwickelten Darmrohre, mit den zahlreichen scharf geschiedenen Muskelbündeln der Füsse u. s. w. haben die jungen Wurzelkrebse ein weit unreiferes Ansehen. Verdauungswerkzeuge scheinen vollständig zu fehlen. Eine kleine, wie es scheint, rings geschlossene Höhlung, die dicht vor dem Schnabel gelegen ist, und bei einer neuen Art, Peltogaster (?) socialis, durch die lebhafte dunkelgrüne Farbe ihres aus I') bis I 2 Kügelchen bestehenden Inhalts leicht in die Augen fällt, ist vielleicht a)s erste Anlage der später der Ernährung dienenden Theile zu betrachten. Die reithlichen Dotterreste, um die ich früher eine Hülle unterscheiden und als Darm deuteı zu können meinte, liegen frei in der Leibeshöhle. Der Schnabel scheint ohne Mundöffnung und ebensowenig ist ein After zu bemerken. Sicher nehmen die Thierchen keine feste Nahrung zu sich. Ebenso fehlen die von den Rankenfüssern wohl als Fresswerkzeuge benutzten Zacken, Haken und Dornen am Grunde der Füsse. Endlich ist das Hinterende nicht schwanzförmig ausgezogen und entbehrt des eigenthümlichen stachelförmigen Fortsatzes.

Zur Schilderung der zweiten Entwickelungsstufe wähle ich Lernaeodiscus Porcellanae, da ich hier namentlich den Bau der Schwimmfüsse vollständiger zu erkennen vermochte. Die beiden anderen beobachteten Arten weichen übrigens nur unerheblich von dieser ab.

Während der ersten beiden Tage pflegt sich der Schwarm der jungen Wurzelkrebse nahe der Oberfläche des Wassers, an der Lichtseite des Glases aufzuhalten. Im Laufe des dritten Tages senkt er sich zu Boden und noch vor Ablauf desselben pflegt ein grosser Theil sich gehäutet und verwandelt zu haben.

Der ziemlich flache Leib des Nauplius klappt sich bei dieser Verwandlung so nach unten zusammen, dass die Seitenränder des Rückenschildes nur eine schmale Spalte zwischen sich lassen, wodurch das Thier (Fig. I) die Gestalt eines 0,2 $\mathrm{mm}$ langen, 0,08 $\mathrm{mm}$ hohen und kaum 0,05 mm dicken Muschelchens bekommt. Die Mittellinie des Rückens ist ziemlich gleichmässig gewölbt und bildet ungefähr einen Viertelkreis. Die freien Seitenränder steigen vom vorderen Ende der Rückenlinie bogig nach unten und hinten, einen Sechstelkreis bildend, dessen Mittelpunkt in die Rückenlinie fällt und dessen Halbmesser sich zu dem der letzteren wie 3 zu1 5 verhält; von da verlaufen sie ziemlich geradlinig (unbedeutend nach innen

I) Die Stirnhörner sind nicht blosse Fortsetzungen des Rückenschildes, von dem sie bei den Wurzelkrebsen bald weit überragt, bald nur am Grunde bedeckt werden; an der Spitze sind sie offen und lier pflegt bei mässigem Druck der Lcibesinhalt der jungen Wrurzelkrebse auszutreten; wiederholt schienen sie mir bei Turzelkrebsen und Balaniden mit wurst- und birnförmigen Schläuchen in V'erbindung zu stehen. Die beiden Fäden an der Bauchfläche dürften allen jungen Wurzelkrebsen zukommen, sie finden sich auch bei Lernaeodiscus Porcellanae, wo ich sie früher vermisste; es fragt sich jedoch, ob sie nicht auch bei anderen Nauplius nur bisher übersehen sind. Sie gleichen den Anhängen an den innereu Fühlern vieler Krebsthiere, die ich mit Leydig für Riechwerkzenge halte, und dürften dieselbe Verrichtung haben. Bei Balaniden sah ich sie unmittelbar vom Gehirne entspringen. 
sich wölbend), in gleicher Riclıtung mit der Sehne der Rückenlinie, die sie um etwa $1 / 5$ ihrer I änge überragen; von den leicht abgestumpften Hinterecken endlich steigen sie in fast gerader Linie nach oben und vorn, um im hinteren Endpunkte der Rückenlinie wieder zusammen zu stossen. In seiner vorderen Hälfte ist der untere Rand mit etwa 10 kurzen schief hinterwärts gerichteten Borsten besetzt; ähnliche Borsten sind bei Sacculina purpurea über die ganze Oberfläche der Schale zerstreut.

So bedeutend diese Wandlung der Gestalt ist, so ist sie doch gering gegen die Veränderungen, die die Anlänge des Thieres erleiden. Vollständig verschwinden die Stirnhörner, der dreieckige Schnabel und die beiden hinteren Fusspaare; letztere werden bei der Häutung unverändert, mit ihrem Inhalte abgeworfen ${ }^{1}$, während aus Schnabel und Stirnhörnern vor der Häutung der lebende Inhalt sich zurückzieht und wie von allen anderen Theilen nur die Chitinhülle abgestreift wird. Das erste Fusspaar verwandelt sich in die eigenthümlichen Haftfüsse. Ziemlich unverändert erhalten sich nur das Auge und die Riechfäden. Das Auge hat in der Regel an Umfang zugenommen, in verschiedenem Grade bei verschiedenen Exemplaren (in dem Fig. I gezeichneten ist es von besonderer Grösse); seine Lage wechselt etwas bei den Bewegungen des Thieres; es ist etwa $1 / 3$ der Länge vom Vorderende, $1 / 3$ der Höhe vom Rücken entfernt. Der Ursprung der Riechfäden (Fig. 2, $r$ ), deren Länge etwas zugenommen hat, liegt jetzt vor dem Auge, zwischen den Haftfüssen, wie bei der sog. Cyprisform der Rankenfüsser. Aeusserst selten nur sah ich bei unbehelligten Thieren ihre Spitze vorn oder unten aus der Schale hervortreten.

Die Haftfüsse gehen, wie erwähnt und wie für die Rankenfüsser schon Krohn nachwies, aus dem ersten Fusspare hervor. Das von Anfang an starke Grundglied beginnt sich bald gegen sein oberes Ende noch mehr zu verdicken und springt dann nach innen und unten bedeutend über das Endglied vor. In diesem angeschwollenen Grundgliede bildet sich aus einem feinkörnigen trüben Gewebe der ganze Haftfuss. (Was Krohn bei einer der Häutung nahen Rankenfüsserlarve dem verdickten Ende der vordersten Füsse ansitzen sah, dürfte wohl eher das Endglied des Naupliusfusses, als das des späteren Haftfusses gewesen sein.)

Die Haftfüsse (Fig. 2) sind dreigliedrig. Das kräftige Grundglied ist vorwärts gerichtet, von $1 / 6$ der Leibeslänge, an Grunde reichlich halb so hoch und gegen die Spitze stark verjüngt; sein Unterrand ist etwas länger als der obere. Das zweite Glied ist walzenförmig und hat etwa $1 / 3$ der länge des Grundgliedes; seine Spitze scheint durch weiche Haut geschlossen. Näher dem Grunde als der Spitze entspringt von seiner unteren Seite das sehicf abwärts gerichtete Endglied, das wenig kürzer, aber viel dünner und kegelförmig zugrespitzt ist. Dicht am Grunde trägt jedes der beiden letzten Glieder unterhalb einen zarthäutigen, zungenförmigen Anhang; der des zweiten Gliedes hat reichlich 2/3. der des dritten etwa die Hälfte der Länge des Grundgliedes. Man sieht in diesen Anhängen meist einige kleine stark lichtbrechende Körnchen, die ich mich nicht

1) Rankenfüsser sah ich noch nicht während der Häutung; ob nicht bei ihnen, wie bei den Garneelen, aus dem dritten Fusspaare sich die Oberkiefer hervorbilden? 
in den Stäbchen an den inneren Fühlern anderer Krebsthiere gesehen zu haben entsinne. Das zweite Glied ist ron dem Grundgliede durch einen vollständigen Ring weicher Haut geschieden. Die Beweglichkeit der Endglieder ist daher eine sehr grosse. Aus demselben Grunde findet man an der Chitinhülle abgestorbener Thiere die beiden letzten Glieder der Haftfüsse stets abgefallen.

An die hintere untere Ecke des Grundgliedes setzt sich, durch ein Gelenk mit ihm verbunden, eine hinterwärts gerichtete Chitinleiste (Fig. 2 u. $\left.3, k^{\prime}\right)$, die mit dem Unterrande des Grundgliedes ziemlich gleiche Jänge hat, und mit dieser verbindet sich knieförmig eine zweite aufwärts gerichtete Leiste (Fig. 2 u. 3, $k^{\prime \prime}$ ) von derselben Länge. Letztere ist oben in zwei gieichlaufende dünne Aeste gespalten, einen äusseren und einen inneren, die etwa $2 / 5$ der Iänge dieser Leiste ausmachen. Die oberen gabligen Enden der rechten und der linken Leiste liegen dicht nebeneinander, nahe dem Rücken und ungefähr um die länge der Leiste vom Vorderende ller Schale entfernt. Diese Leisten dienen als Ansatzstellen für Muskeln, die theils von ihnen in die Füsse gehen, theils sie nach vorn und hinten an die Rückenwand iefestigen.

Die Haftfüsse werden benutzt, wie bei den Rankenfüssern. Zwar sah ich die jungen Wurzelkrebschen nie, wie jene, an der Wand des Glases emporklimmen, sondern stets in der Nähe des Bodens bleiben; allein, wenn sie durch das Deckgläschen beengt, nicht bequem schwimmen konnten, pflegten sie die beiden Haftfüsse abwechseld vorzustrecken, um mit dem Ende des zweiten Gliedes sich am Glase festzuheften und den Leib nachzuzichen. Bisweilen schienen sie auch das Endglied wie einen Haken zu benutzen.

Den hinteren Theil der Schale füllt der die Schwi m $\mathrm{mf}$ üs se und $\mathrm{Sch}$ wanzan hänge tragende Leibesabschnitt. Als erste Anlage dieser Theile unterscheidet man in einem an der Bauchfläche des Nauplius sich bildenden körnigen, trüben Gewebe von unten eine tiefe Längsfurche und schief nach innen und hinten verlaufende Trennungslinien der einzelnen Füsse, von oben eine Scheidung in einzelne Abschnitte durch quere Linien. Durch diese Neubildungen wird eine zuletzt sehr ansehnliche Auftreibung gebildet, die kielförmig nach unten und hinten vorspringt und an ihrem Ende die beiden Spitzen des Hinterleibes mit emporhebt. Wahrscheinlich durch einen an seiner vorderen oberen Ecke sich ansetzenden Muskel wird der neue Leibesabschnitt mehr und mehr nach vorn und oben gezogen, so dass kurz vor der Verwandlung die hintere Hälfte des erwähnten Vorsprungs leer erscheint und nur von den dicht zusammengelegten Borsten der Schwimmfüsse durchsetzt wird.

Nach der Terwandlung erscheint dieser hinterste Abschnitt des Leibes in der Seitenansicht (Fig. 4) als stumpfwinkliges Dreieck. Der obere freie Rand, die längste Seite des Dreiecks, liegt in der Ruhe dicht unter dem Rückenschilde, ist fast $0,1 \mathrm{~mm}$ lang, leicht gewölbt und geht durch abgerundete Ecken über in die kürzeren Seiten, die vorn und unten unter einem Winkel von etwa $120^{0}$ zusammenstossen. Durch den vorderen Rand steht dieser hintere Abschnitt mit dem vorderen Theile des Leibes in Verbindung; der untere Rand, in der Ruhe wagerecht etwas über dem Rande der Schale liegend, trägt die Schwimmfüsse. Eine Scheidung in einzelne Ringe ist nur angedeutet durch schmale Chitinleisten, die auf jeder Seite ron den Füssen der oberen vorderen Ecke zulaufen, 
ohne sie ganz zu erreichen, und durch eine Einkerbung des oberen freien Randes, die die hintere Ecke, den Schwanz, von dem fusstragenden Theile scheidet. Die vorderste leiste bildet den Vorderrand dieses I-eibesabschnitts; in geringer Entfernung von den Füssen sind die Leisten jeder Seite unter sich durch abwärts gewölbte Querleisten verbunden. Der ganze zwischen den Leisten enthaltene Raum ist gefüllt von den mächtigen Muskeln der Füsse; ein starker und langer Muskel entspringt von der vorderen oberen Ecke und geht über das Auge und die gabligen Chitinleisten der Haftfüsse hinweg zur Rückenwand.

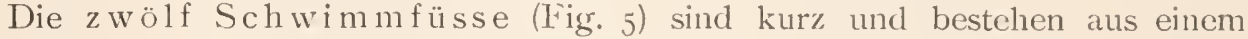
stärkeren (etwa 0,012 mm langen) Grundgliede und zwei zweigliedrigen Aesten, von denen der äussere etwas länger als der innere und als das Grundglied ist. Am Ende jedes Astes stehen drei lange gerade steife Borsten, deren länge etwa der halben Höhe der Schale gleichkommt; eine ähnliche Borste steht am ersten Gliede des inneren Astes, während das erste Glied des äusseren Astes eine etwa dreimal kürzere Borste trägt. Beim lebenden Thiere pflegen beide Aeste und die langen Borsten so dicht an einander zu liegen, dass letztere wie cine einzige starke Borste erscheinen.

Der Schwanz, die über den fusstragenden Theil vorspringende, oberhalb durch eine seichte Kerbe geschiedene hinterste Ecke des Leibes, trägt jederseits cinen zweigliedrigen Anhang mit einer längeren und einer kürzeren Borste am Ende.

Darwin deutet bei den Rankenfüssern den die Schwimmfüsse und später die Ranken tragenden Jeeibesabschnitt als Thorax, den dahinterliegenden als $\mathrm{Ab}$ clomen. Letzteren darf man wohl, namentlich im Hinblicke auf die Garneclen, als dem Schwanze (den beiden letzten Leibesringen) der höheren Krebsthier entsprechend ansehen. $\mathrm{Ob}$ auch ersterer überhaupt bestimmten Ringen der höheren Krebse entspricht, und welchen, wage ich nicht zu entscheiden, möchte ihn aber cher dem Hinterleib, als der Brust derselben gleichsetzen.

Versuche, dic weiteren Schicksale der jungen Wurzelkrebse zu verfolgen, blieben bis jetzt ohne Erfolg, selten überlebten cinzelne, ohne weitere Veränderung, die erste Woche. Eine einzige hierher gehörige Beobachtung führte mir der Zufall zu.

An demselben Pagurus, in den die purpurrothe Sacculina ihre grünen Wurzeln treibt, lebt eine zweite Art von Wurzelkrebsen, Peltogaster (?) socialis n. sp., in Gestalt dottergelber, $5 \mathrm{~mm}$ langer Würste, die in der Mitte festsitzen und an einem Ende die Oeffnung der Bruthöhle haben. Es pflegen + bis 6 gleich alte $\mathbb{W}^{\top}$ ürstchen neben einander zu sitzen. Vier solche beisammensitzende $W^{\top}$ ürstchen, von nur 1,5 $\mathrm{mm}$ Länge, - die kleinsten, die ich sah, - hatten dis Ende, an dem später die Bruthöhle sich öffnet, trichterförmig eingezogen (Fig.6); in cler Mittr der Einsenkung sprang wieder cin kleiner Hügel vor und auf diesem sass die leere Chitinhülle eines Krebschens auf, das ganz clen eben geschilderten glicl. Ausser der Schale waren Schwimmfüsse und Schwanzanhänge mit dem sie tragenden Leibesabschnitte erhalten; von den Haftfüssen waren nur noch die oberen gabligen Chitinleisten vorhanden, die aus der Schale hervorsahen und am Rande jener Einsenkung festzusitzen schienen; zwischen ihnen ging ein gerader Balken von der Schale zum Thiere, vielleicht eine der unteren L.eisten. Die Länge der Schale 
war $0,3 \mathrm{~mm}$, während sie gleich nach der Verwandlung, wie bei Lernaeodiscus, nur $0,2 \mathrm{~mm}$ beträgt. - Ist es die Haut desselben Thieres, das jetzt in Wurmform festsitzt, oder etwa die eines Männchens, das hier in seinem Berufe sterbend hängen geblieben ist?

Desterro, im Mai I 862.

\section{Erklärung der Abbildungen auf Tafel XXilII.}

Fig. I. Zweite Entwickelungsstufe von Lernacodiscus Porcellanae; nach einem am I4. April ausgeschwärmten Thiere am I9. April gezeichnet.

Fig. 2. Die Haftfüsse und die zwischen ihnen liegenden Riechfäden $(r)$ einer solchen Larve. $k^{\prime}, k^{\prime \prime}$ di? knieförmig zusammenstossenden Chitinleisten, die den Muskeln dieser Füsse zum Ansat :e dienen.

Fig. 3. Die knieförmigen Leisten von einer Larve, deren Weichtheile schon durch Verwesung zerstört waien.

Fig. 4. Der die Schwimmfüsse tragende Leibesabschnitt.

Fig. 5. Einer der Schwimmfüsse. $a$ äusserer, $i$ innerer Ast.

Fig $\mathrm{I}-5$ sind $360 \mathrm{mal}$ vergrössert.

Fig. 6. Chitinhülle einer ähnlichen Larve, dem Hinterrande eines jungen Peltogaster socialis aufsitzend; I 80 mal vergr.

Fig. 7. Chitinring der Sacculina purpurea, 25mal vergr. a Ausserhalb der Leibeswand des Pagurus liegende Platte; $b$ der innerhalb des Pagurus sich ausbreitende Kranz.

Diese Figur soll die mangelhafte Fig. 6 meines ersten Aufsatzes über die Rhizocephalen ersetzen (vergl. Seite I46).

\section{$\mathrm{Nachschrift.}$}

Auf die Frage, mit der ich vor wenigen Wochen vorstehenden Aufsatz schloss, wurde mir heute unerwartet Antwort.

Unter einer Gesellschaft von sechs jungen Peltogaster socialis fand sich einer, dessen Hinterende die leeren Häute von $z$ wei Krebschen ansassen, während seine Genossen je eine trugen. Jene Häute können nicht beide dem Peltogaster angehören, und wahrscheinlich also gehört ihm keine; denn für eine verschiedene Deutung der beiden ganz gleichgebildeten Häute liegt kein Grund vor. Man wird sie unbedenklich als Ueberreste von Männchen ansehen können, die in Krebsgestalt dem wurmförmigen Weibchen sich verbunden haben.

Desterro, 26. Mai I 862. 


\section{Ueber die Ursache der Strömungen in der Leibeshöhle der Sertularinen ${ }^{1}$ ).}

In seinen vortrefflichen „I.eçons sur la physiologie et l'anatomie comparcee" bezeichnet Milne Edwards, wie ich so cben lese, die Strömungen in der Leibeshölle der Sertularinen als eine Erscheinung, übır deren Ursachen man noch nichts Sicheres wisse -). Dies veranlasst mich zur Mittheilung einiger vor längerer Zeit ( 1860$)$ niedergeschriebenen Bemerkungen, die mir geeignet scheinen, diese Frage einer abschliessenden Entscheidung näher zu führen.

Die Saftbewegung in der gemeinschaftlichen Höhle des Polypenstockes der Hydroiden ist bald [Grant, van Beneden, Si ebold ${ }^{3}$ )] einem Flimmerepithelium, bald (Ehrenberg.. Lovén) einem Motus peristalticus der Leibeshöhle zugreschrieben worden. Beide Ursachen wirken gleichzeitig.

Dass die namentlich in jungen Knospen stets sehr lebhaften wimmelnden Bewegungen der in der Leibesflüssigkeit schwebenden Theilchen, und dass ähnliche tanzende-Bewegungen dieser Körnchen, dic überall in der Leibeshöhle vorliommen, von Flimmerhaaren bewirkt werden, ist wohl kaum zu bezweifeln.

Aber neben diesen Bewegungen sieht man raschere oder langsamere Strömungen, die oft über weite Strecken des Stammes in gleicher Richtung fortgrehen und eine Anhäufung der Leibesflüssigkeit an bestimmten Stellen zur Folge haben, von welchen eine folgende Strömung in entgegengesetzter Richtung sie wieder hinwegführt. Bei langsameren Strömen lassen sich oft sehr deutlich beiderlei Bewegungen neben einander beobachten, das Fortströmen in der Nitte der Röhre und das Wirbeln einzelner Körnchen am Rande ${ }^{\star}$ ).

Für diese Strömungen nun bleibt kaum eine andere Ursache denktsar, als Zusammenziehung der Leibeswand. Direkte Beweise für eine solche fand ich bei Plumularia laxa n. sp. ${ }^{5}$.

I) Archiv für Naturgeschichte 1863. I. p. 34-36.

2) „On n'est pas encore bien fixé sur la cause de ces courants" op. cit. Vol. 111. p. 50.

3) Auch Milne Edwards schliesst sich dieser Ansicht an.

4) Ein gleichzeitiges Aufwärtsströmen an einer Seite der Röhre und $\Lambda$ bwärtsströmen an der anderen, wie es Milne Edwards (1. c. p. 49) beschreibt, entsinne ich mich nicht, bei einer der von mir beobachteten Arten gesehen zu haben; doch mögen andere Arten sich hierin anders verhalten.

5) Eine besonders zierliche und durchsichtige, hier ziemlich seltene Art. Aus einer auf Tangen hinkriechenden Röhre erheben sich senkrechte etwa $15 \mathrm{~mm}$ hohe Stïmnchen mit 20 bis 3 ofiedrig ge- 
Hier sah ich einmal zwischen der Leibesröhre und deren Chitinhülle einige lose Körnchen, die stets in einer dem Strome innerhalb der Leibesröhre entgegengesetzten Richtung sich bewegten. IVenn der innere Strom durch Zusammenziehung der Leibeswand erzeugt wird, so ist natürlich dieser äussere ein nothwendiger Begleiter desselben, so wie umgekehrt seine Anwesenheit für diese Ursache des inneren beweisend ist. Es ist ganz dasselbe Verhältniss, wie zwischen den beiden entgegengesetzten Strömungen in den Füssen der Pycnogoniden, der des Darminhalts innerhalb und der des Blutes ausserhalb des sich zusammenziehenden Darmblindsacks.

Es lag nun nahe, an der Leibesröhre selbst den Nachweis der Zusammenziehung zu versuchen. An einer Stelle, wo durch den aufsteigenden Strom die Leibesflüssigkeit sich angehäuft hatte, mass ich den Abstand der Leibeswand von der Chitinhülle und fand ihn auf einer Seite $z u \quad 0,004 \mathrm{~mm}$, während sie sich auf der anderen dicht anlagen. Es trat bald darauf ein absteigender Strom ein und als derselbe aufhörte, war jener Abstand auf o,o I $\mathrm{mm}$ gestiegen. Der Durchmesser des Rohres war jetzt 0,042 , war also 0,048 gewesen und hatte sich folglich um $1 / 8$ vermindert.

Diese Beobachtung besteht sehr wohl mit der Angabe van Beneden's, nie Bewegungen an der Röhre der Campanularien gesehen zu haben (wenn auch nicht mit der von ihm behaupteten, „immobilité absolue“); denn dieser „motus peristalticus" fällt vollständig in das Gebiet jener langsamen Bewegungen, die, wie das Fortschreiten der Gestirne, nicht als solche unseren Sinnen sich bemerklich machen, sondern aus vergleichenden Beobachtungen verschiedener Zeiten erschlossen werden müssen.

$$
\text { Desterro, Juni } 1862 .
$$

stellten bis übər $2 \mathrm{~mm}$ langen Aesten, die in derselben Ebene liegend, abwechelnd rechts und links vom Stamme abgehen. Jeder Ast trägt auf seiner oberen Fläche 2 bis 3 ungestielte kegelförmige Becherchen mit weiter kreisförmiger glattrandiger Oeffnung. Die campanularienähnlichen Thiere können sich nicht ganz in diese Becherchen zurückziehen. 


\title{
Ueber eigenthümliche Gebilde in der Samenflüssigkeit von Janthina ${ }^{1}$.
}

\author{
Mit Tafel XXIV.
}

Selten nur verirren sich in den buchtenreichen Meeresarm, der die Insel Santa Catharina von dem südamerikanischen Festlande scheidet, Thiere des hohen Meeres. $\mathrm{Zu}$ diesen bisweilen Jahre lang vermissten Gästen gehören auch zwei Arten von Janthina, die als Begleiter von Velellaschwärmen zu erscheinen pflegen. Die eine, mit spitzerem Gewinde (J. exigua Lam.), von der ausser leeren Schalen nur einmal einige Weibchen gesehen wurden, trägt ihre Eier an dem schaumigen Anhange des Fusses; die andere, wiederholt gefundene, mit flacherem Gewinde (J. pallida Harv.) ist lebendig gebärend, und bei ihr konnte ich mich überzeugen, dass der schaumige Anhang in ganz gleicher Weise beiden Geschlechtern zukommt.

In der Samenflüssigkeit der letzteren Art finden sich sehr eigenthümliche Gebilde, auf die ich die Aufmerksamkeit der Besucher des Mittelmeeres und Anderer lenken möchte, die Gelegenheit haben zur Untersuchung dieser merkwürdigen Schnecken. Mir selbst bietet sich vielleicht in Jahren eine solche Gelegenheit nicht wieder, und dies möge mich entschuldigen, wenn ich abgerissen und unfertig, wie sie sind, meine Beobachtungen über jene Gebilde mittheile.

Schon mit blossem Auge gewahrt man in der Samenflüssigkeit der Janthina $\left.{ }^{2}\right)$ zahlreiche weisse wurmförmige Crebilde, die darin lebhaft herumschwimmen. Ihre Länge beträgt etwa $0,5 \mathrm{~mm}$ (ohne das unten zu erwähnende Schwimmwerkzeug). Das bewaffnete Auge unterscheidet an ihnen zunächst zwei scharf abgesetzte Abschnitte, die der Kürze wegen als Kopf und Schwanz bezeichnet werden mögen. Der Kopf nimmt etwa ein Viertel der Länge ein, ist bald zicmlich regelmässig kegelförmig (Fig. 7), bald in seinem hinteren, dickeren Theile mit unregelmässigen Vorsprüngen versehen (Fig. 8, 9), und vorn biswcilen statt der einfachen in eine doppelte Spitze auslaufend (Fig. 9). Es sind ihm zahlreiche dunkelgerandete Körnchen von verschiedener Grösse eingelagert, die ihn zienlich undurchsichtig machen; eine besondere Haut liess sich um ihn nicht unterscheiden. Der Schwanı,

I) Archiv für Naturgeschichte 1863. I. p. I79-183. Taf. X. Fig. 1-10.

2) Wahrscheinlich nicht während des ganzen Jahres; meine Beobachtungen vor zwei Jahren fielen, wie die diesjährigen, in den Oktober, dem im Mittelmeere der $\Lambda$ pril entsprechen würde. 
von etwa dreifacher Länge des Kopfes, ist vorn weit schmäler als der hintere Kopfrand, verbreitert sich nach hinten allmählich und endet abgerundet; er ist fast ganz undurchsichtig und dicht mit etwa $0,03 \mathrm{~mm}$ langen zarten Haaren besetzt (Fig. 7, 8, 9). Diese Haare sieht man lebhaft sich bewegen, aber nicht regelmässig in gleicher Richtung schlagen, wie Flimmerhaare thun, sondern unregelmässig durcheinander wallen und wimmeln, so dass man in ihnen nicht die Ursache der raschen Bewegung suchen kann, mit der die Gebilde in weiten Bogen durch das Wasser ziehen. Kopf und Schwanz scheinen bei dieser Bewegung als träge Masse ron einer ausser ihnen liegenden Kraft fortgeschleift zu werden; und so ist es in der That. Fast um die doppelte Länge des Kopfes von dessen Spitze entfernt, geht demselben bahnbrechend eine kegelförmige Spitze voraus, mit zarten aber scharfen Umrissen, von der aus, wie ein flatternder Schleier, eine vollkommen durchsichtige zarte Haut etwa bis zur Mitte des Kopfes niederwallt. Bisweilen konnte ich in dieser Haut eine äusserst zarte Längsstreifung erkennen. Ihre Umrisse werden nach hinten zu verschwindend zart, so dass ich sie fast nie bis zum hinteren Rande verfolgen konnte; ein einziges Mal bei einem jüngeren Exemplare (Fig. 6), sah ich deutlich den hinteren Rand, an dem sich die Haut in zarte Fasern aufzulösen schien. Vom Vorderende des Kopfes liess sich einigemal (Fig. 5, 7) ein schmaler, nicht scharf umrandeter Strang bis in die Nähe der kegelförmigen Spitze verfolgen. Ob diese wallende Haut (,undulirende Membran“) eine kegelförmige Hülle bildet, die durch einen mittleren freien Stiel mit dem Kopfe in Verbindung steht, oder ob sie flächenhaft sich ausbreitet und unmittelbar dem Kopfe angeheftet ist, muss ich unentschieden lassen; als ich eben dieser Frage meine Aufmerksamkeit zuwandte, raubte mir die schwarze Wolkenwand eines heraufziehenden Gewitters das zur Fortsetzung gerade dieser Untersuchung so unentbehrliche Licht, und als ich dieselbe wieder aufnehmen konnte, fand ich meinen ganzen Vorrath durch beginnende Zersetzung unbrauchbar geworden. In der Nähe der kegelförmigen Spitze lösen sich von der Haut mehrere schmale Flimmerhaaren ähnliche Zipfel ab. Während des Schwimmens nun schwingen diese Zipfel rasch und kräftig und die ganze Haut ist in lebhafter wallender Bewegung. Im Schlepptau dieses eigenthümlichen Schwimmwerkzeuges fortgezogen, schien mir der Schwanz sich stets völlig ruhig zu verhalten; das ganze Grebilde von der kegelförmigen Spitze der wallenden Haut bis zum abgerundeten Ende (les Schwanzes bildet dann einen schwach gekrümmten Bogen (Fig. 4, 5, 7, 8), und ähnlich gekrümmt ist die Bahn, die es durchzieht. Ruht die Haut und mit ihr der Kopf, so sieht man den Schwanz langsam sich winden und krümmen (Fig. 9), ohne dass dadurch eine merkliche Ortsveränderung bewirkt würde.

Getäuscht durch so mannigfache Bewegungen hatte ich vor zivei Jahren unsere Gebilde für Schmarotzerthiere gehalten, an denen ich freilich vergeblich mich abmühte, Spuren von Mund, Darm u. s. w. zu entdecken. Als ich kürzlich wieder eine männliche Janthina untersuchen konnte, fand ich in deren Samen meine Schmarotzer so dicht gedrängt, dass mir schon dadurch Zweifel aufstiegen, ob ich es nicht vielmehr mit einem wesentlichen Bestandtheile des Samens zu thun habe. Und nun fiel mir dann auch sofort die Aehnlichkeit auf zwischen den wimmelnden Haaren des Schwanzes und Samenfäden, die, der Reife nahe, sich noch nicht von ihrer Bildungsstätte gelöst haben, - und bald gelang es, 
mehrere Schwänze in Gruppen unverkennbarer Samenfäden zu zerdrücken, die aufs Haar den in der Samenflüssigkeit frei umherschwärmenden glichen (Fig. 10).

Somit war die Bedeutung unserer Gebilde als wesentlicher Bestandtheil des Samens festgestellt; aber sind es die Bildungsstätten der Samenfäden, von denen diese später, gereift, sich ablösen, oder sind es Samenträger („Spermatophoren“), um die sich die reifen Samenfäden gesammelt haben? Erstere Annahme ist mir die wahrscheinlichere: es sprechen für sie namentlich mehrfach beobachtete Exemplare (Fig. 6), an denen die Samenfäden nicht nur regungslos waren, sondern mir auch kürzer erschienen. Ausser diesen wurden zahlreiche andere, noch jüngere Formen gesehen; die jüngsten, die zur Beobachtung kamen (Fig. 1), hatten die Gestalt eines langgezogenen Eies von etwa $0,2 \mathrm{~mm}$ länge und $0,1 \mathrm{~mm}$ Dicke. Der grösste Theil dieser eiförmigen Körper erscheint vollkommen durchsichtig, leer; nur das dickere Ende ist vơn einer rundlichen Masse gefüllt, die durch dicht eingelagerte Körnchen undurchsichtig wird. Sie erscheint dunkler auf der der Spitze des Eies zugewandten Seite, heller auf der entgegengesetzten, ohne dass jedoch eine scharfe Grenze zwischen dem dunkleren und dem helleren Theile zu erkennen wäre. Eine solche Grenze hat sich ausgebildet, wenn die Körper zu etwa $0,3 \mathrm{~mm}$ Länge herangewachsen sind (Fig. 2); der hellere und dunklere Theil erscheinen jetzt etwa wie eine Eichel und der sie umfassende Becher. Später verlängert sich der hellere Theil und wächst aus in den Schwanztheil unserer Gebilde (Fig. 3, 4, 5), während der dunklere Kopftheil allmählich Kegelform annimmt (Fig. 4, 5), und der vorderste häutige Theil seine bewegende Thätigkeit beginnt; noch aber unterscheidet sich der Schwanz, im Gegensatze zu späterer Zcit, von dem Kopfe durch sein weit helleres Aussehen und seine Oberfläche ist, statt mit Samenfäden, bedeckt mit kleinen, rundlichen, durchsichtigen Körnchen (Bläschen?) und erinnert dadurch an die kugligen oder länglichen Körper, an denen z. B. in der Leibeshöhle der Ringelwürmer die Samenfäden sich entwickeln.

Desterro, Anfang November 1862.

\section{Erklärung der Abbildungen auf Tafel XXIV.}

Fig. I-0. Eigenthümliche Gebilde aus der Samenflüssigkeit von Janthina, auf verschiedenen Entwickelungsstufen; 9omal vergrössert.

Fig. $1-3$ u. 9 ruhend; Fig. 4-8 schwimmend; in Fig. 9 der Schwanz in langsam windender Bewegung.

Fig. Io. Samenfäden, durch Druck vom Schwanztheile dieser Gebilde abgelöst $360 m a l$ vergrössert. 


\title{
Observations sur la Respiration des Ocypodiens ${ }^{1}$ ).
}

\author{
(Extraites d'une lettre à M. Milne-Edwards et datée de Desterro [Brésil], \\ le 12 juillet 1863 .)
}

Vous avez signalé, chez les Ocypodes, l'existence d'une espèce de surface articulaire entourée de poils à l'article basilaire des pattes de la troisième et quatrième paire. Je trouve, chez l'Ocypode rhombea, qu'il existe entre les bases de ces pattes un orifice assez large qui conduit dans la cavité branchiale, et j'ai pu constater, chez des animaux vivants, l'entrée de l'eau par cet orifice. J'ai vu la même disposition chez deux espèces de Gelasimus, dont l'une me paraît être le Gelas. vocans. Chez cette dernière espèce, les poils qui entourent la surface lisse des articles basilaires des pattes n'ont rien de particulier, tandis que chez l'autre espèce plus petite de Gelasimus et chez l'Ocypode rhombea, ces mêmes poils sont dépourvus de filaments latéraux, plus ou moins moniliformes et remplis d'une substance albuminoïde et peut-être nerveuse (montrant une couleur rose assez vive sous l'influence d'une solution de sucre concentrée et de l'acide sulfurique). Ils ressemblent beaucoup aux appendices qui se trouvent aux antennes antérieures de presque tous les Crustacés, et que je considère avec M. Leydig comme des organes olfactifs. Ces appendices, étant complètement rudimentaires chez l'Ocypode, comme la tige de l'antenne qui les porte, on pourrait soupçonner que chez ce Brachyure terrestre, comme chez les Vertébrés terrestres, les organes olfactifs se trouvassent à l'entrée de la carité respiratoire.

I.es Ocypodes ne sont pas les seuls Brachyures, qui possèdent un orifice afférent de la chambre branchiale, situé en arrière des branchies. En observant les habitudes d'un des plus intéressants de nos Brachyures, le Sesarma Pisonii, qui grimpe sur les Rhizophores, pour en manger les feuilles, j'ai vu que cet animal soulevait la partie postérieure de la carapace et qu'il se formait ainsi une fente assez large au-dessus des bases des pattes de la quatrième et cinquième paire. Il en est de même chez un petit Grapse (voisin du Gr. messor, à ce qu'il me paraît). chez lequel j'ai répété beaucoup de fois cette observation. Il ne soulève jamais

1) Annales des Sciences naturelles 1863. 4. Sér. Zool. T. 20. p. 272. 
la carapace quand il se trouve submergé, tandis qu'il ne tarde pas à le faire dès qu'il respire l'air. Par le soulèvement de la carapace l'ouverture inspiratrice antérieure se rétrécit beaucoup et peut-être se ferme complètement; ainsi il y aurait ici deux orifices afférents dont l'un serait destiné de préférence à la respiration aquatique, tandis que l'autre servirait exclusivement à la respiration aérienne. Enfin, il m'a paru que chez l'Eriphia gonagra et chez quelques autres Brachy'ures (Sesarma, Cyclograpsus, etc.) qui se trouvent souvent dans la nécessité de respirer l'air pendant beaucoup d'heures, il se peut former un petit orifice temporaire à côté des bases des pattes de la cinquième paire, qui irait déboucher au-dessous de la base de l'abdomen. Cet orifice afférent postérieur, qui se trouve chez ces différents Brachyures terrestres ou amphibies, me rappelait la description que vous avez. donnée de la chambre branchiale de la Ranine qui, suivant Rumph, viendrait aussi à terre et grimperait jusque sur le faîte des maisons. 


\section{Ueber den Bau der Scheerenasseln (Asellotes hétéropodes M. Edw. $\left.)^{1}\right)$.}

\section{Vorläufige Mittheilung.}

Scheerenasseln kommen überall an den europäischen Küsten vor; sie wurden bei Neapel und Nizza, an den Küsten Englands und der Bretagne, Norwegens und Dänemarks gefunden und fehlen selbst nicht der salzarmen Ostsee. Da somit überall Gelegenheit zu deren Prüfung ist, scheint es mir nicht unpassend, in Kürze die Hauptergebnisse mitzutheilen, die mir die Untersuchung einer hiesigen, kaum von Tanais dubius Kr. verschiedenen Art lieferte.

Die Gliederung des Leibes, die Bildung der Füsse, den Bau der Mundtheile des Weibchens fand ich übereinstimmend mit den Angaben Kröyers ${ }^{2}$ ).

Der Panzer, der den Kopf und den ersten scheerentragenden Brustring bedeckt, überwölbt, frei nach unten vorspringend, kleine Höhlen zu den Seiten des Leibes.

In diesen Höhlen bewegt sich ein von hinten nach vorn gerichteter Wasserstrom, unterhalten wie bei den Zoëa und wie bei allen erwachsenen Krabben und Krebsen, durch einen, hier lang säbelförmigen Anhang des zweiten Maxillenpaares. - Auch der äussere rückwärts gerichtete Ast des ersten Kieferpaares liegt in dieser Höhle.

Besondere Kiemen, wie sie die Diastyliden (Cumaceen) haben, konnte ich nicht auffinden; dagegen sind wie bei den Zoëa, die Seitentheile des Panzers von sehr reichlichen Blutströmen durchzogen, und sind als Hauptsitz der Athmung anzusehen.

Die Schwimmfüsse des Hinterleibs haben nichts mit der Athmung zu thun; ich sah nie auch nur ein einziges der grossen Blutkörperchen in ilıre langbeborsteten blattförmigen Aeste eintreten.

1) Archiv für Naturgeschichte I864. I. p. I-6.

2) Vergl. Naturhistor. Tidskrift 4. Bind 1842 . S. $167 \mathrm{ff}$. und Ny Rükke 2. Bind 1847 . S. $412 \mathrm{ff}$. Wenn van Beneden (Recherches sur la faune litt. de Belgique. Crustacés. Pl. X VIbis fig. I-8) dem Hinterleibe nur vier dentlich geschiedene Ringe, allen Fï̈ssen der freien Brustringe gleichen Bau und ein kurzes crstes Glied giebt, das den von $\mathrm{K}$ röyer und mir beobachteten Arten fehlt, und wenn er die Kieferfüsse in einer ganz wunderlichen unerhörten Form erscheinen lässt, so dürften alle diese Abweichungen wohl eher auf einer irrthünlithen Auffassung als auf specifischen Verschiedenheiten der von ihm untersuchten Art beruhen. 
Das Herz erstreckt sich durch die ganze Länge der Brust bis in den crsten vom Panzer bedeckten Ring; seitliche Spalten zum Eintritte des Blutes sah ich im

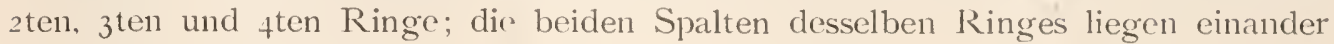
nicht genau gegenüber.

Die Leber besteht, wie bei den Bopyriclen, aus einem einzigen Patare von Blindschläuchen, die vom Kopfe bis in den Hinterleib reichen.

Im Grunde der oberen Fühler liegt ein Gehörwerkzeug, eine kleine ron oben her zugängliche Höhle mit einem Gehörsteinchen.

Die frei vorspringenden Augen liegen nach hinten, aussen und unten ron den vorderen Fühlern, eine Lage, die sich nicht mit der Annahme eines vor dem Fühlerringe liegenden Augenringes verträgt ${ }^{1}$ ).

Die Augen, wenigstens des Männchens, sind beweglich; ihre Chitinhülle (durch Kochen mit Kalilauge und Behandlung mit Säure dargestellt) zeigt in diesem Geschlechte stark nach innen vorspringende linsenförmige Verdickungen. die dem Weibchen fehlen.

Die vorderen Fühler der Jungen und der Weibchen sind plump, wenig beweglich, viergliedrig (das te Glied winzig) und tragen einen einzigen Riechfaden am Ende des dritten Gliedes.

Die Eierstöcke sind einfache Schläuche; die unpaare weibliche Geschlechtsöffnung liegt am Hinterrande des vorletzten Brustringes.

Die Bruttasche, die stets nur wenige, bisweilen nur I bis 3 Eier umschliesst, wird gebildet von vier Paar hinter den Füssen der vier ersten freien Brustring( befestigten Blättern, die für jede Brut sich neu erzeugen.

Die Männchen erleiden vor Erlangung der Geschlechtsreife eine bedeutende Verwandlung und finden sich geschlechtsreif in zwei verschiedenen Formen. Immer sind ihre vordern Fühler lang, schlank, sehr beweglich, reichlich mit Ricchfäden ausgestattet; es fehlen ihnen alle beweglichen Anhänge des Mundes (mit Ausnahme der den Wasserstrom durch die Athemhöhle unterhaltenclen (reisseln); ob ihr Mund geschlossen ist, wurde mir nicht deutlich; ihren Darm fand ich stets völlig leer. Wenn sie also wohl im geschlechtsreifen Zustanck nicht fressen, so werden sie für diese Zeit des Fastens mit einem reichen Vorrath von Fett ausgerüstet. Die Hoden scheinen, wie die Eierstöcke, einfache Schläuclıe $z u$ sein; sie münden in eine grosse querovale unpaare Blase, die im letzten Brustringe unter dem Darme liegt, die Geschlechtsöffnungen schrinen an der Spitze zweier kurzen warzenförmigen Vorsprünge zu liegen, die dieser letzto lirustring beim Männchen trägt. Die Samenkörperchen sind Kügelchen von etwa $0,00+$ mm. Durchmesser; an denen ich weder einen Kern, noch strahlenförmige Fortsätze sah; an einer Stelle haben sie einen winzigen warzen- und knopffürmigen Vorsprung.

Die gewöhnlichere Form der Männchen erscheint verhältnissnlässig ctwas breiter als die Weibchen; ihre Scheeren sincl von sehr abweichender Form, längror, langfingeriger, beweglicher; die Riechfäden steh'n zu je zwei bis lrei (schn' scltrn zu vier) am Grunde des vierten und am Ende clieses und der folgenden Fühlerglieder. Dic andere sehr seltene Form, die man wohl kaum einmal unter 100

1) Wie Claus, kann ich die Augen der Krebse nicht als Gliedmassen ansehen. 
gewöhnlichen Männchen findet, schliesst sich in der Form des Leibes und der Scheeren eng an die Weibchen an; ihre vorderen Fühler gleichen denen der gewöhnlichen Männchen, sind aber noch reichlicher mit Riechfäden ausgestattet, indem dieselben an denselben Stellen wie dort zu je fünf bis sieben beisammen stehen.

Die Entwickelung ist die der Asseln; das Junge im Eie ist nach oben gekrümmt, so dass also die vordere und hintere Hälfte der Rückenfläche einander zugewandt sind, wie es schon $R$ athke bei Ligia und Idothea fand.

Die Leibesringe des ausschlüpfenden Jungen sind vollzählig vorhanden; die Anhänge des Kopfes und der sechs ersten Brustringe sind wohlentwickelt, der längere innere Ast der Schwanzanhänge hat nur drei Glieder, statt der fünf des erwachsenen Thieres; aber es fehlen noch vollständig nicht nur, wie bei vielen anderen Asseln ${ }^{1}$, das letzte siebente Paar der Brustfüsse, sondern auch die fünf Paar Schwinmmfüsse des Hinterleibes. Diese sechs fehlenden Fusspaare treten später gleichzeitig auf.

So weit meine Beobachtungen.

Ich weiss nicht, ob Kröyer und van Beneden, die auch von Männchen und Weibchen sprechen, dieselben anders, als durch die nichts entscheidende Ab- oder Anwesenheit der Brutblätter unterschieden haben, möchte aber immerhin die Vermuthung wagen, dass nicht nur die beiden von Kröyer bei Madeira gesammelten Formen (Tanais Edwardsii und Savignyi) als Männchen und Weibchen zusammengehören sondern ebenso die beiden Formen des Oeresunds ( $T$. Curculio und Oerstedii). - Tanais Edwardsii weicht in ähnlicher IVeise von T. Savignyi ab, wie das Männchen unserer Art von seinem dem T. Savignyi höchst ähnlichen Weibchen. Diesem Weibchen steht ebenfalls T. Oerstedii sehr nahe, während allerdings T. Curculio durch die Bildung des Kopfes und der Scheeren sich weit von unserem Männchen, wie von allen Gattungsgenossen entfernt; aber wenn innerhalb derselben Art verschieden gebildete Männchen sich finden, so darf einc weit auseinanderlaufende Gestaltung derselben innerhalb der Gattung nicht auffallen. Ich führe noch zur Stütze dieser Ansicht an, dass im Greifswalder Bodden zwei Formen von Tanais zusammenleben, von denen die eine häufigere dem T. Oerstedii, die andere, wie die Männchen unserer Art, weit seltenere, dem T. Curculio sehr nahe steht.

Welche Stellung im Systeme gebührt nun diesen Scheerenasseln, die von allen anderen Asseln durch ihre Scheeren, durch ihre Augen, ihre Gehörwerkz'ruge, durch ihren der Athmung dienenden Panzer, durch die Lage ihres Herzens, durch ihre fastenden Männchen, durch die der Hinterleibsfüsse entbehrenden Jungen u. s. w. sich entfernen, und erwachsen, kaum ein wesentliches Merkmai mit ihnen gemein haben? - Die an die Amphipoden, denen ältere Beobachter sie anschliessen, durch die vorwärts gerichteten Fühler, deren vorderes Paar bei Rhoëa zwei Geisseln trägt, durch die abweichende Bildung der beiden vorderen und die (wenigstens bei Tanais) verbreiterten Grundglieder der drei hinteren

1) Nach Milne Edwards bei den Cymothoaden, ich fand es ebenso bei den Bopyriden, bei Ligia nnd Philoscia; nach Untersuchung ziemlich weit entwickelter Eier vermuthe ich ein gleiches Verhalten bei Idothea und Sphaeroma. Die geringe Entwickelung des siebenten Brustringes bei Serolis macht auch hier ähnliche Jugendzustånde wahrscheinlich. 
Fusspaare der Brust, so wie durch Lage und Bau des Herzens erinnern und deren Athmung vollständig wie bei den Jugendformen der Krabben und Krebse vor sich geht?

Die Entwickelung scheint mir unzweideutig zu beweisen, dass sie ächte Asseln sind, dass sie sich nicht den stieläugigen Krebsen und viel weniger noch den Amphipoden annähern lassen, an die die erwachsenen Thiere so vielfach erinnern. Es ist mir ausser zahlreichen Asseln kein Krebs bekannt, der das Ei (oder, wie Ligia, eine anhanglose früheste Larvenhaut $\left.{ }^{1}\right)$ ) verliesse mit bis zum vorletzten Brustringe vollständig entwickelten Gliedmassen, während dieselben dem letzten Brustringe noch fehlen. - Dem Amphipoden-Ei scheint stets ein „Micropyl-Apparat“ zuzukommen ${ }^{2}$ ); die Jungen liegen darin in umgekehrter Weise gekrümmt und verlassen es mit vollzähligen Gliedmassen.

Aber was wollen nun innerhalb der Ordnung der Isopoden die Scheerenasseln bedeuten? - Die Antwort wird verschieden ausfallen je nach den systematischen Grundanschauungen, von denen man ausgeht.

Wer die Arten als unveränderliche Bildungen ansieht, die bei jeder der hundertfach wiederholten Schöpfungen fix und fertig aus den Elementen zusammenschossen, und die Urform (den Typus) jeder grösseren oder kleineren Gruppe aus den der Mehrzahl ihrer Mitglieder gemeinsamen Merkmalen aufbaut, der wird natürlich in den Scheerenasseln die von dem Typus der Isopoden am weitesten abirrende Asselform erblicken.

Wer dagegen mit Darwin als Endziel der Systematik die Aufstellung eines Stammbaumes der Thier- und Pflanzenwelt, und wer daher als Urform einer Gruppe den gemeinsamen Stammvater derselben betrachtet, der wird im Gegentheile zu der Ansicht geneigt sein, dass unter allen Asseln der Gegenwart die Scheerenasseln mit ihren beweglichen Augen und ihrer Zoëa-Athmung der Urassel am nächsten stehen, die vielleicht noch, wie der Urvater aller Malacostraca, eine durch Nauplius und Zoëaformen hindurchgehende Verwandlung zu bestehen hatte.

Desterro, im Juni 1863.

I) Näheres hierüber nächstens.

2) Ich vermisste den "Micropyl-Apparat" bei keinem der zahlreichen von mir hierauf untersuchten Amphipoden aus den Gattungen Gammarus, Amphithoe, Podocerus, Corophium, Orchestia u. a. und fand ihn ebenfalls bei Caprella. 


\title{
Ein Wort über die Gattung Herklotsia J. E. Gray ${ }^{1}$ ).
}

\author{
„In my opinion, this inordinate multipli- \\ cation of genera destroys the main ad- \\ vantages of classification."
}

Darwin, Lepadidae S. $216^{2}$ ).

Herklots hat in seiner Bearbeitung der Seefedern drei Arten von Renilla unterschieden, R. reniformis Pall., violacea Quoy et Gaim., und Edwardsii n. sp. Die von ihm gegebenen Diagnosen enthalten indess kein einziges Merkmal, das die wirkliche Verschiedenheit dieser Arten verbürgte. - Die Gestalt der Scheibe, die Streifung ihrer Unterfläche, die Länge und Form des Stiels sind sämmtlich Verhältnisse, die beim lebenden Thiere in beständigem Wechsel begriffen sind, so dass danach bisweilen dieselbe Scheibe in derselben Minute jeder der drei Arten eingereiht werden könnte. Der angebliche Mangel der „spicules“ bei R. violacea beruht offenbar auf schlechter Erhaltung der Exemplare und die geringe Zahl der Polypen bei R. Edwardsii würde nur dann als bezeichnend gelten dürfen, wenn nachgewiesen wäre, dass von ihr die beobachtete Zahl nicht überschritten würde; denn bei jüngeren Scheiben aller Arten ist die Polypenzahl natürlich eine geringe. Ueber Zahl und Stellung der die Polypenzellen umstehenden Zähne oder sonstige zur sicheren Unterscheidung von Renillaarten brauchbare Merkmale findet man bei Herklots nichts.

Dass man nun auf solche Merkmale, die selbst zur Artunterscheidung völlig ungenügend sind, Gattungen bauen könne, scheint kaum glaublich. Doch dem unermüdlichen Fabricanten neuer Gattungen und Arten in allen Klassen des Thierreichs, Herrn J. E. Gray, ist in dieser Beziehung nichts unmöglich. Er hat denn auch (s. R. Leuckart's Jahresbericht in dies. Archiv. XXVII. Bd. 2. S. 346) die Renilla Edwardsii zum Typus einer neuen Gattung Herklotsia zu erheben verstanden.

Diese Gattung Herklotsia ist ein zu ergötzliches Beispiel der Verirrungen, die der Beobachter der lebenden Thierwelt so manches Mal an den Museums-

I) Archiv für Naturgeschichte I864. I. p. $352-358$.

2) Darwin schrieb diese Worte in Bezug auf die Gattung Scalpellum, deren vier ihm bekannte Arten J. E. Gray in ebenso viele Genera vertheilt hatte. Dabei hat er spasshafter Weise die Zahl der Stücke des Gehäuses, auf welche diese Genera fast ausschliesslich begründet waren, für drei derselben irrig angegeben. 
zoologen zu rügen hat, als dass ich mir das Vergnügen einer kritischen Beleuchtung versagen könnte.

Die von Gray gegebenen Diagnosen der Gattungen Herklotsia und Renilla sind (nach Leuckart's Jahresbericht a. a. O.) die folgenden:

Herklotsia. Disk expanded, upper surface armed with spicula surrounding the edge of the cells, lower moderately striated. The stem inserted in a deep notch on the lower edge, and separated from the disk by a well defined groove. Polypes few, placed in series.

Renilla. Disk smooth above and beneath, without spicula and continued into the stem. Polypes numerous.

Sehen wir uns die einzelnen Merkmale etwas näher an.

„Disk expanded“ - Vortrefflich; - ganz als wollte man die Diagnose einer Vogelgattung mit den Worten beginnen: „Flügel ausgebreitet", als wollte man die zufällige Stellung, die der Ausstopfer einem Thiere gegeben, als Gattungskennzeichen verwerthen. „Disk expanded“, als wäre die Renillascheibe ein starres Gebilde, wie eine Muschelschale oder Krebsscheere, und nicht vielmehr der wechselvollsten Gestaltveränderung in ungewöhnlich hohem Grade fähig. - Entnimmt man zur Ebbezeit eine prächtige dunkelviolette Renilla, bei der je sieben mit goldgelben Kalknadeln durchspickte Zähne den Rand der Zellen umgeben, dem Boden des Meeres, so findet man die Scheibe trichterförmig eingezogen und unmittelbar in den langen, am Ende bald kolbigen, bald zugespitzten Stiel sich fortsetzend. In ein Glas mit Seewasser geworfen, breitet sich die Scheibe zunächst, ohne sich auszudehnen, flach in einer Ebene aus; der Stiel zieht sich aufs Aeusserste zusammen und während er eben etwa die dreifache Länge des Scheibendurchmessers hatte und von der Unterseite gerade abwärts gerichtet war, liegt er jetzt als unbedeutender Vorsprung von kaum $1 / 4$ des Scheibendurchmessers in der Ausbucht der Scheibe und in gleicher Ebene mit dieser. Bei längerem Liegen beginnt die Scheibe sich durch eine in der Mitte ihrer oberen Fläche gelegene grosse Oeffnung ${ }^{1}$ ) allmählich mit Wasser zu füllen. Die Polypen treten hervor, der Durchmesser der Scheibe steigt nach und nach wohl auf mehr als das Fünffache; (genaue Messungen sind mir augenblicklich nicht zur Hand). Dabei wölbt sich die obere Scheibenfläche, die beiden Lappen, zwischen denen der Stiel entspringt, schieben sich übereinander, und auch der Stiel streckt sich wieder und füllt sich mit Wasser. Die vorgestreckten Polypen sieht man ohne äusseren Anlass nur selten sich bewegen, die Scheibe dagegen ist nie in Ruhe; sie zeigt langsame kräftige Zusammenziehungen, die vom Ansatzpunkte des Stieles nach dem gegenüberliegenden Rande der Scheibe fortschreiten und dabei diese durch eine Reihe auffallend verschiedener Gestalten hindurchführen. Auch der Stiel nimmt an diesen Zusammenziehungen Antheil; er schnürt sich dabei bisweilen von der Spitze her zu einem fadenförmigen Strange zusammen, um dann

I) Diese, wie es scheint, bisher übersehene Oeffnung wurde zuerst, vor einigen Jahren, von meiner damals siebenjährigen Tochter Rosa bemerkt, die aus ihr einen kräftigen Wasserstrahl spritzen sah, als sie eine lebende Renilla aus dem Meere nahm. Eine ähnliche Oeffnung fand später, nach brieflicher Mittheilung, Max Schultze bei Pennatula. Auch an der Spitze des Stiels hat Renilla eine kleine Oeffnung, aus der ebenfalls bisweilen ein zarter Wasserstrahl hervorspritzt, wenn man eine aufgeschwellte Scheibe aus dem Wasser nimmt. 
sofort wieder zu einem weiten Rohre sich aufzublähen. - Ganz ähnlich verhält sich Renilla reniformis, nur dass sie nicht die vollkommene Trichterform der anderen Art anzunehmen vermag $\left.{ }^{1}\right)$.

„Upper surface armed with spicula surrounding the edge of the cells" heisst es weiter von Herklotsia und im Gegensatze dazu von Renilla: „disk smooth, without spicula“. WVenn unter „spicula“ Kalknadeln verstanden sind, so begreife ich nicht, wie man von deren Fehlen bei Renilla sprechen kann, da dieselben alle Theile der Scheibe durchsetzen und bei der oberflächlichsten Untersuchung in die Augen fallen. Sollten aber, unpassender Weise, durch diesen Ausdruck die von zahlreichen Kalknadeln gestützten vorspringenden Zähne um den Zellenrand bezeichnet sein, so fehlen diese wahrscheinlich ebenso wenig irgend einer Art; bei $R$. reniformis sind sie wohl entwickelt. Wenn Gray sie vermisste, so lag dies an der schlechten Erhaltung seiner Exemplare. Bei verwesenden und schon bei langsam sterbenden Thieren fallen die oberflächlichen Kalknadeln leicht ab und die Zähne am Zellenrande sind dann nur schwierig nachzuweisen.

„Lower surface moderately striated“ bei Herklotsia, - „disk smooth beneath“ bei Renilla. - Die Streifung der Unterfläche oder richtiger die netzförmige Zeichnung mit langstreckigen strahlig geordneten Maschen bezeichnet die Grenzen der einzelnen Polypenzellen. Wo deren Scheidewände auf die untere Wand der Scheibe stossen, stehen die oberflächlichen Kalknadeln dichter und ausserdem erscheinen, wenn die Zellen sich aufblähen, ihre Grenzen als vertiefte Linien, an deren Stelle umgekehrt beim Einschrumpfen der Zellen wieder deutliche erhabene Linien treten können. Dazwischen liegt natürlich ein Mittelzustand, in welchem abgesehen von den leicht abfallenden zarten Kalknadeln, die Unterfläche glatt erscheint. Daraus ergiebt sich von selbst der systematische Wert dieses Merkmals.

"The stem separated from the disk by a well defined groove" bei Herklotsia, - „the disk continued into the stem“ bei Renilla. Bei Renilla reniformis sieht man fast nie, selten bei älteren, häufig dagegen bei jüngeren Scheiben unserer zweiten Art den Stiel durch eine deutliche tiefe Furche von der Scheibe geschieden. Diese Furche ist aber nicht etwa, wo sie vorkommt, etwas Festes, Bleibendes, sondern tritt nur bei bestimmten Contractionszuständen hervor. Dieselbe Renillascheibe kann, was dieses Merkmal betrifft, in einer Stunde ein Dutzendmal aus einer in die andere Gattung und wieder zurückspazieren.

Ich kann wohl den wirklichen Werth all dieser Gray'schen Gattungsmerkmale nicht besser ins rechte Licht setzen, als indem ich ein untrügliches Recept mittheile, eine Herklotsia bei lebendigem Leibe tuto, cito et jucunde in eine Renilla zu verwandeln. Man setze das Thier in einer flachen Schale, nur so eben von Wasser bedeckt, eine Stunde lang den Strahlen der tropischen Mittagssonne aus, spüle es ab und die Renilla ist fertig. Die Kalknadeln der Oberfläche liegen abgefallen am Boden der Schale, die Zähne am Zellenrande sind zusammengesunken, und bei dem Zustande von Erschlaffung, in dem sich das Thier befindet, ist sicher weder Streifung der Unterfläche, noch eine Furche am Grunde des Stieles vorhanden. Man sieht, für Gray'sche Genera bedarf es keiner jahrtausendelangen natürlichen Züchtung, um eines aus dem anderen hervorgehen zu lassen.

I) Näheres über diese und andere Lebenserscheinungen der Renillen bleibt einem anderen Orte vorbehalten. 
Doch es bleibt uns noch ein Kennzeichen der Gattung Herklotsia: „Polypes few, placed in series“, und dagegen bei Renilla: „Polypes numerous“. Zuerst sei hierzu bemerkt, dass die Ausdrücke few und numerous überhaupt zu denen gehören, die ihrer Unbestimmtheit wegen für immer aus allen Diagnosen verbannt werden sollten. Ist z. B. in unserem Falle bei Io, oder 20 , oder 100 Polypen die Grenze zwischen dem few und dem numerous zu suchen? - Aber abgesehen hiervon, so hätte Herr Gray am Rande jeder beliebigen Renillascheibe schen können, dass hier eine Neubildung von Zellen und Polypen stattfindet, - er hätte sich danach sagen können, dass überhaupt die dem Rande näheren Polypen jünger sind als die mittelständigen; - er hätte sich sagen können, dass auch die polypenreichste Renillascheibe in ihrer Jugend nur wenige Polypen besass und dass somit das few und das numerous nichts mehr und nichts weniger als eine Altersverschiedenheit bezeichnet und wie all seine übrigen Merkmale nicht einmal specifischen, geschweige denn generischen Werth hat.

In den ersten Wochen, das sei hier beiläufig angeführt, sind sogar, wie man sich denken konnte, die jungen Renillen einfache Polypen ohne Kalknadeln; aber schon in dieser frühesten Zeit ist, wie später, der Stiel durch eine l,ängsscheidewand in zwei Kammern getheilt und an der Spitze mit einer Oeffnung versehen. Glücklicherweise hatte Herr J. E. Gray im British Museum keine Gelegenheit, diese jüngsten Renillen zu sehen, auf die sonst unfehlbar vieder ein neues Genus gegründet worden wäre.

Ich habe die Aufstellung der Gattung Herklotsia eine ergötzliche Verirrung genannt. Leider hat die Sache auch ihre ernste Seite. - Die Gattung wurde nicht beiläufig, etıva bei Beschreibung einer neuen Art, von einem Neulinge aufgestellt, sondern in einer Abhandlung, welche eine kritische Revision der systematischen Anordnung der Seefedern zum Zweck hat, und von einem Manne, mit dem sicher Wenige sich messen können, was Reichthum und Vielseitigkeit der auf eigene Anschauung und Untersuchung gestützten zoologischen Kenntnisse betrifft. Welch trauriges Licht wirft es auf den Zustand der heutigen Systematik, dass an solcher Stelle und von solcher Hand ein ähnlicher Missgriff gethan werden durfte. Und der Fall ist kein vereinzelter. Fast jede Seite eines zoologischen Jahresberichtes liefert Belege für die wüste, grundsatz- und haltlose Weise, in der man heutzutage so vielfach ins Blaue hinein Gattungen und Arten fabricirt. Um ihre Wissenschaft vor vollständiger Verwilderung zu bewahren, ist es wahrlich die höchste Zeit, dass die Systematiker sich allen Ernstes der Erörterung der allgemeineren Fragen zuwenden, von denen aus sie allein für ihre Arbeiten festen Boden und sichere leitende Grundsätze gewinnen können. - Die Anregung, die hierzu durch Darwin's Buch über die Entstehung der Arten gegeben wurde, hätte zu keiner gelegeneren Stunde kommen können.

Desterro, 3i. März 1864. 


\title{
Nachtrag zum vorstehenden Aufsatze1).
}

\author{
Von Max Schultze.
}

Fritz Müller's Beobachtung grösserer Oeffnungen zur Wasseraufnahme und Abgabe bei Renilla, welche mir bereits seit längerer Zeit durch briefliche Mittheilungen bekannt war, veranlasste mich die mir zu Gebote stehenden Spiritusexemplare von Pennatula auf solche Oeffnungen anzusehen. Dass bei den Pennatuliden sämmtlich dergleichen Oeffnungen vorhanden seien, war an sich nicht zu bezweifeln, da die Wasserlöcher ein wesentliches Glied in der Organisation der Coelenteraten darstellen. Es handelte sich aber darum, die Lage dieser Oeffnungen, deren bisher Niemand Erwähnung gethan, zu bestimmen und vor allen Dingen festzustellen, ob ein der bei Renilla constanten grösseren mittleren Scheibenöffnung entsprechendes Wasserloch auch den echten Pennatuliden zukomme. Gleich die ersten Nachforschungen bei zwei wohl erhaltenen Exemplaren der Pennatula rubra aus dem Mittelmeere, welche das hiesige anatomische Museum besitzt, führten zu einem sehr bestimmten Resultat, insofern an beiden Exemplaren je eine grössere Oeffnung gefunden wurde, welche offenbar nur zur Wasseraufnahme und Abgabe in das innere Höhlensystem des Stammes dienen konnte. Doch verhielten sich beide Exemplare verschieden. Auf der körnigen hinteren Oberfläche des Stammes von P. rubra verläuft eine mittlere Längsrinne mit glattem Boden und von weisslicher Farbe. Dieselbe beginnt kaum sichtbar am oberen Ende des Schaftes und verbreitet sich nach abwärts, um am Anfange des drehrunden Stieles zu verschwinden. Hier an der Grenze von Fahne und Stiel entsteht aus der Längsrinne an einem der beiden Exemplare eine tiefe seitlich ausweichende Furche, und führt sofort in eine weite Oeffnung, durch welche leicht eine geknöpfte Sonde in das Hohlraumsystem des Stieles vorgeschoben werden kann. Drückt man den Stiel aufwärts nach der Oeffnung zu, so fliesst eine ansehnliche Menge Flüssigkeit aus dem Innern aus. An dem anderen Exemplare fehlt hier an der Hinterseite die tiefere Furche mit der Oeffnung gänzlich, dafür zeigt sich auf der vorderen Fläche in der Höhe des sechsten Polypen tragenden Zweiges etwas seitlich von der Mittellinie in versteckter Lage eine ansehnliche Oeffnung mit wulstigem Rande, durch welche eine geknöpfte Sonde leicht aufwärts und abwärts in das Hohlraumsystem des Körpers vorgeschoben werden kann.

I) Archiv für Naturgeschichte 1864. I. p. 359-360. 
Nach diesem Befunde war ich erstaunt, an mehreren Exemplaren von Pennatula (Pteroeides Herklots) spinosa des hiesigen anatomischen und zoologischen Museums keine Spur einer solchen grösseren Oeffnung zu finden. Ebensowenig bei den kleinen zierlichen Pennatula pulchella. Dagegen fand sich eine den beschriebenen entsprechende Oeffnung an einem Exemplar von Pteroeides japonicum des hiesigen zoologischen Museums und zwar auf der Mitte der Hinterseite des Schaftes in der Höhe des, von unten gerechnet, sechsten Polypen tragenden Armes. Die Sonde glitt von hier aus leicht aufwärts in das Innere.

Ausser diesen grösseren Wasserlöchern kommen bei der Pennatula wie bei Renilla, wie es scheint, allgemein kleinere Oeffnungen vor und zwar constant an der Spitze des Stieles. Bei Renilla sind dieselben von Fritz Müller gesehen. Ihre Anwesenheit bei Pennatula ist leicht zu constatiren, wenn man Exemplare, die nicht gar zu stark in Spiritus erhärtet sind, nach der Spitze des Stieles zu mit den Fingern streicht. Ich sah bei dieser Operation immer mehrere feine Strahlen Flüssigkeit aus winzigen Oeffnungen des Stieles hervordringen. 


\section{Für Darwin $\left.{ }^{1}\right)$.}

Mit 67 Textfiguren.

„Caeterum, nullius in verba jurans, aliorum inventa consarcinare haud institui; quae ipse quaesivi, reperi, repetitis vicibus diversoque tempore observavi, ..... propono."

O. F. Müller, Histor. vermium.

Vorwort.

Die folgenden Blätter wollen nicht die für und wider Darwin's Lehre von der Entstehung der Arten vorgebrachten Gründe aufs neue erörtern und gegeneinander abwägen. Sie wollen einfach auf einige dieser Lehre günstige Thatsachen hinweisen, gesammelt auf demselben Boden Südamerika's, auf welchem in Darwin, wie er uns erzählt, zuerst der Gedanke aufkeimte, sich mit der „Entstehung der Arten, diesem Geheimniss der Geheimnisse“ zu beschäftigen.

Nur durch Herbeischaffen neuen verwerthbaren Stoffes wird sich allmählich die Streitfrage für eine endgültige Entscheiduug spruchreif machen lassen, und dieses erscheint einstweilen wichtiger als eine wiederholte Zergliederung des bereits vorliegenden. Zudem bleibt es billig fürs Erste Darwin selbst überlassen, die Angriffe der Gegner abzuwehren von dem stolzen Baue, den er mit solcher Meisterhand aufgeführt.

Desterro, 7. September 1863 . F. M.

I.

Als ich Charles Darwin's Buch „über die Entstehung der Arten“ gelesen hatte, schien es mir, dass einer der Wege und der sicherste vielleicht, die darin entwickelten Ansichten auf ihre Richtigkeit zu prüfen, der sei, dass man eine möglichst ins Einzelne gehende Anwendung auf eine bestimmte Thiergruppe versuche. Ein solcher Versuch, sei es für die Familien einer Klasse, sei es für die Gattungen einer grösseren Familie, oder für die Arten einer reichen Gattung einen Stammbaum aufzustellen, und von den gemeinsamen Urahnen der verschiedenen engeren und weiteren Kreise möglichst ausgeführte und anschauliche Bilder zu entwerfen, konnte ein dreifach verschiedenes Ergebniss liefern.

I) Leipzig. Engelmann. 1864. 
Es konnten I. Darwin's Vorraussetzungen bei ihrer Anwendung zu unvereinbaren, sich widersprechenden Folgerungen führen, aus denen dann auf die Irrigkeit der Voraussetzungen zurückgeschlossen werden durfte.

Waren Darwin's Ansichten falsch, so war zu erwarten, dass Widersprüche ihre Anwendung im Einzelnen auf jedem Schritte begleiten, und dass sie, sich häufend, die Voraussetzungen, aus denen sie hervorgegangen, mit vereinter Wucht aufs Gründlichste zermalmen würden, so wenig auch die auf jeden besonderen Fall gebauten Schlüsse die Unbedingtheit mathematischer Beweise haben mochten.

Es konnte 2. der Versuch in ausgedehnterer oder beschränkterer Weise gelingen. War es möglich, auf Grund und mit Hilfe der Darwin'schen Lehre zu zeigen, in welcher Folge die verschiedenen engeren und weiteren Kreise aus der gemeinsamen Grundform und von einander sich losgelöst, in welcher Folge sie die jetzt sie bezeichnenden Eigenthümlichkeiten erworben, welche Umwandlungen sie im Laufe der Zeiten erlitten hatten, - war eine solche von inneren Widersprüchen freie Aufstellung eines Stammbaumes, einer Urgeschichte der betrachteten Thiergruppe möglich, so musste diese Aufstellung, je vollständiger sie die bekannten Arten in sich aufnahm, und je tiefer sie in das Einzelnste des Baues hinabzusteigen vermochte, um so mehr in sich selbst die Bürgschaft der Wahrheit tragen, und um so überzeugender den Beweis liefern, dass der Grund, auf dem sie gebaut, kein lockerer Sand, dass er mehr, als blos „ein geistreicher Traum" sei.

Freilich war es 3. auch möglich, und dies musste von vorn herein als der wahrscheinlichere Fall erscheinen, dass der Versuch an den ihm entgegentretenden Schwierigkeiten scheiterte, ohne die Frage, für oder wider, in Anerkennung erzwingender Weise zu entscheiden. Glückte es indess nur, für sich selbst auf diesem Wege zu einem einigermassen gesicherten selbstständigen Urtheile über diese so tief in die höchsten Fragen eingreifende Angelegenheit zu gelangen, so musste auch das schon als reicher Gewinn gelten.

Entschlossen, den Versuch zu 'wagen, hatte ich zunächst für eine bestimmte Klasse mich zu entscheiden. Die Wahl musste sich auf diejenigen beschränken, deren Hauptformen leicht in einiger Mannichfaltigkeit lebend zu erhalten waren. Eine so lange und bunte, und doch so innig verknüpfte Reihe nun, wie sie aus der Klasse der Kruster die Krabben und Krebse, die Maulfüsser, die Diastyliden, die Amphipoden und Asseln, die Ostracoden und Daphniden, die Copepoden und Schmarotzerkrebse, die Rankenfüsser und Wurzelkrebse unserer Küste boten (nur die Phyllopoden und Xiphosuren fehlten), stand mir aus keiner anderen Klasse zur Verfügung. Auch ohne diesen Umstand hätte indessen die Wahl der Kruster kaum zweifelhaft sein können. Nirgends, wie das schon von verschiedenen Seiten ausgesprochen wurde, ist ja die Versuchung dringender, den Ausdrücken: „Verwandtschaft, Hervorgehen aus gemeinsamer Grundform", und ähnlichen eine mehr als blos bildliche Bedeutung beizulegen, als bei den niederen Krustern. Namentlich bei den Schmarotzerkrebsen pflegte ja längst alle Welt, als wäre die Umwandlung der Arten eine selbstverständliche Sache, in kaum bildlich zu deutender Weise von ihrer Verkümmerung durch's Schmarotzerleben zu reden. Es mochte wohl Niemandem als eines Gottes würdiger Zeitvertreib erscheinen, sich mit dem Ausdenken dieser wunderlichen Verkrüppelungen zu belustigen und so liess man 
sie durch eigene Schuld, wie Adam beim Sündenfall, von der früheren Vollkommenheit herabsinken.

Dass bereits ein grosser Theil der weiteren und engeren Kreise, in die sich diese Klasse gliedert, als endgültig festgestellt gelten durfte, während bei zwei anderen Klassen, in denen ich heimisch war, den Ringelwürmern und Quallen. alle versuchten Anordnungen nur als vorläufige Uebersichten erscheinen mussten, war ein weiterer nicht zu unterschätzender Vorzug. Diese unverrückbaren Gruppen, wie die scharfgezeichneten Formen des starren reichgegliederten Hautgerüstes, waren nicht nur als sichere Ausgangs- und Stützpuncte, sie waren auch als wohlthätige unerbittliche Schranken vom höchsten Werthe bei einer Aufgabe, bei der nun einmal, ihrer Natur nach, die Phantasie frei ihre Schwingen entfalten musste.

Indem ich also begann, mir von diesem neuen Standpuncte der Darwin'schen Lehre aus unsere Kruster näher anzusehen, indem ich versuchte, die Anordnung derselben in die Form eines Stammbaumes zu bringen und über den wahrscheinlichen Bau der Stammeltern mir Rechenschaft zu geben, sah ich freilich bald, und ich war darauf gefasst gewesen, - dass es langjähriger Vorarbeiten bedürfen würde, ehe die eigentliche Aufgabe in ernstlichen Angriff genommen werden könne. Die bisherigen systematischen Arbeiten legten meist mehr Gewicht auf die die Gattungen, Familien, Ordnungen scheidenden, als auf die die Glieder jedes Kreises unter sich verknüpfenden Merkmale und lieferten deshalb oft verhältnissmässig wenig verwendbaren Stoff. Vor Allem aber war eine eingehende Kenntniss der Entwickelung unentbehrlich, und Jedermann weiss, wie lückenhaft in dieser Beziehung das bisher Erkannte ist. Diese Lücken waren um so schwieriger auszufüllen, da man, wie van Beneden für die Decapoden bemerkt, wegen der oft unglaublich verschiedenen Entwickelung nächstverwandter Formen, meist Familie für Familie, oft Gattung für Gattung, ja man kann in Hinblick auf Penëus hinzusetzen, bisweilen selbst Art für Art besonders studiren musste, und da diese Untersuchungen, an sich mühsam und zeitraubend, in ihrem Erfolge oft von einem glücklichen Ungefähr abhingen.

Musste so aber auch der "Stammbaum der Krebse“ als ein Unternehmen erscheinen, für dessen befriedigende Ausführung die Kraft und die Lebensfrist eines Einzelnen kaum ausreichen mochte, selbst unter günstigeren Verhältnissen, als eine entlegene Insel, fern vom grossen Markte des wissenschaftlichen Lebens, fern von Bibliotheken und Museen, sie bieten konnte, - so wurde mir doch täglich seine Ausführbarkeit weniger zweifelhaft, und täglich machten mich neue Erfahrungen der Darwin'schen Lehre günstiger gestimmt.

Wenn ich mich nun entschliesse, über die Gründe mich auszusprechen, die sich mir aus der Betrachtung unserer Kruster zu Gunsten der Darwin'schen Ansichten ergaben, und die - neben allgemeineren Erwägungen und beiläufigen Erfahrungen auf anderen Gebieten - wesentlich dazu beitrugen, die Richtigkeit jener Ansichten mir immer wahrscheinlicher zu machen, so bestimmt mich dazu hauptsächlich eine Aeusserung Darwin's. „Wer immer“, sagt er (Uebers. v. Bronn, S. 486), ,sich zur Ansicht neigt, dass Arten veränderlich sind, wird durch gewissenhaftes Geständniss seiner Ueberzeugung der Wissenschaft einen guten Dienst leisten." Dem in diesen Worten enthaltenen Wunsche entspreche ich meinerseits um so lieber, da dies mir Gelegenheit bietet, öffentlich dem Danke Worte zu 
leihen, zu dem ich mich Darwin auf's Tiefste verpflichtet fühle für die Belehrung und Anregung, die ich seinem Buche in so reichem Maasse schulde. So werfe ich denn getrost dieses Sandkorn in die Wagschale gegen den „Berg von Vorurtheilen, unter welchem dieser Gegenstand vergraben ist", unbekümmert, ob auch mich die Priester einer alleinseligmachenden Wissenschaft zu den Träumern rechnen werden und zu den "Kindern an Erkenntniss der Naturgesetze“.

II.

Eine falsche Voraussetzung wird früher oder später, wenn man weiter und weiter den aus ihr fliessenden Folgerungen nachgeht, zu Ungereimtheiten und greifbaren Widersprüchen führen. Solche Widersprüche zwischen den aus Darwin's Lehre für die Klasse der Kruster sich ergebenden Schlüssen aufzufinden, habe ich mich viel bemüht während der nicht kurzen Zeit peinlichen Zweifels, in der das Zünglein der Wage mir völlig ungewiss schwankte zwischen dem Für und dem Wider, und in der jede zu rascherer Entscheidung führende Thatsache mir hoch willkommen sein musste. Ich habe keinen gefunden, weder damals, noch später. Die ich gefunden zu haben meinte, lösten sich bei näherer Betrachtung, oder verwandelten sich selbst in Stützen der Darwin'schen Lehre.

Auch von anderen Seiten sind, soviel mir bekannt geworden, keine nothwendigen Folgerungen der Darwin'schen Voraussetzungen als in offenem, unvereinbarem Widerspruche stehend nachgewiesen worden. Und doch, da zu den Gegnern Darwin's die gründlichsten Kenner der Thierwelt gehören, sollte man meinen, dass es ihnen ein Leichtes hätte sein müssen, ihn längst unter der Menge ungereimter widerspruchsvoller Folgerungen zu erdrücken, wenn solche überhaupt aus seiner Lehre zu ziehen wären. Auf diesen Mangel nachgewiesener Widersprüche glaube ich ganz dasselbe Gewicht legen zu dürfen zu Gunsten Darwin's, das wider ihn seine Gegner dem Mangel nachgewiesener Zwischenformen zwischen den Arten verschiedener Erdschichten beimessen. Letzterem Umstande wird übrigens, abgesehen von den Gründen, die Darwin für ein nur sehr ausnahmsweises Erhaltensein solcher Zwichenformen gibt, keine übergrosse Bedeutung, beizulegen geneigt sein, wer je die Entwicklung eines Thieres an aus dem Meere gefischten Larven verfolgt, und dabei Monate, Jahre lang vergeblich nach Zwisclienformen gesucht hat, von denen er doch weiss, dass sie zu Tausenden ihn umschwärmen.

In welcher Weise nun überhaupt Widersprüche sich als nothwendige Ausflüsse der Darwin'schen Voraussetzungen herausstellen könnten, mögen einige Beispiele veranschaulichen.

Es scheint für alle Krabben, die längere Zeit ausser Wasser sich aufhalten, Bedürfniss $\mathrm{zu}$ sein (weshalb, berührt uns hier nicht), dass von hintenher Luft in ihre Kiemenhöhle eintrete. Diese Krabben nun, die sich mehr oder minder dem Wasser entfremdet haben, gehören den verschiedensten Familien an: den Raniniden (Ranina), Eriphinen (Eriphia gonagra), Grapsoiden (Aratus, Sesarma u. A.), Ocypodiden (Gelasimus, Ocypoda) u. s. w. Die Scheidung dieser Familien würde ohne Zweifel in weit frühere Zeit zu setzen sein, als die Gewohnheit einzelner ihrer Mitglieder, das Wasser zu verlassen. Die auf Luftathmung bezüglichen Einrichtungen könnten also nicht von einem gemeinsamen Stammvater ererbt, also kaum in übereinstimmender Weise gebaut sein. Fünde sich eine solche, nicht auf 
zufällige Aehnlichkeit zurückführbare Uebereinstimmung, so würde sie als Beweis gegen die Richtigkeit der Darwin'schen Ansichten in die Wage zu legen sein. Ich werde weiter unten zeigen, wie in diesem Falle der Befund, weit entfernt solche Widersprüche zu bieten, vielmehr im vollsten Einklange steht mit dem, was sich aus Darwin's Lehre voraussagen liess.

Ein zweites Beispiel. Man kennt vier Arten von Melita (valida, setipes, anisochir, Fresnelii), und ich kann eine fünfte hinzufügen (Fig. I), deren zweites Fusspaar auf der einen Seite eine kleine Hand von gewöhnlicher Bildung, auf der anderen aber eine ungeheure Kneifzange trägt. Diese Asymmetrie ist etwas so Ungewöhnliches unter den Amphipoden, die Bildung der Kneifzange weicht soweit ab von dem, was man sonst in dieser Ordnung sieht, und ist so übereinstimmend bei den fünf Arten, dass man diese unbedenklich als denselben, nur ihnen unter den bekannten Arten gemeinsamen Stammeltern entsprossen ansehen müsste. Einer dieser Arten nun, der von Savigny in Aegypten gesammelten

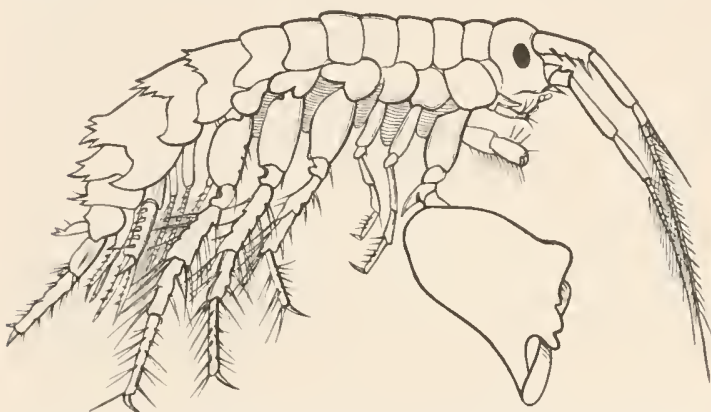

Fig. I. Melita exilii n. sp. Männchen, 5mal vergr. Zwischen den Füssen sieht man die grossen Kiemenblätter vorragen. natürlich erscheinen liessen, jene als eigene Gattung abzuscheiden, diese mit den übrigen Melitaarten vereinigt zu lassen, d. h., im Sinne der Darwin'schen Lehre, anzunchmen, dass alle anderen Melita gemeinsame Stammeltern besassen, die nicht zugleich Stammeltern der Melita Fresnelii gewesen, - so würde das im Widerspruch stehen mit dem aus der Bildung der Kneifzange gezogenen Schlusse, dass Melita Fresnelii und die vier andern genannten Arten gemeinsame Stammeltern besassen, die nicht zugleich Stammeltern der übrigen Melitaarten gewesen. - Es würde folgen

aus der Bildung der Kneifzange:

o

o

M. palmata etc. M. exilii etc. M. Fresnelii. aus der An und Abwesenheit der Nebengeissel:

o

o

M. plamata etc. M. exilii etc. M. Fresnelii.

Wie im ersten Falle, bei den Krabben, eine typische Uebereinstimmung unabhängig von einander entstandener Einrichtungen, so würde im zweiten jede tiefer greifende Verschiedenheit als nächst verwandt anzusprechender Arten ein für Darwin's Lehre sehr bedenklicher Umstand sein. Nun scheint mir aber, dass die Nebengeissel in keiner Weise einen Grund abgeben kann, die enge verwandt- 
schaftliche Beziehung von Melita Fresnelii zu M. exilii u. s. w. zu bezweifeln, welche anzunehmen die eigenthümliche Bildung der unpaaren Kneifzange gebietet. Man muss für's Erste an die Möglichkeit denken, dass die nicht immer leicht aufzufindende Nebengeissel von Savigny doch nur übersehen wurde, wie auch Spence Bate vermuthet. Fehlt sie wirklich, so ist daran zu erinnern, dass ich sie bei Arten der Gattungen Leucothoë, Cyrtophium, Amphilochus finde, bei welchen Gattungen sie von Savigny, Dana. Spence Bate vermisst wurde, dass eine durch den Bau der Hüftblätter (épimères Edw., coxae Sp. B.), der Schwanzfüsse (uropoda Westwood) u.s. w. als echte Amphithö̈ ${ }^{1}$ ) sich ausweisende hiesige Art sie besitzt, dass sie bei manchen Cerapus zu einem kaum nachweisbaren Reste verkümmert, ja dass sie bisweilen in der Jugend vorhanden ist, im reifen Alter (wenn auch vielleicht nie spurlos) schwindet, wie Spence Bate bei Acanthonotus Owenii und Atylus carinatus fand und wie ich für einen durch gefiederte Kiemen merkwürdigen Atylus unseres Meeres bestätigen kann, und dass nach alledem noch heute, wo die wachsende Menge der bekannt gewordenen Amphipoden und die dadurch herbeigeführte Zersplitterung in zahlreiche Gattungen ein Herabsteigen zu sehr kleinlichen Unterscheidungsmerkmalen erfordert, dennoch die Benutzung der Nebengeissel als Gattungsmerkmal beanstandet werden muss und dass also der Fall der Melita Fresnelii kein Bedenken gegen Darwin's Lehre erregen kann.

\section{III.}

Wenn die Widerspruchslosigkeit der Folgerungen, die für ein engeres und somit leichter zu übersehendes Gebiet aus ihr flossen, ein günstiges Vorurtheil für Darwin's Ansichten erwecken musste, so durfte es als ein wirklicher Triumph derselben begrüsst werden, wenn weit greifende Schlüsse, die auf sie gebaut wurden, nachträglich durch Thatsachen bestätigt wurden, deren Bestehen die bisherige Wissenschaft in keiner Weise ahnen liess. Aus manchen Erfolgen dieser Art, von denen ich berichten könnte, wähle ich als Beispiele zwei aus, die mir von besonderer Wichtigkeit waren und Entdeckungen betreffen, deren grosse Bedeutung für die Morphologie und Systematik der Kruster auch die Gegner Darwin's nicht in Abrede stellen werden.

Betrachtungen über die Entwickelungsgeschichte der Kruster hatten mich zu dem Schlusse geführt, dass wenn überhaupt höhere und niedere Kruster von gemeinsamen Urahnen ableitbar wären, auch erstere einst Nauplius-ähnliche Zustände durchlaufen haben müssten. Wenig später entdeckte ich Nauplius-ähnliche Larven von Garneelen (Troschel's Arch. f. Naturgesch. I863. I. S. $8=$ Gesammelte Schriften S. I67) und gestehe, dass dieser Fund für mich den ersten entscheidenden Ausschlag zu Darwin's Gunsten gab.

Die den Krabben und Krebsen, den Amphipoden und Asseln zukommende gleiche Zahl von Leibesringen ${ }^{2}$ ), von denen die sieben letzten stets abweichend

I) Ich nehme diese, wie alle genannten Amphipodengattungen in der ihnen von Spence Bate (Catal. of Amphipodous Crustacea) gegebenen Begrenzung.

2) Wie Claus betrachte ich die Augen der Kruster nicht als Gliedmassen und rechne daher keinen besonderen Augenring an, zälle dagegen das Mittelstück des Schwanzes mit, dem man vielfach die Bedeutung eines Leibesringes abspricht. Gegen die Deutung als Leibesring ist wohl nur der Mangel der Gliedmassen anzuführeu, dafür namentlich das Verbalten des Darmes, der in diesem Stücke auszumünden pflegt, bisweilen selbst es seiner ganzen Länge nach durchsetzt, wie bei Microdeutopus und einigen anderen 
von den vorhergehenden ausgestattet sind, musste unabweislich als Erbtheil derselben Urahnen angesprochen werden. Wenn nun heute noch die Mehrzahl der Krabben und Krebse und überhaupt der stieläugigen Kruster Zoëa-ähnliche Entwickelungszustände durchläuft, und dieselbe Weise der Verwandlung ihren Stammeltern zuzuschreiben war, so musste ein Gleiches, wenn auch nicht für die Stammeltern der Asseln und Amphipoden, so doch für die gemeinsamen Urahnen dieser und der stieläugigen Kruster gelten. Eine solche Annahme aber war jedenfalls sehr gewagt, so lange ihr nicht eine einzige Thatsache aus dem eigenen Gebiete der Edriophthalmen zur Stütze gegeben werden konnte, da der Bau dieser so in sich abgeschlossenen Gruppe fast unvereinbar schien mit manchen Eigenthümlichkeiten der Zoëa. So bildete für mich dieser Punct lange eine der Hauptschwierigkeiten bei Anwendung der Darwin'schen Ansichten auf die Kruster, und kaum durfte ich hoffen, noch jetzt bei Amphipoden oder Asseln Spuren jenes Durchgangs durch die Zoëaform erhalten zu finden und damit einen thatsächlichen Beweis für die Richtigkeit jenes Schlusses zu erlangen. Da machte mich van Beneden's Angabe, dass eine Scheerenassel (Tanais Dulongii), nach Milne Edwards

Amphipoden. Bei Microdeutopus fühlt man sich sogar versucht, wie schon Spence Bate hervorhebt, kleine Fortsätze dieses röhrenförmigen Schwanzstückes als verkümmerte Gliedmassen zu deuten. Auch Bell (British Stalk-eyed Crust. pag. XX) will bei Palaemon serratus Gliedmassen des letzten Ringes in Form kleiner beweglicher Spitzen beobachtet haben.

Man hat mehrfach versucht, den Leib der höheren Kruster in kleinere aus gleicher Ringzahl gebildete Abschnitte zu zerlegen und diese Abschnitte bald aus 3, bald aus 5, bald aus 7 Ringen zusammengesetzt, ohne dass einer dieser Versuche sich allgemeiner Zustimmung hätte erfreuen können. Meine eigenen Untersuchungen leiten mich zu einer Auffassung, die sich nahe an die van Beneden's anschliesst. Ich nehme vier Abschnitte von je 5 Ringen an: Urleib, Vorderleib, Hinterleib, Mittelleib. Der Urleib begreift die Ringe, die die Naupliusförmige Larve aus dem Eie mitbringt; später wird er durch̀ die in seiner Mitte sich entwickelnden jüngeren Abschnitte in Kopf und Schwanz getrennt. Diesem Urleibe gehören die beiden Fühlerpaare, die Kinnbacken (mandibulae) und die Schwanzfüsse (posterior pair of pleopoda Sp. B.) an. Noch beim erwachsenen Thiere verräth sich die Zusammengehörigkeit dieser Endabschnitte bisweilen durch die Aehnlichkeit ihrer Anhänge, besonders die des äusseren Astes der Schwanzfüsse mit dem äusseren Aste (der sog. Schuppe) des zweiten Fühlerpaars. Selbst zu Trägern höherer Sinneswerkzeuge können, wie die Fühler, so die Schwanzfüsse werden, wie das Ohr der Mysis zeigt.

Die zeitliche Folge der Leibesabschnitte scheint ursprünglich die gewesen zu sein, dass erst der Vorderleib, dann der Hinterleib, zuletzt der Mittelleib sich bildete. Der Vorderleib erscheint beim erwachsenen Thiere ganz oder zum Theile mit dem Kopfe verschmolzen, seine Anhänge (siagonopoda Westw.) alle oder theilweise der Nahrungsaufnahme dienstbar und meist scharf von denen der folgenden Gruppe geschieden. Die Ringe des Mittelleibes scheinen stets sofort nach ihrem Auftreten Gliedmassen zu treiben, während die Ringe des Hinterleibes oft während längerer Abschnitte des Larvenlebens, oder selbst für immer (bei manchen weiblichen Diastylideen) sich fusslos erhalten; ein Grund, neben manchen anderen, den Mittelleib der Krebse nicht, wie es üblich ist, dem stets fusslosen Hinterleibe der Insecten gleichzustellen. Die Anhänge des Mittelleibes (pereiopoda) scheinen niemals, selbst nicht in ihrer jugendlichsten Form, zwei gleichwerthige Aeste zu besitzen, - eine Eigenthümlichkeit, die die Anhänge des Hinterleibes auszuzeichnen pflegt. Es ist dieses ein Umstand, der als wichtiges Bedenken gegen die Gleichstellung des Mittelleibes der Malacostraca mit dem bei den Copepoden die Schwimmfüsse, bei den Cirripedien die Rankenfüsse tragenden Leibesabschnitte geltend zu machen ist.

Die Füsse des Hinterleibes und des Schwanzes in eine Gruppe (als fausses pattes abdominales, oder als pleopoda) zusammenzufassen, scheint nicht gerechtfertigt. Wo eine Verwandlung stattfindet, entstehen sie wohl immer zu verschiedenen Zeiten, und durchaus verschieden sind sie fast immer in Bau und Verrichtung. Selbst bei den Amphipoden, wo die Schwanzfüsse den beiden letzten Paaren der Hinterleibsfüsse ähnlich zu sehen pflegen, sind sie in der Regel durch irgendwelche Eigenthümlichkeit ausgezeichnet, und während die Hinterleibsfüsse in ermüdender Einförmigkett sich durch die ganze Ordnung wiederholen, gehören bekanntliclı die Schwanzfüsse zu den veränderlichsten Theilen des Amphipodenleibes. 
in die gleiche Familie mit der gemeinen Wasserassel gehörig, einen Panzer besitze, wie die Decapoden, auf diese Thiere aufmerksam, und eine nähere Untersuchung ergab, dass diese Asseln treuer, als irgend ein anderer der erwachsenen Kruster manche der wesentlichsten Zoëaeigenthümlichkeiten, namentlich deren Athmungsweise bewahrt haben. Während bei allen anderen Asseln die Hinterleibsfüsse der Athmung dienen, sind diese bei unserer Scheerenassel (Fig. 2) reine Bewegungswerkzeuge, in die nie ein Blutkörperchen eintritt, und der Hauptsitz der Athmung ist, wie bei den Zoëa in den von reichlichen Blutströmen durchrieselten Seitentheilen des Panzers, unter welchem ein beständiger Wasserstrom hinzieht, erhalten, wie bei Zoëa und den erwachsenen Decapoden, durch einen Anhang des zweiten Kieferpaares, der allen anderen Edriophthalmen abgeht.

Beide Entdeckungen, das sei nebenbei bemerkt, dankt dieWissenschaft weniger einem glücklichen Zufall, als

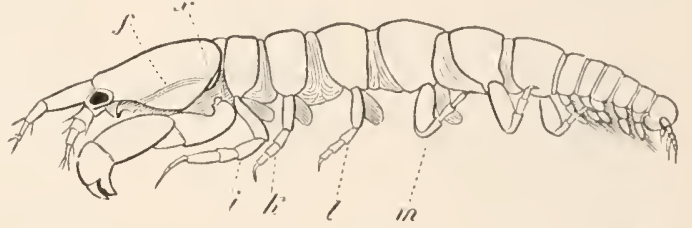

Fig. 2. Tanais dubius (?) Kr. . $25 \mathrm{mal}$ vergr. Man sieht die Eingangsöffnung $(x)$, in die von Panzer überwölbte Höhlung, in welcher ein Anhang des zweiten Kieferpaares ( $f)$ spielt. An 4 Füssen $(i, k, l, m)$ finden sich Anlagen der Blätter, die später die Bruthöhle bilden. unmittelbar Darwin und seiner Lehre.

Penëusarten leben in den Meeren Europa's, wie hier; ihre Naupliusbrut ist sicher manchem der zahlreichen Forscher, die jene Meere ausbeuten, und mir selbst ${ }^{1}$ ) wiederholt unbeachtet durch die Hände gegangen; denn sie hat Nichts, was ihr unter den so mannichfaltigen und oft so wunderlichen Naupliusformen eine besondere Aufmerksamkeit zulenken könnte. Als ich, wegen der Aehnlichkeit der Bewegung in ihr eine junge Penëus-Zoëa vermuthend, zum ersten Male eine solche Larve eingefangen hatte, und nun unter dem Mikroskope einen von jenen Zoëa himmelweit verschiedenen Nauplius fand, hätte ich diesen ohne Zweifel, als der Entwicklungsreihe, die ich verfolgte, völlig fremd, bei Seite geworfen, wenn nicht gerade der Gedanke an frühere Nauplius-ähnliche Zustände der höheren Krebse, die ich freilich kaum noch in der Gegenwart erhalten glaubte, mich lebhaft beschäftigt hätte.

Und hätte ich nicht schon lange unter den Edriophthalmen nach Resten der vorausgesetzten Zoëazustände gesucht und Alles mit Eifer erfasst, was diese widerspenstige Ordnung mir fügsam zu machen versprach, so hätte schwerlich van Beneden's kurze Andeutung mich so elektrisch berührt und zu erneuter Beschäftigung mit den Scheerenasseln angeregt, und dies um so weniger, da ich schon einmal, an der Ostsee mich mit ihnen geplagt hatte, ohne weiter als meine Vorgänger kommen zu können, und da zweimal auf denselben Gegenstand zurückzukommen, nicht eben nach meinem Geschmack ist.

\section{IV.}

Unsere Scheerenassel, die überhaupt in fast allen Verhältnissen ihres Baues ein höchst merkwürdiges Thier ist, lieferte mir noch eine zweite, für die Lehre von der Entstehung der Arten durch natürliche Züchtung, beachtenswerthe Thatsache.

I) Mecznikow fand neuerdings Nauplius-ähnliche Larven von Garneelen im Meer bei Neapel (Anm. aus der engl. Uebersetzung von 1869). 
Wo bei den Krustern hand-, oder scheerenförmige Bildungen vorkommen, pflegen dieselben bei den Männchen stärker, als bei den Weibchen entwickelt zu sein, und schwellen bei ihnen oft zu ganz unverhältnissmässiger Grösse an, wie wir es oben bei Melita sahen. Ein bekannteres Beispiel solcher Riesenscheeren liefern die Männchen der sogenannten Winkerkrabben (Gelasimus), von denen

Fig. $3-6$.

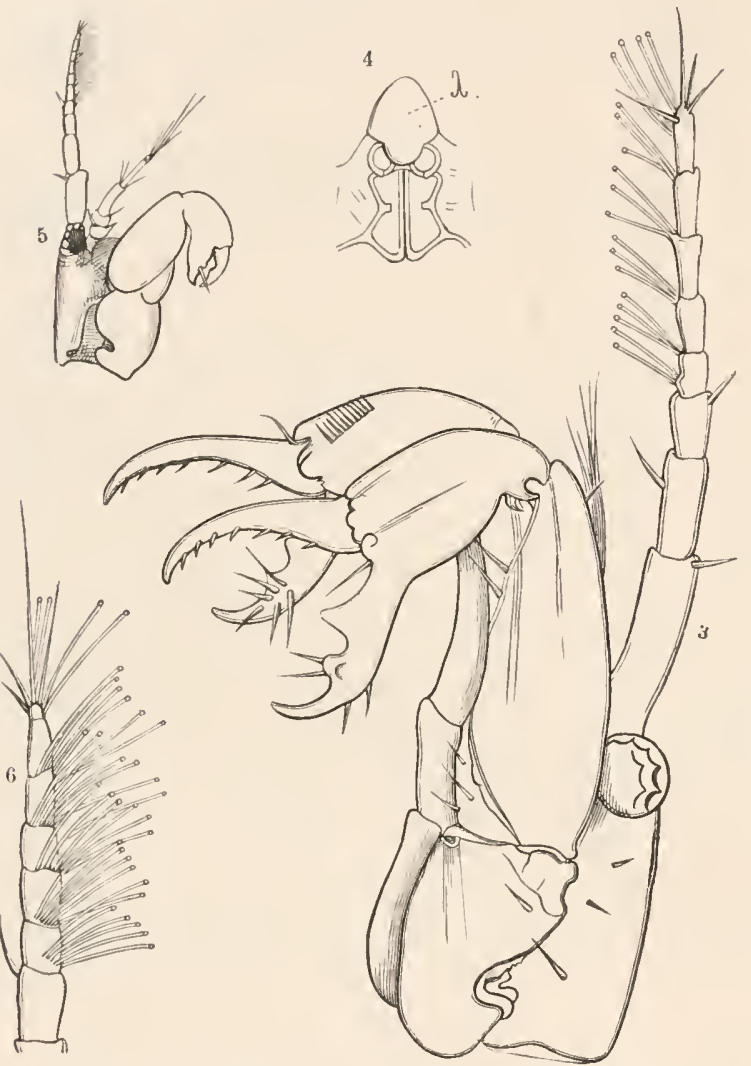

Fig. 3. Kopf der gewöhnlichen Form der Männchen von Tanais dubius (?) Kr. 9omal vergr. Zwischen den Scheerenfüssen ragen die Endborsten des zweiten Fühlerpaares vor. - Fig. 4. Mundgegend desselben, v. unten. $\lambda$. Oberlippe. Fig. 5. Kopf der seltneren Form der Männchen, $25 \mathrm{mal}$ vergr. Fig. 6. Fühlergeissel desselben mit den Riechfäden, 9omal vergr. man sagt, dass sie diese Scheere beim Laufen „hocherhaben tragen, als ob sie damit winkten"; - eine Angabe, die wenigstens nicht für alle Arten richtig ist; eine kleine besonders grossscheerige Art, die ich z. B. in den Mandioccafeldern an der Mündung des Cambriú zu Tausenden herumlaufen sah, hält sie stets dicht an den Leib gepresst. - Eine zweite Eigenthümlichkeit der Krustermännchen besteht nicht selten in einer reichlicheren Entwickelung zarter Fäden an der Geissel der vorderen Fühler, die Spence Bate Hörfäden (auditory cilia) nennt, und die ich, wie vor mir, ohne dass ich es wusste, Leydig als Riechwerkzeuge deutete. So bilden sie, wie auch van Beneden für Bodotria angibt, lange dichte Büschel bei den Männchen mancher Diastylideen, deren Weibchen sie nur in spärlicher Anzahl besitzen. Für die Copepoden machte Claus auf die Verschiedenheit der Geschlechter in dieser Beziehung aufmerksam. Es spricht, beiläufig bemerkt, diese stärkere Entwickelung bei den Männchen, wie mir scheint, sehr zu Gunsten der von Leydig und mir vertretenen Ansicht, da auch sonst ja die männlichen Thiere nicht selten durch den Geruch beim Aufspüren der brünstigen Weibchen geleitet werden.

Bei unserer Scheerenassel nun gleichen die jungen Männchen bis zur letzten der Geschlechtsreife vorausgehenden Häutung den Weibchen; dann aber erleiden sie eine bedeutende Verwandlung. Sie verlieren unter Anderem die beweglichen Anhänge des Mundes bis auf diejenigen, die der Unterhaltung des Athemstromes dienen; man findet ihren Darm stets leer und sie scheinen nur noch der Liebe zu leben. Was aber das Merkwürdigste ist, sie erscheinen nun unter zwei ver- 
schiedenen Gestalten. Die einen (Fig. 3) bekommen gewaltige, langfingrige, recht bewegliche Scheeren und statt des einzigen Riechfadens der Weibchen deren etwa I 2 bis 17 . die zu zwei bis drei an den Gliedern der Fühlergeissel stehen. Die andern (Fig. 5) behalten die plumpe Scheerenform der Weibchen; dafür aber sind ihre Fühler (Fig. 6) mit weit zahlreicheren Riechfäden ausgerüstet, die z11 5 bis 7 beisammen stehen.

Zunächst, ehe ich auf deren Bedeutung eingehe, noch ein Wort über die Thatsache selbst. Es war natürlich daran zu denken, ob nicht etwa zwei verschiedene Arten mit sehr ähnlichen Weibchen und mehr verschiedenen Männchen zusammenlebten, oder ob nicht die Männchen, statt in zwei scharf geschiedenen Formen aufzutreten, nur innerhalb sehr weiter Grenzen veränderlich wären. Ich kann weder das Eine, noch das Andere annehmen. Unsere Scheerenassel lebt zwischen dicht verfilzten Wasserfäden, die einen etwa zolldicken Ueberzug auf Steinen in der Nähe des Ufers bilden. Bringt man eine Handvoll dieses grünen Filzes in ein grösseres Glas mit reinem Seewasser, so sieht man bald seine Wände sich mit Hunderten, ja Tausenden dieser kleinen plumpen weisslichen Asseln bedecken. So habe ich mit der einfachen Linse manches Tausend, und ich habe mit dem Mikroskope sorgfältig viele Hunderte durchgemustert, aber ich habe keine Verschiedenheiten unter den Weibchen und keine Zwischenformen zwischen den zweierlei Männchen auffinden können.

Das Vorkommen nun dieser zweierlei Männchen wird der Schule als blosses Curiosum, es wird denen, welche den .,Schöpfungsplan“ als „freie Conception eines allmächtigen Verstandes“ ansehen, „welche in dessen Gedanken gereift ist, bevor sich dieselbe in greifbaren, äusseren Formen offenbarte", als blosse La un e des Schöpfers erscheinen, da sie weder aus dem Gesichtspuncte praktischer Zweckmässigkeit, noch aus dem „typischen Bauplane“ erklärbar ist. Von Darwin's Lehre aus erhält dagegen diese Thatsache Sinn und Bedeutung, und sie scheint hinwiederum geeignet, Licht $\mathrm{zu}$ werfen auf eine Frage, in der Bronn ,den ersten und erheblichsten Einxvand gegen die neue Theorie" erblickte, - wie es möglich sei, dass aus der Häufung in verschiedenen Richtungen auseinanderlaufender kleinster Abänderungen, Abarten und Arten entstehen, die von der Stammform nett und scharf wie ein gestieltes Dicotyledonenblatt sich abheben und nicht mit ihr und untereinander, wie der unregelmässige krause Iappen einer Blätterflechte mit der übrigen Flechtenmasse verfliessen.

Lassen wir die noch gleichgebildeten Männchen unserer Scheerenassel, meinetwegen, wie Bronn will, nach allen beliebigen Richtungen hin, - - abzuändern beginnen. War die Art ihren Lebensverhältnissen angepasst, war in dieser Beziehung bereits durch natürliche Züchtung das Beste erreicht und gesichert, so hatten neue die Art als Art berührende Abänderungen, als Rückschritte keine Aussicht sich geltend zu machen, mussten vielmehr, wie sie auftauchten, wieder verschwinden und nur für die geschlechtlichen Beziehungen blieb den abändernden Männchen der Kampfplatz geöffnet. Hier konnten sie Vortheile über ihre Mitbewerber erlangen, indem sie entweder ihre Weibchen besser aufzuspüren oder besser zu fassen vermochten. Die besten Riecher besicgten alle, die ihnen in dieser Beziehung nachstanden, wenn sie nicht andere Vorzüge, etwa kräftigere Scheeren, entgegenzustellen hatten. Die besten Packer besiegten alle schwiicher 
berraffneten Kämpen, wenn sie nicht andere Vorzüge, etwa schärfere Sinne, ihnen entgegenstellten. Man begreift, wie auf diese Weise einerseits alle in der Ausbildung der Riechfäden, andrerseits alle in der Ausbildung der Scheeren minder begünstigten Zwischenstufen vom Kampfplatze verschwinden und zwei scharf geschiedene Formen, die besten Riecher und die besten Packer als einzige Gegner übrig bleiben konnten. Zur Zeit scheint sich der Kampf zu Gunsten der letzteren entscheiden zu wollen, da sie in weit überwiegender Mehrzahl, vielleicht zu Hundert auf Einen Riecher vorkommen.

Wenn daher Bronn, um auf dessen Einwand zurückzukommen, „gerne zu Gunsten der Darwin'schen Theorie und zur Erklärung, warum nicht viele Arten durch Zwischenglieder in einander verfliessen, noch irgend ein äusseres oder inneres

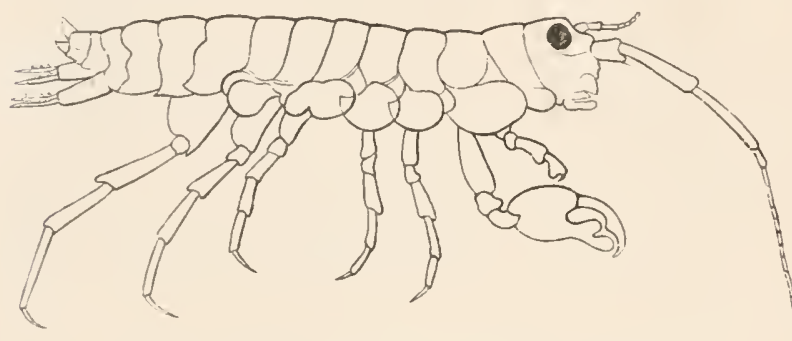

Fig. 7. Orchestia Darwinii n. sp. Männchen.

Princip entdecken möchte, welches die Abänderungen jeder Art nur in einer Richtung weiter drängte, statt sie in allen Richtungen bloss zu gestatten“, - so wird ein solches, wie in diesem, so in vielen anderen Fällen einfach darin zu finden sein, dass eben nur wenige Richtungen offen stehen, nach denen hin die Veränderungen zugleich Verbesserungen sind, in denen also sie sich häufen und befestigen können, während sie in allen anderen als gleichgültig oder nachtheilig „wie gewonnen, so zerronnen“ sein werden.

Das Vorkommen von zweierlei Männchen bei derselben Art mag vielleicht eine nicht allzu seltene Erscheinung sein bei Thieren, wo sich dieselben weit von der Bildung der Weibchen entfernen. Doch nur bei solchen, die man sich in genügender Menge verschaffen kann, wird es möglich sein, sich zu überzeugen, dass man nicht etwa verschiedene Arten oder verschiedene Altersstufen vor sich habe. Ich kann aus dem Bereiche meiner wenig ausgedehnten Erfahrung ein zweites Beispiel geben. Es betrifft einen Strandhüpfer (Shore-hopper, Orchestia). Das Thier (Fig. 7) lebt an sumpfigen Stellen in der Nähe des Meeres, unter moderndem Laube, in der lockeren Erde, welche die Sumpfkrabben (Gelasimus, Sesarma, Cyclograpsus u. s. w.) um den Eingang ihrer Höhlen aufwerfen, ja unter trockenem Kuh- und Pferdedung. Wie es sich so weiter vom Strande entfernt, als die Mehrzahl seiner Gattungsgenossen, - (einige freilich gehen meilenweit in's Land, bis auf tausend Fuss hohe Berge, wie O. tahitensis, telluris, sylvicola) - , so entfernt sich das Männchen noch mehr von allen bekannten Arten durch die gewaltigen Scheeren des zweiten Fusspaares. Nur die Orchestia Gryphus, von der sandigen Küste von Mönchgut, zeigt eine entfernt ähnliche Bildung, wälırend sonst die gewöhnliche Handform der Amphipoden sich findet. Namentlich in der Bildung dieser Scheeren nun findet eine erhebliche Verschiedenheit zwischen den Männchen statt, so gross als sie sonst kaum zwischen zwei Arten der Gattung wiederkehrt, und wie bei der Scheerenassel trifft man nicht etwa eine lange Reihe in einander verfliessender Bildungen, sondern nur zwei durch keinerlei Zwvischenglieder ver- 
bundene Formen (Fig. 8 u. 9). Man würde die Männchen unbedenklich als zwei wohl geschiedene Arten betrachten, wenn sie nicht an gleicher Stelle mit ununterscheidbaren Weibchen zusammenlebten. Dass nun gerade bei dieser Art dic doppelte Scheerenform der Männchen vorkommt, ist insofern beachtenswerth, als die weit von der gewöhnlichen Bildung der anderen Arten abveichende Gestaltung der Scheeren darauf hinweist, dass sie noch neuerdings beträchtliche Veränderungen erlitten habe, und als daher von vornherein gerade bei ihr eher als bei anderen ein solches Vorkommen zu erwarten war.

Fig. 8.

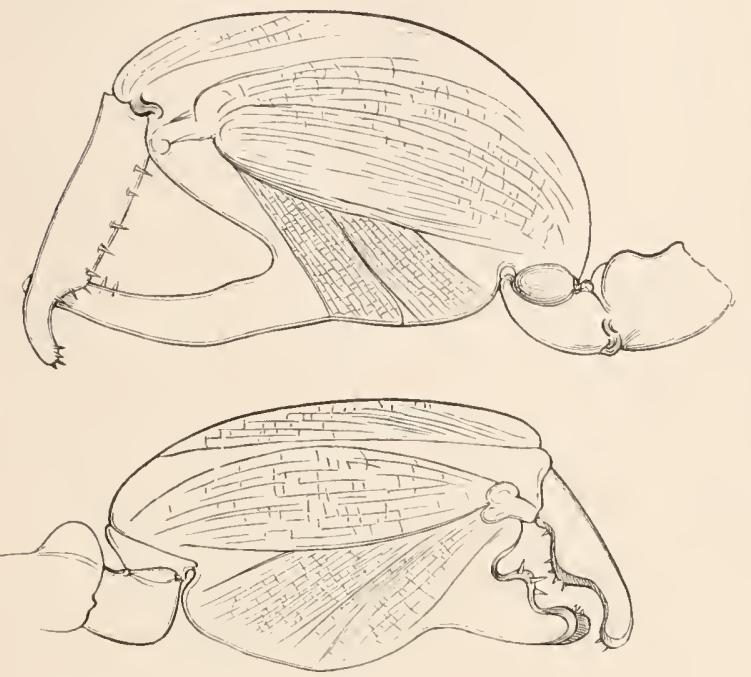

Fig. 9.

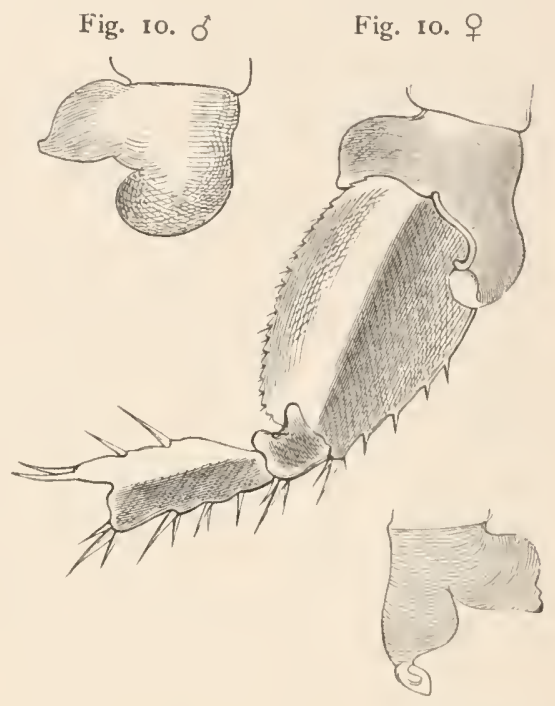

Fig. II.

Fig. 8 u. 9. Die zweierlei Scheeren der Männchen von Orchestia Darwinii. 45 mal vergr.

Fig. Io. Hüftblatt des vorletzten Fusspaares vom Männchen, sowie Hüftblatt nebst den drei folgenden Gliedern desselben Fusspaares vom Weibchen der Melita Messalina. 45mal vergr.

Fig. I I. Hüftblatt desselben Fusspaares vom Weibchen der Melita insatiabilis.

Ich kann mich nicht enthalten, bei dieser Gelegenheit darauf hinzuweisen, dass man (soviel Spence Bate's Katalog ersehen lässt) zu zweierlei verschiedenen Männchen (Orchestia telluris und sylvicola), die zusammen in den Wäldern von Neuseeland gesammelt wurden, erst einerlei Weibchen kennt, und die Vermuthung zu wagen, dass hier ein ähnlicher Fall vorliege. Es ist mir nicht wahrscheinlich, dass von diesen gesellig lebenden Amphipoden zwei nahe verwandte Arten unter den gleichen Lebensbedingungen mit und durcheinander vorkommen sollten.

Wie die Männchen mehrerer Melita-Arten durch die mächtige unpaare Kneifzange, so sind die Weibchen einiger anderen Arten derselben Gattung dadurch vor allen anderen Amphipoden ausgezeichnet, dass bei ihnen eine besondere Vorrichtung entwickelt ist, die dem Männchen das Halten derselben erleichtert. Die Hüftblätter des vorletzten Fusspaares sind in hakenförmige Fortsätze ausgezogen, an die sich das Männchen mit den Händen des ersten Fusspaares festklammert. Die beiden Arten, von denen ich diese Bildung kenne, gehören zu den begattungseifrigsten Thieren ihrer Ordnung, selbst Weibchen, die mit Eiern auf beliebiger 
Entwickelungsstufe beladen sind, haben nicht selten ihr Männchen auf dem Rücken. Beide Arten sind nahe verwandt mit der an den europäischen Küsten weit verbreiteten und häufig untersuchten Melita palmata Leach (Gammarus Dugesii Edw.); leider aber finde ich keinen Aufschluss darüber, ob auch die Weibchen dieser oder einer andern europäischen Art eine ähnliche Vorrichtung besitzen; bei Melita exilii sind alle Hüftblätter von gewöhnlicher Bildung. Doch, wie dem auch sei, mögen sie nun bei zwei oder bei zwanzig Arten sich finden, jedenfalls ist das Vorkommen jener eigenthümlichen hakenförmigen Fortsätze ein sehr beschränktes.

Unsere beiden Arten nun leben geschützt unter flach aufliegenden Steinen in der Nähe des Ufers, die eine, Melita Messalina, so hoch, dass sie nur selten vom Wasser bedeckt wird, die andere, Melita insatiabilis, ein wenig tiefer; beide Arten leben in zahlreichen Schaaren beisammen. Weder ist also zu erwarten, dass häufiger als bei anderen Arten den Liebespaaren störende Einflüsse drohen, noch auch würde es dem Männchen, das etwa sein Weibchen verlöre, schwerer werden als denen anderer Arten, ein neues zu finden. Ebensowenig ist abzusehen, wie diese das Begattungsgeschäft sichernde Vorrichtung am Körper des Weibchens anderen Arten nachtheilig sein könnte. So lange aber weder nachgewiesen ist, dass unsere Arten dieser Vorrichtung besonders bedürftig sind, oder dass dieselbe anderen Arten mehr schädlich als nützlich sein würde, so lange wird man ihr Vorhandensein nur bei diesen wenigen Amphipoden als Werk nicht einer voraus berechnenden Weisheit, sondern eines von der natürlichen Züchtung benutzten glücklichen Zufalls ansprechen dürfen. Bei letzterer Annahme ist das so vereinzelte Vorkommen begreiflich, während man nicht absieht, warum der Schöpfer mit einer Vorrichtung, die er doch mit dem ,allgemeinen Bauplane“ der Amphipoden vereinbar fand, gerade nur diese wenigen Arten beglückte und sie anderen versagte, die unter gleichen äusseren Verhältnissen leben und selbst in dem ungewöhnlichen Begattungseifer ihnen gleichen. In Gesellschaft oder nächster Nachbarschaft der beiden Melita leben nämlich zwei Allorchestes, von denen man ebenfalls fast mehr Pärchen, als einzelne Thiere trifft und deren Weibchen doch nichts von jenen Fortsätzen der Hüftblätter zeigen.

Wie diesen, so wird man, meine ich, gegen die von Agassiz mit so viel Geist und Sachkenntniss vertretene Auffassung der Arten als verkörperter Gedanken des Schöpfers alle ähnlichen Fälle geltend machen dürfen, in welchen Einrichtungen, die allen Arten einer Gruppe gleich nützlich sein würden, der Mehrzahl fehlen und nur einzelnen bevorzugten Günstlingen, die deren nicht mehr als andere bedürftig erscheinen, sich zugetheilt finden.

\section{V.}

Unter den auch in der Naturgeschichte der Kruster zahlreichen Thatsachen, auf die von Darwin's Lehre aus ein neues helles Licht fällt, ist mir neben den zwiefältigen Männchen unserer Scheerenassel und der Orchestia Darwinii noch eine besonders wichtig erschienen, - das Verhalten der Kiemenhöhle bei den luftathmenden Krabben, von denen ich leider einige der merkwürdigsten (Gecarcinus, Ranina) noch nicht untersuchen konnte. Da dies Verhalten, das Vorhandensein eines hinter den Kiemen gelegenen Eingangs, selbst als Thatsache bisher nur bei Ranina beachtet wurde, will ich etwas näher darauf eingehen. Ich erwähnte 
schon, dass, wie es Darwin's Lehre fordert, diese Eingangsöffnung bei den verschiedenen Familien in verschiedener Weise zu Stande kommt.

Bei der Froschkrabbė (Ranina) des indischen Meeres, die sich nach Rumph bis auf die Dächer der Häuser zu versteigen liebt, fehlt nach Milne Edwards die gewöhnliche vordere Eingangsöffnung ganz und der Eingang eines in den hintersten Theil der Kiemenhöhle mündenden Canales findet sich unter dem Anfang des Hinterleibes.

Am einfachsten ist die Sache bei mehreren Grapsoïden. So bei Aratus Pisonii, einer allerliebsten, lebhaften Krabbe, die auf die Manglebüsche (Rhizophora) steigt und deren Blätter benagt. Mit ihren kurzen, aber ungemein spitzen Klauen, die wie Stecknadeln prickeln, wenn sie einem über die Hand läuft, klettert sie mit grosser Behendigkeit die dünnsten Zweiglein hinauf. Als ich einmal ein solches Thier auf meiner Hand sitzen hatte, sah ich, wie es den hinteren Theil seines Panzers hob, und wie sich dadurch jederseits über den letzten Füssen eine breite Spalte erschloss, durch die ich tief in die Kiemenhöhle hineinsehen konnte. Ich habe seitdem das merkwürdige Thier mir nicht wieder verschaffen können, dagegen konnte ich dieselbe Beobachtung oft wiederholen an einem anderen Thiere derselben Familie (einem echten Grapsus, wie es scheint), das häufig an den Felsen unserer Küste lebt. Während der hintere Theil des Panzers sich hebt und die erwähnte Spalte sich bildet, scheint zugleich der vordere Theil sich zu senken und die vordere Eingangsöffnung zu verengen oder ganz zu schliessen. Unter Wasser findet das Heben des Panzers nie statt. Das Thier öffnet also seine Kiemenhöhle vorn oder hinten, je nachdem es Wasser oder Luft zu athmen hat. - Wie das Heben des Panzers zu Stande kommt, weiss ich nicht, doch glaube ich, dass es dadurch geschieht, dass ein häutiger Sack, der unter dem hinteren Theile des Panzers aus der Leibeshöhle weit in die Kiemenhöhle hineinragt, durch Hineintreiben der Leibesflüssigkeit angeschwellt wird. -

Dasselbe Heben des Panzers beobachtete ich auch bei einigen Arten der verwandten Gattungen Sesarma und Cyclograpsus, die in sumpfigem Boden tiefe Löcher graben und manchmal auf dem feuchten Schlamme herumlaufen, oder wie lauernd vor ihren Löchern sitzen. Man muss aber bei diesen Thieren sich oft lange gedulden, ehe sie, dem Wasser entnommen, ihre Kiemenhöhle der Luft erschliessen, denn es besteht bei ihnen eine wundervolle Vorrichtung, vermöge deren sie auch ausser Wasser noch eine Zeitlang Wasser zu athmen fortfahren können. - Die Oeffnungen zum Austritt des Wassers, das der Athmung gedient hat, liegen bekanntlich bei diesen, wie bei den meisten Krabben in den vorderen Ecken des Mundrahmens (cadre buccal Edw.), während von dessen hinteren Ecken aus die Eingangsspalten der Kiemenhöhle über dem ersten Fusspaare sich hinziehen. Der Theil des Panzers nun, der zu den Seiten des Mundes zwischen den beiderlei Offnungen sich hinzieht (die régions ptérygostomiennes), erscheint bei unseren Thieren, und schon Milne Edwards hat das als eine besonders auffallende Eigenthümlichkeit derselben hervorgehoben, in kleine quadratische Feldchen von äusserster Regelmässigkeit getheilt. Dieses Aussehen ist bedingt theils durch kleine warzenförmige Erhöhungen, theils und vorzugsweise durch eigenthümlich knieförmig gebogene Haare, die gewissermaassen ein dicht über der Oberfläche des Panzers ausgespanntes feines Netz oder Haarsieb bilden. Tritt nun eine 
Wasserwelle aus der Kiemenhöhle aus, so verbreitet sie sich im $\mathrm{Nu}$ in diesem Haarnetze und wird durch angestrengte Bewegungen des in der Eingangsspalte spielenden Anhanges der äusseren Kieferfüsse der Kiemenhöhle wieder zugeführt. Während das Wasser so als dünne Schicht über dem Panzer hingleitet, wird es sich wieder mit Sauerstoff sättigen und dann aufs Neue der Athmung dienen können. Zur Vervollständigung dieser Einrichtung tragen die äussern Kieferfüsse, wie ebenfalls längst bekannt, eine vorspringende, mit dichtem Haarsaum bedeckte Leiste, die rorn nahe der Mittellinie beginnt und nach hinten und aussen zur hintern Ecke des Mundrahmens sich hinzieht. Die beiden Leisten der rechten und linken Seite bilden also zusammen ein Dreieck mit nach vorn gewandter Spitze, einen Wogenbrecher, durch welchen das der Kiemenhöhle entströmende Wasser vom Munde abgehalten und der Kiemenhöhle wieder zugeleitet wird. - In recht feuchter Luft kann der in der Kiemenhöhle enthaltene Wasservorrath stundenlang

Fig. 13.

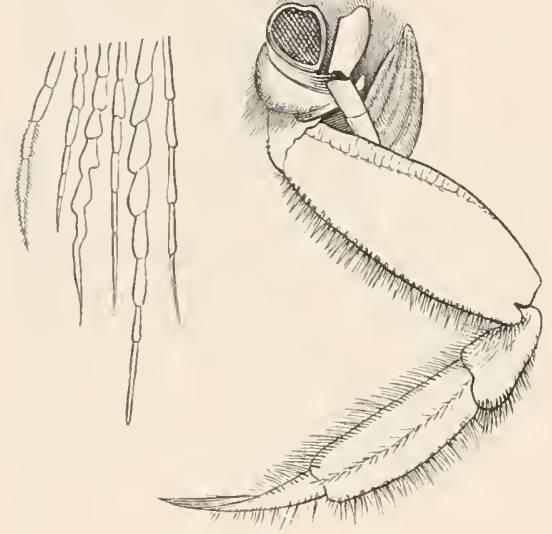

Fig. I 2. Hinterer Eingang in die Kiemenhöhle von Ocypoda rhombea Fabr. Nat. Gr. Der Panzer und der 4. Fuss der rechten Seite sind entfernt.

Fig. 13. Spitzen einiger Haare vom Grundglied des 3. Fusses. $45 \mathrm{mal}$ vergr. vorhalten und erst, wenn er zu Ende geht, hebt das Thier seinen Panzer, um von hinten her Luft zu den Kiemen treten zu lassen.

Bei Eriphia gonagra liegen die der Luftathmung dienenden Eingangsöffnungen der Athemhöhle nicht wie bei den Grapsoiden über, sondern hinter dem letzten Fusspaare, zu den Seiten des Hinterleibes.

Bei den schnellfüssigen Sandkrabben (Ocypoda), ausschliesslichen Landthieren, die im Wasser kaum einen Tag sich lebend erhalten, während weit früher schon ein Zustand gänzlicher Erschlaffung eintritt und alle willkürlichen Bewegungen aufhören ${ }^{1}$ ), kennt man schon längst, ohne jedoch ihren Zusammenhang mit der Kiemenhöhle zu ahnen, eine eigenthümliche Vorrichtung an den Füssen des dritten und vierten Paares (Fig. 12). Diese beiden Fusspaare sind dichter als die übrigen aneinandergerückt; die einander zugewendeten Flächen ihrer Grundglieder, also die hintere Fläche am dritten, die vordere am vierten Fusse, sind eben, glatt, und ihre Ränder tragen einen dichten Besatz langer seidenglänzender, eigenthümlich gestalteter Haare (Fig. I3). Milne Edwards, der ihrem Aussehen nach diese Flächen passend mit Gelenkflächen vergleicht, meint, dass sie dazu dienen, die Reibung zwischen den beiden Füssen zu vermindern. Man musste sich bei dieser Deutung fragen, wie denn gerade bei diesen Krabben und gerade nur zwischen diesen beiden Füssen eine solche die Reibung mindernde Vorrichtung nöthig werde,

I) Da dies nicht im Meere, sondern in Gläsern mit Seewasser beobachtet wurde, konnte man denken, dass die Thiere ermatten und sterben, nicht weil sie unter Wasser sind, sondern weil sie den darin enthaltenen Sauerstoff aufgezehrt. Ich brachte daher in dasselbe W'asser, aus dem ich eben eine bewusst. lose Ocypoda genommen hatte, deren Beine schlaff niederhingen, eine Lupea diacantha, die durch Verweilen an der Iuft in gleichen Zustand gerathen war, und wic jene in der Luft, erholte sich diese im Wasser. 
abgesehen davon, dass die sonderbaren Haarbürsten, die ja im Gegentheil die Reibung mehren mussten, unerklärt bleiben. Indem ich nun die Füsse einer grossen Sandkrabbe in mancherlei Richtungen hin und herbog, um zunächst zu sehen, bei welchen Bewegungen des Thieres Reibung an der bezeichneten Stelle stattfinde, und ob dies vielleicht ihm besonders wichtige, oft wiederkehrende $\mathrm{Be}^{-}$ wegungen seien, - bemerkte ich, als ich die Füsse weit auseinander gespreizt hatte, in der Tiefe zwischen ihnen eine ansehnliche runde Oeffnung, durch die sich leicht Luft in die Kiemenhöhle einblasen, oder auch ein feines Stäbchen einführen liess. Die Oeffnung mündet in die Kiemenhöhle hinter einem kegelförmigen Zapfen, der an Stelle einer bei Ocypoda fehlenden Kieme über dem dritten Fusse steht. Sie wird seitlich begrenzt von Leisten, die sich oberhalb der Einlenkung der Füsse erheben und an die sich der untere Rand des Panzers anlegt. Auch nach aussen wird sie bis auf eine schmale Spalte von diesen Leisten überwölbt. Ueber diese Spalte legt sich der Panzer, der gerade hier weiter als sonst nach unten vorspringt, und so wird eine vollständige Röhre gebildet. Während Grapsus Wasser immer nur von vorn her zu seinen Kiemen treten lässt, sah ich dasselbe bei Ocypoda auch durch die soeben besprochene Oeffnung einströmen.

Mit Ocypoda stimmen in der Lage der hinteren Eingangsöffnung und den sie begleitenden Eigenthümlichkeiten des dritten und vierten Fusspaares zwei andere dem Wasser entfremdete Arten derselben Familie überein, die ich zu untersuchen Gelegenheit hatte. Die eine, vielleicht der Gelasimus vocans, die in Manglesümpfen lebt, und die Oeffnung ihrer Höhle mit einem dicken, mehrere Zoll hohen, walzenförmigen Schornstein zu versehen liebt, hat die Bürsten am Grundgliede der betreffenden Füsse aus gewöhnlichen Haaren gebildet. Die andere, ein kleinerer Gelasimus, in M. Edwards' Naturgeschichte der Kruster nicht verzeichnet, die trocknere Stellen liebt und sich nicht scheut, unter der scheitelrechten Mittagssonne eines Decembertages im glühenden Sande umherzuschweifen, aber auch im Wasser wenigstens mehrere Wochen lang auszudauern vermag, hat dagegen in diesen Bürsten, wie Ocypoda, borstenlose, zarte, ja noch zartere und regelmässiger eingeschnürte Haare ${ }^{1}$ ). Was diese eigenthümlichen Haare bedeuten mögen, ob sie nur fremde Körper von der Kiemenhöhle abhalten, ob sie der vorbeiströmenden Luft Feuchtigkeit geben, oder ob sie etwa, wie ihr Ansehen namentlich bei dem kleinen Gelasimus an die Riechfäden der Krabben erinnert, so auch ähnliche Dienste leisten, das gebührend $\mathrm{zu}$ erörtern würde uns zu weit von unserem Gegenstande abführen. Doch sei bemerkt, dass bei beiden Arten, besonders bei Ocypoda, die Riechfäden an der gewöhnlichen Stelle sehr verkümmert sind, und ihre Fühlergeisseln im Wasser nie die eigenthümlichen schlagenden Bewegungen ausführen, wie man sie bei anderen Krabben und auch bei den grösseren Gelasimus sieht, und dass allerdings wohl bei diesen luftathmenden Krabben, wie bei den luftathmenden Wirbelthieren, der Sinn des Geruchs am Eingange der Athemhöhle $z u$ suchen sein dürfte.

I) Dieser kleinere Gelasimus ist auch dadurch merkwürdig, dass bei ihm besonders augenfällig der chamäleontische Farbenwechsel hervortritt, den manche Krabben zeigen. Der Panzer eines Männchens, das ich eben vor mir habe, prangte vor fünf Minuten, als ich es fing, in seinem hinteren Theile in blendendem Weiss; jetzt zeigt er an derselben Stelle ein mattes Grau. 
Soweit das Thatsächliche in Betreff des Luftathmens der Krabben. Es ist schon oben angedeutet worden, weshalb Darwin's Lehre fordert, dass, wenn überhaupt besondere Einrichtungen für die Luftathınung bestanden, dieselben verschieden in den verschiedenen Familien gebildet seien. - Dass die Erfahrung mit dieser Forderung in vollem Einklang steht, wird um so schärfer zu Gunsten Darwin's betont werden dürfen, als die Schule, weit entfernt, so tiefgreifende Verschiedenheiten voraussehen oder erklären zu können, dieselben vielmehr als etwas höchst Verwunderliches wird betrachten müssen. Wenn bei den nahe verwandten Familien der Ocypodiden und Grapsoïden die grösste Uebereinstimmung herrscht in allen wesentlichen Verhältnissen ihres Baues, wenn für alles Andere, für die Sinne, für die Gliederung der Gliedmassen, für jedes Stäbchen und Haarbüschelchen des verwickelten Magengerüstes, für das Herz und den Kreislauf, wenn für die der Wasserathmung dienenden Einrichtungen bis auf die mikroskopischen Häkchen an den Haaren der die Kiemen abfegenden Geisseln derselbe Bauplan sklavisch festgehalten ist, woher nun auf einmal diese Ausnahme, diese völlige Verschiedenheit für die Luftathmung?

Die Schule wird kaum eine Antwort haben auf diese Frage, sie müsste sich denn auf den mit Recht unter uns in Verruf gekommenen theologisch-teleologischen Standpunct stellen wollen, von dem aus das Zustandekommen einer Einrichtung als erklärt gilt, wenn man ihre „Zweckmässigkeit" für das Thier nachweisen kann. Von diesem aus würde man allerdings sagen können, dass eine über den hinteren Füssen weitklaffende Spalte, die für Aratus Pisonii zwischen dem Laube der Manglebüsche nichts Bedenkliches hatte, nicht passte für die im Sande lebende Ocypoda; dass um dem Eindringen des Sandes vorzubeugen, hier die Oeffnung der Kiemenhöhle an deren tiefster Stelle angebracht, dass sie von ihr aus abwärts gerichtet, dass sie tief zwischen breiten mit schützenden Haarbürsten umsäumten Flächen verborgen sein musste. - Es liegt diesen Blättern fern, im Allgemeinen auf eine Zurückweisung jener Zweckmässigkeitslehre einzugehen. Dem vielen Trefflichen, was seit Spinoza hierüber gesagt ist, wäre auch kaum etwas Wesentliches nachzutragen. Nur das möge bemerkt sein, dass ich es gerade als eine der wichtigsten Leistungen der Darwin'schen Lehre ansehe, die nun einmal auf dem Gebiete des Lebens unabweisbaren Nützlichkeitsbetrachtungen ihrer mystischen Ueberschwenglichkeit entkleidet zu haben. - Für den vorliegenden Fall genügt es, auf den Gelasimus der Manglesümpfe hinzuweisen, der hier mit verschiedenen Grapsoïden dieselben äusseren Verhältnisse theilt, und doch nicht mit ihṇen, sondern mit der sandbewohnenden Ocypoda übereinstimmt.

\section{VI.}

Kaum minder schlagend als das Beispiel der luftathmenden Krabben ist das Verhalten des Herzens in der Abtheilung der Edriophthalmen, die man billig nach dem Vorgange von Dana und Spence Bate, nur in zwei Ordnungen, die Amphipoden und die Asseln, theilt.

Bei den Amphipoden, denen die genannten Forscher mit Recht auch die Caprellen und Wallfischläuse (die lämodipoden Latreille's) zuzählen, hat das Herz unveränderlich dieselbe Lage; es dehnt sich als langer Schlauch durch die sechs dem Kopfe folgenden Ringe und hat drei Paar mit Klappen versehener 
Spalten zum Eintritt des Blutes, die im zweiten, dritten und vierten dieser Ringe liegen. So fanden es La Valette bei Niphargus (Gammarus puteanus) und Claus bei Phronima, und ebenso fand ich es bei einer ansehnlichen Zahl von Arten aus den verschiedensten Familien 1 \%. Die einzige, unerhebliche Ausnahme, auf die ich bis jetzt gestossen bin, bietet die Gattung Brachyscelus ${ }^{2}$; ; hier besitzt das Herz nur zwei Spaltenpaare, indem es nach vorn nur bis in den zweiten Leibesring reicht und des sonst in diesem Ringe liegenden Spaltenpaares entbehrt. ${ }^{3}$ )

Dieser Einförmigkeit gegenüber, die das Herz in der ganzen Ordnung der Amphipoden zeigt, muss es sehr auffallen, es in der nächststehenden Ordnung der Asseln als eines der veränderlichsten Organe wiederzufinden.

Bei den Scheerenasseln (Tanais) gleicht das Herz durch seine langstreckige Schlauchform, sowie durch Zahl und Lage der Eingangsspalten dem Amphipodenherzen, mit dem Unterschiede jedoch, dass die beiden Spalten jedes Paares nicht genau einander gegenüberliegen.

Bei allen übrigen Asseln ist das Herz nach dem Hinterleibe hingerückt. Bei den wunderlich missgestalteten Binnenasseln der Porzellankrebse (Entoniscus Porcellanae) ist das kuglige Herz des Weibchens auf eine kurze Strecke des langgezogenen ersten Hinterleibsringes beschränkt und scheint ein einziges Spaltenpaar zu besitzen. Bei dem Männchen des Entoniscus Cancrorum n. sp. (Fig. I6) liegt das Herz im dritten Hinterleibsringe. Bei den Schildasseln (Cassidina) ist das Herz (Fig. I 4) ebenfalls kurz und mit zwei Spaltenpaaren versehen, die im letzten Ringe des Mittelleibes und dem ersten des Hinterleibes liegen. Bei einer jungen Fischassel

1) Besonders bequem für die Beobachtung der Herzspalten pflegen die Jungen im Ei, kurz vor dem Ausschlüpfen, zu sein; sie sind meist genügend durchsichtig, die Bewegungen des Herzens sind weniger stürmisch, als später, und sie liegen stıll selbst ohne den Druck eines Deckglases. - Bei der lierkömmlichen Ansicht von der Verbreitung der Amphipoden, dass sie an Mannichfaltigkeit polwärts zu-, nach dem Aequator hin abnehmen, mag man es befremdlich finden, wenn ich von einer ansehnlichen Artenzahl an einer subtropischen Küste rede. Ich bemerke also, dass ich in wenigen Monaten und ohne grössere, vom Strande aus unzugängliche Tiefen auszubeuten, 38 verschiedene Arten auffand, darunter 34 neue, - was mit den frïher, namentlich durch Dana bekannt gewordenen schon 60 brasilianische Amphipoden ergiebt, während Kröyer in seinen „Grönlands Amfipoder" aus dem damals schon von weit zahlreicheren Forschern durchsuchten arctischen Meere mit Einschluss von 2 Lämodipoden nur 28 Arten kannte.

2) Nach Milne Edwards' Anordnung würden die Weibchen dieser Gattung zu den Hypérines ordinaires, die bisher unbekannten Männchen zu den Hypérines anormales gehören, deren unterscheidendes Merkmal, die wunderlichen zickzackförmig zusammengelegten unteren Fühler, überhaupt eben nur eine Geschlechtseigenthümlichkeit männlicher Thiere ist. Bei dem Systematisiren nach einzelnen todten Exemplaren, über deren Geschlecht, Alter u. s. w. man nichts weiss, sind ähnliche Missgriffe unvermeidlich. So hat, um ein anderes Beispiel aus neuester Zeit zu geben, ein berühmter Fischkenner, Bleeker, kürzlich zwei Gruppen der Cyprinodonten dadurch unterschieden, dass die einen, Cyprinodontini, eine pinna analis non elongata, die andern, Aplocheilini, eine pinna analis elongata haben sollen; danach würden von einem hier sehr häufigen Fischchen die Weibchen zur ersten, die Männchen zur zweiten Gruppe gehören. Solche Missgriffe sind, wie gesagt, für den »dry skin philosopher unvermeidlich und deshalb verzeiblich; sie beweisen aber immerhin, wie grundsatz- und haltlos vielfach noch die heutige Systematik ins Blaue hinein geht, und wie sehr sie des untrïglichen Prüfsteins für den Werth der verschiedenen Merkmale bedürftig ist, den Darwin's Lehre ihr zu geben verspricht.

3) In Milne Edwards' Leçons sur la physiol. et l'anat. comp. III. p. 197 finde ich die Angabe, dass nach Frey und Leuckart das Herz der Caprella linearis fünf Paar Spalten besitze; ich habe vollkommen durchsichtige junge Caprellen untersucht, - wahrscheinlich Junge der Caprella attenuata Dana, mit der sie zusammen vorkamen, - aber nur die gewöhnlichen drei Spaltenpaare finden können. 
(Anilocra) endlich (Fig. I5) sehe ich das Herz durch die ganze Länge des Hinterleibes sich erstrecken und mit vier (oder fünf?) Spalten versehen, die nicht paarweise, sondern abwechselnd in dem einen Ringe links, im nächsten rechts gelegen sind. Bei anderen Thieren dieser Ordnung, die ich bis jetzt nur beiläufig untersuchte, werden sich voraussichtlich noch weitere Verschiedenheiten finden lassen.

Woher nun in zwei einander so nahe stehenden Ordnungen dort jene Beständigkeit, hier diese Veränderlichkeit desselben hpchwichtigen Organes? Von der Schule wird man keine Erklärung erwarten dürfen, sie wird entweder die Erörterung des Woher als ihrem Gebiete fremd, als jenseit der Grenzen der Naturwissenschaft liegend ablehnen, - oder auch durch eine hochtönende, mit grie-

Fig. 15 .

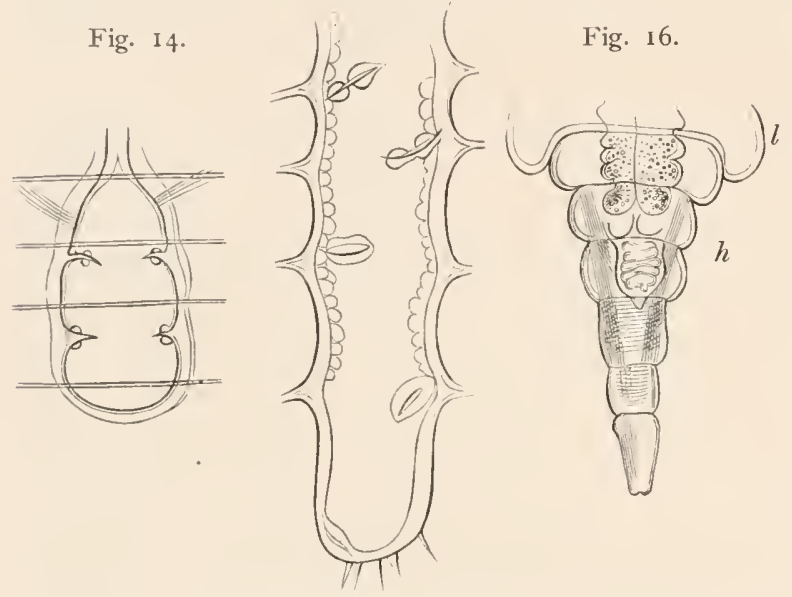

Fig. 14. Herz einer jungen Cassidina. - Fig. 15. Herz einer jungen Anilocra. - Fig. I6. Hinterleib des Männchens von Entoniscus Cancrorum. h. Herz. l. Leber. chischen Worten reich durchspickte Umschreibung des Thatbestandes den zudringlichen Frager zu verblüffen suchen. Da ich leider mein Griechisch vergessen, ist mir der zweite Ausweg verschlossen; da ich aber zum Glück nicht zu den zünftigen Meistern, sondern, mit Freiherrn von Liebig zu reden, zu den „Spaziergängern an den Grenzen der Naturwissenschaft" zähle, kann mich jenes zimperliche Bedenken der Schule nicht abhalten, eine Antwort zu suchen, die sich denn auch von Darwin's Standpuncte aus in ungezwungenster Weise bietet.

Da ausser den Scheerenasseln, welche anderweite Gründe als der Urassel besonders nahestehend anzusehen berechtigen (s. o.), und ausser den Amphipoden auch die Krabben und Krebse ein Herz mit drei Spaltenpaaren und in wesentlich gleicher Lage besitzen, - da dieselbe Lage des Herzens sogar bei den Embryonen der Heuschreckenkrebse (Squilla) wiederkehrt (s. u.), wo das Herz des erwachsenen Thieres und selbst schon, wie ich anderwärts zeigte, das weit von der Reife entfernter Larven als langer Schlauch mit zahlreichen Oeffnungen sich weit durch den Hinterleib streckt, - so darf man unbedenklich das Amphipodenherz als Urform des Edriophthalmenherzens ansehen. Da ferner bei diesen Thieren das Blut von den Athemwerkzeugen ohne Gefässe dem Herzen zuströmt, liegt es auf der Hand, wie vortheilhaft eine möglichst genäherte Lage dieser Organe ihnen sein muss. Als Urform der Athmungsweise hat man Grund, das bei den Scheerenasseln bestehende Verhältniss (s. o.) zu betrachten. Wo nun später, wie bei der Mehrzahl der Asseln, Kiemen am Hinterleibe sich entwickelten, änderte sich, indem es ihnen näher rückte, Lage und Bildung des Herzens, ohne dass für diese jüngere Bildungsweise sich wieder ein gemeinsamer Plan herausstellte, entweder weil diese Umwandlung des Herzens erst nach der Scheidung der Stammform in untergeordnete Gruppen stattfand, oder weil wenigstens zur Zeit dieser Scheidung das 
abändernde Herz sich noch in keiner neuen Form befestigt hatte. Wo dagegen die Athmung dem vorderen Theile des Leibes verblieb, - sei es in der ursprünglichen Weise der Zoëa, wie bei den Scheerenasseln, sei es, indem Kiemen am Mittelleibe sich entwickelten, wie bei den Amphipoden, - da vererbte sich unverändert auch die Urform des Herzens, weil etwa auftauchende Abweichungen eher Nachtheil, statt Vortheil brachten und sofort wieder untergingen.

Ich schliesse diese Reihe vereinzelter Beispiele mit einer Beobachtung, die freilich nur zur Hälfte ins Bereich der Kruster fällt, auf das sich diese Blätter beschränken wollen, und auch mit den eben besprochenen Verhältnissen keinen weiteren Zusammenhang hat, als den, nur von Darwin's Lehre aus eine „verständliche und Verständniss bringende Thatsache" zu sein. Als ich dieser Tage eine Lepas anatifera öffnete, um das Thier mit der Beschreibung in Darwin's "Monograph on the Subclass Cirripedia“ zu vergleichen, stiess ich im Gehäuse dieses Rankenfüssers auf einen blutrothen Ringelwurm mit kurzem, flachen Leibe, etwa $1 / 2$ Zoll lang bei 2 Linien Breite, mit 25 Leibesringeln, ohne vorspringende Borstenhöcker und ohne Gliedfäden. Der kleine Kopflappen trug 4 Augen und 5 Fühler; jeder Leibesring jederseits am Rande ein schief aufwärts gerichtetes Büschel einfacher Haarborsten und ziemlich entfernt davon auf der Bauchseite eine Gruppe dickerer Borsten mit stark hakig gebogener zweizackiger Spitze. Ausserdem fand sich über jedem der seitlichen Borstenbüschel eine Kieme, einfach an wenigen der vordersten Ringe, weiterhin und bis zum Ende des Leibes stark baumförmig verästelt. Das Thier, ein mit Eiern gefülltes Weibchen, gehört nach alledem offenbar in die Familie der Amphinomiden, die einzige Familie, deren Angehörige als treffliche Schwimmer im offenen Meere leben. - Dass dasselbe sich nicht zufällig zur Lepas verirrt habe, sondern ihr als regelmässiger bleibender Gast zugehöre, dafür bürgt seine im Verhältniss zu dem schmalen Eingange des Lepasgehäuses erhebliche Grösse, der vollständige Mangel des Regenbogenschimmers, der die Haut freilebender Ringelwürmer und namentlich auch der Amphinomiden auszuzeichnen pflegt, die Bildung und Stellung der unteren Borsten u. s. w. Dass nun aber gerade ein Wurm aus der Familie der im hohen Meere lebenden Amphinomiden in der ebenfalls an Holz, Rohr u. dgl. im Meere fluthenden Lepas als Gast sich findet, ist ohne Weiteres verständlich vom Standpuncte der Darwinschen Lehre aus, während die Verwandtschaft dieses Schmarotzers mit den freilebenden Würmern des offenen Meeres völlig unbegreiflich bleibt bei der Annahme, dass er selbstständig für den Aufenthalt in der Lepas geschaffen wurde.

Wie günstig nun auch für Darwin sich die besprochenen Beispiele ausnehmen, man wird ihnen, und das mit vollem Recht, das Bedenken entgegenstellen dürfen, dass es eben nur vereinzelte Thatsachen sind, die bei weit über das unmittelbar Gegebene hinausgehenden Betrachtungen nur zur leicht mit dem täuschenden Schimmer des Irrlichts von der rechten Bahn abziehen. Je hochragender der Bau, un so breiter muss die sichernde Unterlage wohl gesichteter Thatsachen sein.

Wenden wir uns denn zu einem weitcren Felde, der Entwickelungsgeschichte der Kruster, auf dem die Wissenschaft bereits eine bunte Fülle merkwürdiger Thatsachen zusammengetragen hat, die aber für sie ein wüstes Haufwerk unhandlichen Rohstoffs geblieben sind, und sehen wir, wie unter Darwin's Hand diese zerstreuten Werkstücke zu einem wohlgefügten Baue sich zusammenschliessen, in 
dem jedes, tragend und getragen. seine bedeutsame Stelle findet. Unter Darwin's Hand, - denn ich werde Nichts zu thun haben, als eben die Bausteine an die Stelle zu setzen, die seine Lehre ihnen anweist. „Wenn die Könige baun, haben die Kärrner zu thun."

VII.

Ueberblicken wir zunächst die vorliegenden Thatsachen.

Unter den stieläugigen Krustern (Podophthalma) kennt man nur äusserst wenige Arten, die in der Gestalt der Eltern, mit vollzähligen, wohlgegliederten Leibesanhängen das Ei verlassen. So nach Rathke ${ }^{1}$ ) der europäische Flusskrebs und nach Westwood eine westindische Landkrabbe (Gecarcinus). Beide Ausnahmen gehören also zu der geringen Zahl im süssen WVasser oder auf dem Lande lebender Krabben und Krebse, - - wie ja auch in manchen anderen Fällen Süsswasser- und Landthiere der Verwandlung entbehren, während ihre Verwandten im Meere eine solche durchlaufen. Ich erinnere an die vorwiegend dem süssen Wasser und dem Lande angehörigen Regenwürmer und Blutegel unter den Ringelwürmern, an die Plattwürmer des süssen Wassers und das Tetrastemma der salzarmen Ostsee unter den Strudelwürmern, an die Lungenschnecken und an die Flusskiemenschnecken, deren Junge (nach Troschel's Handb. der Zoologie) keine mit Wimpern besetzte Mundlappen tragen, während die der so ähnlichen Strandschnecken (Littorina) sie besitzen.

Alle Meerbewohner dieser Abtheilung scheinen eine mehr oder minder beträchtliche Verwandlung $z u$ bestehen. Nur unerheblich scheint dieselbe beim Hummer zu sein, dessen Brut nach van Beneden sich dadurch vom erwachsenen Thiere unterscheidet, dass ihre Füsse nach Art der Mysis einen frei nach aussen ragenden Schwimmast besitzen. Auch scheinen, nach einer von Couch gegebenen Abbildung, die Anhänge des Hinterleibes und Schwanzes noch zu fehlen.

Weit tiefer greifend ist die Verschiedenheit der jüngsten Brut vom geschlechtsreifen Thiere bei der weit überwiegenden Mehrzahl der Podophthalmen, die als Zoëa das Ei verlassen. Diese Jugendform findet sich, soweit die bisherigen Erfahrungen reichen, bei allen Krabben, mit alleiniger Ausnahme jener einen von Westwood untersuchten Art. Ich sage Art und nicht Gattung, denn Vaughan Thompson fand bei derselben Gattung Gecarcinus Zoëabrut ${ }^{2}$ ), die auch bei anderen landbewohnenden Krabben (Ocypoda, Gelasimus etc.) getroffen wird. - Alle Anomuren scheinen ebenfalls als Zoëa ihren Lebenslauf zu beginnen; so die Porcellanen, die Tatuira (Hippa emerita) und die Einsiedlerkrebse. Unter den

I) Gewährsmänner sind nur angeführt bei Thatsachen, die ich selbst zu bestätigen keine Gelegenheit hatte.

2) Bell (Brit. Stalk-eyed Crust. pg. XLV) hält sich berechtigt, Thompson's Beobachtung ohne Weiteres zu ,eliminiren“, weil derselbe nur Eier tragende Weibchen in Weingeist habe untersuchen können. Wer sich aber so viel mit der Entwicklung dieser Thiere beschäftigt, wie Thompson, musste sehr wohl auch an Eiern, die von der Reife nicht allzufern und nicht allzuschlecht crhalten waren, unzweideutig erkennen können, ob daraus eine Zoëa ausschlïpfen werde. Zudem spricht zu Thompson's Gunsten die Lcbensweise der Landkrabben. "Jährlich einmal" erzählt Troschcl's Handb. der Zoologie, "wandern sie in grossen Schaaren zum Mcere, um ihre Eier abzulegen, und nachher sehr entkräftct zu ihren Wohnplätzen zurück, welche nur von Wenigen erreicht werdcn." - Wozu diese aufreibenden Wanderungen zum Mcere bei Arten, deren Junge als Landthicre das Ei und die Mutter verlassen? -- 
langschwänzigen Krebsen kennt man dieselbe früheste Jugendform namentlich von zahlreichen Garneelen; so von Crangon (Du Cane), Caridina (Joly), Hippolyte, Palaemon, Alpheus u. s. w. Endlich ist es nicht unwahrscheinlich, dass auch die jüngste Brut der Heusclireckenkrebse (Squilla) sich hier anschliesst. -

Die wichtigsten Eigenthümlichkeiten nun, welche diese Zoëabrut vom erwachsenen Thiere unterscheiden, sind die folgenden:

Der Mittelleib mit seinen Anhängen, jenen fünf Fusspaaren, denen Krabben und Krebse den Namen der Zehnfüsser danken, fehlt noch vollständig, oder ist doch kaum angelegt; Hinterleib und Schwanz sind anhanglos; letzterer besteht aus einem einzigen Stücke. Den Kinnbacken (mandibulae) fehlen, wie bei den Insekten, die Taster. Die Kieferfüsse, von denen das dritte Paar oft noch fehlt, sind noch nicht in den Dienst des Mundes gezogen, sondern erscheinen als zweiästige Schwimmfüsse. Kiemen fehlen, oder wo sich deren erste Anlagen als kleine warzenförmige Vorsprünge erkennen lassen, sind dieses dichte vom Blute noch nicht durchströmte Zellenmassen, die also mit der Athmung nichts zu thun haben. Ein Austausch zwischen den Gasen des Wassers und des Blutes wird überall an der dünnhäutigen Oberfläche des Leibes statthaben können; als Hauptsitz der Athmung aber darf man unbedenklich die Seitentheile des Panzers bezeichnen. Sie bestehen ganz wie es Leydig von den Daphnien beschreibt aus einem äusseren und einem inneren Blatte, deren Zwischenraum von zahlreichen an den Enden verbreiterten Querbälkchen durchsetzt ist; die Lücken zwischen diesen Bälkchen werden von reicheren Blutströmen durchflossen, als sie sonstwo im Leibe der Zoëa sich finden. Dazu

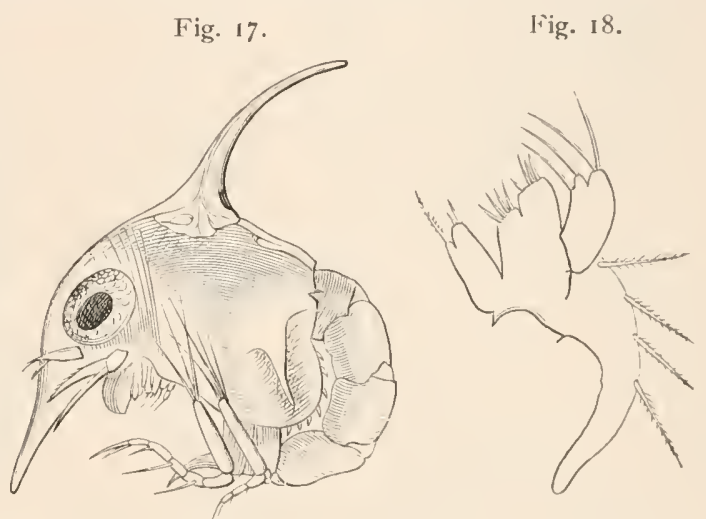

Fig. 17. Zoëa einer Sumpfkrabbe [Cyclograpsus (?)], $45 \mathrm{mal}$ vergr.

Fig. 18. Kiefer (maxilla) des zweiten Paares von derselben, i 8 omal vergr.

kommt, dass ein beständiger Strom frischen Wassers in der Richtung von hinten nach vorn unter dem Panzer hinzieht, unterhalten, wie beim erwachsenen Thiere, durch einen blatt- oder zungenförmigen Anhang des zweiten Kieferpaares (Fig. 18). - Zusatz feiner Farbtheilchen zu dem Wasser lässt selbst bei den kleineren Zoëa leicht diesen Athemstrom wahrnehmen.

Die Zoëa der Krabben (Fig. I7) pflegen sich auszuzeichnen durch lange stachelförmige Fortsätze des Panzers; ein solcher ragt von der Mitte des Rückens empor, ein zweiter von der Stirn nach unten und häufig steht noch ein kürzerer jederseits nahe der hinteren, unteren Ecke des Panzers. Alle diese Fortsätze fehlen jedoch nach Couch bei Maia, nach Kinahan bei Eurynome, und bei einer dritten Art aus derselben Gruppe der Oxyrhynchen (der Gattung Achaeus zugehörig oder nahestehend) finde ich ebenfalls nur einen unbedeutenden Rückenstachel, während Stirn und Seiten unbewehrt sind. Wieder ein Beispiel, das zur Vorsicht mahnt beim Schliessen nach Analogie. Nichts schien näher zu liegen, als die schnabelförmige Bildung der Stirn bei den Oxyrhynchen zurückzuführen auf den Stirn- 
fortsatz der Zoëa, und nun findet sich, dass gerade den Jungen der Oxyrhynchen ein solcher Stirnfortsatz völlig abgeht. - Wichtigere Eigenthümlichkeiten der Krabbenzoëa, wenn auch weniger augenfällig als jene Fortsätze des Panzers, die im Verein mit den grossen Augen ihnen oft ein so wunderliches Aussehen verleihen, sind die folgenden: die vorderen (inneren) Fühler sind einfach, ungegliedert, am Ende mit 2-3 Riechfäden versehen; die hinteren (äusseren) Fühler laufen in einen oft ungemein langen stachelförmigen Fortsatz (styliform process, Spence Bate) aus, und tragen aussen einen bisweilen sehr winzigen Anhang (squamiform process, Sp. B.), der Schuppe des Garneelenfühlers entsprechend ${ }^{1}$ ); daneben ist oft schon die erste Anlage der späteren Fühlergeissel erkennbar. Schwimmfüsse (später Kieferfüsse) sind nur zwei Paare vorhanden; es fehlt das dritte (nicht, wie Spence Bate will, das erste) vollständig, oder ist wie die fünf folgenden Fusspaare

Fig. 19-23.

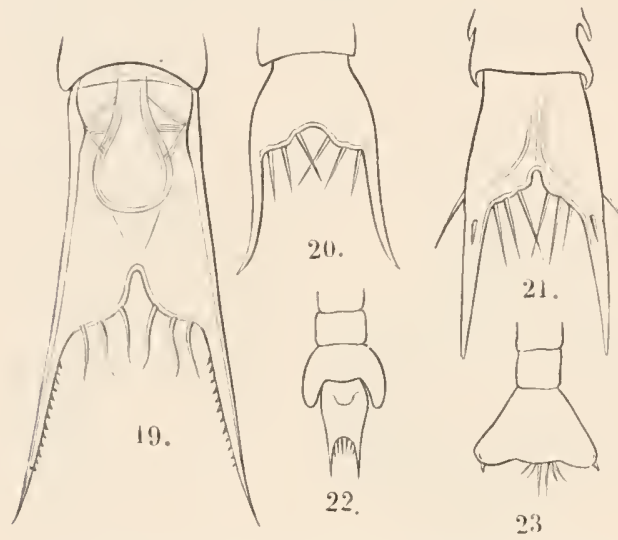

Schwänze verschiedener Krabbenzoëa. Fig. I 9 von Pinnotheres. - Fig. 20 von Sesarma. - Fig. 21 von Xantho. - Fig. 22. 23 von unbekannter Herkunft. nur als winzige Knospe vorhanden. Der Schwanz, von sehr wechselnder Form, trägt immer d rei Paar Borsten an seinem Hinterrande. Die Krabbenzoëa pflegen im Wasser sich so zu halten, dass der Rückenstachel nach oben steht, der Hinterleib nach vorn gekrümmt, der innere Ast der Schwimmfüsse nach vorn, der äussere nach aussen und oben gerichtet ist.

$\mathrm{Zu}$ bemerken ist noch, dass die Zoëa der Krabben. wie auch der Porcellanen, der Tatuira, der Garneelen beim Ausschlüpfen aus dem Eie von einer die Stachelfortsätze des Panzers, die Borsten der Füsse und Fühler verhüllenden Haut umschlossen sind, die sie schon nach wenigen Stunden abstreifen. Bei Achaeus habe ich mir angemerkt, dass der Schwanz dieser jüngsten Larvenhülle an die Garneelenlarven erinnert, und dasselbe scheint bei Maia der Fall zu sein (S. Bell, Brit. Stalk-eyed Crust. pg. 44).

So weit sie beim ersten Anblick sich von ihnen zu entfernen scheinen, so eng schliessen sich an die Zoëa der Krabben die der Porcellanen (Fig. 24) an. Fühler, Mundtheile, Schwimmfüsse zeigen dieselbe Bildung. Der Schwanz aber trägt fünf Paar Borsten, der Rückenstachel fehlt, der Stirnfortsatz dagegen und die Seitenstacheln sind von abenteuerlicher Länge und gerade nach vorn und hinten gerichtet.

Auch die Z ö̈a der Tatuira (Fig. 25) scheint nur wenig von denen der Krabben abzuweichen, denen sie auch in ihrer Bewegungsweise gleicht. Der Panzer besitzt nur einen kurzen, breiten Stirnfortsatz; der Hinterrand des Schwanzes ist mit zahlreichen kurzen Borsten besetzt.

I) In einem Aufsatze über die Verwandlung der Porcellanen habe ich diesen Anhang irrthümlich als "Geissel" bezeichnet (s. Ges. Schriften p. 154). 
Die Zoëa der Einsiedlerkrebse (Fig. 26) besitzt die einfachen inneren Fühler der Krabbenzoëa; die äusseren Fühler tragen auf kurzem Stiele aussen ein ansehnliches der Schuppe der Garneelenfühler ähnliches Blatt, innen einen kurzen dornförmigen Fortsatz und zwischen beiden die noch kurze, aber schon mit zwei

Fig. 24 .

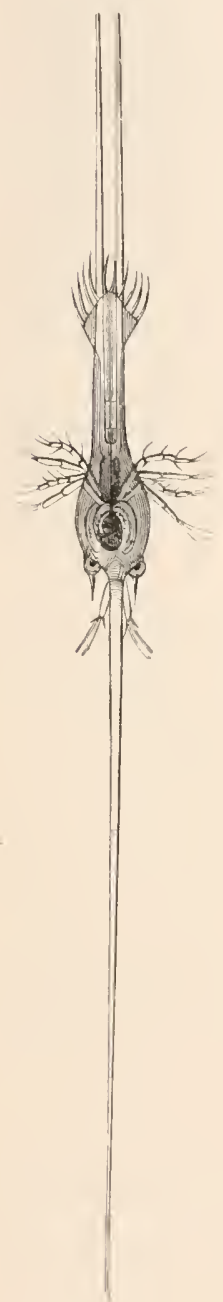

Fig. 25.

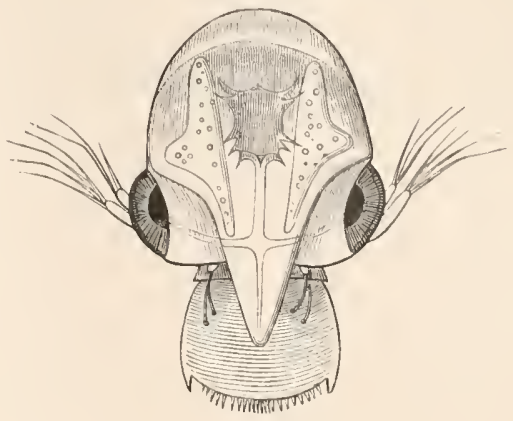

Fig. 26.

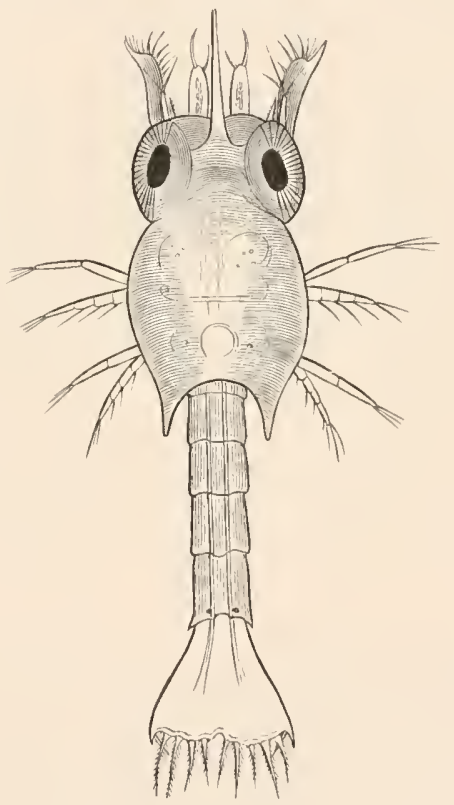

Fig. 27.

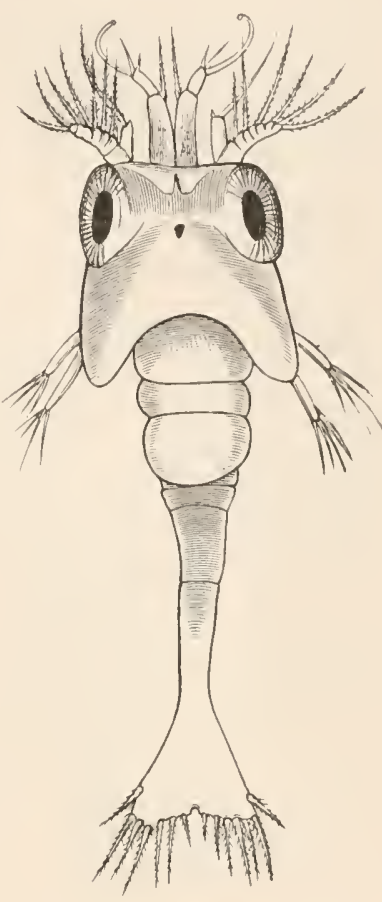

Fig. 24. Zoëa der Porcellina stellicola F. Müll. I $5 \mathrm{mal}$ vergr.

Fig. 25. Zoëa der Tatuira (Hippa eremita L.). $45 \mathrm{mal}$ vergr.

Fig. 26. Zoëa eines kleinen Einsiedlerkrebses. $45 \mathrm{mal}$ vergr.

Fig. 27. Zoëa eines an Rhizostoma cruciatum Less. sich aufhaltenden $\mathrm{Pa}$. laemon. $45 \mathrm{mal}$ vergr.

Endborsten bewehrte Geissel. Wie bei den Krabben finden sich nur zwei Paar wohl entwickelte Schwimmfüsse (Kieferfüsse); aber auch das dritte Paar ist schon als ansehnlicher, zweigliedriger, wenn auch noch borstenloser Stummel vorhanden. Der Schwanz trägt fünf Paar Borsten. Das Thierchen pflegt sich im Wasser gerade ausgestreckt zu halten mit abwärts gerichtetem Kopfe.

In derselben Haltung sieht man gewöhnlich die Zoëa der Garneelen (Fig. 27), die überhaupt im allgemeinen Ansehen mit denen der Einsiedlerkrebse übereinstimmen. Zwischen den grossen zusammengesetzten Augen findet sich bei ihnen ein kleines unpaares Auge. Die inneren Fühler tragen am Ende eines bis- 
weilen ansehnlich langen Grundgliedes innen eine gefiederte Borste, die auch schon bei den Einsiedlerkrebsen sich findet, aussen ein kurzes Endglied mit einem oder einigen Riechfäden. Die äusseren Fühler zeigen eine wohlentwickelte, bisweilen deutlich gegliederte Schuppe und meist nach innen davon einen dornartigen Fortsatz; die Geissel scheint in der Regel noch zu fehlen. Das dritte Paar der Kieferfüsse scheint stets, wenigstens als ansehnlicher Stummel schon vorhanden zu sein. Das spatelförmige Schwanzblatt trägt fünf bis sechs Borstenpaare am Hinterrande.

Die Entwicklung der Zoëabrut zum geschlechtsreifen Thiere verfolgte Spence Bate bei Carcinus Maenas; er wies nach, dass die Umwandlung eine ganz allmähliche ist, dass sich in ihr keine scharfgeschiedenen Entwicklungsstufen, wie etwa beim Schmetterlinge Raupe und Puppe abgrenzen lassen. Leider besitzen wir nur diese einzige vollständige Beobachtungsreihe und ihre Ergebnisse dürfen nicht ohne Weiteres als allgemein giltig betrachtet werden; so bewahren die jungen Einsiedlerkrebse das allgemeine Aussehen und die Bewegungsweise der Zoëa, während die Anlagen der Füsse des Mittel- und Hinterleibes heranwachsen, und erscheinen dann auf einmal, indem diese in Thätigkeit treten, in ganz neuer Gestalt, die von der des erwachsenen Thieres hauptsächlich durch vollkommene Symmetrie des Leibes und durch vier Paar wohlgebildeter Schwimmfüsse am Hinterleibe sich unterscheidet ${ }^{1}$.

Sehr eigenthümlich scheint die Entwicklung der $\mathrm{Panzerkrebse}$ zu sein. Claus fand in den Eiern der Languste (Palinurus) Embryonen mit vollständig gegliedertem Leibe, denen die Anhänge des Schwanzes, des Hinterleibes, und der beiden letzten Ringe des Mittelleibes fehlen; sie besitzen ein einfaches unpaares und ansehnliche zusammengesetzte Augen; die vorderen Fühler sind einfach, die hinteren mit einem kleinen Nebenaste versehen; die Kinnbacken tasterlos; das dritte Paar der Kieferfüsse wie die beiden folgenden Fusspaare in zwei fast gleichlange Aeste gespalten, während das letzte der vorhandenen Fusspaare und das zweite Paar der Kieferfüsse nur einen unbedeutenden Nebenast tragen. Coste will bekanntlich aus den Eiern desselben Krebses junge Phyllosomen gezogen haben, - eine Angabe, die um so mehr einer nähern Begründung bedarf, als die neueren Untersuchungen von Claus über Phyllosoma ihr keineswegs günstig scheinen.

Die grossen zusammengesetzten Augen, die früh bewegt zu werden pflegen und bisweilen schon in frühester Zeit auf langen Stielen stehen, sowie der Panzer, der den ganzen Vorderleib deckt, weisen bei aller Verschiedenheit den bisher betrachteten Larven sofort ihre Stelle unter den Podophthalmen an. Nicht ein bezeichnendes Merkmal aber dieser Abtheilung bleibt der Brut einiger zur Gattung Penëus oder in deren Nähe gehörigen Garneelen. Dieselben verlassen das Ei mit ungegliedertem eiförmigen Leibe, unpaarigem Stirnauge und drei Paar Schwimmfüssen, von denen die vorderen einfach, die beiden anderen zweiästig sind, - in jener unter niederen Krustern so häufigen Larvenform also, der O. F. Müller den Namen Nauplius gab. Keine Spur eines Panzers, keine Spur der paarigen Augen, keine Spur von Kauwerkzeugen neben dem von einer helmförmigen Kappe überwölbten Munde!

I) Die Glaucothoë Peronii Edw. mag ein solcher junger noch symmetrischer Pagurus sein. 
Für eine dieser Arten wurden bereits die Zwischenformen, die vom Nauplius zur Garneele führen, in ziemlich enggeschlossner Reihe aufgefunden.

An die jüngsten Nauplius (Fig. 28) schliessen sich Formen, bei denen hinter dem dritten Fusspaare eine Hautfalte als erste Andeutung des Panzers quer über den Rücken zieht und auf der Bauchseite vier Paar plumpe Zapfen hervorspriessen, - Anlagen neuer Gliedmassen. Innerhalb des dritten Fusspaares bilden sich kräftige Kinnbacken aus.

Bei einer folgenden Häutung treten die neuen Gliedmassen, - Kiefer, vordere und mittlere Kieferfüsse, - in Thätigkeit und damit ist aus dem Nauplius eine Zoëa geworden (Fig. 29), völlig übereinstimmend mit der Zoëa der Krabben in

Fig. 28.

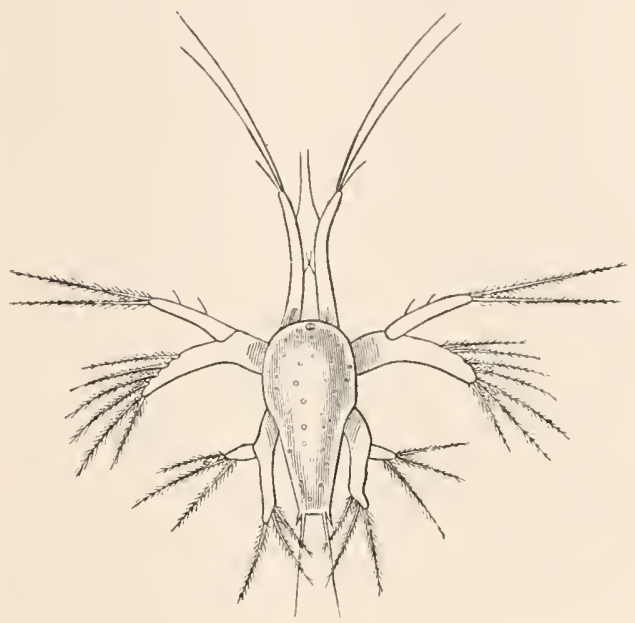
vergr.

Fig. 28. Nauplius einer Garneele. $45 \mathrm{mal}$

Fig. 29. Jüngere Zoëa derselben Garneele. $45 \mathrm{mal}$ vergr.
Fig. 29.

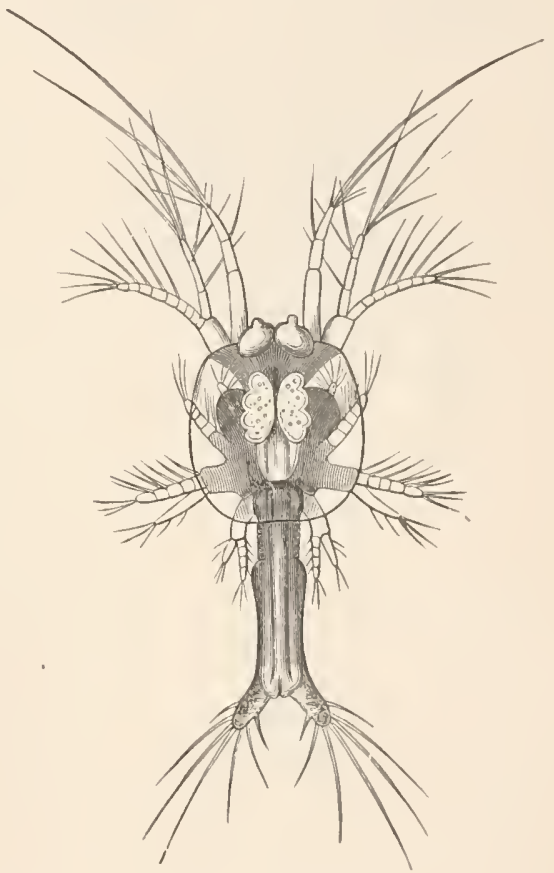

der Zahl der Leibesanhünge, - wenn auch freilich sehr abweichend in Gestalt und Bewegungsweise und selbst in manchen Verhältnissen des inneren Baues. Als hauptsächlichste Bewegungswerkzeuge dienen noch die schlanken langbeborsteten beiden vorderen Fusspaare, die späteren Fühler; das dritte Fusspaar verliert seine Aeste und wird zu tasterlosen Kinnbacken. Die Oberlippe erhält einen ansehnlichen vorwärts gerichteten Stachel, der sich bei allen verwandten Zoëaarten wiederfindet. Die zweiästigen Kieferfüsse scheinen wenig bei der Bewegung witzuwirken. Der gablige Schwanz erinnert mehr an die bei niederen Krustern, namentlich den Copepoden vorkommenden Formen, als an das spatelförmige Schwanzblatt, das die Zoëa der Alphëus, Palaemon, Hippolyte und andrer Garneelen, der Einsiedlerkrebse, der Tatuira, der Porcellanen auszeichnet. Das Herz besitzt nur ein Spaltenpaar und keine sein Innres balkenartig durchsetzenden Muskeln, während bei anderen Zoëa zwei Spaltenpaare und ein innres Balkenwerk stets deutlich erkennbar sind.

Fritz Müllers gesammelte Schriften. 
Während dieses Zoëazeitraums bilden sich (Fig. 30) die paarigen Augen, es bilden sich die Ringe des Mittel- und Hinterleibes, die hinteren Kieferfüsse, die

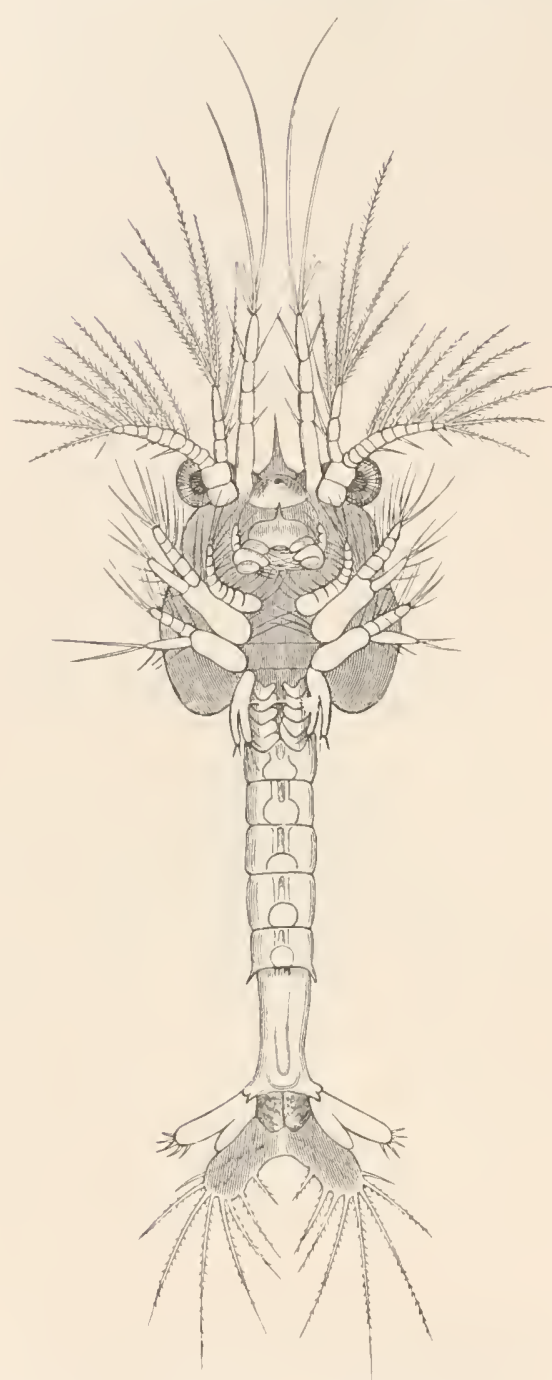

Fig. 3o. Aeltere Zoëa derselben Garneele. $45 \mathrm{mal}$ vergr.

seitlichen Schwanzanhänge und die stummelförmigen Anlagen der Füsse des Mittelleibes. Die Schwanzanhänge spriessen wie andere Gliedmassen frei an der Bauchfläche hervor, während sie bei anderen Garneelen, bei den Porcellanen u. s. w. im Innern des spatelförmigen Schwanzblattes angelegt werden.

Indem die Füsse des Mittelleibes in Thätigkeit treten, geht, unter gleichzeitigen anderen tiefgreifenden Veränderungen, die Zoëa in die Mysis-oder Schizopodenform über (Fig. 31). Die Fühler hören auf, der Bewegung zu dienen; sie werden abgelöst durch den langen Hinterleib, der vor Kurzem noch als unnütze Last mühsam nachgeschleift wurde und dessen kräftige Muskeln jetzt das Thier in munteren Sprüngen durch's Wasser schnellen und durch die langgeborsteten Brustfüsse. Die vorderen Fühler haben ihre langen Borsten verloren und neben dem letzten (vierten) mit Riechfäden ausgestatteten Gliede erscheint ein zweiter anfangs ungegliederter Ast. Der äussere bisher vielgliedrige Ast der hinteren Fühler ist zu einem einfachen Blatte, der Schuppe des Garneelenfühlers geworden; daneben erscheint die stummelförmige Anlage der Geissel, wahrscheinlich als Neubildung, indem der innere Ast vollständig schwindet. Die fünf neuen Fusspaare sind zweiästig, der innere Ast kurz, einfach, - der äussere länger, am Ende geringelt, langbeborstet und wie bei den Mysis in beständiger strudelnder Bewegung. Das Herz erhält neue Spalten und innere Muskelbalken.

Während der Mysiszeit bilden sich Gehörwerkzeuge im Grundgliede der vorderen Fühler, die inneren Aeste der drei vorderen Fusspaare entwickeln sich

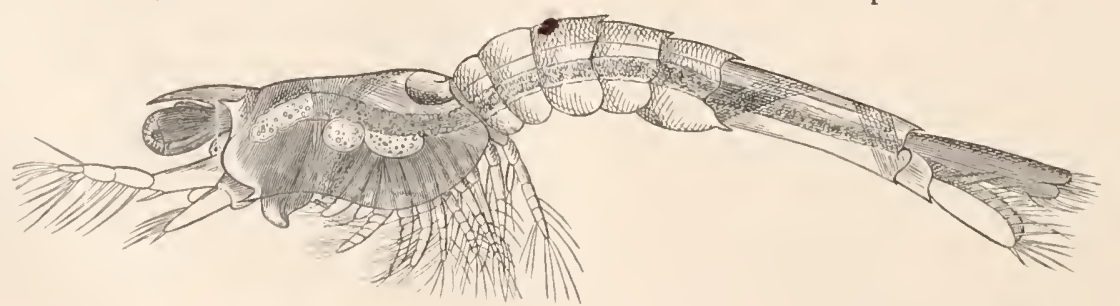

Fig. 31. Mysisform derselben Garneele. $45 \mathrm{mal}$ vergr. 
zu Scheeren, die der zwei hinteren zu Gangfüssen; an den Kinnbacken sprosst ein Taster, am Mittelleibe sprossen Kiemen, am Hinterleibe Schwimmfüsse hervor. Der Dorn der Oberlippe bildet sich zurück. - Das Thier nähert sich so allmählich der Garneelenform, in der das unpaare Auge undeutlich geworden, der Dorn der Oberlippe, die äusseren Aeste der Scheeren- und Gangfüsse verloren gegangen sind, die Taster der Kinnbacken und die Hinterleibsfüsse deutliche Glieder und Borsten erhalten habeu und die Kiemen in Thätigkeit treten.

Bei einer anderen Garneele, deren verschiedene Larvenzustände leicht als zusammengehörig erkannt werden an einem dunkelgelben scharfumschriebenen Fleck, der das unpaare Auge umgiebt, stimmen die jüngsten wahrscheinlich aus Nauplius hervorgehenden Zoëa (Fig. 32) in allen wesentlichen Verhältnissen mit der eben besprochenen Art überein; dagegen ist die weitere Entwicklung namentlich dadurch sehr abweichend, dass weder die Füsse des Mittelleibes noch die des Hinterleibes sich gleichzeitig bilden und dass eine mit Mysis in Zahl und Bildung der Gliedmassen vergleichbare Entwicklungsstufe fehlt.

Zeitig zeigen sich Spuren der äusseren Kieferfüsse. Dann erscheinen Füsse an vier Ringen des Mittelleibes und zwar zweiästig an den drei vorderen, einfach, indem der innere Ast fehlt, an dem vierten Ring. An den inneren Aesten entwickeln sich Scheeren, die äusseren Aeste gehen verloren, ehe noch ein innerer Ast am vierten Ringe aufgetreten ist (Fig. 32). Letzterer erscheint wieder anhanglos, so dass also hier in früherer Zeit vier, in späterer nur drei Ringe des Mittelleibes Gliedmassen tragen. Der fünfte Ring fehlt noch vollständig, während inzwvischen auch sämmtliche Hinterleibsringe Gliedmassen erhalten haben und zwar einer nach dem anderen, von vorn nach hinten. Das erwachsene Thier wird jedenfalls, darauf weisen die drei Scheerenpaare hin, dem der vorigen Art sehr nahe stehen ${ }^{1}$.

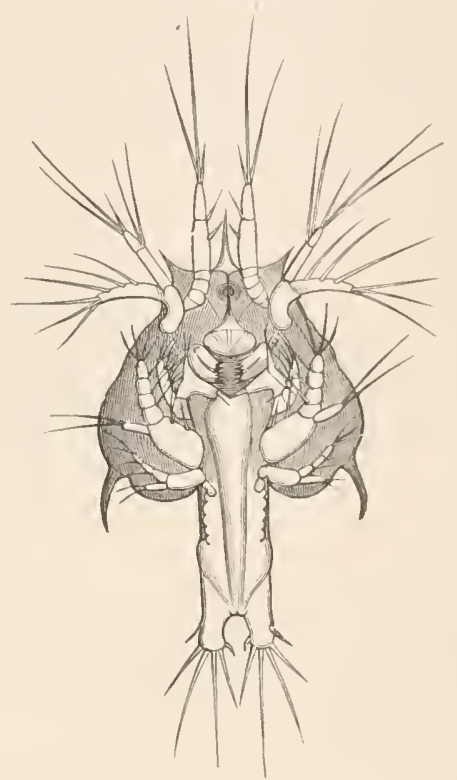

Fig. 32. Jüngste (beobachtete) Zoëa einer anderen Garneele. Man bemerkt die winzigen Knospen des dritten Paares der Kieferfüsse. Die Hinterleibsringe beginnen sich $z u$ bilden. Paarige Augen werden noch vermisst. Vergr. $45 \mathrm{mal}$.

Der jüngsten Zoëa unserer Garneelen sehr nahe stelıt die jüngste der von Claus beobachteten Larven der Schizopodengattung Euphausia; aber während ihre vorderen Fühler schon zweiästig sind, und sie hierin sich weiter vorgeschritten zeigt, fehlen ihr noch die mittleren Kieferfüsse. Auch bei ihr fand Claus das Herz mit einem einzigen Spaltenpaare versehen. Ob nicht auch hier der Zoëa naupliusähnliche Zustände vorausgehen?

1) Die ältesten beobachteten Larven zeichnen sich aus (s. Iï. 33) durch ungewöhnliche Länge der Geissel der äusseren Fühler, und gleichen hierin der von Claus bei Messina gefundenen Sergesteslarve (Zeitschr. für wiss. Zool. Bd. XIII. Taf. XXVII, Fig. 14). Diese ungemeine Länge der Fühler lässt vermuthen, dass sie unserer gemeinsten, vielverspeisten, dem Penëus setiferus von Florida nächstverwandten Garneele zugehören. Das Acanthosoma von Claus (a. a. O. Fig. 13) ist der jüngern Mysisform der von mir im Archiv für Naturgesch. 1863. Taf. II. Fig. 18 (= Ges. Schriften Taf. XXII Fig. I8) abgebildeten Larve ähnlich, die ich auf Sicyonia carinata zu beziehen geneigt bin. 
Die Entwicklungsgeschichte der Mysis, deren nahe Verwandtschaft mit den Garneelen neuerdings wieder allgemein anerkannt wird, hat van Beneden ausführlich geschildert. Soweit ich sie nachprüfte, kann ich dessen Angaben nur bestätigen. - Die Entwicklung des Embryo beginnt mit der Bildung des Schwanzes! Derselbe tritt auf als einfacher Lappen, dessen Rückenfläche der Rückenfläche des Embryo zugewandt ist und dicht anliegt. (Die Jungen anderer stieläugiger Kruster sind bekanntlich im Ei so gekrümmt, dass die Bauchflächen der vorderen und hinteren Körperhälfte einander zugekehrt sind, bei ihnen erscheint also der Rücken, bei Mysis die Bauchseite gewölbt.) Bald nimmt der Schwanz die Gabelform an, die wir bei der zuletzt betrachteten Garneelenzoëa kennen lernten. Dann sprossen am entgegengesetzten Leibesende zwei Paar plumpe säbelförmige Anhänge hervor und dahinter ein Paar leicht zu übersehender Höcker, - Fühler und Kinnbacken. Jetzt birst die Eihaut, ehe noch irgend ein inneres Organ, irgend ein Gewebe ausser den Zellen der Hautschicht gebildet ist.

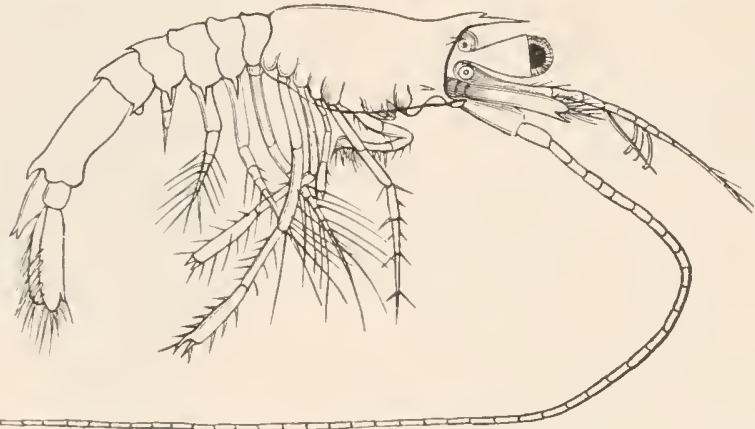

Fig. 33. Aeltere Larve, aus der Fig. 32 gezeichneten Zoëa hervorgehend. Es fehlt der letzte Ring und die beiden letzten Fusspaare des Mittelleibes. Vergr. 2omal.

Male die fünf Paar Hinterleibsfüsse. Kurz nachdem die junge Mrsis die Naupliushülle abgestreift, verlässt sie die Bruttasche der Mutter ${ }^{1}$ ).

Aus der Entwicklungsgeschichte der Maulf üsser, denen man, den Mangel einer besonderen Kiemenhöhle einseitig betonend, eine Zeitlang auch die Mysis, die Leucifer, die Phyllosomen zuzählte, die man aber jetzt wieder, wie ursprünglich Latreille, auf die Heuschreckenkrebse (Squilla), die Glaskrebse (Erichthus) und ihre nächsten Verwandten beschränkt, sind bisher nur sehr vereinzelte Bruchstücke bekannt geworden. Die Verfolgung der Entwicklung im Ei wird erschwert durch den Umstand, dass die Heuschreckenkrebse nicht wie Krabben und Krebse ihr Laich mit sich herumtragen, sondern in die von ihnen bewohnten unterirdischen Gänge absetzen in Gestalt dünner, runder, dottergelber Platten. Das Laich ist deshalb überhaupt schwierig zu erhalten und leider verdirbt es in Tagesfrist, wenn es seiner natürlichen Brutstätte entnommen wird, während man an den Eiern einer einzigen gefangen gehaltenen Krabbe wochenlang den Fortschritten der Entwicklung nachgehen kann. Die Eier der Squilla sterben, wie

I) Van Beneden, der selbst die Augenstiele als Gliedmassen betrachtet, kann doch nicht umhin, bei Mysis zu bemerken: „Ce pedicule n'apparaît aucunement comme les autres appendices et paraît avoir une autre valeur morphologique." 
vom Leibe der Krabbe entfernte Eier, weil ihnen der lebhafte Strom frischen Wassers fehlt, den die Mutter behufs ihrer eigenen Athmung durch ihre Höhle treibt.

Beistehende Abbildung eines Squillaembryo zeigt, dass derselbe einen langen, gegliederten, anhanglosen Hinterleib, einen zweilappigen Schwanz, sechs Paar Gliedmassen und ein kurzes Herz besitzt; letzteres pulsirt nur schwach und langsam. Erhält er vor dem Ausschlüpfen nicht noch weitere Gliedmassen, so dürfte die jüngste Larve auf gleicher Stufe mit der jüngsten Clausschen Euphausialarve stehen.

Von den beiden bis jetzt bekannt gewordenen Larvenformen, die mit Sicherheit, wenn auch nicht dem Heuschreckenkrebse, so doch einem Maulfüsser zuzutheilen sind, übergehe ich die jüngere ${ }^{1}$ ), da deren Gliedmassen sich nicht zuverlässig deuten lassen, und erwähne nur, dass bei ihr die drei letzten Hinterleibs-

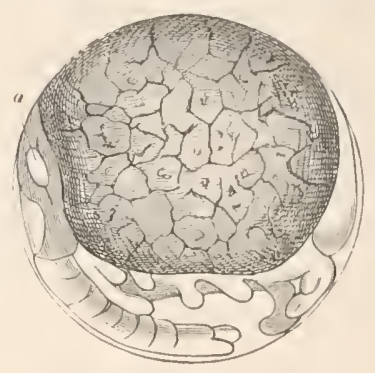

Fig. 34. Embryo einer Squilla, $45 \mathrm{mal}$ vergr. $a$ Herz. ringe noch anhanglos sind. Der älteren Larve (Fig. 35), die namentlich durch die Gestalt der grossen Raubfüsse und des vorhergehenden Fusspaares an die erwachsenen Heuschreckenkrebse erinnert, fehlen noch die sechs den Raubfüssen folgenden Fusspaare. Die entsprechenden Leibesringe sind schon wohl entwickelt, ein unpaares Auge ist noch vorhanden, die vorderen Fühler sind schon zweiästig, während den hinteren die Geissel fehlt, die Kinnbacken sind tasterlos; die vier vorderen Hinterleibsringe tragen zweiästige, kiemenlose Schwimmfüsse; der fünfte Hinterleibsring ist anhanglos; ebenso der Schwanz, der noch als einfaches am Hinterrande mit zahlreichen kurzen Zähnchen besetztes Blatt erscheint. Man sieht, die Larve steht im Wesentlichen auf der Stufe der Zoëa.

\section{VIII.}

Minder mannichfaltig, als die der stieläugigen Kruster ist die Entwicklungsweise der Asseln (Isopoda) und Flohkrebse (Amphipoda), die Leach in der Abtheilung Edrioph-

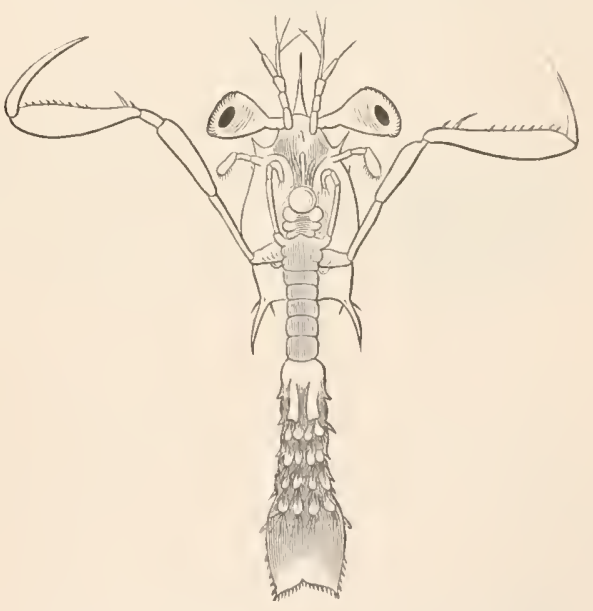

Fig. 35. Aeltere Larve (Zoëa) eines Maulfüssers, I $5 \mathrm{mal}$ vergr. thalmen, der Kruster mit Sitzaugen vereinigte.

Als Beispiel für die Entwicklung der Isopoden mögen die Felsenasseln (Ligia) dienen. Wie bei Mysis ist bei ihnen der Schwanztheil des Embryo nicht nach unten, sondern nach oben gekrümmt; wie dort, bildet sich zunächst eine Larvenhaut, innerhalb deren dann die Assel sich entwickelt. Bei Mysis liess sich diese erste Larvenhaut einem Nauplius vergleichen; bei I.igia erscheint sie als völlig anhanglose Made, die in einen langen einfachen Schwanz ausläuft. Die

I) Archiv für Naturgeschichte, I863, Taf. I. = Ges. Schriften Taf. XXI. 
Eihaut bleibt länger erhalten, als bei Mysis; sie birst, wenn schon die Gliedmassen der jungen Assel vollzählig angelegt sind. Die Rückenfläche der Assel ist etwas hinter dem Kopfe mit der Larvenhaut verwachsen. An dieser Stelle findet sich, nachdem die Verbindung nicht lange vor der Häutung gelöst ist, ein blattförmiger Anhang, der nur kurze Zeit besteht und schon geschwunden ist, ehe noch die junge Assel die Bruttasche der Mutter verlässt.

Das Junge gleicht, wenn es für sich selbst zu sorgen anfängt, den Alten fast in allen Stücken, bis auf einen wichtigen Unterschied: statt sieben besitzt es nur sechs Paar Gangbeine; der letzte Ring des Mittelleibes ist nur wenig entwickelt und anhanglos. Dass auch die geschlechtlichen Eigenthümlichkeiten noch nicht ausgebildet sind, dass den Männchen noch die handförmigen Verdickungen an den vorderen Gangbeinen und die der Begattung dienenden Anhänge fehlen, bedårf kaum besonderer Erwähnung.

Fig. 36 .

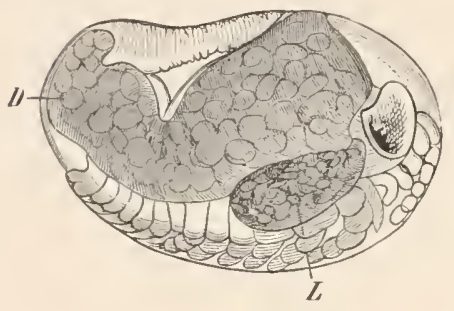

Fig. 37 .

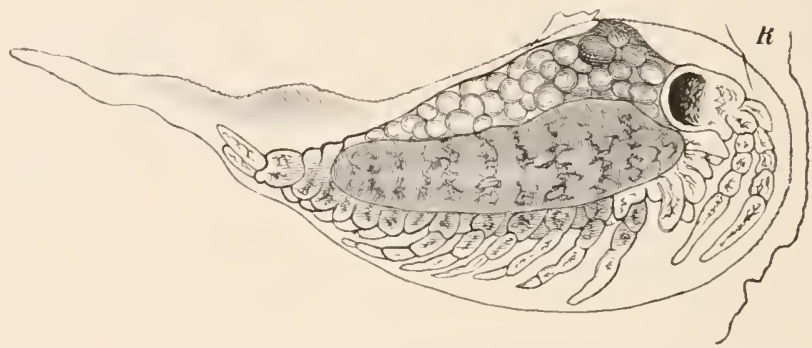

Fig. 38

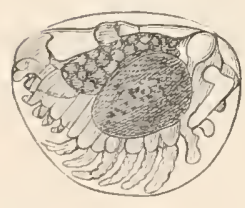

Fig. 36. Embryo von Ligia im Ei, I5mal vergr. D. Dotter, L. Leber.

Fig. 37. Madenförmige Larve derselben. $15 \mathrm{mal}$ vergr. $R$. Rest der Eihaut. Man sieht an der Bauchseite von vorn nach hinten: vordre, hintre Fühler, Kinnbacken, vordre, hintre Kiefer, Kieferfüsse, sechs Gangfüsse, den letzten anhanglosen Ring des Mittelleibes, fünf Hinterleibsfüsse, Schwanzfüsse.

Fig. 38. Embryo einer Philoscia im Ei, $25 \mathrm{mal}$ vergr.

Auf die Frage, inwieweit die Entwicklung der Felsenasseln bei den übrigen Isopoden sich wiederholt, kann ich nur ungenügende Antwort geben. Die Krümmung des Embryo nach oben statt nach unten fand ich wie Rathke auch bei Idothea, und ebenso bei Cassidina, Philoscia, Tanais und den "Bopyriden, vermisste sie überhaupt bei keiner der darauf untersuchsen Asseln. Bei Cassidina ist auch die erste anhanglose Larvenhaut leicht zu erkennen; es fehlt ihr der lange Schwanz, doch ist sie innerhalb des Eies stark gekrümmt, wie bei Ligia, und deshalb nicht mit einer „inneren Eihaut“ zu verwechseln; letzteres könnte man bei Philoscia, wo sie sich eng an die Eihaut anschliesst und nur im Hinblick auf Ligia und Cassidina als Larvenhaut zu deuten ist. - Den blattförmigen Anhang am Rücken kennt man seit lange an den Jungen der gemeinen Wasserassel [Asellus ${ }^{1}$ )]. -

I) Leydig hat diesen blattförmigen Anhang der Wasserasseln der "grünen Drüse“ oder „Schalendrüse" anderer Kruster verglichen; er nimmt dabei an, dass die grüne Drüse ohne Ausführungsgang sei, und beruft sich darauf, dass beiderlei Organe ,an derselben Stelle“ sich finden. Die Deutung ist keine glückliche. Einmal überzeugt man sich, wie auch Claus fand, bei Leucifer sehr leicht, dass die ,grüne Drüse" wirklich am Ende des von Milne Edwards als ,tubercle auditif", von Spence Bate als "olfactory 
- Dass den Jungen der Landasseln (Porcellionides Edw.) und Fischasseln (Cymothoadiens Edw.) das letzte Fusspaar des Mittelleibes fehle, hat schon Milne Edwards bemerkt. Das Gleiche gilt für die Schachtasseln (Idothea), für die lebendig gebärenden Kugelasseln (Sphaeroma) und Schildasseln (Cassidina), für die Bopyriden (Bopyrus, Entoniscus, Cryptoniscus n. g.) und für die Scheerenasseln (Tanaris), also wahrscheinlich für die überwiegende Mehrzahl der Isopoden. Alle übrigen Gliedmassen pflegen bei den jungen Asseln wohlentwickelt zu sein. Nur bei den Scheerenasseln fehlen sämmliche Füsse des Hinterleibes (aber nicht des Schwanzes); sie entwickeln sich gleichzeitig mit dem letzten Fusspaare des Mittelleibes.

Das letzte Fusspaar am Mittelleibe der Larve, das vorletzte also des erwachsenen Thieres, ist fast immer dem vorhergehenden gleichgebildet; eine beachtenswerthe Ausnahme machen jedoch hierin Cryptoniscus und Entoniscus; beachtenswerth als Beleg zu Darwin's Satze, dass „in ungewöhnlicher Weise entwickelte Theile sehr veränderlich" sind; denn für das abweichend gebildete Fusspaar besteht die grösstmögliche Verschiedenheit zivischen den drei bisher beobachteten Arten. Bei Cryptoniscus (Fig. 39) ist dieser letzte Fuss dünn, ruthenförmig; bei Entoniscus Cancrorum ungemein lang, mit stark verdickter Hand und eigenthümlich gebildeter Scheere versehen; bei Entoniscus Porcellanae sehr kurz, unvollständig gegliedert mit grossem eiförmigen Endgliede (Fig. 40).

Einige Asseln erleiden unmittelbar vor dem Eintritte der Geschlechtsreife eine erhebliche Verwandlung;

Fig. 39 .

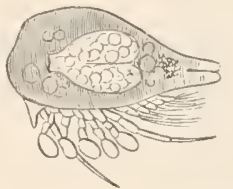

Fig. 39. Embryo von Cryptoniscus planarioïdes, gomal vergr.

Fig. 40. Letzter Fuss vom Mittelleibe von der Larve des Entoniscus Porcellanae, $180 \mathrm{mal}$ vergr.

so die Männchen der Scheerenasseln, von denen schon oben die Rede war, und nach Hesse die Pranizae, bei denen beide Geschlechter in die als Ancëus bekannte Form übergehen sollen. Doch will Spence Bate, ein sorgfältiger Beobachter, mit weit in der Entwickelung vorgeschrittenen Eiern beladene Weibchen in Pranizaform gesehen haben.

Wir treffen in dieser Ordnung zum ersten Male eine weitgehende rückschreitende Verwandlung als Folge des Schmarotzerlebens. Schon bei einigen Fischasseln (Cymothoa) sind die Jungen muntere Schwimmer, die Alten blödsichtige, steife, plumpe Gesellen, deren kurze Klammerfüsse nur noch geringer Bewegung fähig sind. Bei den Lausasseln (Bopyrus, Phryxus, Kepone u. s. w., die man füglich in einer Gattung hätte beisammen lassen können), Schmarotzern der Krabben und Krebse, die hauptsächlich in deren Kiemenhöhle ihren Wohnsitz nehmen, pflegen den erwachsenen Weibchen die Augen ganz zu fehlen; die Fühler verkümmern; der breite Leib ist häufig in Folge des beschränkten Raumes unsymmetrisch entwickelt, seine Ringe sind mehr oder minder verschmolzen, die Füsse verkrüppelt, die Anhänge des Hinterleibes aus langbeborsteten Schwimmfüssen zu blatt- oder zungenförmigen, bisweilen verästelten Kiemen geworden. Bei den zwerghaften Männchen pflegen Augen, Fühler, Füsse besser erhalten zu

denticle“ bezeichneten Vorsprunges ausmündet. Und zweitens ist die Stclle eine so verschiedene, als sie nur irgend sein kann. Dort eine paarige Drüse, am Grunde der hinteren Fühler, also an der Unterseite des $z$ weiten Ringes ausmündend; hier ein unpares Gebilde in der Mittellinie des Rückens hinter dem siebenten Ringe (,hinter der Grenzlinie des ersten Brustseginents“ Leydig) sich erhebend. 
sein, als bei den $W^{\top}$ eibchen; dagegen sind am Hinterleib nicht selten alle Anhänge und bisweilen jede Spur von Gliederung verschwunden. Bei den Weibchen der Binnenasseln (Entoniscus), welche in der Leibeshöhle von Krabben und Porcellanen gefunden werden, schwinden Augen, Fühler, Mundtheile, schwindet die Gliederung des wurmförmigen Leibes, schwinden bei einer Art (Fïg. 4r) sämmtliche Gliedmassen fast spurlos und den Cryptoniscus planarioïdes endlich würde man, wenn nicht Eier und Junge die Krebsnatur verriethen, fast eher für einen Plattwurm als für eine Assel halten. Unter den Männchen dieser verschiedenen Bopyriden nimmt das des Entoniscus Porcellanae die niedrigste Stelle ein; es bleibt lebenslänglich auf sechs Fusspaare beschränkt, die zu ungestalten kugligen Klumpen verkrüppeln.
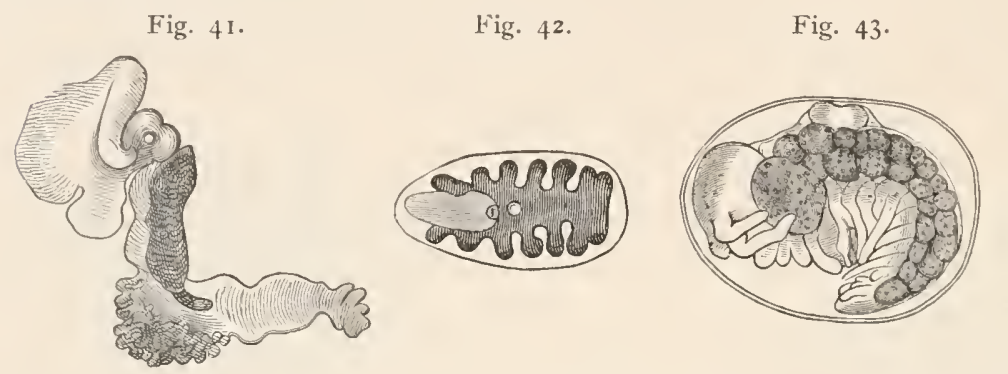
Fig. 41. Entoniscus Cancrorum, Weibchen, 3 mal vergr.

Fig. 42. Cryptoniscus planarioüdes, Weibchen, 3 mal vergr.

Fig. 43. Embryo eines Corophium, gomal vergr.

Die Flohkrebse (Amphipoda) sind schon zeitig im Eie von den Asseln zu unterscheiden durch die abweichende Lagerung des Embryo, dessen Hinterende nach unten gekrümmt ist. Ebenfalls sehr früh zeigt sich bei allen Thieren dieser Ordnung, die bis jetzt darauf untersucht wurden ${ }^{1}$ ), ein eigenthümliches Gebilde am vorderen Theile des Rückens, durch welches der Embryo an die „innere Eihaut" befestigt ist, und das man, unpassend wie mir scheint, als „Mikropylapparat" bezeichnet hat ${ }^{2}$. Man wird durch dasselbe erinnert an die Verbindung der jungen Asseln mit der Larvenhaut, und an das unpaare „Haftorgan“ im Nacken der Wasserflöhe (Cladocera), welches bei Evadne besonders entwickelt ist und während des ganzen Lebens sich erhält, bei Daphnia pulex aber, nach Leydig, ebenfalls nur bei jüngeren Thieren vorhanden, bei ausgewachsenen spurlos geschwunden ist.

Das Junge erhält schon im Eie die volle Zahl seiner Leibesringe und Gliedmassen; wo Leibesringe mit einander verschmelzen, wie die beiden letzten Ringe des Mittelleibes bei Dulichia, die beiden letzten Hinterleibsringe mit dem Schwanze

I) Bei den Gattungen Orchestoidea, Orchestia, Allorchestes, Montagua, Batea n. g., Amphilochus, Atylus, Microdeutopus, Leucothoë, Melita, Gammarus (nach Meissner und La Valette), Amphithoë, Cerapus, Cyrtophium, Corophium, Dulichia, Protella, Caprella.

2) So wenig am Ende der Name zur Sache thut, sollte man doch den Namen „Mikropyle“ auf Canäle der Eihaut beschränken, die dem Eintritte des Samens dienerı. Ueber den „Mikropylapparat“ der Amphipoden aber geht die äussere Eihaut, nach den eigenen Angaben von Meissner und La Valette undurchbohrt hinweg, er scheint nie vor der Befruchtung vorhanden zu sein, erreicht seine grösste Entwicklung in einer späteren Zeit des Eilebens und die ihn durchsetzenden zarten Canäle scheinen sogar nicht immer vorhanden zu sein; überhaupt scheint er mehr dem Embryo als der Eihaut anzugehören. Ich vermochte mich noch nicht zu überzeugen, dass überhaupt die sogenannte „innere Eihaut“ wirklich eine solche sei und nicht etwa eine erst nach der Befruchtung gebildete früheste Larvenhant, wie man in Hinblick auf Ligia, Cassidina und Philoscia annehmen möchte. 
bei Gammarus ambulans und Corophium dentatum n. sp., der letzte Hinterleibsring mit dem Schwanze bei Brachyscelus ${ }^{1}$ ), oder wo ein oder mehrere Ringe fehlen, wie bei Dulichia und den Caprellen, da findet man dieselbe Verschmelzung, denselben Mangel schon bei den der Bruttasche der Mutter entnommenen Jungen. Auch Eigenthümlichkeiten in der Bildung der Gliedmassen, sofern sie beiden Geschlechtern zukommen, pflegen schon bei den ausschlüpfenden Jungen ausgeprägt zu sein, so dass diese in der Regel nur durch plumpere Gestalt, geringere Zahl der Fühlerglieder, der Riechfäden, sowie der Borsten und Zähne, mit denen Leib oder Füsse bewaffnet sind, auch wohl durch verhältnissmässig grössere Nebengeissel von ihren Eltern abweichen.

Eine Ausnahme von dieser Regel machen die meist an Quallen lebenden Hyperinen; bei ihnen haben Junge und Alte oft ein ausserordentlich verschiedenes Aussehen; aber auch bei ihnen findet keine Neubildung von Leibesringen und Gliedmassen, sondern nur eine allmähliche Umwandlung derselben statt ${ }^{2}$. So

I) Nach Spence Bate soll bei Brachyscelus crusculum der fünfte Hinterleibsring nicht mit dem sechsten (dem Schwanze), sondern mit dem vierten verschmolzen sein, was ich bei der grossen Uebereinstimmung, die sonst diese Art mit den beiden von mir untersuchten zeigt, bezweifeln möchte.

2) Spence Bate vermisste bei den Jungen der Hyperia galba sämmtliche Füsse des Hinterleibes und die zwei letzten Fusspaare des Mittelleibes; die sehr auffallende Angabe bedarf um so mehr der Bestätigung, da er diese winzigen Thierchen nur in getrocknetem Zustande untersuchte. Nachträglich wurde mir die erwünschte Gelegenheit, die Entwicklung einer an Rippenquallen, besonders Beroë gilva Eschsch. nicht seltenen Hyperia zu verfolgen. Die jüngsten Larven, aus der Bruttasche der Mutter, besitzen schon säm m t lich e Füsse des Mittelleibes; dagegen vermisse ich, wie Spence Bate, die des Hinterleibes. Anfangs ziemlich einfach, werden diese Füsse bald sämmtlich wie die Vorderfüsse zu reichgezähnelten Greiffüssen und zwar von dreifach verschiedener Form, indem die Vorderfüsse (Fig. 44), die beiden folgenden (Fig. 45) und endlich die drei letzten Fusspaare (Fig. 46) unter sich ähnlich und von den übrigen abweichend gebildet sind. In dieser Gestalt erhalten sich die Füsse sehr lange, während die Hinterleibsanhänge zu kräftigen Schwimmwerkzeugen, und die anfangs, wie mir schien, ganz fehlenden Augen zu gewaltigen Halbkugeln heranwachsen. Bei dem Uebergang in die Gestalt des erwachsenen Thieres erleiden namentlich die drei letzten Fusspaare (Fig. 49) eine bedeutende Ver-

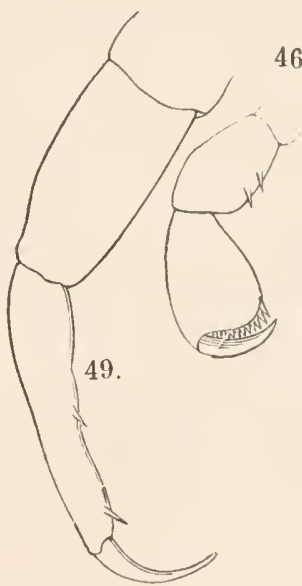

46.

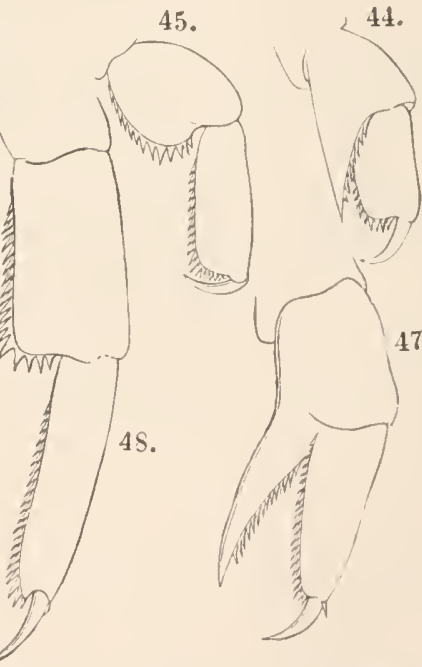

Fig. 4t-46. Füsse einer halbw üchsigen Hyperia Martinezii ${ }^{*}$ ) n. sp. - Fig. 47-49. Füsse eines ziemlich erwachsenen Männchens derselben Art.; und zwar 44 u. 47 vom ersten Paare der Vorderfüsse (gnathopoda), 45 u. 48 rom ersten, 46 u. 49 vom letzten Fusspaare des Mittelleibes, 9 omal vergr. änderung. Die Verschiedenheit der beiden Geschlechter ist bedeutend; die Weibchen sind durch einen sehr breiten Mittelleib, die Männchen (Lestrigonus) durch sehr lange Fühler ausgezeichnet, von denen die vorderen ungemein reichliche Riechfäden tragen. Die jüngsten Larven können natürlich nicht schwimmen; es sind unbehilfliche Thierchen, die sich

*) Benannt nach meinen geschätzten Freunde, dem lielsenswürdigen spanischen Zoologen, Herrn Francisco de Paula Martinez y Saes, zur Zeit auf einer Reise um die Erde. 
gehen, um einige Beispiele zu geben, die gewaltigen Scheeren am drittletzten Fusspaare der Phronima sedentaria nach Pagenstecher aus einem einfachen Fusse von gewöhnlicher Bildung hervor, und umgekehrt bildet sich die Scheere am vorletzten Fusspaare des jungen Brachyscelus zu einem einfachen Fusse um. Bei den Jungen der letztgenannten Gattung ist der lange Kopf in eine kegelförmige Spitze ausgezogen und trägt auffallend kleine Augen; beim Heranwachsen erreichen diese, wie bei den meisten Hyperinen, einen ungeheueren Umfang und füllen fast vollständig den nun kuglig erscheinenden Kopf, u. s. w.

Die Terschiedenheit der Geschlechter, die bei den Gammarinen besonders in der Bildung der Vorderfüsse (gnathopoda Sp. Bate), bei den Hyperinen in der Bildung der Fühler ausgesprochen zu sein pflegt, und oft so beträchtlich ist, dass man Männchen und Weibchen als verschiedene Arten beschrieben und mehrfach sogar in verschiedene Gattungen (Orchestia und Talitrus. - Cerapus und Dercothoë, - Lestrigonus und Hyperia) und selbst Familien (Hypérines anormales und Hypérines ordinaires) gestellt hat, bildet sich erst aus, wenn die Thiere ziemlich herangewachsen sind. Bis dahin gleichen die Jungen im Allgemeinen den Weibchen, sogar in einigen Fällen, wo diese sich weiter als die Männchen von dem „Typus“ der Ordnung entfernen. So ist das zweite Paar der Vorderfüsse bei den männlichen Strandhüpfern (Orchestia) mit einer kräftigen Hand versehen, wie bei der Mehrzahl der Amphipoden, bei den Weibchen in höchst abweichender Weise gebildet. Die Jungen gleichen dennoch den Weibchen. - So fehlen, - ein äusserst seltener Fall ${ }^{1}$ ) -, den Weibchen von Brachyscelus die hinteren (oder unteren) Fühler, das Männchen besitzt dieselben, wie andere Amphipoden, bei den Jungen finde ich, wie Spence Bate, keine Spur davon.

Hervorzuheben ist noch, dass die Ausbildung der geschlechtlichen Eigentümlichkeiten mit erlangter Geschlechtsreife nicht stille steht.

Jüngere geschlechtsreife Männchen von Orchestia Tucurauna n. sp. z. B. haben schlanke untere Fühler mit unverschmolzenen Geisselgliedern, der Greifrand (palm Sp. B.) der Hand des zweiten Fusspaares ist gleichmässig gewölbt, das letzte Fusspaar ist schlank, den vorhergehenden ähnlich. Später verdicken sich die Fühler, die zwei, drei, vier ersten Glieder der Geissel verschmelzen, der Greifrand

namentlich an die Schwimmblättchen des Wirthes festklammern; die erwachsenen Hyperien, die man nicht selten frei im Meere trifft, sind, wie man weiss, die trefflichsten Schwimmer ihrer Ordnung. („Il nage avec une rapiditć extrême“ sagt van Beneden von Hyp. Latreillii Edw.).

Offcnbar ist die Verwandlung der Hyperien als eine erivorbene, nicht als eine ererbte zu betrachten, d. h. das späte Auftreten der Hinterleibsanhänge und die eigenthümliche Fussbildung der Jungen sind nicht mit der geschichtlichen Entwicklung der Amphipoden in Verbindung zu bringen, sondern auf Rechnung des Schmarotzerlebens der Jungcn zu setzen.

Wie bei Brachyscelus ist hier gegen die gewöhnliche Weise der Schmarotzer dem Alter und nicht der Jugend die freiere Beweglichkeit geblieben. Noch auffallender ist ein ähnliches Verhalten bei Caligus unter den schmarotzenden Copepoden. Das junge Thier, von Burmeister als eigene Gattung, Chalimus, beschrieben, liegt mittelst eines von seiner Stirn entspringenden Taues, dcssen Endc in dcr Haut eincs Fisches festsitzt, an diesem vor Anker. Beim Fintritt der Geschlechtsreife wird das Tau gekappt, und nicht seltcn fängt man die erwachsenen Caligus, vortreffliche Schwimmcr, frei im Meerc. - (S. Archiv für Naturgesch. 1852. I. S. 91 = Ges. Schriften p. 59.)

I) „I know of no case in which the infcrior (antennae) are absolete, when the superior are devel oped" Dana. (Darwin, Monograph on the Subclass Cirripedia. Lepadidae. pg. 15.). 
der Hand erhält nahe seiner unteren Ecke eine tiefe Bucht, die mittleren Glieder des letzten Fusspaares schwellen zu einer ansehnlichen Verdickung an. Kein Museumszoolog würde anstehen, zwei besondere Species zu fabriciren, wenn ihm die ältesten und jüngsten geschlechtsreifen Männchen ohne die verbindenden Zwischenformen übersandt würden. Bei jüngeren, aber, wie die mikroskopische Untersuchung der Hoden lehrt, schon geschlechtsreifen Männchen der Orchestia Tucuratinga n. sp. fehlt die in Fig. 5o gezeichnete Bucht des Greifrandes der Hand, sowie der entsprechende Vorsprung des Fingers noch vollständig. - Aehnliches kann man bei Cerapus, bei Caprella und wahrscheinlich überall beobachten, wo überhaupt erhebliche Geschlechtsverschiedenheiten vorkommen.

Fig. 50.

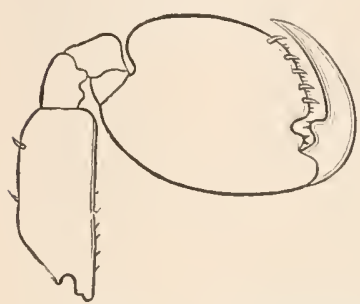

Fig. 51 .

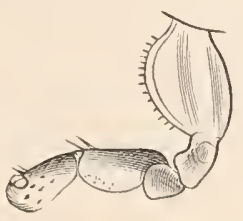

Fig. 52 .

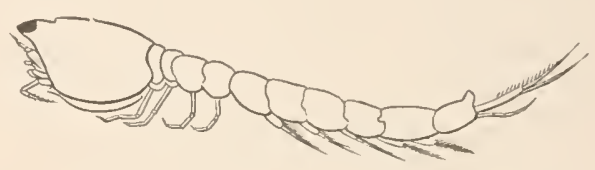

Fig. 50. Vorderfuss des zweiten Paares (second pair of gnathopoda) vom Männchen und

Fig. 5 I vom Weibchen der Orchestia Tucuratinga, I $5 \mathrm{mal}$ vergr.

Fig. 52. Männchen einer Bodotria, Iomal vergr. Man beachte die langen unteren Fühler, die dem Leibe dicht anliegen, und deren Spitze unter den Schwanzanhängen sichtbar ist.

An die artenreichen Abtheilungen der stieläugigen und der sitzäugigen Kruster reiht sich, ersteren wohl näher verwandt als letzteren, die merkwürdige Familie der einäugigen Diastyliden oder $\mathrm{Cu}$ mace en. Die Jungen, die Kroyer der Bruttasche der Weibchen entnahm und die ein Viertel der Länge der Mutter erreichten, glichen dem erwachsenen Thiere fast in allen Stücken. Ob innerhalb der ähnlich wie bei Mysis gebildeten Bruttasche eine Verwandlung stattfinde, wie bei Mysis oder Ligia, weiss man nicht ${ }^{1}$ ).

Gleich dürftig ist unsere Kenntniss der Entwicklungsgeschichte der Muschelkrebschen (Ostracoda). Man weiss kaum mehr, als dass ihre vorderen Gliedmassen sich früher als die hinteren entwickeln (Zenker).

I) Ein zuverlässiger englischer Forscher, Goodsir, beschrieb schon 1843 die Bruttasche und die Eier von Cuma. Kroyer, dessen peinliche Sorgfalt und Gewissenhaftigkeit bewundernd anerkennt, wer je mit ihm auf gleichem Arbeitsfelde zusammentraf, bestätigte I846 Goodsir's Angaben und entnahm, wie oben erwähnt, der Bruttasche weit entwickelte, den Eltern ähnliche Embryonen. Damit ist die Frage, ob die Diastyliden erwachsene Thiere oder Larven seien, vollständig und für immcr entschieden, und nur die berühmten Namen eines Agassiz, Dana, Milne Edwards, die sie trotzdem neuerdings wieder zu Larven stempeln möchten (s. van Beneden, Rech. sur la faunc littor. de Belgiquc. Crustacés. pg. 73. 74), veranlassen mich, auf Grund zahlrcicher eigener Untersuchungen mit van Beneden's Worten zı erklären: „Parmi toutes les formes embryonnaires de podophthalmes ou d'édriopluthalmes que nous avons obscrvées sur nos côtes, nous n'en avons pas vu une seule qui ent même la moindre resscmblancc avcc un Cu in a quelconque." Das Einzige, was aus den von Kroyer aufgestellten, drci Seiten fiillenden Familiencharakteren der Cuniaceen (Kroyer, Nat. Tidsskrift. Ny Raekke. Iid. II. S. 203-206) auf die Larven von Hippolyte, Palaemon und Alphëus passt, ist: „Duo antennarum paria.“ Und das passt bckanntlich so ziemlich auf alle Kruster. Wie wohlbcrechtigt war man also, diese mit jenen zu identificircn. Es genügt ibrigens, einen Blick auf die Palaemonlarve (Fig. 27) und auf dic Cumacec (Fig. 52) zu werfen, unı sich von deren ungeheurer Aehnlichkeit zu überzeugen. 
IX.

Jie Abtheilung der Kiemenfüsser (Branchiopoda) umfasst zwei auch durch ihre Entwicklung geschiedene Gruppen, die Blattfüsser (Phyllopoda) und die $W^{\top}$ asserflöhe (Cladocera). Die letzteren, mit vier bis sechs Paar blattförmiger Füsse ausgestattete winzige Thierchen, die hauptsächlich dem süssen Wasser angehören und in ähnlichen Formen über alle Welt verbreitet sind, verlassen das Ei mit vollzähligen Gliedmassen. Die Blattfüsser dagegen, deren Fusszahl zwischen 10 und 60 Paaren schwankt, und von denen einige zwar in der gesättigten Soole der Salzwerke und der Natronseen leben, aber nur eine, ziemlich abweichende Gattung (Nebalia) im Meere gefunden wird ${ }^{1}$ ), haben eine Verwandlung zu bestehen. Die jüngsten Larven sind Nauplius, die wir schon einmal ausnahmsweise bei einigen Garneelen trafen und die wir von nun ab fast ohne Ausnahme wiederfinden werden. Die bisweilen so zahlreichen Leibesringe und Füsse bilden sich nach und nach von vorn nach hinten, ohne dass durch die Zeit ihres Auftretens oder durch ihre Gestalt scharfgeschiedene Leibesabschnitte bezeichnet werden. Alle Füsse sind im Wesentlichen gleich gebaut und erinnern an die Kiefer der höheren Kruster $\left.{ }^{2}\right)$. Man könnte die Phyllopoden als Zoëa betrachten, die nicht zur Bildung eines eigenthümlich ausgestatteten Hinter- und Mittelleibes gekommen sind, und statt dessen die den Naupliusgliedmassen zuerst folgenden Anhänge in vielfacher Wiederholung erzeugt haben.

Die Entwicklungsgeschichte, wie die ganze Naturgeschichte der Copepoden, - die theils frei lebend das süsse Wasser und in weit mannichfacheren Formen das Meer bevölkern, theils als Schmarotzer Thiere der verschiedensten Klassen belästigen und dabei oft zu wunderlicher Missgestalt verkümmern, - lag . bis vor Kurzem sehr im Argen. Man wusste zwar längst, dass die Cyclopen des süssen Wassers in Naupliusform ausschlüpfen, und kannte cinige andere Jugendzustände derselben; man hatte durch Nordmann dieselbe früheste Jugendform für mehrere Schmarotzerkrebse kennen gelernt, die bis dahin fast allgemein als Würmer gegolten hatten; - aber es fehlten die verbindenden Mittelglieder, welche die Leibesabschnitte und Gliedmassen der Larven auf die des erwachsenen Thieres zurückzuführen erlaubt hätten. Dic umfassenden und sorgfältigen Untersuchungen von Claus haben diese Lücke ausgefüllt und die Abtheilung der Copepoden zu einer der bestgekannten der ganzen Klasse erhoben. Den Arbeiten dieses wackeren Forschers sind die folgenden Angaben entnommen. Ich hebe aus der Fülle wichtiger Thatsachen, die darin niedergelegt sind, nur das für das Verständniss der Krusterentwicklung im Allgemeinen Unentbehrliche hervor, weil, was die Copepoden im Besonderen anlangt, schon durch die Darstellung ihres neuesten Bearbeiters die Thatsachen in's rechte Licht gestellt sind, und Jedem, der offene Augen hat, als wichtige Belege für die Darwin'sche Lehre erscheinen müssen ${ }^{3}$ ).

1) Dürfte man die Phyllopoden als nächste Verwandte der Trilobiten betrachten, worüber ich kein Urtheil wage, so würden sie neben Lepidosteus und Polypterus, Lepidosiren und Protopterus ein weiteres Beispiel liefern für die Erhaltung im Meere längst erloschener Formen im Binnenwasser. Das Vorkommen der Artemien in übersalzenem Wasser würde dabei zeigen, dass sie nicht durch das süsse Wasser, sondern durch die hier geringere Mitbewerbung der Vernichtung entgingen.

2) „Der Kiefer der Krebslarve ist eine Art Phyllopodenfuss" Claus.

3) Das neueste grössere Wrerk von Claus über Copepoden kenne ich noch nicht; doch wird sich von ilım ohne Zweifel dasselbe sagen lassen. 
Alle von Claus untersuchten Larven der freilebenden Copepoden haben in frühester Zeit drei Gliedmassenpaare (die späteren Fühler und Kinnbacken), die vorderen mit einfacher, die zwei nachfolgenden mit zweifachen Gliederreihen oder Aesten. Das umpaare Auge, Oberlippe, Mund nehmen schon ihre bleibende Stelle ein. Die hintere, meist kurze, gliedmassenlose Leibespartie trägt zwei Endborsten, zwischen denen der After liegt. Die Gestalt dieser Naupliusbrut ist äusserst mannichfaltig, bald seitlich comprimirt, bald flach, - bald langstreckig, bald oval, bald rund oder selbst breiter als lang u. s. w. Die Veränderungen, welche die ersten Larvenstadien mit dem weiteren Wachsthume erleiden, beruhen im IVesentlichen auf einer Streckung des Leibes und Hervorsprossen neuer Gliedmassen. „Das nachfolgende Stadium weist schon ein viertes Extremitätenpaar, die späteren Maxillen, auf." Dann folgen auf einmal drei neue Gliedmassenpaare (die Kieferüsse und die zwei vorderen Schwimmfusspaare). Noch bleibt die Larve Nauplius-

Fig. 53 .

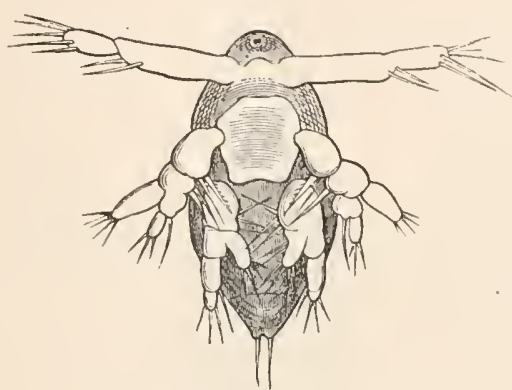

Fig. 54.

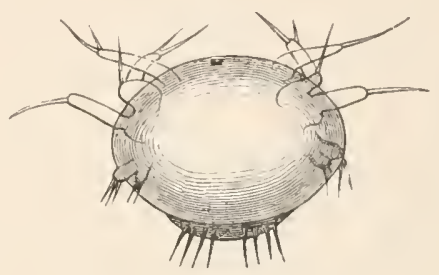

Fig. 53. 54. Nauplius von Copepoden, erstere 90 , letztere $180 \mathrm{mal}$ vergr.

ähnlich, indem die drei vordern Gliedmassenpaare Ruderfüsse darstellen; bei einer neuen Häutung verwandelt sie sich in den jüngsten Cyclops-ähnlichen Zustand, sie gleich nun im Bau der Fühler und Mundtheile dem erwachsenen Thiere, wenn auch die Zahl der Gliedmassen und Leibesringe noch eine viel geringere ist, denn es sind nur, in Form mit Borsten besetzter Wülste, die Anlagen des dritten und vierten Schwimmfusspaares hinzugekommen und der Leib besteht aus dem ovalen Kopfbruststück, dem zweiten bis vierten Thoracalsegment und einem langgestreckten Endgliede. Bei den Cyclopiden haben dic hinteren Fühler ihre Nebenäste verloren, die Kinnbacken vollständig den früheren Schwimmfuss abgeworfen, während bei den übrigen Familien diese Anhänge mehr oder weniger verändert fortbestehen. „Ueber diese Stufe der freien Entwicklung gelangen viele Formen der parasitischen Copepoden, z. B. Lernanthropus und Chondracanthus, nicht hinaus, indem sie weder die Gliedmassen des dritten und vierten Paares erhalten, noch eine Sonderung des fünften Thoracalsegments vom Abdomen zu Stande kommt; andere (Achtheres) sinken sogar durch den späteren Verlust der beiden Schwimmfusspaare auf eine tiefere Stufe zurück. Alle freilebenden Copepoden aber und die meisten Schmarotzerkrebse durchlaufen noch eine grössere oder geringere Reihe von Entwicklungsstadien, in welchen in continuirlicher Aufeinanderfolge die Gliedmassen eine höhere Gliederung crhalten, die hinteren Fusspaare zur Entwicklung kommen und aus dem gemeinsamen Endabschnitt sich der Reihe nach das letzte Thoracalsegment und die cinzelnen Abdominalsegmente sondern." 
Lus der Entwicklungsgeschichte der Schmarotzerkrebse sei nur noch hervorgehoben, dass einige derselben, z. B. Achtheres percarum, zwar auch wie die andern in Nauplius-ähnlicher Gestalt das Ei verlassen, indem der plumpe, ovale, mundlose Leib zwei Paar einfache Ruderfüsse und dahinter als Rest des dritten Paares zwei mit einer langen Borste versehene Auftreibungen trägt, dass aber unter dieser Naupliushaut schon eine weit verschiedene Larve fertig liegt, die nach wenig Stunden ihre unbeholfene Hülle sprengt und nun in einer Gestalt auftritt, „welche in der Gliederung des Körpers und in der Ausbildung der Extremitätenpaare mit dem ersten Cyclopsstadium übereinstimmt" (Claus). Die ganze Reihe von Naupliusstadien, welche die freilebenden Copepoden durchlaufen, wird hier vollständig übersprungen.

Fig. 55.

Fig. 56 .
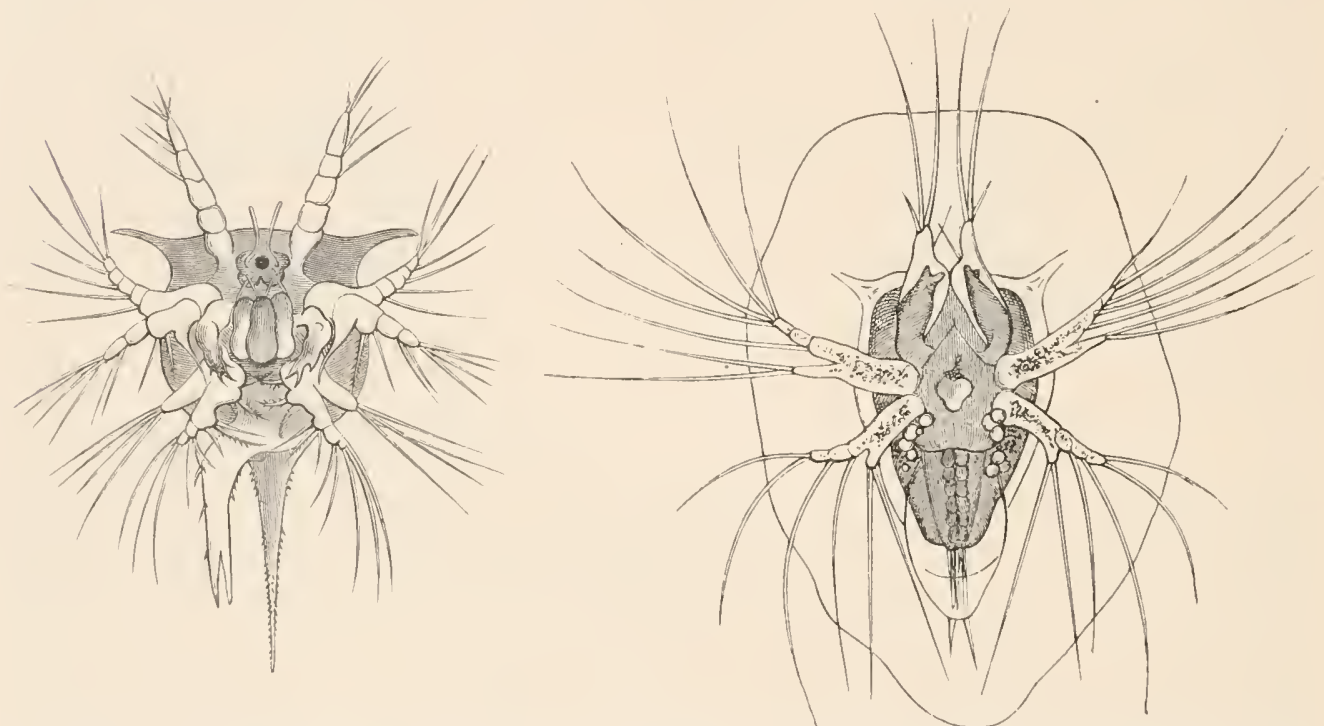

Fig. 55. Nauplius der Tetraclita porosa, nach der ersten Häutung, 9omal vergr. Man sieht um das Auge das Gehirn, von dem die Riechfäden entspringen, und dahinter einige zarte zur Mundkappe gehende Muskeln.

Fig. 56. Nauplius der Sacculina purpurea, kurz vor der zweiten Häutung, r 80 mal vergr. Im ersten Fusspaare sind die späteren Haftfüsse, in Hinterleibe sechs Paar langborstiger Schwimmfüsse zu erkennen.

Eine letzte sehr eigenthümliche Abtheilung der Kruster bilden die beiden Ordnungen der Rankenfüsser (Cirripedia) und der Wurzelkrebse (Rhizocephala) ${ }^{1}$.

1) Ueber die Stellung der Rankenfüsser herrschen die abweichendsten Ansichten. Die Einen weisen ihnen eine sehr untergeordnete Stellung unter den Copepoden an; so Milne Edwards (1852). Im geraden Gegensatz zu dieser Auffassung seines Vaters stellt sie Alph. Milne Edwards als Basinotes allen übrigen Krustern (Eleuthéronotes) gegenüber. Darwin betrachtet sie als besondere den Podophthalmen, Edriophthalmen u. s. w. gleichwerthige Unterklasse. Dies scheint mir das Passendste. Die Wurzelkrebse möchte ich nicht den Rankenfüssern einverleiben, wie Liljeborg, sondern als gleichwerthig gegenüberstellen, wie die Amphipoden den Isopoden. - Man spricht auch wohl von der nahen Verwandtschaft der Rankenfüsser mit den Ostracoden; die Aehnlichkeit aber der sogenannten „,cyprisähnlichen Larven“ oder Rankenfüsserpuppen, wie sie Darwin nennt, mit den Cypris ist eine so rein äusserliche, selbst was die Schale anlangt, dass mir die Verwandtschaft kaum grösser scheint, als etwa die des Peltogaster socialis (Fig. 59) mit der Familie der Schlack- und Leberwürste. 
Auch hier schwärmt die Brut in Naupliusgestalt aus und streift nach Kurzem eine früheste durch keine erwähnenswerthen Eigenthümlichkeiten ausgrezeichnete Larvenhaut ab. Auch hier kehrt dieselbe Birnform des ungegliederten Leibes, dieselbe Zahl und Bildung der Füsse, dieselbe Lage des unpaaren Augres (das indess bei Sacculina purpurea und nach Darwin bei einigen Lepas vermisst wird), dieselbe Lage der "Mundkappe“ wieder, wie sie bei den Nauplius der Garneelen und der Copepoden sich findet. Unterschieden von letzteren sind die Nauplius der Rankenfüsser und Wurzelkrebse durch den Besitz eines Rückenschildes oder Panzers, der bisweilen (Sacculina purpurea) den Körper ringsum weit überragt; unterschieden nicht nur von anderen Nauplius, sondern soviel mir bekannt von allen anderen Krustern dadurch, dass Gebilde, die sonst mit den beiden vorderen Gliedmassenpaaren (Fühlern) verbunden sind, hier von ihnen getrennt auftreten.

Die vorderen Fühler der Copepoden, der Cladoceren, der Phyllopoden (Leydig, Claus), der Ostracoden (wenigstens der Cypridinen), der Diastyliden, der Edriophthalmen und der Podophthalmen tragen mit wenigen, Landthiere oder Schmarotzer betreffenden Ausnahmen, eigenthümliche Fäden, deren ich schon mehrmals als „Riechfäden“ Erwähnung gethan. Ein Paar ganz ähnliche Fäden entspringen bei den Larven der Rankenfüsser und Wurzelkrebse unmittelbar vom Gehirn (Fig. 55).

Am Grunde der unteren Fühler mündet bei Krabben und Krebsen, bei letztern am Ende eines kegelförmigen Vorsprunges die sogenannte "grüne Drüse" aus. Ein ähnlicher kegelförmiger Vorsprung mit dem ihn durchsetzenden Ausführungsgange ist bei den meisten Amphipoden sehr augenfällig. Bei den Ostracoden beschreibt Zenker eine im Grunde der unteren Fühler gelegene Drüse, die am Ende eines ungemein langen „Stachels“ ausmündet. Bei den Nauplius der Cyclops und Cyclopsine findet Claus helle „Schalendrüsen“, die am mittleren Gliedmassenpaare (den hinteren Fühlern) beginnen. Dagegen münden bei den Nauplius der Rankenfüsser und Wurzelkrebse die „Schalendrüsen“ am Ende kegelförmiger Fortsätze von bisweilen abenteuerlicher Länge, die von den Ecken des breiten Stirnrandes ausgehen und bald als Fühler (Burmeister, Darivin), bald als blosse "Hörner des Rückenschildes" (Krohn) gedeutet worden sind. Die Verbindung der "Schalendrüse" mit den Stirnhörnern wurde bei Lepaslarven in unzweideutiger Weise erkannt, wie denn überhaupt die Aehnlichkeit der Stirnhörner mit dem kegelförmigen Vorsprung an den unteren Fühlern der Amphipoden oder des Leucifer eine vollständige ist ${ }^{1}$ ).

Uebereinstimmend in diesen wichtigen Eigenthümlichkeiten bieten die Nauplius der beiden Ordnungen in manchen anderen Stücken erhebliche Unterschiede. Der Hinterleib der jungen Rankenfüsser läuft unterhalb des Afters in einen langen am Ende gablig getheilten schwanzförmigen Anhang aus und über dem After steht ein zweiter langer Stachelfortsatz; der Hinterleib der II'urzelkrebse endet in zwei kurze Spitzen, in eine „bewegliche Schwanzgabel, wie bei den Räderthieren“ (Oscar Schmidt). Die jungen Rankenfüsser haben Mund, Magren, Darm, After und ihre beiden hinteren Gliedmassenpaare sind mit mannichfachen Zacken, Borsten und Haken besetzt, die jedenfalls bei der Nahrungsaufnahme mitwirken. Dies

1) Es mag bei dieser Gelegenheit erwähnt werden, dass bei den Weibchen von Brachyscelus, denen die hinteren Fühler fehlen, doch die kegelförmigen Vorsprünge mit dem sie durchsetzenden Canale erhalten bleiben. 
Alles vermisst man bei den jungen Wurzelkrebsen. Die Nauplius der Rankenfüsser haben als solche mehrfache Häutungen zu bestehen; die Nauplius der Wurzelkrebse können, - mundlos, wie sie sind, - natürlich nicht lange als solche leben und schon nach wenigen Tagen verwandeln sie sich in ebenfalls mundlose „Puppen“, wie sie Darwin nennt.

Der Panzer klappt sich zusammen, so dass das Thierchen ein muschelähnliches Aussehen erhält, die vordersten Gliedmassen verwandeln sich in sehr eigenthümliche Haftfüsse („prehensile antennae“ Darw.), die beiden folgenden Paare werden abgeworfen, wie die Stirnhörner. Am Hinterleibe haben sich unter der Naupliushaut sechs Paar kräftiger, zweiästiger, langborstiger Schwimmfüsse gebildet, und dahinter stehen zwei kurze borstentragende Schwanzanhänge. (Fig. 58.)

Fig. 57 .

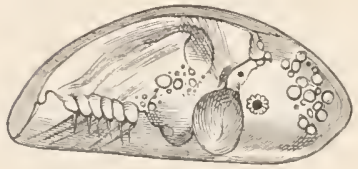

Fig. 58 .

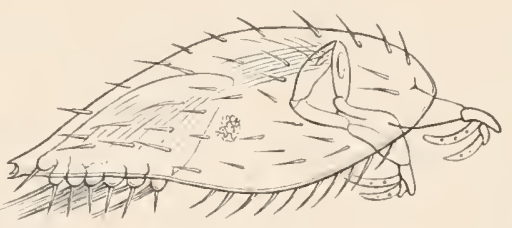

Fig. 57. Puppe eines Balaniden (Chthamalus?), 5omal vergr. Die Haftfüsse sind in den ziemlich undurchsichtigen vorderen Theil der Schale zurückgezogen.

Fig. 58. Puppe der Sacculina purpurea, I 80 mal vergr. Die Fäden an den Haftfüssen mögen die Anfänge der späteren Wurzeln sein.

Die Puppen der Rankenfüsser (Fig. 57), die gleichfalls mundlos sind, stimmen in allen diesen Stücken vollständig mit denen der Wurzelkrebse überein, bis ins Einzelnste der Gliederung und Beborstung der Schwimmfusspaare ${ }^{1}$ ); sie unterscheiden sich von ihnen besonders durch den Besitz paariger zusammengesetzter Augen. Bisweilen scheinen auch Spuren der Stirnhörner zu bleiben ${ }^{2}$.

Wie die Rankenfüsser und Wurzelkrebse im Allgemeinen jetzt einander weit ähnlicher sind, als in ihrem Naupliuszustande, so gilt dasselbe ebenso für die einzelnen Mitglieder jeder der beiden Ordnungen.

Die Puppen beider Ordnungen setzen sich mittelst der Haftfüsse fest; die der Rankenfüsser an Felsen, Muscheln, Schildkröten, Treibholz, Schiffe u. s. w., die der Wurzelkrebse an den Hinterleib von Krabben, Porcellanen, Einsiedlerkrebsen. Der Panzer der Rankenfüsser verwandelt sich bekanntlich in ein eigenthümliches Gehäuse, um dessentwillen man sie früher zu den Mollusken stellte, und die Schwimmfüsse wachsen zu langen Ranken aus, die dem nun geöffneten Munde Nahrung zustrudeln. Die Wurzelkrebse bleiben mundlos; sie verlieren spurlos alle Gliedmassen und erscheinen als wurst-, sack-, oder scheibenförmige mit Eiern gefüllte Auswüchse ihres Wohnthieres (Fig. 59, 60); von der Anheftungsstelle senken sich wurzelartig verästelte geschlossene Röhren in das Innere des Wirthes,

I) Man vergleiche die Abbildung, welche Darwin (Balanidae, Pl. XXX, Fig. 5) vom ersten Schwimmfusse der Puppe von Lepas australis gibt, mit der im Archiv für Naturgeschichte (I863, Taf. III, Fig. $5=$ Ges. Schriften Taf. XXIII) mitgetheilten von Lernaeodiscus Porcellanae. Der einzige Unterschied, dass bei letzteren am Ende des äusseren Astes nur 3 Borsten stehen, bei den Rankenfüssern 4 am ersten, 5 an den folgenden Schwimmfüssen, mag auf einem Irrthum meinerseits beruhen.

2) Darwin beschreibt als ,acoustic orifices“ kleine Oeffnungen in der Schale der Rankenfüsserpuppen, die öfter von einem Rande umgeben, bei Lepas pectinata auf kurzen hornartigen Fortsätzen gelegen sind. Ich trage kaum Bedenken, die Oeffnungen für die der ,Schalendrüse“, die hornartigen Fortsätze für Ueber bleibsel der Stirnhörner zu halten. 
dessen Darm umspinnend, oder zwischen den Leberschläuchen sich ausbreitend. Die einzigen Lebensäusserungen, die diesen Non plus ultra's in der Reihe der rückschreitend sich verwandelnden Kruster geblieben, sind einmal kräftige $\mathrm{Zu}^{-}$ sammenziehungen der Wurzeln und dann ein abwechselndes Ausdehnen und Zusammenziehen des Körpers, in Folge dessen W'asser durch eine weite Oeffnung der Bruthöhle einströmt und wieder ausgetrieben wird ${ }^{1}$ ).

Von mehreren in Bau und Entwicklung abweichenden Rankenfüssern verdient hier Cryptophialus minutus Erwähnung, der von Darwin massenweise in der Schale der Concholepas peruviana bei den Chonos-Inseln gefunden wurde.

Fig. 59 .

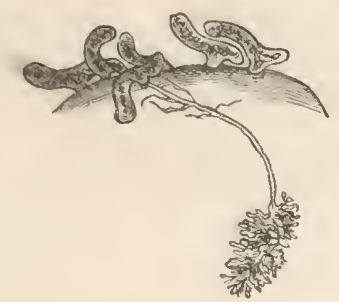

Fig. 60 .

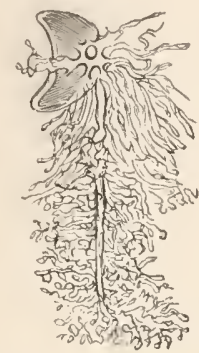

Fig. 6I.

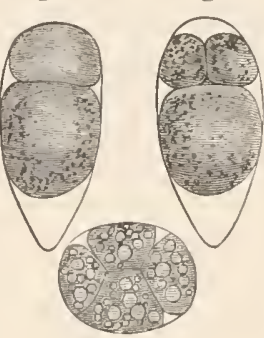

Fig. 64.

Fig. 63 .

Fig. 59. Junge Peltogaster socialis, am Hinterleibe eines kleinen Einsiedlerkrebses; bei einem derselben sind die in der Leber des Krebses büschelförmig verzweigten Wurzeln gezeichnet. Thier und Wurzeln dottergelb.

Fig. 6o. Junge Sacculina purpurea mit ihren Wurzeln; das Thier purpurroth, die Wurzeln dunkelgrasgrün, 5 mal vergr. (vergl. auch Ges. Schriften Taf. XVII).

Fig. 61. 62. 63. Eier von Tetraclita porosa in der Furchung, 9omal vergr. Die grössere der beiden zuerst gebildeten Furchungskugeln ist stets dem spitzen Ende des Eies zugewandt.

Fig. 64. Ei von Lernaeodiscus Porcellanae, in der Furchung, 9omal vergr.

Das anfangs elliptische Ei wird nach Darwin bald am vorderen Ende breiter und erhält drei keulenförmige Hörner, eins hinten, eins an jeder Vorderecke; innre Theile sind jetzt noch nicht $z u$ entdecken. Später schwindet das hintere Horn und im Innern der vorderen lassen sich die Haftfüsse erkennen. Aus dieser „ei-ähnlichen Larve“ (egg-like larva; - I hardly know, what to call it, sagt Darwin) geht unmittelbar die Puppe hervor. Ihr Panzer ist wenig seitlich zusammengedrückt und behaart, wie bei Sacculina purpurea, die Haftfüsse sind von ansehnlicher Grösse, Schwimmfüsse fehlen, wie beim erwachsenen Thiere die entsprechenden Rankenfüsse.

Zum Schlusse dieses Ueberblicks einige W'orte über die frühesten Entwickelungsvorgänge im Ei der Kruster. Vor Kurzem noch galt als allgemeine Regel, dass sich durch theilweise Furchung des Dotters eine Keimscheibe und in dieser, der Bauchseite des Embryo entsprechend, ein Primitivstreifen bilde. Man weiss jetzt, dass bei den Copepoden (Claus), bei den IVurzelkrebsen (Fig. 64), und,

1) Die Wurzeln der an einem kleinen Einsiedlerkrebse schmarotzenden Sacculina purpurea (Fig. 60) machen sich zwei schmarotzende Asseln zu Nutze, ein Bopyrus und der schon erwähnte Cryptoniscus planarioïdes (Fig. 42); sie siedeln sich unter der Sacculina an und bringen sie zum Absterben, indem sie die von den Wurzeln zugeführte Nahrung vorwegnehmen; die Wurzeln aber wuchern auch ohne Sacculina weiter, und erlangen selbst, namentlich wo ein Bopyrus sich aus ihnen nährt, oft eine ungewölnnliche Ausdehnung. 
wie ich hinzusetzen kann, bei den Rankenfüssern (Fig. 6 $_{1}-6_{3}$ ) die Furchung eine totale ist. und die Embryonen ohne vorausgehenden Primitivstreifen in ilurer ganzen Gestalt angelegt werden. Wahrscheinlich wird Letzteres überall der Fall sein, wo die Jungen als wirkliche Nauplius (und nicht blos mit Naupliushaut, wie bei Achtheres) ausschlüpfen. Beiderlei Entwicklungsweisen können bei nächstverwandten Thieren vorkommen, wie Achtheres unter den Copepoden beweist ${ }^{1}$ ).

\section{X.}

Vielleicht vermag ein Anderer, glücklicher als ich, auch ohne Darwin den leitenden Faden zu finden durch den Wirrwarr der bald bei nächsten Verwandten so himmelweit verschiedenen, bald bei Gliedern der entferntesten Kreise so überraschend ähnlichen Entwicklungsformen, die so eben flüchtig an uns vorüberzogen. Vielleicht vermag ein schärferes Auge mit Agassiz den ,seit Urbeginn feststehenden Plan des Schöpfers“2) herauszulesen, der auch hier, wie ein portugiesisches Sprichwort sagt ${ }^{3}$, , ,in krummen Linien gerade“ geschrieben haben mag. Mir will es scheinen, dass von einem allgemeinen Plane, von einer typischen, nach den einzelnen\} Abtheilungen, Ordnungen, Familien gegliederten Entwicklungsweise der Kruster kaum die Rede sein kann, wenn z. B. unter den langschwänzigen Krebsen der Flusskrebs in bleibender Gestalt, der Hummer mit Schizopodenfüssen, Palaemon wie die Krabben als Zoëa, Penëus wie die Rankenfüsser als Nauplıus das Ei verlässt, und wenn immer noch in derselben Unterordnung der Langschwänze Palinurus und Mysis und Euphausia wieder andere und andere Jugendformen zeigen; - wenn neue Gliedmassen bald als freie Stummel an der Bauchseite hervorspriessen, bald unter der glatt über sie hinweggehenden Haut sich bilden und beiderlei Entwicklungsweisen an verschiedenen Gliedern bei demselben Thiere, und an demselben Gliederpaare bei verschiedenen Thieren gefunden werden; - wenn bei den Podophthalmen die Gliedmassen des Mittel- und Hinterleibes bald alle gleichzeitig, bald jene und bald diese früher, und wenn wieder in jeder der beiden Gruppen bald alle Paare gleichzeitig auftreten, bald eines nach dem andern, - wenn unter den Hyperinen bei Phronima ein einfacher Fuss zur Scheere, bei Brachyscelus eine Scheere zum einfachen Fusse wird, u. s. w. -

Und doch sollte ja nach der Lehre der Schule gerade in der Jugend, gerade im Laufe der Entwicklung der „Typus“ am unverhülltesten hervortreten. Aber hören wir, was uns überhaupt die Schule über die Bedeutung der Entwicklungsgeschichte und über ihre Beziehung zur vergleichenden Anatomie und Systematik sagt.

Lassen wir zwei ihrer bewährtesten Meister reden.

I) Es ist nicht die Rede gewesen von den Pycnogoniden, weil ich sie nicht für Kruster halte; nicht von den Xiphosuren und Trilobiten, die ich nie selbst untersuchte, weil ich sie zu wenig kenne und namentlich mit den von Barrande gegebenen Aufschlüssen über die Entwickelung der letzteren nicht im Einzelnen bekannt geworden biu.

2) , , a plan fully matured in the beginning and undeviatingly pursued“, oder: „In the beginning His plan was formed and from it He has never swerved in any particular" Agassiz and Gould, Principles of Zoology.

3) „Deos escreve direito em linhas tortas." Zum Lesen dieser sonderbaren Schrift bedarf man bekanntlich der Brille des Glaubens, die an's Mikroskop gewöhnten Augen selten passt. 
„Indem die vergleichende Anatomie“, sagte Johannes Müller I 844 in seinen Vorträgen über diese Wissenschaft, und die Ansichten meines unvergesslichen Lehrers sind lange Jahre die meinigen geblieben, - „indem die vergleichende Anatomie uns die unendlich mannichfache Gestaltung desselben Organes in der Thierwelt zeigt, gibt sie uns hierin das Mittel, durch Vergleichung dieser verschiedenen Formen das eigentlich Wesentliche, den Typus dieser Organe zu erkennen und davon alles Unwesentliche abzuscheiden. - Hierin dient ihr zur Controle oder Probe die Entwicklungsgeschichte. Da nämlich der Begriff der Entwicklung nicht der des Grösserwerdens ist, sondern der des Fortschritts von einem noch nicht Unterschiedenen, welches aber potentia die Unterschiede in sich enthält, zu einem actu Unterschiedenen, so leuchtet ein, dass, je weniger ein Organ entwickelt ist, es sich um so mehr dem Typus nähert, und dass es bei seiner Entwickelung immer mehr Besonderheiten in sich aufnimmt. Die durch die vergleichende Anatomie und die durch die Entwicklungsgeschichte gefundenen Typen müssen nun übereinstimmen."

Nachdem Johannes Müller dann die Idee einer Stufenleiter der Thiere, und eines Durchlaufens mehrerer Thierstufen während der Entwicklung bekämpft, fährt er fort: „Das Wahre an dieser Idee ist, dass jeder Embryo anfangs nur den Typus seiner Abtheilung an sich trägt, woraus sich erst später der Typus der Klasse, Ordnung u. s. w. entwickelt.“

Agassiz spricht sich 1856 in einem elementaren Werke ${ }^{1}$ ), in das man doch nur aufzunehmen pflegt, was man als wohlgesichertes Besitzthum der Wissenschaft betrachtet, in folgender Weise aus:

„Die Eierstockseier aller Thiere sind vollkommen gleich (identical), kleine Zellen mit Dotter, Keimbläschen und Keimfleck“ (§ 278). „Die Organe des Körpers werden gebildet in der Reihenfolge ihrer organischen Wichtigkeit; die wesentlichsten erscheinen immer zuerst. So die Organe des vegetativen Lebens, Darm u. s. w. später als die des animalen Lebeus, Nervensystem, Skelet u. s. w., und diesen wieder gehen die allgemeineren Erscheinungen voraus, die dem Thiere als solchem zukommen" 2). (\$ 318.) „So bestehen beim Fische die ersten Veränderungen in der Dotterfurchung und der Bildung eines Keimes, - Vorgängen, die allen Thierklassen gemeinsam sind. Dann erscheint die Rückenfurche, die das Wirbelthier kennzeichnet, - das Hirn, die Sinneswerkzeuge; - später bilden sich Darm, Gliedmassen unb die bleibende Form der Athmungswerkzeuge, woraus mit Sicherheit die Klasse erkannt wird. Erst nach dem Ausschlüpfen bezeichnen die Eigenthümlichkeiten der Zahn- und Flossenbildung Gattung und Art" (§ 3 I 9). „Daher gleichen Embryonen verschiedener Thiere einander um so mehr, je jünger sie sind.“ (§ 320.) "Somit ist die hohe Bedeutung der Entwicklungsgeschichte unzweifelhaft. Denn, wenn die Bildung der Organe stattfindet in der ihrer Wichtigkeit entsprechenden Ordnung, so muss selbstverständlich (of itself) diese Reihenfolge ein Kriterium ihres verhältnissmässigen IVerthes für die Systematik (classification)

I) Principles of Zoology. Part I. Comparative Physiology. By Louis Agassiz and A. A. Gould. Revised Edition. Boston, 1856.

2) ,and these, in turn, are preceded by the more general phenomena, belonging to the animal as such." 
sein. Die Eigenthümlichkeiten, welche früher erscheinen, soll man höher werthen (should be considered of higher value), als die. welche später erscheinen." (\$32 r.) „Ein System um wahr und natürlich zu sein, mussübereinstimmen mit der Aufeinanderfolge der Organe in der Entwicklung des Embryo." (\$322).

Ich weiss nicht, ob noch heute Jemand geneigt sein wird, diese Sätze in ihrem ganzen Umfange zu unterschreiben ${ }^{1}$ ). Sicher ist, dass im Wesentlichen gleiche Ansichten noch überall bei systematischen Erörterungen durchklingen, und dass sich bis in die letzten Jahre hinein die wenig glücklichen Versuche wiederholt haben, die Entwicklungsgeschichte als Grundlage der Systematik zu benutzen.

Wie stimmen nun mit diesen Sätzen unsere Erfahrungen aus der Entwicklungsgeschichte der Kruster? Dass diese Erfahrungen sich grösstentheils auf die „freie Verwandlung“ nach dem Verlassen des Eies beziehen, kann der Anwendbarkeit der zunächst für die „embryonale Entwicklung“ im Eie ausgesprochenen Sätze keinen Eintrag thun; Agassiz selbst hebt hervor (\$ 391), dass beiderlei Veränderungen von gleicher Natur und gleicher Wichtigkeit sind und dass kein wesentlicher Unterschied (any radical distinction) dadurch bedingt wird, dass die einen vor, die andern nach der Geburt stattfinden.

„Die Eierstockseier aller Thiere sind identisch, kleine Zellen mit Dotter, Keimbläschen, Keimfleck." Ja, etwa wie alle Insecten identisch sind, - kleine Thiere mit Kopf, Brust und Hinterleib, - wenn man nämlich, nur das Gemeinsame berücksichtigend, absieht von der Verschiedenheit ihrer Entwicklung, von der Ab- oder Anwesenheit und dem mannichfaltigen Bau der Dotterhaut, von der wechselnden Zusammensetzung des Dotters, der verschiedenen Zahl und Bildung der Keimflecken u.s.w. Zahlreiche, leicht zu vermehrende Beispiele solcher tiefgreifenden Verschiedenheiten gibt Leydig's Lehrbuch der Histologie. - Bei den Krustern liefern die Eierstockseier sogar bisweilen treffliche Merkmale zur Unterscheidung von Arten derselben Gattung, wie sie z. B. bei einer hiesigen Porcellana schwärzlichgrün, bei einer zweiten dunkelblutroth, bei einer dritten dottergelb sind; und innerhalb derselben Ordnung zeigen sie erhebliche Unterschiede in der Grösse, die, wie schon van Beneden und Claus hervorgehoben, in innigem Zusammenhang steht mit der späteren Entwicklungsweise.

„Die Organe des Körpers verden gebildet in der Reihenfolge ihrer organischen Wichtigkeit; die wesentlichsten erscheinen immer zuerst." Man könnte den Satz von vornherein als unbeweisbar bezeichnen, da es unmöglich ist, sei es im Allgemeinen, sei es für ein besonderes Thier, eine Reihenfolge der Wichtigkeit unter gleich unentbelrlichen Theilen festzustellen. - Was ist wichtiger, Lunge oder Herz? - Leber oder Niere? Arterie oder Vene? - Man könnte statt wie Agassiz die Organe des animalen Lebens, mit gleichem Rechte die des vegetativen Lebens vorausstellen, da wohl

I) Agassiz' eigene Ansichten sind neuerdings, soviel aus Rudolf Wagner's Anzeige seines „Essay on Classification" zu ersehen ist, wesentlich andre geworden. Eine Kritik der obigen älteren, aber noch heute weitverbreiteten Ansichten trifft Agassiz selbst nicht mehr. Seine neuere Auffassungsweise kenne ich leider eben nur aus R. W.'s etwas confusem Berichte und habe daher geglaubt, mir irgendwelche kritische Bemerkung über dieselbe nicht erlauben zu dürfen. 
diese ohne jene, nicht aber jene ohne diese denkbar sind. Man könnte einwenden, dass ja nach diesem Satze provisorische Organe als die früher entstandenen an Wichtigkeit die bleibenden später gebildeten übertreffen müssten. - Aber halten wir uns an die Kruster. Bei Polyphemus findet Leydig schon wälırend der Furchung die erste Anlage des Darmrohrs. Bei Mysis bildet sich zuerst ein provisorischer Schwanz, bei Ligia eine madenförmige Larvenhaut. Das einfache unpaare Auge entsteht früher und wäre also wichtiger, als die zusammengesetzten paarigen; die Schuppe des Garneelenfühlers wichtiger, als die Geissel ; die Kieferfüsse der Krabben und Krebse wichtiger als Scheeren und Gangfüsse, bei den Asseln die sechs vorderen Fusspaare wichtiger, als das ganz gleich gebildete siebente; bei den Amphipoden das wichtigste aller Organe der bald nach dem Ausschlüpfen spurlos verschwindende „Mikropylapparat"; bei den Cyclopen wichtiger als alle Schwimmfüsse die Borsten des Schwanzes, bei den Cirripedien die hinteren Fühler, von denen man nicht weiss, wo sie bleiben, wichtiger als die Rankenfüsse u.s. w. Die unwesentlichsten aller Organe wären die Geschlechtstheile, die wesentlichste Eigenthümlichkeit aber läge in der bis auf's Eierstocksei zurückführbaren Farbe.

„Embryonen, Jugendzustände verschiedener Thiere gleichen einander um so mehr, je jünger sie sind", oder wie Johannes Müller es ausdrückt, „nähern sich um so mehr dem gemeinsamen Typus“. So verschieden die Begriffe sein mögen, die man mit dem Worte Typus verbindet so wird doch Niemand bestreiten, dass die typische Form des vorletzten Fusspaares der Amphipoden die eines einfachen Gangfusses, und nicht die einer Scheere ist; denn letztere findet sich bei keinem einzigen erwachsenen Amphipoden; man kennt sie nur von den Jungen der Gattung Brachyscelus, die sich also hierin unzweifelhaft weiter vom Typus ihrer Ordnung entfernen, als die Alten. Dasselbe gilt von den jungen Männchen der Strandhüpfer (Orchestia) in Bezug auf das zweite Paar der Vorderfüsse (Gnathopoda). Ebenso wird kaum Jemand anstehen, den Besitz von sieben Fusspaaren als "typische“ Eigenthümlichkeit der Edriophthalmen anzuerkennen, die Agassiz gerade danach Tetradecapoden nennt; die jungen Asseln, die Dodecapoden sind, stehen auch hier dem "Typus“ ferner als die Alten.

Regel ist allerdings, und so lässt es Darwin's Lehre erwarten, dass im Fortschritte der Entwicklung die anfangs ähnlicheren Formen immer weiter auseinandergehen; aber hier, wie in anderen Klassen, sind die Ausnahmen, für die die Schule keine Erklärung hat, zahlreich. Nicht selten könnte man den Satz. geradezu umkehren und behaupten, dass die Verschiedenheit um so grösser wird, je weiter man in der Entwicklung zurückgeht, und das nicht nur in Fällen, wo von zwei nahestehenden Arten die eine sich direct entwickelt, die andere mehrfache Larvenzustände durchläuft, - wie etwa der Flusskrebs und die aus Naupliusbrut hervorgehenden Garneelen. Man kann dasselbe sagen z. B. von Asseln und Amphipoden; bei den erwachsenen Thieren ist die Gliedmassenzahl dieselbe; man kann beim ersten Anblick eines Cyrtophium, einer Dulichia, man kann selbst nach sorgfältiger Untersuchung einer Scheerenassel in Zweifel bleiben, ob man eine Assel oder einen Amphipoden vor sich habe, bei den ausschlüpfenden Jungen ist die Zahl der Gliedmassen verschieden und geht man zurück ins Eileben, so ge- 
nügt der flüchtigste Blick, um an der Krümmung nach oben oder unten selbst die jüngsten Embryonen der beiden Ordnungen zu unterscheiden.

In anderen Fällen gehen die Wege, die von gleichem Ausgangspuncte zu gleichem Ziele führen, in der Mitte der Entwicklung weit auseinander, wie bei den oben geschilderten Garneelen mit Naupliusbrut.

Endlich, damit auch die letzte Möglichkeit erschöpft werde, kommt es vor, dass die grösste Aehnlichkeit in die Mitte der Entwicklung fällt. Das schlagendste Beispiel liefern Rankenfüsser und ITurzelkrebse, mag man nun die beiden Ordnungen mit einander, oder die Glieder einer jeden unter sich vergleichen; aus ganz verschieden ablaufender Furchung (s. Fig. 6r-64) gehen mannichfaltige Nauplius hervor, diese verwandeln sich in äusserst ähnliche Puppen und aus den Puppen werden wieder himmelweit verschiedene geschlechtsreife Thiere.

„Wenn die Bildung der Organe stattfindet in der ihrer Wichtigkeit entsprechenden Ordnung, so muss selbstverständlich diese Reihenfolge ein Kriterium ihres verhältnissmässigen Werthes für die Systematik sein." - Vorausgesetzt nämlich, dass physiologischer und systematischer Werth eines Organes zusammenfallen! - IVie es in christlichen Landen eine Katechismusmoral gibt, die Jeder im Munde führt, Niemand $z u$ befolgen sich verpflichtet hält oder von Anderen befolgt zu sehen erwartet, so hat auch die Zoologie ihre Dogmen, die man ebenso allgemein bekennt, als in der Praxis verläugnet. Ein solches Dogma ist die von Agassiz stillschweigend gemachte Voraussetzung. Unter Hundert, die sich gedrungen fühlen, als Einleitung eines Handbuchs oder einer monographischen Arbeit ihr systematisches Glaubensbekenntniss abzulegen, werden Neun und neunzig damit beginnen, dass ein natürliches System sich nicht auf ein einziges Merkmal stützen dürfe, sondern alle Merkmale, den gesammten Bau des Thieres zu berücksichtigen habe, dass man aber diese Merkmale nicht wie gleichnamige Grössen einfach summiren dürfe, dass man sie nicht zählen, sondern wägen und das jedem einzelnen beizulegende Gewicht nach seiner physiologischen Bedeutung bemessen müsse. - Vielleicht folgt dann noch einiges allgemein gehaltene Wortgeklingel über die vergleichungsweise Wichtigkeit von animalen und vegetativen Organen, von Kreislauf, Athmung u, dgl. - Geht es aber an die eigentliche Arbeit, an das Sichten und Anordnen der Arten, Gattungen, Familien u. s. w., so wird wahrscheinlich nicht Einer der Neun und neunzig sich dieser schönen Regeln erinnern und den hoffnungslosen Versuch ihrer Durchführung im Einzelnen unternehmen.

Agassiz z. B. betrachtet wie Cuvier und im Gegensatz zur Mehrzahl der deutschen und englischen Zoologen die Strahlthiere als eine der grossen Hauptabtheilungen des Thierreichs, trotzdem dass Niemand etwas weiss über die Bedeutung der strahligen Anordnung für das Leben dieser Thiere, und trotzdem dass die strahligen Echinodermen aus bilateralen Larven hervorgehen. Die ,eigentlichen Fische" theilt derselbe in Ctenoïden und Cycloïden, je nachdem der Hinterrand der Schuppen gezähnelt oder glatt ist, - ein Umstand, dessen Wichtigkeit für das Thier verschwindend klein sein muss gegen die Eigenthümlichkeiten der Bezahnung, der Flossenbildung, der Wirbelzahl u. s. w.

Um zu unserer Klasse der Kruster zurückzukehren, hat man bei deren Eintheilung etwa auf die Unterschiede in den „wesentlichsten Organen“ vorwaltende 
Rücksicht genommen? - Etwa auf das Nervensystem? - Bei den Corycaeiden fand Claus alle Bauchganglien in eine einzige breite Masse verschmolzen, bei den Calaniden eine lange Bauchganglienkette, jene also hierin den Spinnenkrabben, diese dem Hummer ähnlich, aber Niemandem fällt es im Traume ein, deshalb an eine Verwandtschaft der Corycaeiden mit den Krabben, der Calaniden mit den Krebsen zu denken. - Oder auf die Organe des Kreislaufs? - Aber da stehen unter den Copepoden die Cyclopiden und Corycaeiden ohne Herz neben den Calaniden und Pontelliden mit einem Herzen. Und ebenso stellen sich unter den Ostracoden neben die herzlosen Cypris und Cythere die, wie ich finde, ein Herz besitzenden Cypridinen. - Oder auf die Athmungswerkzeuge? - Milne Edwards hatte es gethan, als er die Mysis und Leucifer von den Decapoden trennte, aber er selbst hat dies später als Fehlgriff erkannt. Bei einer Cypridina sehe ich ansehnliche Kiemen, die ich bei einer zweiten Art vollständig vermisse, aber dies scheint mir kein Grund, diese Arten selbst nur generisch zu trennen. -

Auf der anderen Seite, was wissen wir von der physiologischen Bedeutung der Segmentenzahl und all der Dinge, die wir als typische Eigenthümlichkeiten der verschiedenen Ordnungen zu betrachten, denen wir den höchsten systematischen Wert beizulegen pflegen?

„Die Eigenthümlichkeiten, welche früher erscheinen, soll man höherwerthen als die, welche später erscheinen. Ein System um wahr und natürlich zu sein, muss übereinstimmen mit der Aufeinanderfolge der Organe in der Entwicklung des Embryo." Sind früher erscheinende Eigenthümlichkeiten höher zu werthen, als später auftretende, so wird in Fällen, wo der Bau des erwachsenen Thieres die eine, der Bau der Larve eine andre Stellung im System fordert, nicht jenes, sondern diese den entscheidenden Ausschlag zu geben haben. Wie man Lernaeen und Rankenfüsser um ihrer Naupliusbrut willen aus ihrem früheren Verbande löste und den Krustern zuwies, so wird man aus gleichem Grunde Penëus von den Garneelen trennen und mit Copepoden und Rankenfüssern vereinigen müssen. Aber davor dürfte wohl auch der eifrigste Embryomane zurückschrecken.

Ein „wahres und natürliches System“ der Kruster würde der Reihenfolge der Erscheinungen nach in erster Linie die verschiedene Weise der Furchung, dann die Lagerung des Embryo, weiterhin die Zahl der im Ei angelegten Gliedmassen u. s. f. zu berücksichtigen haben und dürfte sich etwa in folgender Weise darstellen:

\section{Classis Crustacea.}

Subclass I. Holoschista. Totale Furchung. Kein Primitivstreifen. Naupliusbrut.

Ord. r. Ce rat o metopa. Nauplius mit Stirnhörnern. (Rankenfüsser, Wurzelkrebse.)

Ord. 2. Leiometopa. Nauplius ohne Stirnhörner. (Copepoden, ohne Achtheres u.s.w., Phyllopoden, Penëus.)

Subclass II. Hemischista. Keine totale Furchung.

A. Nototropa. Embryo aufvärts gekrümmt.

Ord. 3. Protura. Der Schwanz bildet sich zuerst. (Mysis.) 
Ord. 4. Saccomorpha. Eine madenförmige Larvenhaut bildet sich zuerst. (Asseln.)

B. Gasterotropa. Embryo bauchwärts gekrümmt.

Ord. 5. Zoëogona. Gliedmassen nicht vollzählig im Ei angelegt. Zoëabrut. (Mehrzahl der Podophthalmen.)

Ord. 6. Ametabola. Gliedmassen vollzählig im Ei angelegt. (Astacus. Gecarcinus. Amphipoden, ohne Hyperia ?)

Die Probe mag genügen. Je weiter man auf diesem Wege ins Einzelne einginge, um so glänzender vürde sich, wie man sich denken kann, die Natürlichkeit einer solchen Anordnung herausstellen.

Alles in Allem genommen, so darf man wohl das Urtheil, das Agassiz über Darwin's Lehre aussprach, mit weit grösserem Rechte auf die eben beleuchteten Sätze anwenden: „Keine Theorie, so plausibel sie auch erscheinen mag, kann in der $W$ issenschaft zugelassen werden, wenn sie nicht durch Thatsachen unterstützt wird."

XI.

Von dem nicht wohl zu umgehenden unerquicklichen Seitenblicke auf die Schule, die so vornehm herabzublicken weiss auf den "geistreichen Traum" Darwin's und auf die „schwindelhafte Begeisterung“ seiner Freunde, wende ich mich zu der angenehmen Aufgabe, die Entwicklungsgeschichte der Kruster aus dem Gesichtspuncte der Darwin'schen Lehre zu betrachten.

Darwin selbst hat bereits die aus seinen Voraussetzungen für das Gebiet der Entwicklungsgeschichte sich ergebenden Folgerungen im dreizehnten Kapitel seines Buches erörtert. Für eine mehr ins Einzelne gehende Anwendung wird es indess nöthig, zunächst im Allgemeinen diesen Folgerungen etwas weiter nachzugehen, als es dort geschehen ist.

Die Veränderungen, durch welche sich Junge von ihren Erzeugern entfernen und deren allmähliche Häufung die Entstehung neuer Arten, Gattungen, Familien veranlasst, können in früherem oder späterem Lebensalter auftreten, in der Jugend oder zur Zeit der Geschlechtsreife. Denn letztere ist bei weitem nicht immer eine Zeit des Stillstandes, wie bei den Insecten; die meisten anderen Thiere fahren auch dann noch fort, zu wachsen und sich zu verändern. (Man vergleiche das oben über die Männchen der Amphipoden Bemerkte.) Gewisse Abweichungen können sogar ihrer Natur nach erst eintreten, wenn das Junge die Entwicklungsstufe der Eltern erreicht hat. So besitzen die Seeraupen (Polynoë) anfangs nur wenige Leibesringe, die während der Entwicklung allmählich zu einer für verschiedene Arten verschiedenen, für jede derselben beständigen Zahl anwachsen; ehe nun ein Junges die Ringzahl seiner Eltern überschreiten könnte, müsste es sie natürlich erreicht haben. Man wird einen ähnlichen nachträglichen Fortschritt überall vermuthen dürfen, wo die Abweichung der Nachkommen in einem $\mathrm{Zu}$ wachse neuer Ringe und Gliedmassen besteht.

Die Nachkommen gelangen also zu einem neuen Ziele, entweder indem sie schon auf dem Wege zur elterlichen Form früher oder später abirren, oder indem sie diesen Weg $z$ war unbeirrt durchlaufen, aber dann stattstille zustehen noch weiterschreiten. 
Die erstere Weise wird vorwiegend gewirkt haben, wo die Nachkommenschaft gemeinsamer Ahnen einen in den wesentlichsten Zügen auf gleicher Stufe stehenden Formenkreis bildet, wie etwa sämmtliche Amphipoden, oder Krabben, oder Vögel. Dagegen wird man zur Annahme der zweiten Weise des Fortschreitens geführt, sobald man von gemeinsamer Stammform Thiere abzuleiten sucht, von denen die einen übereinstimmen mit Jugendzuständen der anderen.

Im ersteren Falle wird die Entwicklungsgeschichte der Nachkommen mit cler ihrer Vorfahren nur bis zu dem Puncte zusammenfallen können, an dem ihre Wege sich schieden, über deren Bau im erwachsenen Zustande wird sie nichts lehren. Im $z$ weiten Falle wird die ganze Entwicklung der Vorfahren auch von den Nachkommen durchlaufen und soweit daher die Entstehung einer Art auf dieser zweiten Weise des Fortschreitens beruht, wird die geschichtliche Entwicklung der Art sich abspiegeln in deren Entwicklungsgeschichte. - In der kurzen Frist weniger Wochen oder Monden führen die wechselnden Formen der Embryonen und Larven ein mehr oder minder vollständiges, mehr oder minder treues Bild der Wandlungen an uns vorüber, durch welche die Art im Laufe ungezählter Jahrtausende zu ihrem gegenwärtigen Stande sich emporgerungen hat.

Eines der einfachsten Beispiele bietet die Entwicklung der WV urmröhren. Gerade durch seine Einfachheit aber scheint es geeignet, auch Manchem, der nicht sehen möchte, die Augen zu öffnen, und mag deshalb hier Platz finden. Vor drei Jahren fand ich an der Wand eines meiner Gläser einige kleine Wurmröhren (Fig. 65), deren Bewohner drei Paar bärtige Kiemenfäden trugen und eines Deckels entbehrten. Man hätte sie danach zur Gattung Protula stellen müssen. Wenige Tage später hatte sich einer der Kiemenfäden am Ende zu einem keulenförmigen

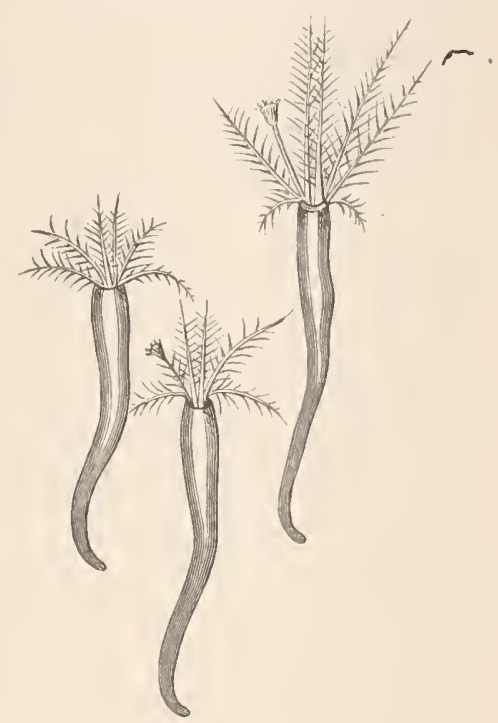

Fig. 65. Fig. 66. Fig. 67.

Fig. 65-67. Junge Wurmröhre, mit der einfachen Linse, etwa $6 \mathrm{mal}$ vergr.

Fig. $65^{1}$, ohne Deckel, Protula. stufe.

Fig. 66, mit bärtigem Deckelstiel, Filogranastufe.

Fig. 67, mit nacktem Deckelstiel, Serpulastufe.

Deckel verdickt (Fig. 66). Jetzt erinnerten die Thiere durch den bärtigen Deckelstiel an die Gattung Filograna, nur dass diese zwei Deckel besitzt. Nach weiteren drei Tagen, während deren ein neues Paar Kiemenfäden hervorgesprosst war, hatte der Deckelstiel seine seitlichen Fäden verloren (Fig. 67) und die Würmer waren zu Serpula geworden. Hier bietet sich von selbst die Annahme, dass die Urwurmröhre eine Protula war, - dass einige Nachkommen derselben, die sich bereits zu vollständigen Protula entwickelt hatten, nachträglich sich durch die Bildung eines Deckels vervollkommneten, der ihre Röhre vor feindlichen Eindringlingen schützte, - dass spätere Nachkommen dieser letzteren endlich die

I) Fig. 65 ist aus der Erinnerung gezeichnet, da mir die Thierchen, die ich anfangs für junge Protula nahm, erst merkwürdig wurden und ich sie zeichnete, als ich das Auftreten des Deckels bemerkte. 
seitlichen Fäden des Deckelstiels wieder verloren, die sie wie ihre Vorfahren entwickelt hatten.

Was sagt die Schule zu diesem Falle? Woher und wozu, wenn die Serpula als fertige Arten entstanden oder erschaffen wurden, diese seitlichen Fäden des Deckelstiels? Sie blos um eines einmal entworfenen unabänderlichen Bauplanes willen hervorspriessen zu lassen, selbst wenn sie sofort wieder als überflüssig eingezogen werden mussten, wäre doch sicher eher Beweis kindischer 'Tändelei oder schulmeisterlichen Pedantismus, als unendlicher Weisheit. Aber nein, ich irre mich, von Urbeginn her wusste ja auch der Schöpfer, dass einst neugierige Menschenkinder über Analogien und Homologien grübeln, dass christliche Naturforscher sich abmühen würden, seine Schöpfungsgedanken nachzudenken; - jedenfalls, um diesen die Einsicht zu erleichtern, dass der Deckelstiel der Serpula einem Kiemenfaden homolog sei, liess er denselben bei seiner Entwicklung einen Umweg machen und durch die Form eines bärtigen Kiemenfadens hindurchgehen.

Die in der Entwickelungsgeschichte erhaltene geschichtliche Urkunde wird allmählich verwischt, indem die Entwicklung einen immer geraderen Weg vom Ei zum fertigen Thiere einschlägt, und sie wird häufig gefälscht durch den Kampf ums Dasein, den die freilebenden Larven $z u$ bestehen haben.

Wie nämlich das Gesetz der Erblichkeit kein strenges ist, wie es individuellen Schwankungen Raum gibt in Betreff der Form der Eltern, so gilt ein Gleiches auch für die Zeitfolge der Entwicklungsvorgänge. Jeder Familienvater, der darauf Acht hatte, weiss ja, dass selbst bei Kindern derselben Eltern z. B. die Zähne weder in genau demselben Alter, noch in derselben Folge hervorbrechen oder gewechselt werden. - Nun wird es im Allgemeinen einem Thiere von Nutzen sein, der V'orzüge, durch die es im Kampfe ums Dasein sich behauptet, so früh als möglich theilhaftig zu werden. Ein verfrühtes Auftreten später erworbener Eigenthümlichkeiten wird meist Vortheil, ein verspätetes Nachtheil bringen; ersteres, wo es einmal zufällig sich zeigt, wird durch die natürliche Auslese erhalten werden. Ebenso jede Abänderung, die den Kreuz- und Querzügen durch mannichfache Larvenzustände eine mehr geradlinige Richtung gibt, den Entwicklungsgang vereinfacht, abkürzt, in frühere Lebenszeit und endlich ins Eileben zurückdrängt.

Da dieser Uebergang einer durch verschiedenartige Jugendzustände hindurchgehenden in eine mehr unmittelbare Entwicklung nicht Folge eines inwohnenden mystischen Triebes, sondern abhängig ist von zufällig sich bietenden Fortschritten, so wird derselbe bei nächstverwandten Thieren auf die verschiedenste Weise vor sich gehelı und sehr verschiedene Zeit zu seinem Ablaufe erfordern können. Eines ist jedoch hierbei nicht zu übersehen. Die geschichtliche Entwicklung der Art dürfte schwerlich je im fortwährend gleichmässigen Flusse vor sich gegangen sein; Zeiten der Ruhe werden mit Zeiten rascheren Fortschreitens gewechselt haben. Formen nun, die in Zeiten rascheren Fortschrittes nach kurzem Bestande von anderen abgelöst wurden, dürften auch der Entwicklungsgeschichte der Nachkommen sich weniger tief eingeprägt haben, als solche, die in Zeiten der Ruhe bei einer langen Reihe aufeinanderfolgender Geschlechter sich unverändert wiederholten. Diese besser befestigten Formen, weniger zu Abänderungen geneigt, werden bei dem Uebergange zu directer Entwicklung zäheren Widerstand leisten 
und auch bei sonst noch so verschiedenem Verlaufe dieses Vorganges in gleichmässiger Weise und bis zuletzt sich erhalten.

Im Allgemeinen wird es, wie gesagt, den Jungen vortheilhaft sein, in Gestalt der Eltern, mit all deren Vorzügen ausgerüstet den Kampf ums Dasein zu beginnen, im Allgemeinen, - doch nicht ohne Ausnahmen. Dass festsitzenden Thieren eine der Ortsbewegung fähige Brut fast unentbehrlich ist, dass die munter durchs Meer schwärmenden Larven träger Schnecken, im Boden wühlenden Gewürmes u. s. w. durch Ausstreuen der Art über weitere Strecken wesentliche Dienste leisten, liegt auf der Hand. In anderen Fällen ist eine Verwandlung dadurch unentbehrlich geworden, dass sich eine Teilung der Arbeit zwischen die verschiedenen Lebensaltern herausgebildet hat, dass z. B. die Larven ausschliesslich das Geschäft der Ernährung übernommen haben. - Ein fernerer in Betracht zu ziehender Umstand liegt in der Grösse der Eier, ein einfacher Bau ist mit weniger Stoff herzustellen, als ein mehr zusammengesetzter; je unvollkommener die Larve, um so kleiner kann das Ei sein, eine um so grössere Menge derselben kann die Mutter bei gleichem Aufwand an Stoff liefern. In der Regel, glaube ich, wird zwar dieser Vortheil einer zahlreicheren den einer vollkommneren Brut bei weitem nicht aufwiegen; wohl aber in Fällen, wo die Hauptschwierigkeit für die Jungen darin besteht, einen passenden Ort für ihre Entwicklung zu finden und wo es daher gilt, die grösstmögliche Menge von Keimen auszustreuen. So bei vielen Schmarotzern.

Es mag hier, wo vom Uebergang der urspünglichen Entwicklung mit Verwandlung in directe Entwicklung die Rede ist, an der Stelle sein, ein Wort zu sagen über den oben berührten Mangel der Verwandlung bei Süsswasser- und Landthieren, deren meerbewohnende Verwandte noch eine solche durchlaufen. Dieses Verhalten scheint in zwiefacher Weise erklärbar. Entweder wanderten besonders Arten ohne Verwandlung ins süsse Wasser ein, oder die Verwandlung wurde bei den Uebergesiedelten rascher beseitigt, als bei den im Meere zurückgebliebenen Genossen.

Thiere ohne Verwandlung konnten natürlich leichter übersiedeln, da sie nur sich selbst und nicht zugleich mannichfache Jugendformen den neuen Verhältnissen anzuschmiegen hatten. Bei Thieren mit Verwandlung aber musste im Allgemeinen die immer bedeutende Sterblichkeit der Larven eine noch grössere sein in neuen, als in altgewohnten Verhältnissen; jeder Schritt zur Vereinfachung des Entwicklungsganges musste also hier ein noch grösseres Uebergewicht über die Artgenossen geben und das Verwischen der Verwandlung daher rascher vor sich gehen. IVas in jedem Einzelfalle stattgefunden hat, ob die Art einwanderte, nachdem sie die Verwandlung verloren, - oder die Verwandlung verlor, nachdem sie einwanderte, wird nicht immer leicht zu entscheiden sein. Wo meerbewohnende Verwandte ohne oder mit geringer Verwandlung sich finden, wie der Hummer als Vetter des Flusskrebses, wird man nach der ersteren, - wo auf dem Lande oder im süssen Wasser noch Verwandte mit V'erwandlung leben, wie bei Gecarcinus, zu letzterer Annahme greifen dürfen.

Wie neben diesem allmählichen Verklingen der Urgeschichte zugleich eine F älschung der in der Entwicklungsgeschichte niedergelegten Urkunde stattfinde durch den Kampf ums Dasein, den die freilebenden Jugendzustände zu bestehen haben, bedarf keiner weiteren Ausführung. Denn selbstverständlich muss 
auf Larven, die für sich selbst zu sorgen haben, der Kampf ums Dasein und die damit verbundene natürliche Auslese in gleicher Weise verändernd und fortbildend wirken, wie auf erwachsene Thiere. Die von den Fortschritten des erwachsenen Thieres unabhängigen Veränderungen der Larve werden um so bedeutender sein, je länger die Lebensdauer der Larve im Vergleich zu der des erwachsenen Thieres, je abweichender ihre Lebensweise und je schärfer ausgesprochen die Theilung der Arbeit zwischen den verschiedenen Entwicklungsstufen. Diese Vorgänge haben in gewisser Weise eine dem allmählichen Verklingen der Urgeschichte entgegengesetzte Wirkung; sie vergrössern die Unterschiede zwischen den einzelnen Entwicklungsstufen und man begreift, wie selbst ein geradliniger Entwicklungsgang durch sie wieder in eine Entwicklung mit Verwandlungen umgebildet werden kann. So lassen sich manche und, wie mir scheint, triftige Gründe für die Ansicht geltend machen, dass die ältesten Insecten den heutigen Geradflüglern, vielleicht den flügellosen Schaben, näher standen als irgend einer anderen Ordnung und dass die ,vollkommene Verwandlung“ der Käfer, Schmetterlinge u. s. w. späteren Ursprungs ist. Es hat, glaube ich, früher vollkommene Insecten, als Raupen oder Puppen, dagegen weit früher Nauplius und Zoëa als vollkommene Garneelen gegeben. Man könnte im Gegensatz zu der ererbten Verwandlung der Garneelen, die der Käfer, Schmetterlinge u. S. w. eine erworben e nennen ${ }^{1}$ ).

Welche der verschiedenen zur Zeit in einer Thierklasse bestehenden Entwicklungsweisen beanspruchen dürfe, als die der ursprünglichen zunächst stehende zu gelten, ist nach dem Obigen leicht zu ermessen.

Die Urgeschichte der Art wird in ihrer Entwicklungs geschichte um so vollständiger erhalten sein, je länger die Reihe der Jugendzustände ist, die sie gleichmässigen Schrittes durchläuft, und um so treuer, je weniger sich die Lebensweise der Jungen von der der Alten entfernt, und je weniger die Eigenthümlichkeiten der einzelnen Jugendzustände als aus späteren in frühere Lebensabschnitte zurückverlegtoderalsselbstständig erworben sich auffassen 1 assen.

Machen wir die Anwendung auf die Kruster.

XII.

Nàch allen im letzten Satze aufgestellten Kennzeichen erscheint bis jetzt die Garneele, die wir (Fig. 28-31) von Nauplius durch Zoëa und Mysis ähnliche Zustände bis zur Gestalt eines langschwänzigen Krebses begleiteten, als dasjenige Thier, welches im Bereiche der höheren Kruster (Malacostraca) die vollständigste und treueste Kunde gibt von seiner Urgeschichte. Die vollständigste, das liegt auf der Hand. Die treueste, das ist anzunehmen, einmal weil die Lebensweise der einzelnen Altersstufen eine minder verschiedene ist, als bei der Mehrzahl der übrigen Podophthalmen; - denn vom Nauplius bis zur jungen Garneele wurden sie frei schwimmend im Meere getroffen, während Krabben, Porcellanen, die Tatuira, Squilla und viele Langschwänze erwachsen unter Steinen, in Felsspalten, Erdlöchern, unterirdischen Gängen, in Sande u. s. w. sich aufzuhalten pflegen,

1) Anmerkung aus der englischen Uebersetzung des Buches siehe am Schlusse dieser Arbeit. 
noch abweichenderer Sitten nicht zu gedenken, wie sic Einsiedlerkrebse, Muschelwächter u. s. w. zeigen, - und zweitens vorzüglich weil die Eigenthümlichkeiten, die namentlich die Zoëa dieser Art vor anderen Zoëa auszeichnen (die Benutzung der vordersten Gliedmassen zum Schwimmen, der gablige Schwanz, das einfachere Herz, der anfängliche Mangel der paarigen Augen und cles Hinterleibes u. s. w.), weder aus einem Zurückverlegen später erworbener Vorzüge in dieses frühere Lebensalter abzuleiten sind, noch überhaupt als Vorzüge vor anderen Zoëa erscheinen, welche die Larve im Kampfe um's Dasein erworben haben könnte.

Eine ähnliche Entwicklung musste einst der Urahn aller Malacostraca durchlaufen, verschieden von der unserer Garneele wohl besonders dadurch, dass sie noch gleichmässigeren Schrittes durchmessen wurde ohne die plötzlichen Wechsel der Form und der Bewegungsweise, die bei letzterer besonders daraus entstehn, dass bei dem Nauplius gleichzeitig vier, bei der Zoëa gleichzeitig fünf Gliedmassenpaare hervorspriessen und mit einem Male in Thätigkeit treten. Es ist anzunehmen, dass sich nicht nur ursprünglich, sondern auch noch bei den Larven der ersten Malacostraca die neuen Leibesringe und Gliedmassenpaare einzeln, zuerst die Ringe des Vorderleibes, dann des Hinterleibes, und zuletzt des Mittelleibes, und zwar in jedem Leibesabschnitte die vorderen früher als die hinteren bildeten, zuletzt also von allen der hinterste Ring des Mittelleibes. - Von dieser ursprünglicheren Weise sind heute noch mehr oder minder deutliche Spuren selbst bei Arten geblieben, bei denen sonst der Entwicklungsgang der Vorfahren schon ziemlich verwischt ist. So bilden sich einzeln, von vorn nach hinten, die Hinterleibsfüsse der Fig. 33 gezeichneten Garneelenlarve und später als sie die letzten Füsse des Mittelleibes; so bei Palinurus die beiden letzten Fusspaare des Mittelleibes später als die übrigen; so entbehren bei jungen Maulfüsserlarven noch die drei letzten Hinterleibsringe, bei älteren noch der letzte derselben der Gliedmassen; so entsteht bei den Asseln noch heute das geschichtlich jüngste Fusspaar später als alle übrigen. Vollständiger erhalten, als bei irgend einem der höheren Kruster ist diese schrittweise von vorn nach hinten vorrückende Bildung neuer Leibesringe und Gliedmassen bei den Copepoden ${ }^{1}$ ).

Die ursprüngliche von der niedersten Stufe, die wir überhaupt freilebend in der Klasse der Kruster kennen, von Nauplius ausgehende Entwicklung der Malacostraca ist heute bei der Mehrzahl derselben ziemlich verwischt. Dass dieses Verwischen wirklich in der Weise vor sich gegangen, die oben aus Darwin's Lehre als deren unmittelbare Folge abgeleitet wurde, wird um so leichter nachzuweisen sein, je mehr dieser Vorgang noch im lebendigen Flusse begriffen, je weniger vollständig er bereits abgelaufen ist. Die schlagendsten Beispiele darf man in der noch unbekannten Entwicklungsgeschichte der verschiedenen Schizo-

1) Man weiss, dass in mehreren Fällen selbst bei erwachsenen Thieren der letzte Ring des Mittelleibes oder einige der letzten entweder ihrer Gliedmassen entbehren oder selbst völlig fehlen. (Entoniscus Porcellanae ${ }^{\circ}$, Leucifer u. s. w.) Das könnte davon herrühren, dass die Thiere sich von dem gemeinsamen Stamme trennten, ehe noch diese Gliedmassen überhaupt gebildet wurden. Doch ist es mir in den Fällen, die ich näher kenne, wahrscheinlicher, dass dieselben später wieder verloren gegangen sind. Dass gerade diese Gliedmassen und Ringe sich leichter verloren, als andere (,Mr. Dana. believes, that in ordinary Crustaceans, the abortion of the segments with their appendages takes alıost always place at the posterior end of the cephalothorax". Darwin, Balanidae, S. III), findet seine Erklärung darin, dass sie als die jüngsten weniger als die anderen durch langdauernde Vererbung befestigt waren. 
poden. Peneïden, überhaupt der langschwänzigen Krebse zu erhalten hoffen. Für jetzt erscheinen als besonders lehrreich die mannichfachen Zoëaformen. Fast alle Eigenthümlichkeiten, durch die sie sich von der Urform der Penëus-Zoëa (Fig. 29, 30, 32) entfernen, lassen sich in der That auffassen als aus späterer Zeit in diesen früheren Lebensabschnitt zurückverlegt. So die grossen zusammengesetzten Augen; so die Bildung des Herzens; so die Raubfüsse bei Squilla; so der kräftige musculöse, gerade ausgestreckte Hinterleib bei Palaemon, Alphëus, Hippolyte und den Einsiedlerkrebsen; - (bei letzteren ist gegenwärtig der Hinterleib des erwachsenen Thieres freilich ein ungeschlachter mit Leber und Geschlechtstheilen gefüllter Sack, aber ziemlich kräftig noch auf der Glaucothoëstufe, und noch kräftiger war er jedenfalls, als diese Stufe noch die bleibende Form des Thieres war). - So auch der meist unter die Brust geschlagene, dabei aber kräftige Hinterleib der Zoëa von Krabben, Porcellanen und der Tatuira; letztere beide schwimmen noch jetzt leidlich mittelst des Hinterleibes, selbst erwachsen; die Krabben wenigstens in der Jugend, als sogenannte Megalops. - So endlich die Verwendung der beiden vorderen Gliedmassenpaare als Fühler. Merkwürdig ist besonders das zweite Fühlerpaar, das bei den verschiedenen Zoëa sich immer einen Schritt hinter dem des erwachsenen Thieres hält. Bei den Krabben fehlt eine „Schuppe“ vollständig; ihre Zoëa haben sie angedeutet in Form eines oft sehr winzigen beweglichen Anhanges. Bei den Einsiedlerkrebsen findet sich ein solcher meist beweglicher dornförmiger Fortsatz als Rest der Schuppe; ihre Zoëa haben eine wohlentwickelte, aber ungegliederte Schuppe, Eine eben solche Schuppe besitzen die erwachsenen Garneelen, bei deren Zoëa erscheint sie noch gegliedert, wie der äussere Ast am zweiten Fusspaare der Nauplius oder der Penëus-Zoëa. -

Die langen stachelförmigen Fortsätze am Panzer der Krabben- und PorcellanenZoëa sind auf diesem Wege nicht zu erklären, doch ist ihr Nutzen für die Larven augenscheinlich. Wenn z. B. der Leib der Zoëa von Porcellana stellicola (Fig. 24) ohne die Fortsätze des Panzers und ohne den nicht steif ausstreckbaren Hinterleib kaum eine halbe Linie, mit den Fortsätzen vier Linien lang ist, so bedarf es eines achtmal weiteren Maules, um das so ausgerüstete Thierchen zu verschlingen ${ }^{1}$ ). Somit können diese Fortsätze des Panzers als von der Zoëa selbst im Kampfe ums Dasein erworben angesehen werden.

Auf ein früheres Eintreten ursprünglich später erfolgender Vorgänge ist auch die Bildung neuer Gliedmassen unter der Haut der Larven zurückzuführen. Der ursprüngliche Hergang war jedenfalls, dass sie erst nach der Häutung frei am Bauche im nächsten Larvenstadium hervorsprossten, während sie jetzt schon vor der Häutung sich entwickeln und so um ein Stadium früher in Thätigkeit treten. Bei Larven, die aus anderen Gründen als der Urform näher stehend gelten müssen, pflegt auch hierin die ursprüngliche Weise vorzuherrschen. So bilden sich die Schwanzfüsse (die „seitlichen Schwanzblätter") frei am Bauche bei Euphausia und den Garneelen mit Naupliusbrut, innerhalb des Schwanzblattes bei den Garneelen mit Zoëabrut, bei Pagurus, bei Porcellana.

I) In ähnlicher Weise dienen der Persephone, einer seltenen Krabbe aus der Familie der Leucosiden, ihre langen Scheerenfüsse. Ergreift man das Thier, so streckt es dieselben stocksteif gerade nach unten und man würde sie wahrscheinlich eher brechen, als biegen können. 
Ein Zusammendrängen mehrerer Stadien in eines und dadurch eine Abkürzung, Vereinfachung des Entwicklungsganges spricht sich aus in dem gleichzeitigen Auftreten mehrerer neuen Gliedmassenpaare.

Wie frühere Jugendzustände nach und nach vollständig verloren gehen können, zeigen Mysis und die Asseln. Bei Mysis findet sich noch ein Rest des Naupliusstadiums; zurückgedrängt in eine Zeit, wo er noch nicht selbst für sich zu sorgen hatte, ist der Nauplius zu einer blossen Haut herabgesunken; bei Ligia (Fig. 36, 37) hat diese Larvenhaut die letzten Spuren von Gliedmassen verloren, bei Philoscia (Fig. 38) ist sie kaum mehr nachzuweisen.

Wie die Stachelfortsätze der Zoëa, so sind die Scheeren am vorletzten Fusspaare des jungen Brachyscelus als von der Larve selbst erworben anzusehen. Die erwachsenen Thiere schwimmen vortrefflich und sind nicht an ihr Wohnthier gebunden; sobald die Chrysaora Blossevillei Less. oder das Rhizostoma cruciatum Less., an dem sie sitzen, in der Nähe des Strandes ein Spiel der WVellen wird, fliehen sie dieselben, sie sind nur von lebensfrischen Quallen zu erhalten. Die Jungen sind unbehülfliche Geschöpfe, schlechte Schwimmer; für sie musste ein besonderes Werkzeug zum Festhalten von grossem Nutzen sein.

Die Entwicklungsgeschichte der verschiedenen Malacostraca im Einzelnen durchzusprechen, dürfte keine dem Zeitaufwande entsprechende Ausbeute liefern; bei vollständigerer Kenntniss würde es lohnender sein. Ich verzichte hier darauf, will jedoch nicht unerwähnt lassen, dass sich dabei manche bis jetzt nicht befriedigend zu lösende Schwierigkeiten herausstellen würden. Auf diese vereinzelten Schwierigkeiten lege ich indess um so weniger Gewicht, als ja noch vor Kurzem, vor Entdeckung der Garneelennauplius, dieses ganze Gebiet der Entwicklung der Malacostraca für Darwin's Lehre fast unzugänglich war.

Auch bei den Widersprüchen, die sich aus der Anwendung der Darwin'schen Lehren auf diesem Gebiete zu ergeben scheinen, verweile ich nicht. Ich überlasse es den Gegnern, sie aufzusuchen. Die meisten sind leicht als nur scheinbar nachzuweisen. Nur zweien dieser Einwendungen, die zu nahe liegen, um nicht gemacht $\mathrm{zu}$ werden, glaube ich vorbeugen $\mathrm{zu}$ müssen.

,Die Eigenthümlichkeiten, in welchen die Zoëa der Krabben, der Porcellanen, der Tatuira, der Einsiedlerkrebse, der Garneelen mit Zoëabrut übereinstimmen und durch welche sie sich gemeinsam von den aus Nauplius hervorgehenden Larven der Penëus unterscheiden, drängen (wird man sagen können) zu der Annahme, dass schon der gemeinsame Stammvater dieser verschiedenen Decapoden in ähnlicher Zoëaform das Ei verliess. Auf diesen Stamnvater würden dann aber weder die Penëus mit ihrer Naupliusbrut, noch selbst, wie es scheint, die Panzerkrebse sich zurückführen lassen. - Die Entwicklungsweise der Penëus, der Palinurus, sowie mehrere eigenthümliche Larven von unbekannter Herkunft, die aber mit aller Wahrscheinlichkeit langschwänzigen Krebsen zuzuschreiben sind, verlangen dagegen die entgegengesetzte Annahme, dass die verschiedenen Gruppen der Langschwänze unabhängig von einander und unabhängig von den Krabben von der ursprünglichen zu ihrer gegenwärtigen Entwicklungsweise gelangten." Darauf ist zu antworten, dass das Vorkommen der Zoëaform bei all den genannten Decapoden, dass ihr Bestehen bei Penëus während des ganzen an Fortschritten reichsten Lebensabschnittes, in dem die weite Kluft von Nauplius bis zum Deca- 
poden sich ausfüllt, dass ihre Wiederkehr selbst in dem so abweichenden Entwicklungsgang der Maulfüsser, dass das Auftreten einer den jüngsten Penëus-Zoëa sich eng anschliessenden Larvenform bei der Schizopodengattung Euphausia, dass die Anklänge an den Bau der Zoëa, die selbst die erwachsenen Scheerenasseln in ihrer Athmungsweise bewahrt haben, - dass Alles dieses die Zoëa als eine jener Entwicklungsstufen bezeichnet, die während einer langen Zeit der Ruhe, vielleicht durch eine ganze Reihe geologischer Formationen als bleibende Form bestanden und dadurch auch der Entwicklung der Nachkommen sich tiefer einprägten und hier einen festeren Kern bildeten inmitten anderer leichter zu verwischender Jugendzustände. So kann es denn nicht befremden, dass auch bei unabhängig erfolgendem Uebergange der ursprünglichen Vetwandlungsweise in directe Entwicklung dennoch in verschiedenen Familien, bei denen die früheren Entwicklungsstufen verwischt sind, das Larvenleben in gleicher Weise mit dieser Zoëaform anhebt. Ausser dem aber, was allen Zoëa gemeinsam ist, und dem, was sich leicht als aus einem späteren Stadium in dieses zurück verlegt erklären lässt, stimmen z. B. die Zoëa der Krabben mit denen von Pagurus und Palaemon in keinerlei Einzelheiten des Baues überein, die eine gemeinsame Ererbung anzunehmen geböten. Somit erscheint die Annahme unbedenklich, dass als Krabben und Krebse sich schieden, die Stammeltern jeder dieser Gruppen noch eine vollständigere Verwandlung durchliefen, dass der Uebergang in die heutige Entwicklungsweise einer späteren Zeit angehört. Man kann für die Krabben hinzusetzen, dass bei ihnen dieser Uebergang nur wenig später stattfand und zwar bevor die heutigen Familien sich trennten. Die Anordnung der Panzerfortsätze und mehr noch die gleiche Zahl der Schwanzborsten bei den verschiedensten Krabbenzoëa (Fig. 19-23) beweisen es. Eine ähnliche Uebereinstimmung in der Zahl so unwichtig scheinender Gebilde ist nur aus gemeinsamer Ererbung erklärbar. Man kann mit Bestimmtheit voraussagen, dass unter den Krabben keine Art sich finden wird, die ähnlich wie Penëus noch heute Naupliusbrut hervorbrächte ${ }^{1}$ ).

Von allen übrigen Krustern entfernen sich, wie wir sahen, Mysis und die Asseln in höchst auffallender Weise dadurch, dass ihre Embryonen nach oben statt wie sonst nach unten gekrümmt sind. Weist, könnte man fragen, diese so vereinzelt stehende Eigenthümlichkeit nicht, im Sinne der Darwin'schen Lehre, auf gemeinsame Ererbung hin? Verlangt sie nicht, dass man einerseits als Kinder gleicher Stammeltern Mysis mit den Asseln, andererseits die übrigen Podophthalmen mit den Amphipoden vereinige? - Ich denke nein. - Nur für denjenigen, der eine Eigenthümlichkeit um desswillen höher werthet, weil sie in früherer Zeit des Eilebens auftritt, besteht eine solche Nöthigung. Wer die Arten nicht als unabhängig und unveränderlich erschaffen, sondern als allmählich geworden ansieht, wird sich sagen, dass, als die Vorfahren unserer Mysis, wahrscheinlich viel später als die der Amphipoden und Asseln, dazu kamen, schon als Embryonen zahlreiche Leibesringe und Gliedmassen zu entwickeln, als sie nun gerade ausgestreckt im

I) Ich darf nicht unterlassen $z u$ bemerken, dass das über die Entwicklung der Krabben Gesagte, eigentlich nur für die von Alph. Milne Edwards als Eustomés zusammengefassten Gruppen der Cyclometopa, Catometopa und Oxyrhyncha gilt. Aus der Gruppe der Oxystomata, so wie der den Krabben nahe stehenden Anomura apterura Edw. sind mir von keiner Art' die frühesten Jugendzustände bekannt geworden. 
Eie nicht mehr Platz fanden und sich daher krümmen mussten, diess eben nur entweder abwärts oder aufwärts geschehen konnte, und dass, welche Umstände auch für die eingeschlagene Richtung entscheidend sein mochten, dabei schwerlich eine nähere verwandtschaftliche Beziehung zu einer der beiden Edriophthalmenordnungen im Spiele war.

Die verschiedene Krümmung des Embryo bei Amphipoden und Asseln ist, das sei hier noch bemerkt, insofern belehrend. als sie beweist, dass die heutige Entwicklungsweise erst nach der Scheidung dieser Ordnungen sich bildete, dass bei dem Urstamme der Edriophthalmen die Embryonen, wenn nicht Nauplius, so doch noch kurzleibig genug waren, um wie die von der Naupliushaut umschlossenen Achthereslarven, gerade ausgestreckt im Eie Platz zu finden. Andererseits zeugt die innerhalb jeder der beiden Ordnungen herrschende Gleichförmigkeit der Entwicklung, die sich bei den Amphipoden z. B. in der Bildung des ,Mikropylapparates", bei den Asseln im Mangel des letzten Paares der Gangfüsse ausspricht, dafür, dass die heutige Entwicklungsweise aus sehr früher Zeit herrührt und bis vor die Trennung der jetzigen Familien zurückreicht. Auch in diesen beiden Ordnungen darf man wie bei den Krabben kaum Spuren früherer Jugendzustände zu finden hoffen, es sei denn in der Familie der Scheerenasseln ${ }^{1}$ \%. Man führe mir einen Amphipoden, eine Assel mit Naupliusbrut vor, deren Bestehen doch bei unabhängig entstandenen Arten nicht auffallender sein würde, als das einer Garneele mit Naupliusbrut, und ich gebe die ganze Darwin'sche Lehre verloren.

Wenn wir bei den Krabben und ebenso bei Asseln und Amphipoden zu der Annahme geführt wurden, dass um die Zeit, wo diese Gruppen von dem gemeinsamen Stamme sich lösten, zugleich eine Vereinfachung ihres Entwicklungsganges stattfand, so erscheint auch dies von Darwin's Lehre aus begreiflich. Wenn irgendwelche einer Thiergruppe günstige Umstände eine weitere Ausbreitung derselben, ein Auseinandergehen in neue verschiedenen Lebensverhältnissen sich anpassende Formen veranlassten, so wird einmal schon diese grössere Veränderlichkeit, die eben in der Bildung neuer Formen sich kundgibt, auch die fast immer vortheilhafte Vereinfachung der Entwicklung begünstigen und es wird ausserdem gerade jetzt, bei dem Einleben in neue Verhältnisse, wie oben in Betreff der Süsswasserthiere angedeutet wurde, diese Vereinfachung doppelt vortheilhaft sein und daher in dieser Beziehung eine doppelt strenge Auslese stattfinden.

Soviel über die Entwicklung der höheren Kruster.

Eines näheren Eingehens in die Entwicklungsgeschichte der niederen Kruster bedarf es nicht nach dem, was im Allgemeinen über die geschichtliche Bedeutung der Jugendzustände gesagt, und nach der Anwendung, die davon eben auf die Malacostraca gemacht wurde. Man sieht ohne Weiteres, wie die von Claus gegebene Schilderung der Copepodenentwicklung fast Wort für Wort als Urgeschichte dieser Thiere gelten kann, man findet in der Naupliushaut der Achthereslarven,

I) Ob der Mangel der Hinterleibsfüsse bei den jungen Tanais ein Erbstück aus der Zeit der Urassel, oder eine später erworbene Eigenthümlichkeit ist, was mir für jetzt annehmbarer scheint, wird sich vielleicht mit einiger Sicherheit entscheiden lassen, wenn man Entwicklung und Lebensweise der Familiengenossen, Apseudes und Rhoea, kennen gelernt hat. Letztere ist bekanntlich die einzige Assel, die noch eine Nebengeissel an den vorderen Fühlern besitzt.

Fritz M üllers gesammelte Schriften. 
in der eiähnlichen Larve von Cryptophialus ganz ähnliche Spuren eines Uebergangs zu directer Entwicklung, wie sie schon die Naupliushülle der Mysisembryonen und die madenförmige Larve der Ligia zeigten, u. s. w.

Es genüge, auf einen wesentlichen Unterschied im Entwicklungsgange der höheren und niederen Kruster hinzuweisen. Bei letzteren werden alle neuen Leibesringe und Gliedmassen, die sich zwischen die Endabschnitte des Naupliusleibes einschieben, in ununterbrochener Folge von vorn nach hinten gebildet; bei ersteren tritt noch einmal eine Neubildung in der Mitte des Leeibes auf, der Mittelleib, der sich auf ähnliche Weise zwischen Vorderleib und Hinterleib drängt, wie diese ihrerseits zwischen Kopf und Schwanz des Nauplius. - Was schon die Vergleichung der Gliedmassen der erwachsenen Thiere wahrscheinlich macht, findet also in der Entwicklungsgeschichte eine neue Stütze, dass nämlich den niederen Krustern, ebenso wie den Insecten, ein dem Mittelleibe der Malacostraca entsprechender Leibesabschnitt völlig abgeht. Dass die Schwimmfüsse der Copepoden, sowie der Puppen von Rankenfüssern und Wurzelkrebsen den Hinterleibsfüssen der Malacostraca entsprechen, d. h. mit ihnen aus gleicher Quelle durch Ererbung sich ableiten, ist wahrscheinlich.

Es wäre leicht, die einzelnen Fäden, welche die Jugendformen der verschiedenen Kruster liefern, zu einem Gesammtbilde der Urgeschichte dieser Klasse $\mathrm{zu}$ verweben. Ein solches Gemälde, mit einigem Geschick angelegt und in frischen Farben ausgeführt, würde sicher mehr Anziehendes haben, als die trockenen Erörterungen, die ich an die Entwicklungsgeschichte dieser Thiere knüpfte. Noch aber wäre die Verschürzung der losen Fäden vielfach eine willkürliche, mit gleichem Rechte so oder so auszuführen; noch wäre manche Lücke nur durch mehr oder minder gewagte Voraussetzungen auszufüllen. Minder auf diesem Gebiete Bewanderte würden dann leicht auch da auf sicherem Boden zu wandeln glauben, wo nur die Phantasie eine luftige Brücke geschlagen; Kenner dagegen würden bald diese schwachen Stellen des Baues herausfinden, aber dann leicht auch das als in der Luft schwebend ansehen, was auf wohlerwogene Thatsachen gebaut wurde. Diesen Missdeutungen seines wirklichen Gehaltes nach einer und der anderen Seite vorzubeugen, wäre es nöthig, ein solches Bild fortlaufend mit langen dürren Erläuterungen zu begleiten. Das hat mich abgehalten, die Umrisse, die ich schon entworfen hatte, weiter auszumalen ${ }^{1}$ ).

Bei dem äussersten, am weitesten in die nebelgraue Urzeit zurückweichenden Vorposten der Klasse, dem Nauplius, angelangt, blickt man sich natürlich um, ob von da aus nicht Wege zu erspähen sind nach anderen naheliegenden Gebieten. Man könnte mit Oscar Schmidt bei der Hinterleibsbildung der Nauplius an die bewegliche Schwanzgabel der Räderthiere erinnern, in denen ja Manche überhaupt nahe Verwandte der Kruster, oder doch der Arthropoden erkennen wollen; man könnte bei den sechs den Mund umstehenden Füssen an einen ursprünglich strahligen Bau denken, u. s. w. Sicheres vermag ich nicht zu sehen. - Selbst nach den näher liegenden Gebieten der Tausendfüsse und der Spinnen finde ich keine Brücke. Nur für die Insecten bietet vielleicht die Entwicklung der Malacostraca einen Anknüpfungspunct. Wie manche Zoëa besitzen die Insecten drei

1) Zusatz aus der englischen Uebersetzung des Buches am Ende dieser Arbeit. Der Herausgeber. 
Paar der Nahrungsaufnahme, drei Paar der Bewegung dienende Gliedmassen; wie die Zoëa, haben sie einen anhanglosen Hinterleib; wie bei allen Zoëa, entbehren bei allen Insecten die Kinnbacken des Tasters. Allerdings des Gremeinsamen wenig, bei dem Vielen, was diese beiden Thierformen unterscheidet. Immerhin mag die Vermuthung, dass die Insecten ihren gemeinsamen Stammvater in einer Zoëa hatten, die sich zum Leben auf dem Lande erhob, weiterer Prüfung empfohlen sein.

Manches in den obigen Aufstellungen mag verfehlt sein, manche Deutung misslungen, manche Thatsache nicht ins rechte Licht gestellt. Eines aber, hoffe ich, soll mir gelungen sein, - unbefangene Leser zu überzeugen, dass wirklich Darwin's Lehre, wie für so viele andere ohne sie unerklärbare Thatsachen, so auch für die Entwicklungsgeschichte der Kruster den Schlüssel des Verständnisses bietet. Die Mängel also dieses Versuches wolle man nicht dem von der sicheren Hand des Meisters vorgezeichneten Plane, man wolle sie einzig dem Ungeschick des Handlangers zur Last legen, der nicht für jedes Werkstück die rechte Stelle zu finden verstand.

In der Vorrede der englischen Uebersetzung des Buches „Für Darwin“, welche von W. S. Dallas F. L. S., London bei John Murray I 869 besorgt wurde, sagt der Uebersetzer, es seien ihm von Fritz Müller mehrere Verbesserungen und Zusätze zu der Arbeit geliefert worden. Die Verbesserungen, welche sich auf Druckfehler und falsche Stellung der Figuren bezogen, sind in dem vorliegenden Abdruck ohne weiteres berücksichtigt. Die Zusätze finden sich an den S. 252 und $25^{8}$ angemerkten Stellen und lauten:

\section{Zu S. 252 :}

I will here briefly give my reasons for the opinion that the socalled "complete metamorphosis" of Insects, in which these animals quit the egg as grubs or caterpillars, and afterwards become quiescent pupa incapable of feeding, was not inherited from the primitive ancestor of all Insects, but acquired at a later period.

The order Orthoptera, including the Pseudoneuroptera (Ephemera, Libellula, \&c.) appears to approach nearest to the primitive form of Insects. In favour of this view we have:-

I, The structure of their buccal organs, especially the formation of the labium, "which retains, either perfectly or approximately, the original form of a second pair of maxillæ" (Gerstäcker).

2. The segmentation of the abdomen; "like the labium, the abdomen also very generally retains its original segmentation, which is shown in the development of eleven segments" (Gerstäcker). The Orthoptera with eleven segments in the abdomen, agree perfectly in the number of their body-segments with the Prawnlarva represented in fig. 33. or indeed, with the higher Crustacea (Podophthalma and Edriophthalma) in general, in which the historically youngest last thoracic segment (see XII), which is sometimes late-developed, or destitute of appendages, or even deficient, is still wanting. 
3. That, as in the Crustacea, the sexual orifice and anus are placed upon different segments; "whilst the former is situated in the ninth segment, the latter occurs in the eleventh" (Gerstäcker).

4. Their palæontological occurrence; "in a fossil state the Orthoptera make their appearance the earliest of all Insects, namely as early as the Carboniferous formation, in which they exceed all others in number" (Gerstäcker).

5. The absence of uniformity of habit at the present day in an order so small when compared with the Coleoptera, Hymenoptera, \&c. For this also is usually a phenomenon characteristic of very ancient groups of forms which have already overstepped the climax of their development, and is explicable by extinction in mass. A Beetle or a Butterfly is to be recognised as such at the first glance, but only a thorough investigation can demonstrate the mutual relationships of Termes, Blatta, Mantis, Forficula, Ephemera, Libellula, \&c. I may refer to a corresponding remarkable example from the vegetable world: amongst Ferns the genera Aneimia, Schizac and Lygodium, belonging to the group Schizceacece which is very poor in species, differ much more from each other than any two forms of the group Polypodiacea which numbers its thousands of species.

If, from all this, it seems right to regard the Orthoptera as the order of Insects approaching most nearly to the common primitive form, we must also expect that their mode of development will agree better with that of the primitive form, than, for example, that of the Lepidoptera, in the same way that some of the Prawns (Penëus) approaching most closely the primitive form of the Decapoda, have most truly preserved their original mode of development. Now, the majority of the Orthoptera quit the egg in a form which is distinguished from that of the adult Insect almost solely by the want of wings; these larvæ then soon acquire rudiments of wings, which appear more strongly developed after every moult. Even this perfectly gradual transition from the youngest larva to the sexually mature insect, preserves in a far higher degree the picture of an original mode of development, than does the so-called complete metamorphosis of the Coleoptera, Lepidoptera, or Diptera, with its abruptly separated larva-, pupa- and imago-states.

The most ancient Insects would probably have most resembled these wingless larvæ of the existing Orthoptera. The circumstance that there are still numerous wingless species among the Orthoptera, and that some of these (Blattidre) are so like certain Crustacea (Isopods) in habit that both are indicated by the same name ("Baratta") by the people in this country, can scarcely be regarded as of any importance.

The contrary supposition that the oldest Insects possessed a "complete metamorphosis", and that the "incomplete metamorphosis" of the Orthoptera and Hemiptera is only of later origin, is met by serious difficulties. If all the classes of Arthropoda (Crustacea, Insecta, Myriopoda and Arachnida) are indeed all branches of a common stem (and of this there can scarcely be a doubt), it is evident that the water-inhabiting and water-breathing Crustacea must be regarded as the original stem from which the other terrestrial classes, with their tracheal respiration, have branched off. But nowhere among the Crustacea is there a mode of development comparable to the "complete metamorphosis" of the Insecta, nowhere among the young or adult Crustacea are there forms which might resemble the 
maggots of the Diptera or Hymenoptera, the larva of the Coleoptera, or the caterpillars of the Lepidoptera, still less any bearing even a distant resemblance to the quiescent pupæ of these animals. The pupæ, indeed, cannot at all be regarded as members of an original developmental series, the individual stages of which represent permanent ancestral states, for an animal like the mouthless and footless pupa of the Silkworm, enclosed by a thick cocoon, can never have formed the final, sexually mature state of an Arthropod.

In the development of the Insecta we never see new segments added to those already present in the youngest larvæ, but we do see segments which were distinct in the larva afterwards become fused together or disappear. Considering the parallelism which prevails throughout organic nature between palæontological and embryonic development, it is therefore improbable that the oldest Insects should have possessed fewer segments than some of their descendants. But the larvæ of the Coleoptera, Lepidoptera, \&c., never have more than nine abdominal segments, it is therefore not probable that they represent the original young form of the oldest Insects, and that the Orthoptera, with an abdomen of eleven segments, should have been subsequently developed from them.

Taking into consideration on the one hand these difficulties, and on the other the arguments which indicate the Orthoptera as the order most nearly approaching the primitive form, it is my opinion that the "incomplete metamorphosis" of the Orthoptera is the primitive one, inherited from the original parents of all Insects, and the "complete metamorphosis" of the Coleoptera, Diptera, \&c., a subsequently acquired one.

Zu S. 258 :

I will only give, as an example, the probable history of the production of a single group of Crustacea, and indeed of the most abnormal of all, the Rhizocephala, which in the sexually mature state differ so enormously even from their nearest allies, the Cirripedia, and from their peculiar mode of nourishment stand quite alone in the entire animal kingdom.

I must preface this with a few words upon the homology of the roots of the Rhizocephala, i.e. the tubules which penetrate from its point of adhesion into the body of the host, ramify amongst the viscera of the latter, and terminate in creal branchlets. In the pupæ of the Rhizocephala (fig. 58) the foremost limbs ("prehensile antennæ") bear, on each of the two terminal joints, a tongue-like, thinskinned appendage, in which we may generally observe a few small strongly refractive granules, like those seen in the roots of the adult animal. I have therefore supposed these appendages to be the rudiments of the future roots. A perfectly similar appendage, "a most delicate tube or ribbon", was found by Darwin in free-swimming pupæ of Lepas australis on the last joints of the "prehensile antennæ". From the perfect accordance in their entire structure shown by the pupæ of the Rhizocephala and Cirripedia, there can be no doubt that the appendages of Sacculina and Lepas, which are so like each other and spring from the same spot, are homologous structures.

Now in three species of Lepas, in Dichelaspis Warvickii and in Scalpellum Peronii, Darwin saw, on tearing recently-affixed animals from their point or support, that a long narrow band issued from the same point of the antenne; 
its end was torn away, and in Dichelaspis, judging from its ragged appearance, it had attached itself firmly to the support. From this it follows that this appendage in Lepas australis can hardly be anything but a young cement-duct. If, therefore. the supposition that the appendages on the antennæe of the pupæe of Rhizocephala are young roots be correct, the roots of the Rhizocephala are homologous with the cement-ducts of the Cirripedia. And this, strange as it may appear at the first glance, seems to me scarcely doubtful. It is true that the act of adhesion of the Rhizocephala has never yet been observed, but it is more than probable that they attach themselves, just like the Cirripedia, by means of the antennæ, and that therefore the points of attachment in the two groups indicate homologous parts of the body. From the point of attachment in the Rhizocephala the roots penetrate into the body of the host, whilst in the Cirripedia, the cementducts issue from the same point. The roots are blind tubes, ramified in different species. The cement-ducts in the basis of the Balanidæe likewise contitute a generally remarkably complicated system of ramified tubes, with regard to the mode of termination of which nothing certain has yet been made out. Individual cæcal branches are not unfrequently seen even in the vicinity of the carina; and, at least in some species, in which the cement-ducts divide into extremely numerous and fine branchlets, forming a network which gradually becomes denser towards the circumference of the basis, these seem nowhere to possess an orifice.

Now as to the question: How were Cirripedia converted by natural selection into Rhizocephala?

A considerable number of existing Cirripedia settle exclusively or chiefly upon living animals; - on Sponges, Corals, Mollusks, Cetaceans, Turtles, SeaSnakes, Sharks, Crustaceans, Sea Urchins, and even on Acalephs. Dichelaspis Darwinii was found by Filippi in the branchial cavity of Palinurus vulgaris, and I have met with another species of the same genus in the branchial cavity of Lupea diacantha.

The same thing may have taken place in primitive times. The supposition that certain Cirripedes might once upon a time have selected the soft ventral surface of a Crab, Porcellana or Pagurus, for its dwelling-place, has certainly nothing improbable about it. If then the cement-ducts of such a Cirripede instead of merely spreading on the surface, pierced or pushed before them the soft ventral skin and penetrated into the interior of the host, this must have been beneficial to the animal, because it would be thereby more securely attached and protected from being thrown off during the moulting of its host. Variations in this direction were preserved as advantageous.

But as soon as the cement-ducts penetrated into the body-cavity of the host and were bathed by its fluids, an endosmotic interchange must necessarily have been set up between the materials dissolved in these fluids and in the contents of the cement-ducts, and this interchange could not be without influence upon the nourishment of the parasite. The new source of nourishment opened up in this manner was, as constantly flowing, more certain than that offered by the nourishment accidentally whirled into the mouth of the sedentary animal. The individuals favoured in the development of the cement-ducts now converted into nutriferous roots, had more than others the prospect of abundant food, of vigorous 
growth, and of producing a numerous progeny. With the further development, assisted by natural selection, of the roots embracing the intestine of the host and spreading amongst its hepatic tubes, the introduction of nourishment through the mouth and all the parts implicated in it, such as the whirling cirri, the buccal organs, and the intestine, gradually lost their importance, became aborted by disuse, and finally disappeared without leaving a trace of their existence. Protected by the abdomen of the Crab, or by the shell inhabited by the Pagurus, the parasite also no longer required the calcareous test, in which, no doubt, the first Cirripedes settling upon these Decapods rejoiced. This protective covering, having become superfluous, also disappeared, and there remained at last only a soft sack filled with eggs, without limbs, without mouth or alimentary canal, and nourished, like a plant, by means of roots, which it pushed into the body of its host. The Cirripede had become a Rhizocephalon.

If it be desired to form a notion of what our parasite may have looked like when half way in its progress from the one form to the other, we may consult the figures given by Darwin (Lepadidæ PI. IV., figs. I-7) of Anelasma squalicola. This Lepadide, which lives upon Sharks in the North Sea, seems, in fact, to be in the best way to lose its cirri and buccal organs in the same manner. The widelycleft, shell-less test is supported upon a thick peduncle, which is immersed in the skin of the Shark. The surface of the peduncle is beset with much-ramified, hollow filaments, wich "penetrate the Shark's flesh like roots" (Darwin). Darwin looked in vain for cement-glands and cement. It seems to me hardly doubtful, that the ramified hollow filaments are themselves nothing but the cements-ructs converted into nutritive roots, and that it is just in consequence of the development of this new source of nourishment, that the cirri and buccal organs are in the highest degree aborted. All the parts of the mouth are extremely minute; the palpi and exterior maxillæ have almost disappeared; the cirri are thick, inarticulate, and destitute of bristles; and the muscles both of the mouth and cirri are without transverse striation. Darwin found the stomach perfectly empty in the animal examined by him. 


\title{
Description of a new Genus of Amphipod Crustacea ${ }^{1}$ ).
} Batea, nov. gen.

\author{
Mit Tafel XXV.
}

Antennæ simple. Coxæ of the first pair of gnathopoda rudimentary, those of the second pair of gnathopoda and the first two pair of pereiopoda largely developed. Coxæ of the second pair of pereiopoda deeply excavated upon the upper part of the posterior margin. First pair of gnathopoda rudimentary, consisting of coxa and basis only; second pair of gnathopoda subchelate. Mandibles having an articulated appendage. Maxillipeds having a squamiform plate on both the basis and ischium joints. Fourth and fifth pairs of pleopoda with styliform rami, sixth pair with subfoliaceous rami. Telson single, deeply cleft.

Species Batea catharinensis, F. M.

I will here add some remarks on the sexual differences of this interesting species. The pereion is somewhat longer and higher in the female; the antennae of the same are shorter. The first joint of the peduncle of the upper antennæ has three, the second four fasciculi of hairs on the inferior side in the male; they are wanting in the female. The long setæ at the extremity of the alternate articles of the flagellum of the first antennæ are directed downwards in the female, backwards in the male. The third and fourth joints of the peduncle of the lower antennæ have fasciculi of short hairs on their upper sides in the male, which are wanting in the female. (The eyes are larger in the male.) The flagellum of the lower antennæ has long upward-directed setæ at the extremities of alternate joints in the female, which do not exist in the male. The first pair of gnathopoda are shorter in the male, with but few hairs near the top; they are as long as the basis of the second pair of gnathopoda in the female, slender, flexible, with long hairs on the anterior margin, and shorter curved hairs at the distal extremity. The coxæ of the second pair of gnathopoda are much higher in the female. The first two

I) Annals and Magazine of natural History 1865. p. 276-277. Plate X. 
pairs of pereiopoda have the carpus and propodos fringed with long hairs at the posterior margin; these hairs are wanting in the female.

Desterro, Brazil, Oct. Io, 1864.

\section{Erklärung der Abbildungen auf Tafel XXV.}

Fig. I. Batea catharinensis, male: $b$, superior antennæ; $g$, maxilliped; $h$, first gnathopod; $h^{1}$, coxa; $h^{2}$, basis; $i$, second gnathopod; $q$, second pleopod; $r$, third ditto; $s$, fourth ditto; $l$, fifth ditto; 7 , posterior pleopod; $z$, telson. 


\section{Ueber Cumaceen ${ }^{1}$ ).}

Beleuchtung der Abhandlung Van Beneden's²) über diese Familie.

Kröyer ${ }^{3}$ ) stellte $\mathrm{s} 846$ die Familie der $\mathrm{Cumaceen}$ auf und schilderte ihren Bau in meisterhafter Weise. Als ich I 857 einige Thiere dieser Familie untersuchte, fand ich, dass Kröyer wie gewöhnlich seinen Nachfolgern nur eine dürftige Nachlese übrig gelassen hatte und hielt desshalb die Mittheilung meiner Beobachtungen für überflüssig. Indessen scheint über der Naturgeschichte der Cumaceen ein eigener Unstern zu walten. Nachdem Goodsir ${ }^{4}$ ) Bruttasche und Eier der Weibchen gesehen, nachdem Kröy er Junge der Bruttasche entnommen und sorgfältig die Unterschiede zwischen Männchen und Weibchen erörtert, hat dennoch Agassiz in den Cumaceen Garneelenlarven finden wollen und unbegreiflicherweise haben die beiden bedeutendsten Forscher auf diesem Gebiete, H. Milne Edwards und Dana der nicht näher begründeten Vermuthung von Agassiz mehr Gewicht beigemessen als den bestimmten unzweideutigen Angaben von Goodsir und Kröyer. Und nachdem Kröyer eine musterhafte Darstellung des Baues und namentlich auch der nicht eben leicht zu entwirrenden Mundtheile gegeben, ist neuerdings $\mathrm{V}$ an Beneden mit einer durchaus verfehlten Auffassung dieser Verhältnisse hervorgetreten und unbegreiflicherweise hat wieder ein Forscher, der eben so scharf zu beobachten als umsichtig die Arbeiten seiner Vorgänger zu würdigen versteht, $\mathrm{C} 1 \mathrm{aus} \mathrm{u}^{5}$ ), der oberflächlichen Darstellung V a n Beneden's den Vorzug gegeben vor der gründlichen Arbeit Kröyer's, des anerkannten Meisters in carcinologischen Untersuchungen. Somit ist, was I857 überflüssig erscheinen musste, I 86 + wieder Bedürfniss geworden, eine erneute eingrehende Schilderung des Baues der Cumaceen. Ich will jedoch diese Schilderung verschieben, bis es mir gelungen ist, die mir bekannt gewordenen Bruchstücke aus der Entwicklungsgeschichte der Cumaceen zu einem einigermassen vollständişen Bilde zu ergänzen, und beschränke mich für jetzt auf eine Beleuchtung der

1) Archiv für Naturgeschichte 1865. I. p. 31I-323.

2) Van Beneden, Recherches sur la faune littorale de Belgique. Crustacés. 186I. S. 7I-87. L.es Cumadés.

3) Kröyer, Naturhistorisk Tidsskrift. Ny Raekke. II. Bd. S. 203-206.

4) Goodsir in Edinburgh New. Philos. Journal I843, und daraus in Bell British Stalk-cyed Crustacea P. $321-333$.

5) Claus, Die freilebenden Copepoden 1843. S. I8. 
Abhandlung Van Beneden's. Es ist hohe Zeit, einer noch weiteren Verbreitung der darin gehäuften Irrthümer vorzubeugen und die älteren richtigen Angaben wieder in ihr Recht einzusetzen.

V. B. beginnt scine Abhandlung mit einer geschichtlichen Einleitung; es wird darin über Kröyer's Aufsatz gesagt, dass er diese Thiere mit der alle seine Arbeiten bezeichnenden Sorgfalt untersuchte (a. a. O. S. 73), und an einer anderen Stelle seiner Abhandlung (S. 78) wiederholt V. B., dass Kröyer diese Kruster mit Sorgfalt und mit vollständiger Kenntniss ihres Baues beschrieben habe. Wer die Cumaceen kennt, wird diesem Urtheile freudig zustimmen; aber es nimmt sich äusserst sonderbar aus in Munde V. B.'s, der, wie wir sehen werden, alle nicht beim ersten flüchtigen Blicke ins Auge fallenden Verhältnisse, die Mundtheile, die Athemwerkzeuge, die Geschlechtsunterschiede u.s. w., in durchaus von K röy er abweichender Weise darstellt und zwar ohne je auch nur mit einem Worte dieser Verschiedenheit zwischen seiner und Kröyer's Darstellung zu gedenken. Dies ist ein erster schwerer Vorwurf, der der Abhandlung V. B.'s gemacht werden muss. Kröyer's Arbeiten sind stets mit so peinlicher Grewissenhaftigkeit abgefasst, dass jeder ernste Forscher es für seine Pflicht halten wird, alle Punkte der eingehendsten Erörterung zu unterzichen, bei denen er sich von Kröyer abzuweichen genöthigt sieht. Fühlt V. B. sich so hoch über $\mathrm{Kr}$ öyer erhaben, dass er erwartet ohne Weiteres seine eigenen Angaben denen des bewährten dänischen Forschers vorgezogen zu sehen? Oder ist er sich der Unterschiede zwischen seiner und Kröyer's Darstellung gar nicht bewusst geworden? Hat er in derselben flüchtigen Weise, in der er seine Beobachtungen angestellt, auch die Arbeiten seiner Vorgänger gelesen?

Wie Kröyer wird auch Spence Bate behandelt. Derselbe hatte ausgesprochen, wie V. B. in seiner geschichtlichen Einleitung (S. 74) berichtet, dass in der Form der Kinnbacken ${ }^{1}$ ) die Cumaceen sich den Amphipoden nähern. V. B. selbst findet dagegen, dass die Kinnbacken der Cumaceen viel von denen der Mysis haben (S. 87); aber wieder hält er es nicht der Mühe werth, auch nur mit einem Worte seine Auffassung der jenes gründlichen Amphipodenkenners gegenüber zu begründen ${ }^{2}$ ).

I) Mit Kröyer übersetze ich mandibulae durch Kinnbacken, maxillae durch Kiefer.

2) Das merkwürdigste Beispiel der harmlosen Selbstgenügsamkeit, die sich in diesem Vcrfahren ausspricht, bietet in derselben Sammlung carcinologischer Aufsätze der die Gattung Naupridia (oder wie V. B. schreibt, Naupredia) betreffende Abschnitt (a. a. O. p. 96). Diese Gattung war bekanntlich von Latreille aufgestellt worden für Caprelliden, die fünf Paar Füsse in ununterbrochener Reihe und eine Kiemse an Grunde des 2ten, 3ten und 4ten Paares haben sollten. Danach hatte man wohl mit Recht vermuthet, dass es sich um Thiere der Gattung Proto Leach (Leptomera Latr.) handle, die zufällig ihre letzten beiden Fusspaare verloren hatten. Dem gegenüber meint V. B.: „ll est inutile de faire remarquer que des carcinologistes ont eu tort de supposer que ces Naupredia ne sont que des Leptomera mutilés; ce sont bien des crustacés complets." Zum Beweise folgt dann eine Beschreibung, die vollständig auf eine Leptomera passen würde, der die letzten beiden Fusspaare fehlen, und die also nur zur Stïtze der von V. B. bekämpften oder vielmehr nicht einmal des Bekämpfens werth gehaltencn Ansicht dienen kann, und zum Schlusse heisst es dann: „on est très-disposé, en les voyant, à les prendre pour des Caprella nutilés; ... . ce sont cependant bien comme nous venons de le voir, des animaux entiers“. Natïrlich: V. B. sagt es; das muss genügen. Daher kein Wort über die Merkmale, durch die man eine Naupridia von ciner verstümmelten Proto unterscheiden könnte; kein Wort über die Merkmale, die ausser dem Mangel zweier Fusspaare die Gattung kennzeichnen sollen; cs muss genügen, dass V. B. das Bcstehen solcher 
Der geschichtlichen Einleitung folgt die Beschreibung dreier von V. B. an der belgischen Küste beobachteten Arten. Zwei derselben, Bodotria Goodsirii und Leucon cercaria werden als neu betrachtet, die dritte als Cuma Rathkii Kr. bestimmt. Vergleicht man nun Beschreibung und Abbildung mit Kröyer's Diagnose, so findet man nicht eines der für diese Art besonders bezeichnenden Merkmale erwähnt oder gezeichnet, weder die gezähnelten Längsleisten des Panzers, noch die sägeartige Bewaffnung oder den grossen („maximum validumque“ $\mathrm{Kr}$.) dornartigen Fortsatz am Hinterrande des letzten Brustringes, noch die Verbreiterung am Ende des Grundgliedes der vom ersten freien Ringe entspringenden Füsse, noch endlich die dreizehn Paare seitlicher Dornen am mittleren Schwanzanhange. Und doch müssten alle diese Verhältnisse, wie ich nach Untersuchung einer nahestehenden Art behaupten darf, bei der von V. B. angewandten Vergrösserung deutlich hervortreten. Dagegen sagt V. B. ausdrücklich, dass man zwischen den drei letzten Ringen der Brust keine anderen als Grössenunterschiede sehe, und dass der mittlere Schwanzanhang leicht gezähnelt, aber borstenlos sei. Doch will ich trotz alledem nicht behaupten, dass die Art V. B.'s doch nicht die Cuma Rathkii Kr. sein könne; denn man darf sich nicht allzusehr auf V. B.'s Zeichnungen und Beschreibungen verlassen ${ }^{1}$ ).

$\mathrm{Zu}$ den einzelnen Angaben der Abhandlung übergehend beginne ich mit einem Punkte, in Betreff dessen die beiden ersten Beobachter, welche mehrere Arten von Cumaceen zu untersuchen Gelegenheit hatten, sich widersprechen. Goodsir schreibt denselben kleine paarige Augen zu, die so dicht beisammen stehen, dass das Thier auf den ersten Blick einäugig erscheint; dabei werden sie, - ob in Folge eines Druckfehlers? - "gestielt, aber sitzend“" 2) genannt. Kröyer bezeichnet die Cumaceen als augenlos. Ich finde bei meinen Arten ein unpaares Auge mit bisweilen sehr ansehnlichen Linsen, so dass also Goodsir's Angaben (von der sich selbst widersprechenden Bezeichnung: "gestielt, aber sitzend" abgesehen) im Wesentlichen richtig sind; denn zwischen zwei bis zu anscheinender Einäugigkeit genäherten Augen und einem einzigen Auge mit paarig angeordneten Linsen ist kein grosser Unterschied. Dass Kröyer die Augen übersah, erklärt sich, wenn sie nicht seinen Arten wirklich fehlen, wohl aus deren blasser Färbung

Merkmale behauptet, dass er sagt: „qu'on pourra joindre divers caractères également importants à ceux que ce savant (Latreille) leur a attribués déjà". - Ich stimme Spence Bate bei (Catalogue of Amphipod. Crustac. p. 382), der die Naupridia tristis V. B. für eine verstümmelte Proto pedata Leach erklärt. Eines muss jedoch anerkannt werden: der Name Naupridia tristis ist vortrefflich gewählt; V. B.'s Aufsatz ist ein trauriges Beispiel der traurigen Ergebnisse, die nur beilüufige Ausflüge in Gebiete, auf denen man nicht heimisch ist, zu liefern pflegen.

I) ,Il est prudent de ne pas trop s'en rapporter au dessin et aux descriptions“ sagt V. B. (S. 77) in Bezug auf Cyrianassa gracilis Sp. B. - Bei V. B.'s eigenen carcinologischen Arbeiten ist solche Vorsicht gewiss an der Stelle. Den trefflichen Spence Bate aber halte ich für Pflicht gegen diesen halben Vorwurf der Unzuverlässigkeit in Schutz zu nehmen. Ich habe bei Bestimmung von gegen 50 Amphipoden unseres Meeres in Spence Bate's Catalogue of Amphipod. Crustacea mindestens die dreifache Zahl von Abbildungen und Beschreibungen nahestehender Arten genau verglichen und mich überzeugt, dass dieser der Wissenschaft so früh entrissene englische Forscher meisterhaft verstand, selbst in kurzen Beschreibungen wirklich bezeichnende Arteigenthümlichkeiten scharf hervorzuheben und sie treu in seinen Zeichnungen wiederzugeben, und dass, einzelne Irrthümer abgerechnet, denen der Beste nicht entgeht, seine $\Lambda$ bbildungen und Beschreibungen als durchaus zuverlässig bezeichnet werden dürfen.

2) „,pedunculated, but sessile" s. Bell, Brit. Stalk-eyed Crustacea S. 323. 
bei den eigentlichen Cuma ${ }^{2}$. V. B. leugnet nun richtig das Vorhandensein gestielter Augen (S. 79) und sagt, dass die Cumaceen sitzende Augen haben, wie die Edriophthalmen (S. 87); über die Beschaffenheit dieser Augen aber finclet sich in der Beschreibung von Cuma kein Wort, und bei Bodotria und Leucon sollen einige Pigmentflecken die Stelle des Auges vertreten. Die Dürftigkeit dieser Angaben, die weit hinter dem schon von Goodsir Gebotenen zurückbleiben, ist um so befremdlicher, da V. B. eine Bodotria untersuchte, bei welcher Gattung das dunkelgefärbte, an der äussersten Spitze des Körpers gelegene Auge dem ersten Blicke seine grossen Linsen zeigt, und da ihm in seinem Leucon cercaria eine so durchsichtige Art vorlag, wie sie noch keinem anderen Forscher zu Gebote gestanden hat. Die Abbildung, die V. B. von dem Augenflecken eines zerquetschten Thieres dieser Art giebt (P1. XIV. fig. 2), mag naturgetreu sein; nur ist für die Untersuchung eines Auges das Zerquetschen eben keine besonders empfehlenswerthe Methode.

In Betreff der F ühler ist hervorzuheben, dass V. B. (S. 86) an den hinteren Fühlern von Leucon ein e kleine Nebengeissel beschreibt, und deren sogar $z$ wei, die eine zweigliedrig, die andere ungegliedert zeichnet (Taf. XIV. fig. 2). Da nicht nur die übrigen Cumaceen, sondern überhaupt alle höheren Kruster im erwachsenen Zustande niemals mehr als einen gegliederten Anhang am zweiten Fühlerpaare tragen, würde das Vorkommen einer und mehr noch das ganz unerhörte Vorkommen zweier Nebengeisseln ein höchst merkwürdiger Umstand sein. Derselbe bedarf indess um so mehr der Bestätigung, da der Widerspruch zwischen Beschreibung und Abbildung kein günstiges Vorurtheil für die Zuverlässigkeit der einen wie der anderen erwecken kann.

Von den Kinnbacken seiner drei Arten giebt V. B. Abbildungen, die auch nicht die leiseste Aehnlichkeit mit einander haben und alle unvollständig und falsch sind. Wie Kröyer richtig angibt, sind die Kinnbacken der Cumaceen, verglichen mit denen anderer höherer Kruster, schlank („elongata angustata“ Kr.), mit starken Zähnen an der Spitze, einem sehr grossen Kaufortsatze und zwischen beiden mit einem Kamme starker Borsten oder Dornen (,pectine setoso“ Kr.) versehen. Bei Cuma hat nun V. B. den Borstenkamm weggelassen und von dem Uebrigen eine ziemlich verquetschte Ansicht gegeben, bei Bodotria nur den Borstenkamm und die Zähne der Spitze gezeichnet, und bei Leucon sind als Kinnbacken zwei plumpe Stummel dargestellt, die am Grunde zusammenstossen und anscheinend durch ein unpaares Stück verbunden sind, wahrscheinlich die Unterlippe des Thieres. Dass nicht nur bei Krustern und Insekten, dass ebenso bei Schnecken, bei Fischen, bei Säugethieren und wo sonst Kauwerkzeuge vorkommen, dieselben bei den Gliedern derselben natürlichen Familie übereinstimmend gebaut sind und dass deshalb wenigstens zwei seiner Abbildungen falsch sein müssen, scheint V. B. nicht in den Sinn gekommen zu sein. Sonst würde er entweder durch erneute Untersuchung übereinstimmende Bilder von den drei Arten zu erhalten gesucht, oder die völlige Verschiedenheit der Kinnbacken bei drei so nahe-

I) Spence Bate hat die Cumaceen richtig als einäugig erkannt, wie ich aus einem Briefe desselben weiss. Seine Abhandlung über diese Thiere habe ich nicht gesehen. - V. B. mag auch diese Arbeit S pence Bate's, obwohl er sein Urtheil darüber abgiebt, nur obenhin angesehen haben, da er seiner Darstellung der Augen nicht gedenkt. 
stehenden Arten als einen in seiner Art einzigen Fall hervorgehoben haben. Aber weder von dem einen noch ron dem anderen ein Wort im Texte, der noch dürftiger ist als selbst die Abbildungen. Die Kinnbacken der Cuma „haben nichts Merkwürdiges, als den Mangel eines Tasters" (S. 83); die von Bodotria ,.sind kurz und plump und ihre freie Spitze ist mit kleinen steifen Borsten besetzt" (S. So) und auch die von Leucon, ,haben nichts Besonderes, als ihre plumpe Form und ihre kurzen zum Kauen dienenden Borsten“ (S. 86).

Die beiden Kieferpa re, von Kröyer richtig beschrieben, sind bei Cuma und Leucon von V. B. vollständig übersehen worden; es werden als solche die beiden ersten Paare der Kieferfüsse beschrieben und abgebildet und zıvar der Abwechslung wegen als vorderer Kiefer bei Cuma (Taf. XII. fig. 4, $e$ ) der erste, bei Leucon (Taf. XIV. fig. 3, b) der zweite und als hinterer Kiefer bei Cuma (Taf. XII. fig. $4, f$ ) der zweite und bei Leucon (Taf. XIV. fig. 3, c) der erste Kieferfuss. Dass bei Leucon wirklich diese Umkehrung der natürlichen Reihenfolge stattgefunden, dass der (Taf. XIV. fig. 3, b) als vorderer Kiefer abgebildete und beschriebene Theil wirklich der zweite Kieferfuss sei, darüber lässt seine Grösse, die Länge des Grundgliedes und die für die Gattung Leucon bezeichnende Gliederzahl (sechs, bei Cuma fünf) keinen Zweifel. Dass (in Taf. XIV. fig. 3,c) statt fünf nur drei Glieder gezeichnet sind, verdient kaum besonderer Erwähnung, da solche Ungenauigkeiten zu häufig wiederkehren, um einzeln aufgezählt zu werden.

Dadurch, dass bei Cuma und Leucon die beiden Kieferpaare übersehen wurden, erhält natürlich V. B. (und Cla us hat sich diese Auffassung angeeignet) für die Cumaceen zwei Leibesringe weniger als für die übrigen Malacostraca und es bleiben ihm nur drei Paar eigentlicher Füsse.

Bei Bodotria wird die Sache noch hübscher. Zunächst versichert V. B. (S. 76), dass hier die Gesammtzahl der Anhänge des Cephalothorax dieselbe sei, wie bei den übrigen Cumaceen, also elf Paar nach V. B.; nur sei das dritte Paar der Kieferfüsse zu eigentlichen Füssen geworden und von letzteren daher ein Paar vorhanden. Weiterhin aber werden (S. 8o) zwei Paar Fühler, ein Paar Kinnbacken, zwei Paar Kiefer, drei Paar Kieferfüsse, ein Paar eigentlicher Füsse mit äusserem Aste und ein Paar einfacher Füsse aufgezählt, was denn doch wohl dreizehn und nicht elf Paar ausmacht. Aber es kommt noch besser! Trotzdem dass ein Paar eigentlicher Füsse mit äusserem Aste, und vier Paare ohne solchen Ast beschrieben werden, versichert V. B. wiederholt (S. 76 und S. 81), dass die Zahl der eigentlichen Füsse sich auf vier Paar beläuft; also eins und vier ist vier!!! - „il n’y a pas de doute à cet égard“, wie V. B. zur Beruhigung derer hinzusetzt, die die Richtigkeit dieser Rechnung bezweifeln möchten. - Ein weiteres IBeispiel seiner neuen Rechenkunst bietet uns V. B. in der Behauptung, dass der Panzer der Bodotria von 10 Ringen gebildet werde ${ }^{1}$ ), dass 4 freie Brustringe vorhanden seien, und dass der ganze Cephalothorax aus derselben Ringzahl wie bei Cuma, nämlich aus $1 \mathrm{I}$ Ringen bestehe; demnach wäre also $10+4=\mathrm{I} 1$.

W as bei Bodotria als Kiefer abgebildet wird (Taf. XIII. fig. 11, I2), mögen Bruchstücke dieser Anhänge oder auch der Kieferfüsse sein, die ich indess nicht

1) , Dix somites concourent a la formation de la carapace“ a. a. 0. S. 74. 
näher zu bestimmen vermag; der Text giebt in diesem Falle noch weniger Anhalt, als sonst, da es einfach heisst: „nous passons sous silence les deux paires de mâchoires". - Um die Verwirrung vollständig zu machen, steht die Erklärung der auf die Gliedmassen von Bodotria bezüglichen Abbildungen (S. 166 und Taf. XIII. fig. 10-15) in Widerspruch mit dem Texte. Die beiden ersten Paare der Kieferfüsse werden als sehr schlank und zart beschrieben und kein äusserer Ast derselben erwähnt; in der Abbildung sieht man dagegen äusserst ansehnliche, kräftige mit äusserem Aste versehene Gliedmassen (fig. I3 und I4). In der Erklärung der Abbildungen wird das zweite Paar der Kieferfüsse als letztes bezeichnet, im Texte ein drittes Kieferfusspaar beschrieben. Im Texte wird das erste eigentliche Fusspaar als zweiästig; dem dritten Kieferfusspaar durchaus ähnlich, aber bedeutend länger geschildert; in der Abbildung (fig. 15) sieht man einen einfachen Fuss kaum halb so lang, als die vorhergehenden Gliedmassen. - Bei näherer Vergleichung ergiebt sich, dass, was in Texte als drittes Paar der Kieferfüsse, erstes und zweites Paar der eigentlichen, in der Erklärung der Abbildungen als erstes und zweites Paar der Kieferfüsse und erstes Paar eigentlicher Füsse bezeichnet wird.

Eine ähnliche Sudelei ist natürlich in keiner Weise zu entschuldigen, aber sie erklärt sich leicht aus dem Umstande, für den diese und andere Abhandlungen desselben Werkes mannichfache Beläge liefern, dass V. B. seine Aufsätze aus einzelnen $\mathrm{zu}$ verschiedenen Zeiten abgefassten Theilen zusammengestückt und dabei sich nicht einmal die Mühe gegeben hat, dieselben noch einmal aufmerksam durchzulesen und mit einander in Einklang zu bringen. V. B. fand bei Untersuchung der Anhänge am Cephalothorax der Bodotria nur elf Paar; da er damals seine neue Gliedmassentheorie noch nicht fertig hatte, benannte er sie im Einklange mit seinen Vorgängern und nahm richtig an, dass er die Kiefer übersehen haben könne ${ }^{1}$ ). Als er später bei Cuma und Leucon in Betreff der Kiefer nicht glücklicher war, hielt er sich überzeugt, dass wirklich nur elf Paar Anhänge vorhanden seien, taufte daher die einzelnen Gliedmassen um und nahm diese neuen Namen auch in die Erklärung der zu Bodotria gezeichneten Abbildungen auf, ohne jedoch die abweichenden ursprünglichen Benennungen im Texte zu ändern.

Ueber die so höchst eigenthümlichen Kiemen der Cumaceen erfahren wir in V. B.'s Abhandlung nicht ein Wort, er scheint dieselben für kiemenlos zu halten, und zu glauben, dass sie mit ihrer dicken verkalkten Haut athmen. Eine besondere Kiemenhöhle spricht er ihnen ausdrücklich ab (S. 87). Und doch sind die Athembewegungen das Erste, was bei Betrachtung einer lebenden Cuma die Aufmerksamkeit fesselt; und doch scheint es kaum möglich, die gewaltig grosse Kieme („branchia maxima“ Kr.) zu übersehen, wenn man eine Cuma mit der Nadel zerzupft; und doch haben bereits Goodsir und Kröyer Lage und Gestalt der Kiemen richtig beschrieben; und doch untersuchte V. B. eine ungewöhnlich durchsichtige Art, bei der das ganze Spiel der Athembewegungen sich aufs prächtigste musste verfolgen lassen.

I) Statt einfach zu erklären: ich konnte die von K röyer beschriebenen Kiefer nicht finden, sagt V. B.: „nous passons sous silence les deux paires de mâchoires". Man merke sich für vorkommende Fälle diesen Euphemismus. 
V. B. versichert, dass er von seinen drei Arten beide Geschlechter lebend gesehen habe (S. 7 ), sowie dass er vollständig die Angaben Kröyer's und Goodsir's über die Eier und Embryonen dieser Thiere bestätigen könne (S. 75).

Ohne diese ausdrückliche Versicherung würde man versucht sein zu glauben, dass ihm überhaupt nie ein Weibchen vorgekommen sei, denn alle von ihm beschriebenen und abgebildeten Thiere sind Männchen. Bei Cuma und Leucon spricht sich V. B. überhaupt nicht über das Geschlecht der dargestellten Thiere aus und erwähnt keinerlei Geschlechtsverschiedenheiten; es beweisen aber die Länge der hinteren Fühler, sowie die Anwesenheit von äusseren Aesten am vierten Paare der Brustfüsse und von Anhängen an den ersten Hinterleibsringen, dass man Männchen vor sich hat und zwar wahrscheinlich noch nicht geschlechtsreife Männchen, wie namentlich die unbedeutende Entwicklung der erwähnten äusseren Aeste vermuthen lässt. Bei Bodotria ist allerdings von Weibchen die Rede; aber die von dem angeblichen Weibchen abgebildeten und als bezeichnend für dieses Geschlecht betrachteten Theile, die des reichen Riechfädenbüschels noch entbehrenden vorderen Fühler, die hinteren Fühler, welche die Länge des Panzers erreichen und, äusserlich ungegliedert, eine vielgliedrige Geissel umschliessen, die borstenlosen Hinterleibsanhänge, gehören sämmtlich einen jungen Männchen an. Bei den Weibchen auch dieser Gattung, die als solche an der Anwesenheit von Eiern, sei es im Leibe, sei es in der Bruttasche, erkannt wurden, finde ich die hinteren Fühler äusserst kurz und den Hinterleib fusslos ${ }^{1}$ ). - Es bleibt nun freilich noch ein höchst auffälliger Unterschied zwischen den Männchen und dem angeblichen Weibchen, letzteres soll an den Hinterecken des Panzers jederseits eine starke Spitze tragen, „die nicht einem wirklichen Dorne gleicht, sondern vielmehr in ihrer ganzen Länge geringelt ist, wie ein fühlerähnlicher Anhang“ (S. 79). Was ist dieser fühlerähnliche Anhang hinten am Panzer, dem Aehnliches im ganzen Bereiche der Kruster nicht gesehen wird? Die Abbildung (Taf. XIII. fig. 6) lässt darüber keinen Zweifel; es ist offenbar einer der beiden Fühler, der sich unter dem Mikroskop zufällig so gelagert hat, dass seine Spitze die hintere untere Ecke des Panzers überragt. Die Ringelung ist ganz dieselbe, wie sie der (fig. 8) in stärkerer Vergrösserung dargestellte Fühler zeigt, und beschreibt man (in fig. 6) um den Ursprung des vollständig gezeichneten Fühlers einen Kreis durch dessen Spitze, so geht derselbe genau auch durch die Spitze des wunderbaren Panzeranhangs.

Dass er mit seinen angeblichen Geschlechtseigenthümlichkeiten der Weibchen in Widerspruch mit $\mathrm{Kröyer}$ steht, demzufolge die Weibchen der Cumaceen verkümmerte nur $1 / 40$ bis $1 / 50$ der Länge des Körpers erreichende hintere Fühler haben u. s. w., scheint V. B. wie gewöhnlich nicht gemerkt zu haben.

Die Em bryon en der Cumaceen sollen im Laufe der Entwicklung die grösste Aehnlichkeit mit denen der Mysis haben (S. 87). Hätte die ganze Abhandlung nicht in jeder Zeile den Beweis geliefert, wie unglaublich oberflächlich V. B. die

I) $\mathrm{Kröyer} \mathrm{sagt} \mathrm{zwar} \mathrm{in} \mathrm{der} \mathrm{Diagnose} \mathrm{von} \mathrm{Bodotria:} \mathrm{quinque} \mathrm{pedum} \mathrm{abdominalium} \mathrm{paria} \mathrm{feminarum}$ permagna, natatoria"; allein er selbst hat diese Gattung nicht untersucht, sondern die Diagnose nach Goodsir's Angaben entworfen, der auch nur ein einziges Exemplar beobachtete; dieses hielt Kröyer, wahrscheinlich wegen des Mangels äusserer Aeste an den vier letzten Paaren der Brustfüsse, irrigerweise für ein Weibchen. 
Cumaceen sich betrachtet hat, so würde man aus dieser Behauptung zu schliessen geneigt sein, dass er überhaupt niemals den Embryo einer Cuma sah. Gerade ihm, der so eingehend und sorgfältig die Entwicklung der Mysis verfolgt hatte, hätte es ja beim ersten flüchtigen Blicke auf einen Cumaceenembryo auffallen müssen, dass hier von der wichtigsten Eigenthümlichkeit der jungen Mysis, von der naupliusähnlichen Larvenhaut mit ihren säbelförmigen Fühlern und ihrem Gabelschwanze, auch nicht die leiseste Spur vorhanden ist; ähnlich ist nur die Lagerung des Embryo, dessen Schwanzende wie bei Mysis und den Isopoden nach oben gekrümmt ist.

V. B. zieht aus seinen Beobachtungen den Schluss, dass die Cumaceen ihre natürliche Stelle im System zur Seite der Mysis finden und zwar wegen des Mangels der Augenstiele eine niedrigere Stufe einnehmen (S. 87). Er stützt sich dabei auf die Aehnlichkeit der Kinnbacken, die aber ganz wie bei den Amphipoden gebaut und denen von Mysis nicht ähnlicher sind, als denen eines beliebigen Decapoden oder Isopoden; auf den Mangel einer besonderen Kiemenhöhle, die aber vorhanden ist; auf die Aehnlichkeit der Verdauungswerkzeuge, die aber einer Magenbewaffnung entbehren (,ventriculus nullis intus organis manducatoriis instructus" Kr.), während die Leberschläuche nicht mehr an Mysis, als an die Asseln erinnern; auf die Bildung der Bruttasche, die aber wie bei den Amphipoden zwischen den vorderen und nicht wie bei Mysis zwischen den hinteren Füssen angebracht ist, endlich auf die Entwicklung, von der so eben die Rede war.

Nach alledem dürfte die Abhandlung Van Beneden's über die Cumaceen in ihrer Art einzig dastehen in der zoologischen Literatur ${ }^{1}$ ). Sie enthält, wie einmal Lessing sagte, und das ist das glimpflichste Urtheil, das sich über sie fällen lässt, - sie enthält viel Neues und Wahres; schade nur, dass das Wahre nicht neu, und das Neue nicht wahr ist.

Desterro, im December I864.

I) Von der schönen Arbeit über die Entwicklung der Mysis abgesehen sind übrigens die meisten Aufsätze in den „Untersuchungen über die Kruster der belgischen Küste“ der Abhandlung über die Cumaceen ziemlich ebenbürtig. Es dürfte kaum der Mühe lohnen, sie in ähnlicher Weise einzeln durchzusprechen. Dieses eine Beispiel wird genügen, um die äusserste Vorsicht bei Benutzung derselben räthlich erscheinen $\mathrm{zu}$ lassen. 


\title{
Ueber die Randbläschen der Hydroidquallen ${ }^{1}$ ).
}

\author{
Mit I Textfigur.
}

In seinen ganz vortrefflichen „Studien über das Gehörorgan der Decapoden“ gedenkt Victor Hensen beiläufig der Randbläschen einer Eucope Ggb., und gibt von denselben eine Beschreibung und Abbildung, die weit abweicht von der Darstellung aller früheren Beobachter ${ }^{2}$ ). Es soll danach an der centralen Seite der "Hörblasen“ oder „Otolithensäcke“, wie Hensen die Randbläschen nennt, eine verdickte Stelle sich finden, von der aus sehr feine Haare nach einem in der Mitte des Sackes liegenden, von einer inneren Blase umschlossenen Steine gehen.

Veranlasst durch die Angaben Hensen's habe ich mir die Randbläschen verschiedener Hydroidquallen noch einmal angesehen und glaube danach behaupten zu dürfen, dass sich dieser umsichtige Beobachter denn doch wohl in seiner Auffassung der Randbläschen von Eucope getäuscht hat, die er nur einmal zu untersuchen Gelegenheit fand.

Ueber die An- oder Abwesenheit der zarten Häärchen kann ich freilich nichts sagen, da diese für mein Mikroskop kaum erkennbar sein würden. Allein es erscheint mir unzweifelhaft, einmal, dass die "Steine“ nicht frei in der Mitte des Randbläschens schweben, nur durch zarte Häärchen gehalten, und zweitens, dass die ,innere Blase“ gar keine Blase ist, sondern ein dichter Körper. Ich glaube mich hiervon selbst bei Eucope überzeugt zu haben, obwohl gerade die vier zugänglichen Arten dieser Gattung wegen der geringen Grösse der Bläschen und der oft in Mehrzahl vorhandenen "Steine" und wegen der meist nicht besonders durchsichtigen Umgebung derselben wenig geeignet sind, befriedigende Bilder zu geben.

Am bequemsten bieten sich die frei über die Scheibe vorspringenden, verkehrt eiförmigen, mit stielförmig verdünnter Basis aufsitzenden Randbläschen der Cunina Köllikeri F. M. der Untersuchung dar. Der "Stein“ ist bei ihnen endständig und von der Basis zieht sich deutlich ein blasser Strang nach dem "Steine" hin, um ihn becherförmig zu umfassen ${ }^{3}$ ). Es ist unmöglich dieses Verhalten in Einklang zu bringen mit Hensen's Darstellung der "Otolithensäcke“

I) Schultze's Archiv für mikrosc. Anat. 1865. Bd. I. p. 143-147. Taf. VII, Fig. 4.

2) Studien über das Gehörorgan der Decapoden, S. 37, Anm. I; Fig. 24, B.

3) Archiv für Naturgeschichte I86r. Taf. IV. Fig. $8 .=$ Ges. Schriften Taf. XV, Fig. 8. 
von Eucope, während man sich nur den Strang verkürzt und dadurch den Stein ins Innere der Blase zurückgezogen zu denken braucht, um die bei den Hydroidquallen gewöhnliche Bildung der Randbläschen $\mathrm{zu}$ erhalten, wie ich sie bei Liriope $\left.{ }^{1}\right)$ beschrieb und auch jetzt wicder bei dieser und anderen Arten sehe. Da ich indessen, wie Agassiz, Cunina nicht zu den Hydroidquallen rechne ${ }^{2}$ ), musste ich billig Bedenken tragen, das bei ihr leicht festzustellende Verhalten der Randkörper als Beweis gegen die Richtigkeit der Darstellung Hensen's geltend zu machen; immerhin konnten ja bei Hydroiden und Aeginiden die Randkörper in völlig verschiedener Weise gebaut sein.

Ich war daher erfreut, bei einer Hydroidqualle auf eine Bildung der Randbläschen zu stossen, die in der Mitte steht zwischen dem bei Cunina und dem bei Liriope $z u$ beobachtenden Verhalten. Diese noch unbeschriebene Qualle, Aglauropsis Agassizii F. M., erinnert durch ihre Gestalt, durch die Bildung und selbst die Färbung des Magens und der Geschlechtstheile an Aglaura hemistoma Pér. et Le S., unterscheidet sich aber von letzterer Gattung durch die Vierzahl der Geschlechtstheile und der Strahlgefässe und die grosse Zahl der Randbläschen. Diese letzteren, von etwa $0,075 \mathrm{~mm}$ Durchmesser, sind stark

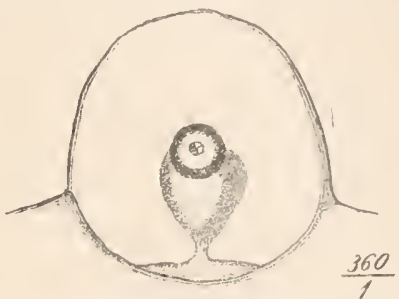

Randbläschen von A gla u rops is Agassizii F. M. Aus dem Grunde der Blase erhebt sich auf einem kurzen dünnen Stiele ein blasser, solider, birnförmiger Körper, der bis in die Mitte der Blase reicht, und in dessen Ende ein kugliger, starklichtbrechender, in Säuren unter Luftentwicklung löslicher Stein eingesenkt ist.

gewölbt; ihr frei vorspringender Abschnitt bildet eine Glocke, deren Höhe etwa $2 / 3$ des unteren Durchmessers beträgt. Aus dem Grunde der Blase erhebt sich nun auf einem kurzen dünnen Stiele ein blasser, nicht hohler birnförmiger Körper, der bis in die Mitte der Blase reicht und in dessen Ende ein kugliger stark lichtbrechender Stein von etwa o,O I5 mm Durchmesser zur Hälfte eingesenkt ist. Der Stein löst sich in Säure unter Luftentwicklung. - Dasselbe Bild, in aller nur wünschenswerthen Klarheit und Schärfe, bot mir eine grosse Zahl von Randbläschen.

Dies stimmt nun wieder völlig zu dem, was ich früher (a. a. O.) von Liriope und Cunina angegeben habe, - ist aber ebensowenig wie jene Angaben mit Hensen's Darstellung zu vereinigen. Dies über den Bau der Randbläschen; nun einige Worte über ihre Verrichtung.

Die Randbläschen der Hydroidquallen gelten jetzt fast allgemein als $\mathrm{Hör-}$ werkzeuge. Agassiz und ich dürften so ziemlich die einzigen sein, die sie noch jetzt als Augen betrachten. Auch Hensen bezeichnet sie ohne Bedenken als „Hörblasen“ und „Otolithensäcke“. Ich muss gestehen, dass gerade Hensen's meisterhafte Darstellung des Gehörorgans der Krebse mich auf's Neue in meiner Auffassung bestärkt hat.

Bei den Krebsen besteht das Ohr in einer als Einstülpung der äusseren Haut zu betrachtenden, häufig offenen Höhle. In dieser Höhle finden sich stets in ganz eigenthümlicher Weise eingelenkte Haare und oft Hörsteine, die mitunter

1) Archiv für Naturgeschichte I 859.S. 314. Taf. XI. Fig. 9-I2.= Ges. Schriften S. 93. Taf. X, Fig.9-I2.

2) Fritz Müller, über die systematische Stellung der Charybdeiden im Archiv für Naturgeschichte 1861. p. 302. = Ges. Schriften S. 126. - Agassiz, Contributions to the natural history of the United States of America. Vol. IV. 1862. S. 9 u. S. 167. 
ganz lose liegen, oder nur durch die in sie eintretenden Haare gehalten werden. Sie bestehen bald blos aus organischem Stoffe, bei Mysis vielleicht aus Fluorcalcium, wie es scheint nie aus kohlensaurem Kalk, und werden bisweilen durch von aussen eingeführte Quarzstückchen $u$. dgl. ersetzt. Gerade bei den höchstentwickelten Formen des Ohres fehlen sie vollständig. Das Wesentlichste von diesen verschiedenen Gebilden sind die Hörhaare, die auch selbständig, ohne Höhle und Steine, auf der Oberfläche des Körpers vorkommen und durch bestimmte Töne in Schwingungen versetzt werden.

Bei den Hydroidquallen haben wir dagegen kuglige oder birnförmige, vorspringende, geschlossene Blasen, die einem wahrscheinlich als Nervenring ${ }^{1}$ ) zu deutenden Streifen aufsitzen; von dem an dieser Stelle meist angeschwollenen Ringe geht ein kugliger oder birnförmiger, sitzender oder gestielter Fortsatz in die Blase hinein (bei Cunina sie vollständig durchsetzend), und umfasst becherförmig eine wahrscheinlich aus $\dot{\mathrm{Ca}} \ddot{\mathrm{C}}$ bestehende Kugel. - Welche Spur von Aehnlichkeit nun zwischen diesen Randbläschen und dem Ohre der Krebse, ausser dass in letzterem auch bisweilen ein kugliges festeres Gebilde sich findet, das aber (nach Hensen) nie aus $\mathrm{Ca} \ddot{\mathrm{C}} \mathrm{zu}$ bestehen scheint? - Und selbst das Vorhandensein der von Hensen beschriebenen Haare zugegeben, würden diese so ungemein blassen und zarten Häärchen eines gallertartig weichen Thieres Steifigkeit und Elasticität genug besitzen können, um durch Schallwellen in regelmässige Schwingungen versetzt $\mathrm{zu}$ werden?

Noch geringer, wo möglich, ist die Aehnlichkeit zwischen den Randbläschen der Hydroidquallen und den Hörblasen mit schwingenden Steinchen, wie sie bei Mollusken und Rippenquallen vorkommen.

Wenn für die Deutung der Randbläschen als Ohren kein weiterer Grund vorzuliegen scheint, als die Aehnlichkeit, die sie beim ersten Anblick, aber nicht bei näherer Vergleichung mit dem Ohre einer Mysis, eines Leucifer, einer Schnecke haben, so ist wohl gegen die Deutung als Augen nichts einzuwenden, als dass die in diesem Falle als Linsen anzusprechenden Theile aus Kalk bestehen. Dieser Grund würde nicht ohne Gewicht sein, wenn alle sonst in der Thierwelt der

I) $\mathrm{Cl}$ a us (Zeitschr. für wiss. Zool. XIII. p. 440) glaubt die Deutung dieses Ringes als Nervenring um so entschiedener zurückweisen zu müssen, ,als es sich hier nicht um einen Gegensatz von Ganglien und nach den einzelnen Organen ausstrahlenden Fasern handelt". Cla us scheint dabei übersehen zu haben, dass bei jener Deutung nicht nur auf Anschwellungen des Ringes Bezug genommen wurde, welche in ihrer Lage den allgemein als Sinneswerkzeuge betrachteten Randbläschen entsprechen, sondern auch auf zarte Stränge (Nerven?), die von den Anschwellungen nach dem Ursprung der Tentakel hin verfolgt wurden. „Der Ring ist absolut abgeschlossen, und was noch mehr sagt, bei den höher organisirten grossen Scheibenquallen überhaupt nicht nachzuweisen", wie $\mathrm{Claus}$ weiter bemerkt. Darauf ist zu erwidern: I) dass in diesem Falle die Grösse den Nachweis des Nervensystems nicht erleichtert, sondern erschwert; 2) dass, wie bei den Rippenquallen, so auch bei den höheren Scheibenquallen, das Nervensystem ganz wo anders liegen kann, als bei den Hydroidquallen; 3) dass, wenn auch nicht bei den echten Scheibenquallen, so doch bei Tamoya ein unzweifelhafter, dem unbewaffneten Auge sichtbarer, Nerven aussendender Nervenring vorhanden ist. Was die dem fraglichen Nervenring bei Liriope u. s. w. aufgelagerten Nesselzellen betriff, auf deren Anwesenheit auch ich aufmerksam gemacht hatte, so können sie, wenn sie überhaupt bei der Frage in Betracht kommen, höehstens für, in keiner Weise gegen die Deutung als Nervenring sprechen; zum Fangen von Beute können sie an jenem Orte nicht dienen; hat ihre Anhäufung längs des Ringes irgend eine Bedeutung für das Thier, so kann es wohl nur die sein, ein wichtiges Organ, wie etwa einen Nervenring zu schützen. Hensen spricht sich bei Eucope fü $r$ die Anwesenheit eines Nervensystems aus. 
Brechung des Lichts dienenden linsenförmigen Gebilde gleiche chemische $\mathrm{Zu}$ sammensetzung hätten. Das ist indessen nicht der Fall, die 4 grossen schönen Linsen von Ampelisca Kr. (Amphipod), und ebensowohl die Cornealinsen, wie sie Cla us nennt, von Coryceus und anderen Copepoden bestehen aus Chitin, und aus Arragonit (nach brieflicher Mittheilung von Max Schultze) die Randkörper der höheren Quallen, die nur als Augen gedeutet werden können, wenn die von Henry James-Clark gegebene Darstellung derselben ${ }^{1}$ ) richtig ist. Wie es bei den Hörsteinen, nach Hensen's Meinung nur auf ,eine gewisse specifische Schwere" anzukommen scheint, so wird bei einer Linse ebenfalls weniger ihre chemische Zusammensetzung, als ihre Durchsichtigkeit, ihr Brechungsexponent und ihre Gestalt in Betracht kommen. Und wie Hensen von den Hörhaaren behauptet und nachweist, „dass wenn nur der Nerv, welchen man in sie eintreten sieht, sensibel ist, tiefe Töne durch sie zur Perception gebracht werden müssen“ (a. a. O. S. 26), so wird man von den Hydroidquallen behaupten dürfen, dass wenn sie nur gegen Licht empfindlich sind, dieses durch die Randbläschen zur Wahrnehmung gebracht werden muss. Das Licht muss an der Oberfläche der Blase, es muss zum zweiten Male an der Oberfläche des Steines gebrochen werden; es muss auf das Ende des die Kugel umfassenden Stieles stärker wirken, als auf jede andere Stelle der Qualle.

Desterro, Januar i 865 .

I) In Agassiz, Contribution etc. Vol. III, Pl. XIb Fig. I6; Vol. IV. p. 4I. 


\title{
Ueber Darwinella aurea, einen Schwamm mit sternförmigen Hornnadeln $\left.{ }^{1}\right)^{2}$ ).
}

\author{
Mit Tafel XXVI.
}

Am Strande der Praia de fora bei Desterro findet sich äusserst selten an Steinen oder Tangen ein kleiner goldgelber Hornschwamm, der sich dadurch vor allen bekannten Schwämmen auszeichnet, dass er ansehnliche sternförmige Nadeln enthält, die nicht aus Kalk oder Kiesel, sondern aus einem, wie es scheint, von dem der Fasern nicht verschiedenen, in kochender Kalilauge löslichen Stoffe bestehen.

Das Aeussere des Schwammes hat, die schöne Goldfarbe abgerechnet, nichts Besonderes. Bald sah ich ihn als ganz dünnes Häutchen einige Quadratlinien bis etwa einen halben Quadratzoll eines Steines überziehen, bald zarte Tange in einer wenige Linie dicken Schicht umwachsen und dann Formen annehmen der ähnlich, die O. Schmidt von Spongelia incrustans abgebildet hat ${ }^{3}$ ). Möglich, ja wahrscheinlich ist es, dass die Stelle, an welcher der Schwamm so äusserst selten vorkommt, nicht sein eigentlicher Standort ist, und dass er an letzterem zu beträchtlicherer Grösse heranwächst und dann auch in eigenthümlicher bezeichnender Tracht auftritt.

Die Spitzen der kegelförmigen Höcker, welche wie bei anderen Hornschwämmen die Oberfläche bedecken, erscheinen heller als die übrige Oberfläche, da sie von den farblosen Enden der in die Höcker aufsteigenden Fasern eingenommen werden. Nur selten tritt beim frischen Schwamm eine oder die andere Faser frei über den Höcker vor; dagegen sehe ich bei einem in Weingeist aufbewahrten Stücke die meisten Fasern hervorstehen. Ein rundes Ausströmungsloch habe ich nur einmal, an einer sonst nicht ausgezeichneten Stelle eines Schwammes gesehen; es hatte wohl kaum I mm Durchmesser. - Mit der einfachen Linse sieht man auf der Oberfläche ein dichtes Netzwerk zarter gesättigt

1) Schultze's Archiv für mikrosk. Anat. 1865. I. p. 344-353. Taf. XXI.

2) Max Schultze, dem ich im vorigen Jahre ein Bruchstück des Schwammes mittheilte, nannte ihn Darwinia (Verhandl. d. naturhist. Vereins d. Rheinlande und Westphalens, Jahrg. XXII, I865, Sitzungsberichte p. 6); da dieser Name seit 1855 von Spence Bate an einen Amphipoden vergeben ist, habe ich ihn in $\mathrm{D}$ a rwinella geändert.

3) Oscar Schmidt, Spongien des adriatischen Meeres. Taf. III, Fig. 7. 
gelber Linien; sie bestehen, wie stärkere Vergrösserungen zeigen, aus spindelförmigen Anhäufungen gelber Körnchen, ganz ähnlich denen, die O. Schmidt von Spongelia elegans gezeichnet hat ${ }^{1}$. Ueber ihnen zieht sich eine dünne, farblose, körnchenfreie Hautschicht hin.

Die zwischen den Hartgebilden liegende Schwammmasse ist sehr weich und wird durch zahlreiche gelbe Körnchen undurchsichtig gemacht. Ich kann über ihren Bau nichts weiter sagen, da ich nie Zeit fand, wenn mir einmal dieser seltene Fund in die Hände fiel, ihn sofort zu untersuchen; schon nach einigen Tagen aber fand ich ihn in Gläsern mit Seewasser immer abgestorben und die Weichtheile so weit zersetzt, dass sie leicht zwischen Fasern und Nadeln herauszuspülen waren. An der Luft geht die schöne Goldfarbe rasch in ein dunkles schmutziges Braun über.

Abweichend, so viel ich weiss, von allen bisher beschriebenen Hornschwämmen, aber übereinstimmend mit zwei anderen hiesigen Arten bilden die schwach verästelten Fasern der Darwinella kein zusammenhängendes Geflecht, sondern steigen entweder ganz getrennt empor (Fig. I) oder verkleben doch nur hie und da miteinander. Den gemeinsamen Boden, von dem sich die Fasern erheben, bildet eine dünne Haut, mit welcher der Schwamm seine Unterlage überkleidet und die in chemischer Hinsicht nicht von den Fasern und Nadeln verschieden scheint; alle diese Hartgebilde bleiben in kalter Kalilauge oder concentrirter Schwefelsäure wenigstens während einiger Stunden unverändert, lösen sich aber rasch in starker kochender Kalilauge.

Die Fasern, deren Verästelungsweise aus den beigegebenen Zeichnungen (Fig. I-4) ersichtlich ist, sind elastisch, blass horngelb und verjüngen sich ganz allmählig nach der Spitze zu; eine $4 \mathrm{~mm}$ lange Faser z. B. von o,o6 auf o,o $6 \mathrm{~mm}$. - Die Spitze selbst ist abgerundet (Fig. 6).

Man unterscheidet an den Fasern eine durchsichtige, anscheinend festere Rinde und ein mehr oder weniger getrübtes, anscheinend weicheres Mark. Die Rinde wird nach der Spitze zu dünner und fehlt der äussersten Spitze ganz. Mark wie Rinde sind deutlich geschichtet. In der Rinde sind die Schichtungslinien im Allgemeinen der Achse der Faser gleichlaufend; kleine Biegungen der Faser werden durch die später abgesetzten Schichten wieder ausgeglichen. Im Marke wiederholen die Schichtungslinien im Allgemeinen die Form der Spitze der Faser, bilden also quere, mehr oder weniger stark nach oben gewölbte Flächen, durch die das Mark oft ein gekammertes Aussehen erhält. Die Schichten des Markes gehen unmittelbar über in die der Rinde; es sind eben dieselben Schichten. Jede neue Schicht, die sich auf der Faser absetzt, bildet eine sie umhüllende zarte Röhre, die oben durch eine dicke gewölbte Kuppel geschlossen ist. Die Röhren bilden die Rinde, die Kuppeln das Mark. - Ich finde bei Darwine lla nichts, was auf ein Wachsthum der Fasern durch „Intussusception“ hinwiese, wie es Schmidt für Spongia annimmt ${ }^{2}$. Natürlich kann ich nicht die Richtigkeit dieser Auffassung für Spongia anzweifeln wollen; für Darwinella aber muss ich meine entschiedene Meinung dahin aussprechen, dass die Fasern einzig durch

I) O. Schmidt, Supplement der Spongien des adr. Meeres. Taf. I, Fig. 9-II.

2) Suppl. der Spongien des adr. Meeres. S. 8. 
Auflagerung neuer Schichten wachsen. Besonders belehrend sind in dieser Beziehung Fasern, deren Wachsthum, - wahrscheinlich dadurch, dass sie über die Oberfläche des Schwammes hervorragten - längere Zeit unterbrochen wurde. Diese stark gedunkelten und verhärteten jedenfalls leblosen Spitzen wachsen später, wenn sie wieder von der Schwammmasse überdeckt werden, in ganz derselben Weise weiter, wie früher (Fig. 7). Bei Fasern, die ihre Spitze verloren hatten (Fig. 8), sieht man nie vom Marke aus einen jungen Zapfen hervorwachsen, wie es Schmidt bei Spongia sah; es lagern sich einfach neue Schichten darüber, durch welche sie weiter wachsen. Man kann daher bei Darwinella nicht sagen, dass die Faser sich „neue Schichten der umgebenden weicheren Muttersubstanz assimilirt"1). Wollte man selbst den allem Anschein nach abgestorbenen Fasern dies Vermögen noch zugestehen, so würde man es doch nicht auf fremde Körper ausdehnen können, auf die der Schwamm in ganz gleicher Weise hornige Schichten absetzt. So sah ich ganze Zweige eines zarten mit Gemellaria verwandten Moosthierstockes vollständig von einer geschichteten Hülle umschlossen und diese Schichten gingen ununterbrochen über in die einer Schwammfaser ${ }^{2}$ ). Auch der Fig. Io gezeichnete Fall, wo ein junger Ast wieder von den später abgesetzten Schichten des Stammes überlagert und in den Stamm wieder aufgenommen worden ist, lässt sich als Beweis dafür anführen, dass ihm keinerlei Wachsthum von innen heraus zukam, dass er sich bei seinem Wachstume vielmehr ebenso leidend verhielt, wie jeder andere feste Körper, auf dessen Oberfläche das Protoplasma des Schwammes erhärtend Schichten absetzt.

Die Aeste treten auf als kugelförmige Hervorragungen der äussersten Schicht des Stammes, unter denen die älteren Schichten unbehelligt und geradlinig fortgehen, so dass die Aeste aussehen wie ganz unabhängige, dem Stamme äusserlich aufgeleimte Gebilde. Anfangs structurlos, mit einfachem Umriss, erscheinen sie bald geschichtet. Die Ursprungsstellen älterer Aeste erscheinen, wie das auch anderen Beobachtern an anderen Schwämmen aufgefallen ist, stark verdickt, indem die äusseren Schichten in immer flacher werdenden hyperbolischen Linien vom Ast auf den Stamm übergehen (Fig. 9). Noch auffallender ist dieselbe Erscheinung an geknickten Fasern (Fig. 9); auch hier folgen die späteren Schichten an der Innenseite des durch die Knickung entstandenen Winkels dessen Schenkeln nicht bis zum Scheitel, sondern biegen in immer grösseren und flacheren Bogen aus der Richtung des einen in die des anderen um. Ebenso geschieht es, wo zwei sich kreuzende Fasern mit einander verkleben, in den von ihnen gebildeten Winkeln.

I) Suppl. der Spongien des adr. Meeres. S. 8.

2) Ich will mir erlauben bei dieser Gelegenheit eine Vermuthung auszusprechen über die sonderbaren aus der Oberfläche der Spongelia fistularis Schmidt (Suppl. S. 28. Taf. II, Fig. 28, 29. Taf. III, Fig. 4) hervorragenden Röhren. Ich fand kürzlich eine Reniera, deren Oberfläche dicht bedeckt war mit kreisrunden auf kleinen Erhebungen angebrachten scharfrandigen Oeffnungen, die in tiefe glattwandige Röhren führten. Dazwischen lagen die gewöhnlichen Ausströmungslöcher. Ich meinte, eine ganz wunderbare neue Gattung gefunden zu haben. Als aber mein Schwamm ruhig in einem Glase mit Seewasser lag, kamen aus jedem Loche die beiden zarten langen Fangfäden einer winzigen Spiodee hervor und tasteten justig umber. Nach dem Trocknen treten die Röhren von Schwammnadeln bedeckt mehrere Millimeter über die eingeschrumpfte Oberfläche des Schwammes hervor. - Sollten nicht die Röhren der Spongelia fistularis auch aus Wurmröhren entstanden sein, die von den Fasern des Schwammes aus mit einer hornigen Hülle umkleidet wurden? 
Diese Ausfüllung geradliniger Winkel durch hyperbolisch gekrümmte Schichten, sowie umgekehrt bei kleineren Biegungen der Faser, die Rückkehr der später abgelagerten Schichten zu geraden Iinien scheinen darauf hinzuweisen, dass sie nicht aus einer ruhenden Umgebung, dass sie vielmehr aus einer über die Fasern hin sich bewegenden Masse abgesetzt wurden. Die Bildungsgeschichte der Fasern scheint, mit Einem Worte, ganz dieselbe zu sein, wie nach Schachts Darstellung ${ }^{1}$ ) die der Zellstofffäden in der Aussackung des Embryosacks von Pedicularis silvatica und im Innern von Caulerpa.

Nicht selten (Fig. 2) sind die Fasern auf weite Strecken dicht bedeckt mit einer bräunlichen einzelligen Alge.

Zwei andere Hornschwämme unserer Küste stimmen im Bau der Fasern vollständig mit Darwinella überein.

Neben den Fasern enthält Darwinella zahlreiche ansehnliche sternförmige $\mathrm{N}$ a deln. Dieselben haben drei bis acht schlanke allmählig zu einer meist scharfen Spitze verjüngte Strahlen, deren Länge von 0,1 bis über $1 \mathrm{~mm}$ wechselt; an derselben Nadel sind sie nahezu gleich lang. Die Anordnung der Strahlen ist eine ziemlich mannichfaltige (Fig. 2-5); bis jetzt kamen zur Beobachtung:

1) Nadeln mit 3 Strahlen; diese genau oder nahezu in derselben Ebene zusammenstossend:

a) unter Winkeln von etwa $\mathrm{I}_{20} \mathrm{O}^{\circ}$;

b) unter Winkeln von $180^{\circ}, 90^{\circ}$ und $90^{\circ}$;

c) unter Winkeln von etwa $180^{\circ}, 120^{\circ}$ und $60^{\circ}$.

2) Nadeln mit 4 Strahlen:

a) rechtwinkliges Kreuz;

b) schiefwinkliges Kreuz mit Winkeln von $\mathrm{I}_{20}{ }^{\circ}$ und $60^{\circ}$; selten;

c) zwei Strahlen bilden einen rechten Winkel, die beiden andern eine auf dessen Ebene senkrechte Gerade; sehr selten;

d) dreistrahliger Quirl, d. h. drei Strahlen in einer Ebene, Winkel ron etwa $120^{\circ}$ bildend, der vierte darauf senkrecht; häufig.

3) Nadeln mit 5 Strahlen:

a) drei Strahlen in einer Ebene; die beiden andern bilden eine darauf senkrechte Gerade; nicht selten;

b) vierstrahliger Quirl; d. h. vier Strahlen bilden ein Kreuz, auf dessen Ebene der fünfte senkrecht steht; häufig.

4) Nadeln mit 6 Strahlen:

a) die Strahlen bilden drei auf einander senkrechte Gerade; nicht selten;

b) fünfstrahliger Quirl; sehr selten.

5) Nadeln mit 7 Strahlen $\}$ selten.

Wie die Fasern zeigen auch die Nadeln eine deutliche Scheidung in Mark und Rinde; die innere Grenzlinie der Rinde pflegt sogar weit schärfer als bei den Fasern hervorzutreten. Nach der Spitze der Strahlen zu wird die Scheidung in Mark und Rinde weniger deutlich. Während bei den Fasern die Rinde nach

I) H. Schacht, Lehrbuch der Anatomie und Physiol. der Gewächse. I. 'Theil, S. 45. Taf. I, Fig. 44, 45. Vergl. auch M. Schultze, Die Hyalonemen. Bonn 1860. pag. 24 Anm. 
der Spitze zu schwindet und diese selbst nur aus dem bogig geschichteten Marke besteht, verjüngt sich bei den Nadeln das Mark rascher als die Rinde und die Spitze scheint marklos zu sein. Eine grössere Markhöhle am Kreuzungspunkte der Strahlen pflegt namentlich bei kleinen drei- oder vierstrahligen Nadeln sehr deutlich zu sein. (Fig. I I.)

Eine Schichtung der Rinde ist bei frischen Nadeln kaum wahrzunehmen; bisweilen sieht man einige recht deutliche oberflächliche Schichtungslinien, aber überzeugt sich dann meist leicht, dass diese nicht der Nadel selbst, sondern nachträglich auf sie abgesetzten Schichten angehören. Nach kurzem Kochen in schwacher Kalilauge, wobei die Nadeln etwas aufgequollen waren, trat dagegen die Schichtung der Rinde deutlich hervor. Das Mark zeigte sich in diesen gekochten Nadeln verschrumpft, wellig gebogen und durch einen deutlichen Zwischenraum von der Rinde geschieden. Ebenso sah ich es bisweilen (Fig. 12) nach mehrtägigem Liegen des Schwammes in Wasser. Einigemal sah ich im Marke, doch nie recht deutlich, Linien, die spitze Winkel, mit der Spitze der Strahlen zugewandtem Scheitel, bildeten; - vielleicht Schichtungslinien, die dann wie bei den Fasern die Form der Spitze wiederholen würden.

Die Nadeln liegen hauptsächlich in den tieferen Theilen des Schwammes, wo sie um die Stämme und älteren Aeste der Fasern oft ein dichtes Gewirre bilden. Nicht selten herrschen bestimmte Nadelformen an bestimmten Stellen vor; so zeigt Fig. 4 lauter vierstrahlige Nadeln und so waren die im Allgemeinen seltenen sieben- und achtstrahligen Nadeln, die mir früher nie vorgekommen waren, an einer kleinen Stelle eines vor Kurzem untersuchten Schwammes, dem Fig. 2 und 3 entnommen sind, ziemlich häufig. Die Nadeln liegen theils frei in der weichen Schwammmasse, theils sind sie mit den Fasern verklebt, oder selbst vollständig in sie eingeleimt. Selten verkleben zwei sich kreuzende Strahlen verschiedener Nadeln. Auch an die die Unterlage des Schwammes überziehende Haut können Nadeln befestigt werden. Es finden sich in diesen Fällen stets die uns schon bekannten hyperbolischen Schichtungslinien.

Meist sind die Strahlen der Nadeln gerade ausgestreckt; doch ist bisweilen der eine oder andere Strahl unter einem stumpfen oder selbst rechten Winkel gebogen und die umgebogenen Spitzen sind dann, soviel ich gesehen, immer festgeleimt; - wahrscheinlich, weil die elastischen Strahlen, durch Druck von aussen gebogen, bei Nachlass des Druckes sich wieder strecken, wenn sie nicht inzwischen an benachbarte Fasern festgekittet worden sind.

Während bei Darwinella die Nadeln ausserhalb der Fasern liegen und nur ausnahmsweise mehr oder weniger vollständig in sie aufgenommen werden, pflegen bei Kieselschwämmen mit entwickeltem Fasergerüste ${ }^{1)}$ die Nadeln den Fasern eingebettet zu sein. Doch ist dieser Unterschied kein wesentlicher; denn auch bei letzteren entstehen die Nadeln wohl immer ausserhalb der Fasern und werden erst später von ihnen umwachsen.

I) Diese Corneosilicispongiae, wie sie Schmidt nennt (Supplement S. 42) können keinenfalls eine systematische Abtheilung bilden, da von nächst verwandten $\Lambda$ rten die einen ein höchst entwickeltes Fasergerüst besitzen können, während bei den anderen kaum die Spitzen der Nadeln durch eine Spur erhärteten Protoplasmas verklebt sind. Das Letztere ist z. B. nach Sch midt der Fall bei seiner Reniera aquaeductus, das Erstere bei einer der genannten bis auf die Farbe höchst ähnlichen hiesigen Art; man wird diese Arten nicht auseinander reissen dürfen. 
Freunden Darwin's werden die eben besprochenen Hornnadeln ein erfreulicher Fund sein, da sie einen willkommenen Anhalt bieten für die Anwendung seiner Lehre auf die Klasse der Schwämme. Wenn irgendwo, so zeigte sich in dieser Klasse die Auffassungsweise von A gassiz in entschiedenem Vortheile über die Lehre Dar w in's. Die gleichen Gestalten (z. B. dreistrahlige Sterne) waren einmal in kohlensaurem Kalk, ein anderes Mal in Kieselsäure ausgeführt, zwei so verschiedenen Stoffen, dass das Band, welches in der Uebereinstimmung der Form sich unverkennbar kund gab, eben nur, wie A gassiz will, ein geistiges sein zu können schien. War die Thierwelt geschaffen nach einem vorbedachten Plane, so leuchtete ein, wie in diesem Plane zuerst im Allgemeinen der Gedanke einer Schwammnadel gefasst, wie eine bestimmte Nadelform vorgezeichnet und wie dann zu deren Ausführung bald der eine, bald der andere Stoff gewählt werden konnte. Wie aber sollte man die Kalk- und die Kieselschwämme aus einer nicht blos gedachten, - wie sollte man sie im Sinne der Darwin'schen Lehre aus einer in bestimmten irdischen Stoffen lebendigen Urform ableiten? Es war offenbar eine dreifache Annahme möglich.

Man konnte Kalk- und Kieselnadeln als wesentlich verschiedene unabhängig von einander entstandene Gebilde betrachten und sich dabei etwa auf die den Kalknadeln mangelnde feine Höhlung in der Achse der Kieselnadeln berufen.

Man konnte zweitens Kieselnadeln aus Kalknadeln oder umgekehrt hervorgehen lassen. Letztere Annahme wurde indess ebenso unwahrscheinlich durch die Verschiedenheit des Stoffes, wie erstere durch die Uebereinstimmung der Formen.

Man konnte drittens zu der Annahme einer einfach hornigen Grundform greifen, die später bei den einen verkalkt, bei den anderen verkieselt sei; aber auch diese Annahme dürfen die Gegner abweisen mit der Forderung, doch irgend welche Spur dieser ,imaginären, nur zur Stütze einer phantastischen Theorie herbeigerufenen" 1) Hornnadeln aufzuweisen. - Nun denn, die Hornnadeln haben nicht nur bestanden, sie bestehen noch und damit ist der dritten, an sich schon ansprechendsten Annahme eine gewisse thatsächliche Stütze gegeben.

Zum Schluss, um auch der Schule gerecht zu werden, die Diagnose der neuen Gattung.

Darwinella: Ceratospongiae fibris dendroideis in rete non conjunctis et spiculis magnis stelliformibus in kali caustico solubilibus praeditae.

Desterro, September 1865.

\section{Erklärung der Abbildungen auf Tafel XXVI.}

Die Abbildungen stellen sämmtlich Fasern und Nadeln der Darwinella a urea dar, und zwar Fig. I-5 bei I 5 maliger, 6- I I bei 9omaliger und Fig. I 2 bei 360 maliger Vergrösserung. - Man beachte in

Fig. I. den häutigen Ueberzug über den Tang, dem die Schwammfaser aufsitzt, das abgebissene Ende des dunkleren von jüngeren Schichten umschlossenen Stammes, die

I) The supposed intermediate forms between the species of different geological periods are, imaginary beings, called up merely in support of a fanciful theory" $\Lambda$ gassiz, Contributions to the Nat. Hist. of the U. S. Vol. III. S. 90. 
Verschmelzung des 2. und 4. Astes, die durch spätere Schichten ausgeglichene Biegung am ersten Zweige des 4. Astes; in

Fig. 2. den dunklen Ueberzug (von einzelligen Algen) auf einem Theile der Fasern und Nadeln; links die grosse achtstrahlige Nadel, unten in der Mitte die Verklebung zweier sich kreuzender Nadeln, rechts die vierstrahlige Nadel, von der ein Strahl an den häutigen Ueberzug des Tanges befestigt ist, während von einem andern sich eine Faser erhebt. (Es sind in dieser Figur kaum die Hälfte der in dem Präparat vorhandenen Nadeln gezeichnet); in

Fig. 3. die fast vollständig eingekittete vierstrahlige Nadel rechts; in

Fig. 4. den Ursprung der Fasern aus der häutigen Ausbreitung und die umgebogenen festgeleimten Spitzen an den beiden obern Nadeln.

Fig. 5. Einzelne Nadeln.

Fig. 6. Spitze einer Faser.

Fig. 7-IO. Unregelmässig geschichtete Fasern, aus deren Schichtung man ebenso ihre ganze Lebens- und Leidensgeschichte herauslesen kann, wie aus den Jahresringen eines Baumes seine mageren und fetten Jahre u. s. w.

Fig. 7. Aus einer Faserspitze, die längere Zeit über ihren Höcker frei vorstand, dabei erhärtete und dunkelte und auf der sich in dieser Zeit eine Diatomee angesetzt hat, erhob sich später eine seitliche Faser, die aber bald dasselbe Schicksal hatte; nachdem beide wieder vom Schwamm überwachsen worden, ist von jeder Spitze ein Zweig weiter gewachsen; in dem Winkel zwischen beiden erscheinen hyperbolische Schichtungslinien.

Fig. 8. Eine Faser wurde abgefressen und entblösst; in der Wundfläche häufte sich Schmutz an; später wurde sie wieder überwachsen und ein junger Ast bildete sich an ihrem Ende.

Fig. 9. Eine Faser wurde rechtwinklig geknickt; der Winkel füllte sich mit hyperbolisch gekrümmten Schichten; an der Aussenseite des wagerechten Schenkels bildete sich ein Zweig, der in der ursprünglichen Richtung der Faser weiter wuchs. Links sieht man eine der Faser aufgeleimte Nadelspitze.

Fig. I o. Zwei entblösst gewesene Faserenden sind verklebt; an der einen sind unter dem Ursprung eines seitlichen Astes einige fremde Körnchen hangen geblieben; der seitliche Ast wurde verbogen, aber die Biegung durch jüngere Schichten wieder ausgeglichen; ungefähr um dieselbe Zeit, und vielleicht durch dieselbe Ursache wurde die Spitze eines jüngeren Zweiges umgebogen, und in Folge davon von den später abgesetzten Schichten des Stammes umschlossen und seinem Bestehen als Zweig ein Ende gemacht. Strahlen.

Fig. I I. Kleine dreistrahlige Nadeln mit grosser Höhle am Kreuzungspunkte der

Fig. I 2. Stück des Strahles einer grossen Nadel, nach mehrtägigem Liegen in Wasser hat sich das Mark deutlich von der Rinde abgehoben und erscheint wellig (schraubenförmig ?) gebogen. 


\section{Notes on some of the Climbing-Plants near Desterro, in South Brazil ${ }^{1}$ ). \\ Aus einem Briefe an C. Darwin. \\ Mit Tafel XXVII.}

In your Paper on the "Movements and Habits of Climbing-Plants", you say that you have seen no tendrils formed by the modification of branches, and you even seem to entertain some doubt whether such tendrils exist. In the genus Strychnos, the tendrils are called by Endlicher ramuli cirriformes, and I have now satisfied myself that they really are of this nature. On the branches of upright shoots of a Strychnos which grows here, the tendrils are disposed in a very regular manner. On the branches, the leaves of the first, third, fifth, \&c. pairs are horizontal, those of the second, fourth, and sixth pairs are vertical in relation to the main axis; and it is from the angles of every under leaf of these latter pairs that the tendrils spring. Now, on the points commonly occupied by tendrils, true branches are sometimes developed. The leaves from the angles of which the tendrils spring are often much reduced in size, while in other cases they are but little or not at all changed. Each tendril bears near its tip a pair of rudimentary leaves; and whilst very young the tendrils are straight, but soon become curved downwards and rolled into a helix, whether they have clasped a support or not. This Strychnos is a very inefficient climber; the short stiff tendrils but rarely catch anything.

A member of the Hippocrateaceæ, probably a Tontelia, is likewise a branch climber. One of its branches, three feet in length, had not as yet developed leaves, and resembled a gigantic tendril, with most of its lateral branchlets already grasping neighbouring objects. From the angles of the tendril-branches, other branches arise, which as far as I have seen, are not sensitive, and never clasp anything. This latter arrangement must be serviceable to the plant; for such branches grow upright without being arrested in their course, whilst the plant is secured by the tendril-branches.

Caulotretus, one of the Leguminosæ, offers another case of tendrils being formed from modified branches. In the species which I observed, the branches bear tendrils only in the angle of their first leaf, and this leaf is always rudimentary. In young shoots it might, at first sight, be thought that tendrils spring from the axils of all their leaves. In this plant every tendril appears to consist

I) Journal of the Linnean Society of London. Bot. I865. IX. p. 344-349. Pl. IX. 
of two parts, separated by a small swelling - the inferior being straight, the superior curved, with its end rolled into a helix. But what appears to be the inferior part of a tendril is in fact the first internode of a young branch, the swelling being its terminal bud, and the tendril really springs from this young branch, from the angle of its first squamiform leaf, but nevertheless accompanied by two stipules. The end of the tendril very soon rolls up into a helix; but it does not lose by this the faculty of catching a support; on the contrary I know of no other tendrils which become entangled with small objects so easily as these rolled-up, highly elastic tendrils of the Caulotretus.

By far more interesting than the tendrils of Strychnos and Caulotretus are those (P1. XXVII. figs. I and 2) of a climbing Papilionaceous plant with a woody stem, which from its general aspect I suppose to belong to the Dalbergiece, Benth. They consist of thin, slender, flexible, leafless branches, with numerous (1 2-25) internodes, armed with sharp, hard, hook-like stipules. The young, soft, herbaceous shoots of this plant which rise from the ground are leafless. I saw one, seven feet high, which in its lower half was naked, while the upper half bore about a dozen tendrils stretched out in every direction. The oldest of these tendrils were from nine to twelve inches long, and armed with from twelve to sixteen pairs of sharp hooks: at the sides of the younger tendrils there were large, foliaceous, deciduous stipules, and at their bases very small bract-like leaves. The hooks of the tendrils are evidently stipules, which so often in this family assume the form of hooks or spines; in fact, while in the older tendrils they are strongly curved, and have a hard, sharp, darkly coloured apex, at the summits of the younger ones they are straight, soft, and green, resembling in this early state the much larger stipules at the bases of the tendrils. Afterwards, on the summit of the shoot, true leaves are developed at the bases of the tendrils instead of the small rudimentary ones; and finally, when the plant has reached the light, and spreads over the upper surface of a thicket or tree, the tendrils disappear. The inverse may be observed when the plant sets out on the conquest of a new dominion, a neighbouring tree for instance. Then a branch bearing only leaves begins to produce on its tip tendrils supported by leaves, and finally, growing rapidly to a long slender shoot, it produces only tendrils, the leaves being replaced by small squamæ. Thus in this plant, the branches assume four different shapes:- Ist, tendrils, leafless, armed with hook-like stipules; 2nd, long, slender, leafless shoots, bearing tendrils and broad deciduous stipules; $3 \mathrm{rd}$, branches with leaves, from the axils of which tendrils spring; and 4th, branches bearing only leaves without tendrils. Between the leaf and the tendril there is an accessory bud (fig. I $b$ ), which often developes into a branch; these branches issuing from the accessory buds seem never to produce tendrils. The tendrils, after having clasped a support, thicken partially where they are in contact with it (fig. I a). Tendrils which have caught nothing behave in different ways. Some wither and fall after contracting irregularly. Others likewise become flexuous, or contract into a spire, or occasionally into a helix, but remain, thickening somewhat and becoming ligneous and rigid. Others produce branches from one or some of their internodes: this also occurs, and perhaps more frequently, with tendrils which have found a support; in this case the tendrils thicken much, and sometimes attain a diameter of more 
than one inch (fig. $2 a$, a thickened tendril clasping a branch of a Psidium; $b$, branch issuing from the tendril; $c$, tendril-bearing branch; $d$, branch from an accessory bud, without tendrils). Lastly, the tendrils even transform themselves into true branches: in this case they may remain nearly straight or become but little flexuous, and at their ends they produce leaves; the first of these leaves have sometimes hook-like persistent stipules, like those of the tendril, while the stipules of the following leaves are deciduous like those on other branches. These tendrils often become much elongated. I saw a shoot, almost all the tendrils of which were developed into serpentine branches; and under each of these branches there was a straight branch from an accessory bud. One of the tendrils was thirty inches long; it had twenty-five pairs of hooks, and at the tip three short internodes with leaves and destitute of hooks; from its seventeenth internode a branch arose. Excepting their hook-like stipules, by which they may be easily recognized, the branches formed by tendrils resemble in almost every respect the ordinary branches; but, as far as I have seen, they never produce tendrils, nor do the branches which spring from an internode of a tendril or (as I have already stated) from an accessory bud.

If we restrict the name of tendrils to filamentary organs used exclusively for climbing, those of the present plant would be excluded; for after having done their work as tendrils, they may be transformed into, and do all the work of branches.

While in this plant the highly modified tendrils may be changed again into true branches, in two other plants which I have seen, the branches themselves, without having suffered any modification, act as tendrils. One of these plants belongs to the Dalbergiea. Many of its branches had clasped small branches of a tree. These tendril branches, as they may be called, had not continued to grow beyond the support; and where they touched it, most of them had thickened: some showed a tendency to spiral contraction, forming a semicircle between the support and the stem. The plant does not twine. I may add that another genus, belonging to the same section of the Leguminosæ, namely Hecastophyllum, is also a branch climber.

The second plant above referred to is a Securidaca (Polygalaceæ), and a most powerful climber (fig. 3). Its branches often curvé in a very odd and complicated manner. Thus I saw a thin branch, which with its lateral twigs had become curved like ribs into semicircles (about four inches in diameter), imitating the bones of the thorax; from the twigs sprang secondary branchlets, which were very regularly curved, twisted together, and formed into a sort of network around the middle hollow space. When the branches wind round a support, they thicken and become more rigid, like true tendrils; but even these thickened parts may bear leaves or secondary branches. In the preceding plant the branches seem to be arrested in their longitudinal growth when they clasp a support; in the present plant they continue to grow, and the same branch may successively catch different objects. The branches which project freely from a thicket are rather thin and slender: with their twigs spreading all in the same horizontal plane and diminishing in length towards the extremity of the branch, and with their leaves arranged in two horizontal rows, they apparently form gigantic bipinnate leaves; 
and when covered with their bluish-purple flowers, this Securidaca is one of the most elegant and magnificent plants of our flora.

From the last two plants it is but one step to the primordial and simplest condition of branch climbers, exhibited by the numerous species which scramble up a thicket without twining and without the aid of rootlets, hooks, or tendrils.

Thus we can trace in the development of branch climbers the following stages:-

I. Plants supporting themselves only by their branches stretched out at right angles - for example, Chiococca.

2. Plants clasping a support with their branches unmodified-Securidaca (Hippocratia according to Endlicher, Gen. Plant. No. 5700, "arbores v. frutices, ramis contortis scandentes").

3. Plants climbing with the tendril-like ends of their branches. According to Endlicher (Gen. P1. No. 5745), this is the case with Helinus ("ramulorum apicibus cirrhosis scandens").

4. Plants with highly modified tendrils, which may, however, be transformed again into branches - for example, the above-mentioned Papilionaceous plant.

5. Plants with tendrils used exclusively for climbing - Strychnos, Caulotretus.

I will here add a few miscellaneous observations. You describe some species of Bignonia in which the tips of the tendrils become enlarged and adhesive after remaining for a short time in contact with some object; but the trifid tendrils of Haplolophium, one of the Bignoniaceæ, terminate (without having come into contact with any object) in smooth shining disks, which, however, after adhesion, sometimes become considerably enlarged. In Cardiospermum you state that the common peduncle which bears the subpeduncles with the flower-buds and the pair of short tendrils, although it spontaneously revolves, does not bend on contact or contract spirally; hence it may be worth mentioning, as showing a difference in the action of the tendrils in related genera, that in Serjania the common peduncle contracts spirally when the single tendril which it bears has clasped, as frequently happens, the plant's own stem.

With respect to spirally twining plants, you state that though the Hibbertia dentata sometimes revolves in one direction and sometimes in the other, yet it invariably twines from left to right. But in another genus belonging to the same family, namely the Davilla, the stem twines indifferently from left to right or from right to left; and I once saw a shoot, ascending a tree about five inches in diameter, reverse its course in the same manner as so frequently occurs with Loasa. Although individuals, as we have just seen, in some few cases twine in opposite directions, yet you say that you have not as yet met with any case of two species in the same genus twining in opposite directions, and you are able to give only two cases of species within the same natural order thus twining. But a Mikania growing here twines from right to left, whilst the Mikania scandens described by you twines in an opposite direction; and I believe that there are species of Dioscorea which twine in opposite directions. Lastly, with respect to the thickness of the support which can be ascended by spirally twining plants, I have lately seen a trunk about five feet in circumference which was thus ascended by a plant apparently belonging to the Menispermaceæ. 


\section{Ueber das Holz einiger um Desterro wachsender Kletterpflanzen ${ }^{1}$.}

Mit Tafel XXVIII.

Wie längst bekannt, sind die holzigen Stämme vieler Kletterpflanzen durch eine vom gewöhnlichen Baue des Dicotyledonenstammes abweichende Bildung ihres Holzes ausgezeichnet. In einem Lande, das an Kletterpflanzen vielleicht reicher ist als jedes andere der Erde, habe ich Gelegenheit gehabt, eine ziemliche Zahl solcher ,anomalen Holzbildungen" und darunter, wie ich glaube, manches Neue zu sehen. Ich will im Folgenden eine kurze Uebersicht meiner Beobachtungen geben, so weit sie den gröberen ohne Mikroskop erkennbaren Bau des Holzes betreffen.

Das Gemeinsame der mannigfachen Abweichungen vom gewöhnlichen Baue, die man an den Stä1mmen holziger Kletterpflanzen beobachtet, besteht darin, dass bei ihnen der Holzkörper der Länge nach in mehr oder minder vollständig geschiedene Stücke zerklüftet oder von Strängen eines weicheren Gewebes durchzogen ist. Die Stämme werden dadurch biegsamer, als wenn dieselbe Holzmasse eine regelmässige dichte Walze bildete. Die Zerklüftung kann auf mehrere wesentlich verschiedene Weisen zu Stande kommen, drei derselben, - durch ungleichmässiges Wachsthum des Holzkörpers, durch Entwickelung der Markstrahlen zu zusammenhängenden Längsplatten, durch Bildung äusserer Holzringe, - finden sich bei Pflanzen der verschiedensten Familien; zwei andere sind jede auf einen kleinen Kreis engverwandter Arten, die kletternden Bignoniaceen und Sapindaceen beschränkt.

Bei einer ersten Gruppe anomaler Stämme wird die Zerklüftung des Holzkörpers durch ein ungleichmässiges Wachsthum desselben hervorgebracht. Indem einzelne Theile im Umfange des Holzkörpers rascher, andere langsamer wachsen oder ganz zu wachsen aufhören, entstehen vorspringende Längswülste, die durch Rinnen oder Spalten geschieden sind. Bei den wenigen Pflanzen dieser Gruppe, die ich gesehen, schienen mir immer die Hauptwülste mit den Blättern abzuwechseln. - Die Rinde umgiebt diese Stämme entweder in gleichmässiger Dicke, oder sie wuchert stärker an denselben Stellen, wo das Holz in Wachsthum zurückbleibt und füllt so die Spalten des Holzkörpers aus.

I) Potanische Zeitung 1866. 24. Jahrg. p. 57-60. 65-69. Taf. III.

Fritz Müllers gesammelte Schriften. 
Im ersteren Falle ist die Zerklüftung des Holzes schon aussen sichtbar. Nur ganz enge Spalten, deren Weite die doppelte Dicke der Rinde nicht übertrifft, sind auch hier von Rinde ausgefüllt; aber der Querschnitt zeigt, dass jede Wand der Spalte ihre eigene Rinde hat. Ich habe diesen Fall gesehen bei einer weissblühenden Lantana ${ }^{1}$ ) (Fig. 3), welche zu den zahlreichen Kletterpflanzen gehört, die ohne andere zu umwinden und ohne die Hülfe von Wurzeln, Dornen oder Ranken in dichtem Gebüsch emporklettern. Der mittlere unzerklüftete Theil des Holzringes ist hier meist so unbedeutend, dass die Stämme beim Zerbrechen leicht in vier Stücke spalten; bei einem Stamm von I $8 \mathrm{~mm}$ Durchmesser kamen nur $4 \mathrm{~mm}$ auf den mittleren Theil und davon reichlich ein Drittel auf das Mark.

Im zweiten Falle, den ich bei Peixotoa, bei Tetrapterys und bei Condylocarpon beobachtete, ist die Zerklüftung des Holzes von aussen nicht zu bemerken.

Von Peixotoa (Fig. 2) habe ich nur kaum fingerdicke Stämme gefunden, auf deren Holzkörper 6 oder 8 seichte Längsfurchen sich hinziehen. Bemerkenswerth ist an diesen Stämmen der weisse brüchige Kork, der unregelmässige hohe Längsrippen bildet und dessen Dicke bisweilen die des Stammes übertrifft.

Bei Tetrapterys (Fig. I) sehe ich an allen mir vorliegenden Stücken sechs oft sehr tief einschneidende schmale Hauptspalten, zwischen denen, in verschiedener Zahl und Anordnung, seichtere Furchen zu verlaufen pflegen. Das Holz der übrigen von mir untersuchten windenden Malpighiaceen ist bis auf das von Dicella (s. u.) regelmässig gebildet.

Höchst eigenthümlich ist die Bildung alter Stämme von Condylocarpon (Fig. 4), einer schönen windenden A pocynee mit glänzenden wirtelständigen Blättern und kleinen goldgelben Blüthen. Das Holz jüngerer Aeste bis zu etwa $1 \mathrm{~cm}$ Durchmesser bildet einen regelmässigen Ring zwischen Mark und Rinde. Wenn die Stämme ungefähr die angegebene Dicke erreicht haben, machen sich seichte Längsfurchen bemerklich, besonders deutlich in der Nähe der Blätter; macht man hier einen Querschnitt (Fig. 4. A), so sieht man, dass von den Furchen aus weisse gefässlose Streifen durch das gelbliche Holz nach dem an dieser Stelle dreikantigem Marke sich hinziehen. Bei etwas älteren Stämmen (Fig. 4. C) sieht man den jüngeren Theil des Holzringes von zahlreichen mehr oder minder tief einschneidenden Längsspalten durchzogen, die von der weissen Rinde ausgefüllt sind. Bis jetzt hat also das Holz die grösste Aehnlichkeit mit dem von Tetrapterys. Später aber wird das Wachsthum des Holzes äusserst unregelmässig; die älteren Spalten werden wieder vom Holze überwuchert und neue bilden sich am Rande, um bald ihrerseits dasselbe Schicksal zu erleiden. So zeigt der alte Stamm (Fig. 4. D) zahlreiche unregelmässig zerstreute Inseln von weisser Rinde inmitten des gelblichen Holzes. Die Zerklüftung des Holzes durch Längsfurchen ist nicht beschränkt auf dicotyledonische Kletterpflanzen; sie findet sich auch an der holzigen Achse der bisweilen über 7o Fuss langen Luftwurzeln eines Philodendron (Cipó d'Imbé der Brasilianer). - (Figr. 21.) - Abweichend vom gewöhnlichen Bau monocotyledonischer Stämme besteht das Holz hier nicht aus

1) Die Gattungen sind nach Endlicher, Genera plantarum, bestimmt; zur Restimmung der Arten lialse ich keine llülfmitte!. 
einzelnen im Parenchym zerstreuten Bündeln, sondern bildet eine zusammenlängende Masse in der Mitte des Stammes, die im Querschnitt eine sechsblättrige Rosette darstellt. Un das Holz liegt ein weiches weisses Parenchym mit zahlreichen Harzgängen, in dessen äussersten Zellenlagen Chlorophyllkörner auftreten, und dieses ist umgeben von einer sehr zähen, leicht abzulösenden schwarzen Rinde.

Bei einer zweiten Gruppe von Kletterpflanzen ist der Holzkörper dadurch in vollständig von einander getrennte Stücke zerspalten, dass die Markstrahlen zusammenhängende durch die ganze Länge des Stammes sich hinziehende Längsplatten bilden. Ausser bei einigen noch unbestimmten Pflanzen fand ich diesen Bau bei Clematis, bei einigen Cocculus-Arten, deren Stamm nicht über fingersdick zu werden scheint, bei einem hier sehr häufigen Cissus und bei Aristolochia (Fig. 5). Der von dickem, deutlich geschichtetem, braunem Korke bedeckte Stamm von Aristolochia ist wie der von Cissus im Querschnitt elliptisch; die Holzbündel sind durch weit breitere Markstrahlen von einander geschieden, als in den übrigen genannten Gattungen. In der längeren Achse des Querschnittes liegen einander gegenüber zwei breite durch secundäre Markstrahlen tief eingeschnittene Holzbündel; zwischen ihnen jederseits 2 oder häufiger 3 schmalere. Das Holz ist gelblich, von weiten Gefässen durchzogen, das seine Bündel trennende und umgebende Gewebe weiss, und nach aussen von jedem Holzbündel liegt ein Streifen eines saftreichen Gewebes, das durch zahlreiche mit bitterem aromatischem Harze gefüllte Zellen eine dunkelbraune Farbe erhält.

Aehnlich ist der Bau des Stammes auch bei Bryonia (Fig. 8). In der Mitte des Querschnitts sieht man einen dunkleren, grünlichen, fünfstrahligen Stern, dessen Strahlen nur durch ganz schmale weisse Linien getrennt werden. Etwas weiter nach außen, mit den Strahlen des Stammes abwechselnd, liegen fünf ähnliche dunkle Flecken, wie jene aus einem saftreichen Gewebe bestehend. Von ihnen gehen breitere, von den Strahlen des Sternes schmalere Holzbündel aus, die durch secundäre Markstrahlen in schmale, bisweilen eine einzige Reihe der sehr weiten Gefässe enthaltende Platten zerklüftet sind. Ein ähnlicher dunkler Fleck wie am inneren findet sich am äusseren Ende jedes Holzbündels.

Bei einer dritten Gruppe anomaler Holzbildungen beschränkt sich das fortlaufende Gewebe (Cambium) nicht wie bei der Mehrzahl der Dicotyledonen auf einen einzigen Kreis, sondern um den mittleren Holzring herum entstehen in der Rinde neue Streifen, Bogen oder vollständige Ringe von fortbildendem Gewebe und von ihnen erzeugt jüngere, den mittleren Holzring umschliessende und durch Rindenschichten von ihm getrennte Holzbildungen. Besonders schön und regelmässig findet sich dieser Bau des Holzes bekanntlich bei verschiedenen Menispermeen, deren Holzkörper überdies durch zusammenhängende Markstrahlplatten zerklüftet ist. Die Stämme erreichen bisweilen eine ansehnliche Dicke und dann wird die Zahl der einander umschliessenden Holzringe eine sehr beträclhtliche; ich habe in meinem Walde am Itajahy Menispermeenstämme gesehen, die fast eine Spanne im Durchmesser hatten und wie gewaltige Taue sich in weiten Bogen von Baum zu Baume spannten. Das in Fig. 12 gezeichnete Holz gehört wahrscheinlich einer Pflanze derselben Familie an; die aus weicherem saftreichem Gewebe gebildeten dunklen Flecken am äusseren Ende jedes Holzbündels lassen die rinander umschliessenden Holzkreise besnnders deutlich hervortreten. - 
Dagegen gehört die Pflanze, von der das Fig. 9 abgebildete Holz entnommen ist, und die ich wie die vorige noch nicht blühend gefunden habe, sicher weder zu den Menispermeen, noch in eine der anderen Familien (Ampelideen, Convolvulaceen, Gnetaceen), in denen nach Kunth (Lehrbuch der Botanik I. S. 149) eine ähnliche Bildung des Holzkörpers vorkommt.

Bei Mucuna (Fig. I3) wächst das Holz regelmässig bis zu einem Durchmesser von 5 bis $6 \mathrm{~cm}$ und darüber; dann bildet sich, durch einen ansehnlichen. bisweilen über I $\mathrm{cm}$ breiten Zwischenraum getrennt, ein äusserer Holzring, um welchen ich bei einem Stamme von etwa $\mathrm{I}_{4} \mathrm{~cm}$ Durchmesser noch die Anfänge eines dritten mehrfach unterbrochenen Ringes sehe. - Die äusseren Holzbündel bilden keinen geschlossenen Ring, sondern sind durch Längsplatten von Parenchym getrennt. Das Holz auch der älteren Stämme ist weich, saftreich und von sehr weiten Gefässen durchzogen. Sehr schön sieht man in den Zwischenräumen zwischen den Holzringen die Basttheile der Holzbündel, wie sie Schacht nennt, die sich durch dunklere Färbung und radiäre Streifung vor dem umgebenden Parenchym auszeichnen. -

Bei den bisher erwähnten Pflanzen besteht kein erheblicher Unterschied zwischen dem Bau des mittleren Holzringes und dem des umschliessenden jüngeren Holzes. Anders ist es bei Securidaca (Fig. 6). Die jüngeren Zweige dieses prächtig blühenden Kletterstrauches sind drehrund und haben ein festes dichtes Holz, in welchem mit blossem Auge kaum Gefässe zu erkennen sind. Wenn die Zweige etwa I cm Durchmesser erreicht haben, oft schon früher, nur selten (z. B. Fig. 6. A) beträchtlich später, beginnt die Bildung des Aussenholzes. Das neue Cambium bildet keine vollständigen Ringe, sondern Bogen von sehr wechselnder Ausdehnung, bisweilen so klein, dass das von ihnen erzeugte Holz nur ein einziges weites Gefäss enthält. Das neue Holz hat Gefässe von ansehnlicher Weite und ist viel weicher als der Kern, welcher sich bisweilen auch durch weit dunklere Färbung auszeichnet. Noch weicher als das neue Holz sind die dessen einzelne Stücke trennenden Bogen, die aus zwei scharf geschiedenen Schichten bestehen. Die Stücke des Aussenholzes lassen sich leicht aus einander nehmen, namentlich wo sie grössere wie $Z$ wiebelschalen über einander liegende Bogen bilden (Fig. 6. B) In Betreff ihrer oft sehr verwickelten Anordnung in älteren Stämmen verweise ich auf die Abbildungen (Fig. 6. C, D). Immer beginnt die Entwickelung des Aussenholzes und immer bleibt sein Wachsthum weit stärker an den Enden eines Durchmessers, welcher auf der durch den Ursprung der zweizeilig angeordneten Blätter gehenden Ebenen senkrecht steht. An dem dicksten Stamme, den ich besitze, beträgt der grösste Durchmesser I $2 \mathrm{~cm}$, der darauf senkrechte $9 \mathrm{~cm}$, der Durchmesser des Kernholzes $6 \mathrm{~mm}$. -

Fast ganz wie bei Securidaca ist das Aussenholz bei einer Hippocrateacee mit nicht aufspringenden saftigen Früchten, also wahrscheinlich einer Tontelea (Fig. 7) angeordnet. Das Holz ist röthlichbraun, der Bast, der in einer dünnen Schicht die einzelnen Lagen des Aussenholzes überzieht, schneeweiss und seidenglänzend. - Es verdient bemerkt zu werden, dass diese beiden so verschiedenen Familien angehörenden Klettersträucher ausser im Baue des Holzes auch in der Art des Kletterns übereinstimmen. Sie gehören zu den wenigen Pflanzen, deren junge Zweige als Ranken dienen, um Gegenstïnde, mit denen sie in Perührıng 
kommen, sich herumbiegen, sich dann verdicken und so den Kletterstrauch befestigen. Ausser bei Securidaca und Tontelea kenne ich diese Weise des Kletterns nur noch bei Hecastophyllum und einer zweiten Papilionacee aus derselben Abtheilung der Dalbergieen. -- Hätten De Candolle und Mohl je einen dieser Zweigklimmer gesehen, so würde es sicher jenem nicht eingefallen sein, die Stengel der windenden Pflanzen mit den Ranken zusammenzustellen, -- noch diesem, das Umschlingen der Stütze bei Schlingpflanzen als Folge einer durch die Berührung erregten Reizbarkeit zu betrachten.

Vielleicht gehört hierher auch das Holz der häufig abgeplatteten Stämme von Dicella, in welchem ebenfalls unregelmässig angeordnete bogenförmige Holzstreifen mit Streifen eines weichen gefässlosen Gewebes wechseln.

Eine vierte Gruppe bilden die Stämme der rankentragenden Bignoniaceen, von denen ich über ein Dutzend Arten untersucht habe. Durchschneidet man einen frischen jüngeren Zweig einer Bignonia, bei dem schon ein dünner fester Holzring um das Mark vorhanden ist, so fallen nach aussen vom Holzringe vier scharf gegen die umgebende Rinde abgesetzte dunklere Flecke ins Auge, die mit den Blättern abwechseln. Seitlich sind sie begrenzt durch gerade, meist gleichlaufende Linien, aussen durch einen nach aussen, innen durch einen nach innen gewölbten Bogen; dieser innere Bogen liegt dem Holzringe dicht an. Bisweilen erkennt man schon jetzt eine, in etwas späterer Zeit meist sehr deutliche, quere Streifung der Flecke, bedingt durch abwechselnde Schichten weicheren und festeren Gewebes.

Diese zwischen Holz und Rinde eingeschalteten, scharf gegen beide abgesetzten Stücke, die anfangs nur vier dünne, saftreiche Längsstreifen bilden, wachsen nun in der Richtung des Halbmessers in gleichem Maasse mit dem Stamme weiter, so dass ihr inneres Ende immer bis in die Nähe des Markes, ihr äusseres bis zu den äussersten Rindenschichten reicht (Fig. 18. 4). So wird durch sie der Holzkörper in vier fast bis aufs Mark getrennte Stücke zerklüftet. Später bildet sich von innen her in den Spaltstücken Holz, das von dem des eigentlichen Holzkörpers nicht auffallend verschieden ist, aber nicht mit demselben verschmilzt, sondern durch eine dünne Schicht unverholzten, dünnwandigen Parenchyms getrennt bleibt. Diese trennende Schicht setzt sich auch längs des weichen Theils der Spaltstücke und bis in die Rinde hinein fort, gegen die sich dieselben, wenigstens in jüngeren Stämmen, wie gesagt, eben so scharf absetzen wie gegen das Holz.

Die jüngeren Stämme der verschiedenen Arten zeigen keine auffallenden Unterschiede in dieser Beziehung; aber aus den gleichen Jugendformen geht im Fortschritte des Wachsthums eine ziemlich mannigfache Bildung der älteren Stämme hervor. Ich habe solche alte Stämme von fünf Arten untersucht; eine derselben ist ein Haplolophium, die anderen, deren Blüthen und Früchte ich nicht kenne, mögen zu Bignonia gehören.

Am einfachsten ist die Wachsthumsweise einer Art mit vierseitigem Stamme (Fig. I5). Die Seitenlinien der Spaltstücke sind bei dieser Art nicht gleichlaufend, sondern haben fast die Richtung von Halbmessern; daher werden die Spaltstücke nach aussen breiter; sie bleiben dabei immer von denselben Geraden begrenzt. Die Holzbildung in den Spaltstücken hält ziemlich gleichen Schritt mit 
der des Holzkörpers, so dass die durch den weichen Rindentheil der Spaltstücke gefüllten Spalten des letzteren eine geringe Tiefe haben. Der Holzkörper wächst rascher längs der ihn von den Spaltstücken trennenden Parenchymplatten; er bildet die Seiten, die Spaltstücke bilden die abgerundeten Ecken des vierseitigen Stammes. Die Parenchymplatten zwischen Holzkörper und Spaltstücken sind bei dieser Art besonders breit und augenfällig. Das Holz hat sehr deutliche Schichtungslinien, deren Wölbung in den Spaltstücken nach innen, in Holzkörper (wenigstens seinem älteren Theile) nach aussen gerichtet ist.

Bei einer zweiten Art (Fig. 14) sind die Seitenlinien der Spaltstücke in jüngeren Zweigen gleichlaufend oder kaum merklich aus einander laufend; wenn die Stämme etwa $1 \mathrm{~cm}$ Dicke erreicht haben, tritt zu jeder Seite jedes Spaltstückes, ihm dicht anliegend, ein neues, etwa halb so breites auf, neben diesem ersten später ein zweites, ein drittes u. s. w. - Das Holz der mittleren Spaltstücke reicht etwa halb so weit nach aussen, als das des Holzkörpers, das der seitlichen um so weiter, je weiter von der Mitte des Stammes sie selbst entstanden sind. Dadurch erhalten die nach aussen erweiterten Furchen, in denen der Rindentheil der Spaltstücke liegt, treppenförmige Seitenwände.

Bei einer dritten Art (Fig. 16) laufen die Seitenlinien der Spaltstücke nach aussen zusammen, und wenn der Stamm kaum I cm Dicke überschritten hat, finden sie sich vollständig vom Holzkörper unwachsen; später bilden sich bisweilen nach aussen von den ersten neue Spaltstücke, die aber bald in gleicher Weise umwachsen werden. Ziemlich tiefe Längsrinnen, die der Holzkörper eines $9 \mathrm{~cm}$ dicken Stammes zeigte, schienen hauptsächlich durch ungleichmässiges Wachsthum des Holzkörpers bedingt zu sein; vier solche Rinnen lagen in der Richtung der Spaltstücke, vier damit abwechselnd; von letzteren war an einem $2,5 \mathrm{~cm}$ dicken Stamme noch nichts zu sehen. Obwohl die vier Stücke des Holzkörpers bei dieser Art nur auf unbedeutende Strecken durch Spaltstücke getrennt sind, scheinen sie doch nicht mit einander zu verwachsen, sondern durch eine zusammenhängende dünne Schicht unverholzten Parenchyms getrennt zu bleiben; eine von dẹm erwähnten $9 \mathrm{~cm}$ dicken Stamme abgesägte, etwa $5 \mathrm{~mm}$ dicke Scheibe bekam beim Trocknen feine Spalten in der Richtung der Spaltstücke und war dann leicht in vier Stücke zu zerbrechen, während die Kraft meiner Hände nicht ausreichte, sie in irgend einer anderen Richtung zu zerbrechen.

Dem der letzterwähnten Art sehr ähnlich ist während langer Jahre der Stamm von Haplolophium gebaut (Fig. 18); nur macht sich ein ungleichmässiges Wachsthum des Holzkörpers früher und in höherem Maasse bemerklich, so dass z. B. ein Stamm von $3 \mathrm{~cm}$ Durchmesser gegen 20 unregelmässig vertheilte Längsrinnen von verschiedener Tiefe zeigte. Auch treten bisweilen nach dem Umwachsen der ältesten Spaltstücke neue, nicht nur in deren Verlängerung. sondern auch mit ihnen abwechselnd auf. - Recht alte Stämme aber (Fig. 18. C) sind durch eine Eigenthümlichkeit ausgezeichnet, die mir bei keiner anderen Bignoniacee vorgekommen ist, durch die Bildung eines äusseren Holzringes. Das Aussenholz ist von dem des mittleren Holzkörpers nicht verschieden.

Weit mehr als bei allen vorhergehenden Bignoniaceen ist das Holz einer fünften $\Lambda$ rt (Fig. 17) zerklüftet. Zweige von 3 bis $+\mathrm{mm}$ Durchmesser besassen nur die 4 gewöhnlichen Schaltstücke; bei 5 bis $6 \mathrm{~mm}$ (liig. 17. A) fanden sich 
mit ihnen abwechselnd vier jüngere; die Spaltstücke hatten jetzt gleichlaufende Seitenlinien; Holztheil und Rindentheil waren von ungefähr gleicher Länge. Leider fehlen mir Zwischenstufen zwischen diesen Zweigen und einem $2 \mathrm{~cm}$ dicken Stamme. Ich habe die Pflanze erst einmal gefunden und konnte mir zwar leicht, als ich die überaus zierliche Bildung des Holzes erkannt, ein langes Stück des einen Baum umwindenden Stammes herausschneiden, aber nur mit Mühe einige dünne Zweige erklettern. - Die Spaltstücke des Stammes haben. abweichend von denen der jüngeren Zweige, die Gestalt einer Raute, deren kürzere Diagonale den nach innen gewendeten Holztheil von dem nach aussen gewendeten Rindentheile scheidet. Bei dieser Gestalt würden sie vom Holzkörper umwachsen werden, wenn dem nicht durch das Auftreten neuer Spaltstücke vorgebeugt würde, die sich an die Seiten der älteren anlegen und etwa halb so breit als diese sind; die Form der Spaltstücke lässt hier die treppenförmige Bildung der Seitenwände der in das Holz eindringenden Spalten noch weit deutlicher hervortreten, als bei der zweiten Art. Ausser den vier ältesten und tiefsten Spalten finden sich noch 4 zweiter und 8 dritter Ordnung, die ebenfalls der Bildung von Spaltstücken ihre Entstehung verdanken. Man kann leicht die zahlreichen Spaltstücke, die das Holz bilden helfen, aus einander nehmen. - Nicht genug mit dieser bedeutenden Zerklüftung; es findet sich noch zwischen den Holztheilen der vier ältesten Spaltstücke ein weisses, weiches Parenchym, das an einigen Stellen meines Stammes 2, an anderen (wie in der Abbildung Fig. 17. B) 3 von den 4 Stücken des Holzkörpers, an anderen alle 4 vollständig von einem schmalen das Mark umschliessenden Holzringe abschneidet. Dies Parenchym steht in Zusammenhang mit den Parenchymplatten, welche die Spaltstücke vom Holzkörper trennen, und scheint aus einer Wucherung desselben hervorgegangen zu sein. Diese Art mit dem stark zerklüfteten Stamme ist, so viel ich bis jetzt gesehen, die einzige windende unter unsern Bignonien; die andern verlassen sich beim Klettern ausschliesslich auf die Ranken ihrer Blätter oder befestigen sich nachträglich durch Haftwurzeln.

Einen auffallenden Gegensatz zu dieser Art bildet, in Lebensweise und Bau des Holzes, eine andere Bignonie, die ich niemals klettern sah, sondern nur als niedrigen Busch mit schwanken, oft niederliegenden Aesten, sie erzeugt meist vollständige dreizählige Blätter und nur wenige einfache Ranken. Ihr Holz erscheint als runde furchenlose Walze, indem die Holzbildung in den Spaltstücken gleichen Schritt hält mit der im eigentlichen Holzkörper. So wenigstens in fingerdicken Stämmen. Ich vermochte nicht die Spaltstücke aus dem Holze herauszunehmen, was bei anderen Arten leicht ist; ich bin an einigen Zweigen sogar in Zweifel über deren Vorhandensein gewesen, während bei anderen namentlich ihr Rindentheil, vier dunklere, scharf umschriebene Flecken in der Rinde bildend, sofort ins Auge fällt.

Eine fünfte Gruppe wird gebildet von den Stämmen einiger kletternden Sapindaceen. Bei ihnen ist der mittlere Holzring umgeben von mehreren Nebenachsen, die mit demselben durch eine gemeinsame Rinde verbunden sind. Ihre Zahl und Anordnung wechselt nach den Arten.

Bei einer Serjania (Fig. I9), die in allen Zäunen in und um Desterro wuchert, finden sich drei Nebenachsen, welche die Hauptachse in ihrer ganzen Iänge be- 
gleiten und beim Ursprung jedes dritten Blattes auf eine kurze Strecke mit ihr verschmelzen (Fig. I 9. A). Die Blätter entspringen zwischen den Nebenachsen von den Seiten des dreiseitigen Stammes in einer bald nach rechts, bald nach links aufsteigenden Schraubenlinie. Steigt die Schraubenlinie nach rechts auf, so entspringt eine Ranke links von jedem Blatte und die links davon verlaufende Nebenachse ist in der Nähe seines Ursprungs mit der Hauptachse verschmolzen; dagegen stehen die Ranken rechts und die rechtsliegende Nebenachse verschmilzt mit der Hauptachse, wenn die Blattspirale nach links aufsteigt. Oberhalb des Blattes ist die dem Blatte gegenüberliegende Nebenachse weiter von den beiden anderen entfernt, zwischen denen das Blatt steht, als diese letzteren von einander (Fig. I 9. B).

Minder einfach ist die Anordnung der Nebenachsen bei einer anderen Sapindacee, von der ich Blüthen und Früchte nicht gesehen habe, also nicht weiss, ob sie zu Paullinia oder Serjania gehört (Fig. 20). Schneidet man einen Stamm in der Mitte zwischen zwei Blättern durch, so sieht man (Fig. 20. A) die Hauptachse von sechs Nebenachsen umgeben, die durch zwei breite Lücken in zwei Gruppen (die eine von 4, die andere von 2) geschieden sind. Verfolgt man diese an älteren Stämmen schon äusserlich als vorspringende Wülste zu erkennenden Nebenachsen am Stamme abwärts, so findet man, dass siè in sehr verschiedener Höhe entspringen. Bezeichnen wir die älteste am tiefsten entspringende mit I, die nächstjüngere mit 2 u. s. f. bis zur jüngsten 6 , so stehen sie um die Hauptachse herum in folgender Ordnung: 3, 6, I, 4, - Lücke - , 2, 5, - Lücke. Jede Nebenachse ist also von der nächstjüngeren durch zwei andere getrennt, oder $3 / 8$ des Umfangs von ihr entfernt.

Verfolgen wir nun unsern Stamm nach oben. Etwas unterhalb des nächsten Blattes trennt sich in der Lücke zwischen 2 und 4 eine neue Nebenachse (7) von der Hauptachse; mit dieser neuen Nebenachse verschmilzt 4 und von 2 geht ein dünnes Holzbündel zu ihr hinüber. Von den verschmolzenen Nebenachsen entspringt das Blatt, die Ranke und etwaige Aeste. Dicht über dem Blatte zeigen sich also die Nebenachsen in der Fig. $20 B$ gezeichneten Anordnung. In grösserer oder geringerer Entfernung vom Blatte trennen sich 4 und 7 wieder; die Hauptachse ist nun von 7 Nebenachsen umgeben, die von einer einzigen Lücke unterbrochen sind und in folgender Ordnung stehen: 3. 6. 1. 4. 7. 2. 5. Lücke. - (Diese Anordnung zeigt die Fig. 1 I 2 in Schacht's Lehrbuch der Anatomie u. Physiol. der Gewächse. II. S. 58). - Meist schon unter der Mitte des Stengelgliedes, bisweilen erst weiter oben verschmilzt die älteste Nebenachse 1. wieder mit der Hauptachse, so dass aufs Neue zwei Lücken vorhanden sind, bei folgender Anordnung der Nebenachsen: 3.6. - Lücke. - 4.7.2.5. - Lücke. Unter dem folgenden Blatte trennt sich eine neue Nebenachse (8) von der Hauptachse, in der Lücke zwischen 3 und 5, verschmilzt mit 5, erhält ein Holzbündel von 3 und trennt sich oberhalb des Blattes wieder von 5. Dann verschmilzt 2 mit der Hauptachse, eine neue Nebenachse löst sich ab in der früher von I eingenommenen Lücke zwischen 4 und 6 und so weiter. - Jede Nebenachse durchläuft also $6 \frac{1}{2}$ Stengelglied; sie trennt sich von der Hauptachse etwas unterhalb eines Blattes, verschmilzt mit der links neben ihr liegenden Nebenachse und erhält ein Holzbündel von der rechtsliegenden; sie trennt sich von jener wieder 
oberhalb des Blattes; am Ende des dritten Stengelgliedes verschmilzt sie für eine kurze Strecke mit der rechts von ihr entspringenden Nebenachse, giebt am Ende des 5 ten. Stengelgliedes ein Holzbündel zu der links entspringenden und verschmilzt wieder mit der Hauptachse in der Mitte des siebenten. Am Ende des achten wird die so entstandene Lücke von einer neuen Nebenachse ausgefüllt. An allen untersuchten Aesten des einzigen weitrankenden Busches dieser Art, den ich kenne, stand jede folgende Nebenachse $3 / 8$ des Unfangs rechts von der vorhergchenden und die Blätter bildeten eine nach rechts aufsteigende Schraubenlinie; doch ist es nicht unwahrscheinlich, dass auch die entgegengesetzte Richtung vorkommt.

Bei zwei anderen rankenden Sapindaceen, unter denen eine hier sehr häufige Paullinia, habe ich den Stamm regelmässig gebildet gefunden.

Der Stamm von Strychnos (Fig. Io) lässt sich in keine der bisher betrachteten Gruppen einreihen. Auf dem Querschnitte des frischen Stammes sieht man um einen mittleren regelmässig gebildeten Kern dunklere Flecken, die bald in ziemlich regelmässige concentrische Kreise geordnet sind, bald ohne Ordnung in den äusseren Holzschichten zerstreut scheinen; nach aussen ist jeder Fleck von einem weissen Bogen begrenzt. Es sind die Querschnitte von Strängen eines weichen, dünnwandigen, in seinem dunkleren Theile saftreichen Gewebes, die den Stamm in seiner ganzen Länge durchziehen. Ausser langen, am Ende spitz zulaufenden Zellen finden sich in diesem Gewebe schmale Markstrahlen.

Zu den sonderbarsten Stammbildungen gehört bekanntlich die von Caulotretus. Die deutschen Ansiedler am Itajahy haben diesen plattgedrückten Stämmen, welche mit regelmässigen, kurzen, welligen Biegungen in die Wipfel der höchsten Urwaldsbäume aufsteigen, den bezeichnenden Namen „Affentreppen“ gegeben. Die Abplattung ist schon an ganz jungen Zweigen vorhanden. Bemerkenswerth ist an diesen jungen Zweigen (Fig. I I) die kreuzförmige Gestalt des Markes. Die Blätter oder Blattnarben finden sich wie bei Securidaca an den Breitseiten der Stämme, so dass, wie hier und wie bei Lantana, Condylocarpon und Tetrapterys, die vorwiegend entwickelten Abschnitte des Holzkörpers mit den Blättern abwechseln. Aeltere Stämme fehlen mir hier.

Soweit die Thatsachen. Nun noch einige Worte über ihre Beziehung zur Frage nach der Entstehung der Arten. Es liegt auf der Hand, dass dieselben der Lehre Darwin's durchaus günstig sind.

Die weit überwiegende Mehrzahl der von mir beobachteten holzigen Kletterpflanzen hat einen auf die eine oder andere Weise zerklüfteten Stamm, den ich noch bei keiner der zahlreichen, darauf untersuchten, nicht kletternden Sträucher und Bäume gefunden. Bei einer Bignonia, die nicht mehr klettert, sind noch die bei verwandten Arten die Zerklüftung bewirkenden Theile vorhanden, aber keine Zerklüftung mehr. Jedenfalls also ist diese Zerklüftung des Stammes den Kletterpflanzen von wesentlichem Nutzen und wo bei einer derselben eine Abweichung vom gewöhnlichen Baue in dieser Richtung eintrat, wurde sie durch die natürliche Auslese erhalten und vervollkommnet. Leichtere Abweichungen vom gewöhnlichen Bau, wie ungleichmässiges Wachsthum des Holzes, Vereinigung der Markstrahlen zu zusammenhängenden Platten, Theilung der Holzbündel in radiärer statt in 
seitlicher Richtung (worauf nach Schacht die Bildung äusserer Holzringe beruht) konnten leicht bei Pflanzen der verschiedensten Familien unabhängig von einander sich ausbilden. Es würde aber im höchsten Grade unwahrscheinlich sein, dass so eigenthümliche Bildungen, wie die Spaltstücke der Bignonien oder die vom Stamme sich loslösenden und nach einem bestimmten Verlauf wieder mit demselben verschmelzenden Nebenachsen der Sapindaceen zweimal bei verschiedenen Pflanzen unabhängig von einander in gleicher Weise sich entwickelt hätten. Diese durfte man also von Darwin's Lehre aus a priori nur bei nächstverwandten Arten zu finden hoffen, die sie von gemeinsamen Vorfahren ererbten. - Wären dagegen die Arten unveränderlich und unabhängig von einander erschaffen, hätte ein Schöpfer jeder die ihren Lebensverhältnissen entsprechenden Einrichtungen zugetheilt, so wäre kein Grund abzusehen, warum derselbe die Bildung des Bignonien- und Sapindaceen-Stammes nicht ebenso unter die entferntest stehenden Familien vertheilt haben sollte, wie die des Stammes von Clematis oder Menispermum ${ }^{1}$ ).

Desterro, October 1865 .

\section{Erklärung der Abbildungen auf Tafel XXVIII.}

Die Figuren sind alle nach Querschnitten frischer Stämme in natürlicher Grösse gezeichnet.

Fig. 1. Tetrapterys.

Fig. 2. Peixotoa.

Fig. 3. Lantana.

Fig. 4. Condylocarpon. A Querschnitt dicht unter einem Blattwirtel. B Querschnitt desselben Stammes etwa $1,5 \mathrm{~cm}$ höher genommen. C Querschnitt eines älteren. $D$ Querschnitt eines alten Stammes, der lange Zeit, - 9 Jahre habe ich ihn so gekannt - , an einer schattigen Stelle der Erde aufgelegen und vielleicht daher eine ungewöhnliche dicke Rinde erhalten hat.

Fig. 5. Aristolochia.

Fig. 6. Securidaca.

Fig. 7. Hippocrateacee (Tontelea?).

Fig. 8. Bryonia.

Fig. 9. Unbestinmt.

Fig. 10. Strychnos

Fig. I I. Caulotretus, junger Zweig.

Fig. 12. Menispermee (?).

Fig. 13. Mucuna.

Fig. 14-17. Verschiedene Bignoniaceen (Bignonia?).

Fig. 18. Haplolophium.

Fig. 19. Serjania. A Durch den Ursprung einer Ranke gemachter Querschnitt; zur Seite der durchnittenen Ranke sieht man die Blattnarbe. $B$ Querschnitt durch die Mitte eines Stengelgliedes; das nächste Blatt unter dem Querschnitt steht zwischen den Nebenachsen I und 2.

Fig. 20. Sapindacee (Paullinia?). A Querschnitt durch die Mitte eines Stengelgliedes. $B$ Querschnitt eines älteren Stammes dicht über einer Blattnarbe. Die Zahlen I. 2. 3. u. s. w. bezeichnen die Reihenfolge des Alters der Nebenachsen.

Fig. 21. Luftwurzel von Philodendron.

I) Ich darf diese Gelegenheit nicht vorübergehen lassen, ohne Darwin öffentlich meinen Dank auszusprechen für dic Uebersendung seiner anziehenden, an trefflichen Beobachtungen reichen Abhandlung ,on the movements and habits of climbing plants", durch die ich zur Beschäftigung mit den in vielen Hinsichten so merkwürdigen Kletterpflanzen angeregt wurde. 


\title{
Ueber die Befruchtung der Martha (Posoqueria?) fragrans ${ }^{1}$ ).
}

\author{
Mit Tafel XXIX.
}

Auf einem Spatziergange traf ich vor Kurzem einen Strauch, der mit weissen herrlich duftenden Blumen geschmückt war. Es fiel mir auf, dass ich in den grossen weitgeöffneten Staubbeuteln keine Spur von Blüthenstaub bemerkte. Dies veranlasste mich zu einer näheren Untersuchung, deren Ergebnisse ich im Folgenden mittheilen will.

Der Strauch gehört in die Familie der Rubiaceen, zur Gruppe der Gardenieen, in die unmittelbare Nähe der Gattung Posoqueria Aubl., von der er vielleicht kaum zu trennen ist. Doch soll Posoqueria (Endlicher genera plantarum No. 3308) „stamina brevissima, apice infracto geniculata" besitzen; letzteres liesse sich, wie man sehen wird, höchstens von den beiden oberen Staubfäden unseres Strauches sagen und gerade diese beiden sind von ansehnlicher Länge. Ausserdem sind wohl, da das Gegentheil nicht bemerkt wird, bei Posoqueria, wie es in der Familie Regel ist, die Staubgefässe frei und alle von gleicher Bildung. Ich schlage für unsere Pflanze, falls sie noch keinen anderen besitzen sollte, den Namen Martha fragrans vor.

Die kurzgestielten Blumen stehen am Ende der Zweige; ihre I I bis $14 \mathrm{~cm}$ lange Röhre hat meist eine ziemlich wagerechte Richtung.

Die Knospe (Fig. I im Längsschnitt) ist wie bei Posoqueria dadurch ausgezeichnet, dass ihr dickeres von den Zipfeln der Blumenkrone gebildetes Ende abwärts gebogen ist und mit der langen Röhre einen stumpfen Winkel bildet. Eigenthümlich ist auch die Knospenlage der Blumenkrone, während sonst bei den Rubiaceen die Zipfel der Blumenkrone eine klappige oder (wie beim Kaffee) eine gedrehte Knospenlage zeigen, werden bei unserer Pflanze die beiden unteren Zipfel von den seitlichen und diese wiecler von dem oberen gedeckt, also vollständig wie bei den Blumenblättern der Schmetterlingsblumen. Nach der Entfaltung der Blumenkrone ist deren in der Knospe so augenfällige Unregelmässigkeit nur noch in der etwas grösseren Iänge und Breite des oberen Zipfels ausgesprochen (Fig. 2). - -

1) Botanische Zeitung 1866. 24. Jahrg. 1. 129-133. Гaf. VI. A. 
Die Staubfäden entspringen in der Röhre der Blumenkrone dicht unter dem bärtigen Schlunde. Der untere Staubfaden ist kürzer, aber breiter als die übrigen; er ist wenig länger als der Durchmesser des Schlundes, nach oben allmählig verjüngt, doppelt so breit als dick und im Querschnitt (Fig. 5) nierenförmig, da seine innere Fläche von einer tiefen längsfurche durchzogen ist, sein Gefässbündel liegt der inneren Fläche viel näher als der äusseren. Die seitlichen Staubfäden sind unbedeutend länger und schmäler, als der untere, und im Querschnitt unregelmässig eiförmig; die oberen Staubfäden endlich sind etwa doppelt so lang, aber nur halb so dick, als der untere, und im Querschnitt den seitlichen ähnlich.

Die Staubbeutel, die am Rücken über der Basis befestigt sind, hängen ziemlich fest zusammen und zwar besonders fest die seitlichen mit den oberen. So bilden sie bis zur Zeit, wo sie sich öffnen, einen blassgelben dick eiförmigen Knopf, dessen stumpf kegelförmige Spitze geschlossen ist, während am unteren Ende ein enger Eingang bleibt zu der von den Staubbeuteln umschlossenen mittleren Höhle. Die äussersten Spitzen der Staubbeutel und die unterhalb des Befestigungspunktes liegenden Theile enthalten keinen Blüthenstaub. Wodurch das Zusammenhalten der Staubbeutel bewirkt wird, ob nur durch das Ineinandergreifen der Unebenheiten ihrer Seitenflächen, oder ob, wie es mir einige Male unter dem Mikroskope schien, durch einen besonderen Kitt, lasse ich unentschieden.

Die Körner des Blüthenstaubes (Fig. 6) sind kuglig, von etwa o,o6 mm Durchmesser; ihre äussere Haut erhält durch netzförmige Verdickungen ein zelliges Ansehen und zeigt gewöhnlich 4, selten 3, höchst selten 5 dünnhäutige Stellen zum Austritt der Schläuche. Jeder dieser Stellen sitzt eine durchsichtige, ziemlich stark lichtbrechende Halbkugel auf, neben welcher oder auch unter welcher, sie wie einen Deckel emporhebend, der Pollenschlauch hervortritt.

In Folge der ungleichen Länge der Staubfäden ist der Staubbeutelknopf schief nach unten gerichtet. Der untere und die beiden seitlichen Staubfäden sind dabei, so lange sie den unversehrten Knopf tragen helfen, ziemlich gerade; die oberen dagegen zeigen eine doppelte Biegung, die bald ziemlich scharf knieförmig, bald sanfter, mehr bogenförmig ist, die erste Biegung liegt etwa in der Mitte ihrer Länge, die zweite nahe ihrem oberen Ende. Man kann daher an diesen Staubfäden einen unteren, mittleren und oberen Abschnitt unterscheiden. In früherer Zeit sind die unteren Abschnitte beider oberen Staubfäden gleichlaufend, die mittleren weichen nach aussen aus einander, die oberen sind wieder nach innen gerichtet und heften sich nahe beisammen an die Rückenfläche ihrer Staubbeutel. Je näher die Reife der Blüthe rückt, um so mehr weichen die unteren Abschnitte der oberen Staubfäden aus einander, so dass zur Zeit des Aufblühens diese Staubfäden ein weites Thor bilden, das etwa so breit als hoch ist (Fig. 2, C).

Die Staubbeutel springen mit längsspalten nach innen auf, etwa einen Tag bevor die Blume sich öffnet, und der Blüthenstaub fällt in die Höhle des Staubbeutelknopfes. Nach dem Aufspringen schrumpfen die Staubbeutel stark zusammen und nehmen eine bräunliche Farbe an. Der Durchmesser des Knopfes sinkt durch dieses Einschrumpfen bis auf etwa die Hälfte (man vergleiche Fïg. I mit Fig. 2), und der Blüthenstaub sämmtlicher Staubbeutel wird dadurch in eine einzige lose zusammenhängende Masse zusammengepresst. 
Nun beginnen die Blumen sich zu öfnen. Zuerst entfalten sich, obgleich zu innerst gelegen, die beiden untern Zipfel; der obere bleibt mit den mittleren bisweilen noch stundenlang zusammenhängend und bildet eine Art gewölbter Oberlippe oder ein Schutzdach über den Staubgefässen. Die entfalteten Zipfel breiten sich wagerecht aus, oder biegen sich selbst mehr oder weniger stark zurück. An dem ersten Strauche, den ich fand, pflegten sie sich meist ziemlich wagerecht zu halten (Fig. 2), an einem andern stark zurück zu biegen (Fig. 3, 4).

Wird jetzt einer der beiden oberen Staubfäden an der Innenseite seiner oberen Biegung (Fig. 2, $A, C, x$ ) berührt, so birst der Staubbeutelknopf in drei Stücke, ein unteres, gebildet von dem unteren, und zwei seitliche, gebildet von je einem seitlichen und einem oberen Staubbeutel. Die seitlichen Stücke schnellen nach aussen, der untere Staubfaden springt nach oben, wodurch - wie bei Catasetum - der Blütenstaub mit grosser Gewalt hinweggeschleudert wird; kaum hier und da bleibt ein einzelnes Körnchen an den Staubbeuteln haftend.

Um Richtung und Anfangsgeschwindigkeit dieses Wurfes festzustellen, wählte ich zwei in jeder Hinsicht möglichst ähnliche frisch aufgeblühte Blumen; ich hielt die erste mit senkrecht gestellter Röhre so, dass ihr Staubbeutelknopf in gleicher Höhe mit der Oberfläche eines Tisches war und schoss ab; der Blüthenstaub fiel auf den Tisch in einer Entfernung von $420 \mathrm{~mm}$. Nachdem nun in $210 \mathrm{~mm}$ Entfernung ein Buch auf den Tisch gestellt war, wurde die zweite Blume von der gleichen Stelle aus abgeschossen; der Blüthenstaub traf das Buch in $65 \mathrm{~mm}$ Höhe. - Ein ähnlicher Versuch mit zwei anderen Blumen ergab für die Weite des Wurfs $480 \mathrm{~mm}$, für die Höhe I Io $\mathrm{mm}$. - Daraus berechnet sich, als Mittel der beiden Versuche, dass der Blüthenstaub mit einer Anfangsgeschwindigkeit von etwa $3 \mathrm{~m}$ in der Secunde, einen Winkel von etwa $50^{\circ}$ mit der Richtung der Blumenröhre bildend, fortgeschleudert wird. Selbstverständlich machen diese Zahlen keinen Anspruch auf Genauigkeit ${ }^{1}$ ). - Bisweilen bleibt bei dem Wurfe der ganze Blüthenstaub in einer Masse vereint, häufiger wird er in kleineren oder grösseren Brocken über eine kürzere oder längere Strecke verstreut. Er haftet leicht selbst an glatten Gegenständen, z. B. der Klinge eines Federmessers.

Die Stelle, deren Berührung die plötzliche Entladung des Staubbeutelknopfes veranlasst, ist eine sehr beschränkte. Man kann die Staubbeutel, man kann den untern und die seitlichen Staubfäden überall berühren, man kann diese Staubfäden durchschneiden, ohne dass der Schuss losgeht; selbst die oberen Staubfäden kann man - mit einiger Vorsicht und einem recht scharfen Messer - sowohl dicht an der Blumenkrone, als dicht an den Staubbeuteln durchschneiden, man kann an der ganzen äussern gewölbten Seite des von ihnen gebildeten Thores hinfahren; aber sobald man, etwa mit der Spitze eines Bleistifts, von oben oder

1) Ist $w$ die Weite, $h$ die Höhe des Wurfs, $\alpha$ der Elevationswinkel, $c$ die Anfangsgeschwindigkeit, so ist bekanntlich tang. $\alpha=\frac{4 \mathrm{~h}}{\mathrm{w}}$ und $\mathrm{c}=\sqrt{\frac{2 \mathrm{gw}}{\sin 2 a}}$. Fiir den ersten Versuch ist $\alpha=37^{0} 56^{\prime}, \mathrm{c}=2,914 \mathrm{~m}$; für den zweiten ist $\alpha=42^{\circ} 30^{\prime} ; \mathrm{c}=3,073 \mathrm{~m}$. Da die Röhre senkrecht stand, ist $90^{\circ}-\alpha$ der Winkel zwischen Röhre und Richtung des Wurfes. - w und $h$ in der angegebenen Weise an zwei verschiedenen Blumen zu bestimmen, hat das Ueble, dass wenn w für beide nicht gleich ist, $h$ zu klein erhalten wird; doch da die Richtung des Wurfs in der Nähe des Scheitels der Parabel nahezu wagerecht ist, wird der Fehler kein allzu erheblicher werden. 
von unten her an der Innenseite des Thores hinstreichend an die obere Biegung der Staubfäden kommt, hat man, ehe man sichs versieht, den Blüthenstaub an der Nase oder im Barte sitzend. Hat man zuvor den unteren Staubfaden durchgeschnitten, so schnellen bei Berührung der bezeichneten Stelle die seitlichen Stücke wie gewöhnlich nach aussen, aber der Blüthenstaub kann natürlich nicht weggeschleudert werden; es bleibt dann gewöhnlich der untere Staubbeutel mit einem der seitlichen Stücke verbunden und in diesem nun aus drei Staubbeuteln bestehenden Stücke bleibt der Blüthenstaub liegen. - Hat man den untern Staubfaden, einen der oberen und den dazwischenliegenden seitlichen durchgeschnitten, so biegen sich die beiden übrigen in derselben Weise wie nach dem Platzen des Knopfes nach aussen; da nun alle Spannung der seitlichen und oberen Staubfäden aufgehört hat, kann man die sonst so empfindliche Stelle auf jede WVeise misshandeln, ohne dadurch den Knopf zu sprengen.

Um das Ausschleudern des Blüthenstaubes zu veranlassen, bedarf es nur einer ganz leisen Berührung an der bezeichneten Stelle. In meiner Stube hatte ich Mühe, die zn Versuchen bestimmten Blumen vor den Fliegen zu bewahren, die oft zur Unzeit den Knnopf entluden. Im Allgemeinen natürlich störend, haben mir einmal diese zudringlichen Eingriffe der Fliegen einen guten Dienst geleistet. Ich hatte im Freien einigemal den Blüthenstaub auf dem oberen Blumenkronzipfel liegend gefunden und wusste mir das nicht recht zu erklären, bis ich sah, wie eine Fliege in eine erst halb geöfnete Blume kroch und hier die Staubladung abschoss, die nun natürlich gegen den noch darüber gewölbten oberen Zipfel der Blumenkrone geworfen wurde. Nachdem die Blume eine Zeitlang geöffnet ist, erfolgt die Entladung auch, wenn man den untern Theil der Naht zwischen den beiden oberen Staubbeuteln berührt.

Ohne äusseren Anstoss scheint keine Entladung stattzufinden. Eine Blume. die ich vor Insekten geschützt hatte, begann bereits zu welken, als am siebenten Tage nach dem Aufblühen durch eine zufällige Berührung der Schuss losging. Indem der untere Staubfaden, den Blüthenstaub auswerfend, nach oben schnellt, legt er sich über den Schlund der Blumenkrone und verschliesst denselben bis auf einen schmalen Spalt jederseits (Fig. 2, D). Sein oberes Ende drückt fest gegen den Rand des Schlundes und biegt sich noch stärker, wenn man diesen wegschneidet. - Der Staubfaden wird nach oben geschnellt und hier festgehalten durch die pralle Füllung der Zellen seiner Rückenwand; wenn man die Rückenhälfte abspaltet, richtet er sich gerade in die Höhe. (Der Versuch ist mir oft misslungen, indem ich bald zu viel, bald zu wenig weggeschnitten hatte.) Spaltet man den unteren Staubfaden bald nach der Entladung des Blüthenstaubes in zwei seitliche Hälften, so biegen sich dieselben ebenso stark nach aussen, als sie nach oben gekrümmt sind. Die Spannung, die das Aufwärtsschnellen des Staubfadens bewirkte, liegt also nur im mittleren Theile der Rückenwand und überwiegt ebenso sehr die der Seitentheile dieser Wand, als die der Innenwand. Somit hat die grosse Breite, die diesen Staubfaden vor den übrigen auszeichnet, nichts mit dem Aufwärtsschnellen zu thun und scheint keinen anderen Nutzen zu haben als den, den Schlund der Blume vollständiger zu schliessen.

Etwa acht bis zwölf Stunden nach der Entladung des Blüthenstaubes beginnt der untere Staubfaden sich langsam zin erheben, etwa zwei Stunden später steht 
er aufrecht, um dann noch langsamer sich naclı aussen zurückzubiegen. Diese zweite dem blitzschnellen Aufwärtsschlagen folgende langsame Bewegung, durch welche der verschlossene Schlund der Blume wieder geöffnet wird, beruht auf einem Einschrumpfen oder Vertrocknen der Rückenwand des Staubfadens. Früher weiss, nimmt dieselbe jetzt eine gelbliche Farbe an. - Man kann das Aufrichten schr rasch bewirken, wenn man die Blume (die Rückenfläche des Staubfadens nach unten gewandt) über einer brennenden Lampe hin- und herfährt.

Der Griffel, der in seiner oberen Hälfte schraubenförmig gedreht ist, reicht etwa bis in die Mitte der Röhre der Blumenkrone; in einer Röhre von $112 \mathrm{~mm}$ Länge hatte er genau $5^{6} \mathrm{~mm}$, in einer andern $108 \mathrm{~mm}$ langen Röhre hatte er $60 \mathrm{~mm}$. Die Narbe ist behaart und zweispaltig; in der Knospe liegen die beiden Hälften aneinander, später weichen sie auseinander.

Im Grunde der Röhre findet sich eine ansehnliche Menge Honig, der bisweilen bis über $1 / 6$ ihrer Länge füllt. - Die Blume ist, wie schon bemerkt, von reiner weisser Farbe und verbreitet einen starken ungemein lieblichen Wohlgeruch.

Es sei hier beiläufig bemerkt, dass weisse Farbe und starker süsser Duft sich sehr häufig beisammen finden. Alle unsere stark duftenden Rubiaceen (Coffea, Gardenia, Randia) sind weissblühend. Unsere zahlreichen gelben und rothen Apocyneen (Allamanda, Echites, Prestonia, Condylocarpon, Lochnera) sind geruchlos, während eine schneeweisse Tabernaemontana die Luft weithin mit betäubend süssen Dufte füllt. Ebenso entbehren unsere blauen, violetten oder rothen Winden (Quamoclit, Ipomoea) des Geruches, während die weissen Riesenblumen von Calonyction lieblich duften. Neben gelben fast geruchlosen haben wir in unseren Gärten und halbverwildert stark riechende weisse Arten von Hedychium und Jasminum. Diese wenigen Beispiele mögen genügen; jeder Pflanzenkenner wird zahlreiche andere hinzufügen können. Wahrscheinlich werden alle diese weissen duftreichen Blumen von nächtlichen Insekten besucht, die, durch die weisse Farbe und den Wohlgeruch angelockt, ihre Befruchtung bewirken oder unterstützen. Calonyction, das mit unserer Martha fragrans auch die ungewöhnliche Länge der Blumenröhre gemein hat, öfnet sich gegen Abend und welkt kurz nach Sonnenaufgang.

Bei Martha fragrans wird nur ein Dämmerungsfalter mit langer Rollzunge den Honig aus dem Grunde der langen Röhre schlürfen nnd nur ein solcher den Blüthenstaub zu der tief verborgenen Narbe bringen können. Nun, wenn ein solcher Schmetterling durch den Duft oder die weisse Farbe einer frisch geöffneten Blume angelockt zu ihr heranfliegt, wird er die Oeffnung der Röhre, die in ihrer Tiefe seine süsse Nahrung birgt, rings von den aufrechtstehenden Staubfäden versperrt finden und nur zwischen den beiden oberen Staubfäden bleibt ihm ein weites Thor geöffnet. Will er aber hier seine Zunge einschieben, so wird er fast unfehlbar an einen der Punkte stossen, deren Berührung den ihm gestellten Selbstschuss entladet. Seine Rollzunge wird von dem kräftig dagegen geschleuderten Blüthenstaube überstreut und zugleich wird ihm der Eingang zum Honigvorrath vor der Nase zugeschlagen und erst nach zwölf Stunden wieder geöffnet. A u f diese Weise wird die Befruchtung der Blume durcli ihren eigenen Blüthenstaub verhindert. - Wahrscheinlich wird sich der getäuschte Schmetterling zu trösten wissen, indem er eine andere Blume - (vielleicht, von dem Schusse verscheucht, an einem anderen Strauche) - aufsucht, deren unterer Staub- 
faden sich bereits nach aussen gebogen hat und ihn ohne weitere Fährlichkeit die Rollzunge bis zum Grunde der Röhre einführen lässt, - wobei dann die durch die ganze Breite der Röhre sich ausspreizende haarige Narbe den anhaftenden Blüthenstaub abfegen und sich so mit dem Staube einer anderen Blume befruchten wird.

Wer in einer mondhellen Nacht bei einem Strauche Wache stehen wollte, würde wohl Zeuge dieses Befruchtungsvorganges werden können, der übrigens so einfach aus dem Baue und den Lebenserscheinungen der Blume sich ergiebt, dass er kaum einer weiteren Bestätigung bedürftig scheint. Dass die Entladung des Staubbeutelknopfes vorzüglich des Nachts und durch Insekten stattfindet, unterliegt übrigens keinem Zweifel. Ich habe meine Pflanzen während mehrerer Wochen täglich besucht und mit einer Ausnahme (5. Decbr.) des Morgens stets fast alle Blumen entladen, gegen Abend aber zahlreiche gefüllte Knöpfe gefunden. So zählte ich am Morgen des 9. Decbr. 44 Blumen, deren unterer Staubfaden den Schlund schloss, die also während der letzten 8 bis I 2 Stunden, also in der Nacht abgeschossen worden waren und 5 noch geladene Blumen; gegen Sonnenuntergang fanden sich 9 im Laufe des Tages entladene, 23 bereits geöffnete schussbereite und eine grössere Zahl dem Aufbrechen nahe Blumen. Früh am nächsten Morgen wurden 53 im Laufe der Nacht entladene Blumen gezählt, deren unterer Staubfaden den Grund schloss oder sich zu heben begann; vön den 7 unentladenen waren mehrere so zwischen Blättern versteckt, dass sie einem Schmetterlinge kaum zugänglich waren. Nur einmal, am 5. Decbr., fand ich des Morgens nur 2 während der Nacht entladene neben etwa 20 schussbereiten Blumen; es hatte die ganze Nacht vom 4. zum 5. December sanft geregnet. Die nächtlichen Schützen, die bei Regenwetter feiern, sind ohne Zweifel Insekten.

Desterro, December i 865.

\section{Erklärung der Abbildungen auf Tafel XXIX.}

Fig. I. Knospe von Martha (Posoqueria?) fragrans, der Länge nach durchschnitten.

Fig. 2. Frisch geöffnete Blume. A Seitenansicht vor der Entladung; $x$ die Stelle, auf deren Berührung die Entladung folgt. - Der Pfeil zeigt die Richtung des Schusses I) Seitenansicht nach der Entladung; $C$ Ansicht von oben vor und $D$ nach der Entladung.

Fig. 3. Längs durchschnittene Blume kurz nach der Entladung.

Fig. 4. Eine solche, einen Tag nach der Entladung.

Fig. 5. Querschnitt des unteren Staubfadens.

Fig. 6. Pollenkorn, io Stunden nach der künstlichen Befruchtung von der Narbe genommen. 


\title{
Nachwort zu vorstehendem Aufsatze ${ }^{1}$.
}

\author{
Von D. F. I. v. Schlechtendal.
}

Ob die von Hrn. Müller beobachtete Pflanze wirklich eine neue Gattung sei, wird nicht eher zu entscheiden sein, als bis dieselbe mit der von Hrn. Prof. Dr. Karsten in Berlin beschriebenen und (nach getrockneten Exemplaren?) von Hrn. Prof. Schmidt abgebildeten Gattung Stannia (beruhend auf der einen Art, St. formosa Karst., bei Tovar in der Nähe von Caracas gefunden) verglichen worden ist, unter gleichzeitiger Beobachtung der Aublet'schen Gattung Posoqueria. Obwohl nämlich die Karsten'sche Pflanze (s. dess. Ausw. n. u. schön blühender Gew. Venezuela's, Heft II. p. 27. t. IX.) durch die Bildung ihrer Staubgefässe eine grosse Aehnlichkeit mit der Pflanze Müller's zu haben scheint, so sind doch noch manche Verschiedenheiten zu beachten und manche Mängel in der Beschreibung durch weitere Betrachtung der lebenden Pflanzen zu beseitigen, ehe ein entscheidendes Urtheil über die beiden Pflanzen abgegeben werden kann, von denen die eine, als ein $12-20 \mathrm{~F}$. hohes Bäumchen, auf den mit Urwald bedeckten Gebirgen bei der Colonie Tovar in einer Höhe von 5-6ooo F. in der Nachbarschaft von Caracas (ungefähr zwischen dem 9- I0 ${ }^{0} \mathrm{~S}$. Br.) von Karsten gefunden ward, die andere aber, als ein Strauch, in der Nähe von Desterro auf der Insel Sta. Catharina (ungefähr zwischen dem $47-48^{\circ} \mathrm{S}$. Br.) durch Fr. M ü 11 er beobachtet wurde. Die verschiedene Richtung der beiderseitigen Blumen, das Fehlen der Angaben über die Knospenverhältnisse der Blumenkrone und über die genauere Beschaffenheit der Corollentheile und deren Neigung zur Symmetrie, so wie das Fehlen der eigentlichen Formen und des Zusammenhangs der Staubfäden und Antheren, über das Trennen der letzteren von einander, über den Geruch der Blumen; weiter die Unkenntniss über die Frucht- und Blattbildung der Pflanze ivon Sta. Catharina fordern zu einer genauen Vergleichung beider Gewächse im frischen Zustande auf, von denen es allerdings sehr wahrscheinlich ist, dass sie einer Gattung, aber wohl zweien verschiedenen Arten angehören. Was die Gattung Posoqueria betrifft, so giebt Karsten schon an, dass Stannia sich von ihr durch die ungleich langen (oder wie ich lieber sage, durch die symmetrisch gebildeten) Staubgefässe unterscheide, und durch die gerade aufrechten, nicht herabhängenden Corollen, durch welche sie sich aber der Müller'schen

1) Botanische Zeitung 1866. 24. Jahrg. p. I33.

Fritz M üllers gesammelte Scbriften. 
mit wagerecht stehenden nähern würde. Aber auch die Staubgefässe von Posoqueria verdienen eine genauere Beachtung, denn ich sehe an der Abbildung in der Encyclopédie méthodique, welche doch gewiss von Aublet entnommen ist, dass die Staubgefässe auch nicht gleich gebildet sein müssen (obwohl davon in Endlicher's Genera nichts steht), während De Candolle sie auch inaequalia nennt, weil unter Fig. $c$, $c$ zwei verschiedenartige abgebildet sind, auch das "Alabastrum hinc gibbum" deutet an, dass hier eine Neigung zur Symmetrie vorhanden sei und dass daher auch hier eine Ungleichheit der Corolleneinschnitte und ein Zusammenhängen der Antheren stattfinden könne, mithin wohl kein zwingender Grund zur Annahme neuer Gattungen vorhanden sei. Der Blüthenstand scheint bei allen eine Cyma composita zu sein, deren einzelne Cymen aber nur 3-1 blumig sind, doch ist nach Abbildungen allein darüber schwer ein Urtheil zu fällen und ich habe bei dieser ganzen Betrachtung absichtlich von der Untersuchung der wenigen Herbarien-Exemplare, welche ich besitze, abgesehen, da eine Untersuchung der Lebenserscheinungen doch nur an der lebenden Pflanze vorgenommen werden kann. 


\title{
Ueber Balanus armatus und einen Bastard dieser Art und des Balanus improvisus var. assimilis Darw.').
}

\author{
Mit Tafel XXX, XXXI und XXXII.
}

I.

Darwin hat bei Acasta purpurata, die in der Rinde einer Isis, so wie bei Acasta cyathus und sulcata, die in Schwämmen leben, am äusseren Aste des vierten Paares der Rankenfüsse den vorderen Rand einiger der unteren Glieder mit starken abwärts gekrümmten Zähnen bewehrt gefunden, durch welche, wie er glaubt, diese Glieder in kieferähnliche Gebilde verwandelt und wunderbar passend werden, irgend welche Beute zu fassen. (Darwin, Balanidae S. 84 und S. 3 I 1.) Von keinem anderen Rankenfüsser ist bis jetzt eine ähnliche Bewaffnung bekannt geworden.

Als ich zum ersten Male in einen Schwamm eingebettete Balaniden traf, sah ich mich natürlich sofort nach dieser Bewaffnung um und hatte die Freude, beide Aeste eines der Rankenfüsse mit ähnlichen aber in weit grösserer Zahl entwickelten Zähnen ausgerüstet $\mathrm{zu}$ finden. Allein bei näherer Untersuchung ergab sich zu meiner grossen Ueberraschung, dass bei meiner Art nicht das vierte, sondern das dritte Paar die Zähne trug und dass dieselbe keine Acasta war, sondern ein ächter Balanus mit porösen Wänden und poröser Basis, im Gehäuse kaum zu unterscheiden von Balanus trigonus Darw.

Vorkommen. Dieser Balanus armatus, wie ich ihn wegen der reichen Bewaffnung seiner Ranken nenne, lebt fast ausschliesslich in Schwämmen. Die drei ersten aufeinandersitzenden Gehäuse, zwei noch mit dem Thiere, traf ich am Strande ausgeworfen und ziemlich abgerieben; sie schienen nicht einem festen Körper aufgesessen zu haben und an geschützten Stellen, besonders unter der tief ausgehöhlten Basis des einen, fand sich lockere Schwammmasse, die sich nach den Nadeln als einer hier nicht seltenen grossen schwefelgelben Papillina entstammend bestimmen liess. Da indess diese Papillina, (und vielleicht überhaupt die ganze Gattung Papillina Schmidt) nichts anderes ist als eine Vioa, die sich in Schneckenhäusern und anderen Kalkgebilden ansiedelt, sie durchlöchert und mit

I) Archiv für Naturgeschichte 1867. I. p. 329-356. Taf. VII-IX. 
der Zeit fast ganz verzehrt, um endlich sie weit überwuchernd zu kuchenförmigen Massen anzuwachsen, die bis über einen Fuss Durchmesser erreichen können, so blieb es zweifelhaft, ob in diesem Falle der Balanus den Schwamm oder der Schwamm den Balanus aufgesucht hatte und dies um so mehr, da die Gehäuse mehrfach von dem Schwamme angefressen waren. - Später habe ich den Balanus armatus oft und zahlreich in einer Reniera wiedergefunden, die in Gestalt, Farbe und Nadelform der Reniera aquaeductus Schmidt nahe steht und sich besonders durch ihr sehr entwickeltes, so leicht wie beim Badeschwamm auswaschbares Fasergerüst auszeichnet. Sehr selten (nur einmal traf ich bis jetzt drei Stück), ist der Balanus in einem unserer gemeinsten Schwämme, der als dunkelrothe mit steilen zackigen Berggipfeln besetzte Nasse ganze Felswände überzieht und in seinen Hartgebilden an Reniera digitata Schmidt sich anschliesst. - Um so. häufiger ist er dagegen an einem achtstrahligen Polypen, Carijoa rupicola F. M. ${ }^{1}$ ), der etwa mannstief unter dem mittleren Wasserstande an einem einzeln stehenden Felsen (nicht weit vom Ufer am Südende der Praia de fora) wuchert und dichte schwach verästelte bis $0,15 \mathrm{~m}$ hohe Gebüsche bildet. Den etwa $2 \mathrm{~mm}$ dicken fleischfarbenen Stamm dieses Polypen pflegt ein dunkeldottergelber Schwamm mit stecknadelförmigen Kieselnadeln als dünne Kruste zu überziehen und an solchen

1) Carijoa rupicola (Fig. 56). Der ganze bis $0,15 \mathrm{~m}$ hohe, gerade aufsteigende oder leicht gebogene, etwa $2 \mathrm{~mm}$ dicke Stamm des Polypenstocks wird gebildet ron einem einzigen Polypen, der seine Tentakel am Ende desselben entfaltet und dessen Leibeshöhle den ganzen Stamm durchzieht. Der Polyp kann sich ins obere Ende des Stammes zurïckziehen. Dieser zurückziehbare Theil ist schneeweiss. Die gefiederten Tentakel laufen in einen dünnen Endfaden aus, der knotig erscheint, wie ihre schlanken seitlichen Anhänge. Unterhalb des Tentakelkranzes finden sich einige zarte Kalknadeln. Die das Magenrohr umgebenden Scheidewände setzen sich durch die ganze Länge des hohlen Stammes fort als acht schwach vorspringende Längslinien; zwei derselben, die nebeneinanderliegen, tragen einen wellig gebogenen häutigen Saum mit verdicktem Rande, in welchem sich ebenfalls in der ganzen Länge des Stammes die dunkelgefärbten, bräunlich violetten Eier entwickeln. Die Wand des Stammes ist unten bis etwa $0,5 \mathrm{~mm}$ dick; nach oben wird sie dünner und biegsam; im unteren Theile erscheint der Stamm glatt, im oberen weicheren Theile von acht Längsfurchen durchzogen. Vorspringende Kalknadeln fehlen. Die Wand erhält Festigkeit durch dichtgedrängte Kalknadeln (Fig. 57), die in der Achse parallelen Ebenen in allen möglichen Richtungen gelagert sind, sie sind gerade oder schwach gebogen mit mehr oder minder zahlreichen Knoten unregelmässig besetzt, die einen sind länger (durchschnittlich 0,25 , einzelne über $0,5 \mathrm{~mm}$ ), schlanker, glatter; die anderen, durch Zwischenformen in erstere übergehend, kürzer, plumper, mit zahlreicheren, stärkeren Vorsprüngen besetzt. Letztere finden sich stellenweise mit einander verschmolzen. - Von dem Stamme entspringen zahlreiche Aeste, meist 4-5 in nahezu gleicher Höhe; die grosse Mehrzahl derselben bleibt kurz (etwa $4 \mathrm{~mm}$ lang) und einfach; einzelne verlängern sich und treiben dann ihrerseits wieder seitliche Zweige. Aeste und Zweige gleichen in ihrem Bau vollständig dem Stamme. Jeder trägt am Ende einen Polypen und ist von dessen Leibeshöhle durchzogen. Die Leibeshöhlen der einzelnen Polypen, die als Stamm, Aeste und Zweige den Polypenstock zusammensetzen, stehen $\mathrm{nicht}$ mit einander in Verbindung. Vom unteren Ende des Stammes entspringen dünnere Röhren, die als Wurzeln dienen nnd wo sie glatten Flächen aufliegen, sich oft abplatten und verbreitern. Bisweilen verwachsen zwei benachbarte Aeste oberflächlich mit einander; häufiger geschieht dies bei den Wurzeln. - Am Lichte verbleicht die Farbe der getrockneten Polypenstöcke sehr rasch vollständig. Auch frisch sind einzelne Stöcke fast farblos, andere aber auch weit dunkler gefärbt, als der Fig. 56 dargestellte. - Der Name Carijoa ist abgeleitet von dem der Bewohner unserer Insel zur Zeit der Entdeckung durch die Europäer, der Carijós. - Ausser dem dottergelben Ueberzuge finden sich minder häufig noch 4 oder 5 Reniera-Arten der Carijoa aufsitzend, dunkelroth, blassviolett, grünlichgrau und schneeweiss gefärbt; man kann sich nichts Bunteres denken, als ein solches gleichzeitig, wie ıch es gesehen habe, von all diesen Schwämmen durchsetztes und umhülltes Carijoagebüsch. 
schwammbedeckten Polypenstämmen fehlt nur selten der Balanus armatus; er sitzt da manchmal zu Io-I2 dicht aneinandergedrängt und ist ebenfalls bis zur Mündung von dem Schwamme überkleidet. - An demselben Felsen leben noch vier andere Balaniden; zu oberst, über dem mittleren Wasserspiegel, Chthamalus stellatus, an der unteren Grenze dieser Art und meist dicht von ihr bedeckt, Tetraclita porosa, besonders an der Seeseite; ein wenig tiefer sitzen einige grosse Gehäuse von Balanus tintinnabulum, dann folgt, bis ins Bereich der an der Landseite des Felsens angesiedelten Carijoa hinabreichend, Balanus improvisus var. assimilis. Letzteren findet man auch in einzelnen Stöcken an Carijoa, bisweilen dem B. armatus aufsitzend, oder ihm als Unterlage dienend. Ein einziges Mal habe ich einen kleinen nur $8 \mathrm{~mm}$ hohen B. tintinnabulum an Carijoa angetroffen.

Bisweilen, doch ziemlich selten, findet man B. armatus an Felsen festgewachsen. Einmal traf ich zwei Gehäuse in Gesellschaft von zahlreichen B. improvisus var. assimilis an einer lebenden Purpurschnecke. Endlich besitze ich zwei Stück. die neben einander auf der Röhre einer Serpula (Eupomatus floribundus F. M.) sitzen, welche dicht daneben zwei Gehäuse von B. improvisus var. assimilis trägt. Dieser gemeinste aller hiesigen Balanen findet sich bisweilen sogar in Reniera als Begleiter des B. armatus vor.

Allgemeines Aussehen. Das Gehäuse des B. armatus ist nach Gestalt und Farbe sehr wechselnd in seinem allgemeinen Aussehen (Fig. I-I3). Zum grossen Theile ist, wie bei anderen Arten, so auch hier diese Verschiedenheit bedingt durch die Unterlage, auf der sich das Thier angesiedelt hat. Am regelmässigsten sind daher im Allgemeinen die in weiche Schwämme eingebetteten Gehäuse, deren Entwickelung nirgends auf Hindernisse stösst. Man findet dieselben hier meist steil kegelförmig, bisweilen fast cylindrisch (Fig. I I), den Längsdurchmesser (vom Rostrum zum Kiel) meist etwas grösser als den Querdurchmesser, Rostrum und Kiel ziemlich gleich hoch, die Basis stets hohl und zwar meist in hohem Grade. Hierin also stimmt B. armatus mit dem verwandten B. spongicola überein und unterscheidet sich wie dieser von den schwammbewohnenden Acasta, bei denen die Basis mit starker Wölbung vorspringt. Selbst in Reniera aber fehlen sehr abweichende Formen nicht; ich habe Gehäuse gesehen, bei denen das Rostrum nur halb so hoch, und wieder andere (Fig. I 2), bei denen es über doppelt so hoch war, als der Kiel.

Besonders mannichfaltig ist die Gestalt der auf Carijoa sitzenden Gehäuse (Fig. $1-9$ u. 13); sie ist verschieden, je nachdem sie längs oder quer, oder schief dem Polypenstamme aufsitzen, der meist eine tiefe Furche in der Basis bildet. Diese ist in der Richtung der Furche verlängert und dies hat wieder Einfluss auf das ganze Gehäuse, so dass noch in der Mitte der Höhe die Breite von $2 / 5$ bis $4 / 3$ der Länge wechselt. Nicht selten sind die einzelnen Gehäusstücke von sehr verschiedener Höhe, bisweilen die sämmtlichen Stücke der einen Seite doppelt so hoch als die der anderen (Fig. 6). Selten ist die Furche der Basis zu einer vollständigen Röhre geschlossen; so in Fig. 9, wo man zwischen Rostrum und Seitenstück die Oeffnung der in der Mitte der Basis beginnenden Röhre sieht, oder in Fig. I3, wo die Oeffnung oben vom Seiten- und Kieselseitenstücke, seitlich und unten von Rostrum und Kiel begrenzt wird. - Einmal traf ich Balanus armatus der Spitze eines Zweiges aufsitzend (Fig. 5) und hier bildete die Basis 
um den Zweig ein kegelförmiges Rohr, länger als die halbe Höhe des Gehäuses; der Durchmesser der Basis war nur halb so gross als die Länge der Mündung. In anderen Fällen wieder (Fig. 8) ist die Basis über doppelt so lang als die Mündung. Auch in der Mitte bauchig aufgetriebene Gehäuse kommen vor (Fig. 2 u. 9). Eine besonders auffallende Form ist die, welche ich Fig. I3 (A von hinten, $\mathrm{B}$ von der Seite) gezeichnet habe. Das Gehäuse sitzt quer auf dem Carijoastamme. Rostrum und Kiel sind ungewöhnlich breit, fast gleichseitig dreieckig; sie umfassen den Stamm und stossen unter ihm auf einer Seite in eiller scharfen Kante zusammen; dagegen sind die Wände der Seiten- und Kieselseitenstücke nur ganz schmale Streifen. Doch man müsste hundert und aber hundert andere und wieder andere Formen zeichnen, wenn man die Mannichfaltigkeit dieser an Carijoa angesiedelten Balanen erschöpfen wollte. Vorherrschend ist indess auch hier und ebenso bei den an Felsen sitzenden Gehäusen eine steile Kegelform. Die beiden an Purpura beobachteten Gehäuse waren flacher als gewöhnlich, ihre Wände minder steil, die Basis grösser im Vergleiche zur Mündung.

Die Oberfläche der Wände ist meist glatt, seltener mit unbedeutenden Längsrippen versehen; stärkere Rippen pflegen die an Felsen sitzenden Gehäuse zu haben. Die Farbe der Wände ist bald ganz blass, bald sind sie heller oder dunkler schmutzig bräunlich purpurn gestreift. Die Radien pflegen eine mehr oder minder deutliche schmutzige Purpurfarbe zu zeigen. Nicht selten zeigt sich eine auffallende Farbenverschiedenheit zwischen den beiden Seiten desselben Gehäuses; kann man hierbei an den Einfluss des Lichtes denken, so ist diese Erklärung nicht anwendbar auf eine Gruppe von drei Gehäusen, von denen das unterste grösste ungewöhnlich dunkel gefärbt, das zweite daraufsitzende fast weiss ist, und das dritte jüngste, das dem zweiten aufsitzt, besonders deutliche weissliche Rippen und dazwischen hellbraune Streifen hat. Die Scheide ist blass; die Deckelstücke bald blass, bald dunkel, meist aber wenigstens nach der Spitze zu röthlich.

Die Oberhaut fand ich nie an den Radien, selten in Spuren am unteren Theile der Wände erhalten; doch besitze ich ein Exemplar aus Reniera, dessen Wände noch vollständig von einem gelblichen Häutchen bedeckt sind und dessen Radien ausserdem durch ihre weisse Farbe sich auszeichnen (Fig. I I).

So verschieden nun in Gestalt und Färbung die Gehäuse des B. armatus auch sein mögen, so stimmen sie doch alle vollständig überein in der eigenthümlichen Form ihrer Mündung, die an die des Bal. trigonus erinnert, aber abweichend von letzterer Art stets deutlich gezähnt ist ${ }^{1}$ ). Die Radien sind immer schief, am meisten die des Rostrum; ihre freien Ränder pflegen mit der Wand des Rostrum einen Winkel von etwas unter, mit der des Seitenstücks von etwas über $60^{0} \mathrm{zu}$ bilden und etwa in der Mitte den Alae des Seitenstücks zu begegnen. Ebenso begegnen sich etwa in der Mitte die Ränder der Radien des Seitenstücks und der Alae des Kielseitenstücks, während die Ränder der Alae des Kiels erst dicht an den Wänden der Kielseitenstücke auf deren Radien stossen. Wie die Zähnelung der Mündung, so sieht man als zweite Eigenthümlichkeit an allen wohlerhaltenen Gehäusen, dass das Rostrum an der Mündung etwas nach innen gebogen ist.

I) Die einzige, aber wohl nur scheinbare Ausnahme bilden die drei Gehäuse, die ich am Strande ausgeworfen gefunden habe; ihre Mündungen sind ganzrandig und ungezähnt; doch glaube ich, dass sie ihre Zähne erst beim Umherrollen im Meere und in der Brandung verloren haben. 
Betrachtet man die Mündung von oben (Fig. 14), so tritt die Zähnelung derselben nicht hervor und man sieht dann auf die grösste Breite der Mündung als Basis einerseits ein gleichschenkliges Dreieck aufgesetzt, dessen Spitze mit einem Winkel von $50-54^{\circ}$ von dem Kiele gebildet wird, andererseits ein niedriges Trapez, dessen ein wenig nach innen gebogene kleinere Basis die Radien des Rostrum bis zu ihrem Kreuzungspunkte mit den Alae der Seitenstücke bilden. Die Seiten des Dreiecks reichen von der Spitze des Kiels bis nahe an die Spitzen der Seitenstücke; die Höhe des Trapezes ist etwa $1 / 4$ von der des Dreiecks, die Höhe des Dreiecks ungefähr seiner Basis, der grössten Breite der Mündung gleich. Die kleinere Basis des Trapezes misst etwa $\% \frac{3}{3}$ der grösseren. - Fünfeckige Mündungen, aus einem Dreieck und einem Trapez gebildet, die die grösste Breite der Mündung zur gemeinsamen Basis haben, kommen auch sonst bei Balanen vor, z. B. bei B. improvisus var. assimilis; eigenthümlich aber ist dem B. armatus die geringe Höhe des Trapezes. Noch niedriger, fast verschwindend, wird dasselbe bei B. trigonus, so dass hier die Mündung wie ein gleichseitiges Dreieck mit zwei leicht abgestumpften Ecken aussieht. - Legt man eine Ebene durch die Spitze von Kiel und Rostrum, parallel der durch die Spitzen der Seitenstücke gehenden Geraden, oder um es mehr praktisch als mathematisch auszudrücken, legt man ein Lineal in der angegebenen Richtung auf die Spitzen von Kiel und Rostrum, so sieht man, dass die Spitzen der Kieselseitenstücke nicht ganz diese Ebene erreichen, und dass die Spitzen der Seitenstücke noch etwas weiter davon abstehen. Es muss auffallen, wie ungemein selten und in wie geringem Grade die Regelmässigkeit der Mündung durch die grössten Unregelmässigkeiten des Gehäuses gestört wird.

Grösse. In dem mit Reniera aquaeductus verwandten Schwamme fand ich nur kleinere Gehäuse, deren Durchmesser der Basis und deren Höhe selten $8 \mathrm{~mm}$ erreichte; grösser werden sie an Carijoa oder an Felsen; die grössten, die ich gesehen, sind die drei aus Papillina. - Hier einige Maasse:

$\begin{array}{llllllcc} & \text { I. } & \text { II. } & \text { III. } & \text { IV. } & \text { V. } & \text { VI. } & \text { VII. } \\ \text { Länge der Basis . . } & 6 & 7,3 & \text { II,3 } & 8,3 & 20 & \text { I 4 } & 6,2 \\ \text { Breite derselben . . } & 5 & 6,8 & 9,3 & 6,9 & \text { I } 4 & \text { I6 } & 6,2 \\ \text { Länge der Mündung } & 3,6 & 5, \text { I } & 6,9 & 5 & 6 & 6 & 2,6 \\ \text { Breite derselben . . } & 2,8 & 3,8 & 5,5 & 4 & 5,4 & 5 & 2 \\ \text { Höhe des Rostrum . } & 5,5 & 8, \text { I } & 9,7 & 7,7 & \text { I7 } & 5 & 4 \\ \text { Höhe des Kiels . . } & 5,5 & 9, \text { I } & \text { I I } & 8,5 & 4 & \text { I } 2,4 & 2,8\end{array}$

I. Mittel aus 8 Messungen; Gehäuse aus Reniera.

II. Mittel aus 5 Messungen; Gehäuse an Carijoa sitzend.

III. Mittel aus 5 Messungen; Gehäuse an Felsen sitzend.

IV. Mittel aus 20 Messungen, worunter die vorstehenden 18 inbegriffen sind

V. und VI. Zwei der Gehäuse aus Papillina, die dem dritten leeren Gehäuse aufsitzen; V hat den Kiel, VI das Rostrum der Mündung des unterliegenden Gehäuses zugewandt; indem nun bei ersterem das Rostrum über 4 mal so lang ist als der Kiel, bei letzterem der Kiel fast 3 mal so lang als das Rostrum, werden die Ebenen der Mündungen aller drei Gehäuse nahezu gleichlaufend.

VII. Gehäuse, das einer Purpura aufsitzt.

Scuta. Die Schilder sind sehr schmal; der Schliessrand (occludent margin) ist fast oder völlig doppelt so lang als der Basalrand, der Rückenrand (tergal 
margin) wenig kürzer als der Schliessrand. Die Spitze ist meist schwach aufwärts gebogen, die Aussenfläche mit stark vorspringenden Anwachsstreifen und I bis 6 Längsreihen meist sehr tiefer, oft (Fig. I5) ansehnlich weiter Gruben bedeckt. Bei 28 aufs Gerathewohl herausgegriffenen Thieren fanden sich im unteren Theile der Schilder einmal jederseits 2, achtmal 3, ebenso oft 4, einmal 5 , einmal 6 Reihen; ferner 6 mal auf dem einen Schilde 3, auf dem anderen 4, zweimal einerseits 4, andererseits 5, endlich einmal auf einer Seite 5, auf der anderen 6 Grubenreihen. Eine einzige Reihe von Gruben habe ich nur bei den beiden auf Purpura sitzenden Thieren gesehen. Auf der Innenseite des Schildes (Fig. I6) sieht man eine nicht sehr breite Gelenkleiste (adductor ridge), die bis über die Hälfte oder selbst bis zum unteren Drittel des Schildes reicht und hier abgerundet oder mit einer kleinen Spitze endet. Die Adductorleiste ist unbedeutend und reicht kaum weiter als die Gelenkleiste nach unten. Bisweilen findet sich eine sehr zarte scharfe Längsleiste zwischen Gelenk- und Adductorleiste. Für den musculus depressor lateralis ist eine meist schmale und tiefe Grube vorhanden. Namentlich bei grösseren Thieren sind die Schilder oft von ungewöhnlicher Dicke.

Terga (Fig. 17, 18). Diese stimmen ganz mit der von Darwin für Balanus trigonus gegebenen Beschreibung überein. Die $6-7$ Leisten für den musculus depressor ${ }^{1}$ ) überragen nie den Basalrand des Rückenstücks. Die Borstenreihen

I) Darwin's Angaben über die Wirknng der drei Muskelpaare, die vom Deckel nach dem Grunde des Gehäuses niedersteigen, scheinen mir nach dem, was ich namentlich an Tetraclita porosa gesehen, nicht ganz richtig zu sein. Durch die depressores scuti laterales wird nach Darwin der Deckel geöffnet. Plötzliche Zusammenziehungen der depressores rostrales bewirken wahrscheinlich die Schläge, die das Thier mit der schnabelförmigen Spitze der Terga austheilt. Durch die gemeinsame Zusammenziehung der drei Paare wird der Deckel mit überraschender Kraft niedergehalten. Gehoben kann der Dekel nur werden durch den Druck des Körpers gegen die Basis (Darwin, Balanidae S. 62).

Versucht man den Deckel einer Tetraclita porosa aus dem Gehäuse zu schneiden, so wird das Messer überall freien Weg finden bis auf zwei einander gegenüberliegende Stellen in der Gegend der Sporen. Hier liegt der Deckel der Scheide eng an; die Haut, die die Basis des Deckels mit der Scheide verbindet, ist hier schmäler und fester als sonst. So wird durch diese beiden Stellen eine freilich etwas verschiebbare Achse gebildet, um die sich der Deckel drehen kann. Man kann nun an frischen Thieren leicht die einzelnen Muskeln fassen und anziehen und so über ihre Wirkung Aufschluss erhalten. Wie schon die Befestigungsweise des Deckels erwarten lässt, wird durch die depressores tergi der Kielrand der Rückenstücke niedergezogen, dagegen die Rostralecke der Schilder gehoben und der Schlussrand nimmt eine fast wagrechte Lage an (Fig. 52). Diese Muskeln allein bewirken das kräftige Niederhalten des geschlossenen Deckels; derselbe stützt sich dabei mit dem Kielrande der Rückenstücke gegen die Scheide, die an dieser Stelle mehr oder weniger deutliche Spuren der Abnutzung zu zeigen pflegt. Durch die depressores scuti aber, die laterales sowohl als die rostrales, wird die Basis der Schilder niedergezogen, dcr Kielrand der Rückenstücke gehoben und der Schliessrand nimmt eine mehr oder weniger steile Lage an (Fig. 53). Weil nun seine Spitze weiter hervortritt, erscheint dabei der ganze Deckel gehoben; das ist aber nur scheinbar; man kann dieses Erheben der Spitze auch hervorbringen, indem man statt von innen an den depressores scuti zu ziehen, von aussen die Rostralecke der Schilder niederdrückt. - Ein Heben und Senken des ganzen Deckels findet überhaupt nur in ziemlich beschränktem Masse statt: in wie weit dabei ein Anstemmen des Körpers gegen die Basis mitwirkt, lasse ich unentschieden.

Das Oeffnen des Deckels wird, glaube ich, nur durch das Andrängen des Thieres gegen die Deckelspalte hervorgebracht; die depressores laterales können ihn nicht öffnen. Wie man sich leicht an Deckeln überzeugt, die man mit der verbindenden Haut herausgenommen hat, drehen sich nämlich beim Oeffnen und Schliessen die beiden Hälften des Deckels um eine durch die Rostralecke der Schilder und die Kielecke der Rückenstücke gehende Achse; was über dieser Achse liegt, entfernt sich beim Oeffnen von der Mittellinie; was darunter liegt, nähert sich derselben. Die depressores scuti laterales aber gehen von unterhalb der Drehungsachse gelegenen Punkten nach unten und etwas nach aussen, können also unmöglich ilare Ansatzpunkte der Mitteliinie nähern, wie es zum Oeffnen des Deckels nöthig wäre. 
auf den Anwachsstreifen der Deckelstücke sind bei Balanus armatus, namentlich auf dem Schilde, stärker entwickelt als bei den wenigen anderen Arten, die ich vergleichen konnte. Kurz und zart sind sie auf der Kielscite (Fig. 19), bis über 0,2 $\mathrm{mm}$ lang und zart auf der Schildseite (Fig. 20) des Rückenstücks; von gleicher Länge, aber weit dicker und dichtgedrängt auf dem Schilde (Fig. 2 I). Es wechseln längere und kürzere Borsten, doch nicht als zwei scharf geschicdene Formen, wie es z. B. bei B. improvisus var. assimilis (Fig. 22) der Fall ist. Die Chitinstränge (tubuli Darw.), die von den Borsten aus wellig gebogen die Deckelstücke durchsetzen, verjüngen sich rasch zu zarten Fäden, die man beim Zerzupfen der durch Säure entkalkten Deckelstücke leicht aus der umgebenden Masse herauszieht ${ }^{1}$ ).

Die Stücke des Gehäuses. Die Röhren, welche die Wände durchziehen, sind ziemlich weit, im obersten Theile dicht ausgefüllt, ohne quere Scheidewände. Die Innenfläche der Wände ist meist in ganzer Länge, bistveilen nur unten längsgerippt. Die R a dien sind aussen glatt, glänzend, mit feiner Streifung in doppelter Richtung, die eine den Scheidewänden, die andere der Naht (sutural edge) gleichlaufend; die erstere Streifung ist immer weit deutlicher; sie ist nicht bedingt durch Vorspringen der Scheidewände. Bei den Radien des Rostrum und der Seitenstücke steht diese Streifung ziemlich senkrecht auf der Wand der Seitenstücke, bei den Radien der Kielseitenstücke senkrecht auf der Wand dieser Stücke. Innen sind die Radien, so weit sie nicht den Alae aufliegen, oft durch die vorspringenden Scheidewände feingerippt; meist sind diese Rippen sehr deutlich, bisweilen aber kaum wahrzunehmen und bisweilen sind die Radien innen ganz glatt. An den Scheidewänden der Radien, deren Zwischenräume bis zur Naht dicht ausgefüllt, aber oft durch röthliche Färbung von den weissen Scheidewänden ausgezeichnet sind, habe ich keine deutliche Zähnelung erkennen können. Die Nähte der Alae sind glatt. Die Scheide hat einen scharfen, frei nach unten vorspringenden Rand.

Basis. Die Basis ist porös. Nur in sehr seltenen Fällen springt sie über den unteren Rand des Gehäuses vor. Auch bei den in Schvämmen angesiedelten Thieren sind die Kittröhren (Fig. 54. 55) wohl entwickelt, während sie von Darw in bei Acasta vermisst wurden. Nach der Behandlung der Basis mit Säure erscheinen sie als farblose, leere Röhren. Ihre Verästelung ist verschieden bei verschiedenen Thieren, aber genau dieselbe für die verschiedenen älteren und jüngeren Röhren desselben Thieres, so dass also die Aeste jedes jüngeren Kreises denen der älteren inneren gleichlaufen. Nicht selten kommen blind endende Ausläufer vor (Fig. 55, $a, b$ ). Am Rande der Basis, den man selten wohlerhalten unter das Mikroskop bekommt, sah ich die Kittröhren in sehr feine netzförmig verbundene Reiserchen sich theilen, ähnlich wie es Da $r$ w in von Bal. tintinnabulum beschreibt und abbildet (Darwin, Balanidae. Pl. 28. Fig. 4, $a$ ).

Mundtheile. Die Oberlippe (Fig. 23) hat drei nahe beisammen stehende Zähne zu jeder Seite des mittleren Einschnitts. Die Kinnbacken (Fig. 24-26) haben vier deutliche Zähne; der fünfte fehlt bisweilen völlig; meist aber ist er als kleiner Höcker über der unteren Ecke des Kinnbackens zu unterscheiden;

I) Bei Tetraclita porosa, wo die Chitinstränge bis zum Ende ziemlich dick bleiben, sah ich aus deren Ende ein blasses Fädchen hervorragen, als wenn ein Nerv in die Stränge einträte; zwischen den Borsten und den Chitinsträngen scheint eine Art Gelenk zu bestehen. 
ich habe einmal bei demselben Thiere den fünften Zahn auf einer Seite ungewöhnlich deutlich entwickelt gesehen, während er auf der anderen vollständig fehlte. Die Ki f e e r haben einen geraden Rand, mit einer ganz winzigen Kerbe (Fig. 27) unter dèn obersten Borsten, oder ohne eine solche (Fig. 28). Für die untersten Borsten ist kein Vorsprung vorhanden. Die oberste und die beiden untersten Borsten sind nur wenig länger als die längsten der mittleren. Nur etwa ein Drittel des oberen Kieferrandes ist behaart.

Rankenfüsse. Erstes Paar: der längere Ast ist etwa doppelt so lang als der kürzere, bisweilen noch länger und hat fast doppelt so viel (I 8-20) Glieder; die letzten Glieder sind bedeutend länger als die unteren, walzenförmig und am Ende mit einem fast vollständigen Kranze von Borsten besetzt. Der kürzere Ast hat meist 9-II kurze Glieder mit dicht beborstetem Vorsprunge an der Beugeseite, der an den mittleren Gliedern am bedeutendsten ist.

Zweites Pa ar: Kurz, plump, dicht beborstet; der vordere oder äussere Ast mit I I-I 3 Gliedern, etwa nur $1 / 5-1 / 4$ länger als der innere; dieser ist 9 - Io-gliedrig und etwa so lang, als der kürzere Ast des ersten Paares. - An abgeworfenen Häuten und meist auch sonst sieht man den längeren Ast gerade ausgestreckt, den kürzeren leicht gekrümmt.

Drittes Paar: Vom Grunde dieses Fusspaares zieht sich eine dicht mit langen dünnen Haaren besetzte Linie nach dem Rücken in die Höhe. Ihrer Länge und Gestalt nach halten die Ranken dieses Paares die Mitte zwischen den kurzen und plumpen Ranken des vorhergehenden und den langen schlanken Ranken der folgenden Paare. Der unbedeutend längere vordere oder äussere Ast hat etwa 15-17 Glieder, der hintere I oder 2 weniger. Die Aeste sind ungefähr so lang wie der längere Ast des ersten Paares. Eine grössere oder geringere Zahl der Glieder beider Aeste sind an der Beugeseite mit starken gekrümmten Zähnen bewaffnet; bei jüngeren Thieren ist die Bewaffnung schwächer und auf einige der mittleren Glieder beschränkt; bei grösseren Thieren pflegen nur die beiden letzten Glieder des äusseren, die vier oder fünf letzten Glieder des inneren Astes der Zähne zu entbehren. Immer ist die Bewaffnung des äusseren Astes (Fig. 44) stärker als die des innern. - Diese hakig nach abwärts gebogenen Zähne (Fig. 46) halten nicht nur den oberen Theil des stark vorspringenden Randes der Beugeseite der Glieder besetzt, sondern erstrecken sich von da aus, allmählich kleiner werdend und endlich in winzige Spitzchen übergehend, über einen grösseren oder geringeren Theil der Aussenfläche der Glieder. Dieser mit Zähnen und Haken besetzte Theil erhebt sich meist als flache Wulst ein wenig über seine Umgebung. Ausser den Zähnen der Beugeseite finden sich besonders an den unteren Gliedern spitze nach oben stehende Dörnchen an der Streckseite, einige ebenfalls aufwärts gerichtete Dornen an der Aussenseite des oberen Randes und ebenda oft mehrere Gruppen sehr zarter Spitzchen.

Die mittleren Glieder des äusseren Astes trageu nach innen von dem Zahnbesatze zwei bis vier Borstenpaare; zu diesen gesellt sich früher oder später eine erst einfache, dann mehrfache Reihe von Borsten am Innenrande des oberen Endes der Glieder und endlich an den letzten Gliedern ein dichter unregelmässiger Borstenbesatz, der oft einen grossen Theil der Innenfläche bedeckt. Am inneren Aste sind schon an den unteren Gliedern die Borsten der Innenfläche zahlreicher. 
Viertes bis sechstes Paar: Die Ranken der letzten drei Fusspaare findet man selten alle unversehrt; bald fehlt der einen, bald der anderen ein grösseres oder kleineres Stück. Diese Verluste werden bekanntlich mehr oder minder vollständig ersetzt, indem sich in den letzten der gebliebenen Glieder eine Zahl von neuen Gliedern bildet und nach der nächsten Häutung in Thätigkeit tritt. Die Häufigkeit solcher Verstümmelungen erlaubt kaum, etwas über dic Gliederzahl dieser Ranken zu sagen. An den letzten Paaren kann dieselbe bis über 45 steigen, und ihre Länge ist oft mehr als 3 mal so gross, als die des dritten Paares. Die Glieder aller dieser Ranken sind dünner, aber weit länger als die der vorderen Paare; die oberen Glieder tragen an der Beugeseite fast immer vicr Borstenpaare, am vierten Fusspaare manchmal nur drei.

Am vierten Fusspaare pflegt die Rückenseite des ersten Gliedes des äusseren Astes mit ziemlich starken aufwärts gerichteten Zähnchen bewehrt zu sein; an den mittleren Gliedern beider Aeste, besonders aber des äusseren, findet man meist ausser den kurzen spitzen Dornen an der Aussenseite des Endrandes in deren Nähe noch mehr oder minder zahlreiche aufwärtsgerichtete Dornen über die Aussenfläche des Gliedes zerstreut; in seltneren Fällen verwandeln sich diese Dornen am äusseren Aste in äbwärts gerichtete schwach gekrümmte Zähne, so dass dann (Fig. 47) eine ähnliche, aber freilich weit schwächere Bewaffnung entsteht, als am dritten Paare.

Das fünfte Fusspaar ist ausgezeichnet durch einen starken, etwas gekrümmten, aufwärtsgerichteten Zahn (Fig. 48), der am Anfange der Rückenscite des zweiten Stielgliedes steht; meist folgt ihm noch ein ähnlicher kleinerer Zahn, seltener deren zwei (Fig. 48), oder gar keiner.

Am sechsten Fusspaare sind die Stielglieder und dic ersten Glieder der Ranken auf der Rückenseite mit sehr zahlreichen kurzen, anliegenden, aufwärtsgerichteten Spitzchen bedeckt.

Ruthe. Am Grunde der Ruthe, zwischen ihr und dem After, ist der gewöhnliche kegelförmige Fortsatz vorhanden; die Ruthe, zu mehrfacher Länge der Ranken ausdehnbar, ist nur mit wenigen kurzen Haaren besetzt.

Eier: o, I7 mm lang; o,o9 $\mathrm{mm}$ dick. An den Larven finde ich nichts Besonderes, sie sind denen von Tetraclita porosa sehr ähnlich.

Verw a d t schaft. Der nächste Verwandte des Balanus armatus ist B. trigonus. $\mathrm{Ob}$ überhaupt ersterer nicht besser als blosse Abart zu betrachten und als B. trigonus var. armatus zu bezeichnen sei, wird nur nach Vergleichung mit zahlreichen Exemplaren des B. trigonus von verschiedenen Fundorten $\mathrm{zu}$ entscheiden sein. Doch lässt sich für seine Artberechtigung anführen, dass B. trigonus bisher nur im indischen und stillen Meere und nicht im atlantischen, dass er nur an Schalen von Weichthieren und an Holz und nicht in Schwämmen gefunden wurde; dass bei B. trigonus das Gehäuse meist flach und gerippt, die Mündung ganzrandig und fast gleichseitig, bei B. armatus das (Tehäuse meist steil kegelförmig und glatt, die Mündung stets deutlich gezähnt und fünfeckig ist; dass dic Schilder bei B. armatus schmäler sind, dass die bei B. armatus $n$ ie vermisste, beim ersten Blick in die Augen fallende Bewaffnung des dritten Fusspaares von Darwin bei B. trigonus ebensowenig erwähnt wird, als der ebenfalls bei $\mathrm{B}$. armatus stets vorhandene starke Zahn am Stiele des fünften Paares. 
Die auf Carijoa sitzenden Gehäuse erinnern bisweilen, bei vorwaltender Entwickelung in die Länge, besonders wenn zugleich die Basis etwas vorspringt, im allgemeinen Aussehen an die auf Grorgonien lebenden Arten, die bei Darwin die Section B. der Gattung Balanus bilden; doch ist diese Aehnlichkeit eben nur Folge der ähnlichen Befestigungsıveise und kaum Zeichen einer näheren Verwandtschaft. - Im Uebrigen gilt von unserer Art, was Darwin über die verwandtschaftlichen Beziehungen des B. trigonus sagt.

Bedeutung der Bewaffnung der Ranken. Wenn auch nicht in gleich mächtiger Weise entwickelt, findet sich eine ähnliche Bewaffnung der Ranken mit Dornen und Spitzchen doch auch bei anderen Balanen. Bei einzelnen Exemplaren von B. improvisus var. assimilis finden sich diese sonst aufwärts gerichteten Dornen an der Aussenseite der Glieder des dritten (Fig. 50) und vierten (Fig. 51) Fusspaares sogar nach abwärts und rückwärts gerichtet, wie bei B. armatus. - Man findet diesen Besatz mit Dornen und Spitzchen fast ausschliesslich an den dem Rande der Deckelspalte zugewandten Flächen; so an der Aussenseite der mittleren Paare und an der Rückenseite des letzten Paares. An dieser Stelle können sie nicht zum Fange irgend welcher Beute, sondern kaum zu etwas Anderem dienen, als zum Reinhalten der Deckelspalte. Man sieht in der That an lebenden Thieren, dass gerade die Ranken des dritten und vierten Paares, deren Aussenflächen besonders reich bedornt sind, beim Vorstrecken und Einziehen der Ranken dicht am Rande der Deckelspalte hinstreichen.

Dass nun gerade bei schwammbewohnenden und sonst keineswegs einander nahestehenden Arten diese Bewaffnung zu mächtigen gebogenen Zähnen entwickelt ist, weist auf einen Zusammenhang zwischen der eigenthümlichen Bewaffnung und dem eigenthümlichen Aufenthaltsorte hin, und es liegt die Vermuthung nahe, dass die Zähne dazu dienen, die rasch wuchernde Schwammmasse zu zerreissen und zu entfernen, welche die Mündung des Gehäuses zu überwachsen droht. Bemerkenswerth ist dabei der Umstand, dass bei Acasta die Zähne am äusseren Aste des vierten, bei Balanus armatus an den Aesten des dritten Fusspaares stehen. Man könnte diesen Umstand in älnnlicher Weise zu Gunsten der Darwin'schen Ansicht von der Entstehung der Arten verwerthen, wie die verschiedene Bildung des hinteren Eingangs zur Kiemenhöhle bei den verschiedenen luftathmenden Krabben ${ }^{1}$ ). Balanus armatus ist weit näher mit anderen nicht schwammbewohnenden Balanen verwandt, als mit Acasta; B. armatus und spongicola einerseits, die Acastaarten andererseits können somit die Gewohnheit sich in Schwämmen anzusiedeln nicht von einem gemeinsamen Urahnen geerbt haben. Einrichtungen, die auf diesen eigenthümlichen Wohnplatz sich beziehen, müssen sich unabhängig von einander bei den einen und den anderen gebildet haben und es kann daher nicht befremden, dieselben bei Balanus armatus und bei Acasta an verschiedenen Stellen des Leibes entwickelt zu finden.

II.

Die Balanen galten bis vor Kurzem allgemein als sich selbst befruchtende Zwitter. Dass indess wenigtens nicht in allen Fällen Selbstbefruchtung stattfindet, wurde durch eine merkwürdige Beobachtung Darwin's bewiesen, der bei mehreren

I) Siehe Fritz Müller, Für Darwin. Leipzig I864, S. $20 .=$ Ges. Schriften S. 212 ff. 
Balanus balanoides die Ruthe verstümmelt und geschlossen und nichts desto weniger in deren Gehäusen wohlentwickelte Larven fand (Darwin, Balanidae S. r ı I). Mir ist es schon lange zweifelhaft gewesen, ob überhaupt die Selbstbefruchtung Regel sei. Wozu die oft den dreifachen Durchmesser des Gehäuses übertreffende Länge der Ruthe, wenn dieselbe ausserhalb des Gehäuses nichts zu suchen hat? - Einige neuerdings gemachte Beobachtungen haben mich in diesem Zweifel bestärkt.

Man weiss, dass die Balanen sehr empfindlich gegen das Licht sind ${ }^{1}$ ), dass sie ihre Ranken sofort einziehen und den Deckel schliessen, sobald man z. B. mit der Hand zwischen ihnen und dem Fenster hinfährt. Merkwürdig ist dabei, dass einzelne Thiere viel scheuer, andere wieder dreister sind, dass erstere immer sich länger geschlossen halten, letztere sich rascher hervorwagen und sogar an das in regelmässigen Zwischenräumen wiederholte Vorüberfahren der Hand sich gewöhnen. Aehnliche geistige Verschiedenheiten fand ich auch, beiläufig bemerkt, $z$ wischen den Thieren einer Gruppe von Eupomatus floribundus. - Als ich nun einmal, diese Beobachtungen wiederholend, dem Spiele der Ranken einiger Balanus armatus zusah, die ich frisch von Carijoa genommen und von ihrem Schwammüberzuge gesäubert hatte, sah ich, wie einer derselben plötzlich mit dem Schlagen der Ranken aufhörte, sie einige Secunden unbeweglich und weit ausgespreizt hielt, und wie während dessen die Ruthe sich zu äusserster Länge vorstreckte und wie tastend oder suchend herumfuhr. Ich beunruhigte nun meine Thiere nicht weiter mit dem Schatten der Hand, um wo möglich dieses neue Schauspiel sich wiederholen zu sehen, und in der That sah ich bald aufs Neue nicht nur bei diesem, sondern noch bei drei oder vier anderen Thieren mehrmals dieselbe Erscheinung. Ich legte nun diese brünstigen Thiere dicht nebeneinander, um ihnen eine gegenseitige Begattung zu erleichtern; allein so oft die langgestreckte Ruthe in den Bereich der Ranken eines Nachbars kam, wurde sie von denselben hin- und hergeschleudert, ohne dass dieser still hielt, um ihr Einlass zu gewähren. Darauf untersuchte ich zwei der Thiere und fand den ganzen Ruthenkanal dicht mit Samen gefüllt, aber bei beiden auch Eier, die bereits die Furchung durchgemacht hatten, also einer Befruchtung nicht mehr bedurften. Bei einer solchen Füllung der Ruthe hatte wohl, indem sie sich zu äusserster Länge ausdehnte. Same ausgetrieben werden müssen (was ich auf einem weissen Teller nicht hatte sehen können); zugleich war aber bei der Länge der meist in seitlicher Richtung sich ausstreckenden Ruthe dieser Same dem durcl die eigenen Ranken erzeugten Strudel entzogen und nachbarlichen Thieren, die dessen bedürfen mochten, anheimgegeben worden. -- Auffallenderweise habe ich die damals gleichzeitig an vier oder fünf Thieren gemachte Beobachtung noch nicht wiederholen können, obwohl ich mehrfach bei zahlreichen frischen Thieren mich danach umgesehen habe.

I) Die Empfänglichkeit der Balanen gegen Lichteindrücke ist nicht abhängig von den durch Leidy entdeckten Augen. Ich hatte einen grossen Bal. tintinnabulum lebend aus seinem Gehäuse genommen und von dem Deckel abgelöst, mit welchem die Augen in Verbindung blieben. Derselbe lag in einem Teller mit Wasser mit halbentrollten Ranken. So oft ihn der Schatten der Hand traf, rollte er mit einer plötzlichen Bewegung die Ranken ein. Bei B. tintinnabulum sind die Augen sehr deutlich; bei B. armatus habe ich sie noch nicht gefunden und die geringere Grösse der letzteren Art trägt daran nicht Schuld; denn auch bei kleineren $B$. tintinnabulum sind sie sehr leicht nachzuweisen. 
Die zweite Beobachtung, die zu beweisen scheint, dass zuweilen sogar eine Befruchtung zwischen verschiedenen Arten von Balanus vorkömmt, ist die folgende: Unter den an Carijoa erbeuteten Balanen, die ich nach dem ersten Anblicke als B. improvisus var. assimilis bestimmt hatte, war mir einer (Fig. 29) durch etwas röthliche Färbung aufgefallen, wie ich sie sonst nie bei dieser unendlich häufigen Art gesehen hatte. Als ich ihn näher ansah, fand ich statt der schmalen mit einem gelblichen Häutchen bedeckten Radien des B. assimilis (wie ich im Folgenden der Kürze wegen statt B. improvisus var, assimilis sagen will) die wohlentwickelten glänzenden Radien des B. armatus mit ihrer eigenthümlichen Streifung. Dabei war aber die Form der Mündung, das Ansehen der Schilder und der Wände mit ihren durchscheinenden Streifen und den bei der röthlichen Färbung doppelt deutlichen Querwänden ihrer Röhren ganz wie bei B. assimilis. Unter Hunderten von B. armatus hatte ich nie entfernt ähnliche Wände, Mündung, Schilder, unter ungezählten Tausenden von B. assimilis nie entfernt ähnliche Radien getroffen; - ich konnte nicht umhin, mir allen Ernstes die Frage vorzulegen, ob ich nicht einen Bastard der beiden Arten vor mir habe, deren Eigenthümlichkeiten hier so wunderbar vereinigt waren. Ich habe später noch drei dieser vermuthlichen Bastarde getroffen; zwei derselben sassen wie der erste unmittelbar auf Carijoa, der dritte (Fig. 3o) auf einem B. assimilis; umgekehrt sass einem der anderen ein B. assimilis auf. Eine nähere Untersuchung dieser vier Thiere ergab nun Folgendes:

A11gemeines Aussehen. In der Form der deutlich gezähnten Mündung (Fig. 3I), deren grösste Breite beinahe in die Mitte zwischen Kiel und Rostrum fällt, in den durchscheinenden Streifen der glatten Wände und der eigenthümlichen in Worten schwer wiederzugebenden Krümmung ihrer Ränder glichen alle vier Thiere dem Bal. assimilis, in der Bildung der Radien, bis auf den etwas schiefer verlaufenden Rand, dem Bal. armatus. Die Färbung war bei einem etwas röthlich, bei den übrigen fast weiss, bei zweien im unteren Theile des Gehäuses gelblich. Zufällig, in Folge ihrer Befestigungsweise, war bei allen die Basis weit länger als breit und das Rostrum höher, bei einem über doppelt so hoch als der Kiel.

Grösse. Mittel aus den Massen der vier Gehäuse: Länge der Baśis 7,1 mm; Breite derselben 3,7 mm; Länge der Mündung 4,3 mm; Breite derselben 3,4 $\mathrm{mm}$; Höhe des Rostrum $8 \mathrm{~mm}$; des Kiels $4,4 \mathrm{~mm}$.

Scuta (Fig. 33. 34). Der Basalrand der Schilder hat über $3 / 4$ der Länge des Schliessrandes und ist sogar länger als der Rückenrand; auf der Aussenfläche, die keine Spur von Gruben oder Längsstreifen zeigt, springen die Anwachsstreifen nur mässig vor; auf der Innenseite ist eine starke Adductorleiste vorhanden, die nach oben mit der Gelenkleiste verschmilzt und nach unten fast bis zum Basalrande $\mathrm{zu}$ verfolgen ist. Die Grube für den depressor lateralis ist flacher und mehr rundlich, als bei Bal. armatus Regel ist.

Terga (Fig. 35. 36). Die Rückenstücke sind wie die Schilder, denen des Bal. assimilis weit ähnlicher als denen des Bal. armatus, und von ersteren kaum durch den etwas breiteren Sporn verschieden. Sie sind breiter als bei Bal. armatus; der Sporn, der noch nicht $1 / 3$ der Breite der Basis einnimmt, ist fast um seine eigene Breite vom Schildrande entfernt; eine flache Längsrinne nimmt 
fast die ganze Breite des Spornes ein. Die Leisten für den depressor carinalis sind sehr stark entwickelt und überragen den Basalrand.

Besonders neugierig war ich auf die Behaarung der Deckelstücken, da hierin Bal. armatus und assimilis sehr von einander abweichen; bei $B$. armatus stehen kurze zarte Haare auf der Kielseite (Fig. I g), lange schlanke Haare auf der Schildseite (Fig. 20) der Rückenstücke, lange starke dicht gedrängte Haare (Fig. 2 I) auf den Schildern; bei Bal. assimilis (Fig. 22) finden sich überall mit je $\mathrm{I}-3$ der längeren zarten Haare abwechselnde kurze dicke Dornen. Ich war überrascht, bei dem vermuthlichen Bastarde weder die eine noch die andere, noch auch eine mittlere Bildung zu finden. Auf dem Rückenstücke (Fig. 37) standen zu beiden Seiten der haarfreien Rinne ziemlich lange und zarte Haare; auf dem Schilde waren dieselben kürzer, aber weder dicker noch gedrängter. Ich will bemerken, dass ich diese Haare nur bei einem Thiere untersucht habe.

Stücke des Gehäuses. Die Stücke des Gehäuses, die sich bei Bal. assimilis schon beim lebenden Thiere leicht auseinandernehmen lassen, hielten bei dem einen (Fig. 29 gezeichneten) Thiere, wo ich sie trennte, selbst nach dem Kochen in Kalilauge noch recht fest zusammen. Die Wände, von denen bereits erwähnt ist, dass ihre ziemlich weiten Röhren im oberen Theile zahlreiche Scheidewände besitzen, sind innen in ihrer ganzen Länge längsgerippt. Der frei nach unten vorspringende Rand der Scheide ist schmaler als bei Bal. armatus, aber stärker entwickelt, als bei Bal. assimilis.

Mundtheile. Die Oberlippe glich bei dem einen Thier (Fig. 38) ganz der von Bal. armatus; auch bei den anderen hatte sie jederseits nur drei Zähne; aber bei zweien (Fig. 39) war der äussere Zahn weit von den anderen entfernt, und bei dem vierten (Fig. 40) waren die beiden äusseren Zähne dicht zusammengerückt und etwas von dem inneren entfernt; weder das Eine, noch das Andere ist mir bei Bal. armatus vorgekommen, ersteres dagegen oft bei Bal. assimilis. Von den zahlreichen Zähnchen, die bei Bal. assimilis die Ränder des mittleren Einschnittes besetzt halten, war nichts zu sehen.

Die Kinnbacken (Fig. 4I. 42) hätte man ebensowohl für die eines Bal. armatus als eines Bal. assimilis halten können, da sie sich bei diesen beiden Arten nicht erheblich unterscheiden.

An den $\mathrm{K}$ iefern waren bei allen vier Thieren die mittleren Borsten kürzer, als es bei Bal. armatus, länger, als es bei Bal. assimilis gewöhnlich ist (Fig. 43); wie bei letzterer Art war mehr als die Hälfte des oberen Randes behaart.

Rankenfüsse. Erstes Paar: Der längere 19-22-gliedrige Ast war bei drei Thieren etwa doppelt so lang, beim vierten nur um 1/4 länger, als der kürzere, der bei zweien I4 Glieder hatte (bei den anderen I I und I3). Eine so grosse Gliederzahl ist mir bei Bal. armatus nicht vorgekommen; bei Bal. assimilis ist -sie oft noch grösser (I5-I8). Bekanntlich sind bei letzterer Art die beiden Aeste in der Regel fast gleich lang; doch habe ich auch bei ihr schon einen Unterschied von 9 Gliedern (I 5 und 24) beobachtet.

Zweites $\mathrm{Paar}:{ }_{3}-\mathrm{I} 6$ Glieder am äusseren, I2-I3 am inneren Aste; bei Bal. armatus $\mathbf{I} \mathbf{I}-\mathbf{I} 3$ an jenem, 9- $\mathbf{~} 0$ an diesem; bei einem Bal. assimilis, den ich eben zur Hand habe, zähle ich 17 und I6. 
Drittes Paar (Fig. 45): Bei drei Thieren fand ich am äusseren Aste 13-16, an inneren 12-14 Glieder: das vierte hatte auf einer Seite 13 und 12, auf der anderen $2 \mathrm{I}$ und 20 Glieder; - Beborstung und Bewaffnung dieses Fusspaares war bei allen vier Thieren die des Bal. assimilis; die Borsten an der Innenfläche der Glieder waren sehr zahlreich (Fig. 45) und auf der Aussenseite fanden sich nur gerade, meist aufwärts gerichtete kleine Dornen und Spitzchen (Fig. 46).

Viertes bis sechstes Paar: Die Beugeseite der oberen Glieder trug am fünften und sechsten Paare der Rankenfüsse bei allen vier, am vierten bei drei Thieren fünf Borstenpaare; das vierte Thier hatte an den Gliedern des vierten Fusspaares nur vier Borstenpaare. - Bei Bal. assimilis ist sechs die gewöhnliche Zahl der Borstenpaare an den Gliedern der hinteren Ranken. Die Aussenfläche der Glieder war am vierten Paare in ähnlicher Weise bewaffnet, wie am dritten. Von dem starken Zahne, der bei Bal. armatus am Stiele des fünften Paares steht, war bei keinem der vier Thiere eine Spur zu finden.

$\mathrm{R}$ uthe wie bei Bal. armatus; bei Bal. assimilis ist dieselbe in der Regel mit längeren und zahlreicheren Haaren besetzt.

Verwandtschaft. Der eben dargelegte Befund scheint mir keine andere Annahme zuzulassen, als die, dass wirklich die vier Thiere Bastarde sind von Bal. armatus und Bal. assimilis. - Wollte man sie nicht als solche gelten lassen, so müsste man sie entweder als Abart, sei es des Bal. armatus, sei es des Bal. assimilis, oder auch als eigene Art betrachten.

Nun aber haben bei B. armatus die Wände niemals durchscheinende Längslinien oder Querscheidewände in den sie durchziehenden Röhren, niemals fällt die grösste Breite der Mündnng fast in die Mitte zwischen Kiel und Rostrum; die Schilder sind immer bedeutend schmäler; nie wurden die Grubenreihen der Aussenfläche vermisst, nie auf der Innenfläche eine bis nahe zum Basalrande zu verfolgende Adductorleiste gesehen; die Rückenstücke haben nie einen so schmalen Sporn, nie eine Längsrinne, nie über den Basalrand vorspringende Leisten für den musc. depressor; niemals wurden die starken gekrümmten Zähne an den Ranken des dritten Paares, nie der starke Zahn am Stiele des fünften Fusspaares vermisst, niemals mehr als vier Borstenpaare an den hinteren Ranken gefunden u. s. w.

Bei Bal. assimilis dagegen, einer hier so gemeinen Art, dass jede Scherbe, jede Schuhsohle, jedes Tauende, das einige Zeit im Meere gelegen, von ihr bedeckt ist, habe ich niemals eine ähnliche röthliche Färbung gesehen, wie sie einer der vermuthlichen Bastarde zeigte, immer fand ich die Radien ganz schmal, mit dünnem Häutchen bedeckt, niemals breit und glänzend; immer zwischen den Haaren der Deckelstücke kurze Dörnchen (Fig. 22) und den Sporn schmaler; immer die Oberlippe mit zahlreichen (Fig. 22--28) Zähnen besetzt, und bei den freilich nicht sehr zahlreichen Thieren, die ich dieser Tage darauf angesehen, fand ich immer, wenigstens an einigen Gliedern der hinteren Ranken sechs Borstenpaare, anderer kleinerer Unterschiede nicht zu gedenken.

Man sieht, die Unterschiede von der einen wie von der anderen Art sind zu bedeutend für eine blosse Abart; sie würden bedeutend genug sein, um unsere Thiere als eigene Art zu betrachten, wenn dem nicht andere Bedenken entgegenständen. Balanen-Arten pflegen nie, wo sie einmal vorkommen, so vereinzelt aufzutreten, dass man im Laufe eines Monats nicht mehr als vier Stück sollte zu- 
sammenbringen können ${ }^{1}$ ). Und wie wunderbar wäre es, wenn zwischen Bal. armatus und Bal. assimilis am Stamme von Carijoa noch eine dritte Art sich ansiedelte, die in so eigenthümlicher Weise zwischen beiden die Mitte hielte, wie unsere Thiere es thun, die fast in Allem, wodurch sie sich von Bal. assimilis entfernen, in der Färbung des einen Gehäuses, in der festeren Verbindung seiner Stücke, in der Bildung der glänzenden gestreiften Radien, im Baue der Oberlippe, übereinstimmen mit Bal. armatus, die fast in Allem, wodurch sie sich von armatus entfernen, in der Bildung der Wände, der Mündung, der Deckelstücke u. s. w., übereinstimmen mit Bal. assimilis und wieder in andern Verhältnissen, wie in der Zahl der Borstenpaare an den hinteren Ranken, genau zwischen beiden in der Mitte stehen.

Nach alledem scheint es mir das Einfachste und Natürlichste, die überraschende Mischung der Merkmale von Bal. armatus und assimilis, die unsere Thiere zeigen, aus einer wirklichen Mischung zu erklären, dieselben also als Bastarde der beiden Arten zu betrachten.

Warum aber, wird man bei dieser Annahme fragen müssen, sind Bastarde von Balanen nicht ungemein häufig, wenn sie überhaupt vorkommen? Die verschiedenen Arten pflegen ja so gewöhnlich sich mit- und durcheinander anzusiedeln, dass man nicht selten drei und mehr Arten in derselben Gruppe vereinigt findet. - Ich kann darauf nur mit Vermuthungen antworten. Um Bastarde von Pflanzen zu erzielen, muss man die Narbe sorgfältig gegen den Blüthenstaub der eigenen Art abschliessen; wird auf die Narbe zugleich Blüthenstaub der eigenen und einer anderen Art gebracht, so bleibt letzterer wirkungslos. In ähnlicher Weise mag bei Thieren, wenn auf das Ei gleichzeitig Same der eigenen und einer anderen Art einwirkt, letzterer wirkungslos bleiben. Wo nun verschiedene Balanusarten in Menge beisammen sitzen, wird den Eiern nie Same der eigenen Art fehlen, also keine Bastarderzengung stattfinden. Eine solche wird nur eintreten können, wenn die Eier eines Thieres nur mit Samen einer fremden Art in Berührung kommen. Dies konnte nun leicht der Fall sein bei einem vereinzelten Bal. assimilis, der sich in ein Carijoagebüsch verirrt hatte und hier, tief versteckt, nur von Bal. armatus umgeben war. - Ist diese Erklärung richtig, so würden unsere Bastarde aus durch Samen des Bal. armatus befruchteten Eiern des Bal. assimilis hervorgegangen sein.

Eine weitere Frage, welche diese Bastarde anregen, ist die, warum dieselben von Bal. assimilis gerade die Bildung der Wände, der Deckelstücke, der Ranken u. s. w., von Bal. armatus gerade die Bildung der Radien, der Oberlippe u. s. w. angenommen haben. - Man wird sagen können, dass die nur quergestreiften Schilder, die schwach bewehrten Ranken des Bal. assimilis, dass die breiten glatten Radien, die sechszähnige Oberlippe des Bal. armatus sich weniger von dem in der Gattung gewöhnlichen Verhalten entfernen, als die tiefgrubigen Schilder und die mächtigen Zähne an den Ranken des Bal. armatus, als die schmalen haut-

I) Ich kann nicht genau sagen, unter welcher $\mathrm{Zahl}$ von Bal. armatus die vier Bastarde gefunden wurden, da ich eine grosse Menge der ersteren verbraucht habe, ohne sie zu zählen; es mögen etwa 400 gewesen sein. Einen Monat oder länger habe ich täglich, so oft das Meer nicht zu bewegt war, an dem Carijoafelsen getaucht und an den heraufgeholten Polypen nicht selten mit einem Male 30 bis 40 Balanen erbeutet. 
bedeckten Radien, und die mit 22-28 Zähnen besetzte Oberlippe des Bal. assimilis. Aehnliches gilt von der einförmigen Behaarung der Deckelstücken. Damit aber ist der Tatbestand nur unter einen gemeinsamen Gesichtspunkt gefasst und nicht erklärt. Darüber hinaus wird man, wie gewöhnlich, so auch hier ohne Darwin's Lehre von der Entstehung der Arten kaum kommen können. Betrachtet man aber die Arten einer Gattung als Abkömmlinge einer gemeinsamen Urform und sieht dabei in Uebereinstimmung mit einer bekannten Erfahrung der Gärtner ihre verschiedenen Eigenthümlichkeiten als um so besser befestigt, als um so weniger veränderlich an, je früher sie erworben wurden, je länger sie sich schon unverändert fortgeerbt haben, so wird begreiflich, dass vor allen fest die schon der Urform eigenen Merkmale haften und dass diese daher bei Kreuzung zweier Arten sich leichter auf den Mischling übertragen werden, als später erworbene Eigenthümlichkeiten von Vater oder Mutter.

Man wird von diesem Gesichtspunkte aus, glaube ich, manche Eigenthümlichkeiten der Bastarde erklären können und umgekehrt vielleicht in manchen Fällen von der Form der Bastarde auf die Urform der Gattung zurückschliessen dürfen, letzteres natürlich nur mit grosser Vorsicht; denn schon die Thatsache, dass die von Männchen der einen mit Weibchen einer anderen Art erzeugten Mischlinge nicht übereinstimmen mit den von Männchen der zweiten mit Weibchen der ersten gezeugten, liefert den Beweis, dass noch andere Umstände bei der Gestaltung der Mischlinge in Betracht kommen.

Desterro, im Februar $186_{5}$.

\section{Erklärung der Abbildungen auf Tafel XXX, XXXI und XXXIl.}

Taf. XXX. Fig. I -28 sind mit Ausnahme von Fig, 22 von Balanus armatus, die folgenden mit Ausnahme von Fig. 32 von einem Bastarde dieser Art und des Balanus improvisus var. assimilis Darw. entnommen.

Fig. I-I3. Balanus armatus und zwar I-9 und I3 von Carijoa. Fig. 2 sitzt dem Rostrum cines anderen B. armatus, Fig. 5 der Spitze eines Carijoazweiges auf. Fig. I3 zeigt dasselbe Thier, A von der Kielseite, B in scitlicher Ansicht. Fig. Io von einem Felsen; der einspringende Winkel der Basis ist bedingt durch die umliegende Schale einer kleinen Miesmuschel. Fig. I I u. I 2 aus einem mit Reniera aquaeductus Schmidt verwandten Schwamme. In allen diesen Figuren, wie in Fig. 29 u. 30 bedeutet $c$ Carina, $r$ Rostrum.

Fig. I4. Umriss der von oben gesehenen Mündung des Gehäuses.

Fig. I 5. Schild von aussen (mit besonders grossen Gruben und entfernten Anwachsstreifen).

Fig. 16. Ein anderes (besonders breites) Schild von innen.

Fig. I7. I8. Rückenstück von aussen und von innen.

Fig. I9-2 I. Bursten der Deckelstücke, nach Behandlung derselben mit Säure, und zwar Fig. I9 von des Kielseite, Fig. 20 von der Schildseite des Rückenstücks. Fig. 2 I vom Schilde.

Fig. 22. Borsten vom Rückenstücke eines Balanus improvisus var. assimilis.

Fig. 23. Oberlippe von Balanus armatus.

Fig. 24. Kinnbacken.

Fig. 25. 26. Untere Ecke zweier anderen Kinnbacken.

Fig. 27. 28. Kiefer.

Fig. 29. Bastard von Bal. armatus und Bal. improvisus, einem Carijoastamme aufsitzend. Von diesem Thiere sind Fig. 3 I, 33-38, 4I-43 entnommen. 
Fig. 30. Ein zweiter Bastard, dem Kieie eines Bal. improvisus var, assimilis aufsitzend, der seinerseits an Carijoa sass. Von diesem Thiere ist Fig. 39 entnommen. Fig. 30.

Fig. 3I. Umriss der von oben gesehenen Mündung des Gelıäuses von dem Bastard

Fig. 32. Umriss der Mündung von Bal. improvisus var. assimilis.

Fig. 33. 34. Schild von aussen und von innen.

Fig. 35. 36. Rückenstück von aussen und von innen.

Fig. 37. Borsten von den Anwachsstreifen des Rückenstücks.

Fig. 38-40. Oberlippe von drei verschiedenen Thieren.

Fig. 4 I. Kinnbacken.

Fig. 42. Untere Ecke desselben.

Fig. 43. Kiefer.

Fig. 44. Vorderer Ast des dritten Paares der Rankenfüsse von Bal. armatus, von innen, weshalb nur die den Rand überragenden Zähne sichtbar sind.

Fig. 45. Derselbe Ast von dem Bastard, von aussen.

Fig. 46. Neuntes Glied vom äusseren Ast des dritten Fusspaares, von einem grossen Balanus armatus, von aussen.

Fig. 47. Zehntes Glied vom äusseren Ast des vierten Fusspaars, von B. armatus, von aussen.

Fig. 48. Zweites Stielglied des fünften Fusspaares von B. armatus.

Fig. 49. Siebentes Glied vom äusseren Ast des dritten Fusspaares, von dem Bastard, von aussen.

Fig. 50. Dasselbe Glied von einem Bal. improvisus var. assimilis, von aussen.

Fig. 5I. Zehntes Glied vom äusseren Aste des vierten Fusspaares, von Balanus improvisus var. assimilis, von aussen.

Fig. 52. 53. Senkrechter Durchschnitt des Gehäuses von Tetraclita porosa, um die Wirkung der Musculi depressores zu erläutern. Auf den Sporen ist durch einen Punkt die Stelle angedeutet, um welche die Muskeln den Deckel drehen; in Fig. 52 sind die depressores tergi, in Fig. 53 die depressores scuti zusammengezogen.

Fig. 54. 55. Kittröhren aus der Basis von zwei in Reniera angesiedelten Balanus armatus. $R$ Rand der Basis. $a^{\prime}, a^{\prime \prime}, a^{\prime \prime \prime}, b^{\prime}, b^{\prime \prime}, b^{\prime \prime \prime}$ blinde Ausläufer; $a^{\prime} b^{\prime}$ sind die ältesten, $a^{\prime \prime \prime} b^{\prime \prime \prime}$ die jüngsten derselben.

Fig. 56. Carijoa rupicola, zum Theil von einem gelben Schwamme überzogen und mit Balanus armatus besetzt.

Fig. 57. Kalknadeln dieses Polypen. 


\title{
Notizen über die Geschlechtsverhältnisse brasilianischer Pflanzen ${ }^{1}$ ).
}

\author{
Aus einem Briefe an Friedrich Hildebrand.
}

Wir sind hier sehr reich an dimorphen Pflanzen (Erythroxylon, Villarsia, Plumbago, Statice, Cordia und namentlich eine Menge von Rubiaceen: Hedyotis, Borreria, Manettia u. s. w.) und trimorphe Arten bietet uns die Gattung Oxalis eine ganze Zahl. Unsere hiesigen Lythrarieen dagegen (Nesaea, Cuphea) scheinen alle monomorph zu sein. $\mathrm{Zu}$ Versuchen an diesen Pflanzen bin ich bis jetzt noch nicht gekommen.

Durch Ihr Buch (Die Geschlechtervertheilung bei den Pflanzen - der Brief ist an F. Hildebrand gerichtet) erhielt ich die erste Kunde von John Scott's Versuchen an Oncidium; ich selbst habe im letzten Sommer zahlreiche Versuche an hiesigen Vandeen angestellt und wie Sc ot t gefunden, dass z. B. bei Oncidium flexuosum, micropogon, unicorne u. a. sowie bei verschiedenen Arten von Notylia, Gomeza, Stigmatostalix und Burlingtonia Bestäubung mit Staubmassen desselben Stockes nie Befruchtung zur Folge hat, während stets Frucht angesetzt wird, wenn man Staubmassen eines fremden Stockes anwendet. Das Merkwürdigste bei dieser Sache scheint übrigens Scott übersehen zu haben: Staubmassen und Narbenflächen desselben Stocks wirken bei diesen Arten als tödliches Gift auf einander - am raschesten bei Notylia, wo gar keine Schlauchbildung eintritt und schon nach etwa zwei Tagen die Staubmassen durch und durch schwarz sind und ebenso die Narbenfläche, und bald darauf die Blüthen abfallen. In anderen Arten beginnt erst nach 7-8 Tagen, nachdem schon lange Schläuche vorhanden, eine Bräunung auf der Grenze zwischen Blüthenstaub und Narbe aufzutreten. Staubmassen einer fremden Art scheinen nie, auch wenn sie nicht befruchtend wirken, eine ähnliche giftige Wirkung zu haben.

Die Eigenthümlichkeit vieler Orchideen, erst lange nach der Bestäubung und lange nachdem die Schläuche des Blüthenstaubes bis zum unteren Ende vor-

I) Botanische Zeitung I868. Bd. 26. Sp. 113-I16. 
gedrungen, ihre Eichen zu entwickeln - die, wie ich von Darwin höre, auch von Ihnen beobachtet wurde (s. Bot. Ztg. I 863) - scheint den Vandeen und Epidendreen sehr allgemein zuzukommen; es ist mir hier noch keine Pflanze aus diesen beiden Gruppen vorgekommen, die zur Blüthezeit schon wohlentwickelte Eichen hatte. Bei einem auch sehr merkwürdigen hiesigen Epidendrum (bei welchem die seitlichen Antheren ebenfalls fruchtbar sind und ihre Staubmassen auf die Narbe fallen lassen, Selbstbefruchtung bewirkend, während die Staubmassen der sonst allein entwickelten mittleren Anthere wie gewöhnlich nur durch Insekten entfernt werden können) werden die Eichen erst etwa $1 / 2$ Jahr nach der Blüthezeit reif zur Befruchtung,

Noch leichter als bei den Lobeliaceen könnte man bei Scaevola sich zu dem Irrthum verleiten lassen - und auch ich bin demselben bei meiner ersten Bekanntschaft mit der Pflanze nicht entgangen - dass hier Selbstbestäubung unvermeidlich, Fremdbestäubung unmöglich sei; in der der Reife nahen Knospe bildet das sogenannte Indusium einen weit über den Narbenkopf vorspringenden Becher mit gewimpertem Rande, der durch die Staubbeutelröhre hindurchwächst, dabei allen Blüthenstaub in sich aufnimmt, und dann nach dem Oeffnen der Blüthe sich schliesst. Beim Aufbrechen der Blüthen sind also die Staubbeutel leer und der Blüthenstaub findet sich am Ende des Griffels in einem wohlverschlossenen Behälter angehäuft. Später wird durch den über das Indusium hinauswachsenden Narbenkopf der Blüthenstaub aus diesem Behälter vorgeschoben. In welcher Weise die Bestäubung zustande kommt, habe ich leider nicht ermitteln können, da die Pflanze nicht in der Nähe von Desterro wächst und in meinem Garten nicht gedeihen wollte.

Noch bevor ich Ihre Versuche an Corydalis cava kennen lernte, hatte ich ähnliche Beobachtungen an Eschscholtzia gemacht. Es findet hier nothwendig Selbstbestäubung statt, aber weder der Staub derselben Blume, noch überhaupt desselben Stockes bewirkte jemals Befruchtung. Die Pollenschläuche schienen in diesem Falle nie tief in das Narbengewvebe einzudringen. - Ein hübscher Versuch, den ich öfter gemacht, ist, dass man auf eine der beiden langen Narben derselben Blume Staub desselben, auf die andere Staub eines fremden Stockes bringt. Geschieht dies früh, sobald die Blumen sich öffnen, so sieht man meist noch an demselben Tage, ehe sie sich wieder schliessen, dass letztere Narbe sich zu erheben beginnt, erstere in unveränderter Stellung verharrt. Tags darauf steht die mit fremdem Staube versehene Narbe senkrecht, die mit Staub des eigenen Stockes bestreute ist wagerecht geblieben. - Da Eschscholtzia hier nicht heimisch ist, weiss ich nicht, ob die Unfruchtbarkeit mit eigenem Pollen wirklich der Art als solcher zukommt, oder bei meinen Pflanzen nur durch die Uebersiedelung in in ein neues Klima bedingt ist.

Ich vermuthe nach mannigfachen beiläufigen Beobachtungen, dass diese Unfruchtbarkeit mit Blüthenstaub desselben Stockes, wie sie nun schon für Corydalis cava, für viele Oncidien und andere Vandeen, und wenigstens als individuelle Eigenthümlichkeit für Eschscholtzia durch Versuche festgestellt ist, namentlich unter den Monocotyledonen eine weite Verbreitung besitzt, und hoffe bald weitere 
Versuche hierüber anstellen zu können. - Vielleicht bringen manche exotische Pflanzen in den europäischen Gärten und Gewächshäusern nur deshalb keine Früchte, weil alle Exemplare des Gartens nur Theilstufen desselben Stockes sind. Mit dieser Vermuthung will ich natürlich nicht in Abrede stellen, dass in vielen anderen Fällen die veränderten Lebensbedingungen Schuld der Unfruchtbarkeit sind. Eine wahrscheinlich schon durch die ersten Ansiedler von den Azoren oder Portugal eingeführte Petersilie trägt hier, in nicht sehr verschiedenem Klima, reichlich Samen. während man seit Jahren hier vielfach Petersilie aus deutschen Samen gezogen hat, ohne dass dieselbe, übrigens kräftig wachsend, je auch nur eine einzigre Blüthe oder Frucht gebracht hätte.

S a. Catharina, i 2. September i 867 . 


\section{Befruchtungsversuche an Cipó alho (Bignonia) ${ }^{1}$ ).}

Die Provinz Santa Catharina ist reich an kletternden Bignoniaceen (Bignonia, Haplolophium, Amphilophium). Mehrere derselben pflegen reichlich zu blühen, alle aber setzen sehr selten Frucht an, und von einigen der gewöhnlichsten blüthenreichsten Arten habe ich noch nie eine Frucht gesehen. Die Blüthen werden fleissig von verschiedenen Kerfen (Käfern, Wanzen, Hummeln) besucht, und häufig wird von denselben die Narbe mit Blüthenstaub versehen. So habe ich von einem grossen Stocke eines Amphilophium, der in meiner Nachbarschaft während des letzten Sommers über vier Monate lang reichlich blühte, ohne eine einzige Frucht zu bringen, - zahlreiche ältere Blüthen untersucht, und in allen zwischen den geschlossenen Lippen der Narbe Blüthenstaub gefunden, der kurze Schläuche getrieben hatte.

Mangelnder Besuch die Bestäubung vermittelnder Kerfe konnte also nicht, wie es bei einigen hiesigen Orchideen der Fall ist, die Ursache des seltenen Fruchttragens sein. Es war vielmehr zu vermuthen, dass auch die Bignonien in die Reihe der Pflanzen gehören würden, welche, unfruchtbar mit ihrem eigenen Blüthenstaube, zur Fruchtbildung der Bestäubung mit Blüthenstaube eines anderen Stockes ihrer Art bedürfen ${ }^{2}$ ).

Zwei reichlich blühende Stöcke einer durch den starken Knoblauchsgeruch ihrer Stengel ausgezeicheten Bignonia (.,Cipó alho" der Brasilianer), die an einem vor mehreren Jahren abgeholzten, jetzt mit niederem Gebüsch und Farrnkraut (Pteris) bewachsenen Hügel in der Nähe meines Hauses wachsen, boten mir Gelegenheit, einige Versuche zur Entscheidung dieser Frage anzustellen.

Die Narbe der Bignonien bildet bekanntlich zwei breite Lippen, die im jungfräulichen Zustande weit klaffen, aber sofort sich schliessen, sobald Blüthenstaub auf dieselben gebracht wird. Man braucht daher bei Befruchtungsversuchen weder die Staubbeutel der zu bestäubenden Blüthen zu entfernen, noch bedarf man sonstiger Vorkehrungen, um der späteren Einwirkung anderweitigen Blüthenstaubes vorzubeugen. Dies gewährt nicht nur eine namentlich für Versuche an wildwachsenden Pflanzen werthwolle Erleichterung, sondern auch den Vortheil, dass das Ergebniss der Versuche durch keinerlei störende Eingriffe beeinträchtigt wird.

Erster Versuch. Am 8. und 9. Januar bestäubte ich an dem einen Stocke (A) 5, an dem anderen (B) 2 Blüthen mit ihrem eigenen Blüthenstaube; ferner

I) Botanische Zeitung 1868. Bd. 26. Sp. 625-629.

2) Vergl. Darwin, Variation of Animals and Plants under domestication. I868. Vol. II. S. I3I. 
am Stocke (A) 9, am Stocke (B) 2 Blüthen mit Blüthenstaube desselben Stockes, aber von verschiedenen Blüthen; endlich 9 Blüthen von (A) mit Blüthenstaub von (B) und 5 Blüthen von (B) mit Blüthenstaub von (A). Am Nachmittag des Io. Januar waren die Blumenkronen aller bestäubten Blüthen abgefallen; die Griffel waren frisch und hatten natürlich geschlossene Narben, während an unbestäubten Blüthen auch nach dem Abfallen der Blumenkrone die Lippen der Narbe noch klaffen.

Am I7. Januar waren alle mit eigenem oder mit Blüthenstaub desselben Stockes bestäubten Blüthen abgefallen; ebenso einige der mit dem anderen Stock gekreuzten Blüthen. Die übrigen zeigten schwellende Fruchtknoten.

Am 25. Januar waren auch diese Blüthen sämmtlich abgefallen, bis auf eine einzige des Stockes (B), bei welcher der Fruchtknoten zu dreifacher Länge des Kelches herangewachsen war.

Am 2. Februar hatte die junge Frucht $0,04 \mathrm{~m}^{2}$ Länge ${ }^{1}$ ) bei $0,02 \mathrm{~m}$ Breite, - am I I. Februar 0,08 m Länge bei 0,04 m Breite, - am 7. März 0,092 m Länge bei $0,048 \mathrm{~m}$ Breite, und damit, wie es scheint, ihre volle Grösse erreicht.

Zweiter Versuch. Am I8. Januar wurden am Stocke (A) 4 Blüthen mit Blüthenstaub desselben Stockes, 6 Blüthen mit Blüthenstaub des Stockes (B) bestäubt.

Am 25. Januar waren die ersteren Blüthen sämmtlich, von den letzteren 3 abgefallen; auch die drei übrigen waren am 2. Februar abgefallen.

Dritter Versuch. Am 2. Februar wurden am Stocke (A) 6 Blüthen mit Blüthenstaub desselben Stockes, 6 mit Blüthenstaub von (B); am Stocke (B) wurde eine Blüthe mit Blüthenstaub desselben Stockes, eine mit Blüthenstaub von (A) bestäubt.

Am 4. Februar waren abgefallen die mit Blüthenstaub desselben Stockes bestäubte Blüthe von (B) und eine der in gleicher Weise bestäubten Blüthen von (A).

Am I I. Februar fanden sich noch 5 der mit (B) gekreuzten Blüthen am Stocke (A) und hatten frische Fruchtknoten; ausserdem war noch eine der mit Blüthenstaub desselben Stockes bestäubten Blüthen vorhanden, fiel aber ab bei leiser Berührung.

Am I4. Februar waren von den 5 eben erwähnten Blüthen noch 2 vorhanden; ihre Fruchtknoten erschienen nicht merklich geschwollen.

Am 22. Februar war von diesen 2 Blüthen noch eine abgefallen; der Fruchtknoten der letzten überlebenden war soweit gewachsen, dass er den Kelchrand $\mathrm{zu}$ überragen begann.

Am 7. März war diese Frucht 0,046 $\mathrm{m}$ lang, 0,024 $\mathrm{m}$ breit, und bis zum 22. März hatte sie ungefähr die Grösse der Frucht des Stockes (B) erreicht.

Vierter Versuch. Am 4. Februar wurden 3 Blüthen des Stockes (A) mit Blüthenstaub eines dritten in der Nähe wachsenden Stockes (C) versehen.

Am II. Februar fielen zwei dieser Blüthen bei leiser Berührung ab, die dritte wurde nicht gefunden, wahrscheinlich war sie schon sammt dem Faden mit dem sie gezeichnet war, abgefallen.

Fünfter Versuch. Am 22. März wurden 5 Blüthen des Stockes (B) mit Blüthenstaub eines vierten in grösserer Entfernung mitten im Urwalde wachsenden Stockes (D) bestäubt.

I) Im Original steht $0,04 \mathrm{Mm}$, ebenso noch $7 \mathrm{mal}$ in diesem und dem 9. folgenden Absatz. Es ist stets $\mathrm{m}$ dafür gesetzt worden. 
Am 3. April hatten sämmtliche fünf Blüthen junge, den Kelchrand bereits überragende Früchte entwickelt.

Sechster Versuch. Am 9. Januar wurden 10 Blüthen des Stockes (A) und 6 Blüthen des Stocke (B), und am ig. Januar wurde eine Blüthe des Stockes (A) mit Blüthenstaub eines Amphilophium bestäubt. Bei mehreren wurde ein beginnendes Schwellen des Fruchtknotens beobachtet, und sie blieben meist länger sitzen, als die mit Blüthenstaub desselben Stockes bestäubten Blüthen. - Alle indess, mit Ausnahme einer einzigen des Stockes (B), fielen im Laufe der ersten beiden Wochen ab.

Der Fruchtknoten dieser einen Blüthe hatte während der ersten Woche (bis zum 17. Januar) etwa gleichen Schritt gehalten mit den mit Blüthenstaub von (A) bestäubten Blüthen des Stockes (B); aber schon am 25. Januar war die eine Frucht, welche die letzteren Blüthen lieferten, zu dreifacher Länge des Kelches herangewachsen, während die erstere, mit Amphilophium gekreuzte, kaum zur Hälfte aus dem Kelche hervorsah, und seit dieser Zeit hat sich dieselbe merkwürdiger Weise in völlig unverändertem Zustande erhalten. Sie ist nicht mehr gewachsen, ist aber immer noch - ein Vierteljahr nach der Bestäubung! frisch und glänzend grün, obwohl viel zu klein, um auch nur einen einzigen Samen zu enthalten. -

Fassen wir das Ergebniss der Versuche kurz zusammen.

Es wurden an 2 Stöcken 29 Blüthen mit Blüthenstaub desselben Stockes (von denselben oder von verschiedenen Blüthen) bestäubt. A11e fielen nach kurzer Zeit ab. An denselben beiden Stöcken wurden 30 Blüthen mit Blüthenstaub anderer in der Nähe wachsender Stöcke bestäubt. Nur 2 Früchte entwickelten sich, aber die meisten Blüthen hafteten länger am Stocke, als im vorigen Falle, und viele zeigten ein beginnendes Schwellen des Fruchtknotens.

Endlich wurden 5 Blüthen eines Stockes mit Blüthenstaub eines entfernt wachsenden Stockes bestäubt. Alle fünf setzten Frucht an.

Die vollständige Unfruchtbarkeit mit eigenem, die vollkommene Fruchtbarkeit mit fremdem Blüthenstaube, wie sie im ersten und dritten Falle sich zeigte, hatte ich erwartet. Die äusserst geringe Fruchtbarkeit aber, die sich im zweiten Falle bei Kreuzung dreier nachbarlich wachsender Stöcke herausstellte, war im hohen Grade auffallend. Sind die drei nachbarlich wachsenden Pflanzen etwa Sämlinge derselben Mutterpflanze, vielleicht selbst aus Samen derselben Frucht entsprossen und wegen zu naher Verwandtschaft so unfruchtbar? Oder sind sie an gleicher Stelle, unter gleichen Lebensbedingungen wachsend, einander so ähnlich geworden, dass der Blüthenstaub der einen kaum mehr auf die andere wirkt, als deren eigener Blüthenstaub? Oder umgekehrt, sind sie etwa nur früher verbundene Theilstücke, Schösslinge eines einzigen Stockes, die durch jahrelanges unabhängiges Leben einen geringen Grad gegenseitiger Befruchtungsfähigkeit erlangt haben? - Oder endlich, war es nur ein neckischer Zufall, dass bei Kreuzung der Nachbarstöcke von 30 Blüthen nur 2, dass dagegen alle mit fernher gebrachtem Blüthenstaube bestäubten Blüthen Frucht ansetzten? - Für jetzt wage ich keine der verschiedenen Möglichkeiten als die wahrscheinlichere zu bezeichnen.

Itajahy (Santa Catharina, Brazil), April i 868. 


\section{Ueber Befruchtungserscheinungen bei Orchidesn ${ }^{1}$ ).}

Aus einem Briefe an Friedrich Hildebrand.

In Ihrem Aufsatze über Fruchtbildung der Orchideen erwähnen Sie der der Gattungen Catasetum und Acropera, und bezeichnen Darwin's Ansicht, dass dieselben getrennte Geschlechter sind, als des experimentellen Beweises bedürftig (mit den betreffenden Worten hat aber nicht die Richtigkeit von Darwi n's Ansicht bezweifelt werden sollen. H.). - An Catasetum mentosum habe ich im December I866 mehrfache Versuche angestellt. Pollinien von demselben oder von einem anderen Stocke, auf die Narbe von Catasetum gebracht, erweichen, zerfallen in Vierlingsgruppen von Pollenkörnern und beginnen Schläuche zu treiben, bewirken aber kein Wachsthum des Fruchtknotens. In einem Falle sah ich die bestäubten Blüthen ein wenig früher welken, als die unbestäubten. Merkwürdig ist und spricht auch für die männliche Natur von Catasetum, dass die Blüthen etwa 2 Tage nach Entfernung der Pollinien zu welken beginnen, während benachbarte Blüthen, die ihre Pollinien noch haben, völlig frisch bleiben! - Die Monachanthus-Form, mit Pollinien von Catasetum bestäubt, bringt riesige Früchte. - Der zu Catasetum mentosum gehörige Monachanthus hat noch eine Klebscheibe und ein elastisches Füsschen, und hat auch kleine Pollinien, aber die Anthere öfnet sich nicht, die Pollinien bleiben eingeschlossen, treten nie in Verbindung mit dem Füsschen, und können somit nie von Insekten entführt werden. Auf die Narbe von Catasetum gebracht (was aber in der Natur unmöglich ist, nicht nur wegen des Eingeschlossenseins der Pollinien, sondern auch weil die Narbe von Catasetum nicht klebrig ist), treiben sie Schläuche; ob sie etwa auch Fruchtbildung veranlassen können, habe ich noch nicht beobachtet. Auffallend ist, wie die Pollenkörner dieser verkommenen Pollinien unter cinander in Grösse und Gestalt verschieden sind. (Nach Darwin's Theorie erklärlich, weil sie der Controle der natürlichen Auslese entbehren.)

An Acropera hat Darwin selbst, wir er mir schrieb, sich von der Irrigkeit seiner früheren Ansicht überzeugt. Ich habe die Gattung hier noch nicht gefunden, aber zwei Arten von Cirrhaea, bei denen ebenfalls die Narbe nur einen sehr engen Querspalt bildet, häufig bestäubt; es lässt sich nur das Ende der langgestreckten Pollinien in den engen Spalt einführen, dieses aber sehr leicht; das

I) Botanische Zeitung. 1868. Bd. 26. Sp. 629-631. 
Pollinium steht in fast ganzer Länge hervor, aber nichts destoweniger findet man es am nächsten Tage tief in dem Griffelkanal. Dicht hinter der engen Eingangsspalte erweitert sich nämlich der Griffelkanal trichterförmig und ist hier mit losem, feuchtem Gewebe gefüllt. In dieser feuchten Umgebung schwillt das eingebrachte Ende des Polliniums und muss daher in den unteren, weiteren Theil des Kanals vordringen. Nachdem das ganze Pollinium eingeschlüpft ist, wirkt die Anschwellung der Säule, die den oberen Theil des Kanals schliesst, gleichfalls mit, das Pollinium weiter hinabzutreiben. - Eine ähnliche Anschwellung der Säule, in Folge deren sich die Narbenkammer im Laufe des ersten Tages oder wenig später schliesst, findet sich als erste Wirkung des Pollens fast bei allen Vandeen, und es scheint, dass Pollinien jeder beliebigen Art diese Wirkung auf die Narbe jeder beliebigen anderen ausüben können.

Das Schwinden der Pollenschläuche der Orchideen kurz nach der Befruchtung, das Sie, gegenüber R. Brown's Ansicht, dass dieselben noch zur Zeit der Fruchtreife vorhanden seien, bei allen von Ihnen untersuchten Arten beobachteten, dürfte doch vielleicht nicht allgemeine Regel sein. Ich meine in wenigen Fällen die sechs Stränge noch in der reifen Frucht gesehen zu haben, kann mich aber leider nicht entsinnen, bei welcher Art.

Ist es Ihnen bei Ihren Bastardirungsversuchen an Orchideen nicht aufgefallen, dass der Embryo der bastardirten Samen oft in Form und Grösse bedeutend vom Typus der Mutter sich entfernt? (ich habe auf diesen Punkt nicht Acht gegeben. H.). - Mir schien es in mehreren Fällen, als gliche der Embryo dem der väterlichen, die Samenhülle derjenigen der mütterlichen Art. Besonders auffallend war mir folgender Fall: die Samen von Epidendrum cinnabarinum haben einen langen, fadenförmigen Stiel, durch dessen ganze Länge sich ein aus mehreren Zellenreihen "bestehender Embryoträger hinzieht; nun hatte ich eine Frucht durch Bestäubung von Cattleya Leopoldi mit Ep. cinnabarinum erhalten. Sie enthielt nur äusserst wenige Samen, aber diese von höchst sonderbarem Aussehen: der lange Embryostiel des Epidendrum war in der kurzen Samenhülle der Cattleya auf die wunderlichste Weise hin- und hergebogen oder zusammengeknäult (es wäre dies wiederum ein Beweis für den direkten Einfluss der Bastardirung auf die durch sie erzeugte Frucht. H.) 


\section{Excursionsberichte aus Südbrasilien $\left.{ }^{1}\right)^{2}$ ).}

Wir brachen am 27. April bei Tagesanbruch auf und marschirten der Mündung des Itajahy zu. Der WVeg führt bald in der Nähe des Flusses hin, bald entfernt er sich davon, grössere Krümmungen desselben abschneidend; - bald durch Weideland, bald durch Zuckerrohr oder Mandiocapflanzungen, selten durch ein Stückchen Urwald. Vom Flusse aus steigt das Land ziemlich steil empor, bald in einer Flucht, bald stufenförmig - in unserer Gegend etwa 30 Fuss, und senkt sich dann wieder ein wenig nach dem Fusse der Berge zu, die bald dicht an den Fluss herantreten, bald, namentlich weiter unten, bis stundenweit davon entfernt sind. In letzterem Falle pflegt die Senkung zwischen dem Flussrand und dem Fusse der Berge sumpfig zu sein.

An dem Zustande des Weidelandes, das mit Zäunen von Palmenlatten oder mit Hecken von stachligen Acacien oder Citronen umgeben ist, konnten wir meist mit ziemlicher Sicherheit die Nationalität der Besitzer erkennen; eine saubere, glatte Grasfläche gehörte sicher einem Deutschen, bei Brasilianern war das Gras oft völlig überwuchert von einer Malvacee mit kleiner gelber Blüthe (Mata pasto, Weidetödter) und von allerlei Buschwerk, namentlich einer Cassia. - Hie und da war die Weide zu einem förmlichen Walde junger Guyavenbäume geworden, an denen wir leider nur noch äusserst wenige Früchte fanden. - Häufig trafen wir weiter unten am Flusse, in Hecken und am Waldrande eine kletternde Amarantacee (Chamissoa), mit reifenden Früchten. Die Blüthen stehen in grossen losen Rispen und sind ganz unansehnlich; später aber färbt sich die Blüthenhülle lebhaft roth und die Pflanze bildet nun eine wahre Zierde der Hecken, noch mehr aber, wenn die Samen reif sind, wie wir sie beim Heimwege trafen; sie erscheinen dann als weisse Perlen in den rothen Rispen. (Der Samen ist schwarz, aber von einem weissen Arillus umhüllt). An einigen Stellen ist das Flussufer von einem undurchdringlichen Walde eines sclıönen Grases eingefasst (Canna brava, d. h. wildes Rohr oder Ubá; Gynerium?), das dem Zuckerrohr ähnlich, aber viel höher ist und auf hohen Stielen grosse Rispen kleiner Blüthen trägt. - Zu Mittag hatten wir in einem deutschen Wirthshause am Gaspar gegessen, unser Nachtquartier schlugen wir in einer brasilianischen Venda auf, der Mündung eines der bedeutendsten Zuflüsse des Itajahy, des J uiiz Alves, gegenüber. - Es wurde hier

I) Aus Briefen an seinen Bruder, Hrn. H. Müller zu Lippstadt, datirt Itajahy, I I. u. I8. Juni 1868.

2) Flora 1869. p. $337-348$ und $353-364$. 
Reis ausgedroschen; in der Mitte der unter freiem Himmel befindlichen Tenne war ein starker Pfosten aufgestellt, an welchen 2 Pferde gebunden waren; ein Negerbursche bestieg ein drittes und trieb die beiden anderen um den Pfosten herum. - Nachdem wir unser stark mit Cuminho (Mutterkümmel) gewürztes Hühnerfricassee verzehrt hatten, streckten wir uns auf eine Rohrmatte nieder.

(28. A pri1). Einige Gäste, die schon lange vor Tage zu Canoe nach dem Luiz Alves aufbrachen, machten auch uns munter und beim ersten Morgengrauen traten wir unsern kurzen Tagemarsch nach der Mündung des Flusses an. Der Weg wandte sich bald vom Flusse nach den hier durch ein breites Sumpfland davon getrennten Bergen und führte erst an deren Fusse hin, dann durch das Sumpfland hindurch dem Flusse wieder zu. Die spärlichen Bewohner trafen wir beim Einernten des Reises beschäftigt.

Statt unserer Gissara-Palme (von den Deutschen gewöhnlich Palmitto genannt), mit schlankem weissem Stamm und glänzend grünen zweizeilig gefiederten Blättern wächst, im Sumpflande die Girivá (gewöhnlich Coqueiro) mit dickerem Stamme und buschigen Blättern, deren Fiedern nach allen Seiten von der Mittelrippe abstehen. Auch trafen wir häufig den gleichfalls sumpfliebenden zierlichen Schlingfarn (Lygodium), von dem ich Dir ${ }^{1}$ ) einmal einige Blättchen schickte. Es ist mcrkwürdig, wie die wenigen Gattungen der durch ihre Sporangienbildung so eigenthümlichen Gruppe der Schizaeaceen (Aneimia, Schizaea, Lygodium die 4te Gattung Mohria kenne ich nicht) sich in ihrem Habitus weiter von einander entfernen, als irgend zwei Arten der Tausende von Arten zählenden Gruppe der Polypodiaceen. Beides, die Vereinzelung der Gruppe und die grosse Verschiedenheit der wenigen Formen, weist auf dieselbe Ursache hin, - ein massenhaftes Aussterben von Mittelformen. - Längs des Weges war rechts und links der Urwald io Klafter breit niedergehanen, um dem Wege mehr Luft und Licht zu verschaffen. Jetzt war an dessen Stelle über mannshohes Gebüsch gewachsen, das in dem Sumpflande grossentheils aus Compositae bestand (Baccharis u. a.). Sehr häufig war eine Baccharis (vielleicht B. triptera), die Johannes ${ }^{2}$ ), als er sie zuerst ohne Blüthen sah, für einen Cactus ansah, und deren blattloser mit 3 breiten Flügeln eingefasster Stengel in der That einer Rhipsalis ähnlich genug sieht. Ich sah hier zum ersten Male eine ausnahmsweise Blätter tragende Pflanze dieser Art. Wir bewunderten die Blüthenpracht einer hier äusserst häufigen Melastomacee (Pleroma), die über und über mit grossen, dunkelblauvioletten Blüthen bedeckt war.

Gegen II Uhr erreichten wir den Itajahy-mirim oder kleinen Itajahy (den kleinen Fluss, wie er hier gewöhnlich heisst); nachdem uns der Fährmann lange hatte warten lassen, ruhten wir jenseits in einem deutschen Wirthshause während des Mittags aus, um dann nach der ein kleines Stündchen entfernten Villa do Itajahy weiter zu gehen. Das Flussufer ist hier niedrig, das Land flach, sandig und sumpfig, und der Pflanzenwuchs verräth die Nähe des Meeres. Am Flussufer ein strauchiger Hibiscus mit grossen gelben Blumen, in sumpfigen Gräben ein schönes wohlriechendes Crinum und ein grosser Farn (Chrysodium), im Gebüsch

I) scil. Hern. H. Müller zu Lippstadt.

2) Neffe des Verf. und Begleiter auf der Tour. 
ein Hedyosmum (Chloranthacee) mit weissen beerenartigen Früchten und eine Norantea (Marcgraviacee) mit sonderbaren becherförmigen Bracteen an den Blüthenstielen.

Der Itajahy erweitert sich vor seiner Mündung zu einem weiten Hafen, der durch eine von Norden her vorspringende schmale flache Landzunge vom Meere geschieden ist. Südlich vor der Mündung ist ein schroffes Felsufer. - Die kleine Villa bietet mit ihren weissen Häusern, meist Kaufläden, einen recht freundlichen Anblick; die Umgegend freilich ist ziemlich öde und bietet nicht einmal Trinkwasser, das vom Nordufer geholt werden muss.

Auf dem Wege vom Kleinen Fluss zur Villa fanden wir reife Früchte einer auch hier nicht seltenen Schlingpflanze mit holzigem Stamme (eine Dilleniacee, vielleicht Curatella "), hier "Cipó páo“ genannt). Die Früchte öffnen sich in sehr eigenthümlicher Weise. Sie springen in Meridianrichtung auf etwa $3 / 4$ des Umfanges auf, dann löst sich die Schale noch etwa zur Hälfte vom Fruchtboden los, und jede der beiden Klappen erhält dann noch einen Sprung von unten nach oben. So entstehen zwei breite, innen scharlachrothe Flügel, deren jeder am Ende einen von schneeweisser saftiger Hülle umschlossenen Samen trägt.

(29. Apri1). In der Nacht hatte es stark geregnet und noch am Morgen regnete es schwach, so dass wir erst ziemlich spät unsere Reise fortsetzen konnten. Vom Itajahy führte unser Weg südwärts, meist in geringer Entfernung von der Küste hin. Die Küste bildet eine Reihe felsiger Vorgebirge, zwischen denen Buchten mit sandigem Strande sich mehr oder weniger tief landeinwärts biegen. An diese schliessen sich dann sandige oder sumpfige Niederungen an.

Nachdem wir einen ersten Berg überstiegen hatten, kamen wir in die sandige Ebene der Praia brava. In dem tiefen weissen Sande wächst nur dürftige Mandiocca (und dazwischen im Sommer Wassermelonen). In dem Gebüsche am Wege herrschte eine Dodonaea mit schmalen weidenähnlichen Blättern vor, die immer schlechten Boden anzeigt. Weiterhin wurde das Land hügelig, mit feuchten Thälern dazwischen, und hier trafen wir zum ersten Male in grösserer Menge die prächtige Indaiá-Palme, deren Stamm selten eine bedeutende Höhe erreicht, während die aufsteigenden Blätter von riesiger Grösse sind (man sagt fast 30 Fuss, doch habe ich sie nicht selbst gemessen). Von einer etwas grösseren Höhe stiegen wir dann zum Strande des Meeres nieder, dem wir etwa $1 / 2$ Stunde lang bis zur Mündung des Cambriú folgten. An der Fluthgrenze krochen weithin im Sande eine weisse und eine rothe Ipomoea und eine Schmetterlingsblume, die in Blüthenfarbe und Blattform der letzteren Ipomoea auffallend glich. Dazwischen häufig Acicarpha mit stachligen Blüthenköpfchen, unsere einzige Pflanze aus der kleinen Familie der Calycereen, der nächsten Verwandten der Compositae. Weiter oben folgte dann ein Gürtel stachliger Bromeliaceen (Dyckia?).

Während wir den Fährmann erwarteten, der uns vom flachen Nord- an das hohe Südufer des Cambriú bringen sollte, fingen wir einige kleine Krabben (Gelasimus), die im Uferschlamme ihre Löcher hatten. - Am Südufer des Cambriú bilden einige schmutzige Kramläden und andere Häuser eine elende Ortschaft. Etwa eine Stunde jenseit derselben kamen wir an den Fuss des durch seinen

I) ist vielmehr Doliocarpus, und wahrscheinlich D. grandiflorus Mart.

Redact. 
schlechten Weg berüchtigten Morro do Boi (Ochsenberg). Das nächtliche Regnen und Nässeln während des Tages hatten den rothen Thonboden gewaltig schlüpfrig gemacht, und das Aufsteigen auf dem steilen Wege mit zahlreichen Steinen und Drecklöchern und überhängenden Buschwerk war keineswegs angenehm; aber noch schlimmer war das Hinabsteigen auf dem steileren Südabhange. Die Maulthiere und Pferde hatten hier, wie überall auf schmutzigen Wegen, eine eigenthümliche Art Treppen gebildet; jedes Thier tritt in die Tapfen seines Vorgängers und so entstehen allmälig tiefe schlammgefüllte quere Löcher, durch quere Wülste festeren Thones geschieden, von denen man bei nassem Wetter nur zu leicht in die Schlammkessel abgleitet. Wir hatten zu viel auf den Weg zu achten, um viel nach dem Urwalde um uns blicken zu können; doch fanden wir auf dem Gipfel des Berges ein prächtiges Exemplar eines Catasetum, das wir uns für den Rückweg hinter einer dicht am Wege stehenden Palme verwahrten. Dasselbe hatte eine über fusshohe Aehre mit ziemlich weit entwickelten Knospen, die schon als männliche zu erkennen waren; von den den männlichen Blüthen eigenthümlichen schlangenzahnförmigen Anhängen der Säule (den „Autennen“ Darwin's) war aber noch keine Spur zu sehen. - Jenseits des Morro do Boi hatten wir noch zwei kleinere minder unwegsame Berge zu übersteigen, ehe wir an den Strand von Porto Bello kamen. Der Weg führte häufig nahe am Meere hin und war reich an wundervollen Aussichten. - Auf Felsen am Wege fanden wir das hübsche Epidendrum cinnabarinum in Blüthe, eine der häufigsten Ochideen der Insel Sa. Catharina, die sich aber nie weit von der Küste zu entfernen und hier ${ }^{1}$ ) ganz zu fehlen scheint. Dasselbe scheint von der prächtigsten unserer Erdorchideen zu gelten, die wir ebenfalls blühend trafen; sie hat grosse rothe wohlriechende Blumen, die denen von Vanilla ähnlich sind (Vanillidium n. gen. mihi).

In der Nähe des Strandes liegt eine kleine jämmerliche Venda, in der wir Nachtquartier suchen mussten, da die Sonne sich zum Untergange neigte.

Hier, soweit wir das Innere sehen konnten, die Beschreibung des 30 Palmen (zu 8 Zoll) langen, 26 Palmen tiefen Hauses: Die Thüre führt in den I I Palmen breiten, I5 Palmen tiefen Laden. Vor dem Ladentisch ein 6 Palmen breiter Raum, in dem rechts an der Wand eine niedrige Holzbank. -- Auf dem Tisch links hinter dem Ladentisch stehen ein paar Kästen, Seife, Lichter, Knöpfe u. dgl. enthaltend, und verschiedene Blechbüchsen, darunter einige Kurbflaschen mit Schnaps. - An der Wand gegenüber dem Ladentisch ein paar Fässer mit Mandiocamehl, Mais und einige Fässer, vielleicht mit Salz. An der Hinterwand, aus deren aus senkrechten und wagrechten Palmenlatten gebildeten Gitterwerk der Lehm fast vollständig herausgefallen war, befanden sich einige Pfund Pulver in Blechbüchsen und trockenes Fleisch. Der ganze Werth der vorhandenen Waaren mochte kaum 20 Milreis übersteigen. - Als wir eintraten, sprangen uns ein paar Jungen entgegen, deren einziger Anzug in einem schmutzigen zerschlissenen Hemde bestand, und die sich seit Wochen nicht gewaschen und in ihrem Leben noch nicht gekämmt zu haben schienen. Kaum sauberer sah die Hausfrau aus, die uns Nachtquartier gewährte und Abendbrod zuzubereiten versprach. Bald erschien auch der Hausherr, Senhor Damiâo, hinkend und schiel-

1) scil. zu Itajahy. 
äugig, der leer vom Fischfang heimkehrte und ein langes Verhör über Woher und Wohin anstellte. Einige fabelhaft zerlumpte Neger kamen, einen Schnaps zu trinken oder Kautabak zu kaufen. Als es dunkel wurde, erschien ein Talglicht, das durch einige Tropfen geschmolzenen Talges auf eine Blechbüchse befestigt, aber wiederholt von den tobenden Jungen heruntergestossen wurde. Zum Abendbrod wurden auf den Ladentisch eine Pfanne mit Eiern, eine Schüssel mit Mandiocamehl, Kaffee und Zucker gesetzt. Dann wurde uns eine schmutzige Rohrmatte, dito Laken, Kopfkissen und Wolldecke gereicht, mit denen wir unser Lager in dem Raum vor dem Ladentisch auf der glücklicherweise ziemlich trockenen Erde herrichteten. - Nachdem wir uns hingelegt, belustigte sich Johannes damit, durch eine der zahlreichen Spalten der Wand dem Abendessen unserer Wirthe zuzusehen und später liess Senhor Damiâo seine Sprösslinge eine endlose Zahl von Padre nosso's und Ave Maria's herbeten, was so stockend ging, dass es jedenfalls nicht tägliche Praxis war, sondern nur geschah, um den Gästen seine Frömmigkeit zu zeigen.

(30. A pril). Sobald der Regen, mit welchem der Tag anbrach, nachliess, machten wir uns auf und beschrieben zunächst einen Halbkreis längs des sandigen Strandes des Busens von Porto bello. Nachdem wir über den Perequé gesetzt, wandten wir uns landeinwärts. Von Perequé bis Tijuccas dehnt sich eine meist fruchtbare Ebene aus, zwischen der und dem Meere die bergige Halbinsel von Porto bello liegt. Unser Weg führte an dem westlichen Fusse dieser Berge hin, durch Ansiedlungen, deren Ansehen zum Theil Wohlhabenheit verrieth. Rechts hatten wir meist schönes Weideland, auf dem hie und da prächtige, über mannshohe Büsche eines Philodendron (Aroidee) mit grossen fiederspaltigen Blättern standen. Das Nässeln, dass uns fast ununterbrochen begleitete, verwandelte sich $\mathrm{ab}$ und $\mathrm{zu}$ in stärkeren Regen, so dass wir in den Häusern am Wege Schutz suchen mussten, und endlich erreichte uns ein ziemlich anhaltender Platzregen, der uns ziemlich durchweicht hatte, ehe wir in einen grossen Schuppen flüchten konnten, in welchem die Trümmer eines Zuckergeschirrs herumlagen.

Von Bobos bis Tijuccas führte unser Weg durch die hier sumpfige Niederung. Hier sah ich zum ersten Male in Brasilien ein Equisetum, und fand einen Strauch, dessen von weisser saftiger Hülle umschlossene Samen nicht aus der geöffneten Frucht herausfielen. Am Nordufer des ziemlich ansehnlichen Tijuccasflusses zieht sich eine volkreiche Villa hin, von Kaufleuten und Handwerkern bewohnt, - Ein deutscher Schneider hat hier ein gutes Wirthshaus, in das wir heisshungrig einfielen, da wir seit unserem aus Kaffee und Mandiocamehl bestehenden Frühstücke nur einige Bananen genossen hatten und durch den Regen unsere Ankunft bis lange nach Mittag verzögert worden war.

Am Ufer des Tijuccas wächst ein riesiges Eryngium, das wir auch am Biguassú wiedersahen, mit über mannshohen schilfartigen Blättern. Merkwürdig, dass so viele Pflanzen der verschiedensten Familien, Gräser, Riedgräser, Typha, Kalmus, Ranunculus Lingua u. s. wv. am Rande der Gewässer dieselbe Schilfform annehmen! -

(r. Mai). Ein frischer Landwind hatte den Regen verscheucht und kein Wölkchen am Himmel gelassen. Auf dem Wege zur Ueberfahrtsstelle über den Tijuccasfluss fanden wir ein den deutschen Arten ganz ähnliches Hypericum in 
Blüthe und jenseits, wo der Weg noch eine Strecke am Ufer hinführte, eine mehrere Fuss hohe strauchartige Mimosa mit reizbaren Blättern. In einer vertrockneten Hibiscusblüthe fing ich einen Käfer, der mich sehr überraschte, da ich von der Existenz der sonderbaren Gattung nichts wusste; die Maxillen desselben waren nämlich fadenförmig und ragten bis über das Ende des Hinterleibes hinaus. Nach meiner Rückkehr sah ich aus Gerstäckers Zoologie, dass das Thier zu der weitverbreiteten und selbst in Südeuropa vertretenen Gattung Nemognatha gehört. Vom Flusse führt der fast immer an Drecklöchern reiche Weg quer durch das sumpfige Uferland. An diesem Wege hatte ich wiederholt während meiner früheren stets im Sommer unternommenen Reisen eine Hippocrateacea in Blüthe gefunden; jetzt trafen wir sie endlich mit Früchten, grossen runden Beeren, die von süssem Schleim umhüllte Samen einschliessen und allein die Gattung Salacia (oder Tontelea) von Hippocratea unterscheiden, welche aufspringende Kapseln und geflügelte Samen besitzt. Ein ähnliches Verhältniss besteht zwischen den in Wuchs und Blüthenbau vollständig übereinstimmenden Gattungen Paullinia einerseits, Serjania und Urvillea andererseits. Offenbar sind in diesen Fällen die der Verbreitung der Samen einerseits durch die Vögel, andererseits durch den Wind dienenden Einrichtungen verhältnissmässig sehr neuen Ursprungs, und das scheint überhaupt sehr häufig der Fall zu sein. Merkwürdig ist, dass selbst in der Familie der Compositae, die seit alter Zeit ihre für die Verbreitung durch den Wind unübertreffliche Federkrone besitzen, neuerdings eine Gattung (Wulffia) Beerenfrüchte $\mathrm{zu}$ bilden begonnen hat. (Eine Wulffia kommt am Morro do boi vor, wo wir uns aber dies Mal vergebens danach umsahen). Nachdem wir das sumpfige Uferland von Tijuccas hinter uns hatten, überstiegen wir eine Reihe niederer Berge, die Morretes, von denen wir öfter herrliche Aussichten aufs Meer, nach den Bergen von Porto-bello und der Insel Avoredo hin hatten. - In der Nähe der Morretes fanden wir die Zäune am Wege überrankt von einer allerliebsten scharlachrothen Winde (Quamoclit), die durch eine beginnende Unregelmässigkeit ihrer Blumen bemerkenswerth ist. Die Blumenröhre ist etwas gebogen und die Staubfäden treten alle dicht an der oberen gewölbten Seite aus der Röhre hervor. - Wir hatten dann ein Thal mit tiefem weissen Sande zu durchwaten, um zu einem zweiten höheren Berge, dem Morro do Mafra zu gelangen, von dem wir zum ersten Male die Berge von Sa. Catharina erblickten. - Jenseits des Morro do Mafra hatten wir rechts vom Wege niedere Hügel, an denen der Weg hin und her, auf und nieder bog, links unter uns tiefes Sumpfland, das sich zum Inferninho hinzieht. Dieser verdient mehr den Namen eines Sumpfcanals, als eines Flusses, ist nur schmal und fast stagnirend. Wir überschritten ihn auf einer hölzernen Brücke, den umgebenden Sumpf auf einem guten Steindamm, und erreichten gegen Mittag den Fuss der zwischen Inferninho und Tijuquinhas aufsteigenden Berge. Hier wohnt seit etwa $3 / 4$ Jahren ein Deutscher, Daniel Schneider, der früher am Itajahy, meinem jetzigen Hause gerade gegenüber wohnte und jetzt in Inferninho einen Kramladen hat. Bei ilım hatten wir uns vorgenommen, den Rest des Tages zu bleiben, um die benachbarten Sümpfe auszubeuten. Allein wir fanden fast die ganze zahlreiche Familie krank am Wechselfieber, das einige schon seit Monaten nicht los wurden. Unsere sonst so blühende Nachbarin sah aus, wie aus dem Grabe gestiegen. Ebenso, hörten wir, solle es in allen Häusern 
bis S. Miguel hin aussehen. Wir haben während des ganzen letzteren, zum Theil recht nassen Sommers, nicht Einen ordentlichen Landwind gehabt, der die Ausdünstungen der sumpfigen Niederungen von Inferninho u. s. w. hätte wegfegen können, und das mag die Veranlassung zu dieser so anhaltenden und ausgedehnten Epidemie gegeben haben. Ich hielt es unter diesen Verhältnissen nicht für gerathen, dicht am Sumpfe, und nicht für angenehm, unter einem Haufen kranker schreiender Kinder zu übernachten, und so brachen wir nach einer gehörigen Mittagsruhe wieder auf, und erreichten gegen Abend, jenseits des unbedeutenden Tijuquinhas und nahe dem Meeresufer, ein „Wirthshaus für Reisende“ wie die deutsche Aufschrift sagte, welches kürzlich ein italienischer Kaufmann eingerichtet hatte. Auch hier litt Alles mehr oder weniger am Wechselfieber.

(2. Mai). Der Weg von Tijuquinhas bis Biguassú führt dicht am Meere hin, das hier wie ein grosser Binnensee erscheint, umschlossen von den malerischen Bergen der vorliegenden Insel Sa. Catharina. Meist steigen die Berge unmittelbar vom felsigen Ufer auf; in der Nähe der unbedeutenden Villa de S. Miguel ist sandiger Strand. Die Küste ist ziemlich dicht von einer meist armen Fischerbevölkerung bewohnt. Die Berge reichen bis an den Biguassú, über den eine hübsche neue Brücke führt und an dessen Südufer wieder eine sumpfige, jetzt von Wechselfieber heimgesuchte Niederung beginnt. In dieser ist der kletternde Sumpffarn (Lygodium) sehr häufig. - Einige verkrüppelte Bäume im Sumpfe waren dicht mit Orchideen bedeckt, Brassavola fragrans, Cattleya amethystina, Epidendrum triandrum m., und Pleurothallis-Arten, fast ausschliesslich auf die Nähe der Küste beschränkte Arten. Etwa eine Stunde von Biguassú hatten wir eine sonderbare Brücke zu passiren, die vor kaum Jahresfrist gebaut worden, deren Pfeiler aber schon ein Hochwasser eingerissen hatte, so dass jetzt nur noch das Geländer mit einigen die rechte und linke Seite verbindenden Balken im Wasser schwamm. Ein Brett war von jedem Ufer schief hinab nach dem Geländer, ein zweites an jedem Ende von einer Seite des Geländers zur andern gelegt. Wir überschritten glücklich diese schmale schwankende Brücke und stärkten uns dann im Hause eines Deutschen durch ein kräftiges Frühstück. Von hier aus diente uns meist der Sand des Strandes als Weg, nur einigemal wurden weiter vorspringende Vorgebirge oder Landzungen abgeschnitten. In der Nähe der Meerenge drängen sich die bis dahin zerstreuten Häuser dichter in eine Strasse zusammen, in der man tiefen losen Sand zu durchwaten hat. In diesem Sande wuchert Vinca rosea und in den Zäunen am Wege blühten zwei Pflanzen, die ich sonst nirgends gefunden habe, eine behaarte weisse Winde (Ipomoea) und ein Plumbago, das vielleicht mit Schiffsballast eingeführt worden ist; denn, wie ich kürzlich erfuhr, ist es eine indische Art, die Plumbago zeylanica. Auch eine andere an der Erde hinkriechende Winde (Evolvulus) mit zierlichen kleinen Blättchen und weissen Blumen habe ich bis jetzt nur auf den Felsen zu beiden Seiten der Meerenge (Estrato) gesehen.

Eine leichte Brise trieb das Fährboot rasch über die Meerenge; drüben wuschen wir unsere Füsse, zogen seit Monaten einmal wieder Strümpfe und Schuhe an und marschirten dann, gegen $3 \frac{1 / 2}{\mathrm{Uhr}}$, in die Stadt Desterro ein.

Der 3. Mai war Sonntag und ich konnte so erst am 4. verschicdene Geschäftsgänge in der Stadt abmachen und erst am 5. setzten wir unsere Reise fort. 
(5. Mai). Wir setzten wieder von der Stadt nach dem Festlande über und folgten nun der Strasse, die die Küste mit dem Hochlande von Lages verbindet; es ist die belebteste Strasse der Provinz, denn einmal liefert uns Lages Schlachtvieh und Pferde, und dann müssen alle Waren, deren die Bewohner des Hochlandes bedürfen, auf Maulthieren hinaufgeschafft werden. Man begegnet daher nicht selten Schaaren (Tropas) von Maulthieren, oder auch Heerden von Pferden oder Rindvieh. Vor letzterem muss man sich hinter die Zäune am Wege, oder in Wald oder Gebüsch zurückziehen. - Nachdem wir einige Hügel überstiegen, kamen wir in ein sandiges Uferland, die Praia comprida (,langer Strand“). Es wohnen hier ziemlich viele, vor langer Zeit eingewanderte Deutsche, die fast vollständig zu Brasilianern geworden sind. Wir sahen hier ein ansehnliches Feld rings mit Pitta (Fourcroya) eingefasst, die meist ihre riesigen Blüthenschäfte (20 bis $30^{\prime}$ hoch) getrieben hatte. - Die Häuserreihe der Praia comprida setzt sich fort bis zur Stadt Sâo José; es ist ein unbedeutender todter Ort, der sich längs der hier hügeligen und felsigen Küste hinzieht. - Vom Maruim, über den (wie über mehrere ihm folgende Gewässer) eine gute steinerne Brücke führt, dehnt sich wieder bis zum Cubatâo ein sandiges und sumpfiges Uferland aus, das bei hoher Fluth zum grossen Theil unter Wasser kommt, wie der Pflanzenwuchs und mehrere nackte Schlammflächen verriethen. In den Gräben längs des Weges liefen zahllose Sumpfkrabben (Cyclograpsus) umher. Am Wege wuchsen Salicornia, Statice, und Sesuvium, und als Gesträuch Laguncularia, Schinus, Myrsine u. s. wv. - Noch bevor wir den Cubatâo erreichten, wandten wir uns, dem Thale dieses Flusses folgend, landeinwärts. Links hatten wir den südlich vom Cubatâo bis ans Meer herantretenden hohen Bergzug des Cambirela, rechts die die Thäler des Cubatâo und Maruim scheidenden Berge mit dem steilen Abhange der Pedra branca. -- Etwa zwei Stunden, bis zu unserer Mittagsstation im Hause eines deutschen Sattlers, blieb das Thal völlig eben. Die Pflanzenwelt bot eben nichts Besonderes; ziemlich häufig war eine hübsche weisse Passiflora, die jetzt wohlschmeckende, aber kleine Früchte trug. - Weiterhin begann das Land sich zu heben, der Weg führte über einige unbedeutende Hügel; bei guter Zeit erreichten wir unser Nachtquartier beim Schmidt Hard.

(6. Mai). Bei Tagesanbruch ging es weiter, zunächst dem am Ufer des Cubatâo liegenden Kirchdorf (Freguezia) S. Amaro zu. Dann hatten wir ein paar ansehnliche Berge zu übersteigen und zwischen ihnen ein fruchtbares Thal (Vargem grande) zu durchwandern und einen grossen Bach zu durchwaten, um endlich von der Strasse nach Lages abzubiegen, den Cubatâo auf einer neuen Brücke zu überschreiten und das Gebiet der Colonie Theresopolis zu betreten, deren Stadtplatz wir in der Mitte des Nachmittags erreichten. - Wir hatten auf diesem Wege mancherlei bei uns nicht wachsende Pflanzen getroffen. So eine grosse Nessel (Urtica) mit weissen Beeren; sie gehört, wie unsere beiden Nesseln, von denen die eine (am Flussufer) mennigrothe, die anderen auf vielverästelten purpurrothen Stielen milchweisse Beeren trägt, zur Untergattung Urera; alle drei sind strauchartig. Dann eine prachtvolle kletternde Cassia mit grossen goldgelben Blüthen (die Gattung ist hier reich an Arten, von denen wir 7 bis 8 auf unserer Reise sahen); eine Hydrocotyle mit vierzipfeligen Blättern, zwei hübsche Lycopodien, eine Begonia mit grossen, unten dunkelrothen Blättern u. s. w. 
17.-10. Mai). Die nächsten Tage benutzten wir zu kleinen Spaziergängen in der Nähe des Stadtplatzes der Colonie. Am 8. kam der Direktor der Colonie, Todeschini, von einer Reise nach Desterro zurück, und holte uns aus dem Wirthshause, in dem wir abgestiegen waren, in sein eigenes Haus, wo wir ganz vortreffliches Quartier, und an unserem liebenswürdigen Wirth, einem früheren österreichischen Offiziere, die angenehmste Gesellschaft fanden. Auch meine anderen Theresopolitaner Bekannten wurden in diesen Tagen aufgesucht, der Ingenieur der Colonie Heeren und der katholische Pastor Roer, Landsmann und naher Bekannter meines Universitätsfreundes Anton Karsch in Münster. Der letztere nimmt lebhaftes Interesse an Naturwissenschaften und besuchte mich, so oft er nach Desterro kam, obwohl man ihn auf der Seereise von Europa herüber vor mir gewarnt hatte als einem schrecklich gottlosen Menschen, der nicht einmal seine Kinder taufen lasse.

Die Colonie Theresopolis ist vor etwa 8 Jahren gegründet worden, auf einem Gebiet, wie man es für Landbau nicht schlechter hätte wählen können. Steile steinige Berge reichen meist bis ans Ufer des Cubatâo und der einmündenden Bäche. Dabei liegt die Colonie schon so hoch über dem Meere, dass Zuckerrohr und Mandioca nicht mehr gedeihen. Dagegen wachsen vortreffliche Kartoffeln. Nur die Nähe der Stadt Desterro, wo die Leute für Butter, Hühner, Eier, Schmalz, auch wohl Speck und Wurst, für Kartoffeln, Mais, schwarze Bohnen guten Absatz finden, macht das Bestehen der Colonie möglich. Doch liegen viele der Anfangs vertheilten Grundstücke, nachdem die Besitzer sich darauf zum Theil jahrelang gequält, jetzt wieder wüste. Die Bewohner sind nach dem zur Colonie gehörigen Capivary, zum Theil auch hieher gezogen. Es sind meist Solinger. Westfalen und Holsteiner.

(II. Mai). Mit Tagesanbruch machten wir uns auf, um am rechten Ufer des Cubatâo aufwärts zu gehen. Derselbe ist hier ein rasch fliessendes Gewässer, das über kleineres und grösseres Gerölle dahinrauscht. Die Anlage des meist guten Weges hat gewaltige Mühe gekostet, da er auf lange Strecken aus dem harten Thonschiefer der steilen Bergwände hat herausgehauen und gesprengt werden müssen. Er führte durch theils bewohnte, theils verlassene Ansiedlungen und oft auf lange Strecken durch Wald. Wir sahen am Wege mehrere Sträucher von Mate oder Paraguaythee, der an einzelnen Stellen der Colonie S. Isabel sehr häufig sein soll und auch hier am Itajahy einzeln vorkommt, dann eine schöne kletternde Fuchsia, einen allerliebsten Farn Ceropteris, dessen Wedel auf der Unterseite mit goldgelbem Staube bedeckt sind, und ein Galium, das unter den deutschen Arten dem G. Aparine noch am meisten ähnlich sieht, aber mennigrothe Beeren trägt. Ein Seitenthal führte uns an den Fuss des hohen Berges, der die Wasserscheide zwischen dem Cubatâo und dem Capivary bildet. Letzter ist etwa 2 Tagereisen von seiner Quelle abwärts von Deutschen bewohnt; dann folgt ein Wasserfall, unterhalb dessen er schiffbar und von Brasilianern bewohnt ist. Er geht in den Tubarâo, der bei der Stadt Laguna mündet. - Der Weg, von Deutschen angelegt, unterscheidet sich durch sein allmäliges Ansteigen sehr vortheilhaft von brasilianischen Bergwegen und war jetzt, bei trockenem Wetter, vortrefflich. Zur Rechten hatten wir oft steile Abhänge von mehreren hundert Fussen. - Bei einer kürzlichen Wegebesserung waren eine Menge Bäume gefällt 
worden, die uns eine sehr erwünschte Gelegenheit boten, Urchideen $\mathrm{zu}$ sammeln. In Blüthe fanden wir ein niedliches Epidendrum (vielleicht variegatum) und blüthenlos verschiedene andere hier ${ }^{1}$ ) fehlende Arten, z. B. das hübsche Oncidium pulvinatum. Häufig blühte auf Bäumen eine prächtige Amaryllis (die zuerst durch Dr. Blumenau in die deutschen Gärten gekommen ist, und in den Catalogen als A. Tettaui geht). Die Aeste mehrerer Bäume waren bedeckt von einem sehr hübschen Moose, von dem ich Dir eine Probe beilege. Bei weitem das Interessanteste waren mir aber fruchtende Exemplare eines Farn, der. soviel ich aus Endlicher's Gen. Plant. sehen kann, eine neue Gattung der Ophioglosseen bildet. An Felsen fanden wir einen anderen sehr hübschen Farn (eine Doryopteris) und eine allerliebste Gesneriacee, auf der Erde eine niedliche Sauvagesia (eine zweite Art dieser den Veilchen verwandten aber regelmässige Blüthen tragenden Gattung wächst am grossen Wasserfall des Itajahy). Auf der Höhe des Berges war ein stattlicher Baumfarn sehr häufig, der keiner der hier vertretenen Gattungen (Alsophila, Hemitelia, Trichopteris) angehört, wahrscheinlich ein Balantium, - dessen Stamm ein höchst wunderliches Aussehen dadurch erhält, dass er von unten bis oben mit einem dichten Filz schwarzer Luftwurzeln bedeckt ist. Unten ist dieser Wurzelfilz so dick, dass der an sich wenige Zoll dicke Stamm manchmal bis gegen 2 Fuss Durchmesser erhält. - Die Ränder des Weges waren hier geschmückt durch drei Arten von Coccocypselum, von denen 2 auch hier vorkommen; es sind das kriechende Rubiaceen, deren ziemlich unansehnliche Blüthen in dichten Köpfchen stehen und deren Früchte, birnförmig oder rundlich, sehr schön blau gefärbt sind. - Ausser der Taguarassú (Riesenrohr) und anderen hiesigen TaguaraArten fanden wir hier (und später anderwärts am Capivary und anderen Stellen der Colonien Theresopolis und S. Isabel) ein grosses Rohr mit dichtem Stamme, die Carahá (spr. Carachá), dessen ältere Stämme oft sehr hübsch gefleckt und dann als Spazierstöcke sehr beliebt sind.

Den Capivary-Abhang unseres Berges stiegen wir auf weniger bequemen, zum Theil mit ähnlichen Treppen, wie am Morro do Boi versehenen Wege hinab, an dessen Besserung wir eine Schaar Arbeiter beschäftigt fanden. - Vom Fusse des Berges gingen wir noch etwa 3 Stunden bald am rechten, bald am linken Ufer des Capivary, den wir ein paarmal durchwateten, abwärts bis zum Wirthshaus von Busch, das wir etwa halb 4 Uhr erreichten. Eine dralle freundliche und gesprächige Frau füllte unsere hungrigen Mägen bald mit solider westfälischer Kost, und bis gegen Abend schlenderten wir dann am Flussufer und in den benachbarten Pflanzungen umher. Wir fanden uns hier umgeben von einer Pflanzenwelt, die von der am Itajahy vielfach abwich, wohl mehr in Folge der bedeutend höheren Lage, als des leichteren sandigen Bodens. Einige schöne Cederstämme (Cedrela) abgerechnet, war der palmenlose Laubwald weit niedriger, als bei uns. Dafür erhoben sich zu doppelter Höhe des Laubholzes stattliche Araucarien, die uns hier ganz fehlen. Ich habe mehrmals in deutschen Büchern für die Jugend unsere Araucaria abgebildet gesehen, jedenfalls nach Gewächshausexemplaren, - kegelförmig mit ganz unten am Stamm beginnenden Aesten; so sind allerdings junge Bäume, z. B. zwei, die vor meinem Hause stehen und vielleicht etwa sechs Jahre

I) scil. zu Itajahy. 
alt sind. Eine alte Araucaria brasiliensis sieht aber gerade aus, wie ein lateinisches $\mathrm{T}$; bisweilen hat der Stamm noch einige wenige Aeste. die in verschiedener Höhe ähnliche T's bilden. - Die Araucarie ersetzt hier am oberen Capivary sowohl unsere Gissarapalme, die Pfosten, Balken und Latten, als die Uricanna (Geonoma), deren Blätter das Dach für die ersten Hütten der Ansiedler liefern. Die Häuser sind aus Araucarienbalken gebaut, die Wände mit Araucarienbrettern verkleidet, die Dächer mit Araucarienschindeln gedeckt. - Die Capoeira, d. h. das 1lach dem Fällen des Urwaldes aufschiessende Buschwerk, bestand vorherrschend aus einer Croton-Art. Ein schönes Abutilon, eine stattliche rothblühende Lobelia, zwei scharlachrothe Salvia-Arten, zwei gelbe Sisyrinchium und mindestens ein halbes Dutzend von den hiesigen verschiedenen Solanum-Arten waren alles hier fehlende Pflanzen. Unter den Solanum trug das Eine rothe kirschenähnliche Früchte.

(I 2. Mai). Von Busch gingen wir noch ein Paar Stunden am Capivary hinab, hauptsächlich, um die Bäume einer kürzlich gefällten Urwaldstrecke nach Orchideen abzusuchen. Ausser der einen Art, die ich dort suchte und reichlich fand (Oncidium unicorne) brachten wir namentlich mehrere Maxillarien mit zurück. - Die Araucarien hören hier schon wieder auf. - Wir sahen einige unzweifelhaft wilde, alte Stämme von Sambucus australis, der dem deutschen S. nigra ziemlich ähnlich ist, und nicht selten seiner als Schwitzmittel benützten Blüthen wegen angepflanzt wird; ferner eine kleine Cucurbitacee (Elaterium), deren scharfe stachlige Früchte beim Aufspringen die Samen weit von sich schleudern und eine (leider nicht blühende) Mutisia mit weissfilzigen Blättern; (eine andere Mutisia mit glatten Blättern auf der Insel Sa. Catharina; die Mutisiae sind meines Wissens die einzigen Compositae mit rankentragenden Blättern). - In grosser Menge fanden wir hier Kürbisse angepflanzt, die ein hier unentbehrliches Winterfutter für's Rindvieh bilden; schon jetzt sahen wir die Viehweiden vollständig vertrocknet. - Kein Winter geht hier ohne Fröste vorüber. Weiter unten am Capivary ist das Klima natürlich milder und zum Bau von Zuckerrohr geeignet. - Unser Nachtquartier nahmen wir wieder bei Busch und kehrten Tags darauf (I3. Mai) auf demselben Wege, den wir gekommen, nach dem Stadtplatz von Theresopolis zurück und ruhten hier einen Tag (I4. Mai) von unserem Capivary-Ausfluge aus.

(15. Mai). Nachmittags gingen wir, in Begleitung des Ingenieurs Heeren, von Theresepolis nach S. Isabel, ich mit meiner grossen Botanisirbüchse, Heeren und Johannes jeder mit einer dicken rothen Wolldecke für die voraussichtlich kalten Nächte beladen. Wir überschritten den Cubatâo auf einer im Bau befindlichen Brücke, folgten dem rechten Ufer des Cederbaches, den wir dann durchwateten, um rechts ab in das Thal eines kleinen Zuflusses desselben einzubiegen. Dieser Bach ist noch unbewohnt, wir gingen also im Schatten eines schönen Urwaldes, in welchem der Baumfarn mit dem dicken schwarzen Wurzelfilze sehr häufig war. - Auf der Höhe eines ansehnlichen Berges erreichten wir die Grenze der Colonie S. Isabel, zu deren weit höher als Theresopolis gelegenem Stadtplatze wir in der Abenddämmerung niederstiegen. Wir trafen schon auf dem Wege unseren Freund Reusing, der uns nach Boa Vista begleiten wollte und uns in seine Junggesellenwirthschaft einführte. Den Nachtisch zu unserem Abendbrod bildeten gekochte Pinhoës (Araucariensamen), die Hauptnahrung unserer Indianer und wilden Schweine. Sie mundeten mir vortrefflich und stehen im Geschmacke 
etwa in der Mitte zwischen Kartoffeln und Kastanien. Wir bereiteten dann unser Lager aus Rohrmatten und einigen schönen Löwen- und Tigerfellen, wie sie hier heissen, d. h. von Puma und Jaguar.

(16. Mai). Am Morgen war es bitter kalt und Alles rings mit starkem Reif bedeckt. Ein steiler Weg, mit Steinen, oft von 3-4 Fuss Durchmesser, übersät, führte uns auf den Morro do Gongo; auf dessen Gipfel trafen wir einen ziemlich kümmerlichen Baumwuchs; Orchideen schienen auf den Bäumen ganz zu fehlen, statt der flechtenähnlichen Tillandsia usneoïdes waren die Aeste hier dicht mit wirklichen Bartflechten bedeckt. Im Gebüsch am Wege, in dem wir mehrere Myrtaceen mit sehr wohlriechenden Blättern, leider ohne Blüthen und Früchte fanden, gab es viele wohlschmeckende schwarze Brombeeren. (Ein anderer Rubus, auf der Insel Sa. Catharina, hat grüne, ziemlich fade Früchte.) Auch trafen wir hier eine Cucurbitacee mit dunkelrothen, kugligen, kirschenähnlichen Früchten mit sehr bitterem Fleisch; und mit reifen Samen eine (weissblühende) I 2- i 5 Fuss hohe einjährige Lobelia. Von Morro do Gongo stiegen wir hinab in's Thal des Rio das Antas. Dieser, wie die anderen Flüsse, die wir bis Boa Vista zu überschreiten hatten, sind Nebenflüsse des Tijucca's. - Ueber einen zweiten unbedeutenden Berg kamen wir zu dem Rio das Capivaras, dessen Lauf wir auf eine längere Strecke erst auf dem rechten, dann auf dem linken Ufer (die eine Brücke verbindet), folgten. An einer Stelle des Flusses wuchs in Menge eine Myriophyllum-ähnliche und wahrscheinlich zu dieser Gattung gehörige Pflanze. Soweit wir ihn begleiteten, fliesst der Capivaras langsam durch ein sumpfiges Thal mit torfartigem Boden. Im Sommer muss hier eine sehr interessante Flora $z u$ finden sein; jetzt blühte leider gar nichts von den verschiedenen neuen Pflanzen, die meine Neugier reizten. An manchen Stellen war (wie später am Taguaras) der Wald fast ausschliesslich gebildet von einer Mimosa (oder doch Mimosee) mit schlankem weissem Stamm und kleiner luftiger Krone aus zarten doppeltgefiederten Blättern. Araucarien waren hier stellenweise sehr häufig. Wir rasteten eine Zeitlang und labten uns an frischem Maisbrod und Lages-Käse im Hause eines früheren Itajahybewohners, dessen dortiges Land ich vor einigen Jahren mit August ${ }^{1}$ ) zusammen kaufte. - Mit neuen Kräften machten wir uns an die Ersteigung des Morro chato („flacher Berg“), der allmälig anstieg, aber dafür stundenlang sich hinzog. Hier (wie auch vor- und nachher) trafen wir am Wege mehrere freie Plätze, auf denen zahlreiche Pfähle in die Erde geschlagen waren, und in der Nähe gewöhnlich Feuerstellen. Es sind Plätze, an denen die Tropeiros übernachten; die Pfähle dienen zum Anbinden der Maulthiere. - Uns begegnete hier ein grosser Trupp Rindvieh, dessen Treiber grossentheils von ziemlich reinem Indianerblut zu sein schienen. Wir mussten in dorniges Gebüsch an einem steilen Bergabhang uns hinaufflüchten; über meinen Begleitern, hinter denen ich botanisirend etwas zurückgeblieben war, erschien da plötzlich ein gewaltiger Ochse, der vom WVege abgekommen war; das Abenteuer ging zum Glück ohne andere Folgen vorüber, als das Heerens Rock in den Dornen jämmerlich zerfetzt wurde und wir andern mehr oder weniger blutige Hände davon trugen. - Von Morro chato aus erblickten wir auch zum ersten Male das Ziel unseres Ausflugs, das Campo von

1) ein Verwandter. 
Boa Vista: die wellenförmigen Umrisse der Berge, die sonst rings den Gesichtskreis begrenzten, waren auf eine Strecke unterbrochen durch eine gerade wagerechte Linie, die links mit einem senkrechten Absturz endete, und auch durch ihre gelbliche Farbe von dem dunkeln Urwalde sich abhob. - Steil führte der Weg hinab in das schmale Thal des Rio bonito und eben so steil auf der anderen Seite in die Höhe. Bei nassem Wetter muss der rothe Thon dieses Weges glatt sein wie Seife, und man begreift kaum, wie er dann zu passiren ist. Ein letzter Berg trennte uns noch von unserem heutigen Reiseziele, dem Rio das Taguaras, an dessen rechtem Ufer wir noch eine Strecke aufwärts gingen bis zu einem der letzten Bewohner, einem früheren Gastwirth aus der Gegend von Essen, der hier einen kleinen Kramladen hat und Reisende beherbergt.

Der ganze Strich, den wir an diesem Tage durchwandert, gehört zum Gebiete der Colonie S. Isabel; die Ansiedlungen liegen ziemlich zerstreut; viele früher bewohnte Stellen sind jetzt verlassen und in der That ist das ungemein bergige, oft steinige und unfruchtbare Land mit seinen Winterfrösten nichts weniger, als einladend für einen Landmann.

In unserem Wirthe fand ich einen alten Bekannten, der bei seiner Ankunft vor 8 bis ro Jahren seinen ersten Kaffee in Brasilien in meinem Hause getrunken hatte. - Den Abend verplauderten wir, um das Feuer in der Küche sitzend, bei einem Glas Grog. - Während des Abends begann der Himmel sich zu umwölken, eine Veränderung, die wir mit getheilten Gefühlen betrachteten: sie war uns angenehm, weil ohne sie die Nacht jedenfalls noch kälter geworden wäre, als die letzte in Isabel, - aber unlieb, weil sie uns die Aussicht von Boa Vista zu verderben drohte.

(I7. Mai). Wir folgten zunächst, langsam aufsteigend, und nach einiger Zeit vom rechten zum linken Ufer watend, dem Rio das Taguaras und gelangten nach kaum einer Stunde an den Fuss des Berges von Boa Vista. Hier begann ein etwas mühsames Steigen. Zunächst einige Stellen mit den bekannten Treppen. bei denen die Maulthiere die Schlammkessel so tief ausgetreten hatten, dass sie über die zwischenliegenden Stufen mit ihrem Bauche hinschleifen mussten. Dann ging es steil hinauf auf steinigem von den zahlreichen Vichtruppen ausgetretenem Wege. Oft hielten uns Brombeergebüsche auf, nicht durch ihre Dornen, sondern durch die Fülle ihrer Früchte. Dazwischen blühten Fuchsien und die prachtvolle strauchartige Melastomacee Pleroma. Ihre ziemlich grossen Blüthen sind beim Aufblühen schneeweiss und färben sich allmälig dunkelpurpurroth; - gleichzeitig schmücken den Strauch die Blüthen mit Weiss, Rosa und dunklem Purpur. Auf mehr als halber Höhe betraten wir eine breite ziemlich ebene Vorstufe. Niedrige Bäume, jetzt meist fast blattlos, aber dicht behangen mit weisslichen Früchten, da und dort hoch überragt von einzelnen Araucarien, und Gebüsch, das namentlich aus mannigfachen strauch- und baumartigen Compositae gebildet war. In einer kleinen Senkung war eine mit Sphagnum bewachsene Sumpfstelle, in der in Menge Xyris und Eriocaulon wuchsen (beides von den auf Sa. Catharina wachsenden verschiedene Arten). - Es begegnete uns hier eine zahlreiche Rinderheerde und kurz darauf hörten wir nahe vor uns einen lauten Schrei, den zunächst wohl keiner von uns weiter beachtete. Als wir aber bald nach einer Biegung des Weges denselben weithin überblicken konnten, und keinen Menschen darauf 
gewahrten, zerbrachen wir uns die Köpfe über den Schrei. „Vielleicht ein Bugre (Indianer)? Dort links unten ist ein grosses Pinheiral (Araucarienwald), in dem sie wohl jetzt zur Zeit der Pinhoës sich herumtreiben mögen.“ - „Nun dann können wir uns auf einen Pfeil aus dem Walde gefasst halten." - Reusig revidirte seinen Revolver und vorsichtig um uns blickend schritten wir weiter. - Als wir den letzten steilen Absatz zum Campo hinaufstiegen, löste sich das Räthsel. Ein Neger kam dahergesprengt, einen Ochsen vor sich hertreibend. Nach der ersten Begrüssung fragten wir ihn: „Vossé gritou?" (Haben Sie geschrieen?) -„Sim Senhores" und er erzählte uns, dass er einem von jener Herde zurückgelaufenen Ochsen nachgesprengt und dabei jenen Schrei ausgestossen; ehe wir an die Biegung des Weges gekommen, war er rasch dahinjagend uns schon aus dem Gesichte gewesen. - Wo möglich noch steiler, als zu der Vorstufe, führte der Weg hinauf auf den Campo. Vielleicht ein zwanzig Fuss unter dem Scheitel des Berges tritt Sandstein an die Stelle des Thonschiefers, der uns bisher begleitet hatte. - Als wir den Scheitel des Berges betraten, hatten wir vor uns eine weite, fast ebene Grasfläche von vielleicht 2 Quadratmeilen, hie und da unterbrochen von kleinen, niedrigen Wäldchen, sogenannte Capâos. Die Waldlosigkeit des Campo von Boa Vista ist jedenfalls nicht eine Folge seiner hohen Lage; denn westwärts sieht man gar manche höhere wohlbewaldete Berge, und bedeutend tiefer als Boa Vista liegt in der Nähe ein kleineres Campo, das von Invernadinha. Vielleicht trägt wohl die Bodenbeschaffenheit daran Schuld, dass keine Bäume gedeihen. Die fast wagrechten Sandsteinschichten, die hie und da ganz nackt zu Tage treten, sind von einer dünnen Erdschichte bedeckt. Der Pflanzenwuchs hatte ein ganz eigenthümliches Gepräge. Die Gräser hart und schmalblätrig, die übrigen allesamt niedrige Pflanzen mit kleinen dichtstehenden Blättern. Einige Sumpfstellen mit Sphagnum und Lycopodium. In Blüthe fanden wir leider fast nichts; kaum eine Polygala vom Habitus der deutschen Arten mit lebhaft dunkelblauen Blüthen und eine kleine Lobelia; von einer wohlriechenden Labiate sammelte ich Samen und ebenso von zwei kaum spannenhohen Sträuchern aus der Familie der Ericeen, einer Gaylussacia mit kleinen gelblichweissen Beeren und (wahrscheinlich) einer Andromeda. Sonst kenne ich von Ericeen hier nur ein Vaccinium in der Nähe der Küste, das ziemlich hoch wird, schöne rothe Blüthen und blaue den Heidelbeeren ähnlich schmeckende Früchte („Comarinhas") trägt. - Wir lagerten uns am Rande eines Capâo's, nachdem wir, um vor Schlangen sicher zu sein, die Pflanzen um uns her mit dem Waldmesser weggeputzt hatten, und verzehrten unser Frühstück aus Maisbrod und Lageskäse. Während Reusing und Johannes sich noch im Grase ruhten, durchstreifte ich mit Heeren den Capâo; die niedrigen knorrigen Bäume waren meist Myrtaceen (wahrscheinlich Eugenia). Sie waren bedeckt mit Flechten und Moosen; doch fehlten auch Orchideen nicht, und ich fand darunter eine mir neue Art (dem Ansehen nach vielleicht ein Oncidium oder eine Gomezia). - Der Boden war zum grössten Theile dicht bedeckt mit stachligen Bromeliaceen.

Wir streiften dann noch einige Stunden auf dem Campo umher, um uns der Aussicht zu erfreuen; denn wirklich verdient der Campo seinen Namen Boa Vista (,schöne Aussicht") in vollem Maasse und der Himmel hatte sich gegen Mittag so weit aufgehellt, dass wir fast nach allen Seiten uns ihrer erfreuen 
konnten. Im Westen der steile zackige Kamm der Serra, durch die der Weg nach dem Hochlande aufsteigt, fern im Norden der Morro bahú am Luiz Alves im Gebiete des untern Itajahy, dessen Quellgebiet eine Tagereise von uns nach Westen lag; hier liegt an seinen Ufern am Wege nach Lages die Militär-Colonie Santa Theresa. Rings um uns ein Gewirr dunkel bewaldeter Berge und Thäler, aus denen nirgends eine Spur menschlicher Ansiedelungen hervorblickte. Das Meer, das von einigen Stellen aus bei hellem Himmel zu sehen sein soll, sahen wir nicht; wohl aber meinten wir die Berge der Insel Sa. Catharina zu unterscheiden. - Der Berg von Boa Vista soll völlig isoliert sein und ringsum gleich steil in die umliegenden Thäler abfallen. - Wir kehrten von Boa Vista wieder in unser voriges Nachtquartier zurück, das wir gegen 4 Uhr erreichten.

(18. Mai). Auf unserem Rückweg nach Theresopolis folgten wir bis zum Capivaras der Lageaner Strasse, auf der wir gekommen waren. Das Wasser des Rio bonito, den wir am Morgen zu durchwaten hatten, war so eisig kalt, dass es mir mehrstündigen Kopfschmerz, Heeren einen tüchtigen Schnupfen verursachte. - Im Thale des Capivaras verliessen wir die Stłasse und wandten uns rechts, um einem Pfade (einer sog. „Picade“) durch den Wald zu folgen. Der schmale Pfad war vielleicht seit Jahren nicht betreten und so verwachsen, dass wir ihn ohne Reusing und Heeren sicher bald verloren hätten. Wir überschritten den Capivaras auf einem darüber gefällten Baumstamme und gelangten bald in die Nähe des unter uns im Thale rauschenden Rio das Antas. Der Wald war fast ohne Unterholz; ausser hohen nicht sehr dicht stehenden Bäumen und dem sehr häufigen Filzfarn war der Boden fast ausschliesslich mit hohem Rohr bedeckt. Wir fanden hier eine prachtvolle Fruchtdolde einer Bomarea (d. h. rankenden Alströmeria); eine Dolde mit über 30 spannenlangen Strahlen und am Ende eines jeden eine Frucht, die nach dem Aufspringen ihrer drei Klappen ein zierlich gestaltetes Körbchen bildet, gefüllt mit kugelrunden schönrothen Samen. Diese schönen Früchte lernte ich erst auf dieser Reise kennen (zuerst am Capivary), während ich die Pflanze auf Sa. Catharina häufig blühend getroffen hatte. So brachte mir diese Reise wieder 4 Pflanzen, deren lebhaft gefärbte Samen nach dem Aufspringen der Frucht nicht ausfallen, und ich kenne nun schon mehr als 20 Familien, in denen solche Pflanzen vorkommen (ausser 2-3 unbestimmten Familien die Commelynaceen, Amarantaceen, Apocyneen, Verbenaceen?, Magnoliaceen, Dilleniaceen, Capparideen, Samydeen, Bixaceen, Cucurbitaceen, Marcgraviaceen, Meliaceen, Sapindaceen, Celastrineen (Evonymus europaeus), Papilionaceen und Mimoseen). - Dem Rio das Antas folgten wir bis in die Nähe des Quellbezirks des Michelsbachs, durchwateten ihn dann und erreichten bald, oben am Michelsbach, die ersten Ansiedler von Theresopolis. Bald kamen wir nun auch, am Michelsbach niedersteigend, auf einen vortrefflich nivellirten glatten Weg, auf dem wir uns ordentlich von unserem Auf- und Niederklettern auf holprigen Wegen erholten und gemächlich dem Stadtplatze zuschlenderten. Mit der Abenddämmerung langten wir hier an. An einem Theile des Michelsbachs (und ebenso des Cederbachs) ist das Thal breiter und die Berge steigen sanfter an und haben besseren Boden, als sonst am oberen Cubatâo und seinen Zuflüssen. An diesen günstiger gelegenen Stellen sind auch die Ansiedler recht gut vorwärts gekommen. 
Am Michelsbach und Cederbach wächst in grosser Menge eine stattliche mannshohe Cleome mit grossen eigenthümlich gestalteten Blüthen und langen sehr samenreichen Schoten, die ich nirgends sonst getroffen habe $\left.{ }^{1}\right)$.

(I g. Mai). Wir hatten unsere Abreise von Theresopolis auf den nächsten Morgen festgesetzt. Aber bei schwachem Ostwind begann es am Abend zu regnen, und da solcher Regen nicht rasch vorüberzugehen pflegt, verschoben wir sie um einen Tag.

(20. Mai). In der That hätte uns der nächste Tag kein besonders Reisewetter geboten, da es fast ununterbrochen nässelte und regnete.

(21. Mai). Viel besser sah es freilich auch am folgenden Himmelfahrtsmorgen nicht aus. Doch trieb uns die Sehnsucht nach den Unsern fort. Die Wege, namentlich die steilen thonigen Bergwege, waren durch den Regen abscheulich geworden. Dabei fing es bald wieder an zu nässeln und von Zeit zu Zeit stärker zu regnen. - Gegen Mittag endlich (wir waren zum Glück unter Dach und Fach, unser Mittagbrod im Hause des Schusters Müller in S. Amaro verzehrend) ergoss sich ein förmlicher Platzregen, den ein Wirbelsturm der Reihe nach gegen alle Seiten des Hauses trieb. Damit hatte indess auch der Regen ein Ende, und bald erschien im Westen ein schmales Streifchen blauen Himmels, das sich langsam ausdehnte; die dicke graue Wolkendecke zog sich mehr und mehr zurück und nach einigen Stunden hatten wir wolkenlosen Himmel über uns. - Wir gingen bis zu unserem früheren Nachtquartier bei Hard.

(22. Mai). Von Hard nach Desterro, wo wir bis zum 25. Mai blieben und einige Ausflüge in die nächste Umgebung machten, um einige hier fehlende Orchideen für meinen Garten zu sammeln.

(25. Mai). Von Desterro nach Tijuquinhas.

(27. M a i). Von Tijuquinhas nach Tijuccas. In der Nähe von Morretes trafen wir einen Baum (eine Sapotacee), dessen Früchte kleinen Orangen einigermassen ähnlich sahen und uns auch von Brasilianern Laranjos do mato (,wilde Orangen") genannt wurden. Sie hatten ein süsses, recht angenehm schmeckendes Fleisch, dessen freilich wegen der grossen Kerne nicht eben viel war.

(28. Mai). Von Tijuccas nach Cambriú. - An dem Strande von Porto bello trafen wir tiefe Ebbe, so dass wir den Perequé bequem durchwaten konnten. Früher trug der Perequè eine Brücke, die aber vor etwa ıo Jahren ein Hochwasser weggeführt hat. Dann konnte man jahrelang den IVeg nur zur Ebbezeit passieren; ich selbst habe einmal einen halben Tag bei Porto bello liegen müssen und musste dann bis an den Hals in's Wasser. Erst nachdem mehrere Menschen im Perequé ihren Tod gefunden, hat man einen Fährmann angestellt. - In dem jetzt vom Wasser entblössten Sande war eine kleine Scutella mit fünf Löchern sehr häufig; sie hält sich dicht unter der Oberfläche auf und ihre Anwesenheit verrät sich durch fünf kleine, den Löchern entsprechende Vertiefungen im Sande. - Vom Morro do Boi nahmen wir unser jetzt blühendes und mit langen „antennae“

I) Nach der mitgeteilten Bleistiftskizze Cleome gigantea Linn., die übrigens stellenweise durch ganz Brasilien, von Rio Grande do Sul bis in das Amazonasgebiet vorkommt.

Redact. 
versehenes Catasetum mit uns. - Wir fanden Nachtquartier in einer äusserst schmutzigen Venda hart am Flussufer des Cambriú, die uns aber wenigstens eine vortreffliche Tainha (Seefisch) zum Abendbrot lieferte.

(29. Mai). Ton Cambrú bis zum kleinen Itajahy, wo wir wegen Regenwetter am 30. Mai liegen bleiben mussten.

(31. Mai). Vom kleinen Itajahy bis zum Gaspar. Wir trafen am Wege eine Sapotacee mit noch wohlschmeckenderen birnförmigen Früchten.

(I. Jun i). Nachts regnete es und bei Nässeln und trübem Wetter legten wir die letzten Stunden nach unserer Heimath zurück. 


\title{
Ueber einige Befruchtungserscheinungen ${ }^{1}$.
}

\author{
Aus einem Briefe an F. Hildebrand.
}

Eschscholtzia californica hat sich in meinem Garten (Itajahy bei St. Catharina) während mehrerer Jahre vollständig unfruchtbar mit eigenem Pollen gezeigt; dasselbe war auch dies Jahr wieder der Fall. Ich hatte schon vor ein paar Jahren diese Beobachtung $\mathrm{D}$ arw in mitgetheilt, der dann auch darauf achtete, aber seine Eschscholtzia fruchtbar mit eigenem Pollen fand. Auf meinen Wunsch erhielt ich von ihm Samen seiner Pflanzen. Leider sind in Folge des unmässig nassen Wetters, dem im November eine ebenso ungewöhnliche Hitze folgte, mehrere der Sämlinge ganz zu Grunde gegangen, und die anderen haben mehr oder weniger gekränkelt; meine Pflanzen hingegen, die seit etwa 6 Generationen hier leben, haben viel weniger gelitten, und nicht eine ist vor dem Blühen eingegangen. Auch während der Blüthe war bald glühende Sonnenhitze, bald schwerer Gewitterregen den Versuchen ungünstig; doch stellte sich soviel heraus, dass diese aus dem von Darwin erhaltenen Samen gezogenen Pflanzen zwar nicht ganz unfruchtbar, aber doch viel weniger fruchtbar waren nach Bestäubung mit eigenem Pollen. Die Versuche an einer dieser Pflanzen waren folgende:

I. Octbr. 23. (31/2 Uhr Nachm.) Eine am Morgen geöffnete Blüthe mit eigenem Pollen bestäubt.

Octbr. 24. Narben verwelkt (würden bei meiner Pflanze frisch geblieben sein).

Novbr. 15. Der Fruchtknoten, bis zu I 2 mm herangewachsen, beginnt zu welken.

II. Novbr. 3. Eine Blüthe $a$ mit Pollen einer anderen Blüthe desselben Stockes bestäubt; eine andere, $b$, mit Pollen einer anderen Pflanze.

Novbr. 5. Narben von $a$ ausgebreitet, frisch; von $b$ aufgerichtet, welkend.

Novbr. 9. Fruchtknoten von $a$ I $2 \mathrm{~mm}$, von $b 26 \mathrm{~mm}$ lang.

Novbr. II. Fruchtknoten von $a 19 \mathrm{~mm}$, von $b 47 \mathrm{~mm}$ lang.

Novbr. 15. Fruchtknoten von $a 30 \mathrm{~mm}$, von $b 56 \mathrm{~mm}$ lang.

Novbr. I8. Fruchtknoten ebenso.

Novbr. 30. Früchte reif; $a$ enthält Io Samen, wovon 4 sehr klein; $b$ enthält 59 Samen.

III. Novbr. 9. Zwei Blumen, $a$ und $b$, ähnlich wie bei Versuch II. bestäubt.

Novbr. Iо. Narben von $a$ frisch; etwas aufgerichtet; von $b$ welk. ganz aufgerichtet.

I) Botanische Zeitung. 1869. Bd. 27. p. 224-226. 
Novbr. 15. Fruchtknoten von $a$ II $\mathrm{mm}$, von $b \quad 18 \mathrm{~mm}$ lang.

Novbr. I8. Fruchtknoten von $a$ i $2 \mathrm{~mm}$, von $b 49 \mathrm{~mm}$ lang.

Novbr. 22. Ebenso.

Die Frucht $a$ verwelkte vor der Reife, die Frucht $b$ lieferte am 4. December 45 Samen.

Von einer anderen Pflanze habe ich einmal nach Bestäubung mit Pollen desselben Stockes eine $56 \mathrm{~mm}$ lange Frucht erhalten, die aber die für ihre Länge unbedeutende Zahl von 24 Samen enthielt. - Die Pflanzen scheinen durch ihren Anbau in einem neuen Klima weit unfruchtbarer mit eigenem Pollen geworden zu sein, als sie bei $\mathrm{D}$ arwin waren, der, wenn ich mich recht erinnere, über $70 \%$ des normalen Samenertrages von selbstbestäubten Pflanzen erhielt.

Vor Kurzem blühte in meinem Garten eine einzelne Scorzonera-Pflanze, und zwar sehr reichlich, ohne aber auch nur einen guten Samen zu bringen; ich habe mehrere junge Pflanzen, und bin neugierig, zu erfahren, ob auch diese unfruchtbar sein werden, ob also die Unfruchtbarkeit Folge des Klima's oder der Bestäubung mit eigenem Pollen war.

Auf der Insel Santa Catharina ist eine Art von Epidendrum nicht selten, bei welcher 3 Antheren fruchtbar entwickelt sind; die beiden seitlichen dienen der Selbstbefruchtung, die mittlere kann, wie bei anderen Epidendrum-Arten, nur durch Insekten entfernt werden, was indess ausserordentlich selten $\mathrm{zu}$ geschehen scheint. Hier am Itajahy kommt nur ein Epidendrum vor, welches jener triandrischen Art so ähnlich ist, dass man es kaum für mehr als eine Varietät halten möchte, und dieses Epidendrum ist monandrisch. Die triandrische Art oder Varietät ist fast geruchlos, die monandrische hat einen sehr starken würzigen Geruch. Das gelegentliche Auftreten der in der Regel fehlenden seitlichen Antheren ist ja auch bei anderen Orchideen beobachtet worden, dass es bei der Art von Sta. Catharina durch natürliche Züchtung wieder zur bleibenden Eigenthümlichkeit geworden ist, mag seinen Grund darin haben, dass die Art wenig oder nicht von Insekten besucht wurde, und dass es ihr deshalb vortheilhafter war, sich selbst befruchten $\mathrm{zu}$ können. Immerhin ist es höchst merkwürdig, bei zwei sonst fast ununterscheidbar ähnlichen Formen eine Verschiedenheit in der Zahl der Antheren anzutreffen, da ja deren Zahl zur Scheidung der beiden Hauptgruppen der Familie dient.

Ueber den Dimorphismus einer Rubiacee, einer Art von Faramea, verspricht Fritz Müller einen eingehenderen Aufsatz; auch hat er ein zur noch nicht genau bekannten Gattung Streptochaeta Nees gehöriges Gras gefunden, dessen Beschreibung sehr wünschenswerth. 


\section{Ueber eine dimorphe Faramea $\left.{ }^{1}\right)$.}

Unter den zahlreichen dimorphen Rubiaceen ist in mehrfacher Beziehung besonders bemerkenswerth ein kleiner Baum, der an manchen Stellen am Itajahy, z. B. in meinem eigenen Walde, ziemlich häufig wächst und im Frühling (October, November) sich mit grossen, schneeweissen Blüthenrispen schmückt. Weiss sind nicht nur die Blumenkronen, sondern ebenso die Kelche, Fruclitknoten, Deckblättchen und die Aeste der Rispe. Der Baum wurde mir in Kew als Faramea bestimmt.

Zunächst fällt die ungewöhnlich grosse Verschiedenheit in der Länge der Griffel und Staubfäden in die Augen. In der langgriffligen Form ist (nach Messungen an I 2 Blüthen von 5 verschiedenen Bäumen) der Griffel 26 bis 37, im Durchschnitt $32 \mathrm{~mm}$, in der kurzgriffligen Form (nach Messungen an I 2 Blüthen von 3 verschiedenen Bäumen) 14 bis 17 , im Durchschnitt $15,7 \mathrm{~mm}$ lang. - Die langen Griffel überragen die Blumenröhre um 7 bis 14 , durchschnittlich um I I,3 mm, die kurzen sind in der Blumenröhre eingeschlossen. - Die Staubbeutel der langgriffligen Form sind in der Blumenröhre eingeschlossen, fast sitzend, und stehen I 2 bis I9, im Durchschnitt I5,2 mm über dem Fruchtknoten, also in gleicher Höhe mit den Narben der kurzgriffligen Form. In der kurzgriffligen Form dagegen werden die Staubbeutel 16 bis 20, im Durchschnitt I8, I mm lang, von den Staubfäden weit über die Blumenröhre emporgehoben, und stehen $3 \mathrm{I}$ bis 37 , im Durchschnitt $34,4 \mathrm{~mm}$ über dem Fruchtknoten, also etwa in gleicher Höhe mit den Narben der langgriffligen Form.

$\mathrm{Zu}$ dieser auffallenden Längenverschiedenheit der Griffel gesellt sich eine sehr abweichende Gestalt der Narben; die langen Griffel theilen sich in zwei ziemlich kurze und breite, die kurzen in zwei lange, schlanke, bisweilen vielfach gewundene Narben.

Die Staubbeutel der kurzgriffligen Form sind ein wenig grösser als die der langgriffligen. Die Farbe der Staubbeutel und des Blüthenstaubes ist kaum verschieden, sehr verschieden dagegen die Grösse der Blüthenstaubkörner, die in der kurzgriffligen Form etwa $1 / 12$, in der langgriffligen nur etwa $1 / 18 \mathrm{~mm}$ Durchmesser haben. Es bestätigt sich also auch in diesem Falle das Gesetz, dass bei dimorphen und trimorphen Pflanzen mit ungleich grossen Blüthenstaubkörnern die grösseren

I) Rotanische Zeitung. 1869. Bd. 27. Sp. 606-6I I. 
Körner in den höher stehenden Staubbeuteln sich finden, - ein Gesetz, das wir für jetzt als Thatsache hinnehmen müssen, ohne es befriedigend erklären zu können.

Während verschiedene Grösse der Blüthenstaubkörner bei dimorphen und trimorphen Pflanzen sehr gewöhnlich ist, bietet Faramea meines Wissens das erste Beispiel einer verschiedenen Beschaffenheit ihrer Oberfläche; die kleineren Blüthenstaubkörner der langgriffligen Form sind glatt, die grösseren der kuszgriffligen Form ziemlich dicht mit kurzen Spitzen besetzt, wie diejenigen vieler IVinden und Malvaceen. In Folge dieser Oberflächenbildung fällt der Blüthenstaub der kurzgriffligen Pflanzen weniger leicht aus den Staubbeuteln heraus (wie man sieht, wenn man die Staubbeutel auf ein Glastäfelchen tupft), haftet dagegen leichter z. B. an den Haaren eines Pinsels. Beides ist von offenbarem Nutzen für die Pflanze; der Blüthenstaub der weit vorstehenden Staubbeutel wird weniger leicht vom Winde verweht werden, dagegen leichter an dem haarigen Leibe besuchender Kerfe haften, welche jedenfalls diese Staubbeutel nur leise berühren. Die Staubbeutel der langgriffligen Pflanzen sind in der Blumenröhre eingeschlossen, und dadurch ihre glatten, leicht herausfallenden Blüthenstaubkörner vor dem Winde geschützt, und besuchende Kerfe werden mit ihren in die enge Blumenröhre eingeführten Saugwerkzeugen derb an diesen Staubbeuteln hin- und herstreichen müssen.

In jüngeren Knospen sind die Staubbeutel bei beiden Formen von Faramea, wie bei anderen Rubiaceen, nach innen gekehrt; sie bleiben so und springen nach innen auf bei der langgriffligen Form; bei der kurzgriffligen Form dagegen findet man schon vor dem Aufblühen die Staubbeutel, in Folge einer Drehung der Staubfäden um ihre Achse, mehr oder weniger nach aussen gekehrt. An den ersten Blüthenständen, die ich untersuchte, waren bei der Mehrzahl der Blüthen sämmtliche Staubbeutel vollständig nach aussen gedreht. Dies ist jedoch, wie ich später fand, keineswegs der gewöhnlichere Fall, und galt nicht einmal für alle Blüthenstände jenes ersten Baumes. Man findet alle möglichen Uebergangsformen von Blüthen, deren Staubbeutel sämmtlich ihre ursprüngliche Richtung unverändert bewahrt haben und nach innen aufspringen, zu solchen, deren Staubbeutel sämmtlich um $180^{\circ}$ gedreht sind, und also genau nach aussen sich öffnen. Die mannigfachen Mittelglieder kommen bei weitem häufiger vor, als die Endglieder der Reihe, und namentlich sind Blüthen mit lauter nach innen aufspringenden Staubbeuteln selten. An ro ohne Wahl herausgegriffenen Blüthen von drei verschiedenen Bäumen hatten sich, nach ungefährer Schätzung, die Staubbeutel etwa um folgende Winkel gedreht:

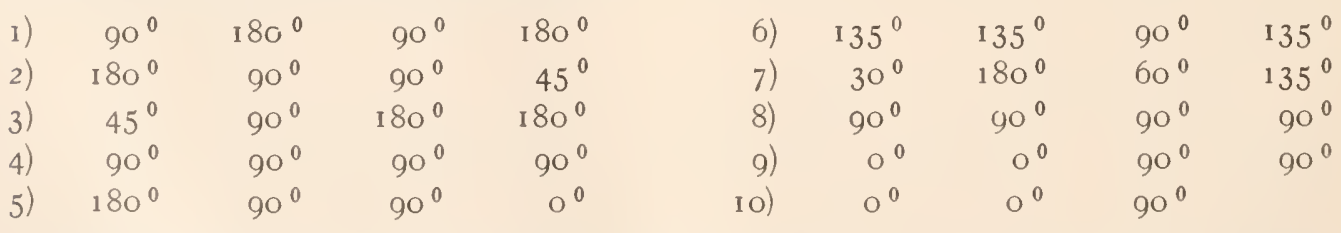

Dreizählige Blüthen, wie die letzte der eben aufgezählten, sind nicht eben selten; weit seltener kommen fünfzählige vor. - Die Drehung findet immer in gleicher Richtung statt, und zwar von O. durch S. nach W., in derselben Richtung also in welcher die jungen Triebe mehrerer keimenden Rubiaceen, z. B. der Manettia- 
Arten, sich bewegen. (Nicht alle klimmenden Rubiaceen drehen sich in dieser Richtung; in entgegengesetzter z. B. Sabicea.)

Die grosse Länge der Staubfäden ist natürlich eine nur langsam und stufenweise erworbene Eigenthümlichkeit der kurzgriffligen Form von Faramea. Seit die allmählich immer länger werdenden Staubfäden die Staubbeutel zu einer solchen Höhe über den Eingang der Blumenrohre emporhoben, dass besuchende Kerfe ihre Saugwerkzeuge nicht mehr zwischen ihnen, sondern unterhalb derselben einführten, hatten nach aussen aufspringende Staubbeutel mehr Aussicht, ihren Blüthenstaub an solche Kerfe abzusetzten, als nach innen aufspringende, und seit jener Zeit würde es für die Pflanze von Vortheil gewesen sein, wenn alle ihre Staubbeutel sich um volle $180^{\circ}$ gedreht hätten. Noch heute ist dieses nicht der Fall; noch heute ist die Richtung, nach welcher hin die Staubbeutel sich offnen, eine sehr wechselnde, selbst nicht für die Staubbeutel derselben Blüthe gleiche; - ein hübscher Beleg dafür, dass im innigsten Zusammenhange stehende, einander ergänzende Eigenthümlichkeiten - wie hier die Länge der Staubfäden und das Aufspringen der Staubbeutel nach aussen - nicht in allen Fällen zu gleicher Zeit erworben zu sein brauchen.

Dieses Schwanken in der Richtung, nach welcher die Staubbeutel der kurzgriffligen Form aufspringen, scheint mir die bemerkenswertheste Eigenthümlichkeit unserer Faramea zu sein, und ich kann mir nicht versagen, bei dieser Gelegenheit an eine zweite Rubiacee $z u$ erinnern, die sich ebenfalls in Bezug auf eine für ihre Befruchtung sehr wichtige Eigenthümlichkeit in einem noch schwankenden, ich möchte sagen unfertigen Zustande befindet. Es ist die Posoqueria (Martha fragrans), deren Blüthenbau ich vor einigen Jahren beschrieben habe 1). (Bot. Zeitg. 1866. No. $17=$ Ges. Schriften S. 299.) Dieselbe kann, wie die tief in der langen Blumenröhre verborgene Narbe beweist, nur durch langrüsslige Abendschmetterlinge bestäubt werden. Die Blüthen dieser Posoqueria öffnen sich meist gegen Abend, allein eine nicht unbeträchtliche Zahl auch zu verschiedenen Zeiten des Tages, bisweilen selbst am frühen Morgen. Da nun auch am Tage zahlreiche Kerfe durch die weithin sichtbaren, stark duftenden Blumen angelockt werden und die Entladung des Blüthenstaubes fast aller zur Unzeit geöffneten Blumen veranlassen, ohne jedoch diesen Blüthenstaub auf die Narbe anderer Blumen übertragen $\mathrm{zu}$ können, so geht der Blüthenstaub fast aller dieser Blumen vollständig verloren. Ich habe selbst mehrmals gesehen, wie Hummeln zu solchen Blumen flogen und deren Blüthenstaub angeworfen erhielten.

Wie es für die kurzgrifflige Form von Faramea vortheilhaft wäre, wenn alle Staubbeutel aller Blüthęn um $180^{\circ}$ gedreht würden und so, genau nach aussen aufspringend, besuchenden Kerfen ihre volle Fläche darböten, so offenbar für Posoqueria, wenn alle Blüthen gegen Abend sich öffneten und kein Blüthenstaub im Laufe des Tages vergeudet würde. Aber trotz der unverkennbaren IVichtigkeit, welche dort die Richtung hat, nach welcher hin die Staubbeutel, - hier die Zeit, zu welcher die Blüthen sich öffnen, sehen wir bei beiden Arten in dieser Beziehung ein Schwanken, welches Denen jedenfalls befremdlich und unerklärlich erscheinen wird, die mit Agassiz in den Arten verkörperte Gedanken des

I) Die Gardenia suaveolens der Flora fluminensis (Pars III. Tab. 9) ist wabrscheinlich dieselbe Pflanze. Fritz Müllers gesammelte Schriften. 
„Schöpfers“ sehen. - Sieht es nicht aus, als hätte der „Schöpfer“ das Richtige wohl eingesehen, aber nicht durchzuführen vermocht - als hätte er gewollt, aber nicht gekonnt? -

Werden nun Faramea und Posoqueria in diesem unfertigen Zustande verharren, oder werden einst alle Staubbeutel der kurzgriffligen Faramea nach aussen aufspringen, alle Blüthen von Posoqueria gegen Abend aufblühen? - Mir scheint es kaum zweifelhaft, dass früher oder später Letzteres der Fall sein wird.

Bei Faramea geht der Blüthenstaub der nach innen aufspringenden Staubbeutel der kurzgriffligen Pflanzen, bei Posoqueria derjenige der vorzeitig sich öffnenden Blumen zum grossen Theil für die Befruchtung verloren; die nach aussen aufspringenden Staubbeutel der ersteren, die gegen Abend sich öffnenden Blüthen der letzteren betheiligen sich fast ausschliesslich an der Bestäubung. Je mehr nach aussen aufspringende Staubbeutel ein Stock der kurzgriffligen Faramea, je mehr rechtzeitig aufblühende Blumen ein Stock der Posoqueria erzeugt, um so zahlreichere Nachkommenschaft wird er unter sonst gleichen Verhältnissen hinterlassen. So wird schon die natürliche Auslese dahin wirken, die Zahl der nach innen sich öffnenden Staubbeutel der kurzgriffligen Faramea, der zur Unzeit sich öffnenden Blüthen von Posoqueria mehr und mehr zu beschränken.

Dass auch, abgesehen von der natürlichen Auslese, namentlich bei Posoqueria, wo bereits die weit überwiegende Mehrzahl der Blüthen gegen Abend sich öffnet, schon aus diesem Grunde, weil sie zur Zeit die zahlreicheren sind, eine stetige Zunahme dieser rechtzeitigen Blüthen zu erwarten sei, werde ich bei einer anderen Gelegenheit nachzuweisen versuchen.

Itajahy, im April i 869 . 


\title{
Umwandlung von Staubgefässen in Stempel bei Begonia. Uebergang von Zwitterblüthigkeit in Getrenntblüthigkeit bei Chamissoa. Triandrische Varietät eines monandrischen Epidendrum ${ }^{1}$ ).
}

\author{
Aus einem Briefe an H. Müller.
}

Mit Tafel XXXIII.

Der von Dir mitgetheilte Fall von Salix cinerea ${ }^{2}$ ) ist mir besonders dadurch merkwürdig geworden, dass ich selbst seit mehr als einem Monat den umgekehrten Fall, die Umwandlung von Staubgefässen in Stempel, bei einer Begonia beobachte, und noch immer fast in jeder frischen männlichen Blüthe eine neue wunderliche und überraschende Zwischenform finde. Ich will Dir zur Probe einige Beispiele mittheilen.

Fig. I. Gewöhnliches Staubgefäss. Fig. 2 und 3. Mittelband mit vorspringendem Winkel und einigen unvollkommenen Narbenpapillen ( $\beta$ ). Fig. 4. Mittelband stark verbreitert, mit Andeutung von Papillen. Fig. 5. Mittelband gegabelt, ohne Papillen. Fig. 6. Staubfächer verkürzt, Mittelband verbreitert, wohlentwickelte Narbenpapillen ( $\beta$ ). Fig. 7. Wohlentwickelte Narbe, weder Blüthenstaub noch Eichen. Fig. 8. Staubfächer und Narbe wohlentwickelt. Fig. 9. Gute Narbe; an jedem Rande des Mittelbandes ein nach innen gebogener, in eine Spitze auslaufender Fortsatz, der eine mit gutem Blüthenstaub, der andere mit guten Eichen. Fig. Io. Gute Narbe; Staubfaden mit tiefer Rinne, deren Ränder ein kurzes Eipolster tragen, an dem zwischen meist unvollkommenen Eichen ein winziges Fach mit gutem Blüthenstaube sich findet. Fig. I I. Zwei umgewandelte Staubgefässe unten verschmolzen; beide mit je 2 Staubfächern, das eine mit, das andere ohne Narbe. Fig. 12. Zwei Staubgefässe aus derselben Blüthe; beide mit schiefer Narbe, das eine trägt Blüthenstaub am Mittelbande selbst, Eichen an einem zweispitzigen Fortsatze; das andere Eichen am Mittelbande selbst, Blüthenstaub an einem Fortsatze. Fig. 13. Zwei hochverwachsene Staubgefässe mit grossen Narben, das eine ohne Blüthenstaub und Eichen, das andere mit tiefer Rinne, von deren Rändern jederseits ein kurzer Fortsatz ausgeht, der eine Blüthenstaub, der andere Eichen erzeugend. Fig. 14. Dem Vorigen ähnlich, aber nur ein Rand der Rinne trägt

I) Botanische Zeitung 1870. Bd. 28. Sp. 149-153. Taf. II.

2) Botanische Zeitung I868. Sp. 843 . 
einen schmalen, langen Fortsatz mit 2 Eichen. Fig. 15. Zwei Staubgefässe verwachsen, a. mit Narbe und tiefer Rinne; an jedem Rande ein kurzer Fortsatz, der eine mit Staubfach, der andere mit etwa einem Dutzend Eichen; $b$. oberer Theil normal, am Rande unterhalb des verkürzten Staubfachs einerseits ein Fortsatz mit Narbenpapillen, andererseits ein Eipolster mit zahlreichen guten Eichen. Fig. I6. Zwei umgewandelte und ein normales Staubgefäss verwachsen. $a$. An einem Rande der Rinne ein Eipolster mit guten Eichen, am anderen (in der Figur nicht zu sehen) ein kurzer Fortsatz mit Staubfach und oberhalb desselben 7 Eichen. b. Sehr grosse Narbe, ein Ast derselben gabelig; Rinne jederseits mit einem Fortsatze; der eine unten mit einem kleinen Staubfache, weiter oben mit 2 Eichen, von denen eins in eine Narbe verwandelt ist! (was ich auch in anderen Blüthen gesehen habe; zwischen normalen Eichen finden sich keulenförmige Körper von Grösse der Eichen, aber gelb, wie die Narben, und mit völlig eben solchen Papillen besetzt! Fig 16. $\beta$ ). Fig. 17. Drei freie umgewandelte Staubgefässe aus derselben Blüthe, $a$. mit kopfförmiger Narbe; Mittelband jederseits in einen etwas einwärtsgebogenen Fortsatz ausgezogen, mit Pollenfach an jedem Rande. $b$. Einseitige Narbe; an einem Rande des Mittelbandes ein Staubfach und oberhalb desselben ein Fortsatz mit papillöser Spitze, am anderen ein einwärts gebogener Fortsatz mit Eichen. c. Die ganze Fläche des verbreiterten Mittelbandes mit einem grossen Eipolster bedeckt; oberhalb desselben an jedem Rande ein kleines Staubfach. Fig. I 8. Drei Staubgefässe verwachsen; $a$. ohne Blüthenstaub, Eichen und Narben; $b$. mit wohlentwickelter Narbe und grossem Eipolster; $c$. ohne Narbe, an einem Rande ein normales, am anderen ein verkürztes Staubfach, unterhalb desselben zahlreiche Eichen, darunter eines $(\beta)$ in eine Narbe verwandelt. Fig. I9. Vier umgewandelte und ein normales Staubgefäss verwachsen; $a . b$. c. mit wohlentwickelten Narben, ohne Blüthenstaub und Eichen; $d$. mit nur einem wohlentwickelten Narbenast, am anderen nur an der Spitze Papillen; ein unregelmässig gebogenes Staubfach unterhalb des letzteren Astes. Fig. 20. Drei Staubgefässe verwachsen; $a$. normal, b. mit kugliger Narbe, ohne Pollen und Eichen, $c$. mit grosser Narbe und kurzem Staubfache an einem Rande u. s. w.

Fig. I-I 9 sind alle von derselben Pflanze; Fig. 20 von einer zweiten; beide wachsen nahe bei einander an meinem Gartenzaun und stammen wahrscheinlich von derselben Mutterpflanze. An der zweiten Pflanze habe ich männliche Blüthen gesehen (leider nicht gezeichnet), bei denen alle Staubgefässe verschwunden waren und ein unterständiger Fruchtknoten sich gebildet hatte. 'Hoffentlich werden sie noch wieder erscheinen. Der Blüthenstand dieser Begonien hat gewöhnlich 5 oder I I Blüthen in der durch Fig. C. und $D$. dargestellten Anordnung. Die gabelständigen männlichen Blüthen enthalten meist lauter normale Staubgefässe, höchstens finden sich solche leise Andeutungen einer Umwandlung, wie in Fig. 2-4. Dagegen finden sich in allen neben den weiblichen Blüthen stehenden Blüthen 1-3, in der zweiten Pflanze häufig 4-5 Staubgefässe stärker umgewandelt und in der Regel verwachsen. - Ich will Samen dieser beiden Pflanzen aussäen, und hoffe so noch mehr Pflanzen mit solchen männlichen Blüthen zu erhalten.

Kürzlich wurde ich auf das getrennte Geschlecht einer Chamissoa aufmerksam deren Blüthen (Fig. $A$. und $B$.) dem Hermaphroditismus noch so nahe stehen, wie 
ich es bei keiner anderen diöcischen Pflanze kenne. Zuerst hielt ich die Pflanze für dimorphisch, aber bei näherem Zusehen ergab sich, dass die Staubgefässe der langgriffligen (weiblichen) Płlanzen völlig pollenlos sind, und dass die Narbenschenkel der kurzgriffligen (männlichen) Pflanzen nie sich auseinanderbiegen. Das Merkwürdige ist nun, dass nicht nur die Narbenpapillen dieser kurzen Griffel noch ziemlich gut entwickelt sind, sondern dass auch der Fruchtknoten ein Eichen enthält, das ich unte:- dem Mikroskop in nichts von dem der weiblichen Pflanze verschieden fand, welches aber natürlich wegen der an einander liegenden Narbenschenkel nie befruchtet werden kann.

Ich meine, Dir früher von einem bei Desterro ziemlich häufigen Epidendrum erzählt zu haben, bei dem auch die beiden seitlichen Antheren fruchtbar entwickelt sind und die Selbstbefruchtung der Blüthen vermitteln. Kürzlich brachte ich von einem gefällten Baume in der Nähe meines Hauses ein Epidendrum mit grossen Knospen heim, das vollkommen jenem von Desterro glich. - Heute Mittag komme ich zufällig bei der Laube vorüber, in deren Schatten ich es hingeworfen hatte, und finde es in voller Blüthe, aber keine Spur seitlicher Antheren! Sonst kaum ein Unterschied, als ein schwacher Wohlgeruch, den die hiesige Pflanze besitzt, die der Insel St. Catharina völlig entbehrt. - Schon im vorigen Jahre habe ich in Blumenau's Garten eine ähnliche Pflanze gesehen, die aber im Habitus sich etwas mehr von der triandrischen Form entfernte, auch, meine ich, noch stärker roch ${ }^{1}$. - Jedenfalls können die beiden Formen, die monandrische des Itajahy und die triandrische der Insel St. Catharina und der gegenüberliegenden Strandgebüsche, nur als Varietäten angesehen werden, trotzdem sie sich in einem Merkmale unterscheiden, welches zur Scheidung der beiden Hauptgruppen der Familien dient, in der Zahl der fruchtbaren Antheren. - Die ursprüngliche Form ist jedenfalls die monandrische des Urwaldes; das Auftreten der seitlichen Antheren ist ein Rückfall in einen längst verlornen Charakter, der in einer des Urwaldes fast ganz entbehrenden Gegend wahrscheinlich deshalb als nützlich durch natürliche Auslese erhalten wurde, weil mit dem Urwalde die zur Befruchtung nöthigen Insekten fehlen mochten, und die einst beseitigte Selbtbefruchtung so wieder vortheilhaft wurde. - Viele auf Insekten angewiesene Orchideen, so das gemeine Oncidium flexuosum, tragen auf St. Catharina fast nie Samen, viel weniger als hier. - Bei Desterro ist die triandrische Varietät ziemlich häufig, hier habe ich von der monandrischen nur die beiden erwähnten Pflanzen bis jetzt gesehen. Ich bin neugierig, wie die geographische Verbreitung der beiden Formen sein wird; die Pflanze kommt z. B. in der Nähe der Mündung des Itajahy vor, wo die Verhältnisse denen der Insel ähnlicher sind, als den hiesigen; doch habe ich dort keine Blüthen gesehen. - Merkwürdig ist auch, dass mit der Nothwendigkeit der Befruchtung durch Insekten auch der Duft verloren gegangen ist.

Itajahy, den I2. April I869.

Nachschrift vom 17. A pril. An einer männlichen Pflanze von Chamissoa sah ich gestern einige Blüthen, deren kurze Griffel klaffende Schenkel hatten, und dass solche Blüthen fruchtbar sind, zeigten einige Früchte an derselben Pflanze.

1) Botanische Zeitung 1869. Nr. 14. = Ges. Schriften S. 350. 


\title{
On the Modification of the Stamens in a Species of Begonia $\left.{ }^{1}\right)$.
}

\author{
Aus einem Briefe an Ch. Darwin.
}

Mit 5 Textfiguren.

My dear Sir,

Itajahy, S. Catharina, Brazil. March 14, 1869.

In your book on 'Variation under Domestication' you mention a remarkable plant of Begonia frigida producing hermaphrodite flowers with inferior perianth. I have lately found an analogous wild plant of another Begonia, which is here a common weed. In this plant all the male flowers show a strong tendency to become hermaphrodite - one, two, or three of the central stamens being transformed more or less completely into pistils. No two of these male flowers appear to be exactly alike; and almost every day affords a new and surprising modification. Here are some cases: -
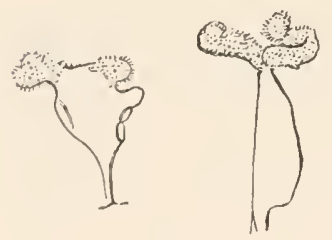

Fig. I.

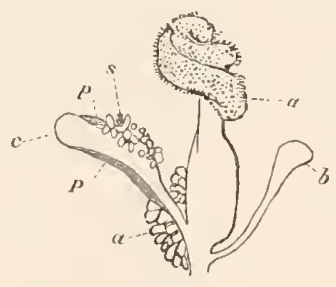

Fig. 3 .

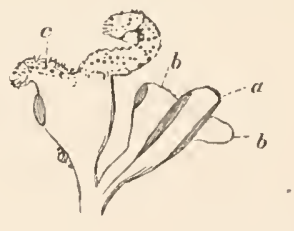

Fig. 4.

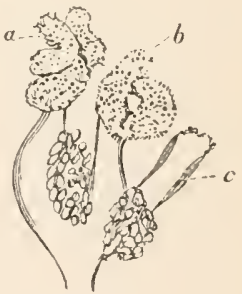

Fig. 5 .

Fig. I. A single stamen modified; connectivum much dilated; on either margin a short anther with good pollen; at the end, well-developed stigmatic papillæ.

Fig. 2. A single stamen modified; a well-developed stigma; neither anthers nor ovules.

Fig. 3. Three modified stamens, united at the base. $a$, well-developed stigma; no pollen; numerous ovules, differing in nothing from those of the normal 오 flowers. $b$, club-shaped, without pollen, ovules, and stigmatig papillæ. $c$, pollen on both margins of the connectivum; ovules on the convex margin; apex of the connectivum smooth, without stigmatic papillæ, but one of the ovules transformed into a stigma.

Fig. 4. Three stamens united. $a$, not modified; $b$, connectivum much dilated, pollen on either margin, neither ovules nor stigmatic papillæ; $c$, well-developed stigmatic papillæ, pollen (a small quantity) on one margin alone of the much dilated connectivum, a few ovules.

Fig. 5. Three stamens, modified and united: $a$ and $b$ without pollen, with large stigmas and numerous ovules; $c$ nearly normal, only the tip of the connectivum being somewhat enlarged and provided with small stigmatic papillæ.

I) Journ. Linn. Soc. (Bot.) I871. XI. p. $472-474$. 
Once I saw (fig. $3, s$ ) in the midst of the white ovules, a dark yellow body of a club-shaped form, having nearly the size of an ovule, covered by club-shaped papillæ exactly resembling in shape and colour those of the stigma; so that in this case an ovule appeared to have been transformed into a stigma!

Since I found this plant, I have been looking out for others; and yesterday $I$ at length met with a second specimen (growing within 2 yards distance from the first), which promises to offer still more curious modifications. Some of the male flowers of this second plant have been transformed completely into female ones with superior perianth, but distinguished from the normal $q$ flowers by the perianth having (as in the male flowers) two large broad outer and two small narrow inner segments (whilst the female flowers have five segments, one being smaller), and by their having from four to five stigmas and as many alæ on the ovarium (the female flowers have three). In one of these abnormal female flowers there were some naked ovules between the stigmas beside those included in the ovarium. In the first plant all the ovules of the male flowers are naked. There are some unripe pods on the second plant, all of which are produced by normal $q$ flowers; as soon as they are ripe I shall send you seeds of this second plant also. 


\section{Botanische Notizen ${ }^{1}$.}

\section{Aus einem Briefe an Friedrich Hildebrand.}

Eine Passiflora-Art wird, wie es Delpino für Passiflora princeps vermuthet, wahrscheinlich ausschliesslich oder doch vorzugsweise durch Kolibri's bestäubt, die die Blumen sehr fleissig besuchen, während ich nie grössere Insekten daran sah. Honig habe ich nie in den Blumen gefunden. Jedenfalls suchen die Kolibri's die kleinen Insekten, die oft in der innersten Kammer der Blume sich finden und, einmal dorthin verirrt, wohl durch die mehrfachen Gitter über dieser Kammer zurückgehalten werden. An einer kleinen, weissblühenden, wohlriechenden Art, die reichlich Honig absondert, sah ich nie Kolibri's. Bei einer Gesneriacee fand ich, dass Honig in den protandrischen Blüthen erst in der zweiten (weiblichen) Periode der Blüthezeit abgesondert wird; Pollen und Honig suchende Bienen müssen also, wenn sie beiderlei Bedürfnisse befriedigen wollen, sowohl jüngere (männliche), als ältere (weibliche) Blumen aufsuchen.

Bei einer Jussieua sind die, sonst in der Familie der Onagrarieen nach innen aufspringenden Antheren eigenthümlich gedreht, so dass sie ziemlich nach aussen sich öffnen, und vor Insekten geschützte Blumen sich nicht selbst bestäuben. Die Nectarien sind sehr zierlich gebildet, von einem Haarsaum überwölbte, halbkreisförmige Gruben. Nicht selten ist bei dieser Art die erste Blume eines Astes fünfzählig, während sonst die Blumen vierzählig sind. Aehnliche Vermehrung der Zahl der Blüthentheile bei den Erstlingsblumen habe ich kürzlich bei einer Pflanze von Eschscholtzia gesehen, wo die $6-8$ ersten Blumen $5-7$ Blumenblätter hatten, bei einem Agapanthus, wo die erste Blume achtzählig war, und bei einem weissen Siphocampylus, wo an einigen Aesten die erste Blume sechszählig war (im vorigen Jahre war an derselben Pflanze die erste Blume 7zählig). Bei einer anderen Art von Jussieua fand ich vor Kurzem eine Blüthe, die statt 8 Staubgefässen damals 20 hatte, indem jedem Kelchblatte 2, jedem Blumenblatte 8 gegenüber standen.

Ein Herr Silveiro da Motta will, wie er im „Auxiliador da Industria nacional" berichtet, grün und roth, sowie gelb und roth gestreiftes Bastardzuckerrohr erhalten haben, indem er je einen grünen und einen rothen sowie einen gelben und einen rothen Steckling in dasselbe Loch pflanzte (man pflanzt als Stecklinge drei Augen enthaltende Stücke der Rohrs). Ich hoffe hier rothes Zuckerrohr er-

I) Botanische Zeitung 1870. Bd. 28. Sp. 273-275. 
halten zu können, und will dann den Versuch, den ich noch mit einigem Misstrauen betrachte, wiederholen.

In die Zahl der mit Blüthenstaub derselben Pflanze unfruchtbaren Arten gehört auch Tabernaemontana echinata. Ich hatte beim Niederhauen eines jungen Waldes der duftigen Blüthen wegen ein Bäumchen dieser Art stehen laśsen, das schon voriges Jahr reichlich blühte, ohne Frucht anzusetzen; auch dies Jahr war fast die Blüthezeit ohne Fruchtansatz vorüber gegangen, als ich etwa eine Stunde von meinem Hause ein anderes blühendes Bäumchen fand. Ich bestäubte nun 3 Blüthen mit Blüthenstaub dieses zweiten Baumes, und alle 3 haben Frucht angesetzt, während mehrere mit Blüthenstaub desselben Baumes bestäubte, wie alle sich selbst überlassenen Blüthen ohne Fruchtbildung abgefallen sind. - Wahrscheinlich ist auch ein Calonyction mit sehr grossen, weissen Blumen mit eigenem Pollen unfruchtbar; wenigstens habe ich durch Bestäubung mit Pollen derselben Pflanze keine Frucht erhalten, habe aber leider nur eine blühende Pflanze, und kann also für jetzt den Gegenversuch mit fremdem Pollen nicht anstellen.

In Betreff der verschiedenen Grösse der Pollenkörner bei den heterostylen Pflanzen spricht Delpino in seinen Note critiche zu Ihrem Buche über die Geschlechtervertheilung die Ansicht aus, dass diese verschiedene Grösse im Zusammenhange stehe mit der verschiedenen Länge des Weges, den die Pollenschläuche zu durchlaufen haben. Sind auch die Pollenschläuche bei ihrem Wachsthum gewiss nicht allein auf den im Pollenkorn enthaltenen Stoff angewiesen, so scheint mir diese Ansicht doch nicht ganz unwahrscheinlich. Man würde in diesem Falle erwarten müssen, auch bei verwandten Arten eine der Griffellänge entsprechende Verschiedenheit im Durchmesser der Pollenkörner $\mathrm{zu}$ finden. Einige allerdings noch nicht zahlreiche Messungen an Convolvulaceen und Salvia-Arten scheinen allerdings für eine solche Abhängigkeit zu sprechen.

An verschiedenen hiesigen Marantaceen habe ich die von Ihnen gesehenen Bestäubungseinrichtungen ebenfalls schon vor längerer Zeit kennen gelernt; unser kultivirter Arrow-root, dessen Blüthen keinen Pollen mehr erzeugen, hat noch den elastisch vorschnellenden Griffel behalten. Die Ursache der so häufigen Unfruchtbarkeit der nur auf ungeschlechtlichem Wege vermehrten Pflanzen ist übrigens bei verschiedenen Arten eine verschiedene: unsere Dioscorea-Arten bringen, mit Ausnahme einer einzigen, überhaupt nie Blüthen, dasselbe soll bei mehreren Varietäten des Zuckerrohrs der Fall sein. Bei den Bananen scheint die Unfruchtbarkeit, wie beim Arrow-root, hauptsächlich in den männlichen Blüthen zu liegen; die Antheren erzeugen zwar meist etwas Pollen, aber äusserst wenig im Vergleich mit der fruchtbaren Musa coccinea, und vertrocknen ohne aufzuspringen; doch ist der Pollen gut, wenigstens bei einer Varietät (Banana de São Thomé), mit deren Blüthenstaub ich Musa coccinea bestäubte und Samen erhielt, die indessen nicht zu keimen scheinen. Beim Ingwer scheinen Pollen, Narbe und Eichen vollkommen normal zu sein, vielleicht ist die Pflanze mit eigenem Pollen unfruchtbar, und bringt hier keinen Samen, weil alle unsere Pflanzen Theile eines einzigen Stockes sind. - Mandioc und Aypim bringen ziemlich häufig Samen, der indess nur selten zu keimen scheint.

Die in einem Ihrer Briefe erwähnten kleinen Blüthen des Kaffeebaumes habe ich vorige Woche in der P'flanzung meines Bruders ziemlich häufig ge- 
funden, halte sie aber (genauere Untersuchung und Experimente vorbehaltend) nicht für weibliche, sondern für verkümmerte unfruchtbare Blüthen, die bei bestimmten Witterungsverhältnissen auftreten mögen. Die Griffel und Narben hatten grünliche Farbe, und, soviel ich mit der Lupe sehen konnte, keine Papillen, überhaupt ein ebenso unreifes Ansehen, wie die Staubgefässe, die von den eingerollten Rändern der Blumenkronzipfel umschlossen werden.

Dass Norantea, wie Delpino vermuthet, von Vögeln bestäubt werde, bezweifle ich, da die Färbung der Blüthen eine dunkle ist; ich habe daran nie Kolibri's gesehen, die allerdings hier sonst bei der Bestäubung der Blüthen sehr thätig mitwirken, aber vor Allem helle, grelle Farbe zu lieben scheinen; scharlachfarbene Salvien, Combretum mit anfangs goldgelben, später orangefarbenen Staubfäden, Manettia u. s. w. werden von ihnen sehr fleissig besucht.

Itajahy, 7. Dezember I 869 . 


\section{Die Bewegung des Blüthenstieles von Alisma ${ }^{1}$.}

An den Ufern des Itajahy, dicht am Wasser und nicht selten überfluthet von dem schwellenden Flusse, wächst in Menge cin stattliches Alisma ${ }^{2}$. Der Blüthenstiel erhebt sich bis mannshoch und trägt drei im Quirl stehende Aeste. Unterhalb der Aeste ist der Blüthenstiel nackt; sein oberer Theil trägt wie die Aeste entfernt stehende Deckblattwirtel, in deren Achseln dicht gedrängt die Blüthen entspringen.

Betrachtet man eine Gruppe dieses A lisma, so fällt es auf, dass die oberen Enden der Blüthenstiele und ihrer Aeste in höchst mannigfacher Weise gekrümmt sind. Die einen stehen fast gerade in die Höhe, andere sind in einfacher Krümmung stärker oder schwächer zur Seite geneigt, bei wieder anderen sind die einzelnen Stengelglieder in verschiedenen Ebenen gebogen. Die Aeste sind bald schief aufwärts gerichtet mit dem Hauptstiele zu- oder von ihm abgewendeter Spitze, bald stehen sie wagerecht $a b$ und ihre Spitze zeigt seitwärts oder niederwärts. Die drei Aeste desselben Blüthenstieles stimmen meist weder in der Stärke noch in der Richtung ihrer Krümmung überein. - Und auch für jeden einzelnen Blüthenstiel sind Grad und Richtung der Krümmung stetem Wechsel unterworfen. Nach Verlauf einiger Stunden wird man nur selten den einen oder anderen in seiner früheren Stellung wiederfinden. Ein Blüthenstiel, der sich vorher etwa nach $\mathrm{W}$ neigte, wird jetzt vielleicht in gleicher Weise sich nach $\mathrm{N}$ oder $\mathrm{O}$ biegen, oder fast gerade sich emporstrecken, oder auch, indem seine einzelnen Glieder nach verschiedenen Seiten sich krümmen, schlangenförmig oder fast schraubenförmig aufsteigen.

Alle diese nach Form und Richtung so wechselvollen Krümmungen beobachtet man jedoch nur an den jüngeren, noch in raschem Wachstum begriffenen Gliedern des Blüthenstieles, namentlich vor dem Aufbrechen der Knospen; die älteren, samentragenden haben sich gestreckt und stehen am Hauptstiele aufrecht, an den Aesten ziemlich wagerecht.

Ich habe einen jüngen Blüthenstiel während dreier Tage, so oft meine Zeit es gestattete, beobachtet und jedesmal die Richtung, nach welcher seine Spitze hinzeigte, aufgezeichnet und die Entfernung der Spitze von der die Verlängerung des unteren nackten Theiles bildenden Verticallinie gemessen. Ich will der Mittheilung dieser Beobachtungsreihe vorausschicken, dass in diesen drei Tagen (8.,

I) Jenaische Zeitschrift für Naturwissenschaft. 1870. V. p. 133-137.

2) Dasselbe wurde mir in $\mathrm{Kew}$ als $\mathrm{Al}$ is ma macrophylla $\mathrm{K}$ th. (?) bestimmt. 
9. und I0. Januar) der untere nackte Theil des Blüthenstieles von o,9 zu I,I Meter Höhe heranwuchs, und dass der obere Knospen tragende Theil am Morgen des 8. Januar 0,1 4, am Morgen des 9. Januar 0,19, am Morgen des Io. Januar 0,25 und am Abend desselben Tages 0,30 Meter lang war. Die Aeste waren noch ganz kurz und ihre Deckblattwirtel dicht zusammengedrängt. - Auch mag erwähnt sein, dass die drei Tage sonnig und ungewöhnlich heiss waren; das Thermometer zeigte um $6^{\mathrm{h}} 45^{\mathrm{m}}$ Vormittags an jedem der drei Tage $24^{\circ} \mathrm{C}$ und um i Uhr Nachmittags $32^{\circ} \mathrm{C}$ am 8. Januar, $34^{\circ} \mathrm{C}$ am 9. und I0. Januar.

\begin{tabular}{|c|c|c|c|}
\hline Zeit de & Beobachtung & $\begin{array}{l}\text { Richtung der } \\
\text { Stengelspitze }\end{array}$ & $\begin{array}{l}\text { Entfernung der Stengel- } \\
\text { spitze von der Verticalen }\end{array}$ \\
\hline $\begin{array}{c}\text { I } 868 \\
\text { Januar } 8 .\end{array}$ & $\begin{array}{l}6^{\mathrm{h}} 45^{\mathrm{m}} \mathrm{Vm} . \\
8^{\mathrm{h}} \\
\mathrm{IO}^{\mathrm{h}} \\
\mathrm{I}^{\mathrm{h}} \mathrm{Nm} . \\
2^{\mathrm{h}} 30^{\mathrm{m}} \\
4^{\mathrm{h}} 45^{\mathrm{m}}\end{array}$ & $\begin{array}{l}\text { SWgW } \\
\text { SSW } \\
\text { SSO } \\
\text { ONO } \\
\text { NOgN } \\
\text { NWgN }\end{array}$ & $\begin{array}{ll}0,044 & \text { Meter } \\
0,054 \quad " \\
0,038 \quad ", \\
0,042 \quad, \\
0,044 \quad " \\
0,044 \quad,\end{array}$ \\
\hline Januar 9. & $\begin{array}{l}6^{\mathrm{b}} 45^{\mathrm{m}} \mathrm{Vm} . \\
9^{\mathrm{h}} 15^{\mathrm{m}} \\
12^{\mathrm{b}} \\
3^{\mathrm{h}} 15^{\mathrm{m}} \mathrm{Nm} . \\
6^{\mathrm{h}} 30^{\mathrm{m}} \\
7^{\mathrm{b}} 30^{\mathrm{hi}}\end{array}$ & $\begin{array}{l}\text { W } \\
\text { SOgS } \\
\mathrm{NO} \\
\mathrm{NWgW} \\
\mathrm{OgN} \\
\mathrm{NWgN}\end{array}$ & $\begin{array}{l}0,026 \\
0,098 \quad, \\
0,036 \quad " \\
0,130 \quad " \\
0,076 \quad " \\
0,140 \quad, " \\
\end{array}$ \\
\hline Januar 10. & 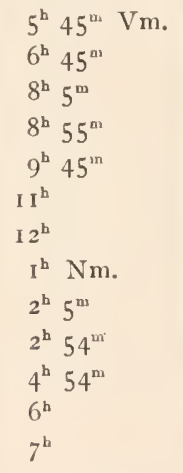 & $\begin{array}{l}\mathrm{O} \\
\mathrm{N} \\
\text { SSW } \\
\text { SWgS } \\
\text { W } \\
\mathrm{O} \\
\mathrm{SSO} \\
\mathrm{W} \\
\mathrm{W} \\
\mathrm{W} \\
\text { OgN } \\
\text { OgS } \\
\text { OgN }\end{array}$ & $\begin{array}{ll}0,055 & \text { Meter } \\
0,098 \quad " \\
0,142 \quad " \\
0,130 \quad " \\
0,084 \quad " \\
0,174 \quad " \\
0,022 \quad " \\
0,208 \quad " \\
0,216 \quad " \\
0,186 \quad " \\
0,065 \quad " \\
0,194 \quad " \\
0,136 \quad "\end{array}$ \\
\hline
\end{tabular}

Am 8. Januar beschreibt also die Spitze des Blüthenstiels in Io Stunden drei Viertel eines Kreises und bewegt sich dabei in gleicher Richtung wie der junge Schössling einer Winde, Bohne oder einer anderen $\mathrm{nach}$ rechts sich windenden Pflanze. Die Krümmung des in Bewegung begriffenen oberen Theiles erleidet dabei keine auffallende Veränderung; die Entfernung der Spitze von der Verticallinie beträgt $1 / 4$ bis $1 / 8$ von der Länge dieses oberen Theiles.

Am 9. Januar wird in gleicher Richtung fast die ganze Windrose $\left({ }^{29} /{ }_{32}\right)$, in $81 / 2$ Stunde (von $6^{\mathrm{h}} 45^{\mathrm{m}} \mathrm{Vm}$. bis $3^{\mathrm{h}} 15^{\mathrm{m}} \mathrm{Nm}$.) durchlaufen, aber statt eines Kreises beschreibt die Spitze jetzt eine langgezogene Ellipse, deren kleine Achse etwa ron $\mathrm{NO}$ nach SW gerichtet und etwa viermal in der grossen enthalten ist. Bei der ersten Beobachtung am Morgen und ebenso Mittags steht der Blüthenstiel fast aufrecht, während er in der Mitte des Vor- und Nachmittags stark gekrümmt 
ist. - Wahrscheinlich wurde von $3^{\mathrm{h}} 15^{\mathrm{m}}$ bis $7^{\mathrm{h}} 30^{\mathrm{m}}$ noch ein fast vollständiger Umlauf in gleicher Richtung gemacht. Ich sage „wahrscheinlich“, denn es muss unentschieden bleiben, ob die Spitze des Blüthenstieles von $3^{\mathrm{h}} 15^{\mathrm{m}}$ bis $6^{\mathrm{h}} 30^{\mathrm{m}}$ durch $\mathrm{S}$, oder durch $\mathrm{N}$ hindurch von $\mathrm{NWgW}$ nach OgN gelangte; da sie indess von da in der am vorigen und am Morgen dieses Tages befolgten Richtung weiter geht, erscheint die erstere Annahme, bei der die Drehungsrichtung sich nicht geändert haben würde, als die bei weitem wahrscheinlichere.

Am nächsten Tage (10. Januar) wird die Bewegung eine weit unregelmässigere. Am frühen Morgen macht das Ende des Blüthenstieles von $5^{\mathrm{h}} 45^{\mathrm{m}}$ bis $8^{\mathrm{h}} 5^{\mathrm{m}}$ fast $3 / 4$ eines Umgangs in des früheren Richtung von $\mathrm{O}$ durch $\mathrm{N}$ bis nach SSW; dann aber statt nach $\mathrm{S}$ weiter $\mathrm{zu}$ gehen, kehrt es nach $\mathrm{W}$ zurück und vollendet in etwas über vier Stunden einen ersten Umlauf in entgegengesetzter Richtung und bis $6^{\mathrm{h}}$ Abends fast $3 /{ }_{4}$ eines zweiten Umlaufs, um sich dann von Neuem in die frühere Richtung zurückzuwenden, indem es von $\mathrm{OgS}$ nach $\mathrm{O}$ statt nach $\mathrm{S}$ zu wandert

Dass beim Umkehren in die entgegengesetzte Richtung, sowohl am Morgen (zwischen $8^{\mathrm{h}} 5^{\mathrm{m}}$ und $8^{\mathrm{h}} 55^{\mathrm{m}}$ ), als am Abend (zwischen $4^{\mathrm{h}} 54^{\mathrm{m}}$ und $7^{\mathrm{h}}$ ) eine sehr bedeutende Verlangsamung der Bewegung sich zeigt, hat nichts Befremdendes. Sehr auffallend aber ist die fast vollständige Unbeweglichkeit, in welcher der stark gebogene Blüthenstiel von $1^{\mathrm{h}}$ bis $2^{\mathrm{h}} 54^{\mathrm{m}} \mathrm{Nm}$. verharrt, während er vorher in einer Stunde mehr als einen Viertelkreis durchlaufen hatte und nachher in zwei Stunden fast $180^{\circ}$ durchläuft. Auch abgesehen von diesem Stillstand und von der Verlangsamung in der Nähe der Wendepunkte ist die Winkelgeschwindigkeit eine sehr wechselnde, bald so rasch, dass ein Umlauf kaum $2 \frac{1}{2}$ Stunde, bald wieder so langsam, dass er über 5 Stunden erfordert haben würde. - In höchst unregelmässiger Weise wechselt endlich an diesem Tage die Krümmung des beweglichen Theiles des Blüthenstieles. Mittags steht seine Spitze ganz in der Nähe der Verticallinie, - eine Stunde später ist sie eine gute Spanne davon entfernt; und während ihr Weg während der ersten Morgenstunden sich auf eine Ellipse mit von N nach S gerichteter grossen Achse zurückführen lässt, beschreibt sie später eine ausserordentlich langgezogene Ellipse, deren grosse Achse von $W$ nach $\mathrm{O}$ gerichtet ist.

Die Unregelmässigkeiten der Bewegung während dieses dritten Tages, gegenüber der regelmässigen Bewegung des ersten Tages, mögen wenigstens zum Theil ihre Erklärung in dem Umstande finden, dass am ersten Tage nur ein einziges Stengelglied, das zwischen dem Ursprung der Aeste und dem ersten Deckblattwirtel gelegene, dass aber am dritten Tage deren drei in Bewegung waren. Vielleicht war (abgesehen von dem Stillstande am Nachmittage und dem zweimaligen Richtungswechsel), die Bewegung jedes einzelnen Gliedes eine ziemlich regelmässige - jedenfalls aber war ihre Winkelgeschwindigkeit eine verschiedene, denn bald waren sie alle drei nach gleicher Richtung gebogen (wie um I Uhr Nm.), bald krümmten sie sich nach verschiedenen, ja, das erste und dritte bisweilen nach fast entgegengesetzten Richtungen (wie am Mittag). Im ersten Falle musste natürlich die Entfernung der Spitze von der Verticallinie vermehrt, im zweiten vermindert werden und ebenso musste dadurch die Winkelgeschwindigkeit des ganzen beweglichen Theiles (dessen Richtung durch die einer vom Ursprung der drei Aeste nach der Spitze gezogenen Geraden bestimmt wurde) bald beschleunigt, bald verlangsamt erscheinen. 
Aehnliche Bewegungen, wie die Blüthenstiele unseres Alisma, vollführen bekanntlich die jungen Schösslinge aller windenden und vieler rankentragenden oder mittelst ihrer Blattstiele klimmenden Kletterpflanzen, bei denen diese Bewegungen durch Darwin so meisterhaft geschildert worden sind.

Dass bisher $n$ u r bei Kletterpflanzen derartige Bewegungen beobachtet wurden, dass sie als eine diesen a usschliesslich zukommende Eigenthümlichkeit erschienen, war eine ernste Schwierigkeit für Darwins Lehre von der Entstehung der Arten.

Dass die Fähigkeit des Windens, deren sich in einigen Fällen fast alle Arten einer grossen Familie erfreuen, in anderen auf vereinzelte Gattungen, oder selbst auf einzelne Arten einer Gattung (z. B. Valeriana) beschränkt ist, weist darauf hin, dass diese Fähigkeit zu sehr verschiedenen Zeiten erworben worden ist, und dass bis in die jüngste Zeit die Umwandlung nicht windender in windende Pflanzen fortgedauert hat. Ferner weist das Vorkommen windender Pflanzen in so verschiedenen Familien, wie es z. B. die Farn, die Dioscoreen, die Asclepiadeen, die Dilleniaceen sind, darauf hin, dass ihre Entstehung sich an eine im Pflanzenreiche weit verbreitete, von der natürlichen Zuchtwahl benutzte und weiter ausgebildete Lebenserscheinung geknüpft haben werde. Da nun das Winden jene eigenthümliche Bewegung der jungen Schösslinge zur nothwendigen Voraussetzung hat, da eine Pflanze nothwendig sich bewegen musste, ehe sie in einer Schraubenlinie sich an anderen emporwinden konnte, so durfte man eben in jener Bewegung diese die Entstehung der windenden Pflanzen vermittelnde Lebenserscheinung suchen, und mit Bestimmtheit erwarten, ähnliche Bewegungen an nicht kletternden Pflanzen auffinden zu können. Es ist zu verwundern, dass Darwins Gegner seinen Freunden noch nicht diese Schwierigkeit vorgehalten, an sie noch nicht die Forderung gestellt haben, solche Bewegungen nicht kletternder Pflanzen - als nothwendige Vorbedingung für die Möglichkeit des Entstehens windender aus nicht windenden Pflanzen - nachzuweisen.

Jetzt würde eine solche Forderung zu spät kommen. Unser Alisma zeigt in der That so deutlich, als irgend eine Kletterpflanze, dies ,spontaneous revolving movement". Ich habe Grund, das Vorkommen ähnlicher Bewegungen bei einigen anderen Pflanzen zu vermuthen, und kann sogar meinen deutschen Landsleuten eine im alten Vaterlande häufig gebaute Pflanze bezeichnen, die wie Alisma kurz vor der Blüthezeit die Stengelspitze im Kreise herumdreht. Es ist der gemeine Lein. Meine Kinder hatten sich vor mehreren Jahren eine Pflanze dieser ihnen bis dahin nur dem Namen nach bekannten Art gezogen und an dieser machte mich meine Tochter Rosa auf die Bewegung aufmerksam. Ich konnte mich mit Sicherheit von deren Vorhandensein überzeugen, wurde aber durch die Ungunst der Witterung gehindert, sie mehrere Tage genauer zu verfolgen.

It ajahy, Februar i 868. 


\title{
Bemerkungen über Cypridina ${ }^{1}$ ).
}

\author{
Mit Tafel XXXIV und XXXV.
}

Die folgenden Bemerkungen über Cypridina stützten sich auf die Untersuchung von drei Arten, die bei Desterro in der Nähe des Strandes gefangen wurden. Zwei derselben, Cypridina Agassizii (Fig. I3-26) und C. nitidula (Fig. 9-12), tragen Kiemen und schliessen sich im Bau der Gliedmaassen an Grube's C. oblonga an. Die dritte, C. Grubii (Fig. 1-8), ist kiemenlos und erinnert durch zwei auffallend lange Endborsten der Fühler an Philomedes longicornis Lilj. - Ich behalte für alle drei, wie überhaupt für alle Muschelkrebse, die seitliche Augen und die bekannten "geringelten Anhänge“ besitzen, den Namen Cypridina bei; denn so lange nicht der Bau der Gliedmaassen bei der Mehrzahl der bekannten Arten so weit erforscht ist, dass man den systematischen Werth der einzelnen Merkmale und die verwandtschaftlichen Beziehungen der einzelnen Arten mit einiger Sicherheit übersehen kann, erscheint mir die Spaltung der Gattung verfrüht.

\section{Dergriffelförmige Stirnanhang.}

Grube sah bei Cypridina oblonga einen dünnen, griffelförmigen, zweigliedrigen Anhang, der ihm innen am Grunde der Fühler zu sitzen schien, jedoch nur einmal, und zwar auf der rechten Seite bemerkt wurde ${ }^{2}$. Ueber dessen Bedeutung blieb er im Ungewissen. - Einen ähnlichen Anhang besitzen die von mir beobachteten Cypridinen. Er ist in der That nur einmal vorhanden, entspringt aber nicht vom Grundgliede der Fühler, sondern in der Mittellinie, dicht unter dem grossen unpaaren Auge.

Von besonderer Länge, fast so lang wie der Endschenkel der knieförmigen Fühler, ist der griffelförmige Anhang bei Cypridina Grubii (Fig. 2 $a$, Fig. 3). Wie bei C. oblonga besteht derselbe aus zwei Abtheilungen oder Gliedern. Das Grundglied ist etwas kürzer und dicker als das Endglied und seine Haut derber; gegen das Ende ist es schwach kolbig angeschwollen. Man erkennt in seinem Innern Längsstreifung, die wohl von zarten Fasern herrührt und zwischen den Fasern sind in dem kolbig verdickten Theile feine Körnchen eingelagert (Fig. $3 a$ ).

I) Jenaische Zeitschrift für Naturwissenschaft 1870. V. p. 255-276. Taf. VIII u, IX.

2) Archiv für Naturgesch. XXV, Bd. I, S. 332. - Taf. XTI, Fig 5, $a$; Fig. A, $a$. 
Das zarthäutige Endglied, das sich gegen die Spitze schwach verjüngt und abgerundet endet, hat einen ganz wasserhellen Inhalt.

Bei Cypridina Agassizii hat der griffelförmige Anhang (Fig. $20 a$, Fig. 2 I) etwa die halbe Länge des Endschenkels der Fühler. Er sitzt auf einem besonderen Vorsprunge dicht unterhalb des mittleren Auges; seine beiden Glieder sind von etwa gleicher Länge, das Grundglied aber ist nur halb so dick als das Endglied, gegen das Ende halsartig eingeschnürt und am Grunde mit einem doppelten Kranze zartester Härchen umgeben. Das Endglied ist am Grunde bauchig angeschwollen und nach dem abgerundeten Ende zu schwach verjüngt.

Bei Cypridina nitidula erschien, an einem in Holzessig getödteten Thiere, der Anhang als einfacher ungegliederter, am Grunde etwas verdickter Stab mit abgerundeter Spitze.

Man wird diesen Stirnanhang der Cypridinen als Sinneswerkzeug betrachten dürfen; welcherlei Empfindungen es vermittle, darüber wage ich keine Vermuthung. Ein „frontales Sinnesorgan“, das freilich nur in seiner Lage mit dem der Cypridinen übereinstimmt, wurde bekanntlich von Claus bei verschiedenen Copepoden nachgewiesen ${ }^{1}$ ).

\section{Die Putzfüsse.}

Die Cypridinen besitzen jederseits etwa in der Mitte der Körperlänge einen langen, dünnen, "geringelten Anhang“ (Fig. I5 h, Fig. 19), der nach dem Rücken in die Höhe steigt und gegen die Spitze hin mehr oder minder zahlreiche, steife, spitze Borsten trägt, welche ihrerseits wieder mit kurzen, spitzen Dörnchen besetzt sind. Milne Edwards deutete diese Anhänge als „pattes ovifères“" ${ }^{2}$ ) und alle späteren Beobachter, die sich überhaupt über deren Verrichtung ausgesprochen haben, sind ihm in dieser Deutung gefolgt; so Baird, Grube und Claus. Grube erinnert dabei „an das ganz ähnlich gebildete Organ, welches beim Weibchen von Limnetis brachyurus als Rückenast des 9. und ro. Fusspaars auftritt und hier nicht zum Halten, sondern zum Tragen der Eier dient, indem sie sich um dasselbe zu einem Klumpen backen". - Eier hat freilich Niemand weder an diesen „eiertragenden Füssen“, noch überhaupt innerhalb der Schale von Cypridina gesehen, und so hätte man sich wenigstens wie Grube auf eine blosse Vermuthung beschränken und nicht wie Andere jene Deutung als ausgemachte Thatsache hinstellen sollen.

Bekanntlich wurde bei $\mathrm{Cy}$ pris dem letzten Fusspaare ebenso allgemein und ebenso ohne jede thatsächliche Begründung dieselbe Leistung zugeschrieben, bis W. Zencker die jedenfalls richtigere Ansicht aussprach, dass diese ebenfalls aufwärts gebogenen, sehr beweglichen Füsse dazu dienen, „die grosse Kiemenplatte mit ihren gefiederten Haaren zu reinigen“3). Das hätte auch für die geringelten Anhänge der Cypridinen auf den rechten Weg leiten können. Dieselben sind in der That nichts Anderes als Putzfüsse. Beobachtet man eine lebende Cypridina nitidula oder eine C. Agassizii mit nicht zu undurchsichtiger Schale,

\footnotetext{
1) Claus, die freilebenden Copepoden. S. 55. Taf. XXXI, Fig. 17.

2) Milne Edwards, Hist. nat. des Crustacés. Explication des Planches, pag. 28.

3) W. Zenker, Studien über die Krebsthiere. S. 17.
} 
so sieht man die geringelten Anhänge, die mit ihrem meist rechtwinklig abstehenden Borstenbesatz fast wie die Bürsten aussehen, deren man sich zum Reinigen von Glascylindern bedient, in fast ununterbrochener, lebhafter Bewegung. Einem Ringelwurm vergleichbar, der aus seiner Röhre weit vorgestreckt nach allen Seiten umhertastet, kriechen sie und biegen sie sich nach allen Richtungen; namentlich an den Kiemen und in deren Umgebung fegen sie und putzen sie fleissig hin und her. Mit den Eiern, die allerdings wenigstens bei C. Agassizii innerhalb der Schale der Mutter sich entwickeln, haben sie nichts zu schaffen. Sie sind bei beiden Geschlechtern in völlig gleicher Weise ausgebildet.

Ich habe die ,geringelten Anhänge" Putzfüsse genannt und damit schon ausgesprochen, dass ich sie als ein Gliedmaassenpaar betrachte; auch von Milne Edwards, Baird und Dana werden sie als Füsse bezeichnet (pattes ovifères, oviferous feet, pes ad ova pertinens). Grube, der sie, wie erwähnt, dem Rückenast des 9. und 10. Fusspaares der weiblichen Limnetis vergleicht, sagt von ihnen: „Bei Cypridina scheint es gar nicht mehr zur Bildung einer freien Fussplatte $\mathrm{zu}$ kommen und blos dieser Anhang ausgebildet $\mathrm{zu}$ sein." Gegen diese Auffassung ist einzuwenden, dass die hinteren Füsse der Muschelkrebse (Cypris, Cythere) gar keinen Rückenast, sondern überhaupt nur eine einzige Gliederreihe besitzen, also ihr gar nicht vorhandener Rückenast sich nicht wohl in den geringelten Anhang umwandeln konnte. Zudem ist auf den Vergleich mit den Eierträgern der Phyllopoden kaum Gewicht zu legen, da die Aehnlichkeit der letzteren mit den Putzfüssen der Cypridinen sich darauf beschränkt, dass beide nach oben gerichtet sind; im Uebrigen ist ihr Bau so verschieden, als ihre Verrichtung; jene sind ungegliederte, nackte Fäden, diese in zahlreiche Ringe gegliedert und mit ansehnlichen Borsten bewehrt. Nach Claus ${ }^{1}$ ) „erscheint das letzte Extremitätenpaar der Muschelkrebse nach dem Rücken zu emporgerichtet, verkümmert zuweilen und wird in seiner Leistung durch einen gekrümmten, geringelten Faden ersetzt, welcher zum Tragen der Eier unterhalb der Schale dient (Cypridina).“ Danach scheint Claus, wenn ich ihn recht verstehe, die ,geringelten Fäden" nicht als das umgewandelte Fusspaar, sondern als ein selbständig entstandenes Gebilde zu betrachten, das die Arbeit des verloren gegangenen Fusspaares übernommen hat. Man würde bei dieser Ansicht sich die Verkümmerung des Fusspaares als Folge der Ausbildung der geringelten Fäden denken können, die seine Arbeit besser verrichteten und es dadurch entbehrlich machten, etwa wie bei einigen Acanthaceen ( $\mathrm{Mendozia)} \mathrm{der} \mathrm{Kelch} \mathrm{verkümmert,} \mathrm{weil} \mathrm{er} \mathrm{durch} \mathrm{die}$ Deckblätter entbehrlich gemacht worden ist.

Einfacher jedoch und natürlicher scheint mir die Annahme, dass die geringelten Anhänge der Cypridinen nichts Anderes sind, als eben das umgewandelte letzte Fusspaar der Muschelkrebse. Bei Cythere schen wir dieses Fusspaar in seiner ursprünglichen Form und Verrichtung, dem vorhergehenden gleichend, abwärts gerichtet, der Ortsbewegung dienend. Bei Cypris ist dasselbe Fusspaar schon nach hinten und oben gebogen und $\mathrm{zu}$ einer neuen Leistung verwendet, doch im Bau noch sehr wenig verändert; nur sind seine Glieder länger, schmächtiger geworden und haben, wie mir scheint, eine bedeutend grössere Beweglichkeit

I) Claus, Grundzüge der Zoologie, 1866. S. 208. 
crlangt; auch die Endklaue ist sehr beweglich und bisweilen (nach Zenker) kammartig gezähnt. Bei C y pridina sind die Putzfüsse in hohem Grade für ihre neue Verrichtung vervollkommnet worden; ihre Beweglichkeit ist auf's Höchste gesteigert, indem ihre Glieder in zahlreiche Ringel zerfallen sind, wie es ja auch mit einzelnen Gliedern an verschiedenen Fusspaaren mancher Garneelen (Lysmata, Stenopus) der Fall ist, und statt der spärlichen Borsten von gewöhnlichem Bau, die sich bei Cypris finden, sind sie mit einer vortrefflichen Bürste ausgerüstet.

Bei dieser Gelegenheit darf ich wohl darauf hinweisen, dass trefflich ausgerüstete Putzfüsse auch unter den höheren Krustern, bei Porcellana, Hippa und Pagurus vorkommen. Es sind dieses die ebenfalls nach dem Rücken in die Höhe geschlagenen, aus dünnen, sehr beweglich mit einander verbundenen Gliedern gebildeten Füsse des letzten Brustringes, die man bisher allgemein als „,verkümmerte“ (Milne-Edwards, Troschel. Vogt, Gerstäcker, Claus etc.), „scheinbar überflüssige" (Vogt) Anhänge betrachtet hat. Ich wurde auf ihre Bedeutung zuerst aufmerksam bei einer Porcellana (Polyonyx Creplinii F. M.), die sich in der Röhre von Chaetopterus aufhält und welcher wegen des reichlichen Schleimes, den ihr Wirth absondert, Reinlichkeit besonders Noth thut. Ich hielt ein eiertragendes Weibchen dieser Art einige Zeit lebendig und dieses liess die durch Länge und Beweglichkeit ausgezeichneten Putzfüsse fast nie ruhen; bald senkte es sie tief in die Kiemenhöhle, bald kehrte es seinen Rücken ab, und bald fuhr es damit zwischen den Eiern herum wie ein Bäcker, der Teig knetet. Später habe ich auch bei anderen Porcellanen, bei Hippa und bei Pagurus die Putzfüsse in Thätigkeit gesehen; sie dienen bei diesen Thieren hauptsächlich zum Reinigen der Kiemenhöhle. Ihre letzten Glieder sind sehr reichlich mit mannichfach gestalteten Borsten besetzt, die Bürsten, Kämme etc. darstellen; bei Hippa sind ausserdem an diesen Putzfüssen die Innenränder der Scheere sehr zierlich gezähnelt. Wäre man nicht gewöhnt gewesen, die Bezeichnung „rudimentär“ und andere, die früher eine nur bildliche Bedeutung hatten, eben deshalb ziemlich leichtfertig und gedankenlos anzuwenden, so hätte der erste Blick auf ihre prächtige Beborstung überzeugen müssen, dass man in diesen Putzfüssen der Anomuren nicht verkümmerte Füsse vor sich habe, sondern im Gegentheil für eine besondere, sehr wichtige Verrichtung umgestaltete und zu grosser Vollkommenheit ausgebildete Gliedmassen. Bei den Krabben, die keine besonderen Putzfüsse haben, wird, beiläufig bemerkt, die Reinigung der Kiemen durch die in der Kiemenhöhle spielenden Anhänge der Kieferfüsse besorgt, deren Borstenbesatz eine reiche Musterkarte verschiedener Kanmformen bietet.

\section{Die Riechfäden und Spürborsten der Fühler.}

Die Fühler (antennes supérieures pédiformes M. Edw.) sind bei verschiedenen Arten von Cypridina in verschiedener Weise gegliedert und mit Borsten ausgerüstet; selbst die beiden Geschlechter derselben Art zeigen Verschiedenheiten in dieser Beziehung und mehr noch in der Ausbildung der Riechfäden.

Von Cypridina Grubi i habe ich nur Männchen gesehen. Die Fühler (Fig. 2, b. Fig. 4) zeigen sechs deutliche Glieder; das erste ist wie gewöhnlich borstenlos und bildet mit dem folgenden ein Knie; das zweite und dritte tragen 
nur wenige kurze Borsten; am Ende des vierten stehen, und zwar an der Unterseite, drei längere, gerade, einfache Borsten und über ihnen die Riechfädenborste (Fig. 4, a). Diese ist mehr als doppelt so lang als die beiden Endglieder des Fühlers zusammen und läuft wie eine gewöhnliche Borste in eine feine dunkelgerandete Spitze aus; ihr unteres Drittel ist spindelförmig verdickt und das zweite Sechstel ihrer Länge an der Unterseite mit einem dichten Büschel zahlreicher Riechfäden besetzt, deren Länge etwa der halben Länge der Borste gleichkommt. Am Ende des letzten Fühlergliedes stehen 5 (oder 6 ?) grössere Borsten, von denen 4 eine besondere Erwähnung verdienen. Zwei derselben (Fig. 4, $\gamma$ ) laufen nämlich nicht in eine scharfe, dunkelrandige Spitze aus, sondern in einen walzenförmigen, am Ende abgerundeten, sehr zarthäutigen Faden, der ganz das Aussehen eines Riechfadens hat. Die beiden anderen Borsten (Fig. 4, $\delta$ ) zeichnen sich durch ihre grosse Länge aus, welche die des ganzen Fühlers übertrifft; in der ersten Hälfte ihrer Länge trägt jede derselben eine Reihe von sieben kurzen Haaren; die beiden ersten sind gewöhnliche Haare, die fünf folgenden zartwandig, Riechfäden ähnlich.

Beim Männchen von Cypridina Agassizii (Fig. 20, b) ist die Gliederung der Fühler ziemlich dieselbe, wie bei C. Grubii, nur sind das 5. und 6. Glied auf der Unterseite mit einander verschmolzen; oberhalb sind sie deutlich geschieden; an den Seiten verläuft die Grenzlinie, allmählich undeutlicher werdend, schief nach unten und hinten. Die Borsten am Ende des Fühlers scheinen von einem besonderen, ganz kurzen siebenten Gliede getragen zu werden. - Der Riechfädenbüschel (Fig. 20, Fig. 22) steht an derselben Stelle wie bei C. Grubii und ist so mächtig und eigenthümlich entwickelt, dass man ihn auf den ersten Blick eher für einen besonderen Ast des Fühlers, als für eine umgewandelte Borste nehmen möchte. Es fehlt nämlich das nackte Ende der Borste, welches dieselbe bei C. Grubii sofort als solche erkennen lässt; der spindelförmig geschwollene Theil, hier allein vorhanden, reicht etwa bis zum Ende des Fühlers; seine grösste Dicke kommt etwa einem Viertel seiner Länge gleich. Seine Wand ist dick, stark und unregelmässig quer gerunzelt. Die Riechfäden stehen in etwa sechs Gruppen am oberen, in etwa fünf am unteren Rande; auch die Spitze gabelt sich in mehrere Riechfäden. Nach aussen und hinten vom Riechfädenbüschel steht eine gewöhnliche Borste. Am Ende des sechsten Gliedes und zwar an der Unterseite steht eine starke Borste, die am Ende in zwei kurze, dünnwandige Fäden mit abgerundeter Spitze ausläuft. - Unter den Endborsten des Fühlers sind hervorzuheben: eine starke, klauenartige Borste (Fig. I7, 8 ) mit leicht aufwärts gebogener Spitze, etwa so lang wie das 5. und 8. Glied zusammen, und eine Borste (Fig. 17, $\gamma$ ), die dünner als die übrigen ist und in einen zarthäutigen Faden mit abgerundeter Spitze ausläuft.

Beim Weibchen von Cypridina Agassizii (Fig. I7) steht an der Stelle des Riechfädenbüschels eine gewöhnliche Borste (Fig. I 7, $a$ ); am Ende des folgenden Gliedes (wahrscheinlich dem 5. und 6. des Männchens entsprechend) findet sich, an gleicher Stelle, wie am 6. Gliede des Männchens, eine ähnliche Borste wie bei jenen, die aber am Ende in drei (bisweilen vier?) Fäden sich spaltet. (Fig. 17, $\beta$ ). Die Endborsten gleichen denen des Männchens; doch sah ich nur an einer derselben, die durch S-förmige Krümmung sich auszeichnet (Fig. I7, d), drei kurze, blasse, seitliche Fäden, während solche beim Männchen zahlreicher vorkommen. 
Bei dem Weibchen von Cypridina nitidula ist die Beborstung der Fühler (Fig. I I) fast ganz wie bei C. oblonga Gr. - Bei letzterer sind das dritte und vierte Glied der Fühler von C. Grubii und C. Agassizii in eins verschmolzen; bei C. $\mathrm{n}$ it idula verschmelzen damit auch noch die beiden folgenden Glieder. Dagegen ist das Endglied (beim Männchen von C. Agassizii das 7.) sehr deutlich abgesetzt. Die Riechfädenborste ist dicker und kürzer, die sechs Riechfäden an deren Ende dagegen viel länger, als bei C. oblonga. Unter den Endborsten läuft, wie bei C. Agassizii, eine (Fig. II, $\gamma^{\prime}$ in eine riechfadenähnliche Spitze aus.

Bei einem Männchen (Fig. 9), das vermuthlich zu derselben Art gehört, bildeten die Riechfäden ein dichtes Büschel wie bei C. Agassizii, während zwei der Endborsten ungemein verlängert sind, wie bei C. Grubii.

Ich kann mich nicht entsinnen, bei anderen Krustern Fächer oder Büschel von Riechfäden am Ende oder an der Seite gewöhnlicher Borsten gesehen zu haben. Die Endborsten mit zarthäutigem Endfaden, dessen abgerundete Spitze bisweilen das Licht etwas stärker bricht, sind gewöhnlichen Riechfäden schon ähnlicher. Was schon Claus als wahrscheinlich aussprach, dass,die Riechfäden „morphologisch den dunkel contourirten Haaren und Borsten entsprechen möchten “ ${ }^{1}$, wird durch ihr Verhalten bei Cypridina zur Gewissheit. - Ebenso eigenthümlich sind die zarten, seitlichen Fädchen an einzelnen Endborsten, namentlich an den beiden langen Borsten der C. Grubii. Diese langen Endborsten, die Liljeborg als Gattungsmerkmal verwerthet, dürften eine Eigenthümlichkeit des männlichen Geschlechtes sein und als Spürborsten beim Aufsuchen der Weibchen dienen; ich habe sie wenigstens nur bei männlichen Thieren gefunden ${ }^{2}$ ).

\section{Die Schwim m füsse}

(,pattes natatoires“ M. Edw. „Aeussere Antennen“ Grube).

Zunächst ein Wort über die Benennung dieses Gliedmaassenpaares, für welches ich die ältere Bezeichnung von Milne Edwards beibehalte, trotzdem kein Zweifel darüber obwalten kann, dass es dem zweiten Fühlerpaare der höheren Kruster entspricht. - Es mag zweckmässig scheinen, einander entsprechende (homologe) Theile überall mit gleichem Namen zu belegen, obwohl ich nichts Uebles darin finden kann, dass wir beim Fisch von Brustflossen, beim Vogel von Flügeln, beim Hunde von Vorderbeinen, beim Menschen von Armen reden. Will man aber gemeinsame Bezeichnungen für Reihen entsprechender Theile einführen, so sollten dieselben so gewählt sein, dass sie entweder überhaupt nichts über deren

I) Claus, die freilebenden Copepoden. 1863. S. 55 .

2) Man elinnert sich, dass bei den Männchen einiger anderen Kruster die hinteren Fühler ausserordentlich verlängert sind; so bei den $\mathrm{Cum}$ a ceen und einigen Hyperinen (den Hypériens anormales M. Edw.). Dabei sind diese Fühler so dünn und muskelschwach, dass sie nicht zum Halten, sondern offenbar nur zum Aufspüren der Weibchen dienen können. Beachtenswerth ist, dass dieselben Fühler, die bei den Männchen so ungewöhnlich verlängert sind, bei den Weibchen sowohl der Cumaceen, als der Hypériens anormales verkümmern, oder sogar (in der Gattung Brachyscelus Sp. Bate) ganz fehlen. Ohne dies Verhalten damit vollständig erklären zu wollen, will ich darauf hinweisen, dass die Männchen diese Fühler nur dann in den ausschliesslichen Dienst des Geschlechtslebens ziehen konnten, wenn ihnen keine anderweitige wichtige Leistung oblag. In diesem Falle aber, wenn sie anderweitig entbehrlich waren, konnten sie bei den Weibchen leicht verkümmern. 
Verrichtung aussagen, oder wenigstens von der ursprünglichen Verrichtung derselben ausgehen. Es liesse sich etwa rechtfertigen, die Flügel der Vögel als Vorderbeine zu bezeichnen; es wäre geradezu lächerlich, die Vorderbeine des Hundes Flügel zu nennen. Und ganz ebenso wie die Flügel umgervandelte Beine, nicht aber die Beine umgewandelte Flügel sind, so sind auch die Fühler der Kruster umgewandelte Schwimmfüsse, nicht aber die Schwimmfüsse von Cypridina, Daphnia etc. umgewandelte Fühler. Es scheint mir daher verkehrt, sie Fühler (Antennen) zu nennen, blos weil sie bei andern Krustern zu Fühlern geworden sind $\left.{ }^{1}\right)$.

Das dicke, muskelreiche Grundglied und die langborstige Geissel der Schwimmfüsse (Fig. 2, Fig. 15, Fig. 20,c) wiederholen sich in sehr gleichförmiger Weise bei allen Cypridinen; um so mannichfacher gestaltet sich nach Art und Geschlecht der innere oder Nebenast dieser Füsse. Er wurde von Baird

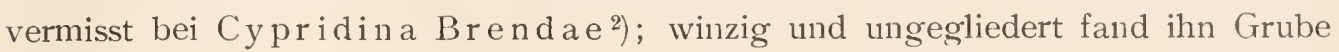
bei C. oblonga; zweigliedrig, mit zwei kurzen, gekrümmten Endklauen ist er nach Baird bei C. Mac Andrei ${ }^{3}$ ). Die von Baird und Grube untersuchten Thiere waren vermuthlich Weibchen. Ziveigliedrig ist der Nebenast auch bei dem Weibchen von Cypridina Agassizii (Fig. I8, $\gamma$ ); das erste Glied ist kurz das zweite reichlich dreimal so lang, fast so lang, wie das dicke Grundglied des Fusses, es ist mit zarten Härchen besetzt, gegen das Ende verjüngt und trägt eine einzige, ihm an Länge etwa gleichkommende Endborste.

Bei den Männchen von Cypridina A gassizii (Fig. 23, $\gamma$ ), und C. Grubii (Fig. 5), sowie bei dem vermuthlich zu C. nitidula gehörigen Männchen ist dieser Nebenast der Schwimmfüsse dagegen dreigliedrig und bildet ein Greifwerkzeug, indem das Endglied sich klauenartig gegen das zweite Glied einschlägt. Bei C. Agassizii und nitidula ist das Endglied um etwa ein Drittel kürzer, bei C. Grubii fast eben so lang, als das zweite Glied; bei den beiden ersten Arten ist das Endglied nach der scharfen Spitze zu verjüngt und hat einen glatten Greifrand; bei C. Grubii ist es in ganzer Länge gleich breit, gegen das Ende stark gekrümmt, am Ende abgerundet und sein Greifrand ist mit einigen Höckerchen besetzt. In der Nähe des Gelenkes trägt das Endglied auf der Aussenseite eine Borste, die bei Cypridina Grubi nur kurz, bei C. Agassizii länger als das Endglied selbst und noch länger bei C. nitidula ist.

5. Die Kinnbackenfüsse. („Pedes mandibulares“ Dana. „Mandibelpalpen“ Grube.) (Fig. 6. Fig. 1 2. Fig. 15, d. Fig. 20, d. Fig. 24 und 25.)

Für Füsse, die an ihrem Grundgliede einen dem Kinnbacken der höheren Kruster entsprechenden Kaufortsatz tragen, ist wohl kein treffenderer Name zu finden, als der ihnen von Dana beigelegte der Kinnbackenfüsse (pedes mandibulares).

I) Wenn Milne Edwards (Hist. nat, des Crust. III. pag. 4II) von den Copepoden sagt: „les antennes... de la seconde paire manquent quelquefois et sont d'autres fois transformées en rames", so ist Letzteres, wie wir jetzt durch Claus wissen, geradezu falsch; sie sind gerade in diesem Falle $\mathrm{nicht}$ umgew andelt, sondern haben ihre ursprïngliche Form und Verrichtung beibehalten.

2) Baird, Nat. Hist. of the British Entomostraca, S. I82. Tab. XXIII, Fig. 6.

3) Baird, a. a. O. S. I8o. Taf. XXII, Fig. 6. 
Grube hat das, was ich mit Dana und Claus Kinnbackenfüsse nenne, Kinnbackentaster (oder vielmehr in wissenschaftlicherem Deutsch: „Ma n dibelpalpen") genannt und noch andere wahrscheinlich den beiden folgenden Gliedmaassenpaaren zugehörige Theile als "sichelförmigen Anhang“ (Fig. I5, e) und ,Mandibellade" (Fig. 15, $\left.f^{1}\right)$ ) demselben Fusspaare zugerechnet. Letzteres ist schon aus dem Grunde nicht gerechtfertigt, weil die Kinmbackenfüsse alle Theile wirklich besitzen, auf die sie irgend rechtmässiger Weise Anspruch machen können. Aber auch abgesehen davon ist die Bezeichnung Kinnbackentaster nicht passend. Bei den $\mathrm{N}$ a uplius der Copepoden wie der höheren Kruster (Penëus) sind clie Gliedmaassen des dritten Paares zweiästige Schwimmfüsse; im Grundgliede derselben entsteht später ein Kaufortsatz, der Kinnbacken (Mandibel). In diesem Zustande verharren sie bei den Muschelkrebsen und vielen Copepoden. Bei diesen Thieren ist also, wie Claus ${ }^{2}$ ) richtig hervorhebt, der sogenannte Taster "der primäre Theil und nichts Anderes, als der Larvenfuss selbst, während wir den Kautheil als ein secundäres Product des basalen Gliedes anzusehen haben". Die Nauplius von Penëus verlieren nun beim Uebergang in die Zoëa-Form diesen „Taster“ vollständig; es bleibt ihnen nur der anhanglose Kautheil. Ebenso sind die Kinnbacken aller unmittelbar dem Ei entschlüpfenden Zoëa stets tasterlos. Erst in weit späterer Zeit sprosst bei vielen höheren Krustern aus dem anhanglosen Kinnbacken wieder ein Taster hervor. Hier ist also der Kautheil das Frühere, der Taster das später Entstehende, gerade umgekehrt wie bei den Muschelkrebsen und Copepoden. Möglich wäre es nun allerdings, dass dieser Taster nichts Anderes ist, als der wieder erschienene und zu einem neuen Dienste verwandte Schwimmfuss des Nauplius, dass also die ,Mandibelpalpen" der höheren und niederen Kruster wirklich homolog sind. Es ist ja nichts Seltenes, namentlich bei Pflanzen, dass längst verlorene Theile gelegentlich wiedererscheinen und auch dafür, dass solche wiedererschienene Theile auf's Neue durch natürliche Züchtung befestigt und zu einer bleibenden Eigenthümlichkeit der Art werden, könnte ich wenigstens ein schlagendes Beispiel geben. - Ebenso möglich ist es aber, dass der gegliederte Anhang am Kinnbacken der höheren Kruster eine Neubildung ist, die mit dem Schwimmfusse des Na uplius in keinem Zusammenhang steht. Neue Gliederreihen haben sich ja an den ursprünglich cinfachen vorderen Fühlern vieler höheren Kruster entivickelt. - Die Bezeichnung des dritten Gliedmaassenpaares der Cypridinen als Kinnbackentaster (Mandibelpalpe) ist daher voreilig, wenn dadurch ausgedrückt werden soll, dass es dem Kinnbackentaster der höheren Kruster entspricht; denn diese Annahme ist unerwiesen und wie mir scheint uncrweisbar. Wäre sie erwiesen, so würde die Bezeichnung dennoch verkehrt sein, weil nicht die Taster der höheren Kruster, sondern die Schwimmfüsse des Nauplius und die ihnen noch so ähnlichen Kinnbackenfüsse der Cypridinen die ursprüngliche Form darstellen. Unpassend wäre endlich der Name "Taster" auch, wenn er die Leistung dieser Gliedmaassen bezeichnen sollte, die offenbar mehr mit der Ortsbewegung des Thieres und dem Herbeischaffen der Nahrung, als mit dem Betasten zu thun haben. Nach alledem darf wohl die Bezeichnung „Mandibelpalpen“ als ungeeignet zurückgewiesen werden.

1) Im Original irrtiumlich I $_{5}, e$.

2) Claus, die freilebenden Copepoden, S. 26. 
Wie Zenker bei Cypris und Cythere, Baird bei Cypridina Brendae und Grube bei C. oblonga, zähle auch ich an den Kinnbackenfüssen fünf Glieder.

Das kurze erste Glied trägt bei Cypridina Agassizii und nitidula einen säbelförmigen, nach innen und oben gerichteten Fortsatz, den Kinnbacken. Fig. 12, $\alpha$. Fig. 25.) - Bei C. Grubii habe ich denselben nicht gesehen. Der gewölbte Rand des säbelförmigen Kinnbackens ist bei C. Agassizii (Fig. 25) in seiner unteren Hälfte mit mehreren (vier) Gruppen kurzer, steifer Haare besetzt, in seiner oberen Hälfte mit sechs zahnartigen Vorsprüngen versehen, von denen der unterste ziemlich lang und scharf, die beiden obersten ganz flach und stumpf sind. Die Spitze des Kinnbackens ist abgerundet und trägt zwei Borsten, die eine kürzer, dicker, gerade, blass, die andere eine gewöhnliche Borste, länger, dünner, gebogen. Unter der Spitze findet sich am gewölbten Rande des Kinnbackens ein flacher Ausschnitt, der mit feinen Härchen besetzt ist und an seinem oberen Ende eine blasse, abwärts gerichtete Borste trägt. Man fühlt sich versucht, die zarten Härchen als Schmeckhärchen zu deuten. - Die Haare und die zahnartigen Vorsprünge des gewölbten Randes finden sich auch bei Cypridina nitidula; der Kinnbacken endet bei dieser Art in eine scharfe Spitze.

Das zweite Glied des Kinnbackenfusses hat bei C. Agassizii und nitidula an seiner hinteren, unteren Ecke einen rückwärts gerichteten Vorsprung (Fig. I 2, $\beta$. Fig. 24, $\beta$ ), der am Ende vier steife Borsten trägt. Bei C. Grubii fehlt derselbe.

Am Ende des zweiten Gliedes steht bei C. Agassizii ein kleiner ungegliederter, dem Hauptaste gleichlaufender Nebenast (Fig. 24, $\gamma$ ), den ich bei C. nitidula und C. Grubii nicht gesehen habe.

In Betreff der bei den einzelnen Arten ziemlich verschiedenen Beborstung der Kinnbackenfüsse verweise ich auf die Abbildungen (Fig. 6, Fig. 12, Fig. 24). - Man erkennt sofort die wesentliche Uebereinstimmung dieses Fusspaares, einerseits mit dem dritten Gliedmaassenpaare der älteren $\mathrm{Nauplius,}$ andererseits mit dem Kinnbacken (dem ersten Kieferpaar nach Zenker) von Cythere und Cypris, zwischen denen es in mancher Hinsicht in der Mitte steht. Wie bei Nauplius überwiegt der eigentliche Fuss an Masse bedeutend den Kaufortsatz und der Nebenast hat gleiche Richtung mit dem Hauptaste. Bei Cythere und Cypris erscheint der Fuss nur noch als Anhang des Kinnbackens, der Nebenast hat sich senkrecht zum Hauptaste gestellt und ausserdem bei Cypris in ein zartes, dreieckiges mit breiten gefiederten Haaren besetztes Blatt verwandelt.

Es versteht sich nach diesem Hinblick auf $\mathrm{N}$ auplius und $\mathrm{Cy}$ there von selbst, dass man nicht nach noch anderen etwa diesem Fusspaare zuzurechnenden Theilen zu suchen hat, und dass die von Grube als „säbelförmiger Anhang“ und "Mandibellade" bezeichneten Theile ihm nicht zugehören können.

Fühler, Schwimmfüsse, Kinnbackenfüsse und Putzfüsse sind bei allen C y p r idinen in ziemlich übereinstimmender Weise gebildet; was zwischen Kinnbackenfüssen und Putzfüssen liegt, bietet dagegen bei den verschiedenen Arten eine in einem Kreise so engverwandter Formen ganz ungewöhnliche Verschiedenheit dar. Diese Theile, die in ihrer Gesammtheit dem 4., 5. und 6. Gliedmaassenpaare von 
Cypris und Cythere entsprechen, sind ebenso schwierig zu untersuchen als zu deuten. Die von Milne Edwards, Liljeborg und Grube gegebenen Deutungen schreben völlig in der Luft; den Aufsatz von Claus ,über die Organisation der Cypridinen" kenne ich leider nicht. Ich selbst habe nur bei Cypridina Agassizii eine einigermassen befriedigende Einsicht in Bau und Zusammenhang dieser Glieđmaassen gewonnen, würde aber auch für diese Art über deren Deutung im Einzelnen nur mehr oder minder begründete Vermuthungen aussprechen können, was ich unterlasse, um die Zahl der nur muthmasslichen Deutungen nicht um noch eine zu vermehren.

\section{A eussere Geschlechtsverschiedenheiten.}

Der langen Spürhaare am Ende der Fühler, die vermuthlich nur den Männchen zukommen, der reichen Riechfädenbüschel, sowie der Greifanhänge an den Schwimmfüssen, die dasselbe Geschlecht auszeichnen, ist bereits gedacht worden. - Bei Cypridina Agassizi sind die Männchen ausserdem viel kleiner (etwa $1,5 \mathrm{~mm}$ lang) als die Weibchen (etwa $2 \mathrm{~mm}$ lang), und daran auf den ersten Blick zu erkennen. Merkwürdig ist es, dass ich von dieser Art stets bei weitem mehr Männchen als Weibchen gefunden habe; eines Tages (1 2. Novbr. I865), an dem ich besonders glücklich im Fange dieser Thiere war, erbeutete ich 57 Männchen und nur 6 Weibchen. - Von C. Grubii habe ich überhaupt nur sehr wenige Thiere gefangen, unter denen sich kein einziges Weibchen befand. - Umgekehrt habe ich von C. nitidula nur Weibchen gesehen, wenn nicht, wie ich vermuthe. ein einzelnes dieser Weibchen in der weisslichen Färbung und dem Glanze der Schale gleichendes Männchen (Fig. 9) derselben Art angehört. In diesem Falle würden die Geschlechter bei dieser Art sich auffallend durch die Gestalt der Schalen und die Grösse der paarigen Augen unterscheiden. Dass die Eier im hinteren Theile der Schale ausgebrütet werden, wie ich bei Cypridina Agassizii fand, würde deren stärkere Wölbung beim Weibchen, - die langen Spürborsten des Männchens würden das stärkere Vorspringen des vorderen Schalentheiles bei diesem Geschlechte erklärlich machen; die grösseren Augen des Männchens würden ebenfalls nichts Auffallendes haben.

Ein letztes unterscheidendes äusseres Merkmal der Männchen bietet ihr sehr ansehnliches Begattungsglied. Um dasselbe zu schwellen und so hervortreten zu lassen, tödtete ich die Thiere, wie Zenker mit Cypris that, in heissem Wasser. - Das Begattungsglied (Fig. 26, p) besteht aus einem dicken, unpaaren Stamme, der sich in einen rechten und einen linken Schenkel gabelt, von denen jeder wieder in einen äussern und einen innern Ast sich spaltet. Bei C. Agassizii sind alle diese Theile ziemlich schlank, der innere Ast erscheint als unmittelbare Fortsetzung des Schenkels, der äussere ist dünner; beide sind nach dem Ende zu verjüngt und haben eine kahle, abgerundete Spitze. Bei C. Grubii (Fig. 7) sind die Schenkel kurz und dick, fast kuglig und springen über die Ansatzstelle der Aeste vor; auf dem Gipfel des Vorsprungs liegt die Geschlechtsöffnung. Die Aeste sind ebenfalls kurz und dick; ihr Durchmesser beträgt kaum ein Drittel von dem des Schenkels; am Ende trägt jeder zwei blasse Borsten. Man fühlt sich versucht, das Begattungsglied für ein umgewandeltes, zweiästiges Fusspaar zu halten. 
7. Die Kiemen.

Die Kiemen der Cypridinen sind bereits vor 30 Jahren von Philippi gesehen und abgebildet, aber nicht als solche erkannt worden. Spätere Beobachter scheinen nur kiemenlose Arten untersucht zu haben. Claus spricht noch 1866 allen Muschelkrebsen Respirationsorgane $a b^{1}$ ). Meiner Angabe, dass bei Cypridina ansehnliche Kiemen vorkommen ${ }^{2}$, scheint derselbe keinen Glauben geschenkt zu haben.

Philippi sah bei Asterope elliptica hinter den Putzfüssen vier wurstförmige Körper am Rücken emporstehen. Das sind die Kiemen. An gleicher Stelle, und bei todten Thieren in gleicher Gestalt, jedoch in grösserer Zahl, finden sie sich bei Cypridina Agassizii (Fig. 15, br. Fig. 26, br.) und nitidula.

Bei Cypridina Agassizii entspringt jederseits dicht neben der Mittellinie des Rückens eine Reihe von sieben (bisweilen nur sechs) schmalen, nach oben kaum merklich breiteren Blättern. Sie sind etwas schief eingefügt, so dass der Hinterrand jedes Blattes den Vorderrand des folgenden von aussen deckt. Nahe dem oberen Ende trägt jedes Blatt einen kleinen, warzenförmigen Vorsprung, durch den wohl eine $z u$ enge Berührung derselben verhütet wird. Dem Rande des Blattes entlang verläuft ein einfacher, ziemlich weiter Hohlraum.

Bei C. nitidula sind, wenn ich mich recht entsinne, die Kiemen zahlreicher. Dagegen ist ihre Zahl geringer bei ganz jungen Thieren. Junge von C. A gassizi i, die die Schale der Mutter noch nicht verlassen hatten (Fig. 14), besassen nur drei Kiemenpaare, die von vorn nach hinten an Grösse zunahmen. Die hintersten Kiemen sind also wahrscheinlich die ältesten.

Der Athemstrom wird unterhalten durch die ununterbrochenen Bewegungen des mit langen Fiederborsten besetzten Blattes (Fig. I5, g), welches Grube den "grossen, blattförmigen Anhang des ersten Maxillenpaares“ nennt ${ }^{3}$ ). Ich habe versäumt, durch Zusatz feiner Farbtheilchen zum Wasser festzustellen, in welcher Richtung der Athemstrom an den Kiemen vorüberfliesst. - Hinter dem letzten Kiemenpaare trägt der Rücken einen kurzen, walzenförmigen, unpaaren Fortsatz, der schief nach vorn und oben gerichtet und mit einigen kurzen Härchen besetzt ist. Bei C. Girubi i fehlt mit den Kiemen auch dieser Fortsatz vollständig.

Höchst auffallend ist es, dass die Kiemen auch Cypridina oblonga zu fehlen scheinen, die sich im Bau der Gliedmaassen auf's Engste an C. A gassizii und nitidula anschliesst. Grube's Zergliederung der C. oblonga ist eine so sorgfältige gewesen, dass er die Kiemen, wären sie in ähnlicher Weise wie bei den letzteren beiden Arten entwickelt, kaum hätte übersehen können.

8. Herz und Blutlauf.

Ein Herz habe ich bei Cypridina Agassizii und nitidula gesehen; die wenigen Thiere von C. Grubii, die ich gefangen, hatten ganz undurchsichtige Schalen und ich kann nicht sagen, ob dieser Art mit den Kiemen nicht etwa auch das Herz fehlt.

I) Claus, Grundzüge der Zoologie, S. 209.

2) Fritz Müller, Für Darwin, 1864, S. 72. = Ges. Schriften S. 247.

3) In Grube's Zeichnung (Arch. für Naturgesch. XXV, Bd. I, Taf. XII, Fig. 4) ist dies Blatt in verkebrter Lage dargestellt; der gewölbte Rand mit dem Fiederborsten ist nicht der vordere, sondern der hintere. 
Die Schale der Cypridinen hängt nur auf eine ganz kurze Stelle mit dem Rücken des Thieres zusammen; an dieser von oben durch die Schale gedeckten Stelle, nach hinten und oben von dem mittleren Auge, liegt das Herz. Es bildet bei Cypridina Agassizii (Fig. I6) einen kurzen Sack, der höher als lang und unten weiter als oben ist.

Vom Laufe des Blutes, das arm an Blutkörperchen ist, habe ich nur wenig gesehen. Die meisten Thiere sind zu undurchsichtig. um mehr als die Bewegungen des Herzens erkennen zu lassen. Nur von C. Agassizi i habe ich ein paar fast farblose Thiere gefangen, die durchsichtig genug waren, um die Blutkörperchen in ihrem Laufe durch Herz und Kiemen verfolgen zu können. In das Herz tritt das Blut von hinten und unten und strömt nach vorn und oben, wo eine grosse Oeffnung zum Austritt des Blutes zu sein scheint. Von da sah ich den Blutstrom sofort nach unten umbiegen, an der Vorderwand des Herzens hinabsteigen und hinter das mittlere Auge treten. In den Kiemen steigt das Blut an deren vorderem Rande in die Höhe, am hinteren Rande wieder hinab. - . In den Fühlern sah ich die Blutkörperchen an der Beugeseite des Knies der Spitze zu, an der Streckseite nach dem Körper zurücklaufen.

\section{Allgemeine Bemerkungen.}

Seit W. Zenker's vortrefflicher Arbeit über Cypris und Cythere werden die Muschelkrebse fast allgemein als besondere Ordnung der Kruster betrachtet. Das will sagen, dass sie sich selbständig vom Urstamme der Klasse. und nicht von einem der anderen Hauptäste desselben abgezweigt haben. Nur Gerstäcker ${ }^{1}$ ) ordnet sie noch neuerdings den Branchiopoden unter. „Die Ostracoden“, sagt derselbe, „schliessen sich den Cladoceren, von denen sie gewöhnlich als eigene Ordnung abgetrennt werden, eben so eng an, wie diese den Phyllopoden ... Die beiden ersten Beinpaare derselben werden zwar gewöhnlich als Maxillen beschrieben, geben sich aber nicht nur durch ihren in mehrere Lappen geschlitzten Stamm, sondern auch durch die besonders am ersten Paare stark entwickelte Kieme $\left.{ }^{2}\right)$ als Analoga der Cladoceren- und Phyllopoden-Beine zu erkennen.“ Gegen diesen Vergleich der Kiefer der Muschelkrebse mit den Beinen der Cladoceren und Phyllopoden ist sicher nichts einzuwenden; nur passt derselbe eben so gut auf die Kiefer der Copepoden und der höheren Kruster (Malacostraca); namentlich bei den Jugendzuständen der letzteren ist die Aehnlichkeit bisweilen eine überraschende, so dass auch Claus den Kiefer der Krebslarven „eine Art Phyllopodenfuss" genannt hat. Diese Uebereinstimmung beweist also nichts für eine nähere Verwandtschaft der Muschelkrebse und Branchiopoden; was sie beweist,

1) Peters, Carus und Gerstäcker, Handbuch der Zoologie, II, I 863 , S. 399.

2) Die bei den Krustern so häufig vorkommenden schwingenden Platten, die mit langen Fiederhaaren besetzt zu sein pflegen, werden, wo man keine besseren Kiemen hat finden können, immer noch häufig, wie hier von Gerstäcker, als Kiemen bezeichnet, - aber ohne allen Grund. In allen Fällen, wo ich diese sogenannten Kiemen an lebenden Thieren nntersuchte, fand ich, dass sie zu den blutïrmsten Theilen des Körpers gehören. Allerdings dienen sie meist der $\Lambda$ thmung, aber nur dadurch, dass sie einen Strom frischen athembaren Wassers zuführen. Noch bei den höchststehenden Krustern, den Krabben, wird der Athemstrom bekanntlich durch eine solche schwingende Platte geregelt, die das gleiche Recht auf den Namen Kieme hat, wie die entsprechenden Platten an den Kiefern von Cy pris. 
ist, dass die Branchiopoden, Copepoden, Ostracoden und Malacostraca erst lange nach der Naupliuszeit, dass sie erst dann von dem gemeinsamen Stamme sich trennten, als auch diese den Kinnbackenfüssen zunächst folgenden, bei allen diesen Ordnungen in ähnlicher Weise gebildeten Gliedmaassen bereits entwickelt waren. Die Stammeltern mögen zu dieser Zeit dieselbe Gliedmaassenzahl besessen haben, wie jetzt $\mathrm{Cypris}$ und $\mathrm{Cy}$ there; wie bei diesen hinter den Kinnbacken noch vier Gliedmaassenpaare sich finden, so sprosst auch bei dem Nauplius von Penëus die gleiche Zahl von Fussstummeln hinter den Kinnbackenfüssen gleichzeitig hervor. Die einzige Ordnung, deren Kiefer in ganz abweichender Weise gebildet sind, bei der überhaupt ähnliche Gliedmaassen fehlen, sind die Pectostraca Haeckel's, die Rankenfüsser und Wurzelkrebse; diese mögen schon früher von dem Urstamme der Classe sich getrennt haben; in diesem Falle wäre die Auffassung von Alph. Milne Edwards die richtige, der sie als Basinotes allen übrigen Krustern (E1e u thér on otes) gegenüberstellt.

Wenn somit Gerstäcker's Bedenken gegen die von Zenker, wie mir scheint, genügend begründete Abtrennung der Muschelkrebse als eigener Ordnung nicht stichhaltig erscheinen, so können andererseits die eigenthümlich entwickelten Riechfäden, der Stirnanhang, die sonderbaren Putzfüsse, die rückenständigen Kiemen der Cypridinen nur als neue Stützen für die Auffassung Zenker's betrachtet werden, welcher namentlich auch Claus, der eben so glückliche wie umsichtige Forscher auf dem Gebiete der niederen Kruster, und E. Haeckel in seinem bewundernswerthen Versuche einer ,genealogischen Uebersicht des natürlichen Systems der Organismen" sich angeschlossen haben.

Für die ziemlich allgemein angenommene nähere Verwandtschaft der Muschelkrebse mit den Rankenfüssern liefert die Betrachtung der Cypridinen keinen neuen Anhalt, man müsste denn den unpaaren Stirnanhang den beiden Fäden vergleichen, welche an ähnlicher Stelle bei den Larven der Rankenfüsser und Wurzelkrebse sich finden. Ich habe früher ${ }^{1)}$ gegen die Annahme einer solchen Verwandtschaft mich ausgesprochen und bis jetzt keinen Grund zur Aenderung meiner Ansicht gefunden. Die Annahme beruht einzig auf der zweiklappigen Schale der Rankenfüsserpuppen; wenn man aber gesehen hat, wie diese Schale durch das Zusammenklappen eines flachen Rückenschildes sich bildet, und wenn man unter den Phyllopoden als nah verwandte Familien die nackten Artemien, die von einem einfachen Rückenschilde bedeckten Apus und die von einer zweiklappigen Schale umschlossenen Limnadien findet, kann man kaum auf diese Bildung der Schale irgend ein Gewicht legen, wenn es sich um die Verwandtschaft ganzer Ordnungen handelt.

Unter den drei Familien der Muschelkrebse stehen offenbar die Cypridinen am höchsten; die hohe Entwickelung der Sinneswerkzeuge, der Augen, der Riechfäden, zu denen sich noch der Stirnanhang und die Schmeckhärchen (?) an Kinnbacken gesellen, sowie der Besitz von Herz und Kiemen, weisen ihnen diese Stelle an. Trotzdem aber stehen die Cypridinen in mehrfacher Beziehung der Urform der Gruppe unverkennbar näher, als Cypris und Cythere; so darin, dass das zweite Gliedmaassenpaar meist noch einen Nebenast besitzt, und dass

I) Für Darwin, S. 59, Anm. = G̈es. Schriften S. 238 . 
das dritte noch einen kräftigen umfangreichen Fuss bildet; beides sind Eigenthümlichkeiten, die an die Gliedmaassenbildung von Nauplius erinnern. Wahrscheinlich gilt dasselbe von dem Begattungsgliede, das viel einfacher gebaut ist, als bei Cythere und Cypris. Keinenfalls haben sich die höher stehenden Cypridinen aus der niedriger stehenden Form der Cypris oder Cythere, sondern als selbstständiger Zweig aus der Stammform der Muschelkrebse entwickelt.

Auf dasselbe Verhältniss stossen wir übrigens auch bei den freilebenden Copepoden, unter welchen ,unstreitig die Calaniden zugleich mit den Pontelliden die höchste Stufe einnehmen" (Claus). Auch hier sind gerade diese höchst stehenden Familien in dem umfangreichen Nebenast der "hinteren Antennen“, sowie in dem zweiästigen, den hinteren Antennen ähnlichen „Mandibularpalpus“ der Urform des Nauplius weit ähnlicher geblieben, als alle übrigen Copepoden, - vielleicht weil sie der ursprünglichen Lebensweise, dem freien Umherschwimmen im offenen Neere, treu blieben.

Calaniden und Pontelliden einerseits, Cypridinen andererseits, stimmen auch darin überein, dass sie die einzigen Familien ihrer Ordnung sind, die ein Herz besitzen und dieses Herz hat bei beiden etwa dieselbe Lage; ob genau dieselbe, ist wegen der bei Cy prid in a mangelnden Gliederung des Leibes nicht zu sagen. Dabei drängt sich denn natürlich die Frage auf, wie diese übereinstimmende Lage des Herzens zu erklären sei. - Ehe ich die Beantwortung dieser Frage versuche, kann ich mir nicht versagen, darauf hinzuweisen, wie scharf und schlagend in diesem Falle der Gegensatz hervortritt, der in der Auffassung der morphologischen Fragen zwischen den Anhängern Darwin's und den Bekennern des Schöpfungsdogma's ${ }^{1}$ ) obwaltet. Während uns die eben aufgeworfene Frage Schwierigkeiten bietet, die wohl kaum befriedigend zu lösen sind, wird sie unseren Gegnern überflüssig, vielleicht lächerlich erscheinen, sie werden es selbstverständlich finden, dass „dem Bauplan der Classe gemäss“ das Herz bei Cypridina an gleicher Stelle liegt, wie z. B. bei Calanus oder Daphnia. Umgekehrt wird es die Anhänger der ,alten Schöpfungshypothese“,

I) Durch Professor Keferstein erhalten wir neuerdings (Bericht über die Fortschritte der Generationslehre im Jahre 1867) die unerwartete Belehrung, dass wir die Gegner Darwin's nicht richtig verstehen, wenn wir glauben, dass sie mit dem Ausdruck Schöpfung wirklich Schöpfung meinen; Schöpfung soll ,nichts weiter als eine uns unbekannte, unfassbare Weise der Entstehung“ heissen. Es soll dadurch nur in verblümter IVeise das verschämte Geständniss ausgesprochen werden, dass man über die Entstehung der Arten ,garkeine Meinung habe“ und haben wolle. Nach dieser Erklärung des Wortes würde man ebensowohl von der Schöpfung der Cholera und der Syphilis, von der Schöpfung einer Feuersbrunst und eines Eisenbahnunglücks, wie von der Schöpfung des Menschen reden können. Natürlich bedeuten dann auch die beliebten Ausdrücke Schöpfunsplan oder Bauplan nicht den Plan des Schöpfers, sondern „,nichts weiter als eine uns unbekannte, unfassbare“ Ursache der Aehnlichkeit verwandter Formen. Verwandtschaft aber bedeutet bekanntlich bei unseren Gegnern nicht wirkliche Verwandtschaft, sondern nichts weiter als Aehnlichkeit. Wenn dieselben von verkümmerten Theilen reden, meinen sie nicht, dass diese Theile wirklich verkümmert sind, d. h. dass sie vordem wohl entwickelt waren, sondern nichts weiter, als dass sie klein und nutzlos sind. Wenn sie aber sagen nutzlos, meinen sie nicht wirklich nutzlos, - Nutzloses konnte ja die unendliche Weisheit nicht schaffen, - sondern nichts weiter als von ,unbekanntem, unfassbarem" Nutzen, etc. etc.

Aber wie kann erwarten, richtig verstanden zu werden, wer immer etwas Anderes sagt, als was er meint? - 
wie sie Weismann nennt, befremden müssen, dass die Kiemen der Cypridinen am Rücken stehen, der bei keinem anderen Kruster Kiemen trägt. Wir dagegen hätten als wahrscheinlich voraussagen können, dass wenn bei Muschelkrebsen Kiemen vorkämen, dass sie dann in ihrer Lage nicht mit denen anderer Kruster übereinstimmen würden. Denn Kiemen haben sich bei den Krustern überhaupt erst spät entwickelt; selbst unter den Podophthalmen und Edriophthalmen sind bis heute die der Urform zunächst stehenden Gattungen (Mysis, Tanais) kiemenlos geblieben. Die Stammeltern der Muschelkrebse besassen sicherlich keine Kiemen. Die Kiemen von Cypridina also und die irgend eines anderen kiementragenden Krusters sind keinenfalls das Erbtheil eines gemeinsamen Ahnen, vielmehr haben sich die der ersteren unabhängig entwickelt und es dürfte desshalb eine abweichende Lage derselben mit grösserer Wahrscheinlichkeit erwartet werden, als eine übereinstimmende. -

Die gleiche Lage des Herzens bei Calaniden, Pontelliden und Cypridinen würde sich, um auf die oben angeregte Frage zurückzukommen, am einfachsten erklären, wenn wir annehmen dürften, dass schon die gemeinsamen Stammeltern der Copepoden und Muschelkrebse ein Herz an gleicher Stelle besassen und auf die genannten Familien vererbten, während dasselbe bei der Mehrzahl der Copepoden sowie bei Cypris und Cythere im Laufe der Zeiten verloren ging.

$\mathrm{Zu}$ Gunsten der Annahme, dass schon die gemeinsamen Stammeltern von Copepoden und Muschelkrebsen eine Herz besassen, lässt sich geltend machen, dass schon die Nauplius von Penëus ein Herz haben, wodurch das sehr frühe Auftreten desselben bei den Krustern wahrscheinlich wird; ferner, dass, wie erwähnt, gerade die mit einem Herzen versehenen und auch sonst höher stehenden Familien beider Ordnungen der Urform unverkennbar ähnlicher sind, als die übrigen niedriger stehenden, des Herzens entbehrenden Familien, dass keinenfalls erstere aus letzteren, dass weit eher letztere aus ersteren hervorgegangen sein können. Dafür, dass das Herz verloren gehen könne, liefern unter den Gliederthieren die Milben den Beweis. Der Mangel des Herzens scheint bei diesen in ursächlichem Zusammenhange $\mathrm{zu}$ stehen mit der geringen Grösse; natürlich ist das Herz um so entbehrlicher, zu je winzigerem Umfange der Körper herabsinkt. Von den Muschelkrebsen wissen wir nun, dass sie früher eine weit ansehnlichere Grösse erreichten; auch ohne die handgreiflichen Beweise, die uns ihre versteinerten Schalen liefern, würde die geringe Zahl an Gattungen armer, scharf geschiedener Familien schliessen lassen, dass wir in den heutigen Muschelkrebsen nur kümmerliche Reste eines früher weit reicher entfalteten Formenkreises vor uns haben. Möglich, dass in gleicher Weise, wie bei den Milben, auch bei ihnen das Herz mit Abnahme der Grösse geschwunden ist. - Es darf dabei auch der Pycnogoniden gedacht werden. Zenker und Krohn haben bei diesen Thieren ein Herz nachgewiesen; bei den Arten, die ich untersuchte, habe ich es nicht gefunden, ohne jedoch dessen Nichtvorhandensein behaupten zu können; jedenfalls aber war es bei ihnen, wenn vorhanden, ziemlich überflüssig; denn es war keine Bewegung des Blutes wahrzunehmen, die nicht aus den Zusammenziehungen der in die langen Beine eintretenden Blindschläuche des Darms zu erklären gewesen wäre. 
Immerhin, wenn auch wahrscheinlich, kann die Annahme eines Herzens für die gemeinsamen Stammeltern von Copepoden und Muschelkrebsen nicht als erwiesen gelten.

Die zahlreichen Copepoden ohne Herz (Cyclopiden, Harpactiden, Peltidien und Corycaeiden) und auch Cypris und Cythere haben im Uebrigen nicht das Aussehen verkümmerter Thiere. Und auch ohne jene Annahme lässt sich die gleiche Lage des Herzens bei Calaniden und Cypridinen erklären, wenn man die Weise ins Auge fast, in der bei den Arten ohne Herz das Blut bewegt wird. „Bei den Cyclopiden, Harpactiden und Peltidien übernehmen die fast rythmischen Bewegungen des Magens, in welchem derselbe zum Theil durch äussere Muskelzüge aufwärts gezogen und dann wieder in entgegengesetzter Richtuug herabgedrängt wird, die Function des fehlenden Circulationsorgans, und bringen die im Leibesraume befindliche Blutmenge in eine gewisse Strömung“" 1). - Ganz dasselbe sah ich bei einer grossen, ziemlich durchsichtigen Cypris, bei welcher gleichzeitig auch die Leberschläuche sich regelmässig zusammenzogen. Die Bewegungen der oberen Magenwand, sowie der von ihr nach oben gehenden Muskeln geben ein so täuschendes Bild eines über dem Magen liegenden Herzens, dass ich immer wieder ein Herz zu sehen glaubte, nachdem ich mich längst auf's Bestimmteste von dessen Abwesenheit überzeugt hatte ${ }^{2}$.

Das Blut wird also von derselben Stelle aus in Bewegung gesetzt bei den Arten mit und bei denen ohne Herz, und an dieser Stelle würde bei letzteren am leichtesten ein Herz sich bilden können, etwa indem die schmalen Muskelzüge, die jetzt hier sich finden, breiter würden, zu einem Schlauche zusammenträten und selbstständig sich zusammenzögen. Die gleiche Lage des Herzens bei Cypridinen und Calaniden würde sich also daraus erklären, dass schon in frühester Zeit, schon bei deren gemeinsamen Stammeltern, wenn denselben auch ein Herz fehlte, doch schon von derselben Stelle aus, wo bei ihren Nachkommen das Herz liegt, die Bewegung des Blutes ausging. - Ich will bei dieser Gelegenheit auf ein ähnliches Verhalten bei Echinodermen-Larven hinweisen. Bei Tornaria, in welcher Alex. Agassiz eine Seestern-Larve vermuthet, liegt bekanntlich über der Grenze von Speiseröhre und Magen eine grosse zum Wassergefässsystem gehörige Blase, von deren vorderem, kegelförmig ausgezogenen Ende ein Muskel zum Vorderende der Larve geht. Muskel wie Blase ziehen sich von Zeit zu Zeit kräftig zusammen. Dicht über der Blase aber fand ich ein Herz. Ich habe die Entwickelung der Tornaria nicht verfolgt; aber nach dem, was wir durch Alex. Agassiz über die Entwickelung des Wassergefässsystems der Seesternlarven wissen, ist jedenfalls jene Blase früher vorhanden gewesen als das Herz; vor dem Auftreten des letzteren wurde das Blut durch die Bewegungen der Blase und ihres Muskels in eine gewisse Strömung versetzt und das Herz bildete sich an derselben Stelle, von der aus schon früher das Blut in Bewegung gesetzt wurde.

I) Claus, die freilebenden Copepoden, S. 61 .

2) In ähnlicher Weise ist vielleicht auch Gegenbaur getäuscht worden, der bei Sapphirina ein Herz beschreibt, dessen Vorhandensein von Claus auf's Entschiedenste in Abrede gestellt wird. - Oder haben etwa die beiden Forscher zwei verschiedene Arten vor sich gehabt, die eine mit, die andere ohne Herz? 
Unter den bis jetzt bekannt gewordenen Copepoden olne Herz stehen einige (z. B. Oithona) den Calaniden so nahe, dass möglicher Weise sich noch Uebergangsformen finden werden, die auch in Bezug auf das Herz die Mitte halten zwischen Calaniden und Cyclopiden oder Corycaeiden, Arten, die ein im Vergleich mit dem der Calaniden unvollkommenes Herz besitzen, und solche Arten dürften dann vielleicht, namentlich durch ihre Entwickelungsgeschichte, Aufschluss darüber geben, ob ihr Herz als ein werdendes oder ein verkümmerndes zu betrachten sei, und damit die Frage entscheiden, ob die Stammeltern der Copepoden und Muschelkrebse des Herzens entbehrten oder mit einem solchen versehen waren.

Itajahy, Februar i 869 .

\section{Erklärung der Abbildungen auf Tafel XXXIV und XXXV.}

Fig. I-8. Cypridina Grubii, Männchen.

Fig. 2. Vorderer Theil des Leibes. $a$ Stirnanhang. $b$ Fühler. $c$ Schwimmfuss.

Fig. 3. Stirnanhang. 3 a der keulenförmige Theil des Grundgliedes, stärker vergrössert.

Fig. 4. Die 4 letzten Glieder des Fühlers. $\alpha$ Riechfädenborste. $\gamma$ Riechfüden am Ende des Fühlers. $\delta$ Spürborsten.

Fig. 5. Greifanhang des Schwimmfusses.

Fig. 6. Kinnbackenfuss.

Fig. 7. Einer der beiden Schenkel des Begattungsgliedes. $\alpha$ äusserer, $\beta$ innerer Ast.

Fig. 8. Eine der beiden Schwanzplatten.

Fig. 9. Männliche Cypridina, vermuthlich das Männchen von C. nitidula.

Fig. 10-I2. Cypridina nitidula, Weibchen.

Fig. I I. Fühler. $\beta$ Riechfädenborste. $\gamma$ Riechfaden am Ende des Fühlers. $\varepsilon$ klauenartige Borste.

Fig. I 2. Kinnbackenfuss. $\alpha$ Kinnbacken. $\beta$ Fortsatz am Grunde des zweiten Gliedes.

Fig. 26. s. u.

Fig. I3-19. Cypridina Agassizii, Weibchen.

Fig. I3. Erwachsenes Weibchen.

Fig. I4. Junges, aus der Schale dieses Weibchens genommen.

Fig. I 5. Weibchen, nach Entfernung der Schale. $b$ Fühler. $c$ Schwimmfuss. $d$ Kinnbackenfuss. e $f g$ viertes bis sechstes Gliedmassenpaar. $h$ Putzfuss. q Unpaarer Fortsatz des Rückens. $b r$ Kiemen.

Fig. I6. Herz. h Putzfuss.

Fig. 17. Fühler. $\alpha$ Borste, die an der Stelle des Riechfädenbüschels des Männchens steht. $\beta$ Riechfädenborste. $\gamma$ Riechfaden am Ende des Fühlers. $\partial S$ förmige Borste mit seitlichen Fädchen. $\varepsilon$ klauenförmige Borste.

Fig I 8. Schwimmfuss, von innen. $\alpha$ Grundglied. $\beta$ erstes Glied des Hauptastes $\gamma$ Nebenast.

Fig. I 9. Putzfuss.

Fig. 20-26. Cypridina Agassizii, Männchen.

Fig. 20. Vorderer Teil des Leibes. $a$ Stimanhang. $b c d e$ wie in Fig. 15 .

Fig. 21. Stirnanhang unterhalb des mittleren Auges.

Fig. 22. Riechfädenbüschel.

Fig. 23. Schwimmfuss. $\alpha \beta \gamma$ wie in Fig. I 8 .

Fig. 24. Kinnbackenfuss. $\beta$ Fortsatz des 2. Gliedes. $\gamma$ Nebenast.

Fig. 25. Kinnbacken.

Fig. 26. (Auf Tafel XXXIV.) Der hintere Theil des Leibes. p Begattungsglied. $q$ unpaarer Fortsatz des Rückens. $b r$ Kiemen. 


\title{
Bruchstücke zur Naturgeschichte der Bopyriden ${ }^{1}$ ).
}

\author{
Mit Tafel XXXVI und XXXVII.
}

Die im Nachstehenden mitgetheilten Beobachtungen über Bopyriden wurden meist in den Jahren I86I und 1862 am Strande von Desterro gesammelt. Sie sind so überaus lückenhaft, dass ich lange Bedenken getragen habe, sie zu veröffentlichen. Ich thue es jetzt, wo ich selbst keine Aussicht mehr habe, sie zu vervollständigen, in der Hoffnung, dass dadurch Besucher der Seeküste zu eingehender Beschäftigung mit diesen merkwürdigen Schmarotzerasseln veranlasst werden mögen, deren Bau, Entwickelung und Lebensweise noch eine reiche Ernte überraschender Thatsachen zu liefern verspricht.

\section{Binnenasseln. (Entoniscus.)}

Binnenasseln wurden bis jetzt in folgenden Decapoden gefunden:

I) in einer bei Desterro unter Steinen ungemein häufigen schwärzlich-grünen Porcellana, von welcher etwa $5 \%$ damit behaftet sind ${ }^{2}$ );

2) in einer ebenda an Felswänden zwischen Sertularien und Moosthieren selten vorkommenden kleineren Porcellana ${ }^{3}$ ). Es wurde ein einziges Mal ein Weibchen von Entoniscus getroffen, das beim Herausnehmen zerriss und von dem ich nicht sagen kann, ob es derselben Art angehört, wie die Binnenassel der gemeinen Porcellana;

3) in Porcellana (Polyonyx) Creplinii F. M. ${ }^{4}$ ). Fast in jeder Röhre von Chaetopterus findet man bei Desterro, wo der genannte Wurm übrigens ziemlich selten ist, diese Porcellana und zwar in der Regel ein Pärchen ${ }^{5}$ ); nur dreimal traf ich einzelne Thiere, einmal ein Weibchen, zweimal ein Männchen. Jedes dieser drei einzeln vorkommenden Thiere beherbergte einen Entoniscus,

I) Jenaische Zeitschrift für Naturwissenschaft I871. 6. Jahrg. S. 53-72. Taf. III u. IV.

2) s. Archiv für Naturgesch. 1862. I. S. I0. Taf. II. $=$ Ges. Schriften S. 147. Taf. XVIII.

3) Alph. Milne Edwards konnte mir weder diese, noch die erstere Art bestimmen.

4) Nach brieflicher Mittheilung von Alph. Milne Edwards ist diese Art der Porcellana biunguiculata Dana (Polyonyx Stimps.) nahe verwandt. Meine Porcellina stellicola (Arch. für Naturg. I862. Taf. VII, Fig. I $=$ Ges. Schriften Taf. XIX Fig. I) scheint nach demselben die Porcellana angusta Dana (Minyocerus Stimps.) zu sein.

5) Einmal traf ich statt der Porcellana Creplinii ein Pärchen der Pinnixa chaetopterana Stimps. - 
während in keinem der paarweise lebenden ein solcher Schmarotzer gefunden wurde. Man darf also wohl annehmen, dass eben wegen des Entoniscus, der wie die Rhizocephalen stets Unfruchtbarkeit seines Wirthes zur Folge hat, jene drei Thiere keinen Genossen gefunden hatten oder von demselben verlassen worden waren ${ }^{1}$ ).

Die Entoniscusweibchen, die in Porcellana Creplinii gefunden wurden, hatten nicht wie die der gemeinen Porcellana röthlich-violette, sondern blass dottergelbe Eierstöcke; ihre Brutblätter erschienen mir weniger stark zerschlitzt und gekräuselt. Männchen und Junge glichen den in der gemeinen Porcellana vorkommenden;

4) in einem Achaeus, der an Felsen zwischen Moosthieren, Ascidien u. s. w. lebt. Der Entoniscus wurde nur einmal gefunden. Ich habe mir von ihm nur angemerkt, dass das Männchen sechs wohlgebildete Fusspaare und ein zweispitziges Schwanzende hat; durch beides unterscheidet es sich von dem des Entoniscus Porcellanae, durch die Form des Schwanzendes auch von dem des Entoniscus Cancrorum ${ }^{2}$ );

5) in mehreren $\mathrm{X}$ antho-Arten der Küste von Desterro. Die Binnenassel dieser Krabben, Entoniscus Cancrorum ${ }^{3}$ ), ist in beiden Geschlechtern und nicht minder in ihrer frühesten Jugendform erheblich verschieden von Entoniscus Porcellanae. Während bei dem Weibchen des letzteren die ganze Länge des Mittelleibes mit gewaltigen, zerschlitzten, vielgefalteten Brutblättern besetzt ist, zwischen deren Falten die Eier sich anhäufen, ist bei Enton iscus Cancrorum eine geschlossene Bruthöhle vorhanden, gebildet von einem einzigen Paare von Brutblättern, das dicht hinter dem Kopfe entspringt. Die Bruthöhle stellt einen Sack von sehr wechselnder Gestalt und Grösse dar, der schief nach vorn gerichtet ist und mit seiner oberen Fläche sich der Unterseite des Kopfes anlegt, welchen er mehr oder weniger weit überragt. Füsse fehlen vollständig, man müsste denn seitliche Wülste, die mehr oder minder deutlich in der Nähe des Hinterleibsendes vorzuspringen pflegen, als Fussstummel ansprechen wollen. Der bei Entoniscus Porcellanae so ungemein lange, mit langen Säbelbeinen ausgerüstete Hinterleib ist bei En t. Cancrorum so plump und fast so regungslos. wie der Mittelleib. Selten sind die Weibchen ziemlich gerade ausgestreckt; meist findet man den Hinterleib in rechtem ${ }^{4}$ ), oder spitzem ${ }^{5}$ ) Winkel aufwärts gebogen. Das Herz liegt oft, wie bei Ent. Porcellanae, in einer bruchsackähnlichen Ausstülpung des Hinterleibes, während in anderen Fällen dessen Haut glatt darüber hinweggeht. Die Hautfalten mit wellig gebogenem Rande, die bei Ent. Porcellanae sich an der Bauchfläche der ersten Hinterleibsringe hinziehen, sind bei Ent. Cancrorum ebenfalls vorhanden und sogar in der Regel weit stärker entwickelt.

I) Die wenig über federkieldicken Ausgänge der Chaetopterus-Röhre, die einige Zoll hoch senkrecht aus dem Schlamme emporstehen, in weichem die Röhre wagerecht eingebettet liegt, sind viel zu eng, um die Porcellana durchzulassen; doch kann diese, wie ich gesehen, die Röhre verlassen, indem sie sie der Länge nach aufschlitzt.

2) s. F. Müller, Für Darwin, Fig. I6. = Ges. Schriften S. 218.

3) s. Taf. XXXVI, Fig. $1-3$ und Für Darwin, Fig. 4r. = Ges. Schriften S. 232.

4) s. Für Darwin, Fig. 4r.

5) s. Taf. XXXVI, Fig. I.

Fritz Müllers gesammelte Schriften. 
Das Männchen von Ent. Cancrorum. hat weder die Klumpfüsse, noch die eigenthümliche Fühlerbildung des Männchens von Ent. Porcellanae, schliesst sich vielmehr in beiden Beziehungen an die Männchen von Bopyrus an ${ }^{1}$ ).

Die Jungen von Ent. Cancrorum (Fig. 2 u. 3) stimmen überein mit denen von Ent. Porcellanae und unterscheiden sich, wie diese, von denen der Bopyrusarten dadurch, dass das letzte Beinpaar des Mittelleibes abweichend von den vorangehenden gebildet ist. Die Unterschiede der Jungen der beiden Entoniscus-Arten bestehen hauptsächlich in Folgendem:

Entoniscus Porcellanae

Länge (am ersten Tage) : o,2 mm. Stirnrand fast gerade.

Heller unpaarer Fleck dicht am Stirnrande.

Greifrand an der Hand der 5 ersten Beinpaare glatt.

Sechstes Beinpaar kurz, 3 gliedrig mit elliptischem klauenlosen Endgliede.

Der letzte Ring des Mittelleibes fehlt (?).

\section{Das fünfte Fusspaar des Hinterleibes} noch wenig entwickelt, borstenlos.

Grundglied der Hinterleibsfüsse mit einer Borste.

Endglied der Hinterleibsfüsse schief abgeschnitten, lanzettförmig.

\section{Entoniscus Cancrorum}

Länge (am ersten Tage): o,3 mm. Stirnrand gewöbt.

Dieser Fleck wurde vermisst.

Dieser Greifrand mit wenigen kleinen Zähnchen bewehrt.

Sechstes Beinpaar lang, 5 gliedrig, mit klauentragender Hand.

Der letzte Ring des Mittelleibes vorhanden.

Das fünfte Fusspaar des Hinterleibes den vorangehenden gleich gebildet.

Dasselbe Grundglied mit 2 Borsten.

Das borstentragende Ende des Endgliedes der Hinterleibsfüsse gerade abgeschnitten.

Der Hauptunterschied der beiderlei Larven liegt in der Bildung des letzten Beinpaares, welches bei Ent. Porcella na e in anscheinend verkümmertem, bei Ent. Cancrorum in besonders entwickeltem Zustande auftritt. Es hat bei letzterer Art zunächst drei lange schlanke cylindrische Glieder, von denen jedes der beiden ersten etwa der halben Breite des Leibes an Länge gleichkommt, das dritte unbedeutend kürzer ist. Dann folgt ein ansehnliches Handglied, welches schief abgeschnitten ist. so dass der obere Rand fast doppelt so lang ist, als der untere; der untere Rand läuf.t in einen kürzern Zahn aus, gegen welchen eine etwa in der Mitte des schiefen Endrandes eingelenkte gekrümmte Klaue einschlägt. Auch der obere Rand läuft in eine scharfe Spitze aus, an welcher eine im Innern des Handgliedes gelegene Drüse zu münden scheint. In der Ruhe liegt dies Beinpaar dem Leibe dicht an und zwar ist dabei das erste Glied nach innen, das zweite nach vorn, das dritte nach hinten gerichtet. - Die Larven des Entoniscus Cancrorum lieben, sich im Wasser umhertreiben zu lassen, in welchem sie dabei in ganz eigenthümlicher Stellung schweben (Fig. 2). Der Hinterleib wird gegen die Brust geschlagen; der Rücken ist nach oben, Kopf und Schwanzende sind nach unten gerichtet; die Beine des sechsten

I) Der Hinterleib des Männchens ist abgebildet in „Für Darwin“ Fig. 16. = Ges. Schriften S. 2 I 8. 
Paares werden lang nach aussen vorgestreckt und etwas nach oben gebogen, so dass beide zusammen einen flachen Bogen darstellen, von dessen Mitte der Körper niederhängt. -

Beim Eindringen in den Leib der Krabben wird wahrscheinlich dies eigenthümlich entwickelte sechste Beinpaar der Larve von besonderer Wichtigkeit sein. -

Das Vorkommen von Binnenasseln in so weit verschiedenen Thieren, wie Porcellana, Achaeus und Xantho sind, berechtigt zu der Erwartung, dass sie auch geographisch eine weitere Verbreitung haben und ebenso wie die Bopyrusarten in allen Meeren sich finden werden. Wer Lust hat, sie aufzusuchen, möge seine Aufmerksamkeit besonders auf solche Krabbenweibchen richten, die leer herumlaufen zur Zeit, wo ihre Genossinnen mit Eiern beladen sind.

\section{Bopyrus resupinatus. (Taf. XXXVI, Fig. 4-9.)}

Wenige Thiere dürften mehr von Schmarotzern geplagt werden, als ein bei Desterro unendlich häufiger kleiner Einsiedlerkrebs, der seine Wohnung meist in der Schale eines Cerithium ${ }^{1}$ ) einnimmt. Weit über die Hälfte dieser Einsiedlerkrebse sind bewohnt von einem im Verhältniss zu seinem Wirthe riesigen Fadenwurm, dessen Windungen durch die Wand des von ihm ausgedehnten Hinterleibes des Krebses hindurchschimmern. Ausserdem leben an dem Hinterleibe desselben zwei verschiedene Arten von Wurzelkrebsen, Sacculina purpurea ${ }^{2}$, und Peltogaster socialis ${ }^{3}$ ), und zwei Asseln, Bopyrus resupinatus und Cry ptoniscus planarioides, und zwar ebenfalls so häufig, dass etwa jeder fünfte Pagurus einen dieser Schmarotzer trägt. Unter 300 Paguren, die ich vom I5. November 186 I bis I3. April I 862 untersuchte, fand ich nämlich 28 I mit Sacculina purpurea, 227 mit Peltogaster socialis, 40 mit Bopyrus resupinatus und 46 mit Cryptoniscus planarioides behaftet. - Im Gegensatz zu diesem vielgeplagten kleinen Pagurus waren weit über hundert Paguren von einer grösseren und weit selteneren Art sämmtlich frei von Schmarotzern; ein hübscher Beleg dafür, dass im Allgemeinen, - aus naheliegenden Gründen, - mit der Häufigkeit einer Art die Zahl und Mannichfaltigkeit ihrer Schmarotzer zunimmt.

I) Dieses Cerithium, vielleicht die häufigste aller bei Desterro lebenden Schnecken, bildet die Hauptnahrung zweier anderen, ebenfalls dort häufigen Schnecken, des Murex senegalensis Lam. und der mit Turbinella angulifera nahe verwandten Turbinella Mülleri Dkr. (n. s.) - Der Murex bohrt ein rundes Loch durch das Gehäuse des Cerithium; wenn dieses dann sterbend seinen Deckel öffnet, so kommt von vorn die Turbinella, um sich am Schmause zu betheiligen. An einigen Stellen des Strandes kann man zur Ebbezeit dutzendweise solche Cerithien sammeln, an denen gleichzeitig hinten ein Murex und vorn eine Turbinella sitzen.

Nach dem Tode der Schnecke dient das Gehäuse des Cerithium nicht nur dem Pagurus mit seinen mannichfachen Schmarotzern zum Aufenthalt, sondern am Eingange der von Pagurus bewohnten Gehäuse siedelt sich nicht selten eine kleine weisse Crepidula an, unter welcher dann wieder bisweilen ein Pinnotheres Schutz sucht.

2) Siehe Archiv für Naturgesch. I862. I, Taf. I, Fig. 5-9. = Ges. Schriften S. I4I Taf. XVII. Ich lasse einstweilen, bis eine wissenschaftliche, d. h. genealogische Anordnung der Rhizocephalen möglich sein wird, den Namen dieser Art ungeändert. Als ich den Namen gab, wusste ich nicht, dass Thompson schon einen anderen Wurzelkrebs Sacculina getauft hatte. Meine Sacculina purpurea gehört nicht zur Gattung Sacculina Thomps., sondern eher zu Peltogaster Rthke.

3) F. Müller, Für Darwin, Fig. 59. = Ges. Schriften S. 241 . 
Die beiden eben erwähnten Asseln, Bopyrus resupinatus und Cryptoniscus planarioides, sind vor allem merkwürdig dadurch, dass sie nicht unmittelbar aus dem Pagurus, sondern aus den Wurzeln der Sacculina purpurea ihre Nahrung ziehen.

Bopyrus resupinatus setzt sich unter Sacculina purpurea fest und zwar dieser seine Bauchseite, dem Pagurus seinen Rücken zuwendend. Ich habe wiederholt solche junge Bopyrus, die sich zum Theil noch wenig von ihrer jüngsten Larvenform entfernten, an dieser Stelle angetroffen. Indem nun der Bopyrus die aus dem Leibe des Pagurus durch die darin verzweigten Wurzeln der Sacculina zuströmende Nahrung sich aneignet, stirbt die Sacculina ab. So hatte ich am 22. Septbr. i 861 einen mit Sacculina behafteten Pagurus in ein Glas mit Seewasser gesetzt; Tags darauf schwärmte junge Sacculina-Brut aus; als ich aber am 26. Septbr. den Pagurus wieder aus seinem Schneckenhause nahm, war die Sacculina verschwunden und an ihrer Stelle sass ein junger Bopyrus, ein jungfräuliches, unbemanntes Weibchen ohne Brutblätter. Mit dem Abfallen der Sacculina sterben indess ihre Wurzeln nicht ab, sondern pflegen im Gegentheil nur um so kräftiger weiter zu wuchern, so dass durch sie oft ein ansehnlicher Theil des Hinterleibes gefüllt wird und schon von aussen dunkelgrün erscheint. Nie habe ich die Zusammenziehungen der Sacculinawurzeln so kräftig und regelmässig erfolgen sehen, als in einem Pagurus, an welchem ein grosser Bopyrus sass, der gewiss schon seit geraumer Zeit die Sacculiua verdrängt hatte. - In einigen wenigen leider nicht näher untersuchten Fällen vermisste ich den grünen Fleck an der Anheftungsstelle des Bopyrus; wahrscheinlich hatte sich derselbe in diesen Fällen, statt unter Sacculina purpurea, unter Peltogaster socialis angesiedelt, dessen glatte Wurzeln nicht zu sehen sind; denn auch unter letzterem Wurzelkrebse habe ich Bopyruslarven getroffen.

Daraus, dass der Bopyrus beim Festsetzen sich der Sacculina und nicht dem Pagurus zuwendet, erklärt sich eine Eigenthümlichkeit, die bei einer nahestehenden und voraussichtlich auch in ihrer Lebensweise ähnlichen Art zu einer wunderlichen Verwechslung Anlass gegeben hat. Hesse hat unter dem Namen Athelgue einen B op yru s beschrieben, bei dessen Weibchen angeblich „die convexe $\mathrm{R}$ ü ck en seite des Cephalothorax von $6-7$ Paaren seitlicher durchscheinender Platten bedeckt ist, unter welchen sich die Bruthöhle für die Eier befindet ${ }^{1}$ ). - Also eine Assel mit rückenständiger Bruthöhle! Gewiss ein nicht minder wunderbares Thier, als etwa ein Känguru mit rückenständigem Beutel, oder ein Käfer mit Flügeln am Bauche. Offenbar hat Hesse Bauchseite und Rückenseite verwechselt, weil sein Athelgue dem Pagurus nicht die Bauchseite, sondern wie Bopyrus resupinatus die Rückenseite zuwendet.

Bopyrus resupinatus verlässt das $\mathrm{Ei}$ als etwa $0,2 \mathrm{~mm}$ lange, 0, I $2 \mathrm{~mm}$ breite, flache asselförmige Larve (Fig. 4), ganz ähnlich denen anderer Bopyrusarten. Die sechs Beinpaare der Brust sind gleichgebildet; das 7 . fehlt, wie wahrscheinlich bei allen jungen Isopoden. Die 5 Hinterleibsfüsse haben, wie bei Entoniscus und fast allen von mir gesehenen Bopyridenlarven, ein einziges Endblatt, die Schwanzfüsse haben zwei griffelförmige Aeste und in der Mitte

1) Gerstäcker, Jahresbericht für I 86 I im Archiv für Naturgesch. 28. Jahrg. Bd. 2. S. 558 . 
seines Hinterrandes trägt der letzte Leibesring einen kurzen kegelförmigen Fortsatz. Bei den Entoniscus-Larven fehlt ein solcher Fortsatz, dagegen scheint er den Larven der echten Bopyriden allgemein zuzukommen und meist stärker als bei Bopyrus resupinatus entwickelt zu sein. Von auffallender Länge sah ich denselben bei einer (im März 1862) im Meere aufgefischten Larve (Fig Io), die ohne Frage von einem Bopyriden abstammt, obwohl sie durch 2 -ästige Hinterleibsfüsse von den übrigen mir bekannt gewordenen Bopyruslarven abweicht. Ueber die morphologische Bedeutung dieses Fortsatzes, der bei der zuletzt erwähnten Larve fast an den Schwanzstachel der Xiphosuren erinnert, bin ich ausser Stande, eine Vermuthung auszusprechen.

Die jüngsten Larven, die unter Sacculina purpurea gefunden wurden, hatten bereits eine Länge von $0,6 \mathrm{~mm}$ erreicht (Fig. 5). Thre Gestalt ist gestreckter geworden, indem die grösste Breite kaum der halben Länge des leeibes gleichkommt; an den vorderen Fühlern hat sich ein Büschel von etwa ıo ansehnlichen Riechfäden entwickelt, die der Larve wahrscheinlich beim Aufsuchen ihres Wohnthieres von Nutzen sind. Die Brust trägt jetzt sieben gleichgebildete Beinpaare. Die Schwimmfüsse des Hinterleibes sind noch unverkümmert, ihr Endblatt mit 5-6 langen Borsten versehen. Die Grundglieder der Schwanzfüsse, bei den jüngsten Larven durch einen breiten Zwischenraum getrennt, nehmen jetzt fast die ganze Breite des letzten Leibesringes ein. Von den anfangs etwa gleichlangen Aesten der Schwanzfüsse ist jetzt der äussere etwa doppelt so lang als der innere.

Nach dem Festsetzen der Larve verkümmern die Riechfäden, die den erwachsenen Thieren vollständig fehlen, und die Schwimmfüsse des Hinterleibes verwandeln sich in Kiemen. Bei dem obenerwähnten jungen Weibchen, das nach dem Abfallen der von ihm verdrängten Sacculina zum Vorschein kam, bestanden die Kiemen aus einfachen zungenförmigen Anhängen; an einigen derselben begann indess schon ein kurzer zweiter Ast hervorzusprossen; zu diesem zweiten kommt später noch ein dritter Ast. Von den Schwanzfüssen bleiben nur kurze abgerundete Stummel übrig, an deren Rande ein breiter Blutstrom hinfliesst und dic also ebenfalls der Athmung dienen. - In diesen Schwanzanhängen fliesst das Blut am Innenrande nach hinten, am Aussenrande nach vorn; in den dreitheiligen Kiemen am Hinterrande der Aeste nach aussen, am Vorderrande wieder nach innen. - Die kurzen plumpen Beine krümmen sich allmählich um den Seitenrand des Leibes nach oben, so dass nur der Bopyrus sich mit denselben an dem Pagurus, dem er, wie gesagt, seine Rückenfläche zuwendet, festhalten kann (Fig. 6).

Beim Herannahen der Geschlechtsreife entwickeln sich an der Bauchseite grosse Brutblätter, die eine sehr ansehnliche Bruthöhle umschliessen. Dieselbe überragt seitlich die Ränder des Leibes, nach vorn den Kopf und ein kurzer abgerundeter Zipfel springt jederseits neben dem Hinterleibe nach hinten vor (Fig. 7, 8). Die vordersten dieser blattförmigen Anhänge, die rinnenförmig zusammengebogen den Kopf überragen, mögen dazu dienen, die aus den Sacculina-Wurzeln zuströmende Nahrung dem Munde des Bopyrus zuzuleiten. -

Nach der Bildung der Kiemen des Weibchens würde Bopyrus resupinatus eher zur Gattung Jone als zu Bopyrus zu stellen sein; doch finden sich zwischen 
der Kiemenform der Jone thoracica und des Bopyrus squillarum so mannichfache Uebergangsformen, dass die erstere Gattung sich nicht von letzterer trennen lässt, obwohl Milne Edwards auf dieselben sogar zwei verschiedene Familien begründete.

Das etwa $2 \mathrm{~mm}$ lange Männchen des Bopyrus resupinatus (Fig. 9) hat die gewöhnliche Gestalt der Bopyrusmännchen; sein Hinterleib zeigt nur sehr undeutliche oder gar keine Spur von Gliederung und ist ganz ohne alle Anhänge; ein breiter Blutstrom zieht an seinem Rande hin.

3. Cryptoniscus planarioides ${ }^{1}$ ). (Taf. XXXVII, Fig. 12-r9.)

Am 8. August I86 I hatte ich eine Anzahl Pagurus aus ihren Cerithiumgehäusen herausgeklopft, um an ihnen nach Sacculina und Bopyrus resupinatus zu suchen: ausser diesen beiden traf ich noch einen dritten Schmarotzer in Form einer flachen milchweissen Scheibe von 5-6 $\mathrm{mm}$ Länge und 2,5 $\mathrm{mm}$ Breite, die etwa in der Mitte der dem Pagurus zugewandten Fläche festsass und in der Nähe der Anheftungsstelle eine Oeffnung zeigte, von der aus sie ganz wie ein Lernaeodiscus oder eine Sacculina sich aufblasen liess. Ich glaubte in diesem Schmarotzer einen neuen IVurzelkrebs vor mir zu haben und wurde in dieser Meinung bestärkt, als ich später (im October) fand, dass an der Anheftungsstelle ein vie bei Sacculina purpurea gebildeter Chitinkranz liegt, von dem aus grüne Wurzeln sich ins Innere des Pagurus senken. Chitinkranz und Wurzeln liessen sich im Zusammenhang mit dem Schmarotzer aus dem Pagurus herauslösen. Nach einer blutrothen Zeichnung auf der Unterseite der milchweissen Scheibe, die an den Darm eines dendrocölen Plattwurms erinnerte, nannte ich das Thier Peltogaster plan a rioides.

Kurz darauf traf ich an demselben Pagurus ganz ähnliche, nur grössere (9- Io mm lange) und anders gefärbte, bald gelbe, bald braunpunctirte Schmarotzer; erstere enthielten Eier mit noch wenig entwickelten, letztere solche mit fast reifen Embryonen. Schon die gelben Eier waren sofort an der Krümmung des Embryo nach oben als Asseleier zu erkennen und in den Eiern der braunpunctirten Thiere fanden sich Larven, die mit denen von Bopyrus und Entoniscus die grösste Aehnlichkeit hatten. Dass ich also in diesen Schmarotzern einen noch mehr als selbst Entoniscus von der Asselform sich entfernenden Bopyriden vor mir hatte, unterlag keinem Zweifel.

Wochenlang liefen nun in meinem Tagebuche bei Aufzählung der an Pagurus erbeuteten Schmarotzer dieser „Bopyrus agnostus“ und „Peltogaster planarioides" neben einander her, ohne dass ich nur an die Möglichkeit dachte, dass letzterer eine jüngere Form des ersteren sein könnte. Und neben diesen beiden wurden noch jüngere, etwa $2 \mathrm{~mm}$ lange, schmutzig röthlichbraune Thiere derselben Art als junge Sacculina purpurea aufgeführt, da sie die gleichen Wurzeln, den gleichen Chitinkranz besassen und in Gestalt und Farbe weit mehr dieser Sacculina als dem milchweissen "Peltogaster planarioides“ ähnlich waren.

Erst am 28. November, als ich gleichzeitig, als Ausbeute von 270 Paguren, 8 Cryptoniscus in den verschiedensten Altersstufen vor mir hatte, 2 junge röthlich-

1) Vergl. F. Müller, Für Darwin, Fig. 39 und 42. = Ges. Schriften S. 231 u. 232. 
braune, 3 milchweisse planarienähnliche („Peltogaster planarioides“), einen gelben mit unreifen, einen braunpunctirten mit fast reifen Embryonen („Bopyrus agnostus“) und endlich einen, der schon seine Brut entleert hatte und nun einen schlaffen häutigen farblosen Sack bildete, - überzeugte ich mich von der Zusammengehörigkeit dieser verschiedenen Formen.

Leider kann ich über den Bau und die Entwickelung dieser in so mannichfachen und völlig unkenntlichen Vermummungen auftretenden Asselart nur äusserst dürftige Mittheilungen machen.

Die beim Ausschlüpfen etwa 0,2 mm langen Jungen ${ }^{1}$ ) sind augenlos; der Vorderrand des Kopfes (Fig. I 2 a) ist halbkreisförmig; an seinen hinteren Ecken stehen die kräftigen sechsgliedrigen, äusseren, dicht neben ihnen nach innen die äusserst winzigen (dreigliedrigen?) inneren Fühler. - Die Brust trägt sechs Beinpaare, von denen das letzte abweichend von den vorangehenden und von denen anderer junger Bopyriden gebaut ist. Das vorletzte Glied, das bei den fünf ersten Beinpaaren eine kurze eiförmige Hand bildet, ist beim sechsten Paare (Fig. 1 $2 b$ ) allerdings auch dicker als die anderen Glieder, aber lang und walzenförmig und trägt nicht ein kurzes einschlagbares, sondern ein wenig oder gar nicht bewegliches, sehr langes borstenförmiges Endglied. - Die Schwimmfüsse des Hinterleibes (Fig. $12 c$ ) haben zwei in verschiedener Höhe eingelenkte Aeste. - Im Anfang des Hinterleibes liegt (im Darme?) eine rundliche Anhäufung eines dunkel braunroth gefärbten Stoffes.

In welcher Weise die jungen Cryptoniscus sich an Sacculina purpurea festsetzen, wurde nicht beobachtet. Die jüngsten festsitzenden Thiere, die gefunden wurden (Fig. 13), hatten bereits die Sacculina verdrängt und vollständig alle Gliedmaassen verloren. Sie erschienen als schmutzig röthlich braune, eiförmige Körper von etwa $2 \mathrm{~mm}$ Länge, die in der Nähe des stumpferen Endes festgeheftet waren. Von inneren Theilen wurde ein vom Anheftungspunkte ausgehender weiter blinder Schlauch gesehen, der jederseits mehr oder weniger tief gelappt oder in 5 bis 6 kurze Fortsätze ausgezogen war, wahrscheinlich die Leber, - und ausserdem am freien spitzeren Ende des Leibes ein kräftig sich zusammenziehendes Herz - Wurden die Thiere vom Pagurus losgerissen, so pflegte der Chitinkranz der Sacculina, die sie verdrängt und aus deren Wurzeln sie nun ihre Nahrung zogen, mit ihnen in Verbindung zu bleiben.

Beim weiteren Wachsthum verwandelt sich der eiförmige Körper, in die Breite und Länge wachsend, in eine immer flachere Scheibe, während gleichzeitig der Anheftungspunkt nach der einen Fläche dieser Scheibe hinrückt. Die Farbe wird heller und geht in ein reines Milchweiss über, auf welchem der jetzt blutroth gefärbte gelappte Schlauch (die Leber?) scharf sich abzeichnet. Diese Färbung zeigen Thiere von 4 bis $7 \mathrm{~mm}$ Länge und 2,6 bis $4 \mathrm{~mm}$ Breite. Die Leber (?) liegt auf der dem Pagurus zugewandten Seite der Scheibe und gleicht jetzt ganz dem Darmrohr einer Clepsine; von dem Anheftungspunkte aus geht nach dem einen stumpferen Ende der Scheibe ein weites unpaares Rohr, welches jederseits etwa 5 Fortsätze bis in die Nähe des Scheibenrandes sendet, - nach dem anderen spitzeren Ende jederseits ein engeres Rohr, das nach aussen 2 bis 3

I) F. Müller, Für Darwin, Fig. 39 . 
ähnliche Fortsätze trägt. Zwischen der Leber (?) und der vom Pagurus abgewandten Fläche der Scheibe liegt der, wie es scheint, unpaare Eierstock, der milchweiss gefärbt ist und fast die ganze Länge und Breite der Scheibe einnimmt (Fig. I4). - Das Herz habe ich bei Thieren in diesem Alter nicht mehr gesehen; es mag vom Eierstock verdeckt oder auch verkümmert sein.

Wie gesagt, pflegt man mit dem Cryptoniscus zugleich den Chitinkranz der von ihm verdrängten Sacculina und bisweilen selbst einen Theil ihrer Wurzeln herauszureissen. Diese feste Verbindung, die mich verleitet hatte, den Cryptoniscus selbst für einen Rhizocephalen anzusehen, wird dadurch bewirkt, dass das Mundende der planarienähnlichen Assel durch den Chitinkranz hindurch in die Wurzeln der Sacculina eindringt und hier zu einem unregelmässig gelappten Knopf anschwillt (Fig. I4 c. Fig. 15). Spuren von Fühlern oder Mundtheilen habe ich an diesem Knopfe nicht gefunden. Die Mundöffnung dürfte am Ende eines rüsselförmigen Fortsatzes zu suchen sein, den ich einmal von diesem Knopfe ausgehen sah (Fig. I5); gesehen habe ich sie nicht.

Die ganze Scheibe bildet einen weiten, jetzt noch leeren Sack, die Bruthöhle, die von einer in der Nähe des Anheftungspunktes liegenden Oeffnung aus sich aufblasen lässt. Wann und auf welchem Wege die Eier aus dem Eierstock in die Bruthöhle gelangen, kann ich nicht sagen.

Bei völlig ausgewachsenen, 9 bis ro $\mathrm{mm}$ langen Thieren findet man die Eier in der Bruthöhle und in denselben den Embryo meist schon mehr oder weniger entwickelt. Thre Farbe hat sich in Gelb verwandelt und da sie die ganze Scheibe füllen, zeigt das ganze Thier dieselbe Farbe (Fig. 16). Wenn die Jungen dem Ausschlüpfen nahe sind, erscheint das Thier mit rothbraunen Punkten besäet (Fig. I7). Aehnliche dunkle Punkte sieht man um diese Zeit bekanntlich an den Eiern der meisten Kruster; aber bei Cryptoniscus sind es nicht, wie sonst, die Augen, deren dunkle Färbung die nahende Reife verkündet; Augen sind überhaupt nicht vorhanden; es findet sich vielmehr, wie bereits erwähnt, im Anfang des Hinterleibes (vielleicht im Darme), eine rundliche, bald regelmässige, scharf umschriebene, bald unregelmässig ausgebreitete Anhäufung eines dunkel gefärbten Stoffes. - Während die Eier in der Bruthöhle sich entwickeln, schwindet allmählich immer mehr der blutrothe Inhalt der Leber (?), so dass zur Zeit, wo die Jungen ausschwärmen, bisweilen kaum noch Spuren davon zu erkennen sind.

Sind die Jungen ausgeschwärmt, so zeigt die Mutter noch einmal ein völlig verändertes Aussehen; es ist von ihr nichts übrig geblieben, als eine leere farblose Haut. In der Oeffnung der Bruthöhle sieht man jetzt mehrere Paare fingerförmiger Anhänge sich lebhaft bewegen, deren Zahl und Gestalt nicht bei allen Thieren dieselbe zu sein scheint. Sie haben wahrscheinlich dazu gedient, in der Bruthöhle den für die Athmung der Eier nöthigen Wasserwechsel zu unterhalten, und sind vielleicht als umgewandelte Hinterleibsfüsse (,fausses pattes abdominales“) zu betrachten. (Man kann dieselben natürlich auch vor dem Ausschwärmen der Jungen zu sehen bekommen, wenn man die Eier durch einen Einschnitt entleert.)

Ebenso tritt jetzt in der ziemlich durchsichtigen Haut deutlich ein Gerüst von Chitinleisten hervor, dessen Anordnung auf der dem Pagurus zugewandten Fläche aus Fig. I 8 ersichtlich ist. In diesen Chitinleisten scheint noch ein Rest der früheren Gliederung des Cryptoniscus erhalten zu sein. 
Wahrscheinlich wird die Mutter bald nach dem Ausschwärmen der Brut absterben und abfallen, und keinenfalls noch einmal in sich Eier und Junge erzeugen. Dafür spricht ihr ganzes Aussehen und namentlich der gänzliche Schwund von Leber und Eierstock. Auch hierin, dass mit einer einmaligen Eiererzeugung sein Lebenslauf abgeschlossen ist, steht Cryptoniscus einzig da unter seinen Verwandten.

Mit diesem Verhalten dürfte die Seltenheit der Männchen im Zusammenhang stehen. Von Bopyrus oder Entoniscus trifft man selten ein Weibchen, dem nicht ein Männchen sich zugesellt hätte. An weit über 5o Cryptoniscus habe ich dagegen ein einziges $\mathrm{Mal}$ eine kleine, 0,9 $\mathrm{mm}$ lange Assel gefunden, die ich als dessen Männchen betrachten zu dürfen glaube (Fig. Ig). In der Bildung der Fühler, der Gliederung der Brust, die 7 Paar gleichgebildeter Beine trägt, und in dem anhanglosen Hinterleibe stimmt es mit der Mehrzahl der Bopyridenmännchen überein; eigenthümlich sind ihm die stark vorspringenden und mit kurzen Dörnchen bewehrten Seitenecken der Leibesringe und der in zwei spitze Zipfel gespaltene und an diesen Spitzen dicht mit kurzen Dörnchen besetzte Schwanz.

\section{Microniscus fuscus. (Taf. XXXVII, Fig. 20.)}

Das Vorkommen der Bopyriden scheint nicht auf Decapoden, Rankenfüsser und Wurzelkrebse beschränkt zu sein, an denen sie allein bis jetzt beobachtet wurden; denn kaum einer anderen Familie dürfte eine Schmarotzerassel zuzurechnen sein, die ich einmal (im November 1864) dem Rücken eines Copepoden aufsitzend fand.

Das Thierchen hatte eine Länge von nur $0,2 \mathrm{~mm}$, wovon $1 / 4$ auf den Kopf und ebensoviel auf den Hinterleib kam; es hatte die Gestalt eines ziemlich stark gewölbten Schildes. Die Leibesringe waren vollzählig und deutlich geschieden. Der Kopf, von einem breiten häutigen Saume eingefasst, trug jederseits nahe seiner hinteren Ecke ein Auge und einen plumpen (ungegliederten?) Fühler. Vordere Fühler wurden nicht gesehen. Die Beine der Brust waren mit Ausnahme des dritten Paares kurze plumpe Klammerfüsse mit dickem kugeligen Handglied und kurzer stumpfer Klaue. Die Beine des dritten Paares, weit länger als die übrigen, ragten weit über die Seiten der Brust vor; ihr letztes Glied bildete ein klauenloses eiförmiges Blatt, das dem Leibe des Wirthes fest anlag. Hinterleibsfüsse und Schwanzanhänge waren borstenlos, - ein Beweis, dass das Thierchen nicht etwa eine noch frei schwimmende Assellarve war, die sich nur vorübergehend an den Copepoden angesetzt hatte. Wahrscheinlich war es noch ein jüngeres Thier, dem möglicherweise noch tiefgreifende Umwandlungen bevorstanden; denn Eier wurden bei demselben noch nicht gefunden. - Seine Farbe war dunkelbraun, die Beine und der häutige Saum des Kopfes farblos.

\section{Zur Systematik der Bopyriden.}

Ueber die systematische Stellung der Bopyriden herrscht unter den Zoologen eine seltene Einstimmigkeit. Man stellt sie allgemein ans Ende der Isopoden, neben die Cymothoiden. Gerstäcker reiht die Bopyriden geradezu der Abtheilung der schwimmenden Asseln ein, während Milne Edwards die Abtheilung der schwimmenden Asseln mit den Cymothoiden schliesst und diesen als besondere 
Abtheilung die festsitzenden Asseln (Jone, Bopyrus) folgen lässt, und wieder Andere (z. B. Claus) die Familien der Asseln, ohne sie in grössere Abtheilungen zu vereinigen, in einfacher Reihe neben einander stellen, an deren Ende dann, neben die Cymothoiden, die Bopyriden zu stehen kommen. Allgemein scheint man also die Cymothoiden als nächste Verwandte der Bopyriden anzusehen. Dieser Ansicht kann ich mich nicht anschliessen; denn ausser dem, was allen Asseln zukommt, haben diese beiden Familien nichts gemein, als die schmarotzende Lebensweise und mit gleichem Rechte würde man z. B. unter den Insecten Läuse und Flöhe neben einander stellen.

Wie bei allen durch's Schmarotzerleben stark veränderten Thieren (Lernäen, Pentastomen u. s. w.) hat man natürlich auch bei diesen schmarotzenden Asseln hauptsächlich die Jugendformen ins Auge zu fassen, um ihre verwandtschaftlichen Beziehungen zu erkennen. Schon der erste flüchtige Blick aber auf die Taf. XXXVI, Fig. 3, .4 und 10 gezeichneten jungen Bopyriden und die zur Vergleichung daneben gestellte junge Cymothoë (Fig. I1) wird Jedem den Eindruck machen müssen, dass die beiden Familien eher an die entgegengesetzten Enden ihrer Ordnung, als neben einander gehören. Eine nähere Vergleichung bestätigt dies.

Bei den Jungen von Cymothoë sieht man wie bei allen schwimmenden Asseln (Sphaeromiden, Cymothoiden) beide Fühlerpaare von nahezu gleicher Länge und Gestalt; bei den jungen Bopyriden, wie bei den gehenden Asseln (Idotheiden, Aselliden, von denen jedoch die Tanaiden auszuscheiden sind, und Onisciden) die vorderen Fühler sehr kurz, selbst wenn sie mit reichlichen Riechfäden ausgerüstet sind (Fig. 5); die hinteren Fühler dagegen, namentlich bei den jüngsten Larven stets von sehr ansehnlicher Länge.

Bei Cymothoë und überhaupt bei den schwimmenden Asseln finden sich tastertragende, bei den Bopyriden wie bei den gehenden Asseln tasterlose Kinnbacken (Mandibeln). Bei Cymothoë und allen schwimmenden Asseln ist der letzte (der Schwanzring) der grösste, bei den jungen Bopyriden wie oft bei den Onisciden der kleinste der Hinterleibsringe. - Bei Cymothoë und den meisten schwimmenden Asseln tragen die Schwanzfüsse zwei grosse blattförmige langbewimperte Endäste; bei den jungen Bopyriden sind diese Endäste griffelförmig, wie bei den Aselliden und Onisciden. - Alle für die schwimmenden Asseln bezeichnenden Merkmale fehlen also den Bopyriden, während sie in der Bildung der Fühler, der Kinnbacken, des Hinterleibes, der Schwanzfüsse an die gehenden Asseln und zwar zumeist an die Onisciden, und unter diesen wieder zunächst an die Gattung Ligia sich anschliessen. Gar manche junge Bopyridenform könnte, vom Rücken betrachtet, für eine mikroskopische Ligia gelten. Abweichend ist, von den verkümmerten Mundtheilen abgesehen, hauptsächlich die Bildung der Hinterleibsfüsse, die bei Ligia der Athmung, bei den jungen Bopyriden der Ortsbewegung dienen, und die Leber, die bei Ligia aus drei Paar, bei den Bopyriden aus einem einzigen Paare langer Blindschläuche besteht. In beiden Beziehungen nähern sich die jungen Bopyriden aber nicht etwa den Cymothoiden, sondern vielmehr den Scheerenasseln (Tanais). - Auch die ungegliederten, aber mit Endborsten versehenen Aeste der Schwanzfüsse stehen in der Mitte zwischen den meist gegliederten borstentragenden Aesten der Scheerenasseln (Tanais) und den ungegliederten borstenlosen Endgriffeln der Felsenasseln (Ligia). - 
Von den verkümmerten Mundtheilen abgesehen, dürften die jungen Bopyriden der Urform der Asseln näher stehen, als irgend andere lebende Asseln, die Scheerenasseln natürlich ausgenommen, die sich indess soweit von allen übrigen Asseln entfernen, dass man sie wohl besser als eigene Unterordnung den eigentlichen Asseln gegenüberstellt. Das Schmarotzerleben, dem die Bopyriden schon seit uralter Zeit sich hingaben und durch welches viele Arten im erwachsenen Zustande bis zur Unkenntlichkeit umgewandelt wurden, dürfte gerade dazu beigetragen haben, dass die Form der freischwimmenden Jungen sich nur wenig veränderte. Den freilebenden Asseln war es vortheilhaft, die Eigenschaften, durch die sie im Kampfe ums Dasein sich behaupteten, möglichst früh zu besitzen; die Jungen nahmen daher allmählich fast vollständig die Gestalt der Eltern an. Anders bei den festsitzenden Bopyriden; die ihnen unentbehrlichen frei beweglichen Jungen wurden nur wenig beeinflusst von den Veränderungen, denen im Laufe der Zeiten die festsitzenden Alten unterlagen, und gleichzeitig wirkte der Kampf ums Dasein während der Zeit des freien Umherschwärmens um so weniger verändernd auf diese jugendlichen Bopyriden ein, einen je kürzeren Abschnitt ihres Lebens diese Jugendzeit umfasste ${ }^{1}$ ).

Statt der herkömmlichen Anordnung der Asseln möchte ich folgende, wahrscheinlich ihrer wirklichen Verwandtschaft besser entsprechende in Vorschlag bringen :

I. Unterordnung. Scheerenasseln.

I. Familie: Tanaiden.

(Asellotes hétéropodes M. Edw.)

II. Unterordnung. Eigentliche Asseln.

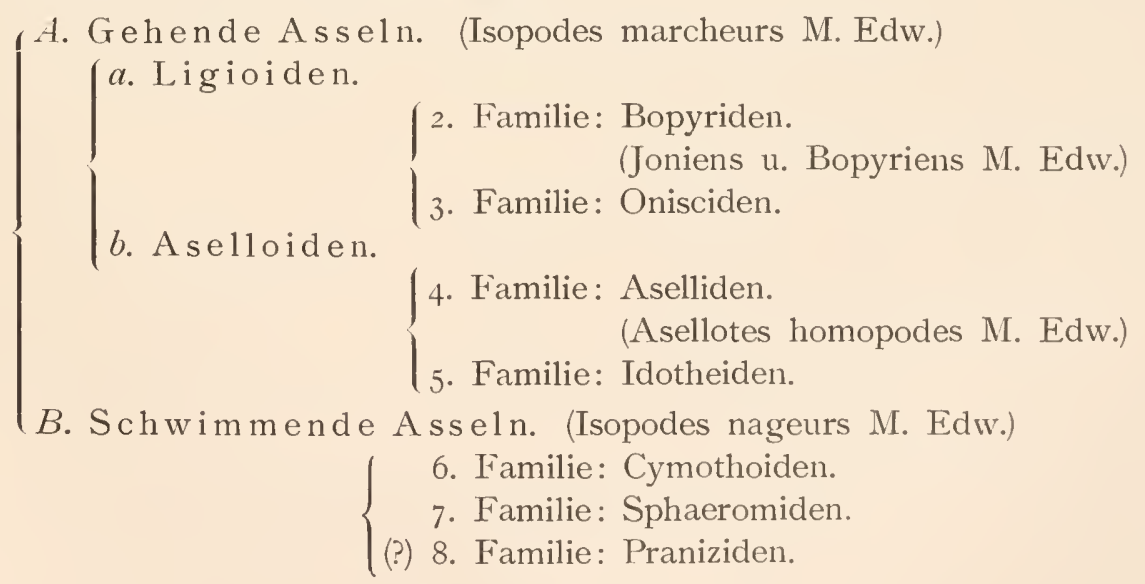

1) Ich vermuthe nach einigen meiner Zeichnungen, dass bei manchen jungen Bopyriden noch eine Spur des zweiten Astes der äusseren Fühler vorkommt. Dies würde der oben ausgesprochenen Ansicht eine wesentliche Stütze verleıhen und ich will deshalb nicht versäumen, die $\Lambda$ ufmerksamkeit späterer Beobachter darauf hinzulenken. - Bis jetzt kennt man im Bereich der Edriophthalmen diesen zweiten Ast der äusseren Fühler (die sogenannte Schuppe des Podophthalmenfühlers) nur bei der Tanaidengattung Apseudes (nach brieflicher Mittheilung von Spence Bate). - 
Die Bopyriden zerfallen in drei (oder vier?) sowohl durch Bau als durch Aufenthaltsort verschiedene Gruppen.

Die erste Gruppe bilden die äusserlich, am Hinterleibe oder in der Kiemenhöhle von Decapoden festsitzenden Arten, für die man bereits eine ganze Zahl von Gattungen aufgestellt hat (Bopyrus, Jone, Phryxus, Gyge, Athelgue u. s. w.), die man aber besser fürs Erste in der einen Gattung Bopy rus vereinigt liesse. Ich habe aus dieser Gruppe 5 Arten beobachtet, den oben besprochenen Bopyrus resupinatus und vier andere, die in der Kiemenhöhle eines Grapsus (Leptograpsus rugulosus?), einer Porcellana, eines Alphëus und einer Hippolyte leben. Thre Jungen sind, soweit ich sie kenne, dadurch ausgezeichnet, dass die sämmtlichen Beinpaare der Brust gleich gebildet sind und dass sie am Schwanzende einen unpaaren griffelförmigen Fortsatz besitzen. - Nach beiden Merkmalen dürfte die in Fig. 10 gezeichnete Larve von einem Thiere dieser Gruppe abstammen.

Die zweite Gruppe umfasst die in der Leibeshöhle von Krabben und Porcellanen lebenden Arten, die Gattung Entoniscus. Das letzte Beinpaar der Brust ist bei den Larven abweichend gebildet, die Hinterleibsfüsse der Larve haben einen einzigen blattförmigen Endast.

Die dritte Gruppe, die Gattung Cryptoniscus, lebt an Rankenfüssern und Wurzelkrebsen. Hierher gehört ausser Cryptoniscus planarioides der in Balanus balanoides lebende Schmarotzer, welchen Goodsir als Männchen dieses Balanus beschrieb, Darwin aber als weibliche Schmarotzerassel erkannte ${ }^{1}$ ), sowie Rathke's an Peltogaster paguri lebende Liriope pygmaea. Nach der mir brieflich mitgetheilten Ansicht eines der gründlichsten Kenner der Edriophthalmen, Spence Bate's, gehören diese drei Arten in eine einzige Gattung, für die ich den Namen Cryptoniscus beibehalten zu dürfen glaube, da der Name Liriope schon vor Rathke durch Lesson an eine Qualle vergeben wurde ${ }^{2}$. - Ein eigenes Urtheil über diese Ansicht Spence Bate's habe ich nicht, da mir die Beschreibung des Balanusschmarotzers von Goodsir und die Arbeit von Lillieborg über Liriope nicht zugänglich sind. - Bei den Jungen von Cryptoniscus planarioides ist, wie bei denen von Entoniscus, das letzte Beinpaar der Brust abweichend gebildet; die Schwimmfüsse des Hinterleibes aber tragen zwei griffelförmige Aeste.

Einer vierten Gruppe endlich scheint der an Copepoden schmarotzende Microniscus zugetheilt werden zu müssen. Bei keinem anderen bekannten Bopyriden ist $\mathrm{zu}$ irgend einer Lebenszeit das dritte Beinpaar der Brust abweichend von den übrigen gebaut.

Wie in vielen anderen Fällen finden wir also auch bei den Bopyriden, dass bestimmte Gruppen verwandter Schmarotzer auf bestimmte Gruppen verwandter Wohnthiere beschränkt sind. Dieses Vorkommen verwandter Schmarotzer an verwandten Wohnthieren, wobei nicht selten dem Verwandtschaftsgrade der Wirthe der Verwandtschaftsgrad der Gäste entspricht, lässt sich auf verschiedene Weise entstanden denken. Entweder war 1. schon die Stammform der Wirthe von der Stammform der Gäste bewohnt und während erstere sich umwandelnd in ver-

1) Darwin, Monograph of the Cirripedia. Lepadidae. S. 55. $\Lambda \mathrm{nm}$.

2) Ueber die Priorität der Lesson'schen Namengebung s. Max Schultze, Arch. für Naturgesch. 1859. I. S. 310 , Anm. = Ges. Schriften S. 93 . 
schiedene Arten, Gattungen, Familien aus einander ging, thaten ein Gleiches, den Veränderungen der Wohnthiere sich anpassend, auch die Schmarotzer. Oder 2. die gemeinsame Stammform der Schmarotzer, die ursprünglich nur an einer bestimmten Art von Wohnthieren lebte und von dieser sich später auf andere verwandte Arten verbreitete, oder auch gleichzeitig auf mehreren verwandten Arten als Schmarotzer sich niederliess, nahm den Eigenthümlichkeiten der verschiedenen Wohnthiere entsprechende neue Formen an und zerfiel so in eine Gruppe verwandter Arten oder selbst Gattungen. Oder es konnten endlich 3. schon ursprünglich verschiedene verwandte Arten an anderen ebenfalls unter sich verwandten Arten zu schmarotzen beginnen. Bald mag vorwiegend die eine, bald die andere Weise, selten wohl ausschliesslich eine derselben die jetzt bestehende Vertheilung der Schmarotzer herbeigeführt haben. Mit Sicherheit den Antheil der einen und der anderen festzustellen, wird vielleicht in keinem Falle möglich sein.

Was die gesammte Familie dęr Bopyriden betrifft, so ist der erste der eben aufgezählten Fälle natürlich sofort auszuschliessen; denn zur Zeit, als die gemeinsame Stammform der Decapoden, Copepoden, Rankenfüsser und Wurzelkrebse lebte, an denen jetzt diese Schmarotzer vorkommen, gab es überhaupt noch keine Asseln. Die grösste Wahrscheinlichkeit hat hier der dritte Fall für sich. Es dürfte einst zwischen den Bopyriden und den übrigen Krustern ein ähnliches Verhältniss bestanden haben, wie gegenwärtig zwischen den Cymothoiden und den Fischen. Alle Cymothoiden scheinen an Fischen ihre Nahrung zu suchen; einige fallen schaarenweise über todte oder auch kranke Fische her; - andere, treffliche Schwimmer, heften sich nur zeitweise schleimfressend oder blutsaugend an lebende Fische, gelegentlich auch, wie ich selbst erfahren, an badende Menschen; - andere endlich, die Minderzahl, sind im Alter festsitzende Schmarotzer mit ziemlich verkrüppelten Bewegungswerkzeugen. Auch deren Vorfahren waren einst ohne Zweifel nur gelegentliche Besucher ihrer Wohnthiere und es ist nicht unwahrscheinlich, dass die Nachkommen mancher Arten, die jetzt noch frei leben, einst zu bleibenden Gästen der von ihnen besuchten Fische werden. Ebenso mögen einst die frei lebenden Vorfahren der Bopyriden an anderen Krustern ihre Nahrung gesucht und von diesen mögen verschiedene Arten nach und nach aus zeitweiligen Besuchern zu festsitzenden Schmarotzern geworden sein.

Anders stellt sich die Sache für die einzelnen Gruppen der Bopyriden. Es ist nicht unwahrscheinlich, dass der gemeinsame Stammvater der Bopyrusarten, es ist so gut wie gewiss, dass derjenige der Entoniscus und ebenso derjenige der Cryptoniscusarten selbst schon ein Schmarotzer war und dass die Mehrzahl der heute mit solchen Schmarotzern behafteten Arten dieselben von ihren Vorfahren ererbt haben.

Besonders merkwürdig ist in dieser Beziehung die Cryptoniscusgruppe durch ihr gleichzeitiges Vorkommen an Rankenfüssern und Wurzelkrebsen. Wenn Schmarotzer, die auf eine bestimmte einzelne Art von Wohnthieren beschränkt und von dieser so völlig abhängig sind, wie es mit Cryptoniscus der Fall ist, durch gelegentliches Verirren der Jungen sich auf andere Arten verbreiten, so wird dies sicher nur auf nahe verwandte Arten, nicht aber auf so weit verschiedene Thiere geschehen, wie jetzt Balanen und Wurzelkrebse sind. Sollte 
auch z. B. gelegentlich die Larve des Goodsir'schen Cryptoniscus, statt den an Felsen haftenden Balanus aufzusuchen, sich in ein Schneckenhaus verirren, in welchem ein mit Peltogaster behafteter Pagurus wohnte, so ist es doch kaum denkbar, dass dieser Peltogaster trotz seiner völlig umgewandelten Form und trotz seiner völlig verschiedenen Nahrung in Geruch und Geschmack und überhaupt in der chemischen Beschaffenheit seiner Säfte dem Balanus so ähnlich geblieben sei, dass die Larve an ihm sich festsetzen und einen passenden Boden für ihre Entwickelung finden sollte. Dies ist um so weniger glaublich, als der Goodsir'sche Schmarotzer nicht einmal die anderen Balaniden, die an gleicher Stelle und untermischt mit Balanus balanoides leben (Balanus perforatus und Chthamalus stellatus) ${ }^{1}$ ), heimzusuchen scheint. Ein Uebersiedeln der Cryptoniscusarten von Rankenfüssern auf Wurzelkrebse oder umgekehrt ist mithin im höchsten Grade unwahrscheinlich; ich bin vielmehr der Meinung, dass die mit Cryptoniscus behafteten Wurzelkrebse dieselben von der Zeit her ererbt haben, wo ihre Vorfahren selbst noch Rankenfüsser waren. Dass von dem gemeinsamen Stammvater der Wurzelkrebse diese Schmarotzer, wie es scheint, nur auf wenige seiner Nachkommen übergegangen sind, ist dabei so wenig befremdlich, als dass oft nur sehr vereinzelte Thiere die ihrer Art eigenthümlichen Schmarotzer beherbergen. - Es würde demnach die Entstehung der Wurzelkrebse in eine verhältnissmässig neue Zeit fallen, in der schon die Familie der Bopyriden in die jetzt bestehenden Hauptgruppen sich aufgelöst hatte, oder mit anderen Worten die Gattung Cryptoniscus würde älter sein, als die ganze Gruppe der Rhizocephalen. Wie in diesem, mögen in manchen anderen Fällen die Schmarotzer zur Bestimmung des beziehungsweisen Alters verschiedener Thiergruppen sich benutzen lassen.

Ich habe im Vorstehenden den Cryptoniscus planarioides als Schmarotzer von Sacculina purpurea, den Bopyrus resupinatus als Schmarotzer von Pagurus bezeichnet, obwohl beide sich jetzt in vollkommen gleicher Weise zu Sacculina und Bopyrus verhalten, nämlich die Sacculina verdrängen, um aus deren im Pagurus fortwuchernden Wurzeln ihre Nahrung zu ziehen. Es wird dies keiner weitläufigen Rechtfertigung bedürfen; denn offenbar ist Cryptoniscus von der Sacculina aus, Bopyrus vom Pagurus aus an den jetzt beiden gemeinsamen Wohnsitz, den Anheftungspunkt der Sacculina an den Pagurus gelangt. Cryptoniscus (Liriope) pygmaeus ist noch einfacher Schmarotzer von Peltogaster paguri, den er nicht verdrängt, und entsinne ich mich recht, so hat man im Vaterlande dieser Thiere auch einen Bopyrus gefunden, der als einfacher Schmarotzer am Hinterleibe von Pagurus lebt. Möglich, dass diese norwegischen Arten einst auch noch die bequeme und ausgiebige Nahrungsquelle entdecken, an der ihre brasilianischen Verwandten sich bereits niedergelassen haben.

Itajahy, Sa. Catharina, Brazil, im December $\mathbf{r} 869$.

\section{Erklärung der Abbildungen auf Tafel XXXVI und XXXVII.}

Fig. I-3. Entoniscus Cancrorum.

Fig. I. Erwachsenes Weibchen.

Fig. 2. Jüngste Larve, in ihrer Lieblingsstellung.

1) Darwin, Balanidae. S. 272 . 
Fig. 3. Jüngste Larve von der Bauchseite, mit ausgebreiteten Gliedmaassen.

Fig. 4-9. Bopyrus resupinatus.

Fig. 4. Jüngste Larve, vom Rücken. l. Leber.

Fig. 5. Aeltere Larve, an einem mit Sacculina behafteten Pagurus gefunden; (die drei letzten Beinpaare der Brust und die Schwimmfüsse des Hinterleibes sind weggelassen).

Fig. 6. Junges Weibchen, vom Rücken. l. Leber. h. Herz.

Fig. 7. Erwachsenes Weibchen, vom Rücken.

Fig. 8. Ein solches von der Bauchseite.

Fig. 9. Männchen. l. Leber. h. Herz. t. Hoden.

Fig. Io. Bopyridenlarve von unbekannter Abkunft. d. Darm. l. Leber.

Fig. II. Junge Cymothoë, der Bruthöhle der Mutter, entnommen.

Fig. I2-I9. Cryptoniscus planarioides.

Fig. I 2. Theile der jüngsten Larve: $a$. Kopf. b. ein Bein des 5. Paares der Brust. c. ein Schwimmfuss vom letzten (5.) Paare des Hinterleibes. Sacculina.

Fig. I3. Junges festsitzendes Weibchen. h. Herz. l. Leber (?). ch. Chitinkranz der

Fig. I4. Halbwüchsiges Weibchen. c. Mundende desselben. L. Leibeswand des Cryptoniscus. $m$. das in die Wurzeln der Sacculina eingesenkte Mundende; zwischen beiden der Chitinring der Sacculina, an dem man den im Innern des Pagurus sich ausbreitenden Kranz $k$. und die ausserhalb desselben liegende Platte $p$. unterscheidet.

Fig. I 5. Mundende eines anderen Weibchens. L. und $m$. wie in Fig. I4. B. Eingang zur Bruthöhle des Cryptoniscus. ch. Chitinring der Sacculina.

Fig. I6. Aelteres Weibchen. wurzeln.

Fig. I7. Weibchen mit fast reifer Brut. Am Anheftungspunkte grüne Sacculina-

Fig. I8. Chitingerüst in der Leibeswand eines alten Weibchens. B. Eingang zur Bruthöhle, in welchem man 4 fingerförmige Anhänge sieht. Ch. Chitinplatte der Sacculina.

Fig. I9. Männchen. h. Herz. l. Leber.

Fig. 20. Microniscus fuscus. 


\title{
Ueber den Trimorphismus der Pontederien ${ }^{1}$ ).
}

\author{
Mit 4 Textfiguren.
}

Vor mehreren Jahren wurde hier als Zierpflanze eine Pontederia (wahrscheinlich Pontederia crassipes) eingeführt, die sich seitdem auf ungeschlechtlichem Wege mit unglaublicher Schnelligkeit vermehrt hat. In einem Graben, in welchen ich vor noch nicht zwei Jahren eine kleine Pflanze dieser Pontederia warf, hat dieselbe auf weite Strecken ihre einheimische Verwandte, die Heteranthera reniformis R. \& P., verdrängt, und entfaltet jetzt täglich Hunderte von Blüthenähren.

Nach Endlicher (Gen. plant. No. 1088, b, $\alpha$.) sollen bei den eigentlichen Pontederien die Staubfäden ziemlich gleich lang sein. Unsere Pflanze dagegen (Fig. 4) hat drei kurze und drei sehr lange Staubfäden; die Staubbeutel der ersteren liegen am Eingange der Blumenröhre, die der letzteren stehen etwa $2 \mathrm{~cm}$ darüber. Die Narbe steht zwischen diesen beiden Gruppen von Staubbeuteln, ganz wie bei der mittelgriffligen Form von Lythrum Salicaria. Es war mir kaum zweifelhaft, dass auch diese Pontederia trimorph sei und dass die, welche ihr Stamina subaequalia zuschrieben, lang- oder kurzgrifflige Pflanzen vor sich hatten, während die hier eingeführte Pflanze der mittelgriffligen Form angehörte. Ich war daher sehr gespannt, die Blumen einer zweiten Art zu untersuchen, die im unteren Laufe des Itajahy-mirim in grosser Menge an den Ufern hin wächst.

Bei einem Ausfluge, den ich deshalb im October 1868 nach dem „kleinen Flusse" machte, (wie von den Anwohnern des Itajahy der Itajahy-mirim gewöhnlich genannt wird), fand ich die Pontederia leider noch nicht in Blüthe. Dagegen leuchteten mir in voller Pracht ihre spannenlangen dunkelblauen Blüthenähren entgegen, als ich vor wenigen Tagen an der Mündung des kleinen Flusses vorüberfuhr. Nach dem Landen gelang es mir, vom Ufer aus einige Blüthen zu erreichen und diese waren - zu meiner nicht geringen Freude - theils lang-, theils kurzgrifflig!

Um auch der mittelgriffligen Form habhaft $\mathrm{zu}$ werden, liess ich mich im Canoe den kleinen Fluss hinauffahren. Von jeder Pflanze, an der wir vorüberkamen, - (eine einzige Pflanze bedeckt oft eine Fläche von mehreren Quadrat-

I) Jenaische Zeitschrift für Naturwissenschaft 1871. Bd. 6. p. $74-7 \%$. 
ruthen) - wurde eine Aehre gepflückt und untersucht; aber umsonst! - Langgrifflig, kurzgrifflig, - kurzgrifflig, langgrifflig ging es fort und fort, bis ich nach stundenlangem vergeblichen Suchen umkehrte, ohne eine einzige mittelgrifflige Pflanze gefunden zu haben. -

Schon beim Beginn der Fahrt fiel es mir auf, dass die Blumen verschiedener Pflanzen sich sehr merklich in ihrer Farbe unterschieden; das Blau der einen war dunkler und rein, das der anderen blasser und ins Violette ziehend. Bald bemerkte ich, dass alle dunklen Blumen kurzgrifflig; die blasseren langgrifflig waren, so dass ich nun schon aus der Ferne die beiden Formen unterscheiden konnte. Unter Hunderten von Pflanzen kam keine Ausnahme vor.

Diese verschiedene Farbe der lang- und der kurzgriffligen Blumen ist eben so auffallend, als das Fehlen der mittelgriffligen Form. Hat die Pflanze, wie es bei manchen auf ungeschlechtlichem Wege rasch sich vermehrenden Arten der Fall zu sein scheint, das Vermögen verloren, keimfähige Samen zu erzeugen und sind alle Pflanzen des Itajahy-mirim nur Theile je eines lang- und eines kurzgriffligen Stockes? - Oder entstehen aus den durch Kreuzung je zweier Formen erzeugten Samen bei Pontederia nur immer wieder diese beiden Formen, aber nicht die dritte, und erben dann mit der Form der Staubgefässe und Griffel die Sämlinge auch die eigenthümliche Farbe des Vaters oder der Mutter? - Ich kann für jetzt keine Antwort geben, sondern nur für die Möglichkeit der einen wie der anderen Annahme auf ein ähnliches Verhalten trimorpher Oxalis-Arten hinweisen. Von einer auf der Insel Santa Catharina ungemein häufigen Art finden sich dort nur zwei Formen, die völlig unfruchtbar sind und sogar in der Regel nur ganz taube („,contabescirte“ Gärtner) Staubbeutel hervorbringen. Aus Samen der langgriffligen Form einer weissen trimorphen Oxalis, die mit Blüthenstaub der längeren Staubgefässe der mittelgriffligen Form bestäubt worden war, erhielt ich nur lang- und mittelgrifflige, aber keine kurzgriffligen Sämlinge. Bemerken will ich noch, dass junge, anscheinend gesunde Früchte sowohl an lang-als an kurzgriffligen Pflanzen von Pontederia in Menge vorhanden waren. -

Die trimorphen Pontederien sind in mehrfacher Beziehung der Beachtung werth. Zunächst schon als Zuwachs zu der noch so geringen Zahl der bisher als trimorph erkannten Pflanzen, die alle der Gattung Lythrum und ihren nächsten Verwandten, sowie der Gattung Oxalis angehören. Dann als trimorphe Monocotyledonen; denn alle bisher bekannt gewordenen dimorphen und trimorphen Arten sind Dicotyledonen. Ferner als weiteres Beispiel für die Richtigkeit einer Vermuthung, die Darwin vor Jahren mir brieflich aussprach, dass nämlich Wasser- und Marschpflanzen besonders zum Dimorphismus geneigt seien. Vor allem aber wegen ihrer unregelmässigen Blüthen ${ }^{1}$ ) und der eigenthümlichen, von Lythrum und Oxalis völlig abweichenden Weise, in welcher bei ihnen der Trimorphismus zu Stande kommt. Bei Lythrum und Oxalis wechseln bekanntlich die längeren und kürzeren Staubfäden miteinander ab; jene stehen den Kelch-, diese den Blumenblättern gegenüber; die Staubbeutel desselben Staubblattkreises stehen in gleicher oder nahezu gleicher Höhe. Bei Pontederia dagegen gehört von den längeren

I) "As yet I know of no case of dimorphism in flowers which are very irregular: such flowers being apparently always sufficiently visited and crossed by insects." Darwin, brieflich, 1867 .

Fritz. Müllers gesammeltr Schriften. 
Staubgefässen eines (Fig. 2, 3, 4, A) dem äusseren, zwei (Fig. 2, 3, 4, B) dem inneren Kreise an, von den kürzeren zwei (Fig. 2, 3, 4, a) dem äusseren, eines (Fig. 2, 3. 4, b) dem inneren Kreise; sowohl die drei längeren, als die drei kürzeren Staubgefässe entspringen neben einander. Sowohl in der Gruppe der längeren als in der der kürzeren Staubgefässe entspringen die den Kelchblättern gegenüberstehenden $(A, a)$ etwas höher, als die den Blumenblättern gegenüberstehenden $(B, b)$, so dass also von den längeren Staubgefässen das mittlere $(A)$, welches von dem unpaaren (vorderen) Kelchblatte entspringt, höher steht, als die seitlichen $(B)$, während umgekehrt von den kürzeren Staubgefässen das mittlere $(b)$, welches von dem unpaaren in beiden Arten mit einem dottergelben Fleck gezeichneten Blumenblatte entspringt, tiefer steht, als seine Nachbarn $(a)$. Bei der mittelgriffligen und

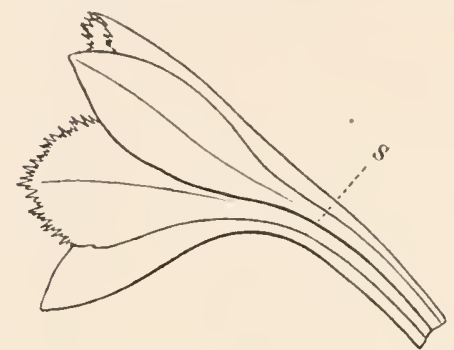

Fig. 1 .

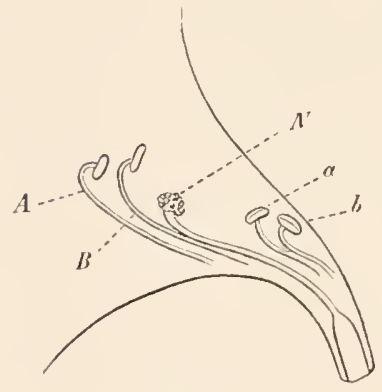

Fig. 4.

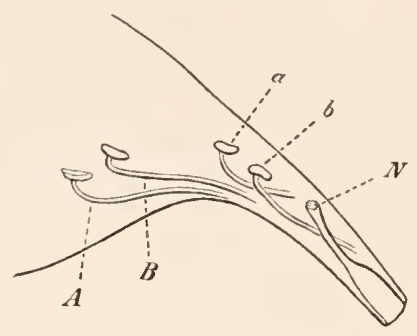

Fig. 2.

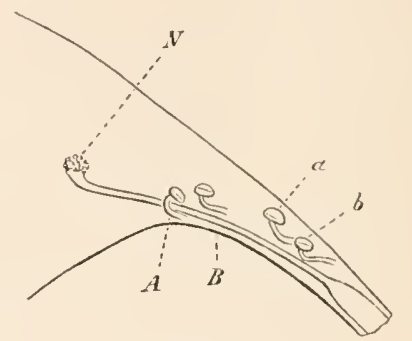

Fig. 3.

Fig. I. Blume der Pontederia aus dem Itajahy-mirim, von der Seite, nat. Gr. $-s$ Spalt zwischen den seitlichen Kelchund seitlichen Blumenblättern.

Fig. 2. Griffel und Staubgefässe der kurzgriffligen Form dieser Art.

Fig. 3. Dieselben von der langgriffligen Form derselben Art.

Fig. 4. Dieselben von der mittelgriffligen Form einer anderen Pontederia (crassipes?). -

In Fig. 2, 3 und 4 bedeuten: $N$. Narbe. $A$. unpaares, $a$ paariges Staubgefäss des äusseren Kreises. $B$ paariges, $b$ unpaares Staubgefäss des inneren Kreises. Ein Staubgefäss $a$, sowie ein Staubgefäss $B$ ist weggelassen.

langgriffligen Form stehen auch die Staubbeutel der beiden seitlichen kürzeren Staubgefässe in nicht ganz gleicher Höhe.

Die Blüthenstaubkörner sind bei der mittelgriffligen Form der Pontederia crassipes (?) ein wenig grösser in den langen, als in den kurzen Staubgefässen. Den Blüthenstaub der Pontederia des Itajahy-mirim habe ich nicht mikroskopisch untersucht. - Die aufwärts gebogene Narbe der langgriffligen 13lumen der letzteren Art ist bedeutend grösser als die der kurzgriffligen, wie es bei vielen anderen dimorphen Pflanzen der Fall ist.

Noch einer Eigenthümlichkeit der Pontederia des Itajahy-mirim mag hier beiläufig erwähnt sein. Die Kelch- uud Blumenblätter sind nur am Schlunde der Blumenröhre mit einander verwachsen, im unteren Theile der Röhre dagegen frei; namentlich bleiben zwischen den seitlichen Kelch- und den seitlichen Blumenblättern deutlich klaffende Spalten (Fig. I, s), durch die man den Griffel von aussen 
sehen kann. Das unpaare Blumenblatt war bei einigen kurzgriffligen Blumen auch in seinem unteren Theile mit den seitlichen Kelchblättern verwachsen. Bei Pontederia crassipes (?) und Heteranthera reniformis sind Kelch- und Blumenblätter zu einer rings geschlossenen Röhre verwachsen.

Die den Pontederien nahe verwandte Heteranthera renifor $\mathrm{m}$ is ist nicht trimorph; die drei kürzeren Staubgefässe der trimorphen Pontederien, die von den seitlichen Kelchblättern und dem unpaaren Blumenblatt entspringen, fehlen hier; das übrig bleibende Staubgefäss des äusseren Kreises ragt weit über die Blumenröhre vor und trägt einen bläulichen Staubbeutel, wvährend die beiden Staubgefässe des inneren Kreises weit kürzer sind und gelbe Staubbeutel tragen. Der Griffel hat bei allen Pflanzen nahezu gleiche Länge und die Narbe steht in gleicher Höhe mit dem blauen Staubbeutel ${ }^{1}$ ).

Itajahy, Sa. Catharina. Brazil, im Dezember i869.

I) Endlicher's Angabe (gen. plant. No. I087), dass Heteranthera „stamina 3, limbi lobis interioribus opposita" besitzt, ist wenigstens für H. reniformis falsch. 


\section{Remarks on some white ants ${ }^{1}$.}

Dr. Hagen also remarked that Mr. Fritz Müller had sent to him some white ants from Itahahy, St. Catharina, Brazil, with the following remarks: -

„These nests of white ants are more or less regular cylinders, one span high and two or three inches thick. By horizontal floors they are divided into twelve or fifteen compartments or chambers. The outer surface bulges out so that one can make out the number of chambers by the enlargements of the cylinder. A pillar goes through all the compartments; close to this, or in it, runs an oblique passage from each chamber to the next. Sometimes all these passages together form a somewhat regular winding stair through all the compartments. For the impregnated female these passages are too narrow, and she can therefore not leave her chamber.

There are, both in the outer wall and in the horizontal divisions, passages too small to admit the passing of the winged ants; but neither in the outside wall nor in the chambers is there any opening to the outside in nests which have not been injured.

In the outside wall the passages run from top to bottom. In the divisions, from circumference to centre without reaching this latter. In the flat compartments they are not to be detected from the outside; in the circumference they appear as flattened ridges. In drying, the outer side of the passages falls off, and then they are to be seen as deep hollows with inflated borders. In undisturbed nests the only entrance seems to be on the upper surface some inches under ground.

The nest is not directly connected with the earth, but is surrounded by about a finger's breadth of free space. The nest can, therefore, as soon as the upper end is freed from earth, be easily taken out of the ground.

I have never found in one of these nests more than one impregnated female. Besides the winged ants, the eggs and the larvæ, there are found two kinds of laborers; of these one kind is distinguished by a truncated nose.

Not in the nest but in the same piece of land, are found, in planting corn, single white ants with disproportionately large heads and long mandibles."

The winged ants were stated by Dr. Hagen to belong to Termes striatus, or perhaps to $T$. similis; the imago is in too bad a condition for accurate determination. The soldier with truncated nose was figured by him as $T$. similis; the soldier with long mandibles, as $T$. cingulatus.

No description of white ants' nests like this has ever been given before.

I) Proceedings of the Boston Society of Natural History. 187I. p. 205, 206. Section of Entomology. January 26. 18\%o. 


\section{Bestäubungsversuche an Abutilon-Arten ${ }^{1}$ ).}

Mit 8 Textfiguren.

Pflanzen, deren eigener Blüthenstaub keine Befruchtung bewirkt, sind besonders bequem zu Bastardirungsversuchen. Das oft so mühsame und häufig nicht ohne schwere Verletzung der Blumen auszuführende Entfernen der Staubbeutel ist bei ihnen nicht nöthig; es genügt die Zufuhr fremden Blüthenstaubes abzuhalten. Ich wählte daher für eine Reihe von Versuchen, durch die ich aus eigener Erfahrung die Gesetze der Bastarderzeugung im Pflanzenreiche kennen zu lernen beabsichtigte, zunächst mehrere selbst unfruchtbare (,self-sterile“ Darwin) Arten der Gattung Abutilon.

Die Ergebnisse, welche die Versuche des vorigen Jahres in Bezug auf Samenertrag lieferten, will ich im Folgenden kurz besprechen, - nicht weil ich denselben einen besonderen Werth beilege, sondern weil ich hoffe, dadurch auch Andere anzuregen zu Versuchen über die mannichfachen Fragen, die sich dabei aufdrängen.

Meine Bestäubungsversuche wurden angestellt:

I) an einem Abutilon vom oberen Capivary, das mir in Kew als verwandt mit Ab. virens bestimmt wurde;

2) an einem hier in Gärten öfter zu findenden Abutilon, das mir ein deutscher Gärtner als Ab. striatum bezeichnete;

3) an einem Bastarde dieser beiden Arten, dessen Mutter das CapivaryAbutilon, dessen Vater das Ab. striatum ist, welchem letzteren es in Wuchs, Blatt und Blüthe weit ähnlicher ist, als der Mutter;

4) an einem am Ufer des Itajahy häufigen Abutilon mit schmalem lanzetförmigem Blatte und rother Blüthe, das von den Brasilianern Embira branca (,weisser Bast") genannt wird.

Ausser dem Blüthenstaube dieser Arten kam zur Verwendung:

5) Blüthenstaub einer weissblühenden Pflanze der Embira branca, die auch durch kleinere Blüthen und I I- bis I 2 fächrige Früchte (bei der rothblühenden Form meist I4-I6fächrig) sich auszeichnete. Meine Kinder fanden eine einzige Pflanze zwischen der gewöhnlichen rothblühenden Form am Rio do Testo, einem Nebenflusse des Itajahy.

1) Jen. Zeitschrift für Naturwissenschaft 1873. 7. Jahrg. S. $22 \quad 45$. 
6) Blüthenstaub eines schönen baumartigen Abutilon mit über mannshohem Stamme und tiefgelappten Blättern, von dem ich eine einzige Pflanze etwa 5 Stunden von hier (am Pocinho) nicht weit vom Ufer des Itajahy fand.

7) Blüthenstaub des Abutilon vexillarium, von dem ich eine Blüthe aus dem Garten des Dr. Blumenau erhielt.

Die Zahl der Fächer ist bei den Früchten dieser verschiedenen Arten sehr unbeständig, daher giebt die Zahl der Samen in der ganzen Frucht kein passendes Maass der Fruchtbarkeit. Bei voller Fruchtbarkeit d. h. wenn alle Eichen sich zu guten Samen entwickelten, würde eine 8 fächrige Frucht des Capivary-Abutilon 64 bis 72 , eine 1 I fächrige 88 bis 99 Samen enthalten; eine 8 fächrige Frucht mit 6o Samen nähert sich also der vollen Fruchtbarkeit weit mehr, als eine i I fächrige mit gleicher Samenzahl; erstere hätte durchsclinittlich 7,5 , letztere nur 5,5 Samen in einem Fache. Diese Durchschnittszahl, die man erhält, indem man die Zahl der Samen durch die Zahl der Fächer theilt, ist für diese Pflanzen das passendste Maass der Fruchtbarkeit,

Die Früchte des Abutilon werden hier oft von kleinen, in ihrem Innern lebenden Raupen heimgesucht; fressen dieselben eine grössere Zahl von Fächern aus, so fällt die Frucht gewöhnlich kurz vor der Reife ab; wo nur wenige, 1, 2 oder höchstens 3 Fächer ausgefressen waren, habe ich die Gesammtzahl der Samen nach der Zahl derer berechnet, die in den unversehrten Fächern sich fanden, also z. B. für eine ı fächrige Frucht, die in 8 unversehrten Fächern 44 Samen enthielt, $\frac{10.44}{8}=55$ Samen angenommen.

\section{Abutilon vom Capivary.}

Zu Versuchen dienten 6 Pflanzen. Vier derselben (I, II, III, IV) sind Geschwister, d. h. stammen von Samen ein und derselben Frucht, die ich im Mai I868 am Capivary pflückte. Die Pflanze $V$ hat die Pflanze II zur Mutter; der Vater, sowie die .Eltern der Pflanze VI, die ebenfalls aus Samen jener einen Frucht gezogen waren, sind durch eine Ueberschwemmung zerstört worden. Der Vater von $\mathrm{V}$ war Mutter von VI.

Die Eigenschaft, mit eigenem Blüthenstaube völlig unfruchtbar zu sein, hatte ich schon früher an all diesen Pflanzen durch Versuche festgestellt; deshalb fehlen solche Versuche fast ganz unter den nachstehend aufgeführten. Wie unbestäubte Blüthen fallen solche, die mit Blüthenstaub desselben Stockes bestäubt wurden, je nach Wetter und Jahreszeit 4 bis 7 Tage nach dem Aufblühen sammt dem oberen Theile des Blüthenstieles ab.

In Betreff der Bestäubung sei erwähnt, dass deren einzige natürliche Vermittler während der Dauer der Versuche (4. Juli bis 4. Oktober) die Kolibris waren, denen überhaupt für unsere Winterflora fast ausschliesslich dieses Geschäft obliegt. Indem diese von unten her ihren Schnabel in die hängenden Blumenglocken stecken, wird ihr Kopf mit dem leicht ausfallenden Blüthenstaube überstreut, den sie dann an die abwärts gerichteten, über die Staubgefässe mehr oder weniger weit vorstelienden Narben der zunächst besuchten Blumen wischen. $\mathrm{Zu}$ anderen Zeiten habe ich auch, doch nur selten, einen grossen gelben Schmetterling ans der Familie der Pieriden an den Blumen dieses Abutilon geselıen. Pei 
der künstlichen Bestäubung wurden (wie auch bei den übrigen Arten) gewöhnlich die ganzen Blumen benutzt, um unmittelbar mit ihren Staubbeuteln die Narben zu betupfen; des Pinsels bediente ich mich nur, wenn die den Blüthenstaub liefernde Blüthe selbst bestäubt werden sollte, also nicht abgeschnitten werden durfte. Zum Schutze der bestäubten Blüthen gegen die Kolibris dienten Gazebeutel ${ }^{1}$ ).

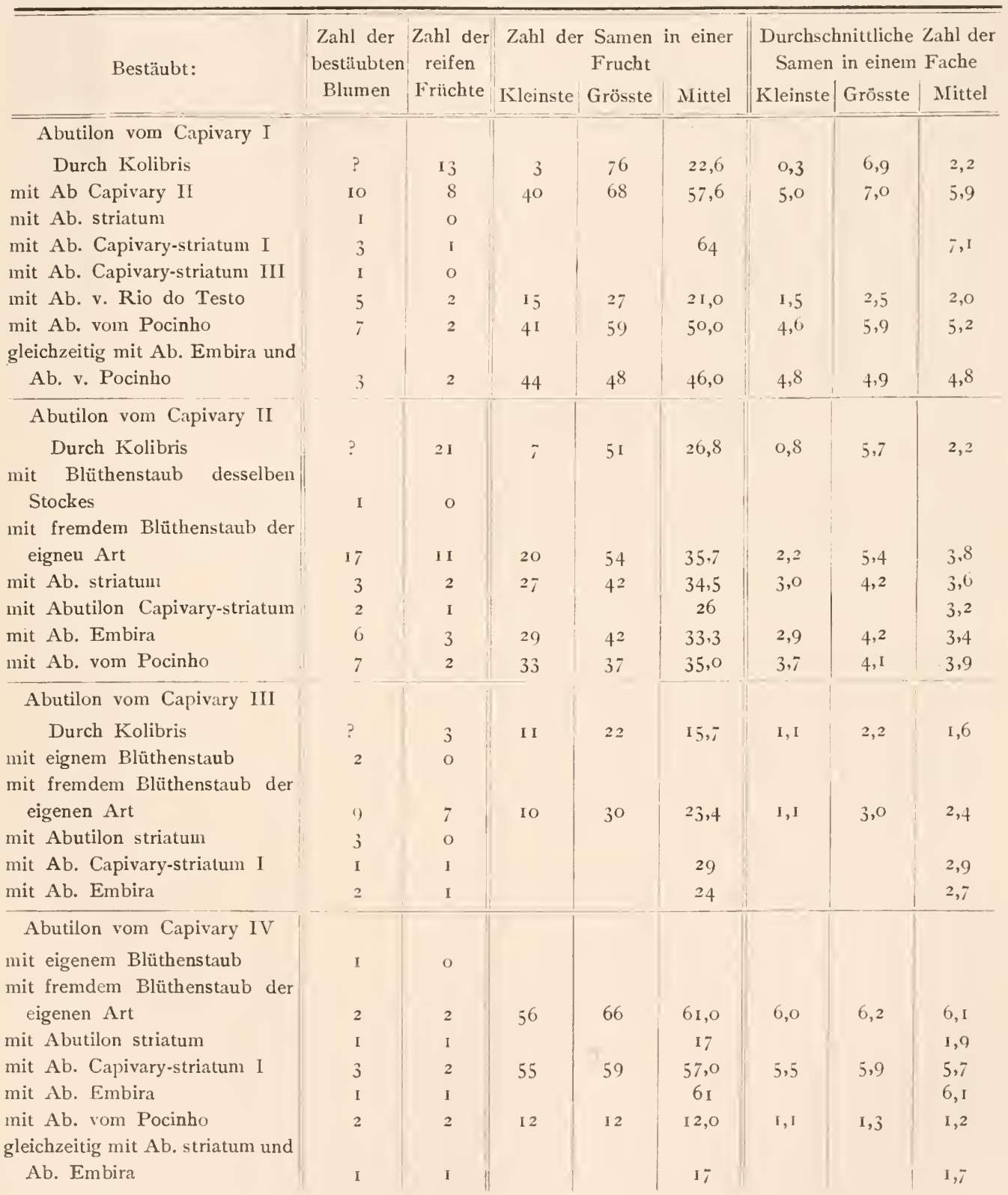

I) Einige der Gazebeutel waren etwas zu enge, so dass sich die Blunienkronen nicht frei genug entfalten konnten; wurden diese Gazebeutel entfernt, so breiteten sich die Blumenkronen weit über das gewöhnliche Maass, fast in eine Ebene aus, während sie ohne vorherige Einengung eine Glocke bilden, deren Höhe grösser ist, als der Halbmesser der Oeffnung. 


\begin{tabular}{|c|c|c|c|c|c|c|c|c|}
\hline \multirow[t]{2}{*}{ Bestäubt: } & \multirow{2}{*}{$\begin{array}{c}\text { Zahl der } \\
\text { bestäubten } \\
\text { Blumen }\end{array}$} & \multirow{2}{*}{$\begin{array}{l}\text { Zahl der } \\
\text { reifen } \\
\text { Früchte }\end{array}$} & \multicolumn{3}{|c|}{$\begin{array}{c}\text { Zahl der Samen in einer } \\
\text { Frucht }\end{array}$} & \multicolumn{3}{|c|}{$\begin{array}{l}\text { Durchschnittliche Zahl der } \\
\text { Samen in einem Fache }\end{array}$} \\
\hline & & & Kleinste & Grösste & Mittel & Kleinste & Grösste & Mittel \\
\hline \multicolumn{9}{|l|}{ Abutilon voun Capivary V } \\
\hline $\begin{array}{l}\text { Durch Kolibris } \\
\text { mit fremdem Blüthenstaub der }\end{array}$ & $?$ & 10 & 9 & 53 & 25,4 & $\mathrm{I}, \mathrm{O}$ & 5,9 & 2,7 \\
\hline eigenen Art & 9 & 8 & 44 & 57 & 49,5 & 4,4 & 6,5 & 5,9 \\
\hline mit Ab. striatum & 5 & 5 & 32 & $6 \mathbf{I}$ & 43,2 & 4,0 & 6,1 & 5,0 \\
\hline mit Ab. Capivary-striatum & 5 & 3 & 56 & 63 & 59,0 & 6,2 & 6,4 & 6,3 \\
\hline mit Ab. Embira & 5 & 5 & 46 & $5^{8}$ & 54,0 & $5, \mathrm{I}$ & 6,4 & 6,0 \\
\hline mit $\mathrm{Ab}$ vom Pocinho & 7 & 2 & 60 & 62 & 61,0 & 6,0 & 6,9 & 6,4 \\
\hline nit A. vexillarium & I & 1 & & & 17 & & & $\mathrm{I}, 7$ \\
\hline $\begin{array}{l}\text { gleichzeitig mit Blüthenstaub der } \\
\text { eigenen Art u. ınit Ab. Embira } \\
\text { gleichzeitig mit Ab. Embira und }\end{array}$ & 2 & 2 & 54 & 54 & 54,0 & 6,7 & 6,7 & 6,7 \\
\hline Ab. striatum ${ }^{1}$ ) & I & I & & & 62 & & & 6,9 \\
\hline \multicolumn{9}{|l|}{ Abutilon vom Capivary VI } \\
\hline Durch Kolibris & $?$ & 18 & 9 & 48 & 22,8 & $\mathrm{I}, \mathrm{O}$ & 5,3 & 2,5 \\
\hline mit $\mathrm{Ab}$. striatum & 6 & 6 & 47 & 70 & $5^{8,9}$ & 5,2 & 7,7 & 6,7 \\
\hline mit Ab. Capivary-striatum III & I & $\left.1^{2}\right)$ & & & 17 & & & 1,7 \\
\hline mit Ab. Capivary-striatum IV & 3 & 3 & 60 & 66 & 64,0 & 6,6 & 6,7 & 6,6 \\
\hline mit Ab. Embira & 3 & 3 & I 5 & 50 & 30,0 & $\mathrm{I}, 5$ & 5,6 & $3, \mathrm{I}$ \\
\hline mit Ab. vom Pocinho & 2 & 2 & 24 & 33 & 28,5 & 2,7 & 3,6 & 3,2 \\
\hline $\begin{array}{l}\text { gleichzeitig mit Blüthenstaub der } \\
\text { eigenen Art und Ab. striatum } \\
\text { gleichzeitig mit Ab. Embira und }\end{array}$ & I & $\mathbf{I}$ & & & 62 & & & 7,7 \\
\hline Ab. striatum & 2 & 2 & 55 & 62 & $5^{8,5}$ & 6,9 & 6,9 & 6,9 \\
\hline \multicolumn{9}{|l|}{$\begin{array}{c}\text { Abutilon vom Capivary I, II, } \\
\text { III, IV, V, VI }\end{array}$} \\
\hline Durch Kolibris & $?$ & 65 & 3 & 76 & $24, I$ & 0,3 & 6,9 & 2,6 \\
\hline $\begin{array}{l}\text { mit eigenem Blüthenstaub } \\
\text { mit fremdem Blüthenstaub der }\end{array}$ & 4 & o & & & & & & \\
\hline eigenen Art & 47 & 36 & IO & 68 & 42,7 & $\mathrm{I}, \mathrm{I}$ & 7,0 & 4,6 \\
\hline mit Ab. striatum & 19 & 14 & I 7 & 70 & $4^{6,8}$ & $\mathrm{I}, 9$ & 7,7 & 5,3 \\
\hline $\begin{array}{l}\text { mit Ab. Capivary-striatum } \\
\text { mit Ab. Embira (einschliesslich }\end{array}$ & 19 & 13 & 26 & 66 & 51,9 & 1,7 & 7,1 & 5,5 \\
\hline des Ab. vom Rio do Testo) & 22 & 14 & 15 & 61 & 37,9 & $\mathrm{I}, 5$ & 6,4 & 3,9 \\
\hline mit Ab. vom Pocinho & 25 & IO & 12 & 62 & 37,3 & $\mathrm{I}, \mathrm{I}$ & 6,9 & 4,0 \\
\hline
\end{tabular}

Wenn bei diesen Versuchen nur etwa $\%$ der bestäubten Blüthen reife Früchte lieferten, so ist der Ausfall fast einzig den Verwüstungen verschiedener Raupen zuzuschreiben; an dem geringen Fruchtertrag nach Bestäubung mit dem Abutilon vom Pocinho trägt der Umstand Schuld, dass dieselbe während tagelang anhaltenden Regenwetters vorgenommen wurde.

I) Wenn gleichzeitig Blüthenstaub zweier fremden Arten zur Bestäubung verwandt wurde, wurde die eine Hälfte der Narben mit der einen, die zweite Hälfte mit der zweiten Art bestäubt. Wo gleichzeitig mit Bliithenstaub der eigenen und einer fremden Art bestäubt wurde, wurde eine einzige Narbe mit dem der eigenen $\Lambda$ rt, alle übrigen mit dem der fremden $\Lambda$ rt versehen.

2) Diese Frucht hätte eigentlich aus der Tabelle wegbleiben sollen, da ihre Samenarmuth davon herrïhrt, dass eine ungenügende Menge Blüthenstaubes zur Befruchtung verwandt wurde. 
Bemerkenswerth ist nun zunächst der Unterschied in dem Samenertrag der durch künstliche und der durch natürliche Bestäubung erzeugten Früchte; erstere hatten durchschnittlich 4,6 , letztere 2,5 ${ }^{1}$ ) Samen im Fach. In der That war aber das Ergebniss der natürlichen Bestäubung durch die Kolibris ein noch weit ungünstigeres, als es hiernach zu sein scheint. Die Pflanzen waren (mit Ausnahme von IV) während der ganzen Dauer der Versuche mit zahlreichen Blüthen bedeckt; (von III. habe ich am 27. August auf einmal ıoo Blüthen abgeschnitten, um deren Griffelzahl zu untersuchen); ich entsinne mich nicht eine ältere Blume gesehen zu haben, deren Narben nicht reichlich mit Blüthenstaub bedeckt gewesen wären, und doch fiel die grosse Mehrzahl, wohl wenigstens $9 / 10$ ab, ohne überhaupt Frucht anzusetzen. Die Mehrzahl der Früchte war sehr arm an Samen, während einige wenige allerdings in Samenzahl mit den reichsten der durch künstliche Bestäubung erhaltenen Früchte wetteiferten. Nach künstlicher Bestäubung mit fremdem Blüthenstaube dagegen setzten alle Blüthen (mit Ausnahme einiger an der Pflanze III) Frucht an, und fast alle Früchte (wieder die Pflanze III ausgenommen) enthielten reichliche Samen. - Schon bei anderen Pflanzen hatte ich Gärtner's Meinung nicht bestätigt gefunden, dass „künstliche Befruchtung der reinen Arten gewöhnlich eine geringere Samenzahl erzeugt, als die natürliche". Meine Erfahrungen an Abutilon stehen zu dieser Meinung Gärtner's, der sich auf eine ungeheure Zahl Jahrzehnte hindurch mit bewundernswerthester Ausdauer und Sorgfalt fortgeführter Versuche stützte, in schneidendstem, jedoch leicht zu erklärendem Widerspruch. Gärtner zog seine Versuchspflanzen in Töpfen, brachte sie während der Blüthezeit in ein geschlossenes Zimmer, castrirte sie und - was wohl die Hauptsache ist -. verwandte wahrscheinlich häufig Blüthenstaub desselben Stocks zur Bestäubung; darin und nicht in der künstlichen Bestäubung d. h. in dem Umstande, dass statt des Rückens einer Hummel oder eines Schmetterlingsrüssels ein Pinsel zur Uebertragung des Blüthenstaubes diente, dürfte die Ursache des geringeren Ertrags seiner künstlich bestäubten Pflanzen zu suchen sein. - Ebenso leicht erklärt sich der geringe Erfolg der natürlichen Befruchtung bei Abutilon; ist ein Kolibri zu einem blüthenreichen Busche herangeflogen, so pflegt er ihn, wenn nicht gestört, emsig von Blüthe zu Blüthe schwirrend, vollständig abzusuchen; ehe er dann einen anderen Busch besucht, pflegt er gewöhnlich einige Zeit auf einem benachbarten Zweig zu rasten, auch wohl inzwischen die Blumen einer anderen Pflanze abzusuchen, (in meinem Garten z. B. die Blüthen einer Manettia. die nahebei an einer Bauhinia rankt oder die leuchtenden Blüthenstände einer Musa coccinea). So werden nur die Blumen, die er von einem anderen Stocke kommend zuerst besucht, eine volle Ladung fremden Staubes erhalten; alle übrigen bekommen Blüthenstaub des eigenen Stockes, entweder rein oder mit einer mehr oder weniger erheblichen Beimengung fremden Staubes, - letzteren aber, wie der Erfolg zeigt, selten in einer zu vollständiger Befruchtung ausreichenden Menge. Daher nur wenige Früchte und von diesen wieder nur ein kleiner Theil mit reichlichem Samen. Es wäre dabei auch an die Möglichkeit zu denken, dass reichliche Bestäubung mit eigenem die spätere Befruchtung durch fremden Blüthenstaub beeinträchtigt, indem entweder einfach der

$$
\text { 1) Soll wohl 2,6 heissen? Herausgeber. }
$$


Zugang zur Narbenoberfläche erschwert, oder auch diese durch längere Einwirkung des eigenen Blüthenstaubes für fremden unempfänglich gemacht wird; wenigstens Letzteres scheint indess kaum der Fall zu sein, soweit ich aus meinen hierauf gerichteten, leider durch die unvermeidlichen Raupen grossentheils vereitelten Versuchen schliessen darf. Für Ersteres scheint das Ergebniss einiger Versuche zu sprechen; so wurden von 2 jungfräulichen frisch aufgeblühten Blumen der Pflanze V. die eine sofort mit fremdem, die andere erst stark mit eigenem und unmittelbar darauf mit fremdem Blüthenstaub bestäubt; erstere gab eine Frucht mit 6,3, letztere mit nur 4,4 Samen im Fach. An der Pflanze II wurden 2 frische Blumen mit Gaze bedeckt, nachdem die eine stark mit Blüthenstaub ihres Stockes bestäubt worden war; fünf Tage später wurden beide mit fremdem Blüthenstaub versehen; die eine, die diesen in jungfräulichem Zustande erhalten hatte, lieferte 4, 4, die andere, auf deren Narben zuvor 5 Tage lang eigener Blüthenstaub gelegen hatte, nur 2, 2 Samen im Fach.

Weiter ist hervorzuheben die auffallende Verschiedenheit im Samenertrage der Pflanzen I bis IV, die wie gesagt aus Samen einer einzigen wildwachsenden Frucht gezogen sind. Der durchschnittliche Ertrag mit fremdem Blüthenstaub der eigenen Art war bei IV: 6, I - bei I: 5,9 - bei II: 3,8 - endlich bei III: 2,4 Samen im Fach; die reichsten Früchte von III enthielten durchschnittlich nicht über 3, die ärmsten von I und IV nicht unter 5 und 6 Samen im Fach. - I869 habe ich von der Pflanze III gar keine Früchte erhalten ${ }^{1}$. - Also nicht blos bei Bastarden und bei illegitimen Sprösslingen dimorpher und trimorpher Pflanzen, sondern auch bei anderen wildwachsenden reinen Arten kommt es vor, dass aus Samen derselben Frucht gezogene Pflanzen sich sehr erheblich in ihrer Fruchtbarkeit unterscheiden.

In Bezug auf die V'erbindung mit fremden Arten ergab sich, dass bei drei Pflanzen (II, III, V) die eine oder andere fremde Art grösseren, bei einer Pflanze (IV) ebenso hohen Samenertrag lieferte, als die eigene Art; bei einer Pflanze (VI) war keine künstliche Bestäubung mit der eigenen Art vorgenommen worden und nur bei einer Pflanze (I) überstieg die Samenzahl in den durch die eigene Art erzeugten Früchten (5,9 Samen im Fach) um etwas die der fruchtbarsten Bastardverbindungen (mit Abutilon vom Pocinho 5,2 Samen).

Der Satz, dass Kreuzung mit fremden Arten immer weniger Samen liefert, als Befruchtung mit der eigenen Art, bestätigte sich also nicht bei obigen Versuchen

Die drei zur Bestäubung verwandten Arten zeigten in Bezug auf die durch sie erzeugte Samenzahl nicht dieselbe Reihenfolge bei den verschiedenen als weibliche Unterlage dienenden Pflanzen des Capivary-Abutilon. Mit III lieferte Striatum doppelt so viel, mit $\mathrm{V}$ noch nicht $1 / 3$ so viel Samen, wie die beiden anderen Arten. Bei IV war das Verhältniss von Embira und Striatum dasselbe wie bei V, wogregen das Abutilon vom Pocinho, das mit $\mathrm{V}$ die reichsten Früchte lieferte, bei IV nur $1 \frac{1}{5}$ soviel Samen gab als Embira. Bei II war der Ertrag für alle drei

I) Diese unfruchtbare Pflanze III ist auch sonst vor ihren Greschwistern ausgezeichnet durch etwas kleinere blassere Plumen, durch längere Griffel, die meist schon aus der Knospe hervortreten, und durch kleinere blassere Narben. Sie ist von kräftigem Wnchs, sehr reichblühend und, wie es scheint, besonders lebenszäh, da sie allein zwei grosse Ueberschwemmungen ïberdanert hat, deren erster mehrere andere an gleichem Orte wachsende Geschwister erlegen sind. 
Arten ziemlich derselbe. Man vergleiche nachstehende (aus den obigen Tabellen entnommene) Zusammenstellung:

$$
\begin{array}{r}
\text { II. P: 3,9.- S: 3,6.- E: 3,4 } \\
\text { IV. E: 6, I. - S: I,9. - P: I, } \\
\text { V. P: 6,4- E: 6, I. - S: I, } 9 \\
\text { VI. S: 6,7- P: 3,2. - E: 3, I }
\end{array}
$$

Es scheint also jede einzelne Pflanze ihre eigenthümliche Empfängnissfähigkeit (,Wahlverwandtschaft" Gärtner) für verschiedene fremde Arten zu besitzen. Doch sind die Versuche bei weitem nicht zahlreich genug, um schon jetzt dieses Ergebniss als gesichert betrachten zu dürfen.

Wirksamer, d. h. samenreichere Früchte erzeugend als der Blüthenstaub der eigenen reinen Art erwies sich ebenfalls bei den Pflanzen I, III und V der Blüthenstaub einer Bastardpflanze: Abutilon Capivary-striatum I.

Es würde voreilig sein, aus diesen Ergebnissen den Schluss ziehen zu wollen, dass im Allgemeinen das Abutilon vom Capivary reicheren oder ebenso reichen Samenertrag liefert mit einer Reihe fremder Arten und einem seiner Bastarde, wie mit Pflanzen der eigenen Art. Ich vermuthe, dass in letzterem Falle die Fruchtbarkeit meiner Pflanzen hinter der normalen zurückblieb und zwar weil alle meine Pflanzen des Capivary-Abutilon sehr nahe Verwandte sind. Wenigsteus aber bieten auch diese Versuche einen neuen, allerdings schon ziemlich überflüssigen Beleg dafür, dass die Fruchtbarkeit nicht als untrüglicher Prüfstein der Zusammengehörigkeit verschiedener Pflanzen zur selben Art zu verwerthen ist. Ebenso zeigen sie, dass die Weise in welcher Gärtner (,Bastarderzeugung“ S. 204) die „Wahlverwandtschaftsgrade der Arten bei der Bastardbefruchtung“ berechnete, indem er das Maximum der bei Bastardbefruchtung erhaltenen Samen mit der mittleren Samenzahl durch „natürliche Befruchtung“ an wilden Pflanzen entstandener guter Früchte verglich, ebenso praktisch unbrauchbar sein kann, wie sie theoretisch falsch ist. Soll der Samenertrag durch Blüthenstaub der eigenen und durch den fremder Arten verglichen werden, so ist es, um ein reines Resultat zu erhalten, natürlich unerlässlich, dass alle übrigen Verhältnisse, die möglicherweise jenen Ertrag beeinflussen könnten, in beiden Fällen möglichst gleich seien. Beiderlei Früchte müssen entweder von wildwachsenden oder von im Garten gezogenen, von in freier Luft oder von im Zimmer stehenden Pflanzen, beide von künstlich bestäubten Blumen gewonnen sein; es müssen entweder Maximum mit Maximum oder Mittelwerth mit Mittelwerth verglichen werden; ja es müssen womöglich beiderlei Früchte zu gleicher Zeit an demselben Stocke gereift sein. Wollte man nach Gärtners Berechnungsweise mit dem mittleren Samenertrag der durch „natürliche Befruchtung“ entstandenen Früchte der Pflanze III $(2,4$ Samen im Fach), das Maximum der Samen vergleichen, die der Blüthenstaub von Abutilon striatum an der Pflanze II erzeugte, $(7,7$ Samen im Fach), so würde die Fruchtbarkeit dieser Bastardverbindung über dreimal so gross sein, als die der reinen Art!

Eine letzte befremdende Thatsacle ist es, dass bei den Pflanzen V und VI die reichsten Früchte aus denjenigen Blumen hervorgingen, die gleichzeitig. mit Blüthenstaub verschiedener Arten bestäubt worden waren. An der Pflanze V z. B. enthielten 5 durch Abutilon striatum erzeugte Früchte durchschnittlich 5,0 
und keine mehr als 6,1 Samen; ebenso viel durch Embira erzeugte Früchte durchschittlich 6,o und keine mehr als 6,4 Samen im Fach, während eine Blume derselben Pflanze, von deren Narben die eine Hälfte mit Abutilon striatum, die andere mit Embira bestäubt wurde, eine Frucht mit 6,9 Samen im Fache lieferte. - Einen ähnlichen Fall werden wir unten noch einmal wiederfinden. - Weitere Versuche werden entscheiden müssen, ob dieser Samenreichthum nach gleichzeitiger Bestäubung mit zweierlei Blüthenstaub ein blos zufälliger war. Ich bin geneigt, aus unten anzuführenden Gründen, das Gegentheil anzunehmen.

\section{Abutilon striatum.}

Ein Abutilon, das mir als striatum bezeichnet wurde, findet sich hier bisweilen in Gärten angepflanzt, wo es niemals Früchte trägt. Ich besitze davon drei, aus

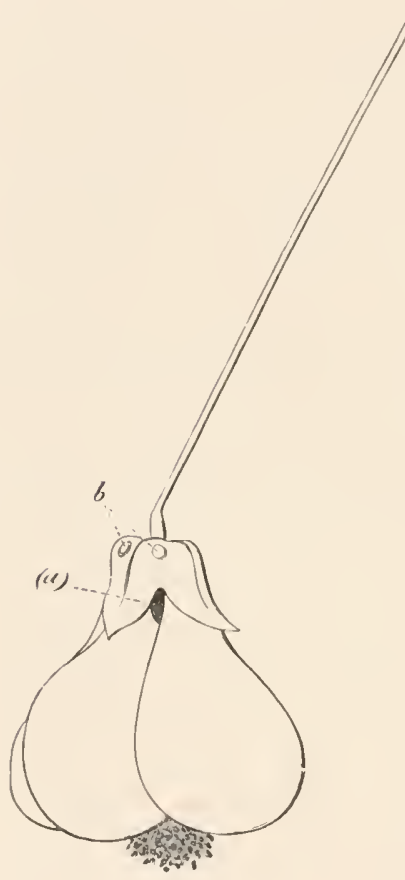
verschiedenen Gärten stammende Pflanzen, die ebenfalls weder jede für sich, noch mit einander gekreuzt jemals Samen tragen, - ein Beweis, dass alle drei auf ungeschlechtlichem Wege von derselben Mutterpflanze abstammen, nur Theilstücke ein und desselben Stockes sind ${ }^{1}$ ). Ich betrachte sie daher im Folgenden als eine einzige Pflanze.

Dieses Garten-Abutilon wird ebenso fleissig, wie die einheimischen Arten, von Kolibris besucht, aber nicht durch sie bestäubt. Das verschiedene Verhalten der Kolibris wird bedingt durch einen Umstand, dem man gewiss kaum irgend welche Bedeutung für das Gedeihen der Art beigemessen hätte, und durch den sie doch hier $\mathrm{zu}$ fast vollständiger Unfruchtbarkeit verurtheilt ist. Die Kelchzipfel nämlich sind beträchtlich kürzer, als bei dem Abutilon vom Capivary, und so wird es den Kolibris möglich, die Spitze des Schnabels am Grunde der Blume zwischen zwei benachbarten Blumenblättern einzuführen, wobei natürlich Staubbeutel und Narben unberührt bleiben. Den Besuch des Kolibris verrathend bleibt ein kleines Loch an der Stelle, wo derselbe die Blumenblätter auseinandergeschoben hat ( $a$ in der beistehenden Figur). Ein einziges Mal sahen meine Kinder einen Kolibri von einer grösseren Art, die sonst Abutilon nicht besucht, von unten her an die Blüthen dieser Art heranfliegen. Im September wurden während einiger WTochen zwei meiner Pflanzen von einem Schwarme kleiner schwarzer Honigbienen (Melipona) besucht, die aber ebensowenig Narben und Staubbeutel berührten; sie bissen sich Löcher in den Kelch (b), un zu dem Honig zu gelangen. Einige grosse Hummeln, die ich zur selben Zeit an diesen Pflanzen sah, benutzten die von den Bienen gebissenen Löcher. - Obwohl also

1) "Je l'ai dit et je le répètc: on ne juge de la parenté que par la féconditéc heisst es in einem Buche, das $/$ u dem Unverdautesten gehört, was gegen Darwin geschrieben wurde. Der berühmte Verfasser würde nach diesem so emphatisch proclamirten Satze meine drei Pflanzen für ebenso viel verschiedene Arten erklären müssen. Ja, streng genommen, müsste er Staubgefässe und Griffel jeder einzelnen Blüthe bei dieser und allen anderen selbst unfruchtbaren Pflanzen als verschiedenen Arten angehörig betrachten. S. Flourens, Examen du livre de M. Darwin. Paris 1864. S. Ior. 
die eine meiner Pflanzen rings von Arten umgeben war, durch deren Blüthenstaub sie leicht zu befruchten ist, wurde doch nur eine einzige Frucht durch ,natürliche Bestäubung" erzeugt.

\begin{tabular}{|c|c|c|c|c|c|c|c|c|}
\hline \multirow{2}{*}{$\begin{array}{l}\text { Abutilon striatum } \\
\text { Bestäubt : }\end{array}$} & \multirow{2}{*}{$\begin{array}{l}\text { Zahl der } \\
\text { bestäubten } \\
\text { Blumen }\end{array}$} & \multirow{2}{*}{$\begin{array}{c}\text { Zahl der } \\
\text { reifen } \\
\text { Früchte }\end{array}$} & \multicolumn{3}{|c|}{$\begin{array}{c}\text { Zahl der Samen in einer } \\
\text { Frucht }\end{array}$} & \multicolumn{3}{|c|}{$\begin{array}{l}\text { Durchschnittliche Zahl der } \\
\text { Samen in einer Frucht }\end{array}$} \\
\hline & & & Kleinste & Grösste & Mittel & Kleinste & Grösste & Mittel \\
\hline auf natürlichem Wege & $\div$ & I & & & 43 & & & 4,8 \\
\hline $\begin{array}{l}\text { mit Blüthenstaub der eigenen } \text { Art } \\
\text { mit Ab. rom Capivary }\end{array}$ & $\begin{array}{c}5 \\
8+x\end{array}$ & $\begin{array}{c}0 \\
7+63\end{array}$ & 8 & 55 & 37,9 & $\mathrm{I}, \mathrm{O}$ & 5,9 & 4,1 \\
\hline mit Ab. Capivary-striatum I & 17 & 9 & 25 & 55 & 37,5 & 2,5 & 5,5 & 4,2 \\
\hline mit Ab. Capivary-striatum IV & I & I & & & 20 & & & 2,2 \\
\hline mit Ab. Embira & $15+x$ & $4+7$ & 17 & 45 & 29,5 & I,9 & 5,6 & 3,3 \\
\hline $\begin{array}{l}\text { mit Ab. vom Pocinho } \\
\text { gleichzeitig mit Ab. vom Capi- }\end{array}$ & 14 & 3 & 21 & 45 & 30.7 & 2,6 & 5,0 & 3,7 \\
\hline $\begin{array}{l}\text { vary und mit Embira } \\
\text { gleichzeitig mit Ab. vorn Pocinho } \\
\text { und mit Embira }\end{array}$ & 2 & 2 & 17 & 36 & 26,5 & 1,9 & 4,0 & 3,0 \\
\hline
\end{tabular}

Die einzige Blüthe, die ohne mein Zuthun Frucht ansetzte, war, wie die Aussaat der Samen gezeigt hat, durch Blüthenstaub des Abutilon Embira befruchtet worden. - An zwei Stöcken, die von den übrigen Abutilonpflanzen ziemlich entfernt stehen, und bei denen daher eine (überhaupt kaum jemals stattfindende) Bestäubung durch Kolibris oder Immen nicht zu befürchten stand, wurde eine grosse Zahl Blüthen an dem einen mit Abutilon vom Capivary, an dem anderen mit Embira bestäubt, ohne dass diese (in der Tabelle mit $\mathrm{x}$ bezeichneten) Blüthen gezeichnet und mit Gaze bedeckt wurden; an ersterem Stocke wurden 63, an dem anderen 7 Früchte geerntet.

Abutilon striatum befruchtet also hier, wie wir bereits sahen und noch weiter sehen werden, fremde Arten und wird von ihnen befruchtet. Somit ist seine Unfruchtbarkeit in unseren Gärten nicht dem Klima, sondern dem Umstande zuzuschreiben, dass wir nur Theile einer einzigen Pflanze hier besitzen. Dasselbe mag der Grund der Unfruchtbarkeit mancher anderen stets auf ungeschlechtlichem Wege vermehrten Pflanzen sein, z. B. des Ingwers und der süssen Bataten, deren Blüthenstaub und Eichen regelmässig ausgebildet zu sein scheinen. Ebenso mag es sich bei manchen in europäischen Gärten unfruchtbaren Pflanzen verhalten. In anderen Fällen findet sich bei solchen Pflanzen allerdings eine mehr oder weniger bedeutende Verkümmerung der Geschlechtstheile; so beim Arrow-root, dessen Staubbeutel ich stets vollkommen leer fand. Ja, einige scheinen sich sogar des Blühens völlig entwöhnt zu haben, wie mehrere Arten von Dioscorea. Die Varietäten des Zuckerrohrs hat man danach in blühende und nicht blühende eingetheilt.

\section{Bastard Abutilon Capivary-striatum.}

Ein grösseres Gewicht für die Unterscheidung von Arten und Varietäten als der unvollkommenen oder vollkommenen Fruchtbarkeit bei der ersten Kreuzung legt Gärtner dem Umstande bei, dass Arten-Bastarde in der ersten Generation fast immer nur einen einzigen Typus zeigen, während bei Varietäten-Bastarden kaum je eine Pflanze der anderen vollkommen gleich ist. Dass dies im Allgemeinen richtig ist, ist nach den so überaus reichen Erfahrungen Gärtner's nicht zu be- 
zweifeln, wie es ja auch vom Standpunkte der Darwin'schen Lehre sich leicht erklärt. Dass aber auch dieser Unterschied zwischen Arten und Varietäten kein durchgreifender ist, zeigt der Bastard Abutilon Capivary-striatum. Von den fünf Pflanzen, die ich I 869 gezogen, trägt jede ihr ganz eigenthümliches Gepräge in Wuchs, Blatt, Blüthe und Frucht. Ich lege eine Skizze der Blüthen von den vier zu Versuchen verwendeten Pflanzen bei, zu der ich noch bemerken will dass I der Riese unter seinen Geschwistern und jetzt über ro Fuss hoch ist, während IV, obwohl ein halb Jahr älter, kaum 2 Spannen Höhe hat. II ist ebenso durch die Länge der Blattstiele wie der Blüthenstiele ausgezeichnet. Bei I und IV (sowie bei der fünften Pflanze, die erst wenige Blumen brachte) strotzen die Staubbeutel von gutem Blüthenstaub; bei II und III sind sie meist völlig leer und farblos, nur in einzelnen Blüthen findet man in einigen wenigen Staubbeuteln eine geringe Menge Blüthenstaubes, der aber, wenigstens bisweilen (Abutilon vom Capivary VI), gut ist.

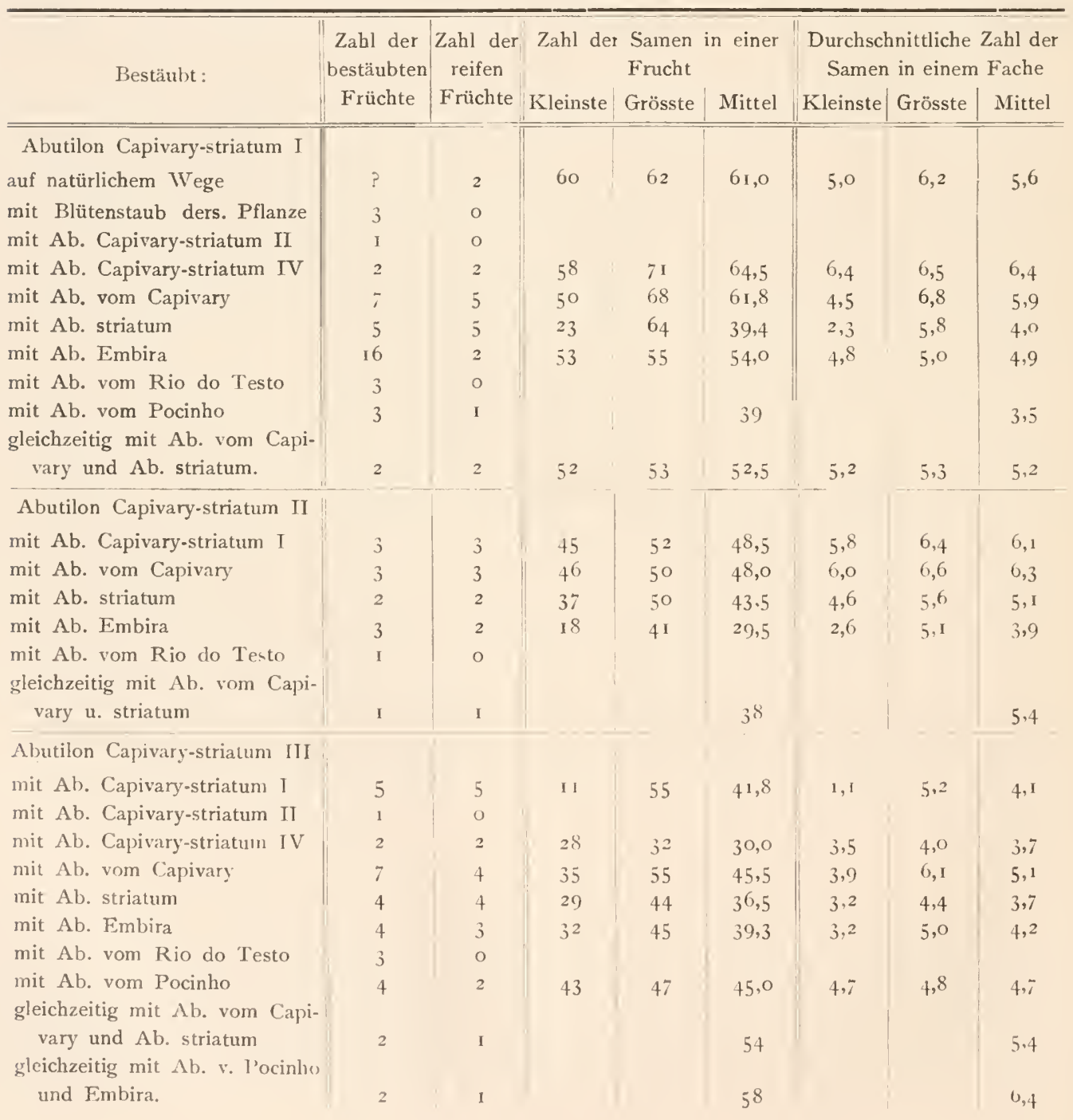



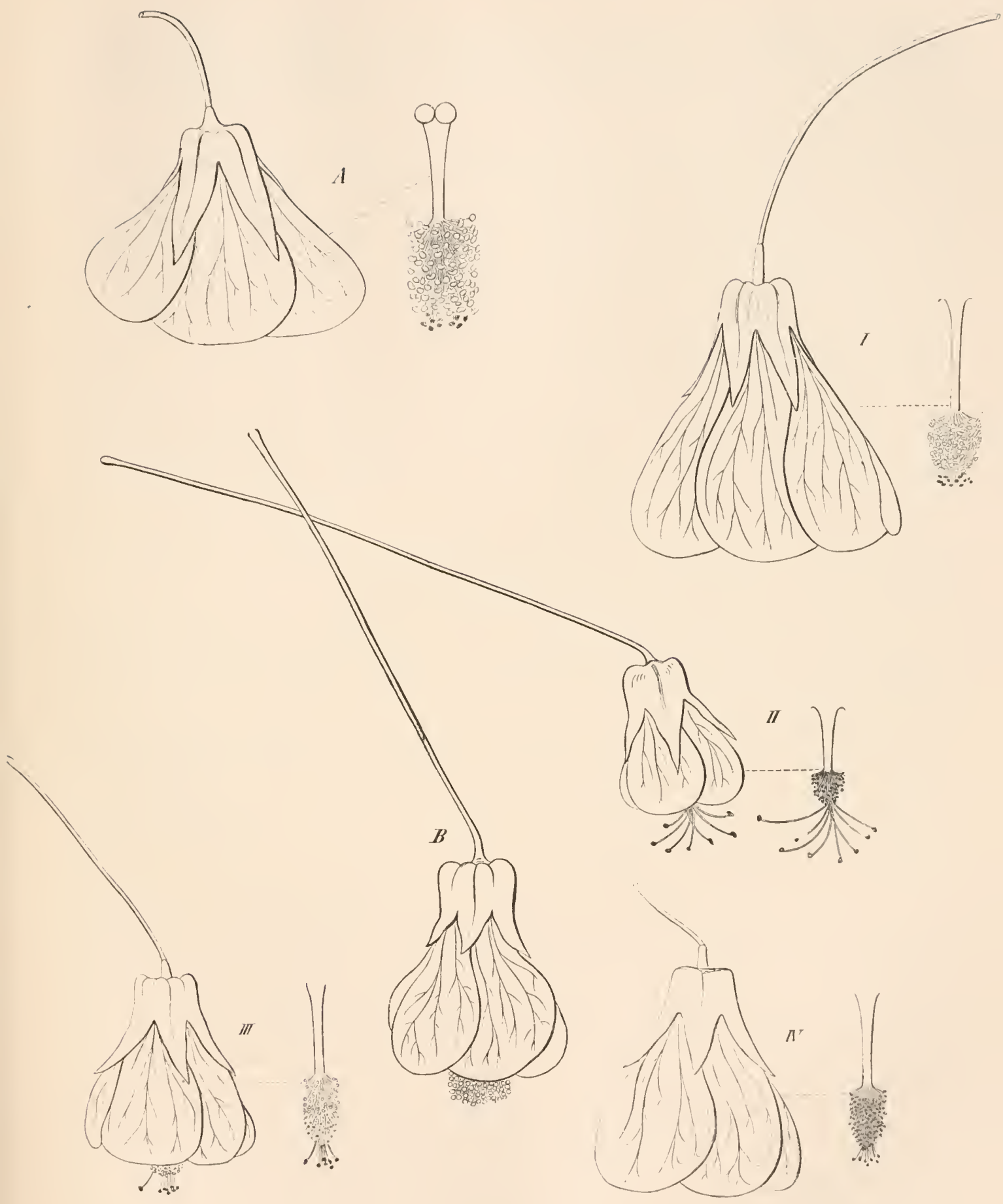

$A$ Blüthe des Abutilon Capivary. $B$ Blüthe von Abutilon striatum. $I, I I, I I I, I Y$ Rlüthen von 2 verschiedenen Pflanzen des Bastards Abutilon Capivary-striatum. 
An der kümmerlichen vierten Pflanze, die nur wenige Blüthen brachte, wurde eine Blume mit Abutilon Capivary-striatum I, drei mit Abutilon vom Capivary, eine mit Abutilon striatum und eine mit Abutilon Embira bestäubt; nur die mit Abutilon striatum bestäubte reifte eine 8 fächrige Frucht mit 35 Samen (4, + Samen im Fach).

Betrachten wir zuerst die an der Pflanze I erhaltenen Ergebnisse. Sie ist, wie beide elterlichen Arten, unfruchtbar mit ihrem eigenen Blüthenstaub; fruchtbar mit dem der Eltern und des Bastards IV und zwar, entgegengesetzt dem gewöhnlichen Verhalten, fruchtbarer mit diesem, als mit jenen. Sie lieferte mit dem Bastard IV einen höheren Samenertrag, als irgend eine Pflanze der mütterlichen Art, wenn mit Blüthenstaub der eigenen Art befruchtet! Wir haben bereits gesehen, dass ihr Blüthenstaub, wenn zur Befruchtung der mütterlichen Art verwendet, meist einen reicheren Samenertrag lieferte, als der der reinen Art. Auch hierin verhält sich diese Pflanze ganz wie ein Varietäten-Bastard.

Die beiden durch „,natürliche Befruchtung“ (wahrscheinlich mit Blüthenstaub des Abutilon vom Capivary) entstandenen Früchte waren im Gegensatz zu der Samenarmuth der meisten derartigen Früchte des Capivary-Abutilon reich an Samen und liefern gerade dadurch einen guten Beleg für die Richtigkeit der oben gegebenen Erklärung jener Samenarmuth. Sie stammen nämlich von den ersten Blüthen der Pflanze, die eine nach der andern aufblühten, also nicht mit Blüthenstaub desselben Stockes bestäubt werden konnten. Die späteren Blüthen sind fast alle zu künstlicher Bestäubung benutzt worden.

Bei Bestäubung mit Embira fielen meist die ganzen Blüthen oder wenige Tage nach dem Abfallen der Blumenkrone die jungen Früchte ab; von i6 (oder mit Einschluss des Abutilon vom Rio do Testo, von 19) Blüthen wurden nur 2 reife Früchte erhalten.

Die Pflanzen II und III, die von männlicher Seite fast vollkommen unfruchtbar waren, lieferten, wie die Tabelle nachweist, ebenfalls einen ziemlich reichen Samenertrag; auffallend ist, dass bei ihnen die Bestäubung mit Embira viel leichter anzuschlagen schien, als bei der ersten Pflanze: von 3 und 4 bestäubten Blumen wurden 2 und 3 Früchte geerntet.

Bei der Pflanze III wiederholt sich die Erscheinung, dass die reichsten Früchte durch Bestäubung mit zweierlei Blüthenstaub erzielt wurden. Das Abutilon vom Capivary erzeugte durchschnittlich 5, I, striatum 3,7 Samen im Fach; beiderlei Blüthenstaub vereinigt gab 5,4 Samen. Ja während Abutilon Embira durchschnittlich 4, 2 -- das Abutilon vom Pocinho 4,7 Samen lieferte, fanden sich in einer durch Blüthenstaub dieser beiden Arten erzeugten Frucht 6,4 Samen. Dies war überhaupt die samenreichste unter I9 Früchten, die von dieser Pflanze geerntet wurden.

Unter den Früchten der dritten Pflanze findet sich eine sehr arme mit nur I I Samen, die aus der Tabelle hätte wegbleiben sollen; die Blume war mit einer unzureichenden Menge von Blüthenstaub aus einem einzigen zweifächrigen Staubbeutel bestäubt worden, wie solche einzeln fast in jeder Blüthe des Bastards I, sowie der mütterlichen Art (des Capivary-Abutilon) vorkamen.

Bemerkenswerth ist noch das Verhalten der Bastardpflanzen gegen Blüthenstaub von Abutilon striatum und ron Embira. Keine Bestäubung schlug sicherer 
an, als die mit Abutilon striatum, der väterlichen Art, - keine schwieriger, als die mit Embira. - I2 Blumen, mit Abutilon striatum bestäubt, lieferten eben so viel Früchte; die einzige Frucht, die an der Pflanze IV reifte, war dieses Ursprungs. Von 3 I Blumen dagegen, die mit Embira (einschliesslich der Abart vom Rio do Testo) bestäubt wurden, wurden nur 7 Früchte erhalten. Diese Früchte aber waren samenreicher $(4,4)$, als die durch Abutilon striatum erzeugten $(3,9)$. Am auffallendsten tritt dieses Verhältniss bei dem Bastard I hervor. wo I9 Blumen mit Embira bestäubt 2 Früchte mit durchschnittlich 4, 9, dagegen 5 Blumen mit striatum bestäubt auch 5 Früchte mit durchschnittlich 4, o Samen im Fach gaben. Nicht immer entspricht also der grösseren Leichtigkeit, mit der die Befruchtung angenommen wird, auch ein grösserer Samenreichthum. Dasselbe gilt wohl überhaupt für alle bei der Fruchtbarkeit der Pflanzen in Betracht kommenden Umstände; im Allgemeinen wird wohl, je leichter die Bestäubung von der Narbe angenommen wird, um so kräftiger auch die Einwirkung des Blüthenstaubs auf den Fruchtknoten, um so sicherer und vollkommener die Befruchtung der Eichen, um so samenreicher die Frucht, um so keimfähiger der Samen, um so kräftiger und fruchtbarer die Nachkommenschaft sein. Einen vollkommenen Parallelismus aber wird man, wie in dem eben angeführten, so in vielen anderen Fällen vermissen.

\section{Abutilon (Embira branca der Brasilianer).}

Bestäubungsversuche wurden an zwei Stöcken vorgenommen; da sich zwischen den Ergebnissen kein erheblicher Unterschied zeigt, fasse ich sie in eine einzige Tabelle zusammen.

Die Vermittler der Bestäubung sind auch hier die Kolibris. Die Blüthen hängen nicht, wie bei den bisher besprochenen Formen, sondern ihre Achse steht fast wagerecht; die Griffel treten nicht gerade aus der Staubfädenröhre hervor, sondern biegen sich beim Austritt fast rechtwinklig um, so dass die Narben nach allen Seiten über die Staubbeutel hinausragen, - eine Lage, die bei der Richtung der Blumenkrone offenbar für die Bestäubung günstiger ist. Zwischen den Staubgefässen pflegt bei dieser Art eine Menge winziger Käfer sich zu sammeln, welche auf die Kolibris ebenso anlockend wirken mögen, wie der Honig, der im Grunde der Blume ziemlich reichlich abgesondert wird ${ }^{1}$ ).

Von den sehr zahlreichen durch ,natürliche Befruchtung“ entstandenen Früchten wurde nur ein kleiner Theil untersucht; das Ergebniss ist, wie man sieht, dasselbe wie bei dem Abutilon vom Capivary, indem sie im Durchschnitt nur etwa halb so viel Samen enthalten, wie künstlich befruchtete.

Bei Bestäubung mit Blüthenstaub desselben Stockes fiel nur in drei Fällen 3-4 Tage nach der Bestäubung die ganze Blüthe ab, in 9 Fällen 4-8 Tage nach der Bestäubung die junge Frucht; in einem Falle hielt sich die Frucht 2 I Tage. Die Unempfänglichkeit für die Bestäubung mit eigenem Blüthenstaube ist also keine so vollkommene, wie bei dem Abutilon vom Capivary.

I) Aus der Menge von Insectenresten, die Darwin, Burmeister u. A. im Magen der Kolibris angehäuft fanden, hat man gewiss mit Recht geschlossen, dass Insecten einen wesentlichen Bestandtheil ihrer Nahrung bilden und nicht blos zufällig mit dem Honig eingeschlürft werden. Wenn man aber nun ungekehrt behauptet hat, dass der Honig nur beiläufig und zufällig mit den Insecten aufgenommen wurde, so liegt dafür auch nicht die Spur eines lieweises vor.

Fritz M üllers gesammelte Schriften. 


\begin{tabular}{|c|c|c|c|c|c|c|c|c|}
\hline \multirow{2}{*}{$\begin{array}{l}\text { Abutilon Embira } \\
\text { Bestäubt: }\end{array}$} & \multirow{2}{*}{$\begin{array}{c}\text { Zahl der } \\
\text { bestäubten } \\
\text { Blumen }\end{array}$} & \multirow{2}{*}{$\begin{array}{l}\text { Zahl der } \\
\text { reifen } \\
\text { Früchte }\end{array}$} & \multicolumn{3}{|c|}{$\begin{array}{c}\text { Zahl der Samen in einer } \\
\text { Frucht }\end{array}$} & \multicolumn{3}{|c|}{$\begin{array}{c}\text { Durchschnittliche Zahl der } \\
\text { Samen in einem Fache }\end{array}$} \\
\hline & & & Kleinste & Grösste & Mittel & Kleinste & Grösste & Mittel \\
\hline $\begin{array}{ll} & \text { Durch Kolibris } \\
\text { mit } & \text { Blüthenstaub desselben }\end{array}$ & ? & I I 4 & 5 & 69 & $3 \mathrm{I}, \mathrm{I}$ & 0,3 & 4,9 & 2,2 \\
\hline Stocks & 13 & o & & & & & & \\
\hline $\begin{array}{l}\text { mit fremdem Blüthenstaub der } \\
\text { eigenen Art }\end{array}$ & $i$ & i & 30 & 69 & 56,7 & 2,1 & 5,7 & $4, \mathrm{I}$ \\
\hline mit der Varietät vom Rio do Testo & 6 & 4 & 59 & 60 & 59,5 & $\left.4,2^{1}\right)$ & $\left.\mathrm{I}, 6^{1}\right)$ & $\left.4,4^{1}\right)$ \\
\hline mit Ab. vom Capivary & 12 & 10 & $2 \mathrm{I}$ & 74 & 49,3 & $\mathbf{I}, 4$ & 4,6 & 3,6 \\
\hline mit Ab. striatum & 16 & 6 & 6 & 23 & 12,0 & 0,4 & 1,9 & 0,9 \\
\hline mit Ab. Capivary-striatum I & 14 & I0 & 8 & 56 & 34,8 & 0,6 & 4,3 & 2,6 \\
\hline $\begin{array}{l}\text { mit Ab, vom Pocinho } \\
\text { gleichzeitig mit Blïthenstaub der } \\
\text { eigenen Art und mit Ab. vom }\end{array}$ & II & 5 & 28 & 43 & 37,4 & 2,0 & 3,3 & 2,9 \\
\hline $\begin{array}{l}\text { Capivary } \\
\text { gleichzeitig mit Ab. vom Capi- }\end{array}$ & I & I & & & 50 & & & 3,8 \\
\hline vary und mit Ab. striatum & 2 & 2 & $4^{2}$ & 55 & $4^{8,5}$ & 3,2 & 4,2 & 3,7 \\
\hline
\end{tabular}

Wenn auch die Befruchtung mit Blüthenstaub der Arten vom Capivary und vom Pocinho, sowie des Bastards Abutilon Capivary-striatum I noch einen höheren Samenertrag lieferte, als die ,natürliche Befruchtung“, so steht doch weit mehr als bei dem Capivary-Abutilon der Ertrag der Bastardfrüchte gegen den der künstlich mit Blüthenstaub der eigenen Art befruchteten zurück. Ob etwa die grössere Geneigtheit des Capivary-Abutilon, Bastardbefruchtung anzunehmen, im Zusammenhang steht mit dessen vollständiger ausgeprägter Selbstunfruchtbarkeit. kann nur durch weit umfangreichere Versuche an zahlreichen auf ihr Verhalten zum eigenen Blüthenstaube genau geprüften Arten entschieden werden. Doch mag erinnert werden an die Schwierigkeit der Bastarderzeugung in der derselben Familie angehörigen Gattung Hibiscus, deren Arten, soweit meine Erfahrung reicht, vollkommen fruchtbar sind mit eigenem Blüthenstaube, sowie andererseits an die überraschende Leichtigkeit, mit der fernstehende selbstunfruchtbare Arten von Vandeen sich kreuzen lassen.

So weit der Bericht über den Samenertrag meiner Bestäubungsversuche. Ich schliesse ihm als nothwendige Ergänzung einige Worte an über die aus dem Samen gezogenen jungen Pflanzen.

Im April i 869 hatte ich frischen hier geernteten Samen von drei verschiedenen Früchten des Capivary-Abutilon ausgesät. Die Pflanzen, durch deren Erzeugung ${ }^{2}$ ) ich diese Früchte erhalten hatte, waren Geschwister, aus Samen derselben Frucht gezogen. Nur 2 Pflänzchen gingen auf von I80 Samen (es sind die oben mit $\mathrm{V}$ und VI bezeichneten Pflanzen). Ich schrieb dies damals der Ungunst der Witterung oder der unpassenden Jahreszeit zu. - Nun aber habe ich von der Ernte, über die ich so eben berichtet, Samen von weit über ıoo Früchten ausgesät und fast alle haben reichliche und kräftige Pflanzen geliefert. Zu gleicher

I) Hier liegt ein mit Sicherheit nicht mehr aufzuklärender Druckfehler des Originals vor. Herausgeber.

2) Soll wohl Kreuzung heissen. Herausgeber. 
Zeit und an gleicher Stelle mit den übrigen wurden auch sieben verschiedene Aussaaten des Capivary-Abutilon gemacht und zwar:

I) zwei Aussaaten von 2 Früchten der Pflanze V, erzeugt durch Blüthenstaub ihres Oheims III. - Gesät am 4. October, gingen nach I4 Tagen reichliche Pflanzen auf, die aber bis jetzt nicht sehr kräftig wachsen.

2) vier Aussaaten von Früchten der Pflanze I, erzeugt durch Blüthenstaub ihres Bruders II. - Zwei Aussaaten vom I. October keimten nach 24, eine vom 20. October nach I 8, eine vom 24. October nach 2 I Tagen. Mehr als 200 Samen lieferten kaum über ein Dutzend so schwächlicher Pflänzchen, dass nur 4 die ersten Wochen überlebten und bis heute ein sehr kümmerliches Wachsthum zeigen ${ }^{1}$ ).

3) eine Aussaat von Samen einer Frucht der Pflanze IV, erzeugt durch Blüthenstaub ihres Bruders II, am I I. October. - Erst nach einem vollen Monat, am i I. November zeigten sich einige Pflänzchen. Ob von den 56 Samen überhaupt mehr als zwei gekeimt haben (soviel Pflanzen sind noch vorhanden), kann ich nicht sagen. Die Pflänzchen zeigen ein etwas kräftigeres Wachsthum, als die unter 2, erwähnten.

I) Das Missrathen dieser Aussaaten war mir sehr verdriesslich, da sie zu Beobachtungen über die Vererbung der Eigenthümlichkeiten einzelner Blüthen bestimmt waren. Ein ähnliches Missgeschick, veranlasst durch Ueberschwemmung, Dürre, Raupenfrass, Ameisen u. s. w. hat bisher fast alle meine derartigen Versuche vereitelt. Das Wenige, was ich hierüber in Bezug auf Abutilon zu sagen habe, mag hier eine Stelle finden.

Die Zahl der Griffel ist bei dem Capivary-Abutilon, wie bei anderen Arten, eine sehr schwankende. Die Pflanze VI wurde aus Samen einer 9 griffligen Blume gezogen, die mit Blüthenstaub einer anderen ebenfalls 9 griffligen Blume befruchtet war; bei ihr herrschen nun die 9 griffligen Blüthen entschieden vor. Ich finde $3^{8}$ Früchte dieser Pflanze verzeichnet, von denen 48 fächrig, 249 fächrig und Io Io fächrig waren; danach würden die 8 griffligen Blüthen I I $\%$, die 9 griffligen $63 \%$, die Iogriffligen $26 \%$ bilden. Leider ist ein Vergleich mit den durch eine Ueberschwemmung zerstörten Eltern nicht mehr möglich. Bei drei noch lebenden Geschwistern dieser Eltern, den Pflanzen I, II, III fanden sich unter Ioo Blüthen bei I bei II bei III

$\begin{array}{crrrrr}\text { mit } & 7 & \text { Griffeln : } & \text { o } & \text { o } & \text { I } \\ , & 8 & , & 3 & 3 & 6 \\ , & 9 & , & 25 & 43 & 39 \\ \text { " } & \text { I0 } & , & 54 & 48 & 5 \text { I } \\ \text {, } & \text { I I } & , & \text { I } 8 & 6 & 3\end{array}$

An der Pflanze I wurde sogar einmal eine Blume mit I2 Griffeln beobachtet. (Man muss beim Zählen der Griffel die Röhre der verwachsenen Staubfäden aufschlitzen, in der sich nicht selten einzelne Griffel verbergen; dadurch wird es eine etwas zeitraubende Arbeit.)

Die Pflanze V stammt von einer 9 griffligen Blume von II, befruchtet mit Blüthcnstaub einer I I griffligen Blume der Mutter von VI; bei ihr fanden sich unter 100 Blumen

$$
\begin{array}{crrr}
\text { mit } & 7 & \text { Griffeln } & 2 \\
" & 8 & , & 27 \\
" & 9 & " & 38 \\
, & \text { IO } & , & 3 \text { I } \\
., & \text { I I } & , & 2
\end{array}
$$

Beim Vergleich mit der Mutterpflanze (II) fällt auf, dass sich das Verbältniss der 9 griffligen zu den Iogriffligen Blumen fast gerade umgekehrt hat; bei der Mutter ist es etwa 9: 10, bei der Tochter etwa I 1 : 9. - Auffallender noch ist die grosse Zahl von Blumen (fast $30 \%$ ) mit weniger als 9 Griffeln, während die Mutter solcher Blumen nur $3 \%$ und darunter gar keine mit ; Griffeln brachte. 
Ich darf nicht unterlasssen anzuführen, dass die Samen der einen noch nicht einmal ganz reifen Frucht, die ich vom Capivary mitgebracht hatte und die so verschrumpft waren, dass sie des Säens gar nicht werth schienen, gut aufgingen. Ich glaube nicht zu irren, wenn ich das verspätete Keimen nur weniger Samen der Pflanzen I und IV, und die Schwächlichkeit der Sämlinge dem Umstande zuschreibe, dass diese Samen durch Geschwister der betreffenden Pflanzen erzeugt worden waren, so dass also bei diesem Abutilon nicht nur die Bestäubung mit Blüthenstaub desselben Stockes völlig wirkungslos wäre, sondern auch die Befruchtung durch die nächsten Verwandten zwar ziemlich reichlichen Samen, aber nur wenige schwächliche Nachkommenschaft erzeugen würde. Ich gedenke diesen Punkt noch ferner ins Auge zu fassen und kann den Wunsch nicht unterdrücken, dass auch mit anderen selbst unfruchtbaren Pflanzen ähnliche Versuche angestellt werden möchten.

An den meisten meiner Versuchsptlanzen hatte ich einzelne Blumen gleichzeitig mit Blüthenstaub zweier verschiedenen fremden Arten bestäubt (und zwar eine gleiche Zahl Narben mit jeder Art). Wie erwähnt hatte ich von solchen Blumen mehrfach besonders samenreiche Früchte erhalten. Diese Versuche waren angestellt worden, um durch sie nach Gärtner's Vorgang über den „Grad der sexuellen Verwandtschaft der beiden Arten zu der weiblichen Unterlage" zu entscheiden, falls der Samenertrag darüber in Zweifel lassen sollte. Das Ergebniss der Aussaat ist nun ein ganz unerwartetes gewesen. Mit Kölreuter's und W. Herbert's früheren Erfahrungen übereinstimmend behauptet Gärtner, dass bei ,gleichzeitiger Bestäubung mit verschiedenen Pollenarten“ nicht etwa "der eine Pollen eine gewisse Zahl von Eichen befruchtet, der andere aber eine andere“, dass vielmehr „nur Eine gleichförmige Befruchtung durch eine von den Pollenarten stattfindet, nämlich durch denjenigen Pollen, welcher die stärkste sexuelle Verwandtschaft zur weiblichen Unterlage hatte" (Gärtner, Bastarderzeugung im Pflanzenreiche S. 36). Der treffliche Gärtner ist vorsichtig genug, dies nur für diejenigen Arten als gültig auszusprechen, an denen er selbst, Kölreuter und W. Herbert die betreffenden Versuche angestellt. - Bei Abutilon scheint nun, soweit ich bis jetzt urtheilen kann, stets das Gegentheil, die Erzeugung von zweierlei Bastarden stattzufinden. Mit Sicherheit kann ich dies für jetzt nur für diejenigen Fälle behaupten, in denen Blüthenstaub von Embira zugleich mit dem einer anderen Art zur Verwendung kam. Denn schon fast vom Erscheinen des ersten Blattes an sind die Bastarde der Embira auf den ersten Blick an ihren langen schmalen Blättern zu erkennen. Ich führe daher einstweilen nur folgende Fälle an:

I) Eine Frucht von Striatum, befruchtet durch Capivary und Embira, lieferte 6 Sämlinge von Striato-Capivary, 3 Sämlinge von Striato-Embira.

2) Eine Frucht des Capivary-Abutilon IV, befruchtet durch Embira und Striatum, lieferte I Sämling Capivary-Embira, 5 Sämlinge Capivary-striatum.

3) Eine Frucht des Capivary-Abutilon V, ebenso befruchtet, lieferte 3 Sämlinge Capivary-Embira, 5 Capivary-striatum.

4) Eine Frucht des Capivary-Abutilon VI. ebenso befruchtet, gab 6 CapivaryEmbira, 5 Capivary-striatum.

5) Eine Frucht derselben Pflanze, ebenso befruchtet, gab 5 Sämlinge CapivaryEmbira, 20 Capivary-striatım. 
In Betreff der vier ersten Fälle muss ich bemerken, dass ich versäumt hatte, die zu dicht stehenden Pflänzchen rechtzeitig zu verpflanzen, und dass daher die Mehrzahl bei einer anhaltenden Trockniss zu Grunde ging; die oben gegebene Zahl der übrig gebliebenen ist zu gering, um weitere Betrachtungen daran zu knüpfen. Dagegen verdient der fünfte Fall noch eine besondere Besprechung. Ich hatte in diesem Falle die Samen jedes Faches besonders ausgesät und dabei die Ordnung, in der die Fächer aneinander stiessen, bemerkt. Die Sämlinge aus einem der $\diamond$ Fächer sind leider alle jung umgekommen. Ich stelle das Ergebniss wohl am anschaulichsten in einer Figur dar, in welcher schwarze Kreise die Bastarde Capivary - Embira, weisse Kreise die Bastarde Capivary-striatum vorstellen mögen. Man sieht, der Blüthenstaub von Embira hat seine Einwirkung auf vier Fächer beschränkt, wahrscheinlich dieselben, deren Narben mit ihm belegt worden waren, während der Blüthenstaub des Abutilon Striatum seinen Ein-

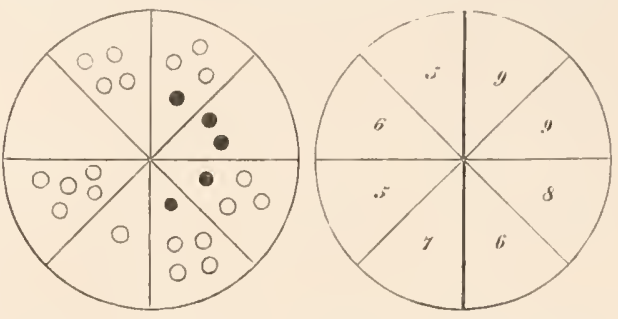
fluss über die ganze Frucht ausgedehnt hat ${ }^{1}$. Ich stelle daneben eine Figur, welche die Zahl der Samen in den einzelnen Fächern der Frucht zeigt, von der diese Sämlinge stammen. Die 4 Fächer rechts sind samenreicher (32), als die 4 Fächer links (23). Die Zahl der Eichen bei diesem Abutilon ist 8 bis 9 im Fach; in 2 oder 3 Fächern der rechten Seite sind also sämmtliche Eichen befruchtet worden. $\mathrm{Ob}$ die samenreichen Fächer die sind, auf welche zweierlei Blüthenstaub einwirkte, kann ich leider nicht sagen. Man lernt ja gewöhnlich erst im Verfolg einer Untersuchung alle Umstände kennen, auf die zu achten von Werth sein kann. Wenn aber Früchte, durch Blüthenstaub zweier fremder Arten erzeugt, sich samenreicher erwiesen, als solche, die dem Blüthenstaube der einen oder andern dieser beiden Arten ilhre Entstehung verdankten, so scheint es allerdings wahrscheinlich, dass in diesen Früchten diejenigen Fächer, auf welche zweierlei Blüthenstaub einwirkte, mehr Samen enthalten werden als die, in welchen nur einerlei Blumenstaub sich geltend machte.

Die Thatsache, dass bei Abutilon aus solchen Früchten zweierlei Bastarde hervorgehen, scheint eine einfache Erklärung für deren grösseren Samenreichthum zu bieten und eben deshalb möchte ich diesen nicht für blos zufällig halten. Der Mangel an „Wahlverwandtschaft“, um mich des bequemen Ausdrucks von Gärtner zu bedienen, giebt sich nicht selten, besonders bei völlig unfruchtbaren Verbindungen, schon auf der Narbe kund, indem Narbe und Blüthenstaub entweder gar nicht oder feindlich ${ }^{2}$, oder unvollkommen, wenige oder nicht ins Narben-

1) Es ist durch Gäıtner bekannt, dass man von einer einzigen Narbe aus alle Fächer eines inehrfächrigen Fruchtknotens befruchten kann; bei dem Abutilon vom Capivary habe ich dasselbe beobachtet. Die Verschmelzung getrennter Carpelle zu einem einzigen Fruchtknoten ist daher nicht bloss ein ,morphologischer Fortschritt", sondern von wesentlichem Nutzen für die Befruchung der Pflanzen.

2) Diese ,tödtliche Bestäubung“, wie er sie nennt, scheint zuerst Gärtner an Lychnis diurna nach Bestäubung mit Pollen von Saponaria officinalis, Silene bellidiflora und Lychnanthus volubilis beobachtet $z u$ haben. Häufig ist sie bei den Vandeen (Oncidium, Burlingtonia, Gomeza, Notylia u. s. w.) nach Bestäubung mit eigenem Blüthenstaub, wie auch nach Bestäubung von Oncidium flexuosum mit Pollinien von Notylia. 
gewebe eindringende Pollenschläuche entwickelnd, auf einander einwirken; in andern Fällen macht sich derselbe erst nach der Befruchtung der Eichen geltend, indem die Samen vor der Reife vertrocknen oder der Embryo sich nur unvollkommen entwickelt. In der Mehrzahl der Fälle aber, in denen die Einwirkung zeugungskräftigen Blüthenstaubes auf eine empfängnissfähige weibliche Unterlage eine hinter der normalen zurückbleibende Samenzahl erzeugt, dürfte dies davon abhängen, dass nur ein Theil der Eichen befruchtet wird. Dass aber einige Eichen eines Fruchtknotens von Blüthenstaub einer fremden Art befruchtet werden, andere nicht, deutet auf eine Verschiedenheit der Eichen oder, mit Gärtner zu reden, darauf hin, dass nicht alle die gleiche Wahlverwandtschaft zu dem fremden Blüthenstaube besitzen. Kommen nun Pollenschläuche von zwei fremden Arten gleichzeitig im Fruchtknoten an, so werden es wahrscheinlich nicht immer dieselben Eichen sein, die für beiderlei Arten sich unempfänglich erweisen; manche, die von der ersten Art nicht befruchtet worden wären, werden es durch die zweite und umgekehrt, wodurch denn natürlich eine grössere Zahl von Samen erzeugt wird, als durch jede einzelne der fremden Pollenarten.

Nach Kölreuter's und Gärtner's Erfahrungen soll, wenn eine zur Befruchtung hinreichende Menge eigenen Blüthenstaubes und gleichzeitig fremder Blüthenstaub auf die Narben gebracht wird, ,der eigene Befruchtungsstoff nur allein angenommen, der fremde hingegen gänzlich verdrungen und von der Befruchtung ausgeschlossen" werden. (Gärtner, Bastarderzeugung S. 34.) Auch dies gilt wenigstens nicht immer für Abutilon. Ich habe an Blumen des Capivary-Abutilon eine Narbe mit Blüthenstaub der eigenen Art, die übrigen mit Blüthenstaub von Abutilon striatum oder Embira bestäubt. Die Bestäubung der einen Narbe würde ausgereicht haben, eine ziemlich samenreiche Frucht zu liefern; so erhielt ich von einer Blume der Pflanze II, in welcher eine einzige Narbe mit Blüthenstaub der Pflanze I bestäubt wurde, eine Frucht mit 54 Samen $(5,4$ im Fach), eine der reichsten Früchte, die ich von dieser Pflanze erntete. Allein aus der ,gemischten Bestäubung" ging dennoch nicht blos die reine Art hervor. So wurde an einer Blume der Pflanze V eine Narbe mit Blüthenstaub der Pflanze II, die sieben übrigen Narben mit Blüthenstaub von Embira bestäubt; aus dem Samen der so erhaltenen Frucht habe ich ro Sämlinge gezogen, von denen 9 Bastarde (Abutilon Capivary-Embira) sind und nur einer der reinen Art (Abutilon vom Capivary) angehört.

Nach der Meinung Kölreuter's und Herbert's sollen „bei einer Vereinigung einer geringen Menge des eigenen mit einer grösseren eines fremden Befruchtungsstoffs" Varietäten (Kölreuter's „Tincturen oder halbe Bastarde“) hervorgebracht werden können, die ,zwar keine wirklichen Hybriden wären, aber in einem gewissen Grade von der natürlichen Form abweichen“. Gärtner bestreitet diese Möglichkeit aufs Entschiedenste. Bei der Leichtigkeit, mit der sich bei ihnen zweierlei Samen in derselben Frucht erzeugen, dürften die in Gärten jetzt so zahlreich vertretenen Abutilon-Arten besonders geeignet sein, solche „Tincturen“ entstehen zu lassen, deren Möglichkeit ich trotz allen Versuchen und Gegengründen Gärtner's nicht von vornherein in Abrede stellen möchte. Der Blüthenstaub wirkt ja nicht nur auf die Eichen, sondern, wie u. A. Mildebrand's Ver- 
suche an Orchideen beweisen, auch auf den ganzen Fruchtknoten. Dass aber ein Fruchtknoten, auf den zweierlei Blüthenstaub eingewirkt, eine der Eigenthümlichkeit der beiden Pollenarten entsprechende Rückwirkung äussern könne auf die in ihm reifenden Samen, scheint mir nicht unwahrscheinlich, wenn ich an das bekannte Beispiel von Lord Morton's arabischer Stute denke, die von einem Quagga-Hengste einen Bastard geboren hatte und später von einem schwarzen arabischen Hengste zwei Füllen warf, deren Beine noch deutlicher gestreift waren, als die des Bastards, ja als die des Quagga selbst.

Auch in dieser Beziehung dürften daher weitere Versuche an AbutilonArten über den Erfolg der gleichzeitigen oder successiven Bestäubung mit verschiedenen Pollenarten wünschenswerth erscheinen.

Itajahy, Sa. Catharina, Brazil, im Januar $187 \mathrm{I}$. 


\section{Bestäubungsversuche an Abutilon ${ }^{1}$ ).}

II. Beispiele von Unfruchtbarkeit als Folge zu naher Verwandtschaft.

Mit 4 Textfiguren.

Die völlige Unfruchtbarkeit gewisser Pflanzen mit Blüthenstaub derselben Blume (Corydalis cava) oder selbst aller Blumen desselben Stocks (Arten von Abutilon, Bignonia, Oncidium u.s. w.) bildet nur einen besonderen Fall des Gesetzes, dass Selbstbestäubung minder kräftige Nachkommenschaft liefert, als Kreuzung. Und dieses Gesetz, für welches jede Blume einen Beleg bietet, die durch Duft oder Farbenschmuck Bienen und Schmetterlinge zum Honiggenuss und dadurch zur Vermittelung der Kreuzung einladet, ist wieder nur ein besonderer Fall eines allgemeineren Gesetzes, dass nämlich enge Inzucht zwischen nahen Verwandten nachtheilig wirkt; denn, als Einzelwesen betrachtet, sind ja eben Staubgefässe und Stempel desselben Pflanzenstocks oder gar derselben Blume die denkbar nächsten Verwandten. Eine noch allgemeinere Fassung lässt sich letzterem Gesetze geben, wenn man in dasselbe die Verminderung der Fruchtbarkeit mit einschliesst, die in allen Graden bis zu völliger Unfruchtbarkeit eintritt als Folge zu geringer Verwandtschaft der gekreuzten Pflanzen, also bei der Bastardzeugung. Jede Pflanze, könnte man sagen, erfordert zur Erlangung möglichst kräftiger und zeugungsfähiger Nachkommenschaft einen gewissen Betrag von Verschiedenheit zwischen den sich vereinigenden männlichen und weiblichen Zeugungsstoffen; sowohl wenn dieser Betrag abnimmt (bei zu naher Verwandtschaft), als wenn er steigt (bei zu geringer Verwandtschaft) nimmt die Fruchtbarkeit ab. Die vollständige Uebereinstimmung zwischen „illegitimen“ Sprösslingen dimorpher und trimorpher Pflanzen einerseits und den Bastarden verschiedener Arten andrerseits berechtigt wohl zu einer solchen Zusammenfassung der beiden durch entgegengesetzte Ursachen bedingten Arten der Unfruchtbarkeit unter einen gemeinsamen Gesichtspunct. Selbstverständlich soll damit das thatsächlich Gegebene nur ausgesprochen, nicht aber erklärt sein. Ebenso soll damit natürlich nur eines der vielen, die grössere oder geringere Fruchtbarkeit einer Verbindung bedingenden Verhältnisse ausgesprochen sein.

Je grösser bei einer Art die zur Erzielung des höchsten Grades der Fruchtbarkeit erforderliche Verschiedenheit der Zeugungsstoffe ist, um so grösser wird

I) Jen. Zeitschrift für Naturwissenschaft 1873 . 7. Jahrg. S. $441-450$. 
im Allgemeinen - (ceteris paribus) - die Verschiedenheit der Pflanzen sein sein dürfen, die überhaupt noch Nachkommen mit einander zeugen können. Mit anderen Worten: Arten, die mit Blüthenstaub desselben Stockes völlig und selbst mit Blüthenstaub nahe verwandter Stöcke mehr oder weniger unfruchtbar sind, werden im Allgemeinen besonders leicht durch Blüthenstaub anderer Arten sich befruchten lassen. Die selbst unfruchtbaren, dagegen zur Bastardbildung so überaıs geneigten Arten der Gattung Abutilon liefern ein gutes Beispiel zu diesem Satze, der auch bei Lobelia, Passiflora, Oncidium sich zu bestätigen scheint.

Ich will diese allgemeinen Betrachtungen hier nicht weiter fortsetzen. Dieselben sollten nur andeuten, in welchem Sinne und in welchem Zusammenhang ich die im Folgenden mitzutheilenden Beispiele von Unfruchtbarkeit zwischen nahen Verwandten aufgefasst zu sehen wünschte.

Im Folgenden bezeichnen $A, C, E, F, M, P$ sechs einheimische AbutilonArten, von denen ich $C$ als Abutilon vom Capivary, $E$ als Embira branca, $F$ als Abutilon vom Pocinho schon in einem früheren Aufsatz erwähnt habe ${ }^{1}$ ). Das Abutilon von Capivary ist von Fenzl Abutilon Hildebrandi getauft worden. Die Namen der übrigen Arten hoffe ich später mittheilen zu können. Mit $S$ ist Abutilon striatum, mit $V$ A butilon vexillarium bezeichnet. Zur Bezeichnung der einfachen Bastarde sind die Buchstaben der stammelterlichen Arten ohne weiteres Zeichen nebeneinander gestellt, und zwar die mütterliche Art voran. So bezeichnet $E F$ einen Bastard, dessen Mutter $E$, dessen Vater $F$ ist. Bei Verbindungen dieser einfachen Bastarde unter sich oder mit einfachen Arten ist ein Punct zwischen das vorangehende Zeichen der Mutter und das nachfolgende des Vaters gesetzt; $F . C F$ hat also $F$ zur Mutter, $C F$ zum Vater, $C E . S$ hat $C E$ zur Mutter, $S$ zum Vater. Die Zahlen rechts unten neben den Buchstaben bezeichnen die einzelnen Stöcke einer Art oder eines Bastards. $F S_{1}, F S_{2}, F S_{3}$ sind also z. B. drei verschiedene Stücke des Bastards FS.

\section{C (Abutilon Hildebrandi, Fenzl).}

Von dieser Art habe ich bereits einige Fälle mitgetheilt, in denen Befruchtung durch die nächsten Verwandten zwar reichlichen Samen, aber nur wenige schwächliche Nachkommenschaft erzeugte ${ }^{2}$ ). Ein weiteres Beispiel lieferten meine Versuche im Jahre i 871 . Die Verwandtschaftsverhältnisse der betheiligten Pflanzen erhellen aus nebenstehender Uebersicht.

Aus Samen einer Frucht der am oberen Capivary wildwachsenden Pflanze $C_{0}$ wurden die Geschwister $C^{\prime}, C^{\prime \prime}, C_{2}, C_{3}$. gezogen. $C_{5}$ hat $C_{2}$ zur Mutter, $C^{\prime \prime}$ zum Vater; $C_{f}$, hat zur Mutter $C^{\prime \prime}$, zum Vater $C^{\prime}$; endlich die Geschwister $C_{7}, C_{8}, C_{9}$ haben

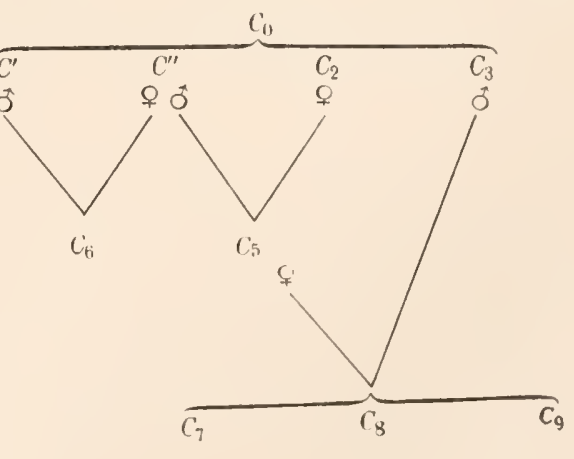

I) Jenaische Zeitschrift für Naturwissenschaft. 7. Jahrg. S. 22. = Ges. Schriften S. 405.

2) Jenaische Zeitschrift für Naturwissenschaft. 7. Jahrg. S. 40. = Ges. Schriften S. 4r 8. 
$C_{5}$ zur Mutter, $C_{3}$ zum Vater. Die mit eigenem Blüthenstaub völlig unfruchtbare Pflanze $C_{7}$ wurde nun befruchtet mit Blüthenstaub ihrer Geschwister $C_{8}$ und $C_{9}$, ihrer Mutter $C_{5}$, ihres Vaters $C_{3}$ und der minder nahe verwandten Pflanze $C_{6}$. Im Samenertrage zeigte sich keine erhebliche Verschiedenheit. Am I7. Februar 1872 wurden je 30 Korn dieser fünferlei Samen gesät. Die durch Blüthenstaub des Vaters $C_{3}$ und des Bruders $C_{9}$ erzeugten Samen gingen gar nicht auf. Von den durch Blüthenstaub der Mutter $C_{5}$ erzeugten Samen keimten zwei oder drei, aber die Pflänzchen gingen schon nach wenigen Tagen wieder ein. Zahlreichere Pflanzen entsprossten den durch $C_{8}$ und $C_{6}$ erzeugten Samen. Erstere, die Kinder des Bruders $C_{8}$, wuchsen sehr kümmerlich; nach vier Monaten waren die größten kaum zollhoch, die kleinsten dagegen der durch Blüthenstaub von $C_{6}$ erzeugten mindestens doppelt so hoch.

\section{Bastard CE.S.}

$E_{1}$ und $\mathrm{E}_{2}$ sind zwei wilde Pflanzen, die ich in meinen Garten versetzt habe, $E_{3}$ ein in meinem Garten aufgegangener Sämling, der wahrscheinlich $E_{1}$ zur Mutter,

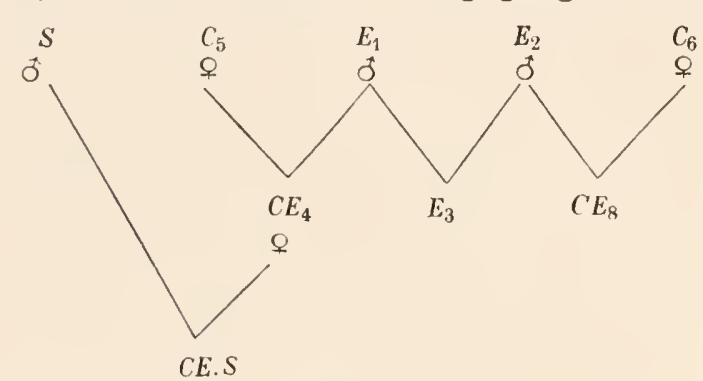

$E_{2}$ zum Vater hat. Das Uebrige ergiebt nebenstehende Uebersicht.

Bestäubung des Bastards CE.S mit $C E_{4}, C E_{8}, E_{3}$ und $S$ lieferte samenreiche Früchte ${ }^{1}$ ). Die Samen wurden am 6. September auf demselben Beete ausgesät. Zuerst keimten, nach I3 Tagen, die durch $C E_{8}$ und $E_{3}$ erzeugten, - dann, nach 15 Tagen, die durch den Vater $S$, - zuletzt, nach i 8 Tagen, die durch die Mutterpflanze $C E_{4}$ erzeugten Samen. Von den drei ersteren erschienen zahlreiche Pflanzen, von den durch $C E_{4}$ erzeugten 46 Samen keimten nur 5, und diese 5 Pflänzchen wachsen bis jetzt (Ende October) sehr kümmerlich; kaum kräftiger sind die durch $S$ erzeugten; am besten von allen gedeihen die durch $C E_{\mathrm{s}}$ erzeugten und ihnen kommen die durch $E_{3}$ erzeugten nahe.

\section{B a stard F.CF.}

Die Geschwister $C F_{1}$ und $C F_{2}$ haben zur Mutter $C_{1}$, zum Vater $F$, die Geschwister $F . C F_{1}$ und $F . C F_{2}$ zur Mutter $F$, zum Vater $C F_{2}$.

I) Gärtner (Bastardzeugung S. 507) fand „zus a mmengesetzte Bastarde“ d. h. solche, „deren weibliche Unterlage ein fruchtbarer Bastard, der männliche Factor aber eine andere reine Art ist", meist völlig unfruchtbar und dies namentlich in den Fällen, wo dieselben durch ,vermittelnde Verwandt$\mathrm{sch}$ a f " entstanden waren, d. h. zwei Arten enthielten, die direct nicht oder nur schwierig zu verbinden waren, wie es in dem Bastard CE.S mit den Arten $E$ und $S$ der Fall ist. Er fand ferner diese durch vermittelnde Verwandtschaft entstandenen zusammengesetzten Bastarde ,dem väterlichen Typus so sehı ähnlich, dass sie nur Varietäten desselben zu sein scheinen“. Die von ihm und Kölreuter beobachteten derartigen Bastarde gehörten den Gattungen Nicotiana, Lobelia und Verbascum an. Für Abut ilon kann ich die von Gärtner aufgestellten Regeln nicht bestätigen. Die hierher gehörigen Bastarde $C E . S, E F . S$ und CS.E sind sämmtlich fuchtbar und keineswegs iluren Vätern besonders ähnlich; in der Blattform steht sogar $C E . S$ der Mutter $C E$ sehr viel näher als dem Vater $S$. 
$F_{. C F_{2}}$ ist nun völlig unfruchtbar mit seinem Vater $C F_{2}$; Io mit Blüthenstaub des letzteren bestäubte Blumen fielen $a b$, ohne auch nur Frucht anzusetzen; dagegen brachten Io gleichzeitig $\left.{ }^{1}\right)$ mit Blüthenstaub des Oheims $C F_{1}$ bestäubte Blumen ebenso viele Früchte mit keimfähigen Samen. Auch mit Blüthenstaub der Mutter $F$, des Bruders $F . C F_{1}$, sowie der Pflanzen $A_{2}, C_{6}$ und $F . E F_{1}$ lieferte $F . C F_{2}$ keimfähige Samen. Mit eigenem Blüthenstaube ist $F . C F_{2}$ völlig unfruchtbar.

Umgekehrt fielen zwei Blumen von $C_{2}$ nach Bestäubung

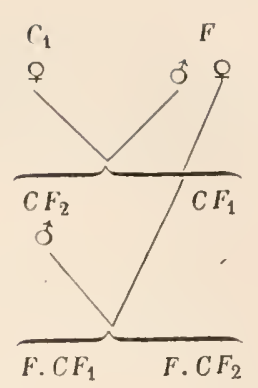
mit $F . C F_{2}$ unbefruchtet ab, während zwei ebenso bestäubte Blumen von $C F_{1}$ reife Früchte brachten, deren Samen leider durch Raupen aufgefressen waren.

Die Pflanze F.CF , an welcher nur wenige Versuche gemacht wurden, scheint sich ähnlich zu verhalten, wie ihr Bruder F.CF .

\section{Bastard FS.}

Von den Arten $F$ und $S$ besitze ich nur je eine Pflanze; die Bastarde $F S_{1}$, $F S_{2}, F S_{3}$ und $S F$ sind also sämmtlich Geschwister. Alle vier zeichnen sich aus durch üppigen Wuchs (sie sind jetzt, ein Jahr nach der Aussaat, von mehr als doppelter Manneshöhe) und durch grosse Fruchtbarkeit ${ }^{2}$ ); ohne mein Zuthun, durch Vermittlung der Kolibris, haben sie sich mit Hunderten von Früchten bedeckt. $\mathrm{Zu}$ Bestäubungsversuchen wurde die Pflanze $F S_{1}$ ausgewählt. Io Blumen mit Blüthenstaub desselben Stockes bestäubt. fielen unbefruchtet ab, während 9 Blumen bestäubt mit $F$, Io Blumen mit $F . E F, 2$ Blumen mit $F V$ ebensoviele samenreiche Früchte brachten. Auch mit $A$, mit $E F$, mit $F E$, mit $M_{2}$, mit $S_{1}$, sowie mit ihren Geschwistern $F S_{2}$ und $S F$ zeigte $F S_{1}$ sich fruchtbar. Die aus diesen verschiedenen Kreuzungen hervorgegangenen Samen erwiesen sich, soweit sie ausgesät wurden, als keimfähig, darunter auch die durch Bestäubung mit $S F$ erhaltenen. Völlig unfruchtbar dagegen zeigte sich die Pflanze $F S_{1}$ mit ihrem Bruder $F S_{3}$; sieben mit dessen Blüthenstaube bestäubte Blumen fielen unbefruchtet ab.

Um zu ermitteln, ob die Unfruchtbarkeit dieser beiden Geschwister eine gegenseitige sei, wurde auch an $F S_{3}$ eine Reihe von Versuchen gemacht. 4 Blumen mit $A$, I Blume mit $F V, 5$ mit $F S_{2}, 5$ mit $S F$ bestäubt lieferten ebensoviele Früchte; ebenso erhielt ich Früchte mit gutem Samen von der Mehrzahl der mit F, FP, $M$ und $S$ bestäubten Blumen, dagegen nicht eine einzige Frucht von 5 Blumen, die mit Blüthenstaub von $F S_{1}$ bestäubt wurden.

I) D. h. es wurden gleichzeitig nicht alle 20 Blumen, sondern jedesmal eine Blume mit $C F_{1}$ und zugleich eine andere mit $C F_{2}$ bestäubt.

2) Soweit meine Erfahrung reicht, sind überhaupt die am üppigsten wachsenden Bastarde auch die fruchtbarsten. Auch nach Gärtner's so ungemein reichen, ein Vierteljahrhundert umfassenden Erfahrungen ,zeigen gerade diejenigen Bastarde, bei welchen man die meiste Fruchtbarkeit bemerkt hat, unter allen die stärkste Luxuriation in allen Theilen“ (Bastardzeugung S. 529). Dass ungekehrt kümmerlich wachsende, zwerghafte Bastarde völlig unfruchtbar zu sein pflegen, ist bekannt. Den üppigen Wuchs so vieler Bastardpflanzen ihrer Unfruchtbarkeit zuzuschreiben, wie Kölreuter wollte, und darin ,un cas très — remarquable d'application de la loi du balancement organique et physiologique" sehen zu wollen, wie noch ganz neuerdings Quatrefages es thut (Charles Darwin et ses précurseurs français. 1870. S. $246 . \Lambda \mathrm{nm}$.), ist hiernach (und aus anderen von Gärtner a. a. O. entwickelten Gründen) durchaus unstatthaft. 
Der Blüthenstaub von $F S_{1}$, der $F S_{3}$ nicht zu befruchten vermochte, erzeugte Früchte mit reichlichen keimfähigen Samen an den Pflanzen $C I, E F_{2}, E J_{1}, F$, $F \cdot K F_{1}, S$ und $S T^{\prime}$; ebenso befruchtete der auf den Narben von $F S_{1}$ wirkungslose Blïthenstaub von $F S_{3}$ die Pflanzen $C T^{r}, E Y_{1}, F . F E_{2}, P$ und $S$.

\section{Bastard $F P$.}

Die beiden Geschwister $F P_{1}$ und $F P_{2}$ scheinen ebenso unfruchtbar mit einander zu sein, wie $F S_{1}$ und $F S_{3} ;$ zwei Blüthen von $F P_{2}$, bestäubt mit $F I_{1}^{\prime}$ fielen unbefruchtet ab; ebenso vier von den fünf mit $\mathrm{FP}_{2}$ bestäubten Blumen der Pflanze $H P_{1}$; auch die Frucht, welche die fünfte dieser Blumen angesetzt hatte, fiel jung ab. Dagegen lieferten beide Pflanzen Früchte und keimfähige Samen mit dem Blüthenstaub ihrer Eltern $F$ und $P$; ausserdem $F P_{1}$ mit $A, C S_{1}$ und $C \mathrm{~T}$. - Der Blüthenstaub beider Pflanzen ist zeugungskräftig; denn er erzeugte keimfähige Samen an den Pflanzen $C V_{,} E V_{1}, F, M_{1}$ und $M_{2}$. An der Pflanze $P$, dem Vater von $F P_{1}$ und $F P_{2}$, erhielt ich von fünf mit Blüthenstaub dieser Kinder bestäubten Blumen nur eine, ziemlich samenreiche Frucht, deren Samen noch nicht auf ihre Keimfähigkeit geprüft wurden.

\section{Bastard F.EF.}

Die vier Pflanzen $E F . F_{1}, E F . F_{2}, F . E F_{1}$ und $F . E F_{2}$ sind Geschwister; sic haben dieselben Eltern $F$ und $E F_{1}$. -

Neun Blumen von $F . E F_{1}$, bestäubt mit Blüthenstaub anderer Blumen desselben Stocks, lieferten keine einzige Frucht. Zwanzig Blumen von $F . E F_{1}$, bestäubt

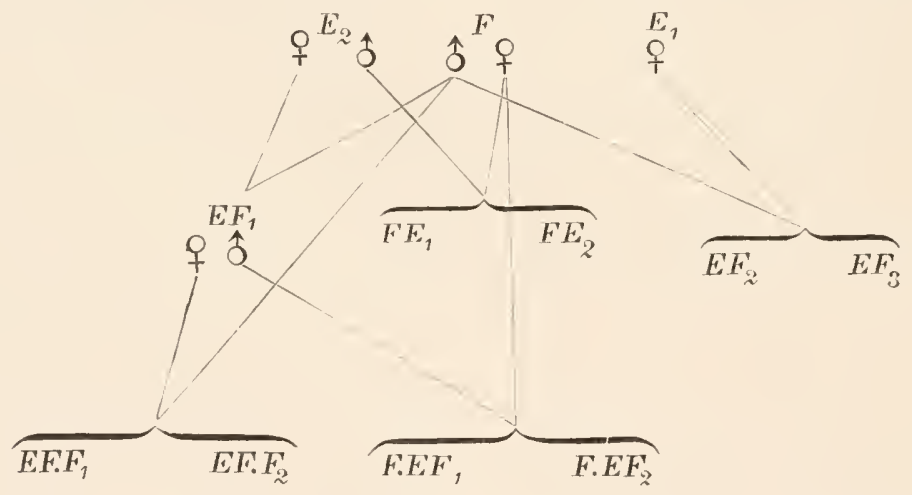

mit Blüthenstaub der Geschwister $F . E F_{2}, E F_{1} F_{1}$ und $E F . F_{2}$, brachten drei Früchte mit durchschnittlich 1,3 Samen im Fach; die samenreichste der drei Früchte hatte durchschnittlich 2,2 Samen im Fach.

Dagegen gaben

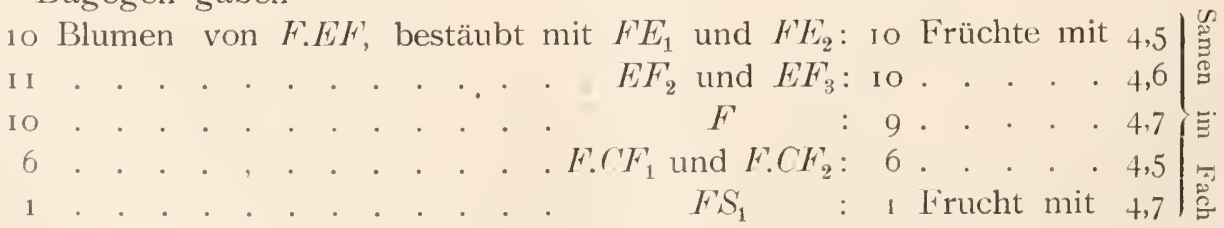

Der geringe Erfolg der Bestäubung mit dem Blüthenstaub der Geschwister lag nicht etwa an der schlechten Beschaffenheit dieses Blüthenstaubes, der sich 
an anderen Pflanzen vollkommen zeugungskräftig erwies; der Blüthenstaub von $F . E F_{2}$ erzeugte samenreiche Früchte an der Pflanze $F S_{1}$, der von $E F \cdot F_{1}$ an $F E_{2}$, der von $E F . F_{2}$ an $F$. Auch der Blüthenstaub von $F . E F_{1}$ erzeugte zahlreiche und, soweit sie ausgesät wurden, sich keimfähig erweisende Samen an den Pflanzen $F, F . C F_{2}, F S_{1}$ und $F S_{2}$. -

Die durch $F . E F_{2}$ erzeugten Samen von $F . E F_{1}$ haben übrigens gekeimt und kräftige Pflanzen gegeben, die bis jetzt im Wachsthum mit den durch $E F_{2}$, durch $F$, durch $F . C F_{2}$ und durch $F S_{1}$ erzeugten gleichen Schritt halten.

\section{VII. $\mathrm{B}$ astarde $E F$ und $F E$.}

Die Verwandtschaftsverhältnisse der betreffenden Pflanzen erhellen aus der bei F.EF gegebenen Uebersicht.

Sowohl die Geschwister $E F_{2}$ und $E F_{3}$, als ihre Halbgeschwister $E F_{1}, F E_{1}$ und $F E_{2}$ wetteifern in üppigem Wuchs und Fruchtbarkeit mit den Bastarden $F S$ und $S F^{1}$ ). - Als Versuchspflanzen dienten die Halbgeschwister $E F_{2}$ und $F E_{2}$. Dieselben sind unfruchtbar mit einander. Sieben Blumen von $E F_{2}$ lieferten mit Blüthenstaub von $F E_{2}$ keine, Io Blumen von $F E_{2}$ mit Blüthenstaub von $E F_{2}$ eine einzige sehr dürftige Frucht, die in 15 Fächern nur I I Samen enthielt. Die Samen scheinen taub zu sein, haben wenigstens, vor I 8 Tagen ausgesät, noch nicht gekeimt.

Auch mit Blüthenstaub von $F E_{1}$ zeigten sich beide Versuchspflanzen unfruchtbar; Io Blumen von $F E_{2}$ gaben mit Blüthenstaub von $F E_{1}$ gar keine, 4 Blumen von $E F_{2}$ eine einzige dürftige Frucht mit nur 8 Samen in 1 I Fächern und diese Samen erwiesen sich bei der Aussaat als taub.

Dagegen erzeugte der Blüthenstaub von $E F_{3}$ ziemlich reichlichen Samenertrag, sowohl bei seinem Bruder $E F_{2}$, als bei seinem Halbbruder $F E_{2}$; i 2 Blumen von $E F_{2}$ gaben, mit $E F_{3}$ bestäubt, io Früchte mit durchschnittlich 3, 5 Samen und Io Blumen von $F E_{2}$, ebenso bestäubt, 9 Früchte mit durchschnittlich 4, 2 Samen in einem Fache.

Mit allen sonstigen Arten und Bastarden, mit denen sie bestäubt wurden, zeigten sich beide Pflanzen fruchtbar; so $E F_{2}^{\prime}$ mit $E, E F . V, F, F S, M$ und $F S$, sowie $F E_{2}$ mit CT, EF.F, EF.S, E.FV, EV, F, FS und $M$.

I) „Wenn zwei Arten fruchtbare Bastarde erzeugen, so müssen wir sie in eine Art zusammenziehen“ sagt Professor Keferstein in seinem „Berichte über die Fortschritte der Generationslehre im Jahre 1867" (S. 190). Diese Forderung des Berichterstatters dürfte wohl kaum unter die ,Fortschritte in der Generationslehre“ zu zählen sein. Schon Gärtner war über diesen Standpunct weit hinaus. So sagt er, um nur eine der vielen bezüglichen Stellen seines Buches anzuführen (Bastardzeugung, S. 382 ): „Knight hat behauptet, dass die Fruchtbarkeit eines Bastards ein directer Beweis davon seie, dass die beiden Eltern $z u$ der nämlichen Species gehören, und dass ein steriler Bastard von verschiedenen Arten abstamme. Im Folgenden wird sich aber die Unrichtigkeit des von Knight behaupteten Satzes unzweideutig ergeben." Nach alle dem, was schon Gärtner und was später Darwin ïber diesen Gegenstand gesagt, bedarf derselbe keiner erneuten Besprechung. Ich möchte nur Herrn Professor Keferstein fragen, in welcher Weise er seine kategorische Forderung ausführen würde, wenn zwei Arten ( $E$ und $S^{r}$ ) zwar mit derselben dritten $\left(F^{\top}\right)$ fruchtbare Bastarde $(E F, F E, F S, S F)$ erzeugen, nicht aber unter sich. - Oder wenn zwei direct nicht $\mathrm{zu}$ fruchtbaren Bastarden vereinbare Arten $(E$ und $S)$ sich durch Vermittlung einer dritten Art $(C$ oder $F$ ) zu fruchtbaren Bastarden (CF.S, LF.S, CS.E) verschmelzen lassen. - 
Umgekehrt befruchtete Blüthenstaub von $E F_{2}$ und $F E_{2}$ fast alle Pflanzen, an denen er versucht wurde; so der von $E F_{2}$ die Pflanzen $C_{7}, C P, C V . E F . S$, $F S_{1}, S T^{\top}$ und der von $F E_{2}$ die Pflanzen $F, F . E F_{1}$ und $F S_{1}$. -

Es beweisen die eben mitgetheilten Beispiele, dass bei den Bastarden von Abutilon und wahrscheinlich ganz ebenso bei den reinen Arten dieser Gattung ziemlich häufig Fälle mehr oder minder vollständiger Unfruchtbarkeit zwischen nahe verwandten Pflanzenstöcken, zwischen Eltern und Kindern. zwischen Geschwistern und selbst Halbgeschwistern vorkommen. Ist die oben ausgesprochene Auffassung des Zusammenhanges zwischen Verwandtschaft und Fruchtbarkeit richtig, so darf man hoffen, ähnliche Beispiele durch zu nahe Verwandtschaft verminderter Fruchtbarkeit auch bei anderen Pflanzen nachweisen $\mathrm{zu}$ können, wird aber völlige Unfruchtbarkeit zwischen Verwandten nur bei solchen Arten zu finden erwarten dürfen, die wie Abutilon mit Blüthenstaub desselben Stockes unfruchtbar sind.

Die üblen Folgen der Inzucht, die sich, wie A butilon zeigt, schon bei der ersten Verbindung $z u$ nahe verwandter Pflanzen bis zu völliger Unfruchtbarkeit steigern können, sind bei allen bisherigen und namentlich auch bei Gärtner's „Versuchen und Beobachtungen über die Bastardzeugung im Pflanzenreich" unberücksicht geblieben, und es bedürfen daher mehrere der aus diesen Versuchen abgeleiteten Sätze einer Nachprüfung. Dies gilt z. B. von dem Satze, dass Bastarde „niemals so viele vollkommene und keimfähige Samen erzeugen, als ihre Stammeltern“ (Gärtner a. a. O. S. 540). Ebenso von dem Satze, „dass der stammelterliche Pollen auf die Bastarde kräftiger wirkt, als der eigene" (Gärtner a. a. O. S. 425). In keinem einzigen der vielen von Gärtner für beide Sätze angeführten Fälle ist aus seinem Buche zu ersehen, ob die geringere Fruchtbarkeit der Bastarde, ob die minder kräftige Wirkung des Bastardpollens Folge gewesen sei der Bastardnatur oder nicht vielmehr zu naher Verwandtschaft der gekreuzten Pflanzen. Kaum findet sich bei Gärtner ein Fall, der schlagender die Richtigkeit des zweiten Satzes zu beweisen scheint, als die oben erwähnte Pflanze $F . E F_{1}$, an welcher 29 theils mit Blüthenstaub desselben Stncks, theils mit dem von $F . E F_{2}, E F . F_{1}$ und $E K . F_{2}$ bestäubte Blumen nur drei dürftige Früchte, dagegen 3 I mit „stammelterlichem Pollen" (von $F, E F_{2}, E F_{3}, F E_{1}, F E_{2}$ ) bestäubte Blumen 29 Früchte brachten, die mehr als dreimal so samenreich waren, als jene. Und doch beweist die Fruchtbarkeit dieser Pflanze mit andern Bastarden $(F S$ und $F . C F)$, sowie die kräftige Wirkung ihres Blüthenstaubes und des Blüthenstaubes ihrer Geschwister auf zahlreiche andere Pflanzen, dass der überaus dürftige Samenertrag der Pflanze $F . E F_{1}$ nach Bestäubung mit $F . E F_{2}, E F . F_{1}$ und $E F . F_{2}$ nicht davon herrührte, dass diese Pflanzen Bastarde, sondern einzig davon, dass sie Geschwister sind. - Für eine grosse Zahl von Bastarden ist allerdings die Richtigkeit beider Sätze ausser Frage, für alle diejenigen nämlich, deren Geschlechtstheile mehr oder minder verkümmert sind; für diese aber besagen sie nur, was sich ganz von selbst versteht und ebenso für alle übrigen Pflanzen gilt, dass gesunde Geschlechtstheile und Zeugungsstnffe zur Zeugung tauglicher sind, als verkümmerte, unvollkommen entwickelte. 
Auch der Satz, dass „die meisten fruchtbaren Bastarde in fortgesetzten Generationen in ihrem Zcugungsvermögen immer mehr und mehr abnehmen" (Gürtner a. a. O. S. 418), bedarf einer neuen Prüfung. Es ist auf diesen Satz von Gegnern Darwin's ganz besonderes Gewicht gelegt worden und Flourens glaubt mit demselben eine scharfe Grenze zwischen Art und Abart ziehen zu können "). Während Blendlinge mit unverminderter Fruchtbarkeit sich dauernd fortpflanzen, soll die Fruchtbarkeit der Bastarde von Geschlecht zu Geschlecht abnehmen und bald völlig erlöschen. Darwin hat bereits mit gewohntem Scharfblick die Vermuthung ausgesprochen, dass diese vielfach beobachtete Abnahme der Fruchtbarkeit Folge sei nicht der Bastardnatur, sondern zu enger Inzucht ${ }^{2}$ ) und ich freue mich in den hier mitgetheilten Beispielen verminderter Fruchtbarkeit und völliger Unfruchtbarkeit als Folge zu enger Inzucht bei Abutilon-Bastarden einen neuen Beleg für die Richtigkeit der Vermuthung Darwin's bieten zu können ${ }^{3}$ ).

Itajahy, October I 872.

I) „Toutes les variétés d'une même espèce sont fécondes entre elles d'une fécondité continue; les espèces d'un même genre n'ont entre elles qu'une fécondité bornée“ Flourens, Examen du livre de M. Darwin, pag. IоI.

2) „I believe in nearly all these cases, that the fertility has been diminished ... by too close interbreeding" Origin of species. $4^{\text {th }}$ edition. pag. 295 .

3) Gerade in dem von Gärtner (a. a. O.) als Beleg seines Satzes angeführten Falle des ,,sehr fruchtbaren Bastards D ianthus Armeria-d el toid es" der sich Jahre lang in Gärtner's Garten von selbst aussäte, dessen Fruchtbarkeit aber von Jahr zu Jahr abnahm und im zehnten Jahre völlig erlosch, ist es kaum zweifelhaft, dass enge Inzucht stattgefunden hat. So viel aus Gärtner's Verzeichniss seiner Versuche zu ersehen ist (Bastardzeugung, S. 689), hat derselbe nur einmal, im Jahre I829, vier Blumen (wahrscheinlich an derselben Pflanze) von Dianthus Armeriamit Dianthus deltoides bestäubt und von diesen zwei Früchte geerntet. 


\title{
Beiträge zur Kenntniss der Termiten ${ }^{1}$ ).
}

I. Die Geschlechtstheile der Soldaten von Calotermes.

\author{
Mit Taf. XXXVIII u. XXXIX.
}

Lespès hat unter den Arbeitern und Soldaten des Termes lucifugus Männchen und Weibchen gefunden. Aeusserlich waren die beiden Geschlechter nicht zu unterscheiden. Bei den weiblichen Arbeitern sah er Eierstöcke mit 12 bis ${ }_{5} 5$ wenig getrennten Eiröhren, die in einen dickeren Eileiter mündeten. Die beiden Eileiter verbanden sich zu einer kurzen Scheide. In den Eiröhren fand sich keine Spur von Eiern, dagegen flüssiges Fett in Kügelchen von oft beträchtlicher Grösse. Die männlichen Geschlechtstheile der Arbeiter waren äusserst gering entwickelt: zwei kaum sichtbare Hoden, deren sehr feine Ausführungsgänge zu einem gemeinschaftlichen Gange sich verbanden; an letzterem sassen verkümmerte Samenblasen. Waren schon bei den Arbeitern alle diese Theile sehr zart und schwierig darzustellen, so fand dies in noch höherem Grade bei den Soldaten statt ${ }^{2}$.

Hagen versuchte vergeblich bei Arbeitern verschiedener Termes- und Hodotermes-Arten innere Geschlechtstheile nachzuweisen ") und ist trotz des Zutrauens, welches ihm die Arbeit von Lespès zu verdienen scheint, der Meinung, dass „die Angabe so auffälliger Thatsachen vor ihrer allgemeinen Annahme eine neue Bestätigung erfordert". Auch Gerstäcker ${ }^{4}$ ) hält das Vorkommen von Männchen und Weibchen unter den Arbeitern und Soldaten der Termiten für „kaum glaublich“.

Weshalb die von Lespès beobachteten Thatsachen „so auffällig“, weshalb die Vertretung beider Geschlechter unter den Arbeitern und Soldaten der Termiten „kaum glaublich“ sei, haben Hagen und Gerstäcker nicht erörtert. Doch hat wohl auch in diesem Falle, um mit Bates zu reden, ,eine irrige Analogie mit den gesellig lebenden Hymenopteren zu falschen Hypothesen geführt" ${ }^{5}$ ), wie das so vielfach in der Naturgeschichte der Termiten geschehen.

\footnotetext{
1) Jenaische Zeitschrift f. Naturwiss. 1873. Bd. VII. p. 333-340. Taf. XIX-XX.

2) Vergl. den Bericht von Hagen in Linnaea entomol. XII, S. 320 u. 322 .

3) Ebenda, S. 22.

4) Lehrbuch der Zoologie von Peters, Canus u. Gerstäcker. II, S. 4 I.

5) Linn. entom. XII. S. 272.
} 
Mir schienen von vornherein die Angaben von Lespès sehr wahrscheinlich und glaubwürdig. Bei den Hautflüglern liegt die Brutpflege den Weibchen ob; wenn bei ihnen ein besonderer Stand für die Brutpflege sich bildete, so war zu erwarten, dass er von den Weibchen sich abzweigen, aus verkümmerten Weibchen bestehen werde. Bei den Termiten dagegen scheint es kaum zweifelhaft, dass die besonderen Stände der Soldaten und Arbeiter nicht aus den geflügelten Thieren, sondern aus deren Jugendzuständen hervorgegangen sind, und wenn dem so ist, so liegt natürlich kein Grund vor für den Ausschluss eines der beiden Geschlechter.

Theoretisch hatte ich also gegen die Angaben von Lespès keinerlei Bedenken. Allein, wie Hagen, habe ich bis jetzt bei Arbeitern und Soldaten mehrerer, sehr verschiedenen Gruppen der Gattung Termes angehörender Arten vergeblich nach sicher als Hoden oder Eierstock zu deutenden Spuren innerer Geschlechtstheile gesucht, und obwohl ich keines besonderen Geschicks im Zergliedern mich rühmen darf, also auf mein Nichtfinden grosses Gewicht zu legen kaum berechtigt war, fingen doch leise Zweifel an der Richtigkeit der Beobachtungen von Lespès sich zu regen an. Um so erfreuter war ich, seine schöne Entdeckung bei den Soldaten der Gattung Calotermes vollständig bestätigen zu können. Die inneren Geschlechtstheile sind bei diesen Soldaten weit weniger verkümmert, als bei Termes 1 ucifugus, und kaum minder entwickelt, als bei den geflügelten Männchen und Weibchen; ja bei zwei Arten ist das Geschlecht der Soldaten sogar äusserlich zu erkennen.

Zur Vergleichung schicke ich die Beschreibung der Geschlechtstheile der geflügelten Männchen und Weibchen von $\mathrm{Cal}$ otermes $\mathrm{Ca}$ e ellae n. s p. ${ }^{1}$ ) voraus. Jeder der beiden Eierstöcke (Fig. I) besteht aus 6 bis 7 spindelförmigen Eiröhren, die dem Ende eines kurzen weiten Eileiters aufsitzen. Zwei oder drei der Eiröhren zeichnen sich vor den übrigen meist durch grössere Dicke und weiter entwickelte Eier aus. Wie überhaupt bei den geflügelteu Termitenweibchen sind selbst die am weitesten vorgeschrittenen Eier noch weit von der Reife entfernt; die grössten erreichen selten mehr als $1 / 5$ der Länge der reichlich I $\mathrm{mm}$ langen reifen Eier (Fig. 5) und treten eben in die Entwicklungsstufe, auf welcher feine Körnchen den bis dahin durchsichtigen Dotter zu trüben und das Keimbläschen der sich in die Länge erstreckenden Eier zu verdecken beginnen (Fig. 4). Die kurzen Eileiter, deren Länge übrigens bedeutenden Schwankungen unterliegt, vereinigen sich zur Scheide, deren äussere Oeffnung von unten her durch das grosse sechste Bauchschild verdeckt wird. Nicht weit vom Ausgange der Scheide liegt die sehr dickwandige Samenblase (Fig. 2 u. 3). Sie fällt sofort ins Auge durch die dicke dunkelgefärbte Haut, welche ihre Höhlung auskleidet. Das Ende dieser

1) Calotermes Canellae n. sp. steht dem C. verrucosus $\mathrm{Hag}$. sehr nahe, unterscheidet sich aber leicht durch geringere Grösse und durch die Zahl der Adern im Randfelde der Flügel.

\begin{tabular}{cc|c} 
& Calotermes Canellae. & \multicolumn{2}{c}{ C. verrucosus. } \\
Länge mit den Flügeln: & Io $\mathrm{mm}$ & I4 $\mathrm{mm}$ \\
Vorderflügel mit & 2) Ader im & I \\
Hinterflügel mit & I Randfelde & ohne
\end{tabular}

C. Canellae lebt hauptsächlich im Holze der Canella preta. seltner in Guamirim, Ceder und Guarajuva.

Fritz Müllers gesammelte Schriften. 
Höhlung ist mehr oder weniger gekrümmt; in der Mitte ist dieselbe mehr oder weniger aufgetrieben und verjüngt sich dann zu einem engen Ausführungsgange. Zwischen Scheide und Mastdarm liegt eine sehr ansehnliche Kittdrüse (.glande sébifique“ Lespès), aus dicht zusammengeknäuelten, schwer zu entwirrenden Röhren gebildet. Man kann an ihr den gemeinsamen Ausführungsgang, zwei zu diesem sich vereinigende Hauptäste und an jedem der letzteren 4 bis 7 Zweige unterscheiden. Bei dem geflügelten Weibchen von Calotermes rugosus Hag. gabelt sich der Stamm nur zweimal, so dass die Drüse aus nur vier langen verknäuelten Röhren besteht. Die Kittdrüse von Calotermes gleicht also weit mehr der von Lespès beschriebenen "glande sébifique“ des Termes luc if u gus, als der von Hagen als Samenblase gedeuteten baumförmigen Drüse mit zahlreichen kurzen gekrümmten Aesten, die derselbe bei der Königin von Termes nigricans und dem geflügelten Weibchen von T. dirus fand.

Die Hoden der geflügelten Männchen von Calotermes Canellae (Fig. 6-13) lassen sich einer Hand mit 3 bis 6 meist kurzen Fingern vergleichen. Ihre sehr wechselnde Gestalt mögen die Abbildungen veranschaulichen. Die beiden Hoden desselben Thieres pflegen einander in Grösse, Zahl, Länge und Stellung der Finger sehr ähnlich zu sein. In den Fingern sieht man stark lichtbrechende Kerne, in der Hand grössere, runde, durchsichtige Zellen, deren Kerne in frischem Zustande wenig hervortreten. Wie die Eierstöcke scheinen sie noch weit von der Reife entfernt zu sein. Die Ausführungsgänge der Hoden, bisweilen dicht unter diesen zu einer kleinen Blase aufgetrieben (Fig. 6 u. 8), münden in eine dickwandige, birnförmige Tasche, die sich in einen über dem achten Bauchschilde sich öffnenden Gang fortsetzt.

Bei den Soldaten von Calotermes Canellae sind die Bauchschilder des Hinterleibes wie die des geflügelten Männchens gebildet, das sechste nicht vergrößert, das siebente und achte ungetheilt und letzteres mit zwei griffelförmigen Afteranhängen versehen. (Beim Weibchen ist bekanntlich das sechste Bauchschild vergrössert, das siebente und achte sind in je zwei kleine seitliche Platten zerfallen und die Afteranhänge fehlen.) Ein äusserer Geschlechtsunterschied ist nicht vorhanden oder doch kaum angedeutet. (Der Hinterrand des achten Bauchschildes schien mir bei den weiblichen Soldaten zwvischen den Afteranhängen in der Regel etwas tiefer ausgebuchtet zu sein, als bei den männlichen; vergl. Fig. 15 u. 16.$)$

Die inneren Geschlechtstheile der weiblichen Soldaten (Fig. 14) unterscheiden sich von denen der geflügelten Weibchen ausser durch geringe Grösse fast nur durch den Mangel der Samenblase, von der ich keine Spur habe finden können. Im unteren Theile der Eiröhren sieht man meist grosse blasse Zellen, von denen zwei die ganze Breite der Eiröhre einzunehmen pflegen, mit grossem Kern und deutlichem Kernkörperchen. Mehrfach sah ich am Anfang jeder Eiröhre ein Häufchen einer undurchsichtigen krümlichen Masse, die ich bei den geflügelten Weibchen dieser Art ebensowenig bemerkt habe, als bei den Soldaten von Calotermes nodulosus und rugosus. Die Eileiter sind im Verhältniss viel länger und dünner, als beim geflügelten Weibchen, die Kittdrüsen stets stark entwickelt.

Auch die Geschlechtstheile der männlichen Soldaten (Fig. 16-18) sind denen der geflügelten Männchen durchaus ähnlich. Die Hoden zeigen ebenso mannich- 
faltige, im Allgemeinen etwas schlankere Formen. Das Gewebe der Hand ist bisweilen von dem der Finger kaum verschieden, kleinzellig, mit stark lichtbrechenden Kernen. In einem Falle (Fig. 17) sah ich den Hoden zu einem kleinen birnförmigen Körper ohne alle Anhänge verkümmert; den zweiten Hoden fand ich bei diesem Thiere nicht.

Bei Calotermes nodulosus Hag. und rugosus Hag., zwei merkwürdigen nahe verwandten Arten, deren sehr eigenthümliche jüngste Larven uns vielleicht in ähnlicher Weise die älteste noch lebende Insektenform zeigen, wie die $\mathrm{N}$ auplius die älteste Crustaceenform, sind die männlichen von den weiblichen Soldaten schon äusserlich an der Bildung des achten Bauchschildes zu unterscheiden. Bei den männlichen Soldaten ist wie bei den geflügelten Männchen der Hinterrand dieses Schildes zwischen den Afteranhängen kaum merklich ausgebuchtet (Fig. 2 I u. 29), bei den weiblichen Soldaten dagegen (Fig. 20 u. 28) tief ausgeschnitten und der dunkle dicke Chitinrand ist in der Mitte dieses Ausschnitts durch dünnere Haut ersetzt, - der erste Schritt zu dem Zerfallen dieses Schildes in zwei seitliche Platten, welches die geflügelten Weibchen zeigen.

Die männlichen Soldaten scheinen wenigstens in manchen Gesellschaften von C. nodulosus weit häufiger zu sein, als die weiblichen. Einmal fand ich unter sieben Soldaten 4 ס, 3 o ; sechs Soldaten aus einer anderen Gesellschaft waren sämmtlich ơ; ein drittes Mal wurde unter sieben Stück ein einziges $q$ gefunden. Von C. rugosus fand ich in einem Falle zwölf männliche und zehn weibliche, in einem anderen sieben männliche und sechzehn weibliche Soldaten.

Ich bedaure, zur Zeit keine. geflügelten Männchen und Weibchen der beiden Arten zur Vergleichung der inneren Geschlechtstheile zur Hand zu haben. Ich kann in dieser Beziehung nur anführen, dass die weiblichen Geschlechtstheile von C. rugosus bis auf die bereits erwähnte Verschiedenheit der Kittdrüse und eine etwas abweichende Form der Samenblase ganz mit denen des C. Canella e übereinstimmen.

Bei den weiblichen Soldaten beider Arten ist wie bei C. Canella e die Zahl der Eiröhren in der Regel sechs, seltener sieben. Bei C. nodulosus (Fig. I9) sind dieselben, wo sie sich an den Eileiter ansetzen, stark eingeschnürt. Deutlich ausgeprägte Eier, die die ganze Lichtung der Eiröhre füllen, habe ich bei den wenigen bis jetzt untersuchten weiblichen Soldaten dieser Art nicht gefunden; dagegen finden sich solche fast bei allen weiblichen Soldaten von C. rugosus (Fig. 26 u. 27), bisweilen bis über 20 in einer Eiröhre. Die grössten, die ich gesehen, hatten 0, I mm Durchmesser bei o,o6 mm Höhe, ihr Keimbläschen 0,02 mm Durchmesser. - Eine Samenblase habe ich nicht gefunden. Die stets stark entwickelte Kittdrüse zeigte sich, wo ich sie entwirren konnte, bei den weiblichen Soldaten von C. rugosus aus vier langen Schläuchen gebildet, wie bei den geflügelten Weibchen derselben Art.

Wenn schon die fingerförmigen Fortsätze der Hoden von C. Canellae an die Eiröhren der Weibchen erinnern, so ist die Aehnlichkeit zwischen Hoden und Eierstock eine noch weit grössere bei den Soldaten von C. nodulosus und rugosus. Als ich den ersten Soldaten von C. nodulosus zergliederte und das Fig. 22 gezeichnete Gebilde fand, wusste ich in der That nicht, ob ich einen verkümmerten Eierstock oder einen Hoden vor mir hätte. Am Ende eines gemein- 
schaftlichen Ausführungsganges sassen, wie am Ende des Eileiters sechs Eiröhren, so hier sechs fingerförmige Anhänge. die aber andererseits wieder durch das kolbig angeschwollene, umgebogene Ende voll stark lichtbrechender Kerne an die Hoden anderer Termiten erinnerten. - Die Hand tritt bei beiden Arten, besonders bei C. rugosus, meist ganz gegen die Finger zurück und fehlt oft vollständig, während das Gewebe der Finger selbst dem des handförmigen Theiles am Hoden des geflügelten Männchens von C. Canella e gleicht und die stark lichtbrechenden Kerne sich auf die Spitze der Finger beschränken. Die Zahl der Finger scheint bei C. n od ul os u s fast ohne Ausnahme sechs zu sein, bei C. r u gos u s öfter sieben. In Betreff der auch bei diesen Arten ziemlich wechselnden Form und Grösse der Hoden verweise ich auf die Abbildungen (Fig. 21-25 u. 29-32). Die häufig einseitige Auftreibung am Anfange des Ausführungsganges (vas deferens), die schon bei $\mathrm{C}$, Ca nella e erwähnt wurde, ist in der Regel vorhanden. Die Ausführungsgänge der Hoden sind weit länger, als bei C. Canellae; die Tasche, in welche sie einmünden, ist namentlich bei C. nodulosus sehr breit, ihr Scheitel nicht, wie bei C. Canellae, abgerundet, sondern ausgebuchtet oder tief eingekerbt, als wäre die Tasche aus zwei kugeligen (C. nodulosus) oder eiförmigen (C. rugosus) Hälften zusammengesetzt.

Auch nachdem ich die Geschlechtstheile der Soldaten von Calotermes kennen gelernt, habe ich bei Arbeitern und Soldaten verschiedener TermesArten, wie Hagen und wie ich selbst schon früher, wiederholt vergeblich nach solchen gesucht und vermuthe, dass nicht unser Ungeschick daran schuld war, dass vielmehr überhaupt bei diesen Arten nichts mehr zu finden sein werde. Wenn Lespès glücklicher war, so mag es daran liegen, dass Termes lucif ugus auch in dieser Beziehung, wie in manchen anderen, den Calotermes näher steht, als die meisten übrigen Termes-Arten. Ich erwähnte schon den ähnlichen Bau der Kittdrüse. Ebenso besitzt T. 1 u cifugus nach Lespès acht Harngefässe, wie auch die Calotermes deren sechs oder acht haben, während sich sonst bei Termes vier zu finden pflegen. Auch die Lebensweise ist insofern ähnlich, als T. lucifugus, wie unsere Calotermes, ohne eigentliches Nest in den Gängen lebt, die er in abgestorbenem Holze nagt. Aus der ganzen Abtheilung der Grattung T erm es, deren Soldaten wie die von Cal ot ermes scharfe beissende Kiefer besitzen, während der Kopf eines nasenartigen Fortsatzes entbehrt, ist mir hier noch keine Art vorgekommen. Sind nun schon bei den Arbeitern und Soldaten von T. Iucifugus die bei den Soldaten von Calotermes noch so überaus deutlichen Greschlechtstheile so weit verkümmert, dass die Eierstöcke mitunter kaum erkennbar sind, nie Spuren von Eiern, dagegen Fettkügelchen enthalten, dass ebenso die Hoden kaum sichtbar sind und dass oft gar nichts zu finden war, so kann es nicht befremden, wenn bei Arten, die sich in anderer Beziehung viel weiter von Cal ot erm es entfernt haben, auch die Verkümmerung der Geschlechtstheile bei Arbeitern und Soldaten weiter fortgeschritten ist, wenn dieselben entweder völlig geschwunden oder doch nicht mehr mit Sicherheit von dem Fettkörper zu unterscheiden sind.

Fast hätte ich vergessen, eine Frage zu beantworten, die man wahrscheinlich stellen wird: warum ich nicht, da ja bei den Arbeitern von Termes lucifugus die Geschlechtstheile leichter nachzuweisen sind als bei den Soldaten, auch die 
Arbeiter von Calotermes auf ihre Geschlechtstheile untersuchte. Die Antwort ist sehr einfach. Den mir bekannten sechs oder sieben Calotermes-Arten fehlt ein besonderer Arbeiterstand.

Zum Schlusse will ich nicht unterlassen, darauf aufmerksam zu machen, dass rings um das Mittelmeer ein Calotermes (C. flavicollis Fabr.) vorkommt und von da leicht lebend nach allen Theilen Europas zu verschicken sein wird, dass somit eine bequeme Gelegenheit geboten ist, vorstehende Angaben an einer Art derselben Gattung nachzuprüfen.

Itajahy, Sa. Catharina, Brazil, im Juni 1872.

\section{Erklärung der Abbildungen auf Tafel XXXVIII und XXXIX.}

Ffg. I-I \&. Calotermes Canellae F. M

Fig. I-4. Geflügeltes Weibchen.

Fig. I. Innere Geschlechtstheile.

Fig. 2 u. 3. Samenblase.

Fig. 4. Stück einer Eirühre.

Fig. 5. Reifes (gelegtes) Ei.

Fig. 6-I3. Geflügeltes Männchen.

Fig. 6. Innere Geschlechtstheile.

Fig. 7-I3. Verschiedene Formen des Hodens.

Fig. I 4-I 5. Weiblicher Soldat.

Fig. I 4. Innere Geschlechtstheile.

Fig. I5. Hinterrand des achten Bauchschildes.

Fig. I6-I8. Männlicher Soldat.

Fig. I6 u. I 7. Geschlechtstheile in Zusammenhang.

Fig. I 8. Hoden.

Fig. I $9-25$. Calotermes nodulosus Hag.

Fig. I 9 u. 20. Weiblicher Soldat.

Fig. 10. Eierstock.

Fig. 20. Achtes Bauchschild.

Fig. $2 \mathrm{I}-25$. Männlicher Soldat.

Fig. 21. Geschlechtstheile im Zusammenhang.

Fig. 22-25. Verschiedene Formen des Hodens.

Fig. 26-32. Calotermes rugosus Hag.

Fig. 26-28. We iblicher Sold at.

Fig. 26. Innere Geschlechtstheile.

Fig. 27. Theil einer Eiröhre.

Fig. 28. Hinterrand des achten Bauchschildes.

Fig. 29-32. Männli cher Solda t.

Fig. 29. Geschlechtstheile im Zusammenhang.

Fig. 30-32. Verschiedene Formen des Hodens. 


\section{Beiträge zur Kenntniss der Termiten ${ }^{1}$ ).}

II. Die Wohnungen unserer Termiten.

Mit I I Textfiguren.

In Betreff des Nestbaues der Termiten finden sich in Hagen's Monographie folgende allgemeiue Bemerkungen: „Bis jetzt scheint es sicher, dass alle Arten gesellschaftlich leben und wenigstens eine Art von Nest bauen. Am unvollkommensten ist dies, wenn sie nur in abgestorbenen Bäumen oder gar nur unter der Rinde wohnen. Hierher scheinen die Calotermes zu gehören. Ueber die Wohnungen der ganz unter dem Erdboden wohnenden Arten ist eigentlich noch nichts bekannt. Dass hier umfangreiche Nester in der Erde angelegt werden, ist aus einigen Beobachtungen wahrscheinlich... Hierher gehören der Vermuthung zu Folge Hodotermes und eine Anzahl der Gattung Termes. Die Hügelbauten über der Erde, die der Gattung T erm es allein zufallen, sind uns am genügendsten bekannt... Ich rechne dahin auch die Thurm- und Pilzbauten... Als letzte Art der Nester bleiben die sogenannten kugeligen Baumnester übrig. Ihr Bau ist uns noch sehr unvollkommen bekannt und eine Königin darin niemals gefunden worden... Baumnester scheint nur Eutermes zu haben, obwohl einige Eutermes auch Hügel bewohnen“" ${ }^{2}$.

Diese kurze, von kundiger Hand entworfene Uebersicht wird genügen, um weitere Mittheilungen über die Wohnungen der Termiten wünschenswerth erscheinen zu lassen, und mag zugleich dienen, für die Beurtheilung des im Folgenden Gebotenen den mit der Naturgeschichte dieser Thiere minder Vertrauten einen Anhaltspunct zu gewähren.

„Ueber die Lebensweise und den Nestbau von Calotermes ist bis jetzt nichts bekannt“" ${ }^{3}$. Ich habe aus dieser Gattung etwa ein halbes Dutzend Arten kennen gelernt (C. Smeathmani m., C. Hagenii m.4), C. rugosus Hag.,

1) Jenaische Zeitschrift f. Naturwiss. 1873. Bd. VII. p. $341-358$.

2) Hagen in Linnaea entomol. XII, S. 30.

3) Hagen a. a. O. S. 38 .

4) Calotermes Smeathmani und C. Hagenii unterscheiden sich von anderen bekanuten Aiten dadurch, dass bei den Soldaten der aufgebogene Vorderrand des Prothorax gezähnelt ist. Auch die Kopfbildung der Soldaten ist eine sehr eigenthümliche. Bei den Soldaten von C. Smeathmani finden sich Flïgelscheiden an Mittel- und Hinterbrust, die bei denen des C. H agenii, wie bei denen unserer anderen Calotermes-Arten fehlen. 
C. nodulosus Hag., C. Canellac m., und ein oder zwei andere der letzten nahestehende Arten). Vom Bau einer Wohnung kann man bei diesen Arten kaum reden. Wie die Larven vieler Käfer, nagen die Larven (und Nymphen) von Calotermes Gänge im Holze abgestorbener Bäume, die sie niemals verlassen. Der Unterschied ist nur der, dass in diesen Gängen neben den Larven auch ein eierlegendes Weibchen mit ihrem Männchen (Königin und König) sich dauernd aufhält, dass man daher bunt durch einander Larven des verschiedensten Alters findet und dass zum Schutze dieser Gesellschaft ein besonderer Soldatenstand vorhanden ist, aus männlichen und weiblichen Larven bestehend, die sich nie in geflügelte Thiere verwandeln.

Die Calotermes findet man hauptsächlich in noch fast gesundem, hartem Holze; der völlig gesunde Kern härterer Tlolzarten wird von ihnen ebensowenig angegriffen, als der stärker vermoderte Splint; zwischen beiden beschränken sich ihre Gänge nicht selten auf eine kaum fingerdicke Schicht. Einzelne Arten haben eine unverkennbare Vorliebe für gewisse Holzarten; so C. Can ella e für Canella preta, C. rugos us für Cangerana, in welchen beiden Hölzern ich noch keine andere Art getroffen habe. Am wenigsten wählerisch scheint C. nodulosus zu sein, der in Peroba, Ariribá, Piquiá, Ceder (Cedrela), der Gissarapalme u. s. w. vorkommt. Selten trifft man zwei oder mehr Arten in demselben Stamme. So leben in einem grossen umgestürzten Guarajuva-Stanme in meinem Walde gleichzeitig C. Hagenii, nodulosus, Canellae und eine vierte Art, die ich im geflügelten Zustande noch nicht kenne. Wenn bei solchem Zusammenleben die Gänge der einen Art auch vielfach zwischen denen der anderen hinlaufen, so scheinen die Thiere sich doch nie in die Gänge einer fremden Art zu verirren.

Die Gänge der Ca loterm es - Gesellschaften sind meist der Achse des Baumes gleichlaufend und zum grossen Theil so eng, dass nur ein Soldat oder eine erwachsene Larve auf einmal hindurch kann. Dies gilt namentlich von den Gängen, welche die Holzschichten quer durchsetzen. Stellenweise finden sich weitere, unregelmässige, meist flache Räume, in denen sich die geflügelten Thiere zu sammeln pflegen. Ein besonderer Raum für König und Königin ist nicht vorhanden. Letztere schwillt nur wenig an und läuft frei in den Gängen umher, hier und da einzelne Eier ablegend, um die sich Larven und Soldaten nicht weiter zu bekümmern scheinen. Sie ist gewöhnlich begleitet von dem Könige und in der Umgebung des Königspaares pflegen die Soldaten häufiger zu sein, als an anderen Stellen. Die Wand der Gänge ist meist mit einer dünnen Kothschicht bekleidet, während man bisweilen grössere Kothmassen am blinden Ende eines oder des anderen Ganges angehäuft findet.

Dächte man sich die Volkszahl einer Calotermes-Gesellschaft in gleichem Raume verzehnfacht oder verhundertfacht, so würden die von der dichtgedrängten Bevölkerung ausgefressenen Gänge immer näher zusammenrücken, die dazwischen liegenden Holzwände würden immer dünner werden und endlich ganz aufgezehrt werden. Die Kothbekleidung der benachbarten Räume würde unmittelbar aneinanderstossen. An Stelle des verzehrten Holzes hätte man einen von Kothwänden durchzogenen und in unregelmässige \%ellen und Gänge getheilten Raum. - Diesen allmäligen Uebergang von weit getrennten, das Holz durchziehenden Gängen zu Kothanläufungen, die in ihrem Gefüge an lockere Brodkrume oder 
an einen Schwamm erinnern, kann man nicht selten beobachten in Baumstämmen, die von einem mit Termes Rippertii nahe verwandten Eutermes ${ }^{1}$ ) bewohnt sind. Beschränken sich diese Kothanhäufungen nicht auf das Innere des Baumes, treten sie aus demselben hervor, so entstehen die bekannten „kugeligen Baumnester", die also ursprünglich nichts anderes sind, als der gemeinsame Abtritt eines Eutermes-Volkes, dann aber auch als Brutstätte für die Eier und als Aufenthalt für die Jungen dienen. - Diese Nester werden also aus dem Baume heraus, nicht an den Baum hinangebaut. Anders mag es bei den von Auguste St. Hilaire und Burmeister erwähnten Baumnestern aus Erde oder Lehm sein; zu solchen von aussen dem Baume angefügten Nestern würde dann auch aussen am Baume ein Gang emporführen müssen; bei unserer Art sind solche vom Neste ausgehende Gänge in der Regel nicht vorhanden.

Der Stoff, aus dem unsere Baumnester bestehen, ist ausschliesslich der Koth der Bewohner. Ich habe oft dem Baue oder vielmehr der Ausbesserung desselben zugesehen. Schneidet man ein Stück des Nestes ab, so ziehen sich die Arbeiter aus den dadurch geöffneten Gängen ins Innere des Nestes zurück; es erscheinen an den Oeffnungen in grosser Zahl die kleinen spitzköpfigen Soldaten, eifrig herumlaufend und mit ihren Fühlern tastend. Nach einiger Zeit kehren die Arbeiter zurück. Jeder betastet zuerst den Rand der zu schliessenden Oeffnung, dreht sich dann herum und legt ein braunes Würstchen auf diesen Rand ab. Dann eilt er entweder sofort ins Innere des Nestes zurück, um den anderen, die dichtgedrängt ihm folgen, Platz zu machen, oder er dreht sich auch wohl noch einmal um, um sein Werk zu betasten und es nöthigenfalls zurecht zu drücken. Einzelne Arbeiter bringen auch wohl zwischen den Kinnbacken kleine Bruchstücke der alten Wände, die beim Oeffnen des Nestes in dasselbe hineingefallen sind, und fügen sie in die im Bau begriffenen, noch feuchten Wände ein. Andere, doch das sieht man nur selten, die nichts aus ihrem Mastdarme liefern können, opfern auf dem Altar des Vaterlandes ihr noch unverdautes Mahl, das sie zwischen den Koth der anderen ausbrechen. In ruhigen Zeiten wird das Letztere wahrscheinlich nicht geschehen, sonder nur, wenn es gilt, rasch das durch den Feind geöffnete Nest wieder zu schliessen. - Die Soldaten haben sich beim Beginn der Arbeit grossentheils wieder ins Innere des Nestes zurückgezogen, vielleicht um Arbeiter herbeizuholen. Einer oder ein paar bleiben bei jeder zu schliessenden Oeffnung. Man sieht sie ab und zu die Arbeiter mit ihren Fühlern berühren, wie um sie zurechtzuweisen oder anzutreiben.

Der Eutermes, der diese Baumnester baut, scheint fast alle unsere Holzarten anzugreifen, doch niemals, wenn sie noch ziemlich gesund sind. Man findet ihn oft in demselben Stamme mit Ca lotermes, diesen dem Kerne, jenen der Rinde näher. Zum Baue des Nestes zieht er härtere, der Verwesung gut widerstehende Stämme z. B. von Cangerana vor. An dickeren Stämmen nimmt das Nest nur eine Seite ein und springt mehr oder weniger stark, halbkugelig oder eiförmig vor; dünnere umgiebt es bisweilen ringsum. An der Spitze von Baumstümpfen bildet es eine rundliche Kuppel oder sieht aus, wie der Knopf einer Stecknadel. Eines der grössten Nester, die ich gesehen, bildete eine unregelmässige Masse

i) Ich möchte den Namen Eutermes auf die Arten mit spitzköpfigen Soldaten beschränken. 
von 3 bis 4 Fuss Durchmesser, welche zwei an der Erde liegende CangeranaStämme umschloss.

Die Oberfläche der Nester zeigt flache, unregelmässige, in einander verfliessende, undeutliche Erhöhungen, die im Verein mit der schwärzlichen Farbe und der kugeligen Gestalt den oft gemachten Vergleich mit einem Negerkopf rechtfertigen. Die Farbe ist übrigens verschieden, bisweile heller, bräunlich häufiger fast schwarz, was theils von der Nahrung der Baumeister, theils vom Alter des Nestes abhängt. Alte Nester sind dunkler und zugleich fester als neugebaute. Die grössere Festigkeit älterer Nester hat wohl ihren Hauptgrund in der grösseren Dicke der Wände, die im Laufe der Zeit durch neue Kothlagen verstärkt werden. Alten Nestern kann man mit dem Messer wenig anhaben, sondern muss zur Axt greifen, um Stücke davon loszuhauen.

Ueber den inneren Bau dieser Nester ist wenig zu sagen. In dem Gewirr unregelmässiger, im Verhältnisse zur Grösse der

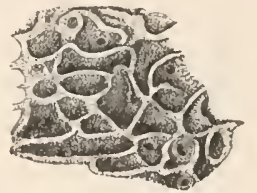

Fig. I. Bruchstïck eines Baumnestes. $(1 / 2$ der nat. Gr.)

Bewohner weiter Räume, die, durch dünne, aber feste Wände getrennt, das ganze Nest durchziehen, habe ich eine bestimmte Anordnung nicht erkennen können.

Oeffnet man ein solches Baumnest, so findet man in den oberflächlicheren Theilen nur Arbeiter und Soldaten, sowie kurz vor der Schwärmzeit (December) geflügelte Thiere. Dringt man tiefer ein, so stösst man auf Larven, die immer kleiner werden, je weiter man ins Innere vorrückt. Dann kommen, zu unglaublichen Mengen in einzelnen, sonst durch nichts ausgezeichneten Räumen angehäuft, die Eier und endlich die Eierlegerin, die Königin mit ihrem Gemahl. In dem ersten Neste, welches ich öfnete, fand ich den Raum, in welchem in diesem Falle zwei Königinnen sich aufhielten, durch nichts ausgezeichnet. In einem anderen Falle waren um die Königin herum die Wände weit dicker als sonst und nur von ziemlich engen Gängen durchsetzt. In diesen Gängen hatte sich der König versteckt, während sie für seine umfangreichere Gemahlin viel zu eng waren.

Wenn man bisher in Baumnestern keine Königin gefunden hat, so wird dies kaum daran liegen, dass man zufällig nur Nester ohne Königin geöffnet hat. Das Nest von Termes Rippertii zum Beispiel, welchem Osten-Sacken zahlreiche Eier und junge Larven entnahm ${ }^{1}$ ), enthielt ohne Frage auch eine Königin. Die Nester sind, wie bereits gesagt, nicht äusserlich dem Baume angeklebt, sondern gleichsam aus dessem Innern hervorgewachsen und gehen ohne scharfe Grenze in denselben über. Sprengt man das Nest vom Baume los, so bleibt immer ein Theil daran oder darin zurück und gerade in diesem innersten Theile des Nestes hat man die Königin zu suchen. Sie da herauszuholen wird aber meist mehr Uebung in der Führung der Axt verlangen, als reisende Naturforscher zu besitzen pflegen.

So weit meine Erkundigungen reichen, gehören alle in Brasilien den Menschen in seiner Wohnung belästigenden Termiten zu den Eutermes mit spitzköpfigen Soldaten; auch hier sind die Erbauer der Baumnester, wie es scheint, die einzigen ihrer Familie, die als unwillkommene Gäste in die Häuser eindringen und dann, wie das auch von den Eutermes anderer Länder berichtet wird, ihre Nester unter dem Dache anzulegen lieben.

1) Linnaea entomol. XIV, S. 119. 
In allen Ständen dem eben besprochenen Eutermes sehr ähnlich ist eine zweite hier häufige Art, die ihre Nester besonders zwischen den Wurzeln alter Stuken der Gissarapalme (Euterpe, Kohlpalme, von den deutschen Ansiedlern Palmite genannt) anzulegen pflegt. Diese Gissarastuken sind überhaupt ein Lieblingsaufenthalt der Termiten; ich habe darin bereits acht verschiedene Arten angetroffen, bisweilen vier bis fünf in demselben Stuken. (Drei Eutermes, darunter der später zu erwähnende Eutermes inquilinus m., Termes saliens m., T. Lespesii m., Anoplotermes pacificus m., Calotermes nodulosus Hag. und C. rugosus Hag.) Wie viele andere Palmen (und überhaupt Monocotyledonen) sendet die Gissara aus dem untersten Theile ihres Stammes dichtgedrängte fingerdicke Luftwurzeln schief zur Erde. Bei alten Stämmen sind die ältesten inriersten Wurzeln verivest; unter dem Stamme bildet sich so eine Höhle, welche die jüngeren, äusseren, höher am Stamme entspringenden Luftwurzeln wie ein kegelförmiger Mantel schützend umschliessen. In dieser Höhle legt der Gissara-Eutermes sein Nest an, doch nie unter lebenden Palmen. sondern erst einige Jahre nach dem Fällen. Das Nest besteht, wie das der Baumtermite, aus dem Kothe der Thiere. Die Wände sind papierartig dünn und so bröcklich, dass die Hand ohne merklichen Widerstand durch das Nest hindurch-

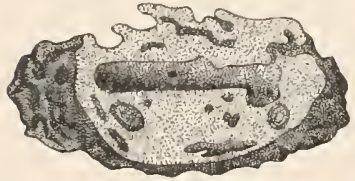

Fig. 2. Königliches Zimmer der Gissara-Termite. $(1 / 2$ der nat. Gr.)

fährt. Die dünnen Kothwände, von hellbräunlicher Farbe, legen sich mehr oder weniger regelmässig wie Zwiebelschalen um einen gemeinsamen Mittelpunct herum, vielfach unterbrochen durch Oeffnungen, welche die so gebildeten concentrischen Räume mit einander verbinden, und auseinandergehalten durch Wände, welche diese Räume in eine Menge unregelmässiger Zimmer und Gänge theilen. In der Mitte des Baues findet sich ein verschieden grosser fester Kern, der das Zimmer des Königspaares umschliesst. In einem Falle, in welchem die schützenden Wurzeln der Palme noch ihre ganze ursprüngliche Festigkeit besassen, fehlte dieser feste Kern; die Wände der Zelle, in der sich die noch ziemlich junge Königin aufhielt, waren noch ebenso papierartig dünn, wie das übrige Nest. In recht alten und volkreichen Nestern kann dagegen der feste Kern die Grösse eines Kindeskopfes erreichen. Derselbe ist sehr hart, nur von engen, für die Königin ungangbaren Wegen durchzogen und birgt in seiner Mitte das meist ziernlich unregelmässig gestaltete königliche Gemach. Nicht eben selten findet man bei dieser Art zwei Königinnen mit einem einzigen König in demselben Neste und demselben Zimmer; der umgekehrte Fall, dass mit einer Königin zwei Könige lebten, ist mir nur einmal vorgekommen. Einmal traf ich, in einem ungewöhnlich grossen und volkreichen Neste gleichzeitig sechs Königinnen und drei Könige. - Ein anderes Mal fand ich in demselben Neste zwei königliche Zimmer, aber nur eins von einem königlichen Paare bewohnt, das andere, von dessen wahrscheinlich längst verstorbenen Bewohnern keine Spur mehr zu finden war, mit junger Brut gefüllt.

Der gefährlichste Feind dieser Art ist das Tatu. Früher oder später, wenn die Wurzeln der Palme morscher werden, erliegen wohl die meisten Bauten den Angriffen desselben. Man sieht in Walde häufig Gissarastuken, durch deren 
Wurzeln an einer Seite die kräftigen Klauen des Tatu einen Weg gebrochen haben, und bisweilen um sie her gestreut Bruchstücke des Termitennestes. Bei einem solchen Ueberfalle, der gewiss einem grossen Theile des Volkes das Leben kostet, ist dann wenigstens das Königspaar durch die dicken harten Wandungen seines Zimmers gesichert. Die erste Königin dieser Art, die ich überhaupt sah, erhielt ich aus einem solchen lose im Walde gefundenen festen Kerne eines zerstörten Nestes.

Auf seiner Reise durch die Provinzen Rio de Janeiro und Minas geraes sah Auguste St. Hilaire Termitenbauten, die mitten auf dem Wege einfache, einen halben Fuss hohe Hügel bildeten. Solche kleine Hügelnester, - ob von derseiben Art gebaut, ist freilich nicht $\mathrm{zu}$ entscheiden, - finden sich auch hier und sind sogar weitaus die häufigsten aller Termitenbauten. Sie sind das Werk des Anoplotermes pacificus m. ${ }^{1}$. Obwohl anscheinend aus Erde gebaut, bestehen auch sie, wie die Eutermes-Nester, aus dem Kothe ihrer Bewohner. Die A noplotermes fressen nämlich Erde, man findet in ihrem Magen völlig verrottete Pflanzenstoffe und einzelne kleine Steinchen. Daher scheinen ihre Nester aus Erde gebaut zu sein; doch habe ich gesehen, wie sie durchschnittene Nester in der Weise der Baumtermiten mit ihrem Kothe ausbesserten, und mich überzeugt, dass diese geflickten Stellen in nichts von dem übrigen Neste sich unterschieden.

Die Form der Nester ist eine sehr wechselnde. Häufig sind sie ganz flach, in Form und Grösse einem Kuhfladen gleichend, in anderen Fällen unregelmässig knollig; bisweilen rundlich, kegelförmig oder kurz walzenförmig. In besonderer Menge traf ich diese Nester auf einem frisch gerodeten Stücke Urwald in der Colonie Dona Francisca, auf schwammigem, sandig-sumpfigem Boden. Stellenweise stand hier alle zıvei bis drei Schritte ein Nest. Die höchsten waren etwa einen Fuss hoch, bei 4 bis 6 Zoll Durchmesser, walzen- oder kegelförmig mit abgerundeter Spitze. Auch die kleineren, faust- bis kopfgrossen waren dort meist doppelt so hoch als dick. In meinem Walde herrschen die flachen, fladenförmigen Nester vor. Die Farbe ist ein bald helleres, bald dunkleres, fast schwarzes Grau. Gewöhnlich lassen sie sich mit der Hand zerbröckeln oder doch leicht mit dem Messer schneiden. Ungewöhnlich dunkelgefärbte und feste Nester fand ich kürzlich nahe dem Gipfel eines unserer höheren Berge (an der Itou pava). Man kann in der Regel zwei, freilich ohne scharfe Grenze ineinander übergehende Theile an diesen Nestern unterscheiden. Der obere Theil bildet eine fast dichte, nur von einzelnen engen Gängen durchzogene erdige Masse, in der sich lebende Wurzeln benachbarter Pflanzen (besonders die einer strauchartigen Piperacee) auszubreiten pflegen.

I) Die Staaten der Gattung Anoplotermes m. zeichnen sich dadurch aus, dass sie, - hierin weiter vorgeschritten, als wir Menschen, - nur Arbeiter, aber keine Soldaten besitzen. Alle Stände, von der jüngsten Larve an, sind dadurch leicht von Calotermes, Termes und Eutermes zu unterscheiden, dass ihrem Vormagen (Kaumagen) die Bewaffnung mit Kauleisten fehlt. Durch äussere Merkmale weiss ich die geflügelten Thiere nicht von Eutermes zu scheiden. Es gehört hierher eine zweite hiesige Art (vielleicht Termes ater Hag.) und wahrscheinlich Termes cingulatus Burm. Der von Hagen unter T. cingulatus beschriebene Soldat gehört nicht zu dieser, sondern zu einer weit verschiedenen Art, '́. saliens m. 
Dieser Theil ist von den Bewohnern ziemlich verlassen. Der untere dichtbevölkerte Theil enthält zahlreiche für die winzigen Bewohner sehr weite, vorherrschend in wagerechter Richtung ausgedehnte unregelmässige Räume, die durch dicke Wände getrennt, und durch engere und weitere Gänge verbunden sind. Das königliche Zimmer ist nur durch seine Grösse, und nicht immer durch diese vor den übrigen Räumen ausgezeichnet und liegt in der Regel ziemlich in der Mitte des unteren Theiles. Mit einer erstaunlichen Menge von Eiern gefüllte Zellen verrathen seine Nähe. Der obere Theil des Nestes ist wahrscheinlich der ältere, dessen früher bewohnte Räume allmälllich mit Koth vollständig ausgefüllt worden sind. Die Nester liegen lose am Boden, oder sind an demselben durch von unten eindringende Wurzeln befestigt. Gern lehnen sie sich an dicke vorspringende Baumwurzeln, und finden sich auch bisweilen in alten stark vermorschten Gissarastuken. Dasselbe Volk besitzt bisweilen, - doch scheint es bei dieser Art selten zu sein, - mehr als einen Bau. In einem kleinen, etwa faustgrossen Neste, in welchem keine Königin lebte, fand ich Eierhaufen und zahlreiche junge Brut; eine Königin fand sich in einem in der Nähe stehenden grösseren Neste. Oeffnungen zum Ein- und Austritt der Bewohner finden sich nur an der unteren, dem Boden aufliegenden Seite des Nestes.

Die Bauten des Anoplotermes pacificus macht sich zuweilen ein winziger Eutermes (Eut. inquilinus m. $\left.{ }^{1}\right)$ ) zu Nutze, der keine eigenen Nester zu bauen scheint. Ich habe diesen Eutermes sowohl in Dona Francisca als hier in Nestern von Anoplotermes pacificus getroffen und zwar hier ein vollständiges Volk mit König, zwei Königinnen, Arbeitern, Soldaten, Eiern und Larven vom verschiedensten Alter. Ob der Eindringling den Erbauer des Nestes vertreibt oder nur alte verlassene Nester sich aneignet, weiss ich nicht. Das Letztere ist wohl wahrscheinlicher. Das Nest, in welchem ich ihn hier fand, war offenbar ein sehr altes und die dasselbe durchziehenden Wurzeln grossentheils verschimmelt. Es hausten darin ausserden zwei Ameisenarten und durch den unteren Theil des Nestes ging eine Strasse von Termes Lespesii. - Eine kleine Gesellschaft von Eutermes inquilinus, nur aus Arbeitern und Soldaten bestehend, traf ich einmal in einem ganz alten modrigen Neste von Termes Lespesii. Bemerkenswerth ist, dass die Arbeiter des Eutermes inquilinus denen des Anoplotermes pacificus täuschend ähnlich sehen, obwohl sich bei genauerer Untersuchung des äusseren und inneren Baues durchaus keine nähere Verwandtschaft beider Arten herausstellt.

Wie mancher alte Baumstumpf in seiner ganzen Ausclehnung von Gängen verschiedener Termitenarten durchzogen ist (Calotermes in festeren Kerne, Eutermes im morscheren Splinte, Züge von Termes saliens oder Lespesii unter der Rinde), so ist auch der Boden des Urwaldes an manchen Stellen vollständig durchwühlt von Termiten und nicht selten durchziehen dieselbe Erdscholle gleichzeitig Gänge von drei bis vier verschiedenen Arten (Termes saliens, L.espesii, Anoplntermes ater (?), Eutermes sp.).

1) Die geflügelten Thiere dieser Art kenne ich noch nicht. König und Königin habe ich mit Hagen's Monographie verglichen und halte danach die Art für unbeschrieben. Die Soldaten sind durch ihren hell bernsteingelben langnasigen Kopf sehr ausgezeichnet. 
Von den Wohnungen dieser unterirdisch lebenden Termiten kenne ich bis jetzt nur die des Termes Lespesii m. ${ }^{1}$ ). Dieselben sind durch eine viel weitere Kluft von den aus einem ordnungslosen Gewirr unregelmässiger Räume bestehenden Nestern unserer Eutermes-Arten getrennt, als diese von den kaum den Namen einer Wohnung verdienenden Gängen der Calotermes, und gehören, wie die riesigen von Smeathman so trefflich geschilderten Hügel des Termes bellicosus, zu den merkwürdigsten Bauten, die überhaupt von Insecten aufgeführt werden.

Die Häuser des Termes Lespesii haben die Gestalt einer dicken, etwa spannenlangen Wurst oder einer Walze, um welche sich flache, durch seichte Furchen geschiedene Wülste gürtelartig herumziehen. Auf $0,1 \mathrm{~m}$ kommen 9 bis 12 solcher Wülste. - Auf diesen Ringwülsten verlaufen schmale, etwa $2 \mathrm{~mm}$ breite Längswülste, jede von einer mittleren Längsfurche durchzogen ( 15 bis 20 auf $0,1 \mathrm{~m}$ ). - Diese Längswülste sind nicht immer genau gleichlaufend und ihre Entfernung ist sehr beträchtlichen Schwankungen unterworfen. Die meisten lassen sich über eine grössere Zahl von Querwülsten, viele über das ganze Haus hin verfolgen, andere nur über ein, zwei oder drei Querwülste. An alten Häusern treten sowvohl Längs- als Querwülste weniger deutlich hervor, als an neueren; besonders bei letzteren öffnen sich beim Austrocknen an der Luft längs der Furchen, die die Längswülste durchziehen, sowie derjenigen, welche die Ringwülste scheiden, schmale Risse oder Spalten. An beiden Enden des Hauses finden sich meist einige kurze Fortsätze und am Ende eines derselben, als einziger Zugang zu dem sonst völlig geschlossenen Hause, eine kleine runde Oeffnung.

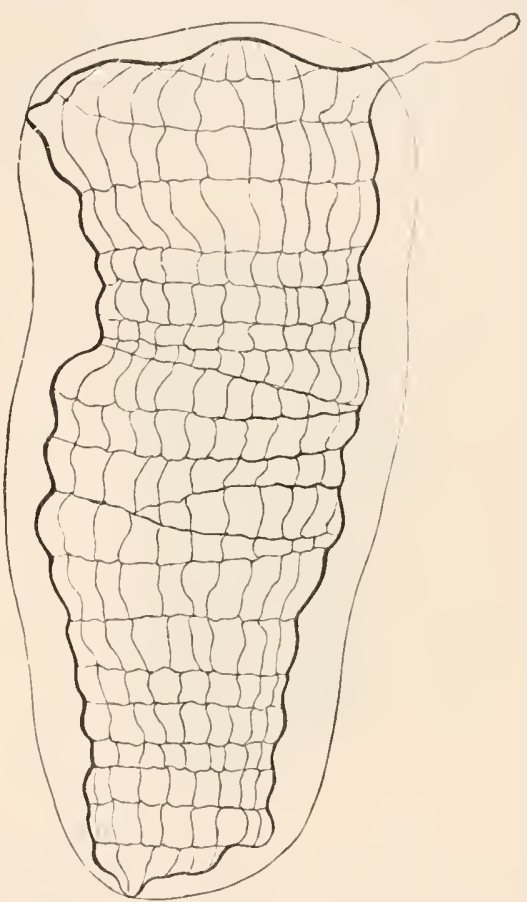

Fig. 3. Haus des Termes Lespesii $(1 / 2$ der nat. Grösse).

Um einen Einblick in das Innere des Hauses zu erhalten, wollen wir es der Länge nach durchschneiden. Wir sehen, dass es aus eben so vielen durch wagerechte Scheidewände geschiedenen Kammern oder Stockwerken besteht, als wir

I) Diese Art ist dem Erdhügelnester bewohnenden $T$. similis Hag. äusserst ähnlich.

$$
\text { T. similis } \mathrm{Hag} \text {. }
$$

Länge mit den Flïgeln: $22-27 \mathrm{~mm}$,

Fühler :

2tes Fühlerglied:

3 tes Fühlerglied: als „breit, nach vorn breiter, gerade alggeschnitten mit scharfen Vorderwinkeln; in der Mitte ein dreieckiger vorspringender Lappen angesetzt". Nicht ein Wort dieser Reschreibung passt auf die Oberlippe des Soldaten von Termes Lespesii. 
äusserlich Ringwülste wahrnahmen; wir sehen, dass die Ringwülste den Kammern, die Ringfurchen den Scheidewänden entsprechen. Wir erkennen auch sofort als Trsache der Risse, die beim Austrocknen entstehen. Röhren, welche die $W^{\top}$ and des Hauses durchziehen und unter den Ring- und Längsfurchen verlaufen. Jedes Stockwerk hat die Gestalt einer flachen Schachtel mit bauchiger Aussenwand. Sehr häufig und vielleicht in allen Fällen, wo nicht äussere Hindernisse die Regelmässigkeit des Baues gestört haben, sind die Kammern fast genau kreisförmig. Ich habe mich davon wiederholt mit dem Zirkel überzeugt und bisweilen bei einem Halbmesser von etwa $3 \mathrm{~cm}$ keine I bis $2 \mathrm{~mm}$ überschreitenden Abweichungen gefunden. Würde ein Mensch wohl im Stande sein, ohne Werkzeuge mit dem 5- bis 6 fachen seiner Länge als Halbmesser einen gleich fehlerfreien Kreis zu beschreiben?

In jedem Stockwerke sind Boden und Decke durch einen dicken, oben und unten verbreiterten Pfeiler verbunden, der bald die Mitte einninmt, bald mehr

Fig. 4 .

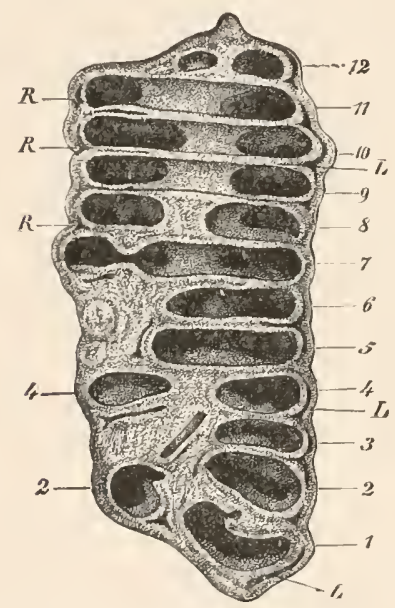

Fig. 5 .

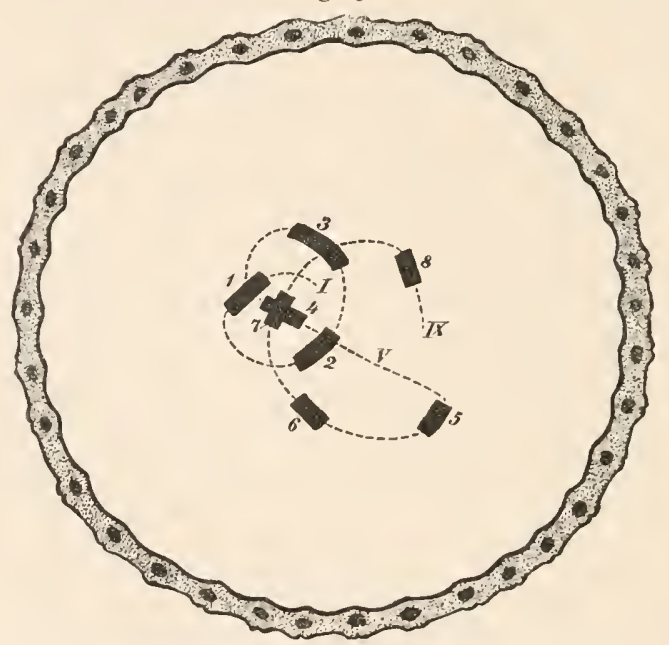

Fig. 4. Haus von Termes Lespesii, Längsschnitt, $1 / 2$ der nat. Gr. 1 bis 12 die 12 Stockwerke des Hauses. $L$ Längscanäle in der Aussenwand. $R$ Ringcanäle zivischen den Stockwerken.

Fig. 5. Projection des aus dem ersten $(I)$ ins neunte $(I X)$ Stockwerk führenden WVeges, aus einem Hause von Termes Lespesii, nat. Gr. $I$ bis 8 die durch die Scheidewände der Stockwerke führenden Gänge.

oder weniger dem Umfang genähert ist. Am Fusse des Pfeilers geht eine runde Oeffnung, die nur ein Thier auf einmal durchlässt, schief durch den Boden ins nächste Stockwerk. Geht man in derselben schief absteigenden Richtung, in der man in dieses Stockwerk eingetreten ist, an dessen Pfeiler weiter, so gelangt man, in der Mehrzahl der Fälle, zu dem am Fusse desselben gelegenen Ausgang. Auf diese Weise bildet der Weg, der vom obersten bis zum untersten Stockwerk durch dic Scheidewände hindurch und an den Pfeilern entlang führt, eine Schraubenlinie oder eine Wendeltreppe, die man sich freilich nicht allzu regelmässig vorstellen darf. Ich gebe als Beispiel diesen $\mathrm{WVeg}$ aus zwei Häusern, wie er sich gerade von oben gesehen (auf cine wagerechte Ebene projicirt) darstellen würde. Bei dem einen Hause (Fig. 5) wurden Lage und Richtung der Verbindungswege für acht aufeinanderfolgende Scheidewände aufgezeichnet. Das Stockwerk $I X$ liegt etwá $0,1 \mathrm{~m}$ über Stockwerk I. - Vom ersten (untersten) Stockwerke bis ins 
fünfte bildet der Weg eine nach rechts aufsteigende Schraubenlinie; im fünften Stockwerk liegen Eingang und Ausgang sehr weit auseinander; es ist fast, als hätten die Baumeister auf diesem langen Wege die bis dahin verfolgte Richtung vergessen, da von da ab der Weg in entgegengesetzter Richtung, links aufsteigend, weiter geht. - Im zweiten Hause (Fig. 6) wurde der Weg durch zwölf Scheidewände hindurch verfolgt. Auch hier ändert sich die Richtung der Wendeltreppe, nachdem man im fünften Stockwerke einen ungewöhnlich langen Weg zwischen Ein- und Ausgang zurückgelegt hat. Ausserdem sind in diesem Hause, wie das nicht selten vorkommt, mehrere Scheidewände von zwei Verbindungswegen durchsetzt. (Aus
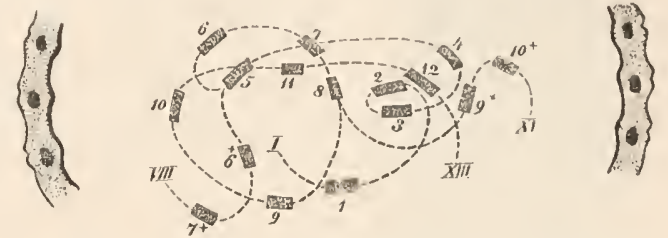

Fig. 6. Projection des aus dem ersten $(I)$ ins dreizehnte $(X I I I)$ Stockwerk führenden Weges, aus einem Hause von Termes Lespesii, nat. Gr. 1 bis 12 die durch die Scheidewände führenden Gänge. .j $6^{+} 7^{+}$VIII Nebenweg aus dem sechsten ins achte Stockwerk. $89^{+} 10^{+}$XI Nebenweg aus dem neunten ins elfte Stockwerk. dem sechsten Stockwerk führen 6 und $6+$ ins siebente, aus diesem 7 und $7+$ ins achte; ebenso führt ein Nebenweg aus dem neunten ins elfte Stockwerk.) In solchen Fällen pflegen dann auch zwei Pfeiler, einer für jeden Durchgang, vorhanden zu sein. - Wege, die aus einem Stockwerke unmittelbar ins zweitfolgende führen und im Innern des Pfeilers des dazwischenliegenden verlaufen (ein solcher Weg geht in Fig. 4 aus dem zweiten ins vierte Stockwerk), scheinen nur äusserst selten vorzukommen.

Der Bauplan des Hauses ist, wie man sieht, ein sehr einfacher; eine meist zwischen 12 und 16 schwankende Zahl flacher kreisförmiger Stockwerke, geschieden durch wagerechte Scheidewände und verbunden durch eine Wendeltreppe, die an einem dicken mittleren Pfeiler hinläuft. Die Regelmässigkeit der Ausführung ist jedoch nur selten eine einigermassen vollkommene. Die Pfeiler stehen

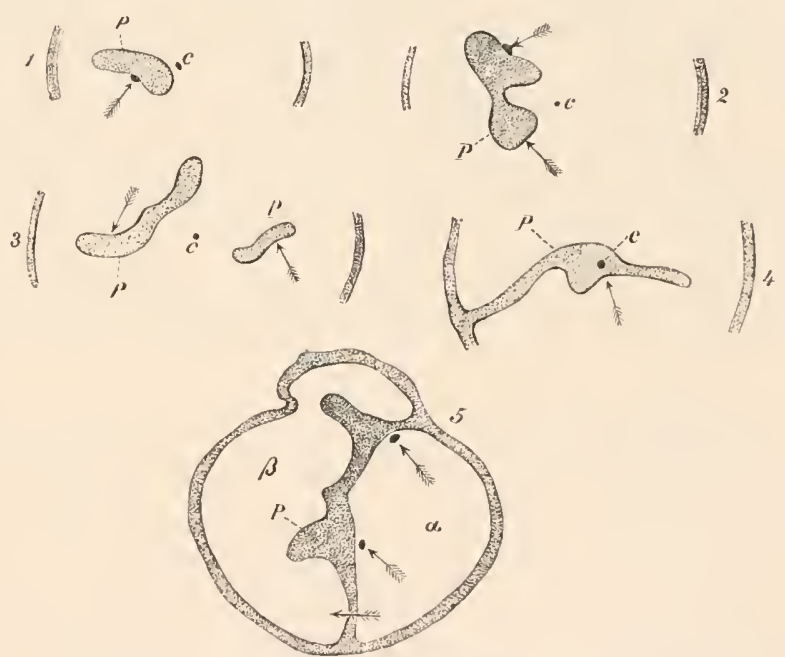

Fig. 7 . Grundriss von fünf Stockwerken aus Häusern von Termes Lespesii, $1 /$ der nat. Gr. - $c$ Mittelpunct des Kammer. $P$ Pfeiler. - Die Pfeile zeigen den Weg ins nächstuntere Stockwerk. - 5 ist durch den wandartigen Pfeiler in zwei Kammern $(\alpha$ u. $\beta$ ) getheilt; aus $\alpha$ gehen zwei Wege ins nächstuntere Stockwerk, einer nach $\beta$ : aus $\beta$ führt kein Weg in das darunterliegende Stockwerk. selten genau in der Mitte, selten in benachbarten Stockwerken genau übereinander. Ihre Dicke, wie diel Form ihres Querschnittes ist sehr veränderlich. Bisweilen dehnen sie sich in die Breite zu Wänden aus, die nicht selten bis zur Aussenwand des Stockwerkes reichen (Fig. 7, 4, so wie im dritten, fünften und sechsten Stockwerk des in Fig. 4 dargestellten Hauses). Ja es kommt vor, dass das Stockwerk durch den wandartigen Pfeiler vollständig in zwei Kammern geschieden wird (Fig. 7, 5). 
Die Stockwerke haben nicht immer alle die gleiche Höhe. Bisweilen ist Boden oder Decke geneigt, so dass ein und dasselbe Stockwerk auf einer Seite höher ist,

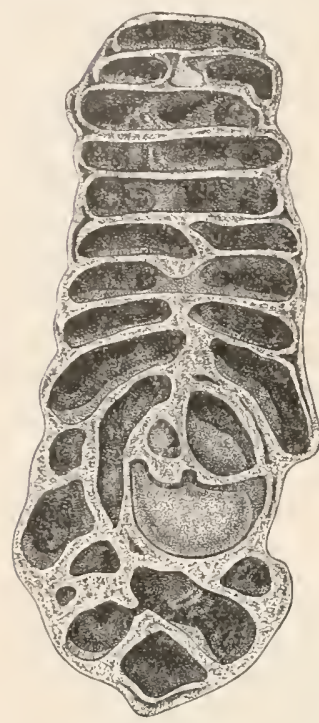

Fig. 8. Haus von T er mes Lespesii, Längsschnitt, $1 / 2$ der nat. Gr. als auf der anderen; oder es reicht ein Stockwerk nicht durch die ganze Breite des Hauses, so dass auf einer Seite das darüber und das darunter liegende Stockwerk in grösserer oder geringerer Ausdehnung zusammenstossen. (Für alle diese Unregelmässigkeiten liefert Fig. 3 Beispiele.) Nicht immer ist der Durchmesser für alle Stockwerke der gleiche; nicht selten ist er für die oberen kleiner. Nicht immer stehen die Stockwerke genau über einander; das eine oder das andere springt nach dieser oder jener Seite vor. In einem Falle sprang jedes folgende Stockwerk nach derselben Seite und gleich stark über das vorhergehende vor, so dass das ganze Haus einen ganz regelmässigen schiefen Thurm bildete. Eine ganz eigenthümliche Abweichung vom gewöhnlichen Bau zeigt das beistehend im Längsschnitt dargestellte Haus (Fig. 8); in seinem unteren Theile finden sich mehrere Kammern, die zusammen eine fast regelmässige Kugel bilden. - Grössere Unregelmässigkeiten der äusseren Form sind wahrscheinlich immer durch Steine, Wurzeln und ähnliche Hemmnisse veranlasst, denen die Thiere beim Ausgraben des Bauplatzes begegnen.

Von den Schwankungen der Grösse mögen die Masse von zehn ohne Wahl herausgegriffenen Häusern eine Vorstellung geben, die nachträglich nach der Zahl der Stockwerke geordnet wurden:

\section{Zah1 der Stockwerke. Höhe. Durchmesser.}

\begin{tabular}{|c|c|c|c|c|c|c|c|c|c|c|c|c|c|c|c|c|c|}
\hline & & & & & I 2 & & & & & & & & I I & $\mathrm{cm}$ & & & $5-6$ \\
\hline I & . & & . & . & I 2 & & . & & & & & & I 2 & " & & . & $5-6$ \\
\hline II & . & . & . & & I 2 & & . & & & & & & I 2 & $"$ & & & $6-7$ \\
\hline$V$ & . & . & & . & 13 & & . & & & & & & I 2,5 & 5, & & & . $6-8$ \\
\hline 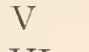 & . & . & . & . & 14 & & . & & & & & & 14 & $"$ & & & $4,5-7$ \\
\hline$V$ & . & . & . & . & 14 & . & . & & & & . & & 14 & $"$ & & & . $6-7$ \\
\hline VII & . & . & & . & 15 & & . & & & & & & I 3 & , & & & $6-8$ \\
\hline VIII & . & . & . & . & $2 \mathrm{I}$ & - & - & & & & & & I 9 & $"$ & & & $4-7$ \\
\hline 8 & & . & & & 22 & & . & & & & & & 20 & $"$ & & & $5-6$ \\
\hline & . & & & . & 24 & & & & & & & & 20 & $"$ & & & $3,5-5$ \\
\hline
\end{tabular}

Die Wände des Hauses und die Scheidewände bestehen nicht aus einer gleichförmigen dichten Masse. Ich sagte bereits, dass sie von ziemlich regelmässig angeordneten Röhren durchzogen sind. An der nachstehend abgebildeten äusseren Oberfläche eines neu angebauten Stockwerkes gewahrt man tiefe Furchen, welche von der Seitenwand her auf die obere Wand treten und mehr oder weniger weit nach deren Mitte sich hinziehen. - Den Furchen entsprechend springt die noch dünne Wand nach innen leistenartig vor. Später werden diese leistenartigen Vorsprünge mehr oder weniger rollständig ausgeglichen. - Ein solches neu auf- 
gesetztes Stockwerk steht, die Mittelsäule ausgenommen, nur in sehr loser Verbindung mit dem nächst älteren; hebt man es ab, so sieht man, dass seine Wand unten in zwei Platten gespalten ist, welche die Decke des darunter liegenden Stockwerkes in zwei, etwa 4 bis $8 \mathrm{~mm}$ von einander entfernten Kreisen treffen. So entsteht ein Ringcanal zwischen je zwei Stockwerken, und da die Furchen auf der äusseren Fläche der Wand erst überbrückt und zu Röhren geschlossen werden, nachdem ein folgendes Stockwerk aufgesetzt ist, bleiben natürlich diese Röhren mit dem Ringcanal in offener Verbindung. Dagegen sind die unter sich zusammenhängenden das ganze Haus durchziehenden Röhren in dem fertigen Hause vollständig abgeschlossen sowohl gegen aussen, als gegen die inneren Räume des Hauses. Diese Bauweise des Termes Lespesii, die von einem Netzwerk hohler Räume durchzogenen Wände, hat man bekanntlich in neuester Zeit auch für menschliche Wohnungen empfohlen; ob sie den Häusern des ersteren denselben Dienst leistet, den man für letztere davon erwartet, nämlich den Luftwechsel zu erleichtern, lasse ich dahingestellt.

Fig. 9.

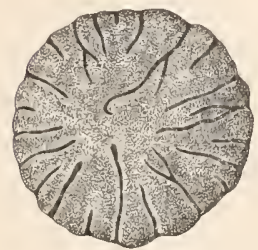

Fig. Io.

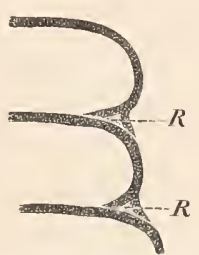

Fig. I I.

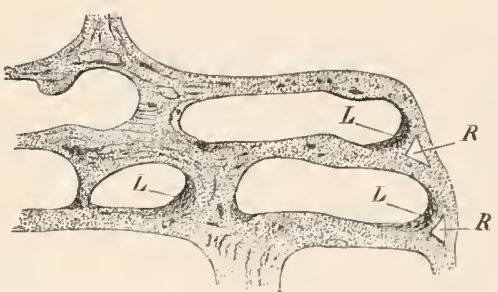

Fig. 9. Dach eines neugebauten Stockwerks eines Hauses von Termes L e sp es ii, v. oben, $1 / 2$ d. nat. Gr.

Fig. Io. Längsschnitt durch die Wand zweier neugebauten Stockwerke eines Hauses von Termes Les pesii, nat. Gr. $R$ Ringcanal.

Fig. I I. Längsschnitt durch einige Kammern eines älteren (dickwandigen) Hauses von Termes Lespesii. Nat. Gr. Der in die feste Grundmasse eingelagerte Lehm ist durch dunklere Punkte und Striche bezeichnet. Grössere Anhäufungen von Lehm bei $L$. $-R$ Ringcanal.

Termes Lespesii verwendet zum Bau seines Hauses nicht ausschliesslich seinen Koth, obwohl dieser die Hauptmasse bildet, sondern gleichzeitig die lehmige oder thonige Erde, in der er dasselbe baut. Die erste dünne Wand eines neuen Stockwerkes besteht fast immer aus reinem Koth. Dickere Lagen von reinem Lehm pflegen die Thiere besonders in den von den Längs- oder Ringcanälen umgrenzten Feldern der Aussenwand, sowohl an der Innen-, wie an der Aussenseite der ersten dünnen Kothwand aufzutragen. Aussen werden diese dann wieder mit einer Kothschicht bedeckt. Anderwärts, so namentlich in den Scheidewänden ist der Lehm meist nur in dünnen Streifen, Plättchen oder einzelnen Körnchen zwischen den Koth eingelagert.

Die Häuser von Termes Lespesii werden in der Erde angelegt, eine Handbreit bis eine Spanne unter der Oberfläche. Als Bauplatz wird eine Höhle gegraben, die einen etwa fingerbreiten leeren Raum um das Haus bildet (s. Fig. 3). Mit den glatten Wänden dieser Höhle steht das Nest durch eine kleine Zahl vom oberen und unteren Ende ausgehender Fortsätze in Verbindung. Durch einen derselben (selten durch mehrere) führt ein Weg aus dem untersten Stockwerke in federkieldicke mit einer' dünnen bräunlichen Kothschicht ausgekleidete Röhren, 
die die Erde auf weite Entfernung durchziehen, und hier und da zu kleinen unregelmässigen Kammern sich erweitern. Sie führen zu alten Baumstumpfen, unter deren Rinde Termes Lespesii bisweilen getroffen wird, zu Gissara-Stuken u. s. w., und ohne Zweifel auch zu anderen Häusern.

Werfen wir zum Schlusse noch einen flüchtigen Blick auf die in den eben beschriebenen Häusern lebenden Thiere, deren Bau und Lebensweise ich später ausführlicher zu besprechen gedenke. - Unter mindestens dreissig Häusern, die ich in den letzten Monaten geöffnet und von denen ich allerdings die Mehrzahl schon mehr oder minder zerbrochen erhielt, waren nur drei von einer Königin bewohnt; in dem einen fand sich der König in derselben, in dem zweiten in einer benachbarten Kammer; in dem dritten Hause, von dem ich nur ein Bruchstück bekam, wurde er nicht gefunden. In diesen drei Häusern befanden sich ausser König und Königin nur Arbeiter und Soldaten, aber weder Eier und Larven, noch Nymphen oder geflügelte Männchen und Weibchen, von denen letztere in vielen, Larven fast in allen übrigen Häusern $\mathrm{zu}$ finden waren. Von Eiern traf ich nur ein einziges Mal einen grösseren Haufen von vielleicht einigen Hunderten, ein paar mal wenige einzelne Eier. - Eier in grösster Menge und junge Larven habe ich dagegen einmal (im October v. J.) zwischen den Wurzeln eines GissaraStukens gefunden, der also von den Thieren als Brüteplatz benutzt wurde. Die Streifzüge, die man ausser dem Neste in den unterirdischen Gängen oder unter Baumrinde antrifft, bestehen wie bei anderen Arten nur aus Arbeitern und Soldaten. Das Vorkommen einer Königin in nur wenigen Häusern und das Fehlen der Eier und Jugendformen gerade in diesern Häusern beweist, dass dasselbe Volk mehrere Häuser besitzt, wenn überhaupt, wie bei den Bienen, gesonderte Völker bestehen, und wenn man nicht auch hier, wie es Bates bei Termes arenarius annimmt, für einen bestimmten Bezirk ,die ganze Masse von dieser Art Termiten als eine einzige grosse Familie betrachten" muss ${ }^{1}$ ).

Bricht man ein kleines Loch in eine Wand des Hauses von Termes Lespesii, so kann man, ganz wie bei den Baumnestern, die Soldaten sehr bedächtig den Schaden untersuchen und dann die Arbeiter mit ihrem Koth denselben wieder ausbessern sehen. Reisst man aber ein grösseres Stück der Wand eines Stockwerkes weg, so ziehen sich die Thiere in die nächstliegenden Stockwerke zurück und schliesen mit Koth die engen Eingänge zu denselben, wozu sie natürlich nur wenig Zeit brauchen. Auf diese Weise lässt sich das Haus leicht Stockwerk für Stockwerk gegen eindringende Feinde vertheidigen.

Termes saliens m. ${ }^{2}$ ) gräbt ähnliche weithin laufende, mit Koth ausgekleidete Gänge, wie T. Lespesii. Sie sind in der Regel etwas weiter, viel häufiger zu grösseren niedrigen Kammern erweitert, der Kothüberzug meist dunkler.

I) Linnaea entomol. XII, S. 273.

2) $\mathrm{Zu}$ dieser Art oder einer kaum verschiedenen gehört der von Hagen unter Termes cingulatus beschriebene und (Linnaea entomol. XII. Taf. I. Fig. 13) abgebildete Soldat. Mit ihren gewaltigen zum Beissen untauglichen Kinnbacken können die Soldaten von Termes saliens nach Art der Odontomachiden über fussweite Sprünge nach rückwärts machen. „Maxillis longis altissime resiliens“ sagt von den Termiten schon Linné, der also von ähnlichen Soldaten Kunde haben musste. Nahe verwandt scheint der ebenda Taf. I. Fig. I5 abgebildete Soldat zu sein. Man kann diese Thiere kaum in der Gattung Termes belassen, die wohl am besten auf die Arten zu beschränken wäre, deren Soldaten scharfe beissende Kinnbacken (Mandibeln) haben und eines horn- oder nasenartigen Fortsatzes am Kopfe entbehren. 
Bald laufen sie fast unmittelbar unter der Oberfläche, bald steigen sie bis über fusstief hinab. In solchen tieferliegenden Gängen habe ich erwachsene Nymphen in grosser Zahl getroffen. Eier und junge Brut findet man nicht selten zwischen den Wurzeln der Gissara-Stuken, wo ich auch einmal zwei geflügelte Tiere sah. Züge von Arbeitern und Soldaten gehen auch unter die Rinde modernder Bäume. Wahrscheinlich wird als Wohnsitz des königlichen Paares ein unterirdisches Haus gebaut. Dass es eine zweite Art unterirdischer Termitennester hier gebe, hat man mir mehrfach berichtet; sie sollen sehr hart, über kopfgross, rundlich und mit einer Art Stiel versehen sein, im Innern aber nicht so regelmässige Kammern haben wie die von Termes Lespesii. Von den mir bekannten Arten könnte nur Termes saliens diese Nester gebaut haben. Ich selbst habe noch keins gesehen.

Itajahy, Sa. Catharina, Brazi1, im Juli 1872.

\section{Nachtrag.}

Weit seltener als die Erbauer der Baumnester und die zwischen Gissarawurzeln hausenden Eutermes kommt hier eine dritte Art dieser Gattung vor, die wie jene beiden gelbgraue Flügel mit rostgelbem Randfelde besitzt. Ihre Wohnungen bilden ansehnliche Kugeln, die im Urwalde lose am Boden liegen. Während die Baumnester durchweg fast gleich dicke und gleich harte Wände haben und während bei den unter Gissara-Stuken häufigen Nestern ein fester Kern von einem lockeren Gefüge papierartig dünner bröcklicher Wände umgeben ist, umschliesst bei diesen Kugelnestern eine ungemein harte dicke Schale die lockere, weichere Mitte. Stehen sie hierdurch in geradem Gegensatz zu den Gissara-Nestern, so stimmen sie mit diesen darin überein, dass ihr Gefüge kein so völlig regelloses ist, wie bei den Baumnestern, dass vielmehr ihre vorwiegend in tangentialer Richtung ausgedehnten Räume eine mehr oder minder regelmässige concentrische Anordnung zeigen.

Tch hatte kürzlich Gelegenheit, eines dieser Kugelnester zu untersuchen. Dasselbe hatte etwa I Meter Durchmesser; die Höhe war etwas geringer, als der wagerechte Durchmesser, da der sonst fast regelmässigen Kugel unten, wo sie dem Boden auflag, ein Abschnitt fehlte. Die Oberfläche des Baues war mit kleinen Moosen und Lebermoosen bewachsen. Die harte Schale, die abzusprengen manchen kräftigen Hieb einer schweren Holzaxt erforderte, war fast einen Fuss dick. Sie bestand aus stellenweise ziemlich regelmässig concentrischen, durchschnittlich etwa $2 \mathrm{~mm}$ dicken Wänden, die durch zahlreiche Pfeiler und unregelmässige Wände verbunden waren. Bei mehreren Zählungen fand ich in der Richtung des Halbmessers 16 bis 18 concentrische Räume auf $0,1 \mathrm{~m}$. - Nach der Mitte des Nestes zu wurden die Wände allmälig dünner; der innerste Kern war leicht mit der Hand zu zerbröckeln. Hier wurde, leider durch einen Axthieb völlig zerquetscht, die Königin angetroffen; sie war durch kein besonderes, festwandiges Zimmer beschützt, welches durch die dicke harte Schale des ganzen Nestes überflüssig gemacht ist. Um sie herum fanden sich Eier und junge Brut 
in ganz unglaublicher Menge. Zahllose geflügelte Männchen und Weibchen hielten sich ausschliesslich in den Räumen der harten Rinde des Baues auf.

Im Innern dieses Nestes herrschte eine ziemlich bedeutende Wärme; sie schien mir etwa der Blutwärme gleich zu sein, eher höher, als niedriger. Mitten im Winter und in tiefem Waldesschatten konnte diese Wärme natürlich nur von den Bewohnern des Nestes selbst erzeugt sein. - Einen saueren Geruch, von dem Beobachter anderer Arten sprechen, habe ich eben so wenig bei diesem grossen Kugelneste, als bei den Nestern anderer hiesiger Arten wahrgenommen, Der nicht sehr starke Geruch war vielmehr hier, wie bei den Baumnestern ein ganz eigenthümlich harziger.

Itajahy, Ende Juli ${ }_{1} 872$. 


\section{Beiträge zur Kenntniss der Termiten ${ }^{1}$ ).}

III. Die „Nymphen mit kurzen Flügelscheiden“ (Hagen), „nymphes de la deuxième forme“ (Lespès). Ein Sultan in seinem Harem.

Mit 3 Textfiguren.

Von der überraschenden Menge verschiedener Zustände, die im Termitenstaate angetroffen werden, bilden - nach der Meinung ihres gründlichsten Kenners ${ }^{2}$ ) - „eigentlich nur die Nymphen mit kurzen Flügelscheiden ein bis jetzt unlösliches Räthsel“. Dem Versuche, dieses Räthsel seiner Lösung näher zu führen, muss ich als Einleitung einige Worte über das geschlechtliche Leben der Termiten vorausschicken.

$\mathrm{Zu}$ einer bestimmten (für verschiedene Arten verschiedenen) Jahreszeit verlassen die geflügelten Männchen und Weibchen das Nest, in welchem sie mehrere Wochen zuvor ihre letzte Häutung bestanden haben, und erheben sich in dichtem Schwarme in die Luft. Nach kurzem Fluge senken sie sich wieder zu Boden und entledigen sich ihrer Flügel. Zum Theil erst jetzt, zum Theil schon während des Fluges beginnt die Jagd der Männchen nach einer Genossin. Die Paare, die sich gefunden, suchen dann ein Nest ihrer Art wieder zu gewinnen. Ehe sie dieses Ziel wieder erreichen, erliegt die übergrosse Mehrzahl der wehrlosen Thiere den Nachstellungen der Ameisen, der Vögel und anderer Feinde. Die Begattung findet weder in der Luft, noch überhaupt ausserhalb des Nestes statt. Erst nachdem ein Paar als König und Königin in einem Neste Aufnahme gefunden hat, folgt der ausserhalb des Nestes gefeierten Verlobung die Vermählung und eine Jahre lange treue Ehe.

Ziemlich abweichend von dieser Darstellung, welche sich in allen wesentlichen Puncten derjenigen anschliesst, die schon vor fast hundert Jahren (I78I) Smeathman gegeben hat, pflegen die Angaben neuerer zoologischer Lehrbücher zu lauten. Man lässt die Termiten sich in der Luft oder doch ausserhab des Nestes begatten, die Männchen nach der Begattung zu Grunde gehen und die befruchteten Weibchen in das Nest zurückgebracht werden.

I) Jenaische Zeitschrift f. Naturwiss. 1873. Bd. VII. p. $45 \mathrm{I}-463$.

I) Hagen in Linnaea enthomol. XIV. S. I 26. 
Dass das Männchen mit seinem Weibchen in das Nest zurückkehrt und in seiner Gesellschaft als „König“ weiter lebt, bedarf keiner weiteren Beweise, nachdem ausser Smeathman auch Savage, Lespès, Bates u. A. solche Könige bei verschiedenen Arten gefunden, und nachdem auch Hagen erklärt, dass ihm „durch vielfache Angaben glaubwürdiger Forscher und durch vielfache Sendungen solcher Nestbewohner die Existenz eines derartigen Königs zweifellos erscheint" 1). Doch mag immerhin erwähnt sein, dass auch ich den König bei acht oder neun Arten der Gattungen Calotermes (rugosus, nodulosus, Hagenii), Termes (Lespesii), Eutermes (inquilinus u. a.) und Anoplotermes (pacificus) gefunden habe. Da die zur Zeit des Schwärmens äusserst winzigen Hoden nach der Rückkehr in ein Nest so bedeutend wachsen, dass sie den grösseren Theil des bisweilen beträchtlich anschwellenden Hinterleibes füllen, so steht die, wahrscheinlich oft wiederholte Begattung im Innern des Nestes ausser Frage. Damit ist allerdings eine frühere Begattung ausserhalb des Nestes nicht ausgeschlossen. Doch ist dieselbe sehr unwahrscheinlich. eben weil zur Zeit des Schwärmens Hoden und Eierstöcke noch sehr wenig entwickelt sind. Selbst bei einer der grössten Arten (Termes dirus) konnte Burmeister die inneren Geschlechtstheile des geflügelten Männchens nicht nachweisen. Auch Hagen untersuchte viele (Alcohol-) Stücke geflügelter Termiten ohne Genitalien zu treffen ${ }^{2}$ ). Hat man doch sogar die grosse Masse eines Termitenschwarmes als „sterile Individuen“ ansehen wollen. Danach lässt sich bemessen, wie klein noch im Verhältniss zu ihrem späteren gewaltigen Umfange die Geschlechtstheile der geflügelten Thiere sind; als Beispiel will ich anführen, dass bei den geflügelten Männchen unserer grössten Eutermes-Art die Hoden kaum o,3 mm Durchmesser haben.

Besässen die Termiten die langen, so leicht ins Auge fallenden und kaum zu verwechselnden Samenfäden der übrigen Insecten, so wäre die Frage, ob die geflügelten Männchen schon zeugungsfähig seien und ob die Weibchen schon ausserhalb des Nestes sich begatten, leicht genug zu entscheiden. Allein in den Hoden geschlechtsreifer Männchen (Könige) verschiedener Arten fand ich nur theils grössere, sehr blasse rundliche Körperchen (von etwa o,008 mm Durchmesser bei Eutermes vernalis m.), die Kern- und hüllenlos zu sein scheinen und bei Wasserzusatz zu mehr als doppelt so grossem Durchmesser aufquellen, theils kleinere ziemlich stark lichtbrechende Kügelchen von kaum 0,002 mm Durchmesser. - Erstere sind wahrscheinlich die befruchtenden Bestandtheile des Samens. Sie sind so blass und ihre Gestalt ist so wenig ausgezeichnet, dass ich noch nicht mit Bestimmtheit sagen kann, ob sie schon bei den geflügelten Männchen sich finden und dass ich sie bis jetzt ebenso vergeblich in der Samentasche von Königinnen, wie in der der geflügelten Weibchen gesucht habe. Habe ich recht gesehen, so sind dieselben bei den geflügelten Männchen (des grossen, Kugelnester bauenden Eutermes) allerdings schon vorhanden, aber noch in Zellen eingeschlossen.

Bis jetzt ist noch kein in der Begattung begriffenes Termiten-Pärchen gegefangen worden. Was man wohl als Begattung angesehen hat, sind jene mehrfach beobachteten gemeinsamen Spaziergänge der Paare, bei welchen das Weibchen voranläuft, das Männchen dicht dahinter, oft mit seinen Kinnbacken den Hinter-

1) Hagen a. a. O. XII. S. I6.

2) Briefliche Mittheilung vom 25. Novbr. 1871 . 
leib des Weibchens erfassend. Diesen eigenthümlichen Spaziergängen habe ich bei Termes Lespesi i wiederholt zugesehen. Brachte ich ausgefärbte Thiere dieser Art aus dem Neste in ein Glas, so pflegten sie nach kurzer Unruhe dicht übereinander geschichtet, wie sie es in den Kammern des Nestes gewesen, still am Boden zu sitzen. Schüttete ich sie dann auf einen Bogen Papier, so schob sich allmählig ein Pärchen nach dem anderen aus dem wimmelnden Haufen hervor, um sich langsam von demselben zu entfernen. Einige Paare trennten sich bald wieder; diese erwiesen sich, soweit sie untersucht wurden, als zwei Männchen. Die anderen, die bei einander ausharrten, bestanden immer aus einem vorangehenden Weibchen und einem nachfolgenden Männchen. Letzteres war bis auf die hintere Hälfte der Flügel, oder, falls es diese schon abgeworfen hatte, vollständig unter den Flügeln des Weibchens verborgen. Blieb es einmal einige Schritte zurück, so schien das Weibchen auf dasselbe zu warten. Nicht selten hatte das Männchen wirklich (wie Rosenschöld angiebt), und nicht bloss scheinbar (wie es Lespès bei Termes lu c if u gus sah) die Spitze des Hinterleibes seiner Genossin eine Zeit lang mit den Kinnbacken (Mandibeln) gefasst. Es schien das eine Art bräutlicher Liebkosung zu sein. Von einer Begattung habe ich dabei so wenig etwas gesehen, als Smeathman, Rosenschöld, Lespès, Tollin u. A. 1). Das Ziel dieser Spaziergänge ist wahrscheinlich ein Nest ihrer Art als neue Heimat.

Die angebliche Begattung in der Luft würde ich mit Stillschweigen übergehen, wenn nicht Azara und Rengger, welche dieselbe in Paraguay gesehen haben wollen, mit Recht den Ruf guter und zuverlässiger Beobachter genössen. Für die Termiten haben sie freilich diesen Ruf nicht gerechtfertigt; Azara schreibt den Termiten sechs Flügel zu, - Rengger will den Boden Viertelstunden weit von männlichen Termiten oder wenigstens von deren Flügeln bedeckt gesehen haben. Leider sagt er ebenso wenig, woran er die Flügel als männliche erkannte, als in welcher Weise die Begattung in der Luft vor sich ging. Vermuthlich haben Beide nichts weiter gesehen, als was auch der dritte Beobachter der Termiten Paraguays, Rosenschöld, berichtet, dass nämlich aus den dichten Schwärmen einer dortigen Art die Thiere paarweise niederfallen, um dann die eben erwähnten Spaziergänge zu beginnen. Bei dem dürftigen Flugvermögen der Termiten und bei dem Mangel von Begattungswerkzeugen halte ich die Begattung in der Luft für geradezu unmöglich.

So viel zur Rechtfertigung Smeathman's gegenüber den Bedenken und der abweichenden Auffassung der „wissenschaftlichen Zoologie“. Seine Darstellung des geschlechtlichen Lebens der Termiten scheint mir, soweit ich nach den in

I) Nur Mènètriès erzählt in einem wunderlich aus Wahrem und Falschem gemischten Berichte (Linn. entomol. S. I16), dass diese Spaziergange mit der Begattung enden. Ich glaube diese Angabe ebenso bezweifeln $z$ dürfen, wie dass die Termiten der Serra da Mantiqueira Bäume entlauben, um die Blätter in ihr Nest zu tragen (wahrscheinlich Verwechslung mit Ameisen der Gattung Oecodoma), dass die Männchen dieser Termiten kräftigere Mandibeln haben als die Weibchen, dass die Werbchen gleich in den ersten $z$ wei bis drei Tagen nach der Heimkehr ihre (bei anderen Arten um diese Zeit ganz unreifen) Eier ablegen und dann aus dem Neste geworfen werden, dass irgendwo in Brasilien gebratene Mandiocwurzeln die Hauptnahrung der Bewohner bildet, u. s. w. - Mènètriès fand während eines fünfjährigen Aufenthaltes in verschiedenen Provinzen Brasiliens, die wahrscheinlich sämmtlich termitenreicher sind, als unsere Santa Catharina, „nie Termiten in wirklichen Urwäldern“. In meinem eigenen Urwalde leben über ein Dutzend Arten. 
Hagen's Monographie gesammelten Thatsachen und nach eigenen Erfahrungen urtheilen kann, durchaus richtig zu sein; allein sie ist, wenn auch nicht für den von Smeathman beobachteten Termes bel1icosus, so doch für manche andere Arten unvollständig. Es finden darin die "Nymphen mit kurzen Flügelscheiden" (oder besser Flügelansätzen ${ }^{1}$ ) keine Berücksichtigung.

Schon früher mehrfach beobachtet, sind diese Thiere zuerst von Lespès ausführlicher besprochen worden. Derselbe unterschied unter den Nymphen des Termes 1 ucifugus, den er bei Bordeaux beobachtete, zwei verschiedene Formen. Die "Nymphen der ersten Form" sind lebhafter, schlanker und haben lange, breite, den vorderen Theil des Hinterleibes ganz bedeckende Flügelansätze, sie beginnen Anfangs Mai sich zu färben und verwandeln sich zwischen 15. und 20. Mai in geflügelte Thiere. Die „Nymphen der zweiten Form“ sind weit seltener; sie sind dicker, schwerfälliger und haben kurze, schmale, seitlich gelegene Flügelansätze. Im Februar, als Lespès sie zuerst fand, hatten diese Nymphen dieselbe Grösse, wie die übrigen $(6-7 \mathrm{~mm})$; später wurden sie grösser $(8-10 \mathrm{~mm})$; aber der Hinterleib allein wuchs, besonders beträchtlich bei den Weibchen. Dann bedecken die Rückenschilder nicht mehr die Seiten und werden selbst oben durch weiche Haut getrennt. Dieser Anschwellung des Hinterleibes entspricht eine stärkere Entwicklung der Geschlechtstheile. Bei den weiblichen Nymphen der ersten Form hatte kurz vor der letzten Häutung jeder Eierstock etwa 12 Röhren, von denen aber nur zwei oder drei unreife Eier enthielten; dagegen fanden sich bei der zweiten Form bis 56 Röhren, in denen bei älteren Nymphen die Eier sichtbar wurden. Auch die Hoden waren bei der zweiten Form viel mehr entwickelt. Die Nymphen der zweiten Form überleben die Verwandlung und das Schwärmen der übrigen und wachsen als Nymphen fort. Erst im Juli beginnen sie sich etwas zu bräunen; sie wurden um diese Zeit immer seltener. --

Leider reichen die Beobachtungen von Lespès nur bis zu dieser Jahreszeit. Er vermuthet, dass die Nymphen der zweiten Form sich im August in geflügelte Männchen und Weibchen verwandeln und schwärmen, und dass aus ihnen König und Königin hervorgehen, während er kleinere Pärchen flügelloser Männchen und Weibchen, die er einigemal in den Nestern von Termes lucifugus fand und als ,petit roi" und "petite reine" bezeichnet, von den Nymphen der ersten Form ableitete. Diese Annahme stützt sich einzig darauf, dass die Entwicklung der inneren Geschlechtstheile bei König und Königin sich zu der bei den Nymphen der zweiten Form etwa ebenso verhielt, wie die bei „petit roi“ und „petite reine“ zu der bei den Nymphen der ersten Form. Diese verschiedene Grösse und diese verschiedene Entwicklung der Geschlechtstheile bei den von Lespès gefangenen Königen und Königinnen dürfte jedoch einfach daraus zu erklären sein, dass dieselben verschiedenen Jahrgängen angehörten.

I) Der Name Flügel scheiden passt eigentlich überhaupt nur für die ältesten Nymphen, aus deren Flügelansätzen bei der nächsten Häutung wirkliche Flügel herausgezogen werden; er ist ganz unpassend in Fällen, wo es gar nicht zur Bildung von Flügeln kommt. So darf man allerdings mit Hagen (Linn. ent. XIV. S. 126) „die Soldatennymphen mit kurzen Flügelscheiden als sehr unverbürgt" aus der Formenreihe der Termiten streichen; wohl aber giebt es Soldaten mit Flügelansätzen, aus denen sich „Flügel entwickeln müssten, wenn nicht überhaupt die Soldaten flügellos blieben" (Hagen, a. a. O. S. 102). So die von Hagen beschriebenen Soldaten des Termes (Termopsis?) occidentis Walker und die des Calotermes Smeathmani, m. 
Schon Hagen hat gegen die Annahme von Lespès geltend gemacht, „dass alle bis jetzt untersuchten Könige und Königinnen die Flügelschuppe genau von der Form und Grösse der Imago zeigen, eine Entwicklung, welche mit den kleinen rudimentären Flügelscheiden jener Nymphen durchaus nicht in Einklang zu bringen ist. Auch der etwaige Gedanke, dass jene Nymphen bei ihrer letzten Häutung aus den rudimentären Scheiden nur Flügelschuppen herauszögen, scheint unpassend, und um so mehr, als die Schuppen eines Königspaares stets deutlich die Abbruchstelle des Flügels zeigen. Uebrigens ist der Prothorax der Königin niemals von dem der Imago in der Form verschieden" ${ }^{1}$ ), während die Nymphen der zweiten Form sich durch breiteren Prothorax auszeichneten.

Als im Juli die Nymphen der zweiten Form sich zu bräunen begannen, als somit ihre letzte Häutung, falls sie eine solche überhaupt noch zu bestehen hatten, nahe bevorstand, waren ihre Flügelansätze noch so winzig, dass sich in ihnen unmöglich Flügel ausbilden konnten, wie sie die im Mai schwärmenden Thiere besitzen. Und selbst, wenn sie solche Flügel bekämen, würden sie mit ihrem dicken Hinterleibe nicht fliegen können, wie wohl Jeder, der lebende Termiten gesehen, zugestehen wird. Es mag hierbei darauf hingewiesen werden, dass BobeMoreau, der lange Jahre hindurch den Termiten in und um Rochefort seine Aufmerksamkeit schenkte (seine Beobachtungen begannen 1797, sein „Mémoire sur les Termites observés à Rochefort etc." erschien r 843), ebenfalls nach der Schwärmzeit noch ,verspätete Nymphen“ antraf, von denen er vermuthet, dass sie ohne weitere Verwandlung untergehen, da in Rochefort nie ein zweiter Ausflug beobachtet wurde. Hagen hält es für sicher, dass Bobe-Moreau und Lespès dieselbe Art untersucht haben, während Lespès glaubt, dass der Termes lucifugus von Bordeaux von der Rochefort-Termite verschieden sei. Wie dem auch sei, es scheint mir kaum einem Zweifel zu unterliegen, dass auch in Bordeaux ein zweiter Ausflug aus den Nymphen der zweiten Form hervorgegangener Männchen und Weibchen nicht stattfinde, dass vielmehr diese Nymphen flügellos bleiben und nie ihr Nest verlassen, in welchem sie unter Umständen zu zeugungsfähigen Männchen und eierlegenden Weibchen sich entwickeln.

Derlei nymphenähnliche geschlechtsreife Thiere sind bereits bei mehreren Arten beobachtet und gewöhnlich als Königinnen beschrieben worden. So bildete Joly eine Königin von Termes luc if ugus ohne Flügelschuppen ab und Lespès berichtet, dass Joly ihm nochmals versichert, dieselbe sei ohne Spur von Flügelschuppen gewesen. Auch das von Burmeister als Königin beschriebene Weibchen von Termes flavipes war flügellos und Hagen, der dasselbe Thier untersuchte, fand darin ,ein dem Habitus nach einer Königin sehr ähnliches Thier mit den kurzen Flügelscheiden einer Nymphe“. Ebenso ist Bates' Königin von Termes arenarius nach Hagen „eine Nymphe mit unentwickelten Flügelscheiden“ ${ }^{2}$ ). Ferner ziehe ich hierher ein im British Museum befindliches (von Walker unter Termes 1ucifugus beschriebenes) Stück von Calotermes flavicollis, „eine Nymphe mit kurzen Flügelscheiden, einer Imago, welche die Flügel verloren hat, täuschend ähnlich. Die völlig schwarze Färbung, der blank polirte Kopf,

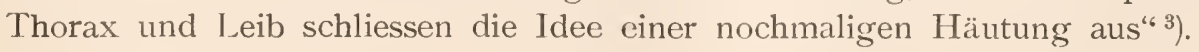

I) Hagen, a. a. O. XII. S. I9.

2) Briefliche Mittheilung vom 2. Januar 1872.

3) Hagen, a. a. O. XII. S. 20 und S. 59. 
Es treten also bei gewissen Termiten-Arten die Männchen und Weibchen unter zwei verschiedenen Formen auf. Die einen aus den „Nymphen der ersten Form" hervorgehend, erhalten Flügel und verlassen in Schwärmen ihren Geburtsort. Nur sehr wenigen Glücklichen unter ihnen gelingt es, später als König und Königin einen erledigten Thron zu besteigen. Die anderen, die geschlechtsreif gewordenen "Nymphen der zweiten Form" sehen nie das Licht des Tages; sie bleiben flügellos und verlassen nie das Nest, in dem sie aufgewachsen sind ${ }^{1}$ ).

$W^{\gamma}$ elche Bedeutung hat nun für die Erhaltung und das Gedeihen der Art jede dieser beiden Formen? - Ein grösserer Termitenstaat entsendet jährlich Hunderttausende geflügelter Männchen und Weibchen, um alle zwei, drei oder vier Jahre ein einziges Königspaar zurückerhalten zu können; so bedeutend sind die Verheerungen, die alle möglichen Insectenfresser, vom Menschen bis zur Ameise, unter diesen ganz wehrlosen Thieren anrichten, so bedeutend die Schwierigkeiten, nachdem Braut und Bräutigam sich gefunden, ein Nest zu erreichen, in welchem ein Königspaar verlangt wird. Wäre es nicht einfacher und sicherer, alle Männchen und Weibchen wohlbehütet daheim zu behalten? Welche Arbeit würden die Termiten sparen, wenn sie nicht Jahr für Jahr jene wolkenartigen Schwärme geflügelter Thiere aufzuziehen hätten, wie sie den grossen Hügelnestern entsteigen $\left.{ }^{2}\right)$ ! Ist es nicht auffallend, dass bei allen Arten, wo dieselbe überhaupt besteht, jene so viel einfachere und sichrere, so viel Arbeit ersparende Weise der Fortpflanzung durch nymphenähnliche Männchen und Weibchen nicht längst auf dem Wege der natürlichen Auslese die andere von so viel Gefahren bedrohte durch ausfliegende Schwärme völlig verdrängt hat, nicht längst zur einzigen geworden ist? Und doch scheinen die daheim bleibenden Männchen und Weibchen nur als seltener Nothbehelf zu dienen für den Fall, dass einmal andere nicht zu erlangen sind.

Wo immer man auf derartige Fragen stösst, darf man sich getrost an Darwin wenden und bei ihm den Schlüssel zu deren Lösung zu finden hoffen. Wer nach eigener Beschäftigung mit dem Gegenstande die volle Tragweite der im i7. Capitel seines Werkes: „The Variation of animals and plants under domestication“ zusammengestellten Thatsachen zu würdigen weiss, wird kaum Bedenken tragen, zuzugestehen, dass durch dieselben das Gesetz wenn nicht bewiesen, so doch im höchsten Grade wahrscheinlich gemacht wird, mit welchem Darwin dieses Capitel

I) Hagen schreibt mir, dass alle Königinnen (von Termes bellicosus, dives, obesus, gilvus), die er bis jetzt aus Asien und Africa sah, wirkliche Imagos sind mit dem Flügelstummel, von dem der Flügel abgebrochen - dagegen alle Königinnen, die er aus Brasilien und überhaupt aus America gesehen (von Termes flavipes, morio (?), similis (?), arenarius), of fen bar N ymphen waren. So auffallend diese Thatsache scheinen mag, wäre es voreilig, daraus schon jetzt schliessen zu wollen, dass im Vorkommen der beiderlei Formen ein Unterschied zwischen der alten und der neuen Welt bestehe. Ich habe hier wohl über hundert wirkliche Königinnen gesehen, - mehr als Hagen aus Asien und Afrika, ehe ich zum ersten Male nymphenähnliche Weibchen traf.

2) Man hat von der Anlage neuer Staaten durch die ausschwärmenden Männchen und Weibchen gesprochen (Rengger, Tollin u. A.) und könnte meinen, dass deshalb das Schwärmen unentbehrlich sei. Den Männchen und Weibchen von $\mathrm{C}$ alotermes will ich die Fähigkeit nicht geradezu absprechen, auf eigne Hand weiter zu leben und eine neue Ansiedlung zu beginnen. Bei allen Arten von Termes, Eutermes, Anoplotermes, deren Lebensweise ich einigermassen kenne, würde ein geflügeltes Pärchen die Begründung eines neuen Staates mit genau demselben Erfolge unternehnen, wie ein Paar neugeborener Kinder, die man auf einer wüsten Insel ausgesetzt hätte. 
schliesst: „that the crossing of animals and plants which are not closely related to each other is highly beneficial or even necessary, and that interbreeding prolonged during many generations is highly injurious".

Nun besitzt bei der Mehrzahl der Termiten-Arten, deren gesellschaftliche Verhältnisse man kennt, jedes Volk (mit seltenen Ausnahmen) ein einziges Königspaar oder auch wohl bisweilen einen einzigen König mit zwei Gemahlinnen. Somit sind sämmtliche in dem Stocke aufwachsende Männchen und Weibchen Geschwister. Die ausschliessliche Fortpflanzung durch eingeborene Männchen und Weibchen würde zur engsten Inzucht führen. Bei dem Schwärmen können sich Männchen und Weibchen aus verschiedenen Stöcken zusammenfinden, deren Verbindung hier wie sonst eine kräftigere Nachkommenschaft liefern wird. Bei der massenhaften Vertilgung durch zahlreiche Feinde, welcher die schwärmenden Termiten ausgesetzt sind, wird es trotz ihrer Unzahl geschehen können, dass ein Volk seinen Thron nicht rechtzeitig mit einem neuen Königspaare zu besetzen vermag. In diesem Nothfalle treten dann als Ersatz die daheim in sicherer Hut gehaltenen nymphenähnlichen Männchen und Weibchen ein und retten das Volk vor dem Aussterben.

Mit dem Umstande, dass erst dann diese Ersatzmännchen oder Weibchen nöthig werden, wenn nach Ablauf der Schwärmzeit kein wirkliches Königspaar sich gefunden hat, mag die verspätete Entwicklung der „Nymphen der zweiten Form" im Zusammenhang stehen. - Dass, wie Lespès berichtet, diese Nymphen der zweiten Form „immer seltener werden, je mehr die Zeit ihrer (nur vermutheten, nicht beobachteten!) Verwandlung herannaht" ${ }^{1}$ ), wäre gewiss höchst befremdlich, wenn dieselben sich wirklich in geflügelte Thiere für einen zweiten Ausflug verwandelten; dagegen erscheint es begreiflich, dass man sie allmälig aussterben verhungern?) lässt, wenn man sie nicht mehr braucht, oder dass man nur so viele am Leben erhält, als man eben braucht.

In überraschender Weise ähnlich sind diese bei den Termiten bestehenden Verhältnisse dem bei Pflanzen der verschiedensten Familien beobachteten Vorkommen geschlossener (,cleistogamer“ Kuhn) Blüthen ${ }^{2}$ ). Wie sich an gewissen Pflanzenstöcken ausser offenen, die Kreuzung verschiedener Stöcke vermittelnden Blüthen andere nie sich öffnende (cleistogame) Blüthen entwickeln, deren Staubgefässe und Stempel stets eingeschlossen bleiben und durch welche die Erhaltung der Art gesichert wird, falls die von der Gunst äusserer Umstände abhängige Fortpflanzung durch offene Blüthen unterbleibt, so entwickeln sich in gewissen Termitenstöcken ausser den ausschwärmenden, die Kreuzung verschiedener Stöcke vermittelnden Männchen und Weibchen andere, nie ausschwärmende (cleistogame) Männchen und Weibchen, die stets im Stocke eingeschlossen bleiben und durch welche die Erhaltung der Art gesichert wird, falls die von der Gunst äusserer Umstände abhängige Fortpflanzung durch ausschwärmende Männchen und Weibchen unterbleibt. TYie die cleistogamen Blüthen mancher Pflanzen jüngeren Knospen der offenen Blüthen, so sind die cleistogamen Männchen und Weibchen der Termiten Jugendzuständen der ausschwärmenden ähnlich; dort bleiben die Blumen-

1) Hagen's Bericht über die Arbeit von Lespès, a. a. O. XII, S. 317 .

2) Vgl. Hildebrand, die Geschlechtervertheilung bei den Pflanzen. 1867. S. 73. Severin Axell, Om anordningarna for de fanerogama växternas befruktning. 1869. S. 10 u. S. 76. 
blätter, hier die Flügel auf einer niederen Entwicklungsstufe stehen. Der verschwenderischen Erzeugung von Blüthenstaub in offenen Blüthen entspricht die verschwenderische Erzeugung geflügelter Männchen und Weibchen, wie die geringe Zahl der Nymphen mit kurzen Flügelansätzen dem spärlicheren Blüthenstaube cleistogamer Blüthen. Wie beim Veilchen die cleistogamen Blüthen später als die offenen, so entwickeln sich bei Termes lucifugus die Nymphen der zweiten Form später als die der ersten. Wie man in Frankreich an der ausländischen Leersia orizoides bis jetzt nur Fortpflanzung durch cleistogame Blüthen beobachtete, so hat man im Garten zu Schönbrunnen bis jetzt nur ein cleistogames Weibchen des ausländischen Termes flavipes gefunden, - wahrscheinlich weil in beiden Fällen im fremden Lande die äusseren Umstände der gewöhnlichen Fortpflanzungsweise nicht günstig sind.

Die im Vorstehenden entwickelte Ansicht über die „Nymphen mit kurzen Flügelscheiden" hatte ich mir nach den in Hagen's Monographie niedergelegten Thatsachen gebildet und in Briefen ausgesprochen, lange bevor ich selbst Gelegenheit hatte, solche Thiere zu sehen. Leider entbehrte gerade der eigentliche Kern dieser Ansicht der thatsächlichen Begründung; es mangelte der Nachweis, dass wirklich die cleistogamen Ersatzmännchen und Weibchen die Fortpflanzung der Art übernehmen in Fällen, wo König oder Königin im Stocke fehlen. Man wird begreifen, mit welch freudiger Ueberraschung ich einen Fund begrüsste, der mir jetzt diesen Nachweis zu liefern gestattet.

Ich hatte (am I I. Nov.) aus einem morschen Gissara-Stuken den festen Kern eines Eutermes-Nestes mit heimgebracht, der ungefähr Grösse und Gestalt eines
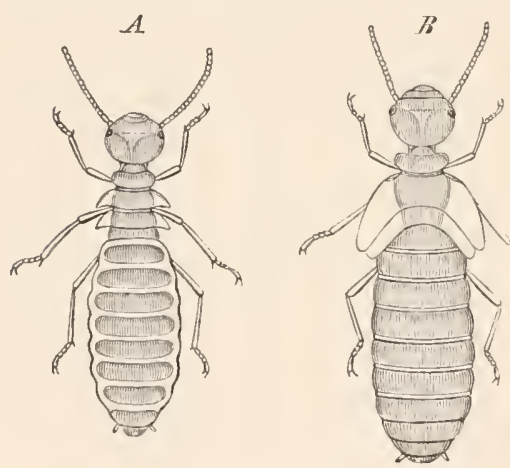

Fig. I. Zwei Ersatzweibchen von Termes lucifugus. $A$ Die gewöhnliehe Form mit kurzen Flügelansätzen. $B$ Die seltenere Form mit längeren Flügelansätzen.
Hühnereies hatte. Um den Kern waren ansehnliche Eiermassen angehäuft und so erwartete ich darin wie gewöhnlich ein Königspaar anzutreffen. Allein statt in seiner Mitte ein grösseres königliches Zimmer zu umschliessen, war der ganze Kern wie ein Schwamm von unregelmässigen Gängen durchzogen und in diesen Gängen sassen, hier und da zu fünf bis sechs dicht zusammengedrängt, nicht weniger als einunddreissig (3 1 ) Ersatzweibchen mit kurzen Flügelansätzen (Fig. I), 6 bis $8 \mathrm{~mm}$ lang, und zwischen ihnen spazierte ein einziger König von ungefähr gleicher Grösse herum, und zwar ein wirklicher König mit grossen schwarzen Augen und Flügelschuppen, von denen die Flügel abgebrochen waren. Eine Königin fehlte. Statt eines Königspalastes, in welchem ein König mit seiner ebenbürtigen Gemahlin in keuscher Ehe lebte, hatte ich also einen Harem vor mir, in dem ein Sultan mit zahlreichen Buhlen sich vergnügte ${ }^{1}$ ).

I) Vermuthlich hat schon Bofinet eine ähnliche Gesellschaft von Ersatzweibchen von Termes luci . f ugus gesehen; es waren ihrer sieben, mitten in einem Balken. Sie waren 8 bis ro mm lang, beinahe weiss oder sehr hellroth. In ihrer Nähe fanden sich mehrere Eierhaufen und sehr zahlreiche Larven, ,genug, um damit ein Liter zu füllen“. (Vergl. Hagen's Bericht, a. a. O. X, S. Izo.) Termes lucifu gus hat sonst, nach Lespès, nur ein einziges Königspaar. Auch die helle Farbe der von Bofinet gefun- 
Im Laufe eines Tages legten diese Ersatzweibchen eine ziemliche Anzahl von Eiern, die von den Arbeitern in kleine Häufchen zusammengetragen wurden. Man sah an ihrem Hinterleibe dieselben wellenförmigen Zusammenziehungen wie bei Königinnen und bei mehreren war ich Zeuge von dem Austritt eines Eies.

Die Farbe dieser Weibchen mit kurzen Flügelansätzen ist ein lichtes Braun, wodurch sie ebenso von den blassen, fast farblosen Arbeitern, wie von dem weit dunkleren König abstechen. Im ganzen sehen sie den Arbeitern ziemlich ähnlich, ähnlicher als einer der anderen Formen ihrer Art; nur sind sie doppelt so gross. Die Flügelansätze sind bei den meisten zu klein, um bei oberflächlicher Betrachtung in die Augen $\mathrm{zu}$ fallen. Der Hinterleib, nur mässig angeschwollen, hat etwa dieselbe eiförmige Gestalt und steht etwa in demselben Verhältniss zur Gesammtlänge wie der des Arbeiters. Namentlich aber ist die Aehnlichkeit des Kopfes (Fig. 2) auffallend; die „hellen, sich kreuzenden Linien“, die den Kopf der Eutermes-Arbeiter auszuzeichnen pflegen ${ }^{1}$ ), sind bei den meisten kaum minder deutlich, als bei den Arbeitern. Die Fühler haben, wie die der Arbeiter, 14 Glieder, während die

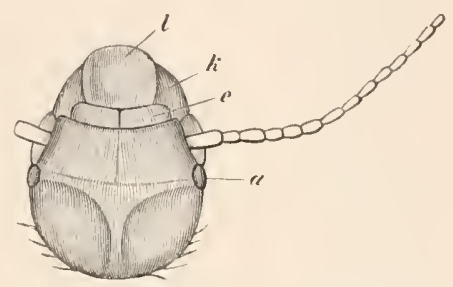

Fig. 2. Kopf eines Ersatzweibchens. $a$ Die beiden kleinen Netzaugen. $l$ Die Oberlippe. $k$ Die Oberkiefer. Soldaten 13, die geflügelten Thiere I 5 Fühlerglieder besitzen. Man könnte den Kopf für den eines Arbeiters halten, fänden sich nicht kleine runde Netzaugen, die sich indessen kaum über ihre Umgebung erheben und kaum etwas dunkler als diese gefärbt sind. Nebenaugen habe ich nicht bemerkt. Der Prothorax erinnert dadurch an den der Arbeiter, dass er einen queren sattelförmigen Eindruck hat, welcher einen vorderen Lappen absondert; doch ist bei den Arbeitern dieser vordere Lappen sehr gross, steil aufgerichtet und in der Mitte seines Vorderrandes seicht eingekerbt; bei den Ersatzweibchen ist er nur klein, sanft aufsteigend und einfach abgerundet. Die Grösse des vorderen Lappens wechselt übrigens; bei einigen wenigen Stücken war er durch einen schmalen Saum ersetzt, und dann ähnelte der Prothorax dem des Königs. Die Flügelansätze nehmen die ganzen seitlichen Ränder des Meso- und Metathorax ein; meist (Fig. 1 A) sind sie kaum halb so lang, als diese Leibesringe breit und bilden dann dreieckige wagerecht nach aussen gerichtete Vorsprünge, deren Hinderrand ziemlich gerade nach aussen, deren Vorderrand schief nach hinten läuft. Bei sehr wenigen Stücken (Fig. 1 B) sind die Flügelansätze bedeutend grösser; auch Meso- und Metathorax sind in diesem Falle stärker entwickelt; die schief nach hinten gerichteten Flügelansätze reichen etwa bis zur Mitte des zweiten Rückenschildes des Hinterleibes;

denen Weibchen passt nicht $z u$ wirklichen Königinnen. - Wenn Hagen vermuthet (a. a. O. XII, S. I 77), dass Lespès möglicherweise gar keine Königinnen, sondern nur grosse Nymphen der zweiten Form gesehen habe, so widerspricht dem die ausdrückliche und Joly gegenüber besonders betonte Versicherung von Lespès (a. a. O. XII, S. 332), dass bei seinen Königinnen stets die Flügelschuppen vorhanden waren. In den verschiedenen Grössenangaben bei Bofinet, Joly und Lespès kann ich keine Schwierigkeit erblicken, da ja die Weibchen nur ganz allmälig von der Grösse der Imago zu jenem fabelhaften Umfange heranwachsen, der die Königinnen der Termiten so berühmt gemacht hat, und also in allen dazwischen liegenden Grössen gefunden werden können.

I) Hagen, a. a. O. XII, S. I87. 
die vorderen Flügelansätze bedecken den Vorderrand der hinteren. - Die Bauchschilder sind wie bei den geflügelten Weibchen gebildet.

Die inneren Geschlechtsteile (Fig. 3) sind von denen der geflügelten Weibchen fast nur dadurch verschieden, dass sie reife Eier enthalten. Jeder Eierstock pflegt deren etwa ein halbes Dutzend $z u$ haben. Die Eiröhren, etwa ein Dutzend für jeden Eierstock (die Zahl scheint ziemlich unbeständig zu sein), sitzen wie bei den geflügelten Weibchen büschelförmig am Ende der kurzen Eileiter, während bei der

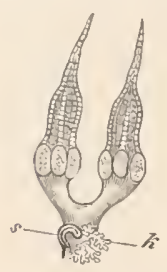

Fig. 3. Geschlechtstheile eines Ersatzweibchens. $s$ Samentasche. $k$ Kittdrüse. ausgewachsenen Königin jeder Eierstock ein langes Rohr bildet, das in ganzer Länge ringsum dicht mit überaus zahlreichen Eiröhren besetzt ist. Samentasche und Kittdrüse haben die gewöhnliche Form. Eine $19 \mathrm{~mm}$ lange Königin, die mir eben zur Hand ist, wiegt etwa 0,2 Gramm; ebensoviel wiegen ${ }_{5} 5$ der Ersatzweibchen. Die Eierstöcke der sämmtlichen 3 I Ersatzweibchen dürften zusammen kaum so viel wiegen und kaum so viel Eier liefern, als die einer einzigen älteren Königin.

Da Lespès und Hagen auch männliche Nymphen mit kurzen Flügelansätzen trafen, so wird wahrscheinlich der König ebenso durch

Ersatzmännchen vertreten werden können, wie die Königin durch Ersatzweibchen. $\mathrm{Ob}$ in einem Neste gleichzeitig für beide Geschlechter eine solche Vertretung stattfinden könne, - ob aus den von Ersatzweibchen gelegten oder durch Ersatzmännchen befruchteten Eiern alle Formen hervorgehen, die das Termitenvolk zusammensetzen, oder etwa nur Arbeiter und Soldaten, ob von allen Arten und in allen Stöcken regelmässig jedes Jahr Nymphen mit kurzen Flügelansätzen erzeugt werden, - das sind Fragen, auf die ich für jetzt selbst nicht mit Vermuthungen antworten mag und deren vollständige I.ösung Jahre lang fortgesetzte Beobachtungen erfordern dürfte.

\section{An hang.}

Uebersicht der im Termitenstaate vorkommenden Formen.

Die jüngsten Larven der verschiedenen Stände fanden Bates, Lespès und auch ich ununterscheidbar ähnlich. Ziemlich früh, noch bevor sie die halbe Länge der erwachsenen Arbeiter erreichen, scheiden sich, durch die erste Andeutung der Flügelansätze, die Larven der später zeugungsfähig werdenden Thiere von denen der Soldaten und Arbeiter, welche letzteren bei Termes saliens und anderen auch an ihrem dickeren Kopfe kenntlich sind. Erst kurz vor der letzten Häutung sind die Larven der Soldaten von denen der Arbeiter zu unterscheiden, so verschieden auch beide im erwachsenen Zustande sein mögen. Eine bis jetzt vereinzelte Ausnahme bildet der von Bofinet beobachtete Soldat, der so klein war, dass er als solcher das Ei verlassen zu haben schien. - Sehen wir ab von den Geschlechtsverschiedenheiten und von den zweifachen Formen der Arbeiter oder Soldaten, die bei einigen Arten vorzukommen scheinen, so erhalten wir also 
für die Gattungen Termes und Eutermes folgende Uebersicht der im Termitenstaate vorkommenden Formen:

I. Jüngste Larven.

2. Larven der nicht zeugungsfähıgen Stände.

4. Larven der Soldaten. 5 5. Larven der Arbeiter.

6. Soldaten.

7. Arbeiter.

8. Nymphen der ersten Form.

Io. Geflügelte Thiere.

I I. König u. Königin.

12. Ersatzmännchen und Ersatzweibchen.

Itajahy, im November 1872. 


\title{
Beiträge zur Kenntniss der Termiten ${ }^{1}$ ).
}

\author{
IV. Die Larven von Calotermes rugosus Hag.
}

Mit Tafel XL-XLIII.

Die Calotermes leben ohne eigentliches Nest in Gängen, die sie im Holze abgestorbener Bäume ausnagen. Ihre Gestalt entspricht dieser Lebensweise. Der langstreckige walzenförmige Leib, dessen Seitenlinien in einer Flucht vom Kopfe bis zum Ende des Hinterleibes fortlaufen, unterscheidet sie auf den ersten Blick von anderen Termiten, deren kleine Vorderbrust eine halsartige Einschnürung bildet zwischen dem Kopfe und dem hinteren Theile des Leibes, deren Hinterleib bei Larven, Arbeitern und Soldaten meist ${ }^{2}$ ) kürzer und länglich eiförmig, deren Beine länger und schlanker sind. Der ,prothorax magnus“"3) ist, weil allen Ständen gemeinsam, jedenfalls das wichtigste äussere Unterscheidungsmerkmal der Gattung Calotermes, wenigstens für Denjenigen, der lebenden Termiten nachgeht; alle übrigen, die Nebenaugen, die Adern im Randfelde der Flügel, die Haftlappen der Füsse, kommen nur den geflügelten Thieren zu, die man unter hundert Fällen kaum zehnmal in einer Termitengesellschaft treffen wird.

Schon die jüngsten Larven pflegen im Allgemeinen die bezeichnete Gestalt ihrer älteren Geschwister zu haben, bei Calotermes, wie bei anderen Termiten. Nur haben sie bei letzteren oft ein ungemein unreifes Aussehen, dicken Kopf, lange, aber plumpe Beine, Fühler u. s. w. und sind sehr träge und unbeholfen in ihren Bewegungen; bei Calotermes dagegen sind sie vom ersten Tage an muntere, lebhafte Thierchen, rascher in ihren Bewegungen, zierlicher in ihrem Aussehen, als ältere Larven und Soldaten, die gerade in dieser Gattung plumper gebaut sind und sich langsamer bewegen, als z. B. bei Eutermes. Es ist derselbe Unterschied, und bedingt durch ähnliche Ursachen, wie zwischen einer jungen Taube und einem Küchen, einer jungen Maus und einem Füllen, - ein Unterschied, der noch um vieles schroffer sich ausprägt zwischen der selbst sich nährenden Raupe einer Blattwespe und der hilflosen Made einer Honigbiene. -

I) Jenaische Zeitschrift f. Naturwiss. 1875. Bd. IX. p. $24 \mathrm{I}-264$.

I) Ausgenommen sind z. B. ältere Larven von Anoplotermes pacificus (Fig. II).

2) Hagen, Linn. entomol. XII, S. 33 . 
Eine Ausnahme von dieser Regel, dass die Jungen das Ei in einer Gestalt verlassen, die sich nur wenig von der älterer Larven unterscheidet, bilden, soweit mir bekannt, nur die beiden Arten Calotermes rugosus Hag. und C. nodulosus Hag. Als ich zum ersten Male zwischen den Soldaten und erwachsenen Larven des Calotermes rugosus, die sich langsam in ihren Gängen fortschoben, zierliche schneeweisse Thierchen herumlaufen sah, deren völlig abweichende Umrisse sich scharf abzeichneten auf dem dunkelblutroten CangeranaHolze, in dem sie lebten, meinte ich eher fremde Gäste, als Junge derselben Art vor mir zu haben. In vollem Gegensatze zu den Soldaten und erwachsenen Larven ist bei den jüngsten die Dreitheilung des Leibes in Kopf, Brust und Hinterleib augenfälliger, der Leib erscheint flacher und breiter, der Hinterleib ist vor der Mitte stärker verbreitet, nach hinten stärker verjüngt, als bei irgend welchen anderen Termiten, und dazu tragen Vorder- und Mittelbrust ansehnliche, wagerecht abstehende, den Kopf seitlich weit überragende flügelförmige Fortsätze (Fig. I-3).

Wir dürfen uns schon jetzt und ehe wir auf eine nähere Betrachtung dieser jungen Larven eingehen, die Frage vorlegen, ob wir es hier mit einem Falle von Anpassung oder von Vererbung zu thun haben, mit anderen Worten, ob die jungen Larven die Eigenschaften, durch die sie sich von ihren älteren Geschwistern auszeichnen, selbst als Larven im Kampfe ums Dasein erworben haben, oder ob ihnen dieselben, nutzlos für sie selbst, nur als Erbstück ihrer vielleicht in ähnlicher Gestalt geschlechtsreifen Ahnen geblieben sind. Im ersteren Falle würde es sich kaum der Mühe lohnen, zu den Hunderten bereits beschriebener sonderbarer Larvenformen noch eine neue zu beschreiben; im zweiten Falle wäre unsere Larve ein überaus merkwürdiges Thier. Denn ist schon Calotermes eine der ältesten, vielleicht geradezu die älteste unter den jetzt lebenden Insectengattungen, (ihr gehören nach Hagen's Meinung ${ }^{1}$ ) die von Goldenberg beschriebenen Steinkohlentermiten an), so würde das etwa in ihren Jugendzuständen erhaltene Bild ihrer Vorfahren eine ähnliche Bedeutung für die Klasse der Insecten beanspruchen dürfen, wie $\mathrm{N}$ a uplius für die Kruster.

Die Antwort kann, scheint mir, schon jetzt, - schon ehe wir die späteren Schicksale der flügelförmigen Fortsätze kennen, - kaum zweifelhaft sein. Die jüngsten Larven von Calotermes rugosus leben mit ihren älteren Geschwistern an demselben Orte, von gleicher Nahrung, unter völlig gleichen Verhältnissen. Schon dies spricht dafür, dass ihre Eigenthümlichkeiten als ererbte, nicht als erworbene aufzufassen sind ${ }^{2}$ ). Wichtiger und ich glaube völlig durchschlagend ist ein anderer Grund. Die älteren Larven haben sich in ihrer Gestalt vollständig ihrem Aufenthaltsorte und ihrer Lebensweise angepasst; sie zeigen die Walzenform, die allen in der Erde wühlenden, in Stein oder Holz bohrenden Thieren eigen ist und oft Thieren der verschiedensten Klassen eine auffallende Aehnlichkeit verleiht; man denke an Regentvurm (Lumbric us) und Blindwühle (Coecilia lu mbricoides), Tatuira (Hippa) und Tatée (Dasypus), Maulwurfsgrille (Gryllotalpa) und Maulwurf (Talpa). Nicht so die jüngsten Larven. Ihre Gestalt ist so ungeeignet

I) Linnaea entomol. XII, S. 73 .

2) Vergl. Fritz Müller, Für Darwin S. 80. 8r. = Ges. Schriften S. 252. 
wie möglich für im Holze nagende Thiere; sie vürden hier gar nicht bestehen können, fänden sie nicht schon durch ältere Genossen für ihren geringen Umfang überflüssig weite Gänge ausgehöhlt. Also die älteren, nicht die jüngeren Larven haben sich ihrer gegenwärtigen, für beide gemeinsamen Lebensweise angepasst; letztere können ihren flacheren Leib, ihre weit vorspringenden flügelförmigen Fortsätze nicht an ihrem jetzigen Aufenthaltsorte erworben, sie können sie nur von anderwärts mit herübergenommen, d. h. von Vorfahren ererbt haben, die unter anderen äusseren Verhältnissen lebten.

Damit erscheinen aber die jüngsten Larven des Calotermes rugosus einer besonderen Beachtung um so mehr werth, je allgemeiner sich sonst die Jugendformen der Insecten als nachträglich erworbene herausstellen, die auf die dunkle Urgeschichte der Klasse auch nicht den Schimmer eines Lichtstrahls fallen lassen.

Die Larven des Calotermes rugosus sind auf ihrer ersten Altersstufe I,5 bis 2,5 mm lang, wovon etwa o,5 mm auf den Kopf, o,3 auf Vorder- und Mittelbrust, der Rest auf Hinterbrust und Hinterleib kommt. Der Kopf ist so breit wie lang, die Vorderbrust mit den flügelförmigen Fortsätzen doppelt so breit als der Kopf, der dritte breiteste Hinterleibsring fast so breit wie die Vorderbrust. Die Larven sind von schneeweisser Farbe, welche von dem durchscheinenden Fettkörper herrührt. So weit sie der Fettkörper nicht verhüllt, sind die inneren Theile grossentheils schon von aussen wahrzunehmen; so das Rückengefäss, die oberflächlichen Luftröhren, Gehirn und Bauchnervenknoten, ein Theil des Darmrohres und der Harngefässe, sowie die Ausführungsgänge der Speicheldrüsen und Speichelblasen.

Der Kopf erscheint von oben gesehen fast kreisrund; in der hinteren Hälfte ist die Rundung fast regelmässig; vorn zeigt er jederseits eine flache Bucht, in der die Kinnbacken sitzen und dicht hinter dieser eine kleine Fühlergrube. Die Fühler sind fadenförmig, etwa $0,7 \mathrm{~mm}$ lang und haben neun deutlich geschiedene borstentragende Glieder. Den Vorderrand des Kopfes überragt die Oberlippe, etwa halb so breit, als die Stirn, mit abgerundeten Ecken. Ausserdem treten (namentlich unter dem Drucke eines Deckgläschens) die Mundtheile über den Rand des Kopfes und der Oberlippe hervor, nicht weniger als 13 verschiedene Spitzen und Spitzchen (Fig. I7). Augen und Nebenaugen fehlen noch vollständig.

Die Breite der Vorderbrust erscheint verdreifacht durch die wagerecht abstehenden flügelförmigen Fortsätze, in welche ihre Rückenplatte nach rechts und links sich ausbreitet. Diese Fortsätze (Fig. 28) sind in der Mitte leicht gewölbt; Vorderrand und Aussenrand bilden einen ununterbrochenen Bogen, der mit dem ausgeschweiften Hinterrande in einer abgerundeten, hinterwärts gerichteten Ecke zusammenstösst. Ganz ähnlich, nur etwas kürzer und schmäler sind die Fortsätze der Mittelbrust. Die einen wie die anderen tragen am Rande vier längere Borsten. Die Hinterecke der vorderen legt sich bei Bewegungen über den Vorderrand der hinteren Fortsätze.

Die Hinterbrust scheint, von oben gesehen, eher dem Hinterleibe als der Brust anzugehören, sie ist vorn schmäler als hinten, wo sie in voller Breite mit dem Hinterleibe verbunden ist und die Seitenränder des Hinterleibes setzen sich in unveränderter Richtung bis zum hinteren Rande der Mittelbrust fort. Auch 
die Rückenplatte der Hinterbrust trägt seitliche Fortsätze, die aber sehr winzig und bei den allerjüngsten Larven kaum wahrzunehmen sind; sie entspringen nicht, wie bei Vorder- und Mittelbrust, vom ganzen Seitenrande, den sie kaum überragen, sondern an dessen vorderer Hälfte.

Die Beine gleichen denen älterer Thiere bis auf die noch fehlenden Enddornen der Schienen: die Füsse haben bereits vier Glieder ${ }^{1}$ ).

Der Hinterleib, der rasch wächst und dessen verschiedene Ausdehnung hauptlich die Verschiedenheit der Länge bei den Larven der ersten Altersstufe bedingt (Fig. $1-3$ ), verbreitert sich bis zu seinem dritten Ringe, um dann nach hinten bis auf ein Drittel oder weniger der hier erlangten Breite sich zu verjüngen und mit der halbkreisförmig abgerundeten zehnten Rückenplatte zu enden. Er ist in der Mittellinie höher als an den Seiten, gegen die er von der Mitte aus dachförmig abfällt; die Bauchseite ist flach. Die abgerundeten mit einigen Borsten besetzten Seitenränder der Rückenplatten pflegen seitlich etwas vorzuspringen. Eine Reihe von sechs kurzen Borsten steht nahe dem Hinterrande jeder Rückenplatte. Die seitliche Verbindungshaut zwischen Rücken- und Bauchplatten ist mit ganz kurzen spitzen Dörnchen besät (Fig. 28). Die Afteranhänge (Fig. 37 aa) überragen den Hinterleib nicht; noch kürzer sind die ungegliederten Bauchanhänge (Fig. 37 ba).

Ich wende mich nun zur genaueren Betrachtung einzelner Theile und der Veränderungen, die sie im Laufe der Entwickelung erleiden.

Fühler (Fig. 13-16). Die Fühler der jüngsten Larve haben neun deutlich geschiedene Glieder; das erste und zweite sind walzenförmig, letzteres dünner und bedeutend kürzer; das dritte etwa von Länge des ersten, nach dem Ende sich verdickend; vom vierten an, dem kürzesten von allen, ninımt die Länge der Glieder zu; die beiden letzten haben etwa die Länge des ersten und dritten. Das vierte bis sechste Glied sind tonnenförmig, das siebente bis neunte umgekehrt eiförmig; das letzte Glied ist merklich dünner, als das vorletzte. Die dünnen Borsten der Fühler bilden an jedem Gliede vom vierten an einen oberen längeren und einen unteren kürzeren Kranz, zwischen denen noch zerstreute kürzere Borsten stehen. Das dritte Glied zeigt sich anfangs nur undeutlich, später immer deutlicher durch zwei Ringfurchen in drei Stücke getheilt; nur das oberste dickste trägt einen Borstenkranz, die beiden unteren sind borstenlos. Gegen Ende dieser Altersstufe sieht man einen unter der Haut liegenden Kreis von Borsten am mittleren Stücke auftreten. Nach der Häutung, auf der folgenden Altersstufe (Fig. 14) erscheint dann das obere Stück des früheren dritten als kurzes viertes Glied, das mittlere als oberstes borstentragendes Stück des dritten Fühlergliedes. In gleicher Weise, durch Abschnürung neuer Glieder am Grunde des dritten findet auch weiterhin die Vermehrung der Fühlerglieder statt, deren Zahl bei den geflügelten Thieren dieser Art auf 16 steigt. Vor der letzten Häutung (Fig. I5) finden sich 15 borstentragende Fühlerglieder, deren drittes durch eine Ringfurche in einen oberen beborsteten und einen unteren borstenlosen Abschnitt getheilt ist. Falls

I) Dieselbe Gliederzahl finde ich an den Füssen der jüngsten Larven bei allen von mir untersuchten Termiten. Hagen unterschied (Linnaea entomol. XII, S. I8) nur „ein kurzes Basal- und ein längeres plumpes Glied, das an der Spitze 2 Klauen trägt", wahrscheinlich, weil seine Stücke nicht gut erhalten waren. Später (Linn. entomol. XIV, S. I 20) sagt er von den kürzlich dem Eie entschlüpften Jungen des Eutermes Rippertii: „die Trennung der drei ersten Fussglieder kaum ersichtlich.“ 
bei jeder Häutung ein neues F ühlerglied hinzukäme (eine nicht unwahrscheinliche, wenn schon noch nicht erwiesene Annahme), so würden die Larven im Ganzen sieben Häutungen zu bestehen haben. - Die Soldaten (Fig. I6) haben gewöhnlich I 3 Fühlerglieder, von denen das dritte bedeutend länger ist als seine Nachbarn; doch schwankt die Zahl von I I bis I 4 .

Die Zahl der Fühlerglieder gibt für die Beurtheilung der Altersstufe der Larven einen bequemen Anhalt, bequemer und sicherer, als die Länge der Larven, die je nach der Füllung des Darmes sehr wechselt; der Hinterleib eines hungernden Thieres kann auf seine halbe Länge zusammenschrumpfen.

Auf Grund dieser Entwickelungsweise darf man auch an den Fühlern der Termiten Schaft und Geissel unterscheiden, ersterer besteht aus den beiden Grundgliedern letztere aus der wechselnden Zahl der übrigen. Von der späteren Entwickelung auf die frühere innerhalb des Eies zurückschliessend, durfte man erwarten, dass die Geissel ursprünglich nur aus einem einzigen Gliede bestehen würde, von dessen unterem Ende sich das vorletzte abschnürt, von diesem das drittletzte u. s. w. Und wirklich sah ich (Fig. 12) im Ei einer anderen Calotermes-Art zu einer Zeit, wo die Beine noch völlig ungegliederte Stummel waren, die Fühler in drei deutliche Glieder (den zweigliedrigen Schaft und die eingliedrige Geissel) getheilt.

Die Zahl der Fühlerglieder ist, wie schon Hagen bemerkt, bei den einzelnen Termitenarten "nicht ganz constant; oft findet sich eins mehr oder weniger" 1 ). Trotzdem bietet diese Zahl meist ein recht gutes Artkennzeichen, wenn man die eben geschilderte Entwickelungsweise berücksichtigt; die verschiedene Gliederzahl beruht fast immer darauf, dass eine der letzten Abschnürungen unterbleibt, oder auch eine mehr als gewöhnlich eintritt; man findet daher bei überzähligen Fühlergliedern das dritte Glied kürzer, bei fehlenden länger als gewöhnlich; seltener finden sich zwei der nächsten Glieder verschmolzen, oder eines derselben in zwei zerfallen. Man hat deshalb stets neben der Zahl der Fühlerglieder auch Länge und Gestalt des dritten und der nächstfolgenden in's Auge zu fassen.

Das dritte Fühlerglied ist bei den Termiten nach Grösse und Gestalt das wandelbarste, mag man verschiedene Arten oder die verschiedenen Stände derselben Art vergleichen. Der Grund mag einfach darin liegen, dass es, wie wir gesehen, das jüngste ist ${ }^{2}$ ).

Mundtheile (Taf. XLI Fig. I7-25). Oberlippe (labrum). Die Oberlippe pflegt in der Gattung Calotermes nicht länger oder selbst kürzer als breit $\mathrm{zu}$ sein, ziemlich geraden Vorderrand, abgerundete Vorderecken zu haben und etwa die halbe Breite der Stirn einzunehmen. So auch schon bei den jüngsten Larven des Calotermes rugosus (Fig. I 7 ol). Eine andere Eigenthümlichkeit dieser Gattung besteht darin, dass nahe dem Vorderrande der Oberlippe eine Querreihe längerer Haare steht (Fig. 23); auch diese sind bei der jüngsten Larve schon vorhanden, wenn auch noch sehr kurz. (Man vergleiche Fig. I 7 ol in Bezug

1) Linn. entomol. XII, S. 6.

2) Dasselbe Verhältniss kehrt auch bei anderen Insecten wieder, z. B. bei den Bienen, bei welchen bekanntlich das dritte bisweilen das kürzeste, bisweilen das längste aller Fühlerglieder ist. Auch bei den Bienen ist, wie mir scheint, das zweite Fühlerglied zum Schafte und nicht, wie es jetzt ïblich ist, zur Geissel zu rechnen. 
auf Gestalt und Behaarung mit Fig. 27, welche die Oberlippe der jüngsten Larve von Anoplotermes pacificus darstellt.)

Kinnbacken (mandibulae). Beim Auskriechen aus dem Ei sind die Kinnbacken weich und weiss; doch bald beginnen sie zu verhärten und ihr Innenrand bräunt sich. Wahrscheinlich sind die Larven von Calotermes rugosus, wie von anderen Calotermes-Arten, im Stande sich selbt zu ernähren, sobald der Nahrungsvorrath, den sie aus dem Eie mitbringen, verbraucht ist, ohne dass sie je von ihren älteren Geschwistern gefüttert werden. Sobald die Verhärtung des Innenrandes eingetreten ist, erscheinen dessen vorher minder scharf ausgeprägte Zähne und Vorsprünge in einer Form (Fig. 20), die kaum von derjenigen der älteren Larven und der geflügelten Thiere (Fig. 25) abweicht. Man unterscheidet dann, wie bei anderen Termiten ${ }^{1}$ ), zwei scharfe Schneidezähne am oberen, eine quergeriefte Kaufläche am unteren Ende des Innenrandes. (Auf der Zeichnung sind die bei Calotermes rugosus schwach entwickelten, nur bei stärkerer Vergrösserung zu erkennenden Querleisten der Kaufläche nicht zu sehen.) Die Richtung der Kaufläche ist bei dem Kinnbacken der rechten und dem der linken Seite sehr verschieden. Eine Gerade, die man von der Spitze des obersten Zahnes nach dem am untern Ende des Aussenrandes liegenden Gelenkhöcker zöge, würde bei den jüngsten Larven des Calotermes rugosus mit der Kaufläche des linken Kinnbackens einen Winkel von etwa $45^{\circ}$, mit der des rechten von etwa $100^{0}$ bilden. Geringer ist die Verschiedenheit der Richtung bei den geflügelten Thieren. Zwischen den beiden oberen Zähnen und der Kaufläche liegt ein dritter Zahn, der am linken Kinnbacken der Kaufläche, am rechten den oberen Zähnen genähert ist. Dieser dritte Zahn des rechten Kinnbackens ist stumpf bei der jüngsten Larve, spitz bei den geflügelten Thieren. - Aehnliche Verschiedenheiten zwischen rechtem und linkem Kinnbacken zeigen auch die übrigen Termiten (sowie nach Westwood ${ }^{2}$ ) die verwandten Psociden); sie machen sich selbst noch geltend an den verkümmerten Kinnbacken der spitzköpfigen Soldaten von Eutermes.

Schneidende Zähne am oberen, eine quergeriefte Kaufläche am unteren Ende des inneren Kinnbackenrandes sieht man, wie bei den Termiten, so auch bei der Zoëa-Form der aus Nauplius-Brut sich entwickelnden Garneelen. Ueberhaupt sind ähnlich gebaute Kinnbacken unter den höheren Krustern sehr häufig, unter den Insecten nicht selten, und man fühlt sich versucht, dabei an gemeinsamen Ursprung zu denken. Für sich allein wird jedoch diesem ähnlichen Bau der Kinnbacken kein grosses Gewicht beizulegen sein; die Einrichtung ist zu bequem, als dass sie nicht leicht selbständig bei verschiedenen Thieren sich hätte ausbilden können. Zeigt doch unser eigenes Gebiss einc ähnliche Verbindung von Schneidezähnen mit dahinterliegenden Mahlzähnen.

$\mathrm{Zunge} \mathrm{(lingua,} \mathrm{hypopharynx)} \mathrm{(Fig.} \mathrm{17} \mathrm{z,} \mathrm{Fig.} \mathrm{19).} \mathrm{Wie} \mathrm{von} \mathrm{vorn} \mathrm{und} \mathrm{oben}$ durch die Oberlippe, so ist die zwischen den Kinnbacken liegende Mundöffnung von hinten und unten durch die sogenannte Zunge gredeckt. Bei den jüngsten

I) Wenn ich von Termiten im Allgemeinen spreche, beziehe ich mich nur auf die mir bekannten Arten. Nach Hagen gibt es Arten mit sechs Zähnen am Innenrande der Kinnbacken. Solche kenne ich nicht.

2) Introduct, to the modern Classific. of Insects. Fig. 59. 2. 3 . 
Larven bildet diese ein ansehnliches gleichschenklig dreieckiges Blatt mit einem Winkel von etwa $45^{\circ}$ an der Spitze; am Grunde, wo sie mit der sogenannten Unterlippe verbunden ist, ist sie etwa so breit, wie die Oberlippe und dabei fast doppelt so lang. Es ist die mittelste, unpaare unter den zahlreichen Spitzen (Fig. I 7), die den Vorderrand des Kopfes überragen.

Später bleibt die Zunge im Wachsthum gegen die benachbarten Theile etwas zurück; sie wird vorn breiter, stumpfer und namentlich wird sie dicker; beim geflügelten Insect (Fig. 24, von der Seite) nähert sich ihre Gestalt der einer menschlichen Zunge; ihre leicht gewölbte obere (vordere) Fläche ist dicht mit kurzen, zarten, rückwärts gerichteten Haaren bekleidet. - In den Eiern einer anderen Calotermes-Art sah ich hinter den Kinnbacken und zwischen den „Unterkiefern“ einen paarigen rundlichen Vorsprung (Fig. I $2 x$ ), dessen weitere Entwickelung zu verfolgen ich bis jetzt keine Gelegenheit hatte und von dem ich unentschieden lassen muss, ob er den inneren Ast des Unterkiefers oder die erste Anlage der Zunge darstellt. In letzterem Falle wäre diese in frühester Zeit zweitheilig, wie sie es gewöhnlich bei den Krustern ist. Bei den Krustern pflegt man bekanntlich dieses unpaare meist zweispaltige Blatt, das von unten her die Mundöffnung deckt, Unterlippe zu nennen und das würde wohl auch für die Insecten der zutreffendste Name sein, wenn derselbe hier nicht unpassender Weise an das zweite Kieferpaar vergeben wäre. - Auffallend ist die Aehnlichkeit zwischen Oberlippe und Zunge bei den jüngsten Larven von A noplotermes pacificus (Fig. 26, 27); beginnt man das Rohr des Mikroskops zu senken, nachdem man die Oberlippe eingestellt, so ist diese kaum verschwunden, wenn auch schon an gleicher Stelle und in täuschend ähnlicher Gestalt die Zunge sich zeigt; man meint noch einmal die ihrer Haare beraubte Oberlippe vor sich zu haben.

Vordere Kiefer (Unterkiefer, maxillae). Taster und äussere Lade (Fig. 1 7, I $8 k t$ und $k l a)$ erscheinen schon bei der jüngsten Larve ziemlich in ihrer späteren Gestalt; an der inneren Lade (Fig. $18 k l i$ i $8^{a}$ ) sind die beiden starken Zähne, in die sich später ihre Spitze spaltet, noch sehr klein und der breite, häutige, am Rande mit kammartig geordneten steifen Borsten besetzte Lappen, in welchen sich später der untere Theil ihres Innenrandes ausbreitet, kaum angedeutet und nur mit ganz kurzen Borsten besetzt. - Bei den Soldaten (Fig. 22) bleiben an beiden Kieferpaaren (wie es überhaupt für die Termiten Regel ist), die Laden in ihrem Wachsthum gegen die Taster zurück, sind aber in ihrer Gestalt kaum von denen der älteren Larven und der geflügelten Thiere verschieden.

Hintere Kiefer (Unterlippe, labium). Das zweite Kieferpaar, die sogenannte Unterlippe, erleidet während der Entwickelung der Larve keine bemerkenswerthe Veränderung. Schon bei der jüngsten Larve ist die, wvie es scheint, allen Termiten gemeinsame Verschiedenheit zwischen äusserer und innerer Lade (Fig. I 8 la u. li) deutlich ausgeprägt; die äussere Lade trägt einzelne kurze Borsten; die innere Lade ist in ihrer unteren Hälfte mit winzigen, sehr kurzen Börstchen bedeckt, ihr oberes Ende ist kahl, zarthäutig an der Spitze meist abgerundet, und nahe der Spitze sieht man einen kleinen dunkelgerandeten Kreis, zu welchem man bisweilen ein Nervenfädchen verfolgen kann, oder an dessen Stelle ein zartes blasses Haar (Eutermes), oder ein "Taststiftchen“ (Termes saliens, Arbeiter). 
Die flügelförmigen Fortsätze (Fig. 28-30). Wir kommen nun zu der auffallendsten und wichtigsten Eigenthümlichkeit unserer Larve, den flügelförmigen Fortsätzen der Vorder- und Mittelbrust. Zunächst ist hervorzuheben, dass dieselben ohne Frage vollkommen gleichwerthige („homodyname“) Gebilde sind. Beide, die Fortsätze der Vorderbrust und die der Mittelbrust, nehmen die ganze Seite der Rückenplatte ein, ragen wagerecht nach aussen, sind leicht gewölbt; Vorder- und Aussenrand sind gewölbt und stossen mit dem ausgeschweiften Hinterrande in einer hinterwärts gerichteten Ecke zusammen; bei beiden zeichnen sich unter den Haaren oder Borsten des Randes vier durch ihre Grösse aus; bei beiden zieht sich am Rande hin ein nicht von besonderen Wänden begrenzter Kanal; beide scheinen ausserdem von unregelmässigen Kanälen oder Lücken durchzogen zu sein. Unter der grossen Zahl junger Larven, die ich lebend beobachtete, sah ich nur bei einer diese Lücken in den Fortsäzen der Mittelbrust von einem ziemlich reichen Blutstrom durchzogen; zahlreiche Körnchen (Blutkörperchen ?) ${ }^{1)}$ traten in den Randkanal ein am Anfang des hinteren Randes, umkreisten zum Theil, im Randkanal fortgehend den Fortsatz, während andere in unregelmässigen Bahnen ihn durchsetzten und traten vorn am Ende des Randkanals in den Leib zurück.

So ähnlich die Fortsätze der Vorder- und die der Mittelbrust bei den jüngsten Larven sind, so verschieden sind ihre späteren Schicksale.

Die Fortsätze der Vorderbrust unterliegen einer rückschreitenden Umwandlung; sie bleiben im Wachsthum zurück und werden geradezu kleiner bei späteren Häutungen. Ist anfangs die Vorderbrust mit ihren Fortsätzen doppelt so breit als der Kopf, so ist sie schon bei Larven mit I I Fühlergliedern nur noch etwa anderthalbmal so breit. Dabei ändert sich ihre Gestalt in der Weise, dass die nach hinten gerichtete Ecke sich mehr und mehr abrundet und schwindet, so dass endlich der Hinterrand der Vorderbrust mit dem Aussenrande der Fortsätze einen durch keine Aenderung der Krümmungsrichtung unterbrochenen Bogen bildet (Fig. 6). Schliesslich bleibt von ihnen nur ein schmaler, etwas herabgebogener Saum übrig, wie ihn auch andere Calotermes-Arten besitzen.

Die Fortsätze der Mittelbrust scheinen, wenn man die Thiere nur oberflächlich von oben betrachtet, noch rascher zu schwinden, als die der Vorderbrust (Fig. 6), Sieht man genauer zu, so findet man, dass sie sich (bei Larven mit i I bis I 2 Fühlergliedern), nach unten und hinten biegen, dicht dem Leibe anlegen und weiterwachsend sich zu den Vorderflügeln entwickeln. Schon sehr frühe und ehe sich noch ihre ursprüngliche Gestalt und Behaarung wesentlich ändert, sieht man, als erste Anfänge der späteren Flügeladern, Luftröhren in sie hineinwachsen. Schon bei Larven mit 10 Fühlergliedern (zweite Altersstufe) sah ich zwei noch ganz kurze Luftröhren. Bei Larven mit I I Fühlergliedern findet man diese Luftröhren bereits vollzählig (Fig. 29), nämlich drei, die der Subcosta, Mediana und Submediana (nach Hagen's Bezeichnung) entsprechen. Die Randader (Costa) erhält keine Luftröhre; sie entsteht aus dem Randkanal des Fortsatzes. (Vergl. die Ver-

1) Bei Krusterlarven ist es mir wiederholt begegnet, dass ich an einzelnen Thieren den Kreislauf bequem verfolgen konnte, während im Blute der Mehrzahl geformte Bestandtheile fast vollständig fehlten und in einigen Fällen konnte ich mich überzeugen, dass bei ersteren nıcht Blutkörperchen, sondern schmarotzende Infusorien mit dem Blute kreisten. 
theilung der Luftröhren in einem ausgewachsenen Flügelansatz des Calotermes Hagenii, Fig. 49.)

Die anfangs sehr winzigen Fortsätze der Hinterbrust holen allmählich die der Mittelbrust ein und sind schliesslich von ihnen nur durch eine etwas verschiedene Anordnung der Luftröhren zu unterscheiden. Bei erwachsenen Larven reichen die Flügelansätze der Hinterbrust bis zum Ende des zweiten Hinterleibsringes. (Fig. Io, von Calotermes $\mathrm{Hagenii,} \mathrm{der} \mathrm{sich} \mathrm{hierin} \mathrm{ganz} \mathrm{wie} \mathrm{Calo-}$ termes rugosus und andere Calotermes verhält.)

Die seitliche Lage der Flügelansätze unterscheidet die Larven der Calotermes von denen der Termes, Eutermes und Anoplotermes (Fig. I I), bei welchen sie dem Rücken aufliegen. Bei letzteren Gattungen verlängern sich in der letzten Zeit des Larvenlebens (bei den sogenannten Nymphen) die Flügelscheiden bedeutend, so dass sie fast bis zum Ende des Hinterleibes reichen; bei Calotermes findet eine solche Verlängerung nicht statt, dagegen eine sehr merkliche Verdickung.

Bei den Soldaten des Calotermes rugosus schwinden auch die Flügelfortsätze der Mittelbrust, wie die der Vorderbrust, bis auf einen schmalen, nach hinten etwas breiteren Saum (Fig, 7, 8). Diese verkümmerten Flügelfortsätze der Soldaten von Calotermes rugosus (Fig. 30) sind bei aller Unscheinbarkeit recht merkwürdige Gebilde. Einerseits verrathen noch die vier Borsten ihres Randes ihre Herkunft aus den ansehnlichen flügelförmigen Fortsätzen der jungen Larven, andererseits lässt der Verlauf ihrer Luftröhren nicht nur die Gattung Calotermes erkennen (an dem langen Aste, den die Subcosta (sc) ins Randfeld abgibt), sondern beinahe die Art (daran, dass sich kurz nach Abgabe dieses Astes die Mediana $(m)$ an die Subcosta (sc) anlegt; denn nur bei Calotermes rugosus und nodulosus findet eine ähnliche Verbindung dieser beiden Adern statt).

Suchen wir die eben dargelegten ,ontogenetischen" Thatsachen für die Urgeschichte (Phylogenie) der Insecten zu verwerthen.

Die flügelförmigen Fortsätze der jüngsten Larven von Caloterm es rugosus sind nicht von diesen erworben, sondern von ihren Vorfahren ererbt worden. Die Fortsätze der Vorder- und die der Mittelbrust sind gleichwerthige Gebilde. Aus den Fortsätzen der Mittelbrust entwickeln sich die Vorderflügel. - Fassen wir diese drei, wie mir scheint, unanfechtbaren Sätze zusammen, so ergibt sich als Antwort auf die Frage nach der Herkunft der Insectenflügel:

I) Die Flügel der Insecten sind nicht aus „Tracheenkiemen“ entstanden $\left.{ }^{1}\right)$. Die flügelförmigen Fortsätze der jüngsten Larven sind gerade die einzigen Theile, denen Luftröhren vollständig fehlen, während sie im ganzen übrigen Leibe reichlich entwickelt sind (s. u.).

2) Die Flügel der Insecten sind entstanden aus seitlichən Fortsätzen der Rückenplatten der betreffenden Leibesringe. - Aehnliche Fortsätze treten in grosser Zahl und Mannichfaltigkeit bei den Krustern auf, den ganzen Leib oder

I) Eine ausführliche Besprechung der Ansicht Gegenbaur's, dass das geschlossene Tracheensystem vieler Insectenlarven als Vorläufer des nach aussen communicirenden zu betrachten sei, und dass die Flügel der Insecten aus Tracheenkiemen hervorgegangen, behalte ich mir für eine andere Gelegenheit vor. 
Theile desselben schildförmig deckend oder schalenartig umschliessend. Falls also, was allerdings noch des Beweises bedarf, die Insecten von Krustern abstammen, würde man die Flügel der ersteren als den Seitentheilen des Rückenschildes der letzteren entsprechende Bildungen ansehen dürfen.

Welche Verrichtung den flügelförmigen Fortsätzen oblag, mit denen die Vorfahren der Termiten ausgestattet waren, darüber lassen sich natürlich für jetzt nur ganz unsichere Vermuthungen aussprechen. - Der Uebergang vom Leben im Wasser zum Leben in trockener Luft ist jedenfalls durch den Aufenthalt an feuchten Orten vermittelt worden. Die Gestalt unserer jüngsten Larven würde nun ganz wohl gepasst haben für den Aufenthalt zwischen feuchtem moderndem Laube. Hier oder an ähnlich feuchten Orten dürften die flügelförmigen Fortsätze in ähnlicher Weise der Athmung gedient haben, wie die seitlichen Fortsätze der Rückenplatte (die „Seitentheile des Panzers") bei Zoëa und Tanais. Für diese Deutung der flügelförmigen Fortsätze als Athmungswerkzeuge in feuchter Luft dürfte namentlich auch ihr vollständiger und bei ihrer Grösse sehr auffälliger Mangel an Luftröhren anzuführen sein. Denn wenn später neben ihnen und mit der Zeit sie vollständig ersetzend, sich die Athmung durch Luftröhren ausbildete, und wenn diese auch sonst überallhin im Leibe sich verzweigten, so blieben sie doch natürlich jenen Flügelfortsätzen fern, so lange diese selbst in anderer Weise die Athmung vermittelten. Erst, als sie einer anderen Verrichtung dienstbar wurden, zu Flügeln sich umwandelten, erhielten auch sie Luftröhren, wie wir es noch heute an diesen Urflügeln der Mittelbrust bei Calotermes rugosus sehen.

Beine (Fig. 31-35). Die vier Fussglieder sind bereits bei den jüngsten Larven deutlich geschieden; die Sohle der beiden ersten springt noch nicht nach unten vor (Fig. 3I), wie es auch später (Fig. 34, 35) nur in mässigem Grade bei Calotermes, meist in weit höherem Grade bei den übrigen hiesigen Termiten der Fall ist. Die drei Enddornen der Schienen, anfangs fehlend oder kaum angedeutet, treten sehr zeitig als winzige Höckerchen auf, erreichen aber erst bei den ausgewachsenen Larven ihre volle Grösse. Der Haftlappen zwischen den Fussklauen (Fig. $35 h$ ) fehlt den Larven und Soldaten. - Das Merkwürdigste an den Beinen der Termiten ist ein Gebilde, das in den Schienen aller Beine bei allen Ständen aller mir bekannten Arten vorkommt und dessen Lage meist schon äusserlich an einem queren Eindruck etwas unterhalb des Kniees, an der Streckseite der Schiene zu erkennen ist. Dasselbe bildet einen birn-oder flaschenförmigen, seltener fast kugligen Körper, der mit kurzem Stiel oder Hals an der bezeichneten Stelle mit der Wand der Schiene verbunden ist. Es scheint nervöser Natur zu sein und erinnert in seiner Lage an das Hörorgan der Laubheuschrecken; mein Mikroskop genügt nicht, um eine befriedigende Einsicht in seinem feineren Bau zu gewinnen. Die aus dem Schenkel in die Schiene eintretende Luftröhre spaltet sich sofort in zwei Aeste, die sich in der Mitte oder gegen das Ende der Schiene wieder vereinigen und von denen der eine in der Gegend des fraglichen, ihm dicht anliegenden Gebildes blasig anschwillt. Diese Anschwellung der Luftröhre fehlt noch bei den jüngsten Larven des Calotermes rugosus (Fig. 32).

In der Regel besteht bei den Termiten kein erheblicher Unterschied zwischen den Beinen desselben Thieres (die Hinterbeine sind etwas länger, die Vorderbeine 
bisweilen abweichend beborstet); nur bei den Arbeitern von Anoplotermes pacificus ist die ganze Vorderschiene merklich verbreitert und die Anschwellung der Luftröhre erstreckt sich bis fast an's Ende derselben (Fig. 36).

Hinterleib. Ueber die Formwandlungen des Hinterleibes ist nur zu sagen, dass er sich allmählich mehr und mehr der Walzenform nähert, wie sie für die erwachsenen Larven und Soldaten von Calotermes bezeichnend ist. Wann der Unterschied zwischen Männchen und Weibchen in der Bildung der achten Bauchplatte des Hinterleibes zuerst sich bemerklich macht, kann ich nicht sagen, da ich nicht darauf geachtet habe.

Aus gleichem Grunde kann ich nicht über etwaige, jedenfalls unerhebliche Veränderungen des Rückengefässes und des Nervensystems berichten.

Verdauungiverkzeuge. Darmrohr. Die enge Speiseröhre der jüngsten Larve von Calotermes rugosus erweitert sich in der Mitte der Brust allmählich, um ohne scharfe Grenze in den spindelförmigen Vormagen (Fig. $38 \mathrm{vm}$ ) überzugehen, der in der Nähe seines hinteren Endes mit einem Kranze von Kauleisten (Fig. $38 \mathrm{kl}$, Fig. 40, 4I) versehen ist. Der Vormagen liegt nicht in der Mittellinie, sondern ist schief nach links und hinten gerichtet (Fig. $6 \mathrm{vm}$ ) und reicht bis in den dritten Hinterleibsring. Sein Ende ist meist ziemlich stark in den Anfang des folgenden Darmabschnittes, des Magens oder Mitteldarmes, eingestülpt. Der Mitteldarm (Fig. $38 m d$ ) wendet sich nach oben, läuft dicht unter der Rückenwand des dritten Hinterleibringes nach rechts und wenig nach vorn, um dann wieder nach links und unten umzubiegen; er bildet so eine fast vollständige Schlinge, und das durch die Einmündung der Harngefässe bezeichnete Ende liegt seinem Anfange nahe. Hinter der Einmündung der Harngefässe erweitert sich der Darm zu einem kugligen Sack oder Blinddarm (Fig. 38 bd), dessen Eingang und Ausgang nahe beisammen liegen; der nun folgende dünnere Theil des Enddarmes (Fig. $38 \mathrm{ed}$ ) beschreibt einen kurzen nach vorn gerichteten Bogen und läuft dann anfangs an der rechten Seite, zuletzt in der Mittellinie nahe der Rückenwand nach hinten und endet mit einem kurzen erweiterten Endstück. Schon sehr zeitig, sobald die Kinnbacken erhärtet sind, findet man $\mathrm{Holz}$ im Darme.

Der anfangs kuglige Blinddarm nimmt rasch an Grösse zu und füllt schon bei halbwüchsigen Larven den grösseren Theil des Hinterleibes, vom dritten Ringe an bis fast an's Ende, in seiner ganzen Breite aus. Bei den Soldaten scheint sein Umfang wieder etwas abzunehmen, und in höherem Grade ist dies bei den geflügelten Männchen und Weibchen der Fall.

Während die übrigen Arten der Gattung Calotermes in dieser Beziehung mit Calotermes rugosus übereinstimmen, zeigen dagegen die Arten der Gattungen Termes, Eutermes, Anoplotermes eine so überraschende Mannichfaltigkeit im Baue ihres Darmrohres, wie sie vielleicht nirgends sonst innerhalb eines Kreises äusserlich so ähnlicher Thiere sich findet. Allen hiesigen Arten gemeinsam und sie von Calotermes unterscheidend ist die Gestalt des Vormagens (Fig. $39 \mathrm{vm}$ ), dessen linke Seitenwand verkürzt, die rechte kuglig aufgetrieben ist, so dass Eingang und Ausgang nicht mehr einander gegenüberliegen, sondern ersterer vorn, letzterer links. Bisweilen ist der mit Kauleisten 
bewehrte Endabschnitt ziemlich scharf abgesetzt, so dass man mit Hagen den Vormagen in Kropf und Kaumagen scheiden könnte.

Die Kauleisten (Fig. 40, 41) sind bei den allerjüngsten Larven des Calotermes rugosus noch weich und farblos und deshalb leicht zu übersehen. Doch bräunen sie sich, wie der Rand der Kirnbacken, sehr zeitig, noch ehe die Zahl der Fühlerglieder wächst; und gerade solche junge Larven sind dann besonders geeignet, ein klares, übersichtliches Bild derselben zu geben. Man unterscheidet sechs Kauwülste erster Ordnung (kw I), die aus einem schmalen aber höheren vorderen und einem flacheren kreisförmig verbreiterten hinteren Theile bestehen; letzterer bleibt farblos; die gleichlaufenden Ränder des vorderen Theiles werden durch dunklere harte Leisten gebildet. - Mit diesen ersten sechs wechseln sechs Kauwülste zweiter Ordnung ( $k w$ II) ab, von jenen durch den Mangel der grossen flachen Scheibe am hinteren Ende unterschieden und endlich wechseln mit diesen zwölf grösseren wieder zwölf bedeutend kleinere Kauwülste dritter Ordnung ( $k w$ III) ab. - Obwohl im Einzelnen bei verschiedenen Arten von Termes und Eutermes ziemlich verschieden gestaltet, lassen sich deren Kauleisten doch alle auf die von Calotermes als ihre Grundform zurückführen, wobei die sechs überall deutlich entwickelten blassen Endscheiben einen bequemen Anhaltspunct bieten. Der soldatenlosen, Erde fressenden Gattung, A n o pl o t e r m es fehlen die Kauleisten.

Speicheldrüsen (Fig. 42). Nach den Angaben Hagen's über Termes bellicosus ${ }^{1}$ ) würden erhebliche Verschiedenheiten im Bau der Speicheldrüsen bei den verschiedenen Ständen derselben Art bestehen; ich habe solche nirgends bei den von mir untersuchten Arten gefunden. Die Termiten scheinen allgemein zwei sehr ansehnliche Speicheldrüsen zu besitzen, die ihrer Hauptmasse nach im Anfang des Hinterleibes, rechts vom Vormagen zu liegen pflegen, sowie zwei grosse dünnhäutige Speichelblasen, die nach hinten noch über die Speicheldrüsen hinausragen. In der dünnen Wand der Speichelblasen konnte ich nie eine Spur von drüsigem Bau gewahren. Die Speicheldrïse bildet bald eine zusammenhängende tiefgelappte Masse, wie bei Calotermes, bald ist sie mehr weniger vollständig in einzelne rundliche, den Endzweigen des baumförmig verästelten Ausführungsganges aufsitzende Theile zerfallen. Der Speichelblasengang (Fig. 42 sbg) liegt nach aussen vom Speicheldrüsengang $(s d g)$; er ist weiter, aber viel dünnwandiger, als letzterer. Die innerste Haut beider Gänge zeigt quere (wahrscheinlich wie in den Luftröhren schraubenförmige) Linien, wie sie ja auch in den Speichelgängen anderer Insecten, z. B. der Bienen, auftreten. Der Speichelblasengang mündet unter spitzem Winkel in den Speicheldrüsengang seiner Seite meist erst beim Eintritt oder nach dem Eintritt in den Kopf. Der rechte und der linke Speichelgang münden entweder getrennt, dicht neben einander, am Grunde der Zunge, wie bei Termes Lespesii und saliens (Fig. 43), oder sie vereinigten sich $\mathrm{zu}$ einem unpaaren, bei Calotermes (Fig. I $8 \mathrm{sg}$ ) ziemlich langen Gange. Bei Termes bellicosus, der auch im Bau der Soldaten die Mitte hält zwischen Calotermes und Termes Lespesii, zeichnet Hagen ${ }^{2}$ ) einen ganz kurzen unpaaren Speichelgang.

I) Linnaea entomol. XII, S. 302.

2) Peters' Naturw. Reise nach Mossambique. Insecten. Taf. III Fig. 18b. 
Schon bei den jüngsten Larven von Calotermes rugosus zeigen sich an den Speicheldrüsen die Eigenthümlichkeiten ihrer Gattung vollständig ausgeprägt. Man kann, wenn man diese Larven von der Unterseite betrachtet, von der Mitte der Unterlippe aus (Fig. I8) den unpaaren Speichelgang ( $s g$ ) nach hinten verfolgen bis zu seiner Entstehung aus den beiden seitlichen Speichelgängen und diese weiter bis über die Stelle hinaus, wo sich Speichelblasengang $(s b g)$ und Speicheldrüsengang $(s d g)$ vereinigen.

Harngefässe. Die jüngste Larve besitzt vier Harngefässe; doch bald sieht man neben ihnen ein drittes Paar hervorsprossen und bei einer Larve etwa vom Alter der Fig. 5 gezeichneten fand ich bereits die volle Zahl, nämlich acht, von denen jedoch vier kürzer und erst kaum halb so weit waren, als die vier älteren. Bei vielen Arten von Termes und ebenso bei Eutermes und Anoplotermes bleibt die Zahl der Harngefässe zeitlebens auf vier beschränkt.

A the mwerkzeuge (Taf. XLIII). Ueber die Luftröhren der Termiten liegen nur sehr dürftige und selbst in Betreff der Zahl und Lage der Luftlöcher nicht übereinstimmende Angaben vor.

Die Luftröhren sind schon bei den jüngsten Larven des Calotermes rugosus wohl entwickelt und gerade bei ihnen leichter als in späterer Zeit im Zusammenhange zu überblicken. Es sind so Paar Luftlöcher vorhanden, zwei in der Brust, acht im Hinterleibe. Das erste Paar liegt zwischen Vorder- und Mittelbrust, das zweite zwischen Mittel- und Hinterbrust. Zwischen Hinterbrust und erstem Hinterleibsringe finden sich keine Luftlöcher. Die übrigen acht Paare liegen am Rande der acht ersten Rückenplatten des Hinterleibes.

Die Verästelung der von den Luftlöchern der Brust entspringenden Luftröhren, welche starke Aeste in den Kopf, andere in die Beine abgeben, ist eine sehr verwickelte; ich habe sie nicht vollständig entwirren können (vgl. Fig. 48 , von der jüngsten Larve einer anderen $\mathrm{Ca}$ lotermes-Art). In die flügelförmigen Fortsätze der Vorder- und Mittelbrust treten während der ersten Altersstufe keine Luftröhren, in die der Vorderbrust auch später nicht.

Die Luftlöcher des Hinterleibes führen zunächst in ein kurzes Sförmig gebogenes blindes Rohr (Fig. 44 ), das vor der Mitte ein ganz kurzes Aestchen hat. Etwa in der Mitte dieses blinden Rohres, oder noch vor derselben entspringt der Stamm der Luftröhren, der jetzt, in frühester Jugendzeit, bedeutend enger ist, als das Sförmige Rohr. Der Stamm der Luftröhren theilt sich bald in einen Bauch- und einen Rückenast ( $b$ und $r$ ), und jeder von diesen wieder in einen vorderen und einen hinteren Zwveig $(b v, b h ; v v, r h)$; ersterer verbindet sich mit dem hinteren Zweige des vorhergehenden, letzterer mit dem vorderen Zweige des folgenden Paares. So wird jederseits sowohl auf der Rücken-, wie auf der Bauchseite ein im Zickzack verlaufendes Längsrohr hergestellt, von welchem in jedem Ring ein nach der Mittellinie sich wendender Querzweig $(b q, r q)$ abgeht. Der Bauchast ist bis zur Theilung kürzer als der Rückenast; bei jenem ist der vordere, bei diesem der hintere Zwveig der längere. - Der quere Zweig des Rückens $(r q)$ verästelt sich, ohne weitere Verbindungen mit anderen einzugehen, und scheint namentlich das Rückengefäss zu versorgen. Der quere Zweig des Bauches $(b q)$ verbindet sich mit dem der anderen Seite und sendet in der Nähe der Mittellinie einen Längszweig $(l)$ nach vorn, einen anderen nach hinten zur 
Verbindung mit dem davor und dem dahinter liegenden Querzweige. Es wird auf diese Weise in der Mitte der Bauchseite eine Leiter von Luftröhren gebildet, zwischen deren Sprossen die Bauchnervenknoten liegen, welche ihre Luftröhren $(n)$, eine von rechts, eine von links, aus der hinter ihnen liegenden Sprosse der Leiter empfangen. - Von der Vertheilung der Luftröhren an das Darmrohr habe ich kein zusammenhängendes Bild erhalten.

Die spätere Entwickelung bringt nur insofern eine Aenderung in den eben geschilderten Verhältnissen der Athemwerkzeuge hervor, als das Sförmige blinde Rohr fast gar nicht weiter wächst und daher schliesslich weit enger ist, als die von ihm ausgehenden Luftröhren. Man vergleiche die bei gleicher Vergrösserung gezeichneten Figuren 46 und 47 , von denen erstere der jüngsten Larve, letztere dem geflügelten Weibchen des Calotermes rugosus entnommen ist. Der frühe Stillstand im Wachsthum des Sförmigen Rohres, sein winziger Umfang beim erwachsenen Thiere, scheinen darauf hinzuweisen, dass dasselbe ein aus entlegener Vorzeit ererbtes, für die heutigen Termiten fast oder völlig nutzloses Gebilde ist. -

Mit Calotermes rugosus stimmen, soweit meine Erfahrung reicht, alle übrigen Arten der Gattung in der Anordnung der Luftröhren überein. Auch bei allen übrigen Termiten scheint Zahl und Lage der Luftlöcher stets dieselbe zu sein; das Sförmige blinde Rohr scheint am Hinterleibe nirgends $z u$ fehlen, an den beiden Paaren der Brust nirgends vorzukommen, so wenig wie bei Calotermes. Im Uebrigen finden sich manche Verschiedenheiten; als Beispiel derselben gebe ich (Fig. 45) die Anordnung der Luftröhren im Hinterleibe von Termes saliens. Es fehlen hier die Längszweige, durch welche bei Calotermes die Leiter in der Mitte der Bauchseite hergestelit wird und auch die Verzweigung des Rückenastes ist eine etwas abweichende.

Dem Calotermes rugosus steht im geflügelten Zustande der C. nodulosus so nahe, dass Hagen zweifelhaft blieb, ob nicht ersterer nur ,eine varietas thorace nigro von C. nodulosus sei“ 1). Auch in ihren Jugendzuständen stimmen diese beiden Arten darin überein und unterscheiden sich von allen übrigen Termiten dadurch, dass die jüngsten Larven flügelförmige Fortsätze an Vorder- und Mittelbrust tragen. Doch scheint die Gestalt der Larven von Calotermes nodulosus (Fig: 9) schon eine weniger ursprüngliche zu sein. Die Fortsätze der Mittelbrust sind nur klein und schmal, der Hinterleib länger, weniger flach, in Mitte weniger verbreitert. - In zweifelhaften Fällen bieten diese augenfälligen Verschiedenheiten der jüngsten Larven ein bequemes Mittel, um zu entscheiden, ob man eine Gesellschaft von Calotermes rugosus oder von C. nodulosus vor sich habe.

Wünschenswerth und wahrscheinlich lohnend wäre die Verfolgung der Entwickelung der Termiten und besonders der Calotermes im Ei. Vielleicht fiele dabei ein ähnliches Streiflicht auf den Ursprung der Luftröhren der Insecten -

r) Linnaea entomol. XII, S. 63 . 
(das mehrerwähnte Sförmige blinde Rohr, von dem die Luftröhren des Hinterleibes ausgehen, erweckt diese Hoffnung), - wie es die spätere Entwickelung der Larve des Calotermes rugosus auf den Ursprung der Flügel wirft. Mir selbst gestattet mein Mikroskop nicht, eine solche Untersuchung mit einiger Aussicht auf Erfolg zu unternehmen.

Itajahy, 3 I. März I874.

\section{Erklärung der Abbildungen auf Tafel XL, XLI, XLII und XLIII.}

Fig. I-8. Calotermes rugosus Hag. Wandlungen der äusseren Gestalt (8: I).

Fig. I-3. Jüngste Larve, mit 9 Fühlergliedern. 3 von der Bauchseite; die 6 Nervenknoten des Hinterleibes schimmern durch.

Fig. 4. Larve mit Io Fühlergliedern. Der Innenrand der Kinnbacken ist hart und dunkel geworden. Die Fortsätze der Hinterbrust sind deutlicher, der Hinterleib länger.

Fig. 5. Larve mit I I Fühlergliedern. Die Fortsätze der Mittel- und Hinterbrust haben sich herabgebogen und liegen den Seiten des Leibes an; der Hinterleib nähert sich der Walzenform; die Schienen haben deutliche Enddornen. Die eigenthümliche Zeichnung des Hinterleibes ist durch das Durchschimmern der in der folgenden Figur im Umrisse gezeichneten Theile bedingt.

Fig. 6. Larve mit I 2 Fühlergliedern. Fühler im Verhältniss viel kürzer, als anfangs. Rückemplatte der Vorderbrust kaum noch breiter als der Kopf, ihrer bleibenden Gestalt sich nähernd. Man sieht durchschimmern: das Rückengefäss $(r g)$ in der Mittellinie; den Vormagen ( $\mathrm{vm}$ ), von der Mittelbrust aus schief nach links bis zum dritten Hinterleibsring sich erstreckend; den Mitteldarm ( $m d)$, der im dritten Hinterleibsring einen Bogen von links und hinten nach rechts und vorn beschreibt; den Blinddarm $(b d)$, die ganze Breite des Hinterleibes bis fast zum Hinterrande der achten Rückenplatte einnehmend, den Enddarm $(e d)$, der anfangs an der rechten Seite des Blinddarms, dann über demselben nach hinten läuft und mit einer Erweiterung endet.

Fig. 7. Soldatenlarve.

Fig. 8. Soldat.

Fig. 9. Jüngste Larve von Calotermes nodulosus Hag. (I5: I).

Fig. IO. Erwachsene Larve von Calotermes Hagenii F. M. (4:I). Flügelansätze den Seiten anliegend.

Fig. II. Erwachsene Larve von Anoplotermes pacificus F. M. (8: I). Flügelansätze dem Rücken aufliegend.

Fig. I 2. Ei eines (namenlosen) Caloterm es aus Canella preta (50:I). L. Oberlippe (labrum). I. Fühler, bereits dreigliedrig. II. Kinnbacken (mandibula). III. Vorderer Kiefer (maxilla). IV. Hinterer Kiefer (labium). $V$-VII. Vorder-, Mittel- und Hinterbein. $X$. Innerer Ast des vorderen Kiefers, oder Zunge? -

Fig. I3-I6. Entwickelung der Fühler von Calotermes rugosus.

Fig. I3. Fühler der Larve Fig. 3 (50: I) ; neungliedrig, drittes Glied mit zwei Ringfurchen.

Fig. I 4. Fühler einer wenig älteren Larve (50:I); zehngliedrig, drittes Glied mit einer Ringfurche.

Fig. I 5. Fühler der Nymphe (50: I); fünfzehngliedrig, das dritte Glied in einen oberen beborsteten und einen unteren borstenlosen Abschnitt getheilt. Beim geflügelten Thiere trägt auch letzerer Borsten, die Fühler sind sechzehngliedrig.

Fig. I6. Fühler des Soldaten (25: I).

Fig. I 7-25. Mundtheile des Calotermes rugosus.

Fig. I 7. Kopf der jüngsten Larve, von oben (50: I) ol Oberlippe. Kb Kinnbacken. $z$ Zunge. Kt Kiefertaster. Kla Aeussere Kieferlade, an deren Innenseite man die Spitze der inneren Lade sieht. Lt Lippentaster. La Aeussere, li innere Lade der Unterlippe. $f$ Erstes Glied des rechten Fühlers. sp Speiseröhre. $h$ Hirn. 
Fig. 18. Vorderer und hinterer Kiefer („Unterkiefer und Unterlippe“) der jüngsten Larve, von unten (IOO: I). Buchstaben, wie in Fig. I7, ausserdem: kli Innere Kieferlade. sp Speichelgang. sbg Speichelblasengang. $s d g$ Speicheldrüsengang.

Fig. I 8 a. Innere Kieferlade, gequetscht.

Fig. I 9. Zunge der jüngsten Larve (50: I).

Fig. 20. Kinnbacken einer Larve mit zehn Fühlergliedern, von oben (90: I).

Fig. 2I-23. Mundtheile des Soldaten (25: I). Buchstaben, wie zuvor.

Fig. 2 I. Hintere Kiefer („Unterlippe").

Fig. 22. Vorderer Kiefer („Unterkiefer").

Fig. 23. Oberlippe. - ep. Epistom.

Fig. 24. Zunge des geflügelten Thieres, von der Seite.

Fig. 25. Kinnbacken desselben, von oben (25: I).

$\left.\begin{array}{l}\text { Fig. 26. Zunge } \\ \text { Fig. 27. Oberlippe }\end{array}\right\}$ der jüngsten Larve des Anoplotermes pacificus (50: I).

Fig. 28-30. Flügelfortsätze der Brust von Calotermes rugosus.

Fig. 28. Von der jüngsten Larve (50: I). $K$ Kopf. $V$ Vorder-, $M$ Mittel-, $H$ Hinterbrust. I-III. Erste bis dritte Rückenplatte des Hinterleibes. Zwischen $V$ und $M^{1}$ ) das zweite, an den Seiten von I-III drittes bis fünftes Luftloch der linken Seite, letztere drei mit dem S-förmigen blinden Rohre.

Fig. 29. Von einer Larve mit elf Fühlergliedern (25: I). In den Flügelfortsatz der Mittelbrust treten Luftröhren ein, als erste Anlage der späteren Flügeladern. sc Subcosta. w Mediana. sm Submediana.

Fig. 3o. Verkümmerter Flügelfortsatz der Mittelbrust des Soldaten (25: I). Buchstaben, wie in Fig. 29.

Fig. 3I-35. Zur Entwickelung der Beine.

Fig. 3 I. Vorderschiene und Fuss der Fig. I gezeichneten Larve (90: I). Enddornen der Schienen fehlen. Fussglieder deutlich geschieden.

Fig. 32. Theil der Vorderschiene der jüngsten Larve (200: I). Die Luftröhre theilt sich bei ihrem Eintritt in die Schiene in zwei jetzt noch gleich starke Aeste.

Fig. 33. Die drei ersten Fussglieder des Mittelbeins der jüngsten Larve, von der Sohle (IOO: I).

Fig. 34. Vorderschiene und Fuss einer $5 \mathrm{~mm}$ langen Larve (90: I). Enddornen der Schienen vorhanden, der eine Ast der Luftröhre aufgetrieben.

Fig. 35. Ende der Schiene und Fuss vom Mittelbein des geflügelten Thieres (IOO: I). $h$ Haftlappen zwischen den Fussklauen. Ir Luftröhre, bis in den Haftlappen zu verfolgen. $s$ Sehne des Beugemuskels.

Fig. 36. Vorderschiene und Fuss des Arbeiters von Anoplotermes pacificus F. M. (50: I). Die reichliche Behaarung ist weggelassen.

Fig. 37. Ende des Hinterleibes der jüngsten Larve von Calotermes rugosus, von unten. $a$ After. aa Afteranhänge (appendices anales). $b a$ Bauchanhänge (appendices abdominales).

Fig. 38. Darmrohr der jüngsten Larve von Calotermes rugosus, etwas aus seiner natürlichen Lage gezogen (I5: I). $v m$ Vormagen. $k l$ Kauleisten. $m d$ Mitteldarm (Magen). $b d$ Blinddarm. ed Enddarm. hg Harngefässe.

Fig. 39. Vormagen $(v m)$ und Anfang des Mitteldarms ( $m d)$ der Nymphe von Anoplotermes pacificus (8: I).

Fig. 40. Endstück des Vormagens („Kaumagen“) einer $3 \mathrm{~mm}$ langen Larve von Calotermes rugosus (90: I). rm Ringmuskeln. kw I, kw II. kw III, Kauwülste erster, zweiter und dritter Ordnung.

Fig. 4I. Ein Theil der Kauwülste, aus demselben Vormagen, ausgebreitet (90: I).

Fig. 42. Speicheldrüse $(s d)$ und Speichelblase $(s b)$ von Cal ot ermes rugosus, Soldat (25: I). sg Speichelgang. sbg Speichelblasengang. sdg Speicheldrüsengang. Ir In der Speicheldrüse sich vertheilende Luftröhre.

I) Zwischen $M I$ und $H$ ? - Herausgeber. 
Fig. +3. Zunge $(z)$ mit den Mündungen der Speichelgänge, von Termes saliens F. M., Arbeiter (45: I).

Fig. 44-50. Vertheilung der Luftröhren. In allen Figuren bedeuten: /l Luftloch. s Sförmiges blindes Rohr. $b$ Bauchast. bv Vorderer, bh Hinterer, bq Querer Zweig desselben. $r$ Rückenast. rv Vorderer, th Hinterer, rq Querer Zweig desselben. l Längszweige zwischen den Querzweigen des Bauchastes. "Z Zweige zu den Bauchnervenlinoten. (Larve).

Fig. 44. Vertheilung der Luftröhren im Hinterleibe von Calotermes rugosus

Fig. 45. Dieselbe von T ermes saliens (Arbeiter).

Fig. 46. Sechstes (VI) und siebentes (VII) Luftloch des Hinterleibes von der jüngsten Larve des Calotermes rugosus (IOO:I). Das Sförmige blinde Rohr viel weiter, als die von ihm abgehenden Luftröhren.

Fig. 47. Sechstes (VI) Luftloch des Hinterleibes von einem geflügelten Ca lot er m es rugosus (IOO: 1). bv VII Vorderer Zweig des Bauchastes der vom siebenten Luftloch des Hinterleibes entspringenden Luftröhre. Das Sförmige blinde Rohr viel enger, als die von ihm abgehenden Luftröhren.

Fig. 48. Vertheilung der Luftröhren in der Brust der jüngsten Larve eines (namenlosen) Calotermes aus Canella preta (5O: r). vb Luftröhre des Vorderbeins; $h b$ Luftröhre des Hinterbeins.

Fig. 49. Vertheilung der Luftröhren im Flügelansatz der Mittelbrust, von einer erwachsenen Larve des Calotermes Hagenii F. M. (25: r). rk Randkanal (später Costa des Flügels). sc Subcosta. $m$ Mediana. $s m$ Submediana.

Fig. 50. Luftloch am Rande der a cht en Rückenplatte des Hinterleibes, von einem geflügelten Weibchen des Termes saliens F. M. (IOO: I). - Ich gebe diese Abbildung, weil nach Hagen die Termiten nur sieben Paar Luftlöcher am Hinterleibe haben sollen. - 


\title{
Larvae of Membracis serving as Milk-cattle to a Brazilian Species of Honey-bees ${ }^{1}$ ).
}

\author{
With 3 Figures.
}

The connection between the ants and the Aphides has long since been generally known; in the proper season we always find ants very busy on those trees and plants on which the Aphides abound, and if we examine more closely we discover that their object in thus attending upon them is to obtain the saccharine fluid which they secrete from two setiform tubes placed one on each side just above the end of the abdomen, and which may well be denominated their milk (Kirby and Spence, "Introduction to Entomology", 7th edition, p. 335). It has also long been observed and described, that not only do the Aphides yield this repast to the ants, but also the Cocci, and that in the tropical regions of India and Brazil, where no Aphides occur, the ants milk the larvæ of several species of Cercopis and Membracis (Kirby and Spence, p. 336; Westwood, "Modern Classification of Insects," II. p. 434). Recently Prof. F. Delpino, of Vallombrosa, near Florence, observed the same connection between Formica pubescens and Tettigometra virescens ("Bolletino Entomologico", anno IV. Settembre I872). But, as far as I know, it has never been observed hitherto that honey-bees also nourish themselves by the secretion of certain hemipterous insects. Hence the following observation, made some months ago by my brother, Fritz Müller (Itajahy, Prov. St. Catherina, Brazil) may be worth publishing.

Among the great number of species of Melipona and Trigona which, in the tropical and subtropical regions of America, as is known, occupy the place of our hive-bee, there is one small species of Trigona which has only once been found by my brother on flowers (of Sicyos angulata), and which seems to nourish itself in a very strange manner. He once found a multitude of them spread over the body, already strongly putrifying, of a large toad; the interior of the large open mouth of the toad was filled with these bees, probably sucking the putrid juice of the dead body. On another occasion he saw a great number of the same

I) Nature, a weekly illustrated Journal of Science. Vol. VIII. 1873. pg. 20I-202. Published by Hermann Müller, Lippstadt.

Fritz Müllers gesammelte Schriften. 
species of bees in the putrifying intestines of a hen. Repeatedly he saw them sucking the juice flowing out of trees.

In consequence of other observations this same species of Trigona is supposed by my brother to suck the secretion of the larvæ of a certain hemipterous insect belonging to the genus Membracis, or to a closely allied one. As I do not precisely know the name of this supposed milk-cow, I here give the illustration of its larvæ and imago, drawn from specimens sent me by my brother.

Fig. I.

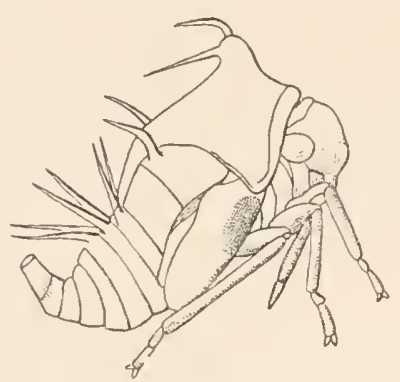

Fig. 2.

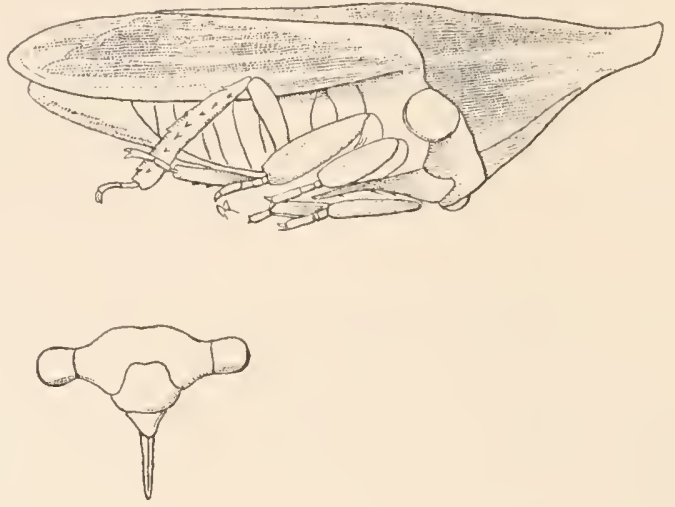

Fig. 3.
Fig. I. Lateral view of larva.

Fig 2. Lateral view of imago.
Fig. 3. Front view of head of imago.

Te found the pedunculi of the flowers of Cassia multijuga pretty frequently occupied by societies of larvæ of this species closely crowded together. Amongst these larvae there was present a great number of the above-mentioned Trigona, marching all the day long amongst and upon them. When taken between the fingers, the larva of Membracis immediately emitted a little drop of a limpid fluid from the upward bent tip of their abdomen-probably a sweet fluid, for the sucking of which the larvæ are visited by the Trigona.

Unfortunately the specimens of this Trigona, enclosed in a letter sent me by brother, arrived here quite broken, so as not to be determinable; but in a future number of this journal I hope to be able accurately to name both the supposed milker and the supposed milk-cow. 


\title{
Larvae of Membracis serving as Milk-cattle to a Brazilian Species of Bees ${ }^{1}$.
}

\author{
With 4 Figures.
}

My letter in Nature, vol. viii. p. 20I, was incomplete so far as the names of the Brazilian insects alluded to are concerned, but I am now enabled accurately to name both the supposed milk-cow and the supposed milker. With regard to the former, Mr. Rogenhofer, of Vienna, has had the kindness to compare my specimens of Membracis with the collection in the museum of that metropolis, and informs me that my Membracis belongs to the genus Potnia of Stäl (Umbonia of Fairmaire), the species most probably being indicator Fairm. As to the Trigona species referred to in the above letter, I have in the meantime received numerous good specimens, not only a number of workers, but also some males, and even one queen. Mr. Frederick Smith has been good enough to compare my specimens with the collection in the British Museum, and has found that they belong to an undescribed species. Having worked through the literature on Trigona and Melipona as completely as possible, and after perusing the descriptions of about one hundred species, not having found a single one of wich all three kinds of individuals are known, I think it will be welcome to the readers of this journal who are interested in entomology, if I do not restrict myself to merely mentioning the name and diagnostics of my new Trigona species, but give a description of its workers, male and queen, adding a brief account of its peculiar habits and economy from my brother's (Fritz Müller) observations.

$$
\text { Trigona cagafog }{ }^{2} \text { ). }
$$

Length of the workers and males $5-5 \frac{1}{2}$, of the queen $6-7 \mathrm{~mm}$. Males and workers are almost alike in size, colour, and outline of the body, and are distinguished from most other species of the same genus by the breadth of their head and the narrowness of their abdomen, which, in the workers, scarcely exceeds half the breadth of the head. In the males the abdomen is equally slender, but the head somewhat less broad; in the queen the head is of the same size and form

I) Nature, a weekly illustrated Journal of Science. Vol. X. 1874. pg. 31-32. Published by Hermann Müller, Lippstadt.

2) I call the species Cagafogo, using the vernacular name for the specific one. 
as in the workers, but the abdomen is so much dilated as to reach one and a half times the breadth of the head.

The head, tegulæ, scutellum, and abdomen, in all three kinds of individuals, are ferruginous, smooth and shining, the posterior margins of the vertex, of the scutellum and of the last segments of the abdomen have a black pubescence; the

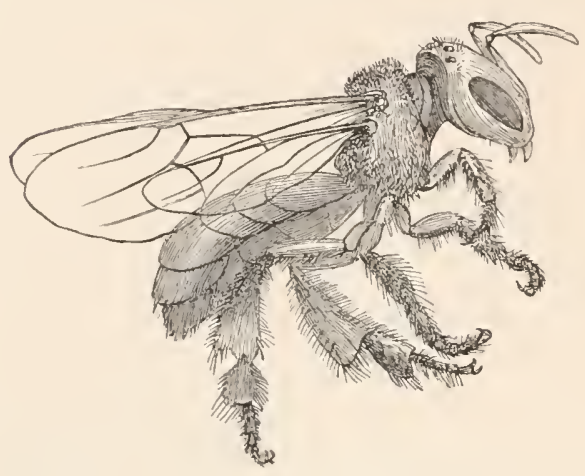

Fig. 1. Cagafogo, worker (side view).

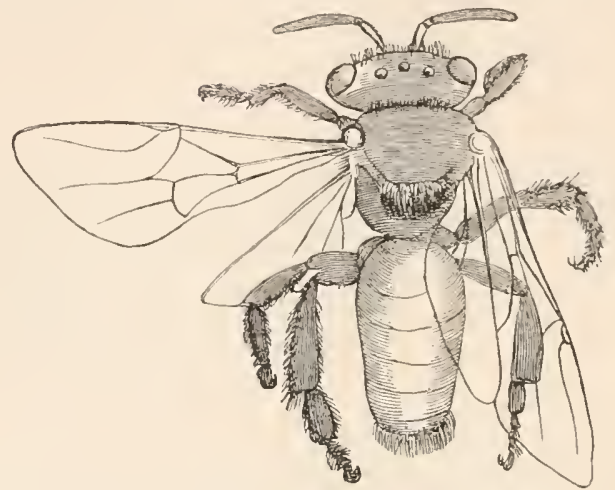

Fig. 2. Cagafogo, male.

rest of the thorax, together with the legs, is black with black pubescence; the antennæ black, the greatest part (乌) or the whole (ठ) of the scape rufo-piceous, the flagellum fuscous beneath. The wings by far exceed the abdomen; the basal portion and radical cell of the anterior wings dark fuscous; their apical portion

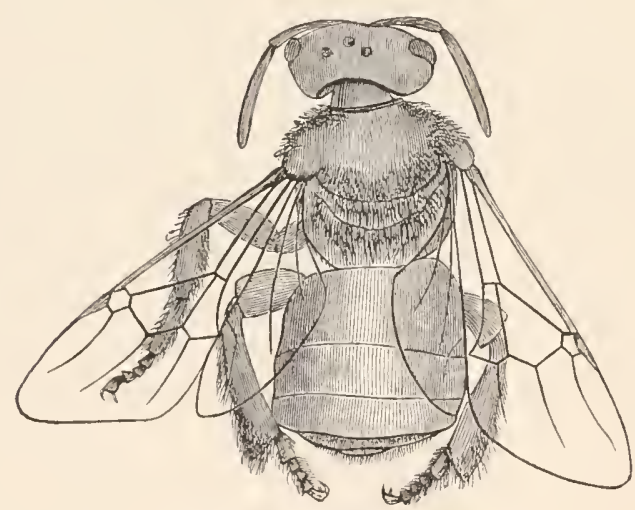

Fig. 3. Cagafogo, queen.

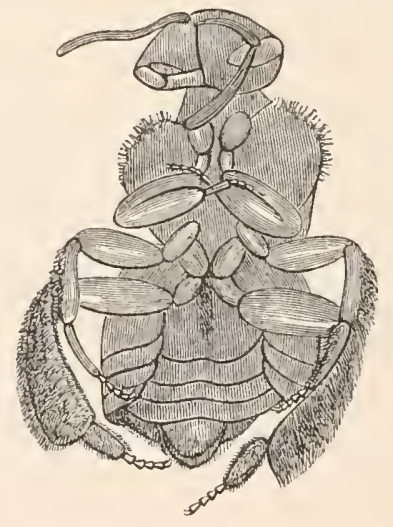

Fig. 4. Cagafogo, queen (from beneath).

and the posterior wings subhyaline; the stronger nervures brown, the feeblest ones pale ferruginous; no cubital cell at all. The mandibles with two teeth at their apex. The tibiz triangular, their outside pubescent from the base to the middle, towards the apex slightly excavated, smooth, shining, and naked. The whole body destitute of feather-like hairs. The unguiculæ of the males are, in this as in other Trigona and Melipona species, two-cleft; whilst those of the workers and females are simple. The queen, besides her larger size and the much dilated abdomen, differs from the workers by the colour of the head being somewhat 
paler, the antennæ longer, the thorax stronger, its anterior and lateral margins and two longitudinal streaks rufo fuscous, the anterior wings provided with a completely closed cubital cell, the legs larger and more robust, especially the anterior and middle tibiæ much thicker, the outside of the posterior tibiæ slightly convex and pubescent nearly as far as the apex, the apex of the posterior tibixe bordered with partly feather-like hairs ${ }^{1}$ ).

The nests of T. cagafogo, like those of many other species, are built in hollow trees. One of two nests which my brother had the opportunity of observing was found in a tree cut down a long time before; but its combs, lying in confusion, probably in consequence of the direction of the trunk having been altered by felling the tree, showed that the nest had probably been built before the tree was felled. In this nest, the inhabitants of which partly perished by having been plastered over with the honey which flowed from the damaged honey-pots during the transport, partly, as is to be supposed, flew away afterwards; besides a great number of workers and a small number of males, only a single queen was found, viz. that illustrated in Figs. 3 and 4. The honey-pots, of the size of large hazelnuts, were closely aggregrated together. The honey was of a very viscous consistence, partly as clear as water, partly lighter or darker yellow; its flavour appeared to my brother insipid, pituitous, and somewhat disagreeable (the latter perhaps, as he supposes himself, because he was conscious of the cagafogos feeding upon carrion). The brood-combs, as with other Trigonas, were simple layers of hexagonal upright cells. The wax, of which both the honey-pots and the brood-combs were built, was nearly of a pure white colour, but it was mixed with such an enoumous quantity of heterogeneous ingredients (perhaps 90 per cent.) that the building appeared of a dirty brown or blackish colour.

Another nest, found by my brother in a trunk of Canella pimenta, about five meters above the ground, was brought safety home after cutting down the tree; but a week afterwards all the inhabitants had flown away.

The most striking feature in the natural history of this stingless bee is its fondness for oily matters, and its singular means of defence, connected with a great irritability. As $\mathrm{i}$ have already stated (vol. viii. p. 20 I) it feeds upon carrion; and is also fond of old stinking cheese. When visiting flowers, it seems to be also guided by its particular taste; it visits in swarms the flowers of a bean with glandular calyx; also a white-flowered Abutilon and Sicyos angulata, the flowers of which are glandular and secrete an oil. It was also observed fertilising the flowers of Asclepias curassavica, milking the larvæ of Membracis, repeatedly sucking the juice flowing out of trees, and devouring the sugar spread to be dried. Its singular means of defence are indicated by the vernacular name Cagafogo (spit-fire), for although stingless, like all other Trigonas and Meliponas, it possesses a very intense venom, which causes a most lively irritation in the skin. Whilst the defenceless species are for the most part very peaceable, the Cagafogos, on the contrary, are so irritable that the observation of their nests proves impossible, unless cold weather or strong breezes from the land keep them quiet.

I) A more full and detailed description of this and some other new species will be given in a separate treatise on Trigona and Melipona, to be published by my brother and myself. 


\title{
Recent researches of Termites and Honey-bees $\left.{ }^{1}\right)$.
}

\author{
(From a letter to Ch. Darwin.)
}

The accompanying letter, just received from Fritz Müller, in Southern Brazil, is so interesting that it appears to me well worth publishing in Nature. His discovery of the two sexually mature forms of Termites, and of their habits, is now published in Germany; nevertheless few Englishmen will have as yet seen the account.

In the German paper he justly compares, as far as function is concerned, the winged males and females of the one form, and the wingless males and females of the second form, with those plants which produce flowers of two forms, serving different ends, of which so excellent an account has lately appeared in Nature by his brother, Hermann Müller.

The facts, also, given by Fritz Müller with respect to the stingless bees of Brazil will surprise and interest entomologists.

Feb. I I.

Charles Darwin.

"For some years I have been engaged in studying the natural history of our Termites, of which I have had more than a dozen living species at my disposition. The several species differ much more in their habits and in their anatomy than is generally assumed. In most species there are two sets of neuters, viz., labourers and soldiers; but in some species (Calotermes Hg.) the labourers, and in others (Anoplotermes F. M.) the soldiers, are wanting. With respect to these neuters I have come to the same conclusion as that arrived at by Mr. Bates, viz. that, differently from what we see in social Hymenoptera, they are not modified imagos (sterile females), but modified larvæ, which undergo no further metamorphosis. This accounts for the fact first observed by Lespès, that both the sexes are represented among the sterile (or so-called neuter) Termites. In some species of Calotermes the male soldiers may even externally be distinguished from the female ones. I have been able to confirm, in almost all our species, the fact already observed by Mr. Smeathman a century ago, but doubted by most subsequent writers, that in the company of the queen there lives always a king. The most interesting fact in the natural history of these curious insects

1) Nature 1874. Vol. IX. p. 308, 309. 
is the existence of two forms of sexual individuals, in some (if not in all) of the species. Besides the winged males and females, which are produced in vast numbers, and which, leaving the termitary in large swarms, may intercross with those produced in other communities, there are wingless males and females, which never leave the termitary where they are born, and which replace the winged males or females, whenever a community does not find in due time a true king or queen. Once I found a king (of a species of Eutermes) living in company with as many as thirty-one such complemental females, as they may be called, instead of with a single legitimate queen. Termites would, no doubt, save an extraordinary amount of labour if, instead of raising annually myriads of winged males and females, almost all of which (helpless creatures as they are) perish in the time of swarming without being able to find an new home, they raised solely a few wingless males and females, which, free from danger, might remain in their native termitary; and he who does not admit the paramount importance of intercrossing, must of course wonder why this latter manner of reproduction (by wingless individuals) has not long since taken the place through natural selection of the production of winged males and females. But the wingless individuals would of course have to pair always with their near relatives, whilst by the swarming of the winged Termites a chance is given to them for the intercrossing of individuals not nearly related. I sent to Germany, about a year ago, a paper on this subject, but do not know whether it has yet been published.

"From Termites I have lately turned my attention to a still more interesting. group of social insects, viz., our stingless honey-bees (Melipona and Trigona). Though a high authority in this matter, Mr. Frederick Smith, has lately affirmed, that 'we have now acquired almost a complete history of their economy,' I still believe, that almost all remains to be done in this respect. I think that even their affinities are not yet well established, and that they are by no means intermediate between hive- and humble-bees, nor so nearly allied tho them, as is now generally admitted. Wasps and hive-bees have no doubt independently acquired their social habits, as well as the habit of constructing combs of hexagonal cells, and so, I think, has Melipona. The genera Apis and Melipona may even have separated from a common progenitor, before wax was used in the construction of the cells; for in hive-bees, as is well known, wax is secreted on the ventral side: in Melipona on the contrary, as I have seen, on the dorsal side of the abdomen; now it is not probable, that the secretion of wax, when once established, should have migrated from the ventral to the dorsal side, or vice versa.

"The queen of the hive-bee fixes her eggs on the bottom of the empty cells; the larvæ are fed by the labourers at first with semi-digested food, and afterwards with a mixture of pollen and honey, and only when the larvæ are full grown, the cells are closed. The Meliponæe and Trigonæ, on the contrary, fill the cells with semidigested food before the eggs are laid, and they shut the cells immediately, after the queen has dropped an egg on the food. With hivebees the royal cells, in which the future queens have to be raised, differ in their direction from the other cells; this is not the case with Melipona and Trigona, where all the cells are vertical' with their orifices turned upward, forming horizontal (or rarely spirally ascending) combs. You know that honey is stored 
by our stingless bees in large, oval, irregularly clustered cells; and thus there are many more or less important differences in the structure, as well as in the economy, of Apis and Melipona.

"My brother, who is now examining carefully the external structure of our species, is surprised at the amount of variability, which the several species show in the structure of their hind legs, of their wings, \&c., and not less are the differences they exhibit in their habits.

"I have hitherto observed here 14 species of Melipona and Trigona, the smallest of them scarcely exceeding 2 millimetres in length, the largest being about the size of the hive-bee. One of these species lives as a parasite within the nests of some other species. I have now, in my garden, hives of 4 of our species, in which I have observed the construction of the combs, the laying of the eggs \&c., and I hope I shall soon be able to obtain hives of some more species. Some of our species are so elegant and beautiful and so extremely interesting, that they would be a most precious acquisition for zoological gardens or large hot-houses; nor do I think that it would be very difficult to bring them to Europe and there to preserve them in a living state.

"If it be of some interest to you I shall be glad to give you from time to time an account of what I may observe in my Melipona apiary.

"Believe me, dear Sir, \&c.,

"Fritz Müller” 


\section{The Habits of various Insects $^{1}$ ).}

(A letter to Ch. Darwin.)

I delayed answering your kind letter of January I till I should have had an opportunity of examining once more some nests of leaf-cutting ants, to which you had directed my attention. In the meantime I received Belt's "Nicaragua," which I have read with extraordinary interest, and for which I must express to you my hearty thanks.

I was much surprised to learn from Mr. Belt's book how closely the fardistant province of Chontales resembles by its vegetation and animal life our own of Sta. Catharina. I am thus enabled fully to appreciate the exactness of many of his statements; he is an excellent observer, and most of his theories are very seducing. As to leaf-cutting ants, I have always held the same view which is proposed by Mr. Belt, viz. that they feed upon the fungus growing on the leaves they carry into their nests, though I had not yet examined their stomachs. Now I find that the contents of the stomach are colourless, showing under the microscope some minute globules, probably the spores of the fungus. I could find no trace of vegetable tissue which might have been derived from the leaves they gather; and this, I think, confirms Mr. Belt's hypothesis. Here, as in Nicaragua, the Cercropiæ are always inhabited by ants, but, I think, by only a single species. I have cut down hundreds of them and never missed the ants. I wonder that it had never occurred to me that the trees are protected by the ants; but there can be no doubt that this is really the case, for young plants of Cercopiæ, not yet inhabited by ants, are often attacked by herbivorous insects.

A few days ago I caught on the flower of a Vernonia a female moth belonging to the Glaucopidæ, of which family there are here numerous species. When I seized it by the wings nearly the whole body became suddenly enveloped in a large cloud of snow-white wool, which came out of a sort of pouch on the ventral side of the abdomen, and consisted of very thin flexuous hairs I- $2 \mathrm{~mm}$. long, three, four, or five of which used to proceed from the same point. I preserved the moth alive for some time, and as often as I seized her by the wings, by inflating the abdomen, a large naked membrane became visible,

I) Nature 1874. Vol. X. p. I02, 103. 
and somewhat protruded behind the first (white) segment of the ventral face of the abdomen (the rest of which is black), and a little more wool appeared under the posterior margin of this segment. I am at a loss as to the meaning of this curious contrivance. There is in the males of the same family an interesting secondary sexual character; they are able to protrude from near the end of the abdomen a pair of long hollow hairy retractile filaments, which in some species exceed the whole body in length, In the beautiful Belemia inaurata there is a second pair of shorter filaments which are wanting in all the other species I examined (Eunomia eagrus, Euchromia jucunda, Agyrta ccerulea, Eudule invaria, Leucopsumis sp., Philoros sp., \&c., the names of which I owe to the kindness of Dr. A. Gerstäcker, of Berlin). In some species, most distinctly in Belemmia inaurata, I perceived a peculiar odour when the filaments were protruded; this, I think, may serve to allure the females, which in all our species appear to be much less numerous than the males.

I mentioned to you that with our stingless honey-bees wax is secreted on the dorsal side of the abdomen; now this is also the case with some of our solitary bees, for instance, Anthophora fulvifrons Sm., and with some species nearly allied to that genus. These solitary bees probably use the wax only to cement the materials with which they build their nests. Our species of Melipona and Trigona also never employ pure wax in the construction of their cells or of the large pots wherein they guard their provisions; they mix it with clay, resinous substances, \&c., so that in some species wax forms hardly io per cent. of the material. The only case, as far as I know, in which pure wax is used, is in the construction of a tube, which Trigona jaty Sm. builds at the entrance of its nest.

Among European Apidæ, Apis and Bombus are the only genera which wet with honey the pollen they are collecting, and in consequence of this habit the hairs on the outside of the tibiæ of the hind-legs have disappeared. This is also the case with our Meliponæ, Trigonæ, and Euglossæ. Now Centris, Tetrapediæ, Epicharis, and some others bees, collect pollen in the same way; but notwithstanding, in some species the hairs on the tibiæ are developed in an extraordinary degree. This seemed to me rather perplexing; till I lately observed several species of Centris and a Tetrapedia gathering sand in the large hairbrushes of the hind-tibiæ, which accounts for the conservation and excessive development of the hairs.

With one of our smallest Trigonæ (T. mivim n. sp.), of which I have two hives in my garden, I have made a long series of observations on the construction of the combs, in which the young are raised. As in all other species the combs are horizontal and consist of a single layer of hexagonal cells, like those of wasps; but the cells are vertical. There is always in this species (other species behave differently) a set of cells constructed at the same time in the circumference of the two or three uppermost combs. When the cells are ready, they are filled with food, which the bees vomit from their mouths, the queen lays an egg into every cell and these are then immediately shut. The eggs at first lie horizontally; but in the course of the first or second day they assume a perpendicular position, with the ticker end turned upwards, dipping but slightly into the 
semi-fluid food. The combs are never used more than once; as soon as the young bees have left them (five to six weeks after the laying of the eggs) they are destroyed and new ones built in their place.

Once I assisted at a curious contest, which took place between the queen and the worker bees in one of my hives, and which throws some light on the intellectual faculties of these animals. A set of 47 cells had been filled, 8 on a nearly completed comb, 35 on the following, and 4 around the first cell of a new comb. When the queen had laid eggs in all the cells of the two older combs she went several times round their circumference (as she always does in order to ascertain whether she has not forgotten any cell), and then prepared to retreat into the lower part of the breeding room. But as she had overlooked the four cells of the new comb the workers ran impatiently from this part to the queen, pushing her, in an odd manner, with their heads, as they did also other workers they met with. In consequence the queen began again to go around on the two older combs, but as she did not find any cell wanting an egg she tried to descend; but everywhere she was pushed back by the workers. This contest lasted for a rather long while, till at last the queen escaped without having completed her work. Thus the workers knew how to advise the queen that something was as yet to be done, but they knew not how to show her where it had to be done. In the same hive there appeared to be two political parties among the workers, dissenting about the construction of the combs, one destroying what the other had begun to build; but it would require a very long and tedious exposition to give you the details of the case.

Our several species of honey-bees differ as much in their mental dispositions as they do in external appearance and size (the smallest species, called Trigona lilliput by my brother, is only about $2^{\circ} 5 \mathrm{~mm}$. long). Some rush furiously out of their nest, whenever an enemy approaches it, attacking and persecuting the offender; others are very tame, and permit close observation off all their work. In one large species I could even observe with a lens the act of their sucking a solution of sugar, which I had given them, and there was no doubt that at least these bees really suck, and do not lap, like dogs or cats, as Milne Ewards, Gerstäcker, and most entomologists think.

There is one species (Trigona liomâo Sm., named for my brother by Mr. Frederick Smith himself) which never appears to collect honey or pollen from flowers, on which, at least, I have never seen it. It robs other species of their provisions and sometimes takes possession of their nests, killing, or expelling the owners. The hives in my garden have often been invaded, and two of them destroyed, by these robbers, and I have seen in the forest several nests, formerly inhabited by other species, occupied by them.

Together with my brother at Iippstadt I intended to publish an essay on the natural history of our stingless boney-bees, but it will probably cost some years to give a tolerably complete account of them.

Itajahy, Santa Catharina, Brazil, April 20. 1874. 


\section{Stachellose brasilianische Honigbienen}

zur Einführung in zoolog. Gärten empfohlen von Hermann Müller auf Grund von Beobachtungen seines Bruders Fritz Müller in Südbrasilien $\left.{ }^{1}\right)^{2}$ ).

Ich möchte Ihnen einige Mittheilungen über die Lebensweise stachelloser brasilianischer Honigbienen machen, welche sich auf Beobachtungen meines Bruders Fritz Müller in Südbrasilien gründen.

Sollte Ihnen dieser Gegenstand als rein zoologischer wenig geeignet erscheinen, um vor die Sitzung der vereinigten zoologischen und botanischen Section gebracht zu werden, oder als ausländischer wenig geeignet für einen Provinzialverein, so möchte ich dagegen geltend machen, dass die Naturgeschichte unserer europäischen Honigbiene, als unserer wichtigsten Blumenbefruchterin, auch für unsere Botaniker von hervorragendem Interesse sein muss, dass aber diese Naturgeschichte durch die Betrachtung der stachellosen brasilianischen Honigbienen, die im Ganzen auf etwas tieferer Entwicklungsstufe stehen, in mehrfacher Beziehung wesentliche Aufklärung erhält.

Während in Europa nur eine einzige Art von Honigbienen vorkommt, unsere allbekannte Apis mellifica, welche stechen kann, sind dagegen die Urwälder Südamerikas von einer kolossalen Mannigfaltigkeit verschiedener Arten von Honigbienen bevölkert, die sämmtlich nicht stechen können, bei denen vielmehr der Giftstachel zu einem völlig nutzlosen Rudiment verkümmert ist. Alle diese Arten, welche man, wohl ohne stichhaltigen Grund, in zwei Gattungen, Melipona und Trigona, getrennt hat und die wir daher hier unter dem Gattungsnamen Melipona zusammenfassen, stimmen ausser der Verkümmerung des Stachels darin überein, dass bei ihnen, nach der Entdeckung meines Bruders, das Wachs nicht auf der Bauchseite, sondern auf der Rückenseite des Hinterleibes abgesondert wird, und zwar an denselben Hinterleibssegmenten, an deren Bauchplatten es sich bei unserer Honigbiene ausscheidet. Im Zusammenhange damit sind dann drittens auch die Organe zum Hervorzichen der Wachstäfelchen andere als bei unserer Honigbiene. Der zahnförmige Fortsatz an der Basis der hinteren Ferse, die sogenannte Wachs-

I) Vortrag in der Sitzung der vereinigten zoologischen und botanischen Section des Westphälischen Provinzialvereins in Münster am 27. December 1874 gehalten, aber wegen unzureichender Zeit bedeutend abgekürzt.

2) Zoolog. Garten I $875 \cdot$ p. $4 \mathrm{I}-55$. 
zange, deren sich unsere Bienen und Hummeln zu diesem Zwecke bedienen, fehlt bei den Meliponen gänzlich, dagegen sind ihre Hinterbeine, da sie nach dem Wachse weiter zu reichen haben, verhältnissmässig länger und am Endrande der Schienen mit einem Kamme aus langen, gebogenen Chitinzähnen ausgerüstet, welcher vermutlich zum Herausgreifen der Wachsblättchen benutzt wird.

Von der Zahl und Mannigfaltigkeit, in welcher diese stachellosen Honigbienen in Brasilien auftreten, kann Thnen die vorliegende Sammlung wenigstens eine schwache Vorstellung geben. Sie finden in derselben nicht weniger als i 8 verschiedene Arten, welche mein Bruder in der unmittelbaren Umgebung seines Wohnsitzes beobachtet hat, die grössten Arten (M. Mondury Sm., M. Gurupú nob. M. Coyrepú nob.) ungefähr von der Grösse unserer Honigbiene, die kleinste Art, von uns M. lilliput getauft, noch nicht einmal $3 \mathrm{~mm}$ lang. Nicht minder mannigfaltig als in ihrer Grösse sind diese Arten auch in ihrer ganzen äusseren Erscheinung, ihrem Geruche, ihrer Flugweise, ihrer Gemüthsart und manchen Eigenthümlichkeiten ihrer Lebensweise. Während z. B. einige (M. Coyrepú nob., M. Gurupú nob., M. limão Smith) ihr lautes Summen augenblicklich verstummen lassen und sich furchtsam zurückziehen, sobald man nur an den von ihnen bewohnten Baumstamm oder Kasten klopft, stürzen dagegen andere (M. Cagafogo nob., M. ruficrus Latr. und M. Trombeta nob.) bei der geringsten Veranlassung hervor, umschwärmen und verfolgen den Angreifer und setzen sich summend und beissend in dessen Bart und Haare fest.

Die wichtigsten Eigenthümlichkeiten in der Staatenbildung, dem Nestbau und der Brutversorgung der Meliponen sind folgende: Auch bei ihnen scheint sich, soweit meines Bruders Erfahrungen reichen, in jeder Gesellschaft nur eine einzige Königin zu finden. Neben ihr fand derselbe allerdings bisweilen eine oder mehrere jüngere Weibchen, die aber wahrscheinlich noch unfähig waren, Eier zu legen. Die Hauptmasse des Bienenvolkes besteht auch bei den Meliponen aus unfruchtbaren Weibchen oder Arbeitern, die in der Regel erheblich kleiner sind als die Königin, und natürlich ist auch eine Anzahl Männchen oder Drohnen vorhanden. Diese sind von gleicher Grösse und Gestalt wie die Arbeiter, aber durch gespaltene Fussklauen und durch den Mangel des Pollen-Sammelapparates an den Hinterbeinen von diesen leicht $\mathrm{zu}$ unterscheiden.

Ihre Nester legen die stachellosen Honigbienen in der Regel in hohlen Bäumen an, deren Zugänge sie, bis auf ein einziges Flugloch, mit Erde oder verschiedenen harzigen, kautschukähnlichen und anderen Pflanzenstoffen vermauern. Diese Baumaterialien tragen sie, ebenso wie den Blüthenstaub, in den Körbchen der Hinterbeine heim. In alten Nestern der M. Coyrepú nob. findet man sogar ansehnliche Mengen von Harz als Vorraths-Baumaterial angehäuft. Für den inneren Ausbau ihres Wohnraumes verwenden die Meliponen Wachs, das sie immer aber erst mit Erde, Harz oder anderen Stoffen vermengen bisweilen (z. B. bei M. Cagafogo nob.) in solcher Menge, dass das Baumaterial wohl kaum zum zehnten Theile aus wirklichem Wachse besteht.

Wenn ich vorhin sagte, dass die Naturgeschichte unserer Honigbienen durch die Betrachtung der Meliponen wesentliche Aufklärung erhalte, so gilt dies namentlich auch in Bezug auf die Absonderung und Verwendung des Wachses. Denn während die meisten einzeln lebenden Bienen ihre Brutzellen ganz ohne 
Wachs bauen und einige derselben (z. B. Anthophora fulvifrons Sm.), wie mein Bruder entdeckt hat, nur ein wenig Wachs erzeugen, das ihnen vermutlich als Bindemittel für Sand, Erde und ähnliche Baustoffe dient, bilden die Meliponen in Bezug auf die Menge des abgesonderten Wachses und die Vermischung desselben mit andern Stoffen eine vollständige Stufenleiter von diesen einzeln lebenden Bienen bis zu unserer reines Wachs verwendenden Apis mellifica und lassen uns somit die allmälige Ausprägung dieser Eigenthümlichkeit gewissermaassen in ihrem Werden erkennen. Eine Abstammung unserer Honigbienen von den Meliponen soll damit nicht behauptet sein; eine solche ist im Gegentheile sehr unwahrscheinlich, da sich nicht wohl voraussetzen lässt, dass die einmal zur Ausprägung gelangte Wachsabsonderung vom Rücken auf die Bauchseite des Hinterleibes gewandert sei. Die Stammeltern der Honigbiene werden wohl von Anfang an aus den Platten der Bauchsegmente das Wachs, anfangs in geringer, allmälig in grösserer Menge ausgeschieden haben; aber in der Vermischung des Wachses mit einer erst überwiegenden, dann immer spärlicheren Menge fremder Zutaten, mögen sie eine ähnliche Stufenleiter dargeboten haben wie die Meliponen.

Der Wachsbau selbst ist bei den Meliponen ein durchaus anderer als bei unserer Honigbiene; er besteht nämlich aus zweierlei ganz verschiedenen Bauten:

I. Zunächt dem Flugloche befinden sich wagerechte, über einander liegende Brutwaben, jede aus einer einzigen Lage regelmässig sechsseitiger Zellen bestehend, die mit ihren Oeffnungen nach oben gekehrt sind, jede Wabe mit der darunter liegenden durch kurze Säulen verbunden. Der ganze Brutraum ist mit einer aus dünnen Wachsplatten gebauten Hülle umschlossen, die schwammartig von weiten, unregelmässigen Gängen durchzogen wird und sich mit den Rändern der Brutwaben durch Wachsbalken verbindet. Abgesehen von der Verschiedenheit des Baumaterials und der gerade entgegengesetzten Richtung der Zellen stimmen also die Brutwaben nebst ihrer Umhüllung in Form und Anordnung annähernd mit unseren Wespennestern überein.

2. In dem Raume, welcher ausser den Brutwaben und ihrer Umhüllung noch frei bleibt und welcher, je nach der Lage des Fluglochs und der Gestalt des bewohnten Hohlraumes über, unter, rechts, links oder hinter dem Brutraume oder an mehreren dieser Stellen zugleich sich vorfinden kann, befinden sich, oft ganz oder theilweise in die schwammige Wachshülle mit eingeschlossen, grosse, rundliche, unregelmässig über einander gehäufte Vorrathstöpfe, theils mit Honig, theils mit Bienenbrot (Blüthenstaub und Honig) gefüllt. Die vorliegenden Honigtöpfe der kleinen M. mirim nob. haben etwa die Grösse einer Flintenkugel und stehen mit unregelmässig nach den verschiedensten Richtungen hin frei in die Luft hinein gebauten Wachsbogen in Zusammenhange, die zunächt als vorläufiges Gerüst gebaut werden und zwischen welche dann diese kleinen Meliponen nach Bedürfnis kugliche Vorrathstöpfe einschalten.

Die Vorrathstöpfe der M. Coyrepú nob. haben fast die Grösse eines Hühnereies, und es mag jeder derselben etwa 2-3 Esslöffel voll Honig fassen. Die Honigtöpfe der M. Mondury Smith, welche ungefähr ebenso gross sind, wie die von Coyrepú, zeichnen sich, noch mehr als die der beiden vorigen Arten, durch die kolossale Wachsverschwendung aus, welche an ihnen zu Tage tritt, wenn wir sie mit dem Wachsbau unserer Honigbiene vergleichen; denn die Wanddicke 
jener schwarzen Honigtöpfe beläuft sich auf $4-10$, an einigen Stellen sogar bis I $8 \mathrm{~mm}$.

Die Vervollkommnung der Wachsbaukunst, welche in unserer europäischen Honigbiene ihren Gipfelpunkt erreicht zu haben scheint, wird also einerseits in stufenweiser immer reichlicherer Wachsabsonderung, andererseits in stufenweise inmer sparsamerer Wachsverwendung bestanden haben, welche letztere den $\mathrm{Zu}$ satz anderer Materialien immer mehr entbehrlich machte, bis zuletzt die erzeugte Wachsmenge und die durch stufenweise Steigerung erlangte Sparsamkeit in der Verwendung des Wachses ausreichten, die gesammten Brut- und Vorrathsbehältnisse aus reinem Wachse aufzubauen.

Wie in Bezug auf die Absonderung und Benutzung des Wachses, so bilden auch in Bezug auf den Aufbau der hexagonalen Zellen und die Versorgung der Brut mit Futter die Meliponen eine lehrreiche Zwischenstufe zwischen den einzeln lebenden Bienen und unserer Honigbiene. Denn während die einzeln lebenden Bienen immer nur cylindrische Brutzellen anfertigen, unsere Honigbienen aber zwei Schichten regelmässig hexagonaler Zellen gleichzeitig aus den entgegengesetzten Seiten einer senkrechten Mittelplatte herausbauen, lassen dagegen die Meliponen die Umwandlung der cylindrischen Zellform in die relmässig hexagonale auf das Deutlichste erkennen. Sie beginnen nämlich den Bau jeder ihrer horizontalen Brutwaben mit einer einzigen cylindrischen Zelle, welche die Mitte der späteren Brutwabe bildet. Nachdem dieselbe mit Larvenfutter und einem Ei versehen und geschlossen worden ist, wird dicht neben sie eine zweite cylindrische Zelle gebaut, die sich nur an der Berührungsfläche mit der ersten abplattet. Nachdem auch diese versorgt und geschlossen ist, werden in die beiden Winkel zwischen den beiden ersten Zellen gleichzeitig zwei neue cylindrische Zellen gebaut, welche sich wieder an den Berührungsflächen mit den schon vorhandenen Zellen abplatten. Nach Versorgung und Schliessung dieser wird in jeden der nun vorhandenen 4 Winkel eine neue Zelle gesetzt und diese Gruppe von 4 Zellen wiederum völlig zu Ende geführt, versorgt und geschlossen, ehe die folgende Zellengruppe, welche 6 nun vorhandene Winkel auszufüllen hat, in Angriff genommen wird; und so fort. Jede Zelle ist also cylindrisch, soweit ihre Seitenwände nicht durch Andrücken an Nachbarzellen abgeplattet worden sind; jede Zelle aber ist regelmässig hexagonal, sobald sie von 6 Nachbarzellen umschlossen wird. Eine Gruppe neuer Zellen wird um die vorhandene Mitte herum immer nur in der Weise angebaut, dass sich die neuen in die Winkel zwischen zwei oder drei bereits vorhandenen Zellen einfügen und so zunächst Cylinder mit 2 oder 3 unter Winkeln von I 20 Grad zusammenstossenden Säulenflächen bilden. Die äussersten Zellen einer jeden Brutwabe sind daher immer, auch wenn die ganze Wabe vollendet ist, cylindrisch gerundet. In der Regel werden von einer neuen Zellengruppe sämmtliche Winkel zwischen bereits vorhandenen Zellen ausgefüllt; bisweilen jedoch wird ein oder der andere Winkel übersehen und dadurch die Regelmässigkeit des Zuwachses der Wabe etwas gestört. Jede Zellengruppe wird erst vollständig vollendet, d. h. von den Arbeitern mit einem ausgespie'nen Gemenge von Blütenstaub und Honig versorgt, von der Königin mit einem Ei belegt und von den Arbeitern durch Einwärtsbiegen der ursprünglich zu hoch gebauten Ränder der Zellenöffnung geschlossen, ehe der Aufbau einer neuen Zellengruppe beginnt. 
Sobald jedoch die erste Wabe eine gewisse Grösse erreicht hat, wird auf ihrer Mitte die zweite Wabe begonnen, und beide werden nun gleichzeitig durch Umbau vergrössert. Ehe noch die erste Wabe vollendet ist, kann die zweite schon so weit herangewachsen sein, dass auf ihrer Mitte der Anfang der dritten Wabe gebaut wird, so dass dann einige Zeit lang drei Waben zugleich im Baue begriffen sind. In Folge der fremden Beimischungen schimmelt das Wachs der Meliponen sehr leicht und hierin mag der Grund liegen, dass sie ihre Brutzellen und in der Regel auch ihre Vorrathstöpfe nicht mehr als einmal benutzen, sondern dieselben, sobald sie leer sind, abbrechen und nach Bedürfnis wieder neue bauen. $\mathrm{Ob}$ auch die vorliegenden enorm dickwandigen Vorrathstöpfe der M. Mondury Smith zu nur einmaliger Benutzung bestimmt gewesen sind, ist mindestens sehr zweifelhaft. Ton den Brutwaben aber werden stets die untersten, sobald die Bienen aus ihnen ausgekrochen sind, abgebrochen, und unter dem alten Wabenbau wird nun ein neuer begonnen.

In Bezug auf die Zellen für die dreierlei Individuen ist der Wabenbau der Meliponen einfacher als bei unserer Honigbiene. Da nämlich die Drohnen sich an Grösse nicht von den Arbeitern unterscheiden, so werden, soweit die Erfahrung meines Bruders reicht, auch keine besonderen Zellen für dieselben angefertigt, und die Zellen der Königinnen unterscheiden sich zwar durch bedeutenderen Umfang und bedeutendere Höhe von den übrigen, liegen aber mitten zwischen denselben, indem sie nur die hexagonale Regelmässigkeit der umgebenden etwas stören und dieselben nach unten oder oben etwas überragen.

Endlich bilden auch in Bezug auf die Versorgung der Larven mit Futterbrei die Meliponen eine lehrreiche Zwischenstufe zwischen den einzeln lebenden Bienen und unserer Honigbiene. Denn wie jene versorgen sie zunächst die Zellen mit Larvenfutter, auf dasselbe wird sodann ein Ei gelegt und nun die Zelle geschlossen, während bekanntlich unsere Honigbiene ihre Eier in die leeren Zellen legt und die Larven dann in den offnen Zellen gefüttert werden. Die Arbeitstheilung dagegen ist bei den Meliponen schon ganz dieselbe wie bei den Honigbienen, indem auch bei ihnen der Königin ausschliesslich das Eierlegen als Aufgabe zufällt, während die Arbeiter alle übrigen Arbeiten verrichten.

Von den Eigenthümlichkeiten einzelner Arten will ich nur einige der hervorstechendsten kurz erwähnen. Einige Arten (M. Coyrepú nob., variabilis nob., Mondury Smith und Gurupú nob.) pflegen ihr Flugloch mit einem kraterförmigen Walle von Erde zu umgeben. M. Jaty Smith, deren vorliegenden Stock ich vom Juli bis November dieses Jahres lebend hatte, baut vom Flugloche aus eine etwa 8- $10 \mathrm{~mm}$ dicke, selten über $4-5 \mathrm{~cm}$ lange Röhre aus reinem weissem Wachs, die sie bisweilen aber nicht immer des Nachts schliesst. M. Trombeta nob. hat ihren (portugiesischen) Namen von ihrem manchmal bis fusslangen, vom Flugloche aus sich allmälig erweiternden, trompetenförmigen Vorbau, der zahlreichen Bienen auf einmal den Einflug gestattet. Das vorliegende Exemplar von Einflugstrompete ist nur 6 Zoll lang und im Eingange 3-4 Zoll weit; es ist aber offenbar auch dies Exemplar nicht auf einmal, sondern in drei auf einander folgenden Perioden gebaut worden, indem zwischen dem Flugloche und dem jetzigen Trompeteneingange auf der Aussenseite der Trompete noch zwei frühere Mündungen sich erkennen lassen. Die ganze Trompete besteht gleichfalls aus Wachs; der ältere Theil ist schwärzlich, der jüngere Rand gelblich grau. Die 
Innenfläche der Trompete ist von vorspringenden Leisten, höheren und niederen, durchzogen, die in verschiedenen Richtungen unregelmässig sich kreuzen und kleine, flache, wabenartige Vertiefungen umschliessen. M. limão (sprich limong!) Smith endlich baut vor ihr Flugloch einen kopfgrossen rundlichen Klumpen von schwärzlichem Wachs, der wie ein Schwamm von unregelmässigenı Gängen durchzogen ist und nach allen Seiten hin zahlreiche Ausgänge bietet.

Eine in mehrfacher Beziehung von den anderen abweichende Art ist M. Cagafogo nob., die sich schon durch den Besitz eines scharfen Giftes auszeichnet. Vor allem eigenthümlich ist ihre Geschmacksrichtung. Andere Bienen, gesellige, wie einsam lebende, scheinen in Bezug auf Geruch und Geschmack im Allgemeinen dasselbe angenehm oder widerlich zu finden wie wir; der Duft der Blumen, der sie anlockt, erfreut auch uns; der Honig ist auch für uns eine leckere Speise. Nicht so M. Cagafogo. Nur selten geht sie auf Blumen und fast nur auf übelriechende; dagegen wird sie von Allem angelockt, was stinkt. Eine halbverfaulte grosse Kröte fand mein Bruder über und über, bis tief in das weite Maul hinein, mit Cagafogo's bedeckt, sie finden sich ein bei den Eingeweiden geschlachteter Thiere, besuchen alten stinkenden Käse, und als mein Bruder einmal den Schädel einer Jararacassú ${ }^{1}$ ) reinigte, der lange in Weingeist gelegen hatte und eben nicht nach Rosen duftete, kam ein Cagafogo auf seine Hand geflogen. Thren Honigbedarf scheint diese Biene meist anderen Quellen zu entnehmen als den Blumen; sie sammelt sich in dichten Scharen an dem aus der Rinde von Bäumen ausfliessenden süssen Safte, dem auch viele Schmetterlinge vor Blumenhonig den Vorzug geben, sowie an gehauenem Zuckerrohr. Und wie viele Ameisen die Blattläuse als Milchkühe benutzen und die an ihrem Hinterleibe sich ausscheidenden süssen Tröpfchen lecken, so macht es die M. Cagafogo mit den Larven einer Membracide 2).

Am auffallendsten weichen in ihrer Lebensweise von allen übrigen vorliegenden Meliponen drei Arten $\mathrm{ab}$, welche sich, anstatt selbst Blütenstaub und Honig einzutragen, durch Raub und Mord oder durch Hinterlist und Betrug von dem Fleisse ihrer Geschwisterarten zu erhalten wissen. Eine wegen ihres citronenähnlichen Geruchs von den portugiesischen Bewohnern Brasiliens Abelha Limão genannte Melipona (Trigona limâo Smith), von glänzend schwarzer Farbe, hat sich des Blumenbesuches so völlig entwöhnt, dass ihre saugenden Mundtheile zu winzigen Rudimenten verkümmert sind. Anstatt den Honig mühsam Tröpfchen für Tröpfchen im Grunde der Blumen aufzusuchen und aufzusaugen, überfällt sie in Scharen räuberisch die Wohnungen anderer Bienen und beraubt sie der Früchte ihres Fleisses, sie erbricht und entleert ihre Honigtöpfe und ihre jüngeren Brutzellen und nimmt bisweilen auch vollständig Besitz von ihren Bau, indem sie die rechtmässigen Herren vertreibt oder tödtet. Ihre Oberkiefer, deren sie sich als Angriffswaffe bedient, haben sich in Anpassung an diese Lebensweise zu enormer Grösse und Kräftigkeit entwickelt.

I) Die gefährlichste dortige Giftschlange.

2) Vgl. meine Aufsätze in der Nature, Vol. VIII Nr. I93, July I0, I873 und Vol. X. Nr. 237, May I4, I874. „Larvae of Membracis serviug as milkcattle to a Brazilian species of honey-bee." In dem zweiten dieser Aufsätze ist auch eine Abbildung und Beschreibung aller drei Arten von Individuen der M. Cagafogo gegeben. $=$ Ges. Schriften S. 481 und 483 .

Fritz Müllers gesammelte Schriften. 
Zwei andere Meliponaarten scheinen in demselben Sinne Kukuksbienen bei den nächstverwandten selbstsammelnden Meliponen zu sein, wie unsere Schmarotzerhummeln bei selbstsammelnden Hummeln. Der Fall ist aber bei den Meliponen in sofern noch interessanter, als bei ihnen der verwandtschaftliche Zusammenhang klarer zu Tage liegt. Während man nämlich bei unseren Schmarotzerhummeln zweifelhaft sein kann und bis zu dieser Stunde in der That noch getheilter Meinung darüber ist, ob sie sich von gemeinsamen Stammeltern oder von bereits differenzirten Arten der Gattung Bombus durch Uebergang zur Kukukslebensweise abgezweigt haben, unterliegt es dagegen bei unseren beiden schmarotzenden Meliponen, wie ich mich durch genaue Untersuchung überzeugt habe, nicht dem mindesten Zweifel, dass jede derselben derjenigen Meliponaart am nächsten verwandt ist, in deren Nestern sie gefunden wird. M. cuculina nob. gleicht in den meisten Stücken, mit Ausnahme der Ausbildung der Hinterbeine, an welchen der Pollen-Sammelapparat wieder verloren gegangen ist, der M. Coyrepú nob., in deren Nest sie von meinem Bruder gefunden wurde, und in demselben Verhältnisse steht M. Gurupina nob. zu M. Gurupú nob. Natürlich sind bei den beiden KukuksMeliponen wie bei allen Kukuksbienen nur Männchen (bis jetzt noch nicht gefunden) und Weibchen vorhanden, keine Arbeiter, und da ihre saugenden Mundtheile durchaus nicht verkümmert sind, so werden sie wohl, ebenso wie alle einheimischen Kukuksbienen, für ihre eigene Beköstigung auf Blumen fliegen und Honig saugen und nur ihre Larven auf Kosten ihrer fleissigeren Geschwisterarten grossziehen, indem sie in die mit Larvenfutter versorgten Brutzellen derselben ihre Eier legen ${ }^{1}$ ).

Das wäre, meine Herren, ein kurzer Auszug aus den umfassenden Beobachtungen, welche mein Bruder Fritz Müller an den Ufern des Itajahy in Südbrasilien über die Lebensweise der Meliponen gesammelt hat. Was mich veranlasst hat, gerade hier diesen Auszug mitzutheilen, ist der lebhafte Wunsch, lebende Meliponastöcke sobald als möglich in unsere zoologischen Gärten eingeführt zu sehen und vor Allem die hier anwesenden Begründer des hiesigen zoologischen Gartens zu veranlassen, demselben sobald als möglich eine Anzahl lebender Meliponenstöcke einzuverleiben.

Dass die eingehende Beobachtung derselben für das Verständniss der Naturgeschichte unserer Honigbiene von höchster Wichtigkeit sein würde, werden Sie wohl, nach den von mir gegebenen Andeutungen, kaum bezweifeln. Dass aber die Einführung lebender Meliponenstöcke in unsere zoologischen Gärten möglich sein würde, dafür glaube ich den vorliegenden Stock der M. (Trigona) Jaty Sn. als Beleg anführen zu dürfen, welchen ich über 4 Monate lebend gehabt habe und welcher, nach meiner Ueberzeugung, auch den Winter überdauert haben würde, wenn ihn nicht auf der Seereise von Brasilien hierher ein künftig leicht z.u vermeidender Unfall betroffen hätte. Da dieser Unfall zugleich, wie ich glaube,

I) Neuerdings hat mein Bruder auch in den Nestern einer dritten Meliponaart (M. variabilis nob.) des Sammelapparates entbehrende Weibchen gefunden, welche dieser Art näher verwandt sind als irgend einer andern; ja er fand sogar bei einer besonderen Farbenabänderung der M. variabilis solche des Sammelapparates entbehrende Weibchen von derselben Farbenabänderung. Dadurch ist die Deutung dieser Weibchen als Kukuksbienen mehr als zweifelhaft geworden. Es sind höchst wahrscheinlich „Drohnenmütter" der betreffenden $\Lambda$ rten, wie solche Vogel (laut der Eichstädter Bienenzeitung 1866 Nr. I) bei einen ägyptischen Bienen beobachtet hat. (Nachträgliche Bemerkung während des Druckes.) 
den Beweis liefert, dass ein nützlicher Instinkt durch Veränderung der Umstände höchst verderblich werden kann, so dürfte seine Mittheilung wohl von allgemeinerem Interesse sein.

Die zierlichen Bienen, welche den vorstehenden Kasten bewohnten, hatten, wie ich mich alltäglich überzeugen konnte, den unter natürlichen Umständen gewiss sehr nützlichen Instinkt, alle, auch die kleinsten Zugänge ihres Wohnraumes, bis auf das Flugloch, mit Harz luftdicht zu verkitten. So oft ich z. B. den Glasdeckel des Kastens nach gewaltsamen Loszwängen mit einem Messer abgenommen hatte, war es nach dem Wiederauflegen desselben die erste Arbeit der Bienen, ihn wieder ringsum luftdicht anzukitten. Für die überseeische Reise nun musste der Kasten mit einem von feinem Drahtnetze umschlossenen Vorhofe versehen werden, in welchen die Bienen fliegen konnten, um Sonnenlicht und vorgesetzten Honig zu geniessen, ohne sich verfliegen zu können. Wahrscheinlich gewöhnten sich nun die Bienen, da sie aus dem Vorhofe nie heraus konnten, denselben als integrirenden Theil ihres Wohnraumes zu betrachten; denn nachdem sie einige Wochen in demselben eingesperrt gewesen waren, machten sie sich daran, auch die vielen tausend Maschen des Drahtnetzes mit kleinen Wachsblättchen luftdicht zuzukitten, und dies wurde von der Tochter meines Bruders, Anna Müller, welche den Stock pflegte und mir überbrachte, leider erst bemerkt. nachdem wohl über neun Zehntel des ganzen Bienenvolks plötzlich gestorben waren. Das plötzliche Hinsterben erfolgte im Verlaufe zweier Tage, noch ehe das Zukitten aller Maschen vollendet war, und es dürfte wohl ein durch den, wenn auch noch nicht vollendeten, doch bereits sehr weit gediehenen Luftabschluss bewirkter Erstickungstod gewesen sein. Da indess während derselben beiden Tage, an welchen das massenhafte Hinsterben erfolgte, das Meer so bewegt war, wie sonst während der ganzen Reise nicht, so muss die Möglichkeit zugestanden werden, dass vielleicht nicht der Luftabschluss, sondern die heftigen Erschütterungen des Stockes Todesursache gewesen sein könnten. Künftige Transportversuche werden entscheiden. Mir scheint die erstere Annahme die bei weitem wahrscheinlichere, und wenn sie richtig ist, so wird diese Gefahr bei künftigen Transporten sehr leicht zu vermeiden sein.

Die Ueberbringerin schaffte nun dem Vorhofe Luft, indem sie zahlreiche Maschen mit einer Stricknadel wieder öffnete, und die noch übrig gebliebenen Bienen - es dürften höchstens 200 gewesen sein - kamen wohlbehalten in Lippstadt an. Bei hellem Sonnenschein kamen sie ziemlich zahlreich aus dem Stocke heraus. Die meisten schwebten, sobald sie die Eingangsröhre verlassen hatten, ihren dünnen Hinterleib hoch hebend und die langen Hinterbeine senkrecht nach unten streckend, längere Zeit schwebfliegenartig vor dem Stocke, das Gesicht der Eingangsröhre zugewendet und allmälig sich von dem Stocke entfernend, als wollten sie sich die Lage desselben gehörig einprägen. An warmen sonnigen Tagen sah ich oft 12 bis 20 gleichzeitig in dieser Weise vor dem Stocke schweben und erst dann dem Stocke den Rücken kehren und rasch wegfliegen, so dass ich sie aus dem Auge verlor, wenn sie etwa einen Fuss weit von dem Stocke rückwärts geschwebt waren. Manche jedoch kamen mit Bruchstücken der Leichen todt gegangener Kameraden beladen aus dem Flugloche, und diese flogen jedesmal, ohne sich erst umzusehen und ohne sich im Fluge zu verweilen, direct weit 
weg. Leider gelang es mir nie, auf den benachbarten Blumen meines Gartens eine dieser kleinen Meliponen anzutreffen; sie müssen über die Gartenhecke weiter weggeflogen sein. Nur auf einem benachbarten Rosenstocke sah ich dann und wann einzelne Exemplare auf den Stengelblättern sitzen und bald sich sonnen, bald mit den Mandibeln die dünne Wachsschicht von der Blattoberfläche abschaben. Unter den heimkehrenden Exemplaren wurde, trotz beständig darauf gerichteter Aufmerksamkeit, niemals ein mit Blüthenstaub beladenes bemerkt. Blumen, welche alle ihre Nahrungsbedürfnisse hätten befriedigen können, haben sie also jedenfalls hier nicht gefunden. Ob sie Honig aus hiesigen Blumen entnommen, ob sie also überhaupt hier Blumennahrung gefunden haben, weiss ich nicht. Der im Vorhof ihnen vorgesetzte Honig von Apis mellifica, mit dem sie auch auf der Reise beköstigt worden waren, wurde von ihnen nicht nur eifrig gesaugt, sondern auch in die Sammelkörbchen der Hinterschienen gehäuft und mit in den Stock genommen, wahrscheinlich um Honigtöpfe damit zu füllen. Da ich sie niemals mit Blüthenstaub heimfliegen sah, so klebte ich, um ihnen Baumaterial zu liefern, an die Vorderwand des Kastens, rechts und links von der Eingangsröhre, je eine IVachskugel etwas grösser als eine Erbse, und zwar rechts Wachs derselben Bienenart, links Wachs ihres Todtfeindes, der schwarzen Raubbiene (M. limão). Anfangs wurden beide Wachssorten gleich eifrig bearbeitet; die Bienchen sassen oft $\mathrm{zu} 4$ bis 5 an jedem Wachsklumpen und bissen mit den Mandibeln kleine Wachsstücke los, die sie entweder unmittelbar in das Nest schleppten oder (häufiger) erst durch zahlreiche weiter abgebissene Stückchen zu einem Klümpchen anhäuften, welches zwischen Kopf und Vorderbeinen gehalten und ebenfalls in das Nest geschleppt wurde; nicht selten beluden sie aucl die Sammelkörbchen ihrer Hinterschienen mit Wachs. Sobald jedoch der Wachsklumpen von M. limão seiner obersten Schicht entkleidet war, verliessen ihn meine Bienchen, die wahrscheinlich nun erst den eigenthümlichen Geruch des Wachses wahrnahmen; von dem Jaty-Wachs dagegen trugen sie nicht nur die erste Kugel vollständig sondern auch noch den grössten Theil einer zweiten Kugel in ihr Nest. Um den inneren Ausbau ihres Wohnraumes kennen zu lernen, brach ich eines Tages im September die aus dünnen Wachsblättchen aufgebaute und von labyrinthischen Gängen durchzogene Hülle, welche in meinem Stocke nicht nur den Brutraum, sondern auch die neben demselben gelegenen Vorrathstöpfe überdeckte, vorsichtig ab und warf die losgebrochenen Stücke in den hinteren noch etwas freien Raum darbietenden Theil des Kastens. Nachdem ich zahlreiche (wenigstens Io) unregelmässig mit einander verbundene Wachsschichten abgetragen hatte, gelangte ich endlich zu einem kleinen, kaum mehr als $30 \mathrm{~mm}$ im Durchmesser betragenden Brutraume, in dessen Mitte sich eine einzige winzige Wabe von nur 7 Zellen befand. Eine dieser Zellen übertraf die übrigen an Höhe und Umfang; sie mochte wohl eine Königinzelle sein. I.inks neben dem Brutraum und seiner Umhüllung fanden sich fünf theils noch offene theils geschlossene, durch Wachsbalken mit einander verbundene kugelige Vorrathstöpfe; etwa von der Grösse einer Flintenkugel; die offnen waren mit klarem durchsichtigem Honig: gefüllt. Ich bekam bei diesem Offenbrechen jedenfalls den grössten Theil, wenn nicht alle in dem Stocke noch lebenden Bienen zu sehen, da sie höchst unruhig sich an die beschädigten Stellen drängten; ich schätzte ihre Zahl auf 100 bis höchstens 200; eine Königin sah iclı unter ihnen nicht. Trotz dieser geringen 
Volkszahl war der von mir angerichtete Schaden schon nach zwei Tagen fast vollständig wiecler hergestellt, mehrere senkreclite Wachswände bis zur Glasdecke des Kastens aufgeführt und zahlreiche den Brutraum unregelmässig umhüllende Schalen neugebaut. Noch an den sonnigen Octobertagen kamen die Bienchen, wenigstens in den Mittagsstunden, recht munter herausgeflogen und gaben mir sogar von ihrer Geistesgegenwart und Ueberlegung noch eine bewundernswerthe Probe. Einige .Honigbienen (Apis mellifica), die ihres Stockes beraubt im Garten umherirrten, drängten sich nämlich in den Vorhof meines Jatystockes, um den dort den Jaty's als Futter hingestellten Honig für sich in Anspruch zu nehmen; aber die Jaty's wussten die riesenhaften Eindringlinge, die ihre eignen Körpermasse wenigstens um das 50 - bis roofache übertrafen, in ebenso muthiger als zweckmässiger Weise am Honigraube zu verhindern; sie flogen denselben an die Flügel und bissen sich in dieselben ein, und zwar in der Regel je zwei in den Vorderrand jedes Vorderflügels nahe seiner Basis. Die Honigbienen suchten nun davon zu kommen, konnten aber nicht fliegen und liefen daher höchst unruhig im Vorhof umher, und die Jaty's blieben mit Ausdauer in die Flügel verbissen, während ihre Kameraden sich nun ungestört des Honiggenusses erfreuten. Ich sah einmal nicht weniger als sechs in dieser Weise von Jaty's gerittne Honigbienen in dem Vorhof umherrennen, und die Jaty's blieben selbst dann noch längere Zeit in die Flügel verbissen, nachdem ich die von ihnen gerittenen Bienen mit einer Pincette ergriffen und durch Zerdrücken von Kopf und Thorax getödtet hatte.

Als Ende October kältere Witterung eintrat, nahm ich den Stock, dessen Volk sich durch einzelne Todesfälle allmälig immer mehr vermindert hatte, in mein Wohnzimmer. Die Zimmerwärme vermochte jedoch niemals, die Thiere aus ihrem Neste hervorzulocken, während sie dagegen, sobald der Stock den directen Strahlen der Sonne ausgesetzt wurde, stets nach kurzer Zeit in grösserer oder geringerer Zahl herauskamen, um im Vorhofe schwebend oder sitzend das Sonnenlicht $\mathrm{zu}$ geniessen. Als am 28. November nach wochenlanger trüber Witterung endlich wieder ein zwar sehr kalter, aber klarer, sonniger Morgen eingetreten war, beging ich die Unvorsichtigkeit, den Stock in das von der Sonne beschienene, aber erst wenige Grad über den Gefrierpunkt erwärmte Fenster meines Wohnzimmers zu setzen. Nach kurzer Zeit kamen alle noch lebenden Bewohner des Stockes, 40-5o an der Zahl, munter hervor, um sich im Vorhofe der Sonnenstrahlen zu erfreuen; aber es dauerte nicht lange, da legte sich eine nach der andern auf den Rücken, zuckte noch einigemale mit Fühlern und Beinen und verendete. Wahrscheinlich hatte der plötzliche Temperaturwechsel sie getödtet. Es gelang nicht, durch Wiedererwärmen eine einzige in das Leben zurückzurufen.

Ich habe die an meinem Jatystocke gemachten Erfahrungen etwas eingehender mitgetheilt, weil ich glaube, dass manche derselben bei künftigen Einführungsversuchen berücksichtigt werden müssen. Obgleich nun allerdings die Möglichkeit, die Meliponen bei uns zu überwintern, noch keineswegs bewiesen ist, so scheinen mir doch die an meinem Jatystocke gemachten Erfahrungen weit mehr für als gegen dieselbe $z u$ sprechen. Jedenfalls aber ist der wissenschaftliche Gewinn, welchen die Einführung lebender Meliponenstöcke in unsere zoologischen Gärten verspricht, so bedeutend, dass keine Geduld und Ausdauer und keine Kosten gescheut werden sollten, um diese Einführung, wenn sie überhaupt möglich ist, auch zu verwirklichen. 


\section{Poey's Beobachtungen über die Naturgeschichte der Honigbiene von Cuba. Melipona fulvipes Guér.*).}

(Auszug mit Anmerkungen.)

Poey's schon im Jahre 1851 erschienene Arbeit über die Honigbiene von Cuba ${ }^{1}$ ), weitaus das Beste, was ich über die Naturgeschichte der stachellosen Honigbiene gelesen habe, - scheint in Europa fast unbeachtet geblieben zu sein; durch einen von einigen Anmerkungen begleiteten Auszug auf sie hinzuweisen, mag daher nicht unangemessen sein. Ich übergehe die Beschreibung der Art und beschränke mich auf die Mittheilungen über deren Lebensverhältnisse, wobei ich meist Poey's eigene Worte beibehalte:

„Melipona 2) fulvipes nistet in hohlen Bäumen ${ }^{3}$ ), und zwar nicht nur in Cedern (Cedrela odorata), wie Humboldt angibt; jeder Baum, der ihr sicheres Obdach verspricht, ist ihr recht. Unter sonst gleichen Umständen dürfte sie Bäumen aus der Familie der Guttiferen den Vorzug geben, die ausser Wohnung ihr auch Harz zu ihrem Bau und Blüthenstaub bieten ${ }^{4}$ ). - Die Bienen passen ihren Bau der Gestalt und den Verhältnissen der vorgefundenen Höhle an, nach welcher sich Länge und Umfang des Nestes richten ${ }^{5}$ ). Ihre erste Sorge ist, Spalten und Ritze zu verschliessen, die dem Licht oder feindlichen Insecten Einlass gewähren könnten ${ }^{6}$ ); sie benutzen dazu gewöhnlich ein Gemisch aus Harz und anderen, anscheinend erdigen ${ }^{7}$ ) Stoffen, welches einen sehr harten, bisweilen zolldicken Kitt bildet. Als einzigen Eingang lassen sie ein Flugloch von o,o1 $\mathrm{m}$ Durchmesser ${ }^{8}$ ), von dem aus ein allmälig erweiterter Gang bis zum oberen Ende des Baues sich fortsetzt ${ }^{9}$. Dann gehen sie an den Bau der grossen Vorrathstöpfe, die zur Aufnahme von Honig und Blüthenstaub ${ }^{10}$ ) dienen, Gestalt und Grösse einer Nuss haben und immer an den beiden Enden des Nestes, oben und unten angebracht sind; zwischen diesen beiden Niederlagen bringen sie die Waben an und umhüllen sie mit einem Mantel aus ziemlich groben Wachsblättern ${ }^{11}$ ). - Die Vorrathstöpfe werden aus dem besten Wachse gebaut, ebenso die Balken, welche das Nest seitlich an den Wänden der Höhle befestigen oder die Waben unter sich verbinden. Die Waben sind wagerecht und einander so nahe, dass sie nur einer

*) Zool. Garten 1875. I6. Jahrg. p. 29I-297. 
Biene den Durchgang gestatten; wie die Waben der Wespen sind sie durch kleine Säulen mit einander verbunden. Ihre obere Seite erscheint leicht vertieft ${ }^{12}$ ). Jede Wabe kann im Durchschnitt 300 Zellen enthalten und es finden sich ihrer in jedem Stocke etwa ein Dutzend ${ }^{13}$ ). Die Zellen sind aus einem Stoffe gebaut, der mehr dem Papier der Wespennester als gewöhnlichem Wachse sich nähert; ihr Boden ist dunkler, dicker und härter $\left.{ }^{14}\right)$. Ihre Gestalt ist sechsseitig mit halbkugligem Boden; ihr Durchmesser beträgt $4,5 \mathrm{~mm}$. Die Zellen bilden eine einzige Schicht; alle sind von gleicher Grösse, olne Unterschied zwischen Arbeiter- und Drohnenzellen. Nie traf ich Zellen, die man ihrer Grösse wegen für königliche hätte halten können; ob vielleicht zuweilen vorkommende querliegende Zellen diese Bedeutung haben, weiss ich nicht ${ }^{15}$ ). Ich habe in meinem Hause Waben gehabt, aus denen ich täglich 20 Arbeiter und 6 Männchen (oder vielmehr, wie Poey später selbst berichtigte, kleine Weibchen) auskriechen sah, ohne einen Unterschied in der Grösse der Zellen zu bemerken. Ich darf nicht mit Stillschweigen übergehen, dass ich am Rande der Waben mehr als einmal einen weissem Wachse ähnlichen, aber dehnbaren Stoff getroffen habe, von Grösse und Gestalt einer Kichererbse, auf kurzem Stiele sitzend, wie ein Pilz ${ }^{16}$ ).

In allen von mir untersuchten Stöcken befand sich sicher nie mehr als eine einzige befruchtete Königin mit angeschwollenem Hinterleib ${ }^{17}$ ). Neben der Königin pflegt man eine grössere Anzahl kleinerer Weibchen anzutreffen; so fand ich in einem Schwarme von 600 bis 1000 Arbeitern (von $12 \mathrm{~mm}$ Länge) 40 solcher kleiner Weibchen (von 10,5 mm Länge) ${ }^{18}$ ).

Diese Bienen sammeln mit grossem Eifer weiche Harze, wie die von Calophyllum Calaba, Garcinia cornea, Laetia apetala, und, wie man mir sagt, auch von Mastix und Cypressen. Haut man die Rinde eines Manajú (Garcinia cornea) an, wie versteckt er auch stehe, so kommen im Laufe des Tages die Bienen herbei, um das für ihr Nest nöthige Harz zu holen; sie tragen es an den Hinterbeinen fort, oft in Klumpen von der Grösse eines Reiskorns. Ist das Harz hart, so tragen sie es mit den Kinnbacken ${ }^{19}$ ).

Ich habe oft Arbeitsbienen heimkehren sehen, die auf dem Rücken des Hinterleibes Blättchen eines weissem Wachse ähnlichen Stoffes trugen; für gewöhnlich waren es 3 oder 4 Stückchen auf dem 3., 4. und 5. Ringe. Ihre Gestalt war die eines dünnen Blättchens, ihre Grösse $0,5 \mathrm{~mm}$; ich kann sie mit nichts besser vergleichen als mit den von der HIonigbiene, Apis mellifica, ausgeschwitzten Wachsblättchen. Ein kleines Klümpchen, das ich aus vielen Blättchen gebildet hatte, liess sich kneten, wie gewöhnliches Wachs; leider ging es verloren, so dass ich es nicht weiter untersuchen konnte. Sind es Wachsblättchen, die die Bienen von der Rinde oder der Blattoberfläche von Pflanzen abgeschabt haben ${ }^{20}$ )?

Zur Aufnahme der Brut stellen die Arbeitsbienen der Königin die leeren Waben zur Verfügung, deren Bau sie von der Mitte aus beginnen; sobald die Zellen fertig sind, werden sie mit einem aus Honig und wahrscheinlich halbverdautem, wieder ausgebrochenem Blüthenstaub bestehenden, halbflüssigen Brei gefüllt. Ist die Zelle voll ${ }^{21}$ ), so eilt die Königin herbei, um ein Ei hineinzulegen, welches wenigstens I mm lang ist, was die geringere Bevölkerungszahl, im Vergleich mit Apis, erklärt. Dann wird die Zelle geschlossen. Der Brei ist so dick, dass die Larve nach dem Auskriechen nicht untersinkt; sie liegt gekrümmt auf 
ihrer Nahrung, die sie allmälig verzehrt. Die Zelle wird von den Arbeitern mit gutem Wachs geschlossen, so dass die Larve keine andere Luft hat, als die anfänglich in der Zelle enthaltene; später wird ein Theil des Wachses wieder entfernt, und ist sie zur Puppe geworden, so ist nur nach das ursprüngliche dünne Deckelchen übrig ${ }^{22}$ ), welches die jungre Biene beim Ausschlüpfen selbst mit den Kinnbacken öffnet. Das Ausschlüpfen beginnt, wie der Bau, in der Mitte der Wabe, und da die Arbeiter die entleerten Zellen sofort abtragen, könnte eine halbleere Wabe die Vermuthung erwecken, es würde der Wabenbau vom Umfange her begonnen. Aus diesem Grunde findet man auch in den Nestern der Meliponen keine leeren Zellen.

Nachts hören alle Arbeiten auf, wenn man dies aus dem Schweigen des Schwarms und der Abwesenheit der Wache am Flugloche schliessen darf ${ }^{23}$ ).

\section{Anmerkungen.}

I) Felipe Poey, Memorias sobre la historia natural de la Isla de Cuba. Tomo I. Habanna I85 I, pag. I 22 .

2) Poey rechnet seine Biene zu Trigona; wenn ich sie, wie Guérin, Melipona nenne, so denke ich dabei natürlich nicht an den müssigen Streit der Systematiker der alten Schule, ob Melipona und Trigona zwei Gattungen bilden oder nur eine; das ist ia lediglich Sache des Beliebens oder höchstens eine Frage der Zweckmässigkeit, und wäre als solche zu bejahen, da die Uebersicht über die zahlreichen und so weit auseinandergehenden Arten stachelloser Honigbienen durch ihre Vertheilung in mehrere Gattungen nur erleichtert werden könnte. Trennt man Trigona von Melipona, so kann fulvipes trotz ihrer gezähnten Kinnbacken nur letzterer Gattung, d. h. dem Verwandtschaftskreise von favosa, anthidiö̈des u. s. w. beigezählt werden, wie Flügelgeäder, Bildung der Hinterschienen u. s. w. beweisen.

3) Dies gilt wahrscheinlich für alle Meliponen und die grosse Mehrzahl der Trigonen (um unter diesem Namen einstweilen die vielgestaltigen von Melipona abzutrennenden Arten zusammenzufassen). Einige Trigonen bauen ihre Nester aussen an die Aeste der Bäume, wie es von Tr. amalthea bekannt ist, und wie ich es bei der nahe verwandten Tr. ruficrus fand. Andere sollen in der Erde nisten, so nach Peckolt unsere Tr. cupira Sm. und nach Angabe meines Neffen Gustav Müller eine andere kleinere Art, in der ich nach dessen Beschreibung Tr, opaca F. u. H. M. zu erkennen glaube.

4) Ich habe von einer Bevorzugung bestimmter Bäume von Seiten einer oder der anderen Bienenart bis jetzt nichts bemerkt.

5) Nicht immer füllen die Nester die ganze Höhlung; bisweilen wird ein Theil derselben einfach unbenutzt gelassen, bisweilen wird der unbenutzte Theil durch eine Wand aus Kitt von dem bewohnten geschieden.

6) Dies geschieht wahrscheinlich, noch ehe der Schwarm in eine neue Wohnung einzieht. So beobachtete ein hiesiger Bienenzüchter, dass Jatys in mässiger Zahl in einen leeren Kasten seines Bienenstandes ein- und ausflogen; erst nach längerer Zeit, nachdem sie das Flugloch in ihrer Weise hergerichtet und wahrscheinlich auch das Innere wohnlich gemacht hatten, folgte diesen Vorläufern der ganze Schwarm. Bringt man einen Schwarm in eine neue Wohnung, so ist die allererste Sorge der Bienen, ihren lose liegenden Bau durch Wachsbalken an Boden und Wänden der neuen Wohnung zu befestigen.

7) Das ist sehr wahrscheinlich; unsere sämmtlichen Meliponen sammeln Erde zu diesem Behufe; dagegen habe ich von unseren zahlreichen Trigona-Arten bisher nur eine, Tr. cupira Sm., Erde sammeln sehen.

8) Der Durchmesser des Fluglochs ist auffallend gross; unsere Meliponen pflegen dasselbe so eng zu machen, dass nut eine Biene bequem hindurch kann. Bei M. Gurupú hat es 6 mm, bei M. pulchella F. u. H. M. (übereinstimmend bei 4 Stöcken) $4 \mathrm{~mm}$ Durchmesser. Doch mögen auch bei Melipona hierin Verschiedenheiten zwischen nahe verwandten Arten vorkommen, wie es bei Trigona in der That der Fall ist; Tr. pigra F. u. H. M., die Preguiçosa der Brasilianer, baut ein enges Flugloch von etwa $2 \mathrm{~mm}$ Durchmesser für den Durchgang einer einzigen Biene; die sehr nahe stehende Tr. mirim F. u. H. M., obwohl noch etwas kleiner, ein viel weiteres von 5-6 mm Durchmesser, in welchem gewöhnlich 4 Bienen rugleich als Wache sitzen. 
9) Vom Flugloch aus pflegt ein weiterer gewölbter Gang aus Kitt oder Wachs auf einc kürzerc: oder längere Streckc ins Nest hineinzugehen. 1 ı einem meiner Preguiçosa-Stöcke geht ein solcher Gang von $6 \mathrm{~mm}$ Halbmesser von dem unten in der Mitte der einen Wand befindlichen Flugloche zuerst $0,06 \mathrm{~m}$ weit in den Winkel zwischen dicser Wand und dem Boden bis zur nächsten Ecke, steigt dann in dieser $0,17 \mathrm{~m}$ senkrecht empor, fast his zur Decke des Kastens und gcht dann in wagerechtcr Richtung auf die anstossende Wand über, wo cr noch weiter gebaut wird. - In einem zweiten Stocke derselben Art steigt der Gang vom Flugloch senkrecht an der betreffenden Wand bis zu deren halber Höle empor und hat bis dahin etwa $0,035 \mathrm{~m}$ Durchmesscr; dann verengt er sich auf etwa $12 \mathrm{~mm}$ Durchmesser und gcht mit veränderter Richtung noch eine lange Strecke auf dieser und der anstossenden Wand weiter. Diese für die winzige Art ungemein weiten Gänge sind aus Wachs gebaut; bei anderen Arten habe ich sic nie in solcher Ausdehnung und immer aus Kitt gebaut gefunden. Dass sie bei M. fulvipes stets vom Flugloche nach dem oberen Ende des Baues hingehen, kann ich natürlich nicht geraclezu bestrciten; bei mehreren meiner Stöcke von Tr. mirim und M. pulchella gehen sie in gerader Richtung ctwa 5 bis 6 cm am Boden des Stockes hin.

Io) Oder vielmehr Bienenbrod; denn wie Apis, Bombus, Euglossa, Epicharis u. s. w. Sammeln auch die Meliponiden nicht trockenen Blüthenstaub, sondern durchfeuchten ihn sofort mit Honig.

II) Diese gegenseitige Lage von Waben und Honigtöpfen sah ich nur, wenn, wie in dem von Poey gezeichneten Neste, der Eingang sich etwa in der Mitte dor Höhe des Nestes befindet. Hat die Höhle ilıren Zugang oben, was die Bienen eben hinnehmen müssen, wie sie es finden, so trifft man die Waben oben, die Vorräthe dirunter; ungckehrt, wenn das Flugloch unten liegt, immer also die Brutwaben zunächst dem Eingange.

12) Eine solche leichte Concavität der oberen Wabenfläche ist mir noch bei keiner Art aufgefallcn.

I3) Die Zellenzahl und somit die Grösse der einzelnen Waben ist oft bedingt durch die Räumlichkeiten, über welche die Bienen zu verfügen haben; in einer weiten, niedrigen Höhle wird man grössere, in einer engen, hohen, kleinere Waben erwarten dürfen. Die Gesammtzahl der gleichzeitig in einen Stocke vorhandenen Zellen ist sehr verschieden, je nach der Art, nach der Jahreszeit und nach der Fruchtbarkeit der Königin. Die fruchtbarste Königin, die ich gesehen, von Tr. mirim, legte im Sommer etwa 150 Eier täglich, was - die Zeit bis zum Auskriechen zu etwa 36 Tagen gerechnet - 5400 Zellen ergibt.

14) Dies gilt wohl auch bei Melipona fulvipes nur für ältere Zellen, in denen die Larven bereits ihre Vorräthe aufgezehrt und sich eingesponnen haben. Ursprünglich sind die Zellen von TVachs; dieses wird aber abgenagt, nachdem die Larve sich eingesponnen, und es bleibt nun oben und unten nur das papierähnliche Gespinnst der Larve; der Boden erscheint jetzt dunkler, dicker und härter, weil auf ihm ein Rest des Futterbreies festgetrocknet ist.

15) Derlei querliegende Zellen habe ich noch nicht gesehen; durch Grösse ausgezeichnete Weiselwiegen sind auch mir bei Melipona noch nicht vorgekommen, doch kenne ich solche von verschiedenen Trigona-Arten.

16) Ganz ähnliche Gebilde findet man regelmässig, zwar nicht an den Waben selbst, wohl aber an der sie umgebenden Wachshülle bei Melipona pulchella. Durch ihre weissliche Farbe stechen sie lebhaft ab von:dem röthlichen Wachse. Sie bestehen aus einem weichen, klebrigen, nicht unangenehm riechenden Harze, das, wie andere Stoffe, wahrscheinlich dem Wachse beigemengt wird.

I7) Guérin hatte bei M. fulvipes zwischen ein paar Hundert Arbeitern etwa ein halbes Dutzend Weibchen gefunden, und wohl nur darauf gründet sich die Angabe, der man hie und da begegnet, dass bei Melipona zahlreiche Königinnen in einem Stocke leben. Um so wichtiger ist die bcstimmte Angabe Poey's, dass nur eine einzige Königin auch bei dieser Art sich findet, wie iclı selbst es stets bei den neun Arten von Melipona und Trigona fand, deren Nester ich untersucht habc.

18) Poey hielt diese kleinen Weibchen Anfangs für Drohnen, hat aber später selbst seinen Irrthum berichtigt. Nur bei Melipona scheinen solche kleine Weibchen vorzukommen. Ob aus ihrer Zahl die Königinnen hervorgehen oder ob sie einen eigenen Stand heiliger Jungfrauen (,parthenogenetischer Weibchen") bilden, bleibt noch zu ermitteln*).

19) Nicht minder eifrig im Sammeln harziger, kautschukïhnlicher und anderer Pflanzensäfte sind unsere hiesigen Bienen, und die verschiedenen Arten haben dabei verschiedcne Liebhabereien. Wohl.

*) Ein genauer Vergleich eines solchen klcinen W'eibchens mit einer befruchteten Königin von Melipona Coyrepú F. u. H. Müll. hat mich ïlıcrzeugt, dass ein merklicher Unterschied, ausser der kolossalen Anschwellung des befruchteten Hinterleibes, zwischen bciden nicht existirt.

Hermann Müller. 
riechende Harze sammelt M. Coyrepú; haut man eine Bicuiba (Myristica) oder einen Blutbaum (Pterocarpus) an, so kann man sicher sein, dass um den ausfliessenden drachenblutähnlichen Saft M. Garupú, Mondury und pulchella sich sammeln; ihr Wachs verdankt demselben seine dunkelbraunrothe oder röthliche Farbe. Tr. mirim sammelt einen ungemein klebrigen fadenziehenden Saft, vielleicht von einer FicusArt; die nahe verwandte Tr. pigra liebt balsamische Stoffe, z. B. Copaivabalsam u. s. w. Dass zum Tragen bisweilen auch die Kinnbacken benutzt werden, habe ich bei Erde eintragenden Coyrepús gesehen, von denen einzelne ausser den Höschen an den Hinterschienen auch noch ein Maulvoll mit heimbrachten.

20) Poey sah also die Wachsblättchen seiner Melipona an ihrer Bildungsstätte; er wusste sie mit nichts besser $\mathrm{zu}$ vergleichen als mit den Wachsblättchen von Apis, und doch, - es scheint fast unbegreiflich, dass er es nicht beim ersten Anblick gethan, - erkannte er sie nicht als solche und versäumte es, sich mit leichter Mühe zu überzeugen, dass sie zwischen den Rückenplatten des Hinterleibes ganz ebenso abgesondert werden, wie die von Apis zwischen den Bauchplatten; er versäumte es, so eine der wichtigsten Thatsachen in der Naturgeschichte der Meliponiden festzustellen, und warum? - weil er bei seiner Beobachtung schon die vorgefasste weitläufig von ihm erörterte Meinung hatte, dass die Meliponen kein Wachs absondern!

21) Poey scheint das Füllen der Zellen und das Eierlegen nicht wirklich gesehen, sondern diese Vorgänge nur erschlossen zu haben, und es bleibt daher für M. fulvipes noch festzustellen, ob die Zellen einzeln, eine nach der anderen, gefüllt und belegt werden, oder ob jedesmal gleichzeitig eine grössere Anzahl fertig gebaut, gefüllt, in rascher Folge belegt und geschlossen wird. Ersteres scheint für die Meliponen, letzteres für die Trigonen Regel zu sein.

22) Oder vielmehr das Gespinnst der Larve.

23) Dies ist keineswegs der Fall; der Wabenbau und andere häusliche Arbeiten gehen die ganze Nacht ununterbrochen fort. Das laute Summen an heissen Tagen hat mit diesen Arbeiten nichts zu thun, sondern wohl hauptsächlich rascheren Luftwechsel durch den Flügelschlag der Bienen zum Zwecke. Fürchten die Bienen für die Nacht Gefahr, so schliessen sie ihr Flugloch mit Wachs oder Harz, natürlich nicht luftdicht, sondern siebartig; man kann dies gewöhnlich in den ersten Nächten beobachten, nachdem man einen Schwarm in eine neue Wohnung übergesiedelt hat.'

I tajahy, Ende März 1875 . 


\section{Aus Brasilien (Meliponen $\left.)^{1}\right)^{2}$ ).}

Herr Redacteur! Gestern brachte mir die Post die No. 23 der Bztg. vom 15./12. 74, für deren freundliche Zusendung ich wohl Ihnen zu danken habe; ich beeile mich, dieser angenehmen Pflicht nachzukommen. Da ich selbst seit einigen Jahren mich mit der Lebensweise der Meliponen beschäftige, brauche ich Ihnen wohl kaum zu sagen, wie lebhaft mich der treffliche Vortrag von Drory erfreut hat, in dem ich so Manches, was ich an meinen eigenen Melipona-Völkern beobachtet hatte, vollkommen bestätigt fand. - Herr Drory hat gewiss Recht, dass praktischen Wert die Meliponen für Europa gar nicht haben; den haben sie seit der Einführung der europäischen Immen selbst hier nicht mehr. Doch ganz abgesehen von allem wissenschaftlichen Interesse, gibt es unter denselben so zierlich gebaute und so hübsch gefärbte Arten, dass ihre Einführung in zoologischen Gärten gewiss des Versuchs wert wäre. Sie drüben einzubürgern, dürfte kaum so schwierig sein, als Herr Drory fürchtet. Mögen auch die in der Nähe des Aequators heimischen Arten vielleicht nicht unter $15^{\circ} \mathrm{R}$. leben können, so sinkt doch schon hier $\left(27^{\circ}\right.$ S. B.), wo noch zahlreiche Arten leben, das Thermometer in kalten Wintern bisweilen auf ${ }^{\circ}{ }^{\circ}$, und manche Arten gehen ja noch südlicher bis Rio Grande und selbst bis in die Laplatastaaten. Diese aussertropischen Arten würden natürlich viel leichter sich drüben eingewöhnen.

Dass der Bau der Meliponen schmutzig-braun ist, dagegen das frische WVachs weiss, will Herr Drory durch die Beimischung eines dunklen Speichels bei der Verarbeitung erklären. Das ist nun wohl ein Irrtum. Trotz der Verarbeitung ist die aus reinem Wachs gebaute Ausflugsröhre unserer Trigona Iaty schneeweiss, das Wachs ihrer Brutwaben und Honigtöpfe bräunlich-gelb. - Die bei verschiedenen Arten sehr verschiedene (graue, gelbe, rötliche, braune bis fast schwarze) Farbe des Wachses rührt gewiss zum grössten Teil von der Beimengung fremder Stoffe her. Teilweise lassen sich diese Stoffe (z. B. Erde, schleimige Zusätze u. dgl.) durch Ausschmelzen wieder abscheiden und man erhält so z. B. aus dem schmutziggrauen Wachsbau unserer Cagafogo (von der ich nicht sagen kann,

1) Von Herm Fritz Müller, kaiserl. Beamten in Brasilien, Bruder des Herrn Professors Dr. H. Müller in Lippstadt. Wir hatten Herrn Fr. Müller, der sich lebhaft mit dem Studium der Meliponen beschäftigt, unterm 15./3. 75 No. 23 der Bztg. I 874 mit dem Aufsatze des Herrn E. Drory über Meliponen gesendet und hierauf obigen Artikel als Antwort erhalten.

Die Redaktion.

2) Eichstädt. Bienenzeitung. 1875. 31. Band. p. 215 (Nördlingen, Becksche Buchhandlung). 
ob es dieselbe Art ist wie die Cagafogo von Bahia) ein fast schneeweisses IVachs. Andere Stoffe, wie Harze, lassen sich so nicht wieder trennen. Die dunkelbraunrote Farbe des Wachses bei mehreren Arten rührt besonders von den drachenblutähnlichen Säften verschiedener Bäume (Pterocarpus, Myristica) her, die von diesen Arten eifrig gesammelt werden.

Die Frage, die neuerdings in Betreff der europäischen Bienen sich erhoben hat und ebenfalls in der mir zugesandten Nummer der Bztg. besprochen ist, ob die ganze Masse des Futtersaftes von den Speicheldrüsen geliefert wird, ist bei den Meliponen leicht dahin zu entscheiden, dass bei ihnen dies nicht der Fall ist; denn der dickliche Futterbrei, auf welchen die Königin ihr Ei ablegt, enthält eine grosse Menge Pollenkörner. Der Futtersaft wird von den Arbeitern ausgebrochen, wie ich unendlich oft gesehen habe.

Wenn bei Ihnen einzelne Bienenvölker sich das Rauben angewöhnen, so haben wir leider eine ganze Art Trigona limào Sm., die sich des mühsamen Selbstsammelns ganz entwöhnt hat und von der Ausplünderung anderer Arten lebt, deren Stöcke sie in dichten Schwärmen überfällt und deren gefährlichster Feind sie ist. Sie raubt ihnen nicht nur ihre Vorräte, sondern leert und zerstört auch die Brutwaben, von denen sie kaum die ältesten schont, in denen die Larven sich bereits eingesponnen haben. - Bisweilen nehmen sie sogar bleibenden Besitz von den überfallenen Wolınungen.

Bei Ihren Bienen werden die Brutzellen mit einem Wachsdeckel geschlossen für die letzte Zeit des Larvenlebens und für die Puppenzeit. Gerade umgekehrt ist es bei unseren Meliponen. Sobald die Königin ein Ei in die gefüllte Zelle gelegt, wird diese geschlossen und so ist die Larve für die ganze erste Zeit ihres Lebens von der äusseren Luft abgeschlossen; erst wenn sie sich eingesponnen hat, wird das Wachs von der Oberfläche der Brutwaben wieder abgenagt, so dass sie nun von der äusseren Luft nur durch ihr eigenes Gespinnst getrennt ist.

Meinen besten Dank für die gütige Uebersendung der so gehaltreichen Nummer Ihrer Bztg. wiederholend, zeichne ich mit etc.

Itajahy, Prov. St. Catharina, 25.4. 1875. 


\title{
On Brazil Kitchen Middens, Habits of Ants etc. $\left.{ }^{1}\right)$.
}

\author{
[Letter to Mr. Darwin.]
}

My dear Sir, - In Desterro I met with two young men (M. Charles Wiener, of Paris, and M. Carl Schreiner, from the National Museum of Rio) who, by order of the Brazilian Government, were examining the "Sambaquis" of our province. I accompanied them in some of their excursions. These "Sambaquis", or "Casqueiros", are hillocks of shells accumulated by the former inhabitants of our coast; they exist in great number, and some of them are now to be found at a distance of several miles from the sea-shore, though originally they were, of course, built near the spot where the shells lived. Some are of considerable size; we were told that a Sambaqui on a little island near San Francisco had a height of about 100 metres; but the largest I have seen myself did not exceed Io or I 2 metres. As to the shells of which they are composed, the Sambaquis may be divided into three classes, viz.: (I) Sambaquis, consisting of many different species of bivalve and univalve shells (Venus, Cardium, Lucina Arca, Ostrea, Purpura, Tritonium, Trochus etc.), all of which are at present living in the neighbouring sea. (2) Sambaquis, consisting almost exclusively of a small bivalve shell, the "Birbigäs" of the Brazilians (Venus flexuosa?), exceedingly common in shallow bays or saltwater lagoas, the bottom of which is of mixed mud and sand. (3) Sambaquis, consisting exclusively of a species of Corbula, which I have not yet seen in a living state; all the Brazilians also, whom I asked, and who are perfectly acquainted with any edible animal of their marine fauna, are unanimous in affirming that this shell does not live now on our coast. From one of these Corbula-Sambaquis I obtained a specimen of a small Melampus, which I have found living near the mouth of some rivulets, where fresh and salt water are mingling in ever-varying proportions. When the lowlands of the lower Itajahy and some of its tributaries were as yet beneath the level of the sea, they would have formed a large estuary, and here probably the Corbulæ lived. The fragments of human skulls which we found in one of these Corbula-Sambaquis were of truly astonishing thickness, whereas those I have seen from other Sombaquis are hardly thicker than our own. Among the tools which are to be found in the Sambaquis, stone-axes are by far the most frequent. But as M. Wiener will probably soon publish a full account of his researches, I will now no longer dwell on this subject.

I) Nature vol. XIII. 1876. p. 304. 305. 
Some time ago I sent to Germany for publication a note on the relation between our Imbauba trees (Cecropia) and the ants which inhabit their hollow stem. As there may be some delay in publishing, I will give you a short abstract. Mr. Belt has already stated that the ants farm scale-insects in the cells of the Imbauba stem, and he believes that their presence must be beneficial. This is no doubt the case; for they protect the young leaves against the leaf-cutting ants (Oecodoma). Now there is a wonderful contrivance by which, as in the case of the "bull's-horn acacia", the attendance of the ants at the right time and place is secured. At the base of each petiole there is a large flat cushion, consisting of most densely-crowded hairs, and within this cushion a large number of small white pear-like or club-shaped bodies (specimens inclosed) are successively developed, which, when ripe, emerge at the surface of the cushion, like asparagus on a bed, and are then greedily gathered by the ants and carried away to the nest. The object of the dense hair-cushion appears to be (I) to secure to the young clubshaped bodies the moisture necessary for their development; and (2) to prevent the ants from gathering the unripe bodies. In most cases it is by honey-secreting glands that the protecting ants are attracted; now Mr. Belt observed ("Nicaragua", p. 225) that the honey-glands on the calyx and young leaves of a Passion-flower were less attractive to the ants than were the scale-insects living on the stems; this would most likely be the case with the Imbauba, and it is probable that the use of the little pear-shaped bodies is to form an attraction stronger than that of the scale-insects, and thus to secure the attendance of the protective ants on the young leaves. As far as I could make out, the club-shaped bodies consist mainly of an albuminous substance. The ant colonies are founded by fertilised females, which may be found frequently in the cells of young Imbauba plants. Each internode has on the outside, near its upper end, a small pit where the wall of the cell is much thinner than anywhere else, and where the female makes a hole by which she enters. Soon after this the hole is completely shut again by a luxuriant excrescence from its margins, and so it remains until about a dozen workers have developed from the eggs of the female, when the hole is opened anew from within by these workers. It would appear that the female ants, living in cells closed all around, must be protected against any enemy; but notwithstanding a rather large number of them are devoured by the grub of a parasitic wasp belonging tho the Chalcididx; Mr. Westwood has observed that the pupæ of the Chalcididæe exhibit a much nearer approach to the obtected pupæ of the Lepidoptera than is made by any other IIymenoptera ("Introd. to the Modern Classif. of Insects," Part XI., p. I62). Now the pupa of the parasite of the Imbauba ant is suspended on the wall of the cell by its posterior extremity just like the chrysalis of a butterfly.

I hope you will have received a paper on Eglea, a curious Decapod inhabiting the mountain rivulets of our Serra do Mar. Lately I obtained a large number of specimens of this Eglea, and among them a female with eggs in an advanced state of development. Thus I was enabled to satisfy myself that, like so many fresh-water and terrestrial animals, the marine allies of which undergo a transformation, our Eglea does not experience any metamorphosis.

Itajahy, St. Catharina, Brazil, Dec. 25, 1875. 


\title{
Einige Worte über Leptalis ${ }^{1}$ ).
}

\author{
Mit 2 Zeichnungen.
}

„Für gevvisse Fälle der Mimicry oder der Bildung der natürlichen schützenden Masken und Nachahmungen ... scheint die natürliche Züchtung nicht auszureichen." ") „Nur da, wo die Stammform, von welcher die Umwandlung zur Maske ausgeht, der nachgeahmten Species ohnehin schon so ähnlich sieht, dass eine Verwechselung von Seiten ihrer Feinde möglich ist, nur da ist die natürliche Zuchtwahl im Stande, die Aehnlichkeit zu vervolikommnen und immer täuschender zu machen. Da dies aber nur bei einem Theil der bis jetzt bekannten Beispiele von Mimicry zutrifft, so müssen in den übrigen Fällen noch andere bis jetzt unbekannte Ursachen thätig gewesen sein.“"3) Aehnliche Bedenken gegen die Entstehung der Mimicry durch natürliche Züchtung sind auch anderwärts laut geworden und verdienen wohl eine eingehende Besprechung.

Die Mimicry, die täuschende Nachahmung anderer Arten, ist, insoweit sie der nachahmenden Art Sicherheit vor Feinden gewährt, nur ein besonderer Fall der schützenden Aehnlichkeit, von deren gewöhnlichster, einfachster Form, der schützenden Färbung, die allmählichsten Uebergänge zu den wundervollsten Beispielen täuschender Nachahmung führen, wie z. B. von einem gewöhnlichen einfach grünen Heuspringer zu einer Pterochroza, deren Flügel ein welkendes Blatt bis ins Einzelnste in unübertrefflicher Weise nachahmen.

Die schützende Färbung kann aber offenbar von jedem beliebigen Punkte aus durch natürliche Züchtung sich bilden. Nehmen wir z. B. einen Schmetterling, der die Gewohnheit hat, mit ausgebreiteten Flügeln an Baumstämmen zu ruhen, wie viele Nachtschmetterlinge und unter den Tagfaltern die Ageronien und die ihnen verwandte Ectima Liria. Selbst die riesigste Art, - etwa, um einen dieser ausfliessende Baumsäfte saugenden Schmetterlinge zu nennen, Erebus Strix, - würde, und wenn sie im blendendsten Weiss prangte, doch nur von einer bestimmten Entfernung her für Vögel unterscheidbar sein und auf eine weit geringere Entfernung hin die Aufmerksamkeit achtlos vorüberfliegender Vögel auf sich ziehen. Jede kleinste Abänderung, die ihre Färbung derjenigen der Baumrinde oder der sie bedeckenden Flechten näher

I) Jenaische Zeitschrift $\mathbf{1 8} 7$ 6. Bd. X. S. I-I2.

2) Oskar Schmidt, Descendenztheorie und Darwinismus. I873. S. I 47.

3) Das Unbew usste, vom Standpuncte der Physiologie und Descendenztheorie. (Anonyme Schrift E. von Hartmanns) I873. S. II. 
brächte, würde die eine wie die andere Entfernung und damit die Wahrscheinlichkeit, von Feinden bemerkt und verzehrt zu werden, verringern und also „die Grundlage für weitergehende Abweichungen nach derselben Richtung in den folgenden Generationen bilden können." (Das Unbewusste, S. Iо.) Von jedem beliebigen Ausgangspuncte aus würde sich also auf dem WVege der natürlichen Auslese jene täuschende Aehnlichkeit mit Baumflechten erreichen lassen, durch welche z. B. Ageronia Epinome plötzlich den Augen des Verfolgers entschwindet, wenn sie sich an einem Baumstamme niedersetzt und die Flügel demselben anschmiegt.

Ganz eben so würde von jedem beliebigen Ausgangspuncte aus die natürliche Züchtung dahin wirken können, ein Thier unter einem zahlreichen Schwarm einer anderen Art für die Augen seiner Feinde verschwinden zu lassen, etıva einen weissen Pieriden unter einem Schwarme bunter Ithomien. Würden die ersten unerheblichen Abweichungen von der urspründlichen weissen Färbung auch nur dadurch nützen, dass ihre Inhaber auf minder weite Entfernung hin die Aufmerksamkeit achtlos vorüberfliegender Feinde auf sich zögen, sie würden eben immerhin nützen und ,ihre Inhaber concurrenzfähiger im Verhältniss zur Stammform machen"; sie würden mithin als Grundlage dienen können für die allmähliche Herausbildung einer Aehnlichkeit, die selbst die scharfen Augen der den Ithomienschwarm nach Beute durchspähenden Vögel zu täuschen im Stande wäre. Möglicherweise haben so die Weibchen der Perrhybris (Pieris) Pyrrha, deren Männchen jetzt eine vorwiegend weisse Oberseite haben, von einer weissen Stammform aus ihre Heliconienähnlichkeit entwickelt, worin nach dem eben Gesagten gewiss keine „sehr schwer wiegende Schwierigkeit“ für die natürliche Züchtung zu erblicken wäre.

Handelte es sich in den erwähnten Fällen zunächst darum, das zu schützende Thier weniger auffallend aus seiner Umgebung hervortreten zu lassen, und konnte dies durch natürliche Auslese von jedem beliebigen Puncte aus erreicht werden, so stellt sich die Sache etwas anders in den Fällen, in welchen ein einzelner Gegenstand als Vorbild der schützenden Nachahmung diente, wie z. B. bei der Nachahmung einer Grabwespe (Pepsis), oder eines Laufkäfers (C icindela) durch Heuschrecken (Scaphura, Phylloxyrtus). Hier ist allerdings von vornherein eine gewisse Aehnlichkeit der nachahmenden und der nachgeahmten Art unerlässlich; doch wird auch hier diese Aehnlichkeit, um dem Eingreifen der natürlichen Auslese als Anhalt dienen zu können, eben nur gross genug zu sein brauchen, um gelegentlich einen in der Ferne achtlos vorübereilenden Feind zu täuschen. Ein wie geringes Mass kaum angedeuteter Aehnlichkeit genüge, um gelegentlich einem Thiere das Leben zu retten, mag ein Fall beweisen, in welchem ich selbst der Betrogene war. Am Stamme einer Cassia, deren ausfliessender Saft die mannichfaltigsten Kerfe anlockt, pflegte vor einiger Zeit auch eine schwarze Wespe mit weissen Flügelspitzen sich einzufinden, deren Stich ich als besonders schmerzhaft fürchten gelernt hatte. Eines Tages traf ich nun an dem Stamme eine Wanze, die höchstens durch die blasseren Spitzen der Flügel an die Wespe erinnerte; als ich sie fassen wollte, hob sie die Flügel in ähnlicher Weise, wie Wespen zu thun pflegen; unwillkürlich zog ich die Hand einen Augenblick zurück und die IVanze entwischte. 
Die Annahme einer so fernen anfänglichen Aehnlichkeit als Ausgangspunct für die Entstehung der Mimicry durch natürliche Zuchtwahl dürfte kaum in irgend einem der bekannten Fälle einem Bedenken unterlicgen. Es ist dabei nicht ausser Acht zu lassen, dass die Scharfsichtigkeit der Feinde, auf die man sich berufen hat, um von vornherein einen erheblichen Grad von Aehnlichkeit zwischen nachahmender und nachgeahmter Art zu verlangen, ja doch auch eine erst allmählich im Kampfe ums Dasein erworbene Eigenschaft ist, die eben dadurch sich steigern musste, dass die verfolgten Arten durch schützende Färbung, durch Mimicry u. s. w. sich den minder scharfsichtigen Verfolgern entzogen. Diese inmer wachsende Klugheit und Scharfsichtigkeit der Verfolger erklärt einerseits die wunderbare Vollendung vieler natürlichen Nachahmungen, macht aber ebenso andrerseits die Annahme einer anfangs sehr geringen Aehnlichkeit um so unbedenklicher.

Nach diesen Vorbemerkungen wende ich mich zur Besprechung des einzigen mir bekannten Falles, für welchen man die Unmöglichkeit der Entstehung der Mimicry durch natürliche Zuchtwahl näher zu begründen versucht hat. Er betrifft die Leptalis arten des Amazonas, welche sich unter die Schwärme der Ithomien mengen und diese durch üblen Geruch und Geschmack geschützten Schmetterlinge aufs Täuschendste nachahmen. Ich will zunächst die betreffende „Ausstellung gegen die Tragweite der natürlichen Zuchtwahl“" wörtlich hersetzen. 1)

„Gewisse weisse Schmetterlinge aus der Familie der Pieriden (Leptalis) ahmen diejenigen Arten der Heliconiden ${ }^{2}$ ), in deren Bezirk sie leben, so täuschend nach, dass man sie äusserlich fast nur durch die Struktur der Füsse unterscheiden kann. Die copirten Heliconiden besitzen einen unangenehmen Geruch und Geschmack, welcher sie vor Verfolgungen der Vögel schützt, und da nur etwa eine Leptalis auf Iooo Heliconiden vorkommt, so reicht dieser Schutz für die ersteren vollkommen mit aus. Nun stehen sich aber beide Gattungen mindestens so fern, wie etwa Fleischfresser und Wiederkäuer unter den Vierfüssern, man kann sich daher leicht denken, eine wie grosse Zahl von Zwischenformen für den Uebergang nöthig war, wenn dieser nur durch Addition zufälliger Individualabweichungen erfolgen sollte. Flügel, Fühler und Abdomen haben sich verlängert, die Farben der nachgeahmten Arten von Gelb und Orange bis Braun und Schwarz werden bis auf die Grade der Durchsichtigkeit und die Zeichnung der kleinsten Flecken und Streifen treulich copirt und selbst die Gewohnheiten sind derart modificirt, dass die Leptaliden dieselben Orte wie ihre Vorbilder besuchen und sogar dieselbe Flugart angenommen haben. - Es ist klar, dass die Aehnlichkeit nützlich ist, aber eben so klar, dass sie erst dann einen gewissen Schutz gewähren kann, wenn sie gross genug wird, um das scharfe Auge der

I) Das Unbewusste, S. Io. II.

2) Die von Leptalis nachgeahmten "Heliconiden“ (Ithomia, Mechanitis u. s. w.) sind neuerdings und mit vollem Rechte aus der Gruppe der Heliconinen ausgeschieden und mit derjenigen der $\mathrm{D}$ a nainen vereinigt worden. Die Gattungeu Heliconius und Eueides, auf die man jetzt die Heliconinen beschränkt hat, enthalten, so viel mir bekannt, keine nachgeahmten, wohl aber verschiedene nachahmende Arten. So ist Eueides $\mathrm{Pavana}$ die gelungenste Nachahmung der so manchen anderen Schmetterlingen (Castnia acraeoides, Dyschema Amphissa, Leptalis sp.) als Vorbild dienendeu Acraea Thalia.

Fritz Müllers gesammelte Schriften. 
Vögel zu täuschen. Es würde also bei der grossen Differenz der äusseren Erscheinung eine Zwischenstufe, welche immerhin dem Aussehn der Heliconiden schon näher steht als dem der Leptaliden, doch noch hinreichend deutliche Abweichungen von den Heliconiden zeigen, um von den Vögeln deutlich erkannt zu werden, also den Inhabern wenig oder gar nichts nützen, und jedenfalls würden solche Zwischenstufen, welche den gewöhnlichen weissen Pieriden noch näher stehen, als dem Aussehn der Heliconiden, in keiner Weise irgend welchen Schutz geniessen, also auch ihre Inhaber nicht concurrenzfähiger im Verhältnisse zur Stammform machen." -

Wie man sieht, geht die ganze Beweisführung von der Voraussetzung aus, dass die Stammform der nachahmenden L e pta 1 is arten ein ,gewöhnlicher weisser Pieride" gewesen sei. Wäre das erwiesen, so würde ich darin inımer noch keine "sehr schwer wiegende Schwierigkeit" für die Selectionstheorie sehen können; allein unbegreiflicherweise ist auch nicht mit einem Worte der Versuch gemacht, die Zulässigkeit und Wahrscheinlichkeit jener Voraussetzung zu prüfen. Weil sie mit den deutschen Weisslingen in dieselbe Familie grestellt wird, soll etwa deshalb die Stammform der südamericanischen Gattung Leptalis auch weiss gewesen sein? Aber fliegen nicht selbst in Deutschland neben dem Kohlweissling der Citronenvogel und gelbe Coli as arten? Mag man mit einiger Wahrscheinlichkeit für die Gattung Pieris eine weisse Stammform annehmen dürfen, da sie neben gelben, rothen, schwarzen und bunten Arten doch auch fast in aller Welt weisse Vertreter hat, so lässt sich diese Annahme doch keineswegs auf alle Gattungen der Familie ausdehnen, z. B. schon nicht auf die deutschen Gattungen Gonopteryx und Colias, eben so wenig auf Terias, Callidryas, Euterpe, Pereute u. s. w., und am allerwenigsten auf die Gattung Leptalis, die ,jedenfalls an die äusserste Peripherie der Pieriden gehört." (Herrich-Schaeffer.) $\mathrm{Zu}$ sehr Laie auf dem Gebiete der Schmetterlingskunde, um nicht meinem eigenen Urtheile zu misstrauen, will ich noch einige bewährte Meister auf diesem Felde sich hierüber aussprechen lassen. „Ce genre," sagt Boisduval1) von Leptalis, „est assez anomal et il se pourrait que plus tard lorsque l'on connaîtra ses métamorphoses il constituât une tribu particulière prés des Héliconides." "The neuration of the posterior wings,“ sagt Doubleday ${ }^{2}$ ) ,and the five-branched subcostal nervure, with four of its nervules very short, running almost directly to the costa, the long slender abdomen, the elongate wings and other characters, bring this genus very near to the Heliconidae." Dass man der Stammform einer so abweichenden Gattung, deren Zugehörigkeit zur Familie noch nicht einmal über allen Zweifel erhaben ist ${ }^{3}$ ), nicht ohne Weiteres Farbe, Gestalt und Flugweise der "gewöhnlichen weissen Pieriden" beilegen darf, liegt auf der Hand. Es fehlt somit der ganzen obigen „Ausstellung gegen die Tragweite der natür-

I) Boisduval, Species général des Lépidoptères. Tom. I. I836. p. 412.

2) Doubleday et Hewitson, Genera of Diurnal Lepidoptera, pag. 36 .

3) Stoll hat als Raupe der Leptalis Amphene eine Raupe abgebildet, die kaum einer anderen Familie, als derjenigen der Danaiden angehören kann. Möglich, dass Stoll in diesem Falle die Leptalis mit ihrem Vorbilde verwechselt und die Raupe des letzteren als die der ersteren abgebildet hat. Ist die betreffende Raupe wirklich die der Leptalis, so würde man, trotz ihrer entwickelten Vorderfüsse und zweispaltigen Fussklauen, kaum an der nahen Verwandtschaft dieser Gattung mit den von so vielen ihrer Arten nachgeahmten heliconierähnlichen Danainen zweifeln können. 
lichen Zuchtwahl" die unentbehrlichste thatsächlichste Unterlage. Dic versäumte Erörterung der Frage nach der Stammform der nachahmenden Leptalisarten würde schwerlich auf einen ,gewöhnlichen weissen Pieriden“, sie würde wahrscheinlich auf den Heliconinen und heliconier-ähnlichen Danainen im Aussehen ziemlich nahe stehende Schmetterlinge hingeführt haben

Versuchen wir das Versäumte nachzuholen. Von den 65 Lepta lisarten, die Kirby in seinem Verzeichnisse der Tagfalter aufzählt ${ }^{1}$ ), überschreiten freilich nur wenige den südlichen Wendekreis; es sind mir hier, unter $27^{\circ} \mathrm{S}$. B., nur fünf Arten vorgekommen und nur von vier kann ich sagen, dass ich sie kenne, da ich die fünfte (Leptalis Thermesia) nur zwei oder dreimal gesehen habe. Die vier häufigeren Arten sind indess wie eigens für die Erörterung der Frage nach ihrer Stammform ausgelesen und so lässt sich vielleicht trotz ihrer so dürftigen Zahl eine leidlich sichere Antwort hoffen. Eine unserer Arten, Leptalis Melia, trägt ihr eigenes Gewvand (hat wenigstens unter den hiesigen Schmetterlingen kein Vorbild); die drei übrigen sind nachahmende Arten und haben ihre Vorbilder in eben so viel verschiedenen Familien. Leptalis Astynome trägt die Maske eines heliconier-ähnlichen Danainen, der Mechanitis Polymnia var. Lysimnia. Eine Art, deren Namen ich nicht erfahren konnte ${ }^{2}$, und die im Folgendem als Leptalis Thalia bezeichnet werden mag, ist eine so gute Nachahmung der Acraea Thalia, dass mir ihre Flügel als die einer unbekannten Acraea bestimmt wurden. Von Leptalis Melite endlich ahmt das Weibchen einen "gewöhnlichen weissen Pieriden“, die Daptonoura Lycimnia (Pieris Flippantha) nach.

Beginnen wir mit dem, was in der obigen Ausstellung als letzte und höchste Leistung der Mimicry betrachtet zu werden scheint: „selbst die Gewohnheiten sind derart modificiert, dass die Leptaliden dieselben Orte wie ihre Vorbilder besuchen und sogar deren Flugart angenommen haben." Vollständiger hätte der Sachverhalt nicht auf den Kopf gestellt werden können. Das Besuchen derselben Orte ist ja selbstverständliche nothwendige Vorbedingung der Mimicry; nie findet sich ein Thier von einer anderswo lebenden Art nachgeahmt. Hätten die nachahmenden mit den nachgeahmten Arten nicht von vornherein an denselben Orten gelebt, dann würde allerdings die Nachahmung nicht durch natürliche Zuchtwahl und wohl überhaupt nicht naturwissenschaftlich zu erklären sein; wir würden Herrn Eduard Hartmann mit seinem wunderthätigen hellsehenden Unbewussten zu Hülfe rufen müssen. Was aber die Flugart betrifft, so sind doch wohl nicht deshalb die Leptalis schlechte Flieger geworden, weil sie dadurch den schlecht fliegenden Ithomien ähnlicher und besser gegen Feinde geschützt wurden; sondern umgekehrt ist deshalb für sie das Verstecken hinter eine schützende Maske zur Nothwendigkeit geworden, weil sie so jämmerliche Flieger sind. Ein Schmetterling mit dem kräftigen Flügelschlage einer P repona kann getrost sein eigenes glänzendes Blau zur Schau tragen.

I) K irby, A synonymic catalogue of Diurnal Lepidoptera. I871. p. 432.

2) Die Namen der anderen Arten, wie der übrigen hier genannten Schmetterlinge danke ich der Güte des Herrn Dr. A. Gerstaecker in Berlin. 
Nachahmende Arten stehen natürlich immer zwischen ihrer Stammform und ihren Vorbilde; sie können niclıt über letzteres hinausgehen. Nicht selten beschränkt sich die Nachahmung auf die Weibchen, oder ist doch bei diesen besser durchgeführt. Wo also merkliche Geschlechtsverschiedenheiten bei nachahmenden Arten vorkommen, wird man folgende Reihe haben: Stammform, Männchen, Weibchen der nachahmenden Art, nachgeahmte Art. Das gibt einigen Anhalt für die Ermittelung der Stammform.

Nun zeigt ein einziger Blick auf die Abbildung der Leptalis A mphione ${ }^{1}$ ) oder besser noch der Leptalis Euno ë2), dass der Schnitt ihrer Vorderflügel nicht etwa mitten inne steht zwischen dem von Pieris und dem von I thomia oder Mechanitis, und nach Doubleday ${ }^{3}$ ) sind bei Leptalis ,im Allgemeinen die Vorderflügel der Männchen kleiner und mehr sichelförmig oder spitz, als die der Weibchen". In Bezug auf die Vorderflügel wird sich im Allgemeinen folgende Reihe herausstellen: Pieris, Ithomia, Leptalis , Leptalis 0. - Darnach würde man als Stammform der nachahmenden I,ep-

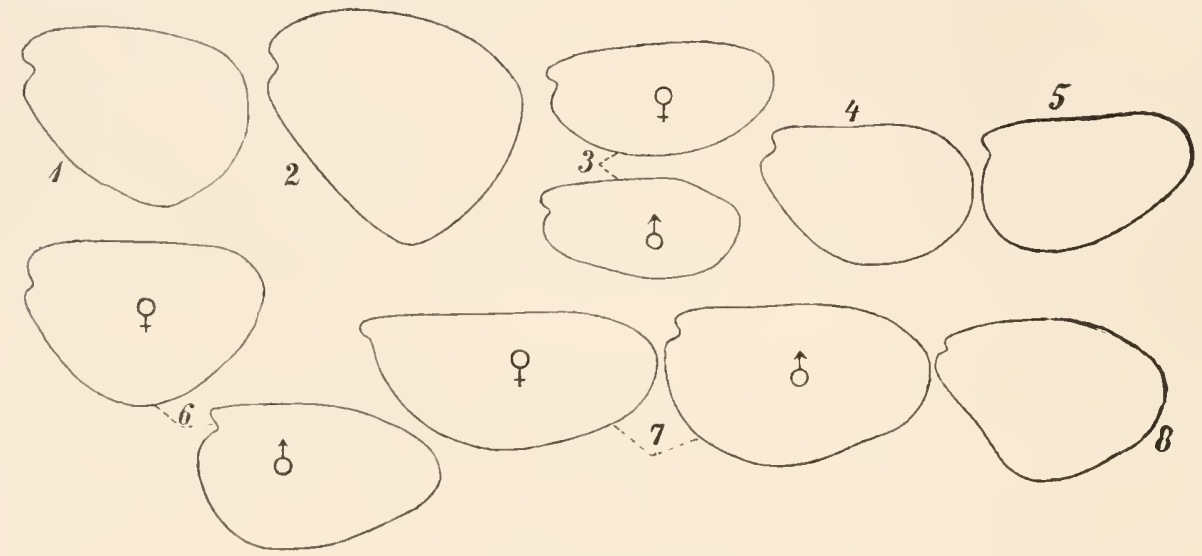

Umrisse von Hinterflügeln:

1. Pieris Aripa Boisd. 2. Daptonoura Lycimnia Cram. 3. Mechanitis Polymnia Linn. var. Lysimnia Fabr. 4. Acraea Thalia L. 5. Leptalis Melia Godt. 6. Leptalis Melite L. 7. Leptalis Astynome Dalm. 8. Leptalis Thalia.

talis arten nicht etwa einen "gewöhnlichen weissen Pieriden", sondern eher einen Schmetterling vermuthen, der im Flügelschnitt mehr noch, als die Heliconier sich von Pieris entfernt. - Doch fassen wir unsere hiesigen nachahmenden Leptalis arten etwas schärfer ins Auge; vergleichen wir sie einerseits mit ihrem Vorbilde, andrerseits mit der nicht nachahmenden Leptalis Meli a und einem "gewöhnlichen weissen Pieriden", etwa der Pieris Aripa oder der Daptonoura Lycimnia, um zu sehen, nach welcher Seite hin wir wohl die Stammform zu suchen haben.

Besonders eigenthümlich ist bei Leptalis Melia die Gestalt der Hinterflügel, ihre grösste Breite liegt bei dieser Art ganz in der Nähe der Flügelwurzel, bei Pieris Aripa und Daptonoura dagegen fast am Ende des Flügels. Ver-

1) Boisduval, Species général des Lépidoptères. Tome I. pl. 18, fig. 2.

2) Doubleday et Hewitson, Genera of Diurnal Lepidoptera. Tab. V, fig. 3.

3) Doubleday et Hewitson, a. a. O. pag. 36. 
gleicht man nuı die Hinterflügel dieser Arten mit denen unsrer übrigen Leptalis und ihrer Vorbilder, so ergeben sich folgende Reihen:

1. Pieris oder Daptonoura. Mechanitis Lysimnia. Leptalis Astynome o Leptalis Astynome ó. Leptalis Melia.

2. Pieris oder Daptonoura. Acraea Thalia. Leptalis Melia.

3. Pieris oder Daptonoura. Leptalis Melite f. Leptalis Melite ó. Leptalis Melia.

Die Endpuncte der Reihen sind immer dieselben: einerseits Pieris und Daptonoura, andrerseits Leptalis Melia; die nachahmenden Arten stehen immer zwischen letzterer und ihrem Vorbilde, und zwar, wo ein auffallender Unterschied der Geschlechter sich findet, die Weibchen näher dem Vorbilde, die Männchen näher der Leptalis Melia. In Bezug auf die Gestalt der Hinterflügel darf man daher mit voller Zuversicht aussprechen, dass die Stammform unserer nachahmenden Arten nicht den ,gewöhnlichen weissen Pieriden“, sondern vielmehr der am entgegengesetztesten Ende der Reihe stehenden Leptalis Melia ähnlich gewesen sei.

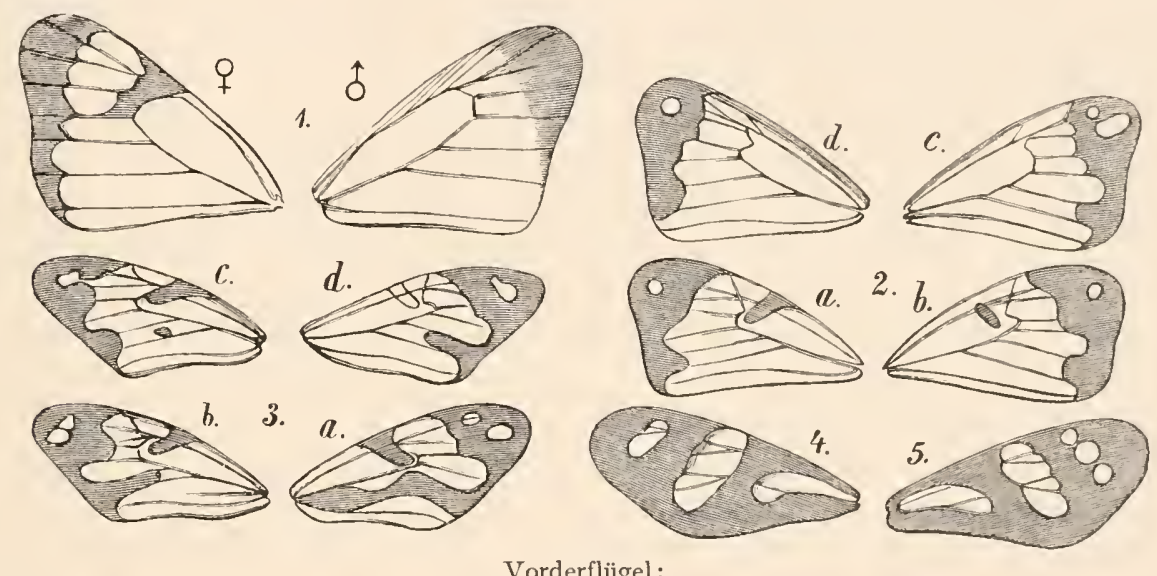

I. Daptonoura Lycimnia Cram. 2. Leptalis Melite L. + . 3. Leptalis Melite L. O. 4. Leptalis Melia Godt. 5. Leptalis Thalia.

Zu dem gleichen Ergebniss führt die Vergleichung der Gestalt der Vorderflügel. Besonders lehrreich ist hier Leptalis Melite. Die Männchen (Fig. 3) haben noch ziemlich den Flügelschnitt der Leptalis Melia (Fig. 4); einzelne Weibchen (Fig. $2 d$ ) haben fast schon die Flügelform ihres Vorbildes, der Daptonoura Lycimnia (Fig. I) erreicht, während andere (Fig. $2 a$ ) sehr merklich dahinter zurückbleiben. Selbst das Flügelgeäder bleibt von dieser Umwandlung des Flügelschnitts nicht unberührt. Bei Leptalis Astynome, Thalia und Melia entspringen die vier Aeste, die von der Subcosta zum Vorderrande gehen $(8,9,10$ und 1 I nach Herrich-Scha effer), sämmtlich jenseits der Flügelzelle; ebenso bei Leptalis Melite 0 , obwohl einer der Aeste (11), oft schon dicht an die Zelle heranrückt; ebenso auch noch bei denjenigen Weibchen, die den Männchen im Flügelschnitt näher stehen; bei denjenigen Weibchen aber, deren Vorderflügel am meisten cler Daptonoura sich nähern, pflegt jener $\Lambda$ st (II) vor dem Ende der Zelle oder doch an deren Ende abzugehen. 
Von der Form wenden wir uns zur Zeichnung der Flügel. Leptalis Thalia steht in dieser Beziehung mitten inne zwischen ihrem Vorbilde, Acraea Thalia, und Leptalis Melia: mit letzterer stimmt sie fast vollständig in der Zeichnung der Yorderflügel (Fig. 4 und 5), mit ersterer in der der Hinterflügel überein. Le ptalis Melite, bei der wir schon im Flügelschnitt ein gewisses Schwanken bemerkten, zeigt sich weit mehr noch in der Flügelzeichnung als noch im Werden begriffene, unfertige, noch nicht zur Ruhe gekommene Art. Von Männchen (Fig. 3 a), die sich in der Zeichnung der Vorderflügel noch ziemlich eng an Leptalis Melia (Fig. 4) anschliessen, bis zu Weibchen (Fig. 2), die schon der Daptonoura (Fig. I) ganz nahe kommen, findet man eine eng geschlossene Reihe von Uebergängen, aber unter vielen Dutzenden von Thieren oft kaum zwei gleich gezeichnete. Der Fortschritt der Zeichnung hält mit dem des Flügelschnittes nicht immer gleichen Schritt; so zeigen die in der Gestalt vorgeschrittensten Flügel (Fig. $2 \mathrm{c}$ und d) oft noch in der dunkeln Vorderecke ansehnliche helle Flecke, die bisweilen bei anderen in der Gestalt dem Vorbilde ferner stehenden (Fig. 2 a, b) schon fast oder selbst völlig verschwunden sind. Was sich aus der Vergleichung des Flügelschnittes in Betreff der Stammform ergeben hatte, wird durch die Betrachtung der Zeichnung nur bestätigt.

Endlich die Färbung. Bei Leptalis Melia ist die Oberseite der Flügel dottergelb und schwarz; auf den Vorderflügeln herrscht das Schwarz, auf den Hinterflügeln das Gelb vor. Bei den Männchen der Leptalis Melite finden wir dieselben beiden Farben; aber das Schwarz tritt mehr zurück, in sehr verschiedenem Grade bei verschiedenen Thieren (Fig. $3 \mathrm{a}-\mathrm{d}$ ), und das Gelb ist ein weit matteres unreines Citronengelb; bei den Weibchen dieser Art zeigt die Oberseite der Flügel fast genau dasselbe unreine Weiss, wie ihr Vorbild, Daptonoura Ly cimnia. Bei Leptalis Thalia schwankt wie bei ihrem Vorbilde, Acraea Thalia, die Farbe innerhalb ziemlich weiter Grenzen; sie kommt der des Vorbildes täuschend nahe, ist jedoch meist weniger gesättigt und pflegt einen Stich ins Gelbliche zu zeigen; bisweilen sieht es aus, als ob auf gelben Grund die Farbe der Acraea aufgepinselt worden wäre. Einmal fing ich mitten im Winter (28. Juli), wo sonst weder Acraea noch Leptalis flogen, eine vereinzelte Leptalis Thalia, bei der die helleren Stellen der Hinterflügel rein schwefelgelb, die der Vorderflügel weisslich gelb waren. - So weist auch die Färbung nicht auf einen "gewöhnlichen weissen Pieriden", sondern auf einen gelb und schwarzen Schmetterling als Stammform der nachahmenden Leptalisarter hin.

Die Vorfahren der jetzt unter der Maske anderer Gattungen auftretenden L,eptalisarten haben ohne Frage schon als sie noch ihr eigenes Gewand trugen, melurere vielleicht in Zeichnung und Farbe ziemlich verschiedene Arten gebildet, für die wir jedoch den schmächtigen Leib, die langen schmalen Vorderflügel, die nahe der Wurzel sehr breiten Hinterflügel und eine hauptsächlich in Schwarz und Gelb ausgeführte, in ähnlicher Weise, wie bei den heliconierähnlichen Danainen angeordnete Zeichnung mit leidlicher Wahrscheinlichkeit als gemeinsame Eigenthümlichkeiten annehmen dürfen.

L eptalis dürfte also jedenfalls kein glücklich gewähltes Beispiel scin, um darauf eine "Ausstellung gegen die Tragweite der natürlichen Zuchtwahl" zu be- 
gründen, und ich bezweifle, dass andere Fälle schützender Aehnlichkeit sich besser dazu eignen würden. Eine andere Frage ist es, ob alle Fälle von Mimicry, namentlich bei den Schmetterlingen, als schützende Aehnlichkeit aufzufassen sind, und ob nicht vielleicht bei diesen mit so ausgeprägtem Farbensinn begabten Thieren die geschlechtliche Auslese bisweilen zur Nachahmung eines augenfälligen schönen Vorbildes geführt habe. Doch auch in letzterem Falle, dessen Vorkommen mir nicht unwahrscheinlich ist, würden wir uns nicht nach ,, his jetzt unbekannten Ursachen" umzusehen brauchen.

Itajahy, April 1875 . 


\title{
Aeglea Odebrechtii n. $\mathrm{sp}^{1}$ ).
}

\author{
Mit Tafel XLIV.
}

In den Bächen, die von der Serra do Mar ostwärts dem Itajahy, westwärts dem Rio das Marombas und durch ihn dem La Plata zufliessen, lebt auf sandigem Grunde ein flinker, flacher Krebs, stellenweise so häufig, dass sich um ins Wasser gehängtes Fleisch in kurzem ihrer 20 bis 30 sammeln. Durch die Güte des Entdeckers, des Herrn Emil Odebrecht, erhielt ich ein (wie er mir sagte, etwa halbwüchsiges) Männchen, und selten hat mich ein Thier mehr überrascht. Denn der nächste Verwandte dieses in den Gebirgsbächen nahe der Ostküste von Südamerica hausenden Krebses lebt im Meere an der Westküste; es ist die Aeglea la evis, die nach der von Milne Edwards gegebenen Beschreibung ${ }^{2}$ ) kaum von unserm Gebirgskrebs zu unterscheiden ist. - In süssem Wasser ist wohl überhaupt aus der ganzen Abtheilung der Anomuren noch keine Art gefunden, und ebenso von den nächstverwandten meerbewohnenden Gattungen (Galathea und den davon abgetrennten Pleuroncodes Stimps., Munida und Grimothea) noch keine an der Ostküste von Südamerica. Wie kommt nun diese Krebsform des Stillen Meeres auf unsere Berge? -

Schion seines Vorkommens willen ist dieser Krebs wohl der Beschreibung werth.

Von oben betrachtet (Fig. I) bildet der Umriss des Körpers eine ziemlich regelmässige Ellipse, die reichlich um die Hälfte länger als breit ist, und deren Vorderende in drei Zähne, einen längeren mittleren und zwei kürzere seitliche ausläuft. Die beiden vorderen Drittel dieser Ellipse nimmt die Kopfbrust, das hintere der Anfang des Hinterleibes ein, dessen Schwanzende nach unten umgeschlagen ist. Der $\mathrm{Panz}$ er ist flach, mit tiefer, sehr augenfälliger Nackenfurche versehen. Seine Rückenwand stösst mit den Seitenwänden in scharfen Seitenkanten zusammen. Der Vorderrand ist mit einem geraden, auf der Oberseite gekielten Stirnschnabel und mit einem Zahne an jeder Seitenecke bewehrt; zwischen beiden liegt jederseits eine Augenbucht, über die der Stirnschnabel etwa doppelt so weit $(4 \mathrm{~mm})$ vorspringt, als die Seitenzähne. Am Seitenrand des Panzers sieht man ausserdem noch zwei kleine, kaum über denselben vorspringende Zähne,

1) Jenaische Zeitschrift 1876. Bd. X. S. I3-24. Taf. I.

2) Hist. nat. des Crustacés. II, S. $25^{8}$. 
den einen dicht hinter der Nackenfurche, den anderen weiter nach vorn, etwa um die Hälfte weiter von dem hinteren Zahne, als von der Vorderecke entfernt. Der Hinterrand des Panzers ist seicht ausgebuchtet. Die Oberfläche des Panzers ist mit kleinen Grübchen ziemlich dicht bestreut, im Uebrigen glatt und ohne auffallende Erhabenheiten; nur im vorderen Theile des Kopfgürtels (arceau céphalique M. Edw.) liegen jederseits hinter der Augenbucht zwei flache Buckel hinter einander, der hintere der Mittellinie etwas näher. Länge des Panzers (bis zur Spitze des Stirnschnabels): $23 \mathrm{~mm}$; Breite zwischen den Vorderecken: 7,5 mm; zwischen den Vorderecken des Schultergürtels (den hinteren Seitenzähnen): $16 \mathrm{~mm}$; in der Mitte des Schultergürtels: $20 \mathrm{~mm}$., am Hinterende: $18 \mathrm{~mm}$. - Die von den scharfen Seitenkanten schief nach unten und innen steigenden Seitenwände des Panzers haben ihre grösste Breite $(7 \mathrm{~mm})$ an der hinteren Ecke des Mundrahmens; von da verschmälern sie sich allmählich nach hinten (bis auf $2 \mathrm{~mm}$ ), rasch nach vorn, wo der Rand des Mundrahmens auf die Vorderecke zuläuft, aber durch eine tiefe Bucht, in der das erste Glied der äusseren Fühler liegt, davon getrennt ist (Fig. 4).

Furchen und Nähte des Panzers. Die Nackenfurche (sillon cervical M. Edw.) fällt nicht mit der Grenznaht zwischen Kopf- und Schultergürtel zusammen; sie berührt dieselbe nur auf kurze Strecken und liegt sonst vor derselben; also auf dem Kopfgürtel. Ihr mittlerer, sehr tief eingedrückter Theil bildet einen nach vorn offenen Halbkreis und verbindet sich durch eine flachere und etwas breitere Stelle mit den wieder tief eingedrückten, gradlinig zum Rande laufenden Seitentheilen. - Auf dem Schultergürtel laufen zwei etwas gebogene, sehr augenfällige Furchen von dessen Vorderrande nach hinten, aber nicht bis zum Hinterrande, sondern nur bis $\mathrm{zu}$ einer nahe an demselben hinziehenden, nicht minder tiefen Furche. Alle diese Furchen sind nicht etwa Nähte, in denen ursprünglich getrennte Stücke des Panzers zusammenstossen, sondern vielmehr durch den Ansatz verschiedener Theile an dessen Innenseite bedingte Eindrücke. Nähte sind dagegen unverkennbar schmälere Linien, die flach, aber scharf eingedrückt auf der Aussenfläche, schwach vorspringend auf der Innenfläche des Panzers verlaufen und als helle Linien erscheinen, wenn man den Panzer gegen das Licht hält.

Die Naht, welche Kopf- und Schultergürtel scheidet, fällt in ihrem mittleren Theile mit der Nackenfurche zusammen; wo diese sich nach vorn krümmt, geht jene ziemlich gerade nach aussen weiter bis etwa halbwegs zwischen Mittellinie und Seitenrand und geht dann in schwach nach vorn gewölbtem Bogen schief nach vorn zum Seitenrande, wo sie wieder mit der hier endenden Nackenfurche zusammentrifft; darauf läuft sie auf der Seitenwand des Panzers schief nach vorn, um im Grunde der Fühlerbucht zu enden (Fig. 4). - Der Kopfgürtel zeigt keine deutlichen Nähte. Um so zahlreicher sind sie auf dem Schultergürtel. Zunächst wird ein mittleres, etwa ein Drittel der Breite einnehmendes Rückenfeld abgegrenzt durch zwei nach aussen von den Längsfurchen in gerader Linie vom vordern zum hintern Rande des Schultergürtels verlaufende Nähte. Dieselben laufen bis zum Hinterrande selbst, nicht blos, wie die Längsfurchen, bis zur hinteren Randfurche. Etwas nach aussen von diesen Längsnähten entspringt von der vorderen Quernaht, da wo sich diese schiof nach vorn wendet, eine schicf nach aussen und hinten zur Mitte der Seitenkante des Schultergürtels verlaufende 
Naht welche die Seitentheile des Rückens in ein dreieckiges vorderes und ein viereckiges hinteres Feld scheidet. Als besonderes Stück ist von dem vorderen Felde der Schulterzahn durch Naht abgegrenzt. Nach aussen ist das vordere Seitenfeld begrenzt durch eine Naht, die vom Schulterzahne aus dicht an der Seitenkante sich hinzieht; am Anfang des hinteren Seitenfeldes geht diese Naht vom Rücken auf die Seitenwand über und läuft hier in der Nähe der Seitenkante bis zum Hinterrande. So gehört von der Seitenkante des Schultergürtels der vordere Theil der Seitenwand, der hintere der Rückenwand an.

Auf den Seitenwänden (Fig. 4) wird zunächst ein schmaler, über den Füssen liegender Streifen durch eine Längsnaht abgesondert, die kurz vor dem Hinterende mit der das hintere Seitenfeld des Rückens nach aussen begrenzenden Naht zusammenfliesst, so dass das hintere, etwas breitere, abgerundete Ende jenes Streifens unmittelbar an die Rückenwand stösst. Ausserdem finden sich zwei Quernälıte. Die vordere geht von der hinteren Ecke des Schulterzahnstückes schief nach hinten und trifft über dem ersten Paare der Lauffüsse die Längsnaht; die hintere begrenzt nach vorn ein kleines dreieckiges, zwischen Rückenwand und den unteren Längsstreifen der Seitenwand eingetheiltes Feldchen.

Der Panzer unserer A e gle a ist in hohem Grade merkwürdig dadurch, dass an ihm neben einander und beide in ungewöhnlicher Deutlichkeit ausgeprägt, die Nackenfurche und die Grenznaht zwischen Kopf- und Schultergürtel sich finden, und dass ebenso auf letzterem ein Mittelfeld durch Längsfurchen und gleichzeitig ein anderes durch Längsnähte abgegrenzt wird. Dieselben Nähte finden sich nach Milne Edwards ${ }^{1}$ ) unter anderen bei Birgus latro; dieselben oder ähnliche Furchen mehr oder minder deutlich bei vielen Krabben und Krebsen. Dass man nun aber nicht ohne Weiteres, wie man zu thun pflegt, Furchen und Nähte als einander entsprechend betrachten darf, dass man keineswegs immer gleichwerthige Abschnitte erhält, wenn man z. B. einmal einen „sulcus cervicalis“, ein andermal eine „sutura cervicalis“ als Grenze zwischen Kopf- und Schultergürtel annimmt, beweist das gleichzeitige Vorhandensein von Naht und Furche bei Aeglea.

Ich kehre zur Beschreibung meines Krebses zurück. Augenhöhlen sind selbst nicht in der unvollständigen Weise, wie sie bei Porcellana vorkommen, vorhanden; die kurzen Augenstiele sind schicf vorwärts gerichtet. Die in neren Fühler sitzen unter und hinter den Augenstielen (Fig. 3), ihr kurzes dickes, nach dem Ende zu breiteres Grundglied trägt keinerlei Dornen oder Zähne; das zweite Glied sitzt an der inneren vorderen Ecke des ersten, ist schlank, walzenförmig, leicht gebogen, überragt kaum die Augen und legt sich in der Ruhe zwischen Augenstiele und Stirnschnabel; das dritte ist etwas kürzer und wird nach unten eingeschlagen; von den Endgeisseln ist die dickere (13 gliedrig) etwa so lang, als das dritte Glied des Stieles, die andere (ı gliedrig) kürzer. Der Stiel der ä us s er en Fühler ist viergliedrig; das erste Glied ist unbeweglich und seine Umgrenzung kaum deutlich zu erkennen; der diesem Gliede eigenthümliche Höcker liegt nahe der vorderen Ecke des Mundrahmens, seine Oeffnung ist nach hinten gerichtet. Das zweite Glied liegt in derselben Querlinie mit dem Grundgliede der inneren Fühler; aussen trägt es einen durch Naht deutlich abgesetzten spitzen, kegel-

1) Annal. des Sc. nat. 3. Série. Zoolg. XVI. fol. 8, pag. 2. 
förmigen Vorsprung (Fig. 4), wahrscheinlich ein Ueberbleibsel des äusseren Astes (der Schuppe des Garneelenfühlers); es ist wie das folgende Glied dick und kurz; das vierte Glied ist weit dünner, walzenförmig, etwa so lang, wie die beiden vorigen zusammen. Die vielgliedrige, unbehaarte Geissel ist $34 \mathrm{~mm}$ lang.

Der Mundrahmen (cadre buccal) ist vorn um die Hälfte breiter als hinten (Fig. 3) und nicht durch scharfe Grenzen von dem vorderen Mundschilde (Epistom) geschieden. Die inneren Mundtheile übergehe ich, da ich sie nicht mit denen der nächstverwandten Gattungen vergleichen kann. Die äusseren Kieferfüsse (Fig. 5) reichen ausgestreckt etwa bis zur Spitze des Stirnschnabels; das zweite Glied des inneren Astes ist ohne blattförmigen Vorsprung nach innen, dreikantig, die innere vordere Kante bewimpert, die innere hintere Kante mit einer Reihe kegelförmiger Zähne bewehrt (wie bei den ächten Galathea im Sinne von Stimpson); das dritte Glied etwa von Länge des zweiten, nicht breiter als das kurze vierte; das fünfte Glied walzenförmig, länger als seine Nachbarn.

Die Brustplatte bildet ein gleichschenkliges Dreieck mit nach vorn gerichteter Spitze, dessen Grundlinie ( $10 \mathrm{~mm}$ ) fast der Höhe (1 $2 \mathrm{~mm}$ ) gleich kommt. Die Grenzen der fünf Stücke, durch deren Verschmelzung sie gebildet ist, sind durch breite, seichte Furchen bezeichnet. An den Hinterecken jedes dieser Stücke springen Gelenkhöcker vor für die betreffenden fünf Fusspaare (äussere Kieferfüsse, Scheerenfüsse und drei Paar Lauffüsse). Der Hinterrand hat eine breite, flache, vorn geradlinige Bucht, in die sich der letzte freie Brustring einlegen kann.

Die Scheerenfüsse sind von mässiger Länge (möglichst gestreckt $30 \mathrm{~mm}$ ), kräftig, mehr nach vorn als nach aussen gerichtet, nach unten sich einschlagend; die linke Scheere ein wenig stärker, als die rechte. Oberarm dreikantig, die innere kürzeste Kante mit fünf spitzen Zähnchen bewehrt; winzige Zähnchen an der Endhälfte der beiden anderen Kanten, die obere die längste ( $7 \mathrm{~mm}$ ). Vor der arm weit kürzer als der Oberarm, innen $5 \mathrm{~mm}$ lang; Vorder- und Hinterrand nach aussen fast in einen Punct zusammenlaufend. Innenrand stark gewölbt, mit 5 Zähnen, von denen der vierte der längste; oben trägt der Vorderarm eine aus kleinen Höckern gebildete, dem Innenrand gleichlaufende Leiste, unten zwei Zähne. Ha nd, links: i $4 \mathrm{~mm}$ lang, I I breit, 5 dick; rechts: $14 \mathrm{~mm}$ lang, 9 breit, 4 dick. Obere Fläche körnig rauh, ohne Zähne oder Dornen; der kurze Innenrand fast halbkreisförmig vorspringend, fein sägezähnig; untere Fläche mit einer von der Spitze zum äusseren Gelenkhöcker laufenden, aus verschmelzenden Höckern gebildeten Leiste. Greifrand in seinem oberen Theile schwach löffelförmig ausgehöhlt, darunter mit einer zahnartig vorspringenden dreieckigen Fläche (diese an der linken Hand weit stärker). Oberer Rand der löffelförmigen Aushöhlung fein gekerbt (links) oder gezähnelt (rechts); an der rechten Scheere setzt sich diese Zähnelung auch auf den Rand des zahnartigen Vorsprungs fort. Daumen $8 \mathrm{~mm}$ lang, ziemlich gerade, sein Greifrand dem des feststelıenden Fingers ähnlich.

Die drei Paar La uffüsse sind schlank, schwach zusammengedrückt, keins ihrer Glieder verbreitert; sie sind unbewehrt, nur die Kanten mit besser fühlbaren als sichtbaren, endwärts gerichteten Dörnchen oder Börstchen besetzt. Das Klauen* glied fast so lang als die beiden vorhergehenden zusammen, dünn, nur schwach gebogen, in eine harte scharfe Spitze auslaufend. Möglichst gestreckt sind die vorderen Lauffüsse $30 \mathrm{~mm}$ lang (Oberschenkel 9, Unterschenkel 4, Fussglicd 5, Klauenglied $7 \mathrm{~mm}$ ), die mittleren $29 \mathrm{~mm}$, die hinteren $27 \mathrm{~mm}$. 
Die Putzfüsse (Fig. 7) sind sehr beweglich an dem ebenfalls sehr beweglichen freien letzten Brustringe eingelenkt; das erste dicke kurze Glied ist fast ganz häutig und trägt nach innen die Ruthe (Fig. $7, r$ ); dann folgen vier dünne langstreckige Glieder, von denen in der Ruhe das erste schief nach hinten und aussen, das zwveite, längste (Oberschenkel) schief nach vorn und aussen, das dritte und vierte (Unterschenkel und Fussglied) gerade nach innen gerichtet sind, so dass die Spitze des Fussgliedes die Ruthe von unten deckt. Ein deutlich abgesetztes Fingerglied konnte ich nicht unterscheiden; ich sah nur am Ende des Fussgliedes zwei rundliche mit je einer Reihe zierlicher Zähnchen besetzte Höcker (Fig. 8) oder Knnöpfchen, als dürftige Reste der Scheerenfinger an den Putzfüssen der verwandten Gattungen.

Der Hinterleib (Fig. 2) ist gross und kräftig, reichlich so lang, als die Kopfbrust; er lässt sich nicht völlig ausstrecken; sein hinteres Ende ist nach unten geschlagen, wobei die Grenze zwischen viertem und fünftem Ring den hinteren Rand bildet. Von der Brust wird durch den nach unten geschlagenen Schwanz nur der letzte freie Ring mit Putzfüssen und Ruthe bedeckt. Der Rücken der vorderen Ringe ist gewölbt (Höhe des Bogens fast $1 / 3$ der Sehne), der des Schwanzes flach. Die Breite sinkt vom 2. bis 6. Ring von iz auf I I $\mathrm{mm}$.

Die Rückenplatte des ersten Ringes ist sehr kurz; ihr gewölbter Vorderrand passt in die seichte Bucht am Hinterrande des Panzers. Dieser Ring ist der einzige, dessen Bauchseite durch einen dünnen, queren, verkalkten Stab gestützt ist; die Bauchseite der übrigen ist ganz häutig; am zweiten Ring fand ich ihren mittleren Theil beutel- oder bruchsackartig vorgetrieben.

Am zweiten bis sechsten Ringe sind die Seitenstücke der Rückenplatte durch sehr augenfällige Furchen vom Mittelstücke geschieden; die Seitenstücke des zweiten Ringes haben einen $4 \mathrm{~mm}$ langen Seitenrand, die der folgenden laufen in eine schwach vorwärts gebogene Spitze aus; ihr zugeschärfter, eingebogener Vorderrand legt sich unter den gewölbten Hinterrand des vorhergehenden; am sechsten Ring ist der Hinterrand der Seitenstücke gerade. Der 2. bis 5. Ring sind etwa gleich lang $(3 \mathrm{~mm})$, der 6 . und 7 . länger $(5 \mathrm{~mm})$. Am sechsten Ringe nehmen die Seitenstücke nur etwa $2 / 3$ der Länge ein; das vierte Drittel bleibt für die Einlenkung der Schwanzfüsse.

Der sie be n tie R ing ist in seiner vorderen Hälfte ziemlich gleich breit $(7 \mathrm{~mm})$; dann laufen die Seitenränder bogig nach dem schwach eingekerbten Hinterende zusammen; in der Mittellinie dieses Ringes verläuft eine seichte Furche. Der Hinterrand ist bewimpert.

Die fünf ersten Hinterleibsringe sind vollkommen anhanglos; der sechste trägt die blattförmigen Schwanzfüsse, die mit dem siebenten Ringe eine sehr ansehnliche (etwa $22 \mathrm{~mm}$ breite, Io $\mathrm{mm}$ lange) Flosse bilden.

Das Grundglied der Schwan z üsse ist von ansehnlicher Grösse, dreieckig; sein Vorderrand legt sich dem Seitenstücke des 6. Ringes an, überragt dasselbe etwas, und reicht, wenn der Schwanz eingeschlagen ist, bis zur Spitze des Seitenstücks des 5. Ringes; der Innenrand schiebt sich unter den vorderen Theil des 7. Ringes; der Augenrand trägt in seiner vorderen Hälfte die beiden Endblätter; diese sind von nahezu gleicher Grösse und Gestalt, eiförmig; $7 \mathrm{~mm}$ lang, das vordere (äussere, untere) $3,5 \mathrm{~mm}$., das hintere (innere, obere) $4 \mathrm{~mm}$ breit. 
Aussen und hinten sind sie bewimpert. Eine Quernaht zeigt keines der Blätter, dagegen die Oberseite des inneren einen fast bis zum Ende desselben zu verfolgenden Kiel.

Die Kiemen, die bei Porcellana und nach Milne Edwards ${ }^{1}$ ) auch bei Galathea die gewöhnliche Form der Krabbenkiemen haben, zeigen bei unserer A eglea einen ganz eigenthümlichen Bau (Fig. 9, Io); jede Kieme besteht aus einem schmalen Blatt, das nahe seinem unteren Ende angeheftet und an seinem freien äusseren Rande dicht mit langen Fäden besetzt ist. Nach beiden Enden des Blattes zu werden die Fäden kürzer. Es scheinen stets drei Reilhen von Fäden vorhanden zu sein, eine mittlere, eine hintere, deren Fäden ein wenig kürzer, und eine vordere, deren Fäden weit dünner und nur etwa $1 / 3$ so lang sind, als die der mittleren Reihe. Der fadenlose innere Rand der Kieme legt sich der Leibeswand an, die Fäden sind nach vorn gerichtet, so dass die hinteren Kiemen die vorderen decken. Von hinten beginnend, findet man zuerst zwei grössere, dann eine etwa dreimal so kleine Kieme, und so wechseln immer zwei grosse mit einer kleinen Kieme. Im Ganzen zählte ich jederseits zwölf. (Für Porcellana gibt Milne Edwards vierzehn an; möglich, dass mir beim Herausnehmen der Mundtheile ein paar winzige vordere Kiemen unvermerkt verloren gegangen.)

Vergleicht man diese Beschreibung der A eglea unserer Gebirgsbäche, die ich nach ihrem Entdecker Aeglea Odebrechtii nenne, mit der Beschreibung, die Milne Edwards ${ }^{2}$ ) von der chilenischen A e glea la evis gibt, so findet man kaum folgende Unterschiede:

Der Panzer der Aeglea laevis ist viel länger als breit, der Hinterleib weniger lang als der Panzer, sein siebenter Ring klein, mit den auf sehr la ngem Grundgliede sitzenden Blättern der Schwanzflosse keinen Fächer bildend. Bei Aeglea Odebrechtii ist weder der siebente Hinterleibsring auffallend klein im Vergleich mit Galathea und Porcellana, noch das Grundglied der Schwanzfüsse auffallend lang im Vergleich mit Galathea strigosa ${ }^{3}$ ). Ferner ist bei Aeglea laevis der Stirnschnabel leicht gekrümmt und die Hand der Scheeren oben mit mehreren kleinen Zähnen bewaffnet.

Die Gattung Aeglea hat in den bisherigen Anordnungen der Krebse eine sehr wechselnde Stellung eingenommen. Von Latreille als Galathea la evis beschrieben, wurde der chilenische Vetter unseres Gebirgskrebses durch Leach als eigene Gattung Aeglea neben Galathea gestellt. Milne Edwards entfernte ihn nicht nur aus der Familie der Galatheiden, die er zu den Panzerkrebsen, also zu den Macruren stellte, sondern brachte ihn sogar in eine andere Hauptabtheilung, zu den Anomuren in die Familie der Porcellanen. Dabei blieben jedoch A eglea und Galathea nächste Nachbarn; denn es schloss (von den Larvenformen Megalops und Monolepis abgesehen) mit $\Lambda$ eglea clie

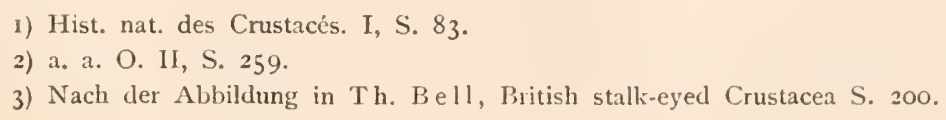


Reihe der Anomuren, und Galathea begann die der Macruren. - Dana brachte auch Galathea zu den Anomuren und gab ihr wieder A eglea als Nachbarn, schob aber zwischen diese und Porcella na mehrere andere Familien, deren Zahl Stim pson noch vermehrte; dieser ordnet ${ }^{1}$ ) die Anomuren mit freiem letzten Brustring (Schizosomi) in folgende Reihe: Porcellaniden, Hippiden, Lithodiden, Paguriden, Aegleiden, Galatheiden. - Thom as Bell vereinigt dagegen wieder ${ }^{2}$ ) die Porcellaniens (Porcellana, Aeglea) und die Galathéides (Galathea, Grimothea) von Milne Edwards in eine einzige Familie, die er zu den Anomuren stellt; welche Auffassung auch unter den deutschen Kennern dieser Klasse jetzt die herrschende zu sein scheint.

Am verkehrtesten ist jedenfalls die Anordnung von Milne Edwards. Zunächst deshalb, weil sich A e gl e a fast in allen Stücken weit enger an Ga la th ea anschliesst, als an Porcella na. Von dem glatten Panzer mit scharfem Seitenrand und dem nach unten geschlagenen Schwanze abgesehen, die allerdings dem Thiere ein ziemlich Porcellana-ähnliches Ansehen geben, hat A eglea mit Porcellana im Gegensatz zu Galath ea kaum etwas gemein, als das kurze, dicke, unbewehrte Grundglied der inneren Fühler und den (bei Porcellana nicht vollständigen) Mangel der Strudelfüsse am Hinterleibe des Männchens; dagegen mit Gal at hea im Gegensatz zu Porcella na den völligen Mangel der Augenhöhlen, die nach unten sich einschlagenden inneren Fühler, den Bau der äusseren Kieferfüsse, die Form der Brustplatte, den kurzen Vorderarm der Scheerenfüsse u. s. w. - Ja

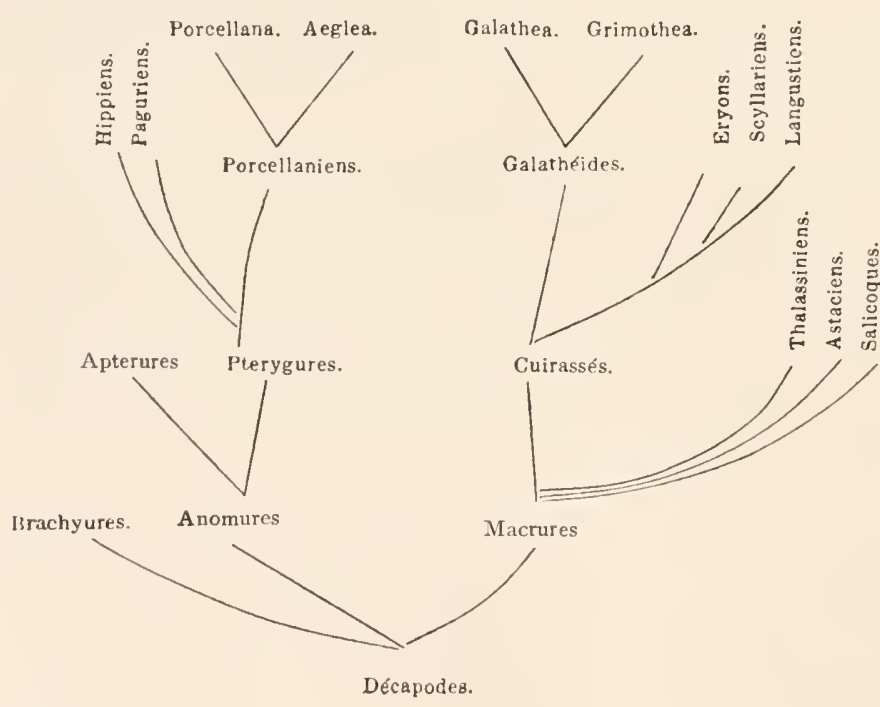
selbst der kräftige, gewölbte Hinterleib mit ganz ähnlich gestalteten Seitenstücken und ähnlich gebauter Schwanzflosse steht dem von $\mathrm{G}$ al a th ea weit näher, als dem von Porcella na. Weit schlimmer ist es, dass die eine der beiden nächstverwandten Gattungen zu den Anomuren, die andere zu den Macruren gestellt ist. Die ganze Unnatur dieses Verfahrens springt sofort in die Augen, sobald man Milne Edwards' Anordnung der Decapoden in die Form eines Stammbaumes bringt.

Danach würden also Galathea und A eglea erst an der gemeinsamen Wurzel der Macruren und Anomuren zusammenhangen und alle diesen beiden Gattungen gemeinschaftlichen Merkmale müsste im Wesentlichen schon der Urahn der Macruren und Anomuren besessen haben! Bei der gewöhnlichen reihenweisen

I) Proceed. Acad. Nat. Sc. Decbr. 1858. S. 65. -

2) British stalk-eyed Crustacea, I 853 , S. 196. 
Anordnung tritt dieser Widersinn nicht so schreiend zu Tage, da ja dabei A eg lea und Galathea immerhin nächste Nachbarn bleiben ${ }^{1}$ ).

Für das Richtigste möchte ich es halten, wie Be11, Gerstäcker, Cla us u. s. w., Galathea, Aeglea und Porcellana mit den neuerdings davon abgezweigten Gattungen in eine gemeinsame Gruppe zusammenzufassen, wobei es natürlich gleichgültig ist, ob man diese als Familie bezeichen oder in die drei Familien der Galatheiden, Aegleiden und Porcellaniden spalten will. Ein endgültiges Urtheil wird sich jedoch ohne Kenntnis der Jugendformen von Galathea und A glea nicht fällen lassen. Die überaus dürftige Abbildung einer Galathea-larve bei $\mathrm{Be} 11^{2}$ ) erinnert weit mehr an die Zoëa der Einsiedlerkrebse, als an die der Porcellanen.

Itajahy, Sa. Catharina, Brazil, Ende Mai 1875 .

\section{Erklärung der Abbildungen auf Tafel XLIV.}

Fig. I. A eglea Odebrechtii, halbwüchsiges Männchen, nat. Gr.

Fig. 2. Hinterleib, möglichst gestreckt, nat. Gr.

Fig. 3. Die Gegend vor dem Munde, nach Entfernung der Kiefer und Kieferfüsse $(2: I)$.

Fig. 4. Seitenwand des Panzers und Stiel der äusseren Fühler (2:I).

Fig. 5. Aeusserer Kieferfuss der linken Seite (3: I).

Fig. 6. Die Zähne am 2. Gliede des inneren Astes dieses Fusses (I2:I).

Fig. 7. Putzfuss der linken Seite (5: I) $r$ Ruthe.

Fig. 8. Ende dieses Putzfusses (I0O: I). Die Borsten sind weggelassen.

Fig. 9. Letzte Kieme der linken Seite, nat. Gr.

Fig. Io. Stück einer Kieme (5: I). $h$ hintere, $m$ mittlere, $v$ vordere Reihe der Kiemenfäden.

I) Der nahen Verwandtschaft zweier Formen, die man aus irgend welchem Grunde auseinander reissen zu müssen glaubt, dadurch Rechnung zu tragen, dass man sie, wenn auch in verschiedene Gruppen, so doch nebeneinanderstellt, ist ein beliebter Kunstgriff der alten Schule. Es ist im Grunde ein einfacher Betrug, wenn auch nur Selbstbetrug. Hätten die vielverspotteten Stammbäume keinen weiteren Nutzen, als derlei Täuschungen sofort zu entlarven und dadurch unmöglich zu machen, so wäre auch dies schon nicht gering anzuschlagen. Hier noch ein dem obigen ganz ähnliches Beispiel aus neuester Zeit (Kir by, A synonymic catalogue of diurnal Lepidoptera. 1871):

\begin{tabular}{|c|c|c|}
\hline ల్ & Heliconius. Eueides & Colaenis, Dione und über 100 \\
\hline 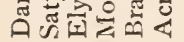 & Heliconinae & Nymphalinae \\
\hline
\end{tabular}

Nymphalidae

Danach hätten Eueides und Colaenis ihren gemeinsamen Stammvater erst in dem gemeinsamen Ahnen der Heliconinen und Nymphalinen, und dieser müsste alle den Gattungen Eueides und Colaen is gemeinschaftlichen Merkmale besessen haben! -

2) British stalk-eyed Crustacea, S. 203 . 


\title{
Ueber das Haarkissen am Blattstiel der Imbauba (Cecropia), das Gemüsebeet der Imbaubaameise ${ }^{1}$ ).
}

\author{
Mit I Textfigur.
}

Thomas Belt gebührt das Verdienst, in seinem vortrefflichen ,Nat u ral ist in Nicaragua", einer wahren Fundgrube anzichender Beobachtungen und anregender Gedanken, hingewiesen $z u$ haben auf die merkwürdigen und wichtigen Wechselbeziehungen zwischen gewissen mit Honigdrüsen ausgestatteten Pflanzen und den Ameisen, welche den Honig lecken und dafür die Pflanzen gegen verschiedene Feinde schützen, unter denen im wärmeren America die Tragameisen, Arten der Gattung Oecodoma, obenan stehen.

Belt gedenkt bei dieser Gelegenheit auch der Imbauba (Cecropia). Der hohle, durch Querwände in Kammern getheilte Stamm dieses Baumes ist stets von Ameisen bewohnt, die hier Schildläuse halten und bei jeder Erschütterung des Baumes zu Tausenden hervorstürzen, um, wen sie da finden, mit höchst empfindlichen Bissen zu verfolgen. Belt glaubt, dass auch diesem Baume die Anwesenheit der Ameisen, denen derselbe so geräumige Wohnung bietet, von Nutzen sei. $\left.{ }^{2}\right)$ Und darin hat er ohne Frage Recht und auch in diesem Falle sind es vornehmlich, wenn nicht ausschliesslich die Tragameisen (Oecodoma), gegen deren Angriffe die im Stamm der Imbauba hausenden Ameisen als treue Wacht und schützendes Heer dienen. Wiederholt sah ich junge Imbaubastämmchen, in denen noch keine Ameisen sich angesiedelt hatten, nie aber solche, die bereits von Ameisen bewohnt waren, durch Tragameisen ihrer Blätter, bis auf die Stiele und Hauptnerven, vollständig beraubt werden.

Was aber veranlasst die Imbauba-Ameisen, so treue Wacht zu halten an den Blättern des Baumes, der ihnen Obdach gewährt? - Erschütterungen des Baumes rufen, wie gesagt, die kleinen Vertheidiger desselben zu Tausenden hervor; aber gerade gegen die Feinde, die Stamm oder Aeste erschüttern, gegen das Faulthier, das ausschliesslich von den Blättern der Imbauba lebt, oder gegen die Axt des Menschen, vermögen sie trotz ihrer empfindlichen Bisse ${ }^{3}$ ) den Baum nicht

I) Jenaische Keitschrift f. Naturwiss. I876. Bd. X. p. 28I-286.

2) Thomas Belt, The Naturalist in Nicaragua. London 1874, p. 222.

3) Die hiesige Imbauba-Ameise gehört zu den stachellosen Arten, bei denen nur der erste Hinterleibsring abgeschnürt ist; das Geäder ihrer Vorderflügel gleicht dem der Formica-Arten mit Discoidalzelle; sie unterscheidet sich von Formica durch die Zahl ihrer Tasterglieder: die Kiefertaster haben fünf, die Lippentaster drei Glieder. 
zu schützen. Das Auf- und Absteigen der Tragameise kann weder auf diese Weise, durch Erschütterung, sich ihnen bemerklich machen, noch wird es überhaupt von den im Innern des Stammes sich aufhaltenden Bewohnern desselben bemerkt werden können. Was also veranlasst die Imbauba-Ameise, die Blätter, - namentlich die bei allen Pflanzen zumeist den Angriffen der Tragameise ausgesetzten jüngeren Blätter zu bewachen?

Ich war vor Kurzem so glücklich, die Antwort auf diese Frage zu finden, und hoffe, sie wird auch Anderen nicht weniger Freude und Ueberraschung bereiten, als mir selbst.

Am Grunde des Blattstiels der Imbauba gewahrt man ein flaches Kissen, das sish etwa $1 \mathrm{~mm}$ über seine Umgebung erhebt und von unten her reichlich die Hälfte des Blattstiels umfasst. An dem Blatte eines 0,07 m dicken Stammes war dieses Kissen in der unteren Mittellinie des Blattstieles $23 \mathrm{~mm}$ breit, erstreckte sich von da, allmählich verschmälert, $35 \mathrm{~mm}$ nach jeder Seite und nahm eine Fläche von etwa $8 \mathrm{qcm}$ ein. So lange dieses Kissen von dem tütenartigen Nebenblatte des nächstunteren Blattes umschlossen wird, ist es weiss; an der Luft färbt es sich bald, erst hell-, dann rehbraun. Den Blättern junger Pflanzen fehlt dieses Kissen; ebenso den ersten Blättern dünner Seitentriebe, die aus geköpften jüngeren Stämmen hervorspriessen; so waren an dem $8 \mathrm{~mm}$ dicken Triebe eines abgehauenen Io $\mathrm{mm}$ dicken Stämmchens die vier ersten Blätter ganz ohne Kissen; das fünfte und sechste zeigten ein kleines Kissen auf einer Seite, das folgende jederseits ein kleines Kissen und dazwischen, in der Mittellinie, einen schmalen Zwischenraum; am achten Blatte war ein vollständiges Kissen, das aber noch durch eine obere und untere Bucht in der Mittellinie auf die Entstehung aus zwei Kissen hinwies; das neunte Blatt endlich trug ein Kissen von gewöhnlicher Form.

Bei der Entwicklung der Blätter zeigt sich das Kissen zuerst als ein seidenartig glänzender weisslicher Fleck, von ziemlich weitläufig stehenden, einzelligen, borstenartigen, leicht gekrümmten Haaren gebildet. Zwischen diesen spriessen später, auf's dichteste gedrängt, vielzellige Haare hervor, gegen deren Zahl die der einfachen Haare fast verschwindet. Sie erreichen eine Länge von reichlich I $\mathrm{mm}$ und bestehen aus etwa einem Dutzend Zellen; die untersten sind gestreckt walzenförmig, die obern eiförmig oder kuglig und dicker als die unteren; die Endzelle läuft in eine kürzere oder längere, häufig gekrümmte, scharfe Spitze aus. Dicht zusammengedrängt bilden diese Haare ein ziemlich festes Kissen, dessen Oberfläche ein einigermassen sammetartiges Ansehen hat. Wasserhell und farblos, bis sie an die Luft treten, beginnen sie an der Luft von der Spitze her sich $\mathrm{zu}$ bräunen und theilweise $\mathrm{zu}$ verschrumpfen.

Wieder später, als diese vielzelligen, am Ende perlschnurförmigen Haare, und erst wenn die Enthülluug des Blattes nahe rückt, entwickeln sich in den Kissen keulenförmige Gebilde, die bis $\mathrm{zu}$ o,8-1 $\mathrm{mm}$ Länge heranwachsen, bei 0,3-0,5 $\mathrm{mm}$ Dicke; ihr Ende ist abgerundet; ihre grösste Dicke fällt bald nahe dem freien Ende, bald gegen die Mitte hin, bald endlich ist ihre Dicke eine fast gleichbleibende, so dass ihre Gestalt zwischen birnförmig, eiförmig und walzenförmig schwankt. Reif erscheinen sie milchweiss, glänzend, etwas durchscheinend. Sie sind nicht saftig und weich, sondern ziemlich fest und schrumpfen beim Trocknen, wobei sie gelblich werden, nur mässig zusammen. Sowie sie ihre volle 
Grösse erlangt haben, lösen sich diese Kölbchen ab und treten allmählich über die Oberfläche des Haarkissens hervor, in welchem sie während ihres Wachsthums versteckt lagen. Sie fallen nun bei leichter Berührung und endlich wohl auch von selbst ab.

Zur Zeit, wo das Haarkissen durch das Abfallen des nächstunteren tütenförmigen Nebenblattes enthüllt wird, pflegt schon eine Zahl dieser Kölbchen mehr oder weniger aus dem Kissen hervorgetreten $\mathrm{zu}$ sein; dabei aber finden sich noch jüngere Kölbchen in allen Grössen im Innern des Kissens. Der Nachschub

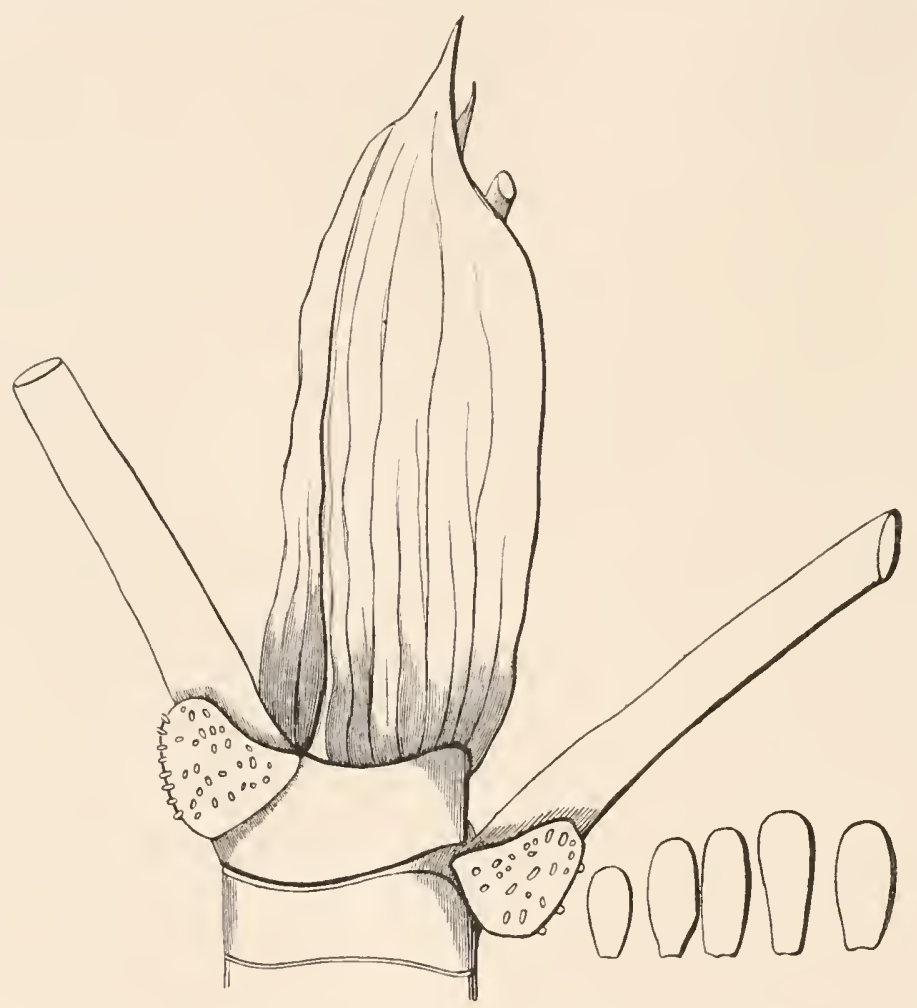

Spitze eines jungen, nicht von Ameisen bewohnten Imbaubastämmchens, nat. Gr. - Die Blätter sind abgeschnitten. Der oberste der drei Blattstiele von dem tütenförmigen Nebenblatte des nächst unteren Blattes umhüllt. Am Grunde der beiden unteren Blattstiele die braunen Haarkissen, mit milchweissen Kölbchen besetzt.

neuer Kölbchen dürfte eine ganze Reihe von Wochen andauern, da sie noch auf dem Haarkissen des dritt- oder selbst viertletzten Blattes sich zeigen. Die Haarkissen der obersten Blätter junger Stämme, die noch nicht von Ameisen bewohnt sind, pflegen reichlich mit Kölbchen geziert zu sein, die wie milchweisse Spargelpfeifen aus braunem Beete hervortreten; man findet ihrer 60 bis Ioo auf einem einzigen Kissen. An Pflanzen aber die von Ameisen bewohnt sind und das ist schon bei daumesdicken Stämmchen fast ausnahmslos der Fall, sieht man in der Regel nur ganz vereinzelte kaum in halber Länge vorragende Kölbchen. Schon hieraus würde sich mit befriedigender Sicherheit schliessen lassen, dass die Kölbchen, sowvie sie reif aus dem Haarkissen sich erheben, von den Ameisen abgeerntet werden, - dass die Besuche, welche die Ameisen beständig bei den jüngeren 
Blättern machen, den Haarkissen am Grunde des Blattstieles, ihren Gemüsebeeten gelten, - und dass in Folge dieser steten Besuche die Tragameisen nicht unbemerkt zu den Blättern der Imbauba gelangen können. Es wurde mir indess auch Gelegenheit, dem Abernten eines Gemüsebeetes alz Zeuge beizuwohnen. Ich hatte die Spitze eines $25 \mathrm{~mm}$ dicken Imbaubastämmchens mit heimgenommen, welches von einem sehr schwachen, wohl kaum einige hundert Arbeiter zählenden, wahrscheinlich noch jungen Ameisenvolke bewohnt war. Der Stiel des obersten bereits vollständig entfaiteten Blattes war noch von dem nächstunteren Nebenblatte umschlossen, und als ich dieses entfernte, zeigte sich das dadurch blossgelegte Haarkissen mit zahlreichen (etwa 50) Kölbchen besetzt. Die Ameisen hatten ihren Eingang in's innere des Stammes ungewöhnlich weit von der Spitze, etwa $0,5 \mathrm{~m}$ unter dem neuen Gemüsebeete; und doch hatte ich dasselbe kaum zugänglich gemacht, so erschienen auch schon die Ameisen auf demselben. Jede packte eines der weissen Kölbchen mit den Kinnbacken und lief damit stammabwärts, um es heimzutragen. Anfangs ging das recht rasch, da die ganz losen Kölbchen eben nur wegzunehmen waren. Bei denen aber, die noch fester sassen, und kaum über halb vorsahen, kostete es oft ziemliche Zeit und Mühe, bis sie nach manchem Ziehen und Wackeln nach verschiedenen Seiten sich lösten und fortgetragen werden konnten. Nach etwa Io bis 15 Minuten waren nur noch vier Kölbchen übrig, an denen verschiedene Ameisen vergeblich ihre Kräfte versucht hatten.

So ist denn der Fall der Imbauba dem der merkwürdigen OchsenhornAcacia ${ }^{1}$ ), den Thomas Belt so lebensfrisch geschildert hat, weit ähnlicher, als Belt glaubte; hier wie dort liefert der Baum seinen Vertheidigern neben Obdach auch Nahrung und wie dort die goldenen Birnen jedes Blattes eine nach der anderen reifen und so dem jungen Blatte für längere Zeit den Besuch der schützenden Ameisen sichern, so bietet auch das Gemüsebeet jedes neu entfalteten Imbaubablattes den Ameisen eine Wochen lang andauernde, Wochen lang sie anlockende Ernte. Dieser fortdauernde Nachschub junger Kölbchen wird ermöglicht — und darin liegt dessen Bedeutung - durch das dichte Haarkissen, welches nicht nur den unter ihm sich entwickelnden Kölbchen die nöthige Feuchtigkeit bewahrt, sondern auch die Ameisen hindert, dieselben vor der Reife anzutasten.

Und nun noch Eins. In der Regel sind es Honigdrüsen, welche die schützenden Ameisen (hier besonders einen kleinen schwarzen Crematogaster) herbeiziehen. Dagegen scheinen die Kölbchen der Imbauba vorwiegend aus einem Eiweissstoffe zu bestehen. Jodlösung färbt sie dunkel gelbbraun, concentrirte Schwefelsäure schön rosenroth. - Da die von ihnen gezüchteten Schildläuse den Imbauba-Ameisen Honig oder eine ähnliche süsse Flüssigkeit liefern, dürften Honigdrüsen auf sie keine allzugrosse Anziehungskraft ausüben und so bietet ihnen die Imbauba als Lockspeise in den von ihnen so eifrig gesuchten Kölbchen nicht eine süsse saftige Frucht, sondern gewissermassen ein Liebig'sches Fleischextract, einen verdichteten Eiweissstoff in möglichst handlicher, bequemer Form. Während wir unsere stickstoffhaltige Nahrung hauptlächlich den Tieren, unsere stickstofflose den Pfanzen entnehmen, ist das Umgekehrte also bei der Imbauba-Ameise der Fall.

Itajahy, 31. October 1875 .

1) Thomas Belt, a. a. O., p. 218. 


\section{Aus Brasilien (Meliponen) ${ }^{1}$ ).}

\section{(Eigentümliche Flugstellen der Bienen.)}

In der von Frau Helene Lieb (Bztg. 1876, Nr. Io u. I I, S. 133) und Herrn Köhler (Nr. I7 u. 18, S. 220) angeregten Frage: was „unsere reinlichen Bienen“ an Tierleichen und Mistpfützen und ähnlichen unsauberen Orten suchen und saugen, will ich eine kleine Beobachtung mitteilen, die als Bestätigung der von Herrn Köhler ausgesprochenen Vermutung dienen mag.

Es war im Quellgebiet des Uruguay, nicht weit von dessen nördlichstem Quellflusse, dem Rio das Marombas, wo wir in einer kleinen, mit halbmannshohem harten Grase bewachsenen, von Bäumen ziemlich freien Lichtung mitten im Urwalde, meilenweit von menschlichen Wohnungen, am 21. November unsere Zelte aufgeschlagen hatten. Wir lagen dort bis zum 26. Am 23. hörte ich nun nahe den Zelten das bekannte Summen einer Honigbiene; sie flog dicht am Boden zwischen zertretenem und verwelktem Grase. Ich fing den an dieser Stelle ganz unerwarteten Gast; es war die gewöhnliche schwarze deutsche Biene. An gleicher Stelle zeigten sich an demselben Tage noch zwei bis drei, und zahlreichere an den folgenden Tagen. Blumen, welche die Bienen hätten anlocken können, gab es nicht in der Nähe; die Blumenröhren eines schönen goldgelben Cestrum, das die Ufer des die Lichtung durchfliessenden Baches schmückte, waren für sie viel zu lang. Was suchten sie also? - Ueber die Antwort blieb ich nicht lange im Zweifel. Die Stellen, wo sie sich niedersetzten, waren solche, an denen der Boden und das trockene Gras mit Harn getränkt zu werden pflegten.

Am 24. erhielten wir eine Ladung frischen Rindfleisches, welches leicht gesalzen, zum trocknen an einer Rohrstange aufgehängt wurde. Alsbald sammelten sich um dasselbe mehrere Arten von Wespen, die grosse Stücke abnagten und forttrugen, sowie in grosser Menge verschiedene stachellose Honigbienen, besonders zahlreich eine kleine schwarze, stark nach Citronen riechende Art, die ich hier zum ersten Male sah (Trigona citriodora 11. sp.). Dieselben drängten sich besonders um die äussersten niederhängenden Zipfel der Fleischstücke, wo die Salzlake sich sammelte und zu einer gesättigten Lösung abdunstete. Schüttelte man diese Zipfel, so purzelten sie dutzendweise in die untergehaltene Flasche. Offenbar war es das Salz, welches sie hierher zog. - Neben den stachellosen Brasilianerinnen fand sich

I) Eichstädt. Bienenztg. I877. Bd. XXXIII. p. 59-60. Nördlingen, Becksche Buchhandlung. 
auch die stacheltragende Honigbiene der alten Welt ein. Ob auch von ihr Salz gesucht und gesaugt wurde?

Woher aber, werden die Leser fragen und fragten wir uns, woher kamen diese Bienen? - Der nächste Bienenstand auf den Campos dos Curitibanos war sicher mehrere Meilen entfernt, von da konnten sie kaum unsere kleine, blumenlose Lichtung tief im Walde so rasch aufspüren. Wahrscheinlicher schien es, dass verflogene Schwärme sich im Walde selbst angesiedelt hatten, und diese Vermutung wurde bald zur Gewissheit; wenige Tage später, als ich selbst den Wald schon verlassen hatte, fanden meine Reisegefährten in einem hohlen Baume einen Bienenschwarm, der ihnen reiche Honigausbeute lieferte.

Blumenau, Sa. Catharina, Brazil, 24./12. I876. 


\section{Ueber Haarpinsel, Filzflecke und ähnliche Gebilde auf den Flügeln männlicher Schmetterlinge ${ }^{1}$ ).}

Die Männchen zahlreicher Arten von Tagfaltern sind ausgezeichnet durch eigenthümliche Haar- oder Schuppenbildungen auf ihren Flügeln. Ich will hier zusammenstellen, was ich in den wenigen mir zugänglichen Schmetterlingsbüchern ${ }^{2}$ ) über diese Gebilde finde, und folge dabei der Anordnung der Gattungen in Kir b y's Verzeichnis der Tagfalter ${ }^{3}$.

I. Danainen.

\section{Nymphaliden.}

Danais. Die đ haben einen Fleck eigenthümlich gebildeter Schuppen am ersten Aste der Mediana oder an der Submediana der Hinterflügel; bisıeilen hat er die Gestalt einer Tasche, die sich auf der Oberseite der Flügel öffnet und (wenigstens bei trockenen Stücken) mit braunem Staube gefüllt ist.

Amauris ( $=$ Danais sect. I, Doubl. gen. D. L.). Die $\delta$ haben einen Fleck eigenthümlich gestalteter, dichtstehender Schuppen an der Submediana der Hinterflügel, nicht weit vom Afterwinkel.

Euploea. Bei den $\delta$ ist der Innenrand der Vorderflügel meist gerundet und springt so vor, dass er ein beträchtliches Stück der Hinterflügel deckt. Bisweilen haben die $\delta$ einen oder mehrere kurze Streifen am Innenrand der Vorderflügel, aus blasseren etwas abweichend gestalteten Schuppen, von mattem, etwas kreidigem Ansehen. Der von dem vorstehenden Innenrand der Vorderflügel bedeckte Theil der Hinterflügel ist oft mit Schuppen von sehr eigenthümlicher Gestalt bekleidet. Sie sind verlängert, haarähnlich, am Grunde etwas

1) Jenaische Zeitschrift 1877. Bd. XI. S. 99-114.

2) Die reichste Ausbeute gab mir: Doubleday and West wood, Genera of Diurnal Lepidoptera. Leider ist mein Exemplar unvollständig. Einzelne Angaben sind entnommen aus: Keferstein, Geschlechtsverschiedenheit der Schmetterlinge in Stett. entomol. Ztg. I853, S. 354. - Butler, Catalogue of the Satyridae in the Brit. Mus. 1868 (Anchiphlebia, Gnophodes, Cyllogenes). - Butler, Catalogue of Fabrician Diurnal Lepidopt. I869 (Agrias). - Herrich-Schäffer, Prodrom. system. Lepidopterorum (Myscelia, Hesperiden). - Felder, Species Lepidopterorum, 1864 (Papilio). - Hewit son, Description of one hundred Hesperidae, 1867 (C a ecina). - Hewitson, Equatorial Lepidoptera collected by Mr. Buckley 1869 (Thecla Bodora). - Boisduval, Spec. gén. Lépidopt. I8 36 (Le p ta lis, Callidryas).

3) Kirby, A synonymic Catalogue of diurnal Lepidoptera 1871 . 
breiter, und enden in eine eiförmige Ausbreitung, die ihnen das Aussehen der Fühler von Pieris gibt. Bei anderen Arten unterscheiden sich die Schuppen dieser Stelle hauptsächlich durch ihre Grösse von den übrigen.

Die $\delta$ von Athesis, Thyridia, Olyras, Dircenna, Ceratinia, Sais, Mechanitis, Ithomia, Melinaea, Tithorea, also fast aller Gattungen, die man neuerdings von den Heliconinen zu den Danainen versetzt hat, haben „einen Haarpinsel auf der Oberseite der Hinterflügel vorne an der Subcostalis" (Herrich-Schäffer), oder richtiger, wie es Doubleday bei Olyras beschreibt, „einen langen Fleck, der mit sehr langen zarten Haaren besetzt ist". Den $\delta$ von Lycorea, die auch in diesen Verwandtschaftskreis gehört, fehlt (nach Herrich-Schäffer) der Haarpinsel, dagegen haben sie (nach Doubleday) ,einen ganzen Haarbusch jederseits am letzten Hinterleibsring, der grossentheils in den Hinterleib zurückgezogen werden kann". -

2. Satyrinen.

Bei den $\delta$ von Antirrhaea Archaea (Anchiphlebia But1.) ist der Innenrand der Vorderflügel wie bei Euploea gewölbt und stark gewölbt ist auch der Vorderrand der Hinterflügel, auf der Unterseite des Vorderflügels findet sich ein kammförmig behaarter Fleck (plaga pectinatim cirrata).

Bei Gnophodes Morpena besitzen die Hinterflügel der $\delta$ einen grossen eirunden weissen Fleck nahe dem Vorderrande, wie bei Arten von Eu ploea.

Die o von Melanitis Suradeva (Cyllogen es Butl.) haben einen grossen dunkeln seidenartigen Fleck auf den Vorderflügeln.

Bei Satyrus Roxelana, Clymene, Maera, Megera, Hiera bei Epinephele Lycaon, Janira, Ida, Tithonus, bei Hipparchia Semele und Arethusa besitzen die $\delta$ auf der Oberseite der Vorderflügel einen dunklen Haarbusch.

Mycalesis. „Das wichtigste Merkmal dieser Gattung besteht im Vorhandensein eines Büschels langer Haare, entweder auf der Oberseite der Vorderflügel, wo sich ein schmaler Schlitz oder besser eine Tasche zu ihrer Aufnahme findet, oder auf den Hinterflügeln, wo sie durch den Innenrand der Vorderflügel bedeckt werden. Dieser Haarbüschel kommt, wie gewöhnlich, nur den $\delta$ zu, und nach seiner Lage lässt sich die Gattung in zwei Gruppen theilen" (W estwood).

Die đo von Bia Actorion sind ausgezeichnet durch einen Büschel langer blass lederbrauner Haare nahe dem Innenrande der Hinterflügel, die willkürlich aufgerichtet und niedergelegt werden können und in der Ruhe in einer langen Tasche eingeschlossen liegen, und ebenso durch einen Fleck mit langen schwarzen seidenartigen Haaren nahe dem Vorderrande der Hinterflügel. Letzterem liegt ein nackter Fleck auf der Unterseite der Vorderflügel, dicht am Innenrande, gegenüber.

3. Elymniinen.

Elymnias (= Melanitis Westw. Gen. D. L.). Die ơ haben Haarbüsche auf der Oberseite der Hinterflügel, nahe der Wurzel.

4. Morphinen.

Amathusia. Auf der Oberseite, nahe dem Innenrande der Hinterflügel und gleichlaufend dem Ende des Hinterleibes findet sich beim of ein kleiner, 
schief aufsitzender Haarbusch; zwischen diesem Haarbusch und dem ersten Aste der Mediana ist eine lange Falte des Flügels, in der einige wenige lange blasse Haare verborgen liegen.

Zeuxidia. Innenrand der Vorderflügel beim $q$ fast gerade, beim $\delta$ sehr stark erweitert und gerundet. Die Hinterflügel des $\delta$ tragen auf der Oberseite, in dem Raume zwischen Costalis und Subcostalis, einen eirunden Fleck mit blass lederbraunen Haaren; ferner in der Mitte der Zelle einen lang eirunden Fleck von braunen, der Länge nach liegenden Haaren und zwischen diesem Fleck und dem innern Winkel der Zelle eine Reihe schief nach dem Hinterleib zu liegender Haare.

Das o von Discophora hat einen seidenartigen Fleck in der Mitte der Oberseite der Hinterflügel.

Tenaris (= Drusilla Swains.). Innenrand der Vorderflügel beim o fast gerade, beim $\delta$ am Grunde verbreitert, in der Mitte ausgebuchtet. Auf dem Hinterflügel, nahe der Wurzel, verborgen unter der Erweiterung der Vorderflügel, ein Haarbusch; ein zweiter langer Haarbusch nahe dem Innenrande, dem Ende des Hinterleibes gegenüber.

Clerone. Innenrand der Vorderflügel beim ơ schwach erweitert. Hinterflügel oben, nahe dem Ende der Brust, beim ơ mit einem Büschel feiner Haare.

Thaumantis. Auf der Oberseite der Hinterflügel, nahe der Wurzel, theilweise vom Innenrande der Vorderflügel bedeckt, beim $\delta$ ein Haarbusch.

5. Brassolinen.

Opsiphanes. Ein langer Haarpinsel in der Mittelzelle der Hinterflügel, auf der Oberseite, nahe dem Ursprunge des ersten Astes der Mediana; ein zweiter Haarpinsel näher dem Innenrande, dicht an der Submediana, etwa der Mitte des Hinterleibes gegenüber. Bei Opsiphanes Soranus ausserdem ein Bündel krummer, blass lederbrauner Haare zwischen Costalis und Subcostalis. - Auch bei Opsiphanes Cassiae sehe ich nahe der Flügelwurzel zwischen Costalis und Subcostalis ein Büschel zarter, aber gerader und dem Flügel gleichfarbiger Haare uud ihnen gegenüber auf der Unterseite der Vorderflügel einen kleinen matten grauen Fleck zwischen Mediana und Submediana, letzterer anliegend.

Caligo. Hinterflügel des ơ mit einem kleinen Haarbusche nahe dem Innenrande, der Mitte des Hinterleibes gegenüber.

Narope. „Die Submediana der Vorderflügel ist beim ơ gebogen, um Raum zu geben für einen Fleck mit langen orangefarbenen Haaren, die auf der Unterseite zwischen Mediana und Submediana entspringen. Ihm gegenüber eine geglättete Stelle auf der Oberseite der Hinterflügel.“

Dasyophthalma. Innenrand der Vorderflügel mehr gewölbt beim $\delta$, als beim $\uparrow$; auf der Oberseite der Hinterflügel des $\delta$ ein eirunder sammetartiger Fleck, den die Subcostalis und ihr Ast durchschneiden; ein kleiner eirunder Fleck nahe der Wurzel der Mittelzelle ist schuppenlos, trägt aber einen aufrechten schwarzen Haarbusch.

6. Acraeinen und 7. Helicon inen.

In den wenigen Gattungen dieser beiden Gruppen scheinen den $\delta$ ähnliche Auszeichnungen zu fehlen. 
8. Nymphalinen.

Das $\delta$ von Lachnoptera trägt auf der Oberseite der Hinterflügel, nahe dem Vorderrande einen eigenthümlichen Fleck haarähnlicher Schuppen. Diese sind lang, fast linienförmig, am Grunde tief ausgerandet und schwach verbreitert, nach der Spitze in einen schlanken Stiel verjüngt und enden in eine fächerähnliche, aussen gefranzte Platte.

Bei Myscelia Orsis ist der „Hinterflügel des ơ von Zelle $5-7$ mit einem Filzfleck"versehen (H errich-Schäffer).

Bei den $\delta$ von Didonis Biblis finde ich einen auf dem dunklen Grunde leicht zu übersehenden ansehnlichen schwarzen Fleck von kohlenartigem Aussehen auf der Unterseite der Vorderflügel nahe dem Innenrande zwischen Submediana und Mediana, an der Stelle, wo letztere ihren ersten Ast abgibt; ein kleinerer ähnlicher Fleck liegt nahe dabei, mehr wurzelwärts. Gegenüber liegt ein kleiner schwarzer Fleck auf der Oberseite der Hinterflügel.

Prepona. Ein Haarbusch steht auf dem Hinterflügel des $\delta$ am Rande der Rinne, die den Hinterleib umschliesst, und ihm gegenüber am Hinterleibe ein eirunder, von einem nackten Saume umgebener Filzfleck. (Butler).

Agrias. „Einige, wenn nicht alle Arten haben Haarpinsel auf den Flügeln“

\section{Lemoniiden (= Eryciniden Swains).}

Aus dieser Familie ist mir kein Beispiel durch eigenthümliche Haar- oder Schuppenbildungen ausgezeichneter Männchen bekannt.

\section{Lycaeniden.}

Thecla. Bei sehr zahlreichen Arten sind die Vorderflügel der $\delta$ bezeichnet mit einem rundlichen, sammet- oder filzartigen Fleck, nahe dem Ende der Mittelzelle, der nicht selten eine mehr oder minder erhebliche Aenderung des Flügelgeäders veranlasst. Bisweilen ist die Verschiedenheit des Aderverlaufs zwischen $q$ und $\delta$ derselben Art so gross, wie sonst zwischen Arten verschiedener Gattungen. Grösse, Gestalt, Lage des Flecks wechseln ungemein. Meist ist er von dunkler Farbe und dann, wenn in gleichfarbiger Umgebung, oft erst nach der Entschuppung als dunkler Fleck der sonst farblosen Flügelhaut deutlich hervortretend. Seltener ist er hell (gelb oder weisslich) auf dunklem (schwarzem oder blauem) Grunde. So bei Thecla Ambrax Westw. (Gener. D. L., Taf. LXXV, Fig. 7). Bei Thecla Bodora Hew. ist die Oberseite der Flügel mattblau, die Vorderflügel mit breitem, braunem Vorderrande und Saum, der Fleck sehr gross und glänzend blau.

\section{Papilioniden.}

1. Pierinen.

Bei den ơ von Leptalis sind nicht selten, wie bei Euploea, Innenrand der Vorder- und Vorderrand der Hinterflügel verbreitert, und es haben in diesem Falle die Hinterflügel oben, die Vorderflügel unten eine grosse glänzende Stelle mit sehr kleinen dicht angedrückten Schuppen, und inmitten derselben einen eirunden, matt kreideweissen oder aschgrauen Fleck. Wenn die Flügel ausgebreitet sind, liegen die Flecken beider Flügel genau aufeinander. 
Die of der meisten Callidryas haben nahe der Wurzel und dem Vorderrande der Hinterflügel einen Fleck von kreidigem Aussehen („sac glanduleux“ Boisduval), dessen Farbe, Grösse und Gestalt nach den Arten sehr wechselt. Bisweilen ist er bedeckt von einer Mähne langer Haare, die in der Mittelzelle wurzeln. In anderen Fällen findet sich ihm gegenüber ein auf der Unterseite der Vorderflügel zwischen Mediana und Submediana liegender Fleck. Dieser Gegenfleck und die Mähne scheinen sich gegenseitig auszuschliessen; wo ich die Mähne finde (Argante, Trite), vermisse ich den Gegenfleck; wo dieser vorhanden ist (Philea, Statira), fehlt die Mähne. Einige Arten (wie die indische Pomona) tragen Haare auch am Innenrande der Vorderflügel. In einigen Fällen endlich (Eubule) fehlen sowohl Haare als Flecken, wenn auch der Fleck der Hinterflügel nicht spurlos.

Bei den oiniger Arten von $\mathrm{Nathalis,} \mathrm{Gonopteryx} \mathrm{und} \mathrm{Colias} \mathrm{kommen}$ ähnliche Flecken vor.

\section{Papilioninen.}

Die erste der von Felder unterschiedenen Abtheilungen der Gattung Papilio enthält den P. Priamus und die ihm nahe stehenden Arten der jetzt wieder eingezogenen Gattung Ornithoptera. Bei den $\delta$ dieser Abtheilung ist der Innenrand der Hinterflügel sehr verbreitert und nach innen geschlagen; die Aussenseite des umgeschlagenen Randes ist schwächer beschuppt, längs der Submediana mit einer Mähne bräunlicher abstehender Borsten besetzt; die Wurzelhälfte des Umschlags ist abermals nach innen geschlagen; die innere Fläche des ganzen Randes ist schwarz beschuppt, ohne Haare.

Bei den ơ der zweiten Abtheilung, die ebenfalls aus Arten der früheren Gattung Ornithoptera besteht, ist der Innenrand der Hinterflügel in ähnlicher Weise nach innen umgeschlagen, jedoch an der Wurzel nicht abermals nach innen, sondern wieder nach aussen zurückgeschlagen; die innere Fläche des umgeschlagenen Randes und das von ihm bedeckte Stück des Flügels ist bräunlichweiss, etwas perlmutterglänzend und mit dichtem gleichfarbigen Pelz bedeckt.

In der fünften Abtheilung, welche Felder mit den nächstverwandten als amerikanische Ornithopteren bezeichnet ${ }^{1}$ ), ist die Bildung der männlichen Hinterflügel ähnlich, wie die der zweiten Abtheilung; dieselben sind am Afterwinkel tief ausgebuchtet, der stark verbreitete Innenrand ist nach innen, der Wurzeltheil des Umschlags aber wieder nach aussen umgeschlagen, die überdeckte Fläche bräunlichweiss beschuppt und bis zur Submediana mit wunderbar dichtem seidenartigem weissen Pelz bekleidet.

\section{Hesperiden.}

In verschiedenen Gattungen ist bei den $\delta$ der Vorderrand der Vorderflügel umgeschlagen („Costalumschlag“" Herrich-Schäffer), und die eingeschlossene Stelle dicht mit blassem Daun bedeckt. Bei anderen Arten (Ismene Oedipodea) haben die $\delta$ einen grossen sammetartigen Fleck nahe der Wurzel der Vorderflügel, bei anderen (Hesperilla) sind sie durch einen "Schuppenwulst" der

I) Die an Aristolochia lebende Raupe unseres Papilio Nephalion, welche derjenigen der Ornithoptera Heliacon. (Boisduval, Spec. gén. Lépid. Pl. I, Fig. I) ganz ähnlich ist, rechtfertigt diese Bezeichnung. 
Vorderflügel ausgezeichnet, während bei Caecina „der Innenrand der Vorderflügel nahe der Wurzel vorspringt, unten geglättet ist und einen Haarbusch der Hinterflügel bedeckt."

Soweit die Tagfalter. Dass auch unter den Nachtschmetterlingen ähnliche Gebilde nicht fehlen, beweist Calesia comosa Guen., deren ơ einen mächtigen Haarbusch auf der Oberseite der Vorderflügel tragen ${ }^{1}$ ).

Wie entfernt auch von Vollständigkeit vorstehende Uebersicht sein möge, sie wird genügen, die weite Verbreitung der betreffenden Gebilde unter den Tagfaltern, sowie nicht minder ihre überraschende Mannichfaltigkeit zu zeigen. Welche Verschiedenheit zwischen dem unglaublich dichten, schneeweissen, seidenartigen Pelz in dem breiten Umschlage der Hinterflügel von Papilio Nephalion, dem von langer Mähne überdeckten unter dem Innenrande der Vorderflügel geborgenen grossen kreidigen Fleck der Hinterflügel von Callidryas Trite, dem zierlichen Haarpinsel mitten auf dem Hinterflügel von Opsiphan es Cas siae, und dem kohlenartigen Fleck inmitten des glänzenden Morphoblau des Vorderflügels einer Thecla! Und doch finden sich bei aller Verschiedenheit gewisse gemeinsame Züge. Gemeinsam ist zunächst der Mehrzahl dieser Bildungen, dass sie für gewöhnlich nicht offen liegen, sondern eingeschlossen sind, sei es, und das ist der häufigste Fall, zwischen Innenrand der Vorder-, und Vorderrand der Hinterflügel, sei es zwischen Innenrand der Hinterflügel und Hinterleib, sei es in einem Umschlag am Vorderrande der Vorder-, oder am Innenrande der Hinterflügel, sei es endlich in besonderen Furchen, Schlitzen oder Taschen. Nicht selten liegt dem Haarbusch oder Fleck eine kahle Stelle oder auch ein ähnlicher Fleck des anderen Flügels oder des Hinterleibes gegenüber. Wo Flecken oder Haarbüsche frei auf der Fläche der Flügel liegen, finden sie sich auf der Oberseite, so dass sie auch in diesem Falle, wenn der Falter mit emporgeschlagenen Flügeln ruht, zwischen den Flügeln eingeschlossen sind. Niemals scheinen sie auf der Unterseite der Hinterflügel und des vorderen, von den Hinterflügeln unbedeckt gelassenen Theiles der Vorderflügel vorzukommen. Die Schuppen der Flecken pflegen sehr dicht gedrängt und daher fast aufrecht zu stehen und bei weitem fester zu haften als die übrigen Schuppen der Flügel. Nach dem Entschuppen bleiben die Flecken nicht nur an den dichtgedrängten Anheftungsstellen der Schuppen kenntlich, es pflegt auch ihre Haut mehr oder weniger getrübt oder selbst dunkel gefärbt zu sein. Nicht selten sind sie von baumartig verästelten oder netzförmig verbundenen Luftröhren durchzogen. - Die zwischen den Flügeln oder zwischen Flügel und Hinterleib verborgenen Pinsel, Mähnen oder Haarbüsche pflegen sich zu sträuben, sobald die Flügel von einander oder vom Hinterleibe entfernt werden Eines willkürlichen Sträubens dürften auch alle frei auf der Fläche der Flügel liegende Pinsel fähig sein; bei Opsiphanes Cassiae kann der in der Mittelzelle der Hinterflügel liegende Haarpinsel zu einer vollständigen Halbkugel sich auseinanderspreizen. -

Die bei weitem häufigste Bildung, Fleck oder Haarbusch am Vorderrande der Hinterflügel, zwischen Costalis und Subcostalis, bedeckt vom Innenrande der

I) Chenu, Encyclop. d'hist. nat. Lépidopt. II, pag. 132, Fig. II4. 
Vorderflügel, kommt bei so weit verschiedenen Faltern vor, bei Danainen ( $\mathrm{E} u$ ploea, Ithomia und Verwandte), bei Satyrinen (Mycalesis, Bia), bei Morphinen (Zeuxidia), bei Brassolinen (Opsiphanes), bei Nymphalinen (Lach noptera), bei Pierinen (Leptalis, Callidryas) und bei Hesperiden (Caecina), dass an Ererbung von gemeinsamen Vorfahren kaum zu denken ist, man müsste denn eine ähnliche Bildung schon dem o" der Stammform aller Tagfalter zuschreiben und annehmen wollen, dass dieselbe der Mehrzahl seiner Nachkommen verloren gegangen sei. Aber mit fast gleichem Rechte würde man dann das o jenes Urtagfalters mit Fleck oder Haarbusch am Innenrande der Hinterflügel ausrüsten müssen, die bei Danainen, Satyrinen, Morphinen, Brassolinen und Nymphalinen vorkommen und an welche sich die bei Papilionen auftretende Bildung anschliesst. Weit wahrscheinlicher ist es, dass diese Ausrüstung der Männchen mit eigenthümlichen Schuppenflecken und Haarbüschen sich erst später und unabhängig in verschiedenen Gruppen gebildet hat. Dafür spricht auch ihre grosse Verschiedenheit innerhalb derselben Familie oder selbst derselben Gattung (M y c a lesis). Was also in dem entferntest stehenden Gruppen der Tagfalter diese Flecken und Haarbüsche Gemeinsames haben, wird, da es sich kaum auf gemeinsamen Ursprung zurückführen lässt, als Anpassung an die gleiche Verrichtung aufzufassen sein. Welches diese Verrichtung sei, darüber sind bis jetzt, soweit mir bekannt, nicht einmal Vermuthungen laut geworden.

Zufällig lernte ich vor kurzem die Bedeutung der Flecken und Haare bei einer Art kennen und konnte seitdem die Vermuthung, dass sie die gleiche Bedeutung auch in allen übrigen Fällen haben möchten, bei mehreren anderen Arten aus verschiedenen Familien bestätigen.

Ich hatte ein jugendfrisches ơ von $\mathrm{Ca} 11$ idryas Argan te gefangen und bog, um einem Freunde die mähnenartige Behaarung der Hinterflügel zu zeigen, Vorderund Hinterflügel auseinander. Dabei kam mir ein deutlicher etwas moschusähnlicher Duft entgegen und ich überzeugte mich, dass derselbe von den beim Auseinanderbiegen der Flügel sich sträubenden Haaren ausging. Diese Beobachtung habe ich dann an zahlreichen Männchen derselben Art wiederholt und nur bei einigen alten abgeflatterten, zerschlissenen Stücken den Geruch nicht sicher wahrnehmen könnien. Von anderen ähnlich ausgestatteten Schmetterlingsmännchen habe ich seitdem nur wenige $\mathrm{zu}$ beriechen Gelegenheit gehabt. An einem ơ von Prepona Laertes bemerkte ich einen nicht eben starken, doch unverkennbaren Geruch, der von dem Haarbusche der Hinterflügel ausging. Mehrere meiner Kinder bemerkten nicht nur denselben Geruch, den sie (ziemlich treffend, wie mir scheint) als Fledermausgeruch bezeichneten; sie fanden auch dieselbe Stelle als Sitz des Geruches heraus. Einen ebenfalls nicht starken, angenehmen, etwas vanilleartigen Geruch verbreitete ein o von Dircenna Xantho; auch hier liess ich meine Kinder den Ausgangspunkt des Geruches aufsuchen, als welchen sie, wie ich selbst, den „Haarpinsel“ am Vorderrande der Hinterflügel erkannten. Weit kräftiger, als bei den drei eben genannten Arten ist der wie bei Prepona fledermausartige Geruch, der von den grossen schwarzen Flecken auf den Vorderflügeln einer der prächtigsten unserer Thecla-Arten (Th. Atys Cr.) ausgeht. Noch mehrere Wochen nach dem Tode ist dieser Geruch deutlich wahrzunehmen. Die Oberseite der Vorderflügel ist bei den $\delta$ dieser Thecla nach innen blau, 
nach aussen schwarz; der schwarze Saum verbreitet sich von der Hinterecke, wo er etwa $1 / 5$, bis zur Flügelspitze, wo er etwa $1 / 3$ der Länge einnimmt; auch der Vorderrand ist bis zur Costalis schwarz. In dem blamen Theile liegen nun zwei grosse tiefschwarze Flecken, getrennt durch einen blauen Streifen. welcher die Lage der die Mittelzelle schliessenden Queradern bezeichnet. Es liegt also der eine Fleck, und zwar ist dieser kleiner, innerhalb, der andere grössere ausserhalb der Mittelzelle. Der innere Fleck ist fünfeckig mit gerundeten Ecken; er füllt das Ende der Zelle vollständig, reicht an der Subcostalis fast bis zum Ursprung ihres ersten Astes, am dritten Aste der Mediana etwa halb so weit und ist wurzelwärts begrenzt durch zwei am verkümmerten Wurzeltheil cler Discoidalis im rechten Winkel zusammenstossende Linien. Der äussere Fleck, durch Queradern vom innern geschieden, stösst nach vorn an die obere Discoidalader, nach hinten an den zweiten Ast der Mediana, überragt also in dieser Richtung den innern um etwa ein Drittel; er bildet ein querliegendes Eirund, dessen Achsen sich etwa wie $5 \mathrm{zu} 6$ verhalten. Die untere Discoidalader und der dritte Ast der Mediana durchschneiden ihn; jenseits des Fleckes erstreckt sich von jedem der drei so gebildeten Stücke aus ein spitzer dreieckiger blauer Fleck in den schwarzen Saum des Flügels. Die Oberfläche beider Flecken mag zusammen fast $1 / 10$ von der des ganzen Flügels betragen. Die dichtgedrängten Schuppen der Flecken haften sehr fest; nach der Entschuppung erscheint der äussere Fleck leicht gelblich getrübt, der innere stark gebräunt und fast undurchsichtig; die Haut des letzteren springt etwas über die untere Fläche des Flügels vor. Vergrössert zeigt der äussere Fleck ausser den dichtstehenden Anheftungsstellen der Schuppen nur einzelne zarte, kaum verästelte Luftröhren, die von den benachbarten Flügeladern her eintreten. Dagegen sieht man in dem innern Fleck (besonders deutlich, wenn man ihn von unten betrachtet), ein ziemlich dichtes Netz nicht sehr feiner Luftröhren und zwischen diesen rothbraune, durchsichtige Punkte.

Von reichlichen baumförmig verästelten Luftröhren ist auch der Fleck der Callidryas Argante durchzogen. Derselbe ist etwas blässer als seine Umgebung, von der er sich nicht scharf abhebt; deutlicher tritt er nach dem Entschuppen als trübe Stelle hervor. Er liegt in dem stumpfen Winkel zwischen der Subcostalis und ihrem Aste, durch einen lichten Saum von beiden Adern getrennt, aus denen Luftröhren zu ihm gehen. Er ist etwa $3 \mathrm{~mm}$ lang bei o,6 mm grösster Breite. Die den Fleck überdeckende Mähne aus etwa $5 \mathrm{~mm}$ langen Haaren entspringt von einem bis $\mathrm{r}, 3 \mathrm{~mm}$ breiten Streifen, der sich in der Mittelzelle von der Wurzel her auf etwa $10 \mathrm{~mm}$ an der Subcostalis hinzieht. ${ }^{1}$.

Was mich nun vermuthen lässt, dass dieselbe Verrichtung, die bei den $\sigma^{*}$ von Callidryas Argante, Thecla, Prepona Laertes und Dircenna $\mathrm{X}$ antho, also Arten aus vier weit verschiedenen Familien, für die Flecken und Haarbüschel ihrer Flügel durch Beobachtung festgestellt wurde, nämlich Gerüche auszuhauchen, die wahrscheinlich ihren Weibchen angenehm sind und sie zur

1) Neben Argante kommt hier eine sehr ähnliche blassere Art oder Abart vor, die ziemlich gut zu Boisduval's Beschreibung von C. Agarithe stimmt und sich in Betreff des Geruchs, wie die ächte Argante verhält. Bei ihr ist der Fleck grösser, er reicht nicht nur bis an die Subcostalis und ihren Ast heran, sondern füllt auch den spitzen Winkel zwischen diesen beiden Adern. Unter den Stücken, die ich eben zur Hand habe, finde ich keine Uebergänge zwischen beiden Formen. 
Begattung reizen, - was mich vermuthen lässt, dass dieselbe Verrichtung allen ähnlichen Gebilden auf den Flügeln männlicher Tagfalter zukomme, ist nicht nur die bei aller Mannichfaltigkeit unverkennbare Aehnlichkeit derselben; es sind mehr noch die bereits hervorgehobenen Eigenthümlichkeiten dieser Flecken, Pinsel u. s. w., welche dieselben für eine derartige Verrichtung besonders tauglich erscheinen lassen. Dieselben sind für gewöhnlich nicht der Luft ausgesetzt, sondern zwischen Vorder- und Hinterflügel oder sonst wie eingeschlossen oder doch in der Ruhe zwischen den aufgerichteten, aneinanderliegenden Flügeln des Falters geborgen. So kann der Riechstoff nicht zur Unzeit verdunsten und kann sich zwischen den dicht gedrängten fast aufrechten Schuppen der Flecken, zwischen den Haaren der Pinsel, Büsche und Mähnen anhäufen. Kaum aber dürfte auf wirksamere Weise ein riechender Stoff zu voller Wirkung zu bringen sein, als wenn man mit ihm die Haare eines Pinsels tränkt und diese dann plötzlich nach allen Seiten auseinanderspreizend für die Verdunstung eine gewaltige Oberfläche schafft.

Wie die Ageronien, die ich im letzten Sommer zahlreich in vier Arten zu beobachten Gelegenheit hatte, wie es scheint, nur während der Liebeswerbung das eigenthümliche knallende Geräusch beim Fliegen vernehmen lassen, so mögen die mit Haarbüschen, Pinseln u. dgl. ausgestatteten Schmetterlingsmännchen dieselben ebenfalls nur bei derselben Veranlassung ihren Duft verbreiten lassen. Kürzlich fing ich ein Pärchen von Hesperia $\mathrm{Orcus} \mathrm{Cr}$, das sich dicht umflatternd im Begriff schien, sich $\mathrm{zu}$ vereinigen. Als ich das im Käscher todtgedrückte Männchen herausnahm, fand ich den Costalumschlag des einen Flügels aufgeklappt und in der Ebene des Flügels ausgebreitet. Es ist mir das bei den $\delta$ dieses und anderer Dickköpfe sonst noch nicht begegnet und ich wüsste nicht, wie ich beim Zusammendrücken der Brust das Aufklappen hätte zu Wege bringen können. Wahrscheinlich war dasselbe schon vorher von dem brünstigen Männchen selbst bewirkt worden.

Von vorn herein habe ich nicht erwartet, bei allen betreffenden Arten auffallende oder überhaupt für menschliche Nasen wahrnehmbare Gerüche zu finden. Wie der Sinn des Geruchs bei uns ein selbst im Vergleich mit vielen Säugethieren höchst dürftig entwickelter ist, so dürfte er dies in noch höherem Grade sein, wenn wir uns mit gewissen Kerfen und namentlich Schmetterlingen messen. Auf welche unglaubliche Entfernungen jungfräuliche Weibchen von Nachtschmetterlingen die Männchen herbeiziehen, ist bekannt. Für die Tagfalter genügt die Sicherheit, mit der sie die als Nahrung für ihre Larven tauglichen Pflanzen herauszufinden wissen, um die Schärfe ihres Geruchsinnes zu beweisen. So mag für Tagfalterweibchen als starker Duft erscheinen können, was für menschliche Nasen nicht $\mathrm{zu}$ erspüren ist. Ich war daher nicht überrascht, an den Filzflecken verschiedener Thecla arten, sowie an dem sehr ansehnlichen, von stattlicher Mähne bedeckten kreidigen Fleck von Callidryas Trite nichts riechen zu können, und vermag darin kein Bedenken gegen die Allgemeingiltigkeit meiner Deutung dieser Flecken $\mathrm{zu}$ finden.

Es sei mir vergönnt, bei dieser Gelegenheit hinzuweisen auf noch einige andere Geruch verbreitende Gebilde bei Schmetterlingen.

Die Männchen der meisten Glaucopiden vermögen am Ende des Hinterleibes auf der Bauchseite zwei lange hohle Fäden vorzustülpen. Bisweilen (L eucop- 
sumus sp.) sind diese Fäden von mehr als Körperlänge und biegen sich dann beim Hervortreten in Gestalt eines Widderhornes. In der Regel sind sie mit Haaren besetzt, die beim Vorstülpen sich aufrichten, und meist verbreiten sie einen mehr oder weniger starken, für uns widerlichen Geruch; besonders stark und nicht unangenehm, zugleich an Blausäure und Chloroform erinnernd, ist derselbe bei der prächtigen Belemnia inaurata (Euchromia Eryx). Ganz ähnliche, stark riechende Fäden fand ich bei einer Motte, deren Namen ich nicht kenne. $\left.{ }^{1}\right)$ - Bei aller äusseren Verschiedenheit sind auch bei diesen Fäden der Glaucopiden-Männchen dieselben beiden Erfordernisse eines Räucherwerkzeugs ausgebildet, die wir bei den Haarpinseln vieler Tagfalter trafen: Schutz vor Verdunstung zur Unzeit und Entfaltung einer grossen Oberfläche, wenn der Geruch sich einstellen soll.

Bemerkenswerth ist, dass in dem Verwandtschaftskreise der Ithomien beiderlei Bildungen vorkommen und sich zu vertreten scheinen; bei Lycorea fehlen die „Haarpinsel“ am Vorderrande der Hinterflügel, die der Mehrzahl der Gattungen zukommen; dagegen besitzen hier die Männchen jederseits am Ende des Hinterleibes einen grossen theilweise einziehbaren Haarbusch. Aehnlich ist es unter den Pierinen. Auch hier giebt es Arten, eine wenigstens ist mir bekannt -, die Gerüche erzeugen nicht an den Flügeln, sondern am Ende des Hinterleibes. Das ơ von Daptonoura Ilaire trägt dicht vor den Afterklappen auf der Bauchseite einen etwa $4 \mathrm{~mm}$ langen, nicht einziehbaren Pinsel grauer Haare, der sich in der Ruhe dicht an den Bauchrand der Afterklappen anlegt, sie ein wenig überragend. Er lässt sich, was man durch Drücken des Hinterleibes bewirken kann, nach allen Seiten auseinanderspreizen und verbreitet dann einen sehr dentlichen, wenn auch schwachen Geruch. Das $q$ der Daptonoura Tlaire habe ich noch nicht gefangen, doch zweifle ich nicht, dass der Haarpinsel nur dem $\delta$ zukommt und dass dessen Geruch dem Anlocken der 우 und nicht der Abwehr von Feinden dient. Gerüche, welche letzteres bewirken, pflegt der Schmetterling natürlich zu entwickeln, sobald er gefangen wird. So stülpen die Weibchen der verschiedenen Maracujá-Falter (Heliconius, Eueides, Colaen is ${ }^{2}$ ), Agrau lis), wenn man sie ergreift, zwischen der 7. und 8. Rückenplatte des Hinterleibes zwei in der Mittellinie zusammenstossende fleischige Wülste vor, die einen mehr oder weniger lebhaften Geruch verbreiten, während ihre Männchen bei gleicher Veranlassung die Afterklappen auseinanderspreizen, an deren Innenseite ähnliche riechende Wülste sitzen. - Fängt man das Männchen von Didonis Biblis, so lässt es auf dem Rücken des Hinterleibes zwischen dem 4. und 5. Ringe zwei rundliche, in der Mittellinie zusammenstehende, mit kurzen grauen Haaren bedeckte riechende Wülste hervortreten; durch Drücken des Hinterleibes kann man noch zwei ähnliche Wülste zwischen dem 5. und 6. Ringe hervortreiben; sie sind mit etwas längeren weissen Haaren besetzt, die sich beim Hervortreten nach allen Seiten auseinanderspreizen. Ich bedauere, nicht angeben zu können, wie sich die Weibchen von Didonis in dieser Beziehung verhalten.

Die durch Bates so berühmt gewordenen Ithomien des Amazonas, die den dortigen Leptalis und manchen anderen nachahmenden Faltern als Vorbilder

I) Dr. Staudinger bestimmte sie als Cryptolechia spec.

2) Obwohl ich die Raupen von Colaenis noch nicht kenne, ist es mir kaum zweifelhaft, dass auch sie, wie die der drei nächstverwandten Gattungen, an Maracujá (Passiflora) leben. 
dienen, sollen durch unangenehmen Geruch vor Verfolgung durch Vögel geschützt sein. $\mathrm{Ob}$ dies derselbe Geruch ist, den die Haarpinsel der Männchen voraussichtlich auch bei ihnen, wie bei der nächstverwandten Dircenna Xantho, verbreiten? In diesem Falle würde sowohl die nach Bates hundertfach überwiegende Zahl der Männchen, als die vollkommene Uebereinstimmung der beiden Geschlechter in Zeichnung und Färbung sich verstehen lassen, Wenn nur Männchen den die Verfolger abstossenden Geruch besässen, so würden diese letzteren bei gleicher Zahl der Geschlechter eben so oft eine geniessbare, wie eine unschmackhafte Beute fangen; sie würden sich deshalb kaum der Jagd auf die Ithomien entwöhnen. Dies aber würde um so sicherer geschehen, je mehr die ungeniessbaren Männchen an Zahl überwögen, je seltener also die Jagd einen schmackhaften Bissen lieferte. Die Weibchen aber, selbst des schützenden Geruches entbehrend, würden nur durch ihre Ununterscheidbarkeit an der Sicherheit Theil haben, welche die Männchen in dem Geruche ihrer Haarpinsel fänden. So wäre in diesem Falle die gleiche Färbung der beiden Geschlechter für die Weibchen eine schützende Aehnlichkeit, auf dieselbe Weise durch natürliche Auslese hergestellt und erhalten, wie die der nachahmenden Leptalis.

Ich schliesse mit dem Wunsche, dass Forscher, denen reiche Sammlungen zugänglich sind, über das Vorkommen und den feineren Bau, und dass Beobachter der lebenden Thiere über etwaige Gerüche der Haarpinsel, Filzflecke und ähnlicher Gebilde auf den Flügeln männlicher Schmetterlinge bald weitere Aufschlüsse geben mögen. Hierzu anzuregen ist der einzige Zweck dieser Zeilen, da, was ich selbst bieten konnte, kaum der Mittheilung werth gewesen wäre.

Itajahy, Santa Catharina, Brazil im April 1876.

\section{Nachtrag.}

Von Didonis Biblis habe ich im Laufe des letzten Monats ausser einer Menge Männchen, die fast täglich in Mehrzahl gefangen wurden, auch eine ziemliche Anzahl Weibchen zu untersuchen Gelegenheit gehabt, welche letzteren, wenigstens jetzt und hier, vielmal seltener sind, als die Männchen.

Die Weibchen besitzen nur die vorderen beiden Wülste, das hintere Paar fehlt ihnen vollständig; die vorderen Wülste sind etwas kleiner, die Haare oder besser haarähnlichen, am Ende verbreiterten und abgerundeten Schuppen derselben spärlicher, als beim ô, doch ihr Geruch nicht minder kräftig. Dieser Geruch, wie der der entsprechenden vorderen Wülste des $\delta$, wurde von meinen Kindern fast einstimmig als unangenehm, widerlich, - dagegen der Geruch der hinteren Wülste des Männchens mit Einstimmigkeit als angenehm, blumenartig bezeichnet und mit dem von Heliotrop verglichen. Diese hinteren weissen, den Weibchen fehlenden Wülste heben sich so grell ab von dem schwarzen Hinterleibe, sie sehen so allerliebst aus, dass sie höchst wahrscheinlich nicht nur durch ihren Duft, sondern auch als Zierrath das Wohlgefallen der Weibchen erwecken. Dasselbe wird auch gelten von den Flecken auf den Vorderflügeln der TheclaMännchen in den Fällen, wo dieselben hell auf dunklem Grunde erscheinen oder, wie bei Thecla Bodora in glänzendem Blau strahlen.

Mai 1876. 


\section{Aus einem Briefe von Fritz Müller aus Brasilien ${ }^{1}$ ).}

... Kürzlich (25. Oct.-20. Dezb. 1876) habe ich nun endlich meinen lang geplanten Ausflug in's Hochland unserer Provinz ausgeführt. Es war eine sehr lohnende und genussreiche, und dabei nach hiesigen Begriffen - mit sehr wenig Beschwerden und Entbehrungen verbundene Reise; ein Europäer würde freilich nicht gerne wochenlang Haus, Stuhl, Tisch, Bett u. s. entbehren mögen. Die Flora im Westen der Serra, im Quellgebiet des Uruguay war mir eine ganz neue, wunderlich gemischt aus brasilianischen Formen, aus anderen, die oft aufs Täuschendste Arten der alten Heimat (Deutschland) glichen (so eine dem Geum urbanum überaus ähnliche Art) und aus der nördlichen Halbkugel eingewandert scheinen, und wieder 'anderen, die von Süden hergekommen sein dürften, z. B. eine sehr häufige Drymis, ein schönblühender Strauch mit sehr aromatischer Rinde. Die bezeichnendsten und auffallendsten Pflanzen jenes Gebietes sind die Araucaria brasiliensis, verschiedene riesige Bambusaceen, die in den meisten Auracarien und Laubwäldern zum Theil fast undurchdringliche Dickichte bilden, und eine überaus häufige Baumform Xaxim (Schasching) genannt (Dicksonia Sellowiana), dessen Stamm mit einem überaus dicken braunen Luftwurzelfilz umpolstert ist; z. B. bei einem Stamme von $0,45 \mathrm{~m}$ Durchmesser kam nur 0,09 m auf den eigentlichen Stamm, der Rest auf den Wurzelfilz. Bisweilen benutzt man diese Farn zu Zäunen; man pflanzt sie dicht nebeneinander, bei weiterem Wachsthum verschmilzt dann dies Filzpolster der benachbarten Stämme miteinander und der ganze Zaun bildet eine einzige zusammenhängende Mauer.

$\mathrm{Zu}$ den an Deutschland erinnernden Blumen gehören auch mehrere Veilchenarten, von denen eine, weissblühend, durch ihre cleistogamischen Blüthen merkwürdig ist, einmal, weil diese Blüthen sich unter der Erde entwickeln, und zweitens, weil hier die sonstige Regel nicht zu gelten scheint, dass offene und cleistogamische Blüthen gewissermassen einander vertreten; oder richtiger, dass letztere die mangelnde Fruchtbarkeit der ersteren ersetzen. Auf der Höhe der Serra fand ich die weissen Veilchen in voller Blüthe, die offen gewesenen Blüthen hatten reichlich Früchte angesetzt und gleichzeitig waren in grosser Anzahl unterirdische Blüthen und Früchte vorhanden. Einige Stunden weiter am Fusse der Serra in der Nähe des Rio Tayó waren die Veilchen bereits fast ganz ver-

\footnotetext{
I) Flora 187\%. p. 239, 240.
}

Fritz Müllers gesammelte Schriften. 
blüht (ich sah sie hier auf der Hinreise blühen); ich konnte nicht eine einzige Frucht über der Erde und nur äusserst wenig unter der Erde finden.

In meiner Nachbarschaft (Blumenau) kann ich mich nicht einer Pflanze mit hygroskopischen in die Erde sich einbohrenden Samen entsinnen, höchst überrascht war ich daher, auf den Campos jenseits der Serra eine ganze Menge anzutreffen. Ausser einem kleinen Storchschnabel- (Erodium?) über ein Dutzend Gräser, Stipaceen, Avenaceen, Andropogoneen u. s. w., und jedenfalls giebt es deren dort noch weit mehr, da ja mein Besuch in den Anfang des Sommers fiel, am 20. November hatten wir noch starken Reif. Unter diesen Grassamen waren manche recht eigentümlich und abweichend von den Formen, die Francis Darwin beschrieben hat. Vor allen interessant war mir eine Aristida, bei der die 3 Aeste der Grannen bis fast $0,2 \mathrm{~m}$ Länge erreichten. Trocknend breiten sich diese Aeste in einer auf der Achse des Samens senkrechten Ebene aus, und der Samen wird durch diese so langen Aeste in fast senkrechter Stellung gehalten. Um die Aristidapflanzen herum pflegten sich noch immer zahlreiche Samen zu finden, die sich schon mehr oder weniger vollständig in den recht harten, trockenen Boden eingebohrt hatten. - Ausser diesen fand ich noch drei andere Arten von Aristida.

Blumenau, Sa. Catharina. 


\section{A correlação das flores versicolores e dos insectos pronubos $^{1}$ ).}

Muito escassas são até agora as observações que possam elucidar a significação biologica das flores versicolores ou de côr mudavel.

Ainda hoje, como, ha perto já de um seculo disse Brotero \%), a côr das corollas é ordinariamente desprezada pelos botanicos modernos. Ha compendios de botanica, aliás excellentes, que nem uma linha dedicam á côr das flores.

Só Delpino ${ }^{3}$ ) trata amplamente deste interessante assumpto e a elle tambem são devidas as unicas observações que possuimos, relativas á funcção das flores versicolores. O distincto professor da universidade de Genova observou os insectos, que visitavam as flores do Ribes aureum e da Caragana arborescens. Em ambas essas plantas as petalas, amarellas a principio, tomam depois uma viva côr alaranjada, e são ambas mellitophilas, isto é, visitadas e fecundadas por hymenopteros apiarios. Ora, Delpino notou que no Ribes aureum, sinão todos os apiarios, ao menos a Anthophora pilipes evitava visivelmente as flores alaranjadas, e que da mesma sorte na Caragana arborescens os apiarios, que a frequentavam, reservavam quasi exclusivamente as suas visitas ás flores amarellas. Elle julga que d'ahi se póde concluir que, em certos casos, a variação das côres nas plantas versicolores, estão em correlação causal com os insectos pronubos, aos quaes denuncia assim o momento propicio para uma visita efficaz das flores. ${ }^{4}$.

Ha pcuco offereceu-se-me uma excellente occasião para, em outra planta de flores versicolores, fazer uma serie de observações, que confirmam inteiramente a opiniăo de Delpino. Estava e ainda está florescendo perto de minla casa um pequeno arbusto de uma especie de Lantana, cujos capitulos de flores se acham na altura de um metro até metro e meio, a mais commoda possivel para observações desta natureza. As flores duram tres dias, sendo amarellas (côr de gemma de ovo) no primeiro, de côr approximada á de laranja, no segundo; rôxas ou purpureas, no terceiro; as côres, pois, são tão differentes, que é impossivel confundil-as.

1) Arch. do Museu Nacional Rio de Janeiro 1877. Vol. II. p. 19-23.

2) Felix Arellar Brotero, Compendio de Botanica. I788. Tomo I. pag. 144. pag. 629 .

3) Frederico Delpino, Ulteriori observazioni sulla dicogamia nel regno vegetal. Parte II fasc. $2^{0}$ 
Emfim, o arbusto é facilmente accessivel por todos os lados, podendo-se escolher sempre o logar mais commodo para observar os insectos visitantes, sem os inquietar ou afugentar. Não devia deixar passar, sem aproveital-a, occasião tão oppurtuna. Fui pois collocar-me de vigia, para espreitar o que haviam de fazer os insectos que viessem visitar as flores da referida Lantana. Pela estreiteza do tubo da corolla, e pelo seu comprimento, de cerca de um centimetro, facil era de prever que os insectos pronubos seriam lepidopteros, sendo estes os unicos capazes de, com a sua tromba delgada e comprida, sugarem o mel no fundo de semelhante corolla. Com effeito só uma unica vez vi uma Augochlora graminea, Sm., hymenoptero da familia das Andrenideas, examinar varias flores, tanto rôxas; como amarellas, sem dellas poder tirar nem mel, nem pollen. De individuos pertencentes aos Lepidopteros vi nas flores desta Lantana i 2 differentes especies, a saber: a Danais Erippus, Cram.; o Heliconius Apseudes, Hübn.; a Colaenis Dido, I..; a Colaenis Julia, Tabr.; a Dione Juno, Cran.; a Hesperocharis Angustia God.; a Eurema Lence, Boisd.; a Pieris Elodia, Boisd.; (ou P. Aripa, Boisd.?) a Daptonoura Lycimnia, Cram,; a Callidryas Apris, Tabr.; o Papilio Thoas, L. e uma pequena especie da familia das Hesperideas, cujo nome ignoro. O Papilio Thoas e a Colaenis Dido foram vistas só uma vez, mas fugiram ao approximar-me; da mesma sorte fugiram a maior parte das outras borboletas, sem que eu pudesse vêr a quantidade de flores que visitavam. Felizmente pude observar à vontade, de 14 de Outubro até 7 de Novembro, perto de 40 individuos das outras dez especies, principalmente (ou por menos medrosas ou por mais absortas no seu trabalho, e por isso as que melhor se prestavam á observação) o Heliconius Apseudes e a Daptonoura Lycimnia.

As observações que pude fazer sobre estas dez especies acham-se reunidas nas notas seguintes:

$1^{0}$ - Heliconius Apseudes. Observei 7 individuos desta especie, por mais ou menos tempo; vi alguns delles visitarem de 20 para 30 e mais flores. E nem sequer uma só vez tocaram uma flor rôxa ou alaranjada, sugando exclusivamente nas flores amarellas ou do primeiro dia. Quanto ao mais, havia certas differenças no modo de proceder dos quatro individuos que pude vigiar por mais tempo no seu trabalho. O primeiro costumava chupar de duas até quatro flores amarellas em cada capitulo, voando depois a outro. O segundo chupava sempre todas as flores amarellas de cada capitulo, cujo numero raras vezes excede a seis; o mesmo fazia quasi sempre o terceiro, nunca enfiando a tromba mais de uma vez na mesma flor; fiquei muito admirado de vêr que até em um capitulo composto de nove flores frescas, misturadas com as do segundo e do terceiro dias, nem se esqueceu de nenhuma, nem visitou duas vezes a mesma flor. Pelo contrario, o quarto varias vezes tornou a chupar em flores que já tinha visitado, e isso em capitulo cujo numero de flores frescas nào excedia a tres ou quatro. As flores desta Lantana não desabrocham senão pelas oito ou nove horas da manhã, segundo se mostra mais claro ou escuro o dia; ora, não é raro vir o Heliconius Apseudes visitar a planta antes deste tempo, quando só ha flores do segundo e terceiro dias; neste caso, conserva-se a pairar e a voltear, librando-se nas azas em cima de um ou de outro capitulo, sem nunca pousar. 
$2^{n}$ - Daptonoura Lycimnia. Pude observar de perto 13 individuos. Nunca chuparam senào flores amarellas. Uma unica vez vi uma borboleta desta especie pousar n'um capitulo, em que só havia flores alaranjadas e rôxas; porém, sem chupar e sem se demorar, abandonou-o, procurando outro com flores novas. Esta especie tambem costuma sugar todas as flores amarellas do capitulo que visita, sem inserir mais de uma vez a sua tromba na mesina flor. Não é muito raro ver a Daptonoura Lycimnia voltar duas e até tres vezes ao mesmo capitulo, immergindo, de cada vez, a tromba em todas as flores do primeiro dia, o que não me lembra ter observado no Heliconius Apseudes.

$3^{0}-7^{0}$ ) Da especie Colaenis Julia, que não era muito rara na Lantana, apenas tres individuos não fugiram antes de me approximar, e sómente estes visitaram as flores amarellas; da mesma sorte dous individuos de Dione Juno, um de Hesperocharis Augustia, um de Eurema Leuce e um de Callidryas Cipris sempre evitavam as flores alaranjadas e rôxas.

$8^{0}$ - Pieris Elodia. Esta especie, muito mais abundante aqui nesta primavera do que costuma ser em outros annos, tambem não é rara na nossa Lantana; mas sendo muito espantadiça, só pude observar tres individuos. O primeiro enfiou a tromba indifferentemente em flores amarellas e alaranjadas, isto é do primeiro e do segundo dia. Os outros dous, porém, só visitavam as flores amarellas; um delles, que observei por muito tempo, nem sempre soube evitar as flores cujo mel já tinha sorvido. Assim é que havendo na circunferencia de certo capitulo sete flores, seis amarellas e uma alaranjada, elle chupou a flor que estava á direita da alaranjada; depois, rodeando o capitulo, passou a chupar a segunda, a terceira e assim por diante até a sexta; evitou a septima, que era a alaranjada, metteu a tromba outra vez na primeira e na segunda, passando em seguida para outro capitulo.

$9^{0}$ - Danais Erippus. E' esta uma especie que se nào póde bem observar sem afugental-a. Observei quatro individuos. Um chupava só flores amarellas, evitando as alaranjadas e as rôxas; os outros tres davam preferencia inequivoca ás flores amarellas, pois que não deixaram de metter a tromba tambem em algumas das alaranjadas e até - uma unica viez - em uma das rôxas. Em 28 de Outubro vi um individuo desta especie pousado nas flores da Lantana antes que houvessem desabrochado as flores rôxas; por isso só podia procurar mel, mas sem achar, nas flores do segundo dia. A Dancis Erippus tem o costume de enfiar a tromba duas, tres e até quatro vezes em seguida na mesma flor da Lantana, porém não em todas; provavelmente só naquellas em cujo fundo encontra mel; nunca vi-o immergir a tromba mais de uma vez em flor alaranjada.

IO" - Finalmente, observei tres vezes uma pequena borboleta da familia das Hesperideas; nào sei si os tres individuos eram da mesma especie, visto como pertenciam a certas especies, numerosissimas nesta familia, que não se podem distinguir á primeira vista. Duas destas Hesperideas, que, entretanto, não observei por muito tempo, só chupavam em flores amarellas; a terceira foi, de todas as borboletas por mim observadas na Lantana, a unica, que não pareceu importar-se com a côr das flores, mettendo indifferentemente a tromba em fiores amarellas, alaranjadas e rôxas. 
As observações que acabo de referir provam sobejamente a funcçìo que coube ás flores versicolores da Lantana. Como nas especies observadas por Delpino, a mudança de côr indica aos insectos pronubos as flores que elles devem visitar para se proverem de mel, e que são justamente as mesmas que precisam de suas visitas para serem fecundadas. E' evidente o beneficio que d'ahi colhe a planta. Si as flores cahissem no fim do primeiro dia, ficava reduzido á terça parte o numero dellas; seriam pois muito menos vistosos os capitulos, e muito menos proprios para prender a attenção das borboletas.

$\mathrm{Si}$ as flores durassem, tres dias, sem mudarem de côr, os insectos pronubos perderiam o melhor de seu tempo em visitas inuteis a flores que por estarem já fecundadas, não precisavam mais dessas visitas. As flores do segundo e terceiro dia, distinguindo-se pela sua côr alaranjada ou rôxa, das flores amarelladas do primeiro dia, continuam a contribuir essencialmente para attrahir os insectos indispensaveis á fecundação, sem comtudo seduzil-os a visitas desnecessarias.

Mas porque motivo as borboletas são levadas a visitarem só as flores do primeiro dia? Será por algum instincto, por algum habito hereditario e congenito, em virtude do qual ellas evitam as flores alaranjadas e rôxas, visitando unicamente as amarellas? Ou deverá cada individuo aprender por si mesmo, pela sua propria experiencia, que sómente as flores amarellas retribuem com doce nectar o importante serviço que elle lhes presta transferindo o pollen de um para o estigma de outra? As differenças individuaes observaveis entre borboletas da mesma especie parecem favorecer esta segunda hypothese. Porém as poucas observações que fiz são ainda muito insufficientes para auctorisarem sobre tal assumpto, resposto definitiva. O Brazil é assez rico em plantas de flores versicolores. Bastará citar varias especies de Lantana e de Combretum, diversas especies de Pleroma (v. g. Pleroma Sellowianum e o magnifico Jaguaritào da ilha de S. Francisco), de Strychnos, de Amphilophium, de Epidendrum, entre outros, o Ep. cinnabarinum), etc.

As flores de todas as especies do genero Lantana e do Epidendrum cimnabarimum săo provavelmente fecundadas por borboletas; as dos generos Pleroma e Amphilophium por apiarios e as do genero Combretum por beija-flores. Conviria verificar por meio de observações directas si em todas essas plantas a mudança das côres tem a mesma significação que the attribuia Delpino. 


\title{
As maculas sexuaes dos individuos masculinos das especies Danais Erippus e D. Gilippus $\left.{ }^{1}\right)$.
}

\author{
Mit Tafel XLV.
}

Na exposiçào que dá dos caracteres genericos dos Danais, diz Doubleday ${ }^{2}$ ) o seguinte a respeito das differenças sexuaes que se encontram nas azas dessas borboletas: "os machos do primeiro grupo (comprehendendo especies africanas que hoje formam o genero Amauris $\left.{ }^{3}\right)$ ) têm uma certa macula formada de escamas muito bastas e de fórma peculiar, situada na nervura submédia das azas posteriores, perto do angulo anal. No segundo grupo (ao qual pertencem todas as especies americanas), a macula sexual «sexual spot» acha-se no primeiro ramo da nervura media. No terceiro grupo, a macula sexual existe ou neste mesmo ramo ou na nervura submédia; toma ás vezes a fórma de um verdadeiro bolso, que se abre na superficie superior da aza e em cujo fundo, ao menos em exemplares seccos, acha-se um pó de côr parda. Nas especies do quarto grupo (que hoje formam o genero Ideopsis ${ }^{4}$ ) falta a macula sexual das azas posteriores).

Tendo-se descoberto recentemente ${ }^{5}$ ) que as maculas sexuaes das azas, caracteristicas dos machos de muitas borboletas, são orgãos odoriferos que exhalam um cheiro ás vezes bastante forte, certamente agradavel ás femeas das respectivas especies, procedi ao exame dessas maculas sexuaes egualmente nas nossas duas especies de Danais (Danais Erippus Cram. e D. Gilippus, Cram.) e achei-lhes uma estructura muito interessante e que me parece merecer descripção circumstanciada. A macula sexual (conservo provisoriamente o nome de Doubleday até ser definitivamente estabelecida a sua funcção) è situada, nos machos do Danais Evippus e do $D$. Gilippus entre a nervura submédia e o primeiro ramo da média da aza posterior, sendo separada do dito ramo unicamente por um intervallo muito estreito que no $D$. Erippus não eguala e no $D$. Gilippus pouco excede o diametro do mesmo ramo (Fig. I, 2, 7 e 8), Ella é visivel em ambas as superficies, superior

I) Arch. do Museu Nacional Rio de Janeiro I877. Vol. II. p. 25-29.

2) Doubleday, Westwood, Hewitson, Genera of diurnal Lepidoptera, pag. 89 .

3) Kirby, a synonymic Catalogue of diurnal Lepidoptera, 1871. pag. 8.

4) Kirby, 1. c. pag. 2.

5) Fritz Müller, no Kosmos, Zeitschrift, I877. I pag. 391=Ges. Schriften S. $5^{87}$. 
e inferior, da aza, formando uma pequena intumescencia preta, mais proeminente na superficie superior. A côr preta não é devida sómente ás escamas de fórma ordinaria que a cobrem, porque subsiste depois de removidas essas escamas, mas á mesma membrana da aza que se acha escurecida e ao mesmo tempo um pouco endurecida neste logar.

A fórma da macula sexual approxima-se da elliptica, sendo o eixo maior parallelo á nervura. Esta macula é muito maior na especie menor, que é o $D$. Gilippus, tendo perto de 4 millimetros de comprimento sobre 1,5 até perto de 2 millimetros de largura, emquanto que no Erippus raras vezes excede a 2 millimetros de comprimento sobre 6 de largura. - A macula sexual é ôca e fórma, como Doubleday o vio em algumas especies do seu terceiro grupo do genero Danais, uma especie de bolsa aberta na superficie superior da aza, onde existe, na margem posterior da macula, uma fenda estreita occupando a metade pouco mais ou menos do ambito. A parede inferior dessa bolsa ou cavidade é formada pela propria membrana da aza; a parede superior separa-se da inferior, a pouca distancia da nervura, sob um angulo muito agudo; a margem livre ou posterior desta parede curva-se ou enrola-se para o interior da cavidade, como é bem visivel em secções transversaes (Fig. 3 e 9).

Cumpre notar que no animal vivo a margem livre da parede superior applica-se perfeitamente á parede inferior, ficando assim a cavidade fechada por todos os lados; é porém facil introduzir pela fenda, que separa as paredes, qualquer objecto delgado; o que sem mais explicação comprehender-se-ha á vista das figuras 3 e 9. - A membrana das azas dos insectos compõe-se, como se sabe, de duas laminas quasi sempre conglutinadas. Estas duas laminas existem tambem nas paredes da macula, ou, para melhor dizer, da cavidade sexual, mas separam-se com muita facilidade, costumando haver, nos exemplares frescos, muito sangue entre ellas. A lamina externa, como jà disse, é dura, quasi preta, coberta de escamas ordinarias.

A lamina interna é muito mais delgada e offerece um aspecto assaz differente nas duas especies.

No D. Erippus (Fig. 4) vêm-se pequenos circulos um pouco mais transparentes do que o resto da membrana, de cerca de $\mathrm{o}^{\mathrm{mm}}, \mathrm{or}$ de diametro, de cujo centro eleva-se um pello recto de cerca de $\mathrm{o}^{\mathrm{min}}, 06$ de comprimento. Esses circulos são dispostos em fileiras regulares, e distam uns dos outros de $\mathrm{O}^{\mathrm{mm}}, \mathrm{O} 3$ até $\mathrm{o}^{\mathrm{mm}}, \mathrm{o} 6$. Alternando com as fileiras dos circulos, acham-se implantadas escamas pardas, opacas, muito menores do que as escamas ordinarias, das quaes se distinguem igualmente pela fórma.

No D. Gilippus (Fig. Io) os circulos são muito mais approximados entre si e chegam até ás vezes quasi a tocar-se; elles são mais transparentes e o resto da membrana mais opaca do que no D. Erippus. Faltam-lhes os pellos, porém ainda se vê no centro um pontinho, ultimo vestigio e prova de sua existencia em tempos passados. As escamas são muito menores do que as do D. Erippus, tendo apenas $\mathrm{O}^{\mathrm{mm}}, \mathrm{o} 4$ de comprimento, o qual é cerca de $\mathrm{o}^{\mathrm{mm}}, \mathrm{o} 8$ no D. Erippus. Provavelmente eram escaminhas destas o "pó de côr parda» que Doubleday viu em certas outras especies de Danais. Não pude perceber cheiro que fosse exhalado pelas azas dos machos de uma ou outra das duas espezies catharinensis, porém 
antes de passar a discutir a significação biologica que possam ter as maculas sexuaes, convem descrever ainda succintamente outro orgão peculiar ao sexo masculino e que parece ter escapado até agora á attençáo dos entomologos. Comprimindo-se fortemente o abdomen, sahe de cada lado do ultimo segmento um tubo membranoso digitiforme (Fig. 6 u 12), fechado na extremidade, que se acha coberta de cabellos escuros os quaes se vão eriçando ao passo que o tubo sahe do abdomen, exhalando, ao mesmo tempo, um cheiro bastante forte no D. Gilippus, e menos forte, sem deixar de ser bem distincto, no D. Erippus; differença esta que depende evidentemente da circumstancia de serem muito mais numerosos, bastos e compridos os pellos naquella primeira especie. - Ao recolher-se no abdomen, o tubo vira-se ou inverte-se de modo que a superfice que era externa vem a ser interna, formando uma bainha ou estojo ao redor dos pellos, que parecem nascer, em fórma de pincel, no fundo do tubo.

Eis os factos. Resta discutil-os. Havendo nas azas de numerosas especies de borboletas, e unicamente no sexo masculino, escamas de fórma peculiar, muitas vezes reunidas em maculas bem circumscriptas e em certos casos recolhidas em sulcos ou pregas da aza - escamas e maculas que indubitavelmente funccionam como orgãos odoriferos - parece muito provavel que as escamas modificadas, encerradas na cavidade da macula sexual dos D. Erippus e Gilippus tenham ou tiveram a mesma funç̧ão. Talvez seja possivel encontrar ainda nas differentes especies de Danais as fórmas intermediarias que liguem as bolsas das nossas especies ás maculas que se acham patentes nas azas posteriores dos machos do genero Amauris.

De mais, não sómente não se percebe cheiro algum exhalado pelas azas de D. Erippus ou Gilippus, do sexo masculino como tambem parece summamente impropria para semelhante funcção uma cavidade que só communica com o ar por meio de uma fenda estreita e além disso fechada, sem haver na aza, ao que parece, mechanismo algum para abril-a. E como existem na extremidade do abdomen orgãos de cuja funcção odorifera não se póde duvidar, era natural a conjectura de serem as maculas sexuaes dos D. Erippus e Gilippus orgãos odoriferos em estado rudimentario, reduzidos a esta fórma pelo desenvolvimento de outros orgãos na extremidade do abdomen, os quaes melhor desempenhavam a mesma funcção. Podiamos citar em apoio dessa conjectura certos factos analogos, que se dão em outras familias de borboletas. Comtudo a affluencia de sangue para as maculas sexuaes, em gráo pouco commum nas azas destes insectos, parece vedar n consideral-as como orgãos rudimentares; pois a ser assim devia tambem suppôr-se que o desenvolvimento dos orgãos das azas estivesse na razão inversa do dos orgãos do abdomen e que aquelles fossem tanto mais rudimentares quanto mais desenvolvidos se mostrassem estes. Ora é justamente o contrario do que se dá.

No D. Gilippus, os orgãos, tanto das azas, como do abdomen, são muito maiores do que os do D. Erippus, nào obstante ser esta ultima especic a mainr das duas.

Como em casos de duvida convem não deixar passar desapercebida circumstancia alguma, por mais insignificante que possa parecer, vou mencionar ainda o facto de ter achado, em alguns machos do D. Erippus, aliás incolumes, completamente descamada uma muito pequena parte da aza junto da fenda da macula 
sexual, como si as escamas tivessem sido levadas d'alli por algum objecto introduzido repetidas vezes na mesma fenda. Nào seria possivel que alguma materia odorosa fosse produzida no interior da macula sexual, e que os pellos dos orgàos odoriferos do abdomen, introduzidos na cavidade dessa macula, alli se impregnassem daquella materia?

A posição das maculas sexuaes é de fórma tal, que a extremidade do abdomen facilmente se lhes póde applicar, e como os pellos dos orgãos odoriferos, an sahirem do abdomen, acham-se unidos em fórma de pincel, não parece impossivel, nem mesmo muito difficil, a sua introducção na fenda das maculas.

Confesso, comtudo, francamente que esta idéa não me parece ainda estar bem assentada. Só um estudo comparativo das numerosas especies do genero Danais poderá dar solução definitiva á tão interessante questão.

\section{Explicação das figuras da estampa XLV.}

As figuras I até 6 referem-se á Danais Erippus (sexo masculino), as figuras 7 até I 2 a Danais Gilippus (sexo masculino).

Fig. I e 7.-Aza posterior, vista de cima, tamanho natural. Os numeros das nervuras são os usados por Herrich Schaeffer, sendo na nomenclatura de Doubleday.

$I^{\text {a }}$ nervura interna.

$\mathrm{I}^{\mathrm{b}}$ submédia.

2 primeiro)

3 segundo ramos da nervura média.

+ terceiro

5 nervura discoidal.

6 segundo $\}$ primeiro $\}$ ramos da nervura subdorsal.

8 nervura dorsal.

$p \quad \gg$ predorsal.

$s$ macula sexual ("sexual spot» Doubleday).

Fig. 2 e 8-Macula sexual, augmentada cinco vezes.

$n$ primeiro ramo da nervura média.

$s$ macula sexual.

Fig. 3 e 9-Secção transversal da mesma macula, augmentada I 80 vezes.

$n$ primeiro ramo da nervura média.

$i$ parede inferior $\}$ da cavidade da macula sexual.

Fig. 4 e Io-Parte da membrana interna da cavidade da macula sexual, augmentada I 80 vezes.

$a$ pontos de inserçâo das escamas.

$b$ uma das escamas.

c pontos de inserção de pellos, que faltão no $D$. Gilippus, restando comtudo os pontos de inserção.

Fig. 5 e II-Escamas ordinarias da superficie superior das azas posteriores, augmentadas I 80 vezes.

a escamas subjacentes ou inferiores,

$b$ escamas superiores.

Fig. $5 \mathrm{~B}$-As mesmas escamas na sua posiçào natural.

Fig. 6 e I 2-Orgàos odoriferos, vistos de cima, augmentados duas vezes.

$a$ ultimo segmento do abdomen.

$b$ orgàos odoriferos. 


\title{
Os orgãos odoriferos das especies Epicaliã Acontius, Linn. e de Myscelia Orsis, Dru. ${ }^{1}$ ).
}

\author{
Mit Tafel XLVI.
}

O genero Epicalia, Westw. (ou Catonephele, Hübn.) tem adquirido certa fama ${ }^{2}$ ) pela differença extraordinaria que exibem no colorido das azas os dous sexos de varias especies suas representantes. Si v. g. comparamos a Epicalia Numilia, Cram. com a Epicalia Acontius, Linn, veremos que as femeas das duas especies, e da mesma sorte os machos, são muito mais semelhantes entre si do que cada uma das femeas ao seu proprio macho. Os machos de ambas estas especies sào ornados com grandes e esplendidas maculas côr de laranja em fundo preto avelludado, havendo tres maculas ellipticas separadas (duas na aza anterior e uma na posterior) na Epicalia Numilia, emquanto que na Epicalia Acontius (Antiochus Fabr.) ha uma só macula na aza anterior, confluindo com a da aza posterior em uma fita ou banda larga, commum ás duas azas. Nas femeas, as maculas das azas são de um amarello côr de enxofre, e de fórma inteiramente differente da que se vê no sexo opposto; na Epicalia Acontius (Medea, Fabr.) cllas formam tres fileiras parallelas, sendo bastante numerosas. Com effeito, a differença, entre os dous sexos, é tào grande que Westwood os collocou em gencros differentes, denominando Myscelia Medéa á femea da Epicalia Acontius.

As duas especies que acabo de mencionar e que săo as unicas Epicalias que até agora encontrei na provincia de Santa Catharina, são muito interessantes tambem pela notavel differença que mostram os machos, aliás tào semelhantes, no tocante aos orgãos odoriferos. Nos machos da Epicalia Numilia nàn me foi possivel achar vestigio algum de semelhantes orgãos; parece que faltam inteiramente nestes insectos. Nos machos da Epicalia Acontius, pelo contrario, elles tomam um desenvolvimento pouco commun e exhalam um cheiro fortissimo. Estes orgàos odoriferos acham-se escondidos entre as azas anteriores e posteriores, occupando a superficie superior destas, e a inferior d'aquellas. Nas azas posteriores vê-sc (Fig. I I), contigua á macula alaranjada (l), outra macula maior ( $m$ ) de côr parda, e que não tem a apparencia avelludada do resto da aza, e póde antes comparar-se a uma especie de feltro. Essa macula feltrada ("Filzfleck» Herrich-Schacffer), é limitada pelas nervuras dorsal (8) e discoidal (5) e por uma recta que do

I) Arch. do Museu Nacional Rio de Janeiro 1877. II. P. 3 I-35.

2) Darwin, Descent of man, I871. Vol. I pag. 388 . 
ponto de separação das nervuras dorsal e subdorsal vai ao ponto em que a nervura discocellular inferior parte da discoidal; ella accompanha a nérvura dorsal (m) cerca de $2 / 5$ de seu comprimento, e a discoidal até um ponto equidistante da margem da aza e do ponto de separação das nervuras dorsal e subdorsal. A sua aria é pouco mais ou menos a oitava parte da aza inteira. A macula não differe muito de um semi-circulo de 12 millimetros, nem a aza de um circulo de 24 millimetros de diametro.

Ordinariamente esta macula é cobcrta pela aza anterior, a qual na superficie inferior é provida (Fig. 1I, m') de uma macula opposta á da aza posterior e quasi identica a esta pela sua apparencia feltrada, côr, fórma, e dimensões, porém menos visivel, não só por contrastar pouco a sua côr com a superficie ambiente, como tambem por ser inteiramente coberta por uma crina de pellos pretos inseridos ao longo da nervura interna (I). Esta macula feltrada das azas anteriores estende-se da nervura interna (1) até ao angulo formado pelo segundo e terceiro ramos $(3 c 4)$ da nervura mediana; como na macula das azas posteriores só uma parte insignificante cáe dentro da cellula media.

A crina, á que acabo de alludir, nasce da margem posterior da macula, ou, o que é o mesmo, da margem anterior da nervura interna, dividindo-se esta cm cinco partes eguaes. A segunda c terceira destas partes, a contar da base da aza, sào occupadas pela crina, composta de bellos pellos pretos de uns sete millimetros de comprimento.

Esta crina cobre exacta e inteiramente a macula feltrada da das azas anteriores, separando-a ao mesmo tempo da das posteriores.

As escamas das maculas felpudas ou odoriferas (fig. 13) distinguem-se das escamas ordinarias (fig. 12):

$1^{0}$; pela sua fórma, principalmente por ser a sua extremidade desdentada.

$2^{0}$; pelas suas dimensões.

Das escamas ordinarias da superficie superior das azas, as superiores (fig. $12, s$ ) têm cerca de $\mathrm{O}^{\mathrm{mm}}, \mathrm{I} 4$ de comprimento sobre $\mathrm{o}^{\mathrm{mm}}, \mathrm{ob}$ de largura; as inferiores ou subjacentes (fig. 12, i) cerca de $\mathrm{o}^{\mathrm{mm}}, 1$ de comprimento sobre $\mathrm{o}^{\mathrm{mm}}, \mathrm{o} 8$ de largura.

Das escamas odoriferas, as superiores (fig. 13,s) tem cerca de $0^{\mathrm{mm}}, 33$ de comprimento sobre $\mathrm{o}^{\mathrm{mm}}, 1$ de largura, e as inferiores (fig. 13, $i$ ) cerca de $\mathrm{o}^{\mathrm{mm}}, 24$ de comprimento sobre $\mathrm{O}^{\mathrm{mm}}$, is de largura.

$3^{0}$; por serem muito mais opacas e apparentemente privadas das linhas longitudinaes tão visiveis nas escamas ordinarias.

$4^{0}$; por serem implantadas mais firmemente na membrana das azas, de modo que passando um pequeno pincel por cima das azas, podem-se remover as escamas ordinarias, ficando quasi incolumes as maculas felpudas.

Todas essas differenças entre escamas ordinarias e odoriferas existem tambem (em quasi todas as especies, cujas azas são dotadas de maculus odoriferas. Os carecteristicos que distinguem a Epicalia Acontius de muitas outras especies š̃o os seguintes:

$I^{0}$; a differença que se observa tambem nas maculus odoriferas entre as escamas superiores e inferiores; porque em geral as escamas odoriferas costumam Ser todas da mesma fórma, sem distincção de superiores e inferiores.

$2^{0}$; a circumstancia de guardarem quasi a mesma distancia nas maculas odoriferas (fig. 15) e no resto das azas (fig. 14) as covinhas ou alveolos, em que as 
escamas se acham implantadas, visto como em geral as escamas odoriferas costumam ser muito mais unidas do que as ordinarias.

Os alveolos das escamas odoriferas (fig. 15), além de serem maiores, são cercados de uma área escura, elliptica ou circular, o que frequentemente se observa tambem em outros casos.

Ainda é digna de se notar a modificação consideravel da fórma das azas que têm acompanhado o desenvolvimento das maculas odoriferas. A margem interna (ou posterior) das azas anteriores é quasi rectilinea nas femeas da Epicalia Acontius (fig. 10) e em ambos os sexos da Epicalia Numilia (fig. 9), emquanto que nos machos da Epicalia Acontius (fig. 11), é muito arqueada, podendo desta sorte cobrir uma parte muito maior das azas posteriores. Da mesma maneira acha-se ampliada a fimbria anterior das margens posteriores. Dahi resulta que a femea da Epicalia Acontius (fig. 10), quanto á fórma das azas, approxima-se mais do macho da Epicalia Numilia (fig. 9), do que do macho de sua propria especie (fig. 11).

Intimamente alliado an genero Epicalia é o genero Myscelia, representado na provincia de Santa Catharina pela Myscelia Orsis, Dru. Já antes de ter podido examinar o macho desta especie, eu soube por Herrich Schaeffer ${ }^{1}$ ), que elles possue uma «macula feltrada» (Filzfleck) na superficie superior das azas posteriores (fig. 1, $m$ ), entre as nervuras quinta e septima, isto é, entre a nervura discoidal e o primeiro ramo da subdorsal. Ha pouco pude convencer-me de que a referida macula exhala um cheiro fortissimo, o qual tem, como a da Epicalia Acontius (sexo masc.), certa semelhança com o de almiscar. A macula, que occupa cerca de I/9 (36 millimetros quadrados): da superficic da aza (315 millimetros quadrados) ainda ultrapassa um pouco as duas nervuras que HerrichSchaeffer the dá por limites; é de côr inteiramente preta, sendo pardacenta a parte circumvizinha da aza que, como a macula, é coberta pela aza anterior, e de um azul brilhante o disco da aza. A estructura da macula pouco differe da da Epicalia Acontius e por isso nào carece descripção circumstanciada; sómente as escamas odoriferas não excedem tanto as dimensões das ordinarias. As azas antertiores sào destituidas de orgàos odoriferos.

Deste modo, no tocante ás maculas felpudas, o macho da Myscelia Orsis occupa uma posição intermedia entre a Epicalia Numilia, que carece de semelhantes maculas, e a Epicalia Acontius, que as possue tambem nas azas anteriores. Avista deste facto, é permittido duvidar sobre si os limites entre os dous generos já s' acham devida e definitivamente estabelecidos. Sabe-se que as femeas da Myscelia Orsis e da Epicalia Acontius concordam tambem perfeitamente no arranjo das maculas das azas, as quaes sào, amarellas nesta, è brancas naquella especie, differindo bastante a este respeito da femea da Epicalia Numilia; facto este que muitu d(-verá contribuir para reforçar aquella duvida.

\section{Explicação das figuras da estampa XLVI.}

As figuras $1,9,10$ e I 1 sào de tamanho natural; as mais são augmentadas 180 : vezes.

As figuras 1 até 8 referem-se a Myscelia Orsis (sexo masculino).

I) Prodrom system. lepidopt. I 1864 pag. $27, \mathrm{n}^{0} 79$. 
Fig. I. - Aza posterior de Myscelin Orsis (sexo masculino), - $n$ - macula feltrada ou odorifera.

Fig. 2.-Escamas da superficie inferior das azas.

Fig. 3.-Ditas do disco da superficie superior.

Fig. 4.-Ditas da margem posterior da superficie superior das azas posteriores.

Fig. 5-Ditas da macula feltrada $-s$ - escamas superiores - $i$ - ditas inferiores ou subjacentes.

Fig. 6. - Alveolos das escamas da superficie inferior das azas posteriores. Como em muitissimas outras especies os alveolos da superficie inferior distinguem-se dos da superior por serem ligados os do mesma fileira transversal por uma linha. teriores.

Fig. 7.-Alveolos das escamas ordinarias da superficie superior das azas pos-

Fig. 8.-Ditos das escamas odoriferas.

Fig. 9.- Contornos das azas de Epicalia Numilia, Cram. (sexo masculino).

Fig. Io.-Ditas de Epicalia Acontius, Linn. (sexo feminino), (Medea, Fabr.)

Fig. I I.-Ditas de Epicalia Acontius, Linn. (sexo masculino), (Antiochus, Fabr.)

$b$-macula alaranjada das azas posteriores.

m- macula feltrada das mesmas azas.

m'-macula feltrada da superficie inferior das azas anteriores, cobertas de uma crina de cabellos pretos.

Fig. 1 2. - Escamas ordinarias da superficie superior do disco das azas posteriores de Epicalia Acontius (sexo masculino).

Fig. 13. - Ditas da macula feltrada das mesmas azas.

Fig. I 4. - Alveolos das escamas ordinarias das mesmas azas.

Fig. 15.-Ditos das escamas odoriferas da macula feltrada das mesmas azas. 


\title{
Os orgãos odoriferos nas pernas de certos Lepidopteres ${ }^{1}$.
}

\author{
Mit Tafel XLVII.
}

Em todas as ordens, disse Darwin, fallando da selecçào sexual e dos caracteres sexuaes secundarios dos insectos ${ }^{2}$, os sexos de muitas especies apresentam differenças, cuja significação não se conhece... Casos destes abundão nos Lepidopteros. Um dos mais extraordinarios é o de terem os machos de certas borboletas as pernas dianteiras mais ou menos astrophiadas. As azas differem tambem muitas vezes nos dous sexos pelas nervuras e ás vezes consideravelmente pela figura, como no Aricoris epitus. Os machos de certas borboletas da America do Sul têm pinceis de cabellos nas margens das azas e excrescencias corneas no disco das azas posteriores. Em certas borboletas da Inglaterra só os machos, como mostrou Mr. Wonfor, são parcialmente cobertos de escamas peculiares.»

Hoje, quasi todas essas differenças sexuaes dos Lepidopteros, completamente inexplicaveis ainda ha poucos annos, tornaram-se claras e intelligiveis depois que se descobrio que ellas se referem, directa ou indirectamente, á producção ou diffusão de um cheiro particular que, de certo, deverá agradar ás respectivas femeas. Pertencem a esta categoria os «pinceis» ou crinas que se encontram frequentemente na margem anterior das azas posteriores, e cujo cheiro é muito intenso na Callidryas Cipris, bem sensivel e muito agradavel na Dircenna Xantho e n'outras especies, e as escamas peculiares de fórmas muito variadas, que existem nas azas dos machos em muitas especies de Satyrinas, Heliconinas, Nymphalinas, Pierinas, etc., ás quaes Bernard Deschamps ${ }^{3}$ ) deu o nome de plumulas, como tambem as "excrescencias corneas» ou "maculas sexuaes que existem no disco das azas posteriores dos machos das Danais Erippus e Gilippus ${ }^{4}$.

I) Arch. do Mus. Nacional Rio de Janeiro 1877. Vol. II. p. 37-42.

2) Darwin, Descent of man 187 I. Vol. I. pag. 344 .

3) Annales des Sc. nat. I 837 , Février, Mars-citado em Chénu, Encyclopédie d'hist. nat. Papillons Tome I, pag. 8.

4) No vol. XI da Jenaische Zeitschrift für Naturrissenschaft. 1877 publicou-se um resumo de quanto achei nos varios autores, que pude consultar, sobre os orgĩos odoriferos nas azas das borboletas, e o primeiro ensaio que apresentei para mostrar a funççio dos ditos orgĩos. = Ges. Schriften pag. 534 . 
Quanto ás differenças que ha na disposição das nervuras das azas, tambem estas em muitos, sinão em todos os casos, são devidas á existencia, nos machos, de um orgão odorifero, pelo qual foram deslocadas certas nervuras, como facilmente se póde verificar nos generos Dircenna, Mechanitis, Thecla (v. g. Thecla Acmon), entre as borboletas diurnas, ou no genero Rhamphidium entre as nocturnas. A figura das azas acha-se tambem frequentemente mais ou menos modificada pelos orgãos odoriferos.

Entretanto estes orgãos odoriferos dos machos e as differenças sexuaes que delles resultam, năo se limitam ás azas: em numerosas especies, mórmente de borboletas nocturnas, elles occupam o abdomen; emquanto que, em algumas outras, desenvolvem-se nas pernas. São orgãos abdominaes estes que, por se acharem, no estado de repouso, quasi sempre recolhidos, ou no interior ou entre es escamas do abdomen, escaparam inteiramente á attenção dos lepidopterologos. A unica noticia que encontrei a respeito delles refere-se ao genero Lycorea em que os machos, segundo Doubleday "têm um grande feixe de pellos de cada lado do ultimo segmento, capaz de ser recolhido em grande parte no interior do abdomen» 1). Como nas Lycoreas e Itunas, assim tambem nos machos das Danais, dos Morphos, das Glaucopideas, das Cryptolechia e de varias outras borboletas nocturnas os orgãos odoriferos estão situados na extremidade do abdomen, tomando ora a fórma de pinceis, ora a de protuberancias mamilliformes ou digitiformes, ora a de tubos filiformes muito compridos e exhalando em quasi todos os casos um cheiro fortissimo. E' muito mais raro estarem collocados os ditos orgãos no lado dorsal, como se vê na Didonis Biblis, ou no lado ventral do abdomen, como acontece na familia das Sphingideas. Si, em muitos outros casos, os orgãos ndoriferos eram de ha muito conhecidos, ignorando-se a sua funcção, e contrario se dá com as Sphingideas; já desde muitos annos sabia-se que os machos de certas especies exhalam um cheiro activo de almiscar; mas não se tinha achado, - talvez nem mesmo procurado o lugar d'onde emanava este cheiro. Emana elle de dous pinceis siduados na base do abdomen e que podem ser recolhidos em uma especie de sulcos formados pelas escamas dos dous primeiros segmentos abdominaes.

Quanto, emfim, aos pinceis e apparelhos analogos, que existem nas pernas de certos lepidopteros, e só no sexo masculino, ninguem até hoje, que eu saiba, fallou na funcçào que elles possam exercer. Entre as borboletas diurnas parecem estes orgãos limitar-se á familia das Hesperideas, na qual se apresentam sob duas fórmas differentes. Nos machos de uma especic da Illa de Java, a Ismene Oedipodea, Swains, as tibias do terceiro par de pernas são, segundo Westwood ${ }^{2}$, de uma grossura extraordinaria e cobertas de densos pellos; em varias outras especies da familia, as mesmas tibias são dotadas, nos machos, de um pincel de pellos compridos. Estes princeis das tibias ("Schienenpinsel») já serviram a HerrichSchaeffer e outros autores, para caracterisar certos generos das Hesperideas, como

I) Doubleday, Westwood, Hewitson, Genera of diurnal lepidoptera, pag. 196. - Os mesmos feixes de pellos apparecem (Tab. XVI. Fig. I. da mesma obra) na figura da Ituna Phenarete sem que o texto os mencione. Nos machos de Ituna Ilione eu tambem os vi.

2) Doubleday-Westwood, Hewitson, Genera of diurnal lepidoptera, pag. 574 . 
Achlyodes, Antigonus e outros. Desde que vi em uma Hesperidea, pertencente, pelos caracteres indicados por Herrich-Schaeffer, ao genero Antigonus, que os pinceis das tibias podem ser recolhidos em una especie de sulco formado pelas escamas do abdomen, não duvidei de que os ditos pinceis tambem fossem orgãos odoriferos, visto que participam de um dos caracteristicos mais frisantes desses orgăos, que consistem em serem elles de uma outra maneira protegidos, no estado de repouso, contra a evaporação de seu aroma. E, com effeito, ha pouco tive a satisfacção de encontrar uma borboleta nocturna, cujas tibias emittiam um cheiro singular, que, sem ser muito forte, não deixava comtudo de ser perfeitamente perceptivel tambem a nós, cujo olfacto é sem duvida muito inferior ao de muitos lepidopteros. Era uma das maiores especies da familia das Erebideas, tendo com as azas abertas $\mathrm{O}^{\mathrm{m}}, \mathrm{Ig}$ de largura, especie essa cujo nome ainda ignoro. Nas femeas dessa Erebidea as tibias de terceiro par de pernas (Fig. 1o) têm a fórma delgada, que costumam ter nos lepidopteros, sendo a sua grossura intermediaria á do femur e á do tarso. Nos machos pelo contrario (Fig. I I e I 2) as mesmas tibias são excessivamente largas, de sorte que a largura $\left(4^{\mathrm{mm}}\right)$ é igual á terça parte do comprimento $\left(\mathrm{O}^{\mathrm{mm}}, \mathrm{I} 2\right)$. A superficie externa é um pouco convexa; no lado interno existe um sulco longitudinal principiando a 3 ou 4 millimetros da base e aprofundando-se ao passo que se approxima da extremidade tarsal da tibia, como melhor se vê em secções transversaes (Fig. I4). Toda a superficie interna, exceptuando apenas a extremidade tarsal e parte do sulco, é coberta de pellos de 4 a 6 millimetros de comprimento, sendo os mais curtos os da margem superior (Fig. I3). Esses pellos são capazes de eriçarem-se, formando uma especie de escova muito densa, e é n'este estado de eriçamento que se percebe o cheiro que desprendem.

Voltando ao estado de repouso, os do meio deitam-se no sulco longitudinal parallelos ao eixo da tibia, sendo cobertos por uma espessa camada dos pellos lateraes da tibia; em cima destes ainda se applicam os densos pellos da margem inferior do femur, que tambem se acham muito mais desenvolvidos no sexo masculino. Desta maneira os pellos inferiores e mórmente os deitados no sulco longitudinal da tibia, acham-se sufficientemente protegidos pela superposição dos pellos marginaes, e dos do femur contra a perda por evaporação de qualquer substancia odorifera, de que elles se possam impregnar no estado de repouso, emquanto que eriçando-se, exhibem uma superficie enorme, e que deve causar uma evaporação correspodente da substancia odorosa. Convem notar que já Linneu deu a uma especie de Erebideas o nome de Noctua odora; é provavel que tenha cheiro bastante forte; si esse odor é peculiar ao sexo masculino e produzido pelas tibias, não sei dizel-o. Ha na mesma familia outras especies, cujos machos têm tibias, de fórma normal, sem a cabelladura desproporcionada da nossa primeira especie, sendo a delles munida só de um pincel de pellos compridos procedente do lado interior da base. Ha ainda outras especies de Erebideas que parecem ser destituidas de orgàos odoriferos nas pernas. Assim como certos generos Hesperideas sĩo caracterisados pelos pinceis que os machos têm nas tibias posteriores, assim tambem os machos do genero Herminia (que alguns entomologos incluem na familia das Pyralideas outros como Speyer, entre as 
Noctuinas), costumam ser munidos de pinceis nas tibias mais ou menos largas; mas, neste caso, as tibias dianteiras são as que apresentam o distinctivo do sexo masculino ${ }^{1}$ ).

$\mathrm{Na}$ familia das Geometrideas um bello e instructivo exemplo de pinceis nas pernas posteriores é offerecido pela Pantherodes pardalaria, Hübn., borboleta que parece habitar todo o Brazil, desde o Equador, até além do tropico do Capricornio. Spix e Martius trouxeram-n'a do Rio Negro ") sendo tambem, ao menos em certos annos, frequentissima na provincia de Santa Catharina. Nesta especie as tibias do $3 .^{0}$ par de pernas são egualmente muito mais grossas nos machos (Fïg. 2 e 4) do que nas femeas (Fig. I), sem comtudo attingirem naquelles a dimensões extraordinarias. A superficie interna é cortada por um sulco longitudinal (Fig. 3 b) e neste sulco acha-se escondido um pincel de pellos finos e compridos, implantados na base da tibia (Fig. 3, a); a diametro destes pellos é de $0,{ }^{\mathrm{mm}} \mathrm{OO} 4$ até ${ }^{\mathrm{o}},{ }^{\mathrm{mm}} \mathrm{O} 1$ e $\mathrm{O}$ seu comprimento egual á da mesma tibia. A côr de pincel varia um pouco nos diversos individuos; os pellos são, uns baios-claros, outros pardos-escuros, e até pretos; predominam geralmente aquelles, ás vezes porém dá-se o contrario. Ao longo das margens do sulco nascem escamas (Fig. 9), que pelas suas dimensões muito maiores, pela fórma e pela côr distinguem-se das que cobrem o resto da tibia (Fig. 8). Aquellas chegain ás vezes a ter quasi $0,{ }^{\mathrm{mm}} \mathrm{Oo} 1$ de comprimento, estas raras vezes excedem á terça parte desse comprimento; aquellas são asymetricas, imitando mais ou menos a fórma da lua crescente, estas são symetricas, de lados parallelos, com 3 ou 2 dentes na extremidade; emfim as escamas maiores das margens do sulco são pallidas, côr de palha; as menores do resto da tibia são pardas, mais ou menos escuras. Inclinando-se para o lado do sulco, as escamas maiores formam sobre elle uma especie de tecto (Fig. 6, $c e d$ ), achandose as da margem inferior cobertas parcialmente pelas da margem superior. Assim fica realisada neste caso, por meios differentes, porém egualmente efficazes, uma cobertura que previne a perda de qualquer aroma que o pincel possa conter. Estendendo-se a tibia, o pincel começa a sahir do seu escondrijo e a eriçar-se, distendendo para todos os lados os seus pellos, mas sem desenvolver cheiro perceptivel ao olphato humano ou pelo menos ao meu. Sem duvida que no vastissimo grupo das borboletas nocturnas, de que ainda não examinei senão um numero muitissimo insignificante de especies, devem existir numerosos outros casos de apparelhos odoriferos tanto nas pernas, como nas azas e n'outras partes do corpo. O fim destas linhas não era. nem podia ser, elucidar perfeitamente o assumpto de que fallei aqui; e sim unicamente apontar aos jovens naturalistas do Brazil mais um campo vasto, inexplorado e que promette uma colheita de factos novos e interessantes.

\section{Explicação da Figura da Estampa XLVII.}

As figuras I até 9 referem-se a Pantherodes pardalaria.

Fig. I. - Perna esquerda do $3 .^{\circ}$ pár da fémea.

1) Tibia élargi et garni de pinceaux de poils extensibles» Chenu, Encyclopédie d'hist. nat. Papillons. Tome II, pag. 2 I 5 .

2) Perty, Delectus animalium articulatorum. 1830, pag. 163. Tab. XXXII Fig. I1. - Perty lhe dí o nome de Phalaena peripicillum. 
Fig. 2. - A mesma do macho.

Fig. 3. - A mesma quebrada no meio da tibia. in terno.

a - Parte superior com o pincel que nasce da base da tibia, vista do lado externo.

$b$ - Parte inferior com o sulco em que se recolhe o dito pincel, vista do lado

Fig. 4. - A mesma com o pincel eriçado, visto do lado externo.

As figuras I e 4 sĩo augmentadas 3 vezes.

Fig. 5. - Secçào transversal da tibia da femea.

Fig. 6. - Secções transversaes da tibia do macho, en 4 differentes alturas, indicadas na fig. 2 a-d ( + margem superior $=$ superficie externa).

As figures 5 e 6 sõo augmentadas 15 vezes.

Fig. 7. - Escamas da superficie superior das azas anteriores.

A. - Escamas superiores.

B. - Escamas subjacentes ou inferiores.

Fig. 8. - Escamas da superficie externa da tibia.

Fig. 9. - Escamas das margens do sulco no lado interno da tibia. As figuras 7 e 9 augmentadas 90 vezes.

As figuras IO e I4 referem-se a uma Erebidea, de I9 centimetros de largura, com as azas abertas.

Fig. IO. - Perna esquerda do $3 \cdot{ }^{0}$ par de pernas, da femea.

Fig. I I. - A mesma do macho, vista do lado externo.

Fig. I 2. - Perna direita, do $3 .^{\circ}$ par de pernas, do macho, vista do lado interno.

Fig. I3. - Articulaçào da tibia com o femur, vista de cima, com os pellos da tibia eriçados.

$s$ - Pellos da margem superior da tibia.

$i$ - Ditos da margem inferior.

As figuras Io e I 3 são augmentadas duas vezes.

Fig. I4. - Secções transversaes da tibia do macho em tres differentes alturas, indicadas na figuras I I $a-c$, augmentadas 4 vezes. 


\title{
Os orgãos odoriferos nas pernas de certos Lepidopteres $\left.{ }^{1}\right)$.
}

\author{
(Supplemento.)
}

Mit Tafel XLVIII.

Conclui a noticia sobre os orgãos odoriferos, que distinguem o sexo masculino de varias borboletas, dizendo que este assumpto promettia uma colheita riquissima de factos novos e interessantes. Parece-me com effeito ser essa uma mina incxhaurivel. Mal se tinham passado quinze dias, quando pude, ás fórmas desses orgàos descriptas naquella noticia, ajuntar outras duas das mais singulares que encontrei nos machos de duas especies de Erebideas.

Uma dellas é um anão nesta familia de gigantes, cuja largura, com as azas abertas, não excede a 4 centimetros. Em certas especiess da mesma familia, como em varias Hesperideas (Achlyodes, Antigonus etc.,) os orgãos odoriferos constituem um pincel de pellos compridos implantado na base das tibias posteriores; a fórma que se reproduz neste caso é a mesma, porém não são as tibias posteriores, mas sim as anteriores, de cuja base nasce o pincel odorifern.

Compõe-se este pincel de pellos pretos, cujo comprimento (4 millimetros) excede tanto o da tibia ( 2 millimetros) como o do femur (3 millimetros). Emquanto em certas Hesperideas o pincel odorifero das pernas posteriores esconde-se entre as côxas posteriores e a base do abdomen, na Erebidea em questào elle se recolhe ao longo do lado inferior de femur cujas margens sàn bordadas de pellos louros, formando uma especie de estojo para o pincel (Fig. I). A tibia anterior não sómente póde estender-se, á maneira do que se observa em outros Lepidopteros, até formar uma linha recta com o femur, mas tambem póde vir além (Fig. 2); c é por mein desta extensào excessiva que elle se desembainha ou sahe de seu estrojo, eriçando-se ao mesmo tempo o pincel odorifero. Na segunda especie, que tem cerca de seis centimetros de largura com as azas abertas, os orgãos odoriferos occupam o femur do segundo par de pernas ou das pernas médias.

Năo é tanto pela sua situação insolita, como pelas suas dimensões que estes orgãơs se tornam mais interessantes, pelas suas proporçoes verdadeiramente mons-

1) Arch. do Mus. Nacional Rio de Janeiro 187\%. Vol. 11. p. 43-46. 
truosas, formando uma especie de pélla, um corpo globuloso ou cllipsoide, cujo diametro é quasi egual ao comprimento do femur (lig. 5, 6 e 7). Nem as pernas anteriores, nem as posteriores (Fig. 3), mostram differença alguma nos dous sexos desta especie; as pernas médias do macho, além do femur profundamente modificado pelo desenvolvimento do orgão odorifero, tambem se distinguem das da femea (Fig. 4) pelo maior comprimento do primeiro articulo do tarso. O femur tem 6 millimetros de comprimento na femea, 7 millimetros no macho, a tibia 5 millimetros em ambos os sexos, a primeiro articulo do tarso 3 millimetros na femea, 2 e $\mathrm{I} / 2$ millimetros no macho, os demais articulos do tarso 4 e $\mathrm{I} / 2$ millimetros em ambos os sexos. Achando-se evidentemente muito tolhida a mobilidade do femur pelo orgão odorifero, este excesso de comprimento do primeiro articulo do tarso talvez sirva para compensar aquelle defeito.

O femur dos machos (Fig. 5) tem uma largura de 2 e $\mathrm{I} / 2$ millimetros, a qual excede um pouco á terça parte do comprimento (7 millimetros), e ao mesmo tempo é summamente achatado, de sorte que as paredes dorsal e ventral quasi que chegam a tocar-se (Fig. 9). A superficie ventral é um pouco convexa, a dorsal concava. O orgão odorifero, que occupa esta superficic concava do femur, compõe-se de uma parte interior, especialmente odorifera, e de outra cxterior, protectora. Aquella consiste $\mathrm{em}$ um sem-numero de escamas odoriferas vastissimas (Fig. 9, b; Fig. I 1), que cobrem toda a superficie dorsal do femur; estas escamas têm a fórma de uma fita estreita de cerca de ${ }^{0},{ }^{\mathrm{mm}} \mathrm{O} 3$ de largura e de 2 até 3 millimetros de comprimento, sendo mais compridas pelo lado da margem anterior ou superior do femur; a sua extremidade é um pouco mais ou menos larga e de fórma oval (com o, ${ }^{\mathrm{mm}} \mathrm{o6}$ de largura sobre $\mathrm{o},{ }^{\mathrm{mm}} 25$ de comprimento).

Sento muito unidas as escamas odoriferas, por causa do alargamento terminal, a superficie da massa compacta em que se acham reunidas é necessariamente maior do que a sua base, isto é, do que a superficie do femur, donde nascem (Fig. 9). Extrabidas do femur, as escamas odoriferas têm a apparencia da paina, e, como certas painas separadas das respectivas capsulas, formam uma massa fôfa de dimensões incriveis; parece impossivel que volume tão grande possa caber em espaço tão limitado. As escamas odoriferas são protegidas de todos os lados e cobertas por uma orladura de escamas largas e de pellos, inseridos ao redor e nas margens do femur. As escamas interiores dessa orladura, as que immediatamente se applicam ás ndoriferas (Fig. $12, a$ ) são ovaes, geralmente com $1,{ }^{\mathrm{mm}} 5$ até $2^{\mathrm{mm}}$ de comprimento sobre $0,{ }^{\mathrm{mm}} 6$ até ${ }_{1},{ }^{\mathrm{mm}_{2}}$ de largura; mais para fóra a sua base prolonga-se em uma especic de peciolo (Fig. 12, b) e, ficando este peciolo cada vez mais comprido e dalgado ao passo que a lamina torna-se cada vez mais estreita (Fig. I 2, c), as escamas transformam-se insensivelmente em pellos (Fig. 12, d) que não poucas vezes mostram a sua origem pela fórma da sua extremidade um pouco alargada. Estes pellos, que compôem a camada externa do involucro das escamas odoriferas (Fig. 9, $d$ ), săn mais compridos na margem anterior ou superior do femur, e mórmente na base desta margem, onde o seu comprimento excede ao do proprio femur.

Ha pois na familia das Erebideas, certas especies cujos machos são providos de orgãos odoriferos nas tibias das pernas posteriores; ha outras em que os mesmos orgãos acham-se nas tibias das pernas anteriores, outros que os possuem no 
femur das pernas médias, e outras ainda em cujas pernas nào se vê apparelho algum que sirva de orgão odorifero. Póde-se concluir dahi que os ditos orgàos não foram herdados do progenitor commun da familia, mas sim adquiridos posteriormente pelas varias especies que hoje gozam destes attractivos sexuaes.

\section{Explicação das Figuras da Estampa XLVIII.}

Fig. I. - Perna anterior do macho de uma pequena Erebidea, augmentada 5 vezes - a - pellos louros guarnecendo a margem do femur - b - pincel de pellos pretos implantados na base da tibia, recolhido na gotteira formada pelos pellos do femur.

Fig. 2. - A mesma perna com o pincel odorifero eriçado.

As figuras 3 até I 2 referem-se a outra especie de Erebideas.

Fig. 3. - Perna posterior direita do macho.

Fig. 4. - Perna média esquerda da femea.

Fig. 5. - Perna média equerda do macho, vista do lado ventral.

Fig. 6. - A mesma, vista do lado dorsal.

Fig. 7. - A mesma, pista da margem anterior ou superior do femur - d - lado dorsal - v - lado ventral.

Fig. 8. - Perna média direita do macho, vista do lado dorsal, depois de removidas as escamas odoriferas - a - escamas - b - pellos que guarnecem as margens do femur, protegendo e abrindo as escamas odoriferas. As figuras 3 até 8 são augmentadas 2 vezes.

Fig. 9. - Secçào transversal do orgào odorifero, augmentada 5 vezes. - a - femur - b - escamas odoriferas - c - escamas protectoras - d - pellos.

Fig. I0. - Escamas pillosas do femur das pernas médias da femea.

Fig. I I. - Escamas odoriferas, cobrindo o lado dorsal do femur das pernas médias no sexo masculino.

Fig. I 2. - a - escamas interiores ovaes - b - escamas pecioladas - c escamas pillosas - $\mathrm{d}-$ pellos da orladura que protege as escamas odoriferas. As figuras IO até I 2 são augmentadas I 5 vezes. 


\title{
Tischgenossenschaft zweier Raupen ${ }^{1}$ ).
}

\author{
Aus einem Briefe an Hermann Müller in Lippstadt.
}

Ich habe kürzlich an Raupen einen hübschen Fall von „Commensalismus“ kennen gelernt. Mein Freund Scheidemantel hat versucht, die Thiere in natürlicher Grösse zu photographiren und ich lege Dir einige dieser Bilder bei.

Die grössere Raupe mit rothem Kopf und durch lange, ästige Brennhaare oder sonst gegen Feinde geschützt, lebt auf Maulbeer- und anderen Bäumen. Wie andere, durch Geruch, Brennhaare oder sonst gegen Feinde geschützte Raupen, sitzt sie auf der Oberseite der Blätter und ist hell gefärbt; der Kopf roth, die Haare weiss. Quer über ihrem Rücken zwischen ihren Dornen und jedenfalls durch diese sich schützend, sitzt nun eine kleine schwärzliche Raupe. - Ich nahm dieselbe ab, aber sie suchte sich bald wieder denselben Platz. Um sie photographiren zu können, wurde die grössere Raupe mit Aether betäubt, sie erholte sich wieder etwas, ist aber doch heute (nach zwei Tagen) in Folge davon gestorben. Die kleinere Raupe hat nun ihren Platz verlassen und bei einer zweiten in derselben Schachtel befindlichen Raupe Zuflucht gesucht, wo sie etwas weiter nach vorn, am Anfang des Hinterleibes sitzt. Bei ihrem früheren Wirth sieht die Stelle, wo sie gesessen, blass und wie abgescheuert aus. Die kleine Raupe frisst von oben her kleine Löcher in das Blatt, auf dem die grössere sitzt. - Hoffentlich werden sich beiderlei Raupen zu Schmetterlingen entwickeln. Meines Wissens ist ein ähnlicher Fall bis jetzt noch nicht beobachtet worden.

Blumenau, 22. October 1876 .

I) Zoolog. Garten 1877. 18. Jahrg. S. 67. 


\section{Der Minhocão $\left.{ }^{1}\right)$.}

Auf dem Hochlande der südlichen Provinzen Brasiliens, dem Quellgebiet des Uruguay und Paraná, hört man von einem wunderbaren, unter der Erde lebenden Riesenthiere erzählen, welches dort Minhocão genannt wird.

Minhocão ist das Vergrösserungswort von Minhoca, Regenwurm, lässt sich also mit Riesenregenwurm übersetzen.

Was man von diesem Minhocão erzählt, klingt grossentheils so unglaublich, dass man sich versucht fühlt, es ohne Weiteres als leere Fabelei zu betrachten. Wer sollte nicht ungläubig lächeln, wenn er von einem 30 Klafter langen, 3 Klafter dicken Wurme hört, der von festem Knochenpanzer umgürtet, gewaltige Fichtenstämme (Araucaria brasiliensis) wie Grashalme zur Seite biegt oder umstürzt, der Bäche in neue Bahnen lenkt, hier trockenes Land zu unergründlichem Sumpf zerwühlt, dort, Abzugsgräben bildend, Sümpfe trocken legt, durch die er seinen Weg nimmt?

Und doch wird man bei unbefangener Prüfung der verschiedenen Angaben über den Minhocão kaum der Ueberzeugung sich verschliessen können, dass wirklich in den ausgedehnten Sümpfen, welche den Lauf vieler kleinerer Zuflüsse der genannten Ströme begleiten, ein solches Thier von ungewöhnlicher Grösse hause, mag auch diese Grösse auf ein weit bescheideneres Maass zurückzuführen sein, als zu dem sie der dem Wunderbaren holde Volksmund aufzubauschen liebt.

Vor etwa acht Jahren zeigte sich ein Minhocão in der Nähe der Stadt La ges. Francisco de Amaral Varella, in Baguaes wohnhaft, sah auf einer Reise nach oder von Lages, etwa io Kilometer von dieser Stadt, am Ufer des Rio das Caveiras ein ihm unbekanntes Thier von riesiger Grösse liegen, fast einem Meter dick, doch nicht sehr lang, mit einem Schweinsrüssel; ob es Beine habe, sah er nicht, Er wagte nicht, allein dasselbe anzugreifen; als herbeigerufene Nachbarn zur Stelle kamen, war es bereits verschwunden, doch nicht ohne eine bleibende Spur zu hinterlassen. Unter dem Boden hinwühlend, hatte es die Erde über sich gelockert und diese war hinter ihm eingestürzt und so ein ziemlich tiefer, etwa einen Meter breiter Graben entstanden. Ein ähnlicher Graben, - ob von demselben Thiere herrührend? - zeigte sich einige Wochen später auf der entgegengesetzten Seite der Stadt, etwa 6 Kilometer von ihr entfernt. Der Wreg des

I) Zoolog. Garten 1877. S. 298-302. 
Thieres führte hier unter den Wurzeln einer grossen Fichte hindurch und soll sich in einem Sumpfe verloren haben. - Herr Friedrich Kelling, dem ich diese Mittheilung danke, lebte damals als Kaufmann in Lages und sah selbst den vom Minhocão aufgewühlten Graben.

Auf einer seiner mühevollen Reisen zur Ermittelung einer Wegelinie von Itajahy nach dem Hochlande der Provinz Santa Catharina kam vor mehreren Jahren Herr Emil Odebrecht in eine breite sumpfige Ebene, welche von einem Arme des Marombas durchflossen wird. Sein Vordringen in diesem Sumpflande wurde sehr erschwert durch schlangenartig gewundene Gräben, die sich in der Nähe des Flusses hinzogen und hie und da mit demselben in Verbindung standen; dieselben waren zu breit, um einfach überschritten, doch schmal genug, um übersprungen zu werden, also etwa von gleicher Breite, wie der Graben, den Herr Kelling bei Lages sah. Herr Odebrecht wußte sich damals die Entstehung dieser Gräben in keiner Weise zu erklären, ist aber jetzt geneigt, dieselben von einem den Sumpf durchwühlenden Minhoção herzuleiten.

Vor etwa I4 Jahren, im Monat Januar, war Antonio José Branco mit seiner ganzen Familie acht Tage von seiner Wohnung abwesend, dic etwa ro Kilometer von Curitibanos in der Nähe eines dem Rio dos Cachorros zufliessenden Baches liegt. Bei der Heimkehr fanden sie ihren Weg unterwühlt, Erdschollen seitwärts aufgeworfen, das unterwühlte Erdreich eingestürzt. Der so gebildete Graben begann an der Quelle eines Baches, dem er bald folgte, bald ihn verliess, Biegungen desselben abschneidend, und endete nach 700 bis 1000 Meter in einem Sumpfe. Die Breite des Grabens soll etwa 3 Meter betragen. Der Bach folgt seit jener Zeit dem vom Minhocão gebahnten Wege. Der Weg des Thieres ist meist unter der Erde und unter dem Bette des Baches hingegangen; verschiedene Fichten wurden umgestürzt und brachen beim Niederfallen auf den unebenen Boden. Eine dicke Fichte, an welcher der Minhocão im Vorbeigleiten die Rinde bis aufs Holz durchgescheuert, soll noch im vorigen Jahre gestanden haben und noch jetzt, umgestürzt, zu sehen sein. - Zahlreich sind damals die Nachbarn, besonders die Bewohner von Curitibanos herbeigeeilt, um sich die durch den Minhocão angerichteten Verwüstungen anzusehen. Man vermuthet, derselbe lebe noch jetzt in dem Sumpfe, dessen Wasser sich zu Zeiten ohne erkennbare Ursache plötzlich trüben soll; ja, man will in stillen Nächten bisweilen im Sumpfe ein dumpfes Grollen, wie von fernem Donner, hören und ein leichtes Erzittern des Bodens in dem nahen Hause spüren!? - Ich hörte über diesen Fall zivei Augenzeugen, einen Sohn, José, des alten Branco, der noch jetzt bei seinem Vater wohnt, und einen Schwiegersohn, Crescentio Fernando da Maia, der vor 14 Jahren ebenfalls in dessen Hause lebte. - Bemerken will ich noch, dass dem Erscheinen des Minhocão längeres Regenwetter vorausging.

In der Nähe des Rio dos Papagaios, eines Zuflusses des Iguassú in der Provinz Paraná hörte man eines Abends (ums Jahr i 849), nach längerem Regenwetter im Hause eines gewissen Joào de Deos cin Geräusch, wie wenn es im nahen Walde wieder regnete, sah aber beim Hinausblicken sternenhellen Himmel. Am folgenden Morgen fand man jenseits eines kleinen Hügels rin grosses Stück Landes völlig durchwühlt und von einigen tiefen Gräben durchzogen; die Gräben führten zu einer von grossen flachen, nackten Steinplatten be- 
deckten Stelle, einem sogenannten Lageado, auf welchem grosse Schollen des weisslichrothen Thones, aus dem das zuvor durchwühlte Erdreich bestand, den weiteren Weg bezeichneten. Derselbe ging von dem Lageado in das durch Felswände eingeengte Bett eines Baches, rechts und links an diesen Wänden Thonspuren zurücklassend und endete an einer steilen Felswand, über die der Bach in einen weiten tiefen Kessel hinabstürzt, um sich bald mit dem Papagaios zu vereinigen, welcher I 4 Tage lang bis zu seiner nahen Mündung in den Iguassú sich trübe zeigte.

Drei Jahre später besuchte Herr Lebino José dos Santos, jetzt als wohlhabender Gutsbesitzer in Guarda-mór bei Curitibanos lebend, diese Gegend. Er sah noch das durchwühlte Feld, die Erdschollen auf den Felsplatten und die Thonspuren in dem felsigen Bette des Baches sehr deutlich; er glaubte aus diesen verschiedenen Spuren schliessen zu müssen, dass dieselben von zwei Thieren herrührten, deren Dicke er auf 2 bis 3 Meter schätzte.

In derselben Gegend war übrigens, wie mir Senhor Lebin o erzählt, schon früher wiederholt der Minhocão gesehen worden. In der Nähe eines Hauses befand sich ein Tümpel, aus dem man den Wasserbedarf fürs Haus holte. Man hatte bemerkt, dass das Wasser durch vom Grunde aufgewühlten Sand bisweilen getrübt und unbrauchbar gemacht wurde. Eines Morgens nun wollte eine Schwarze Wasser holen, fand aber den ganzen Tümpel zerstört und sah in einiger Entfernung ein Thier "so gross wie ein Haus" sich am Boden fortbewegen. Sie lief mit der wunderbaren Kunde heim; die herbeieilenden Bewohner fanden aber nur noch den durchwühlten Boden als Spur des Thieres, das sich bereits über eine nahe Felswand in ein tiefes Wasser hinabgestürzt hatte. Ein junger Mann sah in derselben Gegend plötzlich auf dem Felde eine grosse Fichte umstürzen. Es war windstill, auch hatte er Niemand hacken hören; er lief also hin, die Ursache des Sturzes zu erkunden. Da sah er die ganze Erde in Bewegung und aus ihr hervorbrechend ein riesiges, wurmähnliches schwarzes Thier, „dicker als die dickste Fichte, nicht länger als ein Lasso“ (etwa 25 Meter), mit zwei beweglichen, dem Leibe sich anschmiegenden Hörnern am Kopfe.

In der Provinz São Paulo, - auch hierfür ist Senhor Lebino mein Gewährsmann, - ist nicht weit von Ypanema auf den Campo do Tinga ein Ort, der noch heute Charquinho, d. h. kleiner Sumpf, heisst, weil ein solcher früher da bestanden. Aber vor Jahren wühlte bei nassem Wetter ein Minhocão einen Graben durch den Sumpf nach dem nahen Flusse und verwandelte ihn so in einen dem Y Y anema zufliessenden Bach.

Im Jahre 1849 kam Senhor Lebino auf einer Reise in die Nähe des Arapehy im Staate Uruguay. Dort erzählte man ihm, dass wenige Meilen von seinem Lagerplatze ein todter Minhocão zu sehen sei. Derselbe sei in eine sich allmählich verengende Felsenschlucht gerathen, habe sich da festgeklemmt und so seinen Tod gefunden. Seine Haut sei so dick wie die Rinde einer Fichte und aus harten Schildern gebildet wie die eines Gürtelthieres.

Als ziemlich sichere Thatsache lässt sich aus den vorstehend mitgetheilten und ähnlichen Berichten wohl nur das entnehmen, dass bisweilen im Quellgebiet des Urugua y und des Pa ra ná weithin sich erstreckende Gräben aufgeworfen werden, die kaum einer anderen Ursache als dem Wühlen eines grossen Thieres sich zu- 
schreiben lassen. Dies scheint besonders, wenn nicht immer, nach längerem Regen zu geschehen. Die Gräben scheinen stets von Sümpfen oder Flüssen auszugehen und wieder in solche auszulaufen. Die ebenso dürftigen als unzurerlässigen Angaben über das Thier lassen vollständig über seine Gestalt und selbst über seine Grösse im Unklaren. Doch wird man wohl in ihm einen riesigem Lurchfisch, einen Vetter von Lepidosiren und Ceratodus vermuthen dürfen. Der „Schweinsrüssel“ dürfte auf eine dem Ceratodus ähnliche Kopfbildung, die dem Leibe sich anlegenden „Hörner“ auf ähnliche Vordergliedmaassen, wie sie Lepidosiren besitzt, hindeuten, wenn nur eben diese Angaben selbst auf irgend welches Vertrauen Anspruch machen könnten.

Jedenfalls wird es der Mühe werth sein, dem Minhocão weiter nachzuspüren und ihn wo möglich für einen zoologischen Garten einzufangen. 


\title{
Nectar absondernde Drüsen ${ }^{1}$ ).
}

\author{
(Brief an Fr. Darwin und Erwiderung.)
}

I have briefly described in vol. XV. of the Linnæan Society's Journal, the nectar-glands found at the base of the fronds of the brake fern (Pteris aquilina) which are visited by ants for the sake of their sweet secretion. This case seemed to me to show in a striking manner that extra-floral nectar-glands are not necessarily protective in function, because the fern has, in England at least, extremely few enemies. The following extract of a letter lately received from Fritz Müller (of St. Catharina, Brazil) is of considerable interest in relation to this subject. He states that

"the honey-glands on our Pteris aquilina serve, without doubt, to protect the ferns from the depredations of the leaf-cutting ants (Ecodoma), as is the case with Passiflora, Luffa, and many other plants. The glands of the Pteris are eagerly visited by a small black ant, Crematogaster, of which the Ecodoma seems to stand in great dread. On the other hand, when no protecting ants are present, I have seen (Ecodoma gnawing the young fronds; here, as in other cases, it is only the young leaves that stand in need of protection, the older ones not being attacked by the leaf-cutting ants."

This fact might, no doubt, be used as an argument by those who believe that all nectar-glands were originally developed as protective organs, and this argument would have great force if it could be shown that Pteris aquilina is a form which has arisen in countries where protection is needed; but even in that case there would remain the difficulty of accounting for the continued functional activity of the glands in districts where no such protection is required. Or it may $b_{e}$ said that in past ages the glands on our European Pteris served as a protection against enemies which have now become extinct. But here we are again met by the difficulty of accounting for the continued activity of the glands. It is characteristic of evolution that great changes occur in the functions of organs, and I think that it will generally be allowed that even the the most beautifully adapted apparatus must have originated in an organ

1) Nature 1877 . Bd. XVI. p. 100 u. 122. 
performing some comparatively simple function. The question at issue may perhaps be stated as follows: - In the cases where the nectar-glands are now well developed has there been a special course of structural development in close relation with the need of the plant for protection? Has there been a course of evolution such as we may believe has taken place in the formation of the food-bodies in Acacia spharocephala and Cecropia peltata, or should we not rather believe that the sweet secretion has been developed in connection with some unknown process of nutrition; according to this view, a well developed system of glands may continue merely performing some obscure excretory function, and consequently, although the presence of nectar-glands has undoubtedly been of the utmost importance in determining the survival of certain species, yet it is hardly fair to assume that all nectar glands were originally protective in function. For many plants secrete large quantities of sweet fluid, which serves no such purpose. This argument is given by my father in his "Effects of Cross and SelfFertilisation" (p. 402). In addition to the facts there given in support of this view a curious case described by Prof. H. Hoffmann may be mentioned ("Ueber Honigthau," 1876). He states that numerous large drops of sweetish fluid appeared on the under-surface of the young leaves of a camcllia. He also alludes to a similar abnormal production of honey-dew on an ivy plant.

In the case of introduced plants, we see how an already existing quality may, without any special course of development, become of vital importance to its possessor. Thus, Mr. Belt shows ("Naturalist in Nicaragua," p. 74) that the lime, Citrus limonum, is able to exist in a wild state, because its leaves are, from some unknown reason, distasteful to the leaf-cutting ants; whereas the orange, C. aurantium, and the citron, C. medica, can only survive with the help of man.

Fritz Müller concludes his letter with some curious facts on kindred subjects:-

"The extreme variability of the nectar-glands on the leaves of many plants. is a somewhat remarkable fact. Thus our Citharexylon has normally two large glands at the base of the leaves, but sometimes there is only one, and sometimes none at all; besides these there are small glands scattered over the surface of the leaf, the number of which varies from twenty to none. Similar variations occur in the nectar-glands of Alchornea erythrospermum, and of a Xanthoxylon. It seems to me probable that in all the cases at present known, these glands serve to attract protecting ants; and I here agree with Delpino, although 1 do not hold with him that caterpillars are the chief enemies which are guarded against by Pheidole and Crematogaster; but I think with Belt that these latter ants protect the plant against the leaf-cutting species. Indeed it is precisely those plants which are free from the attacks of ants that seem to be especially well fitted for caterpillars. Thus the larvæ of Gynaeria live on Cecropia peltata, those of Epicalia numilia on Alchornea erythrospermum. On the Cayien (?) whose leaves are furnished with nectar-glands, and are visited by protecting ants, the caterpillars of many species of Callidryas are found. Finally, as far as I know, all the larvæ of the genus Heliconius feed on Passiflora. Moreover, the same relation holds in the case of plants protected in other ways, for instance, by stinging hairs or by poisonous sap. How numerous are the larve found on the European stinging-nettle. In this country we find the caterpillars of 'Ageronien' on the 
stinging Dalechampia; and again those of some species of Danais on Asclepias, which is protected by its milky juice."

Down, Beckenham, May 2 I i 877 .

Francis Darwin.

Mr. Francis Darwin has made an interesting addition to his important discovery of nectar-bearing glands on the young fronds of Pteris aquilina, supplicd from the ever-welcome experience of Mr. Fritz Müller. The latter gentleman finds that in Brazil the Pteris aquilina is protected from the leaf-cutting ants by those attracted to the nectar, and Mr. Darivin adds some speculations on the origin of the glands and their continued functional activity in Europe where they now appear to be useless. On this part of the question I should like to make the following remarks: -

Prof. Heer has shown that in the Miocene plant-beds at Eningen and Radoboj, ants are the most numerous amongst the fossil insects, and in 1849 as many as sixty-six species had been described from these two localities. In I 865 the number found at Eningen alone is recorded as forty-four. I do not know what the total number of species is that have been recorded from the two places up to the present time, but it probably does not fall short of eighty. Amongst the fossil ants from Radoboj there are spezies of the Tropical American genera Atta and Ponera. One of the fossil species of Atta resembles in general form and in the venation of the wings the curious Atta cephalotes of Tropical America.

As there are only about forty species of ants existing now in the whole of Europe it is evident that in the Miocene epoch they must have played a much more important part in Europe than they do now. Plants may then have been exposed to the attacks of ennemies that have become extinct along with the general impoverishment of the fauna and flora of Europe that took place in Post-pliocene times; and the protection afforded by ants attracted to the nectar-bearing glands at the critical stage of the unfolding of the young and tender leaves may have been as important to some plants in Europe, then, as it is to many in Tropical America now.

With regard to the persistency of the nectar-producing glands up to the present time in Europe, it is to be remarked that many plants are identical with those living in the Miocene period and the world-wide distribution of Pteris aquilina seems to indicate that it is of very ancient origin. If a plant has not otherwise varied there is no reason apparent why it should do so in this respect so long as the secretion of nectar is not positively injurious to it. I have recently noticed in my garden that the ants that attend the glands at the bases of the leaves of the cherry, the plum, the peach, and the apricot, stroke with their antennæ some of the glands that are not excreting when they arrive at them, just as they do the bodies of the aphides. I have not actually noticed that this promotes a flow of nectar, but ever since I became a disciple of Darwin I have been convinced that the most trivial circumstance is worthy of notice; and it may be that the slight irritation of the glands kept up by the ants is sufficient to cnsure the perpetuation of a function of the plant now useless to itself. It is, however, perhaps too son to assume that the glands are entirely useless to the 
plants in Europe. Darwin states that there is gond evidence that the absence of glands in the leaves of peaches, nectarines, and apricots leads to mildew ("Animals and Plants under Domestication," vol. II. p. 231).

Darwin refers at the same place to the variations of the glands of the leaves in the above-mentioned fruit trees and I may add that they are extremely variable on the cherry, being sometimes absent, sometimes on the stalk and sometimes on the blade of the leaf. The young leaf in its earliest stage, before it expands, has a complete fringe of them, thus bearing nut Mr. Francis Darwin's theory that the are homologous with the serration-glands of Reinke.

May I suggest to some of your corespondents that information as to how far north in Great Britain or in Europe the glands on the above fruit trees are attended by ants and especially if the wild cherry (which I have not liad an opportunity of observing) is so attended, would be of great interest.

Cornwall House, Ealing, June 81877.

Thomas Belt. 


\section{Ueber Blumen und Insecten ${ }^{1}$ ).}

Brief F. Müllers an Ch. Darwin mit einleitender Bemerkung des letzteren.

The enclosed letter from that excellent observer, Fritz Müller, contains some miscellaneous observations on certain plants and insects of South Brazil, which are so new and curious that they will probably interest your naturalist readers. With respect to his case of bees getting their abdomens dusted with pollen while gnawing the glands on the calyx of one of the Malpighiaceæ, and thus effecting the cross-fertilisation of the flowers, I will remark that this case is closely analogous to that of Coronilla recorded by Mr. Farrer in your journal some years ago, in which parts of the flowers have been greatly modified, so that bees may act as fertilisers while sucking the secretion on the outside of the calyx. The case is interesting in another way. My son Francis has shown that the food-bodies of the Bull's-horn Acacia, which are consumed by the ants that protect the tree from its enemies (as described by Mr. Belt), consist of modified glands; and he suggests that aboriginally the ants licked a secretion from the glands, but that at a subsequent period the glands were rendered more nutritious and attractive by the retention of the secretion and other changes, and that they were then devoured by the ants. But my son could advance no case of glands being thus gnawed or devoured by insects, and here we have an example.

With respect to Solanum palinacanthum, which bears two kinds of flowers on the same plant, one whith a long style and large stigma, the other with a short style and small stigma, I think more evidence is requisite before this species can be considered as truly heterostyled, for I find that the pollen-grains from the two forms do not differ in diameter. Theoretically it would be a great anomaly if flowers on the same plant were functionally heterostyled, for this structure is evidently adapted to insure the cross-fertilisation of distinct plants. Is it not more probable that the case is merely one of the same plant bearing male flowers through partial abortion, together with the original hermaphrodite flowers? Fritz Müller justly expresses surprise at Mr. Leggett's suspicion that the difference in length of the pistil in the flowers of Pontederia cordata of the United States is due to difference of age; but since the publication of my book Mr. Leggett has

1) Nature $1877 . \mathrm{Bd}$. XVII. S. $; 8,79$. 
fully admitted, in the Bulletin of the Torrey Botanical Club, that this species is truly heterostyled and trimorphic. The last point on which I wish to remark is the difference between the males and females of certain butterflies in the neuration of the wings, and in the presence of tufts of peculiarly-formed scales. An American naturalist has recently advanced this case as one that cannot possibly be accounted for by sexual selection. Consequently, Fritz Müller's observations which have been published in full in a recent number of Kosmos, are to me highly interesting, and in themselves highly remarkable.

Down, Beckenham, Kent, November 21 .

Ch. Darwin.

You mention ("Different Forms of Flowers," page 331), the deficiency of glands on the calyx of the cleistogamic flowers of several Malpighiacex, suggesting, in accordance with Kerner's views, that this deficiency may be accounted for by the cleistogamic flowers not requiring any protection from crawling insects. Now I have some doubt whether the glands of the calyx of the Malpighiacere serve at all as a protection. At least, in the one species, the fertilisation of which I have very often witnessed, they do not. This species, Bunchosia Gaudichaudiana, is regularly visited by several bees belonging to the genera Tetrapedia and Epicharis. These bees sit down on the flowers gnawing the glands on the outside of the calyx, and in doing so the under side of their body is dusted with pollen, by which, afterwards, others flowers are fertilised.

There are here some species of Solanum (for instance S. palinacanthum) bearing on the same plant long-styled and short styled flowers. The short-styled have papillæ on the stigma and apparently normal ovules in the ovary, but notwithstanding they are male in function, for they are exclusively visited by pollengathering bees (Melipona, Euglossa, Augochlora, Megacilissa, Eophila, n. g., and others), and these would probably never insert their proboscis between the stamens.

In a few months I hope to be able to send you seeds of our white-flowered violet with subterranean cleistogamic flowers. I was surprised at finding that on the Serra (about I Ioo metres above the sea) this violet produced abundant normal fruits as well as subterranean ones, while at the foot of de Serra, though it had flowered profusely, I could not find a singe normal fruit, and subterranean ones were extremely scarce.

According to Delpino the changing colours of certain flowers would serve to show to the visiting insects the proper moment for effecting the fertilisation of these flowers. We have here a Lantana the flowers of which last three days, being yellow on the first, orange on the second, purple on the third day. This plant is visited by various butterflies. As far as I have sean the purple flowers are never touched. Some species inserted their proposcis both into yellow and into orange flowers (Danais evippus, Pieris aripa), others, as far as I have hitherto observed, exclusively into the yellow flowers of the first day (Heliconius apseudes, Colcenis julia, Eurema leuce). This is, I think, a rather interesting case. If the flowers fell off at the end of the first day the inflorescence would be much les conspicuous; if they did not change their colour much time would be lost by the butterflies inserting their proboscis in already fertilised flowers. 
In another Lantana the flowers have the colour of lilac, the entrance of the tube is yellow surrounded by a white circle; these yellow and white markings disappear on the second day.

Mr. Leggett's statements about Pontederia cordata appear to me rather strange, and I fear that there is some mistake. In all the five species of the family which I know the flowers are so shortlived, lasting only one day, that a change in the length of the style is not very probable. In the long-styled form of our highland Pontederia the style has its full length long before the flowers open. In my garden this Pontederia is visited by some species of Augochlora collecting the pollen of the longest and mid-length stamens; they are too large to enter the tube of the corolla, and have too short a proboscis to reach the honey; they can only fertilise the long-styled and mid-styled forms, but not the shortstyled.

Among the secondary sexual characters of insects the meaning of which is not understood, you mention ("Descent of Man," vol. i., p. 345) the different neuration in the wings of the two sexes of some butterflies. In all the cases which I know this difference in neuration is connected with, and probably caused by, the development in the males of spots of peculiarly-formed scales, pencils, or other contrivances which exhale odours, agreeable no doupt to their females. This is the case in the genera Mechanitis, Dircenna, in some species of Thecla, \&c.

Blumenau, St. Catharina, Brazil, October i 9 1876. (?) 


\section{Maracujáfalter $\left.{ }^{1}\right)$.}

Die Gattungen Heliconius, Eueides, Colaen is und Dione (=Agraulis) werden bis jetzt allgemein in die beiden Familien der Heliconinen und der Nymphalinen vertheilt. Zu letzteren zählt man Colaenis und Dione; Eueides stellt man bald neben Colaenis zu den Nymphalinen (so Doubleday und Felder), bald neben Heliconius zu den Heliconinen (so HerrichSchäffer und Kirby). - Keine dieser Anordnungen ist naturgemäss. Colae$n$ is und Dione müssen von den Nymphalinen getrennt und mit Heliconius und Eueides zu einer eigenen Familie verbunden werden.

Hier in möglichster Kürze der Beweis für diese Behauptung. Die vier genannten Gattungen stimmen überein in folgenden Stücken:

I) Alle ihre Arten leben im wärmeren America und alle, soweit bekannt, legen ihre Eier an Arten von Maracujá (Passiflora). So Heliconius Eucrate, Eueides Isabella und Aliphera, Colaenis Dido und Julia, Dione Vanillae und Juno. - Keine Nymphalinenraupe lebt, soviel bekannt, an Maracujá.

2) Die Eier sind gelb, haben die Gestalt eines Fingerhutes und eine durch Längs- und Querriefen gefelderte Oberfläche. - Aehnliche Eier kommen auch sonst bei Tagfaltern vor; ob bei Nymphalinen, weiss ich nicht. Dagegen finden sich in letzterer Familie ganz abweichende Formen, wie bei Siderone die eines weiten umgedrehten glatten Fingerhutes mit ebener Endfläche.

3) Die Raupen sind Dornraupen. Der Kopf trägt zwei Dornen (die bei Dione Juno nur als zwei kurze Spitzen erscheinen). Die Vorderbrust ist meist unbedornt; nur bei Dione Juno trägt sie ein kleines Dornenpaar. Mittelbrust und Hinterbrust tragen je zwei Dornenpaare, die nicht in einer Querreihe stehen, ein oberes etwa in der Mitte zwischen Vorder- und Hinterrand, und ein unteres dicht am Vorderrand des Ringes. Die Hinterleibsringe, mit Ausnahme des letzten, haben je drei Dornenpaare in einer Querreihe, in der auch die Luftlöcher liegen. Der letzte Ring endlich hat zwei Dornenpaare, von denen das untere weiter nach hinten steht.

Auch unter den Nymphalinen giebt es viele Dornenraupen; aber ich kenne keine mit genau derselben Anordnung der Dornen, die sich auch bei den Raupen von A c raea findet. Allerdings ist die Zahl der N y m phal in e n raupen,

1) Entomologische Zeitung des entomolog. Vereins zu Stettin 1877. 38. Jahrg. S. 492-496. 
die ich selbst untersuchen oder über die ich (durch meinen Bruder Hermann Müller) befriedigende Auskunft erhalten konnte, keine sehr grosse. Neben den Dornraupen aber finden sich unter den Nymphalinen viele andere dornlose, mit hörnertragendem Kopfe, wie Siderone und Protogonius.

4) Alle Maracujáfalter saugen ausschliesslich Blumenhonig, keine Art den ausfliessenden Saft der Bäume, wie unter den Nymphalinen z. B. Epicalia, Temenis, Callicore, Gynaecia, Ectima, Ageronia, Biblis, Aganisthos, Prepona, Agrias, Smyrna, Paphia und Siderone; keine Art setzt sich Feuchtigkeit suchend an den Boden, wie unter den Nymphalinen z. B. Hypanartia, Eunica, Haematera, Apatura u. s. w., oder gar an Pferdedung, wie Pyrameis. - Alle Maracujáfalter scheinen mit Vorliebe die gleichen Blumen zu besuchen; fleissig und andauernd besuchten z. B. alle hiesigen Arten (Heliconius Besckei, Apseudes und Eucrate Eueides, Isabella und Aliphera, Colaenis Julia und Dido, Dione Vanillae und Juno), mit Ausnahme der überaus seltenen Eueides Pavana und Dione Moneta. eine Poinsettia in meinem Garten, an welcher von Nymphalinen nur gelegentlich Anartia Amalthea sich einfand, ohne sich bei dem blüthenreichen Busche zu verweilen.

5) Die Männchen aller Maracujáfalter spreizen, wenn man sie ergreift, die Afterklappen auseinander, an deren Innenseite dann zwei stark und widrig riechende Wülste hervortreten; die Weibchen dagegen verbreiten den gleichen Geruch, indem sie auf der Rückenseite zwischen letztem und vorletzem Hinterleibsringe eine gelbe Wulst hervortreiben. - Unter den Nymphalinen kenne ich nichts Aehnliches.

6) Fühler und Mundtheile stimmen im Wesentlichen bei allen Arten überein, ohne freilich etwas besonders Auszeichnendes $\mathrm{zu}$ bieten. Dies gilt namentlich auch von den längs der Kiefer stehenden Anhängen in Gestalt einer flachgedrückten Keule, die am Ende einen schiefstehenden Stift tragen. Es ist das die gewöhnlichste Gestalt dieser wohl als Schmeckstifte zu deutenden Gebilde, die in einigen anderen Faltergruppen abweichende, bezeichnende Formen annehmen.

7) Die Hinterflügel der Männchen haben auf der Oberseite, nahe dem Vorderrande, soweit dieselben von den Vorderflügeln bedeckt werden, eigenthümlich gestaltete, am Rande gefranste Schuppen, „Duftschuppen“, wie solche von zicmlich ähnlicher Bildung auf der Oberseite der Flügel bei den Männchen des deutschen Baumweisslings (Pieris $\mathrm{Cr}$ ataegi) vorkommen. -- Weder bei den Nymphalinen noch bei Acraea kenne ich solche Duftschuppen. -

8) Dic Längsadern der Flügel tragen auf der Unterscite in eine oder zwei Reihen gestellte schwarze Haare; ähnliche Haare trägt auch der Saum der Flügel. Bei Acraea findet man dieselben Haare und zwar nicht nur auf den ausgebildeten Adern, sondern auch im Verlauf der geschwundenen dritten Innenrandsader der Hinterflügel. Bei den darauf untersuchten Nymphalinen vermisse ich sie. -

9) Das Adergerüst der Flügel ist bei allen Maracujáfaltern ungemein ähnlich. Es fällt diese Uebereinstimmung sofort in die Augen, wenn man, am besten in etwas vergrößerter Zeichnung, das Adergerüst der verschiedenen Arten neben- 
einander vor sich hat. Den Unterschied, der zwischen Heliconius und Eueides einerseits, Colaen is und Dione andrerseits darin besteht, dass jene eine geschlossene, diese eine offene Mittelzelle der Hinterflügel haben, bemerkt man dabei kaum, so sehr verschwindet er unter dem überwiegenden Eindruck des Gemeinsamen. Dieses in Worte zu fassen, würde seitenlange Auseinandersetzungen erfordern. Ich beschränke mich darauf, einige leichter zu übersehende, gerade wegen ihrer anscheinenden Unbedeutendheit als Beweis für die nahe Blutsverwandtschaft sämmtlicher Maracujáfalter besonders schwerwiegende Eigenthümlichkeiten hervorzuheben.

a) Die Mediana der Vorderflügel hat nahe der Wurzel einen nach der Innenrandsader zu vorspringenden kurzen, seine Spitze saumwärts wendenden Sporn; bei den meisten Arten, so auch bei Colaenis Dido und Dione Vanillae sehr cleutlich, ist er nur schwach entwickelt bei Colaen is Julia und Dione Juno. Ein ähnlicher Sporn findet sich auch bei einigen anderen Faltern verschiedener Familien; so bei Morpho und unter den Nymphalinen bei Adelpha (= Heterochroa). Er fehlt, soweit ich sie kenne, bei allen Nymphalinen-Gattungen, die irgenclwie Anspruch auf nähere Verwandtschaft mit den Maracujáfaltern erheben könnten, auch bei Acraea.

b) In die Mittelzelle der Vorderflügel springt aus dem Winkel zwischen Mediana und Subcostalis, mehr oder weniger weit und deutlich, der Stamm der weiterhin geschwundenen Discoidalis vor. Besonders weit vorspringend sieht man dieses Wurzelstück der Discoidalis bei Eueides Aliphera, besonders dick bei Colaenis Dido, am wenigsten deutlich bei Colaenis Julia. Ich habe bei Acraea und vielen Nymphalinen vergeblich nach diesem Ueberbleibsel der Discoidalader gesucht.

c) Nicht weit von der Flügelwurzel wird die Subcostalis plötzlich dünner, indem ihr vorderer Rand gerade fortgeht, der hintere aber dem vorderen sich plötzlich nähert. Es ist die Stelle, wo früher die Subcostalis in ihre beiden Hauptäste sich spaltete, von denen später der hintere bis zu seiner Wiedervereinigung mit dem vorderen geschwunden ist. Man kann bisweilen, z. B. bei Colaenis Dido, Heliconius Eucrate, den Verlauf dieses eingegangenen Astes der Subcostalis noch ziemlich deutlich durch die ganze Mittelzelle hindurch verfolgen. Selbst bei Thieren derselben Art ist diese einstige Theilungsstelle der Subcostalis nicht immer gleich deutlich zu erkennen; besonders deutlich pflegt sie zu sein bei Heliconius Eucrate, Eueides Aliphera, Dione Vanillae und Dione Juno. Ich konnte nichts davon sehen bei Acraea und bei Nymphalinen.

d) Für die Hinterflügel will ich nur an die wurzelwärts gebogene Praecostalis erinnern, welche die Maracujáfalter von Acraea und auch wohl von allen etwa in ihre Nähe zu stellenden Nymphalinen unterscheidet.

Es scheint nicht geboten, die Tragweite der einzelnen hier angeführten Merkmale zu erörtern; für Systematiker der alten Schule schreibe ich nicht; für jeden Anderen liegt, wie mir scheint, deren Bedeutung auf der Hand.

Man möchte fragen, wie es möglich war, class die Meister der Schmetterlingskunde eine Verwandtschaft verkennen konnten, die doch jedem Kinde, wie ich wnn meinen eigenen weiss, beim ersten Anblick der fliegenden Falter sofort ins 
Auge springt und die immer neue Bestätigung erhält, je mehr man die Entwicklung, die Lebensweise, den Bau dieser Thiere kennen lernt.

Dass man Eueides zwischen Heliconius und Colaenis hin und her warf, so lange man diese beiden Gattungen in verschiedene Familien stellte, ist begreiflich. Ist doch Eueides von Heliconius kaum durch kürzere Fühler, von Colaenis kaum durch die geschlossene Mittelzelle der Hinterflügel verschieden (wenigstens als Falter, und die sehr abweichende Puppe kannte man nicht), - ist doch einerseits Eueides Isabella dem Heliconius Eucrate, andrerseits Eueides Aliphera der Colaenis Julia in Schnitt, Zeichnung und Färbung der Flügel so täuschend ähnlich, dass man sie leicht für kleine Stücke dieser Arten halten könnte. Wie man aber Colaenis von Heliconius losreissen konnte, verstehe wer kann. In der ausführlichen Darlegung der Gattungsmerkmale, die Doubleday giebt, findet man als allereinziges erhebliches Merkmal, welches Cola en is von Heliconius unterscheidet, die bei Colaen is offene Mittelzelle der Hinterflügel; aber dieses selbe Merkmal scheidet Colaen is ganz ebenso von etwa 50 der iा 3 von Herrich-Schäffer angenommenen Nymphalinen-Gattungen. Zudem sagt Herrich-Schäffer selbst, dass dieses Merkmal nicht einmal zur Trennung sonst übereinstimmender Arten in verschiedene Gattungen genüge, und vereinigt demgemäss unter Adolias Arten mit offener und solche mit geschlossener Mittelzelle. Und dabei stellt er Heliconius in die erste, Colaenis in die zehnte seiner Tagfalter-Familien!

Häckel's Mahnung an die Naturforscher, sich gründlicher mit Philosophie und namentlich mit Logik zu befassen, scheint in der That nicht überflüssig zu sein.

Itajahy, Sa. Catharina, Brazil, April 1877. 


\section{Die Grannen von Aristida ${ }^{1}$ ).}

Das Hochland der Provinz Santa Catharina ist reich an Gräsern mit drehbaren Grannen. Auf zwei Ausflügen dahin im Vorsommer (November, December) des vorigen und im Nachsommer (Februar, März) dieses Jahres habe ich gegen zwanzig Arten solcher Gräser gesehen. Indem die Grannen je nach der wachsenden oder abnehmenden Feuchtigkeit der Luft sich rechts oder links drehen, bohren sich die unten mit harter, scharfer Spitze und einem schief aufwärts gerichteten Barte steifer Haare versehenen Achrchen in den Boden ein, wie es Francis Darwin vor kurzem bei Stipa ausführlich beschrieben hat (Trans. Linn. soc. vol, I. part. 3. p. 149. 1876). - Unter diesen Gräsern unseres Hochlandes finden sich auch mehrere Arten der Gattung Aristida, bei welchen die das Einbohren in die Erde vermittelnden Einrichtungen den höchsten Grad der Vollkommenheit erreichen. Es ist nämlich bei ihnen die Granne mehr oder weniger tief, bisweilen fast in ganzer Länge, in drei Aeste gespalten, die sich beim Trocknen ziemlich wagerecht ausbreiten (den Samen senkrecht stehend gedacht). So kann das trocken zu Boden fallende Aehrchen niemals flach auf denselben zu liegen kommen, was natürlich das Einbohren erleichtert. Je länger in Verhältniss zur Frucht und zum ungespaltenen Theile der Granne deren Aeste sind, um so steiler wird sich dasselbe stellen müssen; fast senkrecht steht es bei einer Art, deren Grannenäste etwa Spannenlänge $(0,2 \mathrm{~m})$ erreichen. Man hat oft Gelegenheit, die in den Boden eingebohrten Früchte dieser Art zu sehen. Am 7. März kam ich auf der nordwärts nach der Provinz Paraná führenden Strasse in der Nähe des Rio das Pedras an einen kahlen, dürren Abhang, der fast auschließlich mit clieser Aristida bewachsen war. In Folge anhaltender Dürre war der Boden ungewöhnlich hart und seit Monaten nicht von Regen benetzt worden, und doch war - ein ganz eigenthümlicher Anblick - die Erde zwischen den Grasbüschen wie besät mit eingebohrten Früchten, die allesammt senkrecht standen und die langen Grannenäste wagerecht ausbreiteten. Hier und da sprossten schon die jungen, grünen Grasblättchen an der Seite der Grannen hervor. Auf der Erde liegend würden an ähnlichen Stellen bei "trockenem Wetter die Samen nie keimen können, während der Thau der Nacht genügt, sie in die zum Keimen hinreichende Feuchtigkeit bietende Erde einzusenken. Unserem feuchten Küstengebiete

i) Kosmos (Leipzig, Günthers Verlag) 1877 I. p. 353-354. 
scheinen Samen mit Drehgrannen ganz zu fehlen. Dagegen ist wohl die ganze Gattung Stipa vorzugsweise in übertrockenen Gegenden und an übertrockenen Standorten heimisch.

Merkwürdig ist es, dass eine der Aristida-Arten die hoch entwickelten Formen zum Einbohren der Früchte wieder verloren und sich in ganz eigenartiger Weise der Verbreitung durch den Wind angepasst hat. Der dünne Halm dieses Grases wird etwa spannenhoch und trägt vom ersten Drittel seiner Höhe ab paarweise gestellte, in verschiedenen Richtungen sich ausspreizende, gegen o, I m lange, haardünne Aeste, welche ihrerseits in gewöhnlich zwei bis drei Zweige sich theilen. Jeder Zweig trägt ein dünnes Aehrchen, das Aehrchen gegen I $2 \mathrm{~mm}$ lang, eine ungefähr gleich lange, ungedrehte, gerade Granne mit seitlichen, nur etwa ein Viertel dieser Länge erreichenden Aesten, die mit dem mittleren Aste einen ganz spitzen Winkel von nur wenigen Graden bilden. Im Ganzen sind etwa sechs Hauptäste des Halmes und 24 bis 30 Aehrchen vorhanden. Zur Zeit der Reife fällt nun der ganze Halm ab und wird vom Winde über die Grasfluren (Campos) hingetrieben. In Fußpfaden fand ich hier und da völlige Heuschichten dieser sparrig verästelten Aristida-Halme zusammengeweht. Die Aehrchen scheinen sich nie von den Halmen zu lösen. Bricht man sie ab, so sieht man noch die für bohrende Samen so bezeichnende Spitze mit dem Barte schief aufwärts gerichteter Haare, als Beweis, dass die Vorfahren auch dieser Aristida einst das Vermögen sich einzubohren besassen.

Itajahy, April 1877 . 


\section{Beobachtungen an brasilianischen Schmetterlingen $\left.{ }^{1}\right)$. I.}

I. Die Flügeladern der Schmetterlingspuppen.

Mit 6 Textfiguren.

An Schmetterlingspuppen, die eben ihre Raupenhaut abgestreift haben, sieht man häufig durch die noch weichen Flügeldecken die zarten, weissen Luftröhren durchschimmern, welche die erste Anlage des Adergerüstes der Vorderflügel bilden. Bisweilen lassen sich auch die tiefer liegenden Luftröhren der Hinterflügel erkennen, doch vielleicht nie deutlich genug, um ein vollständiges, zusammenhängendes Bild ihres Verlaufes zu gewinnen. Mit dem Erhärten der Puppenhaut pflegt dieses Adergerüst der Puppenflügel undeutlich oder völlig unsichtbar zu werden; selten nur, besonders bei grünen Puppen mit glatten Flügeldecken, z. B. Siderone Ide, bleibt es für eine Reihe von Tagen sichtbar.

Der Verlauf der Luftröhren in den Flügeln der jungen Puppen pflegt nun nicht unerheblich abzuweichen von dem späteren Adergerüst der Schmetterlingsflügel, und wie so häufig Jugendzustände Aufklärung geben über die Stammesgeschichte, so ist unverkennbar auch in diesem Falle der Aderverlauf des Puppenflügels weit ursprünglicher, dem des Urschmetterlings weit näher stehend, als das Adergerüst des Schmetterlingsflügels.

Gerade für die Ordnung der Schmetterlinge muss aber jeder neue Anhalt zur Feststellung ihrer verwandtschaftlichen Beziehungen unter einander und zu anderen Insekten und somit ihres Stammbaumes hoch willkommen sein. Sagte doch schon Latreille: „Lepidopterorum ordo entomologorum scopulus“ und dass dieser Ausspruch noch heute gilt, beweist unter Anderem die geringe Uebereinstimmung zwischen den der neuesten Zeit angehörenden Anordnungen der Tagfalter von Herrich-Schäffer, von Kirby und von Butler.

Doch besser als durch allgemeine Betrachtungen veranschauliche ich wohl durch Vorführen einiger Beispiele die Bedeutung des Flügelgeäders der Puppen.

Ich zeichne zunächst in Fig. I den Vorderflügel der Castnia Ardalus und stelle in Fig. 2 den der Siderone Ide daneben. Die grosse Verschieden-

1) Kosmos 1877. Bd. I. S. $388-395$. 
heit des Adergerüstes springt sofort in die Augen. Bei Siderone eine einfache Mittelzelle und die von ihr nach dem Rande des Flügels gehenden Längsadern, alle anscheinend aus zwei Stämmen entspringend, und zwar 2 bis 4 aus der Mediana, 5 bis 11 aus der Subcostalalis. Bei Castnia dagegen entspringen nur 2 und 3 aus der Mediana, 7 bis 11 aus der Subcostalis, während die dazwischen liegenden 4 bis 6 als Aeste der bei der Siderone fehlenden Discoidalis erscheinen, durch welche die Mittelzelle der Länge nach getheilt wird. Ausserdem wird durch einen Querast zwischen 8 und 9 eine kleine Nebenzelle gebildet. Zwischen Mittelzelle und Innenrand der Flügel verläuft bei Siderone

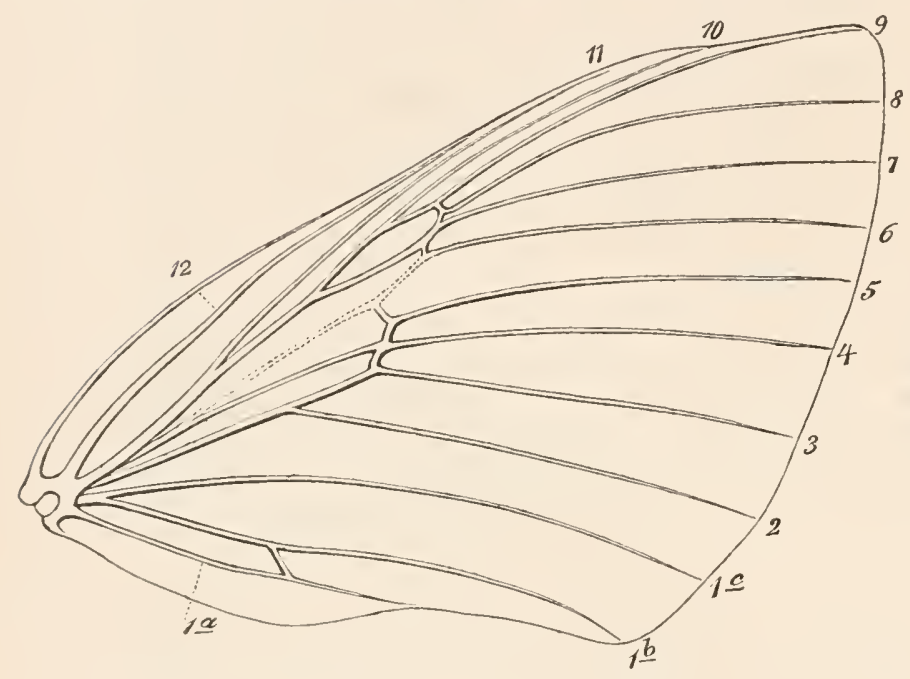

Fig. I. Vorderflügel von Castnia Ardalus.

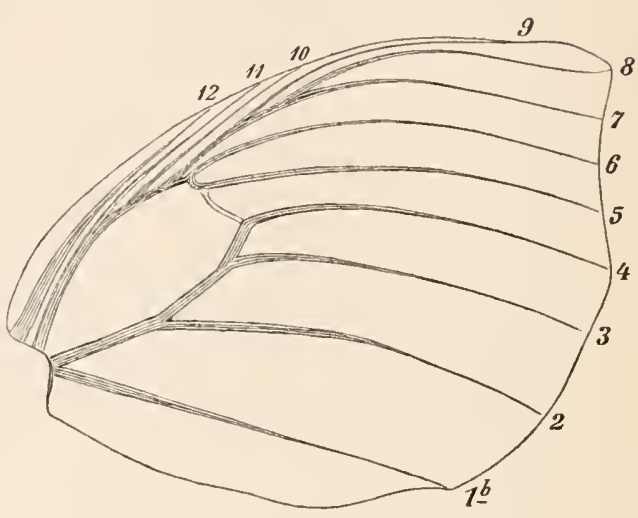

eine einzige einfache Innenrandsader $(1 b)$, während Castnia deren drei besitzt $(1 a, 1 b, 1 c)$, von denen die beiden hinteren $(1 a$ und $1 b)$ durch einen Querast verbunden sind.

Welches der beiden Adergerüste ist nun das ursprüngliche, dem des Urschmetterlings näherstehende? - Gerstäcker, welcher dem Flügelgeäder der Kleinschmetterlinge wegen der drei Innenrandsadern der Hinterflügel grössere „Vollkommenheit" zuschreibt, würde wohl das weit einfachere Adergerüst der Si derone für unvollkommener und daher wohl auch für älter erklären, als das viel verwickeltere der Castnia. - Dr. A. Speyer, der den Saturnien, mit nur einer Innenrandsader der Hinterflügel, hoch entwickelten Flügelbau zuschreibt, und den Weidenbohrer (Cossus), dessen Vorderflügel im Adergerüst sich kaum von denen der Castnia unterscheiden, als eine Form bezeichnet, deren Flügelgeäder dem der Haarflügler (Phryganiden) und somit wahrscheinlich der Urform der Schmetterlinge besonders nahe steht, wäre ohne Frage entgegengesetzter Meinung.

Das Flügelgeäder der Puppe von Si d e ron e I de (Fig. 3), das ich am ersten Tage nach der Verpuppung (10. Juni i 876) zeichnete, entscheidet sofort die Frage. Dasselbe gleicht weit weniger dem des Schmetterlings, der aus der Puppe hervorgeht, als dem der Castnia. Wie bei dieser finden sich drei Innenrandsadern $(1 a, 1 b, 1 c)$, eine Mediana mit zwei $(2$ und 3$)$, eine Discoidalis mit drei $(1$ bis 6$)$ 
und eine Subcostalis mit fünf (7 bis 11) Aesten. Queradern fehlen noch. - Nach einigen Tagen verschmelzen, jenseits des Ursprungs der Ader 11, die beiden Hauptäste der Subcostalis auf eine kurze Strecke, so dass dann auch die von den Aesten der Subcostalis umschlossene Nebenzelle der Castn ia A rdalus nicht fehlt. Später vereinigt sich diese Nebenzelle mit der Mittelzelle, indem die sie trennende

Fig. 3.

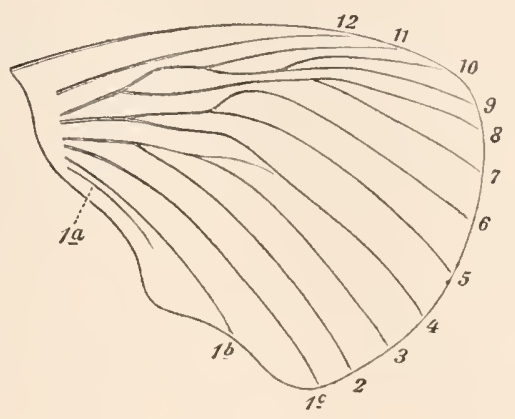

Fig. 4.

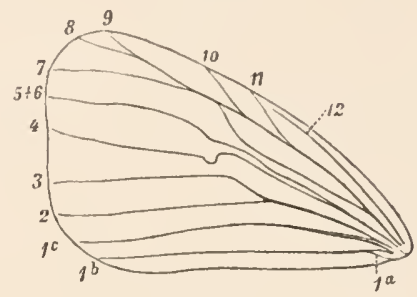

Fig. 3. Flügelgeäder der Puppe von Siderone Ide. (3: 1).

Fig. 4. Flügelgeäder der Puppe von Callidryas Argante. (3: I.)

Ader verkümmert und schwindet. An den Flügeln verschiedener Schmetterlinge ist dieses verkümmerte Stück des hinteren Hauptastes der Subcostalis noch deutlich wahrzunehmen, häufiger noch der verkümmerte Stamm der Discoidalis und die vordere Innenrandsader $(1 c)$.

Als zweites Beispiel gebe ich (Fig. 4) das Flügelgeäder einer jungen Puppe von Callidryas Argante; von dem der Siderone Ide unterscheidet es sich dadurch, dass, wie bei dem Schmetterling, die beiden hinteren Innenrandsadern (1a und $1 b$ ) nahe der Wurzel sich vereinigen, dass die beiden Hauptäste der Subcostalis schon zur Zeit der Verpuppung verschmolzen sind und ebenso fast bis ans Ende die Aeste 8 und 9; endlich dadurch, dass die Discoidalis nur zwei Aeste hat. Es ist also schon in der Puppe, wie beim Schmetterling und wie bei vielen anderen Pieriden, eine Ader weniger vorhanden, als bei Siderone. So viel ich weiss, nimmt man bis jetzt allgemein an, dass die fehlende Ader ein Ast der Subcostalis sei; Doubleday wenigstens beschreibt die Subcostalis als nur vierästig und bezeichnet die Ader 7 als erste Discoidalader. Ein Blick auf die Puppe widerlegt diese Annahme und zeigt, dass die Subcostalis ihre gewöhnlichen fünf Aeste vollzählig besitzt, dass dagegen statt der beiden vorderen Aeste der Discoidalis $(5$ und 6 ) nur ein einziger vorhanden ist.

Ich hoffe, diese wenigen Beispiele werden genügen, dem Verlaufe der Luftröhren in den Flügeln junger Schmetterlingspuppen die verdiente Beachtung zuzuwenden.

\section{Die Duftschuppen der männlichen Maracujáfalter ${ }^{1}$ ).}

Der Geruchssinn spielt im geschlechtlichen Verkehr vieler Thiere eine wichtige Rolle. $\mathrm{Zu}$ diesen gehören auch die Schmetterlinge. Männchen mancher Schwärmer und Nachtschmetterlinge riechen auf unglaubliche Entfernung ihre

1) Vergl. As maculas sexuaes u. s. w. Ges. Schriften S. 551 - Os orgãos odoriferos u. s. w. Ges. Schriften S. 559 und Tafel XLV-XLVIII. 
der Begattung harrenden Weibchen. Aber auch ihrerseits verbreiten viele Schmetterlingsmännchen Gerüche, die jedenfalls den IVeibchen angenehm sind und ihre Geschlechtslust reizen. Von den Männchen des Liguster- und des Windenschwärmers weiss man seit lange, dass sie einen im Fluge besonders stark hervortretenden Moschusgeruch entwickeln, ohne dass man bisher die Stelle, von der dieser Geruch ausgeht, ermittelt hätte. Die Entomologen in Europa haben eben WVichtigeres zu thun. Die Männchen einer Motte der Gattung Cryptolechia und die der Glaucopiden, den deutschen Blutflecken (Zygaeniden) verwandter Schmetterlinge, stülpen am Ende des Hinterleibes ein Paar hohle, behaarte Fäden aus, bisweilen von Körperlänge, von denen ein oft sehr starker, für uns bald widerlicher, bald angenehmer (z. B. wie aus Chloroform und Bittermandelöl gemischter) Geruch ausgeht. Ebenso können bei den prächtigsten der südamerikanischen Schmetterlinge, den riesigen Morpho, die Männchen am Ende des Hinterleibes jederseits eine behaarte, riechende Wulst hervortreten lassen; bei dem im prachtrollsten Blau schillernden M. A don is und dem ähnlichen M. Cytheris ist der Geruch vanilleähnlich. - Weit häufiger als der Hinterleib sind die Flügel der Sitz der das Männchen auszeichnenden Düfte. Um nur einige wenige der durch besonders starken Geruch ausgezeichneten Arten zu nennen, so ist bei dem Männchen des Papilio Protesilaus, eines dem Segelfalter ähnlichen Falters mit schuppenarmen, durchsichtigen Flügeln, der Innen- oder Hinterrand der Hinterflügel breit nach oben umgeschlagen; werden diese Flügel stark nach vorn gezogen, so öffnet sich der Umschlag und es kommt ein sich sträubender, dichter Bart aus langen schwarzen Haaren zum Vorschein, und zugleich wird ein lebhafter Geruch bemerkbar. In der Familie der Weisslinge (Pierinen) zeichnen sich in dieser Beziehung aus Leptalis Thermesia und der durch leicht geschwänzte Hinterflügel merkwürdige Gelbling Callidryas Cipris; bei beiden geht der Geruch aus ron einem mit eigenthümlichen Schuppen bedeckten Fleck, der auf der Oberseite der Hinterflügel nahe dem Vorderrande liegt und bei Callidryas Cipris noch von einer Mähne langer Haare bedeckt wird. Bei den Männchen fast aller Brassoliden, grosser, den Morpho ähnlicher, aber minder glänzend gefärbter Falter, die besonders am frühen Morgen und gegen Abend fliegen, sind die Hinterflügel mit sehr verschiedenartig gelegenen und gebildeten Duftwerkzeugen ausgestattet. Einen ungewöhnlich starken Bisamgeruch bemerkte ich bei einer auf der Höhe der Serra gefangenen Dasyophthalma; hier trägt das Männchen auf der bläulich schwarzen Oberseite der Hinterflügel einen eirunden ockergelben Fleck, welchen die Discoidalader durchschneidet, und dahinter in der Mittelzelle einen langen Pinsel lehmgelber Haare, den der Falter willkürlich aufrichten und ausspreizen kann. Bei den Männchen vieler Thecla-Arten findet sich auf der Oberseite der Vorderflügel am Ende der Mittelzelle ein meist dunkler Fleck, aus sehr fest haftenden, abweichend gestalteten Schuppen gebildet; bei grösseren Arten pflegt ein von diesem Fleck ausgehender Geruch wahrnehmbar zu sein; sehr stark (so dass er auffällt, sobald man das Thier in den Käscher bekommt) und dabei widerlich, fledermausähnlich, ist derselbe bei der prachtvollen Thecla Atys.

Gemeinsam ist allen diesen und anderen Duftwerkzeugen, dass sie, so lange der Schmetterling ruht, wohl geborgen und vor Verdunstung geschützt sind, sei 
es zwischen den Flügeln, oder zwischen Flügel und Hinterleib, sei es in besonderen Rinnen oder durch Umschlag des Randes gebildeten Taschen der Flügel (clahin z. B. der sogenannte "Costalumschlag" am Vorderrande der Vorderflügel bei vielen Dickköpfen), sei es im Innern des Leibes, wie die ausstülpbaren Wülste und Fäden der Morpho und der G1aucopiden. Besonders wirksame Räuchervorrichtungen bilden die Pinsel und Mähnen, die während der Ruhe mit Riechstoff sich sättigen und dann plötzlich, sich ausspreizend, eine ungemein grosse Verdunstungsfläche entfalten.

Man ist wohl berechtigt, allen ähnlichen unter den Tagfaltern sehr verbreiteten Vorrichtungen dieselbe Deutung zu geben, auch wenn bis jetzt ein Geruch noch nicht beobachtet wurde und selbst wenn ein solcher für menschliche Nasen überhaupt nicht wahrnehmbar wäre.

Natürlich sind diese überaus mannigfaltigen Duftvorrichtungen der männlichen Schmetterlinge nicht plötzlich in ihrer jetzigen Vollkommenheit zu Tage getreten; sie haben sich aus einfacheren Zuständen entwickeln müssen. Und da nun viele derselben verhältnissmässig junge Bildungen sind, wie ihre sehr abweichende Gestaltung in nahe stehenden Gattungen, oder selbst innerhalb derselben Gattung (z. B. Papilio) beweist, so dürfte die Hoffnung nicht unberechtigt erscheinen, noch solche einfachere Zustände aufzufinden. Da bisweilen selbst wohlentwickelte Duftflecke (z. B. bei Callidryas Philea ơ) oder Haarbüschel (z. B. Mechanitis Lysimnia d) keinen für uns sicher wahrnehmbaren Geruch verbreiten, so musste man selbstverständlich von vornherein bei derlei einfachen Formen auf Erkennen durch die Nase verzichten und ihre Deutung anderweitig sicher stellen. Es lassen sich nun in der That auf den Flügeln verschiedener Schmetterlinge Schuppenbildungen nachweisen, die man mit Wahrscheinlichkeit als einfachere, ursprünglichere Duftwerkzeuge betrachten kann. Unter diesen sind besonders merkwürdig, weil ihre Deutung als solche wohl kaum einem Zweifel unterliegen kann, die Duftschuppen der männlichen Maracujáfalter.

Die Maracujáfalter, wie ich sie nach den Pflanzen nenne, an welchen, soweit bekannt, die Raupen aller Arten leben ${ }^{1}$ ), bilden eine auf das wärmere Südamerika beschränkte Gruppe engverwandter Arten. Ihre langen schmalen Flügel geben ihnen ein ganz eigenartiges Aussehen, ihre meist schönen, reinen, satten Farben machen sie, wie die Morpho, zu einer wahren Zierde südamerikanischer Landschaften. Man hat aus ihnen vier Gattungen gebildet, Helic on ius, Eucides, Colaen is und Di o ne(-A g r a u $1 \mathrm{is})$ und diese Gattungen bisher allgemein, unbegreiflicherweise möchte man sagen, wenn bei der landläufigen Systematik überhaupt etwas unbegreiflich wäre, - in zwei verschiedene Unterfamilien oder Familien, die Heliconinen und die Nymphalinen vertheilt; man hat Colaenis und Dione oder selbst Eueides von dem nächstverwandten Heliconius losgerissen, um sie mit Ageronien, mit A paturen, mit Sideronen zusammenzuwerfen! Unter sich durch ihre geographische Verbreitung, durch den Bau der Raupen wie der Falter, ja selbst durch ihre Liebhaberei für bestimmte

I) Von den hiesigen Arten wurden auf Maracujá (Passiflora) gefunden die Raupen von Heliconius Eucrate, Eueides Isabella nnd Aliphera, Colaenis Julia und Dido, Dione Vanillae und Juno. 
Blumen ${ }^{1}$ ) auf's Engste verbunden, scheinen sie keiner anderen Tagfaltergattung besonders nahe verwandt $z u$ sein. Am nächsten steht wohl noch Acraea, deren Raupen in allem Wesentlichen mit denen der Maracujáfalter übereinstimmen.

Bei allen darauf untersuchten Männchen der Maracujáfalter nun finden sich auf der Oberseite der Hinterflügel nahe dem Vorderrande, besonders zahlreich längs der Costal- und Subcostalader, zwischen den gewöhnlichen Schuppen einzelne andere von sehr auffallender Gestalt, wie ich sie ähnlich nur bei den Männchen eines Weisslings der Gattung Hesperocharis gesehen habe. Ihr meist ziemlich stark gewölbter Endrand ist dicht mit Fransen besetzt, welche wie durch einen fremden Stoff mehr oder minder mit einander verklebt aussehen. Fast noch rein erschienen die Fransen bei einem Männchen von Eueides Aliphera das ich dieser Tage aus der Puppe erhielt und im Laufe des ersten Tages tötete. - Die Schuppen erscheinen bis auf einen hellen Saum längs des befransten Randes trüb und undurchsichtig; ihr Stiel ist, im Gegensatze zu dem gewöhnlicher Schuppen, dünn, dünnhäutig, und schlaff; das Grübchen, den er eingefügt ist ist mehrfach grösser als bei den anderen Schuppen, kuglig und dabei breit und dunkel gerandet, als enthielte es einen stark lichtbrechenden Stoff. Im Uebrigen ist, wie nachstehende Fig. 5 zeigt, die Gestalt der Schuppen eine ziemlich wechselnde.
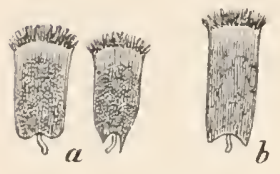
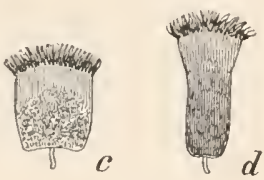

Fig. 5.
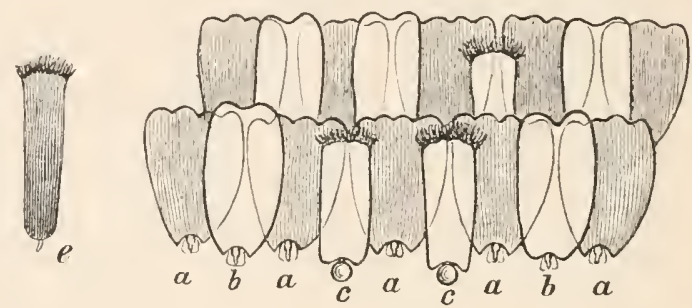

Fig. 6.

Fig. 5. Duftschuppen männlicher Maracujáfalter (Vergr. 180 : 1). a Heliconius Apseudes. $b$ Heliconius Besckei. $c$ Eueides Aliphera. d Colaenis Dido. e Dione Juno.

Fig. 6. Anordnung der Duftschuppen bei Heliconius Besckei. $a$ Unterschuppen. $b$ Deckschuppen. c Duftschuppen.

Bei den Männchen von Colaen is Dido kommen diesse Schuppen auch anderwärts auf der Oberseite der Flügel vor. Genauer habe ich ihre Anordnung erst bei Heliconius Besckei mir angesehen. Wie bekannt, bilden die Schuppen der Tagfalter Querreihen, von denen jede der Flügelwurzel nähere die Einfügungsstellen der folgenden dachziegelartig deckt. In jeder Querreihe wechseln zweierlei Schuppen miteinander ab, die einen, der Flügelhaut aufliegenden (Unterschuppen), sind meist breiter und kürzer, die anderen darüberliegenden (Deckschuppen) schmäler und länger. Wo nun an der bezeichneten Stelle diese regelmässige Schuppenstellung vollständig ausgeprägt ist, pflegen die Duftschuppen

1) Poinsettia pulcherrima wurde im vorigen Jahre in meinem Garten ausser von zahlreichen Thecla-Arten und einigen Eryciniden nur selten und zufällig von anderen Tagfaltern besucht, mit Ausnahme der Maracujáfalter; diese fanden sich regelmässig ein und verweilten andauernd bei der Pflanze, und zwar fast alle hiesigen Arten. Es fehlten nur Eueides Pavana, den ich überhaupt erst drei- oder viermal, sowie Dione Moneta, den ich erst einmal gesehen habe. 
den Ort von Deckschuppen einzunehmen. Doch liegen ihre Einfügungsstellen nur selten in derselben Linie mit denjenigen der anderen Schuppen, vielmehr meist der Flügelwurzel näher. Namentlich längs der Costalader, wo die Duftschuppen am dichtesten stehen, ist die Anordnung der Schuppen eine minder regelmässige und hier sind auch die Duftschuppen anscheinend ganz regellos zwischen die anderen eingestreut.

Was nun die Deutung als Duftschuppen betrifft, so spricht dafür:

1) ihre Beschränkung auf das männliche Geschlecht;

2) ihr Vorkommen an der Stelle, die vor allen anderen häufig von Duftvorrichtungen eingenommen wird. Hier, d. h. auf dem vom Hinterrande der Vorderflügel bedeckten Theile der Oberseite der Hinterflügel, finden sich unter den Danaiden die Duftvorrichtungen bei Arten von Euploea, hier die langen Haarpinsel von Ithomia, Mechanit is und den meisten heliconier-ähnlichen Danaiden; unter den Satyrinen: der grosse weisse Duftfleck von Gnophodes Morpena, der Ilaarbüschel verschiedener Mycalesis-Arten; ein Fleck mit langen schwarzen seidenartigen Laaren bei Bia Actorion; unter den Elymni inen: der Haarbüschel von Elymnias; unter den Morphinen: der eirunde lederbraune Fleck von $\mathrm{Zeuxidia,} \mathrm{sowie} \mathrm{ein} \mathrm{Haarbüschel} \mathrm{von} \mathrm{Tenaris,} \mathrm{Cle-}$ rome und Thaumantis; unter den Brassolinen: der eirunde Fleck von Das yophthalma; unter den Nymphalinen: der Fleck von Lachnoptera; unter den Pierinen: der Duftfleck verschiedener Arten von Leptalis, Callidryas, Nathalis u. s. w.; unter den Hesperiden der Haarbüschel von Caecina; endlich unter den Motten (Hyponomeutiden) der lange graublonde Haarbusch von Trichostibas.

3) die Fransen am Endrande, welche, wie andere Duftvorrichtungen, sowohl die Ansammlung von Riechstoffen begünstigen, so lange die Flügel auf einander liegen, als auch eine rasche Verdunstung derselben, sobald die Flügel sich von einander entfernen;

4) das Grübchen, in welchem der Stiel sitzt, und welches man von ganz ähnlichem Aussehen in unzweifelhaften, starken Geruch verbreitenden Duftflecken antrifft.

Von Gattungen, die man in die Nähe der Maracujáfalter zu stellen pflegt, habe ich nur Acraea, Argynnis und Melitaea (von letzteren beiden alpine Arten, die mein Bruder Hermann gesammelt hat) untersucht, aber an den Flügeln der Männchen nichts den Duftschuppen von Heliconius, Eueides, Colaenis und Dione Aelnnliches finden können. Selbst dieses so unscheinbare Merkmal bestätigt auf's Neue die enge Verwandtschaft unter sich und die Abgeschlossenheit der Maracujáfaltergruppe.

Ausser den Düften, durch welche männliche Schmetterlinge dem umworbenen Weibchen sich angenehm machen, erzeugen manche Schmetterlinge Gerüche, die Insekten fressenden Vögeln oder anderen Feinden zuwider sind und dadurch gegen deren Verfolgung schützen. Man kann sie von ersteren leicht dadurch unterscheiden, dass sie bei beiden Geschlechtern in gleicher WVeise auftreten und dass der Schmetterling sie loslässt, sobald er in Gefahr kommt, sobald er also z. B. angefasst wird. Auch die Maracujáfalter besitzen einen solchen, und zwar einen recht starken schützenden Geruch. Fängt man irgend eine Art, sei es Männchen 
oder Weibchen, so erscheinen am Ende des Hinterleibes gelbe $W$ ülste, je nach dem Geschlechte verschieden gestaltet und gelegen, aber bei Männchen und Weibchen genau denselben widerlichen Geruch verbreitend. Es könnte dieser Umstand gegen die eben gegebene Deutung der Duftschuppen Bedenken erregen; es könnte befremden, dass das Männchen neben dem sehr starken, die Feinde abstossenden, noch einen anderen sehr schwachen, für uns völlig unmerklichen, die Weibchen anlockenden Geruch erzeugen sollte. Darauf lässt sich sagen, dass man bereits wenigstens einen Fall kennt, in welchem gleichzeitig und noch dazu dicht bei einander die beiderlei Gerüche vorkommen. Didonis Biblis, ein hübscher, mittelgrosser, schwarzer Falter mit breitem rothen Bande längs dem Saume der Hinterflügel, besitzt in beiden Geschlechtern auf dem Rücken des Hinterleibes, zwvischen viertem und fünftem Ringe, eine schwärzlich behaarte Doppelwulst, die hervorgestülpt wird, wenn man das Thier ergreift; ausserdem besitzt das Männchen eine dem Weibchen vollständig fehlende weissbehaarte, von dem schwarzen Hinterleib grell abstechende Doppelwulst zwischen dem fünften und sechsten Hinterleibsring, die das gefangene Thier niemals freiwillig hervortreten lässt. Man kann mit einiger Vorsicht bald die vordere, bald die hintere Wulst allein hervordrücken und sich so von der Verschiedenheit der Gerüche überzeugen, von welchen auch für uns der der vordern Wulst unangenehm, der der hintern angenehm ist. Durch diesen Fall verliert die überdies kaum zu umgehende Deutung der Duftschuppen auf den Flügeln der männlichen Maracujáfalter das Befremdliche, was sie für einen vereinzelt stehenden Fall haben könnte. 


\title{
Beobachtungen an brasilianischen Schmetterlingen ${ }^{1}$ ).
}

II. $\left.{ }^{2}\right)$

\author{
3. Die Duftschuppen der Männchen von Dione Vanillae. \\ Mit 7 Textfiguren.
}

Dione Vanillae veranlasst, ja ich darf wohl sagen, zwingt mich, noch einmal auf die Duftschuppen der Maracujáfalter zurückzukommen; so abweichend in Gestalt und Anordnung sind dieselben bei dem genannten Falter von denen der meisten Familiengenossen.

In manchen Jahren der häufigste aller Maracujáfalter, war in diesem Jahre Dione Vanillae hier so selten, dass ich erst vor Kurzem, beim Nahen des Winters, das erste Männchen erhielt. Als ich mich bei diesem an der gewohnten Stelle, an dem von den Vorderflügeln bedeckten Theile der Hinterflügel, nach Duftschuppen umsah, konnte ich keine Spur derselben entdecken; doch belehrte mich sofort das eigenthümliche Aussehen der Adern der Vorderflügel, wo ich sie zu suchen hatte. Die sechs ersten Adern dieser Flügel (nach HerrichSchäffer's Zählungsweise also die Innenrandsader, sowie die Aeste der Mediana und Discoidalis) erscheinen als breite, wulstige, schwarze Striche auf dem fuchsrothen Grunde der Flügel, und bei genauerem Zusehen erkennt man, dass diese Striche zusammengesetzt sind aus einer Reihe quer über die Adern laufender Wülste, zwischen denen nackte, schuppenlose Stellen der Adern durchscheinen. Auf diesen Wülsten nun stehen dichtgedrängte Duftschuppen, deren Gestalt eher an die mancher Satyriden, als an die der übrigen Maracujáfalter erinnert.

So sehr man gewohnt ist, sogenannte „secundäre“ Geschlechtseigenthümlichkeiten in abweichendster Weise bei nahe verwandten Arten ausgeprägt zu finden, befremdete mich doch eine so durchgreifende Verschiedenheit innerhalb eines so eng verbundenen Verwandtenkreises, wie ihn die Maracujáfalter bilden. Das Befremden schwand, als ich mich überzeugte, dass die Anordnung der Duftschuppen bei Dione $\mathrm{V}$ anilla e derjenigen der übrigen Maracujáfalter keineswegs unvermittelt gegenübersteht.

1) Kosmos $1877 / 78$. Bd. II. S. $38-42$.

2) Vergl. Kosmos Bd. I. S. $388 .=$ Ges. Schriften S. 585 .

Fritz Müllers gesammelte Schriften. 
Auch bei Heliconius, wo die Duftschuppen sich auf den von den Vorderflügeln bedeckten Theil der Hinterflügel beschränken, stehen dieselben besonders zahlreich längs der Flügeladern. Bei Colaenis Dido $\delta$ sind, wie ich bereits in meiner ersten Mitteilung erwähnt zu haben glaube, die Duftschuppen nicht auf jene eine Stelle beschränkt, sondern über den ganzen Flügel verbreitet, und zwar stehen sie, wie mich jetzt eine genauere Untersuchung lehrt, ausschliesslich auf den Flügeladern. Sie finden sich auf den Adern 2 bis 8 der Hinterflügel, sowie I bis 7 der Vorderflügel; am zahlreichsten stehen sie auf den von den Vorderflügeln bedeckten Adern der Hinterflügel. Die sämmtlichen Schuppenreihen der Flügel gehen, wie gewöhnlich, ununterbrochen und fast gerade, nur leicht nach der Flügelwurzel zu sich wölbend, über die Adern hinweg, auf welchen die Schuppen gedrängter als sonst stehen. Zwischen je zwei Reihen gewöhnlicher Schuppen steht eine Gruppe von Duftschuppen in einer dichtgedrängten queren Doppelreihe (Fig. 2).

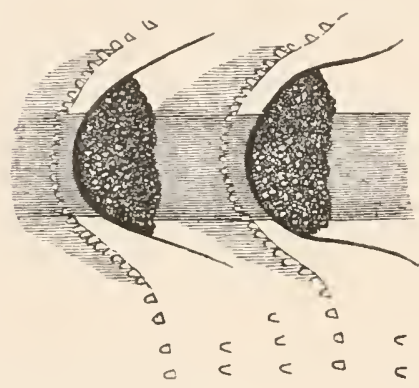

Fig. I.

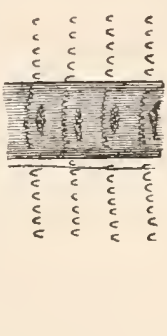

Fig. 2.

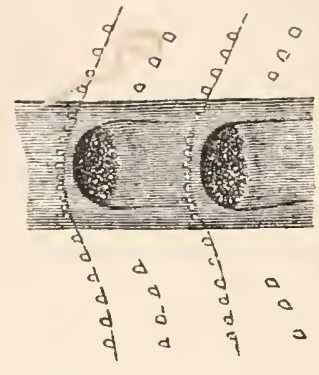

Fig. 3 .

Fig. I. Stück der Innenrandsader der Vorderflügel von $\mathrm{D}$ ion e Vanillae $\delta$ (90: I).

Fig. 2. Stück der 4. Ader der Vorderflügel von Colaenis $\mathrm{Dido} \delta$ (45: I).

Fig. 3. Stück der 2. Ader der Vorderflügel von Colaen is Julia $\delta$ (90:I).

Bei Colaenis Julia $\delta$ sind die Duftschuppen der Hinterflügel auf die von den Vorderflügeln bedeckten Adern 7 und 8 beschränkt; besonders zahlreich finden sie sich auf 7, dem ersten Aste der Subcostalis und sind hier wie bei Colaen is Dido angeordnet. Ausserdem kommen aber auch Duftschuppen auf den Vorderflügeln vor und zwar auf den Adern I bis 3, wo sie eine schon an Dione Vanillae erinnernde Anordnung zeigen. Von den Schuppenreihen geht nur jede zweite, wurzelwärts sich wölbend, ununterbrochen über die Adern hinweg; die Schuppen auf den Adern sind länger, schmäler, stehen gedrängter als sonst und überdecken einen halbkreisförmigen, etwas vertieften, etwa $2 / 3$ der Breite der Ader einnehmenden Fleck, der dicht mit Duftschuppen besetzt ist (Fig. 3).

Bei Dione Juno đo scheinen die Duftschuppen dem von den Vorderflügeln überdeckten Theile der Hinterflügel zu fehlen; zwar findet man bisweilen einzelne zwischen den dieser Stelle entnommenen Schuppen; doch konnte ich nicht feststellen, dass sie wirklich dort festgesessen hatten. Sie kommen dagegen vor auf den Adern 2 bis 6 der Hinter-, sowie I bis 6 der Vorderflügel. Sie sind angeordnet wie bei Colaen is Dido; wo sie besonders reichlich vorkommen, wie auf der Innenrandsader der Vorderflügel, sind die Schuppenreihen auf der Ader stärker gekrümmt und die Gruppen der Duftschuppen sind mehrreihig, so dass die Anordnung sich derjenigen auf den Vorderflügeln von Colaenis Julia nähert. 
Bei Dione Vanillae ठ endlich (Fig. 1) sind die Duftschuppen beschränkt auf die Adern 1 bis 6 der Vorderflügel. Auf 1, der Innenrandsader, nehmen sie die beiden letzten Drittel der Länge ein, auf 2, 3 und 5 die ganze Länge, auf 4 gehen sie wurzelwärts noch über das Ende der Mittelzelle hinaus, während sie auf 6 erst ein Stück jenseits der Mittelzelle beginnen. Es geht bei dieser Art nur jede dritte Schuppenreihe ununterbrochen und stark wurzelwärts gewölbt über die Duftschuppen tragenden Adern hinweg. Der Zwischenraum zwischen je zwei über die Ader laufenden Schuppenreihen wird fast zur Hälfte eingenommen von einem dicht mit Duftschuppen besetzten Felde, welches nach beiden Seiten die Ader überragt.

Wie in Betreff der Anordnung, so bildet auch in Betreff der Gestalt der Duftschuppen Colaen is J ulia ein Verbindungsglied zwischen Colaen is Dido und Dione Vanillae. Die Duftschuppen der Hinterflügel (Fig. 4, A) schliessen sich wie in ihrer Anordnung, so in ihrer Gestalt aufs Engste denen der Cola en is Dido an, während die der Vorderfügel (Fig. 4, B) fast doppelt so lang, weit schlanker und vor dem Ende halsartig verschmälert sind, und so auch in ihrer Gestalt einigermassen an Dione Vanillae erinnern.

Bei letzterer Art (Fig. 5) erreichen die dünnen, stabförmigen Duftschuppen etwa 0,7 mm Länge; einem undurchsichtigen, kolbig angeschwollenen Wurzelende, das an die Duftschuppen mancher Weisslinge erinnert, folgt ein dünner, durchsichtiger Stiel von etwa $1 / 8$ der Gesammtlänge: dann eine schmale, ge-

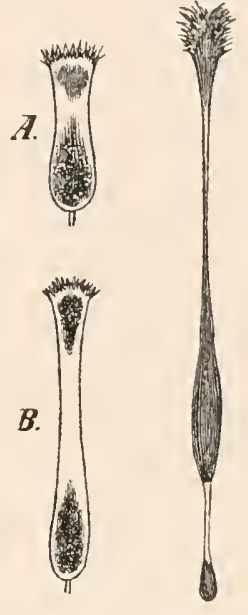

Fig. 4. Fig. 5.

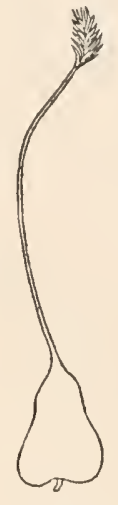

Fig. 6.

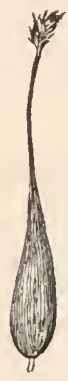

Fig. 7 .

Duftschuppen I $80 \mathrm{mal}$ vergrössert:

Fig. 4. Von Colaenis Julia ${ }^{3}$. $A$ vom Hinterflügel, $B$ vom Vorderflügel.

Fig. 5. Von Dione Vanillae $\delta$

Fig. 6. Von Euptychia cosmopila

Fig. 7. Von Erebia goante $\sigma^{7}$. (Von Hermann Müller auf den Alpen gefangen). streckt lanzettförmige Spreite; diese verjüngt sich nach oben wieder in einen dünnen Stiel, der sich am Ende zu einer schmalen, länglichen, abgerundeten, mit Fransen besetzten Platte erweitert. Die Schuppen, welche dichtgedrängt im Halbkreis das Duftschuppenfeld umgeben, sind etwa dreimal so lang als die übrigen Flügelschuppen und auch abweichend gestaltet, sie scheinen einen schützenden Zaun für die Duftschuppen zu bilden.

Unter den mir bekannten Duftschuppen anderer Schmetterlinge sind die verschiedener Satyriden (Fig. 6, 7) denen der Dione Vanillae ziemlich ähnilich.

In Farbe und Zeichnung, besonders auch in den Silberflecken der Unterseite der Flügel, kommt D i on e V a nilla e manchen Perlmutterfaltern, z. B. der deutschen Argynnis Aglaja, so nahe, dass ich auch diese noch einmal auf Duftschuppen untersuchte. An dem von den Vorderflügeln bedeckten Theile der Hinterflügel, wo ich früher danach suchte, hatte ich keine gefunden; dagegen traf ich sie jetzt, wie bei Dione Vanillae, auf den Adern der Vorderflügel. Sie scheinen sich, bei Argynnis Aglaja und Niobe б, auf die Adern I bis 4 zu beschränken, 
auf denen sie nicht in Gruppen vereinigt, sondern unregelmässig zerstreut stehen. Ihre Gestalt erinnert an die Duftschuppen von Erebia goante (Fig 7). Ihre genauere Beschreibung bleibt billig denen überlassen, die sie in frischem Zustande untersuchen können.

Zum Schlusse eine Uebersicht des Vorkommens der Duftschuppen bei den vorstehend erwähnten Arten:

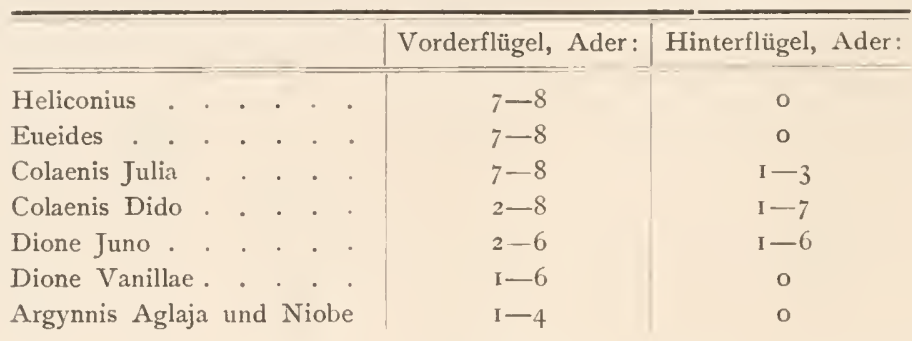

4. Kommt auch geschlechtliche Auswahl von Seiten der Männchen vor?

Bei den Schmetterlingen, wie überhaupt in der Thierwelt, ist es Regel, dass, wenn die Geschlechter verschieden gefärbt sind, die Männchen das glänzendere Gewand tragen. Ebenso ist es Regel, dass die Oberseite der IFlügel lebhafter gefärbt ist, als die Unterseite.

Von beiden Regeln macht Pereute Swainsonii, ein schwarzer „Weissling“, wie Claus die Pieriden nennt, und machen ebenso, so viel ich aus den mir zugänglichen Beschreibungen und Abbildungen ersehen kann, einige andere Arten derselben Gattung (P. Charops und Antodyca) eine Ausnahme.

Die Grundfarbe der Flügel ist schwarz. Die Oberseite zeigt beim Weibchen als einzigen Schmuck eine mattrothe, fleischfarbene, durch die schwarzen Adern unterbrochene Binde, die von der Mitte des Vorderrandes zur Hinterecke geht. Auf der Unterseite ist diese Binde etwas breiter und von viel dunklerem, satterem, lebhafterem Roth; ausserdem finden sich auf der Unterseite der Hinterflügel zwei rothe Flecke an der Flügelwurzel und ein breiter, gelber Streif am Vorderrande (zwischen Costalis und erstem Aste der Subcostalis).

Beim Männchen ist das Roth der Unterseite kaum so lebhaft als das der Oberseite bein Weibchen; auf der Oberseite aber ist die Binde schmäler, weisslich mit kaum noch einem Schimmer von Roth; die sie durchsetzenden Adern sind breiter schwarz gerandet und einzelne schwarze Deckschuppen sind fast über den ganzen helleren Grund der Binde zerstreut. Dabei ist der Hinterrand der Vorderflügel und ein grosser Theil der Hinterflügel grau bereift.

Noch bedeutender ist der Unterschied der Geschlechter bei Per e u t e Ch a rops; Das Roth der Oberseite der Vorderflügel ist beim Weibchen ${ }^{1}$ ) dunkler, lebhafter und über eine grössere Fläche verbreitet, als bei Pereute Swainsonii, beim Männchen ${ }^{2}$ ) dagegen völlig verschwunden.

Nach Wallace soll nun ,bei all den wenigen Arten von Pieriden, bei denen die Weibchen auffallender gefärbt sind als die Männchen, das Weibchen

I) Bois Duval, Spec. général des Lépidopt. I. I836. Pl. I8. Fig. I.

2) Doubleday, Hewitson, Genera of diurnal Lepidopt. Pl. 5. Fig. 2 (Euterpe inarina). 
irgend eine andere geschützte Art derselben (regend nachahmen" ${ }^{1}$ ). Hier indessen haben wir keinen anderen, der Pereute Swainsonii auch nur entfernt ähnlichen Schmetterling. Sollte nun in diesem Falle die lebhaftere Färbung der Weibchen nicht ebenso auf Rechnung geschlechtlicher Auswahl gesetzt werden dürfen, wie sonst der reichere Farbenschmuck der Männchen?

Mehr als einmal habe ich mich überzeugen können, dass selbst bei Sclımetterlingen, deren Männchen an Zahl überwiegen, diese doch nicht blind und ohne Wahl auf jedes beliebige Weibchen losstürzen, das sich ihnen bietet. Ich sah oft, wie ein von einem Männchen umflattertes Weibchen erwartungsvoll seine Flügel ausbreitete und den Hinterleib hob, und wie dann das Männchen noch einige Mal um das Weibchen herum und darauf plötzlich davon flog, während das Weibchen noch längere Zeit in seiner wartenden Stellung verharrte. Um so wählerischer werden aber die Männchen sein dürfen, je geringer ihre Zahl ist. Und bei Pereute scheinen sie bei weitem seltener zu sein als die Weibchen. Bois Duval kannte von P. Charops nur Weibchen, und wenigstens hier und in diesem Jahre dürfte kaum ein Männchen auf 5 bis 6 Weibchen von Pereute Swainsoni kommen.

Fasst man die lebhaftere Färbung der Weibchen der letzteren Art auf als Ergebniss einer von den Männchen geübten Wahl, so erklärt sich auch, weshalb hier gegen die Regel die Unterseite die schönere ist. IVird ein Schmetterlingsweibchen von werbenden Männchen umflattert, so bietet die von der Sonne bestrahlte Oberseite der Flügel letzteren die bequemste Stelle zur Schaustellung glänzender Farben; das mit zusammengeschlagenen Flügeln sitzende Weibchen zeigt dagegen den Augen der Männchen nur deren Unterseite.

Uebrigens fehlt auch dem Männchen der Pereute Swainsonii nicht ein seinem Geschlechte eigenthümlicher Reiz; es trägt auf der Oberseite der Flügel sehr zahlreiche, hoch entwickelte, d. h. von gewöhnlichen Schuppen weit abweichende Duftschuppen, durch deren Gestalt dieser schwarze Falter sich sofort als „Weissling“ ausweist.

1) Da rwin, Descent of Man, 187I, I. p. 4I3. 


\title{
Beobachtungen an brasilianischen Schmetterlingen ${ }^{1}$ ).
}

III. $\left.{ }^{2}\right)$

\author{
5. Acraea und die Maracujáfalter als Raupen, Puppen und Schmetterlinge.
}

Mit 4 Textfiguren.

In einer gedankenreichen Abhandlung, „über den phyletischen Parallelismus bei metamorphischen Arten" hat Weismann ${ }^{3}$ ) für die Schmetterlinge nachgewiesen, dass deren Entwicklungsstufen, Raupe, Puppe und Schmetterling, sich selbständig verändern, dass die auf einer Stufe eingetretene Aenderung ohne Einfluss bleibt auf die vorhergehende und folgende Stufe, dass demnach die Wege, auf welchen die einzelnen Stufen im laufe der Stammesgeschichte sich heranbildeten, keineswegs immer gleichlaufend waren. Dieser Mangel an Uebereinstimmung kann sich kund geben sowohl in ungleichen Abständen der Formverwandtschaft, als in ungleicher Gruppenbildung. In Betreff der ungleichen Abstände sind bald die Raupen einander ähnlicher, formverwandter, als die aus ihnen hervorgehenden Schmetterlinge, bald umgekehrt. In Betreff der ungleichen Gruppenbildung kann wieder ein doppelter Fall eintreten: Raupen und Schmetterlinge bilden ungleichwerthige Gruppen, der eine Theil bildet Gruppen höherer oder niederer Art, - oder sie bilden ungleichgrosse und daher einander nicht deckende, übereinandergreifende Gruppen. Formverwandtschaft und Blutsverwandtschaft fallen also nicht immer zusammen; nach der Aehnlichkeit der Raupen würde man eine ganz andere Anordnung erhalten, als nach der Aehnlichkeit der Schmetterlinge und wahrscheinlich würde keine der beiden der wirklichen Verwandtschaft entsprechen.

Aus diesem in zahlreichen Beispielen dargelegten Thatbestande folgert Weismann, und begründet eingehend und überzeugend diese seine Ansicht, dass eine innere treibende Entwicklungs- oder Umwandlungskraft, wie sie unter mancherlei Namen von verschiedenen Anhängern der Entwicklungslehre angenommen wird, nicht bestehe, dass vielmehr alle Wandlungen und Fortschritte der Arten durch äussere Anstösse hervorgerufen werden. - Ein recht hübsches

I) Kosmos $1877 / 78$. Bd. II. S. $218-224$.

2) Vergl. Kosmos. Bd. I S. $3^{88}$ u. Bd. II S. 38. = Ges. Schriften S. 585 u. 593.

3) Weismann, Studien zur Descendenztheorie II. 1876. S. 139. 
Beispiel für den Mangel an „phyletischem Parallelismus,“ wie es Weismann nennt, zu deutsch für die verschiedene Formverwandtschaft der Raupen, Puppen und Schmetterlinge bieten die fünf Gattungen Acraea, Helic onius, Eueides, Colaenis und Dione (=Agraulis). Der Mittheilung werth scheint mir dieses Beispiel besonders deshalb, weil hier der seltnere Fall eintritt, dass die Puppen es sind, welche grössere Verschiedenheit zeigen, als Raupen und Schmetterlinge.

Die Arten, deren Raupen und Puppen ich beobachtete, sind Acraea Thalia und Alalia, Heliconius Eucrate, Eucides Isabella, Colaenis Dido und Julia, Dione Vanillae und Juno; ausserdem sah ich die Puppe von Eueides Aliphera. Zunächst nur auf diese Arten bezieht sich das Folgende, wenn auch mit grosser Wahrscheinlichkeit vorausgesetzt werden darf, dass sich, - die weit über die Welt verstreuten Arten von Acraca vielleicht ausgenommen, - sämmtliche Gattungsgenossen ihren hiesigen Vertretern ähnlich verhalten werden.

Als Falter bilden die genannten fünf Gattungen zwei scharf geschiedene Familien, die der Acraeinen und die der Maracujáfalter. In letzterer sind die drei Gattungen Heliconius, Eueides und Colaenis nur durch sehr unerhebliche Merkmale geschieden; von Heliconius unterscheidet sich E u eides durch kürzere Fühler, von dieser Gattung Cola en is durch offene Mittelzelle der Hinterflügel. Weiter entfernt sich durch abweichende Bildung der Füsse und die Silberflecke auf der Unterseite der Flügel die Gattung Dione. Höchst auffallender Weise sind in Farbe, Zeichnung und selbst Schnitt der Flügel, einzelne Arten denen anderer Gattungen weit ähnlicher, als ihren eigenen Gattungsgenossen. So sind Acraea Thalia und Eueides Pavana, so wieder Heliconius Eucrate und Eueides Isabella, so ferner Eueides Aliphera und Colae$\mathrm{n}$ is Julia einander täuschend ähnlich und letzteren beiden schliesst sich, wenigstens für die Oberseite der Flügel, Dione Juno an. Ein sicheres Urtheil über die Verwandtschaft der einzelnen Arten wird dadurch erschwert; denn es ist nicht zu sagen, wie viel man bei dieser Aehnlichkeit auf Rechnung der Blutsverwandtschaft, wie viel etwa auf Rechnung täuschender Nachahmung zu setzen habe.

Als Raupen würde man alle hiesigen Arten in eine einzige Gattung stellen müssen; so genau stimmen sie überein in Zahl und Anordnung ihrer Dornen. (Je 4 Dornen, nicht in Querreihe, auf 2. und 3., je 6 Dornen in Querreihe, auf 4. bis 11., und 4 Dornen, nicht in Querreihe, auf dem letzten, I 2. Leibesringe.) Sie sind hierin viel weniger von einander verschieden, als die deutschen Arten der Gattung Vanessa, als z. B. Tagpfauenauge (V. Jo) oder Trauermantel (V. Antiopa) vom grossen und kleinen Fuchse und Admiral (V. Polychloros, Urticae, Atalanta) ${ }^{1}$ ). Allerdings fehlen den Raupen von Acraea Thalia die beiden Dornen des Kopfes, welche die anderen besitzen, und umgekehrt haben sie ein wohlentwickeltes Dornenpaar auf dem ersten Leibesringe, welches den meisten anderen vollständig fehlt; allein dies berechtigt nicht zu einer Trennung; denn die bei Heliconius, Eueides und Colaenis Dido durch Länge ausgezeichneten Dornen des Kopfes sind schon kürzer, als die der nächsten Leibes-

I) We is $m$ a $n n$, a. a. O. S. 178 . 
ringe bei Colaenis Julia und Dione Vanillae und verkümmern zu zwei winzigen Spitzen bei Dione Juno, bei welcher ausserdem der erste leeibesring ein kurzes Dornenpaar trägt. Es steht also die Raupe der Dione Juno derjenigen von A craea Thalia ebenso nahe als derjenigen ihrer Gattungsgenossen I) ione Vanillae.

Wollte man je zwei rerschiedene Raupengruppen bilden, so würde dies geschehen können nicht auf Grund ihrer Formverschiedenheit, wohl aber auf Grund ihrer Nahrungspflanzen. Die Raupen von Heliconius, Eucides, Colaenis und Dione leben auf Arten ron Maracujá (Passiflora), die von Acraea Thalia und Alalia auf Compositen (Mik ania und Vernonia). Diese Raupengruppen würden zusammenfallen mit den aus der Formverwandtschaft der Falter sich ergebenden; sie würden aber immerhin kaum den Werth von f at tungen, nicht wie die der Falter den von Familien beanspruchen können.

Ordnet man die einzelnen Raupenarten nach ihrer Achnlichkeit, so fällt, auch abgesehen von dem verschiedenen Werthe der Gruppen, diese Anordnung nicht zusammen mit der auf die Aehnlichkeit der Falter begründeten. Es ergiebt sich etwa Folgendes:

Falter.

(Nymphaliden mit unten behaarten Flügeladern.)

(Familien :)

Maracujáfalter

(Gattungen:)

Arten :)

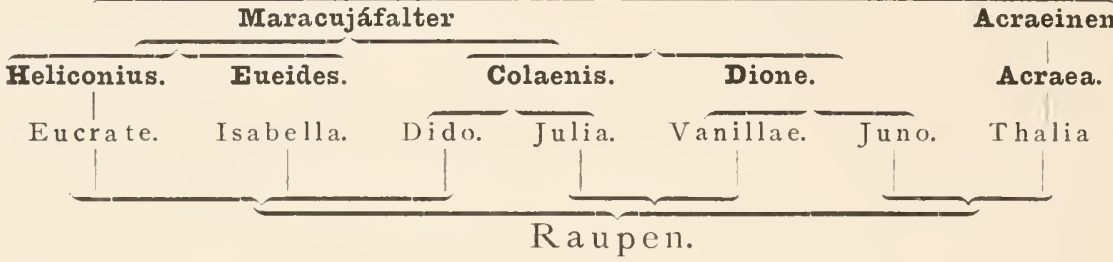

Die Raupen von Eucrate, Isabella und Dido sind in ihrer ganzen Erscheinung so ähnlich, dass man sic für verschiedenfarbige Formen derselben Art halten könnte; sie sind lebhaft gefärbt und sitzen einzeln auf der Oberseite der Blätter. Die Raupen von J uno und Thalia leben gesellig; sic sind braun oder bräunlich; die Dornen des Kopfes sind verkümmert oder fehlen ganz, bei J'u no sind überhaupt alle Dornen so kurz, dass sie sich dadurch im Ansehen noch mehr als selbst Thalia von den übrigen Arten entfernt. Den Raupen von Julia und Vanillae fehlen ebenfalls grelle Farben; sie leben einzeln und halten sich, soviel ich mich entsinne, stets an der Unterseite der Blätter. Der Formabstand der Raupen dürfte kaum ihrer Blutsverwandtschaft entsprechen; vielmehr scheint er, wenigstens was die Färbung betrifft, in Zusammenhang zu stehen mit der verschiedenen Lebensweise. Wie die Falter, so haben auch dic Raupen beim Zerdrücken einen widerlichen Geruch, der sie gewiss für manche Raupenfresser ungeniessbar macht. Geschützt vor solchen Feinden werden sie aber nur sein (worauf Wallace aufmerksam machte), wenn diese sie rechtzeitig und nicht erst nach dem Anbeissen als ungeniessbar erkennen. Leben die Raupen in solcher Menge beisammen, wie es bei Acraea Thalia und Dione Juno der Fall zu sein pflegt, so wird schon der Geruch nahende Feinde abschrecken; die einzeln lebende Raupe wird geschützt sein, wenn sie durch grelle Farben weithin sich kenntlich macht, wie die weisse, schwarzpunktirte und schwarzbedornte Raupe von Heliconius Eucrate, die schwarzbedornte auf blassem Grunde brennend 
roth und schwarz gezeichnete Raupe von Colaenis Dido und die ebenfalls bunte Raupe von Eueides Isabella. Wie augenfällig diese Raupen sind, bewies mir noch dieser Tage meine Tochter Selma, die mir eine kaum halbwüchsige Raupe von Heliconius Eucrate heimbrachte, welche sie bei ziemlich raschem Vorbeireiten auf einem Maracujáblatte hatte sitzen sehen. Fehlt der einzeln lebenden Raupe lebhafte Färbung als „Widrigkeitszeichen" (WV eis mann), so muss sie sich verstecken, wie die von Colaenis Julia und Dione Vanillae. Die Bedornung ist wohl weniger ein Schutz gegen Vögel, als gegen kleinere Feinde; auch sie mag bei den massenhaft zusammenlebenden, einen selbst den Menschen anwidernden Dunst un sich verbreitenden Raupen von Dione J uno überflüssig geworden und daher allmäliger Verkümmerung anheimgefallen sein. Aehnliche Beispiele nahe verwandter Raupen, von denen die einen gesellig, die andern einzeln leben, finden sich auch sonst unter den Tagfaltern; so leben die Raupen von Morpho und Brassolis gesellig, die von Opsiphanes und Caligo einzeln; so die Raupen von Papilio Pompeius gesellig, die von Papilio Nephalion, Polydamas, Thoas u. s. w. einzeln. Und auch in diesen Fällen scheint sich die Formverwandtschaft der Raupen mehr nach ihrer Lebensweise, als nach ihrer Blutsierwandtschaft zu richten, falls nämlich, - und dabei darf man ein grosses Fragezeichen nicht unterdrücken -, letztere in der jetzt üblichen Anordnung der Falter richtig wiedergegeben ist. So sind die geselligen Raupen von Brassolis denen von Morpho bei weitem ähnlicher, als den einzeln lebenden ihrer Familiengenossen Opsiphanes und Caligo

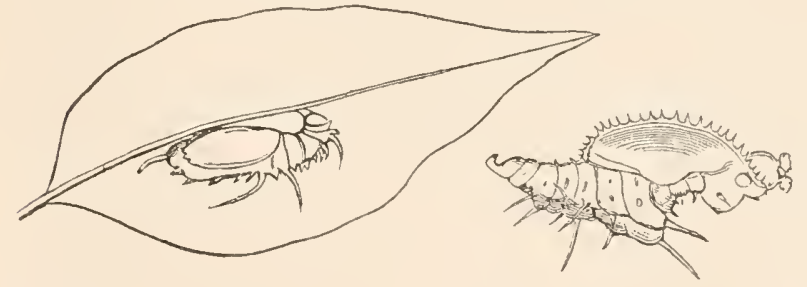

Fig. I.

Fig. 2.

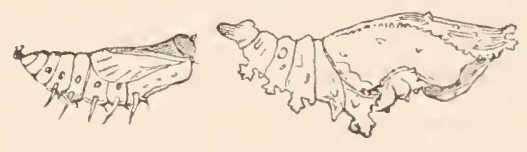

Fig. 3
Fig. 4.

Fig. I-4. Puppen von Acraea Thalia; Heliconius Eucrate; Eueides Isabella und Colaenis Dido in natürlicher Grösse.

Wie erheblich im Vergleich zu der engen Formverwandtschaft aller Maracujáfalter und der nicht minder grossen Aehnlichkeit ihrer Raupen die Verschiedenheit ihrer Puppen sei, zeigt ein Blick auf die vorstehenden Umrisse der Puppen von Heliconius Eucrate (Fig. 2.), Eueides Isabella (Fig. 3) und Colaenis Dido (Fig. 4). Eine Familie, welche diese drei so ungleichen Puppen umfasste, würde auch Raum haben für die der Acraea Thalia (Fig. I).

Die Puppe der letztgenannten Art hat in ihrer Gesammtform nichts Auffälliges, vielmehr eine ganz gewöhnliche Puppengestalt; sie ist ziemlich drehrund, ohne tief ein- oder vorspringende Buchten, Höcker oder I,eisten; ein winziges Spitzchen steht am Kopfe auf jeder Augendecke, ein ähnliches an der Flügelwurzel. Was sie auszeichnet, sind fünf Paar Dornen auf dem Rücken des Hinterleibes. Dieselben finden sich auch bei Acraea Alalia, scheinen aber anderen Arten, z. B. der indischen 
A. Violae, zu fehlen. - Im vorigen Sommer traf ich unter einigen Gesellschaften ron Thalia-Raupen, jede aus Kindern derselben Mutter bestehend, einzelne, die durch viel kürzere Dornen vor ihren Geschwistern sich auszeichneten und sich in Puppen verwandelten, deren fünf Dornenpaare in gleichem Verhältniss kürzer waren, als gewöhnlich, - eine Ausnahme von dem Satze, dass Aenderungen der einen Entwickelungsstufe ohne Einfluss bleiben auf die übrigen. Auf Schmetterling und Puppe kann überhaupt, beiläufig bemerkt, dieser von We ismann aufgestellte Satz nur in beschränkter Weise Anwendung finden. Die Haut der Puppen bildet Scheiden oder Decken für Augen, Fühler, Rüssel, Beine, Flügel des Schmetterlings, und sobald diese Theile beim Schmetterlinge erhebliche Aenderungen erfahren, werden entsprechende Aenderungen bei der Puppe eintreten müssen, wie denn z. B. der ungewöhnlich lange Rüssel mancher Dickköpfe (Hesperiden) eine das Hinterleibsende der Puppe weit überragende Rüsselscheide bedingt. - Die Farbe der Puppe ron Acraea Thalia ist weisslich, die Flügeladern, einige andere Zeichnungen und die Dornen sind schwarz; metallglänzende Spiegelflecke fehlen ihr.

Bei der Puppe von Heliconius Eucrate springt die seitlich zusammengredrückte Flügelgegend stark nach unten vor: die am Flügelrande hin liegenden Fühlerscheiden sind den Fühlergliedern entsprechend sägeartig mit kurzen spitzen Dornen besetzt; statt der winzigen Spitzen von Acraea Thalia trägt der Kopf zwei ansehnliche höckrige Vorsprünge; der Hinterleib erhebt sich jederseits zu einer blattförmigen, nach oben vorspringenden Leiste, die mit fünf Dornen von verschiedener Länge besetzt ist; das vorderste kopfwärts gerichtete Dornenpaar ist das längste. - Die Puppe ist braun und geziert durch vier Paar lebhaft metallglänzender Spiegelflecken, ein Paar dicht hinter den Fühlern, drei Paar, fast zusammenfliessend, auf dem Rücken vor dem längsten Dornenpaare. In der Mitte jedes dieser letzteren etwas gewölbten Spiegelflecken steht ein kleiner Dorn.

Bei der Puppe von Colaenis Dido (welcher die von Colaenis Julia ähnlich ist und an welche auch die von Dione Vanillae und Juno sich anschliessen), fehlen die Dornen, die Flügelgegend ist nur mässig bauchwärts gewölbt, die Fühlerglieder sind nur durch kleine Höcker bezeichnet; statt der blattartigen Leisten trägt der Hinterleib an der Seite des Rückens rechts und links je fünf knorrige oder höckrige Vorsprünge. Spiegelflecken sind in gleicher Zahl und Lage vorhanden, wie bei Heliconius Eucrate; die des Rückens haben statt eines Dornes einen warzenförmigen Vorsprung in der Mitte.

Die Puppen von Heliconius und Colaenis erzeugen, wenn sie sich lebhaft bewegen, und das tun sie bei jeder Störung, durch Reibung der Hinterleibsringe ein namentlich bei Heliconius Eucrate sehr vernehmliches zischendes Geräusch, das vielleicht kleinere Feinde verscheuchen mag. (Sehr laut, so dass meine Kinder sie Schreipuppen nannten, ist das auf diese Weise erzeugte Geräusch bei den Puppen der Epicalia Numilia.)

Sind nun schon bei Heliconius und Colaenis die Puppen viel verschiedener, als die Falter oder Raupen, so gilt dies in noch weit höherem Grade für Eueides im Vergleich mit seinen eben genannten Verwandten. Die Raupen von Eueides haben nichts ihnen Eigentühmliches, auch für die Falter liesse sich ihre Berechtigung, eine eigene Gattung zu bilden, in Zweifel ziehen; als Puppen dagegen 
entfernen sie sich weit - schon durch die Art, wie sie sich aufhängen, - nicht nur von den übrigen Maracujáfaltern, nicht nur von der ganzen grossen Gruppe der Nymphaliden (Danainen, Satyrinen, Elymniinen, Brassolinen, Morphinen, Acraeinen, Maracujáfalter und Nymphalinen umfassend), sondern fast von allen andern Schmetterlingen. Die Raupe setzt sich zur Verpuppung an die Unterseite eines Blattes; die Puppe ist mit dem Hinterende befestigt, hängt aber nicht nach unten, wie die anderen Nymphaliden, sondern ihre letzten Ringe sind so gekrümmt, dass sich die Bauchseite der Puppe der unteren Blattfläche anlegt. Ich kenne unter den nicht gleichzeitig durch einen Gürtel befestigten Puppen keine, die eine solche Stellung annähme; doch scheint etwas ähnliches vorzukommen bei Stalachtis. deren gürtellose Puppe nach Bates „durch die Befestigung am Hinterende in geneigter Stellung erhalten" wird. Bates unterschied durch diese Eigenthümlichkeit die Stalachtinen von den Libytheinen mit ,frei am Hinterende aufgehängter" Puppe.

Ausser durch diese so ganz eigenartige Haltung ihres Leibes ist die Puppe von Eueides Isabella ausgezeichnet durch kürzere hakenartige und längere schmal säbelförmige paarige Fortsätze an Rücken und Kopf. Ihre Farbe ist weisslich, gelblich, auch wohl schmutzig gelblich grau; in letzterem Falle bleiben die vier langen Fortsätze des Rückens, sowie ihre Umgebung und die Spitzen der übrigen Fortsätze weiss oder gelblich. Die Puppe von Eueides Aliphera ist ganz ähnlich, nur sind alle Fortsätze etwas kürzer, die vier langen Fortsätze des Rückens und einige andere Zeichnungen sind schwarz.

Wenn nun, wie Weismann für Raupen und Schmetterlinge nachzuweisen sucht, „der Formabstand stets genau dem Abstande der Lebensweise" entspricht, so legt sich die Frage nahe, welche Verschiedenheit der Lebensverhältnisse den so erheblichen Formabstand zwischen den Puppen so eng verwandter Schmetterlinge, wie die Maracujáfalter es sind, bedingt haben möge. Bei Puppen, die weder essen noch trinken, weder der Liebe nachgehen, noch für Brut zu sorgen haben, kann es sich dabei nur um Schutz vor Feinden handeln. Sollten aber für Puppen nächstverwandter Arten, deren Raupen von nächstverwandten Pflanzen sich nähren, im gleichen Lande, zur gleichen Jahreszeit, die sie bedrohenden Feinde je so verschieden gewesen sein, um so erhebliche Formabstände hervorzurufen? Man darf wohl die Frage mit ziemlicher Zuversicht verneinen und in diesem Falle die Verschiedenheit der Puppen nicht aus dem "Abstande in der Lebensweise“, nicht aus der Verschiedenheit der äusseren Verhältnisse, sondernn daraus ableiten, dass zufällig d. h. in Folge irgend welcher glücklichen, durch irgend welchen äusseren Anstoss veranlassten Abänderung, die einen in einer, die anderen in anderer Weise vor den gemeinsamen Feinden Schutz fanden und, in der einmal eingeschlagenen Richtung durch natürliche Auslese weitergeführt, zuletzt an jetzt so weit auseinanderliegenden Puncten anlangten. Wie nun für die eine oder andere Art die Besonderheiten ihrer Gestalt oder Farbe als Schutz wirksam sein mögen, darauf muss ich die Antwort schuldig bleiben. Nur in Betreff der Puppe von Eueides Isabella will ich mir eine Vermuthung erlauben. Dass sie nicht grün ist, wie andere im Laube hängende Puppen (Siderone, Epicalia, Callidryas u. s. w.) zu sein pflegen, dass ihre Farbe mehr oder minder grell absticht von dem dunklen Grün der Blätter, verbietet an Verstecken zu clenken; dabei ist aber doch ihre 
Farbe zu matt, zu wenig glänzend, um als weithin auffallendes „Widrigkeitszeichen" zu dienen. In beiden Fällen würden zudem die wunderlichen Fortsätze der Puppe unerklärt bleiben.

So kommt man durch Ausschluss anderer Möglichkeiten auf den Gedanken an "Mimicry“, an durch Täuschung des Feindes schützende Aehnlichkeit. Aber Aehnlichkeit womit? - Nicht selten trifft man an Blättern todte, von Pilzen durchwucherte Insecten, aus deren Leibe die weisslichen oder gelblichen Pilze in allerlei wunderlichen Gestalten hervorsprossen. Diese Insecten bilden natürlich keine lockende Beute mehr. An solche Pilzbildungen könnten die Fortsätze der EueidesPuppe erinnern. Allerdings möchte ich nicht behaupten, dass für uns in vollem Lichte die Aehnlichkeit eine täuschende sei. Allein die Puppe hängt im Schatten des Blattes, auch geringere Aehnlichkeit wird minder scharfsichtige und aufmerksame Feinde irre leiten können, und auch die täuschendste Nachahmung hat ja mit minder vollkommenen Graden der Aehnlichkeit beginnen müssen. 


\title{
Der Rückschlag bei Kreuzung weit abweichender Formen ${ }^{1}$.
}

\author{
Mit I Textfigur.
}

„Eine mechanische Theorie der Vererbung müsste zeigen können, dass die Plastidulbewegungen der männlichen und der weiblichen Keimzelle bei ihrem Zusammentreffen in dem Falle der Kreuzung weit abweichender Formen sich gegenseitig so modificiren, dass als Resultante die Bewegungsart der gemeinsamen Stammform daraus hervorgehen muss."

So W e is m a n n ${ }^{2}$ ) bei Besprechung von II ä c k e l's „Perigenesis der Plastidule“, in welcher Schrift Letzterer bekanntlich eine „mechanische Erklärung der elementaren Entwickelungs-Vorgänge“ zu geben versucht.

Die Richtigkeit der Anschauungen vorausgesetzt, in welchen in Betreff der Vererbung Weismann und Häckel sich begegnen, dürfte es nicht schwer sein, die verlangte Erklärung des bei Kreuzungen auftretenden Rückschlages auf mathematischem Wege zu geben und nachzuweisen, dass gerade ein um so auffallenderer Rückschlag zu erwarten ist, in je abweichenderer Richtung sich die Eltern von ihrer gemeinsamen Stammform entfernt haben.

Iören wir zunächst, was uns die beiden genannten Forscher über Vererbung sagen.

Weismann denkt sich die Vererbungsfähigkeit so, „dass dem Keim des Organismus durch die Mischung seiner Bestandtheile eine ganz bestimmte Entwickelungsrichtung mitgetheilt wird, diesclbe Entwickelungsrichtung, wic sie der elterliche Organismus zu Anfang besessen hat". Die „durch Vererbung übertragene Entwickelungsrichtung“ wird aber stets durch äussere Einflüsse „bald hierhin, bald dorthin ein wenig abgelenkt", und das Kind den Eltern deshalb nie völlig gleich. „Die Variabilität ist nichts Anderes, als die Resultantr aus der ererbten Entwickelungsrichtung und den äusseren Einflüssen“" ${ }^{3}$ ).

Nach Häckel setzt sich die Lebensbewegung jeder späteren Plastide, also überhaupt jedes späteren Organismus, — „zusammen einerseits aus der über-

1) Kosmos Bd. II. I877/1878. p. 57-59.

2) We isman $n$, Studien zur Descendenz-Theorie. II. Leipzig I 876 . S. 299.

3) Weismann, Ueber die Berechtigung der Darwin'schen Theorie. Leipzig 1863. S. 24-25. 
wiegenden Reihe der alten Plastidul-Bewegungen, welche durch Vererbung getreu von Generation zu Generation sich erhalten haben, andrerseits aus einem geringen Antheil von neuen Plastidul-Bewegungen, welche durch Anpassung erworben wurden" (Perigenesis, S. 4i). Die individuelle Plastidul-Bewegung, welche der ersten Plastide eines auf geschlechtlichem Wege erzeugten Organismus inne wohnt und dessen "ganze weitere Entwickelung bedingt", ist „die Resultante aus den beiden verschiedenen Plastidul-Bewegungen der weiblichen Ei-Plastide und der männlichen Sperma-Plastide. Wenn wir letztere als die beiden Seiten eines Parallelogramms der Kräfte betrachten, so ist die Plastidul-Bewegung der Monerula und der daraus hervorgehenden Cytula deren Diagonale" (Perigenesis, S. 53). Oder kürzer: „Die kindliche Lebensbewegung ist die Diagonale zwischen der mütterlichen und der väterlichen Lebensbewegung“ (Perigenesis, S. 54).

Ich lasse dahin gestellt, ob man berechtigt ist, auf diese unendlich verwickelten Verhältnisse den Satz vom Parallelogramm der Kräfte anzuwenden. Ich bezweifle es und fürchte, dass man dadurch nicht mehr als den täuschenden Schein einer ,mechanischen Theorie" erhalten werde. Doch die Berechtigung zu gegeben, so würde man in folgender Weise das Ergebniss einer geschlechtlichen Zeugung veranschaulichen können.

Durch den Anfangspunkt o eines rechtwinkligen Coordinatensystems, dessen Achse der $x$ die Entwickelungsrichtung der den Eltern gemeinsamen Stammform bezeichnen möge, lege man zwei Gerade, on und ov, deren Richtung die Ent-

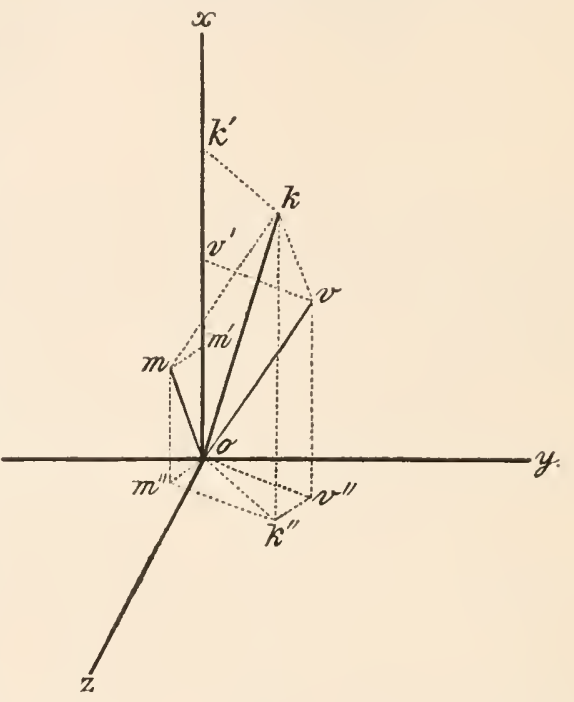
wickelungsrichtung der mütterlichen und der väterlichen Keimzelle darstellen möge. Ausser dieser Entwickelungsrichtung kommt beim Ergebnis der geschlechtlichen Zeugung noch in Betracht, mit welcher Kraft das eine oder andere Geschlecht seine Eigenthümlichkeiten überträgt (,prepotency of transmission“ Darıin). Diese Stärke der Uebertragung werde durch die verschiedene Länge der Geraden om und ov ausgedrückt.

Jede der beiden elterlichen, durch die Keimzelle übertragenen Entwickelungsrichtungen ist nun die Resultante aus der weit überwiegenden Entwickelungsrichtung der gemeinsamen Stammform und aus den, seit der Trennung von den Stammformen erfahrenen Ablenkungen. Wir zerlegen also sowohl om als ov in diese beiden Componenten. Die stammelterliche Entwickelungsrichtung wird dargestellt werden durch die Projektionen om' und ov' der Geraden om und ov auf die Achse der x, die Ablenkung durch die darauf senkrechten Projektionen om" und ov" derselben Gerade auf die Ebene der yz. Da bei Formen, zwischen denen überhaupt fruchtbare Vereinigung möglich sein soll, die erworbene Verschiedenheit gegen die ererbte Uebereinstimmung ïusserst unbedeutend ist, so sind mox und vox stets sehr spitze Winkel. 
Zeichnet man nun die kindliche Resultante ok und zerlegt auch sie in die beiden Componenten ok', welche die von der gemeinsamen Stammform der Eltern ererbte Entwickelungsrichtung, und ok", welche die Ablenkung von dieser Richtung darstellt, so ist in allen Fällen, da mox und vox spit» Winkel sind, ok' $=\mathrm{om}^{\prime}$ +ov', d. h. es summirt sich im Kinde, was die Eltern von gemeinsamen Vorfahren ererbten. Dagegen ist

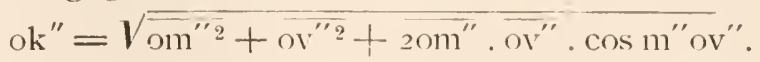

Also nur wenn der Winkel $\mathrm{m}^{\prime \prime} \mathrm{ov}$ " $=\mathrm{o}$ ist, $\mathrm{d}$. h. wenn om und ov in derselben Ebene mit der Achse ox auf derselben Seite dieser Achse liegen, oder mit anderen Worten, wenn Vater und Mutter sich in genau gleicher Richtung, wenn auch verschieden weit von der Stammform entfernt haben, wird $n k^{\prime \prime}=\mathrm{om}^{\prime \prime}$ +ov" sein. Nur in diesem Falle wird keinerlei Rückschlag eintreten; es wird das Verhältniss der stammväterlichen Richtung zur Ablenkung genau dasselbe sein bei dem Kinde, wie es durchschnittlich bei den Eltern war.

$$
\mathrm{ok}^{\prime}: \mathrm{ok}^{\prime \prime}=\frac{\mathrm{om}^{\prime}+\mathrm{ov}^{\prime}}{2}: \frac{\mathrm{om}^{\prime \prime}+\mathrm{ov}^{\prime \prime}}{2}
$$

In allen anderen Fällen ist

$$
o k^{\prime \prime}=1 \overline{\mathrm{om}^{\prime \prime 2}+\overline{\mathrm{ov}^{\prime \prime 2}}+2 \mathrm{om}^{\prime \prime} \cdot \mathrm{ov}^{\prime \prime} \cdot \cos \mathrm{m}^{\prime \prime} \mathrm{ov} \mathrm{v}^{\prime \prime}}<\overline{\mathrm{om}^{\prime \prime}+\mathrm{ov}^{\prime \prime}}
$$

oder

$$
\mathrm{ok}^{\prime}: \mathrm{ok}^{\prime \prime}>\frac{\mathrm{om}^{\prime}+\mathrm{ov}^{\prime}}{2}: \frac{\mathrm{om}^{\prime \prime}+\mathrm{ov}^{\prime \prime}}{2} .
$$

In allen anderen Fällen also ist das Verhältniss der stammväterlichen Entwickelungsrichtung zur Ablenkung grösser beim Kinde, als es durchschnittlich bei den Eltern war, und zwar um so grösser, je grösser der Winkel m"ov" ist, welcher die Verschiedenheit der Richtungen ausdrückt, in denen sich die Eltern von ihrer gemeinsamen Stammform entfernten. So oft demnach Vater und Mutter sich nicht in genau derselben Richtung von der Stammform entfernten, wird das Kind dieser Stammform ähnlicher sein, als es durchschnittlich die Eltern waren, und zwar wird der Rückschlag um so beträchtlicher sein, nicht je ferner die Eltern einander oder der Stammform stehen, sondern in je abweichenderen Richtungen sie sich von letzterer entfernt haben.

Itajahy, Mai 1877. 


\section{Der sprachlose Urmensch und die Sprachlosigkeit der Kinder ${ }^{1}$ ).}

Auf Grund des Satzes, den er auf die geistige Entwicklungsgeschichte der Menschheit ausdehnt, dass „die Ontogenie die abgekürzte Wiederholung der Phylogenie" ist, betrachtet Hellwald (s. Kosmos I. S. 325 u. fgde.) die Sprachlosigkeit der Kinder als einen der schlagendsten Beweise für das einstige Bestehen sprachloser Urmenschen.

Ich bezweifle die Stichhaltigkeit dieses Beweises.

Nicht dass ich Bedenken hätte gegen die für jeden Anhänger der Entwicklungslehre unabweisliche Annahme des sprachlosen Urmenschen, den ich sogar für einen wirklichen, in seinem Gliederbau kaum von uns verschiedenen Menschen, nicht aber, wie Hellwald, für ein auf allen Vieren kriechendes Menschenthier halte. Ebensowenig bestreite ich die Richtigkeit des Satzes, dass in gewissen Fällen "die geschichtliche Entwicklung der Art sich abspiegelt in deren Entwicklungsgeschichte“, eines Satzes, den ich ja selbst zuerst bestimmter und unter Hervorhebung der nothwendigen Einschränkungen formulirt habe. Was ich bezweifle, ist nur die Anwendbarkeit dieses Satzes auf den vorliegenden Fall.

Wer aus der in der Keimesgeschichte erhaltenen Urkunde die Stammesgeschichte einer $\Lambda$ rt zu entziffern unternimmt, stösst nur zu häufig auf Punkte, bei denen er mit Feuerbach's biblischem Theologen ausrufen möchte:

„Dieses Punktum entscheidet, doch ach, s' ist nicht zu erkennen,

$\mathrm{Ob}$ es ein Fliegensch ..., oder ein Gottesdictat."

Ich fürchte, was Hellwald für ursprünglichen Text, für Gottesdictat genommen, die Hilflosigkeit, Geistlosigkeit und die dadurch bedingte Sprachlosigkeit unserer Kinder, dürfte sich bei näherer Betrachtung einfach als - ganz etwas Anderes ausweisen.

Nur in äusserst seltenen Fällen wird überhaupt eine leidlich treue und vollständige Erhaltung der Stammesgeschichte in der Jugendgeschichte erwartet werden dürfen und nur mit äusserster Vorsicht und Umsicht sollte man claher letztere bei Feststellung der ersteren benutzen. - Nehmen wir an, die Jugendgeschichte einer Art wiederhole treu und vollständig deren geschichtliche Entwicklung. Welche Aussicht wäre vorhanden, dass sie sich dauernd so erhalte?

I) Kosmos 1877/78. Bd. II. S. 458-460. Dort (S. 453) findet sich eine Arbeit mit dem Titel „Zum Sprachenursprung“, deren erster Teil von Professor Dr. G. Jäger stammt; diesem ist von der Redaktion des Kosmos die obentsehende Mitteilung Fritz Müllers als zweiter Teil beigefügt. 
Abgesehen von dem ,allmäligen Verklingen der Urgeschichte“ und von jenem Zurückweichen später erworbener Zustände in frühere Lebenszeit, für welches kürzlich Weismann in seiner vortrefflichen Abhandlung über die Schwärmerraupen so schlagende Beispiele gegeben hat, würde bald, welches auch die Lebensverhältnisse der Jungen sein mögen, eine mehr oder minder tiefgreifende $\mathrm{Ab}$ änderung der Jugendformen eintreten und so durch spätere Zuthat die geschichtliche Urkunde unzuverlässig werden.

Entwveder nämlich, und darauf ist bereits von mir und Anderen vielfach hingewiesen worden, würden die Jungen für sich selbst zu sorgen haben, und dann würde auf sie „der Kampf ums Dasein und die damit verbundene natürliche Auslese in gleicher Weise verändernd und fortbildend wirken, wie auf erwachsene Thiere."

Oder aber die Jungen würden vor dem Kampfe ums Dasein und dessen umgestaltender Macht durch die Brutpflege der Alten mehr oder weniger vollständig geschützt, und dann würden sie einer Rückbildung und Verkümmerung verfallen, wie wir sie in ähnlicher Weise und durch ähnliche Ursacheu bedingt bei Schmarotzern zu finden pflegen. Da diese letztere Ursache der Fälschung oder, falls man an dem Worte Anstoss nehmen sollte, der Abänderung des ursprünglichen Entwicklungsverlaufes bisher wenig Beachtung gefunden zu haben scheint, darf ich wohl noch einmal an einige bereits anderwärts erwähnte Beispiele erinnern.

Als ich vor einigen Jahren unseren Termiten nachging, überraschte es mich, in den jüngsten Larven der Gattung Calotermes muntere lebhafte Thierchen kennen zu lernen, rascher in ihren Bewvegungen, zierlicher in ihrem Aussehen als ihre älteren Geschwister; da doch bei anderen Termiten die Larven anfangs schrecklich unbeholfene Dinger sind, die sich kaum von der Stelle rühren, von ganz unreifem Aussehen, mit dickem Kopfe, langen, aber plumpen Beinen u. s. w. Bei letzteren werden die Larven von einer zahllosen Arbeiterschar gewartet, gefüttert, von Ort zu Ort getragen; bei Calotermes fehlt ein besonderer Abeiterstand; die Jungen müssen sich selbst ernähren und finden nur ihre Wohnung, Gänge in dürrem Holze, bereits vor.

Aehnlich ist unter den Vögeln der Unterschied zwischen den Jungen der Nestflüchter und der Nesthocker. Welch reizendes Geschöpfchen ist nicht von der ersten Stunde ein Küchlein oder Entchen, das der Mutter laufend oder schwimmend folgt, selbst sein Futter aufpickt, den warnenden Ruf der Mutter versteht oder, verirrt, sie herbeiruft. Wie viderlich dagegen eine junge Taube, ein junger Sperling, - dieser dickbäuchige, glotzäugige, nackte Fleischklumpen, der nichts versteht, als zum Verschlingen des von der Mutter zugeführten Futters den Schnabel aufzureissen.

Weit tiefer greifenden Verschiedenheiten begegnen wir bei den Hautflüglern; auf der einen Seite die Larven der Blattwespen, den Schmetterlingsraupen ähnlich, mit Füssen, deutlichem Kopfe, wohlentwickelten Mundtheilen; auf der anderen Seite die fusslosen, umbehülflichen Maden der Ameisen, Wespen, Bienen. Jene suchen selbst auf Pflanzen ihre Nahrung, fremden Schutzes gegen Feinde entbehrend. Diese leben theils als Schmarotzer in Pflanzengallen, in Raupen u. s. w., theils an sicherem Ort zwischen reichlich von der Mutter auf- 
gespeicherter Nahrung, theils werden sie von wehrhaften Arbeitern geschützt und gefüttert.

Nun hat man, ganz abgesehen von den Jugendzuständen, ausreichende Gründe zu der Annahme, dass unter den Termiten die Calotermes, unter den Hautflüglern die Blattwespen, unter den Vögeln die Nestflüchter die ältere ursprünglichere Form der betreffenden Gruppen sind; man darf auch ihre Entwicklungsweise als die ursprünglichere betrachten und annehmen, dass die Jungen der nestbauenden Termiten, der Wespen und Bienen, der Nesthocker wie Schmarotzer, durch Nichtsthun, das ihnen die Brutpflege der Eltern gestattete, auf ihren jetzigen, jämmerlich hilflosen Zustand heruntergekommen sind.

In der Klasse der Säugethiere wiederholen sich dieselben Verhältnisse; hier das muthwillig springende Böckchen, dort der blindgeborene Hund, das nackte Mäuschen und unsere eigenen Kinder. Auch hier bewährt sich die in anderen Klassen gewonnene Erfahrung, dass die Jungen um so unentwickelter, um so geistloser, um so Hilfsbedürftiger ins Leben treten, je liebevollere sorgsamere Pflege ihrer hier von Seiten der Eltern wartet.

Es hätte wohl kaum dieses Umblicks in der Thierwelt bedurft, um sich zu überzeugen, dass der hilflose Zustand unserer Säuglinge, dass namentlich der Mangel geistigen Lebens und die damit nothwendig verknüpfte Sprachlosigkeit auf nachträglicher Abänderung des Entwicklungsganges beruhen und nicht auf den Urzustand der erwachsenen Vorfahren zurückzuschliessen erlauben. Fin solches seiner eigenen Sinne und Gliedmassen nicht mächtiges, allen Geisteslebens baares Wesen hat nie auf eigene Hand, nie als erwachsener Urmensch leben können; es hat entstehen und bestehen können nur unter der treuen Obhut der hingebendsten Mutterliebe. Wenn der Zustand unserer Säuglinge nicht als Beweis dienen kann für die Zahnlosigkeit eines nur von Milch lebenden, so kann er es ebensowenig für die Sprachlosigkeit eines auf allen Vieren kriechenden Urmenschen.

Kämen übrigens selbst unsere Kinder auf der Höhe geistiger Befähigung zur Welt, wie sie etwa ein Kälbchen oder Füllen seinen Eltern gegenüber einnimmt; würden sie nicht dennoch sprachlos sein, sprachlos sein müssen? und würde selbst dann ihre Sprachlosigkeit etwas für oder wider die Annahme des sprachlosen Urmenschen beweisen?

Wer es sich klar gemacht, dass der geistige Erwerb der Väter, dass der Besitz bestimmter Kenntnisse, z. B. des zum Sprechen unentbehrlichen Wörterschatzes, den Kindern nicht durch Vererbung, sondern nur durch Ueberlieferung mitgetheilt werden kann, wird über die Antwort nicht in Zweifel sein und dem wird auch die von Hellwald versuchte Anwendung des ,biogenetischen Grundgesetzes" auf die geistige Entwicklungsgeschichte der Menschheit mindestens etwas gewagt erscheinen. 


\section{Pflanzengattungen, an denen mir bekannte Tagfalter- Raupen leben ${ }^{1}$.}

(Erstere geordnet nach Endlicher, Genera plantarum, letztere nach Kirby.)

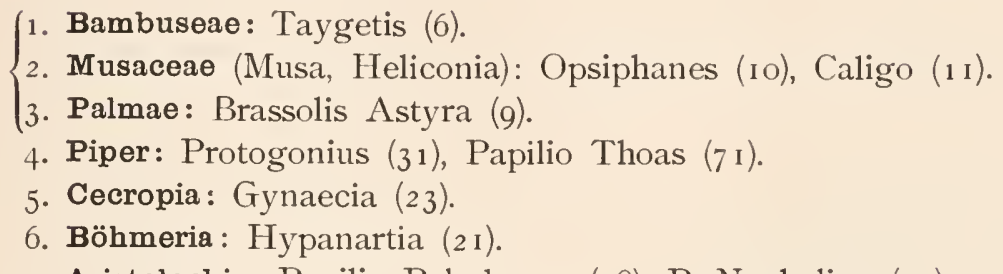

7. Aristolochia: Papilio Polydamas (38), P. Nephalion (39).

8. $\left\{\begin{array}{l}\text { Vernonia } \\ \text { Mikania }\end{array}\right\}$ : Acraea Thalia (12), Acr. Eulalia (I 3).

9. Schoenleinia (Rubiaceae): Adelpha Iphicla (27), Adelpha sp. (28).

Io. Asclepias: Danais Erippus (I), D. Gilippus (2).

I1. Solanum: Dircenna Xantho (3), Mechanitis Lysimnia (4).

12. Cestrum: Ithomia sp. (5).

13. Menispermum: Morpho Hercules (7).

14. Cascaria: Siderone Ide (29), S. strigosus (30), Diorhina Licarsis (32).

15. Passiflora: Heliconius Eucrate (I 4), Eueides Aliphera (15), Eu. Isabella (16), Colaenis Dido (17). C. Julia (13), Dione Juno (19), D. Vanillae (20).

16. Citrus: Papilio Evander (47).

17. Dalechampia: Ageronia Fornax (24), Ag. Amphinome (25).

18. Tragia: Didonis Biblis (26).

19. Alchornea: Epicalia Numilia (22).

20. Cassia: Eurema Sinoë (34), Callidryas Eubule (35), C. Philea (36).

21. Inga (semialata): Callidryas Argante (37), Morpho Epistrophis (8), Thecla Acmon (33).

Verwandte Schmetterlinge haben vorherrschend verwandte Futterpflanzen; besonders merkwürdig Ageronia und Didonis, die als besondere Familien lange im System herumgewandert sind, und erst jetzt als Nachbargattungen sich zusammengefunden haben und deren sehr ähnliche Raupen auf nesselnden Euphorbiaceen leben. - Selten finden sich nichtverwandte Tagfalter-Raupen auf derselben Pflanze zusammen, wie Protogonius und Pap. Thoas, - Siderone und Diorhina, endlich Call. Argante, Morpho Epistrophis und Thecla Acmon.

Blumenau (Prov. Sa. Catharina Brazil), 8. Dec. 1877.

I) Stett. Entom. Zeit. 1878. 39. Jahrg. p. 296. 


\title{
Proboscis capable of sucking the Nectar of Angrecum sesquipedale ${ }^{1}$ ).
}

\author{
Aus einem Briefe an Herm. Müller vom I I. April 1873 .
}

Mit 1 Textfigur.

Mr. W. A. Forbes, in the number for June I2 started the question, whether moths are known to inhabit Madagascar with proboscides capable of such an expansion, as to obtain the last drops of the nectar secreted in the lower part of the whiplike nectaries of Angrecum sesquipedale.

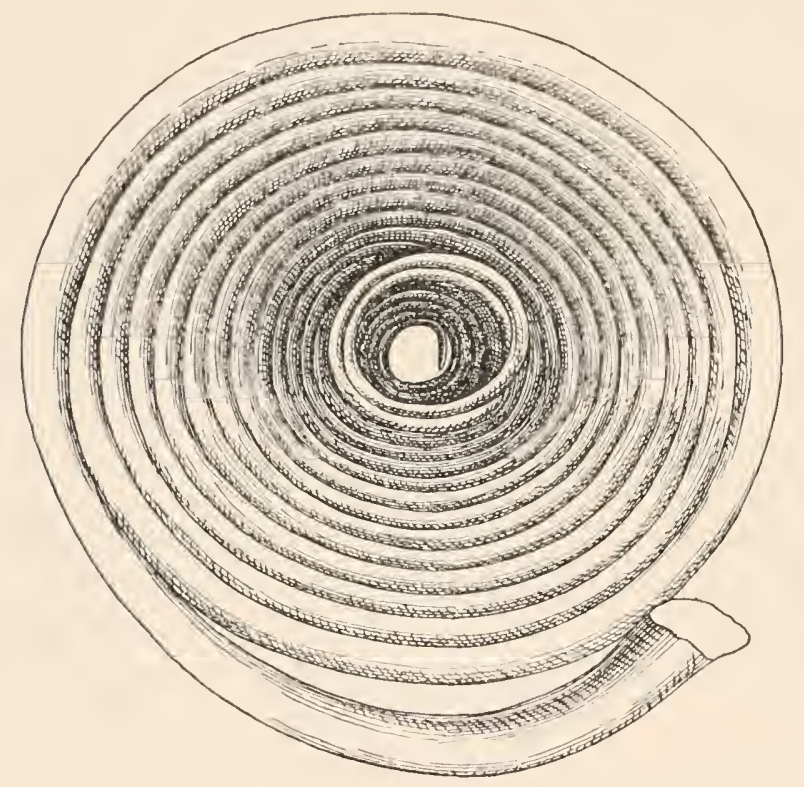

As long a direct ansiver to this question has not been given, it may be of some interest to state in general the existence of moths provided with proboscides sufficiently long for the honey-spurs in question.

Some days ago I received a letter from my brother, Fritz Müller (Itajahy, Prov. Sa. Catharina, Brazil), in which he says: "I recently caught a Sphinx (not determinable by Burmeister's "Brazilian Sphingidæe"), the proboscis of which has a length of about 0,25 metres - a lenght not approached by any honey-tube of this country known to me. I enclose the proboscis." Being unable to get the name of this species of Sphinx, I append the illustration of its proboscis, magnified in the proportion $7: \mathrm{I}$. This proboscis, in its contorted condition forming a roll of $10-\mathrm{I}$ millimetres in diameter, and showing at least 20 elegant windings, in its expanded condition attains a length of between 10 and I 1 inches, and would consequently be adapted to the nectaries of Angrecum sesquipedale, which have been found by Darwin I $1 \frac{1}{2}$ inches long, with only the lower inch and a half filled with nectar. Darwin indeed says, with regard to the fertilisation of Angrecum sesquipedale (p. 198 of his work on Orchids): "there must be moths with proboscides capable of extension to a length of between io and I 1 inches." 2)

Lippstadt, July I

Hermann Müller.

I) Nature 1873. Vol. VIII. p. 223.

2) $2^{\text {nd }}$ edition p. 163. Der Herausgeher. 


\section{Scent-fans of a Sphinx-moth $\left.{ }^{1}\right)$.}

Mit I Textfigur.

Mr. Meldola read the following extracts from a letter from Dr. Fritz Müller to Mr. Charles Darwin, dated from Santa Catharina, Brazil, 27 th November 1877.

"My children lately caught on the flowers of Calonyction (sp.?) a Sphinxmoth, the proboscis of which is 22 centimetres long. As I think that you would be glad to see this curious proboscis I send it to you. ***** During the month of October I have watched for some weeks the butterflies visiting a Lantana near my house, the flowers of which are yellow the first day, orange the second, purple the third day, and falling off on the morning of the fourth. Eight out of eleven species of butterflies (Heliconius apsendes, Colrnis Dido, C. Julia, Dione Juno, Hesperocharis Anguitia, Eurema Leuce, Daptonoura Lycimnia, and Callidryas Cipris) never touched an orange or purple flower, limiting their visits exclusively to the yellow ones. Two specimens of Pieris Aripa (or Elodia?) proceeded in the same way, whilst a third specimen of this Pieris inserted its proboscis indifferently into yellow or orange flowers. Three specimens of Danais Erippus evidently preferred yellow flowers, but sometimes also tried orange flowers, and one of them even once put its proboscis into a purple flower; a fourth specimen of Danais visited yellow flowers only. Lastly, I saw three specimens of Hesperide, but as I clid not catch them, and as the species most closely resemble each other, I do not know whether they belonged to the same species; two visited exclusively yellow flowers, the third indifferently flowers of any colour-yellow, orange, or purple. These observations, of which a full account will be published in the 'Archivos do Museo Nacional do Rio de Janeiro,' ${ }^{2}$ ) confirm those by

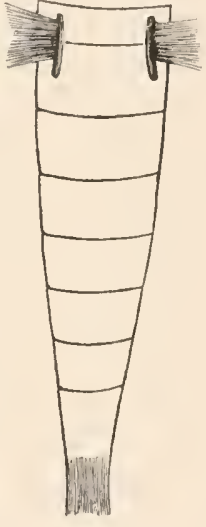

Scent-fans of a Sphinx-moth.

Delpino on Ribes anveum and Caragana arborescens. If the flowers lasted but one day the flowerheads would be by far less conspicuous; if they lasted three days without changing colour, butterflies would lose much time in visiting honeyless, already-fertilized flowers. *** Yesterday I caught, for the first time, the male of a Sphinx-moth which exhaled a strong musk-like odour; as you know, this is also the case with the males of the European S. convolvuli and S. ligustri; but nobody has as yet, so far as I know, indicated the odoriferous organ. It is formed by two pencils of hairs situated on the ventral side of the base of the abdomen, and when at rest are perfectly hidden by the scales (hairs?).

I do not remember whether I have already called your attention to an interesting secondary sexual character observable in several species of Callidryas and some other Pierince. The costal margin of the anterior wing is sharply

I) Proceedings of the Entomological Society of London. I878. p. II-III.

2) Siehe Ges. Schriften S. 547 ff. auch S. 577 . 
scrrated in the males, while it is smooth in the females. In Callidryas Philea some females have the wings smooth, others serrated, but in a far less degree than in the male. This may be a sort of weapon in the battles of the males Whether in Papilio Grayi, P. Cleotas, P. Corcebus, and their allies, the serrated margin of the fore wings is limited to the male sex I do not know, not having yet caught females of these rare species."

Mr. Meldola exhibited the proboscis of the Splinx referred to in the above letter, and also the wings of a male specimen of Callidryas Argante, showing the serrated margin. He remarked that he was indebted to Mr. Darwin for having kindly placed the letter and specimens at his disposal. With reference to the length of proboscis of Sphinx-moths, it was stated that in the British Museum there is a South-American specimen of Macrosilia cluentius, the proboscis of which is 23.5 centimetres $\left(=\left.9^{1}\right|_{4}\right.$ inches) long. Both Mr. Darwin ('Fertilization of Orchids', I862, p. I98) and Mr. Wallace ('Quarterly Journal of Science', Oct. 1867) had predicted the existence in Madagascar of a moth with a proboscis sufficiently long to reach into the nectar of Angrecum sesquipedale, the nectary of which orchid is from ten to fourteen inches in length. This prediction, although not at present specially fulfilled with regard to Madagascar, has becn since shown to have a great amount of probability by the discovery of a Sphinx in South America with a proboscis 25 centimetres $(=9.8$ inches $)$ in length. This specimen was also captured by Fritz Müller (see 'Nature', vol. viii., p. $223=$ Ges. Schriften

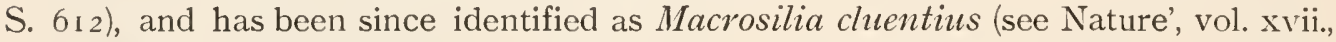
p. $22 \mathrm{I}=$ Ges. Schriften S. 639). The selective discrimination of flowers of certain colours refered to in the foregoing letter appears to afford additional proof of the fact that insects can distinguish colours - a fact of the utmost importance to the theory of sexual selection. With reference to the serrated costal margin of the fore wings of butterflies, Mr. Meldola stated that this character had been shown to exist in the genus Prioneris by Mr. Wallace (Trans. Ent. Soc., ser. iii., vol. iv.), and in the genera Amynthia and Pyrrhosticta by Mr. A. G. Butler, but that, so far as he knew, it was now made known in Callidryas for the first time.

Mr. A. G. Butler stated that in many of the exotic Notodontide he had observed a fan-like tuft in the males. With reference to the Sphingide of Madagascar, he stated that he had measured the proboscis of all the specimens in the British Museum, and none of them exceeded five inches in length. Mr. Butler further remarked that the whole of the Old World species of butterflies separated under the Hübnerian genus Catopsilia, the whole of the New World species separated under the genus Phobis of Hübner, all the species of the true Callidryas, Boisd., and one species only of the genus Aphrissa. Butler, have the serrated costa in the male sex. Aphrissa Godartiana, Swainson, although closely allicd to A. Hartonia, Butler, being similar in colour and pattern, but differing chiefly in size and the shortness of the wings, has a strongly serrated costa, whilst $A$. Hartonia has the costa smooth. With regard to the object of the serrated margin, Mr. Butler stated that he was disposed to accept Fritz Müller's explanation that it may be of use in the battles of the males.

Mr. Bates remarked that in Prioneris the serrated costal margin exists in both sexes. 


\title{
Notes on Brazilian Entomology $\left.{ }^{1}\right)$.
}

\author{
Odours emitted by Butterflies and Moths.
}

Two years ago I ventured to suggest ${ }^{2}$ ) that all those various pencils, tufts or manes of hairs, all those chalky, silky or velvety spots of peculiar scales, as well as the recurved margins or other pouches enclosing pale buff or white down, which distinguish the wings of the male sex in many butterflies, might be odoriferous organs. This suggestion might then have been justly censured as too rash, being founded on the actual observation of odours in four species only, and I felt, of course, the necessity of testing this view by examining as to their odours all living butterflies I might be able to procure. I will here give the results hitherto obtained, enumerating those species ${ }^{3}$ ) in which distinct odours could be perceived, and I hope the facts to be given will fully justify my suggestion.

Odours, as well as colours, may have been acquired by butterflies either for protection or as an attraction beetween the sexes. Protective odours appear to be in most cases equally strong in both sexes, or sometimes stronger in the females; they may exist in the caterpillar as well as in the perfect insect. When capable of voluntary emission, they are emitted as soon as the animal fears some danger, e. g., when it is seized, and this may in some cases serve to distinguish them from sexual odours.

Sexual odours may be divided into two classes.

Firstly, those which give notice to the opposite sex of the existence of, and lead it the way to, the odoriferous animal. Such odours must exist in many female moths wich attract the males from great distances. Among butterflies the males appear to be guided more by the colour than by the odour of their females.

Secondly, those odours which do not serve as a guide, but as an excitement to the opposite sex. They appear to be by far more frequent in the males, though occurring also in some females. Odours of both classes will of course

I) Trans. Ent. Soc. Part. III. 1878. p. 2 I I -223.

2) Jenaische Zeitschrift für Naturwissenschaft, XI. p. 99. = Ges. Schriften S. 534 .

3) I am much indebted for the names of the butterflies mentioned in this paper to Prof. A. Gerstaecker and Dr. O. Staudinger. 
be agreeable to the attracted or allured sex: but in the first class the odour of the female is agreable to the male, because it is the odour of his female; while in the second class the odour emitted by the male is agreeable to the female, males with that peculiar odour having been preferred. The two classes may, of course, graduate into each other.

Colours, whether acquired as an attraction by the males or for the sake of protection by the females, are often transmitted to the opposite sex; with sexual odours of butterflies this seems but very seldom to be the case.

I shall not enter into minute descriptions of the odoriferous organs ${ }^{1}$ ), nor mention those very numerous species, which, though evidently possessing such organs, emit odours too faint for human noses; the only object of this paper being to state that there are a large number of male butterflies provided with special organs for the production and emission of peculiar odours.

\section{Butterflies.}

Family I. Nymphalidæ.

Subfamily I. Danaïnæ.

\section{A. Danaïs group.}

Danaïs Erippus, Danaïs Gilippus²), Lycorea [sp.?] and Ituna Ilione have a pair of finger-like hollow processes at the end of the abdomen, into which they can be retracted, they bear a tuft of black hairs, radiating in every direction and emitting a rather disagreeable odour, when the processes are fully protruded. This odour is extremely strong in Lycorea and Ituna, less so in D. Gilippus, and rather faint in D. Erippus, differences exactly corresponding to the different sizes of the tufts in the several species. The male of Ituna sometimes protrudes his tufts, when he is seized, so that in this butterfly the odour may serve both to repel enemies and to allure females. The well-known "sexual spots", or rather pouches, on the first median nervure of the hind wings of D. Erippus and Gilippus, which are much larger in this latter species, appear to be, by their microscopical structure, scent-producing organs; but as they open only by a narrow slit, odours could hardly be freely emitted. There is one curious circumstance, which may perhaps throw some light on their as yet very doubtful function; the scales, though perfectly preserved everywhere else, are often wanting at the entrance of the pouch, as if they had been scoured away by something introduced into the slit. It would be worth while to see whether this be the case with other species of Danaïs also. Might not the tufts be introduced into the pouches to be impregnated there with odoriferous matter?

I) A series of papers describing odoriferous organs of various butterflies and moths have been sent for publication to the "Archivos do Museu Nacional do Rio de Janeiro". = Ges. Schriften S. 555, 559, $564,625,631$.

2) Kirby (Synon. Cata l. of Diurn. Lepid. I871, p. 7) doubts whether D. Gilippres may not be a variety of $D$. Erippus. But the caterpillars are quite different; those of Erippus have two, those of Gilippus three, pairs of "tentacles". The microscopical structure of the "sexual spot" of the male also shows considerable differences. 


\section{B. Ithomia group.}

The males have a tuft or pencil of long hairs near the anterior margin of the hind wings ${ }^{1}$, which in all our species enits a more or less distinct odour. The odour is rather strong and most agreeable, resembling vanilla, in Dircenna Xantho, rather faint in Ceratinia Eupompe and Ithomia Sylvo; it is still more so in Mechanitis Lysimnia, where I perceived it distinctly in but few males. In Thyridia Megisto the odoriferous tuft is not limited to the male sex; it exists in the females also, but the hairs are shorter and less numerous and the odour emitted is much fainter than in the males. The males have a welldefined brown spot, covered by the tuft; this is hardly distinguishable in the females. As the tuft exists in all the males of the group-which contains about a dozen of genera with more than two hundred species-as it is wanting in almost all the females, and as in Thyridia Megisto it is much less developed in the female sex, there can, I think, hardly be any doubt that it has been acquired as a sexual attraction by the males of the common progenitor of the group, and that it has been but recently transmitted to the females of Thyridia.

\section{Subfamily 2. Satyrinæ.}

The males of Antirrhea Archea have highly-developed odoriferous organs, and emit a strong odour; there is a most elegant mane of pale buff hairs on the under side of the front wings, and opposite to it the hind wings bear an odoriferous spot, which has caused a considerable modification of the neuration of the wing ${ }^{2}$. A second much smaller odoriferous spot exists in the angle between the submedian and internal nervures.

In the allied genus Pievella no trace of odoriferous organs could be found nor any odour perceived.

\section{Suhfamily 4. Morphinæ.}

The wings of the males are known to be generally provided with tufts of hairs or with spots of peculiar appearance, which probably will prove to be odoriferous organs. The only genus, the wings of which are deprived of such organs is Morpho. In compensation the males of all the species of Morpho which I have caught (M. Hercules, Epistrophis, Adonis, Cytheris, Menelaus, Achilles) are able to protrude from the end of the abdomen a pair of hemispherical bodies covered with short hairs, which produce a very distinct odour. In the splendid $M$. Adonis anp the allied $M$. Cytheris this odour is most agreeable, resembling vanilla.

\section{Subfamily 5. Brassolina.}

Pencils of hairs, capable of being erected voluntarily, or spots of peculiar scales are present on the hind wings of most genera. Their position varies much, even within the limits of the same genus. In the males of various species of Caligo, Dasyophthalma and Opsiphanes, I found that very distinct odours were

I) There are two widely-separated tufts in the male of a small species of this group, resembling in size and colour Cyllopoda dichroa, one of our Glaucopide.

2) See Butler, Catal. Satyrid. Br. Mus. 1869, Pl. V. fig. 3. In Buller's figure of the mane ("plaga pectinatim cirrata") the hairs appear to be directed backward, whil the contrary is the case; they are inserted along the subinedian nervure and directed forward. 
emitted by these pencils or spots, the odour being particularly strong in a species of Dasyophthalma.

\section{Subfamily 6. Acræinæ.}

On crushing either sex of Acrea Thalia, a disgusting odour is perceived, which probably renders it unpalatable to most insectivorous animals; there appear to be no special organs for the emission of odours.

\section{Subfamily 7. Heliconinæ ${ }^{1}$ ).}

The butterflies of this subfamily also possess a disgusting odour, and both sexes are provided with special organs for its emission. In the male they are situated between the anal valves, in the female on the dorsal side of the end of the abdomen. The odours emitted appear to be generally stronger in the female $\operatorname{sex}^{2}$ ).

\section{Subfamily 8. Nymphalinæ.}

\section{A. Epicalia group.}

Unusually strong odours are emitted by the males of Myscelia Orsis and Epicalia Acontius. Both of them have a large odoriferous spot on the upper side of the hind wings, and opposite to this a similar spot, covered by a mane of black hairs, is situated on the front wings of Epicalia Acontius. It is very remarkable that the odoriferous organs, which are so highly developed in Epicalia Acontius are completely wanting in Epicalia Numilia, and it is yet more remarkable that they closely resemble in various particulars those of Antirrhea Archea, though they were no doubt independently acquired in both species. In both these butterflies the posterior margin of the front wings and the anterior margin of the hind wings are much dilated; in both of them a mane of long hairs is inserted on the under side of the front wings, along the submedian nervure, covering an odoriferous spot (which is well developed in Epicalia, but most rudimentary in Antirrhaca), and opposite to the mane there is a large odoriferous spot on the hind wings, the central part of which fills the angle between the two subcostal nervures, extending into the three adjoining cells of the wing. If we knew only these two species of Nymphalince and Satyrince we should unhesitatingly assume that their odorifcrous organs, situated on the same place, composed of the same parts, and in the same position, were inherited from common progenitors; and yet this would be a great mistake.

\section{B. Ageronia group.}

In the male of Ageronia Arethusa a rather strong odour is emitted by two large brown spots, situated between the wings, one on the under side of the front wing, occupying the basal half of the cell between the submedian nervure, and first median nervure, the other on the upper side of the hind wings. The microscopical structure of the scales and the wing-membrane of these spots differs

I) I have lately shown (Stettin. Entomol. Zeitung, 1877, p. 492) that the genera Colanis and Dione cannot be separated from Heliconizes and Eueides. Siehe Ges. Schriften S. 579.

2) For a full description of the odoriferous organs of the femalc Heliconina, sce a paper in Zeitschrift für Wissenschaftliche Zoologic, vol. XXX. p. 16\%. = Ges. Schriften S. 643 . 
but little from that of the rest of the wings. In Ageronia Amplinome and Feronia neither odours nor odoriferous organs could be detected.

Didonis Biblis is, so far as odours are concerned, the most interesting of all butterflies that I know. The male is able to emit as many as three different odours. On seizing a Didonis of either sex, it protrudes on the dorsal side of the abdomen, between the fourth and fifth segments, a pair of hemispherical protuberances, covered with greyish hair-like scales and producing a strong, rather disagreeable odour. The male has a second pair of similar protuberances between the fifth and sixth segments of the abdomen, covered with white hair-like scales. These white protuberances he never exposes when caught; they emit an agreeable odour, comparable to that of heliotrope, and are of so elegant an appearance that they probably serve at the same time as an ornament. A very different musklike odour is produced by a black spot, which is situated on the under side of the front wings of the male near the base between the median and submedian nervures. This odour is very faint; it is convenient to remove the abdomen before trying to perceive it. I may add that the hind wings of the male also have a very small greyish spot near the base, which is wanting in the female.

\section{Apatura group.}

A distinct odour issues from the tuft of black hairs which distinguishes the hind wings of the make sex of Prepona Laertes and several other allied species.

\section{Family 3. Lycæenidx.}

It is well known that the males of very many species of Thecla have a "scxual spot" on the disc of the front wings, and that sometimes $(e . g$., in the males of $T$. Acmon) the neuration of the wings is greatly altered by the presence of this spot. In the male of $T$. Atys an unusually strong odour is produced by this "sexual spot", and more or less distinct odours by various other species the names of which $I$ do not know.

\section{Family 4. Papilionidæe. \\ Subfamily I. Pierinze}

The front wings of the male Leptalis Thermesia have a chalky nval spot on their under side, and opposite to this there is a dark-brownish spot on the upper side of the hind wings. Both these spots emit a very strong odour, disagrecable to human noses, but probably not so to his females. A similar, though much fainter odour has been observed in the male Leptalis Astynome and L. Melite.

A very delicious perfume is produced on the upper side of the wings of the male Daptonoura Lycimnia. It is rather faint and often hardly distinguishable when the butterfly is caught. In this case it may easily be rendered distinct by keeping the living animal for some time with the wings closed. On the whole upper surface of the wings there are, among the ordinary scales, in the males of this species (as in many species of Pieris, Hesperocharis, Archonias, Pereute $\& c$.), numberless peculiarly-formed odoriferous scales or "plumules", as they were called by Bernard Deschamps. In Daptonoura Lycimnia these "plumules" are club-shaped and fringed with fine hairs at the end. 
When a female of Daptonoura Lycimmia (and various other butterflies, Callidryas, Anartia, \&c., behave in the same manner) is willing to admit a male, she expands her wings horizontally, lifts a little the end of the abdomen and exposes her copulating organs. Then the male is seen to hover above and to fly around her; but often, far from accepting the offer of the female, which, after a long courtship, finally surrenders herself to his wishes, he suddenly flies away without returning. What may be the cause of his thus abandoning her at the decisive moment? The only thing which he could not perceive, whilst chasing after the female, is that part of her sexual organs which is now for the first time exhibited to him. Now, these copulating parts of the female, when protruded, emit a peculiar odour, and it is probably the individual odour of the several females which determined the decision of the male. In Daptonoura Lycimnia this odour is rather faint, though quite distinct. It is very different from that emitted by the wings of the male.

The male of Daptonoura Ilaire is also provided with "plumules" on the upper side of the wings, but no odour was here perceived. At the same time he has a tuft or pencil of brown hairs at the end of the abdomen, on the ventral side. This tuft is not retractile, but applied to the ventral margin of, and partially hidden between, the anal valves; it may be made to radiate in every direction and then emits a rather strong odour. This tuft of hairs exists in the female also, but it is much shorter, and I could not perceive any odour produced by it.

The males of most species of Callidryas have a chalky spot on the upper side of the hind wings, near the base and the anterior margin; sometimes it is covered by a mane of long hairs, and sometimes the front wings also have a similiar spot opposite to that of the hind wings. I perceived a musk-like odour issuing from this spot and mane in Callidryas Cipris, C. Argante, and C. Trite. It is unusually strong in Cipris, very distinct in Argante, rather faint in Trite. In several males of this last species which I caught two years ago I could not perceive any odour, while I find it to be quite distinct in all those wich I have lately examined. Are those butterflies producing a more powerful perfume in 1878 than they did in 1876 , or have my olfactory organs, by continual exercise, become more acute in the meantime? According to Boisduval, the chalky spot is wanting in the male Callidryas Eubule, and, indeed, it may easily be overlooked through hardly differing in colour from the rest of the wing; but it exists, and is easily discovered by its opacity after denuding the wing. It emits a faint musklike odour.

The females of Callidryas Argante, Eubule, and probably also of other species, show on either side of the protruded copulating organs a small, shining, circular spot, from which a very strong peculiar odour issues, in which some volatile acid seems to predominate.

\section{Subfamily 2. Papilioninæ.}

When special organs for emitting odours are developed in the males of this subfamily, they are placed along the anal margin of the hind wings, which is then usually recurved. It can be expanded, and the odoriferous organs exposed by moving the wings strongly in a forwad direction. In some species a very strong odour is emitted by the upper side of the wings of the male without any 
special organs having been found (but I must add, that I have not yet compared microscopically the wings of the two sexes). This is the case with Papilio Polydamas and Hyperion. In P. Polydamas there appear to be two sets of males emitting equally strong but quite different, odours. This would be analogous to the case of the two sets of differently-coloured females in some species of this genus. P. Polydamas is generally the most common of our Papilios, but in the last summer it has been rather rare, and I have examined but a small number of living males; thus, on examining a larger number, intermediate odours may be found.

In Papilio Scamander or Grayi ${ }^{1}$ ) the black hairs existing in both sexes on the upper side of the hind wings, are much more developed near the anal margin in the males, which emit a strong, most agreeable odour, issuing from these hairs; the females are scentless.

In the male Papilio Protesilaus the hairs near the anal margin of the hind wvings are developed to a long black beard, which is hidden by the recurved margin of the wing, and exhales, when uncovered, a very strong; or rather disagreeable, odour. Beard and odour are wanting completely in the female sex ${ }^{2}$ ).

In the male Papilio Nephalion the pouch formed by the recurved anal margin of the hind wings is filled with an astonishing quantity of white silky down. In a male which I lately caught I perceived a faint agreeable odour on opening the pouch.

\section{Family 5. Hesperidæ.}

The Hesperide agree with moths in many particulars, which are not to be found in any other butterflies. Thus, as in many moths, the tibire of the hind legs are provided in the males of various species with a large pencil of long hairs. It can be hidden in a furrow on the ventral side of the body, between thorax and abdomen. In Plesioneura Eligius, and in a species of Achlyodes, I perceived a very faint odour issuing from the pencils when they were expanding.

\section{Moths.}

In butterflies, as we have seen, the odoriferous organs of the males in most cases are developed on the wings; in but few genera (Danaïs, Lycorea, Ituna, Morpho, Biblis) they were found on the abdomen, and, in some Hesperida, on the hind legs. With moths the case appears to be very different. Though not wanting on the wings, these organs seem to occupy much more frequently the abdomen or legs.

A musk-like odour is known to be produced by several male sphinx moths; I have observed it in Macrosilia Antcus and two other species. It is emitted

I) This butterfly visited in large numbers the flowers of a red Salvia, in the highlands of the province of Santa Catarina, near S. Bento. Some specimens agreed with Boisduval's description of $P$. Scamander, others with that of Papilio Grayi, and most of them were intermediate between the two.

2) Felder (Species Lepidopt. 1864, p. 57) states that among a large number of specimens of Papilio Protesilaus, Agesilaus and Telesilaus he could not find any female. In 1876 Pap. Protesilaus (var. Telesilans) was extremely common, both on the river Itajahy and on the highlands of Curitibanos, and I think I have caught more than a hundred specimens, among which there were but two females. 
by two other species. It is emitted by two pencils of pale hairs on the ventral side of the abdomen, which can be hidden in longitudinal grooves on the first two abdominal segments. To see them in the living male he must be held with the ventral side turned upward, so that he can freely move his wings. As soon as he begins to flutter, the pencils will expand, and when the wings cease to move, they will be laid down again into their grooves.

The males of the Glaucopide are provided with two long hollow retractile filaments, generally beset with hairs, which they can protrude from the end of the abdomen, on the ventral side; sometimes they exceed the body in length, and are then rolled into an elegant helix. They emit, in most cases, a distinct odour, which is very strong in some species (e. g., Belemmia inaurata). Two similar filaments, producing a strong odour, exist in the male of a Cryptolechia. I have seen retractile pencils, tufts of hairs, or hairy protuberances, some of them emitting distinct odours, at the end of the abdomen of various other male moths, of which I do not know the names.

Pencils or tufts of hairs appear to be of rather frequent occurrence on the legs of male moths, e. g., among the Erebidre and Geometrida, and in two or three cases odours were observed to issue from them.

In one of our largest Erebide the tibiæ of the hind legs are much dilated in the male, and densely covered with peculiar hairs, capable of being voluntarily erected; they emit a faint but distinct odour.

As I know as yet but a very insignificant part of our moths, a vast number of other odoriferous contrivances may be expected to be found among the extremely numerous species of these insects.

\section{Sounds made by Butterflies $\left.{ }^{1}\right)$.}

I know here four species of Ageronia (Feronia, Fornax, Amplimome and Arethusa), all of which are rather common in certain localities where their foodplants (Dalechampia) abound. I have frequently heard the noise made by them and can fully confirm Mr. Darwin's statement, that this noise is produced, almost exclusively, when two are chasing each other. Sometimes a short, clicking noise is made, when an Ageronia is caught in the net. On October 3oth, I876, at the mouth of the Rio Trombudo, a tributary of the Itajahy, I saw two butterflies chasing each other, which produced a loud clicking noise, and settled from time to time in the manner of Ageronia, with the wings expanded horizontally, on dry stems of Taguara (bamboo). I, of course, imagined them to be some species of Ageronia, but after having succeeded in catching one of them, found that it was Ennica Margarita. I may observe that the neuration of the wings of that butterfly bears a rather close resemblance to that of Ageronia, so that indeed, it may be more nearly allied to that genus than is generally assumed.

On February 21 st, 1877 , at the foot of the Serra de Itajahy, I heard a noise resembling that of Ageronia, but rather louder, produced by two small brown butterflies, which seemed to be Euptychio, but which I did not succeed in catching.

I) The following notes are supplementary to a paper by Mr. Meldola, entitled "Entomological Notes bearing on Evolution", in Ann. and Mag. of Nat. Hist., Feb. 18;8. 
It has been suggested that the production of sound by Ageronia is connected with the existence of a small membranous sac at the base of the front wings, which in the living insect is filled with air when te costal nervure is compressed. But this sac also exists in several other butterflies, which seem to be incapable of producing sounds, e. g., Pyrrhogyra Edocla and Callicore Eluina. If I remember rightly, in Eunica Margarita the sac is wanting.

\section{Insects distinguishing Colonrs.}

In flowers with changing colours, most of the visiting insects perfectly distinguish the first honey-filled flowers, as I have ascertained by a long series of observations on some species of Lantana. In some species the difference in colour between the fresh flowers and the older ones is but very trifling, a small yellow circle surrounding the entrance to the tube of the corolla during the first day and disappearing afterwards.

A specimen of Victorina Frayja was lately observed settling on the flower of a rose-tree painted on a wall; the painter was much pleased by seeing his skill thus acknowledged by that butterfly.

\section{Mimicry.}

In some years, as I stated in $187 \mathrm{I}$, Mechanitis Lysimnia is here hardly more common than the imitating Leptalis Astynome; but in most years $M$. Lysimnia is extremely abundant and L. Astynome rather rare.

When I descended in a canoe the western branch of the Itajahy (December 16th, 1876), small white butterflies were very common on the banks of the river: all appeared to be of the same species. I caught about a dozen, and on examining them at home found them to be Leptalis Nehemia, which so wonderfully mimics a Pieris, that even Boisduval was deceived and described as Pieris Nehemia. Now, in his case, the model must have been either by far more rare than the copy, or entirely wanting.

On the Itajahy we have three species of Eneides, viz., E. Pavana, Isabella and Aliphera; all of them are rare, and E. Pavana extremely so. This last species closely resembles Acrea Thalia; E. Isabella resembles Mechanitis Lysimnia and Heliconius Encrate, while E. Aliphera mimics Colcnis Julia. I, therefore, formerly thought that the three rare species of Eneides mimicked the three common species of Acrea, Mechanitis and Colcenis. Afterwards, after finding that the several species of Eueides possess a very strong and repugnant odour, I had become somewhat doubtful, and at São Bento I found that E. Aliphera was extremely common, so common, indeed, that repeatedly I caught as many as eight specimens in the net at once, whereas $C$. Julia was so rare that I have only seen two or three specimens altogether. Thus, judging by their relative abundance, an observer on the Itajahy might consider $E$. Aliphera to be a mimic of C. Julia, while an observer at São Bento might take C. Julia to be a mimic of E. Aliphera.

\section{Correlation of Habit with Protective Resemblance.}

Any number of cases might be given. The case which has most struck me is that of the caterpillar of a small moth belonging to the curious Cochliopod 
group. This caterpillar has long lateral processes, overlapping each other, and imitates in a truly wonderful manner a dry leaflet of the food plant Cassia multijuga with the apical half gnawed off. Now, when gliding along slowly and smoothly, as Cochliopod larvæ are accustomed to do, it has the strange habit of making curious waving movements from side to side, just as a dry leaf moved by the wind. A dry leaf marching in a straightforward manner would be a strange thing, and might rouse the attention of some intelligent bird, whilst it would not look at a leaf moved by the wind.

Another curious instance is that of the caterpillar of our Brazilian "leafbutterfly"( Siderone strigosus); when very young it feeds on the tips of the lanceolate leaves of a Casearia, sparing the mid rib, on which it rests. This habit of resting on the denuded ribs of leaves is common to various young caterpillars (Protogonius, Adelpha, Gyncesia), and they are thus very well protected. When somewhat larger, the caterpillars of Siderone strigosus (and of Siderone Ide, which live on the same plant) bite small pieces from the leaf, fastening them to the mid rib, with their margins rolled in, and the brown colour which these bits of leaf soon assume excellently conceal the small brown caterpillar which sits between them; at last the fullgrown larva itself perfectly imitates a rolled dry leaf. 


\title{
Os orgãos odoriferos da Antirrhaea Archaea $\left.\left.\mathrm{Hübner}^{1}\right)^{2}\right)$.
}

\author{
Mit Tafel XLIX.
}

As differenças sexuaes da Antirrhcea Archlea produzidas pelos orgãos odoriferos dos machos já se acham mencionadas por varios autores. Assim Westwood ${ }^{3}$ ), considerando a Antirrhara como terceira secção do genero Hatera, distinguio esta secção pelas azas anteriores do macho dilatadas na margem interna e munidas em baixo de uma crina. Butler ${ }^{4}$ ), tomando a Antirrhea Archea como typo de um novo genero, Anchiphlebia, indicou entre os caracteres distinctivos deste genero não só a margem interna convexa e a "plaga pectinatim cirrosa» das azas anteriores, como tambem uma differença muito notavel entre os dous sexos nas nervuras das azas posteriores «alæ venis posticarum prima et secunda subcostalibus ad origines mari valde approximatis et subparallelis»; ao mesmo tempo tambem elucidou e illustrou por uma figura os referidos caracteres ${ }^{5}$.

Os pinceis de cabellos, barbas ou crinas constituem em muitos casos a parte mais notavel dos orgãos odoriferos dos lepidopteros machos; em muitos casos tambem estes orgãos são accompanhados de modificações mais ou menos profundas das nervuras das azas; parecia-me porém muito estranho terem os machos da Antirrhea Archea uma crina nas azas anteriores e as nervuras alteradas nas posteriores, sem que nestas azas posteriores apparecesse, nas descripções e figuras existentes, outro indicio de orgãos odoriferos. Fui pois, por causa dessa anomalia real ou apparente, examinar com o mais vivo interesse diversos individuos de ambos os sexos desta borboleta assaz rara, ao que me parece, na provincia de Santa Catharina, onde pela primeira vez a vi no mez de Janeiro do corrente anno.

Logo ao apanhal-os convenci-me de que os machos, e só estes, são dotados de um cheiro bastante intenso, emittido pela elegantissima crina das azas anteriores. Tambem não tardei a reconhecer que aquella anomalia era só apparente, visto como ao longo das nervuras modificadas das azas posteriores se estende um orgão

I) Arch. do Mus. Nacional. Rio de Janeiro 1878 . Vol. III. pag. I-7.

2) Нa uma figura de Antirrhaa Archaa representando a femea na Encyclopidie d'Hist. Nat. par le Dr. Chenu. Papillons I, pag. 299, Fig. 514.

3) Westwood, Genera Diurn. Lepidopt. pag. 365. (1851).

4) Butler, Catalogue Satyrid. Brit. Mus. pag. 106. (1868).

5) Butler, Catal. Satyr. Pl. V. Fig. 3.

Fritz Müllers gesammelte Schriften. 
odorifero dos mais singularcs, e comparando os meus exemplares com a figura de Butler cheguei a convencer-me de que este representa erroneamente a crina das azas anteriores, dando aos cabellos uma direcção opposta a que elles realmente têm.

Conviria pois, á vista dos erros e omissões das figuras e descripções existentes figurar e descrever de novo os orgãos odoriferos da Antirrhcea Archca, embora mesmo elles não fossem, como realmente são, em si mesmos muito dignos de nota por diversos motivos.

A margem interna das azas anteriores fórma nas femeas (Fig. I), uma linha quasi recta desde a base da aza até a extremidade da nervura interna; nos machos pelo contrario (Fig. 2), essa margem fórma, entre os referidos pontos, um arco quasi regular de $120^{\circ}$ cle um circulo, cujo centro se acha no vertice do angulo formado pela nervura mediana e o seu primeiro ramo. Da mesma sorte a nervura interna, depois de ter feito um angulo obtuso perto da base, é recta nas femeas, e curvada em forma de $\mathrm{S}$ nos machos. Deste modo a área comprehendida entre as nervuras interna, mediana e o primeiro ramo desta, fica maior na razão de 4:3 nos machos, e a maior parte desta área é occupada, na superficie inferior da aza, pela crina de cabellos louros que caracterisa o sexo masculino. Essa crina romeça a pouca distancia da base da aza; a sua linha de inserção accompanha a nervura interna (da qual fica comtudo separada por um intervallo cuja largura é quasi egual á da mesma nervura), em pouco mais de dous terços de seu comprimento, e depois, diminuindo pouco a pouca o raio da curvatura, dirige-se para diante (isto é, para o lado dorsal da aza), terminando a pequena distancia da do ramo da nervura mediana. Perto da base da aza, os cabellos da crina (Fig. 5) são rectos e medem cerca de 3 millimetros de comprimento; no meio 12 até 16 millimetros: nas extremidades cerca de 8 millimetros de grossura, sendo obtusa a extremidade livre; no ponto onde a crina se affasta da nervura interna os cabellos são maiores, chegando a medir 6 millimetros de comprimento, e um pouco curvos, apresentando a convexidade voltada para a base e margem interna da aza.

Os cabellos não são dispostos em uma só fileira, e sim, como melhor se vê nos seus pontos de inserção, em 3,4 ou 5 camadas, elevando-se este numero a Io ou mais nos dous primeiros millimetros a contar da base da aza. Removida a crina, a parte da aza, que por ella se achava coberta, não apresenta aspecto sensivelmente differente do da superficie cirumvizinha; entretanto o exame microscopico revela differenças profundas na disposição e forma das escamas.

As escamas ordinarias nesta parte (Fig. Io) são dispostas em fileiras regulares, nas quaes as escamas inferiores ou súcubas alternam-se com as escamas superiores ou incubas. A distancia das fileiras é de cerca de $0^{\mathrm{m} m}, \mathrm{o} 8$; a das escamas da mesma fileira de cerca de $\mathrm{O}^{\mathrm{mm}}, \mathrm{O}_{3}$; as escamas superiores ou incubas (Fig. 10, A), são mais compridas $\left(\mathrm{o}^{\mathrm{mm}}, 2\right)$ muito mais estreitas (o $\mathrm{o}^{\mathrm{mm}}, \mathrm{O} 3$ ) e ao mesmo tempo muito mais escuras; as inferiores ou súcubas (Fig. Io, $B$ ) são menos compridas $\left(\mathrm{O}^{\mathrm{mm}}, \mathrm{I} 2\right)$, mais largas $\left(\mathrm{O}^{\mathrm{mm}}, \mathrm{O5}\right)$ e mais pallidas, sendo a extremidade clestas ultimas ou arredondada, como a das incubas, ou denteada.

Debaixo da crina as escamas não são dispostas em fileiras regulares, não se differenceiam em súcubas e incubas; são muito menos bastas do que as ordinarias e nào cobrem inteiramente a aza. Polo laclo da base da aza cllas sĩo sensivel- 
mente menores do que as ordinarias, tendo (Fig. I I) pouco mais ou menos o comprimento das súcubas ordinarias e a largura das incubas; pelo lado da margem externa da aza vão augmentando pouco a pouco de largura de modo que afinal (Fig. I2) pouco se destinguem das súcubas ordinarias apresentando a extremidade arredondada.

Na côr e textura ellas se assemelham ás escamas ordinarias súcubas, mostrando, como estas, bem distinctas as estrias longitudinaes, que costumam ser imperceptiveis nas escamas odoriferas; faltam-lhe tambem todos os outros caracteres que distinguem as escamas odoriferas.

Entretanto a differença singular e notavel entre a area coberta pela crina e a superficie circumvizinha consiste na direcção das escamas. As de fóra invertem, como é regra geral, a sua ponta para o lado da margem externa da aza isto è, para a direita (Fig. 5); as de baixo da crina seguem mais ou menos rigorosamente a direcção dos cabellos que as cobrem (assim, na fig. 5 as escamas da base são dirigidas para cima, as da parte terminal para a esquerda), de modo que em certo ponto as escamas muito vizinhas e separadas apenas pela inserção da crina voltam-se em sentido inteiramente opposto.

Removidas tambem as escamas das azas anteriores, apparece, na área coberta pela crina, uma macula um tanto opaca, de fórma elliptica (Fig. 2, $m$ ), sendo os seus eixos de 7 e 3 millimetros. Si se tirasse uma recta do vértice do angulo, entre o tronco e o primeiro ramo da nervura media para o ponto em que a crina se affasta da nervura interna, essa recta coincidiria com o eixo maior da ellipse. A opacidade da macula, aliás pouco consideravel, devida a um sem-numero de pequenos pontos ou antes circulos de $\mathrm{O}^{\mathrm{mm}} \mathrm{OO} 2$ de diametro apenas, e de contornos escuros, que se acham espalhados neste logar pela membrana da aza.

Assim como a margem interna ou posterior das azas anteriores, da mesma sorte a anterior das azas posteriores é quasi recta nas femeas (Fig. 3), e sensivelmente arqueada nos machos (Fig. 4). A superficie superior destas azas é de côr parda, e nella avistam-se, nos machos, duas maculas que mais se distinguem pela differença do brilho, do que pela côr. A maior (Fig. 4, $m^{\prime}$; Fig. 7,8 e 9) rodeia os angulos formados pela nervura discocellular superior (des) e pelos dous ramos ( 6 e $\quad 7$ ) da nervura subcostal prolongande-se entre estes dous ramos até onde elles acabam de correr approximados e parallelos; á base da macula, de fórma quadrilatera irregular, é cinzenta escura, o prolongamento alvacento, e por isso mais visivel. A macula menor (Fig. $4, m^{\prime \prime}$ ) occupa o angulo situado entre as duas nervuras internas. Ambas as maculas são abundantemente cobertas de escamas especiaes que, pela sua opacidade perfeita e falta de estrias longitudinaes, assemelham-se ás escamas odoriferas de muitos outros lepidopteros; quanto a fórma, as da macula menor (Fig. I5) não differem muito das escamas ordinarias incubas (Fig. I3, A) da parte vizinha da aza; as da macula maior (Fig. I6) são pelo contrario tão estreitas que quasi confundem-se com cabellos; ellas têm cerca de $\mathrm{O}^{\mathrm{mm}}, \mathrm{I} 6$ de con 1 primento, as da macula menor $\mathrm{O}^{\mathrm{mm}} \mathrm{I} 3$ sobre $\mathrm{O}^{\mathrm{mm}}, \mathrm{O} 25$ até 3 millimetros de largura.

Depois de escamadas as azas, as maculas tornam-se muito mais visiveis do que antes, differençando-se não só por certo gráu de opacidade, como tambem pela sua côr cornea, bastante pallida na macula menor, mais accentuada na base 
e assaz escura no prolongamento da macula maior. Na macula menor ramificam-se diversas trachéas delgadas, que nascem das duas nervuras e limitam a mesma macula. Na macula maior as trachéas attingem um desenvolvimento muito mais consideralvel, e ás vezes verdadeiramente monstruoso, variando muito a este respeito, conforme os diversos individuos que se observam. A maior parte das trachéas que percorrem esta macula, costumam apresentar a sua parte bazilar mais ou menos dilatada, e tortuosa, assemelhando-se a veias varicosas (Fig. 8). Em certos individuos (Fig. 9) essa dilatação das trachéas chega ao ponto de ocuparem ellas todas a área da macula odorifera, perdendo ao mesmo tempo as suas ramificações capillares. Descobri este mesmo gráu de varicosidade na Fig. 7 , entre os dous ramos da nervura subcostal, e á esquerda da nervura discocellular superior, emquanto á direita da mesma nervura ha varias fórmas intermediarias entre as trachéas normaes e as excessivamente varicosas e destituidas de ramos capillares.

A variabilidade das trachéas estende-se tambem, ainda que em gráu muito menos consideravel, ás nervuras que percorrem as maculas e das quaes nascem aquellas trachéas; os dous ramos $(6$ e 7) da nervura subcostal ou são quasi parallelos (Fig. 4, Fig. 8), ou convergem (Fig. 7, Fig. 9), ás vezes quasi tocando-se; nas femeas (Fig. 3, Fig. 6) os dous ramos divergem desde o principio. A nervura discocellular superior (des) atravessa a macula ou em linha recta (fig. 8), ou um pouco curvada (Fig. 9).

Essa variabilidade extraordinaria das trachéas da macula odorifera póde servir de exemplo excellente para elucidar a regra admiravelmente discutida por Darwin ${ }^{1}$ ) de que «a parte desenvolvida em alguma especie, n'um gráu ou maneira extraordinaria, em comparação com a mesma parte em especies alliadas, tende a tornar-se consideravelmente variavel». Assim pois a macula odorifera com as veias e trachéas profundamente modificadas si não se achar exclusivamente na Antirrhea Archaa, ao menos parece limitar-se ás tres especies semelhantes reunidas por Butler no genero Anchiphlebia.

Outro ponto notavel é a separação em duas partes do orgão odorifero, parecendo ser reservada ás azas posteriores a producção, e ás anteriores a emissão ou exhalação do cheiro que deve seduzir as femeas amorosas. Quanto á macula opaca das azas anteriores, parece ser um orgão odorifero rudimentario, ficando por ora indeciso, si se acha em via de progresso ou de regresso, si mais tarde deve aperfeiçoar-se ou desapparecer.

Comparando-se os orgãos odoriferos da Antirrhea Archea com os de Epicalia Acontius, que ha pouco descrevi, encontra-se uma conformidade quasi completa entre as suas partes componentes. Em ambas as especies, aquellas margens das azas que mutuamente se cobrem, são consideravelmente dilatadas e arqueadas no sexo masculino; em ambas, a superficie inferior das azas anteriores é munida de uma crina de cabellos compridos inseridos ao longo da nervura interna, e cobrindo uma macula odorifera bem desenvolvida na Epicalia Acontius, rudimentaria na Antirrhera Archara, Opposta á crina, conta em ambas as especies na superficie superior das azas inferiores uma macula odorifera, cuja parte central

1) Darwin, Origrin. of Species. $4^{\text {a }}$ ediçĩo, pag. 177. 
occupa o angulo situado entre os dous ramos da nervura subcostal, estendendo-se d'ahi ás tres cellulas limitantes da aza. Ora tudo isso seria muito simples e explicar-se-hia facilmente si as duas espezies pertencessem ao mesmo genero ou a generos alliados, si todos aquelles caracteres com que concordam os seus orgãos odoriferos, podessem ser derivados de progenitores communs. Longr disso, porém, ellas são de duas sub-familias muito differentes, a Antirrhea pertencendo ás Satyrideas e a Epicalia ás Nymphalideas, e até muitos dos parentes os mais proximos de uma e outra especie são destituidos de semelantes orgãos; faltam, v. g. completamente na Epicalia Numilia. Assim, pois, não póde haver duvida de que os orgãos odoriferos se tenham desenvolvido independentes um do outro nas duas especies, e que tudo quanto elles têm de commum é unicamente devido á circumstancia de se terem elles accommodado á mesma funcção. Os dous orgãos não são pois «homologos» e sim simplesmente "analogos», e constituem um exemplo dos mais notaveis de «convergencia» como modernamente se tem chamado a semelhança que não resulta de herança, e sim provêm da adaptação a circumstancias identicas. Não conheço outro caso que prove tão clara e irrefragavelmente e com tanta força atteste a verdade de uma these que nunca se devia perder de vista em estudos morphologicos. E' a seguinte: $\mathrm{Si}$ em duas especies certos orgãos que servem á mesma funcçào, se acharem no mesmo lugar, e se compozerem das mesmas partes occupando a mesma posição relativa, e exhibindo fórmas semelhantes, tudo isso por si só ainda não constitue prova sufficiente de serem aquelles orgãos homologos, - nem siquer no caso de pertencerem as duas especies á mesma familia.

\section{Explicação das figuras da estampa XLIX.}

As figuras todas se referem á Antirrhcea Archea Hübner; as figuras $1^{\text {a }}$ até a $4^{\text {a }}$ sâo de tamanho natural, as $5^{\mathrm{a}}, 6^{\mathrm{a}}$ e $7^{\mathrm{a}}$ augmentadas 3 vezes, as $8^{\mathrm{a}}$ e $9^{\mathrm{a}}$ I5 vezes, e o resto I 80 vezes.

Fig. I. - Aza anterior escamada da femea. Note-se nesta figura e na seguinte que, além das nervuras bem desenvolvidas, ainda se avistam distinctamente na cellula discoidal os vestigios da nervura discoidal dividida em dois ramos, como do ramo posterior da nervura subcostal.

Fig. 2. - Aza anterior escamada do macho; $l$, inserçào da crina dilatada na base; m, macula opaca.

Fig. 3. - Aza posterior escamada da femea.

Fig. 4.-Dita do macho; $m$ ', macula odorifera maior, coberta pela crina da aza anterior; $m$ ", dita menor escondida entre a aza e o abdomen da borboleta.

Fig. 5. - Crina da superficie inferior das azas anteriores do macho. Na figura publicada por Butler (Catal Satyrid. Br. M. Pl. V Fig. 3) os cabellos parecem ser fixados pela sua extremidade anterior e volvidos para traz. Seria differença especifica? E' muito mais provavel que seja antes erro.

Fig. 6 e 7.- Parte das azas posteriores mostrando a differença que ha nas nervuras entre o sexo feminino (Fig. 6) e o masculino (Fig. 7); 5, nervura discoidal; 6, ramo segundo; 7 , primeiro ramo da nervura subcostal; 8 , nervura costal; des, nervura discocellular superior; $p c$, nervura precostal.

Fig. 8 e 9.- Macula odorifera maior do macho, escamada, de dous differentes individuos, para mostrar a grande variabilidade das trachéas que se ramificam na mesma macula. Para nào complicar a figura, deixou-se de indicar as inserções das escamas. 
Fig. I O. - Escamas ordinarias da superficie inferior das azas anteriores. $A$, incubas. $B$, súcubas.

Fig. I I e I 2. - Escamas da área coberta pela crina.

Fig. I3 e I4. - Escamas ordinarias da superficie superior das azas posteriores, sendo Fig. I3 do angulo situado entre as duas nervuras internas; e Fig. I4 do intervallo entre a nervura discoidal e o segundo ramo da subcostal. $A$, escamas incubas, $B$ escamas súcubas.

Fig. 15. - Escamas da macula odorifera menor.

Fig. I6. - Escamas da maior. 


\section{A prega costal das Hesperideas ${ }^{1}$ ).}

Mit Tafel L und LI.

Fallando nas differenças sexuaes das Hesperideas Westwood disse que «m certos grupos dessa familia o bordo anterior das azas anteriores é recurvado nos machos, sendo o espaço incluso abundantemente vestido de pennugem pallida» ${ }^{2}$ ). Herrich Schæffer deu a este bordo recurvado das azas anteriores o nome de prega costal (Costalumschlag), servindo-se como caracter distinctivo dos generos que o possuem $\left.{ }^{3}\right)$.

Não me consta que já se tenha procedido a um exame microscopico e comparativo da prega costal nas diversas especies em que é clla observada, nem tào pouco que já se tenha emittido alguma opinião sobre a sua funcção; e comtudo a sua estructura é ás vezes tăo variada e diversa, em especies mui semelhantes, que até, sob o aspecto puramente systematico, o estudo deste orgão não deve ser desprezado.

De muitas centenas de Hesperideas cujos machos são dotados da prega costal, só pude conseguir, por aqui, pouco mais de uma duzia, numero tão limitado, que não me permittirá deduzir resultados geraes das minhas observações; será pois o unico fim desta noticia chamar a attenção dos entomologistas sobre um assumpto que tanto a merece.

Nas Hesperideas, como em muitos lepidopteros nocturnos, o bordo anterior das azas anteriores é occupado por uma nervura á que os lepidipterologistas deixaram de dar um nome; e como tenho de mencional-a frequentemente, designala-hei pelo nome de nervura marginal (Fig. 2, 7, I3, 20, 24, 26, m.).

As especies cuja préga costal examinei, são as seguintes $\left.{ }^{4}\right)$ :

Telegonus Midas, Cram. (Fig. I-5). Dividindo o bordo anterior das azas anteriores em cinco partes iguaes, a prega costal occupa a segunda e terceira dessas partes, a contar da base; o seu comprimento é de ${ }_{1} 5^{\mathrm{mm}}$., o a largura de ${ }^{\mathrm{mm}}{ }^{\mathrm{m}} 5$. Desdobrando-se a prega, apparece no bordo da aza, como se vê na Fig. I e 2, uma figura limitada por dous arcos de circulo e dividida em duas

I) Arch. do Mus. Nacion. Rio de Janeiro 1878. Vol. III. p. 4I-50.

2) Doubleday, Westwood, "Genera of Diurnal Lepidoptera", pag. 506,-1852.

3) Herrich Schæffer, «Prodrom. system. lepidopt.», fascic. III-I 868, pag. 52.

4) Usei dos nomes adoptados por Kirby, "Catalogne Diurn.» I.epidopt.-I8; 1 . 
partes, pela corda commum destes arcos. Estas duas partes sào o bordo recurvado da aza limitado pela nervura marginal e a parte da aza coberta por aquelle bordo recurvado. Ambos os arcos que limitam a mencionada figura são orlados de uma cercadura de escamas lustrosas, côr de palha. Uma terceira orla de escamas da mesma côr, porém mais delgadas e compridas, acha-se implantada na extensão da corda commum, cobrindo completamente a parte recurvada da aza. O comprimento das escamas desta terceira orla iguala ou excede pouco a largura da prega: são pois mais compridas no meio da corda $\left(\mathrm{I}, 5\right.$ até $2^{\mathrm{mm}}$.) onde esta mais se affasta do arco; todas ellas têm uma haste delgada e comprida, que em umas (Fig. 3, a) se dilata a pouco e pouco em fórma de leque, estreito triangular com a margem mais ou menos distinctamente denteada, em quanto que em outras (Fig. $3, b$ ) a haste filiforme termina em uma lamina oval, ou em uma fita estreita com a extremidade arredondada. As escamas que limitam a área coberta pelo bordo recurvado da aza (Fig. 4), são de fórma muito variavel, sendo pela maior parte ovaes ou claviformes; quasi todas ellas são marcadas por macula escura, terminal, cheia de granulações opacas, e separada do resto da escama por uma aureola transparente. Essas maculas escuras são ás vezes muito pequenas quasi reduzidas a um ponto, em quanto que em outros casos ellas occupam toda a largura da escama; e nem sempre são exactamente terminaes, apresentando-se ás vezes deslocadas para um ou outro lado, havendo raras vezes duas destas maculas na mesma escama. A aureola que rodeia as maculas escuras, têm em geral a fórma de um arco de circulo, sendo comtudo ás vezes de fórma menos regular.

As estrias longitudinaes que percorrem as escamas, atravessam tambem as aureolas transparentes, tornando-se mais ou menos confusas e indistinctas nas maculas escuras. A opacidade e o aspecto granulado destas maculas são caracteres frequentemente encontrados em escamas odoriferas; ora, como as extremidades das respectivas escamas com as maculas escuras acham-se cobertas pelo bordo livre da prega costal, não parece improvavel que aquellas maculas tambem sejam odoriferas; si assim fosse as escamas maculosas desempenharian ao mesmo tempo duas funç̧ões muito diversas, servindo a parte basal de cercadura para fechar a prega costal, e a terminal do orgão odorifero.

Removendo as escamas inseridas ao longo da linha recta que separa a parte curva do resto da aza, ou cortando transversalmente a prega costal, vê-se, que o espaço, comprehendido entre aquellas escamas e a parte curva da aza, é coberto de um pó, pardacento, composto pela maior parte de particulas soltas (Fig. 5, a) tendo em geral de $\mathrm{O}^{\mathrm{mm}}, \mathrm{OI} 6$ até $\mathrm{O}^{\mathrm{mm}}, \mathrm{O} 25$ de comprimento sobre cerca de $\mathrm{O}^{\mathrm{mm}}, \mathrm{OO}_{+}$ de largura, as dos lados, quasi sempre parallelas, convergindo rarissimas vezes para uma das extrẹmidades, são transparentes, de côr um pouco amarellada, e em geral atravessadas por uma linha mais escura e opaca, no sentido longitudinal.

Entre as particulas soltas ha outras (Fig. 5, b) dispostas em fileiras, por fios curtos e finissimos, como tambem alguns cabellos (Fig. $5 c, d$ ) mais ou menos distinctamente articulados.

Estes cabellos revelam a origem do pó, que enche a cavidade da prega costal, - que se compõe de fragmentos de cabellos articulados. Emfim, para completar a lista das formas que as ascamas podem tomar na prega costal do 
Telegonus Midas, cumpre mencionar ainda certas escamas estreitas de ${ }^{\text {mm }}, 6$ de comprimento sobre $\mathrm{O}^{\mathrm{mm}}, 016$ de largura, que encontrei na cavidade da prega, sem poder indicar o lugar exacto em que ellas se achavam inseridas.

Telegomus (?) especie indeterminada de S. Bento (Fig. 6-9).

Esta especie, de que só pude conseguir um unico exemplar muito estragado, porém com a prega costal bem conservada, é notavel tanto pela extensão da prega costal, que occupa perto de tres quintos do bordo anterior da aza (Fig. 6), como pelo calibre insolito da nervura marginal (Fig. 7, $M$ ), que é muito maior do que o das nervuras costal e sub-costal (Fig. $7, c$ e $s c$ ). A cavidade formada pela prega costal é limitada e fechada em baixo, por escamas numerosissimas as quaes nascem ao longo da linha recta que separa o bordo recurvado do resto da aza, em cima pelo bordo recurvado. A nervura costal é uma cercadura de escamas menores inseridas ao longo desta mesma nervura.

A «pennugem pallida», encerrada no intererior da prega costal, nasce da parede superior da mesma, tanto da nervura marginal, como do bordo recurvado da aza (Fig. 7). Esta "pennugem» compõe-se quasi exclusivamente de cabellos articulados; os articulos, na maior parte soltos (Fig. 8), variam muito em cumprimento e largura; geralmente a largura é de $\mathrm{O}^{\mathrm{mm}}, \mathrm{oo} 8$ até $\mathrm{O}^{\mathrm{mm}}, \mathrm{O} 1$ sobre $\mathrm{O}^{\mathrm{mm}}, \mathrm{O} 4$ até $\mathrm{O}^{\mathrm{mm}}, \mathrm{o} 6$ de comprimento; os que se acham reunidos em numero mais ou menos consideravel costumam ser muito mais estreitos (Fig. 9). Os articulos são transparentes, mas semeados de pontos opacos.

Telegonus Mercatus, Fab. (Fig. 10, 11). A prega costal (Fig. 10, p) é menor do que nas duas especies antecedentes, sendo o comprimento pouco superior á terça parte do bordo anterior da aza, e a largura igualmente pouco mais ou menos a metade da cellula 12 (segundo a nomenclatura de Herrich Schæffer, isto é, do intersticio comprehendido entre a nervura costal e o bordo anterior da aza. No interior da prega encontra-se uma serie de escamas mui curiosas (Fig. I I). Ha, em primeiro lugar, representando a forma primitiva de que as mais podem ser derivadas, escamas maiores, robustas (Fig. 1 I, i), de cerca de $0^{\mathrm{mm}}, 3$ de comprimento, de que um sexto, pouco mais ou menos, é occupado pela lamina terminal triangular ou oval, e o resto pela haste.

Esta, estreitando-se abaixo da lamina terminal, forma uma especie de collo. Em outras escamas semelhantes, porém menores (Fig. 1 I $g, h$ ), o collo costuma ser mais estreito e a lamina terminal menor, nào excedendo e nem sequer alcançando a largura da parte inferior da haste. A metamorphose das escamas continua no mesmo sentido (Fig. $11 e, f$ ) até attingir aquellas formas especiaes (fig. I I $c, d$ ), em que o collo, que liga a lamina terminal â haste, acha-se reduzido a um fio mais tenue.

Finalmente, escamas ha semelhantes a estas ultimas, que terminando como ellas em um fio delgadissimo, ás vezes quasi imperceptivel, não têm lamina terminal (Fig. I I $a, b$ ).

Com certeza, algumas destas escamas eram d'antes providas de laminas; pois, encontrei varias laminas soltas, semelhantes ás da Fig. I I, $c, d$; parecendo-me, porém provavel que algumas d'entre ellas nunca foram providas deste appendice, porque, o numero das laminas soltas não é equivalente ao das escamas. 
Hesperia Syrichthus Fab. (Fig. I 2, I8). Esta especie, que habita não só a America do Sul, como tambem a America Central e a parte meridional dos Estados-Unidos, é muito frequente na provincia de Santa Catharina.

A prega costal dos machos, bastante larga, occupa metade do bordo anterior das azas e estende-se até a nervura costal (Fig. I2).

A nervura marginal (Fig. $13 \mathrm{~m}$ ) é guarnecida de escamas mais ou menos curvas, de forma oval ou orbicular (Fig. 14). Toda a superficie interna da prega costal, desde a nervura costal até a marginal, é revestida de escamas ou cabellos bastos de differentes formas.

Na extensão do bordo curvo encontram-se escamas pallidas (Fig. 15) de forma oval com a extremidade arredondada, de $\mathrm{o}^{\mathrm{mm}}, \mathrm{or}$ até $\mathrm{o}^{\mathrm{mm}}, \mathrm{O} 3$ de largura.

No fundo do angulo formado por este bordo e o resto da aza, acham-se escamas menos pallidas, opacas, muito estreitas, adelgaçando-se em ponta aguda (Fig. I8), de $\mathrm{o}^{\mathrm{mm}}, \mathrm{o} 8$ de comprimento sobre cerca de $\mathrm{o}^{\mathrm{mm}}, 005$ de largura. Emfim, na parte da aza coberta pelo bordo recurvado acham-se escamas de duas formas muito diversas; as da primeira forma (Fig. I7) são lanceoladas, com o ${ }^{\mathrm{mm}}, \mathrm{I} 4$ até $\mathrm{O}^{\mathrm{mm}}, \mathrm{I} 7$ de comprimento, e $\mathrm{O}^{\mathrm{mm}}, \mathrm{O} 3$ até $0,04{ }^{\mathrm{mm}}$ de largura; as da segunda forma (Fig. I6) são muito tenras, transparentas capillares, variando de $\mathrm{o}^{\mathrm{mm}}, 2$ até $\mathrm{o}^{\mathrm{mm}}, 27$ de comprimento e de $\mathrm{O}^{\mathrm{mm}}, \mathrm{OO} 2$ até $\mathrm{o}^{\mathrm{mm}}, \mathrm{Oo6}$ de largura; diminuindo pouco a pouco a largura, ellas terminam em um fio subtilissimo, sendo munidas, na extremidade, uma lamina extremamente exigua, que tem a forma de um triangulo isoscelos obtusangulo. Os lados deste triangulo são linhas mui delgadas quasi imperceptiveis, de modo que, á primeira vista, só apparece a base como linha recta perpendicular no extremo do fio subtilissimo que a sustenta. Estas singularissimas escamas (Fig. I6) da Hesperia Syrichtus, si bem que apparentemente tão diversas das do Telegonus Mercatus, podem, não obstante, ser muito facilmente derivadas da mesma fórma (Fig. I I, $i$ ).

Leucochitonea Arsalte, Linn. (Niveus, Cram.) (Fig. 19-22). A prega costal dos machos é muito menor do que na especie antecedente, occupando apenas um terço do bordo anterior da aza e menos de metade da largu do raintersticio entre a dita prega e a nervura costal.

A pennugem encerrada na prega nasce só da superficie do bordo recurvado da aza e acha-se protegida por duas fileiras ou cercaduras de escamas, das quaes uma é inserida ao longo da nervura marginal (Fig. 20, M), e a outra ao longo da linha recta que separa a parte recurvada do resto da aza; o comprimento destas ultimas escamas iguala a largura, sendo muito mais curtas as inseridas na nervura marginal. A pennugem compõe-se de duas formas differentes, correspondentes ás que se encontram na Hesperia Syrichthus.

As da primeira fórma (Fig. 21) assemelham-se an ferro de uma lança; ellas têm cerca de $\mathrm{O}^{\mathrm{mm}}, \mathrm{I} 5 \mathrm{de}$ comprimento, variando a largura de um nono até um quarto do comprimento, a achando-se a maior largura immediatamente ácima do ponto de insersão, ou á pequena distancia delle, correndo d'ahi aos lados em linha quasi recta á ponta aguda da escama. Estas escamas (que evidentemente correspondem ás representadas na fig. 17 da Hesperia Syrichthus), são pallidas, transparentes, com a ponta mais ou menos opaca, e a base quasi sempre percorrida por uma estria longitudinal composta de granulos opacos. As escamas da segunda 
forma (Fig. 22) têm o mesmo comprimento de $\mathrm{O}^{\mathrm{mm}}, 15$, e são tào delgadas que antes merecem o nome de cabellos, pois que a sua largura raras vezes attinge a $\mathrm{O}^{\mathrm{mm}}, \mathrm{OO} 2$; sendo geralmente muito menores, terminam em um fio subtilissimo, em cujo extremo se vê um botãosinho punctiforme, muitas vezes quasi imperceptivel, e que parece faltar completamente en algumas destas escamas ou cabellos (que correspondem ás da Fig. I6 da Hesperia Syrichtus).

Thymele Simplicius, Stoll. (Eurycles Latr.) Fig. 23-28) Herrich Schæffer ${ }^{1}$ ) distinguiu tres variedades de Eudamus (Goniurus) Eurycles, como elle chamou á especie designada pelo nome de Thymele Simplicius no catalogo de Kirby. Na primeira variedade, as azas seriam destituidas de pontos e maculas transparentes, e só no lado inferior haveria tres pontos costaes. A inda não vi por aqui esta primeira variedade. Na segunda variedade os tres pontos costaes seriam visiveis em ambos os lados da aza, e além disso haveria alguns pontos transparentes pelo meio do bordo anterior; esta segunda variedade, ás vezes tambem por aqui se encontra, sendo os machos sempre providos de prega costal. Emfim, na terceira variedade os pontos e maculas transparentes formariam uma fita estreita, ás vezes interrompida na cellula terceira (como na fig. 25), outras vezes mostrando-se interrompida até além da segunda nervura ou primeiro ramo da nervura media (como na fig. 23). Segundo Herrich Schæffer os dous individuos machos, cujas azas interiores acham-se representadas nas figuras 23 e 25 , pertenceriam a esta terceira variedade, e, não obstante, um delles (Fig. 23 e 24) não possue nenhum vestigio de prega costal, emquanto o outro (Fig. 25 e 26) é dotado de uma prega costal bem desenvolvida.

Como esta terceira variedade abunda no Rio Itajahy, pude examinar um numero avultado de exemplares, e verifiquei que a prega costal falta em todos os machos, em que a fita transparente entra na primeira cellula (Fig. 23), e que existe em todos aquelles em que a mesma fita não passa além da segunda nervura (Fig. 25). Nestes individuos providos de prega costal o numero e a extensão das maculas transparentes são mui variaveis; ha um numero quasi infinito de formas intermediarias entre a segunda variedade de Herrich Schæffer e outras semelhantes aos machos destituidos de prega costal, possuindo, como estes, maculas transparentes nas cellulas $3^{\mathrm{a}}$ e $6^{\mathrm{a}}$, e distinguindo-se dellas apenas pela falta da macula transparente da primeira cellula. Da mesma sorte tambem se observa uma variabilidade consideravel nas escamas de que se compõe a pennugem da prega costal.

As escamas representadas na figura 27 são de individuos que tinham só tres pontos costaes (nas cellulas $7^{\mathrm{a}}$ até $9^{\mathrm{a}}$ ), e careciam de macula transparente na cellula $3^{\text {a }}$ (Fig. 25); as da fig. 18 foram tiradas da prega costal de um macho que tinha quatro pontos costaes (nas cellulas $6^{\mathrm{a}}$ até $9^{\mathrm{a}}$ ) e uma macula transparente na cellula $3^{\mathrm{a}}$. As escamas encerradas na prega costal mostram duas formas principaes: na primeira fórma (Fig. 27, $a, b, c, d$; Fig. 28, $a, b$ ) distingue-se uma parte inferior lanceolada, attenuando-se em uma parte terminal mais ou menos filiforme, cujo extremo se dilata de novo em uma especie de lamina ou leque triangular. $\mathrm{O}$ comprimento destas escamas que em certos machos (Fig. 28) é apenas de $\mathrm{O}^{\mathrm{mm}}, \mathrm{o} 8$ até $\mathrm{O}^{\mathrm{mm}}, 16$, eleva-se em outros (Fig. 27) de $\mathrm{O}^{\mathrm{mm}}, 2$ até $\mathrm{O}^{\mathrm{mm}}, 3$. As escamas da se-

I) Prodrom. system. lepidopt. fascic. III-1868, pag. 6 I. 
gunda forma (Fig. 26, e, Fig. 28. d) costumam ser mais delgadas, sendo ás vezes perfeitamente capilliformes (Fig. 28); cllas transformam-se insensivelmente em fio subtilissimo, em cujo extremo só em poucos casos (Fig. 27,e) pode se distinguir um botàosinho punctiforme. $O$ seu comprimento é o mesmo da primeira forma. Além disso costuma haver algumas escamas mais curtas, espessas e opacas (Fig. 27,f; Fig. 28, c), semelhantes ás da primeira forma. - A prega costal occupa quasi a metade do bordo anterior da aza, porém, é bastante estreita.

$\mathrm{Si} \mathrm{em}$ todos os districtos habitados pela Thymele Simplicius os individuos machos privados de prega costal distinguirem se dos mais, o que acontece aqui, pela fita transparente prolongada além da segunda nervura, convirá consideral-os constitutuidores de uma especie distincta e não como simples variedade. Como quer que seja, porém, é digno de observação que de duas formas tào semelhantes, incluidas na mesma variedade por Herrich Schæffer e outros, uma tenha a prega costal bem desenvolvida, emquanto a outra acha-se inteiramente destituida da mesma prega.

Ninguem até agora parece ter reparado nesta falta da prega costal em certos machos do Thymele Simplicius; provalvelmente estes machos, por causa desta mesma falta, tèm passado por femeas, erro bem perdoavel quando não se podem examinar os animaes vivos, cujo sexo facilmente se conhece pelas partes genitaes.

Thymele Protillus Herr. Sch. (Fig. 30). A prega costal occupa quasi a metade do bordo anterior da aza, estendendo-se um poucn além da macula transparente da cellula I 2. Ha no interior da prega:

I. ${ }^{0}$ Escamas de cerca de $\mathrm{O}^{\mathrm{mm}}, 3$ de comprimento (Fig. 30, a) com a base lanceolada e a lamina terminal arredondada, oval, triangular ou cordiforme de largura variavel.

2. ${ }^{0}$ Cabellos tenuissimos (Fig. 30 b) que têm o mesmo comprimento.

$3 .{ }^{\circ}$ Escamas estreitas (Fig. 30, c) com os lados quasi parallelos, de cerca de $\mathrm{O}^{\mathrm{mm}}, 12$ de comprimento, sobre $\mathrm{O}^{\mathrm{mm}}, \mathrm{OO} 4$ de largura apenas, terminando de repente em um fio subtilissimo, quasi imperceptivel.

$4 .^{0}$ Fragmentos de cabellos articulados (Fig. 30, $d$ ) que em geral nào sào muito abundantes.

Thymele Proteus Linn. (Fig. 29). Nesta especie, muito semelhante á precedente, a prega costal costuma não passar além da macula transparente da cellula 12, sendo tambem mais estreita do que na Thymele Protillus. Predominam no interior da prega os cabellos articulados transparentes (Fig. 29, c), cuja largura raras vezes se eleva a $\mathrm{O}^{\mathrm{mm}}, \mathrm{OO} 4$; o comprimento dos articulos é de $\mathrm{O}^{\mathrm{min}}, \mathrm{o} \mathrm{I} 6$ até mais de $\mathrm{o}^{\mathrm{mm}}, \mathrm{O} 3$. Geralmente acham-se estes articulos reunidos em numero de 7 até I 2. Além disso ha escamas, cuja maior parte (Fig. 29, a) tem cerca de $\mathrm{O}^{\mathrm{mm}}, 2$ de comprimento sobre $\mathrm{O}^{\mathrm{mm}}, \mathrm{O} 2$ de largura; são pallidas e percorridas por uma estria longitudinal de grànsinhos opacos; a base attenua-se insensivelmente, e termina em pequena lamina elliptica; sua largura nào excede, ou nem mesmo attinge a maior largura da base. Ha tambem escamas menores da mesma forma (Fig. 29, b), cuja lamina terminal costuma serr mais estreita ainda, e que não apresentam a estria longitudinal opaca das maiores.

Entheus Vitreus Cram. A prega costal dos mathos desta elegante especie é muito estreita, e encerra cabellos articulados e transparentes; os articulos ou sào 
soltos ou reunidos em numero de $\mathrm{I}_{\mathrm{O}}$, ou mais, e têm geralmente $\mathrm{O}^{\mathrm{mm}}$, Or 5 de comprimento sobre $\mathrm{O}^{\mathrm{mm}}, \mathrm{OO} 4$ de largura; mas tanto o comprimento como a largura são muito variaveis.

Afora estas especies, examinei a prega costal de varias outras, cujos nomes nào conheço; como porém observações, que não podem ser verificadas por outros por nào se conhecerem as especies, em que foram feitos, săo em geral de pouco valor, limito-me a dizer algumas palavras sobre algumas das formas mais notaveis de escamas, ou cabellos, que encontrei na prega costal dessas especies.

Em uma especie de Telegonus (com as maculas transparentes amarelladas, e uma grande macula prateada na superficie inferior das azas posteriores) predominavam, na prega costal, escamas capilliformes (Fig. 31, a) transparentes, muito compridas (tendo até $\mathrm{o}^{\mathrm{mm}}, 36$ ), que de repente attenuam se em fio subtilissimo; cram acompanhadas de algumas escamas (Fig. 31, b), semelhantes ás escamas menores de Thymele Protens (Fig. 29, b), e de alguns fragmentos de cabellos articulados.

Em outra especie os articulos dos cabellos (Fig. 32) que muito variavam em comprimento e largura, eram notaveis por serem ligados por fios assaz compridos, que tambem se conservavam nos articulos soltos.

Emfim, em uma especie muito semelhante ao Achlyodes Thraso, Hübn. (I) a prega costal, que era muito estreita, encerrava escamas lanceoladas mais ou menos opacas (Fig. 33, b, c) e cabellos transparentes (Fig. 33, a) notaveis:por serem providos de uma especie de raiz fusiforme ou appendice vesicular, transparente, de cerca de $\mathrm{o}^{\mathrm{mm}}, 025$ de comprimento, e $\mathrm{O}^{\mathrm{mm}}, \mathrm{oo} 8$ de grossura. Nas outras Hesperideas que examinei encontrei só uma vez uma raiz semelhante em uma escama da prega costal de Telegonus Mercatus (Fig. I I, a). Na sub-familia das Pierinas as escamas odoriferas espalhadas na superficie das azas dos machos são quasi sempre providas de appendices resiculares.

Quanto á funcção da prega das Hesperideas, creio que não póde haver duvida de que tambem pertença á classe dos orgãos odoriferos, os quaes infinitamente diversificados, distinguem o sexo masculino de tantos outros lepidopteros tendo em certas especies do genero Papilio tomado uma forma muito semelhante; não é, porém, a margem anterior das azas anteriores, e sim a posterior das posteriores que se acha recurvada, cobrindo, ora uma escova de pellos compridos, ora uma pennugem pallida muito densa. No Papilio Protesilaus a escova preta incluida n'aquella prega marginal exhala um cheiro muito intenso e desagradavel, emquanto um aroma suave emana da pennugem pallida do Papilio Nephalion. Está pois evidenciada nestas especies de Papilio a funcção odorifera da prega marginal das azas posteriores, e pela analogia manifesta que com ella tem a prega costal das Hesperideas, parece muito provavel que a esta tambem se deve attribuir a mesma funcção.

\section{Explicação das Figuras da estampa L e LI.}

Fig. I, 5.- Telegonns Midas, Cram.

Fig. I. - Aza anterior com a prega costal $(P)$ desdobradid, de tamanho natural.

Fig. 2. - Prega costal desdobrada, augmentada 3 vezes, $M$ nervura marginal, $c$ nervura costal. 
Fig. 3.-Escamas inseridas ao longo do limite entre a margem recurvada e o resto da aza, augmentadas 25 vezes.

Fig. 4. - Escamas inseridas ao longo da area coberta pela margem recurvada augmentadas 25 vezes.

Fig. 5. - Cabellos articulados, formando um pó pardacento no interior da prega costal, augmentado I 8 o vezes; $a$, articulos soltos; $b$, ditos unidos; $c d$, cabellos imperfeitamente articulados.

Fig. 6, 9. - Telegonus, spec. (?), de S. Bento.

Fig. 6. - Aza anterior, com a prega costal $(P)$ fechada, de tamanho natural.

Fig. 7. - Secçào transversal pelo meio da prega costal, augmentada 25 vezes. $M$, nervura marginal; $c$, dita costal; se, dita sub-costal.

Fig. 8. - Articulos soltos dos cabellos do interior da prega, augmentados I 80 vezes.

Fig. 9. - Cabello articulado augmentado i 80 vezes.

Fig. IO, I I. - Telegonus Mercatus, Fab.

Fig. IO. - Aza anterior com a prega costal $(P)$ fechada, augmentada 2 vezes. $I$, nervura sub-mediana ou interna; $2,3,4$, primeiro, segundo e terceiro ramos da nervura mediana; 5 , segundo; 6 , primeiro ramo da nervura discoidal; 7 . quinto; 8 , quarto; 9 , terceiro; $I 0$, segundo; $I I$, primeiro ramo da nervura sub-costal; $I 2$, nervura costal.

Fig. I I. - Escamas encerradas na prega costal, augmentadas i 80 vezes.

Fig. I 2, I 8. - Hesperia Syrichthus, Fab.

Fig. I 2. - Aza anterior, augmentada 3 vezes. $P$, prega costal.

Fig. I 3. - Secção transversal pela prega costal, augmentada 25 vezes. $M, s, s c$, nervuras marginal, costal e subcostal.

Fig. I4. - Escamas inseridas ao longo da nervura marginal, augmentadas 30 vezes.

Fig. I 5. - Ditas da superficie interna da margem recurvada.

Fig. I6, I 7. - Ditas da area coberta pela margem recurvada.

Fig. I 8. - Ditas do fundo do angulo formado pela margem recurvada e o resto da aza. As figuras I 5, I 8 são augmentadas i So vezes.

Fig. I 9, 22. - Leucochitonea Arsalte, Linn.

Fig. I 9. - Aza anterior, augmentada 3 vezes. $P$ prega costal.

Fig. 20. - Secção transversal pelo meio da prega, augmentadas 25 vezes.

Fig. 2 I, 22. - Escamas do interior da prega, augmentadas I80 vezes.

Fig. 23-28. Thymele Simplicius, Stoll (masc.).

Fig. 23. - Aza anterior de um macho sem prega costal, augmentada 2 vezes. As cellulas da aza sâo mumeradas segundo Herrich Schæffer.

Fig. 24. - Secção transversal pela mesma aza no lugar occupado em outros machos pela prega costal, augmentada 28 vezes. M. c. cs. nervuras marginal, costal e subcostal.

Fig. 25. - Aza anterior de um macho provido de prega costal $(P)$, augmentada 2 vezes.

Fig. 26. - Secção transversal pelo meio da prega costal, augmentada 25 vezes, $m . c$. nervuras marginal e costal.

Fig. 27. - Escamas do interior da prega costal.

Fig. 28. - Ditas de outro individuo.

Fig. 29. - Thymele Proteus, Linn. (masc.). Escamas da prega costal.

Fig. 30. - Thymele Protillus, Herr. Sch. (masc.). Escamas da prega costal.

Fig. 31. - Telegonus, especie indeterminada. Escamas da prega costal.

Fig. 32. - Articulos de cabellos da prega costal de uma Hesperidea indeterminada.

Fig. 33. - Cabellos e escamas da prega costal de uma especie muito semelhante ao Achlyodes Thraso, Hü̈n.

As figuras 27-33 sào augmentados, I8o vezes. 


\section{Macrosilia cluentius $\left.{ }^{1}\right)$.}

Aus einem Briefe an H. Müller.

In Nature (vol. viii. p. 223) I have spoken of a Sphin. which, with its proboscis of $0.25 \mathrm{~m}$ length, would be capable of obtaining nearly all the nectar of Angrecum sesquipedale. Lately my brother, Fritz Müller (Itajahy, Prov. St. Cathariaa, Brazil), sent me the wings of another specimen of the same species, and Dr. Staudinger, of Dresden, stated by comparison of these wings with the Sphingidæ of his collection that the name of the species is Macrosilia cluentius, Cramer.

Lippstadt, January 9.

Hermann Müller.

I) Nature Vol. XVII. I878. p. 22 I. 


\section{Ueber die Naupliusbrut der Garneelen ${ }^{1}$ ).}

Nach dem Erscheinen des Aufsatzes über die Verwandlung der Garneelen ${ }^{2}$ ) sprach mir Spence Bate brieflich sein Bedenken aus über die Zusanmengehörigkeit der von mir beschriebenen Jugendformen. Man solle eigentlich niemals Larven auf bestimmte erwachsene Thiere bezichen, ohne sie unmittelbar aus dem Ei und dieses von der Mutter erhalten zu haben. Meine Nauplius seien freischwimmend im Meere gefangen worden und möglicherweise gar keine Penëuslarven. Aehnlich äusserte sich später in einem Briefe Alexander Agassiz, und so eben finde ich dieselben Bedenken wiederholt von Herrn Dr. Paul Mayer ${ }^{3}$ ) in einer Besprechung des neuesten Werkes von Claus: „Untersuchungen zur Erforschung der genealogischen Grundlage des Crustaceensystems“.

Die Entwicklung naupliusähnlicher Larven zu langschwänzigen Krebsen ist von solcher Bedeutung für den Stammbaum der Kruster, dass es nicht überflüssig scheint, solchen Bedenken gegenüber noch einmal auf die Gründe hinzuweisen, welche mich den von mir geschilderten Entwicklungsgang schon jetzt als völlig gesicherte Thatsache betrachten lassen. Ich wiederhole zu diesem Behufe wörtlich, was ich (im October I 864) als Entgegnung auf Spence Bate's Zweifel niederschrieb.

„Die Forderung, dass man Jugendformen nur dann bestimmten Eltern zuschreiben solle, wenn man sie aus den der Mutter entnommenen Eiern erhalten, scheint mir unbillig. Wollte man sie zugestehen, so würde sie natürlich nicht nur für die jüngsten, sie würde mit ganz gleichem Rechte für alle Jugendformen zu stellen sein; für jede würde man verlangen müssen, dass sie entweder aus dem Ei gezogen oder bis zur Geschlechtsreife am Leben erhalten worden sei und unter dieser Bedingung würden wir für immer auf die Entwicklungsgeschichte der meisten Seethiere verzichten müssen. Ich meine, es sei vollkommen genügend, dass man die Endglieder der Reihe durch eine Kette von Zwischenformen zu verbinden vermöge, die so eng schliessen, dass über die Zusammengehörigkeit je zweier einander folgender Glieder vernünftigerweise kein Zweifel obwalten könne. Diesen Beweis aber für die Zugehörigkeit meines Nauplius zu Penëus oder einer nächstverwandten Gattung glaube ich in völlig ausreichender Weise geliefert zu haben. In einer Zeitschrift, die für einen Jahrgang die Zahl von I 2 Tafeln bestimmt hat, durfte ich freilich nicht, wie Spence Bate in seiner schönen Arbeit über die Entwicklung des Carcinus Maenas, für einen einzigen Auf-

1) Zeitschrift für wissenschaftliche Zoologie 1878. Bd. XXX. S. 163-166.

2) Archiv für Naturgeschichte. Bd. XXIX, 1. 1863. S. 8. = Ges. Schriften S. 167.

3) Jenaer Literaturzeitung 1877 . Nr. 16. S. 247. 
satz sieben Tafeln beanspruchen; ich musste mich darauf beschränken, aus gegen 50 Blättern mit Zeichnungen über die Entwicklung der aus Naupliusbrut hervorgehenden Garneelen einige wenige der bezeichnendsten Formen herauszuheben. Dabei schien es mir, als selbstverständlich, nicht nöthig, ausdrücklich zu bemerken, dass die geschilderten Umwandlungen der einen Form in die andere, nicht etwa zu den wenigen gegebenen Zeichnungen hinzugedichtet, sondern dass sie nach sorgsamer Untersuchung zahlreicher Larven dargestellt wurden.

Nur an einer Stelle standen mir Zwischenformen nicht in reicher Auswahl zu Gebote; zwischen dem a. a. O. Taf. II (= Ges. Schriften Taf. XXII) Fig. 2 abgebildeten Nauplius und der Fig. 4 gezeichneten Zoëa habe ich, wie ich auch angeführt habe, nur zwei Zwischenformen (wenigstens von derselben Art) zu beobachten Gelegenheit gehabt; einen älteren Nauplius, dessen drittes Fusspaar ich in Fig. 3 zeichnete, in vier Exemplaren und eine jüngere Zoëa.

Da eben gegen diesen Punkt und so viel ich weiss, ausschliesslich gegen diesen, gegen die Zugehörigkeit der Nauplius zu den Zoëa sich die Bedenken derer richten, welche an die Umwandlung eines Nauplius in einen langschwänzigen Krebs nicht glauben mögen, so seien noch einmal die Eigenthümlichkeiten zusammengestellt, in denen die ältesten Nauplius mit den jüngsten Zoëa übereinkommen.

Fürs Erste haben sie dieselbe höchst eigenthümliche Bewegungswe ise, durch welche sie auf den ersten Blick von a11en anderen Krustern unseres Meeres sich unterscheiden.

Zweitens haben sie dieselbe $\mathrm{F}$ ärbung; namentlich zeigen die beiden vorderen Gliedmassenpaare und das gablige Schwanzende ein eigenthümliches nach der Spitze zu dunkleres Braun, das ich ebenfalls bei keinem anderen Kruster unseres Meeres kenne.

Drittens: Die verhältnissmässige Länge der beiden ersten Gliedmassenpaare, ihr ganzes Aussehen ist dasselbe; nur sind sie bei der Zoëa deutlicher gegliedert und das zweite ist etwas reichlicher beborstet; statt drei stehen z. B. am Ende des inneren Astes vier Borsten. Ebenso ist das Hinterende der Zoëa nur dadurch verschieden, dass seine Aeste weiter auseinanderstehen und dass jeder derselben statt sechs, wie beim älteren Nauplius, anfangs sieben, später acht Borsten trägt.

Viertens: Aus der (Fig. 3 gezeichneten) Bildung des dritten Gliedmassenpaares des ältesten Nauplius geht hervor, dass er nach der nächsten Häutung Mandibeln haben muss mit spitzem vorspringendem Zahne und breiter quergeriefter Kaufläche, und dass die Mandibel einen borstenlosen dunkelbraunen Anhang tragen muss. Eine solche Mandibel hat, einen solchen Anhang trägt die jüngste Zoëa, und, wohlgemerkt, der Nauplius wurde beobachtet am 24. Januar, die Zoëa am 3. Januar, wo ich gar nicht wusste, was dieser Anhang der Mandibel bedeute. Ich kenne bei keinem anderen jugendlichen oder erwachsenen Krebs einen ähnlichen Anhang.

Fünftens: An dem ältesten Nauplius sieht man, dass die nächste Entwicklungsstufe vier weitere Gliedmassenpaare besitzen muss; vier weitere Gliedmassenpaare, in ihrer Gestalt den im Nauplius vorhandenen Anlagen entsprechend, besitzt die jüngste Zoëa.

Sechstens: Die Bildung des Herzens, des Darmes, der Leber ist genau dieselbe bei dem ältesten Nauplius und der jüngsten Zoëa. 
Siebentens: Bei dem ältesten Nauplius wurde nahe dem Stirnrande jederseits ein trübes feinkörniges Gewebe und darüber vorspringend ein rundliches Knöpfchen gesehen; ganz dasselbe sieht man bei der jüngsten Zoëa. Aus jenem Gewebe entwickeln sich später die paarigen Augen und an ihnen erhält sich bis zur Mysisform das Knöpfchen (a. a. O. Fig. 9, o). An den Augen kein es einzigen anderen Krebses kenne ich ähnliche Knöpfchen.

Und was sind nun neben all diesem Gemeinsamen die Unterschiede? Dass die Zoëa ein wenig grösser, dass der beim Nauplius bereits angedeutete Rückenschild wohl entwickelt ist, dass die in der Anlage vorhandenen Füsse in Thätigkeit getreten, dass einige neue Borsten hinzugekommen sind, - Fortschritte, die allesammt vorauszusagen waren.

Ich sollte meinen, diese Gründe müssten so ziemlich genügen, auch den ärgsten Zweifler zu überzeugen. Doch, wenn denn nun einmal mein Nauplius nicht von einem Penëus stammen, nicht zu einem Penëus werden soll, so sage man mir, was er denn möglicherweise sein könne. Einen Vater muss ja doch das Kind haben.

Noch weniger als den Garneelen wird man ihn natürlich einem anderen Krebse aus der Abtheilung der Malacostraca, etwa einer Krabbe oder Assel zutheilen wollen. Es bleiben also in unserem der Phyllopoden entbehrenden Meere nur die Copepoden mit den Lernaeen und die Rankenfüsser mit den Wurzelkrebsen als mögliche Endpuncte seiner Entwicklung.

Nun zu einem Rankenfüsser oder Wurzelkrebs kann er unmöglich werden; schon die Bildung des Herzens, der Leber, der Mandibeln beweist es. Zudem fehlen ihm die "Stirnhörner" der Rankenfüsserlarven; es fehlen die Zacken und Zähne mit denen beim Nauplius der Rankenfüsser das dritte Gliedmassenpaar bewaffnet ist. Nahe dem Uebergang in eine zweite Entwicklungsstufe, wie der (a. a. O. Fig. 2 gezeichnete) Nauplius ist, würde man bei einem Rankenfüsser oder Wurzelkrebs sechs neue Fusspaare unter der Haut desselben, nicht aber deren vier frei am Bauche hervorsprossen sehen, u. s. w. - Weit ähnlicher als denen der Rankenfüsser ist derselbe gewissen Naupliusformen der Copepoden. Auch bei diesen finden sich Entwicklungsstufen, auf welchen ausser den drei ursprünglichen Gliedmassenpaaren Anlagen von vier neuen Paaren zu sehen sind. Allein ich kenne weder aus eigener Erfahrung, noch finde ich unter den zahlreichen Abbildungen, die das vortreffliche Copepodenwerk von Claus zieren, irgend eine Mandibelform, die der unseres Nauplius zu vergleichen wäre. Zudem bleibt bei allen Copepoden des Meeres, mit Ausnahme der Corycaeiden, das dritte Gliedmassenpaar wohlbeborstet als Mandibularanhang erhalten; die Corycaeiden aber, von Anderem abgesehen, haben kein Herz, das unser Nauplius besitzt. Dazu kommt, dass derselbe die Länge eines halben Millimeter erreicht, also danach eher für einen geschlechtsreifen Copepoden, als für die früheste Jugendform eines solchen gelten könnte. Einem Copepoden zugehörig, müsste er von einer unbekannten riesigen Art aus einer noch unbekannten Familie abstammen und es wäre ziemlich wunderbar, dass mir diese Riesenart im Laufe langer Jahre nicht ein einziges Mal ins Netz gegangen."

Itajahy, St. Catharina, Brazil, Juni 1877 . 


\title{
Die Stinkkölbchen der weiblichen Maracujáfalter. $\left.{ }^{1}\right)$.
}

\author{
Mit Tafel LII.
}

Die Weibchen der durch die engsten Bande der Blutsverwandtschaft verbundenen Gattungen Heliconius, Eueides, Colaenis und Dione (=Agraulis), die ich unter dem Namen der Maracujáfalter (nach der Futterpflanze ihrer Raupen) zusammenfasse, treiben, wenn man sie ergreift, am Ende des Hinterleibes, und zwar auf dem Rücken zwischen vorletztem und letztem Leibesrringe eine grosse gelbliche widerlich riechende Wulst hervor, die durch eine seichte Längsfurche in eine rechte und eine linke kuglig gewölbte Hälfte getheilt wird (Fig. I $W$, Fig. $3 A, W$ ). Die Männchen dieser Falter besitzen zwei kleinere, denselben Geruch verbreitende Wülste an der Innenseite der Afterklappen.

Nun hatte ich kürzlich ein Weibchen unseres schönen grünen Schmetterlings, der Colaenis Dido, gefangen. Beim ersten Ergreifen wurde, wie gewöhnlich, die grosse Stinkwulst rasch vorgestülpt. Als sich aber das Thier beruhigt hatte und nun aufs Neue gereizt wurde, wölbte sich diese Wulst ziemlich langsam hervor, und dabei fiel mir auf, dass der Geruch nicht allmälig zunahm, sondern ganz plötzlich eine sehr merkliche Steigerung erfuhr. Es ergab sich, dass diese Steigerung bedingt war durch das Hervortreten zweier winziger Gebilde, die ich bis dahin übersehen hatte, gestielter Kölbchen, Stecknadeln oder den Schwingkölbchen der Fliegen vergleichbar, deren eines zu jeder Seite unterhalb der Stinkwulst am Hinterrande des vorletzten Ringes sitzt. Man braucht nur die Köpfchen dieser Stinkkölbchen abzuschneiden, um sich zu überzeugen, dass von ihnen wirklich die Verstärkung des von der Stinkwulst entwickelten Geruches ausgeht.

Bei der Uebereinstimmung aller Maracujáfalter in Bau und Lebensweise bis in die kleinlichsten Einzelheiten hinein durfte ich erwarten, dass auch die Stinkkölbchen nicht auf diese eine Art beschränkt sein würden und ich fand sie wirklich bei allen Arten, die ich darauf untersuchen konnte, nämlich ausser bei Colacnis Dido, wo ich sie zuerst sah, auch bei Colaenis Julia, bei Heliconius Apseudes, Besckei und Eucrate, bei Eueides Isabella, bei Dione Juno und Vanillae. So liefern die Stinkkölbchen einen neuen Beweis für die Zusammengehörigkeit der vier Gattungen, die man bis jetzt allgemein unter die beiden Familien der Heliconinen und der Nymphalinen vertheilt, wobei Eueides

1) Zeitschrift für wissensch. Zoolog. 1878. Bd. XXX. S. 167-170. Taf. IX. 
bald ersteren (Herrich-Schaeffer, Kirby), bald letzteren (Doubleday, Felder) zugezählt wird. Theils aus diesem Grunde, theils um ihrer selbst willen sind diese eigenthümlichen Gebilde wohl näherer Betrachtung werth.

Wie erwähnt sitzen die Stinkkölbchen, eines auf jeder Seite, am Hinterrande des vorletzten Leibesringes unterhalb der Stinkwulst und zwar am Ende der Bauchplatte dieses Ringes. Von da springen sie, wenn die Stinkwulst vorgestülpt wird, nach hinten und etwas nach aussen vor. Sie bestehen aus einem etwa ein Millimeter langen Chitinstift, der am Ende keulenförmig verdickt ist. Die Verdickung ist eine ganz allmälige und erreicht kaum den doppelten Durchmesser des Stieles bei Heliconius Apseudes und Eucrate (Fig. $5 A, B$ ); etwas stärker ist die birnförmige Verdickung bei Eueides Isabella (Fig. $6 A, B$ ) und mehr noch bei Dione Juno (Fig. $7 B$ ); sie nähert sich der Kugelform bei Dione Vanillae (Fig. $8 A$ ), Heliconius Besckei (Fig. $4 A$ ) und Colaenis Dido (Fig. 2 B); bei der letztgenannten Art erreicht der kuglige Knopf am Ende des Stieles fast $0,5 \mathrm{~mm}$ Durchmesser.

Der Stiel ist meist braun, bald heller, bald dunkler; ganz blass, fast farblos ist er bei Eueides Isabella (ron der ich jedoch nur ein eben ausgeschlüptes Weibchen untersuchte), dagegen schwarz bei Dione Juno. Der Kopf ist meist heller als der Stiel, gelblich oder bräunlich; dunkler fand ich ihn bei Dione Vanillae.

Der Kopf der Stinkkölbchen ist besetzt mit Schuppen, die je nach den Arten sehr verschieden gestaltet sind. Der Form gewöhnlicher Schmetterlingsschuppen nähern sie sich am meisten bei Heliconius, besonders bei Heliconius Apseudes (Fig. 3 B). Hier findet man einzelne ganz regelmässige Schuppen, deren Seitenränder vom Anheftungspuncte aus geradlinig unter mehr oder minder spitzem Winkel auseinanderlaufen und deren Endrand in etwa fünf lange spitze Zacken ausläuft, Schuppen also, wie sie nicht selten auf den Flügeln vieler Nachtschmetterlinge vorkommen. Die bisweilen fast dornartigen Zacken des Endrandes sind von festerem Gefüge als die Spreite der Schuppe, die häufig gefaltet oder zerknittert erscheint. Dazwischen kommen zahlreiche minder regelmässige, doch aus derselben Grundform ableitbare Schuppen vor. - Aehnlich, doch im Allgemeinen weniger regelmässig und noch mehr zusammengefaltet oder verbogen sind die Schuppen bei Heliconius Besckei (Fig. $4 B$ ) und Eucrate (Fig. $5 C$ ).

Bei Eueides Isabella (Fig. 6C) sind die Schuppen der Stinkkölbchen von festerem Gefüge; die Seitenränder laufen, ehe sie auseinanderweichen, erst eine Strecke in gleicher Richtung und bilden so einen Stiel, der etwa $1 / 3$ bis $1 / 2$ der ganzen Länge einnimmt; die Spreite ist kleiner als bei Heliconius und spaltet sich in gewöhnlich drei lange spitze Zipfel.

Weit derber noch sind die Schuppen der Stinkkölbchen bei Dion e V a nilla e (Fig. 8 B); die Spreite ist hier ganz geschwunden; es bleiben nur der Stiel und die langen spitzen dornartigen Zacken, so dass die Schuppen die Gestalt zwei bis vierzinkiger oft wunderlich gebogener und verkrümmter Gabeln annehmen.

In wieder anderer Weise, ebenfalls kaum noch als solche erkennbar, finden sich die Schuppen bei Dione Juno (Fig. 7 B) umgewandelt. Ein langer, selten gerader Stiel erweitert sich am Ende in eine winzige Spreite, die auch ganz fehlen kann; von der Spreite oder dem Ende des spreitelosen Stieles entspringen ent- 
weder unmittelbar ein oder zwei (selten drei) Borsten, oder es ist zwischen Spreite und Borsten noch eine Art Stiel eingeschaltet, der meist gerade und dabei viel kürzer und dünner ist als der Stiel der Spreite. Diese verschiedenen Theile bilden nun alle möglichen Winkel miteinander, so dass eine unglaubliche Mannigfaltigkeit seltsamer Formen entsteht. Es kommt auch vor, dass der Stiel, statt in eine Spreite sich zu erweitern, sich gabelt, und dass jeder Ast am Ende ein oder zwei Borsten trägt.

Im Gegensatz zu den festen gabligen Dornen von Dione Vanillae sind die Schuppen der Stinkkölbchen bei Colaen is (Fig. 2 C) in schlaffe, dünnhäutige, meist stark gefaltete und zerknitterte Lappen umgewandelt, mit aller Zacken entbehrenden Rändern. -

Welches nun auch die Form der Schuppen sei, man bekommt von ihnen am frischen Stinkkölbchen meist so gut wie nichts zu sehen, ausser etwa bei eben der Puppe entschlüpften Thieren. Es häuft sich zwischen ihnen eine meist gelbe, riechende Masse an, die jedenfalls an der Oberfläche der Stinkwulst ausgeschieden wird. Durch diese werden sie mit einander verklebt und oft vollständig überdeckt, so dass der Stiel nun am Ende eine fast glatte oder leicht höckrige Kugel trägt, deren Durchmesser bisweilen das doppelte, ja dreifache von dem der keulenförmigen Verdickung am Ende des Stieles erreicht (Fig. $2 A$, $5 A, 7 A$ ). Durch Weingeist, Aether oder Benzin lässt sich die verklebende Masse erweichen, theilweise lösen, und dann mehr oder weniger vollständig entfernen. Was ungelöst bleibt, erscheint bald in Form stark lichtbrechender Kügelchen (Fig. $5 B$ ), bald auch als unregelmässige Schollen.

Ausser bei den Weibchen der Maracujáfalter sind mir ähnliche Stinkkölbchen noch bei keinem Schmetterlinge vorgekommen. Ueberhaupt scheinen die bei beiden Geschlechtern auftretenden Stinkvorrichtungen unter den Schmetterlingen weit weniger verbreitet und weit weniger mannigfaltig $\mathrm{zu}$ sein, als die dem männlichen Geschlechte eigenthümlichen Duftvorrichtungen, von denen man, einmal darauf aufmerksam geworden, täglich neue und überraschende Formen findet.

It ajahy, St. Catharina, Brazil, Juni i 877 .

\section{Erklärung der Abbildungen auf Tafel LII.}

Fig. I. Colaenis Julia ㅇ. Ende des Hinterleibes mit vorgestülpter Stinkvorrichtung, von oben, etwa $5: 1$. W, Stinkwulst, $K$, Stinkkölbchen.

Fig. 2. Colaenis Dido o. $A$, Stinkkölbchen in frischem Zustande, $15: 1 ; B$, dasselbe mit Weingeist und Benzin gereinigt, I5: I; C, Schuppen desselben, 90: I.

Fig. 3. Heliconius Apseudes gedrückter Stinkvorrichtung, von der Seite, I5: I; $W$, Stinkwulst, $K$, Stinkkölbchen, $B$, Schuppen des Stinkkölbchens, 90: I.

Fig. 4. Heliconius Besckei q. A, Kopf des Stinkkölbchens, gereinigt, 45: I ; $B$, Schuppen desselben, $90: \mathrm{I}$.

Fig. 5. Heliconius Eucrate + . A, Stinkkölbchen in frischem Zustande, $15: 1$; $B$, Kopf desselben, gereinigt, 45: I; $C$, Schuppen desselben, 90: I.

Fig, 6. Eueides I sa bell a 9 . A, Stinkkölbchen eines eben ausgeschlüpften Thieres, $15: 1 ; B$, Kopf desselben, $45: 1 ; C$, Schuppen desselben, $90: 1$.

Fig. 7. Dione Juno 9 . $A$, Stinkkölbchen im frischen Zustande, I5: I; $B$, Kopf, desselben, gereinigt, 90:1 (nur ein kleiner Theil der Anhänge gezeichnet).

Fig. S. Dione Vanillae o. $A$, Stinkkölbchen, 15: I; $B$, domartige Schuppen desselben, $90: \mathrm{I}$. 


\title{
Ueber Numenia Acontius,
}

\author{
mitgetheilt von Herm. Müller $\left.{ }^{1}\right)$.
}

Ich erlaube mir Ihnen von dem Inhalte eines Aufsatzes meines Bruders Fritz Müller Mittheilung zu machen, den ich so eben empfing. Er bespricht Numenia Acontius, und erörtert die auffallenden Verschiedenheiten der beiden Geschlechter dieser brasilianischen Falterart, deren Männchen als Papilio Medea, dessen Weibchen als Papilio Antiochus von Fabricius beschrieben und bis vor wenigen Jahren allgemein von den Entomologen benannt worden ist. Als bedingend für den verschiedenen Schnitt der Flügel beider Geschlechter wird eine hochentwickelte starkriechende Duftvorrichtung nachgewiesen, welche das Männchen zwischen beiden Flügeln trägt. In Bezug auf die verschiedene Färbung beider Geschlechter wird als wahrscheinlich zu erweisen gesucht, dass zuerst die Weibchen, unter den Männchen wählend, die Medeazeichnung ausgebildet haben; dass später dieselbe auch auf die Weibchen übertragen worden ist und sich bei ihnen in mehreren Arten bis zum heutigen Tage erhalten hat, dass aber der Geschmack der Weibchen im Laufe der Zeit sich geändert hat, wodurch Zeichnung und schmückende Farbe der Flügel der Männchen völlig umgeprägt worden sind.

Lippstadt, I $0 . / 6.78$.

I) Zoolog. Anzeiger 1878. I. Jahrg. S. I3, I4. 


\title{
Ueber Gerüche von Schmetterlingen $\left.{ }^{1}\right)$.
}

\author{
Aus einem Briefe an Herm. Müller.
}

Ich werde nächstens die Schmetterlingsarten zusammenstellen, an denen ich bis jetzt thatsächlich Gerüche wahrgenommen habe. Es scheint, dass meine Nase durch fortdauernde Uebung immer schärfer wird. Bei Daptonoura Lycimnia rieche ich jetzt bei jedem frisch gefangenen Männchen den eigentümlichen Duft; Callidryas Trite or fand ich vor zwei Jahren stets geruchlos; gestern fing ich ein ¿', das deutlich roch. Bei Didonis Biblis ot riecht auch der schwarze Fleck an der Unterseite der Vorderflügel, und zwar schwach moschusartig, so dass dieses Thier drei verschiedene Gerüche entwickelt. Bei Callidryas haben auch die $q$ stark riechende Drüsen an den Genitalien, welche die brünstigen $q$ vordrängen; der Geruch ist säuerlich, der der $\delta$ moschusartig.

Itajahy, Sa. Catharina, i6. April.

I) Zoolog. Anzeiger 1878, I. Jahrg. S. 32. 


\section{Ueber die Vorteile der Mimicry bei Schmetterlingen ${ }^{1}$ ).}

Es ist merkwürdig, wie man sich bisweilen Jahre lang über Fragen den Kopf zerbricht, deren Lösung so einfach ist, dass man kaum begreift, wie man nur einen Augenblick darin eine Schwierigkeit hat finden können. So ist es mir mit der Mimicry der Schmetterlinge gegangen, Danainen, Ithomiinen, Acraeinen, Heliconiinen scheinen alle gleich gut durch widrigen Geruch und Geschmack geschützt zu sein, und doch gibt es unter ihnen eine Menge nachahmender Arten. Besonders stark ist der Geruch der Eueides-Arten, und doch ist Eueides pavana ein Nachbild von Acraea Thalia, E. Isabella von Helic. Eucrate oder Mechanitis Lysimnia und E. Aliphera gleicht bis auf die Grösse der Colaenis Julia. - Welchen Vortheil kann nun eine solche durch anwidernden Geruch geschützte Art davon haben, dass sie einer anderen ebenfalls geschützten gleicht? - Wenn ihre Feinde aus "Instinct“ diese geschützte Art meiden, keinen; wenn dagegen, und das ist ja so wie so das Wahrscheinlichere, ihre Feinde sie erst durch Erfahrung als ungeniessbar kennen lernen müssen, einen um so größeren, je weniger zahlreich sie ist. Der Nutzen, den zwei ungeniessbare Arten von ihrer Aehnlichkeit haben, verhält sich umgekehrt wie das Quadrat ihrer Individuenzahl. Statt einer allgemeinen übrigens höchst einfachen Deduction ein Beispiel. - Es mögen in einem bestimmten Bezirke zwei ungeniessbare Arten leben, von der einen Io,ooo, von der anderen 2000 Stück. Die in demselben Bezirke lebenden Feinde mögen jährlich I 200 Stück einer ungeniessbaren Art vertilgen, bis sie sie als solche meiden. So viel würde jede Art verlieren, wenn sie verschieden wären; sind sie so ähnlich, dass die an einer gemachten Erfahrungen auch der andern zu gute kommen, so wird die erste Art 1000 die andere 200 Stück verlieren, erstere also durch die Achnlichkeit 200 also $2 \%$ der Gesammtzahl, letztere dagegen Iooo d. h. $50 \%$ der Gesammtzahl gewinnen. - Aus dieser Betrachtung ergibt sich ferner, dass wahrscheinlich in manchen Fällen (z. B. Thyridia und Ituna) die Frage, welche von beiden Arten Urbild, welche Nachbild sei, eine müssige ist; jede hat Vortheil davon gehabt, der anderen ähnlich zu werden; sie können einander entgegengekommen sein.

1) Zoolog. Anzeiger 1878, I. Jahrg. S. 54, 55 . 


\section{Wo hat der Moschusduft der Schwärmer seinen Sitz?')}

I. Unter den Tausenden europäischer Schmetterlingsjäger scheint sich noch keiner diese Frage vorgelegt zu haben. Mit der Frage wäre ja sofort auch die Antwort zur Hand gewesen, da man eben einfach der Nase nachzugehen braucht, um den Ausgangspunkt eines starken Geruches zu finden.

Während in Europa der Windenschwärmer nicht selten ist, von dessen Männchen man seit lange den Moschusgeruch kennt, habe ich hier heute zum ersten Male ein bisamduftendes Schwärmermännchen gefangen, von einer kleinen, nur 0,04 Meter langen Art, deren Namen ich nicht weiss. Es umflog gegen Abend die reichblüthigen grossen, blauen Dolden eines Agapanthus in meinem Garten.

Beim Beriechen ergab sich sofort, dass der sehr kräftige Geruch von der Bauchseite des Hinterleibes ausging. Als ich nun, die Brust zwischen Daumen und Zeigefinger fassend, den Schwärmer mit aufwärts gekehrter Bauchseite festhielt, bemerkte ich, dass, so oft das Thier mit den Flügeln schwirrte, jederseits am Anfange des Hinterleibes ein blonder Haarpinsel bisamduftend sich ausspreizte. Beruhigte sich das Thier, so legte sich der Pinsel wieder in eine Längsrinne, die sich jederseits über den grösseren Theil der beiden ersten Hinterleibsringe erstreckte, und verschwand, indem sich die die Rinne begrenzenden Schuppen über ihm zusammenschlossen. Während der Ruhe war von dem Pinsel nichts, von der Rinne kaum etwas zu sehen. Letztere lässt sich am todten Thiere sichtbar machen durch Zusammendrücken des Hinterleibes von hinten nach vorn; zwischen den auseinander weichenden Schuppen zeigte sich dann der Boden der Rinne als schmaler, nackter Längsstreif.

Also wieder - nur an einem neuen Orte - dieselbe wirksame Form der Duftvorrichtungen, die als Träger deutlich wahrnehmbarer Gerüche auf den Flügeln und am Ende des Hinterleibes bei verschiedenen Tagfaltermännchen gefunden wurde. Ich bezweifle kaum, daß auch die unter Dickköpfen und Nachtschmetterlingen vorkommenden „Schienenpinsel“ (Herrich-Schäffer), die z. B. bei den Männchen von Pantherodes pardalaria, einem zeitweise hier häufigen, prachtvoll pantherartig, schwarz auf gelb gefleckten Schmetterling, mächtig entwickelt sind,

1) Kosmos 1878. Bd. III. S. $84-85$. 
der Verbreitung eines die Weibchen anlockenden Duftes dienen, obwohl ich einen solchen noch nicht habe wahrnehmen können.

$\mathrm{Ob}$ bei den Männchen des Winden- und des Ligusterschwärmers der Moschusduft von der gleichen Stelle ausgeht? Und ob auch die für menschliche Nasen geruchlosen Schwärmermännchen ähnliche Duftpinsel besitzen? Beides ist wahrscheinlich. Möge es bald durch Beobachtungen entschieden werden.

II. Obige Vermuthung gründete sich hauptsächlich auf das Verhalten des Schienenpinsels bei Pantherodes pardalaria (vergl. auch Ges. Schriften S. 559 und Taf. XLVII), der am Anfang der Hinterschiene entspringend, deren volle Länge erreicht, und sich für gewöhnlich in einer tiefen Längsrinne birgt, die an der Innenseite der Schiene sich hinzieht und überdacht wird von eigenthümlichen, sehr grossen Schuppen ihres Randes. Die Entfaltung des Pinsels scheint durch schr kräftiges Strecken der Schiene bewirkt zu werden.

Jene Annahme hat sich inzwischen bestätigt. An einem unserer Schmetterlingsriesen aus der Familie der Erebiden, mit etwa o, I9 Meter Flügelspannung, konnte ich einen wenn auch nicht besonders starken, so doch ganz unverkennbaren, eigenthümlichen Geruch an den IIinterschienen des Männchens wahrnehmen. Schlank bei dem Weibchen, ist bei dem Männchen dieser Art die Hinterschiene stark verbreitert (4 Millimeter breit bei I 2 Millimeter Länge), und ihre ganze Innenseite ist mit einem dichten Walde von Haaren bedeckt, die sich zu einer gewaltigen Bürste aufsträuben können, während sie in der Ruhe der Schiene dicht anliegen. Dabei liegen zu unterst, in einer seichten Längsrinne, die Haare der Mittellinie, überlagert von einer dicken Schicht der seitlichen Haare, welche dabei schief nach der Mittellinie und dem Ende der Schiene zu gerichtet $\operatorname{sind}^{1}$.

Wie wahrscheinlich aus über die ganze Fläche der Flügel verstreuten Duftschuppen die mannigfachen, auf bestimmte Stellen beschränkten Duftwerkzeuge der Flügel hervorgegangen sind, so lässt sich auch der Schienenpinsel von Pantherodes unschwer ableiten aus einer die ganze Innenseite der Schiene bedeckenden Behaarung, wie sie das eben erwähnte Erebidenmännchen zeigt, und zwar um so unbedenklicher, als auch in der Familie der Erebiden lange, am Anfange der sonst unbehaarten Hinterschienen sitzende Haarpinsel vorkommen.

Bei den mir bekannten Dickköpfen findet sich an den Hinterschienen keine Vorrichtung zur Bergung des Pinsels; dagegen sah ich bei einer der ansehnlicheren Arten dieser Familie, wahrscheinlich einem Antigonus, dass der Schienenpinsel in einer durch die Schuppen des Hinterleibes gebildeten Furche versteckt lag.

Itajahy, 26. November 1877 .

I) Diesem Erebiden ähnlich scheint sich ein javanischer Dickkopf, Ismene Oedipodea, zu verhalten, bei dessen Männchen die Hinterschienen sehr stark verdickt („,extremely thick“) und dicht behaart (,very densely hairy") sind. (Doubleday, Westwood, Hew itson, Genera of diurnal Lepidoptera, p. 514.) - Es darf bei dieser Gelegenheit daran erinnert werden, dass schon Linné einer Erebidenart den Namen "odora" gab; Näheres über dieselbe weiss ich nicht. 


\section{In Blumen gefangene Schwärmer $\left.{ }^{1}\right)$.}

Die Arten der im wärmeren Asien heimischen Gattung Hedychium werden ausschliesslich durch Schmetterlinge befruchtet, wie ihre lange enge Blumenröhre beweist.

Eine der hier eingeführten Arten, mit leuchtend rothen geruchlosen Blumen, hat sich in wunderbar vollkommener Weise der Uebertragung des Blüthenstaubes durch die Flügel langrüsselicher Tagfalter angepasst; sie ist bis jetzt die einzige Pflanze, bei der man diese eigenthümliche Art der Bestäubung beobachtet hat ${ }^{2}$ ).

Eine ziveite Art, mit grösseren, rein weissen, besonders Abends stark duftenden Blumen und etwa o, I Meter langer, also das Mass der Tagfalterrüssel weit übersteigender Blumenröhre, wird fleissig besucht von Schwärmern mit entsprechend langem Rüssel. Doch wird diesen Schwärmern der Zugang zum Honig nicht selten versperrt durch unberufene Gäste. Ein schmales kurzflügliges, schwarzes Käferchen, das sich in Menge auf allen möglichen Blumen einzufinden pflegt, dringt häufig auch in die Blumenröhre des weissen Hedychium und neben ihm bleibt dann kein Raum für den Rüssel der Schwärmer.

Falls in der Heimat der Hedychien ein ähnlicher Käfer gleich häufig die Arbeit der die Bestäubung vermittelnden Schwärmer stört, würde die natürliche Auslese die Entstehung engerer Blumenröhren begünstigen, in denen keine Käfer sich festsetzen könnten. In der That giebt es ein solches engröhriges Hedychium mit hellgelber, schwach duftender Blume. Allein auch diese für Käfer unzugänglichen Blumenröhren haben ihre Gefahren, - für die Schwärmer, wie für die Blumen. Incidit in Scyllam, qui vult vitare Charybdim. Grössere Schwärmer mit langem und verhältnissmässig dickem Rüssel vermögen diesen in die enge Röhre wohl einzuführen, aber nicht - oder doch nicht immer - wieder herauszuziehen und sind dann einem langsamen Hungertode preisgegeben. Macrosilia rustica und Antaeus scheinen nicht selten diesem Schicksale zu erliegen; andere Schwärmer habe ich noch nicht als Gefangene des Hedychium getroffen. Einer meiner Freunde fand einmal in seinem Garten die eiförmigen Blütenähren dieses Hedychiums ringsum behangen mit gefangenen, zum Theil schon todten Schwärmern. Ich selbst sah noch vor Kurzem (am Morgen des 30. Januar) ein Männ-

I) Kosmos 1878. Bd. III. S. 178-179.

2) Vergl. Hermann Müller in: Nature, Vol. XIV, p. 173. - 1876. 
chen von Macrosilia Antaeus zwischen den Blumen des gelben Hedychium hangen; es schien todt; doch als ich die Blütenähre abschnitt, begann es wieder zu schwirren und, ansehnliche Duftpinsel am Grunde des Hinterleibes entfaltend, einen starken Geruch zu verbreiten, der mehr an den der Beutelratten als an Moschus erinnerte. Welche vergeblichen Anstrengungen das Thier schon gemacht hatte, um sich zu befreien, dafür zeugte der Zustand der Blume, in deren Röhre sein Rüssel festsass. Blumenblätter, Staubbeutel, Narbe waren vollständig zerstört und nichts übrig geblieben, als die dickwandige und durch feste Deckblätter geschützte Blumenröhre. Alle Anstrengungen aber schienen nur dazu gedient zu haben, den Rüssel immer tiefer in die enge Röhre hineinzuzwängen; denn es war der 9o Millimeter lange Rüssel nicht nur bis zum Grunde der 65 Millimeter langen Blumenröhre vorgedrungen, sondern seine Spitze hatte sich sogar von da in einer Länge von 8 bis ı Millimeter wieder aufwärts gebogen. -

Während sonst süsser Nectar die Kerfe lohnt, die als Liebesboten den befruchtenden Staub von Blume zu Blume tragen, führt hier die Begegnung von Schmetterling und Blume zu gegenseitigem Verderben. Wie mag es in der Heimat des Hedychium sein? Ob auch dort in gleicher Weise gefährdete Schwärmer leben und ob diese etwa die Gefahr kennen und meiden gelernt haben?

Ich empfehle dieses Beispiel der an den Honig spendenden Blumenröhren zum Verderben der Blume und zu eigenem langsamen Hinsterben aufgehängten Schwärmer zur Beachtung erstens frommen Gemüthern, die auch in den Wechselbeziehungen zwischen Blumen und Kerfen das Walten einer allweisen, allgütigen Vorsehung zu bewundern lieben, und zweitens Freunden des nie irrenden Unbewussten, denen zufolge „das Hellsehen des Instinktes ja gerade immer solche Punkte betrifft, welche die bewusste Wahrnehmung überhaupt nicht zu erreichen vermag" 1). Hier wäre ein solcher Punkt, „für welchen der Mechanismus der sinnlichen Erkenntniss nicht ausreicht"; die todtbringende Enge der Blumenröhre, zu der ein einladend weiter Eingang führt, ist von aussen nicht zu erkennen; aber kein unbewusstes Hellsehen warnt den Schwärmer und kein Gott erlöst mitleidig die nutzlos verschmachtenden Opfer.

Itajahy, 28. Februar 1877 .

I) Hartmann, Philos, des Unbewussten. VI. Aufl. S. 368 . 


\section{Blumen der Luft $^{1}$ ).}

\section{(Ein Falter mit Blumenduft).}

Mit Bezug auf diesen von Jean Paul ihrer glänzenden Farben wegen den Tag-Schmetterlingen beigelegten Namen (Vergl. Kosmos 1. S. 260) schreibt HerDr. Fritz Müller aus Itajahy in einem Privatbriefe vom I. März c.:

„Im vergangenen Monat machte ich einen mehrwöchentlichen Ausflug nach dem Hochlande im Norden unserer Provinz, São Bento im Quellgebiete des Rio negro, der mir recht hübsche Ausbeute, aber fast nur von speciell lepidopterologischem Interesse lieferte. Häufig war dort der von Boisduval als très rare bezeichnete Papilio Grayi, dessen Männchen wirklich auch in Betreff des Geruches als „Blume der Luft“ bezeichnet werden kann. Der von den Hinterflügeln ausgehende Duft ist so stark und so würzig, dass ich den Schmetterling wie eine Blume, zum gelegentlichen Daranriechen in der Hand getragen habe."

I) Kosmos 1878. Bd. III. S. I87. 


\section{Die Königinnen der Meliponen $\left.{ }^{1}\right)$.}

Die schönste unter den stachellosen Honigbienen des südlichen Brasiliens ist die Coyrepú oder grosse Mandaçaia. Sie hat etwa die Grösse einer europäischen Honigbiene; ihre etwas geringere Länge wird durch grössere Breite aufgewogen. Kopf und Brust sind glänzend schwarz, der oben unbehaarte Hinterleib rothbraun, mit vier dottergelben Querbinden geziert. Im April I873 entnahm ich einem hohlen Baumstamme ein Volk dieser schönen Biene, um es in meinem Garten lebend $z u$ beobachten. Nachdem ich Brutwaben und Honigtöpfe und mit ihnen die grösste Zahl der Bewohner herausgenommen hatte, bemerkte ich zwischen den in der Höhle des Baumes zurückgebliebenen bunten Erbauern des Nestes etwas kleinere Bienen, deren einfarbiger, glänzend brauner Hinterleib mit eigenthümlich seidenartig glänzenden, bräunlichen, hinterwärts gerichteten Haaren bekleidet war. Sie waren im ganzen Aussehen so verschieden, dass ich gar nicht an die Möglichkeit dachte, sie könnten derselben Art angehören. Ich fing neun dieser Bienen; alle waren Weibchen, wie die zwölfgliedrigen Fühler und die einfachen Fussklauen bewiesen (bei den Männchen der Meliponiden sind die Fussklauen gespalten); allein ihre Hinterschienen besassen nicht die nackte, glänzende, vertiefte Aussenfläche, das „Sammelkörbchen“, in welchem die Arbeiter der Meliponen den Blüthenstaub heimtragen. Die Aussenfläche der Hinterschienen war gewölbt und behaart, zum Blüthenstaubsammeln kaum tauglich. Dies legte den Gedanken nahe, es seien „Kukuksbienen“, die ihre Eier in die mit Futterbrei gefüllten Brutzellen ihrer Verwandten einschmuggeln. Unter den Hummeln kennt man ja eine ganze Anzahl solcher schmarotzenden Arten.

Bald darauf erhielt ich ein Volk einer zweiten Melipona-Art, der Gurupú. Sie ist so gross wie die vorige Art, matt schwarz und auf der ganzen Oberseite, auch des Hinterleibes, mit dichter, senkrecht abstehender, bräunlicher oder schwärzlicher Behaarung bekleidet. Nach wenigen Wochen ging dieses Volk zu Grunde, wahrscheinlich weil wegen Weisellosigkeit die älteren Arbeiter sich zerstreut hatten; die zurückgebliebenen Drohnen und jüngeren Arbeiter mussten dann Hungers sterben, nachdem sie die vorhandenen Vorräthe aufgezehrt hatten. Eines Tages vermisste ich die Wache am Flugloche, es flogen keine Bienen mehr, da-

1) Kosmos 1878. Bd. III. S. 228-23I. 
gegen liefen zahlreiche Ameisen aus und ein. Ich fand bei Untersuchung des Stockes todt oder sterbend 294 meist noch nicht ausgefärbte Arbeiter, 59 Drohnen, die dagegen fast alle schon ausgefärbt waren, und 2 I zum Theil noch in den Brutzellen eingeschlossene Weibchen, täuschend ähnlich den bei den Coyrepú gefundenen, wie sie durch die aussen gewölbten und behaarten Hinterschienen von den Arbeitern, und höchst augenfällig durch die braungelbe, seidenglänzende, hinterwärts gerichtete Behaarung des Hinterleibes von allen übrigen Bewohnern des Stockes sich unterscheiden.

Eine eingehendere Untersuchung, die mein Bruder Hermann Müller vornahm, ergab, dass diese abweichenden Weibchen der beiden Stöcke verschiedenen Arten angehörten, von denen jede trotz des ganz verschiedenen Aussehens in vielen Punkten sich eng anschloss an die Arbeiter, in deren Gesellschaft sie gefunden worden war.

Im Freien habe ich nur einmal ein solches Weibchen gefangen, so ähnlich den früher gesehenen, dass mir bei oberflächlicher Betrachtung kein Unterschied auffiel; indess wollte ein glücklicher Zufall, dass dasselbe, wie mein Bruder feststellte, einer dritten Art angehörte, und sich ebenso an unsere dritte grössere Melipona-Art, die Mondury (Melipona Mondury Smith = Fulva Lep.) anschloss, ıvie die beiden ersteren an die grosse Mandaçaia und die Gurupú.

Häufiger als die genannten drei grösseren ist hier eine vierte, kleinere (6 bis 7,5 Millimeter lange) Melipona-Art, die ebenfalls den Namen Mandaçaia führt und besonders durch ihre aussergewöhnliche Veränderlichkeit merkwürdig ist. Kopf und Brust sind matt schwarz, der oberseits unbehaarte, glänzende Hinterleib ist bald ganz schwarz, bald schwarz mit röthlichem Grunde, bald braunroth, bald röthlich, und auf dem Rücken mit vier, seltener fünf, gelben oder auch weisslichen, ununterbrochenen oder mehr oder weniger breit unterbrochenen Querlinien gezeichnet. Das Schildchen ist bald glänzend schwarz, bald gelb. Die Kinnbacken (Mandibeln) sind bald ganzrandig, bald mehr oder minder deutlich gezähnt, so dass nach diesem Merkmal, durch welches Latreille die Gattung Melipona und Trigona unterschied, von den Arbeitern dieser Art einige zu Melipona, andere zu Trigona gehören würden. Von dieser Art besass ich gegen Ende des Jahres I874 drei Völker, alle mit schwarzem, quergestreiftem Hinterleib, zwei auch mit schwarzem Schildchen, während bei dem dritten gelbe und schwarze Schildchen in ungefähr gleicher Häufigkeit vorkamen.

Am 31. Oktober I874 sah ich zum ersten Male auch bei dieser Art ein Weibchen, welches durch einfarbig braunen Hinterleib mit hinterwärts gerichteter, seidenglänzender, gelbbrauner Behaarung in dem Gewimmel der Arbeiter sich bemerklich machte; es war etwas kleiner als diese. Bald fand ich diese Weibchen auch in den beiden anderen Stöcken, und zwar in der Farbe des Schildchens übereinstimmend mit den Arbeitern des betreffenden Volkes. Unter dem Volke, dessen Arbeiter bald schwarze, bald gelbe Schildchen trugen, fing ich fünf solcher Weibchen mit schwarzem und ebenfalls fünf mit gelbem Schildchen.

Nach diesem Funde war natürlich nicht mehr daran zu denken, dass diese Weibchen fremde Eindringlinge, dass sie Kukuksbienen sein könnten; es waren ohne Frage Weibchen der Art, bei welcher sie lebten. Ob jungfrïuliche Köni- 
ginnen oder ob etwa ein besonderer Stand heiliger Jungfrauen '), die, ohne von einem Manne zu wissen, Drohneneier legen, wie die von Vogel beobachteten „Drohnenmütterchen“ der ägyptischen Bienen, kann ich noch nicht endgültig entscheiden; da jedoch bis auf den riesig angeschwollenen Hinterleib mein Bruder die Königin der Coyrepú völlig übereinstimmend fand mit den kleinen Weibchen desselben Volkes, so ist das Erstere mir wahrscheinlicher.

So haben wir denn hier vier Melipona-Arten, deren fruchtbare Weibchen, seien es Königinnen oder heilige Jungfrauen, überraschend ähnlich sind, während die unfruchtbaren Weibchen (Arbeiter) und die Männchen (Drohnen) jeder Art sich weit von denen der übrigen Arten und von den fruchtbaren Weibchen der eigenen Art entfernen.

Wie mag dieses Verhalten zu erklären sein?

Dass die Weibchen mehrerer verwandten Arten einander sehr ähnlich, die Männchen dagegen von einander und von den eigenen Weibchen sehr verschieden sind, kommt auch bei den Schmetterlingen vor, und man darf in diesem Falle annehmen, wie Darwin überzeugend nachgewiesen hat, dass die unansehnlicheren Weibchen die ursprüngliche Zeichnung und Färbung bewahrten, während die Männchen ihr glänzendes Kleid der von den Weibchen geübten geschlechtlichen Auslese verdanken. Auch bei unseren Meliponen wird man die übereinstimmende Tracht der fruchtbaren Weibchen als Erbtheil einer gemeinsamen Stammform ansprechen dürfen, und man würde ebenso die Verschiedenheit der Männchen ohne grosse Bedenken der geschlechtlichen Auslese zuschreiben, wenn es sich eben nur um die Männchen handelte. Das Auffallendste aber in diesem Falle ist nicht die Verschiedenheit der Männchen, sondern dass die unfruchtbaren Weibchen das Gewand der Männchen und nicht das der fruchtbaren Weibchen tragen. Drohnen und Arbeiter stimmen in Grösse, Gestalt und Färbung fast vollständig überein; nur die Farbe des Gesichtes ist bisweilen abweichend; ausserdem fehlen den Drohnen die Sammelkörbchen der Hinterschienen, ihre Fussklauen sind gespalten, ihre Fühler dreizehngliedrig.

Leider ist - und damit fehlt jedem Erklärungsversuche der sichere Boden - bei stachellosen Honigbienen noch nicht festgestellt, wodurch die Entstehung der drei verschiedenen Stände bedingt ist, und sie stehen in ihrem Bau und namentlich auch in ihrer Brutpflege den stachelbewehrten Honigbienen der alten Welt nicht nahe genug, um ohne Weiteres das bei letzteren Erforschte auf sie übertragen zu dürfen. Die in einschichtigen wagerechten Waben angeordneten Brutzellen sind bei den Meliponen sämmtlich von gleicher Grösse, mögen sie für Männchen, fruchtbare oder unfruchtbare Weibchen dienen (bei den nahe verwandten Trigonen kommen besondere, sehr grosse „Weiselwiegen“ vor). Die Brutzellen werden mit Futterbrei gefüllt, bevor das Ei gelegt wird, und sobald dies geschehen, sofort geschlossen. Wenn also aus den Eiern Weibchen oder Männchen hervorgehen, je nachdem sie befruchtet werden oder nicht, so kann wenigstens die Königin nicht durch verschiedene Grösse der Zellen veranlasst werden, die Befruchtung zu vollziehen oder zu unterlassen, und wenn die Ent-

I) Ich schlage diese in der christlichen Mythologie seit lange in gleichem Sinne ïbliche deutsche Bezeichnung vor an Stelle des langathmigen Fremdwortes: „parthenogenetische Weibchen“. 
wickelung der Weibchen zu Königinnen oder Arbeitern bedingt ist durch verschiedene Ernährung der Larve, so könnte dabei nur die Beschaffenheit, nicht aber die Menge des Larvenfutters in Betracht kommen. In einem wichtigen Punkte stimmen übrigens die Meliponen mit den europäischen Bienen überein: Die fruchtbaren Weibchen entwickeln sich rascher, die Drohnen langsamer als die Arbeiter, und diese Uebereinstimmung spricht allerdings zu Gunsten der Annahme, dass auch die Ursachen, welche die Entstehung des einen oder des anderen der drei Stände bedingen, dieselben sein mögen. Ist dies aber der Fall, so muss es um so befremdender erscheinen, dass die von den Drohnen gezeugten fruchtbaren Töchter das Gewand des Vaters nicht erben, während die von der Königin 'vaterlos erzeugten Söhne es erhalten.

Es ist kaum denkbar, dass Arbeiter und Drohnen unabhängig von einander dasselbe von dem der Königin so weit verschiedene Aussehen erlangt haben; vielmehr wird dasselbe von einem der beiden Stände erworben und dann auf den andern übertragen worden sein.

Die Annahme, dass die Arbeiter zuerst die alterthümliche, von der Königin ziemlich treu bewahrte Tracht ablegten, und dass von ihnen aus die neue Tracht auf die Drohnen überging, würde die weitere, durch nichts zu stützende Annahme fordern, dass nicht nur in seltenen Ausnahmefällen, wie bei der europäischen Biene, sondern regelmässig die Arbeiter der Meliponen Drohneneier legen.

Bei weitem wahrscheinlicher scheint es, dass, wie bei vielen Schmetterlingen, zunächst die Männchen der verschiedenen Arten durch geschlechtliche Auslese sich immer weiter von einander und von ihren Müttern entfernten. Die ganz eigenthümliche und bis jetzt wohl beispiellose Weise der Vererbung, durch welche diese allmälig anwachsende Verschiedenheit der Männchen in gleichem Grade auch auf die unfruchtbaren, aber gar nicht auf die fruchtbaren Weibchen übertragen wurde, dürfte vielleicht damit in Zusammenhang stehen, dass Drohnen und Arbeiter dasselbe, die Königinnen aber ein anderes Larvenfutter erhalten.

Doch statt weitere unbeweisbare Möglichkeiten aufzusuchen, will ich lieber einfach gestehen, dass ich eine befriedigende Erklärung bis jetzt nicht zu geben weiss. 


\title{
Hesperiden-Blumen Brasiliens $\left.{ }^{1}\right)$.
}

\author{
(Aus einem Briefe an Herm. Müller.)
}

Eine werthvolle Vervollständigung erfährt der zweite Theil meines Aufsatzes über die Insekten als unbewusste Blumenzüchter (Kosmos, Bd. III. S. 403 fgde.) durch folgende briefliche Mittheilung meines Bruders Fritz Müller aus Blumenau, Südbrasilien vom 18. Sept. I 878:

„Hier wird sich vielleicht eine besondere kleine Gruppe von Blumen unterscheiden lassen, die von langrüsseligen, gegen Abend fliegenden Dickköpfen (Hesperidea) gezüchtet sind. Lange Blumenröhren, sehr eng, oder doch mit sehr engem Eingang, geruchlos, violett. Dahin namentlich Franciscea und Bouchea (Verbena) laetevirens, vielleicht auch andere Verbenen. Von Tagfaltern habe ich Franciscea in meinem Garten niemals besucht gesehen; dass sie keine Schwärmerblume sei, zeigen die Farbe und Geruchlosigkeit. Dickköpfe, und zwar nur einige wenige, gegen Abend fliegende Arten „habe ich ofter daran gefangen. - (Uebrigens giebt es auch, jedoch bei uns nicht wild, eine Franciscea mit kleineren, wohlriechenden Blumen, - vielleicht eine Anpassung an Schwärmer.)" - E. Krause hat einmal im Kosmos (Band III. S. 48) behauptet, dass blaue und violette Blumen bei Dämmerungs-Beleuchtung besonders augenfällig seien und dass man daher vermuthen könne, dass sie vorzugsweise von DämmerungsInsekten befruchtet werden möchten. Mit dieser Behauptung stimmt es sehr gut überein, dass die gegen Abend fliegenden Hesperiden, vorstehender Mittheilung zufolge, sich violettfarbige Blumen gezüchtet haben.

I) Kosmos 1878/79. Bd. IV. S. 481, 482 . 


\section{On a remarkable case of mimicry of Eueides pavana with Acraea Thalia ${ }^{1}$.

\author{
(Letter to Mr. Meldola.)
}

Mr. Meldola communicated the following note on a remarkable case of mimicry observed by Dr. Fritz Müller: - "I have just reared from the caterpillar state ten specimens (being five males and five females) of Eueides pavana. This is one of our rarest butterflies, and I think I have not yet caught more than half-a-dozen, all of which were females. These resemble Acrea Thalia so closely that before they are caught they can be distinguished only by the club of the antennæe being yellow, while it is black in Acrea. Now in the male of Eueides pavana the club of the antennæ is black also, and this has no doubt been the cause of my never catching any male. I know of no other case in which the males of a mimicking butterfly resemble more closely the mimicked one than the females do, while the inverse is well known to be of rather frequent occurrence."

i) Trans. Ent. Soc. London 1879. Proc. p. II. 


\section{Epicalia Acontius ${ }^{1}$ ).}

\section{Ein ungleiches Ehepaar.}

\section{Mit 6 Textfiguren.}

Ich lege dem Leser hier die Flügel zweier Schmetterlinge vor, in welchen derselbe wohl kaum Mann und Weib einer Art vermuthen dürfte. Wenigstens hat nicht nur Fabricius dieselben als zwei verschiedene Arten beschrieben, den

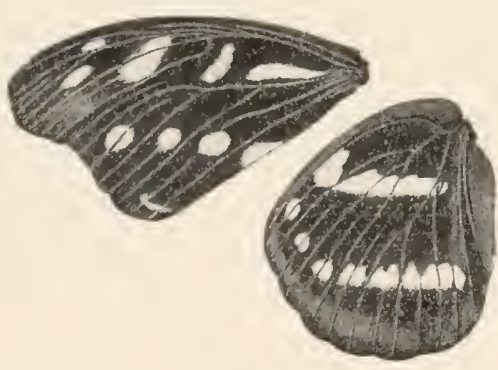

Fig. I.

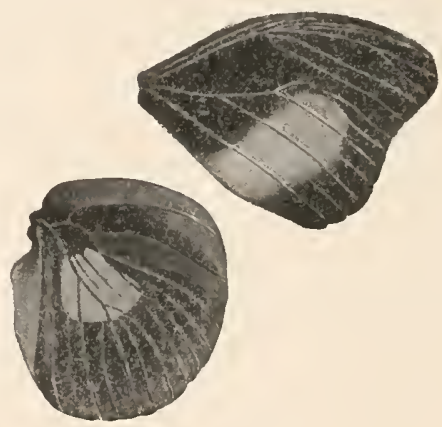

Fig. 2

Oberseite der Flügel von Epicalia Acontius Linn.

Fig I. Flügel des Weibchens (Papilio Medea Fabr.). Fig. 2. Flügel des Männchens (Papilio Antiochus Fabr.)

Die Aderung ist stärker ausgedrückt, als sie in Wirklichkeit erscheint. Auf den sammetschwarzen Grunde, der an denjenigen Theilen der Unterflügel, die von den Oberflügeln oder dem Hinterleibe bedeckt werden, einem stumpfen Schwarzgrau Platz macht, treten die Adern nur als schwarze Rippen hervor.

Mann als Papilio Antiochus, das Weib als Papilio Medea, und als solche erscheinen sie noch 1869 in Butler's Verzeichniss der Fabricius'schen Schmetterlinge, sondern Westw ood hat dieselben in dem Prachtwerke über die Tagfaltergattungen sogar zu zwei verschiedenen Gattungen gestellt, zwischen die er nicht weniger als fünfzehn andere einschob, den Mann zu Epicalia, das Weib zu Myscelia. Die Leser von Darwin's „Descent of Man" werden sich vielleicht erinnern, dass er bei Erörterung der geschlechtlichen Auslese dieses durch die ungewöhnliche Verschiedenheit der Geschlechter veranlassten Missgriffs gedenkt, und es mag Manchem,

1) Kosmos 1878/79. Bd. IV. S. 285-292. 
der mit ausländischen Faltern wenig vertraut ist, erwünscht sein, ein Beispiel dieser Verschiedenheit näher kennen zu lernen.

Von wem und auf Grund welcher Thatsachen die Zusammengehörigkeit der beiden angeblichen Arten zuerst ausgesprochen worden ist, weiss ich nicht; doch will ich zur Beruhigung etwaiger Zweifler bemerken, dass dieselbe auch nach meinen Erfahrungen kaum einem Bedenken unterliegen kann. Von einer ähnlichen Art (Epicalia Numilia, - das Weibchen hiess früher Myscelia Micalia) habe ich die beiden nicht minder verschiedenen Geschlechter aus Raupen gezogen, und Antiochus würde hier ohne Weib, Medea ohne Mann sein, falls die beiden nicht als Gatten zusammengehörten.

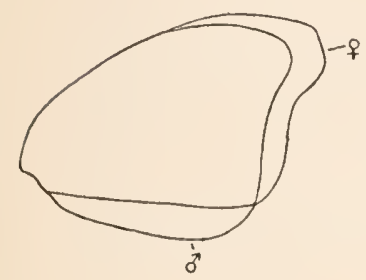

Fig. 3 .

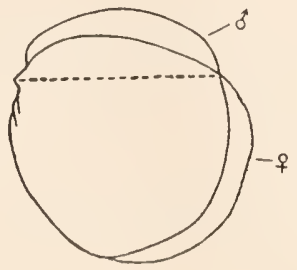

Fig. 4.

Flügel der beiden Geschlechter von Epicalia Acontius über einander gelegt.

Fig. 3. Vorderflügel, Fig. 4. Hinterflügel. ơ Männchen (Antiochus), $Q$ Weibchen (Medea).

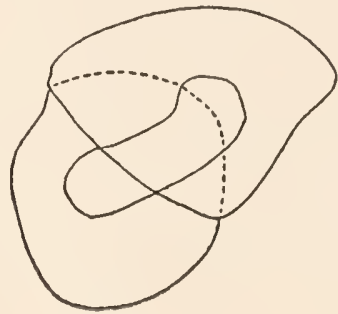

Fig. 5 .

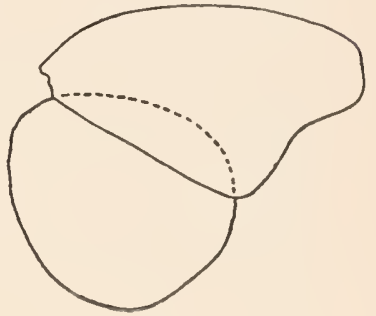

Fig. 6.

Lage der Flügel beim fliegenden oder mit ausgebreiteten Flügeln sitzenden Schmetterlinge.

Fig. 5. Antochius, Fig. 6. Medea.

Die Abbildung zeigt nur Umriss und Zeichnung, nicht die Farbe der Flügel; die Grundfarbe ist bei beiden Geschlechtern schwarz, beim Männchen von sammetartigem Aussehen; die helleren Farben sind blass schwefelgelb bei Medea, leuchtend orange bei Antiochus. Die Vorderflügel des letzteren legen sich so weit über die Hinterflügel, dass die Flecken beider Flügel einen einzigen bilden, und, nur durch den schmalen Hinterleib getrennt, der an dieser Stelle einen Anflug derselben Farbe zeigt, erscheinen die Flecken beider Seiten als zusammenhängendes breites Querband. Bei Medea werden die ausgebreiteten Flügel so gehalten, dass die Flecken aller vier Flügel drei gerade, gleichlaufende Querbinden bilden, welche durch gleichgefärbte Flecken auf dem Leibe des Falters vervollständigt werden. Ausser der blassgelben Zeichnung trägt jeder Flügel von Medea einen kleinen zimmetbraunen Fleck.

In ähnlicher Weise unterscheiden sich in Zeichnung und Farbe die beiden Geschlechter von Epicalia Numilia. Bei Epicalia Acontius tritt dazu noch eine sehr erhebliche Verschiedenheit des Flügelschnittes.

Zunächst verläuft bei Medea, wie bei beiden Geschlechtern von Epicalia Numilia, der Hinterrand der Vorderflügel in gerader Linie, während er bei Antiochus stark gekrümmt ist; ebenso ist auch der Vorderrand der Hinterflügel bei diesem weit stärker gekrümmt, als bei jener. In Folge davon greifen die Flügel von Antiochus bei weitem mehr über einander; fast die halbe Breite der Hinterflügel ist unter den Vorderfügeln versteckt; die zwischen beiden Flügeln verborgene Fläche ist reichlich doppelt so breit bei Antiochus, als bei Medea. 
Nun, solche gekrümmte Ränder, welche die zwischen den Fiügeln eingeschlossene Fläche vergrössern, pflegen ein unfehlbares Zeichen einer an dieser Stelle versteckten Duftvorrichtung zu sein. Wie sehr man sich auf dieses Anzeichen verlassen kann, dafür ein Beispiel, welches mich selbst überrascht hat. Einer anderen Frage wegen sah ich vor einigen Monaten Doubleday's Schilderung der Gattung Ageronia durch und stiess bei der Beschreibung der Vorderflügel auf die früher nicht beachteten Worte: „the inner margin in the male occasionally dilated" (Innenrand beim Männchen bisweilen erweitert). Sofort griff ich zum Netz, ging in meine Bananenpflanzung, wo damals einige übereife Früchte nicht selten von Ageronien besucht wurden, fing auch glücklich ein Männchen der prächtig blauen Ageronia Arethusa und wusste wenige Minuten nach dem Lesen jener Worte, dass dieses Männchen einen ziemlich starken Geruch besitzt, der von grossen, doch wenig von ihrer Umgebung abstechenden, zwischen den Flügeln verborgenen Duftflecken ausgeht. - Auch bei Antiochus trügt dieses Zeichen nicht; er trägt zwischen den Flügeln eine hochentwickelte, starkriechende Duftvorrichtung, auf die ich später zurückkommen werde, und durch welche die starke Krümmung der übereinandergreifenden Flügelränder bedingt wurde und erklärt wird. Wem darüber ein Zweifel bleiben sollte, der betrachte das ganz ähnliche Männchen der Epicalia Numilia, dessen sammetschwarze Flügel ebenfalls mit leuchtend orangefarbenen Flecken prangen; ihm fehlt die Duftvorrichtung vollständig und die betreffenden Flügelränder verlaufen genau wie beim Weibchen. Eine zweite Verschiedenheit des Flügelschnittes, die auch bei anderen Epicalien wiederkehrt (z. B. bei Numilia), und über deren Bedeutung ich nichts zu sagen weiss, besteht darin, dass bei Medea der Vorderflügel länger ist und seine Spitze fast sichelartig über den ausgebuchteten Aussenrand vorspringt.

WVenden wir uns nach Erledigung des Flügelschnittes wieder zu Zeichnung und Farbe. WVenn sonst bei Faltern oder Nachtschmetterlingen Mann und Weib so verschiedenes Gervand tragen, dass dadurch ihre Zusammengehörigkeit verhüllt wird, so pflegt das Weibchen entweder in der Unscheinbarkeit seines eigenen Kleides oder, wenn es grelle Farben zeigt, in der Nachahmung einer anderen Art Schutz zu finden. Ersteres gilt z. B. für Thecla Hemon; das Weibchen ist düsterbraun, das Männchen (Thecla Acmon) glänzend blau. Letzteres sehen wir bei Dyschema Amphissa; das Männchen ist weiss, das bunte Weibchen ist einer der zahlreichen Nachahmer von Acraea Thalia. - VVeder das Eine, noch das Andere ist bei Epicalia Acontius der Fall. Medea trägt kein fremdes Kleid; denn nicht nur fehlen hier ähnliche, nicht verwandte Falter, die als Vorbild hätten dienen können, sondern - was schwerer wiegt - eine ähnliche Zeichnung kehrt wieder bei einer ganzen Zahl von Arten derselben und verwandter Gattungen. Das Weibchen von Myscelia Orsis z. B. zeigt genau dieselben drei gleichlaufenden Fleckenreihen. - Noch weniger wird man Medea unscheinbar nennen können; das helle, grelle Gelb auf schwarzem Grunde macht sie weithin sichtbar. Gerade in letzter Zeit habe ich mehrfach Gelegenheit gehabt, sie neben ihrem Manne auf Bananen sitzen $\mathrm{zu}$ sehen, und stets ist mir, wenn ich von ferne herankam, das Weibchen zuerst in die Augen gefallen. Uebrigens scheint Medea auch mehr noch als Antiochus das Sitzen mit ausgebreiteten Flügeln zu lieben. 
Woher also die so auffallende, in Zeichnung und Farbe gleich stark ausgeprägte Verschiedenheit zwichen Mann und Weib? - Nach der von Darwin (Descent of Man. I., p. 388) gegebenen Auseinandersetzung darf es als erwiesen gelten, so gut eben in derlei Fragen etwas zu erweisen ist, dass die Stammform cler Gattung in ähnlicher Weise gezeichnet war, wie jetzt Medea und die Weibchen mancher anderen Arten aus denselben und aus verwandten Gattungen," und dass, wenn statt dessen heute auf den Flügeln von Antiochus im Sammetschwarz das "Goldorange glüht", dies der von den Weibchen geübten geschlechtlichen Auslese zu danken ist.

Wie aber steht es mit Medea? Ist bei ihr die früher beiden Geschlechtern gemeinsame Tracht einfach durch Vererbung erhalten worden, ohne jetzt eine weitere Bedeutung zu haben, oder hat sie eine solche und welche? Ist sie Putzoder Trutzfärbung, oder beides? - denn das Eine schliesst das Andere nicht aus.

Theile ich auch nicht Professor Gustav Jaeger's Ansicht, dass Gelb in (ler Regel Trutzfarbe sei ${ }^{1}$ ), so möchte ich doch die Möglichkeit nicht in Abrede stellen, dass es bei Medea als solche diene. Wenn Epicalia Acontius, Mann oder Weib, von einer Banane aufgescheucht, an der sie saugten, sich ganz in der Nähe mit flach ausgebreiteten Flügeln auf ein Bananenblatt setzen, so sieht das ganz aus, als wollten sie sagen: "Seht mich doch an! was wollt ihr von mir?" Inmerhin aber würde dies nur die Erhaltung der ursprünglichen Farbe und Zeichnung oder ihre Fortbildung zu noch grellerer Augenfälligkeit erklären, nicht aber die Weise, in der sie sich bei den Weibchen einiger verwandten Arten umgestaltet hat. Leider kenne ich von diesen Arten nur sehr wenige, Epicalia Numilia und Myscelia Orsis lebend, Epicalia Chromis und Myscelia Cyaniris aus Abbildungen. Bei Epicalia Chromis und Myscelia Orsis ist die Zeichnung kaum von der unserer Medea verschieden, bei Myscelia Cyaniris bilden die Flecken sechs statt drei Querbinden (weiss auf blauem Grunde; ich weiss nicht, welchen Geschlechts das abgebildete Thier ist), beim Weibchen von Numilia sind die Flecken grossentheils geschwunden und eine breite gelbe Binde geht auf den Vorderflügeln schief vom Vorderrande nach der Hinterecke zu. Diese Umprägung der ursprünglichen Zeichnung in neue ansprechende Muster hat wohl kaum anders vor sich gehen können, als unter der Leitung eines Auges, das an ihnen Gefallen fand, also durch geschlechtliche Auswahl von Seiten der Männchen. Danach wären die Männchen der Geschmacksrichtung, wie sie schon die gemeinsamen Vorfahren der Gattungen Myscelia und Epicalia besassen, theils vollständig treu geblieben, theils hätten sie sich nur wenig von derselben entfernt, während die Weibchen der meisten Arten seit lange einer völlig neuen Geschmacksrichtung huldigen. „Denn das Weib ist falscher Art und die Arge liebt das Neue“.

1) Kosmos. Bd. I. S. 486 ff. - Ich komme vielleicht später ausführlich auf diese Frage zurück. Für jetzt nur eine thatsächliche Berichtigung. Orangen sind keineswegs durch die gelbe Farbe und das flüchtge Oel ihrer Schale vor Vögeln geschützt. In Gegentheil lockt kein anderes Obst eine solche Menge und Mannigfaltigkeit gefiederter Gäste aus dem Walde herbei, wie eben die Orangen. Dazu kommt ein Heer aller möglichen Kerfe: Wespen, Wanzen, Käfer, Fliegen, Schmetterlinge. Schon Darwin sah bei Rio de Janeiro Ageronia besonders zwischen Orangenbäumen. - Wenn J a e ge r bei Begründung seiner Ansicht das stechende Wespen- und Hornissenvolk voranstellt, das in den Farben Oesterreichs trutzt, so lässt sich diesem die Korallenschlange gegenüberstellen, die die Farben des deutschen Reiches trägt. 
Dabei wäre noch zweierlei zu bemerken. Erstens pflegt man, nach D a rw' in's Vorgange, bei der geschlechtlichen Auslese meist nur den „W'ettkampf der Männchen um den Besitz der Weibchen“ zu berücksichtigen. Indess hat schon Haeckel (Generelle Morphologie 1866. II. S. 244) mit Recht hervorgehoben, dass, wie unser eigenes Beispiel lehrt, es ebenso einen „Wettkampf der Weibchen um den Besitz der Männchen“ giebt und dass die „männliche Zuchtwahl“ ebenso umgestaltend auf die Weibchen wirken muss, wie die „weibliche Zuchtwahl“ auf clie Männchen. Dass auch bei den Schmetterlingen eine solche von den Männchen geübte Wahl sich beobachten lässt, darauf habe ich bereits in diesen Blättern (Kosmos, Band II. S. +2$)^{1}$ ) hingewiesen. Dass aber - dies wäre das Zweite - die beiden Geschlechter ganz verschiedenen Geschmack zeigen, auch dafür geben ja wir selbst das Beispiel. Vieles, was wir als geistigen oder leiblichen Vorzug an Frauen schätzen, würde diesen und würde uns selbst an Männern missfallen und umgekehrt. Doch fehlt es auch nicht an unzweideutigen Beispielen unter den Schmetterlingen selbst, wenn auch auf dem Gebiete eines anderen Sinnes. Hat ein Männchen, etwa von Callidryas Argante, lange ein Weibchen umflattert und mit dem Bisamhauch seiner Flügel umduftet, und zeigt sie endlich sich bereit, ihm zu willfahren, indem sie die Flügel ausbreitet und das Hinterleib-Ende emporhebt, - so sieht man nicht selten, dass der Bewerber noch einige Mal um sie herum und dann auf Nimmerwiedersehen davon fliegt. Nun aber ist das Einzige, was das Männchen erst jetzt an dem umworbenen Weibchen kennen lernt, der eigenthümliche Duft, welcher von den jetzt zum ersten Male vor ihm entblössten Theilen an Ende des Hinterleibes ausgeht. Nur dieser also kann noch im letzten Augenblicke entscheidend auf ihn wirken. Bei den Weibchen von Callidryas ist dieser Geruch sehr stark und, worauf es hier ankommt, er ist nicht moschusartig, sondern säuerlich, himmelweit verschieden von dem Flügelduft der Männchen.

Wie nun aber auch die Erhaltung und bei einigen Arten die mehr oder minder erhebliche Umgestaltung der Medea-Zeichnung geschehen sein mag. von jener Zeit ab, wo sie noch beiden Geschlechtern der Vorfahren in gleicher Weise zukam, Eines lässt sich mit voller Zuversicht aussprechen: Entstanden sein kann diese so auffallende und eigenatige Zeichnung der Medea weder durch den alleinigen Einfluss äusserer Verhältnisse (Wärme, Feuchtigkeit, Nahrung u. s. w.), noch durch innere „Wachsthumsgesetze“, noch endlich allein durch natürliche Züchtung als Trutzfärbung, sondern hauptsächlich und wesentlich nur durch geschlechtliche Auswahl. Dass äussere Verhältnisse Farbe und Zeichnung der Schmetterlinksflügel beeinflussen können, hat $W$ eismann überzeugend nachgewiesen; ebenso zeigte derselbe, dass Zeichnungen, die durch solche oder andere Verhältnisse auf irgend einem Ringe einer Raupe entstanden, nicht selten auf andere Ringe sich ausbreiten. Dasselbe wird an den Flügeln der Falter geschehen können. Zeichnungen, die aus irgend welcher Ursache in irgend einer Flügelzelle auftraten, werden an entsprechenden Stellen der übrigen Zellen sich wiederholen können. Soweit solche Zeichnungen als Widrigkeitszeichen dienen, können sie durch natürliche Züchtung grellere Farben erhalten und sich vergrössern. So

1) Siehe Ges. Schriften, S. 597 . 
könnte aus einem einfarbigen grauen oder braunen ein bunter Sclimetterling werden, und die an entsprechenden Orten der verschiedenen Flügelzellen sich wiederholenden Zeichnungen würden dann meist nicht verfehlen, einen angenchmen Eindruck auf uns zu machen. Es könnte so ein für uns schöner Schmetterling entstehen, ohne dass irgend welche Auslese in Bezug auf Schönheit stattgefunden hätte. Allein dies hat seine leicht zu bezeichnenden firenzen. Allen diesen blind wirkenden Ursachen ist es gleichgiltig, was aus ihnen hervorgeht, ob z. B. die Zeichnung der Vorder- und Hinterflügel zusammenpasst oder nicht, und ob dies in der einen oder anderen Stellung der Flügel geschicht. Wo wir also etwa eine gerade Iinie sehen, die ununterbrochen über die Oberseite der Vorder- und Hinterflügel hinweggeht, und zwar nur bei einer einzigen, ganz bestimmten Haltung der Flügel wie sie der Schmetterling beim Fliegen oder beim Sitzen mit ausgebreiteten Flügeln annimmt, während bei jeder anderen gegenseitigen Lage der Flügel die Linie entweder unterbrochen oder geknickt erscheint ${ }^{1}$ ), - da dürfen wir mit an Gewissheit grenzender Wahrscheinlichkeit behaupten, dass ein überwachendes Auge bei der Entstehung dieser Linie mitgewirkt hat. Dasselbe gilt für alle zusammenhängenden oder zusammenstimmenden Linien, die durch nicht entsprechende Punkte der verschiedenen Flügelzellen hindurchdringen.

Sehen wir uns Medea hierauf an. Wie gesagt, bilden die schwefelgelben Flecken drei gleichlaufend über alle vier Flügel hinwegzichende Querbinden, jedoch nur bei einer ganz bestimmten gegenseitigen Lage der Flügel. Die Regelmässigkeit hört sofort auf, sobald man die Vorderflügel weiter nach vorn zieht oder nach hinten schiebt; im ersteren Falle stossen nicht nur die betreffenden Fleckenreihen der Vorder- und Hinterflügel nicht mehr aneinander, sondern es treten auch die Flecken am Vorderrande der Hinterflügel zu Tage, die mit den übrigen nicht in gerader Linie liegen und vorher durch die Vorderflügel bedeckt wurden. In Betreff des zweiten oben bezeichneten Merkmals ist besonders die hintere Fleckenreihe der Hinterflügel beachtenswerth; in jeder Flügelzelle liegt ein gelber Fleck, jedoch nicht an entsprechenden Punkten der einzelnen Zellen; denn in letzterem Falle würden sie einen Bogen bilden und nicht eine gerade Linie. Dass nun der Schönheitssinn eines prüfenden Auges es war, der den ursprünglichen Bogen zur geraden Linie streckte, das kann kaum schlagender bewiesen werden, als dadurch, dass die beiden vordersten, diesem Auge unzugänglichen, weil durch die Vorderflügel bedeckten Flecken dieser Reihe ihre ursprüngliche Lage bewahrt haben und aus der geraden Linie der übrigen heraustreten.

Wahrscheinlich waren es die Weibchen, welche, unter den Männchen wählend, zuerst bei diesen die eigenthümliche Medea-Zeichnung ausbildeten. Später wurde dieselbe auch auf die Weibchen übertragen und hat sich bei ihnen in melıreren Arten bis zum heutigen Tage erhalten. Der Geschmack der Weibchen änderte

1) Schmetterlingsspiesser, die die Flügel aller Falter nach derselben Schablone auseinanderspreizen, verhunzen dadurch oft vollständig die eigenthümliche Schönheit ihrer Zeichnung. So erseheinen in den nach solchen verzerrten Leichen gemachten Abbildungen von Miscelia Cyaniris und Chromis in Doubleday's Gen, of Diurn. Lep. Pl. XXVIJ. Fig. I u. 2 die Vorderflügel viel zu weit nach vorn gezogen. Noch mehr verunstaltet erscheint Epicalia Pierretii in der Abbildung Pl. XXIX. Fing. 4, wcleber gewiss Niemand ansieht, dass die grossen orange Flecken der rechten und linken Sente eine einzige zusammenhängende Querbinde bilden. - 
sich im Laufe der Zeit, und dadurch wurden die Männchen vollständig umgeprägt, Zeichnung und schmückende Farbe der Flügel völlig verändert.

Die kleinen zimmetfarbenen Flecken, von denen eines auf jedem Flügel von Nedea steht (doch nicht an entsprechenden Stellen, auf den Vorderflügeln in Zelle 5, auf den Hinternflügeln in Zelle I), sind sehr veränderlich in Grösse und Schärfe des Umrisses und dadurch in ihrer Augenfälligkeit. Ist es ein werdender oder ein vergehender Schmuck? Da sie sich nicht nur bei der sehr ähnlichen Epicalia Chromis, sondern auch bei dem in der Zeichnung schon recht abweichenden Weibchen der Epicalia Numilia, ja sogar, wenigstens an den Hinterflügeln, bei dem Männchen von Epicalia Pierretii wiederfinden, so stammen sie jedenfalls nicht aus neuester Zeit. Vielleicht ist in ihnen ein letzter Rest einer dritten, noch älteren Ausschmückung der Epicalien erhalten.

Hiermit schliesse ich die Betrachtung unseres ungleichen Ehepaares und will nur noch hinzufügen, dass dasselbe nur einen besonders ausgezeichneten Fall in einer langen Reihe ähnlicher bildet! Wohl bei den meisten Faltern mit deutlich ausgeprägter Geschlechtsverschiedenheit, bei welchen die Färbung des Weibchens diesem nicht zum Schutze oder Trutze dient, zeigen uns Farbe und Zeichnung der Weibchen eine ältere, die der Männchen eine neuere Geschmacksrichtung der Art. Es darf, wem reiche Sammlungen offen stehen, hieran die Hoffnung knüpfen, mit Aussicht auf Erfolg die Frage in Angriff nehmen zu können, was denn überhaupt Schmetterlinge schön finden und wie sich bei ihnen, je nach den verschiedenen Familien, Gattungen, Arten, der Schönheitssinn entwickelt und im Laufe der Zeit fortgebildet habe.

Vergleicht man nun noch die Duftvorrichtungen der Antirrhaea Archaea mit denen der Epicalia Acontius, welche ich oben beschrieb, so findet man eine fast vollständige Uebereinstimmung. Bei beiden Arten sind die übereinandergreifenden Ränder beider Flügel im männlichen Geschlechte bedeutend erweitert und gebogen; bei beiden ist die Unterfläche der Vorderflügel ausgerüstet mit einer Mähne langer Haare, welche längs der Innenrandsader entspringen und einen bei Epicalia Acontius wohlentwickelten, bei Antirrhaea Archaea kaum angedeuteten Duftfleck bedecken. Gegenüber der Mähne liegt bei beiden Arten auf der Oberseite der Hinterflügel ein Duftfleck, dessen mittlerer Theil den Winkel zwischen den beiden Aesten der Subcostal-Ader einnimmt und von da in die drei anstossenden Flügelzellen übergreift.

Das Alles wäre nun sehr einfach und würde sich schr leicht erklären, wenn die beiden Arten zu derselben oder zu nahe verwandten Gattungren gehörten, wenn also alle jene Merkmale, in denen ihre Duftwerkzeuge übereinstimmen, von gemeinsamen Vorfahren abgeleitet werden könnten. Doch dem ist nicht so. Sie gehören zu sehr verschiedenen Unterfamilien, Antirrhaea zu den Satyrinen, Epicalia zu den Nymphalinen, und zudem entbehren viele der nächsten Verwandten der einen wie der anderen $\Lambda$ rt ähnlicher Vorrichtungen; Duftwerkzeuge fehlen z. B. vollständig bei Epicalia Numilia. Es kann daher kein Zweifel darüber bestehen, dass die Duftworrichtungen sich unabhängig von einander bei den zwei Arten entwickelt haben und dass Alles, was sie Gemeinsames haben, einzig dem Umstande zuzuschreiben ist, dass sie sich derselben Verrichtung angepasst haben. Die beiden Duftwerkzeuge sind also nicht stammverwandt (homolog), sondern ein- 
fach formverwandt (analog) und liefern ein Beispiel, und zwar eins der bemerkenswerthesten, der "Convergenz", wie man neuerdings die Aehnlichkeit genannt hat, die nicht auf Ererbung beruht, sondern von Anpassung an gleiche Verhältnisse herrührt.

Ich kenne keinen anderen Fall, der so klar und eindringlich die Wahrheit eines Satzes bewiese, den man bei morphologischen Untersuchungen nie aus den Augen verlieren sollte, nämlich: Wenn bei zwei Arten gewisse W'erkzeuge, die derselben Verrichtung dienen, an gleichem Orte sich finden und aus denselben Theilen in derselben gegenseitigen Lage und von älnnlicher Form bestehen, so liefert alles dies für sich allein noch keinen vollgültigen Beweis dafür, dass diese W'erkzeuge „homolog" sind, - selbst dann nicht, wenn beide Arten derselben Familic angehören. 


\section{Kritik über ${ }^{1}$ )}

Dr. Paul Kramer: Theorie und Erfahrung, Beiträge zur Beurteilung des Darwinismus, Halle, L. Nebert $1877^{2}$ ).

„Die Principien des Darwinismus können zur Erklärung der Thatsachen nichts beitragen, durch sie wirdkeineunsvor Augen liegende Wirklichkeit verständlich. Dies das kurze Resultat und das einfache Ergebniss vorstehender theoretischer Betrachtungen." So verkündet Verf. am Schlusse des ersten, ,mathematische Entwickelungen" überschriebenen Capitels seiner Schrift.

Diese „mathematischen Entwickelungen" erklärt Prof. S. Günther (Kosmos, III. S. 292) für „planmässiger, umfassender und deshalb auch wichtiger“, als verschiedene früher gegen den Darwinismus gerichtete mathematische Betrachtungen und glaubt, ,der gebotenen Leistung einen entschiedenen Werth zusprechen zu müssen." Nur dieses einer so berufenen Feder entflossene günstige Urtheil veranlasst mich, auch meinerseits über die genannte Schrift mich auszusprechen; sonst würcle ich dieselbe der Beachtung nicht werth halten und den Verf. nicht in dem stolzen Bewusstscin stören, D arwin gründlich abgeführt zu haben.

Prof. Günther hat sich, als Mathematiker, „vornehmlich mit dem Gange der Untersuchung beschäftigt, die empirische Grundlage der Prüfung Anderen überlassend“; als Nicht-Mathematiker werde ich umgekehrt hauptsächlich die Voraussetzungen ins Auge fassen, auf welchen Verf. seine „mathematisch eingekleideten Schlüsse" aufbaut,

Verf. stellt sich die Aufgabe, darzulegen, wie weit auf dem Gebiete der secundären Geschlechtscharaktere „die Darwinistische Methode eine natürliche und der Wahrscheinlichkeit nach zum Ziele führende“ ist. Behufs der „Entwickelung einer Findamentalformel" werden nun im ersten $\Lambda$ bschnitt der mathematischen Entwickelungen folgende „Vorbedingungen“ aufgestellt:

Erste Vorbedingung. Es seien pa Weibchen und ma Männchen einer Thicrart in einem gewissen Gebiete vorhanden. Letztere allein mögen nach einer bestimmten Richtung veränderlich sein und zwar mögen immer ${ }_{n^{1}}^{\frac{n^{1}}{n}}$ derselben während der Entwickelung zum reifen Alter abändern, also $n-\frac{n^{1}}{n}$ unverändert bleiben. Der Bruch $\frac{n^{1}}{n}$ wird Variabilitätscoëfficient genannt. - Zunächst

1) Kúsmos 1878/79. Bd. IV. S. 495-502.

2) Dem Referenten erst im September 1878 zugegangen. 
ein Wort über die vom Verf. eingeführte Bezeichnung. Es handelt sich in der ganzen Untersuchung nie um die absolute Zahl der Weibchen und Männchen, sondern stets nur um deren Verhältnisszahl; warum also nicht einfach sagen: die Zahl der Männchen sei das $m$ fache von der der Weibchen, wo $m$ ein beliebiger echter oder unechter Bruch sein kann; weshalb drei Buchstaben, a, p, m, wo einer genügt? Und warum für den Variabilitätscoëfficienten zwei Buchstaben, wo einer ausreicht? Dieselbe eigenthümliche Art der Bezeichnung wiederholt sich auch später; für fünf in Betracht gezogene Grössen kommen zehn Buchstaben zur Verwendung. Schon dadurch erhalten die „mathematischen Entwickelungen" eine gewisse schwerfällige Unbeholfenheit, durch die sie auch sonst sich auszeichnen, und die Fundamentalformel gewinnt sicher nicht an Uebersichtlichkeit und Verständlichkeit dadurch, dass die Grössen, auf welche es ankommt, als solche gar nicht darin auftreten.

Der Variabilitätscoëfficient wird, ohne dass dies irgendwo ausdrücklich gesagt wird, (der Verf. scheint es als selbstverständlieh anzusehen) als gleichbleibend angenommen. Er soll der gleiche sein für Thiere, deren Vorfahren seit langer Zeit unverändert geblieben, und für Thiere derselben Art, deren Vorfahren in dieser Zeit von Geschlecht zu Geschlecht sich fortwährend geändert haben. Wer die Darwin'sche Theorie an der Erfahrung zu prüfen unternimmt, der sollte doch wissen, dass eine solche Annahme unvereinbar ist mit den allbekannten. Jahr für Jahr tausendfältig aufs Neue bestätigten Erfahrungen der Gärtner und Thierzüchter.

Zweite Vorbedingung. „Die Anzahl der Jungen betrage stets das rfache der vorhandenen Paare. Die Zahl r heisse der Vervielfältigungscoëfficient. Er ist unter allen Umständen eine ganze Zahl." - Unter allen Umständen? Doch wohl nur dann, wenn alle Paare gleich fruchtbar sind. Und das ist ein Umstand, der in der Wirklichkeit vielleicht niemals eintritt. Immer oder fast immer schwankt die Zahl der Jungen in engeren oder weiteren Grenzen. Mögen $b_{1}, b_{2}, b_{3} \ldots b p$ die Anzahl der Jungen, je eines der $p$ in einem Gebiete vorhandenen Paare bezeichnen, so ist allerdings jede dieser Zahlen eine ganze Zahl und ebenso $\mathbf{\Sigma} b=p r$; die Wahrscheinlichkeit aber, dass auch $r=\frac{\Sigma_{b}}{p}$ eine ganze Zahl sei, ist $=\frac{\mathrm{I}}{\mathrm{p}}$. Wie gross ist also z. B. die Wahrscheinlichkeit des nach dem Verf. „unter allen Umständen“ eintretenden Falles, dass $r$ eine ganze Zahl ist, für die Ehen im deutschen Reiche? Unter allen Umständen beweist der Verf. durch diese wunderliche Belıauptung, die ïbrigens ohne Einfluss ist auf den Gang der mathematischen Entwickelungen, wie vollberechtigt gerade er ist, den Darwinisten Mangel an Vorsicht, Klarheit und Schärfe vorzuwerfen. In derselben „zweiten Vorbedingung“ wird die Annahme gemacht, die wir uns merken wollen "dass eine besondere Auswahl won Seiten der Weibchen oder Männchen nicht eintrete."

Dritte Vorbedingung. „Nach der Erzeugung der Jungen mögen die alten Thiere sämmtlich zu Grunde gehen." Passt für zahlreiche Thiere.

In der vierten Vorbedingung wird der Bruchtheil von unveränderten Eltern abstammender Jungen, der während des IIeranwachsens stirbt, mit ${ }_{t}^{1}$ be- 
zeichnet und $\mathrm{Abnahmecoëfficient} \mathrm{genannt;} \mathrm{es} \mathrm{wird} \mathrm{angenommen,} \mathrm{dass} \mathrm{dieser}$ Abnahmecoëfficient „bei zunehmender Variirung“ sich ändere, und zwar bei einmal variirten Thieren $u m \frac{t^{1}}{t} \cdot \frac{p^{1}}{\rho}$, bei zweimal variirten um $\frac{t^{1}}{t} \cdot \frac{2 p^{1}}{\rho}$ u.s. w., so dass also „der Abnahmecoëfficient im Verhältniss der abgelaufenen Variationsperiode sich ändert." Worauf gründet sich diese Annahme? Wenn durch den Kampf ums Dasein eine natürliche Auslese stattfindet, dann allerdings wird in Folge der Auslese, aber nicht als unmittelbare Folge der Abänderung. der Abnahmecoëfficient, oder sagen wir kürzer die Sterblichkeit der bevorzugten Varietäten kleiner, diejenige der in ungünstiger Richtung abweichenden grösser sein, als die der unveränderten Thiere. Wo aber keine Auslese eintritt, da besteht kein nothwendiger Zusammenhang zwischen Abänderung und Sterblichkeit. Und selbst zugestanden, dass jede Abänderung auch die Sterblichkeit der heranwachsenden Jungen irgendwie beeinflusse (warum nicht ebenso den "Variabilitäts-“ und den „Vervielfältigungscoëfficienten?"), zugestanden, dass der Abnahmecoëfficient eine Funktion sei der ,abgelaufenen Variationsperiode“, woher in aller Welt die Berechtigung zu der Annahme, dass die Veränderung des ersteren den letzteren proportional sei? - Wir wissen nicht, ob überhaupt $y=f(x)$. Was schadet es? Nehmen wir an, es sei $y=C \mathrm{x}$ ! Gewiss ein gutes Beispiel der ,äussersten Vorsicht", mit welcher Verf. (S. 68) sich bewusst ist, zu Werke gehen zu müssen. Und wenn nun das Variiren eine Aenderung der Sterblichkeit zu Wege bringen soll, weshalb soll diese Aenderung erst bei den Jungen der variirenden Thiere eintreten, wie in des Verf. mathematischen Entwickelungen, und nicht schon bei den variirenden Thieren selbst? - Die ganze Annahme ist aller thatsächlichen Begründung bar, aufs Gerathewohl aus der Luft gegriffen.

Schlimmer noch steht es mit der fünften Vorbedingung; denn sie schlägt allen Thatsachen geradezu ins Gesicht. „Die Anzah] der Männchen, sowie der Weibchen mögen sich im Laufe der Zeiten nicht änd ern.“!!! Vermag der Verf. ein einziges Dorf, eine Stadt, ein Land aufzuzeigen, dessen Bewohnerzahl nicht „im Laufe der Zeiten“, nein, nur im Laufe eines einzigen kurzen Menschenalters sich nicht geändert? Vermag er eine einzige Thieroder Pflanzenart nachzuweisen, für welche, nur während zehn oder zwanzig Generationen, ein unveränderter Bestand nicht bewiesen, nein, nur wahrscheinlich gemacht werden kann? Von selteneren Thieren und Pflanzen weiss ja jeder Sammler, wie sehr ihre Zahl in verschiedenen Jahren wechselt; ebenso ist es von schädlichen Thieren bekannt, wie ihre Zahl bald rasch zu einer allgemeinen Landplage anschwillt, bald ohne menschliches Zuthun ebenso rasch zurücksinkt. Bei anderen Arten pflegt man ihre wechselnde Häufigkeit weniger zu beachten; doch könnte ich eine lange Reihe einschlägiger Beispiele anführen. Es ist ja übrigens dieses Auf- und Abwogen im Kampfe ums Dasein, bei den ewigen Wechsel der äusseren Verhältnisse (Wetter u. s. w.), selbstverständlich. Es mag hier zu Lande, wo der Einfluss des Menschen noch verschwindend klein ist, vielleicht mächtiger hervortreten, als wo Feld und Wald seit lange dem Anbau und der Pflege des Menschen unterworfen wurden. Für die Wirksamkeit natürlicher Auslese sind, beiläufig bemerkt, die Zeiten äusserster Bedrängniss, durch die wohl jede Art wiederholt hindurchgehen muss, von der grössten Bedeutung. 
Aber wie kommt der Verf. zu dieser Annahme von der Unveränderlichkeit der Individuenzahl, welche die Lehre von der Unveränderlichkeit der Arten weit hinter sich lässt? Er giebt uns selbst die Antwort: „Unter dieser Bedingung ist es möglich, die Resultate zu einer Gleichung zusammenzufassen". Die Annahme ist also einfach gemacht, weil Verf. sie für nöthig hielt, um eine „Fundamentalformel“ zu gewinnen, um dem Darwinismus mit „mathematischen Entwickelungen" zu Leibe gehen zu können. Ob sie wahr sei, oder auch nur wahrscheinlich, ist Nebensache. Kümmerte sich Virchow um die Wahrheit der gehüssigen Denunciation, die er in München gegen den Darwinismus schleuderte?

Sechste Vorbedingung. 1) ,Jedes Männchen möge sich immer nur mit einem einzigen Weibchen paaren und 2) diejenigen Männchen oder Weibchen, welche nicht beim ersten Male (?) einen Gefährten finden, mögen unfruchtbar zu Grunde grehen." Ersteres gilt für einzelne Thiere; was der zweite Theil der Annahme sagen soll, ist mir unerfindlich.

Siebente Vorbedingung. .,Eine einmal gewonnene Charaktereigenthümlichkeit verde ungeschwächt auf die männlichen Jungen vererbt. Diese Vorbedingung ist der Ausdruck eines Hauptgedankens der Darwinistischen Theorie und wird hier zu Grunde gelegt, da die Betrachtungen sich zunächst ganz eng an die Grundsätze des Darwinismus anschliessen sollen." - Aber wo hat Dar win, wo hat einer seiner Anhänger, je eine ähnliche, aller Frfahrung zuwiderlaufende Behauptung ausgesprochen? Welchem Thier- oder Pflanzenzüchter fällt es ein, eine „einmal gewonnene Charaktereigenthümlichkeit" sofort als sicher befestigt zu betrachten und auf ihre, ,ungeschwächte“ Vererbung zu rechnen? Soweit mir bekannt, haben alle Darwinisten, die über Vererbung gesprochen, dabei stets den Rückschlag im Auge behalten. - Wie verträgt sich übrigens mit dem hier vorgegebenen ganz engen Anschlusse an die Grundsätze des Darwinismus der kurz vorher aufgestellte ultra-immutabilistische Satz von der Unveränderlichkeit der Individuenzahl?

Dies sind die Annahmen, an welche sich des Verf. „mathematisch eingekleidete Schlüsse“ knüpfen. Zum Theil, und es sind dies gerade die wichtigsten, sind sie willkürlich aus der Luft gegriffen oder stehen in offenem Widerspruche mit aller Erfahrung, zum Theil haben sie nur eine beschränkte Gültigkeit, während der Rest nur eine Bezeichnung gewisser Verhältnisse durch Buchstaben enthält Ich verliere kein Wort über den Werth, der demnach den Ergebnissen des Verf. beizulegen ist.

Im zweiten Abschnitte der „mathematischen Entwickelungen“ wenclet Verf. die gewonnene Fundamentalgleichung an auf den Fall, dass die Anzahl der Männchen das mfache von der Anzahl der Weibchen ist" und stellt sich als Hauptaufgabe, „die nach x Generationen vorhandene Anzahl von veränderten und unveränderten Männchen zu bestimmen“. Es wird dabei die Ansicht ausgesprochen und der Rechnung zu Grunde gelegt, dass „eine ererbte und eine selbst erfahrene Veränderung wesentlich gleichbedeutend sind“. - Verf. wird von jedem Gärtner oder Thierzüchter hören können, ob wirklich eine zum ersten Male auftretende und eine seit einer langen Folge von Generationen fortgeerbte Veränderung "wesentlich gleichbedeutend" sind in Bezug auf den Punkt, der allein hier in Frage kommt, die wahrscheinliche Veränderlichkeit der Nachkommen. - 
Das vom Verf. gewonnene Ergebniss hätte unter den von ihm gemachten Voraussetzungen wohl auf einfacherem Wege gefunden werden können. Da Verf. in diesem Abschnitte den Abnahmecoëfficienten als constant annimmt, da nach seinen V'oraussetzungen weder die absolute Zahl, noch die Verhältnisszahl der Männchen und Weibchen, ebensowenig die Fruchtbarkeit der Paare und die Sterblichkeit der Jungen in irgend welcher Beziehung stehen zu dem Zahlenverhältniss der mehr oder minder oft abgeänderten Männchen, so hängt dieses einzig und allein ab von dem als constant angenommenen Variabilitätscoëfficienten.

Mögen die männlichen Nachkommen jedes Paares sich in zwei Gruppen spalten, von denen die eine unverändert, dem Vater gleich, die andere weiter verändert ist, und mögen diese in dem Verhältnisse $\mathrm{I}: \mathrm{v}^{r}$ stehen. Für drei aufeinanderfolgende Generationen ergiebt sich dann:

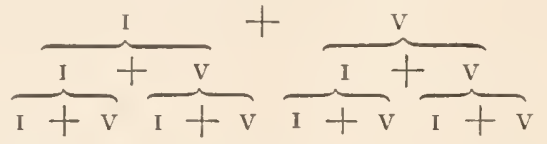

In der dritten Generation hat man also eine Gruppe unveränderter, drei Gruppen einmal, drei Gruppen zweimal und eine Gruppe dreimal abgeänderter Männchen; die Zahlen der Männchen je einer dieser viererlei Gruppen stehen im Verhältniss von $\mathrm{I}: \mathrm{v}: \mathrm{v}^{2}: \mathrm{v}^{3}$. Also verhalten sich die unveränderten $\mathrm{zu}$ den einmal, zweimal, dreimal veränderten Männchen, wie $\mathrm{I}: 3 \mathrm{v}: 3 \mathrm{v}^{2}: \mathrm{v}^{3}$. Man sieht sofort, wie das in den folgenden Generationen weitergeht. Für die xte Generation werden die Verhältnisszahlen der keinmal, einmal, zweimal,... bis x mal abgeänderten Männchen dargestellt durch die $(\mathrm{x}+\mathrm{I})$ Glieder der Potenz $(\mathrm{I}+\mathrm{v}) \mathrm{x}$. Für die Männchen, welche $y$ mal abgeändert haben, hat man also $x_{y} \cdot v^{y}$, wo $x_{y}$ der $y^{\text {te }}$ Binominalcoëfficient von $\mathrm{x}$.

Setzt man $\mathrm{x}=10, \mathrm{v}=1 / 2$ und multiplicirt mit $2^{10}$, so erhält man die vom Verf. auf Seite 22 gegebenen Zahlen.

Zur Erlangung dieses der einfachsten Ueberlegung sich mühelos bietenden Ergebnisses hat der V'erf. I5 Seiten und eine weitschichtige Rechnung mit zehn Buchstaben gebraucht. Ein einziger thut's auch, wie man sieht.

Verf. knüpft hieran u. a. folgende Bemerkung: „Einzig und allein in dem einzigen, aber undenkbaren Falle, dass n der Einheit gleich ist" (d. h. dass alle Männchen variiren), „finden sich künftighin nur veränderte Formen, in allen übrigen Fällen bleibt in einer guten Anzahl Nachkommen die alte Form erhalten." Verf. scheint vergessen zu haben, dass es zwischen 2 und $\mathrm{I}$ auch noch Zahlen giebt wenn auch keine ganzen; für alle diese zwischen I und 2 liegenden Werthe von $n$ aber tritt, unter den Voraussetzungen des Verf., die Zahl der unveränderten Männchen zurück gegen die der am meisten veränderten. Für $11=1,5,(v=2$ nach der oben gebrauchten Bezeichnung), würden die vom Verf. gegebenen Zahlen in gerade umgekehrtem Sinne gelten: unter $3^{10}=59049$ Männchen würden sich ein unverändertes, 20 einmal veränderte u. s. w., dagegen 5 I20 neunmal und I024 zehnmal veränderte finden. Wäre 59049 die Zahl der Männchen in einem bestimmten Gebiete, und wären die Männchen hundertmal zahlreicher als die Weibchen, so würde die Wahrscheinlichkeit, dass jenes eine unveränderte Männchen eine Genossin fände, nur 1/100, die Wahrscheinlichkeit, 
dass eins der 20 einmal veränderten Männchen zur Paarung gelangte, nur 1/5 sein. Wahrscheinlich also würden schon in der elften Generation alle unveränderten und einmal veränderten Männchen verschwunden sein, und so, selbst ohne Auslese, nach und nach alle minder veränderten Männchen aussterben.

Das Ergebniss dieses zweiten Abschnittes ist, dass, wenn keine besondere Auswahl von Seiten der Weibchen stattfindet, - wir erinnern uns, dass dies eine der Vorbedingungen des Verf. war, - „ein Chaos von ineinanderfliessenden Männchenformen“ entsteht. Das aber steht „mit der Erfahrung im schneidenden Widerspruch“; also „folgt nothwendig, dass der Darwinismus für die Erklärung der sekundären Geschlechtscharaktere nicht ausreicht." - Wir könnten uns des Verf. Vordersätze wohl gefallen lassen und nur bedauerı, dass sie auf so völlig haltlosen Grundlagen ruhen; denn wahrscheinlich würde die Mehrzahl der Naturforscher aus denselben Vordersätzen den Schluss ziehen; also folgt nothwendig, dass bei Entstehung des secundären Geschlechtscharakters eine besondere Auswahl im Spiele gewesen ist.

Der dritte Abschnitt der ,,mathematischen Entwickelungen“ erwägt den Fall, dass die Eltern nur allmälig absterben, sieht also ab von der dritten Vorbedingung des ersten Abschnitts. Ob die Untersuchung den verwandten „umfänglichen mathematischen Apparat" wirklich verlangt, wie Professor Günther glaubt, möchte ich bezweifeln; jedenfalls hat dieser umfängliche Apparat zur Folge gehabt, dass V'erf. die weitschichtige Rechnung nicht über die dritte Generation hinausgeführt hat. Und so kann, ganz abgesehen von der Unhaltbarkeit der Voraussetzungen, das Ergebniss dieses Abschnittes nicht einmal als mathematisch bewiesen betrachtet werden; denn aus den ersten Gliedern einer Reihe lässt sich kein Schluss ziehen, der über sie hinausreicht, so lange nicht das Gesetz, nach welchem sie fortschreitet, erkannt ist. Wie nöthig diese von jedem besonnenen Mathematiker geübte Vorsicht sei, dafür liefert Verf. in demselben Abschnitte ein schlagendes Beispiel. Unter der Voraussetzung, dass „ein Theil der jedesmal vorhandenen Eltern dreimal zu einer Brut gelangt und das Absterben der alten Thiere dabei derart geregelt ist, dass im Laufe jeder Entwickelungsperiode der dritte Theil dieser ursprünglich vorhandenen Thiere zu Grunde geht, so dass also ein Drittel noch zur dritten Brut gelangt", kommt nämlich Verf. nach (obendrein falscher) Berechnung von nur zwei Gliedern der betreffenden Reihe zu dem Schlusse, dass unter den genannten Bedingungen und bei unveränderter Sterblichkeit $(1 / \mathrm{t})$ der Jungen, die Fruchtbarkeit der Pare (r) mit der Zeit wachsen muss!!! - „Doch lasse man dies noch einen Augenblick ausser Acht", fügt der Verf. hinzu, kommt aber nie wieder auf diese Frage zurück und lässt so den Leser in Zweifel, ob ihm überhaupt klar geworden, was er eigentlich aus seinen Formeln herausgelesen hat. Mit dem weitschichtigen Apparate des Verf. würde man Bogen brauchen, um die auf flacher Hand liegende Verkehrtheit seines Schlusses mathematisch nachzuweisen. Und doch ist die Sache höchst einfach. Die vom Verf. mit $z=\frac{r(t-r)}{t(m+r)}$ bezeichnete Grösse, die also der Fruchtbarkeit der Paare (r) proportional ist, so lange $m$ und $t$ sich nicht ändern, drückt nichts anderes aus, als die Zahl der bei jeder Brutzeit neu hinzutretenden Männchen, verglichen mit der als Einheit betrachteten Gresammt- 
zahl derselben. Wir wollen ebenso mit Y und X die Zahl der Männchen bezeichnen, welche beziehungsweise zum zweiten oder dritten Male die Brutzeit erleben. Dann ergiebt sich, da von den erwachsenen Männchen jeder Brut $2 / 3$ die zweite, $1 / 3$ die dritte Brut erleben sollen, für sieben aufeinanderfolgende Brutzeiten:

\begin{tabular}{|c|c|c|c|}
\hline & $\mathrm{X}$. & Y. & Z. \\
\hline I & & $2 / 3=1458 / 2187$ & $1 / 3=729 / 2187$ \\
\hline II & $1 / 3=729 / 21 \mathrm{s7}$ & $2 / 9=4861 / 2187$ & $4 / 9=972 / 2187$ \\
\hline III & $1 / 9=243 / 2187$ & $s / 27=945 / 2187$ & $16 / 27=1296 / 2157$ \\
\hline IV & $4 / 27=324 / 2187$ & $32 / 81=864 / 2187$ & $37 / 81=999 / 2187$ \\
\hline $\mathrm{V}$ & $16 / 81=432 / 2187$ & $74 / 81=666 / 2187$ & $121 / 243=1059 / 2187$ \\
\hline VI & ${ }^{37} / 243=333 / 2187$ & $\left.{ }^{24} 2\right|_{729}=726 / 2187$ & $376 /{ }^{29}=1128 / 2187$ \\
\hline VII & $121 / 129=363 / 2187$ & ${ }^{752} / 2187$ & $1072 / 2187$ \\
\hline
\end{tabular}

Die Rechnung ist leicht fortzusetzen und es ergiebt sich, was schon die vorgeführten Glieder veranschaulichen, dass Z (und das ihm proportionale r) keineswegs mit der Zeit wächst, dass sich vielmehr Gruppen von je drei Werthen bilden, in der Weise, dass $\mathrm{Z}^{\mathrm{I}}<\mathrm{ZII}<\mathrm{ZIII}>\mathrm{Z}_{\mathrm{IV}}<\mathrm{ZV}^{\mathrm{V}}<\mathrm{ZVI}^{\mathrm{VI}}>\mathrm{ZVII}_{\mathrm{VI}}<\ldots$. und dass $(\mathrm{ZIII}-\mathrm{ZI})>(\mathrm{ZVI}-\mathrm{ZIV})>(\mathrm{ZIX}-\mathrm{ZVII})>\ldots$ dass sich also Z mit der Zeit einem Grenzwerthe nähert, der, wie schon die vorstehenden Glieder errathen lassen, $=1 / 2$ ist; ebenso nähert sich $\mathrm{Y}$ dem Werthe $1 / 3$ und $\mathrm{X}$ dem Werthe $1 / 6$, so dass schliesslich $\mathrm{X}: \mathrm{Y}: \mathrm{Z}=\mathrm{I}: 2: 3$.

Es liegt ja auf der Hand, sobald bei jeder Brutzeit gleichviel frische Männchen eintreten, von denen $2 / 3$ zur nächsten, $1 / 3$ zur übernächsten Brutzeit übrig bleiben, dass dann, bei gleichbleibender Gesammtzahl das Verhältniss der drei Altersklassen das eben angegebene sein muss. Verf. hat bei seiner Rechnung angenommen (und dieselbe Annahme ist deshalb obiger Tabelle zu Grunde gelegt), dass das Weiterleben gewisser Paare über die erste Brutzeit hinaus erst gleichzeitig mit dem ersten Auftreten der Variabilität der Männchen eingetreten sei, - eine äusserst unwahrscheinliche Annahme. Die weit natürlichere Annahme, dass beim Eintritt der Variabilität schon Männchen von drei Altersklassen im Verhältniss von $3: 2: 1$ vorhanden gewesen, würde die Rechnung sehr vercinfacht, z. B. für $Z$, wie schon erwähnt, den constanten Werth $1 / 2$ gegeben haben. Noch einfacher und thatsächlich vorkommenden Verhältnissen mehr sich nähernd, wäre es wohl gewvesen, jedes erwachsene Männchen drei Bruten erleben, jedes Mal also ein Drittel der Gesammtzahl neu hinzutreten zu lassen ${ }^{1}$ ).

1) Verf. findet richtig für die erste Brutzeit $Z=1 / 3$, für die zweite aber nicht $Z=4 / 9$, sondern $z=\frac{-2+V \text { to }}{3}$. Obwohl er nämlich selbst ausrechnet, dass für aufeinander folgende Bruten der Werth von $Z=\frac{\mathrm{r}(\mathrm{t}-\mathrm{I})}{\mathrm{t}(\mathrm{I}+\mathrm{m})}$ sich ändert, obwohl er also diese verschiedenen Werthe in demselben Ausdrucke nicht mit demselben Buchstaben hätte bezeichnen dürfen, hat er dies doch gethan in den S. 27 aufgestellten Ausdrücken. - Ein starkes Stück für einen preussischen Oberlehrer! - Daher jener Irrthum. Führt man statt $\frac{\mathrm{r}(\mathrm{t}-\mathrm{I})}{\mathrm{t}(\mathrm{I}+\mathrm{m})}$ den Buchstaben $\mathrm{Z}$ ein, und bezeichnet die dem verschiedenen Alter der Thiere entsprechenden beiden Werthe durch $Z^{\circ}$ und $Z^{\prime \prime}$, so erhält man zur Bestimmung von $Z^{\prime \prime}$ die Gleichung: $a m=\frac{a m}{3}+\frac{2 a m}{3}\left(Z^{\prime}+Z^{\prime \prime}\right)+$ am $Z^{\prime} Z^{\prime \prime}$, oder: ${ }^{2} / 3\left(Z^{\prime}+Z^{\prime \prime}\right)+Z^{\prime} Z^{\prime \prime}=2 / y$, also, da $Z^{\prime}=1 / y$ ist, $Z^{\prime \prime}=4 / y^{\prime}$ 
Ich lialte ein, um die Leser nicht zu ermüden. Dic noch folgenden Abschnitte der „mathematischen Entwickelungen“ sind den vorangehenden ebenbürtig. Als Beweis genüge ein einziges Beispiel aus dem VI. Abschnitte, der überhaupt durch unglaubliche Naivität - bezeichnendere deutsche Ausdrücke sind unparlamentarisch - sich auszeichnet. Bilden die Weibchen in der ersten Generation 2, in der zweiten $4=2^{2}$, in der dritten $8=2^{3}$, in der vierten $16=2^{4}$ Gruppen - so weit geht die Berechnung des Verf. - von denen immer die Hälfte schwächlich, die Hälfte kräftig sind, und ,sind s ooo Entwickelungsperioden verflossen, so hat man schon Ioo I verschiedene Gruppen unter den schwächlichen Weibchen, und ebenso Ioos rerschiedene Gruppen unter den kräftigen Weibchen der letztgenannten Generation." Seit wann ist $2^{100 n}=2 \times 100 \mathrm{I}$ ? - Man meint in 1001 Nacht zu lesen, statt in "mathematischen Entwickclungen" eines preussischen Oberlehrers. -

Dem mathematischen Theile der Schrift schliessen sich drei weitere Capitel an, in denen ich Nichts finde, was der Beachtung und Besprechung werth wäre. Sie enthalten weder neue Thatsachen, noch Gedanken. Wenn in zweiten Capitel Verf. an „Beispielen zum Schlussverfahren Darwinistischer Schriftsteller“ nachzuweisen sucht, wie schlecht es mit deren Logik bestellt sei (dabei manchen Missverständnissen verfallend, wie bei zweien der drei Beispiele, die er der Schrift des Ref. „Für Darwin“ entlehnt), so räume ich für meinen Theil willig ein, dass mich der Darwinismus anfangs zu manchem übereilten Schluss, zu manchem unhaltbaren Erklärungsversuche verlockt hat; zum Glücke habe ich sie meist für mich behalten. Anderen mag es ähnlich gegangen sein. Man darf uns wohl verzeihen, dass uns bisweilen das neue Licht geblendet, die neue Erkenntniss berauscht hat. Aber was haben einzelne Irrthümer, Fehlschlüsse, Uebertreibungen seiner Anhänger zu thun mit der Wahrheit des Darwinismus? Und was bedeutet die Bemängelung einzelner misslungener Erklärungsversuche durch Herrn Oberlehrer Dr. Paul Kramer in Schleusingen, gegenüber den Tausenden von Thatsachen, welche, den gesammten Inhalt weiter $W$ issensgebiete umfassend, nur von der Abstammungslehre und rom Darwinismus aus zu verstehen sind?

Itajahy, September 1878 . 


\title{
Phryganiden-Studien $\left.{ }^{1}\right)$.
}

\author{
(Mit einer Einleitung von Herm. Müller.)
}

Mit 3 Textfiguren.

I. Einleitung.

Zur Feier des Tages, an welchem unser verehrter Meister Charles Dar win sein siebenzigstes Lebensjahr vollendet, überreiche ich der dem Ausbau seiner Entwickelungslehre gewidmeten Zeitschrift einige Aufsätze meines Bruders Fritz. Müller über eine Insektenfamilie, welche gerade jetzt im Lichte dieser Lehre einem eingehenden Verständnisse sich zu eröffnen verspricht. Es ist die Familie der Haarflügler (Trichoptera) oder Frühlingsfliegen (Phryganiden). Ich hoffe im Interesse der Leser dieser Aufsätze zu handeln, wenn ich den wesentlichsten Inhalt der im ersten derselben erwähnten S p e y e r'schen Abhandlung hier wiedergebe.

Mein Freund Dr. A. Speyer, der schon im Jahre 1839 in Oken's "Isis" (S. 94) eine wahre Verwandtschaft zwischen Lepidopteren und Pryganiden behauptet hatte, war auch der Erste, der sich fast 30 Jahre später durch die Darwin'sche Theorie und durch die Stammbaum-Entwürfe Haeckel's, in denen über die Abstammung der Schmetterlinge eine bestimmte Ansicht nicht gewagt worden war, veranlasst fand, eine genauere anatomische und physiologische Vergleichung der Eigenthümlichkeiten beider Gruppen zur weiteren Begründung seiner Ansicht ins Auge zu fassen. Wenn er auch leider mitten in seinen Untersuchungen, durch ein dauerndes Augenleiden genöthigt, abbrechen musste, so genügen doch die von ihm angestellten und in dem hier citierten Aufsatze mitgetheilten Vergleichungen wenigstens, um es im höchsten Grade wahrscheinlich zu machen, dass die Ordnung der Schmetterlinge entweder von den Frühlingsfliegen oder von ihnen nahe stehenden, wenig verschiedenen Stammeltern derselben abstammt. Denn fast sämmtliche Eigenthümlichkeiten des Körperbaues und der Lebensweise der Frühlingsfliegen kommen auch theils den Schmetterlingen überhaupt, theils gewissen, den Phryganiden am nächsten stehenden Schmetterlingen $\mathrm{zu}$.

Den Schmetterlingen im Allgemeinen sind mit den Frühlingsfliegen gemein: Gestalt und Grössenverhältnisse des Kopfes und der drei Brustringe, die schmale Vorderbrust, die am meisten ausgebildete Mittelbrust, die Form und Zahl der

1) Kosmos 1878/79. Bd. IV. S. 386-396. 
Ringe des Hinterleibes, der beim Männchen ähnlich gebildete Organe zum Festhalten bei der Begattung trägt, Beine mit dicht zusammenstossenden Hüften und fünf Fussgliedern, Umriss und Bau der Flügel, vielgliedrige, in der Regel lange, borstenförmige F ühler, dreigliedrige Lippentaster, ungetheilte Unterlippe, zu , kaum sichtbaren Rudimenten verkümmerte Oberkiefer, im Wesentlichen gleiche, vollkommene Umwandlung, vegetabilische Nahrung. wurmförmige, dreizehnringlige Larven mit abgesondertem, hornigem Kopfe, und drei Paar vier- bis sechsgliedrigen, hornigen Brustfüssen, als Mundtheile der Larven eine quere, eingekerbte oder zweilappige Oberlippe, starke, feste, meist gezähnelte Oberkiefer, kegelförmige, gegliederte, tastertragende Unterkiefer, welche die Unterlippe zwischen sich fassen und mit ihr die Mundhöhle von unten schliessen, an der Unterlippe zwei Lippentaster und zwischen ihnen die Spindel, in denen die Spinngefässe münden.

Als besonders auffallende Eigenthümlichkeiten der Frühlingsfliegen, die auch bei gewissen, ihnen am nächsten stehenden Faltern sich finden, seien hier noch ferner hervorgehoben: Das Leben der durch Kiemen athmenden Larven im Wasser, das Sich-Bergen derselben in selbstverfertigten röhrigen Hülsen, aus denen die Brustfüsse zum Kriechen vorgestreckt werden, während sich das Ende des Körpers durch Nachschieber oder Häkchen an die Röhre anklammert, das Verpuppen in diesen Wohnungen, die bisweilen schneckenhausförmige Gestalt derselben (bei Psyche helix unter den Faltern, bei Helicopsyche unter den Frühlingsfliegen), die Flügelfaltung in der Ruhe, die Art des Fliegens und am Boden Hinrutschens, die oft rudimentäre Beschaffenheit der Mundtheile, die Bekleidung: der Flügel mit Härchen, die sehr locker in die Flügelmembranen eingepflanzt sind, fünf- oder sechsgliedrige Kiefertaster, Puppen mit frei abstehenden Scheiden der äusseren Organe.

Durchgreifend verschieden sind die Phryganiden von den Lepidopteren nur durch die Gebrauchsfähigkeit der Beine gegen Ende des Puppenzustandes und durch die Umbildung ihrer während des Jugendzustandes (wie bei den Schmetterlingen) beissenden Mundtheile zu Schöpf- und Leckorganen. Während sich nämlich bei den Schmetterlingen die Unterkiefer zu hornigen Halbrinnen gestalten, die sich zu einem aufrollbaren Saugrohr zusammenlegen, bilden sich bei den Frühlingsfliegen die Mundtheile durch Verschmelzung von Unterkiefer und Unterlippe zu einer rinnenförmigen Schnauze, die Flüssigkeiten nur schöpfen oder lecken kann. Dagegen finden sich die beiden, den Lepidopteren eigenthümlichen, die Wurzel der Vorderflügel bedeckenden Anhänge (Schulterdecken, tegulae) in unvollkommener Entwickelung auch schon bei den Phryganiden, und das Flügelgeäder der letzteren, welches man bei oberflächlicher Betrachtung auch als einen durchgreifenden Unterschied derselben von den Lepidopteren hätte geltend machen können, beweist ja, wie aus den vorliegenden Beobachtungen meines Bruders hervorgeht, die Abstammung der Schmetterlinge von den Frühlingsfliegen oder nahen Verwandten derselben gerade in der unzweideutigsten Weise.

Als den Frühlingsfliegen noch am nächsten stehende Schmetterlinge sind nach Speyer Psychiden, Tineinen, Hepialiden und besonders Mikropteryginen, als am weitesten von ihnen entfernte die Tagfalter $z u$ betrachten.

Lippstadt, Januar I 879 .

Herm. M üı1ler. 
2. Die Flügeladern der Phryganiden und der Schmetterlinge.

Auf die nahe Verwandtschaft der Haarflügler (Trichoptera) oder Frühlingsfliegen (Phryganiden) und der Schmetterlinge ist schon - selbst in vordarwinischer Zeit, che noch dabei an wirkliche Verwandtschaft gedacht wurde - vielfach hingewiesen worden.

In neuerer Zeit hat mein Bruder Hermann Müller die Xbstammung der Schmetterlinge von den Haarflüglern zu begründen versucht, besonders aber ist die nahe Verwandtschaft dieser beiden Gruppen aufs Entschiedenste betont worden einerseits ron einem bewährten Meister der Schmetterlingskunde, Dr. A. S p e y er, dessen Abhandlung "Zur Genealogie der Schmetterlinge“ (in der Stettiner entomologischen Zeitung ron 1869) das Beste ist, was bis jetzt über diesen (regenstand gesehrieben wurde, andererseits von dem eifrigsten Forscher auf dem Gebiete der Haarflügler, Mr. R. Mac Lachlan ${ }^{1}$ ).

Mac Lachlan bemerkt, dass dic Anordnung des Flügelgeäders durchaus nicht unverträglich sei mit einer solchen nahen Verwandtschaft, und Dr. S peyer hebt hervor, dass zwischen dem Flügelgeäder gewisser Hepialiden und Cossiden unter den Schmetterlingen und dem ron Ptilocolepus und Rhyacophila unter den Haarflügeln ,nicht nur Uebereinstimmung in den wesentlichsten Punkten, sondern eine bis in Detail gehende Aehnlichkeit stattfindet." Beide aber unterlassen es, diese Uebereinstimmung des Flügelgeäders im Einzelnen nachzuweisen. Ich will versuchen, dies nachzuholen und dadurch für die Zusammengehörigkeit der beiden Gruppen einen neuen Bewcis liefern.

Im ersten Bande des „Kosmos“ (S. 390)²) findet sich das Flügelgeäder von zwei jungen Schmetterlingspuppen abgebildet. Von dem der fertigen Schmetterlinge unterscheidet es sich dadurch, dass r) alle Qucradern noch vollständig fehlen, dagegen 2) verschiedene Längsadern, die später mehr oder weniger vollständig schwinden, noch in ganzer Länge vorhanden sind. Nach Haeckel's ,biogenetischem Grundgesetze" darf man in diesem Puppengeäder einen ursprünglichen Zustand erblicken. Dies giebt einen einfachen Weg an die Hand zur Vergleichung des Flügelgeäders der Schmetterlinge und Haarflügler. Man wähle einen Schmetterling mit möglichst unverstümmelten Längsadern und zeichne das Geäder mit I Jinweglassung aller Queradern.

Von Haarflüglern habe ich zu diesem Behufe gleich den ersten in Kole11 ati's Monographie zur Erläuterung des (ieäders abgebildeten Oberflügel genommen (von Glyphidotaulius umbraculum Kol.), von den Schmetterlingen den

I) In England pflegt man dic Haarflügler als besonderc Ordnung zu betrachten, in Dcutschland reiht man sie als Familie der Phryganiden den Netzflüglern ein und stellt diese Ordnung und die Schmetterlinge meist so ziemlich an die entgegengesetzten Enden der Insektcnklasse. In Bezug auf diese $\Lambda$ nordnung untcrschreibe ich, was Mac Lachlan sagt: „Ich erhcbc nachdriicklichen Protest gegen eine so weite Trennung der beiden Geschlechter, in Anbetracht, dass, welches auch das Verhältniss der Haarflügler zu den anderen Linné'schen Gruppen der Netzflügler sein mag, ihrc Verwandtschaft zu den Schmetterlingen eine nahe ist, und dass ein Versuch, sie so weit von einander zu entternen, eine Beleidigung für Beide ist (Linnean Soc. Journ. Zool. Vol. XI. p. I00).

2) Ges. Schriften S. 587 , 
im „Kosmos“ (Bd. I, S. 389) ${ }^{\text {) }}$ dargestellten Oberflügel der Castnia Ardalus. Ausser den Queradern sind auch die Innenrandsadern weggelassen.

Man erkennt sofort die vollständige Uebereinstimmung in Zahl und Verästelung der Adern. Dem Vorderrande zunächst eine einfache-Ader (sc) (Subcosta der Haarflügler, Costalis der Schmetterlinge). Dann ein Stamm (Subcostalis der Schmetterlinge), der sich in zwei Aeste spaltet, einen vorderen einfachen $(r s c)$ (ramus radii subcostalis der Haarflügler, erster Ast der Subcostalis bei den Schmetterlingen genannt), und einen hinteren, zweimal gabelig gespaltenen $(r d)$ (ramus radii discoidalis der Haarflügler, 2. bis 5. Ast der Subcostalis bei den Schmetterlingen). Dann folgt eine dritte Hauptider $(r t h)$, die sich in einen vor-
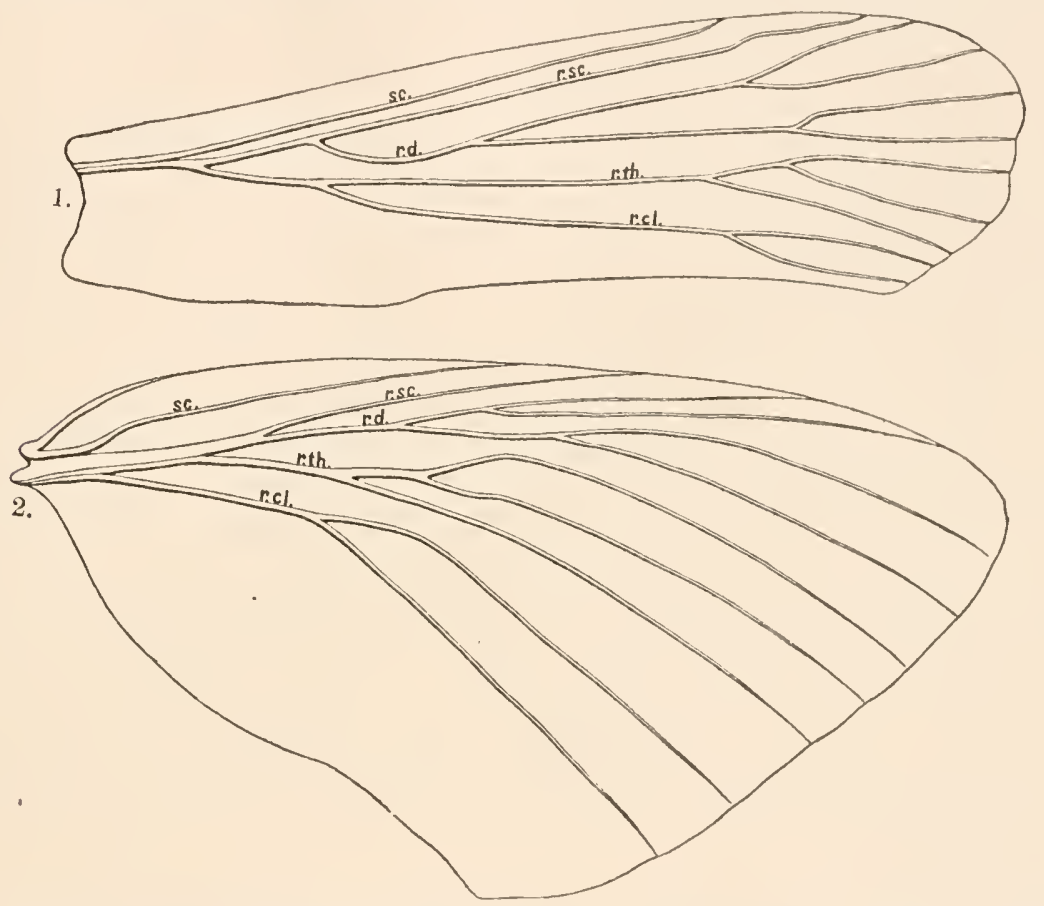

I. Vorderflügel von Glyphidotaulius umbraculum Kol. (Nach Kolenati, Gener. et spec. Trichopt. pars I. 18.48. Tab. I. Fig. I A). S. 586.$)$

2. Vorderflïgel von Castnia Ardalus Dalm. (Nach „Kosmos“, Bd. I. 1877. S. $389=$ Ges. Schriften

In beiden Flügeln sind die Innenrandsadern und Queradern weggelassen.

deren gegabelten und hinteren einfachen Ast spaltet (ramus thyrifer der Haarflügler, bei den Schmetterlingen heissen die beiden Aeste der Gabel Discoidalrippen, der einfache hintere Ast wird als dritter Ast der Mediana bezeichnet; doch hatte mich schon das Puppengeäder von Siderone Ide gelehrt, dass er zur Discoidalis gehört). Endlich ein vierter Hauptast $(r c l)$ mit zwei Endzweigen (ramus clavalis der Haarflügler, Mediana oder Subdorsalis der Schmetterlinge).

Dass nicht jeder beliebige Schmetterling, mit jedem beliebigen Haarflügler verglichen, eine so vollständige, so auf den ersten Blick erkennbare Uebereinstimmung zeigt, bedarf wohl kaum besonderer Erwähnung. Doch sind in der

I) Ges. Schriften S. 580 . 
Regel etwaige Abweichungen unschwrer auf die hior dargestellte Grundform zurückzuführen. Umgekehrt aber steht auch Castnia keineswegs unter allen Schmetterlingen in ihrem Flügelbaue den Haarflüglern am nächsten. Weit enger schliesst sich diesen Hepialus an in der Gestalt der Flügel, in dem Vorhandensein einer Querader, welche nahe der Flügelwurzel bei den Haarflüglern Costa und Subcosta verbindet, sowie eines häutigen Anhanges am Innenrande der Flügelwurzel, besonders aber dadurch. dass die Hinterflügel denselben Aderlauf wie die Vorderflügel zeigen, während bei Castnia und den meisten anderen Schmetterlingen, statt der elf in den vorstehenden Figuren gezeichneten Adern der Vorderflügel, die Hinterflügel ${ }^{1}$ ) nur sieben besitzen.

Itajahy, September 1878 .

\section{Wasserthiere in den Wipfeln des Waldes.}

An einem heissen Sommertage stand ich - vor mehr als 25 Jahren - mit einem Freunde unter einem Urwaldsbaume, gegen dessen eisenharten Stamm wir unsere Aexte wohl schon eine Stunde lang schwangen. Dieser Arbeit noch wenig gewohnt, begannen meine Arme zu erlahmen, und einen Augenblick ausruhend, liessen wir die lexte sinken. Da, horch, fallen rings um uns schwere Tropfen nieder aus der hohen Krone des Baumes. „Der Baum fängt an zu weinen“, rief mein Freund, „er kommt!" Und kaum hatte er noch einige wichtige Hiebe geführt, da begann auch, unter lautem Aechzen, der stolze Stamm sich langsam doch sichtlich zu neigen und in beschleunigtem Falle schmetterte er krachend zur Erde. - Wie manches Mal habe ich seit jenem Tage die Thränen aufathmend begrüsst, mit denen ein Urwaldriese seinen nahen Fall beweinte!

Die Aeste fast aller grösseren Bäume sind hier reichlich bewachsen mit ananasähnlichen Pflanzen (Bromeliaceen), zwischen deren stachlichen, am frunde oft bauchigen Blättern das Regenwasser sich sammelt. Sind diese nie völlig̣ trockenen WVasserbchälter bis zum Rande gefüllt, so giebt ihr Ueberfliessen die erste Kunde von dem sonst noch unmerklichen Weichen des Baumes aus seiner Gleichgewichtslage.

Ausser dem Wasser sammeln sich zwischen den Blättern der Bromelien dürres Laub, Holzstückchen, Blüthen, Früchte, Samen, die hineinfallen oder von Wind oder Vögeln hineingetragen werden. Vermodernd mögen sie zur Ernährung der Bromelien beitragen. Es sammelt sich ferner, theils zwischen den stachligen Blättern Schutz, theils zwischen jenen pflanzlichen Abfällen Nahrung suchend, eine ziemlich mannigfaltige Gesellschaft von Thieren. - Ausserhalb des WVassers Asseln, Tausendfüsse, Spinnen, Ameisen (namentlich verschiedene Poneriden), Landplanarien u. s. w. - Im Wasser Käfer. Blutegel (eine der deutschen

I) Die Herren Insektenbeschreiber, die bereits hunderte von Bänden mit unnützem Ballast gefüllt haben, haben nicht nur in jeder Insektengruppe eine eigene Namengebung für die Adern unh Zellen der Flügel eingeführt, sie haben bisweilen sogar bei Vorder- und Hinterflïgel derselben Thiere entsprechende Adern mit verschiedenen, verschiedene mit gleichen Namen belegt. So bei 'den Haarflüglern. Der ramus thyrifer der Vorderflügel heisst bei $\mathrm{Kolen}$ a ti ramus subdiscoidalis im Hinterflügel, der ramus clavalis der Vorderflügel heisst im Hinterflügel cubitus; diesen selben Namen cubitus führen im Vorderflügel die Innenrandsadern, welche im Hinterflïgel costulae genannt werden! 
Clepsine bioculata ähnliche Art), kleine Frösche und deren Kaulquappen, sowie verschiedene Larven von Fliegen, von Wasserjungfern und anderen Kerfen 1).

$\mathrm{Zu}$ diesen seit Jahren mir bekannten Bewohnern der Bromelien habe ich heute einen recht merkwürdigen neuen gefunden, der mich besonders deshalb erfreute, weil ich ausdrücklich ausgezogen war, ihn $z u$ suchen $\left.{ }^{2}\right)$. Es begegnet einem nicht oft, dass man sich vorsetzt, ein bestimmtes unbekanntes Thier zu entdecken und es wirklich auch entdeckt. Seit Monaten hatte ich unsere fliessenden und stehenden Gewässer eifrigst nach Larven von Frühlingsfliegen (Phryganiclen) durchsucht und etwa ein halbes Schock verschiedener Arten zusammengebracht. Da fiel mir ein: sollten nicht ebenso gut, wie Wasserjungfern, auch Phryganiden als Larven in dem Wasser der Bromelien leben können? Mit dem Waldmesser bewaffnet ging ich sofort in meinen Wald und hatte wohl kaum ein Dutzend Bromelien abgehauen und untersucht, als ich auf das erste ganz eigenartige Phryganidengehäuse stiess. Ich habe deren jetzt elf vor mir. -Man hätte sich eigentlich, was ich freilich nicht gethan, im Voraus sagen können, wie sie etwa aussehen würden. Sand und Steine, woraus unsere meisten Arten bauen, giebt es in den Wipfehn des Urwaldes nicht; nur dürres Laub steht da reichlich zur Verfügung. Ferner wäre die gewöhnliche drehrunde Form der Phryganidengehäuse höchst unbequem gewesen in den engen Räumen, zwischen breiten, ziemlich dicht aneinander liegenden Blättern, ganz ebenso wie unter Baumrinde, wo daher vorwiegend flach gedrückte Thiere hausen. So sind denn die bis $15 \mathrm{~mm}$ langen, $4 \mathrm{~mm}$ breiten Gehäuse nicht drehrund, sondern kaum halb so hoch als breit, mit scharfen Seitenkanten, so dass der Querschnitt, wie der einer Linse, von zwei ziemlich gleich gewölbten Bogen gebildet wird. Die Bauchseite des Gehäuses besteht meist aus fünf, die über die vordere Oeffnung vorspringende Rückenseite aus sechs Blattstückchen, von denen jedes mit einem Hinterrande den Vorderrand des vorhergehenden deckt. Am hinteren Ende liegen Rücken- und Bauchwand dicht aneinander.

Was ich für mehrere andere Bewohner der Bromelien nur vermuthe, glaube ich für diese Phryganidenlarve mit ziemlicher Sicherheit aussprechen zu können, dass sie nämlich in diesem Wasser über der Erde, in den Wipfeln der Bäume, ihren ausschliesslichen Wohnsitz habe, und ich glaubte aus diesem Grunde auf sie als ein der Beachtung werthes Thier aufmerksam machen zu dürfen. Denn nicht nur ist sie mir bị jetzt in unseren fliessenden und stehenden Gewässern nirgends begegnet, sondern es ist auch die Gestalt ihres Gehäuses dem eigenthümlichen Aufenthaltsorte trefflich angepasst. Sie hat in unseren Bächen und stehenden Gewässern einen nahen, ziemlich seltenen Verwandten, dessen in ähnlicher Weise aus Blättern gebautes Haus bedeutend grösser und minder regelmässig aus weniger zahlreichen Blattstücken zusammengefügt ist. Ich besitze ein solches Gehäuse von $4 \mathrm{~cm}$ Länge bei $6 \mathrm{~cm}^{3}$ ) Breite im Lichten, aus zwei oberen und zwei unteren Blattstücken bestehend, von denen eines $2 \mathrm{~cm}$ breit ist, also seitlich weit über den inneren Raum des Gehäuses hinausragt.

I) Anm. d. Red. Dass diese Natur-Aquarien sich zuweilen auch mit Blumen schmücken, die ihnen eigenthümlich sind, wurde in "Kosmos" (Bd. I. S. 8o) crwähnt.

2) Siehe Ges. Schriften S. 720.

3) Heisst wohl mm, s. auch Talel LIV, fig. 16. Der Herausgeber. 
Wenn einmal eine Phryganide mit solchen aus Blättern bauenden Larven zufällig ihre Eier in das Wasser der Bromelien absetzte, so konnte wohl hier ihre Brut weit leichter als die anderer Arten mit anderen Gewohnheiten sich erhalten und mit der Zeit den neuen Verhältnissen noch enger sich anpassen; für die meisten von unseren Arten, deren Larven nur in reinem, rasch fliessendem $\mathrm{II}^{\top}$ asser gedeihen, wäre eine solche Uebersiedelung unmöglich.

Wenn für die Puppen der Haarflügler die Stunde der Erlösung gekommen ist, durchnagen sie mit scharfen Kinnbacken den Verschluss ihres engen Gicfängnisses und schwimmen an die Oberfläche des Wassers, um hier oder auch ausserhalb des Wassers ihre Puppenhaut abzustreifen. Als Schwimmbeine dienen ihnen dabei hauptsächlich die Mittelbeine, deren Füsse mit einer Doppelreihe langer Wimpern besetzt sind; ähnlich sind bisweilen auch die Vorderbeine ausgerüstet, während die wimperlosen Hinterbeine beim Schwimmen unthätig dem Hinterleibe anliegen. Die Bewimperung der Beine ist bei verschiedenen Arten verschieden lang und dicht, über eine verschiedene Zahl von Fussgliedern ausgedehnt, fehlt aber, soviel mir bekannt keiner der in Bächen und Teichen lebenden Arten. Dagegen ist diese Ausrüstung zum Schwimmen den Bewohnern der Bromelien vollständig verloren gegangen; ihre Beine sind ganz wimperlos. Sie bedürfen des Schwimmens nicht, um an die Luft zu gelangen und hätten zwischen den einander umschliessenden Blättern der Bromelien nicht einmal Raum dazu.

Das Fortbestehen der Bewimperung ihrer Mittelbeine dürfte den Puppen der Bromelien-Bewohner kaum einen merklichen Nachtheil gebracht haben; ebensowenig scheint es wahrscheinlich, dass das Auftreten unbewimperter Beine durch die veränderten Lebensbedingungen hervorgerufen oder begünstigt worden sei. Auch bei anderen Haarflüglern dürften bisweilen, als Rückschlag in eine längst vergangene Zeit, unbewimperte Beine auftreten; allein bei ihnen müssen solche des Schwimmens unfähige Puppen zu Grunde gchen, ohne Nachkommen zu hinterlassen. In den Bromelien dagegen wirkt solchem Rückschlage keine Auslese entgegen und die unbewimperte Urform der Beine konnte auf diese Weise allmälig wieder zur Alleinherrschaft gelangen. Dass sie es gethan, ist ein Beweis dafür, dass die Puppen schon seit lange an Orten heimisch sind, wo der Mangel der Schwimmfähigkeit ihnen keinen Nachtheil brachte.

Noch ein zweiter Bewohner unserer Bromelien scheint besonderer Beachtung würdig, ein kleiner Laubfrosch, mit Füssen ohne Schwimmhaut. Er trägt nämlich, wie die berühmte Wabenkröte, seine verhältnissmässig sehr grossen Eier auf dem Rücken; bei einem solchen Fröschchen, welches ich lebend vor mir habe, füllen neun Eier die ganze Länge der Breite des Rückens von den Schultern bis zum Hinterende ${ }^{1}$.

Itajahy, September 1878 .

4. Die Grumicha ${ }^{2}$.

Unter dem Namen Grumicha hat A ug. Saint-Hilaire Larvengehäuse ciner Frühlingsfliege aus Flüssen Brasiliens beschrieben: Röhren aus hartem,

1) Siehe Ges. Schriften S. 776 .

2) Siehe Ges. Schriften S. 705, Tafel LIII, Fig. 8. 
hornähnlichem Stoffe, glatt, glänzend, schwarz wic Ebenholz, leichı gekrümmt und allmälig verjüngt, wie ein Horn. Solche Gehäuse kommen auch in den Zuflüssen des Itajahy vor, wo diese in steinigem Bette rasch dahinfliessen, uncl zwar zwei Arten, eine kleinere, nur 8 bis $10 \mathrm{~mm}$ lang, wurde erst in einem einzigen kleinen Bergbache getroffen (Affenwinkel in Blumenau); eine grössere, zwei- bis dreimal so lang, lebt stellenweise häufig in grösseren Bächen (Garcia, Warnow, Neisse).

Die Röhren dieser grösseren und häufigeren Art erreichen beim Männchen (Fig. I A) meist 17-20, beim Weibchen (Fig. I B) 25-30 mm länge. Zur Verpuppung heftet dic Larve ihre Röhre an einen Strin oder an andere schon festsitzende Röhren und zwar mittelst einer kurzgestielten Scheibe. Die Larven lieben sich gesellig festzusetzen und man findet nicht selten mehr als hunclert Röhren an einander gekittet. Dicht hinter dem Eingange wird die Röhre durch einen Deckel geschlossen. Deckel, Haftscheibe und deren Stiel bestehen aus

I. Zur Verpuppung angeheftete Grumicharöhren, nat. Grösse. $A$ eines Männchens, $B$ eines Weibchens. - 2. Deckel der Röhre eines Männchens. - 3. Deckel der Röhre eines Weibchens. - 4. Querwand am Hinterende der Röhre eines Weibchens.

Fig. 2-4 achtmal vergrössert.
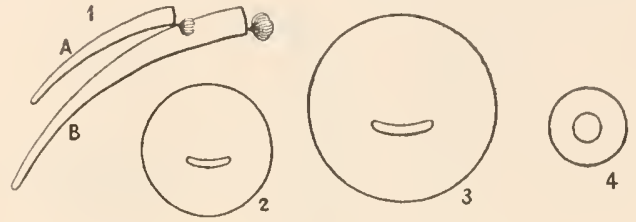

demselben Stoffe, wie das Gehäuse; ganz ähnliche Haftscheiben, Stiele und Deckel werden auch von anderen verwandten Larven gefertigt, die ihre Röhren aus Steinen aufbauen; bei Letzteren hat wohl noch Niemand in Zweifel gezogen, dass der Stoff dazu von den Spinndrüsen der Larve geliefert wird; dasselbe wird also auch für diese Gebilde bei der Grumicha gelten, und ebenso für deren ganze Röhre, die ja aus demselben Stoffe besteht.

Etwas unter seiner Mitte, also der Bauchseite der Röhre näher, hat der Deckel (Fig. 2, 3) eine schmale, quere, gerade oder häufiger letıvas gebogene Oeffnung. Eine zweite kreisförmige Oeffnung findet sich in der Mitte der Querwand (Fig. 4), die schon vor dem Festsetzen das hintere Ende der Röhre schliesst. Diese beiden Oeffnungen ermöglichen den für die Athmung der Puppe nöthigen Wasserwechsel. Nach Ablauf der Puppenzeit schneidet die Puppe mit ihren scharfen Kinnbacken den Deckel ringsum los, verlässt gegen Abend ihre Röhre und streift ausserhalb des Wassers ihre Puppenhaut ab, um als graue unscheinbare Motte der Liebe nachzugehen.

An den von der Puppe selbst abgelösten Deckeln lässt sich nun selır bequem deren spaltförmige Oeffnung messen und es ergiebt sich dabei, dass die Grösse dieser Oeffnung so genau, als man es eben messen kann, übereinstimmt mit derjenigen der hinteren kreisförmigen Oeffnung der Röhre. Letztere hat bei den grösseren weiblichen Puppen durchschnittlich 1/3 mm Durchmesser, ihre Grösse ist also $\frac{\pi}{36}=0,08$; qmm. - Für die vordere Oeffnung wird man ohne erheblichen Fehler die Grösse dem Produkt aus Länge und Breite gleichsetzen dürfen; als Mittelwerth von 17 ohne Wahl gesammelten Deckeln weiblicher Puppen ergab sich auf cliesem Wege o,os 5 qmm. 
Das wäre nun wieder, wie beim Wabenbau der Bienen, eine Gelegenheit, das unberusste Hellsehen des Instinktes oder das mathematische Genie des kleinen Baumeisters zu bewundern, der trotz so abweichender Gestalt beiden Oeffnungen gleiche Grösse zu geben weiss. Im Grunde mag aber die Sache ziemlich einfach sein; es wird ja der Larve nur zugemuthet, dass sie zu unterscheiden wisse, wann sie von einem gleichmässigen Wasserstrome gebadet wird. Ist eine der Oeffnungen kleiner, so fliesst durch sie das Wasser schneller und nach ihr zu ist der Wasserstrom im Innern der Röhre beschleunigt oder von ihr weg verlangsamt, je nachdem sie Aus- oder Eingangsöffnung ist.

Unter Tausenden festsitzender Grumicha-Gehäuse, die ich gesehen - man hebt bisweilen Hunderte an einem einzigen Steine aus dem Wasser - - habe ich einige wenige getroffen, die nicht durch einen hornigen Deckel, sondern durch ein quervorliegendes Steinchen geschlossen waren. Dieser Tage hatte ich zwei dieser Röhren mit heimgenommen. Nach Entfernung des Steinchens zog ich aus ihnen Puppen hervor, die nicht nur der Art, sondern sogar der Gattung nach von denen der Grumicha verschieden waren. Bei Grumichapuppen überragen z. B. die Fühler, selbst der Männchen, nur wenig den Hinterleib; jede Schiene trägt am Ende zwei, in Länge wenig verschiedene Spornen. Die Puppen der beiden Röhren mit Steinverschluss hatten Fühler von mehrfacher Körperlänge; Vorder- und Mittelschienen hatten je zwei Spornen, aber von sehr ungleicher länge; die Hinterschienen hatten ausser den beiden Endspornen auch noch Mittelspornen, - anderer Unterschiede nicht zu gedenken.

Der im ersten Augenblicke befremdliche Fund erinnerte mich an die Bienen (Trigona limào) und Termiten (Eutermes inquilinus), die, statt selbst zu bauen, die Bauten ihrer Verwandten sich zu Nutze machen. Warum sollten nicht auch die prächtigen Grumicharöhren, die ja nach dem Ausschlüpfen der ursprünglichen Bewohner hier und da in Menge zu haben sind, ihre Liebhaber finden? Es scheint übrigens der fremde Gast keine besondere, ausschliesslich die Grumicharöhren bewohnende Art. sondern nicht verschieden zu sein von einer hier ziemlich häufigen Larve, die für gewöhnlich ein passendes Stück eines hohlen oder weichmarkigen, leicht auszuhöhlenden Aestchens als Wohnung benutzt. - Auch bei den Gehäusen der Haarflügler also darf man nicht immer ohne Weiteres den Inhaber als Erbauer ansehen.

Itajahy, Oktober 1878 .

5. Helicopsyche ${ }^{1}$ ).

Bei Erörterungen über die Verwandtschaft der Haarflügler (Trichoptera. Phryganiden, Frühlingsfliegen, Sclmetterlingsfliegen) mit den Schmetterlingen pflegt in erster Reihe der ähnlichen Entwickelungsweise und des Umstandes gedacht zu werden, dass fast alle Larven der einen und einige wenige der anderen Gruppe sich tragbare Gehäuse bauen. „Die Larven der Phryganiden“, sagt z. B. Dr. A. Speyer (Zur Generalogie der Schmetterlinge), „wohnen grösstentheils, die der Schmetterlinge wenigstens theilweise in tragbaren, mit anorganischen, vegetabilischen oder animalischen Stoffen und allerlei Abfällen bekleideten, selbst ver-

I) Siehe Gies. Schriften S. 721 . 
fertigten, röhrigen Hülsen, aus denen nur die Brustfüsse zum Kriechen vorgestreckt werden, während sich das Ende des Körpers durch Nachschieber oder Häkchen an die Röhre anklammert. Sie verpuppen sich in diesen Wohnungen, welche bei manchen Arten beider Gruppen eine ungemeine Aehnlichkeit zeigen, bei beiden nach den Arten charakteristisch verschieden gebaut sind. Die bei den Insekten so auffällige Form des gewundenen Schneckenhauses wiederholt sich bei Schmetterlingen, wie bei Phryganiden (Psyche helix, Helicopsyche)."

$\mathrm{Ob}$ wirklich das Bauen tragbarer Gehäuse eine von den gemeinsamen Vorfahren der ohne Frage nahe verwandten Haarflügler und Schmetterlinge ererbte Gewohnhelt sei, scheint mir noch nicht über allen Zweifel erhaben zu sein, ausser Zweifel aber, dass die überraschende Aehnlichkeit einzelner Gehäuse aus beiden Gruppen nicht eine ererbte, sondern eine später erworbene ist, dass z. B, die auffallende Form des gewundenen Schneckenhauses nicht auf engere verwandtschaftliche Beziehungen zwischen Psyche helix und Helicopsyche hinweist.
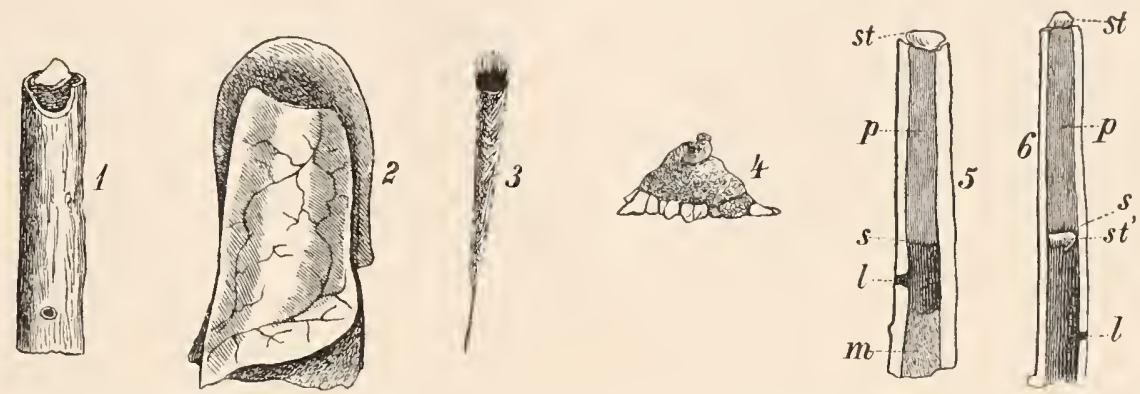

1-3. Gehäuse verschiedener Haarflügler, nat. Grösse, von der Bauchseite. - 4. Helicopsychegehäuse mit vier Schneckenwindungen und schornsteinartig emporstehendem, ungewundenem Afterende; 3 mal vergrössert. - 5, 6 Holzröhren von Puppen (von Macronema?) bewohnt, der Länge nach durchgeschnitten, nat. Grösse. - st, st' Steinchen, zum Verschluss der Röhren. - $p$ Puppenhülle, aus Seide gesponnen. $-s$ Siebförmige hintere Querwand der Puppenhülle. - l Loch durch die Wand der Röhre, unentbehrlich, wenn dieselbe (Fig. $5 \mathrm{~m}$ ) hinten durch das Mark des Zweiges geschlossen, überflüssig, wenn dieselbe (Fig. 6) hinten offen ist ${ }^{1}$.

Die Aehnlichkeit dieser Larvengehäuse mit wirklichen Schneckenhäusern ist in manchen Fällen so täuschend, dass man sie mehrfach als solche beschrieben (z. B. Valvata arenifera Lea und V. lustrica Say), und dass Swainson für sie eine eigene Schneckengattung, Thelidomus, gebildet hat, — so täuschend, dass man sie als Nachahmung von Schneckenhäusern, als einen Fall von Mimicry zu betrachten versucht ist. $\mathrm{Ob}$ dies etwa für Psyche helix zutrifft, deren Vorkommen und Lebensweise ich nicht kenne, ob diese in ihrer Schneckenähnlichkeit Schutz gegen Feinde findet, weiss ich nicht. Für Helicopsyche ist eine solche Erklärung ihrer Schneckenform bestimmt abzuweisen; hier, wo diese Thiere in mehreren Arten ungemein hüufig sind, leben sie nie in Gesellschaft von Schecken; überhaupt sind mir hier keine Schnecken bekannt, die den Helicopsychen in Grösse und Gestalt ähnlich wären. Welches mag also wohl der Ursprung der Schneckenform der Helicopsychengehäuse, ja der Schneckenform überhaupt sein?

I) Vergl. auch Ges. Schriften, Tafe] LIII und LIV. 
Die Gehäuse verschiedener Haarflüglerlarven zeigen Vorrichtungen, durch welche, wenn das Thier Nahrung suchend umherkriecht, das vorgestreckte Kopfende von oben gedeckt, möglichst den Blicken und Angriffen etwaiger Feinde entzogen wird. Hagen's Abhandlung ${ }^{1}$ ) „über Phryganiden-Gehäuse“ bietet mehrfache Beispiele; mehrere andere habe ich hier kennen gelernt. Die Larven einer durch Fühler von drei- bis vierfacher Körperlänge ausgezeichneten Art (Macronema?) richten sich hohle oder von ihnen ausgehöhlte Stücke dünner Zweige (Fig. 1) dadurch zur Wohnung her, dass sie von der als Bauchseite benutzten Wand des Einganges ein halbkreisförmiges Stück herausnagen und unter der nun dachartig vorspringenden Rückenwand ein Steinchen beweglich anspinnen, welches als Deckel den Eingang schliesst, wenn sie sich zurückziehen, und auch, wenn sie hervorkommen, den Kopf von vorn und oben schützen hilft. - Einige Arten aus der Familie der Leptoceriden (= Mystaciden), darunter auch die Bewohner der Bromelien, bauen ihr Haus aus Blattstücken (Fig. 2), von denen eine nach den Arten wechselnde Zahl die Bauchseite, eben so viel oder eins melnr die Rückenseite bilden. Das vorderste Blattstück des Rückens springt dachartig weit über den Eingang des Hauses ror. - Eine andere Leptoceridenlarve bekleidet ihr kegelförmiges Gehäuse (Fig. 3) mit schmalen Holzstückchen, die auf dem Rücken der Länge nach, an den Seiten schief von vorn und oben nach hinten und unten gelagert sind; auch bei ihr springt die Rückenwand des Einganges weit über die Bauchwand vor, und ausserdem wird noch der Vorderrand des Rückens von etwa einem halben Dutzend schützend sich über den Eingang vorstreckender Hölzchen überragt. - Besser noch als eine gerade vorspringende, würde eine gleichzeitig leicht abwärts gebogene Rückenwand den Eingang schützen; eine solche aber, falls sie nicht bei jedem Weiterbau abgebrochen und neugebaut werden sollte, müsste zu mehr oder weniger gebogenen Röhren führen, wie sie unter den Leptoceriden häufig vorkommen und endlich zu schneckenartig gewundenen Gehäusen.

Wie die schneckenförmigen Gehäuse der Helicopsychen unter den Haarflüglern, so stehen die regellos gebogenen Röhren der Wurmschnecken (Vermetiden) verreinzelt da unter den regelmässigen Schneckenhäusern ihrer Verwandten, und es ist eine hübsche Bestätigung von $\mathrm{H}$ a eckel's biogenetischem Grundgesetz, dass, wie manche von diesen (z. B. Magilus antiquus) bekanntlich ihr Haus regelmässig beginnen und dadurch ihre Abstammung von regelrechten Schnecken bekunden, so jene bisweilen noch einen ältesten ungewundenen Theil des Gehäuses erhalten zeigen (Fig. 4), der wie ein kleiner Schornstein emporragt und die Abstammung von Vorfahren beweist, die noch ungewundene Röhren bauten.

Itajahy, December 1878 .

6. Gedankenlose Gew ohnheit.

Wem wäre es nicht schon begegnet, dass er eine Handlung, die er bei bestimmtem Anlasse anzuführen sich gewöhnt hat, gedankenlos auch in Fällen ausgeführt, wo dieselbe völlig zwecklos, oder selbst zweckwidrig war? Dass es mit

1) Stettin. Ent. Zeit. 1864. XXV. S. 113 und 221. 
den ererbten Gewohnheiten der Thiere, dem nach $\mathrm{H}$ artman n unfehlbaren Instinkte, nicht anders ist, dafür giebt die eben erwähnte, in Holzröhren (Fig. 5) lebende Larve (von Macronema?) ein recht schlagendes Beispiel.

In Zweigen, die sie sich selbst aushöhlt (Fig. 5) - es ist das der häufigere Fall - richtet sie sich für die Verpuppung in folgender Weise ein: Durch die Wand der hinten durch das Mark $(m)$ des Ziveiges geschlossenen Höhle nagt sie von innen her ein kleines Loch $(l)$; den Eingang verschliesst sie durch einen Stein (st); dann spinnt sie eine dünne, die Innenwand der Röhre überkleidende seidene Puppenhülle $(p)$; die vordere Querwand dieser Puppenhülle überzieht und hält den Stein des Eingangs; zwischen Stein und Röhrenwand ist die Puppenhülle siebartig durchlöchert, und ebenso bildet die hintere Querwand ein Sieb $(s)$. Die so eingeschlossene Larve oder spätere Puppe unterhält nun behufs der Athmung einen beständigen Wasserstrom durch ihr Haus; derselbe tritt durch das vordere Sieb ein, durch das hintere Sieb aus der Puppenhülle in den hinteren Raum der Höhle und aus diesem durch das seitliche Loch nach aussen. Dieses Loch ist also von höchster Wichtigkeit für den Inhaber der Röhre. - Ergreift die larve von einem hohlen Zweige Besitz (Fig. 6), so sichert sie sich auch hinten gegen feindliche Angriffe durch einen Stein (st'); diesen bringt sie entweder am Ende des Zweiges an, oder wie es scheint, häufiger) im Innern des Zweiges, dicht am hintern Siebe der Puppenhülle. Nun, auch in diesem Falle unterlässt sie nicht, durch die Wand der hinten offenen Röhre gewohnheitsgemäss das völlig nutzlose, übliche I.och (Fig. 6, l) zu nagen.

Itajahy, December 1878 . 


\section{Ueber Phryganiden ${ }^{1}$ ).}

\section{Aus Briefen an Hermann Müller in Lippstadt.}

Blumenau, i8. Nov. i 878 .

Von Phryganidenlarven habe ich neuerdings wieder mehrere neue gefunden. Besonders reich an eigenthümlich gestalteten Larvengehäusen scheint hier die Gruppe der Hydroptiliden zu sein; Hagen kannte (Stettin. Ent., Zeit., I864) nur 4 hierher gehörige Gehäuse. Ich habe schon 9 gefunden, die man in 6 ganz verschiedene Gattungen bringen müsste:

I. Muschelähnliche Gehäuse, vorn und hinten mit engem, spaltförmigen Eingang (wie Hydroptila). Sie werden auf der scharfen Kante getragen. (Besonders muschelähnlich sehen sie aus, wenn sie aus stabförmigen Diatomeen gebaut sind, die dann gleichsam Anwachsstreifen bilden.)

I) Ober- und Unterrand gleichlaufend, fast gerade; aussen mit feinem Sande bekleidet. Larven mit 3 Schwanzkiemen.

2) Von ähnlicher Gestalt, aber aus Algen oder Diatomeen gebaut. Larve kiemenlos.

3) Rückenkante stark gewölbt, Gehäuse ohne fremde Stoffe gebaut.

II. Gehäuse aus Diatomeen, seitlich zusammengedrückt, vorn und hinten mit schmalem Spalt, auf der Rückenkante mit 2 Schornsteinen (ich nenne sie einstweilen Diraminus). Zur Verpuppung werden sie aufrecht festgeheftet und es stehen bisweilen ganze Dörfer dieser Häuser auf den Steinen. Der Nutzen der Schornsteine ist offenbar, dem zum Athmen nöthigen Wasser freieren Zutritt zu gewähren. Die Larven in den Muschelhäuschen, die solcher Röhren entbehren, sieht man fast beständig in ihrem Hause lebhafte schlängelnde Bewegungen mit dem Hinterleibe machen, - jedenfalls zur Herbeiführung frischen Wassers. Die Dicaminuslarven thun dies niemals.

III. Fast walzenförmig, aussen mit feinem Sande bekleidet. Winzige Röhren, nur $2 \mathrm{~mm}$ lang, bei etwa $0,5 \mathrm{~mm}$ Durchmesser.

IV. An beweglichem Stiele festsitzende Gehäuse.

V. Schildförmige, ringsum befestigte Gehäuse, einer Eierhülse ron Nephelis ähnlich, an jedem Ende mit einem kleinen Loch. Endlich:

1) Zonlog. Anzeiger 1879. 2. Jahrg. S. 38-40. 
VI. Flaschenförmige Gehäuse (lagenopsyche nov. gen.). Diese sind besonders morkwürdig. Von fast allen bekannten Hydroptilidengehäusen, deren Vorder- und Hinterende gleich und gleichmässig zum Aus- und Einkriechen der Larve benutzt zu sein pflegt, unterscheidet sich das Gehäuse der Lagenopsyche durch die grosse Verschiedenheit der beiden Enden: vorn eine runde Oeffnung, hinten ein langer schmaler Spalt. - Alle übrigen Phryganiden sehen aus dem zuletzt gebauten weiteren Theile ihrer Röhren heraus, Jagenopsyche zum zuerst gebauten Ilalse der Flasche. - Auch für die veränderte Jage der Puppe im Gehäuse (für welche vorn, oben und unten ist, was für die Larve hinten, rechts und links war) kenne ich kein anderes Beispiel. - Die Imagine's pflegen in den ersten Nachmittagsstunden auszukriechen.

\section{Blumenau, I3. Oct. I878.}

Die Zahl der Arten von Phryganidengehäusen, die ich bis jetzt hier gefunden, beträgt etwa dreissig und ich bin eben dabei, einen durch Abbildungen erläuterten Bericht über dieselben für die Archivos unseres Museu nacional zu schreiben $\left.{ }^{1}\right)$.

\section{Blumenau, I. Nov. I878.}

$\mathrm{Zu}$ meiner Arbeit über Phryganidengehäuse habe ich die Abbildungen (3 Tafeln, dicht gefüllt) fertig. - Mit dem Texte hoffe ich rasch zu Ende zu kommen und will dann an eine genauere Untersuchung der Larven gehen. Die Gehäuse habe ich von folgenden Arten abgebildet:

I-4. Rhyacophiliden, bewegliche Steinhäuschen. I. ohne grössere Oeffnung im Dach, 2. mit einer Oeffnung in der Mitte des Daches, ohne Schornstein, 3 u. 4. mit Schornstein.

5 u. 6. Hydropsychiden. 5. Grosse Hydropsychide, die ein sehr rohes Haus baut. 6. Rhyacophylax n. g., von deren wundervollem Bau ich Dir im letzten Briefe eine Photographie schickte.

7-i5. Leptoceriden. 7. Holzröhren, 8. und 9. Grumicha, ro. Grumichinha (d. h. kleine Grumicha), I I. Röhre aus Callitrichesamen, I2 u. I3. Nectopsyche n. g. (?), wovon ich Dir einige Röhren schicke. Die Larve schwi mmt, was, soviel mir bekannt, keine der bisher bekannten Phryganidenlarven kann. Die Hinterbeine sind langbewimperte Schwimmbeine. Das fertige Insect (ठ) ist cin prächtiges Thierchen; die Vorderflügel beschuppt (!), gelb, mit silbernen Querbinden und einigen grossen tiefschwarzen Flecken.

I 4 u. I5. Grössere und kleinere Röhren aus Steinchen.

I6-2I. Sericostomiden. I6. Gehäuse aus Blättern, i7. desgl., in Bromelien lebend, is $8-2 \mathrm{r}$. Helicopsychearten.

22-30. Hydroptiliden. 22. Winzige $2 \mathrm{~mm}$ lange Röhre, 23-25. denen von Hydroptila ähnliche Gehäuse mit Sand (23), Diatomeen (24), oder olne fremde Zuthat (25) gebaut.

26. Diaulus n. g. aus Diatomeen, mit 2 Schornsteinen.

27 u. 28. Lagenopsyche n. g., flaschenförmige Gehäuse.

29. Rhyacopsyche n. g. an beweglichem Stiele festsitzende Gehäuse.

I) Siehe Ges. Schriften S. 694. 
30. Peltopsyche n. g. Schildförmige, festsitzende, einer Nepheliseierhülse ähnliche Gehäuse, von denen es mir noch nicht ausser allem Zweifel ist, ob sie wirklich Hydroptiliden zugehören.

Phryganiden und Limnophiliden werden hier wohl fehlen.

Blumenau, 13. Jan. 1879\%).

Bei den Helicopsyche-Puppen unserer Bäche sind die vier ersten Fussglieder zweizeilig lang und dicht bewimpert an dem Mittel-, schwächer an dem Vorderfuss, wie eben bei anderen Phryganiden auch. Bei der Helicopsyche der W'asserfälle, die an feuchten Felswänden lebt, fehlt diese Bewimperung; ebenso bei einer kleinen an gleicher Stelle lebenden Hydropsychide. Dass auch die BromelienPhryganide dieser Schwimmhaare entbehrt, schrieb ich schon früher. - Diese Beispiele scheinen mir wichtig, weil sie recht schlagend zeigen, dass man die Verkümmerung nutzlos gewordener Theile nicht immer einfach und unmittelbar als Folge des Nichtgebrauchs betrachten kann. Durch Unthätigkeit erworbene Rückbildung mag allerdings schliesslich zu erblicher Verkümmerung führen und Aehnliches auch bei andern Theilen stattfinden. Allein die Schwimmhaare der Phryganidenpuppen stehen zur Zeit, wo sie in Thätigkeit treten, gar nicht mehr in lebendiger Verbindung mit dem Thiere; sie sitzen der Puppenhaut auf, die das zum Auskriechen reife Insect 1nse umhüllt; ob sie gebraucht werden oder nicht, kann ihre Entwickelung bei den Abkömmlingen des Insects in keiner Weise beeinflussen. Weshalb also schwinden sie so rasch, sobald eine Art von ihren nächsten Verwandten sich nach einem Orte entfernt, wo sie nicht schwimmen kann, während in anderen Fällen nutzlos gewordene Theile (z. B. die nicht durchbrechenden Zähne im Oberkiefer der Wiederkäuer) sich durch unermessliche Zeiträume forterben?

Die Nutzlosigkeit entzieht zunächst den betreffenden Theil der Wirkungder natürlichen Auslese; Thiere, bei denen der Theil weniger oder gar nicht entwickelt ist, werden nicht ausgemerzt. Allein vereinzelt auftretende Abänderungen haben ja, - den Schluss hätte Kramer leicht in kaum anfechtbarer Weise ziehen können, - nicht die mindeste Aussicht herrschend zu werden, im Gegentheil alle Aussicht, bald wieder spurlos zu verschwinden. Daher eben, wo kein andrer Grund für deren Verschwinden hinzutritt, das überraschend zähe Vererben nutzloser Bildungen. WVelches ist nun bei den Phryganiden dieser Grund, der das rasche Schwinden der nutzlos gewordenen Schwimmhaare bedingt? Möglicherweise könnte Stoffersparnis, wie es in manchen anderen Fällen fast zweifellos geschieht, auch hier mit in Betracht kommen. Weit wahrscheinlicher aber ist mir, dass das Verschwinden der Schwimmhaare wesentlich als Rückschlag aufzufassen ist (wie ich in den meinem vorigen Briefe beiliegenden Mittheilungen aussprach). Die Neigung zum Rückschlag, wie man sie sich auch körperlich begründet denken möge, ist ja wahrscheinlich allgemein verbreitet; sie wird im Zaume gehalten durch die natürliche Auslese; fällt diese weg, so wird die Zahl der dem Rückschlage verfallenden Thiere mit jeder Generation wachsen und rasch der jüngere, wieder nutzlos gewordene Erwerb, hier z. B. die Schwimmhaare, aufs Neue verloren gehen. Theile, die aus sehr alter Zeit stammen (Zähne der Säugethisre), werden kaum je durch Rückschlag bei einzelnen Individuen

1) Zoolog. Anzeiger 1879. 2. Jahrg. S. 180-182. 
fehlen, werden also auch, falls sie nutzlos werclen, wenigstens aus diesem Grunde, nicht leicht wieder verloren gehen.

Blumenau, I2. Febr. $1879 \%$.

Gerade zur rechten Zeit (ich war eben dabei, abgeworfene Puppenhäute verschiedener Phryganiden zu untersuchen und $z u$ zeichnen) traf hier ein treffliches Buch von Dr. Palmén aus Helsingfors ein: „Zur Morphologie des Tracheensystems". Derselbe weist nach, dass das Erhaltenbleiben der Tracheenkiemen bei der Imago von Pteronarcys regalis, das eine sonderbare Ausnahme zu bilden schien, allgemeine Regel ist für alle Perliden. Bei einer Art (No. 7 in Holzröhren lebend, Tetracentron?) konnte ich mich in der That sofort überzeugen, dass die Kiemen an der Purpenlaut ganz leer sind, also gehüutet, nicht abgeworfen werden, und fand clieselben auch bald darauf an einer frisch ausgekrochenen Imago. Bei einer anderen Art aber (No. 15. Steinröhren) werden die Kiemen der Puppen bei der Verwandlung abgeworfen, so dass also Palmén's Vermuthung sich nicht für alle Phryganiden bestätigt. - Diese Ueberbleibsel der Kiemen bei geflügelten Insecten (- dass sie auch bei Pteronarcys ganz functionslos sind, hat Hagen nach Benbachtung lebender Thiere ausgesprochen, -) ist höchst merkwürdig. Man hat also zweierlei „rudimentäre Organe" zu unterscheiden: 1. solche, welche erwachsenen Vorfahren nützlich waren und von diesen ererbt wurden; 2. solche, welche nie von erwachsenen Vorfahren in tauglichem Zustande besessen wurden, die viclmehr von Jugendzuständen erworben und von cliesen auf das erwachsene Thier übertragen wurden. - Ein zweites Beispiel der letzten Art bietet dieselbe Phryganide (No. 7, Tetracentron?). Auf dem Rücken des I Iinterleibs der Imago zeigt der Vorderrand cles III. bis VI. Ringes eigenthümliche Vorsprünge, die den übrigen Ringen fehlen; ausserdem finden sich zwei dunkle Chitimplättchen am Ende des V. Ringes. Es sind diese, der Imago jedenfalls ganz nutzlosen Vorsprünge und Plättchen Ueberbleibsel der auf dem Hinterleibsrücken der Puppe an den genannten Ringen entwickelten Zahnplatten, die gerade bei dieser Art sehr stark entwickelt sind. Diese den Puppen zum Vor- und Rückwärtskriechen in ihren Gehäusen dienenden Zähne sind in Zahl und Gestalt schr mannichfaltig und dürften gute Gattungsmerkmale geben.

Die Puppe einer unsrer Arten, einer Rhyacophilide, deren Larve frei zwischen dicht verflochtenen Podostomeen in Stromschnellen sich aufzuhalten liebt, hat an Vorder- und Mittelfüssen wohlentwickelte Fussklauen. Um zwischen dem Gewirr der Podostomeenzweige herauszukriechen, werden sie ihr sehr nützlich sein.

Nach dem Verhalten der Puppen dürften die Trichoptera naturgemäss in zwei Hauptabtheilungen zu bringen sein: die einen (Rhyacophiliden und Hydroptiliden) ruhen vollständig in rings geschlossenen Gespinusten; die Gespinnste oder Gehäuse aller anderen (I.eptoceriden, Sericostomiden, Hydropsychiden und wohl auch die hier fehlenden Limnophiliden und Phryganiden) haben an beiden Enden Oeffnungen, durch welche ein steter Wasserstrom hindurchgeht, unterhalten durch fortwährende Bewegungen der Puppe. Dieser Wasserstrom gibt, beiläufig bemerkt, ein treffliches Mittel, sich vom I,eben der Puppe zu überzeugen und rechtzeitig, ehe sie die ganze Gesellschaft verpesten, etwa gestorbene

I) Zoolog. Anzeiger 1879. 2. Jahrg. S. $283-284$. 
$\mathrm{zu}$ entfernen. Ehe ich diese regelmässige Aussonderung etwaiger Leichen vorzunehmen verstand, habe ich mich vergeblich bemüht, von verschiedenen gemeinen Arten Imagines zu erziehen.

\section{Blumenau, 6. April I879 ${ }^{1}$.}

An die London. Entomol. Society habe ich einen Bericht über unsre Phryganiden geschickt und darin auch auf eine Eintheilung dieser Ordnung hingewiesen, zu der mich die Beobachtung der lebenden Puppen geführt hat ${ }^{2}$. Entweder nämlich sind die Puppengehäuse an beiden Enden mit kleinen Oeffnungen versehen, durch welche die Puppe einen beständigen Wasserstrom unterhält, die Puppe ist also in steter Bewegung; oder die Puppe ist von einem rings geschlossenen Gespinnst umgeben, in welchem sie völlig bewegungslos ruht. Zu letzterer Abtheilung gehören die Rhyacophiliden (Gespinnst frei im Gehäuse) und Hydroptiliden (Gespinnst mit der Wand des Gehäuses verschmelzend), zur ersten Abtheilung die übrigen fünf Familien. Schon Eat on hat auf Grund des Baues der Imago die Hydroptiliden den Rhyacophiliden angereiht. - Schon früh haben wahrscheinlich die Trichoptera sich in diese beiden Hauptgruppen geschieden, von denen jede noch jetzt durch ziemlich ursprüngliche Formen vertreten ist, deren Larven frei leben, deren Kiefertaster in beiden Geschlechtern gleich gebildet sind und deren Flügelgeäder sich ebenfalls als der Urform nahe stehend ausweist (einerseits die Hydropsychiden, andererseits die Rhyacophiliden). Die typische Form der Gehäuse ist ebenfalls verschieden; die der ersten Abtheilung werden an dem sich erweiternden Mundende weitergebaut; bei der zweiten Abtheilung ist in der Regel kein Unterschied zwischen Vorder- und IIinterende; die Larve benutzt beide Oeffnungen gleichmässig als Thüren u. s. w.

Meine allerdings noch ganz provisorische Auffassung des Stammbaums der Trichoptera ist die beistehend dargestellte.

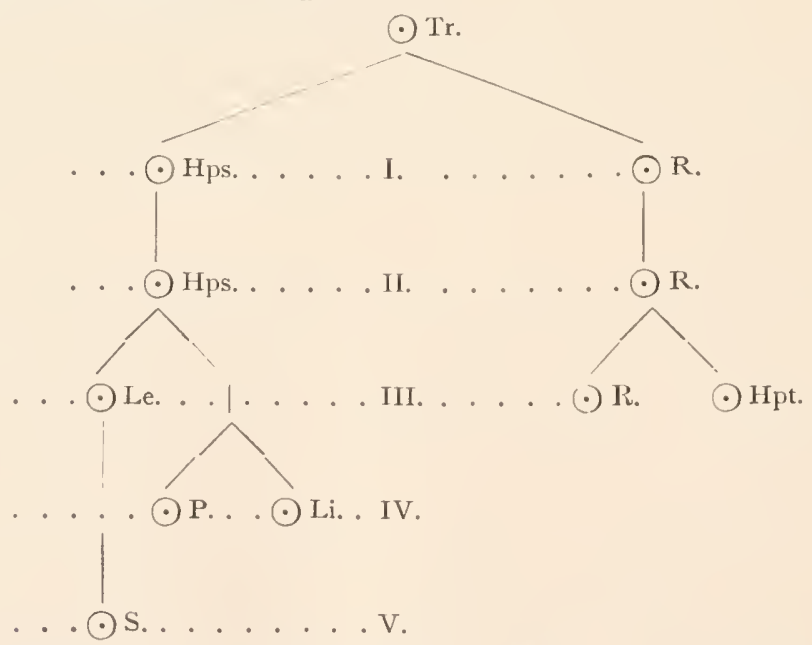

$\left(\operatorname{Tr} .=\right.$ Trichoptera, R. $=$ Rhyacophilidae, $\mathrm{Hpt}_{\mathrm{p}}=$ Hydroptilidae, Hps. $=\mathrm{Hy}_{\mathrm{-}}$ dropsychidae, Le. = Leptoceridae, Li. = Limnophilidae, P. = Phryganidae, S. = Sericostomidae.)

I) Zoolog. Anzeiger 1879. 2. Jahrg. S. 405-407.

2) Siehe Ges. Schriften S. 766 . 
Phyletische Stufen: I. Ohne Larvengehäuse (jetzt noch ein Theil der Rhyacophiliden und Hydropsychiden). II. Mit festsitzendem Larvengehäuse. III. Mit freiem Larvengehäuse, fünfgliedrigen Kiefertasten bei ơ und q. IV. Kiefertasterglieder weniger zahlreich beim $\delta$ als beim $q$, doch von gleicher Gestalt. V. Glieder Kiefertaster der $\delta$ in Zahl und Gestalt verschieden von denen der $q$.

Ich meine, ich habe Dir noch nicht von einer allerliebsten Einrichtung bei unsrer kleinen Grumicha geschrieben (es ist das beiläufig eine neue, Leptocerus sehr nahe stehcnde Gattung Grumichella m.). Sie befestigt nämlich nicht, wie die grosse Grumicha und andere Trichopteren, vor der Verpuppung ihre Gehäuse, sondern deren Deckel. Gewöhnlich sitzen die Gehäuse mit den Mundende nach oben an senkrechten Felsen, an denen eine dünne Wasserschicht niederfällt. Gegen dieses Wasser würden die Puppen nach Lösung des Deckels kaum aus dem festsitzenden Gehäuse auskriechen können, oder doch von demselben übel zugerichtet werden. So aber bleibt der Deckel am Felsen sitzen, wenn er von Gehäuse ringsum gelöst ist, und in letzterem wird die Puppe von dem stürzenden Wasser fortgerissen, um an einem ruhigeren Orte herauszukriechen und sich zu verwandeln. 


\section{Sobre as casas construidas pelas larvas de Insectos Trichopterenlarven der Trichopteros da provincia Provinz Santa Catharina de Sa. Catharina ${ }^{1}$. \\ Ueber die von den verfertigten Gehäuse').}

Mit Tafel LIII, LIV und LV.

Introducção.

A ordem dos insectos trichopteros é de subido interesse debaixo de dous pontos de vista distinctos: o genealogico e o biologico.

No systema genealogico dos insectos, os trichopteros occupam, em relação aos lepidopteros, a mesma posiçăo que, entre os mammiferos, como hoje quasi todos admittem, compete aos macacos antropomorphos em relaçăn an homem; é summamente provavel que os lepidopetros sejam descendentes de algum trichoptero extincto, ou ao menos que ambas as ordens se tenham originado e desenvolvido de um typo primitivo commum, do qual menos se tivessem afastado os modestos trichopteros, e muito mais os brilhantes lepidopteros. Ora, si este motivn, para se dar maxima importancia á pequena ordem dos trichopteros, é de data muito recente, ao contrario já em tempos remotissimos as casas ou estojos que as larvas desses in-

1) Archiv. do Museu Nacional do Rio de Janeiro 1878. vol. III. p. 99-I24. Est. VIII-X.

\section{Einleitung.}

Die Ordnung der Trichopteren ist unter zwei verschiedenen Gesichtspunkten von hohem Interesse: dem genealogischen und dem biologischen.

In dem genealogischen System der Insekten nehmen die Trichopteren in Bezug auf die Schmetterlinge dieselbe Stcllung ein, die unter den Säugethieren, nach der heute fast allgemeinen Annahme, den anthropomorphen Affen in Bezug auf den Menschen zukommt; es ist im höchsten Grade wahrscheinlich, dass die Schmetterlinge von irgend einen ausgestorbenen Trichopteron abstammen, oder wenigstens, dass beide Ordnungen aus einer gemeinsamen Stammform hervorgegangen sind, von der sich die unansehnlichen Trichopteren weniger, die farbenprächtigen Schmetterlinge viel weiter entfernt haben. Wenn nun dieser Grund, der kleinen Ordnung der Trichopteren cine grosse Wichtigkeit beizulegen, von sehr neuem Datum ist, so

I) Zeitschr. wiss. Zoologie 1880. Bd.35. S. 47-74 mit Taf. IV-V. Aus dem Portugiesischen übersetzt von dem Bruder des Verfassers, Dr. Hermamn Müller in Lippstadt. 
sectos construem haviam despertado vivo interesse ans que entào se entregavam ao estudo da biologia dos insectos. Na opiniào de varios auctores o xylophthoro ou

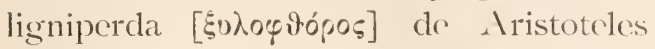
teria sido uma larva de Phryganea; todavia, comn elle se não refere á vida aquatica deste animal, é mais provavel que tiresse sido a larva de algum lepidoptero, do grupo das Psychideas talvez. Mas seja isso como fôr, o que é verdade é que os grandes observadores do seculo passado, a quem tanto deve a biologia dos insectos, Réaumur. De Geer e Roesel, fizeram tambem estudos muito importantes sobre a historia natural e a estructura dessas larvas de trichopteros, assim como de suas casas.

No seculo actual deram-sc a um estudo especial dos mesmos animaes, Pictet, Kolenati, Hagen, Mac Lachlan e outros. Entretanto, todos esses trabalhos ficaram quasi exclusivamente adstrictos á Europa, sendo ainda hoje a historia natural das especies extraeuropéas como que um terreno virgem e desconhecido á sciencia.

Em I 864, Hagen, publicou uma lista descriptiva de todas as casas de Trichopteros, de que tinha visto exemplares ou achado alguma noticia em outros auctores ${ }^{1}$ ); devendo notar-se que do vasto territorio do Brasil, só se acham mencionadas nesta lista de I5O especies a Grumicha de Saint Hilaire, e uma especie de Helicopsyche. Assim, pois, não será fóra de proposito dar uma breve noticia das especies que observei na provincia de Santa Catharina. Por mais deficiente e incompleta que seja

1) Hagen, Ueber Phryganiden-Gehäuse. Stettiner entomol. Zeitung. Bd. XX V. 1864. p. I 14 e p. 221. haben dagegen schon in sehr entfernten Zeiten die Gehäuse oder Futterale, die die Larven dieser Insekten bauen, das lebliafteste Inter'sse Derer erregt, die sich damals dem Studium der Biologie der Insekten hingaben. Nach der Meinung verschiedener Schriftsteller wäre der Holzverderber (\$0خopirópos) des Aristoteles eine Phryganidenlarve gewesen; doch ist es, da er nichts von der WasserI.ebensweise dieses Thieres erwähnt, wohl wahrscheinlicher, dass es die 1 arve irgend eines Schmetterlinges, vielleicht aus der Gruppe der Psychiden, gewesen sein mag. Dem sei aber wie ihm wolle, jedenfalls haben die grossen Beobachter des vergangenen Jahrhunderts, denen die Biologie der Insekten so viel verdankt, Réaumur, De Geer und Roesel, auch sehr wichtige Studien über die Naturgeschichte und den Bau der Trichopterenlarven, so wie ihrer Gehäuse gemacht.

Im gegenwärtigen Jahrhundert widmeten sich dem speciellen Studium dieser Tiere Pictet, Kolenati, Hagen, Mac Lachlan und Andere. Alle diese Arbeiten blieben indessen fast ausschliesslich auf Europa beschränkt, so dass die Naturgeschichte der aussereuropäischen Arten fast noch heute ein jungfräuliches und der Wissenschaft unbekanntes Gebiet ist.

Im Jahre I 864 veröffentlichte Hagen ein Verzeichniss nebst Beschreibungen aller Trichopteren-Gehäuse, von denen er Exemplare gesehen oder über die er bei anderen Schriftstellern irgend eine Angabe gefunden hatte ${ }^{1}$; in dieser Liste von 150 Arten finden sich aus dem ungeheuren Gebiet Brasiliens nur eine Grumicha von Saint Hilaire und eine Helicopsyche-Art erwähnt. Hiernach wird es also nicht unzıveckmässig sein, eine kurze Mittheilung über diejenigen Arten zu machen, die ich in der Pro-

I) Hagen, Ueber Phryganiden-Gehäuse. Stettiner entomol. Zeitung. Bd. XXV. I864. S. 114 und 221. 
ainda a minha lista das especies catharinenses, ao menos mostrarí quantas fórmas inesperadas e curiosas podem ainda deparar-se aos que quizerem explorar as aguas do Brasil á busca das larvas de Trichopteros. Limito-me por esta rez ás casas construidas pelas larvas, referinclo-me apenas de passagem a um ou outro ponto notavel da estructura ou dos costumes de seus habitantes, cuja descripçào reservo para outro trabalho.

Quando, ha 25 annos, Bremi propoz o genero Helicopsyche, de que n'aquella épocha apenas se conheciam as casas das larvas, baseou-se no facto capital de que "todas as observaçòes feitas até entào a esse respeito provaram sempre que as differenças existentes no typo de architectura das casas de Phryganideas indicam generos distinctos». Sigo o exemplo de Bremi, propondo generos novos para varios typos inteiramente novos de casas de Trichopteros; semelhante procedimento me parece assaz justificado, comquanto sejam ainda desconhecidos os insectos perfeitos, no facto da transformação que soffrem as larvas constructoras daquellas casas. Tomemos o exemplo das Helicopsyches, tão notaveis pelas suas casas encaracoladas. Tres casos podiam apresentar-se. Primeiro, que os insectos perfeitos, nascendo das especies já tão numerosas e espalhadas por todo o mundo, daquellas casas encaracoladas, fossem todos tão semelhantes entre si e tão differentes de todos os mais Trichopteros, que constituissem um genero distincto; neste caso não haveria duvida alguma sobre o genero Helicopsyche. vinz Santa Catharina beobachtet habe. Denn mag auch meine Liste der Arten dieser Provinz noch so mangelhaft und unvollständig sein, so wird sie wenigstens zeigen, wie viel unerwartete und merkwürdige Formen noch aufgefunden werden können, wenn man die Gewässer Brasiliens auf Trichopterenlarven durchsucht. Ich beschränke mich für dies Mal auf die von den Larven gebauten Gehäuse und nehme höchstens nebenbei Bezug auf die eine oder andere bemerkenswerthe Eigenthümlichkeit des Baues oder der Gewohnheiten ihrer Bewohner, deren Beschreibung ich einer anderen Arbeit vorbehalte.

Als Bremi vor 25 Jahren die Gattung Helicopsyche aufstellte, von der man in jener Epoche kaum die Gehäuse der Larven kannte, stützte er sich auf die Hauptthatsache, dass ,alle bis dahin in dieser Iinsicht gemachten Beobachtungen immer bewiesen hatten, dass die in der Grundform des Baustiels der Phryganiden-Gehäuse bestehenden Verschicdenheiten verschiedene Gattungen anzeigen“. Ich folge dem Beispiele Bremi's, indem ich für verschiedene ganz neue Grundformen (Typen) von TrichopterenGehäusen -neue Gattungen aufstelle; ein solches Vorgehen scheint mir hinlänglich gerechtfertigt, wie sehr auch die vollkommenen Insekten noch unbekannt sein mögen; denn die Larven, welche die Gehäuse bauen, werden durch sie auch umgeformt. Nehmen wir z. B. die Helicopsyche-Arten, die sich durch ihre schneckenförmig eingerollten Gehäuse so sehr auszeichnen. Drei Fälle können sich darbieten. Erstens könnten die vollkommenen Insekten, die aus den schon so zahlreichen und durch die ganze Welt verbreiteten Arten dieser schneckenförmigen Gehäuse hervorgehen, alle unter sich eben so ähnlich und von allen übrigen Trichopteren, die eine besondere 
Em seczundo logar, podia-se suppôr que fossem todos os trichopteros nascidos de casas encaracoladas, tão smelhantes ás especies de algum outro genero, que, no estado de insectos perfeitos, nàn se podessom distinguir genericamente; tambem neste caso, (que nào se verifica na Helicopsyche borealis, Hag), teria sido conveniente conservar o genero Helicopsy'clee, visto como o caracter das casas encaracoladas é, sem duvida nenhuma, muito mais importante e signal muito mais seguro de affinidade do que aquellas ligeiras differenças nas nervuras das azas e outras do mesmo jaez, hoje usadas para distinguir os generos dos Trichopteros. Poderá, emfim, acontecer que as varias especies cujas larvas construem casas encaracoladas, estejam no estado de insectos perfeitos, tão diversos entre si, que conviria separal-os em diversos generos; tambem neste caso deveria subsistir o nome de Helicopsyche, para designar por uma unica palavra os constructores das casas encaracoladas, e devia subsistir com o mesmo direito com que continuam a ser usados os nomes de Bipimnaria, Pluteus, de Nauplius, de Zoëa, etc. Ora, tudo o que acabo de dizer a respeito das Helicopsyches, vale tambem para todos os generos que vou propôr neste trabalho.

$\S \mathrm{I}$.

As casas das Rhyacophylideas (fig. $1-4$ ).

Segundo Pictet ${ }^{1}$ ), as larvas das Rhyacoplitideas vivem sem casa em

I) Citado por Hagen, 1. c. p. 142.
Gattung bilden, eben so verschieden sein; in diesem Falle würde über die Gattung Helicopsyche gar kein Zweifel sein.

An zweiter Strulle könnte man annehmen, dass alle Trichopteren, die aus schneckenförmigen Gehäusen hervorgehen, den Arten irgend einer anderen Gattung so ähnlich wären, dass sie im Zustande der fertigen Insekten niclit generisch unterschieden werden könnten; auch in diesem Falle: (der sich in Helicopsyche borealis Hag. nicht bewahrheitet) würde es passend sein, dic Gattung Helicopsyche festzulalten, da ja ohne irgend welchen Zweifel das Merkmal der schneckenförmigen Gehäuse viel wichtiger ist und viel sicherer auf Verwandtschaft hinweist als jene leichten Unterschiede in den Flügelnerven und andere desselben Schlages, die man heute anwendet, um die Gattungen der Trichopteren zu unterscheiden. Endlich wird es sich treffen können, dass die verschiedenen Arten, deren Larven schneckenförmige Gchäuse bauen, im Zustande fertiger Insekten so verschieden unter sich sind, dass es passend sein wïrde, sie in verschiedene Gattungen zu trennen; auch in diesem Falle müsste der Name Helicopsyche bestehen bleiben. um mit einem einzigen Worte die Erbauer schneckenförmiger Gehäuse zu bezeichnen, und müsste mit demselben Rechte beibehalten werden, mit dem man fortfährt, die Namen Bipinnaria, Pluteus, Nauplius, Zoëa u. s. w. zu gebrauchen. Alles was ich soeben hinsichtlich der Helicopsyche-Arten gesagt habe, gilt aber ganz eben so für alle Gattungen, die ich in dieser Arbeit aufstellen werde.

1) Die Gehäuse der Rhyacophiliden (Fig. I-4).

Nach Pictet ${ }^{1}$ ) leben die Larven der Rhyacophiliden ohne Gehäuse in fliessen-

1) Citirt von Hagen, 1. c. S. 142. 
aguas correntes, e só quando estão para se transformar em nymphas, - construem nas pedras uma casa tosca e immovel; nào obstante, o proprio Pictet já figurou uma casa movel, feita de pedras pela larva de uma especie desta familia ${ }^{1}$ ). Depois de construida ou fixada a casa, as larvas das Rhyacophilideas, antes de se transformarem, ainda fazem an redor de si um segundo, involucro, ou casulo de uma membrana assaz resistente, de fórma oval, fechado de todos os lados. o qual se acha solto no interior da casa de pedras. Por este segundo involucro as nymphas das Rhyacophilideas facilmente se distinguem das de todos os mais Trichopteros. Nos corregos e ribeiros affluentes do rio Itajahy ha algumas especies desta familia que, no estado de larvas, parecem prescindir de casas; os casulos de suas nymphas acham-se cobertos de algumas pedrinhas toscamente accumuladas, formando um monticulo tão irregular que nào merece o nome de casa. Muito mais frequentes sào algumas outras especies que já no estado de larvas vivem em casas moveis. Estas casas (fig. I-t) são feitas de pedras de fórma oval, com dous orificios ou portas nos dous extremos do lado ventral. Não ha differença entre os extremos anterior e posterior da casa, podendo a larva sahir indifferentemente por uma ou outra porta. Antes de se transformar em nympha, a larva remove a parede ventral, fixando: toda a margem da abobada da casa a alguma pedra maior, e an mesmo tempo reune mais firmemente umas ás outras as pedrinhas da mesma abobada. den Gewässern und bauen nur, wenn sie sich verpuppen wollen, auf den Steinen ein rohes und unbewegliches Gehäuse; gleichwohl hat schon Pictet selbst ein bewegliches Gehäuse abgebildet, das von der larve einer Art dieser Familie aus Steinen verfertigt war ${ }^{1}$ ). Nach dem Bau und der Befestigung ihres Gehäuses machen die Larven der Rhyacophiliden, bevor sie sich umwandeln, um sich herum noch eine zweite Hülle, einen Kokon aus einer ziemlich widerstandsfähigen Haut, von ovaler Form, der sich, von allen Seiten geschlossen, lose im Inneren des Steingehäuses befindet. Durch diese zweite Hülle unterscheiden sich die Puppen der Rhyacophiliden leicht von denen aller übrigen Trichopteren. In Quellen und Bächen, die dem Itajahy zufliessen, giebt es einige Arten dieser Familie, die im Larvenzustande von Gehäusen abzusehen scheinen; die Hüllen ihrer Puppen finden sich mit einigen roh zusammengehäuften Steinchen bedeckt, die ein so unregelmässiges Häufchen bilden, dass es den Namen eines Gehäuses nicht verdient. Viel häufiger sind einige andere Arten, die schon im Larvenzustande in bewveglichen Gehäusen leben. Diese Gehäuse (Fig. I-4) sind aus Steinen verfertigt, von ovaler Form, mit zwei Oeffnungen oder Thüren an den beiden Enden der Bauchseite. Es ist kein Unterschicd zwischen dem vorderen und hinteren Ende des Gehäuses; die Larve kann eben so gut aus der einen wie aus der anderen Thür hervorkommen. Bevor sie sich zur Puppe umwandelt, entfernt die Larve die Bauchwand, heftet den ganzen Rand des Gewölbes ihres Gehäuses an irgend einen grösseren Stein und verbindet gleichzeitig die Steinchen dieses Gewölbes fester mit einander. 
As casas de todas as larvas de Trichopteros devem ser atravessadas continuamente por uma corrente de agua fresca, que mantém a respiraçào dis mesmas larvas. Ora, as duas portas das casinhas moveis das Rhyacophilideas acham-se, como já disse, na parede rentral, e applicadas á pedra en que vivem; circumstancia esta utilissima, de certo, para impedir a entrata de qualquer inimigo, porém muito desfavoravel á circulaçào da ag̣ua. Este inconveniente acha-se remediado de differentes maneiras pelas diversas especies catharinenses. Em uma especie pequena (fig. 1), cujas casas raras vezes excedem a $5^{\text {mm }}$ de comprimento sobre $3^{\mathrm{mm}}$ de largura, as pedrinhas da abobada são ligadas de maneira a deixarem entre si pequenos orificios ou intersticios irregulares, de numero, tamanho e fórma muito variareis. As rezes, perto de um ou outro extremo, encontra-se um orificio um pouco mainr. Esta especic vive em varios corregos menores de curso rapido; ceralmente no lado superior das pedras, as casas clas nymphas (fig. 1, $b^{\prime}$ - $B^{\prime}$ ), costumam ser fixadas ao lado inferior das mesmas pedras. Outra especie (fig. 2), que encontrei no ribeirào da Gruta dos Macacos ("Affenwinkel. dos allemàes da colonia de Blumenau) e que costuma empregar pedras relativamente grandes na construcçào de suas casas, deixa um unico buraco maior no centro da abobada. Este buraco é frequentemente quadrangular e limitado por quatro pedras, fechando-se quando a larva rai transformar-se en nympha.

En quasi todos os logares em que um ribeirăo maior ou menor corre rapidamente $\mathrm{cm}$ um leito de pedras, estas acham-se cobertas de milhares de casin-
Die Gehäuse aller Trichopterenlarven müssen beständig von einem Strom frischen Wassers durchflossen werden, der die Athmung dieser Larven unterhält. Nun befinden sich dic beiden Thüren der beweglichen Häuschen der Rhyacophiliden, wie schon gesagt, in der Bauchwand und dem Steine angedrückt, auf dem sie leben; dieser Umstand, der gewiss sehr nützlich ist, um den Eintritt irgend wolches Ficindes zu verhindern, ist dagegen für die Cirkulation des Wassers sehr ungünstig. Dirses Hindernis findet sich bei verschiedenen Arten von St. Catharina auf verschiedene Weise beseitigt. Bei einer kleinen Art (Fig. 1), deren Gehäuse in seltenen Fällen $5 \mathrm{~mm}$ Länge bei $3 \mathrm{~mm}$ Breitc überschreiten, sind die Steinchen des Gewölbes derart mit einander verbunden, dass sie zwischen sich kleine Oeffnungen oder unregelmässige Zwischenräume lassen, die an Zahl, Grösse und Form mannigfach wechseln. Bisweilen finclet sich nahe dem einen oder anderen Ende eine etwas grössere Oeffnung. Diese Art lebt in verschiedenen kleineren Quellen von raschem Lauf; gewöhnlich auf der oberen Seite der Steine; die Gehäuse der Puppen (Fig. 1 B, B') pflegen an der unteren Seite derselben Steine befestigt zu werden. Eine andere Art (Fig. 2), die ich im Bache "Affenwinkel" (Gruta dos Macacos) antraf, und die verhältnissmässig grosse Steine beim Bau ihrer Gehäuse anzuwenden pflegt, lässt eine einzige grössere Oeffnung in der Mitte des Gewölbes. Diese Oeffnung ist häufig viereckig und von vier Steinen umgrenzt; sie wird goschlossen, wenn die Larve sich zur Puppe umwandeln will.

An fast allen Stellen, wo ein grösserer oder kleinerer Bach in einem Bette von Steinen schnell fliesst, finden sich diese mit Tausenden von Rhyacophiliden- 
has de Rlyyacophilideas (fig. 3), que, em vez de um simples buraco, possuem no meio da abobada uma chaminé ou cano mais ou menos alto, construido geralmente de pedrinhas muito mais miudas do que as do resto da casa.

As fórmas ' côres dessas casinhas variam ao infinito, segundo o caracter mineralogico do material que para a sua construcceào as larvas encontram nas ạuas, não só nos differentes ribeiros que habitam, como tambem na mesma localidade. As tres casinhas da fig. 3 foram tiradas com algumas duzias de outras nào menos diversas de uma unica pedra do Ribeirào do Garcia. As casas das nymphas, fixadas geralmente no lado inferior das pedras, não têm mais chaminé. Por causa da extrema variabilidade c irregularidade destas casinhas, é quasi impossivel decidir, sem um exame minucioso das larvas e nymphas que as habitam e dos insectos perfeitos em que estas se transformam, si todas ellas pertencem a uma só especie. As que no mez de Agosto achei no Ribeirão da Triste Miscria (Trauriger Jammer, dos allemães de Blumenau), distinguiam-se por uma chaminé menos alta, menos estreita, e frequentemente um pouco inclinada (fig. 4). Talvez seja especie differente.

\section{$\$ 2$.}

As casas das Hydropsychideas (fig. 5-6).

Não se conhece larva da familia das Hydropsychideas, que faça casa movel; quasi todas ellas vivem ( $\mathrm{m}$ escondrijos de construcção muito rude, sendo, ou corredores assaz compriclos e tortuosos, cobertos de pedras, fragmentos de plantas, etc., ou tambem canaes cylindricos cujas paredes, tecidas pela larva, se compõem de seda e barro ou arcia fina, häuschen (Fig. 3) bedeckt, die, statt einer cinfachen Oeffnung, in der Mitte des Gewölbes einen Schornstein oder eine Röhre besitzen - mehr oder weniger hoch, im Allgemeinen aus viel kleineren Steinchen gebaut, als das übrige Gehäuse.

Die Formen und Farben dieser Gehäuse variiren ins Unendliche nach dem mineralogischen Charakter des Baumate rials, welches dic Larven in den Gewässern antreffen, nicht nur in den verschiedenen Bächen, die sie bewohnen, sondern auch an derselben Lokalität. Die drei Gehäuse von Fig. 3 wurden mit einigen Dutzend anderen, nicht weniger verschiedenen einem einzigen Steine des Baches Garcia entnommen. Die Gehäuse der Puppen, die gewöhnlich an der Unterseite der Steine befestigt sind, haben keinen Schornstein mehr. Wegen der ausserordentlichen Variabilität und Unregelmässigkeit dieser Häuschen ist es, ohne eine minutiöse Untersuchung der Larven und Puppen, die sie bewohnen, und der fertigen Insekten, in die diese sich umwandeln, kaum möglich zu entscheiden, ob sie alle zu einer einzigen Art gehören. Die, welche ich im Monat August im Bache ,Trauriger Jammer" (Triste Miseria) fand, unterscheiden sich durch einen weniger hohen, weniger engen, und oft etwas geneigten Schornstein (Fig. 4). Sie bilden vielleicht eine verschiedene Art.

2) Die Gehäuse der Hydropsychiden (Fig. 5, 6).

Aus der Familie der Hydropsychiden ist keine larve bekannt, die ein bewegliches Gehäuse anfertigt; sie leben fast alle in Verstecken von sehr roher Bauart: entweder in ziemlich langen, gekrümmten Gängen, die mit Steinen, Pflanzenbruchstücken u. S. w. bedeckt sind, oder auch in cylindrischen Kanälen, deren von der Larve gewebte Wände 
como os construidos pela larva de Hydropsyche maculicomis ${ }^{1}$ ). Na provincia de Santa Catharina abunda, por baixo das pedras, em quasi todas as aguas correntes, uma larva desta familia, a maior de todas as larvas de Trichopteros que por aqui ha. Ella vive em uma especie de canal on corredor cobcrto de pedras irregularmente accumuladas e em geral muito mal seguras por alguns fins de seda. Para se transformar em nympha ella construe uma casa de pedras firmemente ligadas, ás vezes enormes para animal tão pequeno. A fórma externa clessas casas (fig. $5, A$ ), fixadas no lado inferior de pedras maiores, é muito irregular, variando an infinito, segundo a fórma das pedras empregadas na sua construcção. Ellas encerram uma cavidade cylindrica ou oval de cerca de $20^{\mathrm{mm}}$ de comprimento sobre $6^{\mathrm{mm}}$ de largura. A camada interior da parede da casa é feita de barro, areia ou pedrinhas muito intimamente unidas pela seda que fornecem os «sericterios» ou glandulas fiandeiras da larva. A superficie interna da casa é lisa; cm cada extremidade a parede é perfurada de cerca de meia duzia de buraquinhos para receber a agua necessaria á respiração da nympha. Contiguo á superficie interna da casa de pedras achase um casulo de seda branca, ligeiraramente amarellada (fig. $5, B$ ). A membrana do casulo, comquanto tenuissima, é muito resistente; os extremos (ou bases do cylindro), são crivados de buracos numerosissimos de cerca de $\mathrm{O}^{\mathrm{mm}} \mathrm{O} 8$ de diametro (fig. $5, B^{\prime}$ ).

I) Westwood, Introduction to modern classification of Insects. II. p. 62. fig. 68,8 . aus Seide und Thon oder feinem Sand bestehen, wie die von der Larve von Hydropsyche maculicornis gebauten ${ }^{1}$ ). I1 der Provinz Santa Catharina ist in fast allen fliessenden Gewässern auf der Unterseite der Steine eine Larve dieser Familie ungemein häufig, die grösste aller bis jetzt bekannten Trichopterenlarven. Sie lebt in einer Art Kanal oder Gang, der von unregelmässig zusammengehäuften und mit einigen Seidenfäden im Allgemeinen sehr schlecht befestigten Steinen bedeckt ist. Um sich in eine Puppe umzuwandeln, baut sic ein Gehäuse von fest zusammengehefteten, bisweilen für ein so kleines Thier auffallend grossen Steinen. Die äussere Form dieser mit ihrer Unterseite an grössere Steine befestigten Gehäuse (Fig. $5 A$ ) ist sehr unregelmässig, nach der Form der bei ihrem Bau verwendeten Steine ins Unendliche wechselnd. Sie umschliessen einen cylindrischen oder ovalen Hohlraum von ungefähr $20 \mathrm{~mm}$ Länge bei $6 \mathrm{~mm}$ Breite. Die innere Wandschicht des Gehäuses ist aus Thon, Sand oder Steinchen verfertigt, die mittels der von den Seiden- oder Spinndrüsen der Larve gelieferten Seide sehr innig vereinigt sind. Die innere Oberfläche des Gehäuses ist glatt; an jedem Ende ist die Wand von ungefähr einem halben Dutzend kleiner Löcher durchbohrt, um das zur Athmung der Puppe nöthige Wasser aufzunehmen. Unmittelbar an der inneren Oberfläche des Steingehäuses befindet sich ein Kokon von weisser, schwach gelblicher Seide (Fig. $5 B$ ). Die Haut des Kokons ist zwar sehr dünn, aber in hohem Grade widerstandsfähig; die Enden oder Grundflächen des Cylinders sind von sehr zahlreichen Löchern von ungefähr o,o8 mm Durchmesser siebartig durchlöchert (Fig. 5, B').

I) Westwood, Introduction to modern classification of Insects, II, p. 62, Fig. 68, 8. 
Mais rara é outra especie da mesma familia (fig. 6), que só se encontra em corregos de curso muito rapido, v. g. na -Gruta dos Macacos» e na Triste Miseria de Blumenau. As suas casas são das mais interessantes, nàn só na ordem dos Trichopteros, como dos insectos em geral, podendo rivalisar com as do cupim, das formigas, marimbondos, abelhas, etc. Estas casas nunca sào feitas por baixo, mas sim por cima clas pedras; sàn construidas sem grande arte, a nada mais são do que tubos ou canaes de cerca de $7^{\text {mm }}$ de comprimento sobre $2^{\mathrm{mm}}$ de diametro, feito de fibras vegetaes irregularmente sobrepristas ou entrelaçadas, ou tambem de pedrinhas. Cada casa tem um vestibulo ou varanda, dilatando-se em fórma de funil, cuja entrada mede até $7^{\mathrm{mm}}$ de altura sobre outro tanto ou mais de largura. As paredes lateraes são geralmente feitas de fibras entrelaçadas, servindo de tecto uma rede degantissima de seda, cujas malhas quadrangulares costumam ter $\mathrm{o}^{\mathrm{mm}}{ }_{2}$ até $\mathrm{O}_{1}^{\mathrm{mm}_{3}}$ de largura. As casas sào invariavelmente orientadas de tal maneira que a corrente d'agua venha bater na entrada do funil. Raras vezes estas larvas vivem solitarias; geralmente fazem as suas casas contiguas umas ao lado das outras, formando ás vezes uma longa fileira interrupta, perpendicular ao curso da agua, interceptando (r retendo desta sorte em seus funís tudn quanto a agua possa trazer de comestivel. Para a transformação em nymphas parece que as larvas sempre substituem pequenas pedras ás fibras vegetaes das suas casas; sendo essas pedrinhas fortemente unidas a cobrindo uma cavidade de cerca de $7^{m m}$ de comprimento sobre $3^{\mathrm{mm}}$ de largura (fig. $6, B, B^{\prime}$ ), cuja parede é interiormonte revestida, como na especie precedente, de uma membrana resistente. Nessas casas de nymphas não ha mais varanda, a qual não sei si foi removicla
Seltener ist eine andere Art derselben Familie (Fig. 6), die man nur in Quellen von sehr raschem Lauf, z. B. im „Affenwinkel" und im "Traurigen Jammer" der Kolonie Blumenau antrifft. Ihre Gehäuse gehören zu den interessantesten, nicht nur in der Ordnung der Trichopteren, sondern der Insekten überhaupt; sie können mit denen der Termiten, Ameisen, IVespen, Bienen u. s. w. wetteifern. Diese Gehäuse sind niemals auf der Unterseite, sondern auf der Oberseite der Steine angeheftet; sie sind ohne grosse Kunst gebaut und sind nichts weiter als Röhren oder Kanäle von etwa 7 mm Länge bei $2 \mathrm{~mm}$ Durchmesser, hergestellt aus unregelmässig über einander gelegten oder durch einander geflochtenen Pflanzenfasern, oder auch aus Steinchen. Jedes Giehäuse hat einen Vorhof oder eine Veranda, die sich trichterförmig erweitert, deren Eingang bis zu $7 \mathrm{~mm}$ Höhe bei doppelt so viel oder mehr Breite misst. Die Seitenwände sind gewöhnlich aus durch einander geflochtenen Fasern hergestellt und dienen als Deckung für ein höchst zierliches Netz von Seide, dessen viereckige Maschen gewöhnlich 0,2 bis $0,3 \mathrm{~mm}$ Weite haben. Die Gehäuse sind unabänderlich derart orientirt, dass der Wasserstrom in den Eingang des Trichters schlagen muss. In seltenen Fällen leben diese Larven einzeln. Gewöhnlich machen sie ihre Gehäuse dicht neben einander, so dass sie bisweilen eine lange ununterbrochene Reihe bilden, die senkrecht zum Laufe des Wassers steht und auf diese Weise in ihren Trichtern Alles auffängt und zurückhält, was das Wasser Geniessbares mit sich bringen mag. Pei der Umwandlung in Puppen scheinen die Larven die vegetabilischen Fasern ihrer Gehäuse immer durch kleine Steine zu ersetzen; diese Steinchen sind fest vereinigt und bedecken einen Hohlraum 
pela larva ao preparar a casá para sua transformação, ou destruida a pouco e pouco pela corrente d'agua. Os insectos em que finalmente sc transformam os moradores dessas interessantissimas casas assemelham-se, pela estructura das antennas e nervuras das azas, ao genero Smicridea, Mac Lachlan. Assim como ambos os sexos de Smicridea, as femeas têm tambem um unico esporão nas tibias anteriores, quatro nas intermediarias c quatro nas posteriores; porém, os machos têm só dous nas tibias posteriores. E' um caso analogo ao do genero Heteroplectron, Mac Lachl.. da familia das I.eptocerideas, em que as tibias posteriores dos dous sexos differem da mesma maneira. Proponho para o habil architecto e tecelàn o nome de Rlyyacophylax.

\section{$\$ 3$.}

As casas das Leptocerideas (fig. 7-15).

As casas de todas as especies desta familia são moveis, tendo quasi a fórma de canudos estreitos, conicos, um pouco arqueados. As larvas das diversas especies differem muito entre si, nãn si) quanto ao material que empregam na construcção de suas casas ou estojos, como tambem em relação an modo de fixal-as ou fechal-as quando estão para se transformar em nymphas.

$\Lambda$ casa, a mais simples e rncle (fig. 7), é de uma larva que se serve para este von etwa $7 \mathrm{~mm}$ länge bei $3 \mathrm{~mm}$ Breite (Fig. $6 \mathrm{~B}, \mathrm{~B}^{\prime}$ ), dessen Wand inwendig, eben so wie bei der vorhergehenden Art, von einer widerstandsfähigen Haut ausgekleidet ist. An diesen Puppengehäusen ist niemals eine Veranda; ich weiss indess nicht, ob dieselbe von der Larve entfernt wird, wenn sie das Gehäuse für ihre Umwandlung zurichtet oder ob sie allmählich durch die Strömung des Wassers zerstört wird. Die Insekten, in die sich die Bewohner dieser interessantesten Gehäuse endlich umwandeln, sind im Baue der Fühler und Flügelnerven der Gattung Smicridea Mac I achlan ähnlich. Eben so wie beide Geschlechter von Smicridea haben die Weibchen einen einzigen Sporn an den vorderen, vier Sporne an den mittleren und vier an den hinteren Schienen; die Männchen dagegen haben nur zwei Sporne an den hinteren Schienen. Der Fall ist analog dem der Gattung Heteroplectron Mac Lachlan, aus der Familie der Leptoceriden, bei der die Hinterschienen beider Geschlechter in derselben WVeise differiren. Ich schlage für den geschickten Baumeister und Weber den Namen Rhyacophylax vor.

3) Die Gehäuse der Leptoceriden (Fig. 7-I5).

Die Grehäuse aller Arten dieser Familie sind beweglich und haben fast alle die Form enger, kegelförmiger, ein wenig gebogener Röhren. Die Larven verschiedener Arten sind sehr unter sich verschieden, sowohl in Bezug auf das Material, das sie beim Bau ihrer Gehäuse oder Futterale verwenden, als auch hinsichtlich der Art, dieselben zu befestigen und $z u$ verschliessen, wenn sic im Begriff sind, sich in Puppen umżı. wandeln.

Das einfachste und roheste Gehäuse (Fig. 7) ist das einer Larve, die sich zu 
fim de fragmentos de ramos que nunca escasseiam nos corregns do mato. Si os ramos são ôcos, servem sem mais preparação; a larva corta um pedaço de comprimento conveniente e tira roendo um pedacinho semi-circular da margem ventral da entrada (fig. $7, A, C$ ), ficandn desta sorte a cabeça da larva coberta e protegida pela margem dorsal da mesma entrada. Frequentemente a larva fica a esta margem superior da entrada uma ou algumas pequenas pedras, protegendo assim ainda mais a entrada. Si os ramos forem massiços, a larva tem de préviamente excaval-os, devendo, além disso, fazer um buraquinho lateral na extremidade posterior do tubo que tiver excavado, para a sahida da agua que tem servido á respiração. Os páosinhos habitadns por larvas adultas têm geralmente de 30 até $35^{\mathrm{mm}}$ de comprimento, chegando só raras vezes a medir $5 \mathrm{O}^{\mathrm{mm}}$ ou mais. Um só vi eu que tinha $80^{\mathrm{mm}}$ de comprimento sobre $3^{\mathrm{mm}}$ de diametro; talvez a larva deixasse de cortar parte delle por ser muito leve. Em approximando-se a época da transformação, a larva fixa a sua casa pela margem ventral da extremidade anterior, por baixo de alguma pedra maior ou de algum tronco de arvore cahido n'agua Feito isso, tapa a entrada com uma pedra (fig. $7, A^{\prime}, p$ ) ligada, ou para melhor dizer, collada á extremidade anterior de casulo membranoso da nympha (fig. 7 , $\left.A^{\prime}, n\right)$. No insersticio, entre a pedra e a parede do tubo, o casulo é crivado de buracos de cerca de $0,{ }^{\mathrm{mm}} \mathrm{I} 2$ de diametro. Da mesma sorte acha-se um crivo transversal (fig. $7, A^{\prime}, A^{\prime \prime}$ ) no extremo posterior do casulo da nympha; crivo este que é quasi coriaceo, e mais grosso e duro do que a membrana que reveste a parede do tubo. A's vezes acontece que o mesmo crivo applica-se an orificio lateral do tubo (fig. $7, B, B^{\prime}$ ). $\mathrm{Si}$ o tubo é ôco, geralmente a larva diesem Zwecke der Bruchstücke kleiner Zweige bedient, die in den Waldbächen stets in reichlicher Menge vorhanden sind. Wenn die Zweige hohl sind, werden sie ohne weitere Vorbereitung in Gebrauch genommen; die Larve schneidet ein Stück von passender I,änge $a b$ und nagt ein halbkreisförmiges Stück aus dem Bauchrande des Einganges (Fig. $7 A, C$ ), so dass der Kopf der Larve von dem Rückenrande desselben Einganges bedeckt und geschützt bleibt. Oft befestigt die Larve an diesen oberen Rand des Einganges einen oder einige kleine Steine, wodurch sie den Eingang noch mehr schützt. Wenn die Aeste nicht hohl sind, so hat die Larve sie erst auszuhöhlen, dann muss sie ausserdem ein seitliches Loch in das hintere Ende der von ihr ausgehöhlten Röhre machen, für den Austritt des Wassers, das ilır zur Athmung gedient hat. Die von erwachsenen Larven bewolnnten Stäbchen haben gewöhnlich 30 bis $35 \mathrm{~mm}$ Länge; nur in seltenen Fällen erreichen sie $50 \mathrm{~mm}$ oder mehr; ein einziges sah ich, das $80 \mathrm{~mm}$ Länge bei $3 \mathrm{~mm}$ Durchmesser hatte. Vielleicht hatte die Larve desshalb unterlassen, einen Theil desselben abzuschneiden, weil es sehr leicht war. Wenn die Zeit ihrer Umwandlung herannaht, befestigt die Larve ihr Gehäuse mit dem Bauchrand des vorderen Endes an die Unterseite irgend eines grösseren Steines oder in das Wasser gefallenen Baumstammes. Dies gethan, stopft sie den Eingang mit einem Stein zu (Fig. 7, $\left.A^{\prime} p\right)$, den sie an das vordere Ende des häutigen Puppenkokons (Fig. $7 A^{\prime}$ ' $)$ heftet oder, besser gesagt, leimt. In dem Zwischenraum zwischen dem Steine und der Wand der Röhre ist der Kokon von L,öchern von ungefähr O,I $2 \mathrm{~mm}$ siebartig durchlöchert. Eben so befindet sich ein Quersieb (Fig. $7 A^{\prime}, A^{\prime \prime}$ ) am hinteren Ende des Puppenkokons. Dieses Sieb ist fast lederartig und dicker und 
tapa-o com uma pedra tambem na extremidade posterior; algumas vezes, comtudo, a larva introduz uma pedrinha no interior do tubo, applicando-a ao crivo (fig. $7, C, C$ ). Tambem neste caso as larvas fazem o buraco de costume (fig. 7 , $\left.C^{\prime}, o\right)$ na parede do tubo, buraco que, por mais indispensavel que seja, quando o tubo fôr fechado posteriormente, é absolutamente superfluo c inutil quando fôr aberto. E' um dos exemplos mais frisantes para refutar a pretendida «infallibilidade do instincto».

Sob o nome de Grumicha, descreveu Aug. St. Hilaire ${ }^{1}$ ) «tubos de uma substancia dura, cornea, de meia pollegada de comprimento, lisos e polidos. pretos, arqueados, a pouco e pouco adelgaçados como um chifre, habitados por uma larva e vivendo em rios do Brasil». Essa descripção, applica-se perfeitamente aos estojos de uma larva da familia das Leptocerideas, assaz frequente $\mathrm{cm}$ alguns affluentes maiores do rio Itajahy (Ribeirào do Garcia, Warnow, Neisse). Só os estojos d'aqui (fig. $8, A$ ) são um pouco maiores; talvez St. Hilairc tenha visto só as larvas ainda não adultas. Em todo n caso, si não fôr a mesma, é ao menos muito semelhante á nossa a especie descripta pelo celebre naturalista francez. Medi 20 estojos, fixados e por isso, adultos de femeas que tinham $26^{1 \mathrm{~mm}}$ de comprimento $\left.{ }^{2}\right)$, termo medio, variando entre 24 e $28^{\mathrm{mm}}$; da mesma sorte 20 estojos fixados de machos tinham

I) Voyage au Brésil. Tom III, I830, p. 62.

2) Pelo comprimento de estojos curvados entendo a corda entre os extremos e não o comprimento do arco.

Fritz Müllers gesammelte Schriften. härter als die Haut, welche die Wand der Röhre auskleidet. Manchmal trifft es sich, dass dasselbe Sieb sich an die Seitenöffnung der Röhre anlegt (Fig. 7 $\left.B, B^{\prime}\right)$. Wenn das benutzte Zweigstück hohl ist, so verstopft es die Larve gewöhnlich auch am hinteren Ende mit einem Stein; manchmal indess holt die Larve ein Steinchen in das Innere der Röhre und legt es an das Sieb (Fig. 7 $\left.C . C^{\prime}\right)$. Auch in diesem Falle machen die Larven aus Gewohnheit ein Loch in die Seitenwand der Röhre (Fig. $7 C^{\prime}, o$ ), ein Loch, das, wie unentbehrlich es sein mochte, wenn die Röhre hinten geschlossen war, durchaus überflüssig und unnütz ist, wenn sie offen war. Es ist dies eines der passendsten Beispiele, um die angebliche „Unfehlbarkeit des Instinktes“ zu widerlegen.

Unter dem Namen Grumicha beschrieb Aug. St. Hilaire ${ }^{1}$ ) „Röhren aus einer harten, hornigen Substanz, von halber Daumenlänge, glatt und glänzend, schwarz, gebogen und an Dicke allmählich abnehmend wie ein Horn, ron einer Larve bewohnt und in den Flüssen Brasiliens vorkommend". Diese Beschreibung passt vollständig auf die Futterale einer Larve aus der Familie der Leptoceriden, die in einigen grösseren Zuflüssen des Rio Itajahy (den Bächen Garcia, Warnow, Neisse) ziemlich häufig ist. Nur sind die Gehäuse von hier (Fig. $8 A$ ) ein wenig grösser; vielleicht hat St. Hilaire nur die noch nicht erwachsenen Larven gesehen. In jedem Falle ist die von dem berühmten französischen Naturforscher beschriebene Art der unserigen, wenn nicht gleich, wenigstens sehr ähnlich. Ich mass 20 angeheftete, also erwachsene Futterale von W'eibchen, dic durchschnittlich $26 \mathrm{~mm}$ Iänge ${ }^{2}$ ) hatten und

1) Vnyage au Brésil. Tom. 1II, 1830, p. 62.

2) Unter Länge der gekrüınmten Futterale verstehe ich die Schne zwischen den Endpunkten, und nicht die Länge des Bogens. 
I $8^{\mathrm{mm}}$ de comprimento, termo medio, variando entre 16 e $21^{\mathrm{mm}}$. Os estojos são curvados quasi uniformemente em toda a sua extensão; o raio da curvatura é cle cerca de 3 centimts., augmentando um pouco na extremidade anterior. Os estojos dos machos correspondem a $\operatorname{arcos}$ de $36^{\circ}$, os das femeas a arcos de $52^{\circ}$, pouco mais ou menos. A extremidade posterior ou anal do estojo tem cerca de $\mathrm{I}^{\mathrm{mm}}$ de diametro, a anterior ou oral cerca de $2^{\mathrm{mm}}$ nos estojos dos machos, e $3^{\mathrm{mm}}$ nos das femeas. A extremidade posterior é fechada por uma parede transversal, da mesma substancia do estojo, tendo no centro um buraco circular cujo diametro é de $1 / 4$ até $1 / 3$ de millimetro (fig. 8, B). As larvas gostam de fixar-se em commum, umas ao lado ou até nos estojos das outras. Nào é raro encontrar grupos de mais de cincoenta, e até de com estojos collados uns aos nutros. Os estojos são fixados só pelo extremo anterior por meio de um pequeno disco adhesivo, substentado por um curto pé ou esteio; esses discos peciolados, que são da mesma sustancia dos estrjos, nascem geralmente da margem lateral, raras vezes da margem dorsal, quasi nunca da margem ventral do orificio oval do estojo; ás vezes o estojo é fixado por dous ou tres discos em differentes direcções. Depois de fixado o estojo, quer em uma pedra, quer em outro estrjo, é tapado por uma tampa ou parede transversal situada a pequena distancia (sempre inferior a I millimetro) do orificio anterior. Essa tampa ou operculo tambem é feita da mesma substancia do estojo. Apresenta uma fenda transversal, situada um pouco abaixo do centro da tampa, e geralmente arqueada, voltando o lado convexo para abaixo (fig. 8, $C$, J)). Medi os operculos de i 7 femeas $\mathrm{c}$ de outros tantos machos, o que se póde muito farimente fazer depois que clles zivischen 24 und $28 \mathrm{~mm}$ variirten; 20 cbenfalls festgeheftete Futterale von Männchen hatten durchschnittlich I $8 \mathrm{~mm}$ Länge und variirten zwischen 16 und $21 \mathrm{~mm}$. Die Futterale sind in ihrer ganzen Ausdehnung fast gleichmässig gekrümmt; der Radius der Krümmung beträgt ungefähr $3 \mathrm{~cm}$ und nimmt am vorderen Ende ein wenig zu. Die Futterale der Männchen entsprechen Bogen von ungefähr $36^{\circ}$, die der Weibchen Bogen von ungefähr $52^{\circ}$. Das hintere oder Afterende des Köchers hat ungefähr I mm Durchmesser, das vordere oder Mundende ungefähr $2 \mathrm{~mm}$ bei den Futteralen der Männchen und $3 \mathrm{~mm}$ bei denen der Weibchen. Das hintere Ende ist durch cine Querwand verschlossen, aus derselben Substanz wie das Futteral; diese hat in der Mitte ein kreisförmiges Loch, dessen Durchmesser $1 / 4$ bis $1 / 3 \mathrm{~mm}$ beträgt (Fig. 8 B). Die Larven befestigen sich gern gemeinsam, die cinen neben oder selbst an den Futteralen der anderen. Nicht selten trifft man Gruppen von mehr als fünfzig und selbst Hundert an einander geleimter Futterale. Die Futterale sind nur mit dem vorderen Ende mittels einer kleinen Haftscheibe befestigt, die von einem kurzen Fuss oder Stiel getragen wird. Diese gestielten Scheiben, welche aus derselben Substanz wie die Gehäuse bestehen, entspringen gewöhnlich vom Seitenrande, in seltenen Fällen vom Rückenrande, fast niemals vom Bauchrande der Mundöfnung des Futterals; manchmal ist das Futteral durch zwei oder drei Scheiben in verschiedenen Richtungen befestigt. Nachdem das Gehäuse, sei es an einem Stein, sei es an einem anderen Gehäuse, befestigt ist, wird es mit einem Deckel oder einer Querwand verschlossen, die in geringer Entfornung (immer unter $1 \mathrm{~mm})$ von der äusseren Ocffnung liegt. Dieser Stöpsel oder Deckel wird ebenfalls aus clerselben Substanz verfertigt 
sĩo removidos pelas nymphas, ao sahirem do estojo paral soffrer a sua ultima metamorphose. O diametro dos nperculos das femeas varia de 2 a $2,{ }^{\text {mm }} 4$ (termo medio: $\left.2,{ }^{\mathrm{mm}} 24\right)$; o dos operculos dos machos de $\mathrm{I}, 6$ até 1 , ${ }^{\text {mmg }} 8$ (termo medio: $\left.\mathrm{I}^{\mathrm{mm}} 64\right)$; o comprimento da fencla era n'aquellas de 0,5 até $0,{ }^{\text {mmg }}$ (termo medio: $0,{ }^{\mathrm{mm}} 69$ ); nestas de 0,45 atć $0,{ }^{\mathrm{mm}} 6$ (termo medio: $\left.O{ }^{\mathrm{mm}} 5_{2}\right)$; emfim, a largura da fenda é nas primeiras de o, I até $\mathrm{O}^{\mathrm{mm}}{ }^{\mathrm{m}} \mathrm{I}_{5}$ (termo medio: $0,{ }^{\mathrm{mm}} 123$ ); nas segundas de 0,07 até $0,{ }^{\mathrm{mm}}{ }_{12}$ (termo medio: ${ }^{\mathrm{o}}{ }^{\mathrm{mm}} \mathrm{Og}$ ). Multiplicando o comprimento pela largura ter-se-ha, sem erro notavel, a área cla fencla, a qual para os estojos das femeas seria, pois, de ${ }^{\mathrm{mm}}{ }^{\mathrm{mm}} \mathrm{O} 55$ quadrados. Ora, a área do orificio circular na extremidade posterior, cujo diametro é de $1 / 3^{\operatorname{mn}}$ nas femeas e igual a ${ }_{36}^{\pi}=0,{ }^{\mathrm{mm}} \mathrm{O} 87$ quadrados. Assim os dous orificios anterior e posterior, pelos quaes clá-se a entrada e saliida da agua, que mantem a respiração da nympha, têm áreas iguaes, apezar de suas formas tão diversas.

Quanto á substancia de que são constituidos os estojos da Grumichu, acreditava Bremi que era fornecida pelas proprias larvas; a Hagen peln contrario parecia mais provavel que fosse composta de fibras vegetaes ${ }^{1}$ ). Acho que

1) Hagen, I. c. p. 227. wie das I'utteral. Er bietet eine Querspalte dar, die ein wenig unter der Mitte des Deckels liegt und gewöhnlich gekrümmt ist, so dass sie ihre konvexe Seite nach unten kehrt (Fig. 8, C D). Ich mass die Deckel von 17 Weibchen und von eben so viel Männchen, was sich sehr leicht ausführen lässt, nachdem sie durch die Puppen entfernt worden sind, die das Futteral verlassen haben, um ihre letzte Umwandlung zu erleiden. Der Durchmesser der Deckel der WVeibchen variirt von 2 bis $2,4 \mathrm{~mm}$ (Durchschnitt: $2,24 \mathrm{~mm})$; der der Deckel der Männchen von I,6 bis I, 8 mm (Durchschnitt: $1,6+\mathrm{mm}$ ); die Länge des Spaltes ist bei jenen 0,5 bis $0,8 \mathrm{~mm}$ (Durchschnitt: o,69 mm); bei diesen $0,+5$ bis $0,6 \mathrm{~mm}$ (Durchschnitt: 0,5 ? $\mathrm{mm}$ ); die Breite des Spaltes endlich beträgt bei den crsteren o, I bis o, $15 \mathrm{~mm}$ (Durchschnitt: 0, I $23 \mathrm{~mm}$ ); bei den letzteren 0,07 bis $0,12 \mathrm{~mm}$ (T)urchschnitt: $0,09 \mathrm{~mm}$ ). Indem man die Länge mit der Breite multiplicirt, erhält man ohne merklichen Fehler den Flïchenraum der Spalte, der für die Futterale der Weibchen hiernach 0,085 Quadratmillimeter betragen würde. Nun ist der Flächenraum der kreisförmigen Oeffnung: am hinteren Ende, dessen Durchmesser bei den Weibchen $1 / 3 \mathrm{~mm}$ beträgt, gleich $\frac{\pi}{36}=0,087$ Quadratmillimeter. Die beiden Oeffnungen, die vordere und hintere, durch die der Eintritt und Austritt des Wassers stattfindet, welches die Athmung der Puppe unterhält, haben alsı gleiche Flächenräume, trotz ihrer so verschiedenen Gestalt.

Was den Stoff betrifft, aus dem dic Futterale der Grumicha verfertigt werden. so glaubte Bremi, dass er von den Larven selbst geliefert würde; Hagen dagegen hielt es für wahrscheinlicher, dass er aus Pflanzenfasern zusammengesetzt wäre \$).

I) IIagren, 1. c. S. 227 . 
esta opinião de Hagen não póde ser admittida, porquanto, entre os operculos escuros, quasi homogeneos, duros e elasticos da Grumicha, e as recles ou crivos que se encontram nos extremos clo casulo das nymphas de certas Hydropsychideas (fig. $5, B^{\prime \prime}$ ), nas quaes podem-se distinguir todos os fios de que são teciclas, ha tantas fórmas intermediarias, que nào é possivel pôr em clurida que umas $e$ nutras sejam produzidas do mesmo modo. Assim, pois, as Hydropsychideas não podem nas suas casas de pedras, fechadas de todos os lados, confeccionar os seus casulos de nenhum material estranho. Tambem no caso das Helicopsyches e outras especies, ninguem de rerto porá em duvida que os operculos de suas casas, já muito mais semelhantes aos da Grumicha, sejam feitas cle uma substancia secretada pelos sericterios ou glandulas fiandeiras das respectivas larvas. Ora, entre a substancia do operculo e a do estojo da Grumicha năo ha differença; este tambem é de certo um producto exclusivo da larva. Hagen não teria com certeza commettido semelhante erro se tivesse estudado os operculos da Grumicha; mas nos tres estojos que elle examinou, achou os orificios buccal e anal, tapaclos $\mathrm{com}$ pequenas pedras, sem descobrir outro operculo.

Esta observaçĩo de Hagen foi para mim por muito tempo um problema, do qual em vão me esforcei por achar algruma solução plausivel. Duvidar de um facto tão obvio e averiguado por observador tão consciencioso e digno de toda a confiança, era-me impossivel. Mas, por outro lado, como acreditar que larvas, que fazem casas identicas, as fixassem e fechassem de modo tr̃o completamente diverso?
Ich finde diese Meinung Hagen's unzulässig, weil es zwischen den dunkeln, fast homogenen, harten und elastischen Deckeln der Grumicha, und den Netzen oder Sieben, die man an den Enden der Puppenkokons gewisser Hydropsychiden (Fig. $5 B^{\prime}$ ) antrifft (bei denen alle Fäden, aus denen sie gewebt sind, unterschieden werden können), so viele Z $\mathbf{Z}$ ischenformen giebt, dass es unmöglich in Zweifel gezogen werclen kann, dass die einen und ancleren auf dieselbe Weise hervorgebracht werden. Nun können die Hydropsychiden in ihren von allen Seiten geschlossenen Steingehäusen ihre Kokons nicht aus irgend einem äusseren Material anfertigen. Eben so wird bei dem Gehäuse der Helicopsyche und anderer Arten sicher Niemand in Zweifel ziehen, dass die Deckel ihrer Gehäuse, die denen der Grumicha schon viel ähnlicher sind, aus einem Stoffe verfertigt werden, der von den Seiden- oder Spinndrüsen der betreffenden Larven abgesondert wird. Zwischen der Substanz des Deckels und des Futterals der Grumicha ist aber gar kein Unterschied; dieses ist also sicher ebenfalls ein ausschliessliches Produkt der Larve. Hagen würde sicherlich einen solchen Irrthum nicht begangen haben, wenn er die Deckel der Grumicha studirt hätte; aber bei drei Futteralen, die er untersuchte, fand er die Mund- und Afteröffnung mit kleinen Steinen verstopft, ohne einen anderen Deckel zu entdecken.

Diese Beobachtung Hagen's war für mich lange Zeit hindurch ein Räthsel, für welches ich mich vergeblich bemühte, irgend eine plausible Lösung zu finden. An einer so leicht festzustellenden und von einem so gewissenhaften und durchaus zuverlässigen Bcobachter ermittelten Thatsache zu zweifeln war mir unmöglich. Aber wie andererseits glauben, dass Larven, die identische Gehäuse machen, sie in so grundverschiedener 
Entretanto o facto é muito simples. Os estojos de Hagren eram estojos de Grumicha, habitados, fixados e fechados por outra especie intrusa.

No Ribeirăo do Garcia, perto de um lugar onde abundam as Grumichas, eu tambem achei, ha pouco, alguns estojos de Grumicha fechados por uma pedra, e fixados pela margem ventral do orificio anterior por meio de um disco (fig. $9, d$ ) coriaceo transversal, sem peciolo, e de côr pardacenta. Abrindo um destes estojos, vi que não encerrava nympha de Grumicha, e sim uma nympha identica, ou ao menos muito semelliante á dos páozinhos (fig. 7). O estojo era revestido, como a cavidade dos páozinhos, por uma membrana que formava ao redor da nympha um casulo terminado posteriormente por um crivo transversal; sendo tambem crivada a membrana que fechava o intersticio situado entre a pedra que serve de operculo e ○ estojo (fig. 9, $B$ ).

Os insectos, cujas larvas vivem, como intrusas, nos estojos da Gmumicha, e os dos páozinhos, sãn muito semelhantes; de uns e de outros vi só muito poucos, e ainda nào os examinei minuciosamente; por ora, a unica differença, que thes achei, consistia na côr, muito mais pallida em todos os intrusos, e mais escura nos insectos dos páozinhos. Về-se, por este exemplo, que nào sào sómente as casas de cupim e de abelhas, mas tambem as dos Trichopteros, que podem ser habitadas por especies intrusas, e que por isso nem sempre os insectos desta ordem podem ser considerados sem mais prova e exame, como os archi-
Wreise befestigen und rerschliessen sollten?

Indessen ist die Thatsache selır einfach. Die Futterale Hagen's waren Grumichafutterale, bewohnt, befestigt und verschlossen von einer anderen, eingedrungenen Art.

In Bache Garcia, nahe ciner Stelle, wo Grumicha sehr häufig ist, habe ich ebenfalls kürzlich einige Grumichagehäuse gefunden, die durch einen Stein verschlossen und mit dem Bauchrande der vorderen Oeffnung mittels ainer stiellosen, bräunlichgelb gefärbten, lederartigen Querscheibe (Fig. 9, d) befestigt waren. Indem ich eines dieser Futterale öfncte, sah ich, dass es keine Grumichapuppe, sondern vielmehr einc Puppe enthielt, die mit derjenigen der Holzstäbcheı (Fig. 7) identisch oder ihr wenigstens sehr ähnlich war. Das Futteral war, wie die Höhlung der Stäbchen, mit einer Haut ausgekleidet, die um die Puppe herum einen hinten von einem Quersieb begrenzten Kokon bildete; eben so war auch die Haut, die den zwischen dem Futteral und dem als Deckel dienenden Stein befindlichen Zwischenraum verschloss (Fig. 9 B), siebartig durchlöchert.

Die Insekten, deren Larven als Eindringlinge in den Grumichafutteralen leben, und dic der Stäbchen, sind sehr ähnlich; von den einen und anderen sah ich nur schr wenige und habe sie noch nicht im Einzelnen untersucht; bis jetzt besteht der einzige Unterschied, den ich zwischen ihnen gefunden habe, in der Farbe, die bei allen Eindringlingen viel blasser, bei den Insekten der Stäbchen dunkler ist. Man sieht aus diesem Beispiele, dass nicht nur die WTohnungen der Termiten und Bienen, sondern auch die Gehäuse der Trichopteren von eingedrungenen Arten bewohnt sein können, und desshalb auch die Insekten dieser 
tectos das casas, em que tiverem soffrido a sua transformaçào.

No Ribeirào da Grutu dos Macacos Affenwinkel» vive uma segunda especie de Grmmicha (fig. 10), que ainda não ('ncontrei em outra parte. E' muito menor. c por isso vou designal-a pelo diminutivo Grumichinlia. O seu comprimento nào exicede a $10^{\mathrm{mm}}$. Os estojos das cluas especies são curvados exactamente da mesma mancira. sendo o raio da curvatura cle $3 \mathrm{~cm}$., pouco mais ou menos. Tambem em tudo o mais, as duas especies sào muito semelhantes, e, abstrahindo-se do tamanho, a descripção de St. Hilaire applica-se tambem perfeitamente á Grumichinha; sào tubos de uma substancia dura, cornea, lisos, polidos, pretos, arqueados, levemente adelgaçados como um chifre: D'ahi seria difficillimo distinguir as duas especies antes de haver a Grumicha ultrapassado as dimensões da Grumichinlıa, se não fosse assás differente a estructura das larvas que produzem estojos tão semelhantes. Facilmente se distinguem as duas especies pela côr das pernas, mesmo sem proceder a um exame minucioso de sua estructura; sendo as pernas da Grumicha pretas e lustrosas, e as da Grumiclininla pallidas e pardacentas. De vinte estojos adultos (já fixados) que medi, o menor tinha $6^{\mathrm{mm}}$, o maior $\mathrm{Io}^{\mathrm{mm}}$ de comprimento, sendo o comprimento médio de $7^{\mathrm{mm}}$; não havendo, como na Grumicha dous grupos bem separados de estojos maiores e menores, correspondentes aos dous sexos masculino e feminino. A maneira de fixar e fechar os estojos é quasi identica á da Grumicha; sómente é de notar que o peciolo do disco adhesivo nasce da margem ventral da entrada, o que quasi nunca se dá com a Grumicha; além disto a fenda do operculo
Ordnung nicht immer ohne weitere Probe und Untersuchung als die Verfertiger der Gehäuse, in denen sie ihre Umwandlung durchmachen, betrachtet werden können.

Im Bache „Affenwinkel“ lebt eine zweite Grumicha-Art (Fig. 10), die ich sonst noch nirgend angetroffen habe. Sic ist viel kleiner und ich will sie desshalb mit dem Verkleinerungsworte Grumichinha bezeichnen. Ihre Länge übersteigt nicht $10 \mathrm{~mm}$. Die Futterale beider Arten sind genau auf dieselbe Weise gekrümmt, inden der Radius der Krümmung ungefähr $3 \mathrm{~cm}$ beträgt. Eben so sind in allen oder den meisten Stücken beide Arten sehr ähnlich und, abgesehen von der Grösse, passt die Beschreibung St. Hilaire's eben so gut auf Grumichinha; es sind „Röhren von einer harten, hornigen Substanz, glatt, glänzend, schwarz, gebogen und an Dicke etwas abnehmend, wie ein Horn". Es würde daher selır schwierig sein, beide Arten zu unterscheiden, bevor die Grumicha die Dimensionen der Grumichinha überschritten hat, wenn nicht der Bau der Larven, die so ähnliche Futterale hervorbringen, ziemlich verschieden wäre. Die beiden Arten lassen sich leicht an der Farbe der Beine unterscheiden, selbst ohne dass man auf eine Untersuchung der Einzelheiten ihres Baues eingeht; denn bei Grumicha sind die Beine schwarz und glänzend, bei Grumichinha blass und bräunlichgelb. Von 20 erwachsenen (schon befestigten) Gehäusen, die ich mass, hatte das kleinste $6 \mathrm{~mm}$, das grösste $10 \mathrm{~mm}$ Länge, im mittleren Durchschnitt betrug die Länge $7 \mathrm{~mm}$; zweierlei scharf getrennte Gruppen grösserer und kleinerer Futterale, wie sie bei Grumicha den beiden Geschlechtern entsprechen, sind bei Grumichinha nicht vorhanden. Ihre Art und Weise, die Futterale zu befestigen, ist fast dieselbe wie bei Grumicha; nur ist zu bemerken, dass der Stiel 
(fig. Io, $B$ ) acha-se sempre collocada por cima do centro e não por baixo, como na Grumicha (fig. 8, $C, D)^{1}$ ).

Em um ribeirinho, tributario do Ribeiriò do Garcia, em cujas aguas quasi estagnadas abunda uma especie de Callitriche, achei una larva de um Trichoptero, que, pelas suas pernas posteriores, muito delgadas e compridas, parece pertencer á familia das Leptocerideas, larva esta que faz a sua casa com as sementes da mesma Callitriche (fig. I I). A's vezes, em parte da casa, as sementes são substituidas por pequenos fragmentos do casulo da Callitriche. As sem entes são collocadas transversalmente isto é, em planos perpendiculares ao eixo da casa, a qual é quasi cylindrica, um pouco mais estreita na parte posterior As casas têm de 5 a $6^{\mathrm{mm}}$ de comprimento sobre cerca de $2^{\mathrm{mm}}$ de diametro. $\mathrm{O}$ aspecto da entrada é bastante variavel, segundo o numero das sementes que a limitam; ás vezes é um triangulo equilatero ou isosceles (fig. I $1, B$ ). outras vezes um quadrilatero regular ou irregular, etc. Quando estão para se transformar, as larvas fecham a entrada com uma membrana transversal, deixando no centro um pequeno buraco.

Nos remansos dos ribeiros maiores, v. g. do Ribeirào do Garcia, vive nos troncos de arrores que alli apodrecem, ou tambem nas pedras, uma larva da familia das Leptocerideas (fig. I2), que faz os seus estojos ou casas de fibras vegetaes ou pedacinhos de madeira estreitos e compridos que ella provavel-

1) No salto da «Triste Miseria» de Blumenau, vive una terceira especie ainda menor de Grumichas, cuja descripcĩo darei em um supplemento í estc trabalho. der Klebscheibe vom Bauchrande des Einganges ausgeht, was bei Grumicha fast niemals vorkommt: ausserdem befindet sich die Spalte des Deckels (Fig. Io $B$ ) immer über dessen Mitte und nicht unter derselben wie bei Grumicha (Fig. $8 C, D)^{1}$ ).

In einem Bächelchen, das in den Bach Garcia fliesst, und in dessen etwas sumpfigem Wasser eine Callitriche-Art ungemein häufig ist, fand ich eine Trichopterenlarve, die nach ihren sehr dünnen und langen Hinterbeinen zur Familie der Leptoceriden zu gehören scheint. Sie verfertigt ihr Gehäuse aus den Samen dieser Callitriche (Fig. I I). Manchmal sind in einem Theil des Gehäuses die Samen durch kleine Bruchstücke der Kapseln der Callitriche ersetzt. Die Samen sind quer gestellt, d. h. senkrecht zur Achse des Gehäuses, das fast cylindrisch, nur am hinteren Ende etwas verengt ist. Die Gehäuse haben 5 bic $6 \mathrm{~mm}$ Länge bei etwa $2 \mathrm{~mm}$ Durchmesser. Ihr Eingang sieht sehr verschieden aus, je nach der Zahl der Samen, die ihn umgrenzen, manchmal stellt er ein gleichseitiges oder gleichschenkeliges Dreieck dar (Fig. I I $B$ ), andere Male ein regelmässiges oder unregelmässiges Viereck u. s. w.. Wenn die Larven im Regriff sind, sich zu verwandeln, schliessen sie den Eingang mit einer Querhaut, in deren Mitte sie ein kleines Loch lassen.

In stehendem Wasser der grösseren Bäche, z. B. des Baches Garcia, lebt an Baumstämmen, die dort verwesen, oder auch an Steinen, eine Larve aus der Familie der Leptoceriden (Fig. I 2), die ihre Futterale oder Grehäuse aus Pflanzenfasern oder dünnen und langen IIolzstückchen macht, die sie wahrscheinlich

I) In der Gebirgsschlucht: "Trauriger Jammer“ in Blumenau lebt eine dritte, noch kleinere Art von Crumicha, deren Beschreibung ich in einem Nachtrage zu dieser Arbeit geben werde. 
mente tira das arvores em que vive. A largura destes pequenos fragmentos $\therefore$ ordinariamente de cerca de $0,{ }^{\mathrm{mm}} 25$. variando o comprimento, de 1 até mais de $10^{\mathrm{mm}}$. O maior dos estojos ainda livres, que vi tem $20^{\mathrm{mm}}$ de comprimento, da extremidade posterior até á margem superior, e $17^{\mathrm{mm}}$ até $i$ margem inferior da entrada; o diametro é de $2^{\mathrm{mm}}$ na entrada, e de $1^{\mathrm{mm}}$ na extremidade posterior; é pois muito adelgaçado, e ao mesmo tempo muito pouco arqueado, sendo o raio da curvatura da face ventral de cerca de $8 \mathrm{~cm}$. As fibras são dispostas em sentido longitudinal, parallelamente ao eixo, na face dorsal da casa; cerca de meia duzia dessas fibras longitudinaes prolongam-se além da margen superior da entrada, escondendo e protegendo a cabeça da larva. As fibras da face dorsal têm 5 a $6^{\mathrm{mm}}$ de comprimento, havendo comtudo algumas de mais de I $\mathrm{O}^{\mathrm{mm}}$. As fibras das faces lateraes têm o mesmo comprimento e uma direcção obliqua, convergindo para o lado ventral e o extremo posterior da casa, e formando um angulo muito agudo com as do lado opposto. Emfim na face ventral, as fibras são muito mais curtas, de 1 até $2^{\mathrm{mm}}$ de comprimento, formando na parte anterior da casa angulos quasi rectos nào só as cle um, como as de outro lado. Esta disposição das fibras é quasi a mesma em todas as casas que vi, si ben que nem sempre seja tão regular como a que acabo de descrever. As larvas frequentemente fixam no extremo posterior da casa uma ou duas fibras muito longas, que excedem ás vezes o comprimento de toda a casa. Em uma das casas vi coberta a maior parte da superficic só de pedacinhos pretos de madeira, que apenas têm metade dà largura habitual, provenientes provavelmente do tronco de alguma samambaia. As casas das nymphas são mais curtas do que as das von clen Bäumen entnimmt, an denen sic lebt. Die Dicke dieser kleinen Bruchstücke ist gewöhnlich ungefähr $0,25 \mathrm{~mm}$, bei einer zwischen I bis I o mm wechselnden Länge. Das grösste der noch freien Futterale, das ich sah, hatte 20 mm I,änge vom hinteren Ende bis zum oberen Rande und I7 $\mathrm{mm}$ bis zum unteren Rande des Einganges; der Durchmesser beträgt $2 \mathrm{~mm}$ am Eingang und I mn am hinteren Ende; es ist also stark verdünnt, und gleichzeitig sehr wenig gebogen, da der Radius der Krümmung der Bauchfläche ungefähr $\delta \mathrm{cm}$ beträgt. Auf der Rückenfläche des Gehäuses sind die Fasern, der Länge nach, parallel der Achse geordnet; etwa ein halbes Dutzend dieser Längsfasern verlängern sich über den oberen Rand des Einganges hinaus und verbergen und schützen so den Kopf der Larve. Dic Fasern der Rückenfläche haben 5 bis $6 \mathrm{~mm}$ länge, einige kommen indess vor von mehr als ro mm Länge. Die Fasern der Seitenflächen haben dieselbe Länge und eine schiefe Richtung, indem sie nach der Bauchseite und dem hinteren Ende des Gchäuses zu konvergiren und mit denen der entgegengesetzten Scite cinen schr spitzen Winkel bilden. Auf der Bauchseite endlich sind die Fasern viel kürzer, von I bis $2 \mathrm{~mm}$ längc, und dic der einen bilden mit denen der anderen Seite in vorderen Theile des Gehäuses ziemlich rechte Winkel. Diese Anordnung der Fasern ist bei allen Gehäusen, die ich geschen habe, ziemlich dieselbe, wenn sie auch nicht immer so regelmässig ist, wic ich soeben beschrieben habe. Dic Larven befestigen häufig am hinteren Ende des Gehäuses eine oder zwei sehr lange Fasern, die manchmal länger sind als das ganze Gehäuse. An einem der Gchäuse sah ich den grössten Theil der ()berfläche nur mit schwarzen Holzfäiserchen bedeckt, die kitum die I Iälfte 
larvas adultas; oito, que medi, variavam entre 9 e $10,{ }^{\mathrm{mm}} 5$ de comprimento; costumando as larvas cortar a parte posterior de suas casas antes de fixal-as.

Ambas as extremidades de cada casa sìo fixadas por meio de um disco adhesivo peciolado, que geralmente parte da margem ventral, e raras vezes da margem lateral (como acontece na extremidade anterior da fig. 12, $A, A^{\prime}$ ). Os dous orificios anterior e posterior sìo fechados por um operculo membranoso, apresentando no centro uma fenda elliptica de cerca de $\mathrm{O}^{\mathrm{mm}}{ }_{1}$ de largura sobre $\mathrm{O},{ }^{\mathrm{mm}}+$ de comprimento. A fenda posterior é vertical, dirigindo-se do lado dorsal ao ventral; ignoro ainda qual a direcçăo da fenda anterior por só ter visto operculos soltos.

Pelo modo de fixar os seus estojos, assim como pela direcção vertical da fenda posterior, assemelha-se á especie precedente uma outra (fig. 13), cujos estojos são aliás de aspecto muito diverso. São tubos estreitos, roliços, quasi rectos, e pouco adelgaçados na parte posterior. Estes tubos são feitos de uma membrana resistente e elastica, coberta de areia tĩo fina que mais facilmente se descobre pelo tacto do que pela vista, dando aos tubos um aspecto perfeitamente liso c polido. A côr pardo-escura ć devida a supracitada membrana; e nào á areia que os cobre, a qual é geralmente composta de grăozinhos de quarzo hyalino de $\mathrm{O}^{\mathrm{mm} \mathrm{O}_{5}}$ até $\mathrm{O}^{\mathrm{mm}} \mathrm{I}$ de diametro. O comprimento dos estojos fixados é de 7 a $8,{ }^{\mathrm{mm}} 5$; o diametro anterior dos maiores é de cerca de $1,{ }^{\mathrm{mm}} 2$, e dos menores $0,{ }^{\mathrm{mm}} 9$, de modo que mais differem elles pela der gewöhnlichen Dicke batten und wahrscheinlich von dem Stamme einer-Samambaia entnommen waren. Die Puppengehäuse sind kürzer als die der erwachsenen Larven; acht, die ich mass, variierten zwischen 9 und 10,5 $\mathrm{mm}$ Länge; das kommt daher, dass die Larven gewohnt sind, den hinteren Theil ihrer Gehäuse abzuschnciden, bevor sie dieselben befestigen.

Beide Enden jedes Gehäuses werden mittels einer gestielten Haftscheibe befestigt, die gewöhnlich vom Bauchrande, in seltenen Fällen (wic z. B. am vorderen Ende der Fig. $12 A, A^{\prime}$ ) vom Seitenrande ausgeht. Die vordere und hintere Oeffnung sind beide mit einem häutigen Deckel verschlossen, der in der Mittu einen elliptischen Spalt von ungefähr $0,1 \mathrm{~mm}$ Breite bei $0,4 \mathrm{~mm}$ Länge darbietet. Der hintere Spalt ist senkrecht, von der Rücken- nach der Bauchseite gerichtet: welche Richtung der vordere Spalt hat, weiss ich noch nicht, da ich nur lose Deckel gesehen habe.

In der Art, ihre Futterale zu bebefestigen und in der senkrechten Richtung des hinteren Spaltes stimmt mit der eben besprochenen Art eine andere (Fig. 13) überein, deren Futterale übrigens von sehr verschiedenem Ausschen sind. Es sind enge, runde, fast gerade, im hinteren Theile etıvas verdünnte Röhren. Diese Röhren sind aus einer widerstandsfähigen und elastischen Haut gemacht, die mit so feinem Sande bedeckt ist, dass man ihn leichter durch das Gefülıl als durch das Gesicht entdeckt, da er den Röhren ein vollkommen glattes und glänzendes A ussehen gibt. Seine dunkelbraune Farbe verdankt das (ichäuse der oben crwähnten Haut, nicht dem Sande, der sie bedeckt und der gewöhnlich aus durchsichtigen Quarzkörnchen von 0,05 bis o,1 mm Durchmesser zusammengesetzt ist. Die Länge der befestigten l'utterale 
grossura do que pelo comprimento, sendo o diametro da extremidade posterior igual a $2 / 3$ pouco mais ou menos do da extremidade anterior.

Entre os estojos livres encontrei alguns, cujo comprimento era quasi o dobro do dos fixos; nestes estojos a extremidade posterior era muito delgada e sensivelmente curva. Sào os estojos fixados pela margem ventral de ambas as extremidades; sendo os discos adhesivos ordinariamente bilobados ou chanfrados (fig. I 3, $A^{\prime}$ ).

Os orificios anterior e posterior são fechados por um operculo membranoso. O operculo anterior (fig. ${ }_{13}, A$ ") tem um orificio central e circular de $0,{ }^{\mathrm{mm}} \mathrm{O} 75$ de diametro, ao redor do qual vêm-se tres zonas ou anneis concentricos, muito distinctos; o segundo é mais escuro do que o primeiro e o terceiro eleva-se como um vallo circular por sobre o nivel delles; sendo muito variavel a largura relativa dos tres anneis.

O operculo posterior (fig. I 3, $A$ "') tem um orificio central elliptico, sendo os eixos da ellipse de cerca de $0,{ }^{\mathrm{mm}} 25 \mathrm{e} \mathrm{O},{ }^{\mathrm{nm}} \mathrm{I}$; o eixo maior é vertical como na especie precedente. Até ha pouco considerei como muito rara esta especie, tendo achado só alguns estojos, tanto em diversos ribeiros menores, como no Ribeirào do Garcia: novamente porém descobri um ponto neste mesmo ribeirão, onde quasi não havia pedra em que nào se achassem fixados de dez a vinte ou mais destes estojos.

A semelhança das duas ultimas especies não se limita aos estojos fixados e fechados do mesmo modo; e a sua beträgt 7 bis $8,5 \mathrm{~mm}$; der vordere Durchmesser der grössten beträgt ungefähr I,2 $\mathrm{mm}$, der der kleinsten $0,9 \mathrm{~mm}$, so dass sie mehr in der Weite als in der Länge differieren, da der Durchmesser des hinteren Endes immer ungefähr $2 / 3$ von dem des vorderen Endes beträgt.

Unter den freien Futteralen traf ich cinige, deren Länge fast das Doppclte der befestigten betrug; bei diesen Futtcralen war das hintere Ende stark verdünnt und merklich gekrümmt. Dic Futterale werden mit dem Bauchrande beider Enden festgeheftet; die Haftscheiben sind gewöhnlich zweilappig oder ausgeschnitten (Fig. I $3 A^{\prime}$ ).

Die hintere und vordere Oeffnung werden beide mit einem häutigen Deckel verschlossen. Der vordere Deckel (Fig. I3, A") hat in der Mitte eine kreisrunde Oeffnung von $0,075 \mathrm{~mm}$ Durchmesser, um welche hcrum man drei sehr verschiedene concentrische Zonen oder Ringe sieht; die zweite ist dunkler als die erste, und die dritte erhebt sich wie ein ringförmiger Wall über das Niveau der beiden anderen; die verhältnismässige Breite der drei Ringe ist sehr variabel.

Der hintere Deckel (Fig. I $3 A$ "') hat in der Mitte eine elliptische Oeffnung; die Achsen der Ellipse betragen ungefähr 0,25 und $\mathrm{o}, \mathrm{I} \mathrm{mm}$; die grössere Achse steht, wie bei der vorhergehenden Art, senkrecht. Bis vor Kurzem betrachtete ich diese Art als sehr selten, da ich sowohl in verschiedenen kleineren Bächen als im Bache Garcia nur wenige Futterale gefunden hatte; neuerdings aber habe ich in demselben Bache eine Stelle entdeckt, wo sich fast an jedem Steine Io bis 20 oder mehr dieser Futterale angeheftet finden.

Die Achnlichkeit der beiden letzten Arten beschränkt sich nicht auf die in gleicher Weise befestigten und ver- 
affinidade manifesta-se tambem pela estructura das larvas, nymphas e insectos perfeitos. As larvas são as unicas entre todas as dos Trichopteros catharinenses que sabem nadar, servindo-se para isso das pernas posteriores, distinguindo-se tambem das outras larvas da familia das Leptocerideas por antennas mais desenvolvidas. As nymphas têm na extremidade do abdomen duas pontas fortes e longas que ellas fazem sahir da fencla posterior com um movimento de vai-e-vem, movimento que provavelmente serve para produzir a corrente d'agua necessaria á respiraçào. Emfim os insectos perfeitos da ultima especie sào dos mais lindos que ha na ordem dos Trichopteros; as suas azas anteriores, amarellas, cobertas de escamas, como nos Lepidopteros, são ornadas de listras transversacs prateadas, a de malhas pretas redondas. Os insectos da especic precedente têm côres semelhantes, porém muito mais desmaiadas.

Ha ainda, nas aguas de Santa Catharina, um outro typo de estojos de Leptocerideas representado por duas especies muito semelhantes, mas de tamanho muito differente (fig. I 4 e 1.5). Esses estojos são feitos de pequenas pedras, e são conicos, curvados, fixados, para a transformação, pela margem ventral de ambas as extremidades, e tapados com pedras, ficando uma fenda semi-lunar guarnecida de dentes ao longo da margem ventral.

Os estojos da especie maior (fig. 14) sào construidos de pedrinhas de cerca de 0 , ${ }^{\text {mm }} \mathrm{S}$ de diametro (variando comtudo de menos de $0,{ }^{\mathrm{mm}} 3$ até $\left.2^{\mathrm{mm}}\right)$; os das larvas adultas são menos curvados e alargados na extremidade anterior do que os das mais novas. Em uma casa de $9^{m m}$ de schlossenen Futterale; ihre Verwandtschaft zeigt sich auch im Bau der Larven, Puppen und fertigen Insekten. Ihre Larven sind die einzigen unter allen der Trichopteren von Sa. Catharina, die schwimmen hönnen, wozu sie sich der I linterbeine bedienen; von den anderen Larven der Familie der 1.eptoceriden unterscheiden sie sich auch durch entwickeltere Fühler. Die Puppen haben am Hinterleibsende zwei starke und lange Spitzen, die sie mit einer hin- und hergehenden Bewegung aus dem hinteren Spalt hervortreten lassen; diese Bewegung dient wahrscheinlich dazu, die für die Athmung nöthige Wasserströmung hervorzubringen. Die fertigen Insekten der letzten Art endlich gehören zu den schönsten, die es in der Ordnung der Trichopteren giebt; ihre gelben, wie bei den Schmetterlingen mit Schuppen bedeckten Vorderflügel sind mit silbernen Querstreifen und schwarzen runden Flecken geschmückt. Die Insekten der vorhergehenden $\Lambda \mathrm{rt}$ haben ähnliche, jedoch viel verwaschenere Farben.

Es gibt noch einen anderen Typus von Leptoceriden-Futteralen in den Gewässern von Santa Catharina, der durch zwei sehr ähnliche, aber an Größe schr verschiedene Arten (Fig. I 4 und 15) vertreten ist. Ihre Futterale sind von kleinen Steinchen gemacht; sie sind kegelförmig; gekrümmt; für die Umwandlung werden sic mit dem Bauchrande beider Enden befestigt und mit Steinen verschlossen, so dass eine halbmondförmige Spalte frei bleibt, die längs des Bauchrandes mit Zähnen besetst ist.

Die Futterale der grösseren $\mathrm{Art}$ (Fig. 14) sind aus Steinchen von ungefähr o,8 mm Durchmesser (im Ganzen wechseln sie ron weniger als o, 3 bis $2 \mathrm{~mm}$ ) angefertigt; die der erwachsenen I arven sind weniger gekrümmt und am vorderen Ende erweitert, als die der jüngern. 
comprimento o extremo anterior tinha $3^{\mathrm{mm}}$, o posterior $\mathrm{I}^{\mathrm{mm}}$ de diametro, sendo o raio da curvatura do lado ventral de cerca de $\mathrm{I}^{\mathrm{cm}}$. Pelo contrario, em um estojo já fixado de $15^{\mathrm{mm}}$ de comprimento, o extremo anterior tinha 4 , o posterior $3^{\mathrm{mm}}$ de diametro, e o raio da curvatura do lado ventral tinha cerca de $3^{\mathrm{cm}}$. O orificio posterior do estojo das larvas (fig, I4, $A^{\prime}$ ) é fechado por uma parede transversal de uma substancia parda ou preta, dura, semelhante á dos estojos da Grumicha, à qual geralmente se acham colladas algumas pedrinhas; essa parede occupa os dous terços inferiores da altura do dito orificio, ficando aberto o terço superior ou dorsal, sendo este orificio limitado em baixo por uma linha recta. Os estojos são fixados em angulos reintrantes ou fendas, do lado inferior das pedras, pela margem ventral de ambos os extremos, por meio de um ligamento duro, curto e largo, occupando $1 / 4$ até $1 / 3$ da circumferencia do estojo (fig. I $4, B^{\prime}, C^{\prime}, E$ ).

Para poder fixar a margem iventral do extremo posterior, a larva deve evidentemente remover a parede transversal que alli ha; quando depois vai fechar de novo a sua casa, segue um plano inteiramente diverso, deixando uma fenda estreita entre as margens ventraes da parede transversal e do estojo (fig. 14, $E$ '). Além disso ella faz nesta fenda, ao longo da margem ventral do estojo, uma fileira de 12 para I $_{5}$ dentes (fig. 14, $B^{\prime \prime}$ ), que constam da mesma substancia dura e escura do operculo. O extremo anterior é fechado da mesma maneira, notando-se que os dentes a fenda costumam ser menores e mais numerosos (fig. 14, C"). A superficie externa dos operculos é quasi sempre
An einem Gehäuse von $9 \mathrm{~mm}$ länge hatte das vordere Ende $3 \mathrm{~mm}$, das hintere $1 \mathrm{~mm}$ Durchmesser; der Radius der Krümmung der Bauchseite betrug ungefähr $1 \mathrm{~cm}$. Dagegen hatte an einem schon befestigten Futteral von $15 \mathrm{~mm}$ länge das vordere Ende $4 \mathrm{~mm}$. das hintere $3 \mathrm{~mm}$ Durchmesser, und cler Radius der Krümmung der Bauchseite betrug ungefähr $3 \mathrm{~cm}$. Die hintere Oeffnung des Larvenfutterals (Fig. I $4 A^{\prime}$ ) ist mit einer Querwand verschlossen, die aus einer braunen oder schwarzen, harten Substanz, ähnlich der der Grumichafutterale besteht, an welche angeleimt sich gewöhnlich einige Steinchen finden; diese Wand nimmt die zwei unteren Drittel der Höhe der besagten Oeffnung ein; das obere, dorsale Drittel lässt sic offen; diese Oeffnung ist unten von einer geraden Linie begrenzt. Die Futterale sind in einspringenden Winkeln oder Spalten der unteren Seite der Steine befestigt und zwar mit dem Bauchrande beider Enden, mittels eines harten, kurzen und breiten Bandes, das $1 / 4$ bis $1 / 3$ des Umfanges des Futterales einnimmt (Fig. I 4 $\left.B^{\prime}, C^{\prime}, E^{\prime}\right)$.

Um den Bauchrand des hinteren Endes befestigen zu können, muss die Larve offenbar die dort vorhandene Querwand entfernen; wenn sie dann ihr Gehäuse wieder verschliessen will, befolgt sic einen ganz verschiedenen Plan, indem sie einen engen Spalt zwischen den Bauchrändern der Querwand und des Futterals frei lässt (Fig. ${ }_{4} E^{\prime}$ ). Uebcrdies macht sie in diesen Spalt, längs dem Bauchrande des Futterals, eine Reihe von 12 bis 15 Zähnen (Fig. 14 B'), dic aus derselben harten und dunkeln Substanz bestehen, wie der Deckel. Das vordere Ende wird auf dieselbe Weise befestigt; nur pflegen die Zähne des Spaltes kleinor und zahlreicher zu sein (lig. 14 C"). Die äussere Oberfläche 
coberta de pequenas pedras chatas (fig. $\left.14, B^{\prime}, C^{\prime}\right)$. A fenda posterior não se acha geralmente na extremidade. e sim um pouco recolhida para dentro, sendo a parte ventral do operculo um tanto curvada para o interior do estojo (fig. 14, $\left.E^{\prime}, E^{\prime \prime}\right)$.

Assim como na Grumicha, os estojos das nymphas podem ser scparados pelo seu tamanho em dous grupos distinctos, tendo os maiores (fig. 14, D,E) cerca de $15^{\mathrm{mm}}$, e os menores (fig. $\mathbf{1} 4, B, C$ ) cerca de $12^{\mathrm{mm}}$ de comprimento; é muito provavel que, como naquella especie, os maiores sejam habitados por femeas e os menores por machos.

Os estojos da especie menor (fig. 15) são em tudo semelhantes aos da maior; o comprimento dos adultos é de 8 até $9^{\mathrm{mm}}$, sendo o diametro anterior de cerca de 2 e o posterior de cerca de $\mathbf{I},{ }^{\mathrm{mm}} 5$, e o raio da curvatura do lado ventral de certa de $15^{\mathrm{mm}}$. São construidos de pedrinhas menores, não excedendo geralmente a $0,{ }^{\mathrm{mm}} 5$. O orificio da parte superior da parede transversal que tapa o orificio posterior (fig. ${ }_{15}, A^{\prime}$ ) é de fórma oval, sendo limitado em baixo por um arco, ə não por uma linha recta, como na especie maior. Esta parede costuma ser de côr parda centa, mais escura em redor do buraco, algumas vezes pallida c outras preta.

A maneira de fechar e fixar o estojo para a transformação em nympha é identica á da especie maior; a unica differença digna de notar-se está nas pedras usadas no operculo anterior; em vez de algumas pedras menores chatas e que não se elevam a cima do plano da entrada, a especie menor tapa os orificios tanto anterior como posterior do estojo com uma unica pedrinha, que der Deckel ist fast immer mit kleinen flachen Steinen bedeckt (Fig. ${ }_{4} B^{\prime}, C^{\prime}$ ). Der hintere Spalt findet sich in der Regel nicht am Encle, sondern ist ein wenig nach innen zurückgezogen, inclem der Bauchtheil des Deckels sich etwas in das Innere des Futterals krümmt (Fig. I 4 E', E').

Wic bei Grumicha können die Juppengehäuse nach ihrer Grösse in zwvei verschiedene Gruppen getheilt worden; dic grösseren (Fig. 14, D, E) haben ungefähr $15 \mathrm{~mm}$, die kleineren (Fig. ${ }_{4} B, C$ ) ungefähr $12 \mathrm{~mm}$ länge; es ist schr wahrscheinlich, class, wic bei jener Art die grösseren von Weibchen, die kleineren von Männchen bewohnt sind.

Die Futterale der kleineren Art (Fig. I5) sind im Ganzen denen der grösscren ähnlich; die Länge cler erwachsenen beträgt $8-9 \mathrm{~mm}$, der vordere Durchmesser ungefähr 2, der hintere ungefähr I $1 \%$ mm, der Radius der Krümmung der Bauchseite ungefähr $15 \mathrm{~mm}$. Sie sind aus kleineren Steinchen angefertigt, dic im Allgemeinen $0,5 \mathrm{~mm}$ nicht überschreiten. Die Oeffnung des obcren Theils der Querwand, wclche die hintere Oeffnung verschliesst (Fig. ${ }_{5} A^{\prime}$ ) ist von ovaler Form, unten von einem Bogen begrenzt, und nicht von einer geraden Linic wie bei der grösseren Art. Diese Wand pflegt von bräunlicher Farbe zu scin, dunkler um die Oeffnung herum, manchmal blass, andere Male schwarz.

Die Art, das Futteral zur Verwandlung in die Puppe $\mathrm{zu}$ verschliessen und zu bofestigen ist dieselbe wie bei der grösseren Art; der einzige bemerkenswerthe Unterschied besteht in den zum vorderen Deckel gebrauchten Steinen; statt einiger kleinerer platter Steine, die sich nicht über die Ebene des Einganges crheben, verstopft die kleinere Art sowohl die vordere als die hintere Oeff- 
costuma sahir muito para fóra dos mesmos orificios (fig. ${ }_{15}, B^{\prime}, B^{\prime \prime}$ ).

Por mais irregulares que pareçam estas pedrinhas, vistas de fóra. ellas não deixam comtudo de ser escolhidas com muito cuidado; examinando-as depois de removidas pela nympha an sahir do estojo, vê-se que todas ellas têm uma face quasi plana e circular, igual ao orificio do estojo, para o interior do qual está voltada.

\section{$\$$ t.}

Casas de especies de posição incerta (fig. 16-17).

Ainda não pude examinar insectos perfeitos, nem mesmo nymphas das duas especies seguintes, nem tão pouco achei nas larvas caracteres que me permittissem determinar com certeza a familia a que pertencem; só posso dizer que, ou são Leptocerideas ou Sericostomideas. Em favor desta ultima familia podem ser citados os angulos anteriores do prothorax, prolongados nas larvas da primeira especie em pontas agudas e compridas, o que faz lembrar os angulos anteriores dos segmentos thoracicos pontudos que, segundo Pictet, caracterisam as larvas do genero Trichostoma da familia das Sericostomideas ${ }^{1}$ ). As casas das duas especies são achatadas e feitas de folhas: as da primeira especie (fig. I6) constam quasi sempre de quatro pedaços de folhas, formando dous o lado ventral e os outros dous o lado dorsal; o seu tamanho, assim comn a sua figura são extremamente variaveis, como mostram as figuras $16, A, B, C, D$, todas de tamanho natural. O que é constante é:

I) Westwood, Introduct. to mod. classif. of Insect. I1. p. 68. nung des Futterals mit einem einzigen Steinchen, welches weit über diese Oeffnungen nach aussen vorzuspringen pflegt (Fig. $\left.{ }^{5}, B^{\prime} B^{\prime \prime}\right)$.

So unregelmässig diese Steinchen, von aussen geschen, erscheinen, so sind sie doch stets mit vicler Sorgfalt ausgesucht; wenn man sie untersucht, nachdem sie die Puppe bei ihrem Ausschlüpfen aus dem Futteral entfernt hat, sieht man, dass sie alle eine fast ebene und kreisförmige Fläche haben, gleich der Oeffnung des Futterals, dessen Innerem diese Fläche zugewendet ist.

4) Gehäuse von Arten unsicherer systematischer Stellung

(Fig. 16, 17).

Von den beiden folgenden Arten habe ich bis jetzt weder die fertigen Insekten, noch auch die Puppen untersuchen können, eben so wenig habe ich an den Larven Merkmale gefunden, die mir gestattet hätten, die Familie, zu der sie gehören, mit Sicherheit zu bestimmen; ich kann nur sagen, dass es entweder I.eptoceriden oder Sericostomiden sind. $\mathrm{Zu}$ Gunsten dieser letzteren Familie können die Vorderecken des Prothorax angeführt werden, die bei den Larven der ersteren Art in scharfe und lange Spitzen ausgezogen sind, was an clie zugespitzten Vorderecken der Brustringe erinnert, die, nach Pictet, die Larven der Gattung Trichostoma aus der Familie der Sericostomiden charakterisieren ${ }^{1}$ ). Die Gehäuse beider Arten sind plattgedrückt und aus Blättern gemacht; die der ersteren Art (Fig. I6) bestehen fast immer aus vier Blattstücken, von denen zwei die Bauchseite und die beiden anderen die Rückenseite bilden; ilıre Grösse und Gestalt sind im höchsten

I) Westwood, Introduct. to mod. classific. of Insects. II. p. 68 
$I^{0}$, que as duas folhas anteriores cobrem a parte anterior das posteriores; $2^{0}$, que a folha dorsal anterior estende-se muito além da ventral, protegendo deste modo a cabeça da larva; $3^{0}$, que a face superior das folhas é roltada para o interior da casa o a face inferior para fóra. Esta ultima regra parece não ter excepção, em talvez que dous motivos concorra para que a larva colloque as follhas sempre desta maneira, porque, não sú a face inferior ć menos livre por causa das nervuras, como tambem é mais facil curvar qualquer folla, de modo que a face inferior se torne convexa e a superior concava, do que em sentido oppostn. As folhas estendem-se geralmente para os lados, muito além da cavidade interna da casa (fig. $16, E$ ), que é revestida de uma membrana tenuissima, cuja secção transversal é de fórma elliptica, sendo a altura igual é metade pouco mais ou menos da largura. As dimensões da cavidade interna são muito menos variaveis do que as das folhas; clla poderá ter uns $15^{\mathrm{mm}}$ de comprimento sobre $4^{\mathrm{mm}}$ de largura e $2^{\mathrm{mm}}$ de altura. $A$ casa das nymphas é fixada sómente pelo extremo anterior, por meio de alguns fios de seda, partindo de cada lado da entrada, c a cavidade interna fechada em um e outro extremo por um crivo (fig. i6, $\left.D^{\prime}\right)$. Esta especie, si bem que não seja muito frequente, vive nas localidades as mais differentes, tanto em aguas quasi estagnadas, como em corregos de rapido curso. Para fixar-se, ella prefere ás pedras os troncos de arvores que cahiram n'agua.

A segunda especic (fig. 17) é muito notavel pelo lugar insolito, em
Grade wechselnd, wie dic Figuren I6 $A$, $B, C, D$, alle in natürlicher (rrösse, zeigen. Was konstant ist, ist I) dass die beiden vorderen Blätter den vorderen Theil der hinteren bedecken; 2) dass das vordere Rückenblatt sich nach vorn weit über das Bauchblatt hinaus ausdehnt, so dass es auf diese Weise den Kopf der Larve schütat; 3) dass die obere Fläche der Blätter dem Inneren des Gehäuses zugekehrt und die untere nach aussen gewendet ist. Diese letzte Regel scheint keine Ausnahme zu haben, und es wirken vielleicht zwei Beweggründe dahin zusammen, dass die Larve die Blätter immer in dieser Weise legt, da nicht nur die untere Fläche wegen der Nerven weniger glatt ist, sondern es auch leichter ist, irgend ein Blatt so zu krümmen, dass die untere Fläche sich konvex biegt und die obere konkav, als in entgegengesetztem Sinne. Die Blätter dehnen sich im Allgemeinen nach den Seiten weit über die innere Höhlung des Gehäuses (Fig. I6 $E$ ) aus, die mit einer sehr dünnen Haut ausgekleidet ist; der Querschnitt derselben ist von elliptischer Gestalt, ungefähr halb so hoch als breit. Die Dimensionen des inneren Hohlraumes sind viel weniger variabel als die der Blätter; er hat etwa I $_{5} \mathrm{~mm}$ Länge bei $4 \mathrm{~mm}$ Breite und $2 \mathrm{~mm}$ Höhe. Das Puppengehäuse ist nur mit dem vorderen Ende befestigt, und zwar vermittelst einiger Seidenfäden, die von beiden Seiten des Einganges ausgehen; der innere Hohlraum ist an jedem der beiden Enden mit einem Siebe (Fig. I6 D') verschlossen. Diese Art ist zwar nicht sehr häufig, sie lebt aber an den verschiedensten Oertlichkeiten, sowohl in fast stagnirenden Gewässern, als in Quellen von raschem Lauf. Um sich festzusetzen, zieht sie den Steinen die ins Wasser gefallenen Baumstämme vor.

Eine zweite Art (Fig. I7) ist sehr bemerkenswerth durch den ungewöhn- 
que as larvas têm a sua residencia. Entre as folhas das Bromeliaceas que abundam como parasitas nas arvores do matto virgem, ajunta-se e conserva-se por muito tempo agua de chuva, assim como uma variedade extraordinaria de substancias regetaes: fragmentos de ramos, folhas, flores. fructos e sementes, que ás vezes alli gorminam; não é raro vêr-se um pésinho de gissara elevando-se entre as folhas de alguma Bromelia; encontra-se emfim, nutrindo-se daquelle's restos vegetaes mais ou menos apodrecidos ou transformados em humus, uma multidào de animaes terrestres e aquaticos: Planarias (Geoplana), Hirudineas (Clepsine), Oniscos, Centopeias, Formigas, larvas de dipteros, de Lavadeiras, Pererecas, etc. Um dia limbrei-me que, como tantas outras larvas aquaticas, tambem podia viver naquelles tanques acreos a larva de algum Trichoptero. Tomei o facão e fui an matto. Mal tinha cortado c examinado uma duzia de Bromelias, encontrei logo uma casa de Trichoptero, differente de todas quantas tinha visto em outros logares, com quanto muito semelhante ás da especie precedente. Como a daquella, esta é feita de pedaços de folhas, e com effeito é a só cousa que a larva tem alli á sua disposição. A construcção da casa é apparentemente muito semelhante á da ultima especie, mas bastará apresentar as seguintes differenças para bem distinguil-as:

$1 .{ }^{0}$ As casas são muito menores; a maior que vi tem $14^{\mathrm{mm}}$ de comprimento sobre $4^{\mathrm{mm}}$ de largura; a cavidade interna tem cerca de $2^{\mathrm{mm}}$ de largura sobre $1^{\mathrm{mm}}$ de altura. lichen Ort, an dem die Larve ihren Wohnsitz hat. Zwischen den Blättern der Bromeliaceen, die an den Bäumen des Urwaldes in reichlicher Menge schmarotzen, sammelt und erhält sich auf lange Zeit Regenwasser, so wie auch eine ausserordentliche Mannigfaltigkeit vegetabilischer Substanzen: Bruchstücke von Zweigen, Blätter, Blüthen, Früchte und Samen, die bisweilen dort keimen; nicht selten sieht man ein Gissara-Stämmchen sich zwischen den Blättern einer Bromelie erheben; endlich trifft man hier eine Menge Land- und Wasserthiere, die sich von den mehr oder weniger verwesten oder in Humus umgewandelten vegetabilischen Ueberresten nähren: Landplanarien (Geoplana), Blutegel (Clepsine), Asseln, Tausendfüsse, Ameisen, Dipterenlarven, Wasserjungfern etc. Eines Tages fiel mir ein, dass. eben so gut wie so viele andere wasserbewohnende Larven, in diesen luftigen Wasserbehältern auch irgend eine Trichopterenlarve leben könnte. Mit dem Waldmesser bewaffnet ging ich sofort in den Wald und hatte wohl kaum ein Dutzend Bromelien abgehauen und untersucht, als ich auf ein Trichopterengehäuse stiess, das von allen, die ich an anderen Orten gesehen hatte, verschieden war, wenn es auch denen der vorigen Art sehr ähnlich ist. Wie diese ist es aus Blattstücken gemacht und in der That ist das das einzige Baumaterial, das die Larve hier zu ihrer Verfügung hat. Der Bau des Gehäuses ist anscheinend sehr ähnlich dem der letzten Art, es wird aber hinreichen folgende Unterschiede hervorzuheben, um sie sicher zu unterscheiden :

ı) Die Gehäuse sind viel kleiner; das grösste, das ich gesehen habe, hatte $14 \mathrm{~mm}$ Länge bei $4 \mathrm{~mm}$ Breite; der innere Hohlraum hatte etwa $2 \mathrm{~mm}$ Preite bei I $\mathrm{mm}$ Höhe. 
2. ${ }^{\circ}$ O numero dos pedaços de folha é muito maior; geralmente é de 11 (sendo 5 ventraes e 6 dorsales; fig. 17 $A, A^{\prime}$ ) ou de i 3 (sendo 6 ventraes e 7 dorsaes; fig. $\left.17, B, B^{\prime}\right)$; a casa menor que tenho visto tem $7{ }^{m m} 5$ de comprimento, e é composta de 9 pedaços (4 ventraes e 5 dorsaes).

$3 .{ }^{0}$ Esses pedaços de folhas sĩo mais distinctos e regularmente curvados no meio das faces dorsal e ventral.

4. ${ }^{\circ}$ Os mesmos pedaços não excedem muito os lados da cavidade interna; dahi resulta um aspecto muito mais regular e uniforme dessas casinhas.

As arestas lateraes são agudas e quasi rectilineas ou parallelas (fig. I $7, A$ ), ou convergindo sensivelmente para o extremo posterior (fig. I 7, B). A largura desmedida e as margens irregulares de muitas casas da especie precedente não conviriam ao domicilio apertado do hospede das Bromelias ${ }^{1}$ ).

\section{$\$ 5$.}

As casas das Sericostomideas (fig. I 8-21).

A familia das Sericostomideas é até agora representada na provincia de Santa Catharina só polo genero Helicopsyche.

Ora, as casas encaracoladas deste genero já foram descriptas tantas vezes que só valeria a pena fallar nas especies catharinenses, quando fosse possivel comparal-as com as numerosas especies publicadas por varios auctores, e apontar os seus caracteres distinctivos.

I) $\mathrm{Ha}$ ainda uma terceira especie, intermediaria, nas dimensũes da casa e no numero das folhas de que é feita, entre as duas descriptas; hei-de descrevel-a, no supplemento que opportumamente darei ao presente trabalho.

Fritz Müllers gesammelte Schriften.
2) Die Zahl der Blattstücke ist viel grösser; in der Regel beträgt sic II (wovon 5 auf die Bauchseite, 6 auf die Rückenseite kommen, Fig. I7 $A, A^{\prime}$ ) oder I3 6 auf der Bauch-, 7 auf der Rückenseite, Fig. $\left.17 B, B^{\prime}\right)$; das kleinste Gehäuse, das ich gesehen habe, hat $7,5 \mathrm{~mm}$ Länge und ist aus 9 Stücken (4 Bauch- und 5 Rückenstücken) zusammengesetzt.

3) Diese Blattstücke sind schürfer von einander abgesetzt und in der Mitte der Rücken- und Bauchfläche regelmässig gekrümmt.

4) Sie gehen über die Seiten des inneren Hohlraumes nicht viel hinaus; die Gehäuse haben daher ein viel regelmässigeres und gleichartigeres Aussehen.

Die Seitenkanten sind scharf und fast geradlienig, entweder parallel (Fig. 17 A) oder nach hinten merklich konvergirend (Fig. $17 \mathrm{~B}$ ). Die übermässige Breite und die unregelmässigen Ränder vieler Gehäuse der vorhergehenden Art würden für den engen Wohnsitz des Bromeliengastes nicht passen ${ }^{1}$ ).

5) Die Gehäuse der Sericostomiden (Fig. I 8-2 I).

Die Familie der Sericostomiden ist bis jetzt in der Provinz Santa Catharina nur durch die Gattung Helicopsyche vertreten.

Nun sind die schneckenförmigen frehäuse dieser Gattung schon so viele Male beschrieben worden, dass es sich nur dann der Mühe lolnnen würde, von den Arten von Santa Catharina zu sprechen, wenn es möglich wäire, sie mit den zahlreichen, von verschiedenen Autoren ver-

I) Es gibt noch eine dritte $\Lambda \mathrm{rt}$, die in den Dimensionen des Gehäuses und der Zahl der Blätter, aus denen es gemacht ist, zwischen den beiden beschriebenen die Mitte hält. Ich werde sie in einem Nachtrage zu dieser Arbeil beschreiben. 
Limito-me, pois, a dar as figuras das formas que encontrei.

A primeira dellas (fig. I 8) é frequente em diversos corregos de curso rapido $\mathrm{c}$ muito abundante acima do Salto da «Triste Miseria» ("Trauriger Jammer») de Blumenau. Si me não engano, foi esta mesma especie que vi na Serra do Itajahy. A segunda (fig. 19) foi achada só no Ribeirão Branco ("Weissbach»), affluente do Itajahy; a terceira (fig. 20) en remansos do Ribeirão do Garcia; a quarta (fig. 2 1) rarissima, ao que parece, tanto no Ribeirão do Garcia, como em alguns ribeirinhos menores.

Já que fallo das Helicopsyches não devo deixar de tocar em um trecho de Hagen ${ }^{1}$ ) relativo a esses animaes; depois de citar o facto observado por Shuttleworth de se acharem as larvas ou nymphas em todas as casas providas de operculos, Hagen continúa: "dahi resultaria que estes animaes, contra o costume das Pliryganideas, já como larvas, munem as suas casas de um operculo, o que em outras especies só se encontra no estado de nymphas.» Ora, todas as larvas de Trichopteros fixam e fecham as suas casas antes de se transformarem em nymphas; todas cllas, depois de prompta a casa para a transformação, ainda se conservam no estado de larvas por mais algum tempo. As Helicopsyches, a este respeito, em nada se distinguem dos demais Trichopteros; ellas tambem fazem o operculo da entrada só quando estão para se transformar, e depois de terem fixado a sua casa.

\footnotetext{
I) Hagen, I. c. P. I 25.
}

öffentlichten Arten zu vergleichen und ihre unterscheidenden Merkmale festzustellen.

Ich beschränke mich daher darauf, die Abbildungen derjenigen Formen zu geben, denen ich begegnet bin.

Die erste derselben (Fig. I 8 ) ist häufig in verschiedenen Quellen von raschem Lauf, ungemein häufig über der Waldschlucht "Trauriger Jammer" in Blumenau. Wenn ich mich nicht irre, war es diese nämliche Art, die ich auf der Serra do Itajahy gesehen habe. Eine zweite (Fig. I9) wurde nur in dem "Weissbach" (Ribeirão Branco), einem Zufluss des Itajahy, gefunden; eine dritte (Fig. 20) in stehendem Wasser des Baches Garcia; eine vierte (Fig. 21), wie es scheint, sehr seltene, sowohl im Bache Garcia als in einigen kleineren Bächen.

Da ich von den Helicopsyche-Arten spreche, so darf ich nicht unterlassen, eine Stelle Hagen's ${ }^{1}$ ) die sich auf diese Thiere bezieht, zu berühren. Nachdem er die von Shuttleworth beobachtete Thatsache citirt hat, dass sich in allen mit Deckeln versehenen Gehäusen Larven oder Puppen fanden, fährt Hagen fort: „daraus würde sich ergeben, dass diese Thiere, gegen die Gewohnheit der Phryganiden, schon als Larven ihre Gehäuse mit einem Deckel versehen, der bei anderen Arten nur im Puppenzustande angetroffen wird“. Nun befestigen und verschliessen aber alle Trichopterenlarven ihre Gehäuse, bev or sie sich in Puppen umwandeln; a 1le bleiben, nachdem das Grehäuse für die Verwandlung bereit ist, noch einige Zeit im Larvenzustande. Die Helicopsyche-Arten unterscheiden sich in dieser Beziehung in Nichts von den übrigen Trichopteren; sie machen ebenfalls den Deckel des Einganges erst, wenn sie im Begriffe stehen sich zu ver-

I) Hagen, 1. c. S. 125 . 


$$
\S 6 .
$$

As larvas das Hydroptilideas (fig. $22-30$ ).

Resta a familia das Hydroptilideas, que, em relaçào ás casas ou estojos clas larvas, é aqui de todas a mais rica em fórmas inteiramente novas e interessantes. Hagen conhecia em 186+ as casas de quatro especies desta familia; por aqui já encontrei nove novos especies constituindo seis typos differentes.

As casas da primeira especic (fig. 22) são as que mais se parecem com as das outras familias; a não terem dimensões muito inferiores ás que se observam nas Leptocerideas e Sericostomideas, podiam passar por casas de alguma especie dessas familias. São canudos ou tubos, cujo comprimento não excede a $2,{ }^{\mathrm{m} m} 5$, tendo $0,{ }^{\mathrm{mm}} 5$ de largura; são feitos de uma membrana elastica, resistente, coberta de areia finissima e de côr pardoclara. Não são roliços e sim achatados, sendo a sua altura igual á metade pouco mais ou menos da largura; a face ventral ou é plana (fig. 22, $C^{\prime}$ ), ou mais frequentemente um pouco concava (fig. 22, $A^{\prime}$ ); vistos por cima mostram os ladns ou rectos, convergindo algum tantn para o extremo posterior (fig. 22, $A$ ) ou um pouco convexos (fig. 22, $B, C$ ).

O orificio oval acha-se na face ventral, sendo ás rezes protegido por uma especie de escudilho mais largo do que n resto do tubo (fig. $22, B, D$ ). $\mathrm{O}$ orificio anal é, ou terminal ou ventral. Os tubos são fixados pela margem ventral de ambas as extremidades, havendo clous discos adhesivos, ou um só bilobado na wandeln und nachdem sie ihr Grehäuse befestigt haben.

6) Die Larven der Hydroptiliden (Fig. 22-3o).

Noch übrig ist die Familie der Hydroptiliden, die in Bezug auf die Gehäuse oder Futterale der Larven bis jetzt von allen die reichste an ganz neuen und interessanten Formen ist. Hagen kannte im Jahre 1864 die Gehäuse von vier Arten dieser Familie; bis jetzt habe ich schon neun neue Arten angetroffen, die sechs verschiedene Ty pen darstellen.

Die Gehäuse der crsten Art (Fig. 22) sind diejenigen, die denen der anderen Familien noch am meisten ähnlich sehen. Da sie in ihren Dimensionen nicht viel hinter denen zurückstehen, die bei den Leptoceriden und Sericostomiden angetroffen werden, so könnten sie für Gehäuse einer Art dieser Familien durchgehen. Es sind dünne Röhren, deren Länge nicht über $2,5 \mathrm{~mm}$ hinausgeht, bei $0,5 \mathrm{~mm}$ Breite; sie sind aus einer elastischen, widerstandsfähigen Haut gemacht, die mit feinstem Sande ron hellbrauner Farbe bedeckt ist. Sie sind nicht walzenförmig; sonclern abgeplattet, so dass ihre Höhe ungefähr die IIälfte der Breite beträgt; dic Bauchfläche ist entweder eben (Fig. $22 C^{\prime}$ ), oder häufiger ein wenig konkav (Fig. $22 A^{\prime}$ ); voll oben gesehen zeigen sie die Seiten entweder gerade, nach dem hinteren Ende etwas konvergirend (Fig. $22 A$ ) oder etwas konvex (Fig. 22, $B, C$ ).

Die Mundöffnung befindet sich an der Bauchseite, sie ist manchmal von einer Art Schild bedeckt, welches breiter ist, als der übrige Theil der Röhre (Fig. $22 B, D$ ). Die Afteröffnung liegt entweder am Ende oder auf der Bauchseite der Röhre. Die Röhren sind mit dem Bauchrancle beider Enden befestigt; 
extremidade oval, e um disco simples na anal (fig. 22, C). Esta especie pigméa é assás frequente debaixo das pedras, em quasi todos os ribeiros maiores ou menores. As larvas desta especie e da seguinte são as unicas da familia das Hydroptilideas, em que vi branchias; são tres fios compridos na extrenidade do abdomen.

As tres especies seguintes (fig. 23, 25) construem os seus estojos segundo o typo do genero Hydroptila, do qual entretanto se distinguem os insectos perfeitos por terem um esporão nas tibias anteriores. Os estojos são comprimidos lateralmente, abrindo-se em cada extremo por uma fenda vertical muito estreita. As casas da primeira destas tres especies (fig. 23) têm cerca de $3^{\text {mm }}$ de comprimento sobre $\mathrm{I}^{\mathrm{mm}}$ de altura $\mathrm{e}$ $\mathrm{O},{ }^{\mathrm{mm}} 5$ de largura, apresentam uma côr acinzenta, e são feitas de uma membrana resistente, coberta de areia fina. A secção transversal (fig. 23, C'), é lenticular; as margens dorsal e ventral são rectas e quasi sempre parallelas (fig. 23, $A, B$ ); ás rezes porém convergem um pouco para um dos extremos (fig. 23, C). Os extremos são arredondados, semicirculares (fig. 23, A,C); ís vezes formam arcos maiores de $180^{\circ}$, sendo neste caso mais largos do que a parte intermediaria (fig. 23, B). Não ha differença entre extremo anterior ou posterior, nem tão pouco entre aresta dorsal ou ventral. A larva sahe indifferentemente de um oul outro extremo. Para a transformaçĩo, as casas são fixadas nos dous extremos por ligamentos fibrosos.

$\mathrm{Na}$ fórma e nas dimensões sĩo muito semelhantes as casas desta especie ás da seguinte (fig. 24); porém é facil- am Mundende haben sie zwei Haftscheiben oder eine einzige zweilappige am Afterende eine einfache Scheibe (Fig. 22 C). Diese winzige Art ist in allen grösseren und kleineren Bächen ziemlich häufig auf der unteren Seite der Steine. Die Larven dieser und der folgenden Art sind die einzigen aus der Familie der Hydroptiliden, bei denen ich Kiemen gesehen habe; es sind drei lange Fäden am Ende des Hinterleibes.

Die drei folgenden Arten (Fig. 23-25) bauen ihre Futterale nach dem Typus der Gattung Hydroptila, von der sich indess die fertigen Insekten dadurch unterscheiden, dass sie einen Sporn an den Hinterschienen haben. Die Futterale sind seitlich zusammengedrückt und öffnen sich an jedem Ende mit einem sehr schmalen senkrechten Schlitz. Die Gehäuse der ersten dieser drei Arten (Fig. 23) haben ungefähr $3 \mathrm{~mm}$ Länge bei I $\mathrm{mm}$ Höhe und $0,5 \mathrm{~mm}$ Breite; sie sind aus einer widerstandsfähigen Haut gemacht, mit feinem Sand bedeckt und von aschgrauer Farbe. Ihr Querdurchschnitt (Fig. $23 C^{\prime}$ ) ist linsenförmig; Rückenrand und Bauchrand sind gerade und fast immer parallel (Fig. 23 A, B); manchmal indessen konvergiren sie ein wenig nach einem Encle (Fig. 23 C). Die Enden sind abgerundet, halbkreisförmig (Fig. $23 A, C$ ); bisweilen bilden sie Bogen von mehr als $180^{\circ}$ und sind in diesem Falle breiter als der mittlere Theil (Fig. 23 B). Es besteht kein Unterschied zwischen Vorder- und Hinterende, eben so wenig zwischen Rücken- und Bauchkante. Die Larve tritt ohne Unterschied aus dem einen oder anderen Ende hervor. Zur Verwandlung werden die Gehäuse an beiden Enden mit faserigen Bändern befestigt.

In der Gestalt und den Dimensionen sind die Gehäuse dieser Art denen der folgenden (Fig. 24) sehr ähnlich; doch 
limo distinguir as casas pela differença do material de que sào compostas, e as larvas pela falta de branchias. Tambem se manifesta, no arranjo dos matcriaes, uma differença muito notavel entre as margens dorsal e ventral, sendo pela margem dorsal que começa a construcção da casa. Os extremos anterior e posterior são iguac's. Algumas casas sĩo feitas com pedacinhos verdes, provenientes talvez de alguma alga (fig. $24, A$ ), de especie differente. O maior numero das casas (fig. $24, B, C$ ) são feitas de Diatomeas (fig. $24, D$ ), varinhas microscopicas, rectangulares, de cerca de $0,{ }^{\mathrm{mm}} 25$ de comprimento sobre $\mathrm{O},{ }^{\mathrm{mm} \mathrm{O}} \mathrm{I}$ até $\mathrm{O},{ }^{\mathrm{mm} \mathrm{OI}} \mathrm{O} 5 \mathrm{de}$ largura; as estrias concentricas, produzidas pelo arranjo dessas varinhas, dão ás casinhas a apparencia de umas conchinhas bivalvas microscopicas, ou de miudas Limnadias.

De par com essas varinhas, ou tambem por si sós, as larvas empregam outra especic de uma bella côr de laranja (fig. $24, D^{\prime}$ ), composta de articulos de $\mathrm{O},{ }^{\mathrm{mm}} \mathrm{O} 2$ até $\mathrm{O},{ }^{\mathrm{mm}} \mathrm{O} 25$ de largura, que das pallidas e transparentes varinhas se destacam como umas grinaldas de ouro. As casas sào fixadas (fig. $24, B, C$ ), como as da especie precedente.

As casas da terceira especie catharinense (fig. 25), que as construe pelo typo de Hydroptila, são compostas só de uma substancia transparente, sem côr, produzida pela propria larva, sem concurso de corpos estranhos.

Ellas têm de 3 até $3,{ }^{m m} 5$ de comprimento sobre I até $\mathrm{I},{ }^{\mathrm{mm}} 25$ de altura e $0,{ }^{\mathrm{nm}} 3$ de largura; săo pois fortemente comprimidas, mórmente na parte superior (fig. $25, B$ ', $B^{\prime \prime}$ ). sind deren Gehäuse an der Verschiedenheit des Materials, aus dem sie zusammengesetzt sind, und ihre Larven an dem Fehlen der Kiemen sehr leicht zu unterscheiden. Auch zeigt sich bei ihnen in der Anordnung der Baustoffe eine sehr bemerkenswerthe Verschiedenheit zwischen dem Rücken- und dem Bauchrande, indem der Bau des Gehäuses vom Rückenrande her angefangen wird. Das vordere und hintere Ende sind gleich. Manche Gehäuse sind aus grünen Stengelchen gemacht, die bisweilen von einer Alge herstammen (Fig. 24, A); bisweilen scheinen sie verschiedener Art. Die zahlreichsten Gehäuse (Fig. 24, B, C) sind aus Diatomeen (Fig. 24, D) gemacht, rechteckigen mikroskopischen Stäbchen von etwa $0,25 \mathrm{~mm}$ länge bei o,or bis o,OI5 $\mathrm{mm}$ Breite; die koncentrischen Streifen. die durch die Anordnung dieser Stäbchen hervorgebracht werden, geben den kleinen Gehäusen das Aussehen winziger Muscheln.

Zusammen mit diesen, oder auch für sich allein, verwenden die Larven eine andere Art Stäbchen von einer schönen Orangefarbe (Fig. 24, D'), die aus Gliedern von 0,02 bis $0,025 \mathrm{~mm}$ Breite zusammengesetzt sind, und sich von den blassen, durchscheinenden Stäbchen wie goldige Guirlanden abheben. Die Gehäuse werden wie die der vorhergehenden Art befestigt (Fig. 24, B, C).

Die Gehäuse der dritten catharinensischen Art (Fig. 25), die nach dem Typus von Hydroptila gebaut werden, sind nur aus einer farblosen, durchscheinenden Substanz zusammengesetzt, die von der Larve selbst hervorgebracht wird, ohne Hinzunahme fremder Körper.

Sie haben 3 bis $3,5 \mathrm{~mm}$ Länge bei I bis I,25 mm Höhe und 0,3 mm Breite; sie sind also stark zusammengedrückt, besonders im oberen Theile (Fig. 25, I', $\left.B^{\prime \prime}\right)$. 
A margem rentral é quasi recta, a parte média da margem dorsal muito convexa, e os extremos arredondados. Não ha differença entre os dous extremos providos de fenda estreita.

A casa é fixada nas pedras em posição rertical por meio de fibras que parecem estender-se ao longo de toda a margem rentral.

As tres especies precedentes năo são muito raras nas pedras do Ribeirão dos Bugres, que desagua na margem direita do Itajahy, perto de 2 kilometros abaixo do Ribeirão do Garcia. Uns poucos de exemplares foram tambem achados em outros logares.

O mesmo Ribeirão dos Bugres é tambem o domicilio predilecto da seguinte especic (fig. 26), cujas casinhas representam um typo inteiramente novo. Por causa das duas chaminés, de que as casinhas são providas, dei a esse typo o nome de Diaulus (ótavios $=$ a dous canos), dedicando a especie Diaulus Ladislavii ao illustrado Director Geral do Museu Nacional do Rio de Janeiro.

As casas, de cerca de $2,{ }^{\mathrm{mm}} 5$ de comprimento sobre $0,{ }^{\mathrm{mm}} 75$ de altura. São fortemente comprimidas dos lados, de modo que a largura seja igual de um terço até um meio de altura. A secção transversal é elliptica ou lenticular; as margens dorsal e ventral são quasi rectas, parallelas; os dous extremos, entre os quaes não ha differença, são arredondados e providos de uma estreita fenda. Da margem dorsal elevam-se dous canos quasi cylindricos, de cerca de $0,{ }^{\mathrm{mm}}{ }_{2}$ de diametro, e outro tanto de altura, ou verticaes, ou um pouco inclinados para os extremos da casa. A distancia dos dous canos geralmente iguala ou excede de pouco á metade do comprimento da casa; ás vezes, comtudo, essa distancia
Der Bauchrand ist fast grerade, der mittlere Theil des Rückenrandes sehr konvex, die Enden abgerundet. Zwischen den beiden mit enger Spalte versehenen Enden ist kein Unterschied.

Das Gehäuse wird mittels Fasern, die sich dem ganzen Bauchrande entlang zu erstrecken scheinen, in senkrechter Stellung an den Steinen festgeheftet.

Die drei vorhergehenden Arten sind nicht sehr selten an den Steinen des Bugres-Baches, der fast zwei Kilometer unterhalb des Baches Garcia auf der rechten Seite in den Itajahy mündet. Einige wenige Exemplare wurden auch an anderen Stellen gefunden.

Derselbe Bugresbach ist auch der Lieblingswohnsitz der folgenden Art (Fig. 26), deren Häuschen einen ganz neuen Typus darstellen. Wegen der beiden Schlote oder Röhren, mit denen diese Häuschen versehen sind, habe ich diesem Typus den Namen Diaulus (ócav $0 \varsigma=$ zweiröhrig) gegeben; die Art Diaulus Ladislavii, habe ich zu Ehren des Direktors des National-Museums von Rio de Janeiro benannt.

Die Gehäuse, von ungefähr 2,5 $\mathrm{mm}$ Länge bei $0,75 \mathrm{~mm}$ Breite, sind von den Seiten stark zusammengedrückt, so dass ihre Breite ein Drittel bis ein Halb der Höhe beträgt. Der Querdurchschnitt ist elliptisch oder linsenförmig ; Rückenund Bauchrand sind fast gerade und parallel; die beiden Enden, zwischen denen kein Unterschied ist, sind gerundet und mit einem schmalen Schlitz versehen. Vom Rückenrande erheben sich zwei fast cylindrische Röhren, von ungefähr $0,2 \mathrm{~mm}$ Durchmesser und doppelt so viel Höhe, entweder senkrecht oder ein wenig nach den Enden des Gehäuses geneigt. Der Abstand der beiden Röhren ist im Allgemeinen gleich oder wenig grösser als die IIülfte 
(é sí de um terço do dito comprimento, ou ainda menor. Em uma só casa (fig. 26, B), entre milhares que vi, encontrei tres canos, em vez de dous. As casas do Diaulus Ladislazii sc̃o contruidas com as mesmas varinhas rectangulares e transparentes (fig. 24, D), empregadas por uma das especies precedentes e que abundam nas podras, onde vivem essás larvals. A disposição das varinhas (fig. 26, C) faz ver que a construcção da casa começa pelo meio da margem dorsal; a parte superior dos canos é feita só de uma membrana transparente sem varinlias. Obscrvei muitas vezes com o microscopio, dentro das suas casas, as larvas vivas desta especic, assim como da especie da fig. 23. A fórma das casas, abstracção feita dos canos do Diaulus, é quasi identica, mas o procedimento das larvas é muito diverso. As das casinlas providas de chaminés conservanı-se quietas, quasi sem movimento, as das casas só providas de duas fendas estreitas agitam quasi ininterruptamente o seu abdomen, executando movimentos serpentinos ou ondulatorios. A razão dessa differença é evidente. As portas estreitas, que têm a vantagem de difficultar a entrada de qualquer inimigo, têm ao mesmo tempo o inconveniente de difficultar a passagem da agua indispensavel á respiraçăo da larva, que por isso precisa de fazer reforços continuos para renoval-a. Nas casas do Diaulus Ladislavii as chaminés dão facil accesso á agua, e as larvas podem descançar quando as outras trabalham. der Länge des Gehäuses; bisweilen jcdoch ist der Abstand nur ein Drittel dieser länge oder noch kleiner. Bei einem einzigen Gehäuse (Fig. 26, $I 3$ ) unter Tausenden, dic ich sah, habe ich drei Röhren statt zwei angetroffen. Die Gehäuse des Diaulus Ladislavii sind aus denselben rechteckigen und durchsichtigen Stäbchen (Fig. 24, D) gebaut, dic von einer der vorhergehenden Arten verwendet werden und die sich an den Steinen, wo ihre Larven leben, in reichlicher Menge vorfinden. Die Anordnung der Stäbchen (Fig. 26,C) lässt erkennen, dass der Bau des Gehäuses mit der Mitte des Rückenrandes angefangen Ivird; der obere Theil der Röhren wird nur aus einer durchscheinenden Haut, ohne Stäbchen, gemacht. Oftmals habe ich die Larven dieser, wie auch der Art von Fig. 23, mit den Mikroskop lebend in ihren Gehäusen beobachtet. Die Form der Gehäuse ist, abgeschen von den beiden Röhren des Diaulus, fast dicselbe, aber das Verhalten der Larven ist sehr verschicden. Dic der mit Schloten versehenen Häuschen verhalten sich ruhig, fast bewegungslos, die der nur mit zwei schmalen Schlitzen versehenen Häuschen dagegen machen mit ihrem Hinterleib fast ununterbrochen lebhaft schlängelnde Bewegungen. Der Grund dieser Verschiedenheit ist leicht einzuschen. Die engen Thüren, die den Vortheil haben, den Eintritt irgend eines Feindes zu hindern, haben gleichzeitig die Unbequemlichkeit, den Durchgang des für die Athmung der Larve unentbehrlichen Wassers zu erschweren; diese ist dadurch genöthigt, zur Erneuerung desselben ununterbrochene Anstrengungen zu machen. In den Gehäusen des Diaulus Ladislavii geben die Schlote dem Wasser leichten Zutritt und die Larven können ausruhen, während die anderen arbeiten. 
E' bem curioso que as larvas tão differentes como as do Diaulus Ladislavii e as Rhyacophilideas que fazem casinhas moveis de pedras (fig. 3 ), se sirvam do mesmo expediente para facilitar a circulação da agua nas suas casas, inteiramente diversas em tudoo mais. Para a transformação em nymphas, as casas do Dianlus Ladislaziisão fixadas no lado superior de pedras em posição vertical, c por toda a margem ventral. As larvas gostam de estabelecer-se umas ao lado das outras, de modo a formarem ás vezes verdadeiras aldeias dessas linclas casinhas de duas chaminés.

Depois de fixada a casa, a larva tece um casulo oval, um pouco mais largo no extremo anterior, fechado de todos os lados, como o das Rhyacophilideas, do qual se distingue por não ser solto, e sim continuo com as paredes da casa. Como o Diculus, procedem a este respeito tambem as tres especies precedentes.

Em alguns ribeirinhos de curso lento, cheios de Heteranthera reniformis, de Callitriche e de Spirogyra, abundaram no mez de Agosto larvas e nymphas de uma especie interessantissima de Hydroptilideas (fig. 27), á qual, pela forma de seus estojos, e pela planta em que vivem, e de que se nutrem as larvas, dou o nome de Lagenopsyche Spirogyra. Uma segunda especie do mesmo genero, para a qual, por causa da transparencia perfeita de seus estojos, proponho o nome de Lagenopsyche hyalina (fig. 28) vive debaixo de pedras, em corregos de curso mais rapido, como 110 Ribeirão dos Bugres.

Para se formar uma idéa dos estojos de Lagenopsyche, imagine-se cortada a base de uma garrafa, e comprimida
Es ist sehr merkwürdig, dass so verschiedene Larven wic die des Diaulus Ladislavii und der Rhyacophiliden, die bewegliche Häuschen aus Steinen (Fig. 3) machen, sich zur Erleichterung der Cirkulation des Wassers in ihren Gehäusen desselben Auskunftsmittels bedienen, obgleich diese Gehäuse doch übrigens ganz verschieden sind. Zur Verwandlung in Puppen werden die Gehäuse des Diaulus Ladislavii mit dem ganzen Bauchrande in senkrechter Stellung an der oberen Seite von Steinen befestigt. Die Larven setzen sich gern Seite an Seite neben einander fest, so dass sie bisweilen ganze Dörfer dieser niedlichen Doppelschlothäuschen bilden.

Nachdem das Gehäuse befestigt ist, webt die Larve einen ovalen, am vorderen Ende etwas erweiterten Kokon, der auf allen Seiten geschlossen ist wie der der Rhyacophiliden, von dem er sich dadurch unterscheidet, dass er nicht frei liegt, sondern mit den Wänden des Gehäuses zusammenhängt. Wie Diaulus verhalten sich in dieser Beziehung auch die drei folgenden Arten.

In einigen kleinen, langsam fliessenden Bächen, die mit Heteranthera reniformis, Callitriche und Spirogyren erfüllt sind, waren Mitte August Larven und Puppen einer sehr interessanten Hydroptiliden-Art (Fig. 27) sehr häufig, der ich, nach der Form ihrer Futterale und der Pflanze, auf der sie leben und von der sich die Larven nähren, den Namen Lagenopsyche Spirogyrae gegeben habe. Eine zweite Art derselben Gattung, für die ich, wegen der vollkommenen Durchsichtigkeit ihrer Futterale, den Namen lagenopsyche hyalina vorschlage (Fig. 28), lebt unter Steinen, in Quellen von rascherem laufe, wie im Bugresbache.

Um sich eine Vorstellung von den Larven von lagenopsyche zu machen, denke man sich den Boden einer Flasche 
depois a parte inferior dessa garrafa sem base até se tocaren as margens oppostas. A bocca da garrafa é circular; mais para traz a secção transversal ć elliptica, tornando-se os dois cixos da ellipse cada vez mais differentes; n cixo maior vai augmentando, o menor conversa-se quasi igual ao diametro da bocca até perto do extremo opposto, onde rapidamente decresce, reduzindo-se a zero no extremo mesmo em que as paredes oppostas se applicam uma it outra. A larva sahe do seu estnjo pela bocca, podendo comtudo sahir tambem pelo extremo opposto, afastando uma da outra as paredes contiguas da fenda, e carrega o estrjo em posição tal que o eixo maior de qualquer secção é vertical e o menor horizontal (fig. 27, C). Em quanto nas casinhas do Diaulus Ladislavii não ha differença entre os dous extremos, e sim differença muito grande entre os lados dorsal e ventral, nos estojos de Lagenopsyche pelo contrario, as margens dorsal e ventral são identicas, volvendo o animal para cima, ora uma, ora outra indifferentemente, e os duos extremos sãn muito diversos, sendo o anterior uma bocca circular c o posterior uma fenda vertical.

Os estojos sìn feitos sem corpos estranhos, só com a substancia fornecida pelos enormes sericterios, ou glandulas fiandeiras da larva, substancia esta que produz, pelo endurecimento, uma membrana coriacea e elastica.

A construcçào dos estnjos começa pela bocca da garrafa (fig. $27 A, B$, $C, D)$ e parece que a larva, continuando abgeschnitten und dann den unteren Theil dieser bodenlosen Flasche zusammengedrückt, bis sich die entgegengesetzten Ränder berühren. Die Mündung der Flasche ist kreisförmig; weiter hinten ist der Querdurchschnitt elliptisch, so dass die beiden Achsen der Ellipse immer verschiedener werden; die längere Achse nimmt nämlich mohr und mehr $z u$, während die kürzere bis nahe dem entgegengesetzten Ende etwa gleich dem Durchmesser der Mündung bleibt; hier nimmt sie plötzlich ab und reducirt sich an dem Ende selbst, in welchem die entgegengesetzten Wände sich an einander legen, auf Null. Dic Larve tritt aus ihrem Gehäuse durch die Mündung hervor, kann jedoch auch aus dem entgegengesetzten Ende hervortreten, indem sie die sich berührenden Wände des Spaltes von cinander entfernt; sie trägt das Futteral in solcher Stellung, dass die grössere Achse jedes Querschnittes senkrecht, die kleinere wagerecht steht (Fig. 27 C). Während bei den Häuschen von Diaulus Ladislavii kein Unterschied zwischen den beiden Enden, dagegen ein schr grosser Unterschied zwischen Rücken- und Bauchseite besteht, sind bei den Futteralen von Lagenopsyche im Gegenthcile Rücken- und Bauchrand identisch, so dass das Thier ohne Unterschied den einen oder den anderen nach oben kehrt, dagegen die beiden Enden schr verschicden, indem das vordere eine kreisförnige Mündung, das hintere einen vertikalen Spalt darstellt.

Die Futterale werden, ohne fremde Körper, nur aus einem Stoffe gemacht, den die ausserordentlich grossen Seidenoder Spinndrüsen dor l arve licfern; aus diesem Stoffe wird, indem er erhärtet, eine lederartige elastische Haut.

Der Ban der Futterale beginnt mit der Mündung der Flaschr (Fïg. $27 \mathrm{~A}$, $B, C, D)$ und es scheint, dass die larve, 
para traz a sua obra, está ao mesmo tempo reforçando de novas camadas a parte anterior; ao menos alli as paredes da garrafa sào muito mais grossas, sendo tenuissimas no extremo opposto. A todas as mais larras de Trichopteros, cujas casas têm os duos extremos differentes, serve de porta o extremo mais novo; sendo as de Lagenopsyche as unicas cuja porta se acha no extremo mais antigo. A esta porta ou bocca da garrafa se dá desde o principio o seu diametro definitivo, sem se alargar mais tarde. Parece-me provavel que as larvas de tenra idade vivem sem estojos; ao menos os menores estojos que vi eram habitados por larvas já assás crescidas, ás quaes quasi que năo podiam dar protecção alguma; eram funís muito curtos de membrana tenuissima, nos quaes nem a metade da larva cabia. Provavelmente a utilidade principal do estojo consistirá em proteger năo a larva, mas sim a nympha, que é incapaz. de fugir e defender-se. A bocca de garrafa tem, na Lagenopsyche Spirogyre, cerca de $\mathrm{O},{ }^{\mathrm{mm}} 5$ de diametro, sendo o comprimento de $3,{ }^{\mathrm{mm}} 5$ até $4,{ }^{\mathrm{mm}} 5$, e a altura do extremo posterior de $\mathrm{I},{ }^{\mathrm{mm}} 25$ até $1,{ }^{m m} 5$. Nem na fórma, nem nas dimensões, as garrafas da Lagenopsyche hyalina (fig. $28, A$ ) se distinguem notavelmente das da $L$. Spirogyre. A differonça nais patente entre as duas especies, consiste na apparencia dos estojos, os quaes sào incolores e perfeitamente transparentes na L. hýalina, de uma côr roxo-escura, tirando mais ou menos ao pardo na L. Spirogyre, côr esse que é mais escura e ás vezes quasi preta, do lado da bocca, ficando para traz cada rez mais clara e desmeiada. Seja dito no passagem que as larvas das duas especies facilmente se distinguem pelas pernas intermediarias e posteriores, providas de unhas muito mais com- indem sie ihr W'erk hinten fortsetzt, gleichzeitig den vorderen Theil mit neuen Schichten verstärkt; wenigstens sind dort die Wände der Flasche viel dicker, während sie am entgegengesetzten Ende an dünnsten sind. Allen übrigen Trichopterenlarven, deren Gehäuse zwei scrschiedene Enden haben, dient das neueste Ende als Thür; die von Lagenopsyche sind die einzigen, deren Thür sich am ältesten Ende befindet. Dieser Thür oder Flaschenmündung wird ron Anfang an ihr definitiver Durchmesser gegeben; sie crfährt später keine Erweiterung. Es erscheint mir ivahrscheinlich, dass die Larven im zarten Alter ohne Futterale leben; wenigstens waren die kleinsten Futterale, die ich gesehen habe, von schon ziemlich herangewachsenen Larven bewohnt, denen sie kaum irgend einen Schutz gewähren konnten; es waren sehr kurze Trichter von äusserst dünncr Haut, in denen noch nicht einmal die Hälfte der Larve Platz hatte. Wahrscheinlich wird der Hauptnutzen des Futterals darin bestehen, nicht die Larve, sondern vielmehr die Puppe zu schützen, die unfähig ist $z u$ fliehen und sich $z u$ verteidigen. Die Mündung der Flasche hat bei Lagenopsyche Spirogyrae ungefähr $0,5 \mathrm{~mm}$ Durchmesser, während die Länge 3,5 bis $4,5 \mathrm{~mm}$ und die Höhe des hinteren Endes 1,25 bis 1,5 $\mathrm{mm}$ beträgt. Weder in der Form noch in den Dimensionen unterscheiden sich die Flaschen von Lagenopsyche hyalina (Fig. 28 A) bemerkenswerth von denen von L. Spirogyrae. Ein auffallenderer Unterschied zwischen beiden Arten besteht in dem Aussehen der Futterale, die bei L. hyalina farblos und vollständig durchsichtig, bei L. Spirogyrae von einer dunkelrothen, mehr oder weniger ins Braune spielenden Farbe sind; diese Farbe der Spirogyraefutterale ist am Munde dunkler, bisweilen fast schwarz, 
pridas na $L$. Spirogyra do que na L. hyalina. As larvas de Lagenopsyche Spirogyre fixam os seus estojos na face inferior das follhas de Heteranthera ou Callitriche (contei 17 estojos cm uma unica folha de Heteranthera)-as da L. hyalina no lado inferior de pedras. Para este fim o estujo é deitado cm um dos lados, e depois fixado de cada lado de um e outro extremo por meio de discos adhesivos peciolados; todos esses peciolos são simples na L. Spirogyre (fig. 27, E, F), na L. hyalina, os do extremo opposto á bocca da garrafa dividem-se em dous ramos, cada um dos quaes termina por um disco (fig. $28, B, C^{\prime}$ ).

Fixado o estrojo, a larva fia o seu casulo fechado de todos os lados, que se confunde com as paredes do estojo, do qual deixa desoccupado cerca de meio millimetro no extremo mais largo. Esse extremo, que cra o posterior para a larva, é o anterior para a nympha, porque antes de se transformar, a larva muda duas vezes a sua posiçăo; primeiro (fig. $27, E$ ) volta a cabeça para o extremo mais largo, e depois (fig. 27, $F)$ volve as costas para a superficie livre do estojo. Muito differentes em tudo o mais, os estojos de Lagenopsyche assemclham-se, no modo por que são fixados, aos da Hydroptila flabellifera de Bremi, achados na Suissa, e que, segundo Hagen, podiam pertencer ao genero Agrayléa ${ }^{1}$ ).

I) Hagen loc. cit. p. 115 e p. $234, n^{0} 44$ bleibt dagregen hinten jedes Mal heller und verwaschen. Nebenbei sei bemerkt, dass sich die Larven beider Arten leicht an den Mittel- und Hinterbcinen unterscheiden lassen, die bei I.. Spirogyrae mit viel längeren Krallen versehen sind, als bei 1. hyalina. Die Larven der l agenopsyche Spirogyrae befestigen ihre Futterale an der unteren Seite der Blätter von Heteranthera oder Callitriche (ich habe 17 Futterale an einem cinzigen Blatte von Heteranthera gezähit) - die der L. hyalina an der Unterseite von Steinen. $\mathrm{Zu}$ diesem Zwecke wird das Futteral auf eine Seitc gelegt, und dann jederseits an beiden Enden mittels gestielter Haftscheiben befestigt. Alle diese Stiele sind bei L. Spirogyrae (Fig. 27 $E, F$ ) einfach; bei L. hyalina dagegen theilen sich die des dem Munde entgegengesetzten Flaschenendes in zwei Aeste, deren jeder mit einer Scheibe endigt (Fig. $28 \mathrm{~B}, \mathrm{C}$ ).

Nachdem das Futteral befestigt ist, spinnt die Larve ihren an allen Seiten geschlossenen Kokon, der mit den Wänden des Futterals verschmilzt; von diesem bleibt nur etwa ein halbes Millimeter am breiteren Ende unbesetzt. Das Ende, welches für die Larve das hinterc war, ist für die Puppe das vordere, denn bevor sic sich umwandelt, wechselt die Jarve zwei Mal ihre Stellung; zuerst (Fig. $27 \mathrm{E}^{7}$ ) wendet sie ihren Kopf nach dem breiteren Ende und dann (Fig. $27 \mathrm{~F}^{\mathrm{T}}$ ) drelıt sie den Rücken an die freie Obcrfläche des Futterals. Obgleich übrigens sehr verschieden, gleichen die Futterale von Lagenopsyche in der Art, wie sie befestigt werden, denen der Hydroptila flabellifera Bremi, die in der Schweiz gefunden worden sind und nach Hagen zur Gattung Agraylea ${ }^{1}$ ) gehören können. 
() primeiro ensaio de classificaçào las casas dos Trichopteros, parece ter sido feito por Willughby; foi publicado em 1710 na Historia Insectorum de Ray.

Is casas sào divididas em duas classes principaes ${ }^{1}$ ):

Insecta aquatica thecis se contegentia sunt rel theca.

I. immobili seu lapidibus affixa ... ... vel.

II. mobili aut portatili, migratoria .

Esta classificaçào de IV'illughby, é ainda seguida por Hagen ${ }^{2}$ ), que tambem distingue: $I^{0}$ casas fixadas immoveis; $2^{0}$ casas livres moveis.

E, com effeito, todas as especies conhecidas podiam ser referidas a uma dessas duas classes. Hoje o caso é diverso; nos corregos de Santa Catharina ha uma larva para a qual Willughby cleveria estabelecer uma terceira classe: theca lapidibus affixa, mobili sendo os seus estojos fixados por meio de uma corda flexivel (fix. 29). Proponho para esta curiosa especie o nome de Rhyacopsyche Hagenii, dedicando-a ao distincto entomologista do Museu de Cambridge, Dr. H. A. Hagen. A fórma dos estojos desta especie varia um pouco com a idade da larva, conformando-se com o volume crescente do abdomen, que, na familia das Hydroptilideas costuma attingir nas larvas adultas, a uma grossura ás vezes extraordinaria. Os estojos das larvas menos velhas, que vi, eram cylindricos, quasi rectos, abertos nos dous extremos, de cerca de $4,{ }^{m+\prime} 5$ de comprimento sobre $0,{ }^{\prime \prime m} 4$ de diametro. Da margem de um dos orificios parte uma corda de fios, geralmente pouco distinctos, mais ou

I) Hagen loc. cit. p. I 39. Westwood Introduct. Vol. II. p. 63.

2) IIagen loc. cit. p. 142 e 223 .
Der erste Versuch einer Einteilung der Trichopterengehäuse scheint von Willughby gemacht worden zu sein; er wurde 1710 in der Historia Insectorum von Ray veröffentlicht.

Die Gehäuse werden in zwei Hauptklassen getheilt ${ }^{1}$ ):

„Insecta aquatica thecis se contegentia sunt vel theca

1. immobili seu lapidibus affixa ... ... vel

II. mobili aut portatili, migratoria".

Dieser Eintheilung Willughby's ist noch Hagen ") gefolgt, der ebenfalls unterscheidet: 1) befestigte, unbewegliche Gehäuse; 2) freie, bewegliche Gehäuse.

Und in der That können alle bekannten Arten auf eine dieser beiden Klassen bezogen werden. Heute liegt der Fall anders; in den Quellen Santa Catharina's giebt es eine Larve, für die Willughby eine dritte Klasse aufstellen müsste: "theca lapidibus affixa, mobili", da ihre Futterale mittels eines biegsamen Seiles befestigt sind (Fig. 29). Ich stelle für diese merkwürdige Art den Namen Rhyacopsyche Hagenii auf, indem ich sie dem ausgezeichneten Entomologen an Museum zu Cambridge, Dr. H. A. Hagen, widme. Die Gestalt der Futterale dieser Art ändert sich etwas mit dem Alter der Larve, entsprechend dem wachsenden Umfange des Hinterleibes, der in der Familie der Hydroptiliden bei erwachsenen Larven eine bisweilen ausserordentliche Dicke zu erreichen pflegt. Die Futterale der weniger alten Larven, die ich gesehen habe, waren cylindrisch, fast gerade, an beiden Enden geöffnet, von ungefähr 4,5 $\mathrm{mm}$ Länge bei $0,4 \mathrm{~mm}$ Durchmesser. Vom Rande

1) Hagen, 1. c. p. I39. Westwood, Introduct. Vol. II. p. 63 .

2) Hagen, l. c. S. 142 und 223. 
menos torcidos, cujo comprimento costuma ser quasi igual ao do estojo, pelo outro extremo, a corda é fixada no lado superior de alguma pedra. A cor, do estojo é parda, desmaiada; não ouso decidir si é feito sem corpos extranlos, ou si entram na sua composiçào fragmentos microscopicos de algas. Mais tarde apparece n'aquelle lado do cylindro, de que nasce a corda, uma especie de hernia (fig. 29, $A, B, C, H$ ), formada por uma membrana mais lisa e pallida, que vai augmentando com o correr do tempo, tanto em comprimento como em largura, até occupar finalmente cerca de tres quartos do comprimento do cylindro (fig. 29, C), sendo no meio tão larga como este. O limite entre o cylindro primitivo e esse accrescimo de data mais recente é geralmente muito bem traçado quando a larva está para se transformar, fechando primciro (fig. $29 D, E$ ) a extremidade do estojo opposta á da corda por uma membrana homogenea, igual á do estojo; ao mesmo tempo toda a parede do estojo começa a engrossar muito por meio de novas camadas, pelo que a sua côr se torna cada vez mais escura. Depois, o comprimento da corda fica muito reduzido, e esta transforma-se em uma haste curta e rija, capaz de sustentar o estojo em posição vertical. Finalmente o segunclo orificio do estojo é tambem fechado (fig. $29 \mathrm{~F}$ ), A nympha acha-se collocada no estojo com a cabeça para cima, fazcndo para cima, fazenclo para sahir um buraco no extrema superior.

Esta Hydroptilidea é muito rara; pelo menos aincla não achei logar onde ella abundasse. einer der Oeffnungen geht ein Seil ab, aus in der Regel wenig unterscheidbaren, mehr oder weniger gedrehten Fäden, dessen Länge der des Futterals ungefähr gleich zu sein pflegt; mit dem anderen Ende ist das Seil an der oberen Seite irgend eines Steines befestigt. Die Farbe des Futterals ist verwaschen braun; ich wage nicht $z u$ entscheiden, ob es ohne fremde Körper gemacht wird, oder ob mikroskopische Algenfragmente in scine Zusammensetzung eintreten. Später erscheint an der Seite des Cylinders, von der das Seil ausgeht, eine Art Bruch (hernia) (Fig. $29 A, B, C$ ); er wird von einer glatteren, blassen Haut gebildet, die mit der Zeit, sowohl an Länge als an Breite, immer mehr zunimmt, bis sie schliesslich fast drei Viertel der Länge des Cylinders einnimmt (Fig. 29 C) und in der Mitte eben so dick wie dieser ist. Die Grenze zwischen dem ursprünglichen Cylinder und diesem Zuwachs neuern Datums hebt sich im Allgemeinen sehr scharf ab; wenn die Larve im Begriff steht, sich zu verwandeln, verschliesst sie zuerst (Fig. 29 D, E) das dem Seilende entgegengesetzte Ende des Futterals mit einer homogenen, der des Futterals gleichen Haut. Gleichzeitig beginnt die ganze Wand des Futterals mittels neuer Schichten sich bedeutend zu verdicken, wodurch ihre Haut jedes Mal dunkler wird. Dann verkürzt sich die Länge des Seiles bedeutend und es verwandelt sich in einen kurzen und festen Schaft, der im Stande ist, das Futteral in aufrechter Stellung zu tragen. Endlich wird die zweite Oeffnung des Futterals ebenfalls verschlossen (Fig. $29 \mathrm{~F}^{\prime}$ ). Die Puppe befindet sich in dem Futterale mit dem Kopfe nach oben; zum Ausschlüpfen macht sie am oberen Ende ein Loch.

Diese Mydroptilide ist schr selten; ich habe wenigstens noch keine Stelle gefunden, wo sie häufig wäre. 
Vive em varios ribeiros (Jordão, Gruta dos Macacos, Triste Miseria, etc.), preferindo logares onde o courso da agua é muito rapido. Parece nutrir-se das algas que costumam cobrir as pedras de semelhantes localidades.

Fixando-se por uma corda, não póde ser levada pela corrente da agua, participando deste modo das vantagens das casas immoveis, sendo an mesmo tempo capaz de pastar em área maior do que si a casa fosse immovel; a larva póde sahir indifferemente de uma e outra porta de sua casinha, e provavelmente poderá mudar o comprimento da corda. Este singular costume de fixar a casa por uma corda flexivel deverá parecer muito estranho a quem só estudar as casas e as larvas mortas. Quem observar as larvas vivas poderí facilmente convencer-se de que varias outras especies tambem costuman fixar, si bem que temporariamente, as suas casas. Pondo v. g. larvas de Helicopsyche em um copo de vidro, em cujas paredes verticaes ellas só com muito custo podem subir e segurar-se, carregadas, como andam, de pesadas casas de pedras, năo obstante, param muitas vezes durante horas inteiras em algum ponto destas paredes. Examinando essas larvas paradas, vê-se que estão perfeitamente recolhidas na casa, sem se segurarem pelas pernas, e, sacudindo leremente o copo, conhece-se que se têm fixado com alguns fios de seda. E' bem sabido que varias lagartas de Lepidopteros, que vivem cm estojos (Psyche), procedem da mesma maneira, fixando por aiguns fios os estojos, e recolhendo-se no interior quando querem descançar.
Sie lebt in verschiedenen Bächen (Jordan, Affenwinkel, Trauriger Jammer u. s. w.), zieht aber Stellen vor, wo der Lauf des Wassers sehr rasch ist. Sie scheint sich von Algen zu nähren, die gewöhnlich die Steine solcher Stellen bedecken.

Da sie sich mit eirem Seile festheftet, so kann sie nicht von der Strömung des Wassers weggeführt werden und theilt auf diese Weise den Vortheil der unbeweglichen Gehäuse; gleichzeitig ist sic aber im Stande, eine weit grössere Fläche abzuweiden als wenn das Gehäuse unbeweglich wäre; die Larve kann ohne Unterschied aus der einen oder anderen Thür ihres Häuschens hervortreten und wird wahrscheinlich die Länge des Seiles verändern können. Diese sonderbare Gewohnheit, ein Haus an einem biegsamen Seile zu befestigen, wird dem sehr seltsam erscheinen müssen der nur die Gehäuse und die todten Larven studirt. Wer die lebenden Larven beobachtet, wird sich leicht überzeugen können, dass mannigfache andere Arten ebenfalls ihre Gehäuse zu befestigen pflegen, wenn auch nur vorübergehend. Wenn man z. B. Larven von Helicopsyche in ein Wasserglas setzt, an dessen senkrechten Wänden sie, da sie mit schweren Steinhäusern belastet wandern, nur mit vieler Mühe emporklimmen und sich festhalten können, so verweilen sie trotzdem oftmals während ganzer Stunden an irgend einem Punkte dieser Wände. Untersucht man diese LarvenHalteplätze, so sieht man, dass die Larven sich vollkommen in das Gehäuse zurückgezogen haben, ohne sich mit den Beinen festzuhalten, und wenn man das Glas leicht schüttelt, überzeugt man sich, dass sie sich mit einigen Seidenfäden angeheftet haben. Es ist wohl bekannt, dass verschicdene Schmetterlingsraupen, die in Futteralen leben (Psyche), auf dic- 
Concluo a serie de formas novas que acabo de descrever com uma especie (fig. 3o) de que ainda não vi o insecto perfeito, mas sómente fragmentos de nympha, e por issก não sei con certeza a que familia pertence. $\mathrm{O}$ abdomen da larva adulta é excessivamente dilatado, mais do que em qualquer outra especie catharinense, e foi principalmente por este motivn que a colloquei aqui.

As casas sĩo immoveis, sendo fixadas por toda a face ventral sobre as pedras de ribciros maiores de curso rapido.

Ha alguns annos vi-as em grande abundancia no Ribeirào do Wamow (affluente do Itajahy), sendo porém muito raras no Ribeirão do Garcia. Ellas são ellipticas, tendo + a $5^{\text {mum }}$ de comprimento, e $2,^{\mathrm{mm}_{2}}$ até $2,^{\mathrm{mm}} 5$ de largura, e raras vezes elevam-se no centro a mais de $0,{ }^{\mathrm{mm}} 5$.

São pois achatadas, semelhantes a um escudo, ou, melhor ainda, aos casulos que encerram os ovos da Nephelis z'ulgaris, hirudinea frequentissima nas aguas da Europa. Assim como esses casulos de Nephelis, ellas são de côr parda, e feitas de uma substancia coriacea, producto secretado provavelmente pelas glandulas fiandeiras da larva. A parede dorsal é muito mais espessa do que a ventral, a ponto de quasi não se poder separar incolume da pedra, em que estiver collocada. Na face dorsal quasi sempre elevam-se linhas parallelas que, perpendiculares ao eixo maior da ellipse, vão ininterruptas de uma a outra margem lateral. A distancia de uma a outra linha costuma variar de $0,{ }^{\text {,im }} \mathrm{o} 8$ selbe Weise vorschreiten, indem sie mit einigen Fäden die Futterale festheften und sich in das Innere derselben zurückziehen, wenn sie sich ausruhen wollen.

Ich schliesse die Reihe neuer Formen, die ich soeben beschrieben habe, mit einer Art (Fig. 30), von der ich noch nicht das vollkommene Insekt, sondern nur Bruchstücke der Puppe gesehen habe und desshalb nicht mit Sicherheit weiss, zu welcher Familie sic gehört. Der Hinterleib der erwachsenen Larve ist äusserst stark verbreitert, mehr als bei irgend einer anderen catharinensischen Art; das ist der Hauptgrund, wesshalb ich sie hier besprochen habe.

Die Gehäuse sind unbeweglich, indem sie mit der ganzen Bauchfläche an den Steinen grösserer Bäche von raschem Laufe befestigt sind.

Vor einigen Jahren sah ich sie in grosser Menge im Bache W'arnow (einem Zufluss des Itajahy), wogegen sie im Bache Garcia sehr selten sind. Sie sind elliptisch, von 4 bis $5 \mathrm{~mm}$ Länge und 2,2 bis $2,5 \mathrm{~mm}$ Breite; in seltenen Fällen erheben sie sich in der Mitte auf mehr als $0,5 \mathrm{~mm}$.

Sie sind also abgeplattet, ähnlich einem Schild, oder, noch besser, den Kapseln, welche die Eier der Nephelis vulgaris, eines in den Gewässern Europas sehr häufigen Blutegels, umschliessen. Eben so wie diese Kapseln von Nephelis sind sie von brauner Farbe und aus einer lederartigen Substanz gemacht, die wahrscheinlich von den Spinndrüsen der Larve abgesondert worden ist. Die Rückenwand ist viel dichter als die Bauchwand, so dass sie kaum unversehrt von dem Stein, an dem sie sitzen, getrennt werden können. Auf der Rückenfläche erheben sich fast immer parallele Linien, die, senkrecht zur grösseren Achse der Ellipse, fast ununterbrochen von einem zum anderen Seitenrande ver- 
até $\mathrm{O}^{\mathrm{mm}}{ }^{12}$. Uma vez vi essas linhas substituidas por fileiras transversaes de pequenos tuberculos: em outros casos as linhas são mais ou menos indistinctas. Perto de cada extremo do eixo maior ha um pequeno orificio circular ou elliptico, que a larva parece fechar completamente antes de passar ao estado de nympha.

Proponho para o habitante dessa curiosa casa o nome de Peltopsyche Sieboldii, dedicando a especie ao veneravel veterano dos zoologos allemães o professor Carl Theodor von Siebold.

Taes são as casas de Trichopteros que até agora achei na provincia de Santa Catharina. Sem duvida o numero das especies que habitam as aguas desta provincia deve ser muito maior, e a minha lista precisará de supplementos, provavelmente mais extensos do que a primeira. Comtudo, imperfeito e incompleto como é, o presente trabalho talvez possa servir para animar outros naturalistas a, não só colleccionarem em outras partes do Imperio as tão curiosas casas do Trichopteros, como tambem a se entregarem ao estudo muito mais interessante da biologia de seus habitantes.

Itajahy, Outubro de 1878 .

\section{Explicação das figuras da estampa LIII-LV ${ }^{1}$.}

Fig. 1 e 4. Casas de Rhyacophilideas, augmentadas duas rezes (o que d'ahi por diante, mais brevemente, fica indicado por $2: \mathrm{I})$.

Fig. ז. Do Ribeirào dos Bugres $A, A$ ' - casa livre de larva. $A$ - vista de cima. laufen. Der Abstand von einer zur anderen Linie pflegt von o,os bis $0,12 \mathrm{~mm}$ zu variiren. Einmal sah ich diese Linien durch Querreihen kleiner Höcker ersetzt; in anderen Fällen sind die Iinien mehr oder weniger unbestimmt. Nahe jedem Ende der grösseren Achse befindet sich eine kreisförmige oder elliptische Oeffnung, die die Larve vollständig zu verschliessen scheint, ehe sie in den Puppenzustand übergeht.

Ich stelle für den Bewohner dieses merkivürdigen Grehäuses den Namen Peltopsyche Sieboldii auf, indem ich diese Art dem chrwürdigen Veteranen der deutschen Zoologen, dem Professor Carl Theodor v. Sicbold widme.

Das sind die Trichopterengehäuse, die ich bis jetzt in der Provinz Santa Catharina gefunden habe. Ohne Ziveifel muss die Zahl der Arten, die die Gewässer dieser Provinz bewohnen, sehr viel grösser sein und meine Liste wird Nachträge, von wahrscheinlich grösserer Ausdehnung als diese Liste selbst, erfordern. Unvollkommen jedoch und unvollständig wie sie ist, kann die vorliegende Arbeit vielleicht dazu dienen, andere Naturforscher anzuregen, in anderen Theilen des Reichs nicht nur die so merkwürdigen Gehäuse der Trichopteren zu sammeln, sondern sich auch dem viel interessanteren Studium der Biolngie ihrer Einwolnner zu widmen.

$$
\text { It ajahy, Oktober } 1878 \text {. }
$$

\section{Erklärung der Abbildungen auf Tafel LIII-LV.}

Fig. I-4. Gehäuse von Rhyacophiliden. Vergr. $2: 1$.

Fig. I. Aus dem Bugresbache. $A, A$, freies Larvengehïuse; $A$, von oben $A$ ', von 
A' - vista da face ventral, mostrando as duas portas da casa. $l$,,$B^{\prime}$ - casa fixada de nympha. $B$ - vista de cina. $B^{\prime}$ - vista de face ventral; nào havendo mais parede ventral, vê-se a cavidade interior da casa.

Fig. 2. Da Gruta dos Macacos («Affenwinkel»). Casas livres de larvas. $A, B$-vistas de cima. mostrando o orificio dorsal. A'-a casa - 1 - vista da face ventral.

Fig. 3. Do Ribeirĩo do Garcia. Casas livres de larvas, com chaminé, vistas do lado.

Fig. 4. Da Triste Miseria de Blumenau ("Trauriger Jammer»). $A, B$ - casas de larvas, livres, vistas de lado. $C, C^{\prime}$ - casa de nymplia, fixada, sem chaminé. $C$ - vista de cima. C'-vista cla face ventral; vê-se no interior o casulo solto da nympha.

Fig. 5 e 6. Casas de Mydropsychideas, de tamanho natural.

Fig. 5. Do Ribeirìo dos Bugres. $A$, $A$ - casa de nympha. $A$ - vista de cima. $A$ '- vista da face ventral, com a cavidade interna aberta. $B$ - casulo membranaceo de nympha, incluido na casa de pedras. $\quad{ }^{\prime}$ 'crivo do extremo do mesmo casulo (15: I).

Fig. 6. Rhyacophyla.ı. Da Gruta dos Macacos. $A$-casa de larva, immovel, com varanda em fórma de funil, coberta de uma rede. $B, B^{\prime}$ - casa de nymphas. $B$-vistas de cima. $B^{\prime}$ - vistas da face ventral.

Fig. 7 e I5. Casas de Leptocerideas.

Fig. 7. Ramos habitados por larvas de Leptocerideas, de tamanho natural. $A$-casa de nympha. $A^{\prime}-$ a mesma cortada longitudinalmente. $p$ - pedra tapando a entrada. $n$ - casulo membranaceo da nympha. crcrivo no extremo do casulo. $c a$ - tubo excavado pela larva. o- buraco na parede do tubo. $m$-medulla do ramo.

A" O crivo (cr), 8: $\mathbf{I}$.

$B$ Outro ramo encerrando a nympha, notavel por achar-se o crivo do casulo applicado ao orificio lateral do tubo. $\quad{ }^{\prime}$ 'esse orificio com o crivo, $8: \mathbf{I}$.

C Ramo ôco, encerrando a nympha. C'- secçìo longitudinal do mesmo; as lettras como em $A^{\prime}$. der Bauchseite geschen und die beiden Thüren des Gehäuses zeigend. $B, B$ ', festgcheftetes Puppengehäuse; $B$. von oben $B^{\prime}$, von der Bauchseite gesehen; da es keine Bauchwand mehr hat, sieht man in $B^{\prime}$ den inneren Hohlraum des Geläuses.

Fig. 2. Aus dem Affenwinkel. Freie Larvengehäuse; $A, B$. von oben gesehen, die Rückenöffnung zeigend; $A^{\prime}$, das Gehäuse $A$ von der Bauchseite gesehen.

Fig. 3. Aus dem Bache Garcia. Freie Larvengehäuse mit Schornstein, von der Seite gesehen.

Fig. 4. Aus dem ,Traurigen Jammer" von Blumenau. $A, B$, freie Larvengehäuse, von der Scite gesehen; $C, C^{\prime}$, befestigtes Puppengehäuse ohne Schornstein; $C$, von oben, C', von der Bauchseite gesehen; man sielit im Innern den losen Puppenkokon.

Fig. 5 und 6. Gehäuse von H y dropsychiden, in $n$ atürl. Grösse.

Fig. 5. Aus dem Bugresbache. $A, A^{\prime}$, Puppengehäuse; $A$, von oben $A^{\prime}$, von der Bauchseite gesehen, mit geöffnetem, inneren Hohlraum; $B$, häutiger Puppenkokon, aus dem Steingehäuse, in dem er eingeschlossen lag, herausgenommen; $B$, Sieb am Ende dieses Kokons. I5 : I. (Gattung Macronema des Nachtrags).

Fig. 6. Rhyacophylax. Aus dem Affenwinkel. $A$, unbewegliches Larvengehäuse mit trichterförmigem, von einem Netz bedeckten Vorhof; $B, B$, Puppengehäuse; $B$, von oben, $B$ ', von der Bauchseite gesehen.

Fig. 7-I5. Gehäuse von Leptoceriden.

Fig. 7. Von Leptoceridenlarven bewohnte Zweige, in natürl. Grösse. $A$, Puppengehäuse ; $A$ ', dasselbe im Längsdurchschnitt : p, Stein, der den Eingang verschliesst; n, häutiger Kokon der Puppe; $c r$, Sieb am Ende des Kolions; $c a$, von der Larve ausgehöhlte Röhre; 0 , Loch in der IVand der Röhre; m, Mark des Zweiges.

1", das Sieb $\left(c r^{\circ}\right) . \quad 8: \mathrm{I}$.

$B$, anderer, die Puppe einschliessender Zweig, dadurch bemerkenswerth, dass das Sieb des Kokons sich der Seitenöffnung der Röhre angelegt findet; $B$, diese Oeffnung mit dem Siebe. 8: I.

$C$, hohler, die Puppe einschliessender, \%weig; $C$ ', Längsdurchschnitt desselben; dio Buchstaben wie bei $d^{\prime}$. (Gattung Tetracentron des Naclitrages.) 
Fig. 8. Gnumicha, do Ribeirão do Garcia. A Grupos de estojos fixados, de tamanho natural; os maiores são de femeas, os menores de machos. $B$ Tampa do orificio posterior, com buraco central e circular, 8: I. $C$ Tampas anteriores de femeas, com fenda transversal abaixo do centro, 8: I. D- dita de um macho, 8: I.

Fig. 9. Estojo de Grumicha, occupado por nympha intrusa, tapado com umà pedra (p) e fixado por um disco transversal, sem peciolo (d). cr-logar onde no interior ha um crivo transversal. Do Ribeirào do Garcia. De tamanho natural.

$B$. Pedra que servio de tampa ao estojo $A$, removida pela nympha ao sahir do estojo, com o annel crivado que a ligava ao estojo $(5: \mathrm{I})$.

Fig. IO. Gmimichinha, da Gruta dos Macacos. A Estojos de nymphas fixados, de tamanho natural. $B$ Tampa anterior com fenda transversal acima do centro, I 5 : I.

Fig. II. A Casa feita de sementes de Callitriche, de um ribeirinho tributario do Ribeirào do Garcia, 3: I. A' Entrada da mesma casa, fechada por uma membrana transversal, com buraco central, i 5: I. $B$ Entrada de outra casa, ainda aberta, 3: r.

Fig. I 2. Casas de pedacinhos de madeira, do Ribeirào do Garcia 2: I. $A, A^{\prime}$ Casa de nympha fixada. $A$ - vista do lado ventral. $A^{\prime}$ - vista do lado esquerdo. $A^{\prime \prime}-$ tampa anterior. $A$ "' - dita posterior da mesma casa, 8: I. $B$ Casa de larva livre, vista do lado ventral.

Fig. I3. A, Estojo de nympha coberto de areia finissima, do Ribeirão do Garcia, visto do lado direito, 3: I. A', Extremo posterior do mesmo estojo, com o disco adhesivo, I 5: I. A'"-tampa anterior. A"'-dita posterior do mesmo, $15: \mathrm{r}$.

Fig. I4. Canudos de pedras, especie maior, do Ribeirão dos Bugres, vistos do lado direito, de tamanho natural, sendo $A$ - casas de larvas livres. $B, C$ - casas de nymphas fixadas, menores (de machos?). $D, E$ - ditas maiores (de femeas?) $A^{\prime}$ -
Fig. 8. Grumicha vom Bache Garcia. A, Gruppen festgehefteter Futterale in natürlicher Grösse; die grösseren sind von Weibchen, die kleineren von Männchen; $B$, Deckel der hinteren Oeffnung mit kreisförmigem Loch in der Mitte. 8: I. C, vordere Deckel von Weibchen, mit Querspalt unter der Mitte. 8: I. D, desgleichen von einem Männchen. 8: $\mathrm{r}$.

Fig. 9. A, Grumichafutteral, von einer eingedrungenen Puppe besetzt, mit einem Steine $(p)$ verschlossen, und mit einer ungestielten Querscheibe $(d)$ befestigt: $c r$, die Stelle, wo inwendig sich ein Quersieb befindet. Aus dem Garciabache. Natürliche Grösse. (Der Eindringling $=$ Tetracentron spec. des Nachtrages.)

$B$, Stein, der dem Futteral $A$ als Deckel gedient hat, durch die Puppe bei ihrem Ausschlüpfen aus dem Futteral entfernt, mit dem siebförmig durchlöcherten Ringe, der den Stein mit dem Futterale verband. 5: I.

Fig. Io. Grumichinha (Grumichella des Nachtrages), aus dem Affenwinkel. $A$, festgeheftete Puppenfutterale; in natürl. Grösse. $B$, vorderer Deckel mit Querspalt über der Nitte. I $5: 1$.

Fig. I I. A, aus Samen von Callitriche gemachtes Gehäuse, aus einem kleinen Bache, der in den Garciabach fliesst. 3: 1 . $A$, Eingang desselben Gehäuses, mit einer Querhaut verschlossen, die in der Mitte ein Loch hat. I $5:$ r. $B$, Eingang eines anderen, noch geöffneten Gehäuses. 3: r.

Fig. I2. Gehäuse aus Holzstückchen, aus dem Garciabache. $2: \mathrm{I} . \quad A, A^{\prime}$, festgeheftetes Puppengehäuse; $A$, von der Bauchseite, A', von der linken Seite gesehen; $A$ ", vorderer, A"', hinterer Deckel clesselben Gehäuses. $8:$ I. $B$, freies Larvengehäuse, von der Bauchseite gesehen. (Setodes spec, des Nachtrages.)

Fig. I3. $A$, mit feinstem Sande bedecktes Puppenfutteral, aus dem Garciabache, von der Seite gesehen. 3: I. A', hinteres Ende desselben Futterals mit der Haftscheibe. 15: I. $A^{\prime \prime}$, vorderer, $A^{\prime \prime}$, hinterer Deckel desselben. I5: I. (Setorles gemma.)

Fig. I4. Steinröhren, grössere Art (Marilia major des Nachtrages) aus dem Bugresbache, von der rechten Seite gesehen, in natürlicher Grösse. $A$, freie Larvengehäuse; $B, C$, kleinere befestigte Puppengelıäuse (von Männchen?); $D, E$, desgl. grössere (von 
paredes transversaes do extremo posterior das casas de larvas A, 3:1. B'. $C^{\prime}$ Extremo anterior das casas de nymplias $(\mathrm{B}, \mathrm{C})$, 3: I. $B^{\prime \prime}$ Fenda do extremo posterior da casa de nympha B, I5: I. C"'-Dita do extremo anterior de C, I5: I. - E'-Extremo posterior da casa de nympha E, $3:$ I. E' Secçio longitudinal do mesmo extremo, 6: I.

Fig. I5 - Canudos de pedras, especie menor, da Gruta dos Macacos, vistos do lado direito, de tamanho natural, sendo $A$ casas de larvas, livres, $B$ casas de nymphas, fixadas. $A$ ' parede transversal do extremo posterior da casa de larva, 25: I. $B^{\prime}$ extremo posterior, $C^{\prime \prime}$ dito anterior de $B, 4:$ I. $B$ "' fenda do extremo posterior e $B^{\prime \prime}$ margem ventral da fenda anterior de $B$, I $5:$ I.

Fig I6-I7. Casas de posição systematica incerta.

Fig. I6. Casas de folhas, de diversos ribeiros, de tamanho natural, $A, A^{\prime}, B, B^{\prime}$, $C^{\prime}$ - Casas de larvas livres, sendo $A, B, C$ vistas de cima, $A^{\prime}, B^{\prime}$ da face ventral. $D$ - Casa de nympha, fixada, or indica o logar, em que se acha o crivo posterior. $D$ - Crivo anterior da mesma casa, 5: I. $E$ - Secçào transversal de uma casa, de tamanho natural.

Fig. I7. Casas de folhas de larvas vivendo entre as folhas de Bromeliaceas parasitas do mato virgem, $2: 1$. $A, B$, vistas de cima, $A^{\prime}, B^{\prime}$ as mesmas, vistas da face ventral. $C, C$ ' Secciòes transversaes de uma casa, $5: \mathbf{I}$.

Fig. I 8 - 21. Casas de Sericostomideas do genero Ilelicopsyche, $2: \mathrm{I}$.

Fig. I 8. Do Ribeirâo da Triste Miseria de Blumenau. $B, " B$, $P^{\prime \prime}$ - - Tampas de casas de nymphas, 8: 1 .

Fig. I 9. Do Ribeirào Branco («Weissbach»). $B, B^{\prime}, B^{\prime \prime}$ - Tampas de casas de nymphas, 8: I.

Garcia.

Fig. 20. De remansos do Ribeirão do

Fig. 2 I. Do Ribeirìo do Garcia. 8 : I.
Weibchen?); A', Querwände des hinteren Endes der Larvengehäuse $A, 3:$ I ; $B^{\prime}, C^{\prime}$, vorderes Ende der Puppengehäuse $B, C$, 3: I ; $B^{\prime \prime}$, Spalt am linteren Ende des Puppengehäuses $B$, I 5 : I; $C^{\prime \prime}$, Spalt am vorderen Ende von $C$, I5: I; $E$, hinteres Ende des Puppengehäuses $E, 3:$ I ; $E$ ", Längsdurchschnitt desselben Endes, 6: I.

Fig. I 5. Steinröhren, kleinere Art (Marilia minor (les Nachtrages) aus dem Affenwinkel, von der rechten Seite gesehen, in natürlicher Grösse. $A$, freie Larvengehäuse ; $B$, festgeheftete Puppengehäuse; d' Querwand des hinteren Endes des Larvengehäuses, I 5 : I ; $B$ ', hinteres, $B^{\prime \prime}$, vorderes Ende von $B, 4: \mathrm{I} ; B^{\prime \prime}$, Spalt des hinteren Endes und $B^{\prime \prime}$, Bauchrand des vorderen Spaltes von $B$, I5: I.

Fig. I6-I7. Gehäuse von un sicherer systematischer Stellung. (Gattung Phylloicus, zu Mac Lachlan's vierter Sektion der Leptoceriden gehörig; laut Nachtrag!)

Fig. I6. Blattgehäuse von verschiedenen Bächen (Phylloicus major des Nachtrages), in natürlicher Grösse. $A, A^{\prime}, B, B^{\prime}, C$, freie Larvengehäuse; $A, B, C$, von oben, $A^{\prime} B^{\prime}$, von der Bauchseite gesehen; $D$, festgeheftetes Puppengehäuse; $c r$, bezeichnet die Stelle, an der sich das hintere Sieb befindet, $5:$ I ; $D$ ', vorderes Sieb desselben Gehäuses, 5: I; E, Querdurchschnitt eines Gehäuses, in natürl. Grösse.

Fig. I 7. Blattgehäuse von Larven, die zwischen den Blättern im Urwalde schmarotzender Bromeliaceen leben (Phylloicus Bromeliarum des Nachtrages). 2: I. $A, B$, von oben gesehen; $A$ ', $B$ ', dieselben von der Bauchseite gesehen; $C, C$ ' Querdurchschnitte durch ein Gehäuse. 5: I.

Fig. I $8-2$ I. Gehäuse von Sericostomiden der Gattung Helicops yche. $2:$ I.

Fig. I 8. Vom Bache „Trauriger Jammer" in Blumenau. $B, B^{\prime}, B^{\prime \prime}$, Deckel von Puppengehäusen. $8: \mathbf{I}$.

Fig. I9. Vom Weissbach (Ribeirĩo branco). $B, B^{\prime} B^{\prime \prime}$, Deckel von Puppengehäusen. $8: \mathbf{I}$.

Fig. 20. Aus stehendem Wasser cles Baches Garcia.

Fig. 2I. Aus dem Bache Garcia.

Fig. 22-3o. Ge hä us e von Hydroptiliden. $S:$ I. 
Fig. 22. Canudinhos, cobertos de areia finissima, do Ribeirão dos Bugres. $A, A$, $B$ Casas de larvas livres, sendo vistas A - da face rentral, $A$ '- do lado esquerdo, B (outra casa) de cima. C-casa de nympha, fixada, vista de cima. $C^{\prime}$ - a mesma, do lado esquerdo. $C$ " - a mesma, vista da face ventral. $D$-Casa de larva, vista de cima, I 5: I.

Fig. 23. $A, B, C-$ Casas de larvas, cobertas de areia do Ribeirĩo dos Bugres, vistas do lado. $C$ - Secçìo transversal de C.

Fig. 24. - Casas de outra especie, do mesmo Ribeirìo dos Bugres. A-Casa de larvas, livre, de algas (ou outros fragmentos de plantas) verdes. $B, C$ Casas de nymphas, fixadas, de Diatomaceas. $D, D^{\prime}-O$ material para a construcçào destas casas, 90: I.

Fig. 25. Casas transparentes, construidas sem corpos estranlıos, do Ribeirão dos Bugres. $A$ - Casa de larva, livre. $B$ - casa de nympha, fixada pela margem ventral. $B^{\prime \prime} B^{\prime \prime}$-Secções transversaes de $B$.

Fig. 26. Casas de Diaulus Ladisianii, do Ribeirão dos Bugres. A - Casa normal, de dous canos. A'-Secção transversal da mesma, I5: I. $B$ Casa de tres canos (unica que se achou). C'-Casa de larva ainda em via de construcção, como se vê dos extremos ainda pouco prolongados além dos canos, 25:1.

Fig. 27. Casas de Lagenopsyche Spirogyra, de um ribeirinho affluente do Ribeirĩo do Garcia (nas terras de Heurique Kohler). $A, B, C, D$ Casas de larvas de differente idade, livres, vistas do lado. $E$-Casa fixada, cuja larva ainda não se transformou em nympha, vista de cima. $F$-Casa de nympha fixada, vista de cima. $F^{\prime \prime}, F^{\prime \prime}$, F"' - Secçĩes transversaes da mesma casa pelos pontos $f^{\prime}, f^{\prime \prime}, f^{\prime \prime}$.

Fig. 28. Casas de Lagenopsyche hyalina, do Ribeirão dos Bugres. $A$ - casa de larva. $B, C$-de nymphas.

Fig. 29. Casas de Rhyacopsyche Itagenii, do Ribeirão da Gruta dos Macacos ("Affenwinkel»), en cima do salto do mesmo ribeirão. $A, B, C$-Casas de larvas de
Fig. 22. Mit feinstem Sande bedeckte Röhrchen aus dem Bugresbache. $A, A^{\prime}, B$, freie Larvengehäuse; $A$, von der Bauchseite; $A$, von der linken Seite gesehen; $B$, anderes Gehäuse, ron oben gesehen: $C$, festgeheftetes Puppengehäuse, von oben gesehen; $C^{\prime}$, dasselbe, von der linken Seite; C", dasselbe von der Bauchseite gesehen; $D$, Larvengehüuse von oben gesehen. I $5:$ I.

Fig. 23. $A, B, C$, mit Sand bedeckte Larvengehäuse aus dem Bugresbache, von der Seite gesehen; C', Querdurchschnitt von $C$.

Fig. 24. Gehäuse anderer Art, aus demselben Bugresbache. A, freies Larvengehäuse, aus grünen Algen (ocler anderen Pflanzenfragmenten); $B, C$, festgeheftete Puppengehäuse, aus Diatomeen; $D, D$ ', das Baumaterial dieser Gehäuse. $90: 1$.

Fig. 25. Durchscheinende Gehäuse, ohne fremde Körper gebaut, aus dem Bugresbache. $A$, freies Larvengehäuse; $B$, mit dem Bauchrande festgeheftetes Puppengehïuse; $B$ ', B', Querdurchschnitte von $B$.

Fig. 26. Gehäuse von Diaulus La dislavii aus dem Bugresbache. $A$, normales Gehäuse, mit zwei Schornsteinen; $A$ ', Querdurchschnitt desselben, I5: I; $B$, Gehäuse mit drei Schornsteinen (das einzige, das gefunden wurde); $C$, Larvengehäuse, welches noch im Bau begriffen ist, wie man an den noch wenig über die Schornsteine hinaus verlängerten Enden sehen kann. 25: I.

Fig. 27. Gehäuse von Lagen opsyche Spirogyrae, aus einem kleinen Nebenbächlein des Garciabaches (im Gebiete von Henrique Koehler). $A, B, C, D$, freie Larvengehäuse, in verschiedenen Zuständen, von der Seite gesehen; $E$, befestigtes Gehïuse, dessen Larve sich noch nicht zur Puppe umgewandelt hat, von oben gesehen; $F$, befestigtes Puppengehäuse von oben gesehen; F", F', F'", Querdurchschnitte desselben Gehäuses durch die Punkte f', f", f'".

Fig. 28. Gehäuse von Lagenopsyche hyalina, aus dem Bugresbache. $A$, Larvengehäuse; $B, C$, Puppengehäuse.

Fig. 29. Gehäuse von Rhyacopsyche Hagenii, aus dem Bache „Affenwinkel“. $A, B, C$, Larvengehäuse in verschiedenen Zustïnden, an einem biegsamen Seile be- 
differente idade, fixadas por uma corda flexivel, abertas em ambos os extremos. $h$ - parte mais nova da casa. $D E$ - Casas de larvas, já fechadas em um dos extremos. $F$. Casa de nympha fechada de todos os lados, fixada por um esteio curto, rijo. $F^{\prime}$-Secçìo transversal da mesma casa.

Fig. 30. Casas de Peltopsyche Sieboldii, do Ribeirìo do Garcia. A - casa de larva, $B$ - de nympha, sendo uma e outra fixadas por toda a face ventral. $A^{\prime}-$ Secção transversal do $A$. festigt, an beiden Enden offen; $h$, neuerer Theil des Gehäuses; $D, E$, Puppengelaäuse, an einem Ende bereits geschlossen; $F$, Puppengehäuse, von allen Seiten geschlossen, auf einem kurzen, kräftigen Stiele befestigt; F' Querdurchschnitt dessellsen Gehäuses.

Fig. 30. Gehäuse von Peltopsyche Siebolklii aus dem Bache Garcia. A, Larvengehäuse; $B$, Puppengehäuse, beide nit der ganzen Bauchfläche befestigt; $A^{\prime}$, Querdurchschnitt von $A$. 
Sobre as casas construidas pelas larvas de Insectos Trichopteros da provincia de Sa. Catharina').

Supplemento.

\section{Ueber die von den Trichopterenlarven der Provinz Santa Catharina verfertigten Gehäuse'1).}

Mit Tafel LVI.

Com este supplemento tenho em vista não só completar a lista das especies catharinenses, como tambem precisar a sua posição systematica melhor do que me foi possivel, quando só conhecia as suas larvas e nymphas. Hoje já tenho seguido a transformação de maior numero até o estado de insectos perfeitos.

\section{$\S \mathrm{I}$.}

II ydropsychideas.

Esta familia foi dividida por MacLachlan ${ }^{2}$ ) em cinco secçôes, de que ao menos tres se acham representadas na provincia de Santa Catharina.

A casa da fig. 5 (Est. LIII) pertence ao genero Macronema, que constitue a segunda secçãode Mac-Lachlan. Apezar de rico em especies espalhadas por todos os paizes tropicaes, e estender-se na America do Norte até $46^{\circ}$ e na Asia até $55^{\circ}$ de

I) Archiv. do Museu Nacional do Rio de Janeiro I 878. vol. III. p. I25-I34. Est. XI.

2) Mac-Lachlan, a monographic revision and synopsis of the Trichoptera of the European fauna: Part. VII, 1878 .
Mit diesem Nachtrage beabsichtige ich nicht bloss die Liste der catharinensischen Arten zu vervollständigen, sondern auch ihre systematische Stellung, besser als es mir möglich war, so lange ich nur ihre Larven und Puppen kannte, zu präcisiren. Heute bereits habe ich die Verwandlung der meisten bis zum Zustande der fertigen Insekten verfolgt.

$$
\text { I) Hydropsychiden. }
$$

Diese Familie ist von MacLachlan $\left.{ }^{2}\right)$ in fünf Sektionen getheilt worden, von denen in der Provinz Santa Catharina sich wenigstens drei vertreten finden.

Das Gehäuse (Taf. LIII. Fig. 5) gehört zur Gattung Macronema, die Mac Lachlan's zweite Sektion ausmacht. Obgleich sie reich ist an über alle tropischen Länder verbreiteten Arten und sich in Nordamerika bis zum ${ }_{4} 6$, in Asien bis zum

1) Zeitschr. wiss. Zoologie 1 88o. Bd.35.S. 74-87.

2) Mac Lachlan, A monographic revision and synopsis of the Trichoptera of the European fauna: Part. VII. 1878 . 
latitude, nada se sabia até agora das larvas deste genero e das suas casas.

O genero Rhyacophylax (Est. LIII, fig. 6) deverá entrar na quarta secção, distinguido-se de todos os mais gencros, não só desta secçào, como de toda a familia das Hydropsychideas pelo numero dos esporões nas tibias dos machos $(\mathrm{I}, 4,2)$,

Provavelmente ha de ser da quinta secção uma pequena Hydropsychidea, de que ainda não vi os insectos perfeitos, e cujas larvas costumam abundar nas paredes verticaes de rochedos, que o chuvisco de alguma cachoeira conserva sempre humidas. Ao menos as casas construidas pelas larvas (fig. I, $A, B)$ são muito semelhantes ás de Tinodes (Hydropsyche) maculicornis Pict.

Essas casas, agarradas aos rochedos, têm geralmente de um até dous centimetros de comprimento sobre outros tantos millimetros de largura, sendo algum tanto adelgaçadas em um e outro extremo; ás vezes o seu comprimento se eleva, sem notavel augmento da largura, a mais de quatro ou cinco centimetros.

As mais compridas costumam ser mais ou menos tortuosas, assemelhandose a certos vermes (Geoplanas ou $\mathrm{Ne}$ mertineas) não só pela fórma como tambem por serem molles.

A sua côr é cinzenta, mais ou menos esverdinhada.

São feitas de seda misturada e cobertas de algas microscopicas, diatomeas, etc. São semi-cylindros, pois não têm parede ventral, servindo como tal a pro-
55. Breitengrade ausdehnt, wusste man noch Nichts von den Larven dieser Gattung und von ihren Gehäusen.

Die Gattung Rhyacophylax (Taf. LIII Fig. 6) wird in die vierte Sektion eintreten müssen; sie unterscheidet sich von allen übrigen Gattungen, nicht nur dieser Sektion, sondern der ganzen Familie der Hydropsychiden, durch die Zahl der Sporne an den Schienen der Männchen $(1,4,2)$.

In die fünfte Sektion ist wahrscheinlich eine kleine Jydropsychide einzureihen, von der ich die fertigen Insekten noch nicht gesehen habe, und deren Larven an senkrechten Felswänden, die vom Staubregen irgend eines Wasserfalles immer feucht gehalten werden, gewöhnlich sehr häufig sind. Wenigstens sind die von den Larven verfertigten Gehäuse (Fig. I, A, B) sehr ähnlich denen von Tinodes (Hydropsyche) maculicornis Pict.

Diese an den Felsen festsitzenden Gehäuse haben im Allgemeinen I bis $2 \mathrm{~cm}$ Länge bei doppelt so viel $\mathrm{mm}$ Breite; an beiden Enden sind sie etwas verdünnt; bisweilen steigert sich ihre Länge, ohne merkliche Zunahme der Breite, auf 4 bis $5 \mathrm{~cm}$.

Die längsten sind gewöhnlich mehr oder weniger gekrümmt, so dass sie gewissen Würmern (Geoplana oder Nemertinen) ähneln, und zwar nicht nur in der Gestalt, sondern auch darin, dass sie weich sind.

Ihre Farbe ist aschgrau, mehr oder weniger grünlich.

Sie sind aus vermischter Seide gemacht, und mit mikroskopischen Algen, Diatomeen u. s. w. bedeckt. Sie sind halb cylindrisch und haben keine Bauch- 
pria rocha, á qual se applicam os bordos lateraes do semi-cylindro.

As larvas que tecem e habitam essas casinhas, não attingem ás vezes nem á decima parte do comprimento clas casas; assim, quando ellas estão para se transformar em nymphas, sé conserram uma pequena porção de cerca de cinco millimetros de comprimento, da sua morada (fig: I, C), cujas paredes ellas engrossam muito, ficando ao mesmo tempo com o augmento da grossura as paredes mais resistentes, duras equasi cartilaginosas. As casas das nymphas adherem firmemente aos rochedos, emquanto as clas larvas são quasi livres, não oppondo resistencia sensivel ao serem removidas.

No rio Itajahy encontrei na superficie de pedras, parcialmente cobertas de Podostemeas, umas poucas de casas de uma Hydropsychidea, pertencente provavelmente tambem á quinta secçào de Mac-Lachlan, notaveis por serem extremamente semelhantes ás casas do genero Peltopsyche da familia das Hydroptilideas. Assim como estas, são escudos chatos ellipticos, de côr parda mais ou menos escura, de cerca de $7^{\mathrm{mm}}$ de comprimento sobre $3^{\mathrm{mm}}$ de largura. São pois maiores do que as das nossas especies de Peltopsyche. Falta-lhes uma parede ventral, sendo os bordos fixados ás pedras. São feitas de seda, que fórma uma membrana muito resistente, quasi coriacea, e cuja superficie interna é muito mais pallida ou até perfeitamente branca. Ainda não vi os insectos perfeitos, porem as nymphas mostram pelo numero dos esporões das tibias (2, 4, 4), pelos palpos maxillares, e por outros caracteres, que não pertencem ao genero Peltopsyche, nem a outro genero de Hydroptilideas e sim ás Hydropsychideas. wand, da der Fielsen, dem sie die Seitenränder des Halbcylinders anlegen, selbst als solche dient.

Die Larven, die diese Gehäuse weben und bewohnen, erreichen bisweilen noch nicht einmal ein Zehntel der Länge der Gehäuse; auch behalten sie, wenn sie im Begriff sind, sich in Puppen umzuwandeln, nur ein kleines Stück, von etwa 5 mm Länge, von ihrer Wohnung (Fig. 1, C), deren Wände' sie sehr verdicken; gleichzeitig mit der Zunahme an Dicke werden die Wände widerstandsfähiger, hart und fast knorpelig. Die Puppengehäuse haften fest an den Felsen, während die der Larven fast frei sind und dem Versuche, sie zu entfernen, keinen merklichen Widerstand entgegensetzen.

Im Flusse Itajahy traf ich an der Oberfläche von Felsen, besonders solcher, die mit Podostemeen besetzt waren, einige wenige Gehäuse einer Hydropsychide, die wahrscheinlich ebenfalls in die fünfte Sektion Mac Lachlan's gehört; sie sind bemerkenswerth wegen ihrer ausserordentlichen Aehnlichkeit mit den Gehäusen der Gattung Peltopsyche aus der Familie der Hydroptiliden. Eben so wie diese sind es platte elliptische Schilde von mehr oder weniger dunkelbrauner Farbe von ungefähr $7 \mathrm{~mm}$ Länge bei $3 \mathrm{~mm}$ Breite. Sie sind also grösser als die unserer Peltopsyche-Arten. Es fehlt ihnen eine Bauchwand, da die Ränder an die Felsen festgeheftet sind. Sie sind aus Seide gemacht, die eine sehr widerstandsfähige, fast lederartige Haut bildet und deren innere Oberfläche blässer oder bis vollkommen weiss ist. Ich habe die fertigen Insekten noch nicht gesehen, aber die Puppen zeigen durch die Zahl der Schiensporne (2, 4, 4), durch die Kiefertaster und durch andere Merkmale, dass sie nicht zur Gattung Peltopsyche, auch nicht zu einer anderen Gattung der Hydroptiliden, sondern zu den Hydropsychiden gehören. 


\section{$\$ 2$. Leptocerideas.}

Mac-Lachlan divide esta familia em quatro secções de que só a primeira falta á fauna catharinense.

A' segunda secçùo, limitada na fauna européa ao genero Odontocerum, pertencem ás duas especies cujos tubos construidos de pedrinhas se vêm nas fig. I 4 e 15 da Est. LIV. Elles deverào constituir um genero novo, para o qual proponho o nome de Marilia, chamando as duas especies Marilia major (fig. I +) e Marilia minor (fig. 15). Distingue-se esse novo genero de Odontocerum pelas antennas năo denteadas, pelos olhos enormes dos machos (tocando-se no vertice dos machos da Marilia minor, e separados sómente por um intervallo estreito nos da Marilia major), por confluirem nas azas tanto anteriores como posteriores o raio («radius») e o primeiro sector apical, e por outros caracteres.

As duas especies de Marilia, cujas casas descrevi, frequentam varios ribeiròes. Ha uma terceira especie, ao que parece, rarissima, cujas larvas achei do rio Itajahy. As casas differem das na Marilia major quasi que por serem apenas muito curtas; é pois escusado de dar uma figura dellas; ter-se-ha uma idéa exacta da sua fórma imaginando-se cortada a metade posterior das casas da Marilia major. (Est. LIV., fig. 14, A.) A só casa dessa terceira especic que agora tenho, tem $6^{\mathrm{mm}}$ de comprimento. sendo o diametro da entrada de $2^{\mathrm{mm}} \mathrm{e}$ o do extremo posterior de $1,{ }^{\mathrm{mm}} 5$. O extremo posterior é tapado, como nas outras Marilias, por uma parede transversal com buraco elliptico na parte superior. Cumpre notar que a substancia de que é feita essa parede e com que se acham

\section{2) Le eptoceriden.}

Mac Lachlan theilt diese Familie in vier Scktionen, von denen der Fauna von Santa Catharina nur die erste fehlt.

Zur z weiten Sektion, die in der europäischen Fauna auf dic Gattung Odontocerum beschränkt ist, gehören dic beiden Arten, deren aus Steinchen gebaute Röhren in Fig. 14 und 15 (Taf. LIV) dargestellt sind. Sie werden eine neue Gattung bilclen müssen; ich schlage für dieselbe den Namen Marilia vor und nenne die beiden Arten Marilia major (Fig. I4) und Marilia minor (Fig. 15). Diese neue Gattung unterscheidet sich von Odontocerum durch die nicht gezähnten Fühler, durch die sehr grossen Augen der Männchen (auf dem Scheitel der Männchen von Marilia minor berühren sich die Augen; bei Marilia major sind sie nur durch einen schmalen Zwischenraum getrennt), durch das Verschmelzen des Radius und der ersten Endader (sector apical) sowohl auf den Vorder- als auf den Hinterflügeln, und durch andere Merkmale.

Dic beiden Arten Marilia, deren Gehäuse ich beschrieben habe, sind in verschiedenen Bächen häufig. Es giebt eine dritte, anscheinend sehr seltene Art, deren Larven ich im Flusse Itajahy gefunden habe. Die Gehäuse unterscheiden sich von denen von Marilia major fast nur dadurch, dass sie viel kürzer sind, so dass es überflüssig ist, eine Abbildung von ihnen zu geben; um eine genaue Vorstellung von ihrer Gestalt zu gewinnen, braucht man sich nur von den Geliäusen von Marilia major (Fig. I 4 d Taf. LIV) dic hintere Hälfte abgeschnitten zu denken. Das einzige Gehäuse dieser dritten Art, welches ich jetzt habe, hat $6 \mathrm{~mm}$ Länge, $2 \mathrm{~mm}$ Durchmesser des Einganges und I,5 mm Durchmesser des hinteren Endes. Das hintere Ende ist, wie bei den anderen Marilia-Arten, 
grudadas umas ás outras, as pedrinhas da casa, é muito pállida, quasi sem côr, em quanto é preta ou parda escura nas duas outras especies.

Talvez deva ser incluida tambem nesta mesma segunda secção de MacLachlan, a Grumicha (Est. LIII, fig. 8); ao menos fica excluida da quarta secção pela falta de cellula mediana, e da terceira por possuir, em todas as azas, a segunda forquilha apical («apical fork»).

Entrem na terceira secção de MacLachlan as especies das figuras 7, 9, 10, 12 e I $_{3}$ (Est. LIII e LIV) e provavelmente, a julgar pelo comprimento das pernas posteriores das larvas, a da fig. 11. As ditas especies pertencem a tres differentes generos.

Tetracentron. - Os insectos, cujas larvas vivem ou em páosinhos ôcos (Est. LIII, fig. 7) ou intrusas em estojos de Grumicha (Est. LIII, fig. 9), exhibem todos os caracteres assignalados por Brauer no genero Tetracentron de que até agora só eram conhecidas duas especies (T. sarothropus Br. e T. amabile Mac-Lach1.), ambas naturaes da Nova Zelandia.

Os tubos de Grumicha não são os unicos sujeitos a ser approveitados por larvas intrusas; tambem os de varias especies menores, como de Setodes gemma (Est. I.JV, fig. I3), Marilia minor (Est. LIV, fig. I5) e Grumichella (Est. I.III, fig. Io) acham-se ás vezes occupadas por larvas, que provavelmente tambem pertencem ao genero Tetracentron. Acompanham as larvas intrusas dos tubos de Grumicha nĩo só no costume de se apoderarem de casas alheias, como durch eine Querscheidewand mit einem elliptischen Joch im oberen Theile verschlossen. Die Substanz, aus der diese Vand gemacht ist und mit der die Steinchen des Gehäuses an einander geleimt sind, ist sehr blass, fast farblos, während sic bei den beiden anderen Arten schwarz oder braun ist.

Vielleicht muss in dieselbe zweite Sektion Mac Iachlan's auch die Grumicha (Taf. LIII, Fig. 8) eingeschlossen werden; wenigstens wird sie von der vierten Sektion durch das Fehlen der Medianzelle, von der dritten durch das Vorhandensein einer zweiten Endgabel („apical fork“) in allen Flügeln ausgeschlossen.

In die dritte Sektion Maclachlan's gehören die Arten der Figuren 7, 9, I 0, 12, I 3 (Taf. LIII u. LIV) und wahrscheinlich, nach der Länge der Hinterbeine der Larven zu urtheilen, die von Figur 11. Die genannten Arten gehören zu drei verschiedenen Gattungen.

Tetracentron. - Die Insekten, deren Larven in hohlen Stäbchen (Taf.LIII, Fig. 7) oder als Eindringlinge in den Gehäusen von Grumicha (Taf. LIII, Fig. 9) leben, bieten alle von Brauer für die Gattung Tetracentron angegebenen Merkmale dar, von der bis jetzt nur zwei Arten (T. sarothropus Br. und T. amabile Mac Lachl.), beide in Neu-Seeland einheimisch, bekannt waren.

Die Grumicharöhren sind nicht dic einzigen, die von eingedrungenen Larven benutzt werden; auch die verschicdener kleinerer Arten, wie Setodes gemma (Taf. LIV, Fig. 13), Marilia minor (Taf. L.IV, Fig. 15) und Grumichella (Taf. LIII, Fig. 10) finden sich bisweilen von Larven besetzt, die wahrscheinlich ebenfalls in die Gattung Tetracentron gehören. Sie stimmen mit den eingedrungenen Larven der Grumicharöhren nicht nur in der Gewohnheit überein, sich fremder Gehäuse zu be- 
tambem em sua estructura, v. g.: as tibias posteriores são divididas em duas articulações.

Essas larvas que vivem intrusas nos tubos de Setodes, Marilia e Gm michella, costumam fixar pedacinhos de madeira no extremo anterior dos mesmos tubos. Esses páosinhos, ás vezes muito mais grossos e compridos do que os proprios tubos, ou se applicam a elles ou divergem para varias direcções formando com o tubo angulos raras vezas maiores de 30 gráos. (Vejase fig. 3, sendo $A$ até $G$ tubos de Setodes gemma, $H$ e $I$ tubos de Marilia minor e $K$ um tubo de Grumichella.)

E’ provavel que os páosinhos sirvam para encobrir os tubos e subtrahil-os desta sorte aos inimigos de seus proprietarios legitimos. Com effeito, cm certos casos (fig. 3, $G$ e $K$ ) é difficil descobrir-se o tubo entre os páosinhos que o rodêam.

Si bem que seja do mesmo genero, nào sei se pertencerá á mesma especie uma larva que achei no Ribeirão de Bugres (fig. 4); ella morava em um páosinho ôco e apezar de ser este aberto na parte posterior, ella fez um pequeno buraco e cobrio a abertura com um pedaço de madeira, debaixo da qual ficava perfeitamente escondida: além disso furou pedaços monores aos lados c na face ventral do extremo anterior de sua casinha.

Grumichella (fig. 2). Os insectos cujas larvas fazem os estojos que descrevi sob o nome de Grumichinha (Est. LIII, fig. Io) são parentes proximos do genero Leptocerus, do qual comtudo se distinguem por possuir nas azas poste- mächtigen, sondern auch in Eigrenthümlichkeiten des Baues, z. B. darin, dass die Hinterschienen in zwei Glieder getheilt sind.

Die Larven, die als Eindringlinge in den Röhren von Setodes, Marilia und Grtmichella leben, pflegen an das vordere Ende dieser Röhren Holzstückchen zu befestigen. Diese Holzstückchen, die bisweilen viel dicker und länger sind, als dic Röhren selbst, legen sich entweder an diese an oder stehen in verschiedenen Richtungen unter Winkeln von selten mehr als $30^{\circ}$ von der Röhre ab. (Siehe Fig. 3, in welcher $A$ bis $G$ Röhren von Setodes gemma, $I I$ und $I$ Röhren von Marilia minor und $K$ eine Röhre von Grumichella darstellt.)

Wahrscheinlich dienen diese Holzstückchen oder Stäbchen dazu, die Röhren zu verdecken und auf diese Weise den Feinden ihrer legitimen Eigenthümer zu entziehen. In der That ist es in gewissen Fällen (Fig. $3 G$ und $K)$ schwer, die Röhre zwischen den sie umgebenden Stücken zu entdecken.

Wenn auch zu derselben Gattung, so dürfte doch nicht zu derselben Art eine Larve gehören, die ich im Bugresbache gefunden habe (Fig. 4); sie wohnte in einem hohlen Stäbchen und machte, trotzdem dass dies am oberen Ende offen war, ein kleines Loch, und bedeckte die Oeffnung mit einem Holzstück, unter dem sie vollkommen verborgen blieb; ausserhalb dieses Holzstückes befestigte sie an den Seiten und an der Bauchfläche des vorderen Endes ihres Häuschens kleinere Stückc.

Grumichella (Fig. 2). Die Insekten, deren Larven die Futterale machen, die ich unter dem Namen Grumichinha (Taf. L.III, Fig. Io) beschrieben habe, sind nächste Verwandte der Gattung Leptocerus, von der sie sich jedoch dadurch 
riores as forquilhas apicaes $3^{\mathrm{a}}$ e $5^{\mathrm{a}}$, quer em um quer em outro sexo, emquanto que no genero Leptocerus falta a $3^{\mathrm{a}} \mathrm{e}$ existe $a I^{a}$ que não se encontra nas Grumichinhas.

Proponho para estes insectos o nome generico de Grumichella. Até o anno passado só tinha achado as Grumichinhas no Ribeirão da Gruta dos Macacos (Affenwinkel) onde são bastante raras; pois vivem em muito maior abundancia nas cachoeiras de varios ribcirões (da Trisiste Miseria, do Caeté, etc.), preferindo os rochedos verticaes ao longo dos quaes corre uma tenuissima camada d'agua.

O extremo posterior dos canudos de Grumichinha é fechado, como na Grumicha, por uma parede transversal com um buraco central, por baixo deste buraco eleva-se da parede terminal do canudo das Grumichinhas uma saliencia triangular, especie de esporão (fig. $2, A$, $B, C, D)$ ou recto ou um pouco curvado para cima. Inserido em alguma fenda microscopica da rocha, este esporão poderá servir para segurar as Grumichinhas.

Por outro meio ainda muito mais singular, as Grumichinhas sabem escapar aos perigos de que parecem inevitavelmente ameaçadas nas cachoeiras que habitam.

Outros Trichopteros e entre elles tambem a Grumicha, quando as nymphas estão para se transformar em insectos perfeitos, cortam com as mandibulas o rebordo da tampa que fecha a entrada do tubo; feito isto a tampa cahe, fixando-se o tubo; então a nympha sahe e nadando á superficie d'agua ahi soffre sua ultima transformação. Os canudos das Grumichinhas achando-se geralmente fixados com a entrada volvida para unterscheiden, dass sie in den Hinterflügeln sowohl in dem einen als im anderen Geschlechte die Endgabeln $3^{\mathrm{a}}$ und $5^{\mathrm{a}}$ besitzen, während in der Gattung Leptocerus $3^{\text {a }}$ fehlt, dagegen $\mathrm{I}^{\mathrm{a}}$ vorhanden ist, die bei den Grumichinhas nicht angetroffen wird.

Ich schlage für diese Insekten den Gattungsnamen Grumichella vor. Bis vergangenes Jahr hatte ich die Grumichinhas nur im Bache "Affenwinkel“ gefunden, wo sie ziemlich selten sind; in weit grösserer Menge leben sie an den Wasserfällen verschiedener Bäche (Trauriger Jammer, Caeté u. s. w.), da sie senkrechte Felsen vorziehen, an denen eine sehr dünne Wasserschicht herabläuft.

Das hintere Ende der Grumichinharölren wird, wie bei Grumicha, durch eine mit einem centralen Loch versehene Querwand verschlossen; unter diesem Loch erhebt sich von der Endwand der Grumichinharöhre ein dreieckiger Vorsprung, eine Art Sporn (Fig. $2 A, B, C$, $D)$, entweder gerade oder ein wenig nach oben gebogen. In irgend einen mikroskopischen Spalt des Felsens eingefügt wird dieser Sporn zum Festhalten der Grumichinhas dienen können.

Noch viel seltsamer ist die Art, wie die Grumichinhas den Gefahren zu entgehen wissen, von denen sie an den Wasserfällen, die sie bewohnen, unvermeidlich bedroht erscheinen.

Andere Trichopteren, unter ihnen auch Grumicha, durchschneiden, wenn die Puppen bereit sind, sich in fertige Insekten zu verwandeln, mit den Mandibeln den Rand des Deckels, der den Eingang der Röhre verschliesst; wenn dies geschehen ist, fällt der Deckel, während er an der Röhre befestigt bleibt; alsdann kriecht die Puppe hervor und erleidet, an der Oberfläche des Wassers schwimmend, hier ihre Umwandlung. 
cima, em rochedos onde a agua das cachoeiras lhes cahe do alto, as nymphas depois de removida a tampa, tenros c frageis animalsinhos que são, não poderiam sahir de seus estojos sem ficarem quasi infallivelmente esmagados pela força d'agua.

Esse perigo é felizmente evitado de um modo simplicissimo; o peciolo do disco por meio do qual os tubos das nymphas se acham grudados ás pedras não procede como nas Grumichas, do bordo do tubo e sim da tampa (fig. 2, E). Assim, desde que a tampa fôr separada do tubo, aquella fixa-se ás pedras, incolume dentro de seu estojo, e a nympha é levada pelas aguas até parar em algum remanso, onde descansada póde metamorphosear-se.

Os tubos das Grumichinhas provenientes das differentes cachoeiras costumam apresentar certas differenças: os da Gruta dos Macacos são perfeitamente lisos e pretos; os da Triste Miseria são geralmente menos escuros, menores e providos de estrias circulares mais ou menos distinctas; os de uma cachoeira perto do Belxior (fig. 2, $B, B$ ') costumam ter um esporão muito curto. Mais differentes são os do Ribeirão do Caeté, que são geralmente mais compridos, menos grossos, com o esporão curvado visivelmente para cima (fig. $2, C, D$ ), e a tampa em vez de mostrar uma fenda semilunar em cima do centro, como as de outras cachociras (Est. LIII, fig. $10, B$ ) tem além de uma fenda de fórma differente e variavel, um ou dois buracos menores situados em baixo da fenda principal (fig. $2, E, F, G$ ).
Da die Röhren der Grumichinha sich in der Regel, mit dem Eingange nach oben gekehrt, an Felsen befestigt finden, wo das Wasser der Wasserfälle aus der Höhe auf sie herabfällt, so würden die Puppen, zarte und zerbrechliche Thierchen wie sie sind, nach der Entfernung des Deckels nicht aus ihren Futteralen hervorgehen können, ohne fast unfehlbar durch die Gewalt des Wassers zerquetscht zu werden.

Diese Gefahr wird auf eine höchst einfache Weise glücklich vermieden : der Stiel der Scheibe mittels welcher die Röhren der Puppen an die Felsen geleimt sind, geht nicht, wie bei Grumicha, rom Rande der Röhre, sondern vom Deckel aus (Fig. 2 E). Sobald daher der an die Felsen befestigte Deckel von der Röhre getrennt ist, wird die Puppe, in ihrem Gehäuse unversehrt, durch das Wasser bis zu irgend einer ruhigen Stelle fortgeführt, wo sie ausschlüpfen und sich verwandeln kann.

Die von verschiedenen Wasserfällen stammenden Röhren der Grumichinhas scheinen gewisse Verschiedenheiten darzubieten: die des Affenwinkels sind vollständig glatt und schwarz; die des Traurigen Jammers sind im Allgemeinen weniger dunkel, kleiner und mit mehr oder weniger deutlichen ringförmigen Streifen versehen; die eines WVasserfalls nahe bei Belxior (Fig. 2, $B, B^{\prime}$ ) pflegen einen sehr kurzen Sporn zu haben. Abweichender sind die vom Bache Caeté; sie sind im Allgemeinen länger, weniger dick und mit einem deutlich nach oben gekrümmten Sporn (Fig. 2, $C, D$ ) versehen; ihr Deckel zeigt nicht, wie bei den Exemplaren anderer Wasserfälle, einen halbmondförmigen Spalt über der Mitte (Taf. LIII, Fig. 10, $B$ ), sondern ausser einem Spalte von verschicdener und wechselnder Gestalt, ein oder zwei kleinere Löcher, die unter dem Hauptspalt liegen (Fig. 2, $E, F, G)$. 
Nào sei si esta ultima differença será constante, porque só tenho examinado cerca de meia duzia de tampas do dito ribeirào; de nutras lncalidades examinei mais de 4o, encontrando sempre a fenda semi-lunar.

Cumpre notar que ha só uns i6 a 20 kilometros da Gruta dos Macacos ao Ribeirào do Caeté; e scria pois muito interessante a existencia de variedades locaes tão distinctas em logares tão pouco distantes.

Setodes (fig. 5 e Est. LIII, fig. 12; Est. LIV, fig. I3). Os insectos cujas larvas construem os canudos das figuras 12 (Est. LIII) c I3 (Est. LIV) são muito semelhantes não só na fórma e nervuras das azas anteriores como tambem por outros caracteres á Setodes punctata c viridis que Mac-Lachlan considera como as especies typicas do genero Sedotes. Comtudo as azas posteriores são mais largas nas especies catharinenses do que naquellas duas européas, assemelhando-se mais ás do genero

\section{Homilia.}

Si por este motivo as nossas especies tiverem de ser removidas do genero Sedotes, restringido, como foi, por MacLachlan, ao menos foram parte do dito genero no sentido mais amplo, em quo até ha pouco costumava ser tomado.

A respeito daquellas duas especies, diz Mac-Lachlan que sĩo verdadeiras joias entre os 'Trichopteros curopeos. Outro tanto e com mais direito ainda se póde dizer a respeito de uma das nossas especies (a da fig. 13), cujas azas anteriores amarelladas ou de um amarello alaranjado acham-se atravessadas de listras brancas prateadas e ornadas de malhas pretas avelludadas. Proponho para esta bellissima especie o nome de Setodes gemma.
Ich weiss nicht, ob dieser Unterschied sich als konstant herausstellen wird, da ich nur ungefähr ein halbes Dutzend Deckel ron dem genannten Bache untersucht habe: von anderen Lokalitäten habe ich mehr als 4o Deckel untersucht und immer einen halbmondförmigen Spalt gefunden.

Es muss bemerkt werden, dass es rom Affenwinkel zum Bache Caeté nur I 6 bis 20 Kilometer sind; die Existenz so verschiedener Lokalvarietäten an so wenig von einander entfernten Orten würde daher sehr interessant sein.

Setodes (Fig. 5 und Taf. LIII, Fig. I2; Taf. LIV, Fig. 13). Die Insekten, deren Larven die Röhren von Fig. 12 und $\mathrm{I}_{3}$ bauen, sind in Gestalt, Nerven der Vorderflügel und anderen Merkmalen schr ähnlich der Setodes punctata und viridis, die MacLachlan als typische Arten der Gattung Setodes betrachtet. Doch sind die Hinterflügel bei den catharinensischen Arten weniger breit als bei den beiden europäischen; sie gleichen mehr denen der Gattung Homilia.

Wenn unsere Arten aus diesem Grunde aus der Gattung Setodes in dem von MacLachlan beschränkten Sinne entfernt werden müssten, so würden sie wonigstens zu dieser Gattung in dem bisher gebräuchlichen weiteren Sinne zu stellen sein.

In Bezug auf jene beiden Arten sagt MacLachlan, dass es wahre Juwelen seien unter den europäischen Trichopteren. Dasselbe lässt sich mit noch melır Recht von einer unserer Arten (der von Fig. 13) sagen, deren gelbliche oder orangegelbe Vorderflügel von weissen, silbernen Bändern durchschnitten und mit sammetschwarzen Flecken verziert sind. Ich schlage für diese schönste Art den Namen Setodes gemma vor. 
Encontrei novamente uma terceira especie do mesmo genero (fig. 5), cujas larvas e nymphas (muito raras) habitam embaixo de pedras em varios ribeiroes (v. g. no Ribeirão dos Bugres), preferindo os logares em que a agua está quasi parada. Os estojos das larvas (fig. 5, $A, A^{\prime}$ ) são canudos rectos conicos, feitos de seda misturada e coberta com miudissimos grãos d'areia. O maior que vi tem $\mathrm{I} 4^{\mathrm{mm}}$ de comprimento, sendo o diametro da entrada de $2^{\text {mm }}$ e o do extremo posterior apenas de $0,{ }^{\mathrm{mmm}} 25$.

A estes canudos acham-se fixados de um e outro lado da face dorsal, pedacinhos de madeira ou outros fragmentos vegetaes, cobrindo grande parte dos canudos os quaes ultrapassam, mais ou menos; os da parte anterior, geralmente maiores e mais proeminentes, costumam ser dirigidos obliquamente para traz formando com o eixo do tubo angulos de uns $1_{5}$ a 20 gráos.

Segundo a natureza desses appendices que variam consideravelmente nas suas dimensões, fórmas e côres, tambem varia ao infinito o aspecto do estojo (fig. $5, A, B, C, D$ ). Como as das ou tras duas especies catharinenses, as larvas desta especie tambem cortam a parte posterior de seus estojos antes de o fixarem, de modo que os estojos das nymphas (fig. $5, B, C, D$ ), são mais curtos do que os das larvas adultas (fig. $5, A$ ). A maneira de fixar e fechar os estojos tambem é a mesma das outras duas especies. Os insectos perfeitos são bichinhos muito modestos tendo azas pallidas unicolores.

A' quarta secrüo de Mac-Lachlan pertencem as duas especies cujas larvas
Neuerdings habe ich eine dritte Art derselben Gattung gefunden (Fig. 5), deren (sehr seltene) Larven und Puppen in verschiedenen Bächen (z. B. dem Bugresbache) unter Steinen wohnen, indem sie diejenigen Oertlichkeiten vorziehen, an denen das WVasser fast stille steht. Die Larvenfutterale (Fig. 5, $A, A^{\prime}$ ) sind gerade, kegelförmige Röhren, aus Seide gefertigt, die mit äusserst winzigen Sandkörnchen vermischt und bedeckt sincl. Das grösste, das ich gesehen habe, hatte 14 mm Länge, während der Durchmesser des Einganges $2 \mathrm{~mm}$, der des entgegengetzten Endes kaum 0,25 mm betrug.

An diesen Röhren finden sich, der einen oder der anderen Seite der Rückenfläche angeheftet, Holzstückchen oder andere Pflanzenfragmente, die einen grossen Theil der Röhre bedecken und mehr oder weniger über sie hinausgehen; die des vorderen Theiles sind im Allgemeinen grösser und hervorragender; sie pflegen, unter Winkeln von I $_{5}$ bis 20 Grad mit der Achse, schräg nach hinten gerichtet $\mathrm{zu}$ sein.

Nach der Natur dieser Anhänge, die in ihren Dimensionen, Gestalten und Farben beträchtlich variiren, variirt das Aussehen des Futterals (Fig. 5, A, B, $C, D)$ ebenso ins Unendliche. Wie die beiden anderen catharinensischen Arten, so schneiden auch die Larven dieser Art, bevor sie sich festsetzen, den hinteren Theil ihrer Futterale ab, so dass die Futterale der Puppen (Fig. 5, $I, C, I$ ) kürzer sind als die der erwachsenen Larven (Fig. 5, A). Auch die W Veise, die Futterale zu befestigen und zu verschliessen, ist dieselbe wie bei den beiden anderen Arten. Die fertigen Insekten sind viel unansehnlicher; sie haben blasse einfarbige Flügel.

Zur vierten Sektion MacLachlan's gehören die beiden Arten, deren Larven in 
vivem em casas de folhas (Est. LIV, fig. 16 e 17 ), e sobre cuja posição systematica fiquei em duvida no meu primeiro trabalho. Não eram ainda conhecidas as larvas e suas casas de especie alguma desta secção. Os insectos perfeitos distinguem-se de todos os generos até agora estabelecidos nesta secção pelo raio (radius) que se une ao primeiro sector apical nas azas tanto anteriores como posteriores, pela cellula discoidal aberta nas azas posteriores e pela falta nas mesmas azas da primeira furquilha apical, existindo só as furquilhas $2^{\text {a }}$, $3^{\mathrm{a}}$ e $5^{\mathrm{a}}$. Segundo Nac-Lachlan em todas as mais especies da quarta secçĩo as azas posteriores tem a cellula cliscoidal fechada, e possuem as furquilhas apicaes $\mathrm{I}^{\mathrm{a}}, 2^{\mathrm{a}} \cdot 3^{\mathrm{a}}$ e $5^{\mathrm{a}}$.

Proponho para as nossas especies o nome de Phylloicus (é́) casia) chamando a maior Pliylloicus major e a menor, tão notavel por viverem suas larvas nas Bromelias, Pliylloicus Bromeliarum.

As duas especies são muito interessantes pelo numero dos esporões das suas tibias. Ha um genero californico Heteroplectron em que os machos tem 2, 4, 2 esporões (isto é, 2 nas tibias anteriores, 4 nas intermedias e 2 nas posteriores) e as femeas 2, 4, 4. Ora ambos os sexos de Plylloicus major tem 2, 4, 4 e ambos os sexos do Phylloicus Bromeliarum tem 2, 4, 2 esporões.

Em tudo mais, as duas especies são tão semelhantes que seria um grande absurdo o querer separal-as em dois generos, fornecendo assim um magnifico exemplo para fazer prevalecer a regra hoje geralmente reconhecida de ser sufficiente para a separação generica
Blattgehäusen leben (Taf.LIV, Fig. I 6, I 7) und über deren systematische Stellung ich in meiner ersten Arbeit im Zweifel blieb. Von keiner Art dieser Sektion waren bisher die Larven und ihre Gehäuse bekannt. Die fertigen Insekten unterscheiden sich von allen bis jetzt in dieser Sektion aufgestellten Gattungen durch den Radius. der sich in den Vorder- wie in den Hinterflügeln mit dem ersten Endnerven (sector apical) vereinigt, durch die in den Hinterflügeln offene Discoidalzelle und durch das Fehlen der ersten Endgabel in denselben Flügeln, in denen nur die Gabeln $2^{\mathrm{a}}, 3^{\mathrm{a}}$, und $5^{\mathrm{a}}$ vorhanden sind. Nach MacLachlan haben bei allen oder den meisten Arten der vierten Sektion die Hinterflügel eine geschlossene Discoidalzelle und besitzen die Endgabeln $1^{\mathrm{a}}, 2^{\mathrm{a}}, 3^{\mathrm{a}}$, und $5^{\mathrm{a}}$.

Ich schlage für unsere Arten den Namen Phylloicus (éùi. ov, Blatt, oixos, Haus) vor und nenne die grössere Art Phylloicus major, die kleine, die durch den Aufenthaltsort ihrer Larven an Bromelien so bemerkenswerth ist, Phylloicus Bromeliarum.

Die beiden Arten sind sehr interessant durch die Zahl ihrer Schienensporne. Es giebt eine kalifornische Gattung Heteroplectron, in der die Männchen 2, 4, 2 Sporne (d. h. zwei an den Vordervier an den Mittel-, zwei an den Hinterschienen) und die Weibchen 2. 4, 4 haben. Bei Phylloicus major haben nun beide Geschlechter 2, 4, 4 und bei Phylloicus Bromelarium beide Geschlechter 2, 4, 2 Schiensporne.

Im Uebrigen aber sind beide Arten so ähnlich, dass es eine grosse Thorheit sein würde, sie in zwei Gattungen trennen zu wollen. Sie liefern daher ein vortreffliches Peispiel dafür, dass die heute allgemein als richtig ancrkannte Regel, dass irgend welcher Unterschied in den 
qualquer differença no numero dos esporòes ${ }^{1}$ ).

E para tornar ainda mais frisante este exemplo ahi está uma terceira especie catharinense internedia, em todos os respeitos, entre as outras duas e a que por isso dou o nome de Phylloicus medius, a qual tem 2, 4, 4 esporões como o Pliylloicus major, em quanto que por todos os mais caracteres mais se parece com o Pliylloicus Bromeliarum que só tem 2, 4, 2. As larvas desta terceira especic vivem de preferencia nos menores fios d'agua em cujo leito ingreme a agua gotteja lentamente de pedra em pedra. Suas casas são muito semclhantes ás do Plyylloicus Bromeliarum, sendo comtudo maiores e compostas de menor numero de folhas; costumam ter tres ou quatro pedaços de folhas na parede ventral e quatro ou cinco na dorsal, em quanto que as casas das Plıylloicus Bromeliarmm só contam geralmente 5 ou 6 na parede ventral e 6 ou 7 na dorsal, tendo as do Plyylloicus major 2, tanto na ventral como na dorsal. - Quando estão para se fixar as larvas do Phylloicus medius fecham a entrada da casa com mais um pedacinho de folha que ajuntam á parede ventral. O mesmo fazem as larvas do Phylloicus Bromeliarum, deixando de fazel-o as do Phylloicus major.

\section{§3.}

Sericostomideas.

Helicopsyche (fig. 6, 7). As differentes especies deste genero distinguem-se não

I) It has become a recognised rule that a difference in the number of spurs in two insects otherwise allied is sufficient for generic separation. Mac-Lachlan, op. cit. part I, I874, p. I2.

Fritz Müllers gesammelte Schriften.
Schienspornen zur generischen Trennung ausreichend sei, keineswegs immer zu gelten braucht ${ }^{1}$ ).

Um dieses Beispicl noch schlagender zu machen, giebt es noch eine dritte catharinensische Art, die in jeder Hinsicht zwischen den beiden anderen in der Mitte steht, und der ich desshalb den Namen Phylloicus medius gegeben habe; sie hat 2, 4, 4 Sporne wie Phyllnicus major, während sie sich in Bezug auf alle übrigen Merkmale mehr wie Phylloicus Bromeliarum verhält, der 2, 4, 2 hat. Die Larven dieser dritten Art leben vorzugsweise in den kleineren Wasseradern, in deren Bett das Wasser langsam von Stein zu Stein tropft. Thre Gehäuse sind sehr ähnlich denen von Phylloicus Bromeliarum; jedoch sind sie grösser und aus einer kleineren Zahl von Blättern zusammengesetzt; sie pflegen auf der Bauchseite drei oder vier, auf der Rückenseite vier oder fünf Blattstücke zu haben; während die Gehäuse von Phylloicus Bromeliarum in der Regel auf der Bauchseite fünf oder sechs, auf der Rückenseite sechs oder sieben, und die von Phylloicus major jederseits zwei haben. Wenn die Larven von Phylloicus medius sich festheften wollen, schliessen sie den Eingang des Gehäuses mit einem weiteren Blattstück, das sie der Bauchseite hinzufügen. Dasselbe thun die Larven von Phylloicus Bromeliarum, während die von Phylloicus major es unterlassen.

3) Sericostomiden.

Helicopsyche (Fig. 6, 7). Die verschiedenen Arten dieser Grattung

I) "It has become a recognised rule that a difference in the number of spurs in two insects otherwise allied is sufficient for generic separation." MacLachlan, op. cit. part I. 1874. p. 12. - Uebrigens weicht im letzten Satze der Uebersetzer insofern wesentlich von dem Autor ab, als er wörtlich den Schluss zicht, welchen jener nur denken lisst. Der Herausgeber. 
só pela fórma das casas encaracoladas, que suas larvas construem, como tambem pelas tampas com que as mesmas casas são fechadas antes das larvas passarem ao estado de nympha. Já dei as figuras das tampas de duas especies (Est. LIV, fig. $18,19, B$ ) em que ellas possuem uma simples fenda transversal.

Nas tampas das casas da fig. 20 (Est. LIV) os bordos desta fenda são guarnecidos de uma filcira de dentes havendo cerca de uma duzia de dentes de cada lado.

A fórma da fenda, como a dos dentes, é sujeita a bastantes variações, como mostram as figuras $6, A, B, C$.

Nas tampas das casas da fig. 21 (Est. LIV), não ha fenda, a agua necessaria á respiração da nympha é introduzida por numerosos buraquinhos, formando uma especie de crivo embaixo do centro da tampa (fig. 7).

Entre as Helicopsyches ha tambem uma especie que vive fóra d'agua nos rochedos expostos ao chovisco das cachoeiras (v. g. na Gruta dos Macacos e na Triste Miseria de Blumenau); suas casas são muito semelhantes ás da fig. 2 I Est. LIV) mas as tampas são providas de uma fenda simples.

\section{$\S 4$.}

Hydroptilideas.

Em companhia das larvas de Hydroptilideas (fig. 1) de Leptocerideas Grumichinha (fig. 2), e de Sericostomideas (Helicopsyche) que povîam os rochedos das nossas cachoeiras, vivem tambem as larvas de uma especie de Hydroptilideas (fig. 8).

Suas casinhas tem cerca de $3^{\text {min }}$ de comprimento sobre $0,{ }^{\mathrm{mm}} 6$ de altura, sendo comprimidas dos lados; em um dos extremos ellas são arredondadas no outro, unterscheiden sich nicht allein durch die Gestalt der schneckenförmigen Gehäuse, die ihre Larven bauen, sondern auch durch die Deckel, mit denen diese Gehäuse verschlossen werden, bevor die Larven in den Puppenzustand übergehen. Ich habe bereits die Abbildungen der Deckel zweier Arten gegeben (Taf. I.IV, Fig. $18,19 B)$, bei denen sie einen einfachen Querspalt besitzen.

Bei den Deckeln der Gehäuse von Taf. LIV, Fig. 20 sind die Ränder dieses Spaltes mit einer Zahnreihe besetzt, die etıva ein Dutzend Zähne an jeder Seite hat.

Die Form des Spaltes wie die der Zähne ist ziemlichen Abänderungen unterworfen, wie Fig. $6 A, B, C^{\prime}$ zeigen.

An den Deckehn der Gehäuse von Taf.LIV, Fig. 21 ist kein Spalt vorhanden; das zur Athmung der Puppe nöthige Wasser wird durch zahlreiche kleine Löcher eingeführt, die unter der Mitte des Deckels eine Art Sieb bilden (Fig. 7).

Auch unter den IIelicopsychen giebt es cine Art, die ausserhalb des Wassers lebt, an Felsen, die dem Staubregen der Wasserfälle ausgesetzt sind (z. B. im Affenwinkel und Traurigen Jammer in Blumenau); ihre Häuser sind sehr ähnlich denen von Fig. 21, aber die Deckel sind mit einem einfachen Spalte versehen.

4) Hydroptiliden.

In Gesellschaft der Larven von IIydropsychiden (Fig. 1), Leptoceriden (Grumichinha, Fig. 2) und Sericostomiden (Helicopsyche), die die Felsen unserer Wasserfälle bevölkern, leben auch die Larven einer Art von Hydroptiliden (Fig. 8).

Ihre Häuschen haben ungefähr $3 \mathrm{~mm}$ länge bei $0,6 \mathrm{~mm}$ Höhe; sie sind von den Seiten zusammengedrückt; an dem einen Ende sind sie abgerundet, am 
depois de se terem mais ou menos estreitado, são cortadas transversalmente (fig. 6, A), E' por este extremo que a larva costuma deitar fóra a cabeça para comer ou andar e é por elle tambem que a casinha é fixada e pendurada nos rocheclos (fig. 8, $B, C$ ). Depois de fixada a casa, a larva tece um casulo fechado por todos os laclos occupando quasi toda a casa com cujas paredes se confunde e deixando apenas vasio só um espaço estreito na extremidade inferior. Dentro deste casulo a nympha acha-se collocada com a cabeça para baixo. Toma pois como a da Lagenopsyche, no interior de sua casa, uma posição opposta á que costumava ter a larva.

Quanclo em Outubro do anno passado descrevi as casas de Peltopsyche (Est. I.V, fig. 3o) ainda estava em duvida sobre a posição systematica desse novo genero. Desde então tive occasião de me convencer pelo exame de grande numero de larvas e nymphas, de que não errei, collocando-o na familia das Hydroptilideas.

E' um dos generos mais extraordinarios, distinguindo-se dos mais, não só da dita familia, como de toda a ordem dos Trichopteros por uma structura muito insolita e complicada das antennas dos machos. Convenci-me tambem de que a falta clas estrias, na parede dorsal das casas, não é só uma variação individual, como tambem indica differença especifica dos habitantes, sendo muito differentes as nymphas e a structura das antennas dos machos das duas especies. A especie de casas estriadas Peltopsyche Sicboldii (Est. I.V, fig. 30), é muito mais frequente, e abunda em quasi todos os ribeirões maiores, que desaguam no rio Itajahy (Garcia, En- anderen, nachdem sie sich mehr oder weniger verengert haben, gerade abgeschnitten (Fig. 6 A). Durch clieses Ende pflegt die larve den Kopf herauszustecken, um zu essen oder zu wandern; mit diesem Ende wird auch das kleine Gehäuse befestigt und an den Felsen aufgehängt (Fig. $8 \mathrm{~B}, \mathrm{C}$ ). Nachdem das Gehäuse befestigt ist, wvebt die larve einen an allen Seiten geschlossenen Kokon, der fast das ganze Gehäuse einnimmt, mit dessen Wänden er verschmilzt, indem er nur einen engen Baum am unteren Ende frei lässt. In diesem Knkon liegt die Puppe mit nach unten gerichtetem Kopfe. Sie nimmt also, wie die von Lagenopsyche, im Innern ihres Gehäuses eine entgegengesetzte Lage ein als sie im Larvenzustande zu haben pflegte.

Als ich im Oktober des vergangenen Jahres die Gehäuse von Peltopsyche (Taf. LV, Fig. 30) beschrieb, war ich über die systematische Stellung dieser neuen Gattung noch im Zweifel. Seitdem habe ich Gelegenheit gehabt, mich durch die Untersuchung einer grossen Zahl von Larven und Puppen zu überzeugen, dass ich nicht geirrt habe, indem ich sie in die Familie der Hytdroptiliden stellte.

Es ist eine der ausserordentlichsten Gattungen, die sich von den meisten, nicht nur der genannten Familie, sondern der ganzen Ordnung der Trichopteren clurch einen sehr ungewöhnlichen und komplicirten Bau der männlichen Fühler auszeichnet. Auch habe ich mich überzeugt, dass das Fehlen der Streifen auf der Rückenwand der Gehäuse nicht bloss eine individuelle Abänderung ist, sondern eine Artverschiedenheit der Bewohner anzeigt, indem die Puppen und der Bau der männlichen Fühler beider Arten sehr verschieden sind. Die Art mit gestreiften Gehäusen, Peltopsyche Sicboldii (Taf. LV, Fig. 3o) ist viel häufiger und kommt in fast allen grösseren Bächen, 
cano, Warnow etc.); a de casas lisas, para a qual proponho o nome de Peltopsyche Mac Lachlani, foi até agora encontrada só no Ribeirão do Warnow, onde vive em companhia do Peltopsyche Sieboldii.

$\S 5$.

Casas de origem incerta

(fig. 9).

Em varios ribeirões encontrei em logares onde a agua estava quasi parada, adherentes a troncos de arvores que ali estavam apodrecendo, certos estojos mais ou menos cylindricos de 3 para 4 centimetros de comprimento sobre 6 a I o milimetros de diametro, compostos de pedaços de foihas e outros fragmentos vegetaes agglomerados com pouca regularidade. Essas substancias formavam varias camadas sobrepostas, de modo que o diametro da cavidade interior era muito menor do que a da superficie externa; não chegando ás vezes a attingir mesmo metacle d'elle. Segundo as substancias de que se compõem, o aspecto desses estojos é muito differente.

Assim o estojo da fig. 9, $A$ (do Ribeirão dos Bugres), é construido quasi que exclusivamente com folhas dicotyledoneas, encontrando-se entre estas tambem, algumas sementes de alguma planta da familia das compostas; pelo contrario, entram na construcção do estojo da fig. 9, $B$ (do Ribeirĩo do Garcia) só fragmentos de folhas monocotyledoneas provenientes talvez de alguma palmeira.

Todos os estojos que até agora vi já eram vazios, não contendo mais sinãn fragmentos soltos de esqueleto de larvas que, ainda que obviamente provenham da larva de algum Trichoptero, não me permittem decidir a que familia devem pertencer. die in den Itajahy münden (Garcia, Encano, Warnow u. s. w.) in grosser Menge vor. Die Art mit glatten Gehäusen, für die ich den Namen Peltopsyche MacLachlani vorschlage, wurde bis jetzt nur im Bache IVarnow angetroffen, wo sie in Gesellschaft der PeltopsycheSieboldii lebt.

\section{5) Gehäuse ungewissen Ursprungs (Fig. 9).}

In verschiedenen Bächen habe ich an Orten, wo das Wasser fast still stand, an dort in Verwesung begriffenen Baumstämmen haftend, mehr oder weniger cylindrische Köcher von 3 bis $4 \mathrm{~cm}$ Länge bei 6 bis $10 \mathrm{~mm}$ Durchmesser angetroffen, die aus ziemlich unregelmässig an einander gefügten Blattstücken und anderen Pflanzenfragmenten zusammengesetzt waren. Diese Substanzen bildeten verschiedene über einander gelegte Schichten, so dass der Durchmesser der inneren Höhlung viel kleiner als der der äusseren Oberfläche war, und bisweilen nicht einmal auch nur annähernd die Hälfte desselben erreichte. Nach den Substanzen, aus denen sie sich zusammensetzen, ist das Ausschen dieser Futterale sehr verschieden.

So ist das Futteral Fig. 9, $A$ (aus dem Bugrebache) fast ausschliesslich aus Dicotyledonenblättern verfertigt, zwischen denen man einigen Compositen-Samen begegnet. Dagegen treten in den Bau des Futterals Fig. 9, $B$ (aus dem Bache Garcia) nur Bruchstücke von Monokotyledonenblättern ein, die vielleicht von einer Palme stammen.

Alle Gehäuse, die ich bis jetzt gesehen habe, waren schon leer und enthielten nur noch abgelöste Bruchstücke des Larvenskeletts, die zwar offenbar von einer Trichopterenlarve herrühren, aber nicht zu entscheiden gestatten, zu welcher Familie sie gehören müssen. 


\section{Explicação das figuras da estampa $L^{2} I^{1}$ ).}

Fig. I (dimens. nat.). A, $B$ Casas de larvas de uma Hydropsychidea, vivendo nos rochedos de cachoeiras. $C$ casas de nymphas da mesmas especie. C" secçio transversal de uma destas casas, augmentada tres vezes.

Fig. 2 (augm. I 5 vezes). $A, B, C \mathrm{Ex}-$ tremo posterior de casas de nymphas de Grumichella, visto de cima. $A^{\prime}, B^{\prime}, C^{\prime}$ Dito visto do laclo esquerdo, sendo $A, A^{\prime}$ cla cachoeira da Triste Miseria de Blumenau, $B, B^{\prime}$ de uma cachoeira perto de Belxior, $C, C^{\prime}$ do Ribeirào do Caeté. $D$ Casa de uma larva novinha da mesma especie, do Ribeirìo do Caeté, vista do lado direito. $E$, $F$, $F$ Tampas de casas de nymphas do mesmo ribeirào.

Fig. 3 (augm. 3 vezes). Tubos habitados por larvas intrusas. (Tetracentron ?) sendo $A$ até $G$, tubos de Setodes gemma, $H$ e $I$ tubos de Marilia minor e $K$ um tubo da Grumichella.

Fig. 4. Casa de uma larva (Tetracentron. ${ }^{2}$ ) do Ribeirào dos Bugres vista pela face ventral (augm. 2 vezes).

Fig. 5 (augm. 2 vezes). Tubos de umá especie de Setodes. $A, A$ ' Tubo de larva visto debaixo em $A$, de cima em $A^{\prime}$. B. $C, D$ Tubos das nymphas. $D$ ' Tampa do extremo posterior de $D$ (augm. 6 vezes).

Fig. 6. A tampa da casa de Helicopsyche da fig. 20 (Est. LIV) augm. I 5 vezes. $B, C$ Fendas de outras tampas da mesma especie augm. 45 vezes.

Fig. 7. Tampa da casa de Helicopsyche da fig. 2 I (Est. LIV) augm. I 5 vezes.

Fig. 8 (augm. 8 vezes). Casas de Hydroptilideas das cachoeiras, sendo o $A$ casa de larva, $B$ e $C$ casas de nymphas fixadas e suspensas pelo extremo posterior.

Fig. 9 (dimens. nat.). Estojos de algum Trichoptero de posiçĩo incerta, sendo $A$ do Ribeirìo dos Bugres, $B$ do Ribeirào do Garcia.

\section{Errata.}

Por um descuido deixei de examinar no anno passado os palpos dos machos

\section{Erklärung der Abbildungen auf Tafel LVI.}

Fig. I. (Nat. Grösse.) $A, B$, Larvengehäuse einer Hydropsychide, die an den Felsen von Wasserfällen lebt; $C$, Puppengehäuse derselben Art; C', Querdurchschnitt durch eines dieser Puppengehäuse. 3: I.

Fig. 2. (I 5 malige Vergrösserung.) $A$, $B, C$, hinteres Ende der Puppengehäuse von Grumichella, von oben gesehen; $A^{\prime}, B^{\prime}, C^{\prime}$, desgleichen,: von der linken Seite gesehen; $A, A$ ', vom Wasserfall des „Traurigen Jammers', in Blumenau; $B, B^{\prime}$, von einem Wasserfall in der Nähe von Belxior; $C, C^{\prime}$, aus dem Bache Caeté; $D$, Gehäuse einer jungen Larve derselben Art, aus dem Bache Caeté, von der rechten Seite gesehen; $E, F, G$, Deckel von Puppengehäusen aus demselben Bache.

Fig. 3. (3 malige Vergrösserung.) Von eingedrungenen Larven bewohnte Röhren (Tetracentron?). $A-G$, Röhren von Setodes gemma; II, I, Röhren von Marilia minor ; $K$, eine Röhre von Grumichella.

Fig. 4. Gehäuse einer Larve (Tetracentron?) aus dem Bugresbache, von der Bauchseite gesehen. $2:$ I.

Fig. 5. (2 malige Vergrösserung.) Röhren einer Setodesart. A, Larvenröhre von unten; $A$, dieselbe von oben gesehen; $B, C, D$, Puppenröhren; $D$ ', Deckel des hinteren Endes von $D .6:$ I.

Fig. 6. Der Deckel des Helicopsychegehäuses von Fig. 20. (Taf. LIV). I 5 : I. $B, C$, Spalte anderer Deckel derselben Art. $45: \mathrm{I}$.

Fig. 7. Deckel des Helicopsychegeluäuses von Fig. 2 I. (Taf. LIV). I5 : I.

Fig. 8. (8 malige Vergrösserung.) Hydroptilidengehäuse von den Wasserfällen. $A$, Larvengehäuse ; $B, C$, festgeheftete und am hinteren Ende aufgehängte Puppengehäuse.

Fig. 9. (Nat. Grösse.) Futterale irgend einer Trichoptere unbestimmter systematischer Stellung. $A$, aus dem Bugresbache; $R$, aus dem Bache Garcia.

\section{Berichtigung eines Irrthums.}

Durch eine Nachlässigkeit habe ich im vergangenen Jahre versäumt, die

I) Arch. do Mus. Nac. 1878. III. 2 I3. 2 I 4 . 
e por isso colloquei crradamente a Grumicha na familia dos Leptocerideas (ou Mystacideas), seguindo o exemplo de Hagen que a chama de Leptocerus Grumicha. O insecto perfeito concorda nos esporões das tibias e outrous caracteres com o gencro Barypenthus, de que Burmeister descreveu duas especies provenientes de Nova-Friburgo. Ora, esse genero, a que a Grumiclia parece ser alliada foi tambem collocada novamente na familia das Leptocerideas por Mac Tachlan. O meu, erro provém da nimia confiança que puz nesses dous distinctos entomologistas, que hoje são as primeiras autoridades no tocante aos Trichopteros. -
Taster der Männchen zu untersuchen und desshalb irrthümlicherweise die Grumicha in die Familie der Leptoceriden (oder Mystaciden) versetzt, indem ich dem Beispiele Hagen's folgte, der sic Leptocerus Grumicha nennt. Das vollkommene Insekt stimmt in den Schienspornen und anderen Merkmalen mit der Gattung Barypenthus überein, von der Burmeister zwei Arten von Neu-Freiburg beschrieben hat. Nun ist diese Gattung, der die Grumicha verwandt zu sein scheint, von MacLachlan ebenfalls kürzlich in die Familie der Leptoceriden gestellt worden Mein Irrthum kam von dem zu grossen Vertrauen her, das ich in diese beiden hervorragenden Entomologen setzte, die heute in Bezug auf Trichopteren die ersten Autoritäten sind.

Fritz Müller. 


\title{
Extracts from letters regarding Brazilian caddis-flies ${ }^{1}$ ).
}

\author{
(Letter to Mr. M’Lachlan.)
}

Mr. M'lachlan exhibited the cases and sixteen species of Brazilian caddisflies, with the insects bred from the larvæ that manufactured some of them, sent to him by Dr. Fritz Müller, from Santa Catharina. Included were the cases exhibited at the meeting of the $4^{\text {th }}$ December last. Some extracts (with notes) from Dr. Fritz Müller's letters are here given: -

"Helicopsyche. In some cases of one of the species you will see, well preserved, the oldest part of the case, which peeps out like a chimney from the conical top. There are here two or three other species of Helicopsyche, one of which lives on rocks continually wetted by the spray of waterfalls: the pupa of this species is deprived of the long hairs which exist, in other species, on the first four joints of the fore and middle legs, and which the pupæ, after leaving the case, use in swimming to the surface. On the rocks it is, of course, neither necessary nor possible to swim. Should not Brauer's Setotricha be a Helicopsyche? the neuration of the wings is very similar to that of our species ${ }^{2}$. In the pupa of Helicopsyche ceylanica, Brauer ('Voyage der Novara', Neuroptera) describes the first joint of the maxillary palpi in either sex as being much shorter than the second; but this is not the case with our species, which in their maxillary palpi agree with Sctotricha. Perhaps there may not be any real difference in this respect between $H$. ceylanica and the Brazilian species. Brauer's figure of the palpi of Helicopsyche looks as if there were something wanting at the base. There are several other differences between the larvæ and pupæ of Helicopsyche I have examined and Brauer's description of $H$. ceylanica; whether they be real or not I am .unable to decide. The anterior margin of the pronotum of the larva is armed, in our several species, with a row of strong spines, straight or curved at the end. The branchixe described by Brauer I have been unable to find in any of our species. The hooks at the apex of the abdomen are quite different

I) Proceedings Ent. Soc. London 1879. p. VI-VIII.

2) I have already called attention to the probability that Satotricha may be allied to Helicopsyche, in my 'Revision and Synopsis of European Trichoptera' (pt. V., p. 269, Nov. 18;6). - R. M'L. 
from Brauer's description. The lateral tubercles of the first segment of the abdomen are beset with pairs of microscopical spines. In describing the legs of the pupa, Brauer says that the skin of the pupa bears but few hairs; if indeed the fore and middle legs of the pupa were hairless, or nearly so, $H$. ceylanica would probably not live in the water, but on wet places, where the pupa is not obliged to swim. According to Brauer there should be a pair of horny plates, armed with hooks, on the back of abdominal segments $2-6$; in our species these exist only on segments $3-6$, but there is a second pair on segment 5 , with the hooks curved in an opposite direction. Brauer's figure of the apex of the abdomen shows it as deprived of appendages. I cannot help thinking this must be an error; all our species have well-developed appendages bearing the usual four long hairs.

"The pupæ of a species of Hydropsichido living on the same rocks here likewise have hairless legs, and this is also the case with the species of Leptoceride which inhabits Bromelice, while, in a closely allied species ${ }^{1}$ ) living in rivulets, the hairs on the fore and middle feet are well-developed, as you will see by the pupa-skins I send you.

"Of the other species I send you, one agrees in almost every particular with Brauer's description of the New Zealand genus Tetracentron, so that I presume it will belong to that genus ${ }^{2}$. The larva lives in hollow sticks of wood; but, where the black Dentalium-like tubes abound, it sometimes usurps the tubes of this latter species. The tubes described by Hagen (Stett. entom. Zeit., I864, p. 226 , No. 23) as Leptocerus? grumicha, Vallot, must have been inhabited by strangers, for they were closed by stones, whereas the legitimate owners make a circular corneous operculum, with a subcentral opening. Though these black tubes are extremely abundant in some places, I have only a few ill-preserved insects, which I hope to replace by better ones ${ }^{3}$ ).

"There is another smaller species which also lives in the tubes made by different Trichoptera, and which has the curious custom of fixing to the mouths of the usurped cases sticks of wood. Even to a practised eye it is often difficult to discover them among the irregular straggling sticks. I have not yet bred the insect of this species, but judging from the structure of the larva it must be nearly allied to Tetracentron.

"Hydroptilida. The cases of my former letter, which you were inclined to doubt as belonging to Trichoptera, are those of Hydroptilidce. I have often reared the imago. The family appears to be very rich here. I already know the larvæ of eleven or twelve species. The most curious of them are two species

I) This insect belongs to Section iv. of Leptocerida, according to the system adopted in my 'Revision and Synopsis of European Trichoptera'. It probably forms a new genus allied to Anisocentropus and Ganonema. The cases of it, and of that inhabiting the Bromelia, are formed of large pieces of leaves (or entire small leaves) attached flatly in a longitudinal manner. - R. M'L.

2) It does agree with Tetracentron in almost every particular. - R. M'L.

3) These black tubes have probably been described as actual shells of Dentalium. Vallot (Mém, Acad. Dijon, 1855) cites doubtfully Dentalium corneum, Gmelin, which has since been referred as the case of a Trichopterous insect, as identical therewith, and renames it Phryganea grumicha. The insects sent by Dr. Fritz Müller belong to the Leplocerida, but to an undescribed genus of uncertain affinities - R. M'L. 
which, no doubt, form a new genus (Peltopsyche). The larvae live in fixed flat shield-like cases, resembling the egg-cases of Nephelis, transversely striated in one species $(P$. Sieboldi), smooth in the other (P. Maclachlani). The antenne of the male are very curious, and very different in the two species. Spurs 2.4.4. The antennæe of $P$. Sieboldi are 13 -jointed in the male, and the number is probably the same in P. Maclachlani; in the female the joints are more numerous ${ }^{1}$ ).

"Chimarrha? The larva of some Rhyacophitide" (Chimarrha?) live in movable cases. These larvæ remove the ventral wall of their houses before fixing them to some stone.

"The number of species of Trichoptera that I have seen here, either in the larval or perfect state, is about forty."

I) The structure, and especially the habits, of Peltopsyche differ so much from other IIydroptilida that one is tempted to doubt if it really belong to the family. - R. M'L. 


\section{On a trichopterous insect belonging to the family Leptoceridae with branchiae ${ }^{1}$ ).}

The Secretary exhibited a specimen, in alcohol, of a trichopterous insect, showing tracheo-branchiæ, sent from Brazil by Dr. Fritz Müller, who communicated the following note concerning it: -

"I send you cnclosed a trichopterous insect belonging to the family Leptoceridee, which shows very distinctly the branchiæ lately discovered in the imago stage of this order by Dr. Palmén ${ }^{2}$ ), of Helsingfors. As these branchiæe cannot be readily seen excepting immediately after transformation, I think many members of the Entomological Society may not yet have seen them. I may add that Dr. Palmén's view, that the branchiæ persist in all those Trichoptera the larvæ and pupa of which possess them, does not hold good. At least in one species of Leptoceride I have observed that they are cast when the pupa undergoes its final transformation."

Mr. M'Lachlan said that the discovery by Dr. Palmén of branchiae in the perfect insects of many Trichoptera was an extension of the observations originally made by Newport ${ }^{3}$ ), and after him by Gerstäcker and others, as to the existence of branchire in the imagos of various Perlide. Dr. Palmén appeared to be of opinion that these persistent branchiæ serve no functional purpose in Trichoptera, and alludes to them more particularly as proving that the branchial system of the larva and the stigmatic system of the imago have no genetic connection, since in the imago branchiae and stigmata may exist side by side. Mr. M'Lachlan further alluded to the existence of marked branchial filaments in the imago of various other genera of European Trichoptera not especially alluded to by Dr. Palmén, such as Diplectrona, Plectrocnemia and allics, Ptilocolopus, \&c., and thought they might yet be found to serve a functional (respiratory) purpose. The insect sent by Dr. Fritz Müller showed two or three branchial filaments on each side of most of the abdominal segments.

1) Trans. Ent. Soc. London 1879. Proc. p. XIII. XIV.

2) 'Zur Morphologie des Tracheensystems', 1877.

3) Ann. \& Mag. Nat. Hist. 1844. Trans. Linn. Soc. xx. p. 425 (1851). 


\section{Notes on the Cases of some South Brazilian Trichoptera $)^{2}$ ).}

little is known about the cases of extra-European Trichoptera. A short account of those observed by me in Southern Brazil may therefore be of some interest.

Of the seven families into which Trichoptera are at present divided, only five have as yet been found here, viz., Sericostomide, Leptoceride, Hydropsychide, Rhyacophilide and Hydroptilide. These may be grouped into two main divisions according as their pupæ are active or inactive. In the first group comprising the Sericostomide, Leptoceride and Hydropsychide, the case of the pupa is provided with small openings at either end, through which a continual current of water passes moving from the anterior to the posterior extremity. The pupa is in incessant activity to maintain this current; this is done, at least in most species, principally by the appendages at the end of the abdomen, which may be seen playing in the opening at the hind-end of the case. In the second group, containing the Rhyacophilide and Hydroptilide, the larva spins a cocoon closed all around, in which the pupa lies quite motionless. This cocoon is either free within the case (Rhyacophilide), or confluent with the walls of it (Hydroptilide). The fixity or mobility of the cases does not afford a distinctive character of the two last-named families; for there are not only Rhyacophilideous larvæ living in portable cases and Hydroptilideous larvæ living in fixed ones, but there are even cases fixed and movable at the same time, being fastened by a long flexible string (Rhyacopsyche).

\section{Sericostomidx.}

This family, as far as I know, is here represented only by the curious genus Helicopsyche, of which I have seen about half-a-dozen species. The case of one species is remarkable for the first built portion of it being straight. When pre-

I) Trans Ent. Soc. London 1879. P. I3 I-I44.

2) Figures and full descriptions of the cases mentioned in the following notes have been sent for publication to the "Archivos do Museu Nacional do Rio de Janeiro". (- Ges. Schriften S. 644 ff.) [Some additional notes appear in the Report of the Proceedings of the Meeting of the Entomological Society, held on the 2nd April, I 879; cf. Proceedings, pp. vi-viii. (= Ges. Schriften S. 762) -Ev.]. 
served in adult specimens, this oldest portion peeps out from the top of the heliciform case like a little chimney. Most of the larve of Helicopsyche are rather sluggish animals, often resting motionless on the same spot for the whole day; they then retire into their cases after having fixed them temporarily with some threads of silk, a custom which is to be observed also in various Leptocerideous larvæ. In none of our species have I seen branchiae, which, according to Brauer, exist in Helicopsyche ceylanica. Before passing into the pupa state, the larva shuts its case with a flexible corneous covering, provided in most of our species with a long, simple transverse slit; in one species the margins of the slit are serrated, and in another species there is no slit at all, but a sieve-like spot near the centre of the corering. As to the pupæ, Brauer says, that those of $H$. ceylanica have a pair of hook-bearing corneous patches at the basis of the abdominal segments from the second to the sixth, and there are also five pairs in his figure. This would be very strange, for the number and shape of these patches is generally very constant within the limits of the same genus, and in all our species of Helicopsyche there are four pairs only, situated at the basis of the third, fourth, fifth and sixth abdominal segments; each patch bears near its posterior end two or three short, rather blunt teeth, which are directed backwards. There is also, as usually, a pair of corneous patches at the end of the fifth abdominal segment, armed with strong, sharp, curved teeth, which are directed forwards.

One of our species of Helicopsyche lives on rocks wetted by the spray of waterfalls; it is by far more lively than the other species. The waterfalls, which are of very frequent occurence in all our mountain rivulets, are generally frequented by threc more species of Trichopterous larvæ, belonging to three different families (Leptoceride, Hydropsychidee and Hydroptilide). Now the pupæ of those four widely-different species agree in their feet of the second pair of legs being deprived of the fringes of long hairs, by the aid of which the pupæ of other Trichoptera swim to the surface of the water when they are about to undergo their final transformation.

In those species of Helicopsyche, which I have bred, the perfect insects used to emerge from the pupæ soon after sunset.

\section{Leptoceridæ.}

Of M'Lachlan's first section of this family $I$ have not yet seen here any species.

\section{Section II.}

Two of our genera appear to belong to this section.

Genus I.

(Near Odontocerum, though distinguished by numerous differences. Antennæ not dentate; eyes of the $\delta$ very large, meeting on the vertex in one species and nearly so in another; radius of the anterior wings confluent at its apex with the first apical sector, \&c.)

The case of the larva is a slightly-curved, cylindrical, firm tube, built with sand grains; the tail-end is closed with a transverse wall, having at its upper or dorsal margin a rather large oval or semicircular opening. Before its change the 
larva cuts a portion of the tail-end of its tube and then fixes the ventral side of either end and closes them by a single stone (in one species), or by a wall built of several fragments of stone (in a second species), in such a way that there remains at the ventral side of each extremity a narrow crescentic slit, the ventral margin of which is beset with a row of teeth. It is curious that the manner of closing the tail-end should be quite different in the larva and in the pupa cases. The pupa has five pairs of corneous patches at the basis of the abdominal segments (from third to seventh), each of the patches bearing a single blunt tonth, and there is the usual pair of patches at the end of the fifth segment, having two short sharp teeth.

The perfect insects emerge from the pupa in the evening, generally later than Helicopsyclie. On this occasion the fasciculate branchia of the pupa are shed, like those of Epliemeride, and this is the most remarkable feature of the genus; for it appears, that in most Trichoptera the branchiæe of the pupa subsist in the imago in a rudimentary condition.

There are here two species of this genus, differing much in size, the larvæ of which live in clear rivulets; a third species of larvæ, building unusually short and wide tubes, of which I have seen but hery few specimens in the River Itajahy, probably belongs to the same genus.

\section{Genus II. Grumicha, of Saint Hilaire.}

The wings having no median cell, the insect cannot be placed in M'Lachlan's fourth section, while, by the moderate length of the antennæ and the presence of the apical fork, No. 2, in all the wings it is excluded from Section III. Thus I place it here, though it shows no particular relation to Odontocerum. (Spurs 2, 2, 2. Discoidal cell closed, and radius connected to the first apical sector by a transverse nervule in all the wings. Apical forks, Nos. I, 2, 3, 5 in the anterior I, 2, 5 in the posterior, wings.) The wellknown black Dentalium-like tubes of the larvae are frequent in some of the larger tributaries of the Itajahy. The larvæ are remarkable for the tibiæ of the hind legs consisting of two joints. The tail-end of the tube is closed with a transverse wall, having a central circular opening: Before its change the larva fixes the mouth-end of its tube by a petiolated disc to some stone or to other tubes of the same species. Clusters of more than a hundred specimens are sometimes found. The mouth-end of the tube is closed with a circular covering, provided with a transverse opening beneath its centre.

\section{Section III.}

\section{Genus I. Tetracentron, Brauer.}

One species of this New Zealand genus is extremely common here. The larva, which, like those of Grumicha, have two-jointed tibix on the hind legs, lives in sticks of wood, fragments of branches, of petioles of Cecropia leaves, \&c. These are hollowed out in convenient lengths, and a semicircular piece is cut away from the ventral side of the mouth-end, so that the dorsal side projects, protecting the larva when crawling about; besides this, for more protection, a small stone is fastened to the projecting dorsal side, which closes the entrance when the larva retires into its case, and covers its head when feeding. Near the 
end of the boring a small hole is gnawed through the wall of the stick for the issue of the respiratory current. For its transformation the larva fixes the ventral side of the mouth-end of its case to some stone or tree (preferring the latter, when obtainable), and closes the entrance with a stone; the interior of the stick is clothed with a silken tissue, forming a cylindrical cocoon, closed with a sieve at either end; the centre of the anterior sieve is attached to the stone, which serves as a covering. It often happens that the larvæ find hollow sticks; but even then they gnaw, before their change, a quite purposeless hole through the wall of the stick. (See Kosmos, "Gratulationsheft zum 7o jährigen Geburtstage Ch. Darwins", p. 395, fig. 6. ${ }^{1)}$ The pupre agree in the number and arrangement of the corneous patches of the abdomen with those of Helicopsyche, but each patch is armed with from four to six sharp hooks. The branchire of the pupa are not shed in the final transformation; they can easily be seen in the imago when it is put into spirits of wine immediately after issuing from the pupa.

Sometimes tubes of Grumicha are met with, which, instead of a corneous covering, are shut with a stone (such were, e. g., the tubes described by Hagen in Stettin, entom. Zeit. I864, p. 226), and these, on examination, are found to contain pupæ, not of the maker of the tube, but of an intruding Tetracentron. I do not know whether it is a distinct species.

In some small mountain rivulets I have found tubes of various smaller Leptoceride (Setodes (?), Grumichella, \&c.) tenanted by intruders, which have the curious habit of fastening to the mouth-end of the tube bits of wood or sticks, sometimes much longer than the tube, and concealing it almost completely. I have not yet seen the imago, but the larva agree (e. g., in the two-jointed tibire of the hind legs) with those inhabiting hollow sticks.

\section{Genus II. Grumichella, nov. gen.}

(Very nearly related to Leptocems. The neuration of the anterior wings is quite the same; in the posterior wings apical fork No. 1 is wanting, while Nos. 3 and 5 are present in both sexes. Proportion of the joints of the maxillary palpi $10,15,20,9,17$.

The larvæ inhabit waterfalls and rapids of mountain rivulets. But for size their tubes closely resemble those of Grumicha, which are thrice as long. It is rather curious that those almost identical tubes should belong to species quite different in their larval, pupal and imago states.

The tubes of Grumichella show tivo interesting contrivances, by which they are adapted to their peculiar habitat-1, from the wall which closes the tail-end of the tube, and which has, as in Grumicha, a central circular opening, there projects, on the ventral side of the opening, a short, stout, triangular tooth or spur, which, being inserted into minute crevices of the rocks, probably serves to give hold to the tubes; 2, the little petiole or foot-stalk of the disc, by which the pupa case is fastened, does not proceed, as in Grumicha, from the margin of the tube, but from the corneous covering. The pupa cases being usually fastened with the mouth-end turned upwards to perpendicular rocks, along which a thin sheet of water is pouring down, if the tubes were fastened, the pupa, after having

I) $=$ Ges. Schriften S. 685 . 
loosened the covering, would hardly be able to creep out of their tubes, and, if they succeeded in doing so, the tender, fragile creatures would almost infallibly be crushed. But now, after loosening the covering which remains fastened to the rock, they are within their tubes safely carried away by the water to some quiet place, where they may with leisure creep out and undergo their final transformation. The pupa is remarkable for its last abdominal segment being unusually long (as long as the three preceding ones), and tapering towards the end. Number of dorsal patches as in Helicopsyche, each patch armed with two short, sharp teeth.

\section{Genus III. Setodes (?).}

There are here three species agreeing in general appearance and in the neuration of the anterior wings (one of them even in colouring) with Setodes punctata and viridis; but the posterior wings are broader.

The larvæ, the antennae of which are longer than in any other Leptocerideous larva known to me, live in narrow, cylindrical, straight or slightly-arcuated leathery tubes. Before its change the larva considerably shortens its tube, the ventral side of either end of which is then fixed by means of a disc, usually bilobed, and the extremities closed with coverings having a central circular or elliptic opening. The appendages at the end of the abdomen of the pupa are very long; the number of the dorsal patches is as in Grumichella, \&c., those at the basis of the $4^{\text {th }}, 5^{\text {th }}$ and 6 th segments have two or three teeth, but those at the basis of the third and at the end of the fifth segments have two pairs of teeth, those of one pair being much smaller.

In one of the three species the slightly-arcuated brown tubes are covered with very fine sand; the larvae of this species swim very well, their hind legs being furnished with long fringes. The imago is the most beautiful Trichopterous insect I have ever seen.

In the second species the straight tubes are covered with narrow bits of wood or other vegetable fibres; those on the back are arranged longitudinally, projecting considerably beyond the mouth-end of the tube; those on the sides and beneath are disposed in an oblique direction.

In the third species to either side of the back of the straigth tube there are fixed a row of bits of wond, projecting laterally, and generally decreasing towards the tail-end.

\section{Genus IV.}

From the great length of its hind legs I suppose that a little larva, which makes curious nearly cylindrical cases with the seeds of Callitriche, must be placed in this section.

\section{Section IV.}

The cases of the three species of this section, with the larva of which I am acquainted, differ from those of all other Leptoceride by their inner silken tube being much flattened, the height being equal, or nearly so, to half the breadth. The external aspect of the cases is yet much more flattened and broad; for they are covered with bits of leaves, which laterally project more or less beyond the inner tube. 
In the largest species the cases of adult larvæe are usually made of four leaves (sometimes there are but three), two forming the ventral and two the dorsal side; the anterior dorsal leaf is produced far over the ventral one, so as to protect the larva when moving about. This species lives in rivulets. The case of the pupa is fixed at the mouth-end, either extremity of the interior tube being closed with a sieve.

In the smallest species, which lives on trees between the leaves of Bromelie, there are generally five or six bits of leaves on the ventral, and one more (six or seven) on the dorsal side of the tube. Before its change the larva closes the mouth end by fastening one more bit of leaf to the ventral side.

This is also done by the third species, intermediate between the other two in size as well as in the number of leaves used in the construction of its case; there are generally three or four on the ventral and four or five on the dorsal side. This species lives principally in very small rivulets, with hardly any water, trickling along a declivitous rocky ground.

To the different habitat of these three species corresponds a remarkable difference in the feet of the pupæ. In the first species there are not only dense fringes of long hairs on the second pair, but similar hairs, though much less developed, exist also on the feet of the fore-legs. These fringes are rather rudimentary in the third species, and completely wanting in the Bromelia species, which in this respect agrees with the waterfall Trichoptera.

The pupæ have more dorsal patches than any other of our Leptocerida; for there is a pair on the eighth abdominal segment also, and besides this, there is on the back of the ninth segment a pair of long spear-shaped horny processes.

The first species emerges from the pupa in the evening, as most Leptocerida do, but the Bromelia species usually during the first hours of the afternoon (at least in captivity). The branchiæe of the pupa subsist, in a rudimentary condition, in the perfect insect.

The three species agree, not only in the construction of their cases, in the structure of their larvæ and pupæe, but also in the neuration of the wings and other characters of the perfect insects (in all the wings the radius is confluent at its apex with the first apical sector; in the posterior wings the discoidal cell is open, the apical forks Nos. 2, 3 and 5 being present). It would be most unnatural to separate them into two genera, and yet they differ in the number of spurs. In the Bromelia species there are 2, 4, 2 in both sexes, while the other two have $2,4,4$. In any other respect the intermediate species resembles more closely to the Bromelia species than to the larger one, with which it agrees in the number of spurs.

\section{Hydropsychidæ.}

\section{Genus I. Macronema.}

The larva of one species is extremely common, being met with almost everywhere under large stones. The larva makes a very rude dwelling with irregularlyaccumulated and loosely-connected stones. The case of the pupa is by far more solid and regular, at least when viewed from within. The inner room is oval, 
the surface smooth, and the stones of the wall firmly connected. At either end a few small openings may be detected, leading through the wall. Within the case there is a cylindrical silken cocoon, which is loosely connected with, but may be easily separated from, the wails of the stone-case, and which has a transverse sieve at either end.

\section{Genus II. Tinodes (?).}

Cases similar in general appearance to those of Tinodes maculicornis are very common on rocks exposed to the spray of waterfalls. They consist of a soft silken ribbon interwoven and covered with microscopical algæ, diatoms and mud, and curved into a semicylinder. These canals without a basal wall can hardly be called "tubes". The larva is remarkable for its very long spinneret, which projects beyond the head. I have not yet seen the imago.

\section{Genus III.}

I do not know the imago; in the pupa I found 2, 4,4 spurs. The cases, of which I have seen but very few specimens in the River Itajahy, are interesting on account of their close resemblance to those of the Hydroptilideus genus Peltopsyche; indeed, before I had an opportunity of examining the larvæ and pupæ I supposed them to be some new species of Peltopsyche, or even unusually large specimens of Peltopsyche Maclachlani. They are flat, elliptical, smooth, buffcoloured shields, with a small opening at either end, fixed to the upper side of stones.

\section{Genus IV. Rhyacophylax, nov. gen.}

(Apears to be nearly related to Smicridea, but the number of spurs is different, being $x, 4,4$ in the 9 , and $x, 4,2$ in the 8 .)

This is, no doubt, as to the cases, the most curious of all our Hydropsychide. The cases themselves are rather rude canals, covered with irregularly-interwoven vegetable fibres, but at its mouth-end each case has a large funnel-shaped verandah, covered with a very beautiful silken net. The larva live in the rapids of various rivulets, and the entrance of the verandah is invariably directed towards the upper part of the rivulet, so as to intercept any eatable things brought down by the water. Generally, a more or less considerable number of larvæ build their cases close together, so as to form transverse rows, on the upper side, of stones. Lately, I saw, on a large stone, about half-a-dozen parallel rows, at some distance from one another; one of them, being about $0.2 \mathrm{~m}$. long, must have been composed of about thirty cases. Before the end of the larval period the vegetable fibres are replaced by small stones, and the verandah is destroyed, either by the larva or by the current of the water. One day, when I was taking to my house a stone with beautiful Rliyacopliylax cases, some of the larvæ left their houses, crept to the edge of the stone and then descended, suspending themselves in the air, like spiders, by a thread of silk. The larva of Grumichella, also, may be seen suspending themselves in the water in a similar way. Such a faculty must prove highly serviceable to larva living in rapids, where they might otherwise be easily swept away by the current. 


\section{Rhyacophilidae.}

\section{Genus I.}

(Spurs of a 8 pupa 2, 4, 4.)

The larva lives, principally, without any case, between the etangled stems of various Podostemea, which densely cover the stones in the rapids of the Itajahy and its tributaries. It is carnivorous, fragments of insect larvæe (Hydropsychide, Perlide, \&c.) being found in its intestines, and its anterior legs are armed with very powerful and curious forceps; the femur is very thick, and has on its distal inferior angle a stout process, resembling the thumb on the hand of a crab; the tibia and tarsus are extremely short, so that the curved claw impinges against the process of the femur. The cocoon of the pupa, also, is not protected by a regular case; sometimes there are some loosely-connected stones around it, but at other times it appears to lie, without any special protection, between the Podostemer. The feet of the first and second pair of legs are provided in the pupa with strong well-developed claws, which I have not yet seen in any other Trichopterous pupa. They are, probably, very useful to the pupa of this species, which has to make its way between the densely-intricate stems of Podostemece.

\section{Genus II.}

The larva of some smaller species of Rhyacophilide build portable cases, agreeing with those of most Hydroptilide in not showing any difference between the two extremities. They are built of stones, oval, with a flat bottom, on either end of which there is an opening; the stones generally being of comparatively large size, the external aspect is often very irregular. As the two doors of these little stone-houses are in the flat bottom, they would not freely admit the water necessary for respiration, when the larva is at rest, and there are special contrivances for the access of water varying in the several species. In one species, frequenting small mountain rivulets, small passages are left between the stones of the dorsal side of the house. In another species, which often covers by countless thousands the stones in clear streams, an upright cylindrical chimney, made of grains of sand, rises from the middle of the house; its height sometimes equals, or even exceeds, the length of the house. When the larva is about to change, the bottom and chimney are removed, the borders of the vault are fixed to the stone, on which it lives, and then a cocoon of the usual form is spun.

\section{Hydroptilidxe.}

In Hagen's list of South American Neuroptera (Synopsis of the Neuroptera of North America, 186r, p. 299), no species of this family is mentioned, and yet it will probably prove to be one of the most numerous Trichopterous families in this country, including the most varied and remarkable larval cases.

\section{Genus I.}

There are here various species, the cases of which resemble more or less closely the well-known cases of Plirixocoma pulchricomis, being much compressed from the sides and opened by a narrow slit at each end. They are either 
naked, or covered with very fine sand, or with algæ or diatoms, which in one species are arranged in an extremely elegant manner. The cases of the pupx are fixed either along the whole ventral margin or at the two ends, or in one species, abounding on the rocks of waterfalls, at one end only.

\section{Genus II.}

Very minute, nearly cylindrical, coriaceous, brown tubes; covered with very fine sand, which in the pupa state are fixed at either end to the underside of stones, showing generally two adhesive discs on the anterior, and a single one on the posterior end. They are common almost everywhere.

\section{Genus III. Diaulus Ladislavii.}

Strongly-compressed oval cases, elegantly covered with diatoms, with a narrow slit at each end and having on the dorsal margin two (or, as I have seen in one specimen, three) cylindrical chimneys. The observation of living larvæ of this and of the first genus leaves no doubt as to the use of the chimneys. Those inhabiting cases opened only by a slit at each end are seen moving incessantly, and working very hard, in order to maintain a current of water through these narrow passages; those of Diaulus, on the contrary, may remain motionless for a very long time, the water necessary for respiration having a free access through the chimneys. The cases of the pupæ are fixed in an upright position along the whole ventral margin on the upper side of stones, and often these little houses form large villages of a rather picturesque aspect.

\section{Genus IV. Lagenopsyche.}

An approximative idea of the cases may be formed by imagining the bottom of a bottle to be cut away and then its under part to be compressed until the opposite sides touch each other, thus transforming the wide circular opening into a narrow slit. The mouth of the bottle represents the mouth-end of the larval case, and the long narrow slit at the tail-end is held in an upright position. In one species (L. lyvalina) the case is quite colourless and perfectly hyaline; in a second species (L. Spirogyre) it has a dark violet, or brownish, or blackish, colour, darker towards the mouth-end. For transformation the case is placed on one of its broad sides, and then fixed on either side of each end by means of petiolated discs; at the mouth-end of the larval case there are two discs in both the species, and as many exist at the opposite end in L. Spirogyra, but in L. hyalina there are four, the petioles dividing before they expand into discs. After having fixed its case the larva turns its head towards the broader end of it, so that the mouthend of the larval case becomes the tail-end of the pupa case, and vice versâ. L. hyalina lives in small rivulets under stones, L. Spirogyre in slowly-moving or even standing waters filled with Spirogyra, Callitriche and Heteranthera reniformis; the larvæ are to be met with among the Spirogyrce, on which they seem to feed; the pupx are fixed to the under side of the leaves of Callitriche or Heteranthera. The perfect insects emerge early in the afternoon.

\section{Genus V. Rhyacopsyche Hagenii.}

The larva live in rapids of mountain rivulets. The brown coriaceous cases of younger larvæ are nearly cylindrical and widely open at each end, afterwards 
they are widened in the middle, corresponding to the increasing thickness of the abdomen of the larvæ; from one end there proceeds a string of silken threads, generally about as long, but sometimes even more than twice as long as the cases, by which the latter are fastened to the upper side of stones. Thus the larva is secured against being carried away by the current, and at the same time by the mobility of its case its pasture ground is greatly enlarged, and the more so as it can issue indifferently at either end of its tube. It feeds on microscopical algæ. Before its change the string is much shortened and thickened, being thus transformed into a rigid footstalk, able to sustain the case in an upright position. The case of the pupa is somewhat compressed, oval or club-shaped, rounded at the upper, attenuated at the lower, end. The pupa emerges, for its final transformation, at the upper end of the case.

\section{Genus VI. Peltopsyche.}

The larvæ live in larger tributaries of the Itajahy, preferring rapids. One species ( $P$. Maclachlani) has as yet been found only in one single rapid near the mouth of the Warnow. The cases resemble in shape, colour and size the wellknown egg-cases of Nephelis, and are fixed, often in very large numbers, to the upper side of stones; they are made of a brown, rather tough, coriaceous substance. Their upper wall forms a rather flat elliptical shield, smooth in P. Maclachlani, transversely striated in P. Sieboldii; the basal wall is very thin, and firmly glued to the underlying stone, so that it can hardly be separated without being torn. At either end of the case there is a small circular opening. In most Hydroptilide the abdomen of the older larva is much swollen; in Peltopsyche it is so in a quite extraordinary degree, filling nearly the whole case. The very slender anterior part of the body is bent and hidden beneath the huge abdomen, of which it appears to be only an insignificant appendage. The pupre are remarkable for the unusually great difference which the complicated corneous patches on the back of the abdomen show in the two species. The perfect insects differ from all known Trichoptera by the antennæ of the $\delta$, some of the basal joints of which are produced into long processes exhibiting a complicated structure, very different in the two species, and which $I$ have not yet been able to unravel in a satisfactory manner. From what I have seen, I am led to suppose that these strangely modified basal joints of the antennre may be odoriferous organs. 


\title{
On a frog having eggs on its back.
}

\section{On the abortion of the hairs on the legs of certain coddis-flies (Phryganiden) ${ }^{1}$ ).}

\author{
(Letter to Ch. Darwin.)
}

Mit 3 Textfiguren.

Several of the facts given in the following letter from Fritz Müller, especially those in the third paragraph, appear to me very interesting. Many persons have felt much perplexed about the steps or means by which structures rendered useless under changed conditions of life, at first become reduced, and finally quite disappear. A more striking case of such disappearance has never been published than that here given by Fritz Müller. Several years ago some valuable letters on this subject by Mr. Romanes (together with one by me) were inserted in the columns of Nature. Since then various facts have often led me to speculate on the existence of some inherent tendency in every part of every organism to be gradually reduced and to disappear, unless in some manner prevented. But beyond this vague speculation I could never clearly see my way. As far, therefore, as I can judge, the explanation suggested by Fritz Müller well deserves the careful consideration of all those who are interested on such points, and may prove of widely extended application. Hardly anyone who has considered such cases as those of the stripes which occasionally appear on the legs and even bodies of horses and apes-or of the development of certain muscles in man which are not proper to him, but are common in the Quadrumana - or again, of some peloric flowers - will doubt that characters lost for an almost endless number of generations, may suddenly reappear. In the case of natural species we are so much accustomed to apply the term reversion or atavism to the reappearance of a lost part that we are liable to forget that its disappearance may be equally due to this same cause.

As every modification, whether or not due to reversion, may be considered as a case of variation, the important law or conclusion arrived at by the mathematician Delbœuf, may be here applied; and I will quote Mr. Murphy's condensed statement ("Habit and Intelligence", 1879, p. 24I) with respect to it: "If in any species a number of individuals, bearing a ratio not infinitely small to the entire

1) Nature 1879. Vol. XIX. p. 462-464. 
number of births, are in every generation born with any particular variation which is neither beneficial nor injurious to its possessors, and if the effect of the variation is not counteracted by reversion, the proportion of the new variety to the original form will constantly increase until it approaches indefinitely near to equality." Now in the case advanced by Fritz Müller the cause of the variation is supposed to be atavism to a very remote progenitor, and this may have wholly prevailed over any tendency to atavism to more recent progenitors; and of such prevalence analogous instances could be given.

Charles Darwin.

\section{My Dear Sir,}

If I remember well, I have already told you of the curious fauna which is to be met with between the leaves of our Bromeliæe. Lately I found, in a large Bromelia, a little frog (Hylodes?), bearing its eggs on the back. The eggs were

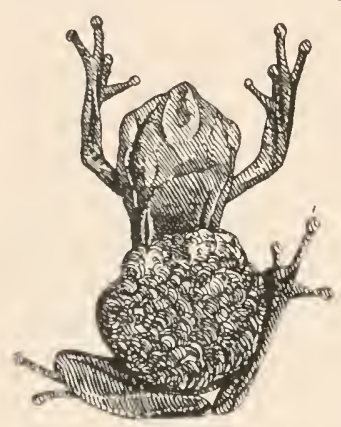

Fig. I. very large, so that nine of them covered the whole back from the shoulders to the hind end, as you will see on the photograph accompanying this letter, Fig. 1 (the little animal was so restless that only after many fruitless trials a tolerable photograph could be obtained). The tadpoles, on emerging from the eggs, were already provided with hind-legs; and one of them lived with me about a fortnight, when the fore legs also had made their appearance. During this time I saw no external branchiæ, nor did I find any opening which might lead to internal branchiæ.

There is here another locality in which a peculiar fauna lives, viz., the rocks of waterfalls, which are of very frequent occurrence in almost all our mountain rivulets. On these rocks, along which the water is slowly trickling down, or which are continually wetted by the spray of the waterfall, there live various beetles not to be met with anywhere else, larvæ of diptera and caddis-flies, and a tadpole remarkable for its unusually long tail.

The pupæ of caddis-flies living on the rocks of waterfalls (I examined three species belonging to the Hydropsychide, Hydroptilide and Sericostomidee. [Helicopsyche]), as well as those living in the Bromelize (a species belonging to the Leptoceride), are distinguished by a very interesting feature. In other caddisflies the feet of the second pair of legs (and in some species those of the first pair also) are fringed in the pupæ with long hairs, which serve the pupa, after leaving its case, to swim to the surface of the vvater for its final transformation. Now neither on the surface of bare or moss-covered rocks, nor in the narrow space between the leaves of Bromelix, the pupæ have any necessity, nor would even be able, to swim, and in the four species living on such localities which I examined, and which belong to as many different families, the feet of the pupæ are quite hairless, or nearly so, while in allied species of the same families or even genera (Helicopsyche) the fringes of the legs, used for swimming, are well developed.

This abortion of the useless fringes in the caddis-flies inhabiting the Bromelia and waterfalls appears to me to be of considerable interest, because it cannot be 
considered, as in many other cases, as a direct consequence of disuse; for at the time when the pupe leave their cases and when the fringes of their feet are proving either useful or useless, these fringes as well as the whole skin of the pupa, ready to be shed, have no connection whatever with the body of the insect; it is therefore impossible that the circumstance of the fringes being used or not for sivimming, should have any influence on their being developed or not developed in the descendants of these insects. As far as I can see, the fringes, though useless, would do no harm to the species, in which they have disappeared, and the material saved by their not being developed appears to be quite insignificant, so that natural selection can hardly have come into play in this case. The fringes might disappear casually in some individuals; but, without selection, this casual variation would have no chance to prevail. There must be some constant cause leading to this rapid abortion of the fringes on the feet of the pupæ in all those species in which they have become useless, and I think this may be atavism. For caddis-flies, no doubt, are descended from ancestors which did not live in the water, and the pupæ of which had no fringes on their feet. Thus there may even now exist in all caddis-flies an ancestral tendency to the production of hairless feet in the pupæ, which tendency in the common species is victoriously counteracted by natural selection, for any pupa, unable to swim, would be mercilessly drowned. But as soon as swimming is not required and the fringes consequently become useless, this ancestral tendency, not counterbalanced by natural selection, will prevail, and lead to the abortion of the fringes.

I do not remember having seen, in any list of cleistogamic plants, the Podostemaceæ. These curious little aquatic plants, which Lindley placed near the Piperaceæ,
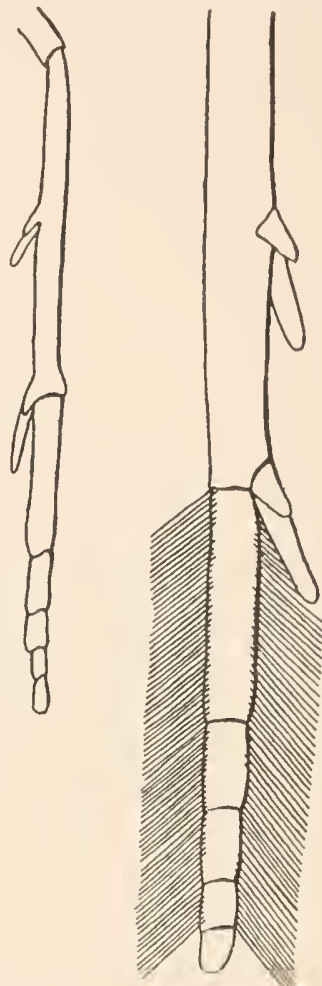

Fig. 2. Fig. 3 .

Fig. 2. Tibia and tarsus of the two pairs of legs of the pupa of a species of Leptoceridæ, inhabiting Bromeliæ.

Fig 3. The same of a nearly allied species inhabiting rivulets. Kunth between the Juncagineæ and Alismaceæ, and which Sachs considers as being of quite dubious affinity, cover densely the stones in the rapids of our rivers; on the branches which come above the surface of the water, there are pedunculated, open, fertile flowers; but there are numerous sessile flower-buds also on the branches, which probably remain submerged for ever; I have not yet ascertained whether these submerged flowers are fertile; if they are so, they can hardly fail to be cleistogamic.

Blumenau, St. Catharina, Brazil, January 21, 1879.

Fritz Müller. 


\section{Bud-Variation in Bananas ${ }^{1}$.}

In my garden there is a large plant (planted about eleven years ago) of a variety of banana, distinguished by purplish stems and petioles, red fruits, and by a very peculiar flavour of the latter. From the centre of this plant, covered by the rotten stems of former years, there are now growing green stems, with green petioles; one of them has already produced fruits, which were green when immature, and yellow when ripe, and the flavour of which I found to be but slightly altered. All the young stems growing from the circumference of the plant are purplish.

May not many of the varieties of bananas have been produced by budvariation?

Itajahy, April 7. I879.

1) Nature 1879. Vol. XX. p. I46. 


\section{Schützende Färbung und die Farbenempfindung der Tiere $\left.^{1}\right)$.}

Den im Kosmos (Bd. II, S. 59) besprochenen Mittheilungen hat Sir John Lubbock eine neue Reihe werthvoller, scharfsinnig ausgedachter und sorgsam durchgeführter Versuche an Ameisen folgen lassen 1). Unter anderen stellte er eine lange Reihe lehrreicher Versuche an über das Verhalten der Ameisen gegen verschieden gefärbtes Licht und schliesst aus denselben: I) Ameisen haben das Vermögen, Farben zu unterscheiden; 2) sie sind sehr empfindlich gegen Violet und 3) scheint es, dass ihre Farbenempfindungen sehr verschieden sein müssen von den unsrigen. Auch der dritte dieser Sätze erhält durch Sir John Lubbock's Versuche eine, wie mir scheint, ausreichende, thatsächliche Begründung.

Das häufige Vorkommen des Daltonismus, einer so tief greifenden Verschiedenheit der Farbenempfindung unter den Menschen, lässt es nicht unwahrscheinlich erscheinen, dass ähnliche und noch erheblichere Verschiedenheiten zwischen den verschiedenen Arten der Thiere bestehen. Auf dieselbe Vermuthung führt das Verhalten gewisser Schmetterlinge und Bienen gewissen Blumen gegenüber. Wenn z. B. Callidryas scheinbar achtlos an blauen Blumen vorüberfliegt und benachbarte gelbe oder rothe aufsucht, die uns weit weniger augenfällig vorkommen, möchte man diesen Falter für blaublind halten, wie den Homer des Dr. Magnus. Umgekehrt sammelte sich an einem himmelblauen Salbei meines Gartens, ohne den daneben blühenden, von Callidryas besuchten, leuchtend rothen Salbei zu beachten, Melissoda Latreillii, eine prächtige, blau glänzende Biene, deren Männchen sich durch ungewöhnlich lange Fühler auszeichnen.

Und doch darf man wohl behaupten, dass die Mehrzahl der höheren WVirbelund Gliederthiere die Farben in ganz ähnlicher Weise empfindet und unterscheidet, wie wir. Das soll natürlich nur sagen, dass sie dieselben Farben empfinden, wie wir, und dass ihnen und uns dieselben Farben gleich, oder ähnlich, oder verschieden und zwar in ähnlichem Grade verschieden erscheinen. Mehr können wir ja auch von unseren Mitmenschen kaum behaupten, mit denen wir uns über ihre Farbenempfindungen durch die Sprache verständigen können. Den Beweis für meine Behauptung liefert das weite Gebiet der schützenden Färbungen

1) Kosmos 1879. Bd. V. S. 62-63.

2) Journ. Linn. Soc. Zool. Vol. XIV. pag. 266. 
und täuschenden Nachahmungen. Die Feinde, vor denen die betreffenden Thiere auf diesem Wege geschützt werden, müssen natürlich eben so getäuscht werden, wie wir. Sie können also r) nicht auffallende Farbenunterschiede bemerken, wo uns solche entgehen; sonst würde eben für sie keine täuschende Aehnlichkeit vorhanden sein in allen Fällen, wo sie für uns besteht. Sie müssen aber auch 2) alle dieselben, oft recht feinen Farbenabstufungen unterscheiden, in welchen Vorbild und Nachbild übereinstimmen; sonst hätten sie nicht durch Vertilgung aller minder genau übereinstimmenden Nachahmer die Uebereinstimmung auf einen oft so wunderbaren Grad der Vollkommenheit treiben können.

Vor einem Daltonisten würde ein kirschrother Käfer im grünem Laube geschützt sein. Es wäre wohl möglich, dass ähnliches auch in der Thierwelt vorkäme, und vielleicht sind solche Fälle bisher nur deshalb nicht beobachtet worden, weil man nicht an die Möglichkeit ihres Vorkommens gedacht hat. Jedenfalls aber dürften sie nur seltene Ausnahmen von der allgemeinen Regel bilden. Itajahy, November 1878 . 


\section{Ituna und Thyridia' ${ }^{1}$.}

Ein merkwürdiges Beispiel von Mimicry bei Schmetterlingen ${ }^{2}$ ).

Mit 4 Textfiguren.

Die Gattungen Ituna und Methona wurden I 847 von Doubleday errichtet und zwischen Eutresis und Thyridia in die Familie der Heliconien eingereiht, aus welcher sie später mit den Ithomien und deren ganzer Vetterschaft zu den Danainen versetzt wurden. Methona hat man neuerdings mit Thyridia Hübn. vereinigt und neben dieser steht noch in Kirby's Verzeichniss der Tagfalter (1871) die Gattung Ituna.

Man scheint diese beiden Gattungen also von jeher als nächste Verwandte betrachtet $\mathrm{zu}$ haben und noch $\mathrm{zu}$ betrachten. Und doch ist ihre Aehnlichkeit keine ererbte, auf Blutsverwandtschaft beruhende, sondern eine erworbene, durch Nachahmung entstandene. Merkwürdig schon dadurch, dass die Thiere nicht etwa nur lebend flüchtige Sammler, sondern, sorgfältig verglichen, gelehrte Forscher zu täuschen vermochten, wird die Aehnlichkeit der genannten Gattungen in noch höherem Grade beachtenswerth dadurch, dass sie sich herausbildete zwischen Thieren, welche beide durch Ungeniessbarkeit geschützten Faltergruppen angehören. Auf diese Nachahmung unter geschützten Arten findet die für die grewöhnlichen Fälle der Mimicry zutreffende Erklärung (und eine andere ist bis jetzt meines Wissens nicht gegeben worden) keine Anwendung.

Ituna Ilione und Thyridia Megisto, deren Flügel ich hier vorlege, sind zwei bei uns ziemlich seltene Falter. Zu der Aehnlichkeit der Flügel, die sich in der Anordnung der gelblichen Glasflecken, der schwarzen Adern und Binden, welche diese Flecken durchziehen und trennen, und der weissen Flecken ausspricht, welche den schwarzen Saum der Flügel zieren, kommt noch die lange gelbe Fühlerkeule und die schwarzweisse Zeichnung des Leibes beider Arten. Beide Falter theilen mit den Ithomien die Vorliebe für die weissen Blüthenköpfchen

1) Kosmos 1879. Bd. V. S. 100-108.

2) Anm. d. Red. d. Kosmos. Dieser Aufsatz, wie auch der über Epicalia Acontius (Kosmos IV. S. $285=$ Ges. Schriften S. 660 ), waren bereits vor dem Abdrucke der WVallace'schen Arbeit über die Farben der Pflanzen und Thiere in unseren Händen, woraus sich, bei der Entfernung des Herrn Verf., erklärt, dass er die neueren IV allace'schen Aufstellungen nicht berüicksichtigt hat. 
eines Adenostemma, das am Saume des Waldes, wie am Rande durch den Wald führender Wege zu wachsen pflegt, besuchen aber auch andere, besonders weisse Blumen derselben Familie (Compositae), z. B. Vernonia, Mikania, Baccharis; auf Blumen aus anderen Familien entsinne ich mich nicht, sie gesehen zu haben.

Die Merkmale, durch welche Doubleday die Gattung Ituna von der im Aussehen so ähnlichen Methona und Thyridia schied, würden nicht hindern, die-

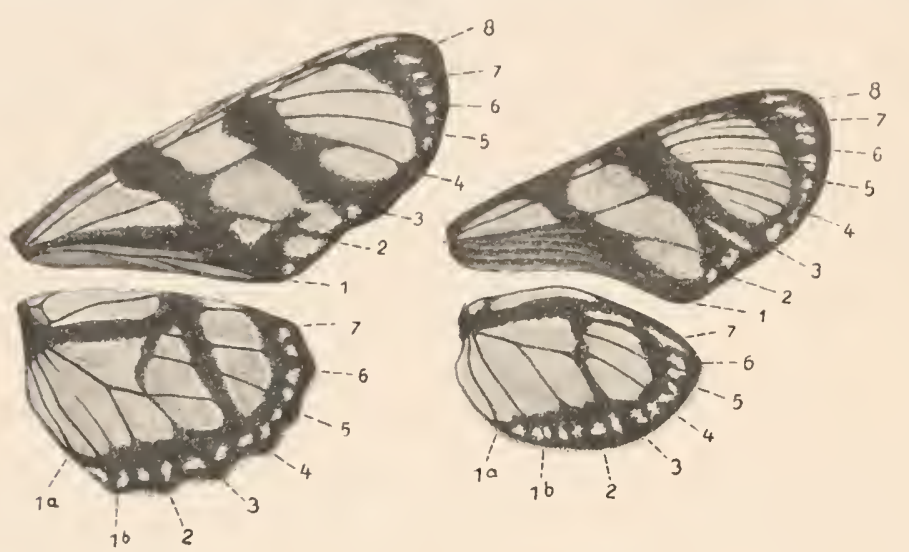

Fig. 1 .

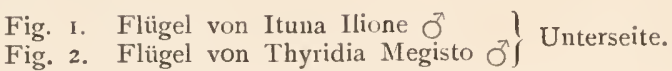

Die Zahlen am Flügelrande bezeichnen die Flügelrippen nach Herrich $\mathrm{Schäffers} \mathrm{Zählungsweise.}$ selben als nächste Verwandte zu betracliten, und auch die Unterschiede, auf welche ich jetzt hinweisen will, mögen recht unerheblich erscheinen; sie erhalten ihre Bedeutung dadurch, dass sie sich wiederholen in einer langen Reihe verwandter Arten, von denen die einen mit Ituna, die anderen mit Thyridia übereinstimmen, dass sie also hinweisen auf eine vor langer Zeit erfolgte Scheidung der Danainen in zwei Gruppen, deren eine Ituna, deren andere Thyridia angehört, und dass sie somit eine gleich frühe Trennung dieser beiden Gattungen beweisen.

Zunächst sieht man am Hinterflügel beider Arten zwischen je zwei Flügelrippen zwei weisse Randflecken; auch zwischen Rippe $1 b$ und 2 hat Ituna dieselbe, Thyridia dagegen die doppelte Zahl, also vier solcher Flecken. Es sieht aus, als wäre das Feld zwischen diesen beiden Rippen ein Doppelfeld, und das ist es auch. Ursprünglich hatte jeder Schmetterlingsflügel, wie viele Nachtschmetterlinge und die Puppen der Tagfalter beweisen, drei Innenrandsadern zwischen Mittelzelle und Innenrand; bei den Tagfaltern ist die vorderste dieser drei Adern oder Rippen ( $c$ ) geschwunden, wenn auch nicht immer spurlos; bei Acraea Thalia z. B. ist ihr Verlauf an den Hinterflügeln durch eine Reihe schwarzer Haare bezeichnet, wie sie auch längs der übrigen, wohl entwickelten Flügelrippen stehen. In vielen anderen Fällen ist von der geschwundenen Flügelrippe $(1 c)$ selbst kaum noch etwas zu sehen, aber ihr früheres Vorhandensein verräth sich noch in der Zeichnung der Flügel, welche das Feld zwischen Rippe I $b$ und 2 als ein doppeltes erscheinen lässt. In anderen Fällen hat sich auclı diese Andeutung des ursprünglichen Zustandes verloren, und das frühere Doppelfeld zeigt dieselbe Zahl von Punkten oder Flecken, wie alle übrigen. WVie bei Thyridia erscheint nun das betreffende Flügelfeld noch als Doppelfeld bei Dircenna, Ceratinia, Mechanitis, Melinaea, überhaupt bei dem ganzen Verwandtschaftskreise der Ithomien; dagegen wie bei Ituna einfach bei Lycorea und Danais (sowie, nach Abbildungen zu schliessen, bei Hestia und Euploea). 
Ein zweites, die Gattungen Thyridia und Ituna unterscheidendes Merkmal besteht in dem Vorhandensein einer kleinen ,Wurzelzelle“, wie sie HerrichSchäffer nennt, an Grunde der Hinterflügel von Ituna; dieselbe kommt auch bei Lycorea und Danais vor, fehlt dagegen bei Thyridia, wie bei allen übrigen Verwandten der Ithomien. Diese "Wurzelzelle" pflegte Herrich-Schäffer, wo er sie fand, als Familien-Merkmal zu benutzen. Er unterschied z. B. durch deren Fehlen oder Vorhandensein die Familien der Heliconinen und Danainen, welch' letztere er auf die Gattung Danais beschränkte. Hätte er also bei Ituna und Lycorea die allerdings recht winzige Wurzelzelle nicht übersehen, so würde er schon diese beiden Gattungen von den Ithomien getrennt und Danais angeschlossen haben.

Fig. 3. Vordere Hälfte der Flügelwurzel der Hinterflügel von Ituna Ilione $\bar{\sigma}$.

Fig. 4. Vordere Hälfte der Flügelwurzel der Hinterflügel von Thyridia Megisto $\overbrace{}^{\top}$.

$P C$ Präcostalis. $C$ Costalis. $S C$ Subcostalis. $I V Z$ Wurzelzelle.

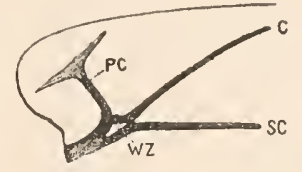

Fig. 3 .

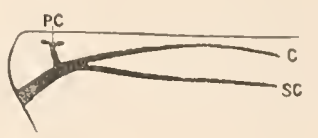

Fig. 4.

Drittens schliesst sich auch in der Bildung der Duftwerkzeuge der Männchen Thyridia an die Ithomien, Ituna an Lycorea und Danais an. Die Männchen von Ithomia und ihren Verwandten besitzen bekanntlich einen duftenden „Haarpinsel auf der Oberseite der Hinterflügel, vorn an der Subcostalrippe“ (Herrich Schäffer), dessen sich schon Herrich-Schäffer zur Unterscheidung derselben bediente. Gerade bei Thyridia Megisto ist der Geruch dieser Haarpinsel recht kräftig, und es ist die einzige mir bekannte Art, bei welcher diese von den Männchen erworbene Auszeichnung auch auf die Weibchen übertragen worden ist, freilich bei letzteren weit dürftiger entwickelt und schwächer duftend. Bei Ituna fehlt den Hinterflügeln dieser Haarpinsel; dagegen besitzen die Männchen, wie schon Doubleday wusste, zwei fingerförmige Fortsätze am Ende des Hinterleibes, die willkürlich ausgestülpt und eingezogen werden können; sie tragen einen mächtigen schwarzen Haarbusch, der sich beim Vorstülpen nach allen Richtungen, wie eine Kugelbürste, ausspreizt und einen sehr starken, für mich widerlichen, Schnupftabaksgeruch verbreitet. Dieselben Duftbüschel am Ende fingerförmiger Fortsätze finden sich in ganz gleicher Weise bei Lycorea und ebenfalls, wenn auch minder mächtig entwickelt und schwäicher duftend, bei Danais Gilippus und Erippus, bei welchen man sie bis jetzt übersehen zu haben scheint.

Auf Grund dieser Merkmale, von denen namentlich die ersteren, weil offenbar bedeutungslos für die Wohlfahrt der Thiere, als sichere Zeichen gemeinsamen Ursprungs gelten dürfen, sind die Ithomiinen und die eigentlichen Dana inen (Danais, Lycorea, Ituna; - Hestia und Euploea kenne ich nur aus Abbildungen) als zwei seit langer Zeit getrennte Gruppen zu betrachten, die sich mindestens so fern stehen, wie etwa Acraeinen und Maracujáfalter. Auch diese beiden Gruppen unterscheiden sich durch das Feld zwischen Rippe i $b$ und 2 der Hinterflügel, welches bei den Acraeinen wie bei den Ithomiinen ein Doppelfeld, bei den Maracujáfaltern wie bei den Danainen einfach ist. Die Raupen der 
Acraeinen und Maracujáfalter stimmen vollständig überein, nicht so die der Danainen und Ithomiinen; erstere, so weit bekannt, auf Asclepiadeen lebend, tragen auf dem Riicken zwei (Danais Erippus), drei (Danais Gilippus) nder vier (Euploea Midamus) Paar langer, fadenförmiger, weicher, nicht zurückziehbarer „Tentakel“; letztere, so weit bekannt, auf Solaneen oder den nahe verwandten Scrofularineen lebend, sind entweder ganz ohne Anhänge oder haben unterhalb der Luftlöcher fleischige, kegelförmige Fortsätze (Mechanitis Lysimnia) ${ }^{1}$ ).

Wenn nun nach allen Merkmalen Thyridia zu den Ithomiinen, Ituna zu den echten Danainen gehört (wenn also letztere nicht, wie $\mathrm{K}$ irby thut, durch die Ithomiinen-Grattung Athesis von Lycorea getrennt werden darf), so könnte die Aehnlichkeit dieser beiden Gattungen nur dann eine von gemeinsamen Ahnen ererbte sein, wenn in ihnen dic Tracht der Urahnen aller Ithomiinen und Danainen sich erhalten hätte. Daran aber ist nicht $z u$ denken. Hätten die Urahnen Flügel mit ausgedehnten Glasflecken besessen, so würden nicht so zahlreiche Arten beider Gruppen $\mathrm{zu}$ der ursprünglichen Bildung vollständig beschuppter Flügel zurückgekehrt sein. Auch würden mit gleichem Rechte Lycorea und verschiedene in Zeichnung und Färbung ihr auffallend ähnliche Ithomiinen beanspruchen dürfen, die uralte Familientracht bewahrt zu haben.

So liegt also ein Fall erworbener Aehnlichkeit vor, ein Fall von Nachahmung oder Mimicry. Aber welche der beiden Arten, Ituna Ilione oder Thyridia Megisto, ist das Urbild, welche das täuschende Nachbild? Doch kann darüber je ein Zweifel sein? Ist nicht das Vorbild immer eine häufige, in zahllosen Schwärmen auftretende, das Nachbild eine hundertfach seltenere Art? Trägt nicht das Vorbild die ererbten Farben seiner Gattung und Familie, während das Nachbild, mit fremden Federn geschmückt, seine ursprüngliche Familientracht abgelegt hat? Und ist nicht das Vorbild durch widerlichen Geschmack und Geruch ungeniessbar und dadurch sicher vor Feinden, und sucht nicht eben deshalb das Nachbild unter seiner Maske Schutz, weil es ohne diese als leckerer Bissen verspeist werden würde? - Schade nur, dass all' diese Kennzeichen gar manchmal im Stiche lassen.

Die nachahmende Art kann, wenigstens in einzelnen Bezirken, häufiger sein, als ihr Vorbild. Es können ja, wenn beide Arten in ein neues Gebiet sich verbreiten, hier die Verhältnisse der ursprünglich häufigeren ungünstig, der selteneren günstig sein, und es kann so das ursprüngliche Zahlenverhältniss sich umkehren; ja dasselbe kann im Laufe der Zeit am alten Wohnsitz der Arten geschehen. In der Provinz Santa Catharina ist Archonias (Euterpe) Tereas fast das ganze Jahr hindurch an Waldwegen häufig; dagegen gehört sein Vorbild, Papilio Nephalion, zu den seltenen Schmetterlingen. Das Zahlenverhältniss verschiedener Arten wechselt bisweilen recht erheblich in auf einander folgenden Jahren; es kann ein völlig umgekehrtes sein auf ziemlich nahe liegenden Gebieten. Hier am Itajahy ist Colaenis Julia bei weitem häufiger als der täuschend ähnliche, nur kleinere Eueides Aliphera; dagegen fand ich vor einigen Monaten im Norden

I) Die von Boisduval (Spec. gén. Lépidopt. Pl. 4 Fig. 9) abgebildete, der Stalachtis (Nerias) Euterpe zugeschriebene Raupe scheint die ciner Mechanitis zu sein; sie gleicht aufs Haar der von Mechanitis Lysinnia. Ein Blick auf diese Figur und Fig. Io und I I derselben Tafel, welche Raupen echter Danainen darstelleı, zeigt sofort die grosse Verschiedenheit zwischen Danainen- und Ithomiinen-Raupen. 
unserer kleinen Provinz, auf dem Hochlande bei S. Bento, den Eueides Aliphera in solcher Menge, dass ich einige Male ihrer acht mit einem Schlage des Netzes fing, während ich Colaenis Julia im Laufe einer Woche kaum zwei- oder dreimal sah. Es scheint sogar der Fall nicht undenkbar, dass das Urbild einer nachahmenden Art ausstirbt und letztere erhalten bleibt. So könnten, nach der Meinung von Mr. Trimen und Mr. A. G. Butler ${ }^{1}$ ), Papilio Antimachus und Papilio Zalmoxis Nachahmungen riesiger, ausgestorbener oder noch unbekannter Acraea-Arten sein. Im vorliegenden Falle sind, wenigstens in Santa Catharina, beide Arten selten, und ihre Zahl giebt somit keinen Anhalt zur Ermittelung des Urbildes.

Das zweite Kennzeichen, dass das Urbild sein eigenes, die Maske ein fremdes Gewand trägt, findet eine um so leichtere und sichere Anvendung, je verschiedeneren Gruppen die beiden ähnlichen Arten angehören, je weiter also die nachahmende Art von dem gewohnten Aussehen ihrer Verwandten sich entfernen musste. Wenn gewisse Heuschrecken (Scaphura) sich in Grabwespen (Pepsis), wenn andere (Phylloscyrtus) sich in Raubkäfer (Odontocheila), wenn wieder andere sich sogar in Spinnen $\left.{ }^{2}\right)$ verkleiden, so kann in diesen Fällen um so weniger ein Zweifel darüber sein, welches die nachahmende Art sei, als sofort auch der Nutzen der Verkleidung in die Augen springt ${ }^{3}$ ).

Auch bei manchen anderen, sich minder fern stehenden Arten, leistet dieses Kennzeichen noch gute Dienste; so ist die schwarze Archonias Tereas mit dem weissen Flecken der Vorder-. dem rosenrothen der Hinterflügel eine ganz fremde Erscheinung unter ihren Gattungs- und Familiengenossen, während Papilio Nephalion einer langen Reihe ähnlich gefärbter Arten angehört, so dass man, auch wo dieser Papilio selten, Archonias Tereas aber häufig ist, doch nicht in Versuchung kommen kann, letzteren Falter als Vorbild des ersteren anzuschen.

Je näher verwandt die beiden ähnlichen Arten sind, je ähnlicher sie schon von vorn herein waren, um so misslicher wird im Allgemeinen die Anwendung dieses zweiten Kennzeichens werden; es wird völlig unanwendbar sein, wo der nächste Verwandtenkreis der einen wie der anderen Art überhaupt einer gemeinsamen, eigenthümlichen, scharf ausgeprägten Form, Zeichnung und Färbung entbehrt. Colaenis Julia und Eueides Aliphera können hier wieder als Beispiel

I) Raphael Meldola, Entomological Notes, bearing on Evolution. Ann. and Magaz. of Nat. hist. February I 878 . p. 157 .

2) Ich habe diese Verkleidung nirgends erwähnt gefunden; ich sah sie ein einziges Mal. Auf einem Blatt sass ein Thier, das ich zunächst für eine Spinne hielt. welches aber docl ein etwas befremaliches Aussehen hatte; ich besah es von allen Seiten, ohne ins Klare zu kommen, was es sei, bis es aufsprang und wegflog. Das Wunderlichste daran waren die langen, spinnenartig in die Quere gestellten Beine.

3) Und doch ist dieses unmöglich scheinende Missverständniss einem dentschen Professor gelungen. In seinem sehr frisch und anregend gescliriebenen, an nenen Thatsachen und Gedanken reichen Buche: „Die Insekten“, das freilich über ausländische Arten auch sonst manches Verkehrte bringt, spricht Professor Vitus Graber (Bd. II, I. S. 72) von ,gewissen Sandwespen, welche, un ihre Beute, das Grillengenus Sphacura, leichter zu überlisten, sich in den Habit ilırer Opfer werfen.“ Das „Grillengenus Sphacura" soll jedenfalls die Locustinengattung Scaphura sein. Der Herr Professor hat es für gut befunden, den Namen ebenso zu verdrehen, wie dic Thatsache. Die Wespe sieht nicht Heuschrecken ähnlich, sondern die Heuschrecke Wespen ähnlich aus. Die Wespe trägt allerdings Heuschrecken. und zwar nichts als Heuschrecken, für ilıre Brut ein, darunter aber niemals, so viel ich gesehen, Scaphuren. Diesen dient eben ihre täuschende Wespenähnlichkeit als Schutz. 
dienen. In der Gattung Colaenis findet sich neben der feurig rothen Julia die grüne Dido und andere Arten mit wieder anderer Färbung und ganz abweichendem Flügelschnitt. In der Gattung Eueides aber steht neben der feurigrothen Aliphera die bunte Isabella und die Acraea-ähnliche Pavana.

Von den beiden Gattungen, von welchen wir ausgegangen sind, besitzt nun wohl Thyridia eine grössere Zahl ziemlich ähnlicher Verwandten (z. B. Dircenna), als Ituna, und man dürfte vielleicht letztere um so eher für die nachahmende Art halten, als sie auch in Betrcff der Blumen die Geschmacksrichtung der Ithomiinen und nicht die der blutsverwandten Danais zu theilen scheint.

Dass endlich drittens das Vorbild durch unangenehmen Geruch und Geschmack vor Feinden geschützt ist, während die nachahmende Art eines solchen Schutzes entbehrt und eben deshalb die Verwechselung mit dem unschmackhaften Vorbilde ihr nützlich wird, würde Vorbild und Nachbild sicher unterscheiden lassen, wenn alle für insektenfressende Vögel unschmackhafte Kerfe auch für uns einen anwidernden Geruch besässen und wenn nicht auch für uns widerlich riechende Schmetterlinge als Nachahmer aufträten.

Die Ithomien des Amazonas und ihre Verwandten (z. B. Mechanitis) werden, wie Bates beabachtete, von so vielen Schmetterlingen aus den verschiedensten Familien nachgeahmt, dass man sie gewiss mit Recht als durch Unschmackhaftigkeit gegen die Verfolgung der Vögel gesichert betrachtet, und doch hat man bei ihnen, so viel ich weiss, einen widerlichen Geruch noch nicht wahrgenommen ${ }^{1}$ ); der Geruch, den die Duftpinsel der Männchen verbreiten, ist meist

I) Woher rührt wohl die von Professor Delboeuf (Kosmos, Bd. II, S. Io6) angeführte Angabe, dass "die Heliconiden" (es handelt sich a. a. O. nicht um Heliconius, sondern um Ithomia!), "wenn sie in Gefahr kommen, eine ekelerregende Flïssigkeit aussondern, welche sie zum unangenehmsten aller Nahrungsmittel macht."? - Wahrscheinlich entfloss sie der Feder eines jener zahlreichen Nachbeter von Bates und $\mathrm{W}$ allace, welche die bahnbrechenden Arbeiten dieser unübertrefflichen Beobachter über Mimicry und schützende Aehnlichkeit bis zur völligen Plattheit breit treten und dabei glauben, durch Uebertreibung und eigene Zuthat dem oft aufgewärmten Gerichte neue Würze geben zu müssen. Wenn Bennett (a. a. O.) meint, dass man zwischen der Urform von Leptalis und deren durch ihre Aehulichkeit mit Ithomia geschützten Nachkommen mindestens tausend Zwischenformen annehmen müsse, so ist auch das eine solche von völliger Unkenntniss des Gegenstandes zeugende Uebertreibung, und der auf diese Annahme gestützte Beweis, dass die Minicry der Leptalis nicht durch natürliche Auslese habe entstehen können, ein Luftgebilde, auf welches der treffliche Ausspruch Harvey's passt, an den $\mathrm{Huxlcy}$ kürzlich crinnert hat (Nature XVII, p. 4I8), und den ich in des Letzteren Uebersetzung anführen will: „For those who read the words of authors and to whom impressions of their own senses do not represent the things signified by those words, conceive, not true ideas, but false eidola and inane phantoms; whence they fill their minds with shadows and chimaeras, and their whole theory (which they think to be science), represents but a waking dream or a sick man's delinium." - Bennett hat schwerlich jemals selbst Leptalis und Ithomia fliegen sehen. Auch er nimmt offenbar an, wie Andere, die ähnlichc Einwürfe gemacht haben, dass die Stammform von Leptalis weiss gewesen sei. Dass sie dies aller Wahrscheinlichkeit nach nicht war, dass sic vielmehr wahrscheinlich ähnlichen Flügelschnitt, ähnliche Zeichnung und Färbung besass, wie viele Ithomiinen, habe ich anderwärts nachzuweisen vcrsucht (Jenaische Zeitschr., X, S. I. I $876=$ Ges. Schriftcn S. 5II). Wenn es heute wcisse Leptalis-Arten giebt, zum Theil gewöhnlichen Weisslingen (Pieris) so ähnlich, dass sie von Bois duval als Pieris beschrieben wurden (Lcptalis Nchemia), so sind dies Nachahmer von Weisslingen. Auch wenn man den Tetrag der ursprünglichen Verschiedcnleit zwischen Leptalis und Ithomia möglichst hoch anschlïgt und ihn vergleicht mit dem Betrag individueller Verschiedenheit bei verïnderlichen Schmettcrlingsarten, werden einige Dutzend Zwischenformen mchr als genügen, die Lücke zu füllcn, wobei schon die erste dieser $Z$ wischcnformcn eine merkbare Anniherung an die ge- 
sehr schwach und nichts weniger als unangenehm, vielmehr vanille- oder rosenähnlich; in ihm kann also die Ursache der Unschmackhaftigkeit wohl um so weniger gesucht werden, als er seinen Sitz in den Flügeln hat, die gar nicht mit gefressen werden. So haben wir also zahlreichen Nachahmern als Vorbild dienende Arten ohne für uns erkennbare Widrigkeit.

Auf der anderen Seite befindet sich unter den mannigfachen Nachahmern der hier zweimal im Jahre in zahlloser Menge erscheinenden Acraea Thalia auch der wohl mehr als tausendmal seltnere Eueides pavana, der dieselbe Stinkvorrichtung am Ende des Hinterleibes und denselben widrigen Geruch besitzt, wie alle übrigen Maracujáfalter. Ebenso ist die Aehnlichkeit der drei in gleicher Weise stinkenden Vettern Eueides Aliphera, Colaenis Julia und Dione Juno sicher höchstens zum kleineren Theile ererbt, wenigstens zum grösseren Theile aber nachträglich erworben. Ferner haben die kräftig stinkenden Eueides Isabella und Heliconius Eucrate cntweder einander oder gemeinsam die (von dem äusserst schwachen, für uns meist kaum wahrnehmbaren Dufte der Männchen abgesehen) für uns geruchlose Mechanitis Lysimnia nachgeahmt, und unter den zahlreichen Schmetterlingen, die den drei letztgenannten ähnlich genug sind, um gelegentlich mit ihnen verwechselt zu werden, befinden sich auch Arten aus den Gruppen der Ithomiinen (Melinaea) und der echten Danainen (Lycorea).

In die Reihe dieser Fälle nun, in welchen die beiden ähnlichen Arten gleich gut durch Unschmackhaftigkeit geschützt scheinen, gehören auch Thyridia und Ituna. Erstere gehört zu den Ithomiinen, von deren Ungeniessbarkeit eben gesprochen wurde, letztere zu den Danainen, welche als Vorbilder nachahmender Arten eine ähnliche Rolle spielen in der alten Welt, wie die Ithomiinen in der neuen. Ja sie trotzen noch nach ihrem Tode vermöge ihrer Ungeniessbarkeit dem in Gestalt von Milben und ähnlichem Geschmeiss verkörperten Zahne der Zeit. Mr. Raphael Meldola legte im vorigen Jahr der Londoner entomologischen Gesellschaft die letzten Reste einer grösstentheils durch Ungeziefer zerstörten alten indischen Schmetterlingssammlung vor. „Die überlebenden Stücke gehörten alle zu geschützten Gattungen (Euploea, Danais und Papilio), was beweist, dass die Eigenschaft, die diese Kerfe umschmackhaft macht, in gewissem Grade auch nach dem Tode erhalten blieb“ ${ }^{1}$ ).

Was bedeutet nun diese Mimicry geschützter Arten? Welchen Vortheil kann es dem seltenen Eueides pavana bringen, der gemeinen Acraea Thalia so wunderbar ähnlich zu sein? Welchen Nutzen kann es überhaupt für zwei Arten haben, einander ähnlich zu sein, wenn jede für sich durch Ungeniessbarkeit vor Verfolgung geschützt ist? - Offenbar gar keinen, wenn insektenfressende Vögel, Eidechsen u. s. w. die Kenntniss der für sie geniessbaren und ungeniessbaren Kerfe mit auf die Welt bringen, wenn ein unbewusstes Hellsehen ihnen sagt, unter welchem Gewande sie einen leckeren Bissen zu verfolgen, unter welchem einen ekelhaften zu meiden haben. Wenn aber jeder einzelne Vogel erst durch

schützte Art zeigen, also einen merkbaren Vortheil ihren Verfolgern gegenüber haben wird. Man darf nicht ausser Acht lassen, dass es sich eben nur um eine Maske, nicht aber um tiefgreifende Umwandlungen des Baues handelt.

I) Nature, Vol. XVI, p. I55. - Kosmos I, S. 442. 
eigene Erfahrung diese Unterscheidung lernen muss, so wird auch von den ungeniessbaren Schmetterlingsarten eine gewisse Zahl dem noch unerfahrenen jugendlichen Nachwuchse der Schmetterlingsfresser zum Opfer fallen. Wenn nun zwei ungeniessbare Arten einander zum Verwechseln ähnlich sind, so wird die an einer derselben gemachte Erfahrung auch der anderen zu Gute kommen; beide zusammen werden nur dieselbe Zahl von Opfern zu stellen haben, die jede einzelne stellen müsste, wenn sie verschieden wären. Sind die beiden Arten gleich häufig, so werden beide aus ihrer Aehnlichkeit den gleichen Nutzen ziehen; jede wird die Hälfte des Tributes sparen, den sie der jugendlichen Unerfahrenheit ihrer Feinde $\mathrm{zu}$ bringen hat. Ist aber die eine Art häufiger, so wird sich der Nutzen ungleich vertheilen, und zwar der verhältnissmässige Vortheil, der für jede der beiden Arten aus ihrer Aehnlichkeit erwächst, sich umgekehrt verhalten, wie das Quadrat ihrer Häufigkeit ${ }^{1}$. Mögen z. B. in einem gewissen Bezirke während eines Sommers 1200 Schmetterlinge einer ungeniessbaren Art vertilgt werden, bis diese als solche erkanut ist, und mögen daselbst 2000 von einer, I 000 von ciner zweiten ungeniessbaren Schmetterlingsart leben. Sind sie ganz verschieden, so wird jede $\mathrm{I} 200$ Stück verlieren; sind sic täuschend ähnlich, so wird sich dieser Verlust im Verhältniss ihrer Häufigkeit unter sie vertheilen, die erstere wird 200, die zweite 1000 verlieren. Erstere gewinnt also durch die Aehnlichkeit 1000 oder 5o Proz. der Gesammtzahl, letztere nur 200 oder 2 Proz. ihrer Gesammtzahl. Während also die Häufigkeit der beiden Arten sich verhält wie I : 5, verhält sich der Vortheil, den sie von der Aehnlichkeit haben, wie 25: r.

Handelt es sich um zwei Arten, von denen die eine sehr häufig, die andere sehr selten ist, so fällt der Vortheil so gut wie ganz auf Seite der selteneren Art. Wäre z. B. Acraea Thalia tausendfach häufiger als Eueides pavana, so würde letztere einen millionenfach grösseren Nutzen von der Aehnlichkeit dieser beiden Arten haben, für Acraea ist dieser Nutzen so gut wie Null. So konnte Eueides pavana durch natürliche Auslese zu einer der gelungensten Nachahmungen von Acraea Thalia herangebildet werden, obwohl er eben so umschmackhaft ist, wie die nachgeahmte Art.

Sind dagegen zwei oder auch mehrere ungeniessbare Arten nahezu gleich häufig, so wird Aehnlichkeit ihnen nahezu gleichen Vortheil bringen, und jeder Schritt, den die eine oder andere in dieser Richtung thut, wird durch natürliche

I) Seien $a_{1}$ und $a_{2}$ die Zahlen zweier ungeniessbaren Schmetterlingsarten in einem bestimmten Bezirk während eines Sommers, und sei n die Zahl der Schmetterlinge einer wohl unterschiedenen Art, die im Laufe des Sommers verzehrt werden, bis deren Ungeniessbarkeit allgemein bekannt ist.

Wären die beiden Arten ganz verschieden, so verlöre also jede n Stück. Sind sie dagegen ununterscheidbar ähnlich, so verliert die erste $\frac{a_{1} n}{a_{1}+a_{2}}$, die zweite $\frac{a_{2} n}{a_{1}+a_{2}}$

Der absolute Gewinn durch die Aelınlichkeit ist also für die erste Art $n-\frac{a_{1} n}{a_{1}+a_{2}}=\frac{a_{2} n}{a_{1}+a_{2}}$ und ebenso für die zweite $\frac{a_{1} n}{a_{1}+a_{2}}$.

Dieser absolute Gewinn, verglichen mit der Häufigkeit der Art, giebt als relativen Gewinn für die erste Art $\mathbf{I}_{1}=\frac{\mathrm{a}_{2} \mathrm{n}}{\mathrm{a}_{1}\left(\mathrm{a}_{1}+\mathrm{a}_{2}\right)}$ und für die zweite Art $\mathbf{I}_{2}=\frac{\mathrm{a}_{1} \mathrm{n}}{\mathrm{a}_{2}\left(\mathrm{a}_{1}+\mathrm{a}_{2}\right)}$, woraus sich sofort ergiebt $\mathrm{I}_{1}: \mathrm{I}_{2}=\mathrm{a}_{2}{ }^{2}: \mathrm{a}_{1}{ }^{2}$. 
Auslese erhalten werden Sie werden einander entgegen kommen und man wird schliesslich nicht sagen können, welche von ihnen den anderen als Vorbild gedient hat. So erklären sich jene Fälle, wo mehrere verwandte ungeniessbare Arten, z. B. Colaenis Julia, Eueides Aliphera und Dione Juno einander ähnlich sind, wo diese Aehnlichkeit sich nicht als ererbte auffassen lässt, und wo doch auch keine der Arten vorwiegende Ansprüche zu haben scheint, den anderen als Vorbild gedient zu haben.

Es dürften hierher auch Ituna und Thyridia gehören, wenn schon wahrscheinlich Ituna die grössere Strecke des Weges zurückgelegt hat, der von früherer Verschiedenheit zu ihrer jetzigen Aehnlichkeit geführt hat.

Itajahy, September 1878 . 


\title{
Ein Käfer mit Schmetterlingsrüssel ${ }^{1}$ ).
}

\author{
Von H. Müller mit einer Beobachtung von F. Müller.
}

Mit I Textfigur.

Bienen und Schmetterlinge haben, als die umfassendsten Insektenabtheilungen die sich ausschliesslich mit Blumennahrung beköstigen, nicht nur als unbewusste Blumenzüchter, die bedeutendste Rolle gespielt ${ }^{2}$ ); sie sind auch selbst durch ihre Anpassung an die Gewinnung dieser Kost in der durchgreifendsten Weise umgestaltet worden, besonders in ihren der Nahrungsgewinnung am unmittelbarsten dienenden Organen, den Mundtheilen. Während aber die Bienenfamilie von dem ursprünglichen Grabwespenmunde der Prosopis bis zu dem ausgeprägten Saugrüssel der Hummel und Honigbiene die mannigfachsten Abstufungen darbietet, und so die stattgehabte Umwandlung uns noch heute fast Schritt für Schritt erkennen lässt, besteht dagegen zwischen den Rüssel der Schmetterlinge und dem Munde ihrer muthmaasslichen Stammeltern, der Phryganiden, eine Kiluft, die durch keine Zwischenstufe überbrückt wird. Denn die sehr unausgebildeten Rüssel gewisser Falter sind gewiss nur als nachträgliche Verkümmerungen, nicht aber als Ererbungen von uralten Stammeltern her zu betrachten.

Die Erklärung dieses auffallenden Unterschieds liegt in der alltäglichen Erfahrung, dass für raschere und erfolgreichere Leistungen auf irgend einem besonderen Gebiete einseitige Beschränkung auf dasselbe eine der ersten Vorbedingungen ist. In einseitiger Beschränkung auf Gewinnung tief geborgenen Blumenhonigs wurden aber die Bienen von den Schmetterlingen von Anfang an in mehrfacher Hinsicht übertroffen.

Während nämlich die Bienen, gleich ihren muthmaasslichen Stammeltern, den Grabwespen, auf die Anfertigung und Sicherstellung ihrer Bruthöhlen einen sehr bedeutenden Theil ihrer Zeit und Kraft zu verwenden haben, liegt den Schmetterlingen, gleich ihren muthmaasslichen Stammeltern, den Phryganiden, keine andere Brutversorgung ob, als das Ablegen der Eier an einen passenden Ort und allenfalls noch die schützende Ueberkleidung derselben (z. B. mit Afterwolle, beim Schwammspinner, Liparis dispar u. a.). Während daher bei den

\footnotetext{
I) Kosmos $1879 / 80$, Bd. VI, S. 302-304.

2) Siehe Kosmos Bd. III, Heft 5 u. 6.
} 
blumenstet gewordenen Grabwespen, den Bienen etc. eine Anpassung der Mundtheile an die Gewinnung tiefer geborgenen Blumenhonigs nur in sofern möglich war, als die zur Herstellung der Bruthöhlen hauptsächlich gebrauchten Oberkiefer dadurch unbehindert blieben, konnten sich die Mundtheile der nur nach Liebe

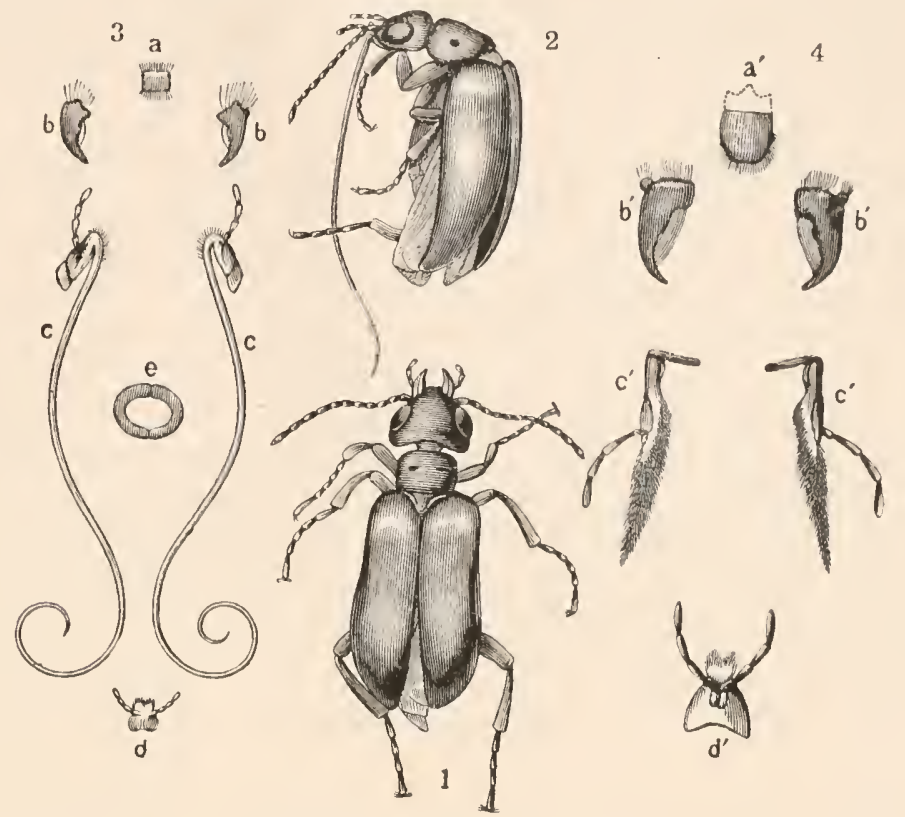

I Nemognatha vom Itajahy von oben gesehen. 2 Desgleichen von der Seite (2: I), $s$ Saugrüssel. 3 Mundtheile derselben. 4 Mundtheile der Nemognatha chrysomelina aus Südfrankreich (4: 1). a Oberlippe, $b$ Oberkiefer, $c$ Unterkiefer, $d$ Unterlippe, $e$ die beiden Kieferladen im Querschnitt, stärker vergrössert.

und Blumensüssigkeiten umherflatternden Falter in einseitigster und ungebundenster Weise der Gewinnung tiefer geborgenen Honigs anpassen. Von durchgreifender Entscheidung für den raschen Erfolg dieser Anpassung war dann weiter die einseitige Beschränkung derselben auf ein Paar einzelne Stücke der Mundtheile, die Kieferladen. Denn diese konnten, indem sie sich verlängerten, rinnig aushöhlten und zu einer Röhre zusammenlegten, durch Naturauslese gewiss sehr bald zum typischen Schmetterlingsrüssel ausgeprägt werden. Bei den Bienen dagegen wurde derselbe Anpassungsvorgang nicht nur durch den gleichzeitigen Gebrauch der Oberkiefer für die Brutversorgung, sondern auch, und wahrscheinlich noch weit wirksamer, dadurch bedeutend verlangsamt, dass eine grössere Mannigfaltigkeit von Theilen, nämlich Unterkiefer, Unterlippe und Lippentaster, zu einem complicirten Saugapparate sich zusammenlegten und nun sämmtlich in gleichem Sinne zugleich gesteigert werden mussten.

Während daher die Ausprägung des typischen Bienenrüssels erst im Verlaufe vielfacher Verzweigung der Bienenfamilie durch zahlreiche Schritte langsam und allmählich zur Vollendung gediehen ist, scheint dagegen die Vollendung des Schmetterlingsrüssels schon bei dem ursprünglichen gemeinsamen Stamme der Schmetterlingsfamilic, noch vor seiner Differenzirung in verschiedene Zweige, er- 
folgt zu sein. So allein, so aber auch in einfachster Weise, scheint mir die unüberbrückte Kluft zwischen Phryganidenmund und Falterrüssel erklärbar.

Für die Richtigkeit der einzigen vielleicht etwas zu gewagt erscheinenden Voraussetzung dieser Erklärung, dass nämlich die Umbildung zweier Kieferladen in einen Schmetterlingsrüssel in verhältnissmässig sehr kurzer Zeit möglich gewesen sein müsse, tritt die Käfergattung Nemognatha als unantastbarer Zeuge ein, indem sie in ihren jetzt noch lebenden Arten dieselbe Umbildung uns thatsächlich vor Augen stellt.

Bei der in Südfrankreich einheimischen Nemognatha chrysomelina nämlich sind die Kieferladen, wenn auch bereits stark verlängert, doch noch von ganz derselben Bildung wie bei anderen Käfern auch. Bei einer schwärzlich blauglänzenden Nemognatha Südbrasiliens dagegen, die mein Bruder Fritz Müller am Itajahy oft wiederholt an Winden saugend beobachtete, haben sich die Kieferladen ausserordentlich verlängert, rinnig ausgehöhlt und zu einem Saugrüssel zusammengelegt, der, abgesehen von der ihm fehlenden Zusammenrollbarkeit, ganz wie ein Falterrüssel gebraucht wird. Hier hat sich also in der verhältnissmässig kurzen Zeit der Differenzirung einer Gattung in einzelne Arten dasselbe ereignet, was wir, um die unüberbrückte Kluft zwischen Schmetterlingsrüssel und Phryganidenmund verstehen zu können, für die Stammeltern der Schmetterlinge voraussetzen mussten.

Hermann Müller. 


\title{
Wasserthiere in Baumwipfeln $\left.{ }^{1}\right)^{2}$.
}

\author{
(Elpidium Bromeliarum.)
}

Mit I Textfigur.

Es ist nicht zu verwundern, dass die feuchten, schatttigen, mit mancherlei Nahrung gefüllten Verstecke zwischen den Blättern der Bromelien von allerlei Gethier benutzt werden, und dass manche dieser Thiere sie zu ihrem Lieblingsaufenthalt erkoren haben oder ausschliesslich ihnen ihre Eier anvertrauen. So werden, nach den fast dreissigjährigen Erfahrungen meines Freundes Friedenreich, fast alle Käfer der Bromelien nur in ihnen gefunden und dasselbe scheint für die zahlreichen Larven von Kerfen der verschiedensten Ordnungen und für die Kaulquappen baumbewohnender Frösche zu gelten, welche hier ihre Verwandlung durchmachen.

Höchst überraschend dagegen ist es, dass unter diesen Wasserthieren in den Wipfeln des Waldes auch ein Krebschen lebt, dessen Verwandte man im Meere zwischen Tangen zu treffen gewohnt ist. Es ist ein wenig über $\mathrm{I} \mathrm{mm}$ langes Muschelkrebschen aus der Familie der Cytheriden.

Von den beiden artenreichen und über die ganze Erde verbreiteten Gattungen Cypris und Cythere, in welche der unermüdete Erforscher der süssen und salzigen Gewässer von Dänemark, Otto Friedrich Müller, die ihm bekannten Muschelkrebschen vertheilte, lebt die Cypris fast ausschliesslich in süssem, die Cythere in salzigem Wasser; nur ganz vereinzelte Ausnahmen von dieser Regel sind bis jetzt bekannt geworden. Auch hier kannte ich bisher Cythere nur aus dem Meere, aus süssem Wasser nur Cypris. Und nimmer hätte ich erwartet, meine alten Bekannten aus der Ostsee, die ich einst mit Max Schultze barfuss im Greifswalder Bodden watend gesammelt, hier auf den Bäumen meines Waldes wiederzusehen.

Auf den ersten Blick freilich erkannte ich die Cythere der Bromelien nicht als Verwandte ihrer in Meere lebenden Vettern, da sie sich in der Gestalt ihrer zweiklappigen Schale weit entfernt von allen anderen Cytheren, ja von allen mir bekannten Muschelkrebschen. Ganz allgemein besitzen diese letzteren seitlich zusammengedrückte Schalen, die weit höher als breit sind und in der Regel die Gestalt einer Bohne oder einer Miesmuschel haben. Bei der Bewohnerin der Bromelien dagegen ist die Breite der Schale viel grösser als die Höhe; dazu ist die Bauchseite flach und von einer Längsfurche durchzogen, so dass sie an eine

I) Kosmos I $879 / 80$. Bd. VI. S. $386-388$.

2) Siehe Kosmos, Bd. IV. S. $390=$ Ges. Schriften S. 680. 
Kaffeebohne erinnert. Jene fallen daher ausser Wasser auf die Seite, diese kommt auf den Bauch oder auch wohl auf den Rücken zu liegen. Das ist wohl eine Anpassung an ihren Aufenthaltsort. Im Meere klettern die Cytheren an dünnen Tangzweigelchen; in den Bromelien müssen sie sich auf den breiten, glatten Flächen aneinanderliegender Blätter bewegen.

Ich sagte, dass mir unter den lebenden Muschelkrebschen keine ähnliche Schalenform bekannt sei, wohl aber kommt merkwürdigerweise unter den ältesten

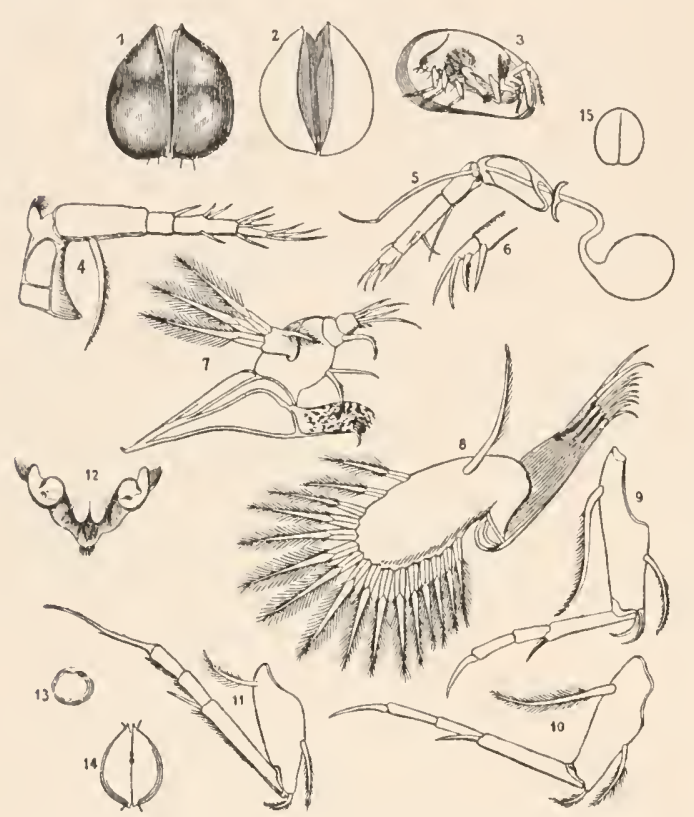

Elpidium Bromeliarum Fr. Müller, ein Bäume bewohnender Muschel-Krebs.

I von oben, 2 von unten, 3 nach Entfernung der rechten Schale von der Seite gesehen. 4 Vorderer Fühler. 5 , 6 Hinterer Fühler des Männchens und Weibchens. 7 Mandibel. 8 Maxilla. 9, I0, I I Füsse vom 1., 2. und 3. Paar. I2 Leibesende des IVeibchens von unten. 13 und 14 Ei und Junges aus der Schale der Mutter. I5 Elpe pinguis Barr.

Die Vergrösserung ist bei $\mathbf{I}-3=10: \mathbf{1}$, bei $4-12$ $=72: \mathrm{I}$ und bei 13 und $14=36: \mathrm{I}$. lassen, sind die jungen Elpidien nur o,2 Millimeter lang). Da also die Besiedelung der Bromelien mit Elpidium ganz dem Zufall anheimgegeben scheint, muss es um so mehr überraschen, dass man diese Krebschen fast in jeder Bromelie antrifft.

Es kann kaum ausbleiben, dass sie dann und wann auch in andere Gewässer verschleppt werden, wie man ja umgekehrt bisweilen in den Bromelien einzelne eingeschleppte Cyclops trifft. Doch habe ich mich bis jetzt in unseren von mannichfachen andern kleinen Krebschen (Cyclops, Canthocamptus, Cypris, Chydorus, Alona, Camptocercus, Pasithea, Moina, Ceriodaphnia, Simocephalus u. s. w.) bewohnten Gewässern vergeblich nach Elpidium umgesehen. Es scheint ausserhalb der Bromelien nicht zu gedeihen.

It ajahy, November I 879 . versteinerten Cytheriden, die Bar$\mathrm{r}$ ande aus den silurischen Schichten Böhmens beschrieben hat, eine Art vor, Elpe pinguis, von welcher unser Bromelienkrebschen ein getreues $\mathrm{Ab}$ bild in fünfmal verjüngtem Massstabe ist. Letzteres habe ich daher Elpidium Bromeliarum genannt; denn obwohl ohne hervorstehende Eigenthümlichkeiten im Bau seiner Gliedmassen, passt es doch in keine der Gattungen, in welche man neuerdings die alte Gattung Cythere aufgelöst hat.

Soweit ich mich bis jetzt nach ihm habe umsehen können, vom Meere bis etwa ıoo Kilometer landeinwärts, ist hier Elpidium überall in den baumbewohnenden Bromelien des Urwaldes häufig. Da es nicht, wie andere Thiere, die mit ihm in den Bromelien hausen, von Baum zu Baum, ja nicht einmal von Bromelie zu Bromelie wandern kann, muss seine Verbreitung durch Käfer (Agabus, Laccophilus, Hister u. s. w.) oder andere Bewohner der Bromelien bewirkt werden, denen die winzigen Thierchen anhaften. Wenn sie die Schale der Mutter ver-

.




\title{
Descripção do Elpidium Bromeliarum').
}

\author{
Crustaceo da familia dos Cytherideos.
}

\author{
Mit Tafel LVII.
}

Já nos tempos geologicos mais remotos, de que nos ficaram restos fosseis, os Cytherideos achavam-se representados por numerosas especies, e desde então elles se têm mostrado frequentes até hoje. As especies fosseis viviam todas no Mar, sendo que ainda hoje estes pequenos Crustaceos encontram-se em todos os mares. Na agua doce, povoada pela familia alliada dos Cyprideos, elles são excessivamente raros; ainda não sobe a meia duzia o numero das especies observadas nos Estados Unidos, na Inglaterra e na Scandinavia. A essas pouquissimas especies da agua doce vou ajuntar mais uma, que ha pouco achei n'aquelles tanquezinhos, que nas arvores do matto virgem formam-se entre as follhas das Bromeliaceas parasitas. Ella ali vive em abundancia e quasi que nào ha Bromelia sem a sua colonia de Cytherideos; é provavel que, com as Bromelias, ella se estenda por todo o Brazil.

Além de ser notavel por esse domicilio singular, que ella habita e por ser a primeira especie de agua doce achada na America do Sul, a especie das Bromelias é interessante tambem pela sua forma insolita. As conchinhas bivalvas das numerosas especies nào só da familia dos Cytherideos, como de toda a ordem dos Crustaceos Ostracodes, costumam ser comprimidas lateralmente, tendo o feitio de um mexilhão ou de um feijão preto; na especie das I3romelias, pelo contrario, a conchinha assemelha-se a um grăo de café, sendo a largura muito maior do que a altura, a face dorsal convexa, a ventral plana e percorrida por um sulco longitudinal. Por este feitio da conchinha a especie se afasta de todos os Ostracodes da actualidade até agora descriptos e só entre as especies fosseis mais antigas ha uma especie muito semelhante. E' a Elpe pinguis (fig. 26) descoberta por Barrande nas camadas silurianas da Bohemia; desta, com effeito, a especie das Bromelias parece ser uma cópia fiel em escala cinco vezes menor.

Foi por este motivio. que lhe dei o nome de Elpidium Bromeliamm.

As conchinhas do Elpidium Bromeliarum (fig. 1-4) têm até $1,{ }^{\mathrm{mm}} 3$ de comprimento; já com metade desse comprimento todos os membros têm adquirido a sua fórma definitiva e os animaes começam a propagar-se. A largura é egual á cerca de seis setimos e a altura á metade pouco mais ou menos do comprimento.

I) Arch. do Mus. Nac. do Rio de Janeiro 1879. Vol. IV. p. 27-34. 145. Est. II. 
A parte posterior da conchinha é mais larga e mais alta do que a anterior, a face dorsal é convexa, a ventral plana. O ligamento elastico, que une os bordos dorsaes das duas valvulas da conchinlıa e pelo qual, como nas conchas dos molluscos Lamellibranchios, as valvulas são abertas, desde que os musculos adductores deixam de se contrahir, estende-se até ao extremo posterior da face dorsal, acabando a pouca distancia do extremo anterior. A valvula esquerda é quasi insensivelmente mais comprida do que a direita, de modo que o seu bordo cobre o desta, quando se fecha a conchinha.

Ao longo do bordo ventral as partes sobrepostas das cluas valvulas, na occasião de estar fechada a conchinha, são assás largas (fig. 2); ellas são transparentes, menos grossas do que o resto das valvulas e formam um sulco longitudinal nas conchas fechadas. A superficie da conchinha é lisa e lustrosa; ha nella alguns pellosinhos muito raros, curtos, delgados, pela maior parte rectos; só uns 5 oul 6 , inseridos ao longo do borclo anterior de cada valvula, sào curvos, sendo a sua ponta volvida para baixo. A côr das conchinhas é parda, ora mais pallicla, ora mais escura; o pigmento é granuloso e encerrado em cellulas grandes polygonaes, situadas por baixo da camada chitinosa externa das valvulas; o pigmento começa a depositar-se ao redor dos nucleos das ditas cellulas (fig. 6) e acaba por enchel-as inteiramente, ficando transparentes só os nucleos e os limites entre as cellulas. Perto do extremo anterior do ligamento dorsal elastico ha em cada valvula uma macula redonda, transparente, destituida de pigmento; para vêr bem essas duas maculas cumpre encarar de frente as conchinhas; ellas são geralmente tanto mais visiveis, quanto mais escuras forem as conchinhas; servem de janellas para admittir a luz aos olhos. Tambem falta o pigmento no logar em que se inserem os musculos adductores das valvulas As impressões musculares (fig. 4m, fig. 6), que mostram differenças caracteristicas nas diversas especies 'de Cytherideos e Cyprideos, distam do extremo anterior cerca de dous quintos do comprimento das valvulas, achanclo-se só pouco acima do nivel da face ventral; ha uma macula maior composta de quatro impressões ellipticas, contiguas, de que as duas extremas são menores e cujos eixos maiores vão obliquamente de cima e de cliante para baixo e para traz; além disso, ha uma impressão muito menor, quasi circular, ás vezes pouco visivel, situada um pouco adiante das quatro maiores.

Os dous olhos simples, existentes nas familias dos Cypricleos e Cytherideos costumam confluir em um unico olho impar, naquella familia e ser separados nesta. Além disso, segundo Zenker, os olhos dos Cythericleos adheririam ás valvulas. Ha comtudo excepções a esta regra em uma e outra familia e entre ellas figura tambem o Elpidium Bromeliarum.

Esta especie tem um unico olho impar com duas lentes lateraes (fig. 7-9) situado em baixo do extremo anterior do ligamento elastico, junto do logar em que anteriormente o corpo do animal separa-se das valvulas; não adhere á conchinha e sim póde ser movido com o corpo um pouco para traz e para diante. A fórma do bulbo coberto de pigmento preto é bastante variavel, parecendo serem as differenças independentes tanto da edade como do sexo dos animaes. As antennas anteriores (figr. 3, a, figr. 10) tem cinco articulos; a articulação entre o primeiro e segundo permitte um movimento extenso de cima para baixo; a 
mobilidade dos mais articulos é muito limitada; o primciro e o segundo são muito mais grossos e compridos do que os outros articulos; o terceiro e o quinto têm só metade pouco mais ou menos do comprimento do quarto, o qual se formou pela confluencia de dous, como mostra a disposição das suas sedas; em certos, bem que rarissimos, individuos, esses dous articulos primitivos se têm conservado perfeitamente separados, constando neste caso as antennas de seis articulos. E' uma prova do pouco valor, que na classificação dos Cytherideos possa ter o numero dos articulos das antennas, que. certos autores têm usado como caracter distinctivo dos generos novamente estabelecidos na dita familia. No extremo do primeiro articulo, ha no lado superior externo um pequeno processo triangular ou digitiforme, guarnecido de pellosinhos bastos, tenros, curtos, rectos. Do segundo articulo nasce, a alguma distancia da base do bordo inferior, um pello grosso, flexivel, plumoso na parte terminal, cujo comprimento excede o do primeiro articulo da antenna; no extremo do terceiro articulo ha no bordo superior uma seda curta e rija; ha duas sedas semelhantes no meio, e tres mais compridas no extremo do bordo superior, uma no meio e outra no extremo do bordo inferior do quarto articulo; emfim, ha tres ou quatro sedas no extremo do articulo quinto ou terminal da antenna.

As antennas posteriores (fig. 3, $a$ 2; fig. I1-12), inseridas um pouco em baixo e para fóra das anteriores, têm quatro articulos, de que o terceiro é n mais comprido; o primeiro é um pouco menos comprido, porém muito grosso; o segundo e o quarto são muito mais curtos; não parece haver mobilidade alguma entre os articulos segundo e terceiro; o segundo articulo póde descrever um arco consideravel para baixo, e o quarto é capaz de se mover tanto para cima como para baixo.

No extremo do segundo articulo ha no lado inferior uma seda delgada e comprida, chegando até ao fim do articulo seguinte, o articulo terceiro é munido de duas sedas curtas pelo meio do lado inferior, de um pello delgado perto do extremo do lado superior e de um forte espinho recto e movel no extremo do lado inferior; emfim o articulo terminal é armado de tres espinhos fortes, moveis, cujas pontas são curvadas algum tanto para baixo. Nas fêmeas (fig. I I) esses tres espinhos são lisos; nos machos (fig. I2) o primeiro, geralmente um pouco mais curto do que os dous terminaes, é serreado, isto é, provido de uma fileira, de dentes agudos.

No extremo do articulo basal das antennas posteriores, articúla-se ainda como nos mais Cytherideos, um appendice biarticulado (fig. II, a), muito esbelto, em cuja ponta se abre um canal, que rem de uma bexiga (fig. I I, b) cheia de um liquido um pouco amarellado e mais refringente do que a agua. Comprimindo a antenne isolada com a bexiga, entre laminas de vidro, vi algumas vezes sahir esse liquido da ponta do appendice em um fio delgado, que não se misturava com a agua. Pela posicăo, que occupa o appendice, poderia elle ser comparado ao ramo externo existente nas antennas posteriores de muitos Crustaceos; é comtudo mais provavel, que corresponda ao processo conico das antennas posteriores dos Amphipodes, en cuja ponta tambem se abre o canal excretorio de uma glandula. A bexiga é muito maior no Elpidium liromeliarum, do que (segundo Zenker) na Cythere viridis do mar Baltico. 
As partes bocaes constam de dous pares de appendices, designados geralmente pelos nomes de mandibulas e maxillas, (ou, por Zenker, de primeiro e segundo par de maxillas).

As mandibulas (fig. $3, m, d$; fig. I 3 ) têm, como nos generos Cypris e Cythere, uma grande parte basal triangular, percorrida e como que esteiada por diversas varas chitinosas. A parte inferior da base do triangulo prolonga-se em um processo mandibular, terminado por uma serie de dentes agudos. Do bordo anterior da mandibula nasce um grosso palpo, composto de tres ou quatro articulos, que, com excepção do ultimo, são pouco distinctos. O palpo tem duas sedas maiores no primeiro articulo, uma curvada e plumosa no extremo do penultimo e umas quatro no ultimo articulo. Do lado externo do primeiro articulo do palpó eleva-se uma lamina membranosa, volvida para cima, cujo bordo superior se prolonga em tres pellos grossos, compridos, rectos, flexiveis e plumosos, com excepção de uma curta parte basal, que é núa.

IIa na mesma lamina um quarto pello, semelhante aos outros tres, porém muito curto e dirigido em sentido opposto. Em individuos sufficientemente transparentes se póde vêr, que a lamina está em movimento continuo na parte da conchinha situada para diante dos musculos adductores.

As maxillas (fig. 3, mx; fig. I 4) mostram una grossa parte basal, de cujo bordo terminal nascem quatro! processos quasi cylindricos, contiguos, parallelos, armados na ponta de pellos ou sedas; destes processos o que prolonga o bordo inferior ou interno da maxilla termina em duas sedas; de que a inferior tem a metade terminal plumosa e curvada para baixo; cada um dos dous processos intermedios acaba em tres sedas rijas, agudas, um pouco curvadas; emfim o quarto processo, formando o prolongamento do bordo superior da maxilla, é mais comprido que os outros e acaba em duas sedas mais compridas tambem; este quarto processo é biarticulado nos generos Cypris e Cythere, porém na especie das Bromelias não me foi possivel distinguir dous articulos. Ha na maxilla, como na mandibula, uma lamina membranosa, guarnecida de compridos pellos plumosos; ella é muito maior do que a das mandibulas; o numero dos pellos marginaes parece ser de $16 \mathrm{em}$ todos os animaes adultos. Além dos pellos marginaes ha um que nasce á pouca distancia do bordo e se estende em sentido opposto; é semelhante em tudo ao pello que se acha no segundo articulo das antennas anteriores. A lamina membranosa da maxilla é dirigida para fóra e está em movimento vibratorio constante no espaço situado atraz dos musculos adductores.

A's partes bocaes seguem tres pares de pernas (fig. 3, p 1, p 2, p 3 ; fig. 15-17); muito semelhantes entre si, tendo comtudo cada par certos caracteres distinctivos. As pernas são compostas de cinco articulos; o articulo basal é muito mais grosso do que os mais, tendo o bordo posterior mais comprido e mais convexo do que o anterior; quando o animal está andando este articulo está virado para baixo, recolhidas as pernas na conchinha, dirige-se obliquamente para diante. $A$ pouca distancia da base nasce do bordo posterior um pello plumoso semelhante ao do segundo articulo das antennas anteriores; nos dous primeiros pares de pernas o comprimento desse pello excede an do articulo basal, no terceiro par é muito mais curto. 
Um segundo pello semelhante, porém, muito menor, nasce no meio do bordo anterior, e um terceiro, muito mais curto ainda, no extremo do bordo anterior do articulo basal. Ao lado deste terceiro pello ha no primeiro par de pernas (fig. 15) um gancho ou espinho forte, curvado e agudo, que falta aos dous pares posteriores.

Os articulos segundo até quarto são esbeltos, quasi cylindricos, dirigidos para traz, sendo o comprimento do segundo articulo igual ou pouco superior ao do terceiro e quarto unidos. No extremo do lado ventral do segundo articulo ha nos dous primeiros pares de pernas um espinho forte, curvado um pouco para baixo, o qual se acha substituido no terceiro par por uma seda recta, muito mais tenra. $\mathrm{O}$ articulo quinto ou terminal forma nos dous primeiros pares uma unha vigorosa esbelta, pouco curvada, cujo comprimento iguala ou pouco excede ao do articulo antecedente. No terceiro par de pernas (fig. 17) o articulo terminal é muito mais comprido e delgado do que nos pares anterinres, igualando o comprimento do segundo articulo, a sua metade basal é recta, a terminal um pouco curvada, havendo um pequenino espinho entre essas duas metades.

$\mathrm{Na}$ configuração das partes bocaes e das pernas não ha differença entre os dous sexos.

As partes genitaes, situadas posteriormente ás pernas, são muito volumosas e complicadas nos machos (fig. 19-22). O membro viril (fig, 19, $m v$.) é um gancho duro, escuro, curvado em semicirculo, movido por um forte musculo. Para dentro e para diante do membro ha, como nas Cytheres examinadas por Zenker, um processo digitiforme (fig. 19-22, $p d$.) ha tambem, como nas Cytheres, uma grande lamina terminal de forma muito variavel (fig, 19-22, $l t$; fig. 20-21), de cuja face ventral nasce junto da base um pello quasi igual em comprimento á mesma lamina. Os orificios genitaes das femeas (fig. $18, o g$ ) săo situados de um e outro lado do abdomen entre o terceiro par de pernas e os appendices caudaes.

Os appendices caudaes (fig. 18, 19,22,ac.) são duas pequenas laminas triangulares ou ovaes, munidas de duas sedas plumosas terminaes e de uma terceira seda mais comprida, que nasce de sua face ventral e que parece faltar ás vezes nos machos.

O corpo ainda se prolonga um pouco além dos appendices caudaes, terminando em uma protuberancia guarnecida de curtos pellinhos.

Os ovos (fig. 23) quasi esphericos, de cerca de $0,{ }^{\mathrm{mm}} 1$. de diametro, desenvolvem-se como na Cypridina Agassizei ${ }^{1}$ ), dentro da conchinha da màe. Nas femeas maiores conta-se ás vezes mais de trinta entre ovos e filhos. Os filhos ali ficam até terem chegado a $0,-2$ até $0,{ }^{m m} 25$ de comprimento. A sua conchinha então já tem approximadamente a sua forma caracteristica e definitiva (fig. 2.4, 25); ella mostra só quatro pellos, havendo um junto de cada extremo de uma e outra valvula; o olho e os musculos abductores se acham situados muito mais para traz do que nos animaes adultos, devido isso á circumstancia de estar ainda pouco desenvolvida a parte posterior do corpo; em lugar dos tres pares de pernas, ha apenas um unico par de ganchos simples; as antennas, pelo contrario, já possuem a sua organisação definitiva.

1) Fritz Müller, Bemerkungen über Cypridina, Jenaische Zeitschrift für Naturw. I87o. Vol. V. pag. $255 .=$ Ges. Schriften S. 367 . 
O Elpidium é quasi o unico entre os numcrosos visitantes e habitantes das Bromelias, que nellas nasce e morre. Muitos animaes vão visitar as Bromelias, seja para se agasalharem, seja para se nutrirem das substancias organicas, que entre as suas folhas se accumulam, seja emfim para alli depositarem os seus ovos. Esses visitantes passageiros sĩo variadissimos; ha entre elles Vermes Turbellarios (Geoplana), Crustaccos Itsópodes (Pliloscia) Arachnides, Myriapodes, muitos Insectos, Batrachios (pererecas) e até cobras. Outras especies vivem lá como larvas, sahindo depois de concluida a sua metamorphose, como sejam as pererecas e varios insectos Orthopteros (Agrionideos), Neuropteros, Trichopteros, Coleopteros (Parnideos) e Dipteros (Culicideos, Tipulideos, Syrphideos e outros). Nem para aquelles visitantes nem para estas larvas ha difficuldade alguma em explicar a sua estada nas Bromelias. Com o Elpidium o caso é differente. Nào podendo esses pequenos Ostracodes migrar de uma Bromelia e muito menos ainda de uma arvore a outra, como é que não obstante isso podem elles estabelecer novas colonias? Elles não poderão fazer as viagens necessarias sinão adherindo ao corpo de qualquer visitante das Bromelias. Apezar de assim parecer abandonada ao acaso a sua transmigração, ella se faz com a mesma regularidade com que o pollen das flores é transportado de uma planta a outra pelos insectos pronubos, como prova o facto de quasi não haver Bromelia sem a sua colonia de Elpidium.

Resta resumir os caracteres, pelos quaes o genero Elpidium pode ser distinguido dos mais, que se têm estabelecido na familia dos Cytherideos: Conchinha com a face ventral plana e a largura muito superior á altura. Olhos reunidos en um unico impar. Antennas anteriores com cinco (ou excepcionalmente seis), posteriores com quatro articulos. Ultimo articulo das antennas posteriores com tres espinhos, sendo um delles serreado nos machos. Pernas iguaes nos dous sexos, semelhantes entre si. Articulo basal do primeiro par de pernas armado de um gancho terminal. Articulo ultimo (unha) do terceiro par muito comprido e delgado. Appendices candaes nũo articulados, munidos de tres sedas.

\section{Explicaçĩo das figuras da estampa LVII $\left.^{1}\right)$.}

São augmentadas 25 vezes as figuras $\mathrm{I}-4 ; 90$ vezes as figuras 5 e $23-25 ;$ I 80 vezes as figuras $6-22$.

Fig. I.- Elpidium Bromelianm, visto da face dorsal.

Fig. 2.- $\mathrm{O}$ mesmo, face ventral.

Fig. 3.- Femea; vista do lado direito depois de removida a valvula do mesmo lado; $o$ olho. $a$ antenna anterior. $a$ " antenna posterior. $m d$ mandibula. mx maxilla. $p$, $p ", p^{\prime \prime \prime}$ pernas. og orificio genital. ac appendice caudal.

Fig. 4.- Individuo menor, visto do lado direito. $m$ impressões musculares.

Fig. 5.- Impressões musculares da valvula esquerda.

Fig. 6.- Fragmento de uma valvula.

Fig. 7.- Olho visto do lado direito.

Fig. 8, 9.- O mesmo visto de cima, de dous differentes individuos.

Fig. Io.- Antenna anterior.

1) Zur Beurteilung dieser Tafel im Vergleich der Textabbildungen aus Kusmos (Ges. Schriften S. 792 siehe die Erklärung aus dem Zool. Anzeiger Bd. IV. 1881. S. $505=$ Ges. Schriften S. 83 I. 
Fig. 1 I.-Antenna posterior de uma femea. a appendice biarticulado, en cuja ponta se abre o canal excretorio da bexiga $b$.

Fig. I 2.- Extremo da antenna posterior de um macho.

Fig. I3.- Mandibula.

Fig. I 4.- Maxilla.

Fig. I 5.- Perna do primeiro par, distinguindo-se pelo gancloo no extremo do articulo basal.

Fig. 16.- Perna do segundo par.

Fig. I 7.- Perna do terceiro par, distinguinclo-se pelo comprimento do articulo terminal (unha).

Fig. I8.-Extremo posterior do corpo de uma femea, face ventral. ac appendices caudaes. og orificios genitaes.

Fig. I 9.- Orgãos genitaes do lado direito de uma macho, vistos da face ventral. ac appendices caudaes. It lamina terminal. mo membro viril. $p d$ processo digitiforme.

Fig. 20, 2I.- Lamina terminal dos orgìos genitaes de outros dous machos.

Fig. 22.- Extremo posterior do corpo de um macho, visto da face dorsal. ac appendices caudaes. It laminas terminaes dos orgìos genitaes. $p d$ processos digitiformes.

Fig. 23.- Ovo, tirado da conchinha de uma fêmea.

Fig. 24.- Larva, tirada da conchinha, da sua màe, vista do lado dorsal, o olho. $m$ musculos adductores.

Fig. 25.- Secçào transversal da mesma. Arthropoden.

Fig. 26.-Elpe pinguis Barr, copiada de Gerstaecker, Klassen und Ordnungen der 


\section{On a curious insect from Brazil $\left.{ }^{1}\right)$.}

The Secretary also exhibited a photograph on behalf of Dr. Fritz Müller, and read the following note: -

"I take the liberty of sending you a photographic copy of some drawings of a very curious dipterous insect. The larva is remarkable for having six segments only, each being provided on the ventral side with a complicated disk, by which it firmly adheres to the rocks of rapids. The first segment of the larva is a cephalothorax, comprising the head, thorax, and first abdominal segment of the pupa. The pupa, which is firmly cemented to the rocks, has its antenne, wings and legs free, not adherent to the body. The perfect insect is remarkable for the dimorphism of the females. One set of females agrees in the want of mandibulæe and the structure of the oval parts with the males. They are probably honey-sucking. The other set of females are provided with mandibulæ, like the blood-sucking females of Culex, Tabanus, \&c. In the size of the eyes and the structure of the feet the blood-sucking females differ much less from the males than the honey-sucking females do. I have lately sent to the 'Archivos do Muséu Nacional do Rio de Janciro' a description of this insect, accompanied by seven plates, three of which refer to the highly interesting structure of the larva."

i) Trans. Ent. Soc. London 1879. Proc. p. L. 

Gesammelte Abhandiungen von N. Pringsheim. Ileransgegehen von

Vier Bände. $1895-96$. lit einem Bildnis des Verfassers mul 28 lithogr. Tafeln. 1895. Preis: 20 Alar. Zweiter Band: Phycomyceten, Charen, Moose, Parne. Nit 32 lithographischen Tafeln. 1895 .

l'reis: 15 Mark.

Dritter Band: Zellenbau, Morphologisches, Historisches. Mit 13 lithographischen Tafeln. 1S9ti.

P'reis: 12 Mlark.

Vierter Band. Chlorophyll, Assimilation. Lichtwirkung, Sauerstoffabgabe, osmotische Versuche. Mit 2:2 lithograjphisehen Tafeln und 7 Aluhild im Text. 1596.

I'reis : 13 Mlark.

Kein sehöneres Denkmal hïtte dem rerstorbenen Gelehrten gesetzt werden kïnnen, als os von semen hindern dureh dis lleransqabe der gesimmelten Werki desselhen geschalı. Es sind wortgetrene Abdrïclie ron Abhandhungen, welche in den Scluriften der Königlichen Akademie der Wissenschaften 2,1 Berlin, in den Jahrbüchern für wissenschaftliche Botanik, in den Berichten der Dentschen lotanischen Gesellschaft usw., zum Teil anch als vollstimlige Broschüren wrschenen sint

Exkursionsflera von Java, umfassend die Blïtenpflanzen. mit besonderer (ava, Beriicksichtigung der im Hochgebirge wildwach senden Arten. Im Aufrage des Hollïndischen Kolonialministeriums bearbeite von Dr. S. H. Koorders.

Erster Band: Monolotyledonen. Mit einer chromolithographisehen Tafel (j Lichtelrucktafeln und 30 Abbildungen im Text. (XXY und $413 \mathrm{~s}$. gr. $\mathrm{S}^{\prime \prime}$.) 191]. Preis: 24 Mlark.

Zweiter Jand: Dikotyledonen (Aphichlanwleac). Mit 7 Lichtdrncktafeln und 90 Abbildngen im Text. (VI und $7.12 \mathrm{~K}$. gr. 80.) 1912. Preis: 36 Mark.

Dritter band: Dikotyletonen (Matachlamydeac). Nlit (j Lichtelucktafeln, 4 Karten und 19 Abbill. im Text. (IX und 498 S. gr. 80.) 1912. Preis:28 Mark. Vierter band: Itlas. I. Abt.: Fantilie 1-19. 1913. I'reis: 2 Mark 50 Pf

\section{Flora der Umgebung der Stadt São Paulo in Brasilien.}

Von Dr. A. Usteri, ehemals Professor an J'olytechnikum São J'aulo. Mi

1 Karte, 1 Tafel und 72 Ablildungen in T'ext. 1911. P'reis: 7 Mark

Vorliegende Arbeit ist die erste systematisehe Bearbeitung der Flora von Sã Paulo. Sie wird wegen iluer Figenart unl Reichloaltigkeit für weite Kreise der Botaniker und Geographen vou Interesse sein. Die reiche Illustrierung erhöht den Wert des Bnches. Der erste Teil gilst einen Einhlick in die pflanzengeographischen Verhältnisse des (iebiets, während der zwnite ein Jestimnen dev in dieser fiegend wild wachsenden Pflanzen ermöglicht.

\section{Biologische und morphologische Untersuchungen über Wasser- und Sumpfgewächse. Von Prof. 1)r. Hugo Glück in Heidellerg.}

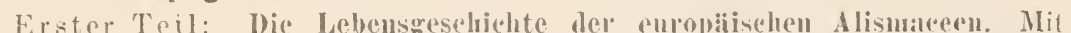
25 Abbildungen im Text und 7 lithograph. J)oppeltafeln. 1905. I'reis: 20 Mark.

\%weiter Teil: Untersmehnuen äber die mittelenropaisehen UltrienlariaArten: iiber dic Turionenbildung der Ulldoularia-liten: iiber die Turionenhildum bej Wasserpllanzen. sowie iber (celatophyllum. Mit 28 Abbiklungen im Text und (j lithographischen I)oppeltafeln. 190,i. Preis: is Mark. 1) ritter Teil: Dic Uferllora. Mit 105 Abbilcl. m 'Text mols lithogr. Dopreltafeln. 1911. Preis: 33 Mark. Vierter (Schlu ß-)Te il: Submerse mulschwimmblatflora. (In Vorbereitung.) Illustrierter l'rospelit kostenfrei.

Die Entstehung der Pflanzengallen, verursacht durch Hymenopteren. Vom l'rol. 1)r. Werner Magnus. Mit 39 Albihlungen in Text mol 4 Dopeltafeln. (VIil, l(i) S. (r). S".) 1914. l'reis: 9 Mark.

\section{Zentralblatt fïr Z, oologic, Bd. J, 1915}

Diese schöne und itufierst wertvolle, für den Zoologen wio für den botaniker gleich iuterressanto. Irlobil, in weldher Verf. zalılreiche eigene Beobachitungen niederolegt hat, glioder sich im I. ,speziallen 'Teil" folgendermaßen: A. Cynipiniden. 1. Mhodites rosne 1. anf liose rominu. 2. Rhorlites

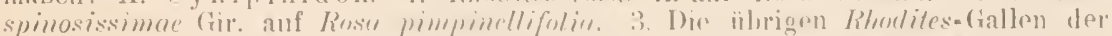

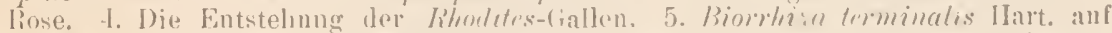

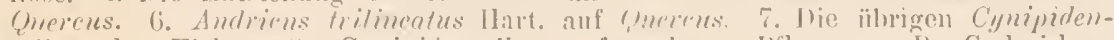
gallen der Eiche. 8. Cymividengallen auf anderen I'flanzen. B. Calciden. 1. Isosoma auf Luftwurzeln rom Ficus. 2. Isusema nefhidenrmm I. (). W. auf Catlleya. 3. Blastophagn mrossormm auf Firns rerire. C. Te nthedinen.

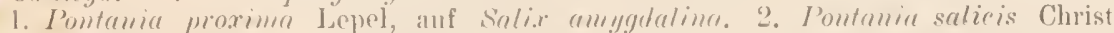
anf Sorliti merpmea. 3. Pontania resieator Bremi anf Salix mrpmere. I. Die inderen Pomtaniegallen der Wride. 5. Die Wintstelumg der Pontriria-Blattgallen. Im, , allgemeinen Teil" weist der Verf. die Richtigkeit seiner vielfach im Gegensitz zil den Untersuchungen frïherer lisohachiter stohenden allgemeinen sehlïsse fïr die Aetiologie dieser Gallen mach.... v. Dalla Torre. 
Die Pflanzengallen (Cecidien) Mittel- und Nordeuropas, inre und Biologie der Bestimmungstabellen. Voll Dr. H. Ross, Konservator am Kgl. Botanischen Museum in München. Mit 233 Fig. auf 10 Tafeln, nach der Natur gezeichnet ron Dr. G. Dunzinger, München, und 24 Abbildungen im Text. (IX, 350 S. gr. 8०.) 1911.

Preis: 9 Mark.

Inhalt: I. Teil. Erklärung des Begriffs „Galle": Nomenklatur. - Die Gallen erzeugenden Tiere (Cccidozoïn). - Dic Gallenerreger aus dem Pflanzenreich (Cecidophyten). - Verteilung der Gallen am Pflanzenkörper. - Einteilung der Gallen. Bedingung für dic Entstehung der Gallen. Die Gallen erzeugenden Stoffe. - Beständigkeit 'der Gallformen. - Anzahl der Galltiere. Larrenkammer. - Schutzeinrichtungen, Inncugalle, Ueberwinterung der Gallen. - Verpilztc Tiergallen. Milbenhäu-chen (Acarodomatien). - Verbänderungen (Facciationen). - Untersuchungsmethoden, Zucht, Präparieren und Aufbewahren der Gallen. - - Hilfsmittel für das studium der Gallenbildungen. - Nutzen und Viele der Gallenkunde und Gallen forschung.

II. Teil. Bestimmungstabellen. - Erklärung der Abkürzungen und Zeichen iu den Bestimmungstabellen. - Sachregister zun I. T'eil. - Alphabethisches Verzcichnis der Gallenerrerer nach den Artnamen. - Alphabetisches Verzeichnis der Gallenerreger nach den natürlichen Ordnungen und Klassen. - Erklärung der Figuren auf Tafel $I-X$

\section{Untersuchungen uiber die Vermehrung der Laubmoose durch}

organe und Stecklinge. Von Dr. Carl Correns, a. ö. Prof. der Botanik in Tübingen. Mit 187 Abbildungen im Text. (XXIV, 472 S. gr. S $^{n}$.) 1899

Preis : 15 Mark

Inlialt: Einleitende Bemerkungen. - Spezieller Teil: 1. Die Vermehrung durch Brutorgane. 2. Die Vermehrung durch Stecklinge. - Allgem einer Teil: Morphologie und Phylogenie der Brutorgane. 2. Bau und Entwicklung der Brutorgane. Adblösung. Verbreitung. 3. Keimung der Brutorgane und der Stecklinge. 4. Bedingungen für die Keimung. Weitere Entwicklung. Vorkommen der Brutorgane. Bedingungen für ihre Bildung. 5. Verwertung der Brutorgane für die Systematik Uebersicht über die untersuchten Brutorgane. - Literaturverzeichnis. - Register der Pflanzennamen.

\section{Das Kapland, insonderheit das Reich der Kapflora, das Wald}

\section{gebiet und die Karroo. Pflanzengeographisch dargestellt von}

Rudolf Marloth. (Mit Einfügung hinterlansener Schriften A. F. W. Schimpers.) Mit 192 Abbildungen im Tert, 28 Tafeln in Heliogravüre und 8 Karten. (Wissenschaftl. Ergebnisse der deutscher Tiefsee-Expedition auf dem Dampfer Valdivia 1898-1899. Bd. II, 3.) 1.908. (Fol.) $\rightarrow$.

Preis: 100 Mark.

Inhalt: J. Teil: Die allgemeinen Verhältnisse der Vegetation Südafrikas. 1. Orographie und Hydrographie: 2. Abriß der geologischen Entwicklung des Landes. 3. Klimatologie. - II. Teil: Allgemeine Pflanzengeographie Südafrikas. 1. Geschichte der Iflanzengeographie Siidlafrikas. 2. Die pflanzengeographische Gliederung Südafrikas. - III. Teil: Das Reich der Kapflora. A. Allgemeine Verhältnisse. B. De Religionen und Formationell. 1. Küstell und Niederungen. 2. Hügel und Vorberge. 3. Die Bergregion. 4. Die Hochgcbirgs. kämme und Gipfel. 5. Isolierte Artile der Kapflora. 6. Das Gebiet der Hartlaubgehölze. - IV. Teil: Die Wälder der Südküste. - V. Teil: Das zentrale Gebiet. 1. Die Karroo. (1. Die große Karro. 2. Die kleine Karroo. 3. Die Westkarroo.) 2. Das karroide Hochland. 3. Das kleine Namaland. - VI. Teil: Allgemeine Oekologie der Pflarizen Südafrikas. - VII. Teil: Der Ursprung der Kapflora. 1. Ueber die Vermischung der Begriffe Kapflora und Flora Südafrikas. 2. Die Beziehungen der Flora des südwestlichen Kaplandes zu anderen Ländern. 3. Uebersicht der Anschauungen über den Ursprung der Flora Südafrikas und der eigentlichen Kapflora. 4. Ueber Veränderungen in der Verteilung ron Land und Meer im Bereiche Südafrikas seit der Kreidezeit. 5. Die Aenderungen des Klimaś Südafrikas seit der Kreidezeit. 6. Verbreitungsgelegenheiten und Verbreitungswege der Pllanzen. 7. Versuch einer Darstellúng des Entwicklungsganges der Kapflora. 8. Andeutungen über den Entwicklungsgang der Karrooregetation. - Anhang: Die Kulturpflanzen.

Botanische Z:itung:

Marloth hat es mittels seiner lebendigen Sprache meisterhaft verstanden, hier alle jene feinen und feinsten Farbennuancierungen der prächtigen Kapflora dem Leser wiederzugeben... Was das Buch Marloths nun so überaus anregend und anzieher 1 macht, das sind außer der schon hervorgehobenen, pracht $\mathbf{p} 0 \mathrm{ll}$ plastischen, farbenroichen Sprache die Ueberfülle ökologischphysiologischer und biologischer Momente. Fs gehört eben die ganze liebevolle Hingabe, der ganze weitsehauende und niemals an Einzelheiten haften bleibende Geist Marloths dazu, eine Flora so in jeder denkbaren Hinsicht mit gleicher Genauigkeit erforschen zu können. Dabei ist noch in Betracht zu ziehen, daß der Verf. nur mit größter Schwicrigkeit die nötigste Literatur erlangen konntc. R. Muschler. 